\title{
The Ransom and Sarah Williams Farmstead: Post-Emancipation Transitions of an African American Family in Central Texas Vol. 1
}

Douglas K. Boyd

Prewitt and Associates, Inc.

Aaron R. Norment

AmaTerra Environmental, Inc.

Terri Myers

Maria Franklin

Nedra Lee

See next page for additional authors

Follow this and additional works at: https://scholarworks.sfasu.edu/ita

Part of the American Material Culture Commons, Archaeological Anthropology Commons, Environmental Studies Commons, Other American Studies Commons, Other Arts and Humanities Commons, Other History of Art, Architecture, and Archaeology Commons, and the United States History Commons

Tell us how this article helped you.

This Article is brought to you for free and open access by the Center for Regional Heritage Research at SFA ScholarWorks. It has been accepted for inclusion in Index of Texas Archaeology: Open Access Gray Literature from the Lone Star State by an authorized editor of SFA ScholarWorks. For more information, please contact cdsscholarworks@sfasu.edu. 


\title{
The Ransom and Sarah Williams Farmstead: Post-Emancipation Transitions of an African American Family in Central Texas Vol. 1
}

\author{
Authors \\ Douglas K. Boyd, Aaron R. Norment, Terri Myers, Maria Franklin, Nedra Lee, Leslie L. Bush, and Brian S. \\ Shaffer

\section{Licensing Statement} \\ This is a work for hire produced for the Texas Department of Transportation (TxDOT), which owns all \\ rights, title, and interest in and to all data and other information developed for this project under its \\ contract with the report producer. The report may be cited and brief passages from this publication may \\ be reproduced without permission provided that credit is given to TxDOT and the firm that produced it. \\ Permission to reprint an entire chapter, section, figures or tables must be obtained in advance from the \\ Supervisor of the Archeological Studies Branch, Environmental Affairs Division, Texas Department of \\ Transportation, 125 East 11th Street, Austin, Texas, 78701
}




\title{
THE RANSOM AND SARAH WILLIAMS FARMSTEAD: POST-EMANCIPATION TRANSITIONS OF AN AFRICAN AMERICAN FAMILY IN CENTRAL TEXAS
}

\author{
VOLUME I \\ by \\ Douglas K. Boyd \\ Aaron R. Norment \\ Terri Myers, \\ Maria Franklin \\ Nedra Lee \\ Leslie L. Bush \\ and \\ Brian S. Shaffer
}

Principal Investigators: Douglas K. Boyd and Aaron R. Norment

REPORTS OF INVESTIGATIONS NUMBER 173

Prewitt and Associates, Inc. Cultural Resources Services Austin, Texas

PAI Project Nos. 205037, 206064, 207044, 209003, 209015, 210007, 211018, and 214032

ARCHEOLOGICAL STUDIES PROGRAM, REPORT NO. 139

\author{
Texas Department of Transportation \\ Environmental Affairs Division \\ Austin, Texas \\ CSJ No. 1200-06-004
}

May 2015

TEXAS ANTIQUITIES PERMIT NO. 4736 
THE RANSOM AND SARAH WILLIAMS FARMSTEAD: POST-EMANCIPATION TRANSITIONS

OF AN AFRICAN AMERICAN FAMILY IN CENTRAL TEXAS

COPYRIGHT @ 2015

Texas Department of Transportation (TxDOT)

This is a work for hire produced by the Texas Department of Transportation (TxDOT), which owns all rights, title, and interest in and to all data and other information developed for this project under Contract No. 575xxSA006 (Work Authorization Nos. 57520SA006 and 57550SA006), Contract No. 577xxSA001 (Work Authorization No. 57719SA001), Contract No. 579xxSA002 (Work Authorization Nos. 57903SA002, 57904SA002, and 57909SA002), Contract No. 571xxSA002 (Work Authorization Nos. 57101SA002 and 57103SA002), Contract No. 571xxSA001 (Work Authorization No. 57114SA001), and Contract No. 573xxSA003 (Work Authorization No. 57313SA003). Brief passages from this publication may be reproduced without permission provided that credit is given to TxDOT and Prewitt and Associates, Inc. Permission to reprint an entire chapter, section, figures, or tables must be obtained in advance from the Supervisor of the Archeological Studies Program, Environmental Affairs Division, Texas Department of Transportation,

125 East 11th Street, Austin, Texas, 78701. Copies of this publication have been deposited with the Texas State Library in compliance with the State Depository Requirement.

jointly published by the

Texas Department of Transportation

Environmental Affairs Division

Archeological Studies Program

Scott Pletka, Ph.D., Supervisor

Archeological Studies Program, Report No. 139

CSJ No. 1200-06-004

and

Prewitt and Associates, Inc.

Cultural Resources Services

Austin, Texas

PAI Project Nos. 205037, 206046, 207044,

209003, 209015, 210007, 211018, 213002, and 214032

Reports of Investigations, No.173

Printed by OneTouchPoint/Ginny's in Austin, Texas

ISBN: 978-1-935545-07-1 


\section{DEDICATION}

This book is dedicated to the direct descendants of Ransom and Sarah Williams and to the many other African Americans in the greater descendant community who participated

and contributed to this project. We hope the contributions

of the Williams family and all the black freedmen pioneers in Texas will long be remembered. 


\section{VOLUME I}

CHAPTER 1: Introduction to the Ransom and Sarah Williams Farmstead Archeological Project

CHAPTER 2: History of Investigations at Site 41TV1051

CHAPTER 3: Work Accomplished and Methods of Investigation

CHAPTER 4: Allen's Prairie, Mountain City, and Antioch Colony: African American Pioneers in Slavery and Freedom

CHAPTER 5: Ransom and Sarah Williams: Freedman Farmers in Travis County

CHAPTER 6: Landscape Analysis of the Williams Farmstead

CHAPTER 7: Cultural Features Associated with the Williams Farmhouse

CHAPTER 8: Descriptions of Material Culture from the Williams Farmstead

CHAPTER 9: Vertebrate Faunal Remains

CHAPTER 10: Macrobotanical Remains

CHAPTER 11: Spatial Analysis of Material Culture and Features

\section{VOLUME II}

CHAPTER 12: Narratives of Black Household Life in Rural Central Texas, Ca. 1920s-1950s

CHAPTER 13: Late-Nineteenth-Century African American Life in Central Texas as Seen Through Contemporary African American Newspapers

CHAPTER 14: Post-Emancipation Transitions of the Williams Family: Summary and Conclusions REFERENCES CITED

APPENDIX A: Property History for Lands Owned by the Williams Family and Ownership Maps for the John G. McGehee Headright League

APPENDIX B: Material Culture Database and Artifact Tables

APPENDIX C: Database of Vertebrate Faunal Remains (electronic format only)

APPENDIX D: Database of Macrobotanical Remains (electronic format only)

APPENDIX E: Neutron Activation Analysis of Historic Stoneware Ceramics from the Williams Farmstead and Selected Central Texas Potteries

APPENDIX F: African American Newspapers in Austin, Texas, 1868-1907 


\section{TABLE OF CONTENTS VOLUME I}

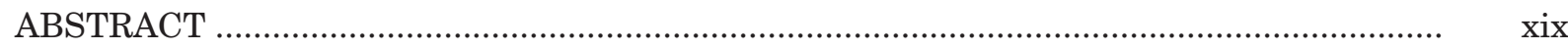

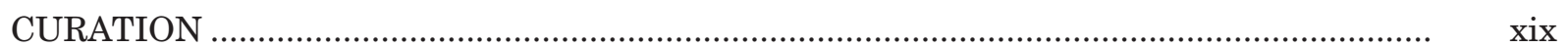

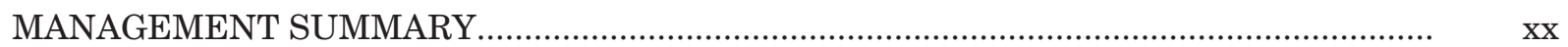

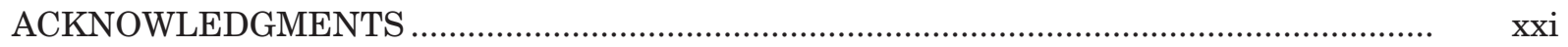

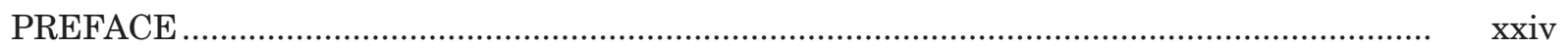

CHAPTER 1: INTRODUCTION TO THE RANSOM AND SARAH WILLIAMS

FARMSTEAD ARCHEOLOGICAL PROJECT …............................................ 1

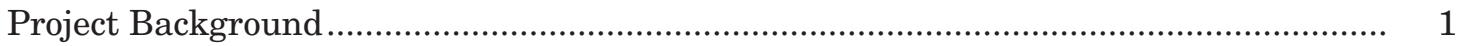

Post-Emancipation Transitions in the African Diaspora ............................................ 4

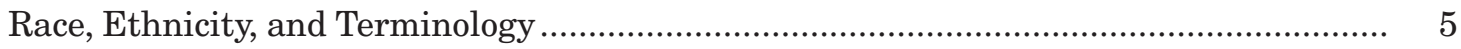

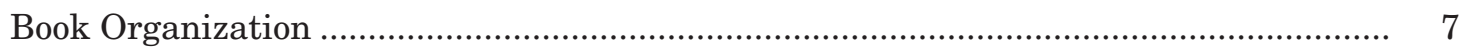

CHAPTER 2: HISTORY OF INVESTIGATIONS AT SITE 41TV1051 _..................................... 9

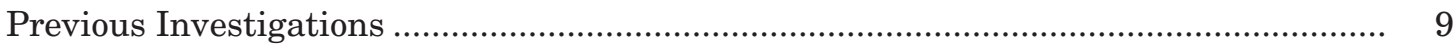

Investigations by Prewitt and Associates, Inc........................................................... 14

Initial Historic Research....................................................................... 14

Historic Context Development ............................................................... 15

Archeological Testing and Data Recovery .................................................... 15

Planning the Williams Farmstead Archeological Project................................ 15

CHAPTER 3: WORK ACCOMPLISHED AND METHODS OF INVESTIGATION.................... 21

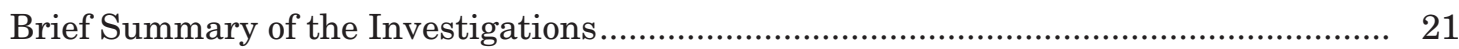

National Register Testing ........................................................................ 21

Data Recovery Investigations..................................................................... 22

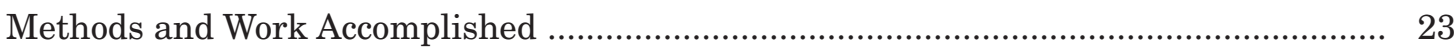

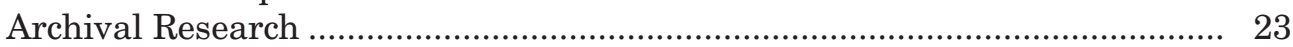

Request for Public Input and MOCHA Involvement .................................... 24

Use of Secondary Sources .......................................................................... 25

Use of Primary Sources.............................................................................. 26

Community Outreach and Oral History Research ......................................... 28

Archeological Landscape Analysis ................................................................ 31

Archeological Excavations .......................................................................... 31

The Artifact Assemblage .............................................................................. 38

Analysis of Material Culture and Features .................................................. 38

Artifact Conservation ............................................................................... 41

CHAPTER 4: ALLEN'S PRAIRIE, MOUNTAIN CITY, AND ANTIOCH COLONY:

AFRICAN AMERICAN PIONEERS IN SLAVERY AND FREEDOM ............... 43

White Settlers of Northern Hays County ......................................................................... 43

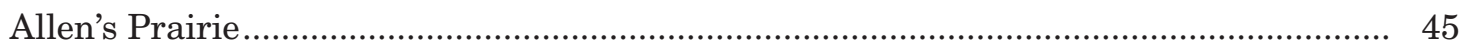




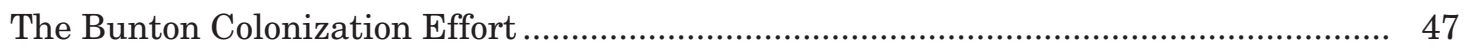

Bastrop Settlement on Cedar Creek ............................................................. 48

Mountain City in Hays County ............................................................................. 49

First Settlers of Mountain City ….................................................................. 49

Mountain City Families ............................................................................. 50

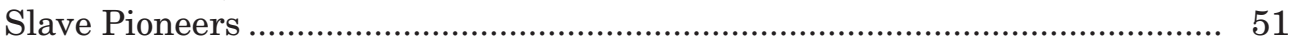

Mountain City on the Eve of the Civil War....................................................... 51

"The Peculiar Institution" in Texas and Hays County ............................................... 53

Slavery in the Bunton Family ...................................................................... 54

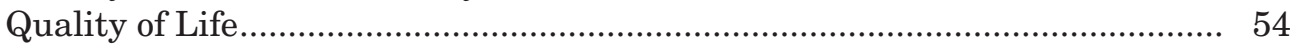

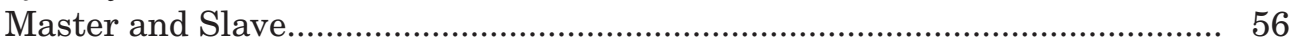

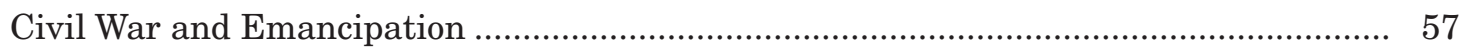

Seeds of Antioch Colony .......................................................................................... 58

The Freedmen's Bureau ................................................................................... 58

The Role of Freedmen Colonies ................................................................ 58

Antioch in the Context of Freedmen Colonies ................................................. 59

Antioch Predates Land Sales..................................................................... 59

How Antioch Colony Came About ............................................................... 60

Land Sales and Other Theories ..................................................................... 64

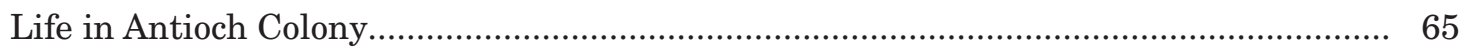

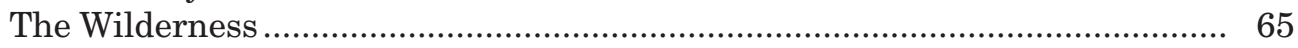

Early Agriculture ..................................................................................... 66

Household Composition and Demographics of the Early Settlement ............. 67

The Community ............................................................................................... 68

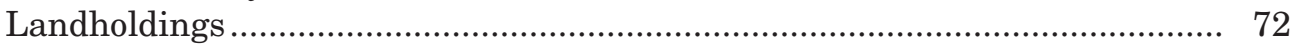

Railroad Bypasses Mountain City and Antioch............................................... 74

The Twentieth Century ................................................................................... 74

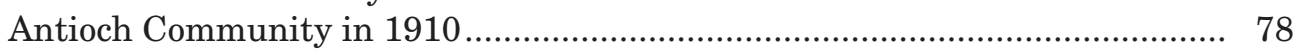

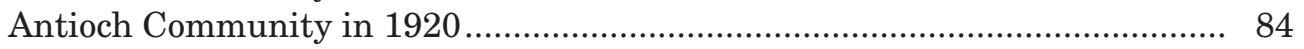

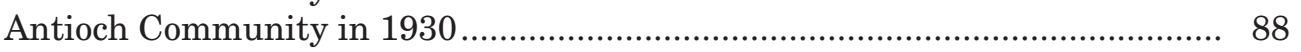

Antioch Colony Today................................................................................. 93

CHAPTER 5: RANSOM AND SARAH WILLIAMS: FREEDMAN FARMERS

IN TRAVIS COUNTY ............................................................................. 95

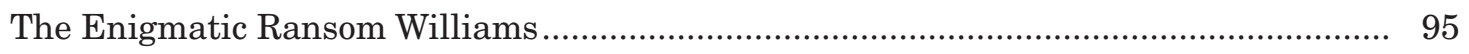

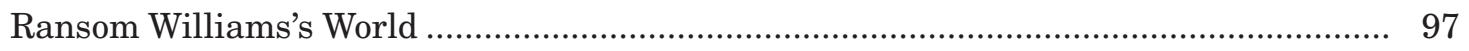

Horseman and Taxpayer in Hays County .................................................... 98

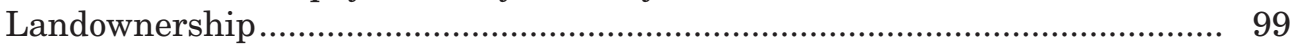

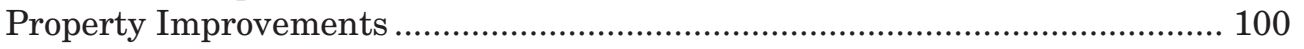

Establishing a Home ....................................................................................... 101

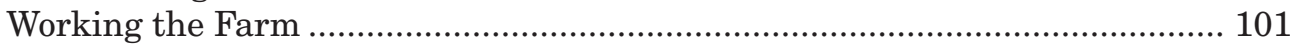

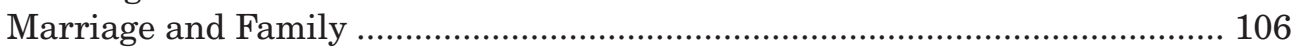

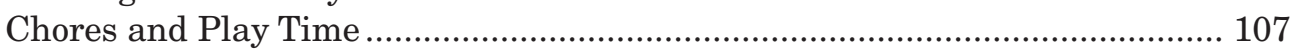

Who Was Sarah Houston? ......................................................................... 113

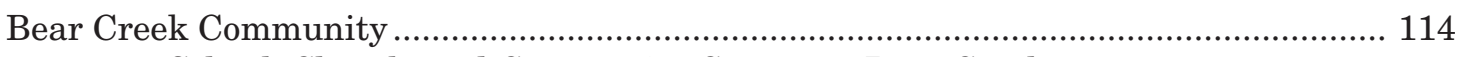

School, Church, and Community Center on Bear Creek.................................. 114

Freedman on Bear Creek................................................................................. 120

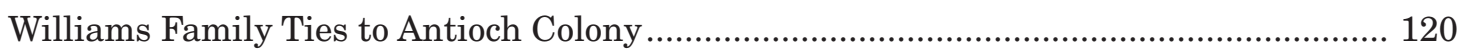

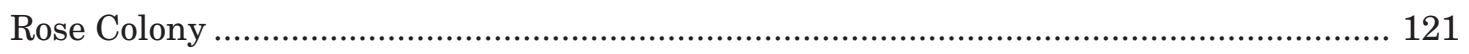

Freedmen Families of Rose Colony …....................................................... 124 
Characteristics of the Bear Creek/Rose Colony Community .......................... 127

Rose Colony School................................................................................... 128

African Methodist Episcopal Church ............................................................ 129

A Case Study: The Dodson Family in Slavery and Freedom ........................... 130

Reflections on Rose Colony ........................................................................... 132

Ransom Williams's Descendants

The End of an Era on Bear Creek ...................................................................... 132

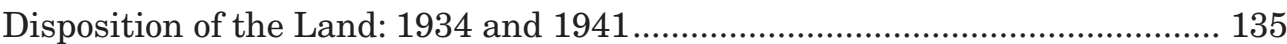

Will and Clara (Franklin) Williams ............................................................... 136

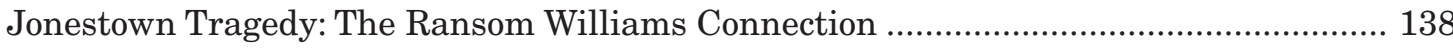

Ransom Williams's Descendants at Jonestown .............................................. 139

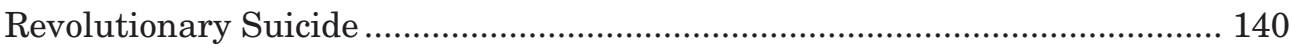

Postscript: Searching for Ransom and Sarah's Graves ................................................... 141

CHAPTER 6: LANDSCAPE ANALYSIS OF THE WILLIAMS FARMSTEAD ............................ 143

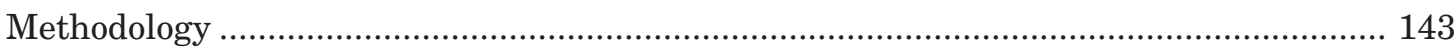

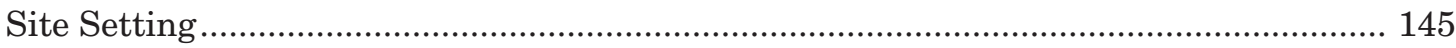

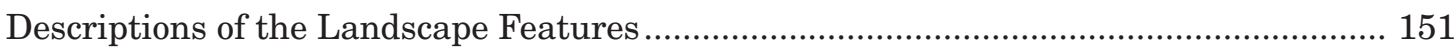

Linear Rock Features .................................................................................... 151

The Livestock Pond and Rock Alignment P ............................................. 175

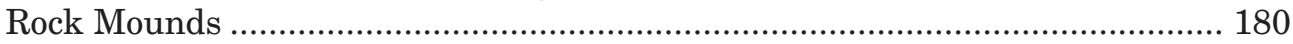

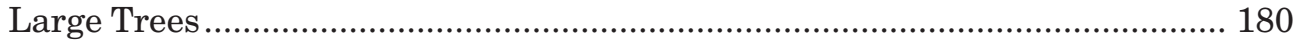

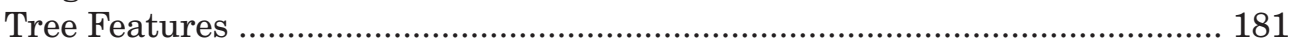

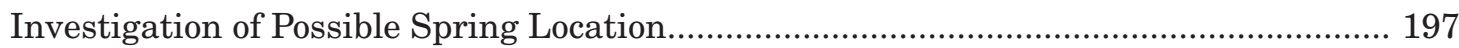

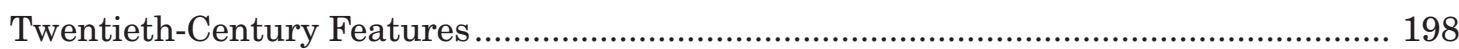

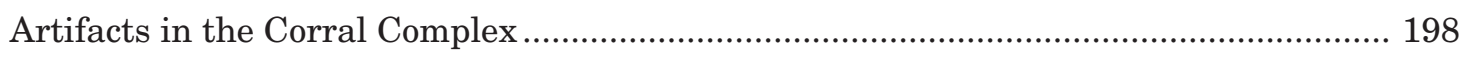

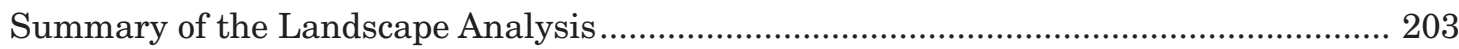

CHAPTER 7: CULTURAL FEATURES ASSOCIATED WITH THE WILLIAMS
FARMHOUSE

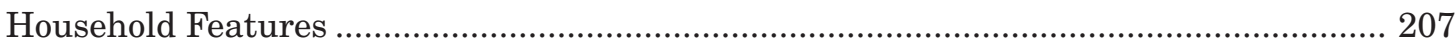

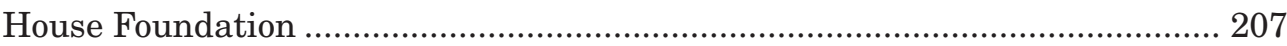

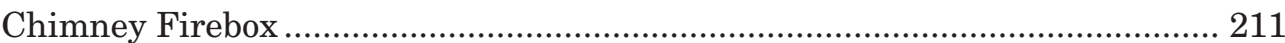

Subfloor Storage Pit (Potato Cellar) ................................................................ 217

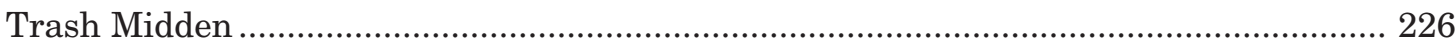

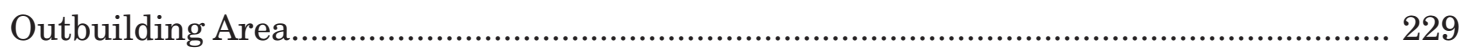

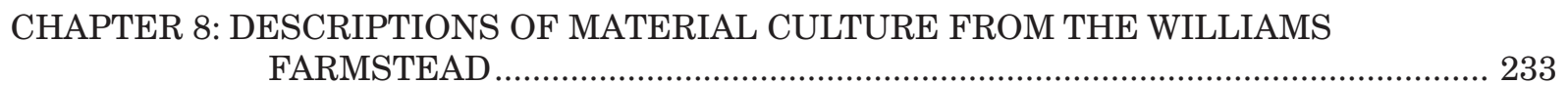

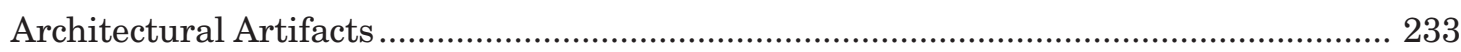

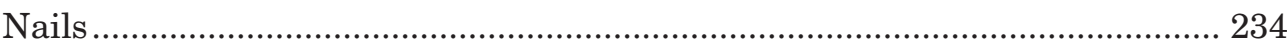

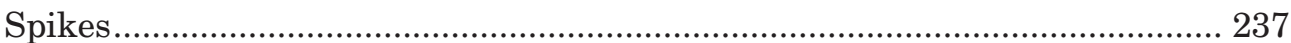

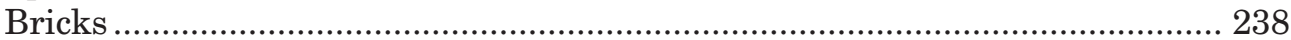

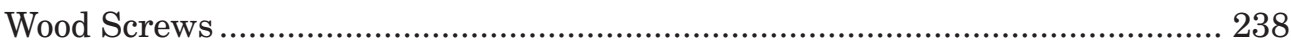

Miscellaneous Architectural Hardware ......................................................... 239

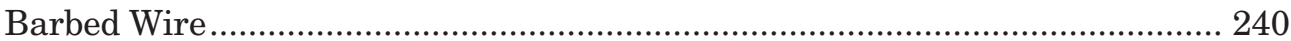

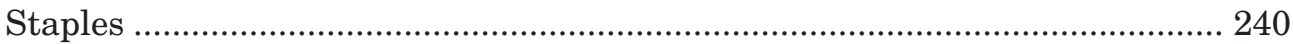

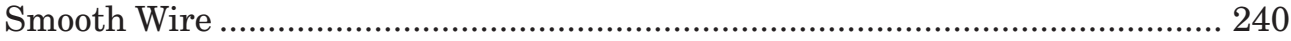

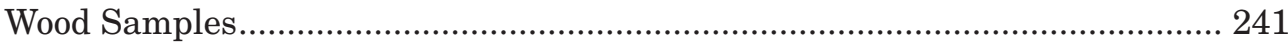


Mortar Samples ...................................................................................... 242

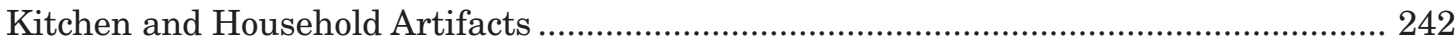

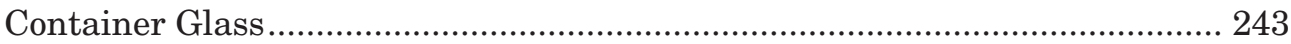

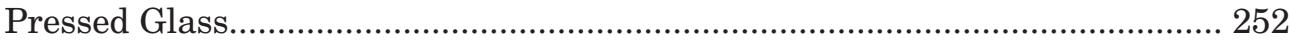

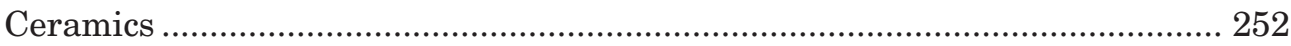

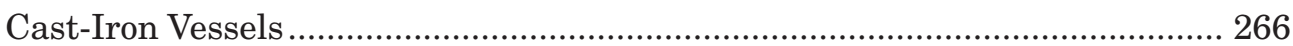

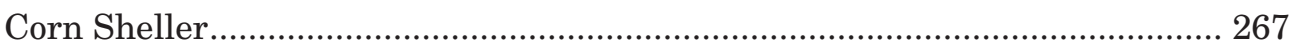

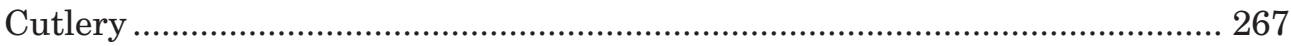

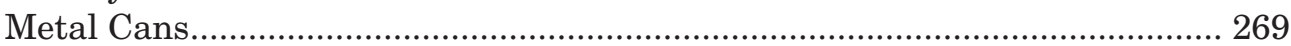

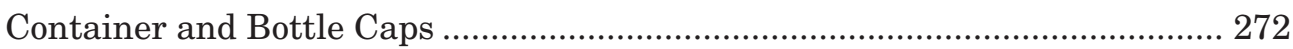

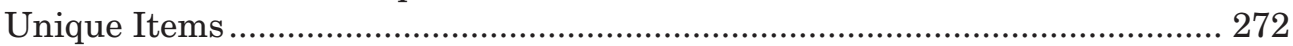

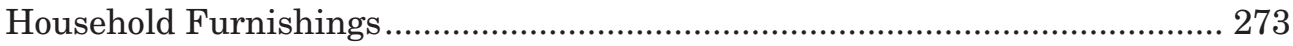

Candle Lantern and Oil Lamps ...................................................................... 278

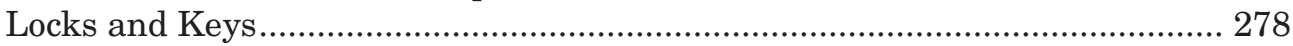

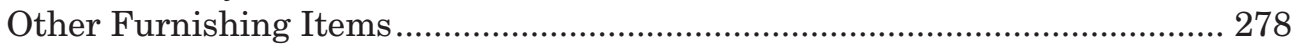

Miscellaneous Household Hardware .............................................................. 278

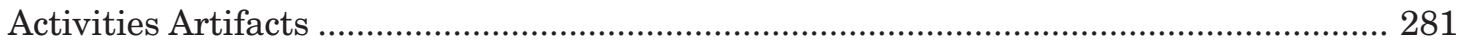

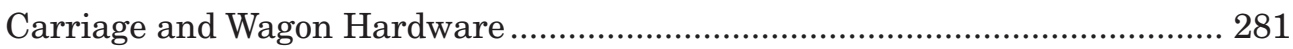

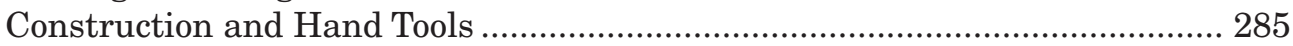

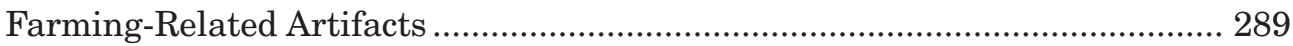

Horse Tack and Harness Equipment ............................................................. 291

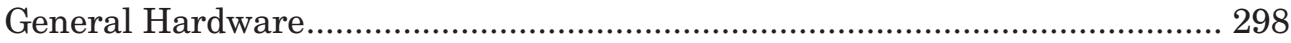

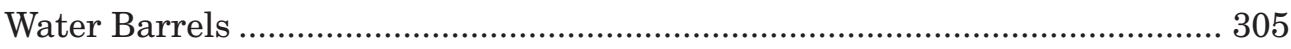

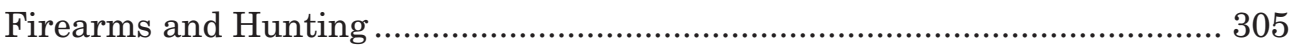

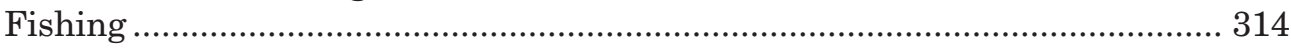

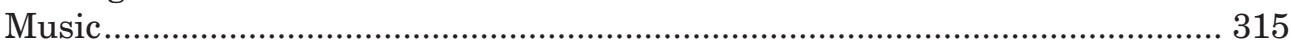

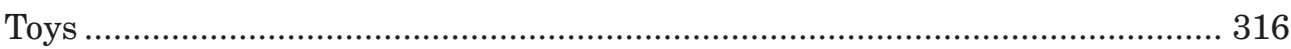

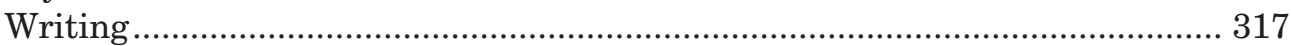

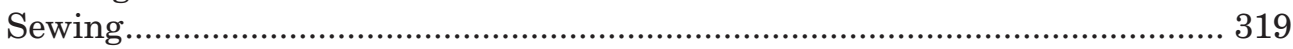

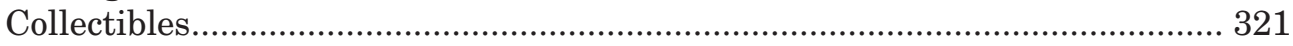

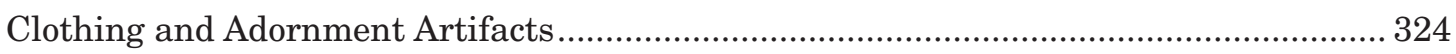

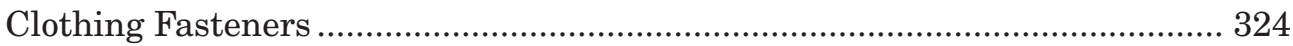

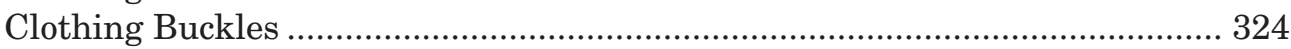

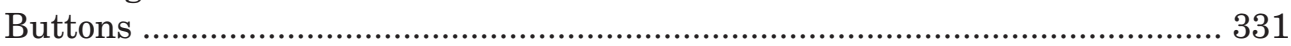

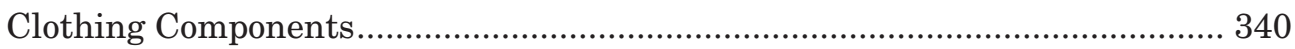

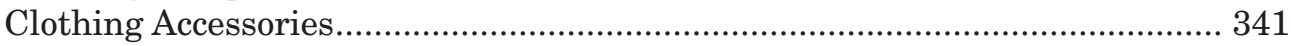

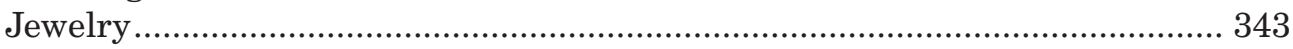

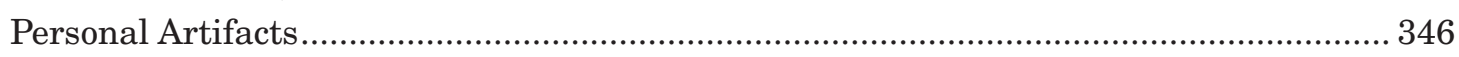

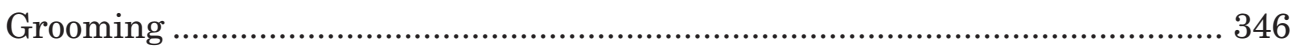

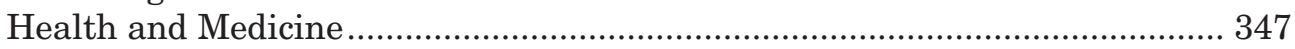

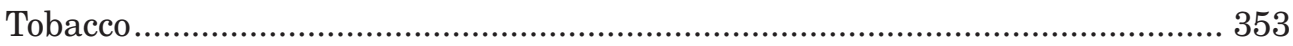

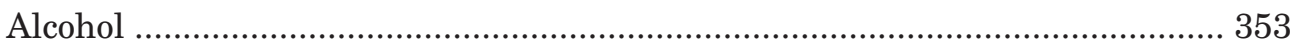

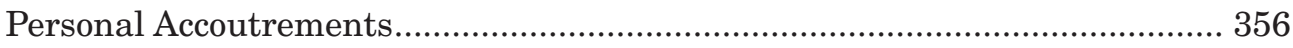

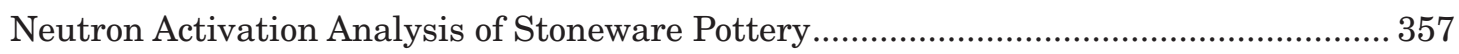

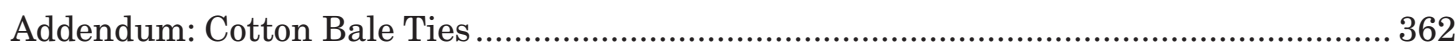

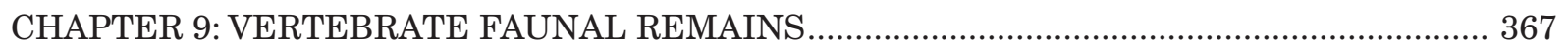

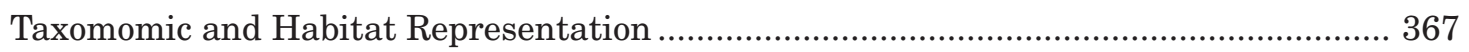

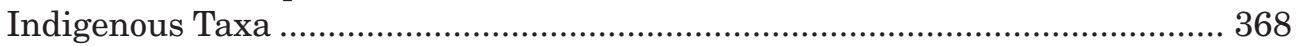

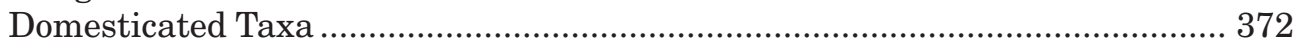

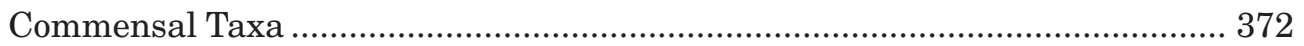




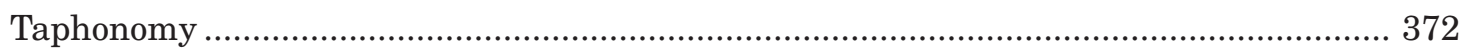

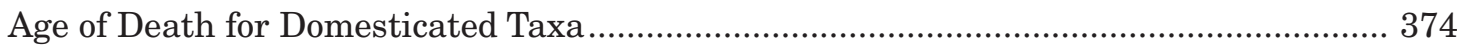

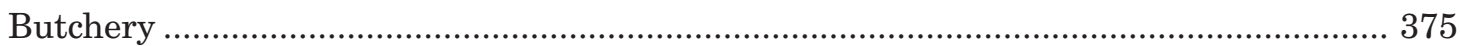

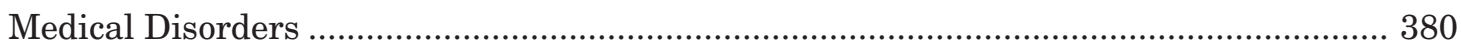

Discussion of the Williams Farmstead Faunal Remains .............................................. 380

Comparison of Faunal Remains from Five African American Sites in Texas ................... 380

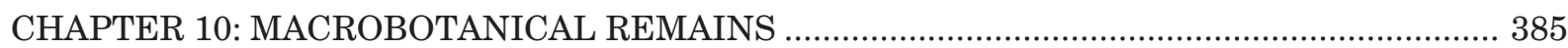

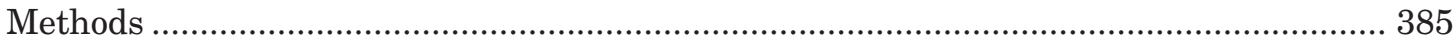

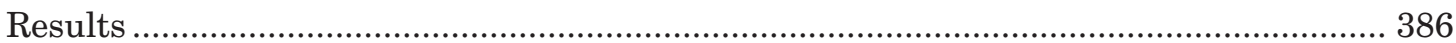

Summary of Architectural Samples ……...................................................... 386

Summary of Botanical Samples .................................................................. 387

Summary of Flotation Sample Recovery....................................................... 388

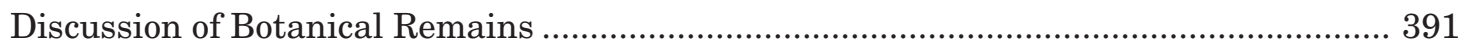

CHAPTER 11: SPATIAL ANALYSIS OF MATERIAL CULTURE AND FEATURES ................. 393

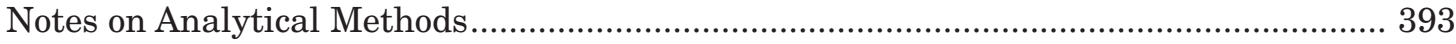

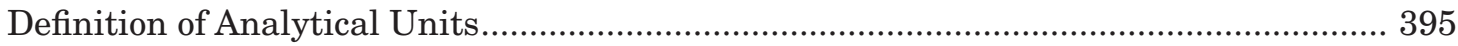

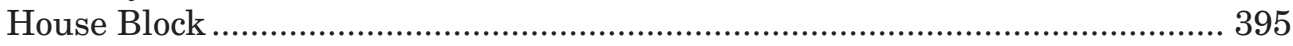

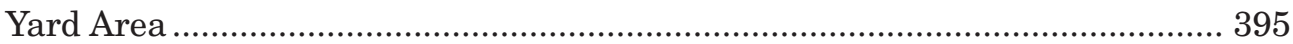

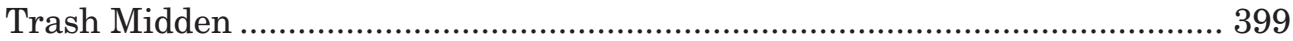

Possible Outbuilding ..................................................................................... 400

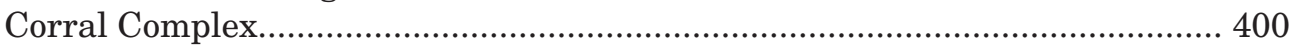

Functional Comparisons of the Analysis Units ............................................................... 400

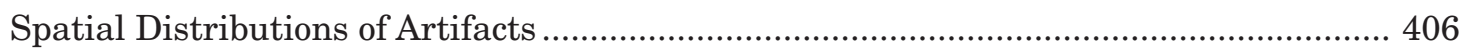

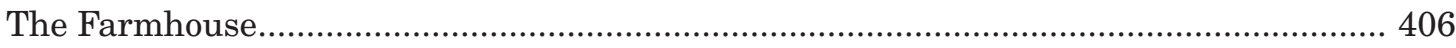

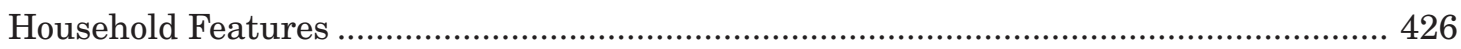

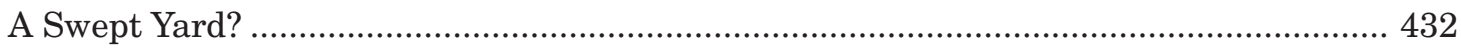

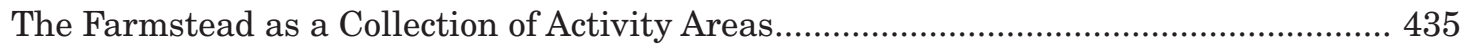

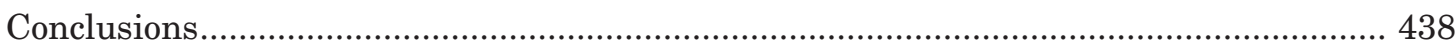




\section{LIST OF FIGURES}

1.1. Location map of the Ransom and Sarah Williams farmstead.

2.1. Map of the farmstead features and areas where buried metal artifacts were identified at 41TV1051 by ACSG in 2003.

2.2. Map of archeological features and excavations in the main portion of 41TV1051

by ACSG in 2003

3.1. Photograph of many of the people who gave oral history interviews for the

Williams Farmstead Archeological Project.

3.2. Overview map of excavations and landscape features inside the State-owned right of way at the Williams farmstead

3.3. Map of the excavations in the main house area.

3.4. Map of excavation unit designations in the main house area, including the house block, the outbuilding block, and the midden block

3.5. Map of the shovel test designation within the 20x24-m shovel testing grid around the house excavation block.

3.6. Overview map of the excavations and cultural features in the northern portion of the farmstead.

4.1. Map of the Mountain City area in northern Hays County in relation to Austin and surrounding communities

4.2. Section of an 1880 General Land Office map showing the 1835 leagues in the Mountain City area of northeastern Hays County.

4.3. Sketch of the remains of the Victor Labenski log cabin by Bill Green .............................. 47

4.4. Livestock brands registered to Bunton freedmen in Hays County .................................... 60

4.5. Map of initial landowners in the core area of Antioch Colony, 1870-1871 ....................... 61

4.6. Map of Antioch Colony landowners, ca. 1925 …............................................................. 88

4.7. LeeDell Bunton, a descendant of the original Antioch Colony settlers who grew up in the freedmen community, unveils a Texas Historical Marker....

5.1. Map of the Ransom Williams farmstead in relation to Bear Creek, Onion Creek, and surrounding communities in northern Hays and southern Travis Counties......

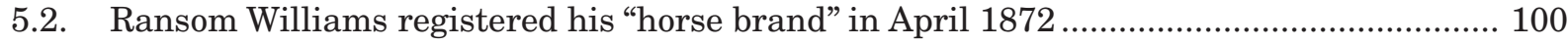

5.3. Map of lots and landowners along Bear Creek, ca. 1873 ................................................. 114

5.4. A 1914 school district map showing the relative approximate locations of the Bear Creek community, Rose Colony, and Manchaca Springs

5.5. A 1914 school district map showing the approximate location of the Townsley Store about 2 miles east of the Williams farmstead....

5.6. Travis County road map, 1932, showing locations of three schools at Manchaca............... 122

5.7. Land map of Hays County, 1880, showing relative locations of the Williams farmstead, Antioch Colony, and the Rose Colony School....

5.8. Travis County survey map of Bear Creek Road, ca. 1898-1902, showing the "Estate of John Hughs" along the Travis-Hays county line. 
5.9. A section of a ca. 1925 map showing the subdivision of the John McGehee,

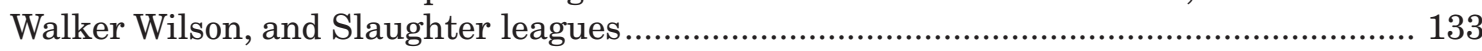

5.10. Photographs of Will and Clara (Franklin) Williams ....................................................... 135

5.11. Arnold and Novella (Harris) Williams, ca. 1977 ................................................................ 136

5.12. Three great-granddaughters of Ransom and Sarah Williams ......................................... 137

5.13. Family tree of the three great-granddaughters of Ransom and Sarah Williams. .............. 138

5.14. Photographs of Sarah Williams's grave and headstone at the San Marcos-Blanco Cemetery in Hays County, Texas.... 142

6.1. Map showing the relationship of the 45 -acre Williams farmstead property

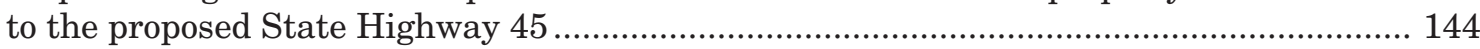

6.2. Maps showing the location of the Williams farmstead .................................................. 147

6.3. Map showing the 45-acre Williams farmstead and farmhouse location in relation to Bear Creek and the area topography ........................................................... 148

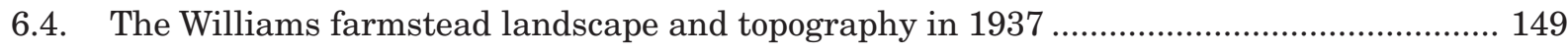

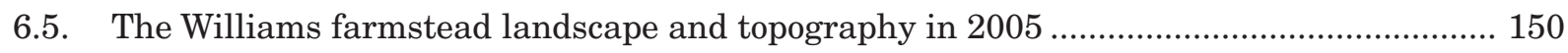

6.6. Map of the linear rock features at the Williams farmstead ............................................... 153

6.7. Photographs of relatively intact sections of Rock Wall A ................................................. 155

6.8. Profile of Rock Wall A2 near its east end......................................................................... 156

6.9. Photographs of Rock Alignment B2 ......................................................................... 157

6.10. Schematic profile of Rock Alignments B1 and B2 showing the swale between them......... 158

6.11. Photograph and profile of Rock Wall C1, looking south.................................................. 159

6.12. Photographs of Rock Wall C3 in the LCRA easement .................................................... 161

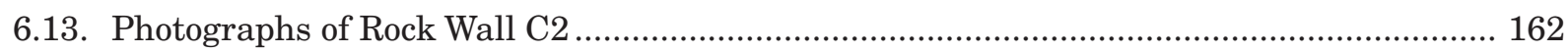

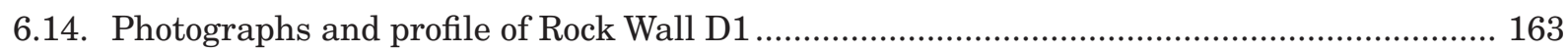

6.15. Overview photographs of Rock Wall E1 .......................................................................... 164

6.16. Photographs and profile of intact sections of Rock Wall E1 ............................................. 165

6.17. View of the north end of Rock Wall E2 in the LCRA easement, looking southeast ............ 167

6.18. Overview photograph of Rock Wall F1, looking west from the location of Tree 38 ............ 168

6.19. Overview photograph of the northwestern end of Rock Wall F2, looking northwest.......... 169

6.20. Photograph and profile of Rock Wall F1 at the center of the wall ..................................... 170

6.21. Photograph and profile of Rock Wall F1 at the west end of the wall ................................ 171

6.22. Photograph of the best-preserved section of Rock Wall F2 ............................................. 172

6.23. Photographs showing the relationship between Rock Wall F and Rock Alignment G........ 173

6.24. Photographs of limestone rocks in Rock Alignment G2 ................................................. 174

6.25. Complete iron barrel hoops found just north of Rock Wall F1 in the vicinity

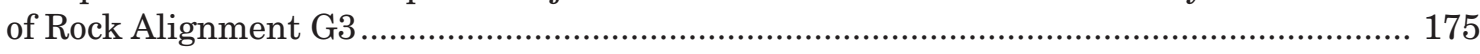

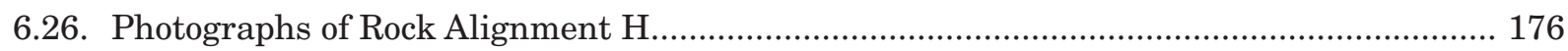

6.27. Plan and profile of the livestock pond and Backhoe Trench 1.......................................... 177 
6.28. Photograph of Rock Wall E1 showing the pond location to the left of the rock wall.......... 178

6.29. Photographs of the livestock pond area and Rock Alignment $\mathrm{P}$....................................... 179

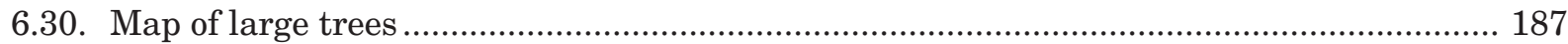

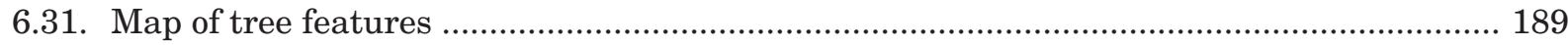

6.32. Photographs of Tree 1 near the Williams house ............................................................. 190

6.33. Photographs of embedded barbed wire in Tree 38 at Rock Wall F1 ................................. 192

6.34. Photographs of embedded barbed wire in Tree 50 ............................................................ 193

6.35. Photograph of barbed wire embedded in Tree 51 ......................................................... 194

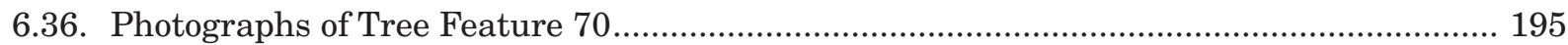

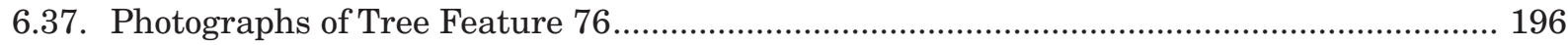

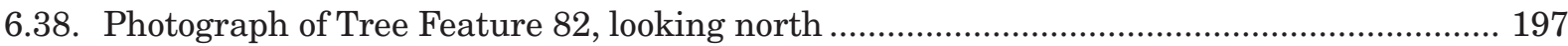

6.39. Map of twentieth-century features ................................................................................ 199

6.40. Map of surface-collected and metal-detected artifacts found in the corral complex........... 202

7.1. Map of cultural features associated with the Williams farmhouse .................................. 208

7.2. Overview of the house excavation block with the intact chimney base and

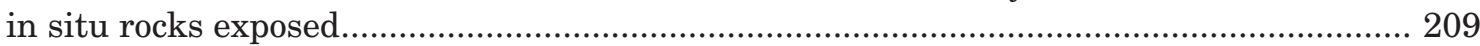

7.3. Plan map of house excavation block showing the intact chimney base and

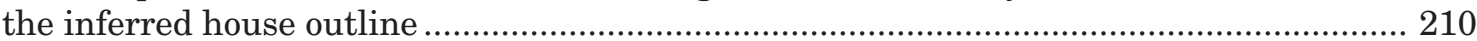

7.4. Photographs of the rock pile and chimney base at the Williams house, looking east......... 212

7.5. Views of the chimney base and firebox at different stages of excavation, looking east...... 213

7.6. Views of the fully exposed chimney base and firebox ...................................................... 214

7.7. Profile views of fill in the subfloor storage pit (Feature 1) .............................................. 218

7.8. View east of the subfloor pit in relation to chimney firebox............................................ 222

7.9. Plan map showing the spatial relationship between the chimney firebox and

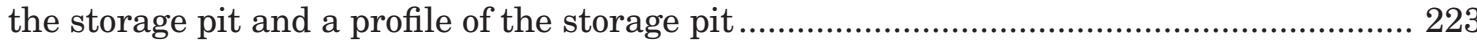

7.10. The globe and banner maker's mark used by the Alfred Meakin company between 1891 and 1897

7.11. Schies glass jar lids from excavations and selected patent drawing for the Schies "JAR CLOSURE." 225

7.12. Views of the east midden located on the west side of Rock Wall C2 227

7.13. View of the east slope midden excavations, looking east and downslope from Rock Wall C2 . 228

7.14. Photographs of the outbuilding area northwest of the house ......................................... 230

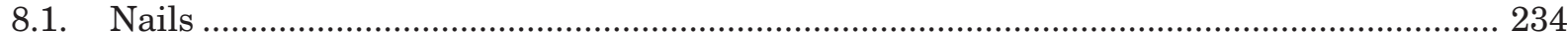

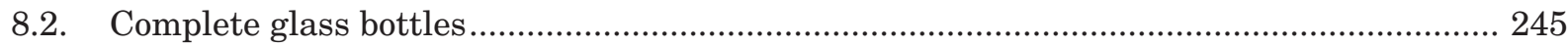

8.3. Glass bottle necks showing a variety of neck and mouth finishes .................................... 246

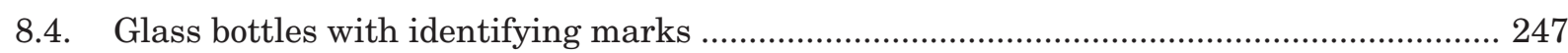

8.5. Glass bottle closures identified as the Schies jar closures ............................................... 248 


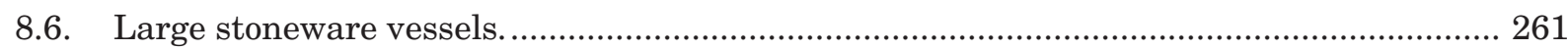

8.7. Stoneware and yellowware vessels and maker's marks .................................................. 262

8.8. Various whiteware vessels, including annular ware, undecorated whiteware, Victorian majolica, and embossed whiteware .................................................................. 263

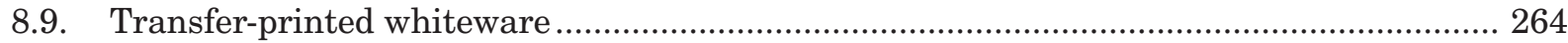

8.10. Base and body fragment of a large cast-iron dutch oven.................................................. 268

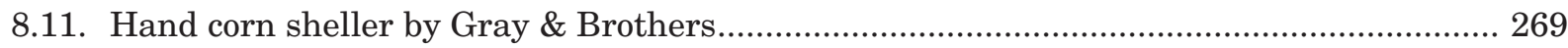

8.12. Patent drawings for the "Corn Husker" patented on December 27, 1870,

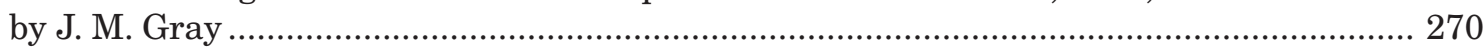

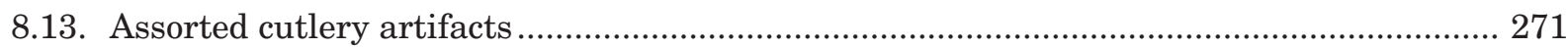

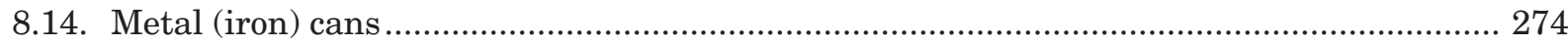

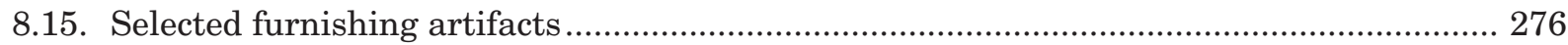

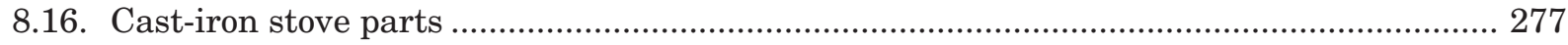

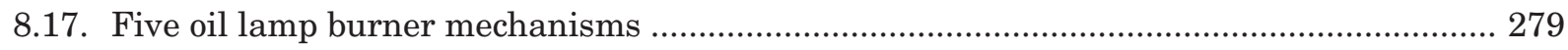

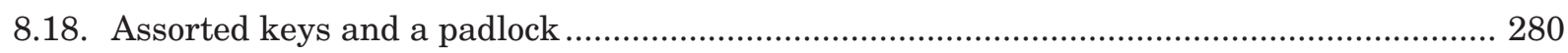

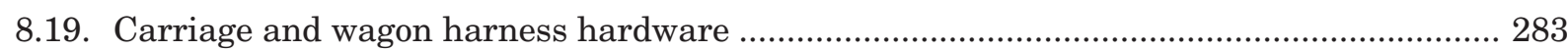

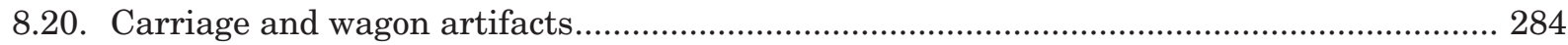

8.21. Brake ratchet and 1872 patent drawing for an "Improvement in

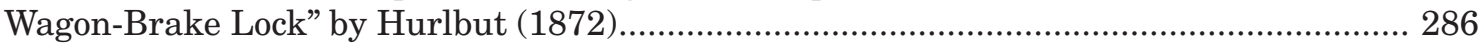

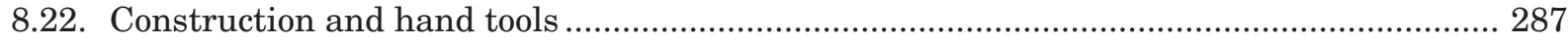

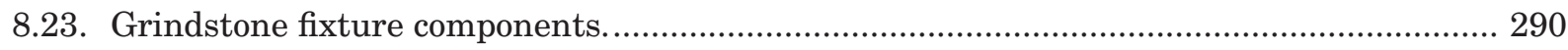

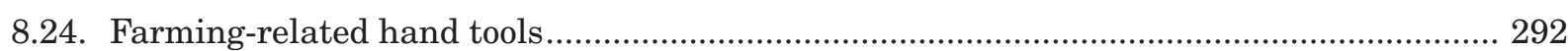

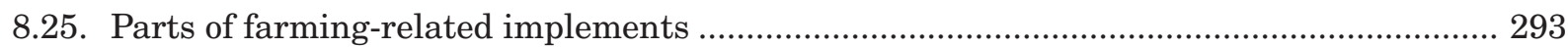

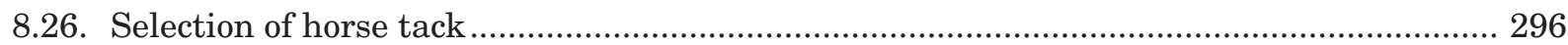

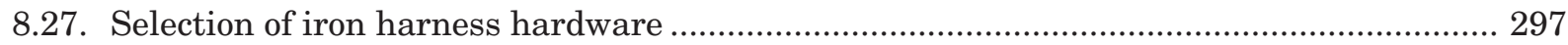

8.28. Horsehoes, muleshoes, and horseshoe nails ..................................................................... 299

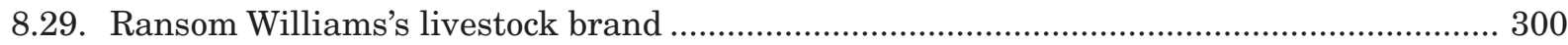

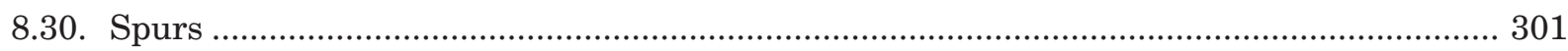

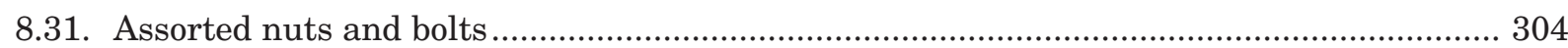

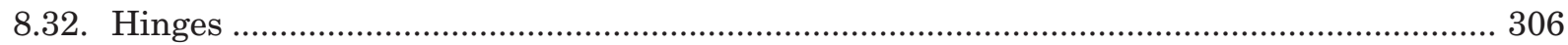

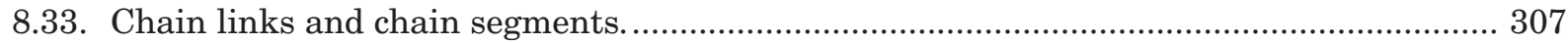

8.34. Barrel band sections showing the overlapping ends and connecting rivets ....................... 308

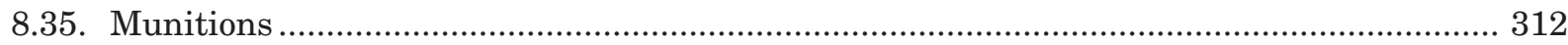

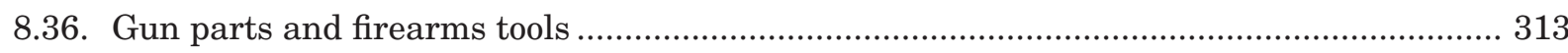

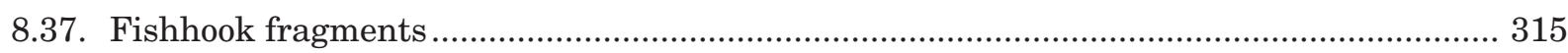

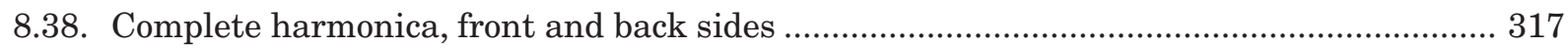

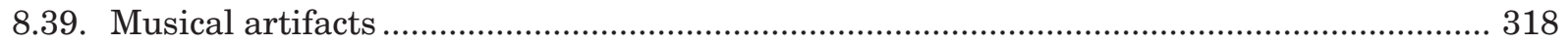




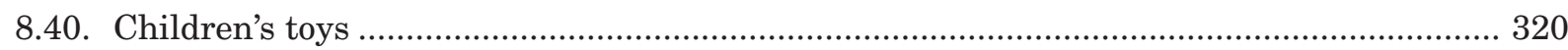

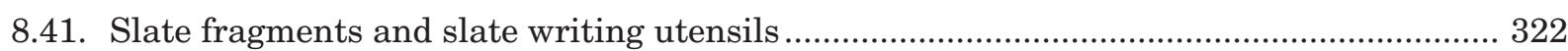

8.42. Graphite pencil leads and pencil fragments with metal ferrules and erasers ................... 323

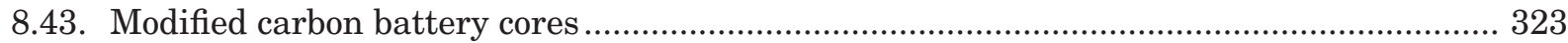

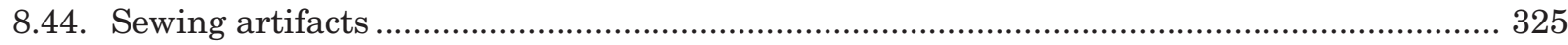

8.45. Modified hematite nodules and quartz geofact …............................................................ 326

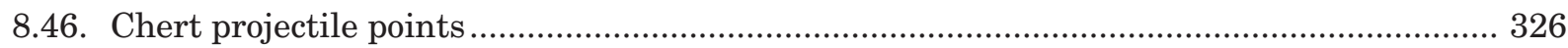

8.47. Spoon commemorating the sinking of the USS Maine in 1898 _....................................... 327

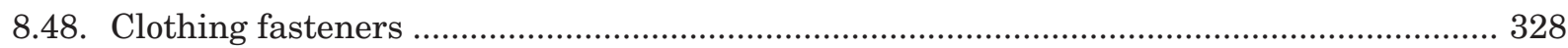

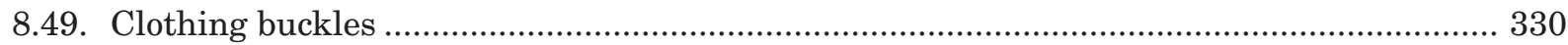

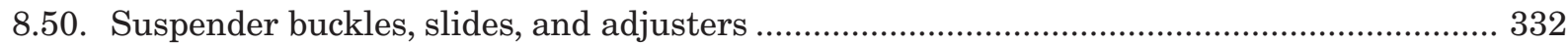

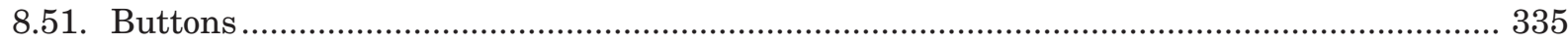

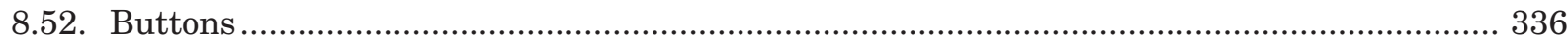

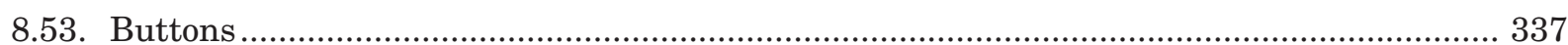

8.54. Button line size chart from the 1895 Montgomery Ward catalog .................................... 337

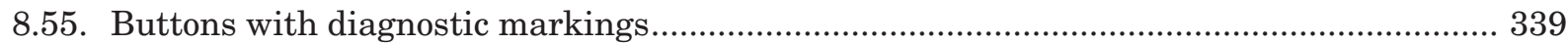

8.56. Graph of buttons by material and size group .................................................................. 342

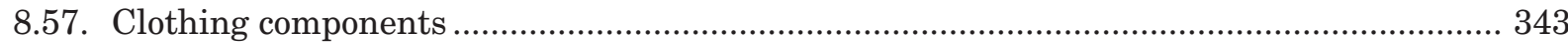

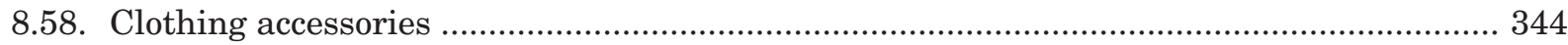

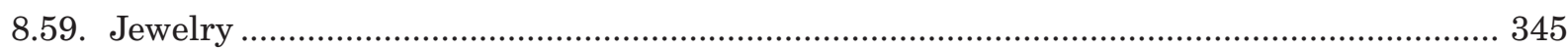

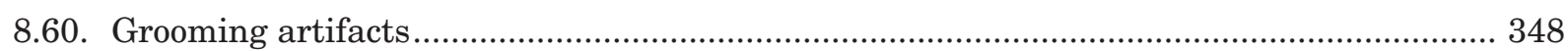

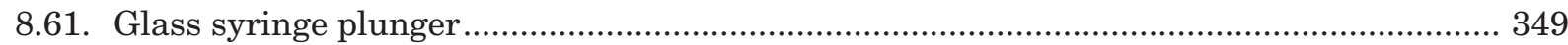

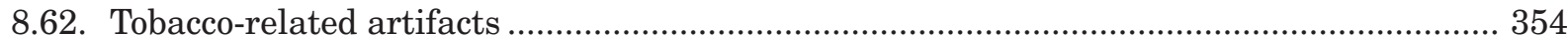

8.63. Amber glass bottle body fragment with raised circle and embossed label:

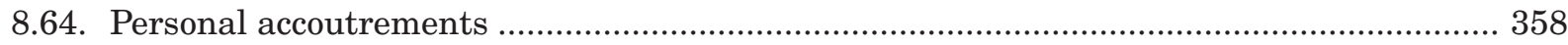

8.65. Bivariate plot of chromium and cesium showing the 50 samples in the stoneware analysis and geochemical groups defined by MURR ....................................... 361

8.66. Cotton bale tie found in the Williams farmhouse and patent drawings............................ 364

9.1. Dynamic loading impact point on medium to large mammal long bone fragment............. 374

9.2. Cut and chopped rabbit bone recovered from the house block ......................................... 379

9.3. Chicken coracoid with three cuts at articulation of pectoral girdle

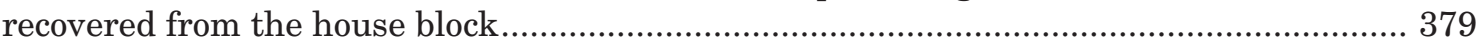

10.1. Graph of plant taxon representing wood fuel recovered as hand-collected samples .......... 389

10.2. Graph of plant taxon representing wood fuel recovered from flotation samples ................ 390

11.1. Map of the Williams farmstead analysis units for the spatial analysis of material culture. 
11.2. Views of the house area before and during the data recovery excavations 397

11.3. Map of the shovel tests and $1 \times 1-m$ excavation units in the yard area..... 398

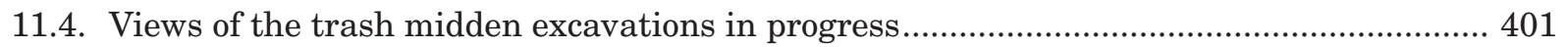

11.5. Views of the possible outbuilding excavations, looking north ........................................... 402

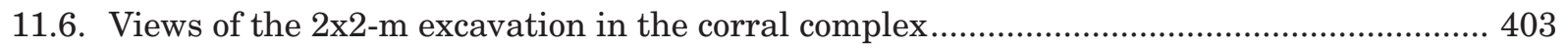

11.7. Graph of excavated artifacts showing quantity by functional group and analysis unit 405

11.8. Graph of excavated artifacts showing the percentage by functional group and analysis unit.... 405

11.9. Graph of all excavated artifacts showing artifact density numbers by functional groups and analysis units .... 408

11.10. Graph of the all excavated artifacts showing the artifact density cumulative percentage by functional groups and analysis units.... 408

11.11. Map of raw artifact counts for all excavated artifacts in the house block, yard area, trash midden, and possible outbuilding analysis units 409

11.12. Artifact density map showing all excavated artifacts in the house block, yard area, trash midden, and possible outbuildings.... 410

11.13. Artifact density map for the activities functional group in the house block, yard area, trash midden, and possible outbuilding analysis units

11.14. Artifact density map for the architectural functional group in the house block, yard area, trash midden, and possible outbuilding analysis units. 412

11.15. Artifact density map for the clothing/adornment functional group in the house block, yard area, trash midden, and possible outbuilding analysis units 413

11.16. Artifact density map for the kitchen/household functional group in the house block, yard area, trash midden, and possible outbuilding analysis units .

11.17. Artifact density map for the personal functional group in the house block, yard area, trash midden, and possible outbuilding analysis units

11.18. Map of the house block showing the hypothesized structure footprint including the locations of the house walls, a porch, and a doorway.... 416

11.19. Drawing of a single-pen log cabin that approximates what the Williams house may have looked like. 417

11.20. Photograph of preserved wooden logs running east to west at the northwest corner of the chimney base. 418

11.21. Photographs of selected architectural and household items from the house block 419

11.22. Maps showing distributions of cut nails and wire nails in the house block, yard area, midden, and outbuilding....

11.23. Distribution map of buttons in the house block, yard area, outbuilding, and midden

11.24. Schematic profile showing the relationship of the fireplace, the reconstructed wooden floor, and the reconstructed subfloor storage pit ....

11.25. Prehistoric dart point found in the bottom of the chimney firebox...... 431

11.26. Map of shovel test recovery in the yard area around the Williams house. 434 


\section{LIST OF TABLES}

2.1. Historical and archeological investigations of the Ransom and Sarah Williams farmstead (41TV1051)

3.1. Backhoe trenches excavated during the 2007-2008 testing phase at the Williams farmstead

3.2. Test units excavated at the Williams farmstead.

3.3. Excavations at the Williams farmstead by area and type............................................. 37

4.1. The Bunton brothers' slaves who later founded Antioch Colony, 1860 ............................ 55

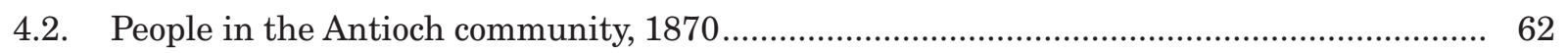

4.3. Agricultural statistics for seven freedmen in Antioch community, 1870 ........................ 67

4.4. The Antioch Colony in the 1875 tax records .................................................................... 68

4.5. People in the Antioch community, 1880 ....................................................................... 70

4.6. The Antioch Colony landholdings in the 1880 tax records ................................................. 73

4.7. People in the Antioch community, 1900 ..................................................................... 75

4.8. People in the Antioch community, 1910 .................................................................... 79

4.9. People in the Antioch community, 1920 ..................................................................... 85

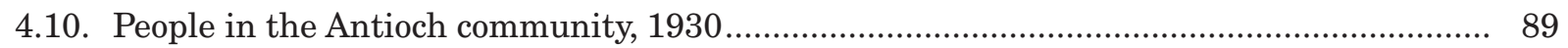

5.1. Analysis of agricultural statistics for seven freedmen in Antioch Colony, 1870 ............... 103

5.2. Hays and Travis County ad valorem tax data for Ransom Williams from

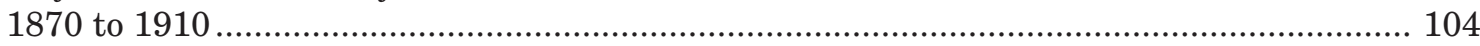

5.3. Travis County ad valorem tax data for Will and Charley Williams from

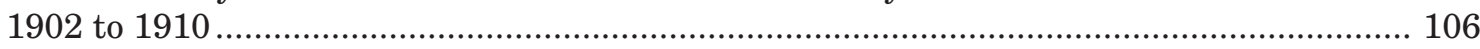

5.4. Landmark events for the Ransom Williams family .......................................................... 108

5.5. Timeline of the Williams family in the McGehee League, southern Travis County ........... 111

5.6. Known services in communities of Hays and southern Travis Counties,

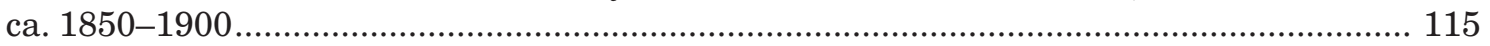

5.7. Ethnicity of the Ransom Williams family according to official records ........................... 120

6.1. Natural and manmade features and archaeological excavations documented

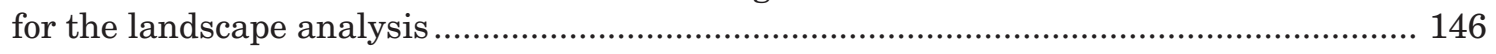

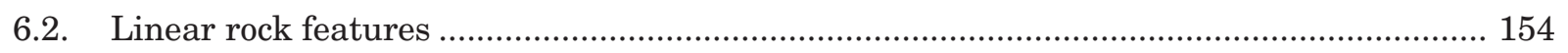

6.3. Estimated age of white oak trees by trunk diameter .................................................... 181

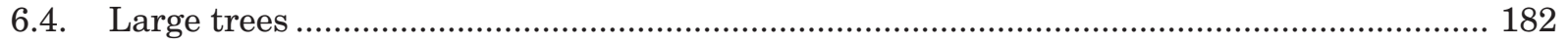

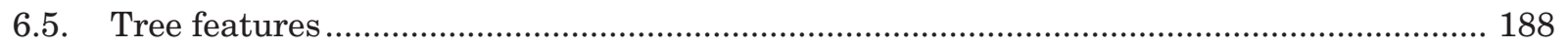

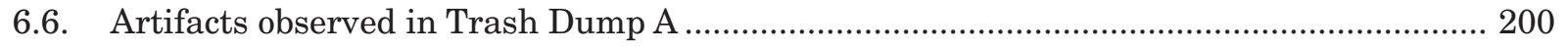

6.7. Surface-collected and metal-detected artifacts recovered from the

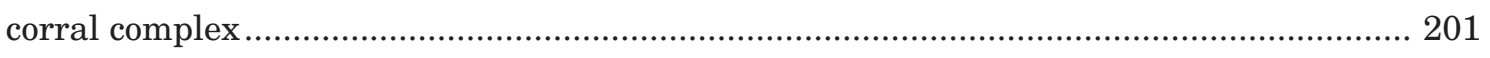

6.8. Artifacts recovered from Excavation Unit Z in the corral complex ................................ 202 
6.9. Components commonly associated with late-nineteenth-century farmsteads in central Texas 205

7.1. Artifacts from the chimney firebox excavation ............................................................... 216

7.2. Artifacts recovered from the subfloor storage pit ........................................................... 219

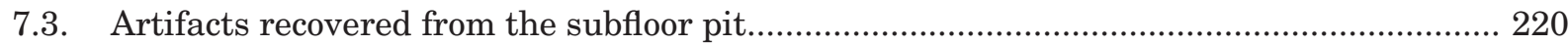

7.4. Activities artifacts recovered from the subfloor storage pit ............................................ 221

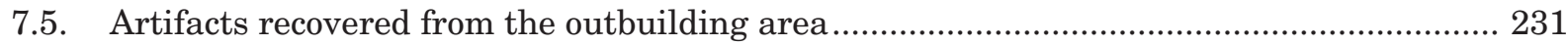

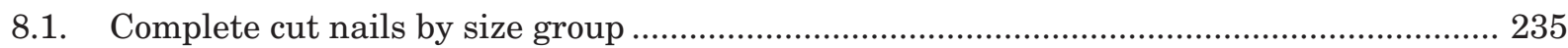

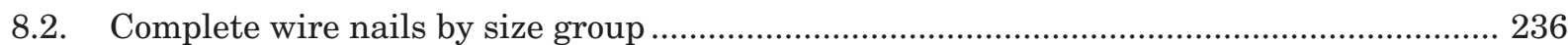

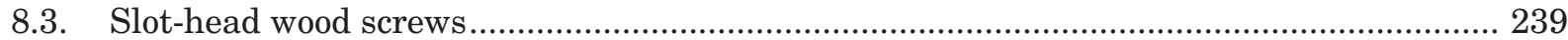

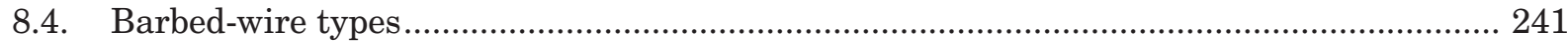

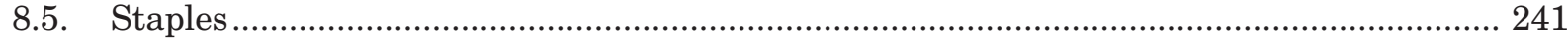

8.6. Glass containers by bottle manufacture type, inferred contents, and

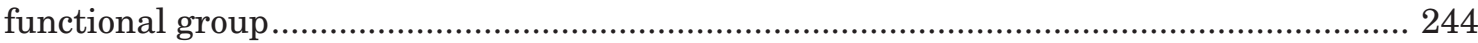

8.7. Glass bottles and closures with diagnostic markings.................................................. 249

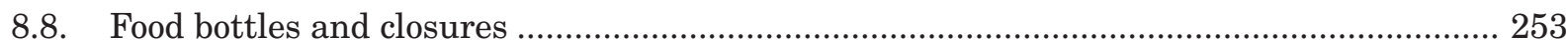

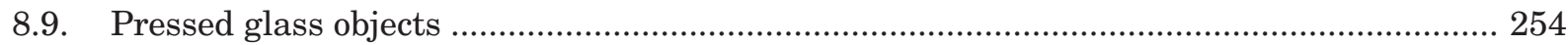

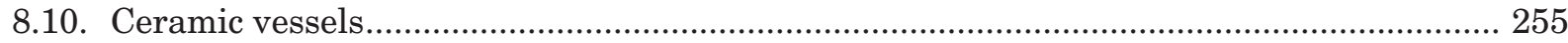

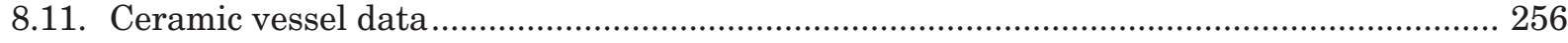

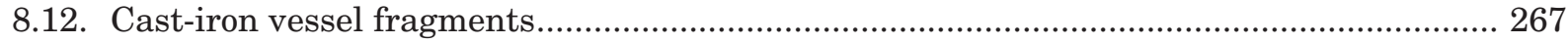

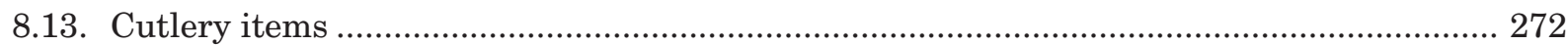

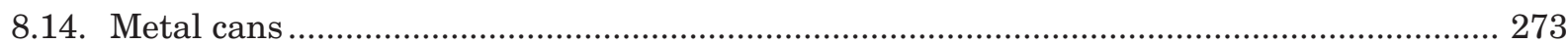

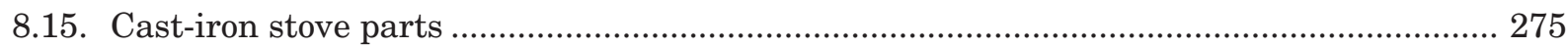

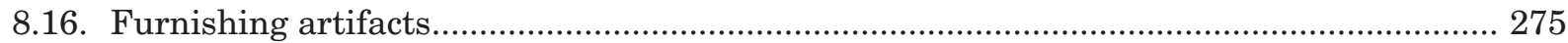

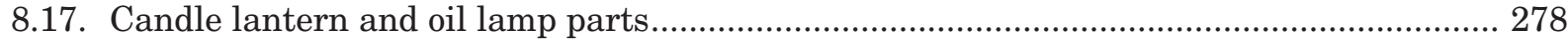

8.18. Miscellaneous household hardware ................................................................................... 281

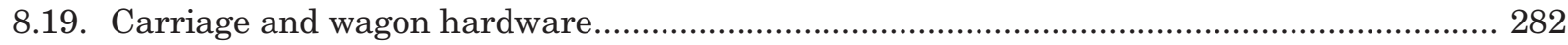

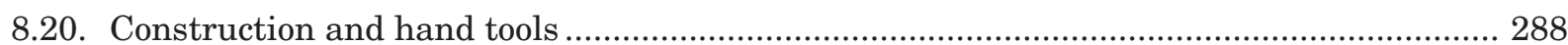

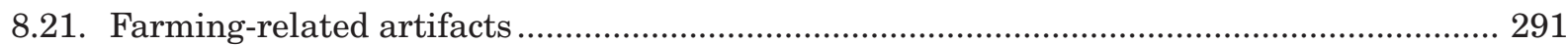

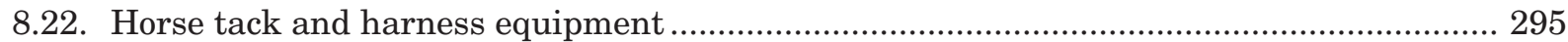

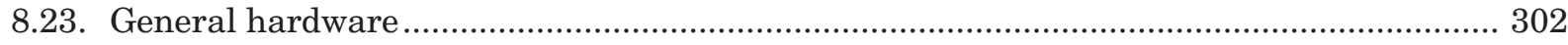

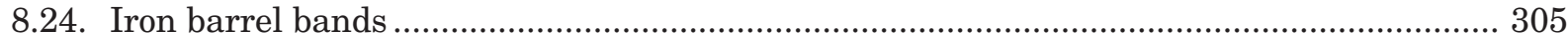

8.25. Minimum number of barrel bands and band sizes .......................................................... 309

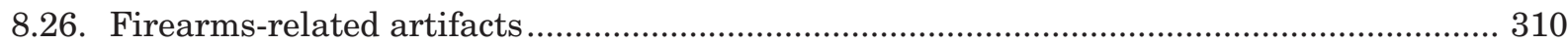

8.27. Cartridge headstamp marks and munitions makers...................................................... 311

8.28. Minimum number of guns represented in the assemblage ............................................. 315

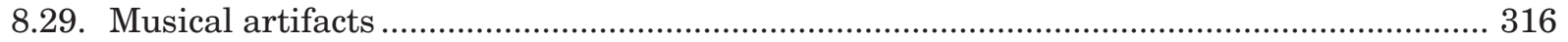




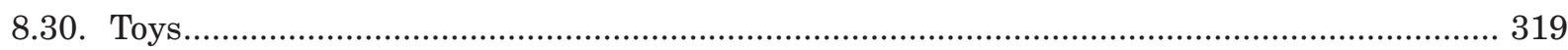

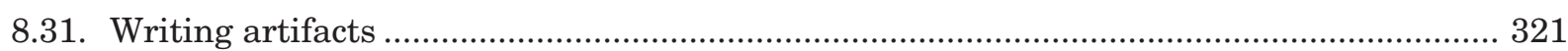

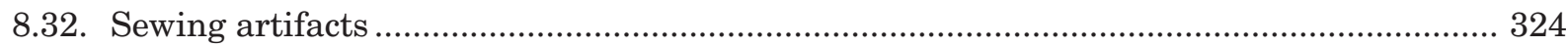

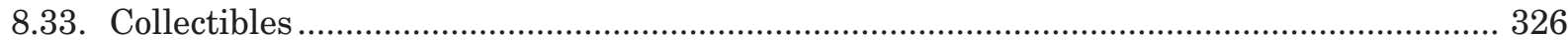

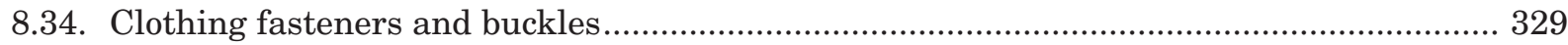

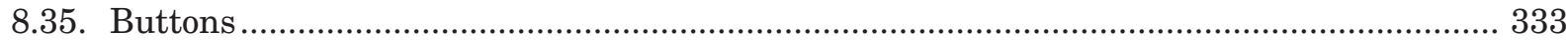

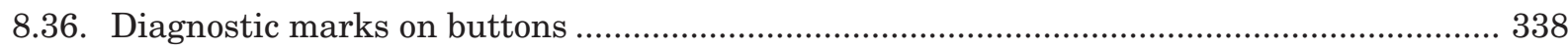

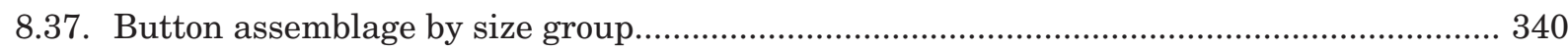

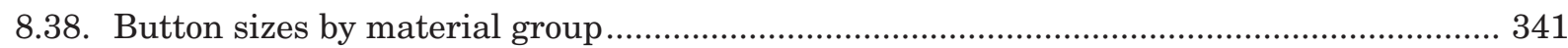

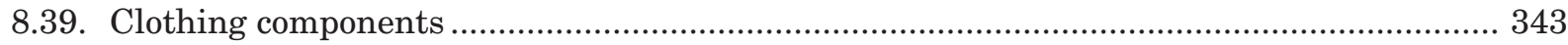

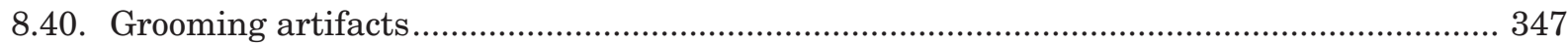

8.41. Medicine and probable medicine bottles ....................................................................... 350

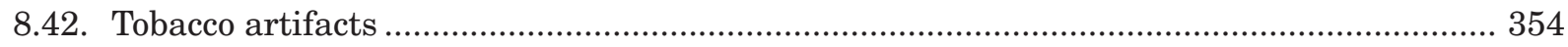

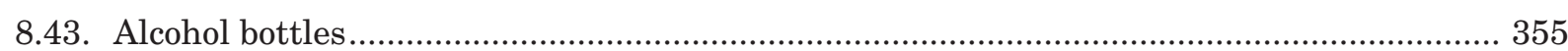

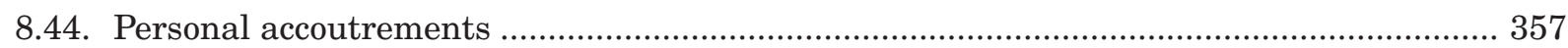

8.45. Neutron activation analysis results for the Williams farmstead study sample................. 360

9.1. Bones by analysis unit and recovery method................................................................... 368

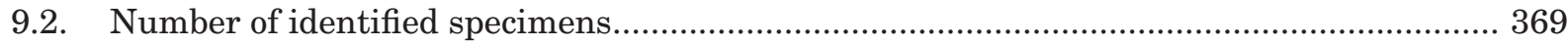

9.3. Minimum number of individuals for identified taxa ........................................................ 371

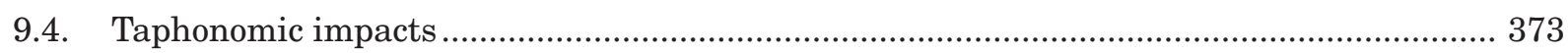

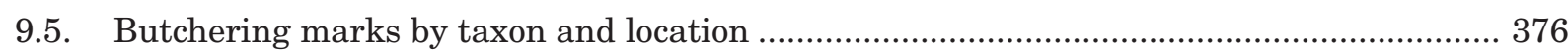

9.6. Comparison of vertebrate taxa recovered from five African American

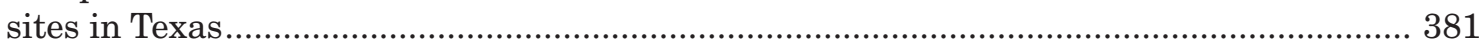

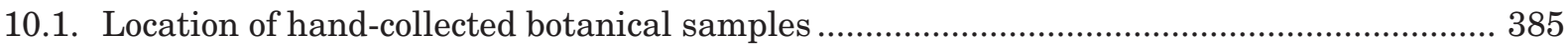

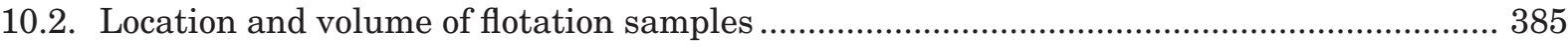

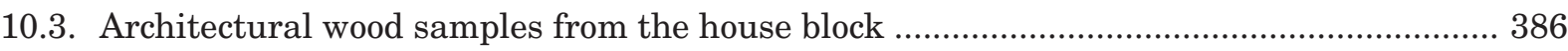

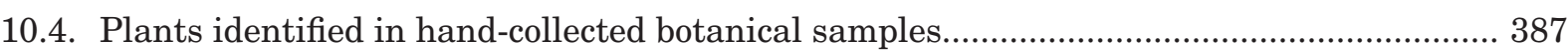

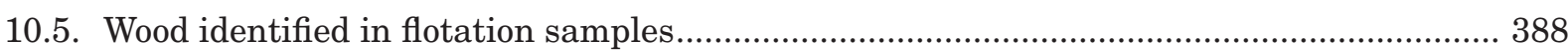

10.6. Carbonized nonwood plants identified in flotation samples............................................. 389

10.7. Uncarbonized seeds recovered from flotation samples .................................................... 390

10.8. Summary of all nonwood plants recovered from the Williams farmstead........................... 390

11.1. Material culture by type, functional group, and collection method .................................. 394

11.2. Artifact quantities for all excavated artifacts by functional group and and

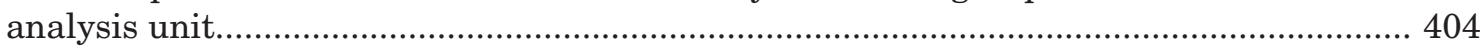

11.3. Artifact densities by functional group and analysis unit ............................................... 407

11.4. Square cut nails, wire nails, and fence staples by analysis unit...................................... 421

11.5. Cut nails found in the house block excavations by size group .......................................... 426 


\begin{abstract}
In conjunction with the proposed construction of the southwest segment of State Highway 45 in southern Travis County, the Texas Department of Transportation sponsored archeological testing and data recovery efforts at the Ransom Williams farmstead. Prewitt and Associates, Inc., conducted an interdisciplinary community-based historic archeological study of the farmstead from 2005 through 2011. Extensive archival research reveals that the 45 -acre farm was owned and occupied by Ransom Williams and his wife Sarah, both former slaves, from about 1871 to ca. 1905 . The Williams family lived in the predominantly white rural community of Bear Creek, but they had connections to the nearby freedmen communities of Antioch Colony in northern Hays County and Manchaca in southern Travis County. The stories of the Ransom Williams family and their connections to these communities are enhanced by extensive oral history research, with over 46 hours of taped and transcribed interviews with 27 descendant community members.

Data recovery investigations focused on a landscape archeological study to define the layout and design of the entire farmstead, including a stock pond and a network of dry-laid rock walls that facilitated water drainage, demarcated property boundaries, and formed livestock pens. Intensive hand excavations were used to examine features associated with the Williams house, outbuildings and activity areas, and a large trash midden. This work recovered more than 26,000 artifacts. They constitute an impressive material culture assemblage that is associated, with few exceptions, with the Williams family tenure on the land.

The combined archival data, oral history interviews, and archeological evidence tell the fascinating story of how one African American farm family lived and thrived in central Texas during Reconstruction and into the Jim Crow era.
\end{abstract}

\title{
CURATION
}

All of the project records and artifacts recovered from the archeological investigations at the Ransom Williams farmstead (one component of site 41TV1051)-including the testing and data recovery phases-will be submitted for permanent curation to the Texas Archeological Research Laboratory at the University of Texas at Austin.

The Dolph Briscoe Center for American History at the University of Texas at Austin is the repository for the Williams Farmstead Oral History Collection. Archived materials include the original audio and video files for all of the oral history interviews, the original full transcriptions of the interviews, digital photographs and historical documents, and the signed release forms for all the interviews, photographs, and documents donated by various families.

Professional videotaping for the Ransom Williams Farmstead Archeological Project was done by two different groups, and the footage includes scenes of fieldwork and interviews at the archeological site along with analysis work, recovered artifacts, and interviews filmed at the Prewitt and Associates' office and laboratory and in other locations in Austin. The Liberal Arts Instructional Technology Services (LAITS), at the University of Texas at Austin filmed onsite in July 2009. These digital video files are housed at the LAITS office on the UT campus. KLRU-TV filmed at the Prewitt and Associates laboratory in January 2010. These digital video files, along with some subsequent follow-up interviews and onsite footage, are housed at the KLRU television studio in Austin. 


\section{MANAGEMENT SUMMARY}

The Ransom Williams Farmstead Archeological Project was a historic archeological study undertaken by Prewitt and Associates, Inc. (PAI) for the Archeological Studies Program, Environmental Affairs Division, Texas Department of Transportation (TxDOT) in conjunction with planned road improvements for the southwest segment of State Highway 45 (TxDOT CSJ No. 1200-06-004). The archeological remains of a late-nineteenth-century farmstead were the focus of the archeological and historical investigations, although the farmstead is only one component of 41TV1051, a large site that has a prehistoric component along with other later historic archeological remains. The 45-acre farmstead was occupied from about 1871 to ca. 1905, and it is associated with an African American family who bought the land only six years after emancipation. The family consisted of Ransom Williams, his wife Sarah, and their nine children.

Archeologically, the area that was investigated was approximately 16.8 acres of the original 45-acre property that fell within the right of way for the proposed State Highway 45 Southwest roadway. Because the proposed road construction would impact this area, TxDOT had to look at the potential effects as required by the Antiquities Code of Texas. TxDOT's Archeological Studies Program began planning for this project many years ago. In 2003, they contracted for an archeological survey and preliminary archeological investigations of 41TV1051. In 2005, PAI was contracted to conduct additional archival research, followed by onsite test excavations in 2007-2008. This work led to data recovery investigations in 2009, along with archival research and extensive oral history research involving the African American descendant community.

This project was an interdisciplinary study that involved collaboration by many researchers and institutions. The work by PAI and its many consultants spanned a period of about eight years, from 2005 to 2013 , and the work reported herein was authorized by ten work authorizations (WA Nos. 57520SA006, 57550SA006, 57719SA001, 57903SA002, 57904SA002, 57909SA002, 57101SA002, 57103SA002, 57114SA001, and 57313SA003). The onsite archeological studies were authorized by Antiquities Permit No. 4736, issued by the Texas Historical Commission in November 2007. The original scope of work for this permit was only for the archeological testing in order to evaluate the site's research potential. When the site was found to be eligibile for listing on the National Register of Historic Places, the terms of the permit were expanded to accommodate data recovery investigations, archival research, and descendant community outreach.

To satisfy the public outreach requirements for this project, TxDOT, PAI, and Texas Beyond History have collaborated to produce a substantial Texas Beyond History Internet exhibit on the multidisciplinary historical and archeological studies of the Williams Farmstead. In addition, plans are being discussed for creating a museum exhibit in the Austin area. 


\section{ACKNOWLEDGMENTS}

The Ransom Williams Farmstead Archeological Project was a collaboration among many individuals. As the work proceeded, the project became more complex and involved increasingly more collaborative efforts that contributed to the overall success of the historical research, the archeological investigations, and the outreach activities involving the descendant community.

The project was funded and directed by the Archeological Studies Program, Environmental Affairs Division, Texas Department of Transportation. Our work was overseen by Dr. Scott Pletka, program director, and Jon Budd, project manager for the proposed State Highway 45 Southwest toll road improvements. All phases of the work were reviewed by the Texas Historical Commission's Archeology Division; reviewers were Dr. James Bruseth, division director (retired), and Mark Denton, coordinator for state and federal reviews.

Prewitt and Associates, Inc. (PAI) directed the investigations at the Williams farmstead. PAI project personnel for the testing and data recovery efforts were:

Douglas K. Boyd, principal investigator

Aaron R. Norment, project archeologist and co-principal investigator

Jennifer K. McWilliams, project archeologist

Rob Thrift, laboratory supervisor and field crew member

John Dockall, field crew member

Karen Gardner, archeological database manager

Nedra Lee, field crew member and laboratory assistant

Felton Pierre, field crew member

Jodi Skipper, field crew member

Ishan Gordon, field crew member

Valerie Prado, field crew member

Bethany Duke, field crew member

The publication was produced by Elaine Robbins (editor), Brian Wootan (graphics), Sandy Hannum (graphics and layout), and Jenny McWilliams (artifact photography).

Two consultants were major partners in this project and deserve special recognition. Dr. Maria Franklin, associate professor in the Department of Anthropology and the Center for African and African American Studies at University of Texas at Austin, coordinated the community outreach efforts and directed the oral history interviews that were a major component of the overall project. Project historian Terri Myers, principal of Preservation Central, Inc., in Austin conducted extensive archival research. The work done by Franklin and Myers was critical to the success of this project.

Four other consultants conducted special studies and wrote sections of this book. Leslie Bush (Macrobotanical Analysis in Manchaca, Texas) analyzed the plant remains recovered from the farmstead, and Brian Shaffer (an independent faunal analyst in Denton, Texas) examined the animal bones. The neutron activation analysis of stoneware ceramics was conducted by Drs. Jeffrey Ferguson and Michael Glascock of the Archaeometry Laboratory, Research Reactor Center, University of Missouri, Columbia. Molly Morgan of San Marcos assisted in this effort by doing the logistical legwork to obtain ceramic, kiln brick, and clay samples for this analysis.

Special thanks to Joe Rogers of Hereford, Texas, for his valuable help in identifying tool artifacts. An avocational archeologist and collector of old tools who demonstrates late-1800s carpentry techniques, the West Texas A\&M University teacher became an unpaid team member who assisted in the identification of many artifacts, especially parts of tools we were having trouble identifying. We 
regularly sent him emails of artifact photos, and he would respond (often within a matter of minutes) with a precise identification supported by published references and Internet links to illustrate how our parts fit together to make the complete tool.

The 27 oral history informants who were interviewed by Maria Franklin or Nedra Lee have made a significant contribution to African Diaspora studies in Texas and our understanding of the post-emancipation Jim Crow era. Although they were formally acknowledged in the 2012 oral history report, it would be remiss not to mention them here because of their important role in this project. These individuals are:

Jewel (Williams) Andrews
Annie (Dotson) Axel
Estelle (Hargis) Black
Earlee Bunton
LeeDell Bunton, Sr.
Lee Wildon Dawson
Joanne Deane
Cedel (Sorrells) Evans
Ruth (Harper) Fears
Lillie Grant
Moses Ollie Joe Harper, Sr.
Samuel Harper
Corrine (Williams) Harris
Earselean (Sorrells) Hollins
Lourice (Williams) Johnson
Joan Nell (Revada) Limuel
Lillie (Meredith) Moreland
Winnie (Harper) Moyer
Minnie (Harper) Nelson
Robbie (Dotson) Overton
Marcus Leon Pickard, Jr.
Rene Pickard
Kay (Hollins) Randall
Floris Lean Sorrells
Essie Mae (Owens) Sorrells
Anthy Lee (Revada) Walker
Marian (Harper) Washington

\author{
Austin, Texas \\ Austin, Texas \\ Austin, Texas \\ Austin, Texas \\ Phoenix, Arizona \\ Lockhart, Texas \\ Manchaca, Texas \\ Cedar Park, Texas \\ Buda, Texas \\ Austin, Texas \\ Austin, Texas \\ Buda, Texas \\ Austin, Texas \\ Austin, Texas \\ Austin, Texas \\ Buda, Texas \\ Manchaca, Texas \\ Buda, Texas \\ Buda, Texas \\ Austin, Texas \\ Dallas, Texas \\ Menard, Texas \\ Austin, Texas \\ Austin, Texas \\ Austin, Texas \\ San Antonio, Texas \\ Buda, Texas
}

Many of these people and their families visited the data recovery excavations in 2009 and saw the artifacts in the PAI laboratory in 2009 and 2010. Some of them participated in videotaped interviews and appeared in the Ransom Williams segment of the Juneteenth Jamboree 2010 (see below). Thanks also go to Bernadette Phifer, director of the George Washington Carver Museum and Cultural Center in Austin, for hosting the oral history book release event on July 19, 2012.

Special thanks to Mr. LeeDell Bunton for sharing his knowledge of Antioch, a freedmen community near Buda that has many connections to this project. He was one of the first informants we met, and he took Franklin and Boyd to visit archeological sites at Antioch, including his boyhood home and the locations of the original church and school. He also freely shared his extensive family genealogical data with the project team-research that became especially important when we realized that the Williams family was related to the Buntons of Antioch. 
Many thanks to the members of the Manchaca Onion Creek Historical Association for its interest in our project and assistance with our research. The group visited the site excavations in the summer of 2009 and visited the laboratory to see the artifact collection. They even helped us identify some "unknown" artifacts in our collection. Special thanks to Marilyn Dunnahoo McLeod, who provided the research team with her extensive family genealogy and research files. As it turns out, she is one of the few people who had actually heard of Ransom Williams because her greatgrandparents, Daniel and Mary Ann Labenski, were neighbors of Ransom and Sarah Williams for 30 years. Fortunately for our project, Marilyn had recorded her Aunt Cordelia's recollections of the log cabin "owned by a black man named Rance."

In the realm of public outreach, thanks go to many people. Molly Walberg (author) and Marsha Miller (photographer) wrote and illustrated an article on the Williams Farmstead Archeological Project for the magazine Life \& Letters, published by the University of Texas's College of Liberal Arts. María de la Luz Martínez edited the article that appeared in Current Archeology in Texas published by the Texas Historical Commission. Daniel Garza and his team with Liberal Arts Instructional Technology Services (LAITS) at the University of Texas shot video of onsite activities and interviews during the 2009 data recovery, and this digital footage is archived for future use.

Many thanks to the folks at KLRU-TV who produced the best public outreach product any archeological project could hope for-a television documentary! KLRU producer Michael Emery heard about our project from Marilyn McLeod. He became very interested in the Ransom Williams story, and the end result of this interest was that Emery featured a 28-minute segment on the Williams farmstead project in the hour-long Juneteenth Jamboree 2010 program, which aired on KLRU on June 17, 2010. It was a pleasure working with Emery and the KLRU cameramen, Derek Joyoprayitno, Robert Moorhead, Daniel Veliz, Richard Welch, and Alex LaRotta.

Part of TxDOT's formal public outreach plan for the Williams farmstead project involved the creation of an online exhibit for the Texas Beyond History website. This exhibit was in its final editing stages as this book was being produced. Thanks go to the many people involved in the TBH effort: Susan Dial (TBH editor) and Heather Smith (TBH assistant editor) for editing and producing the exhibit; Frank Weir (Austin artist and retired archeologist) for his lifeways reconstruction paintings; Elaine Leibick for creating the fourth-grade school curriculum lesson plans and an online kids' activity; and Carol Schlenk for creating the seventh-grade school curriculum lesson plans and an online kids' activity. Because the Williams farmstead was the first TBH exhibit to incorporate audio and video clips and other special effects, Susan and Heather had to overcome many technological obstacles. They deserve many kudos for their outstanding work.

Two groups must be acknowledged for providing outside funding to help the Williams Farmstead Archeological Project in the public outreach realm. The Travis County Historical Commission and the Texas Historical Commission approved a Certified Local Government grant to assist in the public outreach activities. Thanks to TCHC chair Barry Hutchinson and members Bob Ward and May Schmidt. The Travis County Archeological Society also provided some funds for these efforts. Most of the funding provided by these grants went toward the development of the school curriculum and kids' activities on TBH. 


\section{PREFACE}

Ransom and Sarah Williams saw many changes in their lives during the last half of the nineteenth century as they raised their children on their small family farm in central Texas. Perhaps the most significant change for them, as with most blacks that lived through the Civil War in the Southern states, was the transition from being enslaved to being free. The concept of being a slave is abstract to most modern Americans. It is something we read about in history books. We may discuss it and debate it, but most of us do not truly understand what it meant to be enslaved. The idea that people were property — owned, sold, traded, and tended like livestock—is appalling today, but it was legal and sanctioned less than 150 years ago.

The end of legal slavery in the southern United States was a slow process that took place over many decades, and slavery was one of the key issues that caused the rift between the northern and southern states. But for enslaved people in Texas the initial discovery of their legal freedom was an abrupt event indeed. As noted by historian Michelle Mears, "it is difficult to imagine life as a slave, or how it would feel suddenly, after a lifetime of slavery, to be freed." The first official announcement of freedom was the Emancipation Proclamation by president Lincoln in 1863, but this had little impact on the enslaved peoples in the Confederate States. Real freedom did not come until after the end of the Civil War, and it came to Texas in June of 1865, when federal troops arrived in Galveston. The following proclamation was read on June 19, 1865:

The people of Texas are informed that, in accordance with a proclamation from the Executive of the United States, all slaves are free. This involves an absolute equality of personal rights and rights of property between former masters and slaves, and the connection heretofore existing between them becomes that between employer and hired labor. The freedmen are advised to remain quietly at their present homes and work for wages. They are informed that they will not be allowed to collect at military posts and that they will not be supported in idleness either there or elsewhere.

By Order of: G. Granger Major General Commanding

This short and simple statement (Granger 1865) had a tremendous impact on all Texans. Because of the importance of this date, Juneteenth has become an annual celebration for African Americans throughout the state and is sometimes called "Freedom Day" (Sitton and Conrad 2005:104107). It is celebrated by individual families with quiet meals, by small neighborhood groups with festive picnics and barbecue cookouts, and by whole communities with large feasts and parades. For many African Americans, June 19th—not July 4th—is their Independence Day.

The proclamation of June 19, 1865, set in motion the systematic freeing of slaves all across Texas, but it took most of that summer for the word to spread across the state. For most slaves in Texas, the first time they heard about the possibility of freedom was probably the day they were set free. The news of their freedom was often met with a combination of joy, apprehension, and fear (Sitton and Conrad 2005:10). The average freed black had few possessions, little or no money, few marketable skills, and could not read or write. In short, most freed blacks had few options.

Learning that you were now a free person was one thing, but actually realizing freedom in white-dominated society was something else entirely. Being truly free involved gaining both economic and social freedom. As we have learned from painful civil rights lessons over many years, the process of emancipation for blacks in America has taken a century and a half and is, in some ways, still not complete. The Black Codes, or Jim Crow laws, of the late-nineteenth and early-twentieth centuries were just one way in which white authorities kept blacks on the bottom rungs of the social and economic ladders. Historically, one of the most important steps in the quest for economic and social 
freedom was for freedmen to acquire land of their own. But land acquisition was not an easy task for most freedmen, especially when many white Southerners wanted to prevent freedmen from becoming landowners (Schweninger 1997:145).

Immediately following emancipation, most freedmen were simply hired as employees by their former owners. In fact, even the 1865 Emancipation Proclamation suggested that "The freedmen are advised to remain quietly at their present homes and work for wages" (Granger 1865). This was the most expedient course of action at the time, because most white landowners still needed labor to run their farms and most freedmen needed jobs and only knew how to farm. Despite this, some blacks chose to move on and seek other opportunities, often in the nearest towns. For freedmen lucky enough to have acquired some special skills while enslaved, they could find better jobs or even start their own businesses. One example is the Wilson family of potters from Guadalupe County. Several Wilsons had learned to make pottery as slaves, and upon obtaining freedom they established several independent pottery manufacturing businesses collectively known as the Wilson potteries (e.g., Brackner 1981, 1984; Brown 2002; Morgan 2009). Having some special skill or craft was a distinct advantage enabling some freedmen to prosper.

Following emancipation, it was common for blacks to congregate into freedmen communities, which might be in isolated rural communities where farm laborers settled or near towns and cities (Mears 2009:3-11; Sitton and Conrad 2005:1-4). Freedmen often pooled their labor and money in order to buy lands for these settlements. There were undoubtedly many hundreds of freedom colonies across Texas, and at least two hundred were mentioned in the 1996 Handbook of Texas (Tyler et al. 1996, as noted by Sitton and Conrad [2005:3]). Despite the numbers and historical significance of these communities, "Southern historians have ignored freedmen's settlements" (Sitton and Conrad 2005:3). Two notable exceptions are the books Freedom Colonies by Thad Sitton and James Conrad (2005) and And Grace Will Lead Me Home:African American Freedmen Communities of Austin, Texas 1865-1928 (2009) by Michelle Mears. These are important contributions that begin to fill this gap in knowledge regarding freedmen communities.

Without doubt, landownership was one of the most important keys to success for freed blacks in the decades following emancipation. This sentiment was observed by many white Southerners and expressed by many former slaves, including one man who said in 1865: "What's de use of being free, if you don't own land enough to be buried in?" (Schweninger 1997:145). A passion for the land was in their blood as most former slaves had tilled land and watched others prosper from their labor. The desire to own their own piece of land was a common hope among freedmen seeking economic freedom and security.

In Texas, acquisition of lands by African Americans came about slowly at first and then increased dramatically. "In 1870 , only 1.8 percent of the state's black farmers owned land, but by 1890 an astonishing 26 percent of them did. Just after the turn of the century, black landownership peaked at 31 percent" (Sitton and Conrad [2005:2] based on data in Schweninger [1997:Table 16]). For blacks in the late nineteenth and early twentieth centuries, freedmen communities offered relative safety in numbers, and they were a safe place for people to buy land. From a historical perspective, one of the rarer circumstances for freedmen becoming landowners was for an individual to be able to save enough money to purchase their own farm independent of the freedom colonies. Yet this is precisely how Ransom Williams may have acquired his land.

The primary subjects of this book are Ransom and Sarah Williams, an African American couple who raised their children and operated a small family farm in central Texas from about 1871 to ca. 1905. But the bigger story is about African American transitions after emancipation. Ransom Williams was a black man who purchased a 45 -acre farm in 1871 , at a time when few blacks could 
afford any land at all. Ransom and Sarah were former slaves ${ }^{1}$ who married and raised children on their own farm. Although they were illiterate, they made sure that their children attended school and learned to read and write. The Williams family prospered when most blacks were struggling as low-wage laborers or falling into an oppressive system of sharecropping for white landlords. They were a black family living within a rural white farming community, yet they managed to stay below the radar and avoid the racial violence that was a very real threat for all southern blacks, especially those who lived in rural areas (Autopsis.org 2012; Carrigan 2004; Crouch 1984; Mears 2009:8-9; Sitton and Conrad 2005:14). Despite their isolation, the family maintained ties to nearby black communities, first with Antioch Colony and later with the black community at Manchaca. The story of Ransom and Sarah Williams is not a simple tale, but rather a series of embedded tales within a larger, more complicated story.

This book tells the story of Ransom and Sarah Williams as it was discovered through an extensive multiyear, multidisciplinary archeological project to mitigate the construction impacts of a planned roadway. Funded by the Texas Department of Transportation and undertaken in compliance with various state laws, archeological investigations were conducted to define the physical remains of the farmstead, while archival research, oral history interviews, and many other special studies provide complementary evidence. Our primary goal was to weave together the various lines of evidence to interpret the post-emancipation transitions of one African American farm family that lived in central Texas during the Jim Crow era. A second and much bigger goal was to place this freedmen family into a broader historical context that contributes to a greater understanding of the African diaspora in Texas and the United States. We hope that we have accomplished these goals.

—Douglas K. Boyd and Maria Franklin

\footnotetext{
${ }^{1}$ While no documents have been found that prove Ransom or Sarah were slaves, a great deal of circumstantial evidence indicates this was the case. The most compelling evidence is simply the law of probability. In 1860 there were 182,566 "Black" and "Mulatto" slaves in Texas and only 355 "Free Colored" people (U.S. Bureau of the Census 1860). Born before 1846, Ransom was from the slave state of Kentucky and almost certainly came to Texas as a slave. Sarah was born in Texas in 1851. Statistically speaking, the probability that Ransom or Sarah had not been slaves prior to 1865 is exceedingly low.
} 


\title{
INTRODUCTION TO THE RANSOM AND SARAH WILLIAMS FARMSTEAD ARCHEOLOGICAL PROJECT
}

\author{
Douglas K. Boyd and Aaron R. Norment
}

\section{PROJECT BACKGROUND}

In the summer of 2005, Jon Budd at the Texas Department of Transportation (TxDOT) invited Prewitt and Associates, Inc. (PAI) archeologist Douglas Boyd and historian Terri Myers to visit the Ransom Williams farmstead. Set in a densely wooded area surrounded by urban sprawl in southern Travis County, the farmstead occupied a part of archeological site 41TV1051 (Figure 1.1). The larger multicomponent site was first discovered in 1981, but the remains of this farmstead-which consisted mainly of a chimney base and rock pile from a chimney collapse and a scatter of house foundation stones-were not discovered until 2003, when TxDOT archaeologists were looking at a proposed route for State Highway 45.

At first glance, it looked like just another typical late-nineteenth- and early-twentiethcentury farm and ranch occupation. It appeared ordinary in the sense that there are thousands of similar sites scattered across central Texas, providing abundant evidence of intensive agricultural use that characterized the region and indeed much of the state. Many old farmsteads contain few extant structures and features, and they have only sparse artifacts to mark where structures once stood or farm and ranch activities had occurred. Because farms and ranches were often occupied continuously for a century or more, the archeological remains at many sites are severely mixed and heavily overprinted with twentieth-century debris. At these kinds of sites, it is often impossible to separate the features and artifacts into meaningful temporal groups or associate particular materials with specific people. A lengthy occupation often makes it difficult or impossible to use material remains and standard archeological techniques to study the various peoples who lived at different times. Quite frankly, there are many historic sites where investigating the archeological remains is simply not productive, and one can learn a great deal more about the place and the people by using archival records or interviewing informants who remember the historic activities at the site. So why would 41TV1051 be any different?

Indeed, when the farmstead component was first recorded and investigated by Archeological and Cultural Sciences Group archeologists in 2003 , it did not look all that impressive. There wasn't much to make it stand out from hundreds of other historic farmstead sites in central Texas. But Boyd and Budd agreed that the site was worth a second look. In 2005, TxDOT contracted with PAI to continue the process of assessing the site's significance through archival research. PAI hired historian Terri Myers, principal of Preservation Central, to serve as a consultant for the historic research.

When PAI started this work, there were problems linking the modern location of the old farmstead to its historic location on old county plat maps, as well as some uncertainties in the property chain of title, which tracks the landownership through time. Myers had done some of the previous research pertaining to this site, and she already knew much about the history of the local area. Having wasted some time researching the wrong property because the exact site location had been misplotted on historic maps, Myers knew that our first task was to get the location right. TxDOT provided precise GPS locational data, and PAI graphics 
The Ransom and Sarah Williams Farmstead

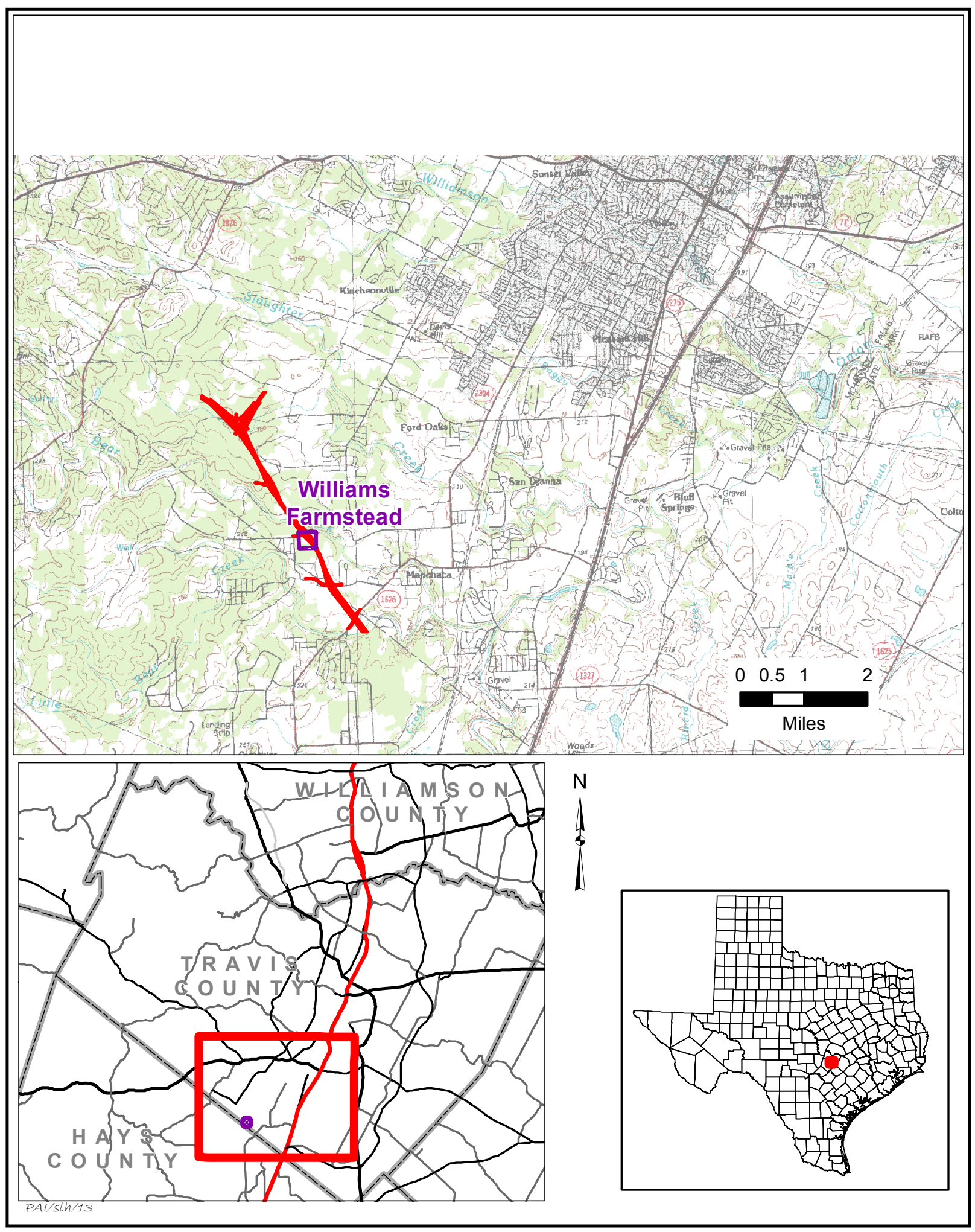

Figure 1.1. Location map of the Ransom and Sarah Williams farmstead. 
supervisor Sandy Hannum went through a painstaking process of georectifying modern and historic aerial photographs and maps. She was then able to confidently plot the Williams property and link it back to historic aerial photographs and maps. Once this was done, Myers discovered that the farmstead remains were located within a 40-acre block shown on an 1871 subdivision of the McGehee League, granted by the Republic of Mexico in 1835. This block comprised most of a 45 -acre property purchased by Ransom Williams in 1871 . Myers also discovered something that would dramatically change the archeologists' view of the importance of the site: Ransom Williams was an African American. Williams purchased his farm only six years after emancipation, and he farmed the property for about 30 years.

As Sitton and Conrad (2005:2) note in their book on black freedman colonies, Texas was a relatively good place for African Americans to be in the decades following emancipation compared with the rest of the Southern states. This was especially true for those freedmen who wanted to own land. They note that:

Landownership rose more precipitously in Texas than in any other southern state. In 1870 only 1.8 percent of the state's black farmers owned land, but by 1890 and astonishing 26 percent of them did. Just after the turn of the century, black Texas landownership peaked at 31 percent... Many-perhaps mostof these new black Texas landowners resided in freedmen's settlements, informal communities of black farmers and stockmen scattered across the eastern half of Texas.

Given this historical background, we must conclude that black ownership of a farm so soon after emancipation was not in itself a rare event. Rather, the uniqueness of the Ransom Williams farmstead project lies in the fact that archeologists in Texas have not successfully identified and investigated many black farmstead occupations. Although various level of archeological and historical investigations have occurred at many thousands of historic farm and ranch sites all across Texas, very few of them have focused on farmsteads occupied by African American landowners or tenants. As a result, our historical knowledge of black-owned farms is sketchy at best. Furthermore, such sites have even more rarely been intensively studied using a combination of archival, oral history, and archeological techniques. Only a handful of African American occupation sites have seen moderate or extensive archeological investigations, and very few of those are from the post-emancipation period. ${ }^{1}$

In summary, the Ransom Williams farmstead is a significant historic archeological site because:

- It is an African American-owned farmstead with a single-family occupation that occurred during a relatively short time span, from ca. 1871 to ca. 1905 ;

- Even though the land was used for agriculture after the Williams family left the property, there is no historical or archeological evidence that any one else actually lived on the original 45 -acre property. This means that there is little or no overprinting or mixing of material remains from later times;

- African American occupation sites, particularly African American-owned farmsteads, are seriously underrepresented in the archeological record of Texas;

- The period of significance for the Williams farmstead is the post-emancipation era in the late nineteenth century-a period and research topic that have received relatively little historical attention and virtually no archeological attention.

- When it comes to minority peoples whose stories have long been ignored in official records and sanctioned histories, the physical remains preserved in archeological sites become an increasingly important form of evidence needed to tell the full story.

\footnotetext{
${ }^{1}$ African American freedmen farmsteads that have had substantial archeological investigations include the Mingo and Nancy Burleson homestead and two tenant farms in Navarro County (Jurney and Moir 1987), the Rubin and Elizabeth Hancock farmstead in Travis County (Blake and Myers 1999), the Ned Peterson farmstead in Brazos County (Carlson 1995a), and the John Derrick, John Hancock, and Wallace Carter farmsteads in Delta County (Green et al. 1996). These sites are discussed in Chapter 14 .
} 
In addition, a few other specific historical factors make the Ransom and Sarah Williams farmstead unusual and contribute to the site's overall significance.

- The Williams family did not live in a freedmen colony or African American neighborhood. They chose to live in a rural area surrounded by white neighbors. This type of black landownership appears to be fairly rare historically, and it is indeed rare for such locations to be recognized as archeological sites.

- The man Ransom Williams is somewhat of an anomaly from a historical perspective. Various historical documents show his ethnicity as Negro or black, while others list no ethnicity or race at all. This is, of course, circumstantial evidence, but it suggests that he was probably a mulattothe son of white and black parents. And records show that Ransom's wife, Sarah, was indeed a mulatto.

- There is circumstantial evidence that suggests that the Williams family is related to the Bunton family. We have identified and interviewed members of the black Bunton family (such as LeeDell Bunton) who are related to Ransom and Sarah Williams but in ways that remain unclear. The black Bunton family is intimately tied to the Antioch Colony freedmen community near Buda, and their ancestors were slaves at the Mountain City plantation, which was owned by John Wheeler Bunton.

- We have identified direct descendants of Ransom and Sarah Williams, and can trace the Williams family history from the 45-acre farmstead in the late nineteenth century to a historic East Austin neighborhood in the twentieth century. As part of this project, we have conducted oral history interviews with Mrs. Corrine Harris, Mrs. Jewel Andrews, and Mrs. Lourice Johnson, all great-granddaughters of Ransom and Sarah Williams (Franklin 2012).

A substantial number of artifacts associated with the Williams family were found during the archeological investigations, and these material remains constitute an important collection that documents late-nineteenth-century African
American life. However, the true significance of the Ransom Williams farmstead is not in the material remains themselves, but in the stories that these remains can reveal in conjunction with other forms of evidence. In this book, the stories that are told of the Ransom Williams family and the farmstead where they lived are derived, in large part, from the historical documents and archeological remains. But these two data sets do not tell the full story. The Ransom Williams story is far richer because the archeological research project was designed with a significant community outreach component and sought to record modern perspectives and historical memories through oral history interviews. This oral history research provides a critical link in the African Diaspora story in America, bridging the gap from a nineteenth-century, post-emancipation farm owner to the modern African American community. Consequently, the final point that must be made is that the Ransom Williams farmstead is significant for what it contributes to our understanding of the history of post-emancipation transitions of African Americans in Texas and the United States-a history that is important for all Americans. The farmstead is also significant because it is important to the modern African American community.

\section{POST-EMANCIPATION TRANSITIONS IN THE AFRICAN DIASPORA}

One important question should be addressed at the outset. Why are African diaspora studies important to Texas history? The reason is simple: The state's history has long been told from the biased perspectives of the white males who dominated the state's political, economic, and academic realms in the nineteenth and twentieth centuries. Consequently, the perspectives of women and minority groups are seriously underrepresented in official state histories. To fill in the gaps and reveal a more complete history, the roles of underrepresented minority groups must be studied. Such efforts should involve the use of primary historical documents, oral histories, and archeological evidence, and they should reach out to the descendant communities of the people being studied. 
Renowned anthropologist Leland Ferguson ${ }^{2}$ (1992:xxxiv) said: "The evolution of African American archeology demonstrates how our view of the past is affected by the world around us, even for so-called objective social scientists like archeologists." This statement is undeniably true, and it is fortunate that American archeologists and historians have generally become more cognizant of the realities of researcher bias and the validity of multiple and varied perspectives on the past. African American archeology has only emerged as a viable research theme and a relevant social science in the past three or four decades. Not surprisingly, this emergence followed closely on the heels of the civil rights movement. It was not until the late 1960s that archeologists began seriously investigating archeological sites associated with slavery and the African diaspora in the United States and to look at life from the perspectives of the enslaved (Ferguson 1992:xxiii-xli).

Looking specifically at Texas, its seems that African American archeology has lagged behind that of other states. With a few exceptions, historic archeology in the state has not focused on African American life, even when the archeological investigations were of antebellum plantations. While we may lament that fact that the Williams farmstead site will be destroyed when the State Highway 45 Southwest roadway extension is constructed, this road project presented an unprecedented opportunity that would not have been available otherwise. Thus, the Ransom and Sarah Williams Farmstead Archeological Project makes a valuable contribution to the study of the post-emancipation African diaspora.

\section{RACE, ETHNICITY, AND TERMINOLOGY}

Many terms related to race and ethnicity are used frequently in anthropology, and their use and misuse can be debated at great length. Without digressing into these debates, our purpose here is to clarify selected terms as they are used in this book. The following simple definitions are used:

${ }^{2}$ Leland Ferguson is distinguished professor emeritus in the Department of Anthropology at the University of South Carolina.
African American: "a black American of African descent" (Random House, Inc. 2010).

Black: One formal definition is "a member of any of various dark-skinned peoples, esp. those of Africa, Oceania, and Australia" and (noun) "African-American" (Random House, Inc. 2010). More importantly, "black" is a term that young Americans of African descent began using during the politically tumultuous 1960 s in place of “negro." After 1867, Afro-American and African American became the preferred terms promoted by black leaders (Bennett 1967), but "black" is commonly used interchangeably with "African American" today.

Black Codes: "Black Codes were the laws passed by Southern state legislatures to define the legal place of blacks in society after the Civil War. In Texas, the Eleventh Legislature produced these codes in 1866. The intent of the legislation was to reaffirm the inferior position that slaves and free blacks had held in antebellum Texas and to regulate black labor. The codes reflected the unwillingness of white Texans to accept blacks as equals and also their fears that freedmen would not work unless coerced. Thus the codes continued legal discrimination between whites and blacks" (Moneyhon 2010). Black Codes are often called Jim Crow laws (see below).

Caucasian: "a member of the peoples traditionally classified as the Caucasian race, esp. those peoples having light to fair skin" (Random House, Inc. 2010).

Culture: "the behaviors and beliefs characteristic of a particular social, ethnic, or age group" (Random House, Inc. 2010). Thus, we may refer to black culture and white culture.

Euro-American: "an American of European and especially white European descent" (Merriam Webster 2010).

Ethnic: "pertaining to or characteristic of a people, esp. a group (ethnic group) sharing a common and distinctive culture, religion, language, or the like" (Random House, Inc. 2010). 
Ethnicity: "relating to or characteristic of a human group having racial, religious, linguistic, and certain other traits in common" (Random House, Inc. 2010).

Freedman (and Freedmen): "A man who has been freed from slavery" (Random House, Inc. 2010). As used in this book, freedmen refers to the African Americans in Texas after the 1865 Emancipation Proclamation.

Jim Crow: "A practice or policy of segregating or discriminating against blacks, as in public places, public vehicles, or employment" (Random House, Inc. 2010). The name is derived from the name of a black character that first appeared in a song in 1828, and became a common black caricature in minstrel shows during the nineteenth century. According to the Jim Crow Museum of Racist Memorabilia (2010), "The name Jim Crow is often used to describe the segregation laws, rules, and customs which arose after Reconstruction ended in 1877 and continued until the mid-1960s."

Jim Crow Laws: The common name for many different "Black Codes" enacted by states, counties, and cities in the Southern states to solidify white superiority and legalize discrimination against African Americans.

Race: One formal definition is "a group of persons related by common descent or heredity" (Random House, Inc. 2010). But "race" is a term that is much debated from many different perspectives, and this definition has biological connotations that are not accepted by most social scientists. From an anthropological perspective, "race" is a social category that European colonists began to use as early as the seventeenth century in the Americas. Although it is a social invention, historically people have nonetheless relied on perceived physical differences (especially skin color) as a means of categorizing people into "races" (e.g., black white, Indian). There is now overwhelming scientific evidence that demonstrates that there is more variation within "racial" groups than between them. Still, "race" continues to heavily influence social relations (e.g., racism) even though people are becoming increasingly aware that race is not biological. ${ }^{3}$

White: "for, limited to, or predominantly made up of persons whose racial heritage is Caucasian" and "a person whose racial heritage is Caucasian" (Random House, Inc. 2010).

For our purposes in this book, we use the terms "African American" and "black" more or less interchangeably, as we do the terms "EuroAmerican" and "white." Many of the terms referring to race and ethnicity that were encountered during the archival research are no longer in use, and some are now considered derogatory. The historical terms used to denote African Americans in public records include:

B, M, and Y: Acronyms for Black, Mulatto, and Yellow; used in the slave schedules of census records from 1860 and earlier.

Black: Commonly used in census records dating to 1910 or later.

Colored: Commonly appears in official county documents, such as deed records, tax rolls, and voter registration records, from the late-nineteenth and twentieth centuries.

Free Man of Color (FMOC or FMC): Used in nineteenth and twentieth-century documents in the Southern states. In Texas, FMC or FMOC appears in some county deed records.

Mulatto: "The offspring of one white parent and one black parent: not in technical use" (Random House, Inc. 2010). Commonly used in census records to denote any person of mixed ancestry.

Negro: "a member of the peoples traditionally classified as the Negro race, especially those who originate in sub-Saharan Africa: no longer in technical use" (Random House, Inc. 2010). Commonly used in census records dating to 1910 and later.

3The American Anthropological Association's "Statement on 'Race" may be found at http://www. aaanet.org/stmts/racepp.htm (statement drafted May 17,1998$)$. 
Yellow: Another term for mulatto people of mixed ancestry that was sometimes used in census records.

\section{BOOK ORGANIZATION}

This book presents the results of the archeological and archival investigations as well as the oral history research and interviews. Chapter 2 reviews the history of the investigations conducted at the Williams farmstead (Chapter 2). Chapter 3 describes the archeological methods and work accomplished. Chapters 4 and 5 present histories of the area of Travis County where the farmstead is located and of the Williams family based on Myers's archival research and Franklin's (2012) oral history research. Chapter 4 presents the history of the people, both EuroAmericans and African Americans, who lived in the Allen's Prairie and Mountain City areas of northern Hays and southern Travis Counties. Much of this research focuses on the freedman community called Antioch Colony in northern Hays County. Antioch is important for three reasons: (1) this community is in close proximity to the Williams farmstead (about 4 miles away); (2) the community provided a support network for the Williamses and other rural black families living in the area; and (3) some of the people living at Antioch were related to the Williams family. The historical view is narrower in Chapter 5, which focuses on what we know about Ransom Williams, how he came to own a 45-acre farm, how he met and married Sarah Houston, how they raised a family together, and what became of their descendants. The black community at Manchaca, which was called Rose Colony but is not as well documented as Antioch, plays an prominent role in this chapter, and most or all of the Williams children likely attended the Rose Colony School (about 3 miles away).

Chapters 6-11 explore the physical evidence based on extensive investigations of the farmstead property. Chapter 6 presents a landscape analysis of the Williams farmstead. Based on an examination of modern and historical maps and aerial photographs and an intensive survey of the site topography and natural features, this chapter analyzes how Ransom Williams organized his farm and used the available resources for maximum benefit. Based on the archeological excavations, Chapter
7 summarizes the cultural features associated with the house, yard, and possible outbuilding, and Chapter 8 describes the material culture with the artifacts grouped into functional categories. Chapters 9 and 10 were written by consultants who specialize in their respective fields. Brian Shaffer describes the animal bones that comprise the faunal assemblage in Chapter 9, and Leslie Bush describes the plant remains recovered from the farmstead in Chapter 10. The faunal and botanical remains provide important evidence of subsistence practices and foodways.

All of the archeological evidence is synthesized in Chapter 11, a comprehensive spatial analysis of the artifacts and features in the vicinity of the Williams farmhouse. This chapter looks at the patterning of artifacts by functional group to infer the activities that occurred inside and under the house and in the surrounding yard. The material remains are also analyzed to reveal the activities represented by the large trash dump area east of the house and in the location of a possible outbuilding northwest of the house.

In Chapter 12, Maria Franklin considers the evidence derived from 39 of the 46 hours of oral history interviews that were transcribed and published as part of this project (Franklin 2012). In this chapter, she draws on these oral recollections to tell a more complete story of rural farm life. But she also uses the oral history evidence to look at more complex issues, such as the household economy and deviations from stereotypical gender roles, that may affect the interpretation of archeological evidence.

In Chapter 13, Nedra Lee presents an interesting snapshot of African American life in nineteenth-century central Texas as it is portrayed in contemporary black newspapers. She examines the role of the black press in African American communities and looks at the particular issues of importance to those communities, such as church, education, and business, as well as local, regional, and world news. The examination of black newspapers also reveals much about the advertising and consumption of products and services within the black community. Lee also discusses the ever-present threat of racial violence in the late nineteenth century as revealed in the contemporary news coverage.

The final chapter, Chapter 14, synthesizes the various lines of evidence discussed in the previous chapters to present a broader historical 
perspective. The archival, oral history, and archeological evidence are combined to reveal the story of how the Ransom and Sarah Williams family, through hard work and perseverance, made their way in late-nineteenth-century Texas. It is a post-emancipation success story of the kind not found in other Texas historical narratives.

The six appendixes to this book provide extensive technical data that support the historical and archeological interpretations for the Williams farmstead. Appendix A is a series of maps that display the property history for the John G. McGehee headright league, which encompassed the Williams farm. Appendix B contains a comprehensive database of artifacts recovered, followed by a series of tables that summarize the various groups and types of artifacts in the farmstead assemblage (the database and tables are only in electronic format on the CD accompanying this report). Appendixes $\mathrm{C}$ and $\mathrm{D}$ are inventories of the faunal and botanical remains recovered (tables are only in electronic format on the CD accompanying this report). Appendix E is a technical report by Jeffrey Ferguson and Michael Glascock on the geochemical sourcing study of historic stoneware pottery from the Williams farmstead (using neutron activation analysis). And finally, Appendix F provides a series of data tables (in electronic format only) compiled for the African American newspapers analysis by Nedra Lee. 


\title{
HISTORY OF INVESTIGATIONS AT SITE 41 TV1051
}

\author{
Douglas K. Boyd
}

This chapter provides a chronological summary of the archeological and historical investigations conducted at 41TV1051 (Table 2.1). ${ }^{4}$ The site was referred to as the Ransom Williams farmstead in earlier phases of work, but this was changed to the Ransom and Sarah Williams farmstead in later phases. This was done to explicitly to assign equal importance to the male and female roles and to acknowledge that it was the married couple, not just the man, that operated the farm and raised the family.

\section{PREVIOUS INVESTIGATIONS}

Archeologists from the University of Texas at Austin's Texas Archeological Survey discovered and recorded site 41TV1051 in 1985 while conducting a survey along Bear Creek for a residential developer. The archeologists-David O. Brown, Abby Treece, and Dana Anthony-documented a large prehistoric site and a smaller historic ranching complex dating to the 1930s or 1940s (Brown 1986). The area now recognized as the Ransom Williams farmstead, which is located about a quarter-mile north of the later ranching complex, was not documented during this investigation.

During this project, the Texas Archeological Survey archeologists also recorded archeological site 41TV1049, a historic farmstead located

\footnotetext{
${ }^{4}$ It is important to note that this site actually contains three components: one prehistoric and two historic. The Ransom and Sarah Williams farmstead is the only component that was intensively investigated. Throughout this report, the references to the Williams farmstead all relate to the earlier of two historic components, with features and materials remains dating from approximately 1871 to 1905 .
}

about a half-mile southeast of the Ransom Williams property. Although it is outside of the current project area, the site is worth noting because it was an Anglo-owned farmstead contemporaneous with the Ransom Williams farmstead. Brown (1986:14) describes the site as consisting of:

... a cut limestone cistern, stone chimney footing, and a stone wall tightly circling the house on all four sides. Remains of the stone chimney are strewn about the footing and some possible stone foundation blocks are located along one edge of the former structure. The remaining foundation stones and the arrangement of the cistern and chimney suggest that the house was quite small, perhaps no more than 12 by 12 feet. Artifactual remains primarily included metal debris such as barrel hoops, springs, cans and parts of an old automobile. Although the artifacts present on the surface at the site do not indicate any particular time period, the cistern construction, the chimney footing, and the small size of the house may well indicate a nineteenth century occupation.

Because the structural remains at 41TV1049 were well preserved, the archeologists spent additional time recording the site and shovel testing (Brown 1986:17). They noted that the chimney had fallen into the area where the house had been, and that some of the chimney rocks had been removed. Five shovel tests showed that there were no significant 
The Ransom and Sarah Williams Farmstead

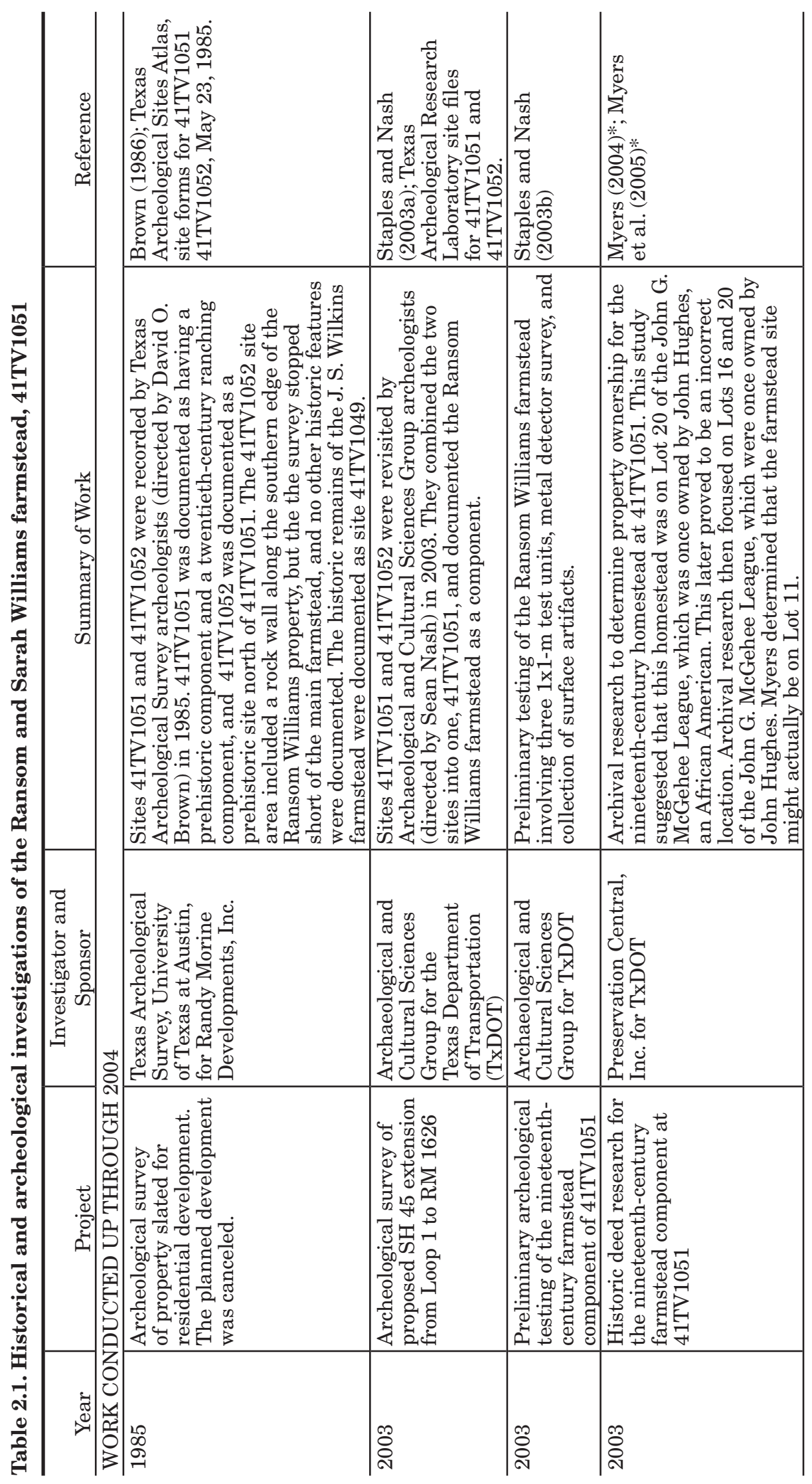


Chapter 2: History of Investigations

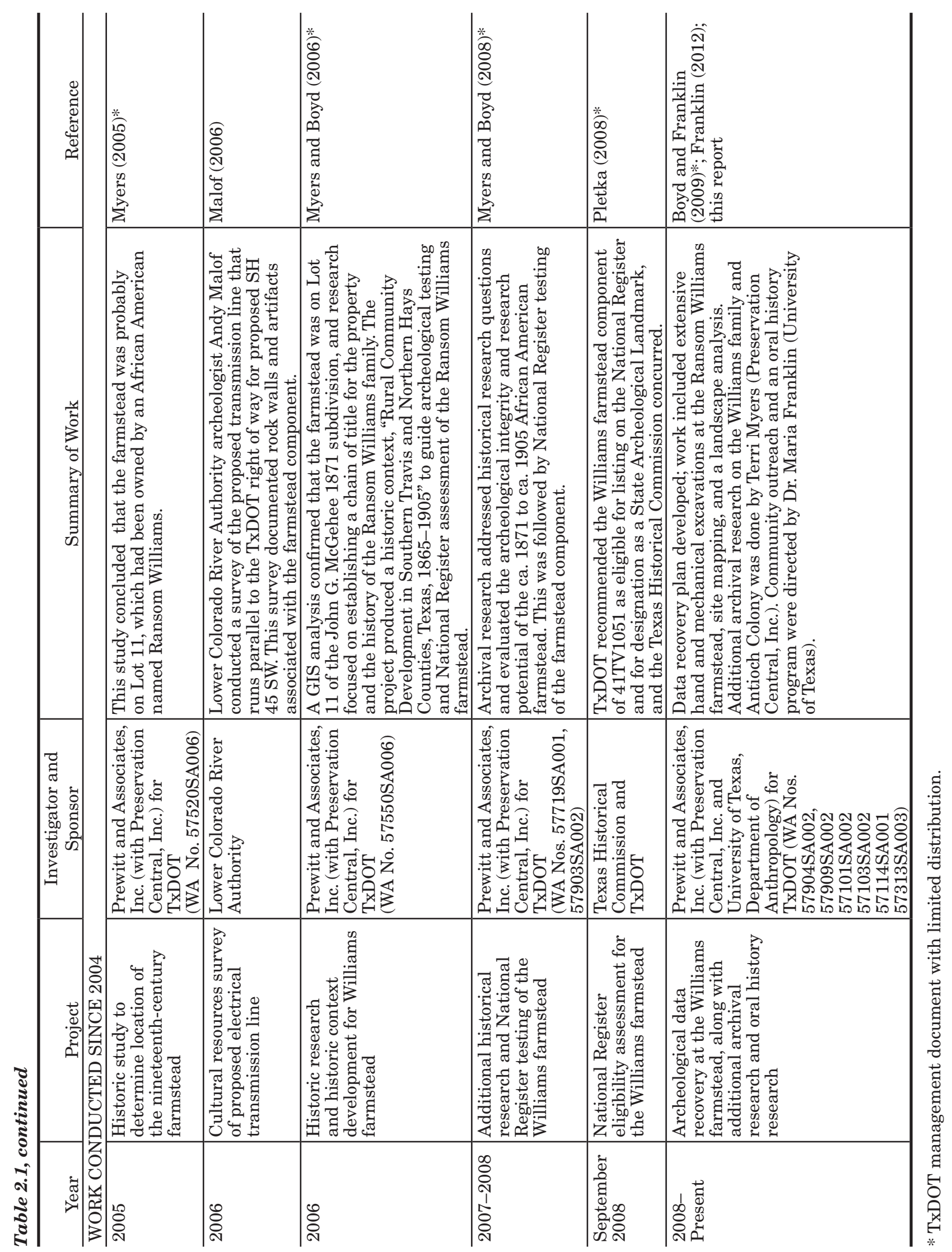


subsurface deposits in and around the house area. They followed up with archival research and determined that J. S. Wilkins had purchased the property on which 41 TV1049 is located in 1871, and he kept it until 1893. They concluded that Wilkins built the house soon after 1871 and that he probably lived on the property until 1893, and possibly even after 1894 or 1895 (Brown 1986:20-21). Notably, J. S. Wilkins and Ransom Williams both acquired their properties in 1871 and were neighbors for at least 22 years. Thus, 41TV1051 and 41TV1049 are both latenineteenth-century farmsteads that were part of the Bear Creek Community, one owned by an African American and one by an Anglo. Twentyfive years later, when the Texas Department of Transportation's (TxDOT) road improvement project emerged, site 41TV1049 was located outside the right of way for State Highway 45 Southwest, so no archeological investigations could be conducted there. This is unfortunate from an archeological perspective because the Wilkins farmstead would have made an excellent site for comparative study of material culture, farm layout, and activities.

Site 41TV1051 was revisited in June 2003 by Gregory D. Staples and William J. Wagner III of Archaeological and Cultural Sciences Group (ACSG) during a survey of the State Highway 45 extension for TxDOT. The site boundary was expanded at this time, and the revised site included three components (Staples and Nash 2003a). One was a prehistoric component that was formerly designated as 41TV1052. The second component was the 1930s-1940s historic ranching complex that was originally recorded as 41TV1051. Both components were recommended as not eligible for National Register listing or State Archeological Landmark designation. The third component was a farmstead that included a limestone rock scatter and chimney fall, several prominent rock walls marking field or property boundaries, four concrete water troughs, and artifact scatters; it was recommended as potentially eligible.

Although no historical research was done for this phase, the researchers concluded that the farmstead component at 41TV1051 appeared to represent a late-nineteenth and early-twentieth-century occupation. They also noted that it might be the homestead of John G. McGehee, the man who received the original land grant in the Bear Creek area from the Republic of Mexico.
Because of this, Staples and Nash (2003a:80-81) recommended that the homestead component at 41TV1051 warranted archival research and limited archeological testing to obtain a controlled sample of artifacts.

In October and November 2003 ACSG archeologists conducted this testing on the homestead component at 41TV1051. Based on their historical research, Staples and Nash (2003b) concluded that this site was not associated with McGehee but was probably the homestead of a man named John Hughs (also Hughes), who was probably an African American. Three 1x1-m test units were hand excavated (Figures 2.1 and 2.2). Two were dug inside the house area and west of the chimney base and rubble pile, and one was dug at the location of a suspected outbuilding. They recovered a broad range of historic artifacts dating to the late-nineteenth and early-twentieth centuries. The investigations also included clearing of leaf litter from around the house area to map the rocks associated with the structure, and a metal detector survey to map the locations of concentrations of buried metal artifacts in and around the house area. The latter involved no digging, and the metal artifacts were left in place. Based on the historical and archeological evidence, it was recommended that the 41TV1051 farmstead was not eligible for listing on the National Register of Historic Places or for designation as a State Archeological Landmark (Staples and Nash 2003b:61).

TxDOT asked historian Terri Myers, principal of Preservation Central, Inc., to conduct comprehensive historical research on Lots 20 and 16 of the McGehee Survey (Myers 2004; Myers et al. 2005). This research focused on Lots 16 and 20 because they were owned by John Hughs. During this research, however, Myers discovered that 41TV1051 was probably not located on either of these lots. These efforts to establish the ownership history of the farmstead continued from 2003 to 2005. However, these investigations did not provide conclusive evidence of precisely where this component was located relative to historic property maps. It was not until August 2005 that the precise location of the late-nineteenth-century archeological remains was determined. On TxDOT archeologists Jon Budd and Al McGraw visited 41TV1051 and used a global positioning system (GPS) instrument to obtain accurate UTM coordinates for the homestead component. It was at 


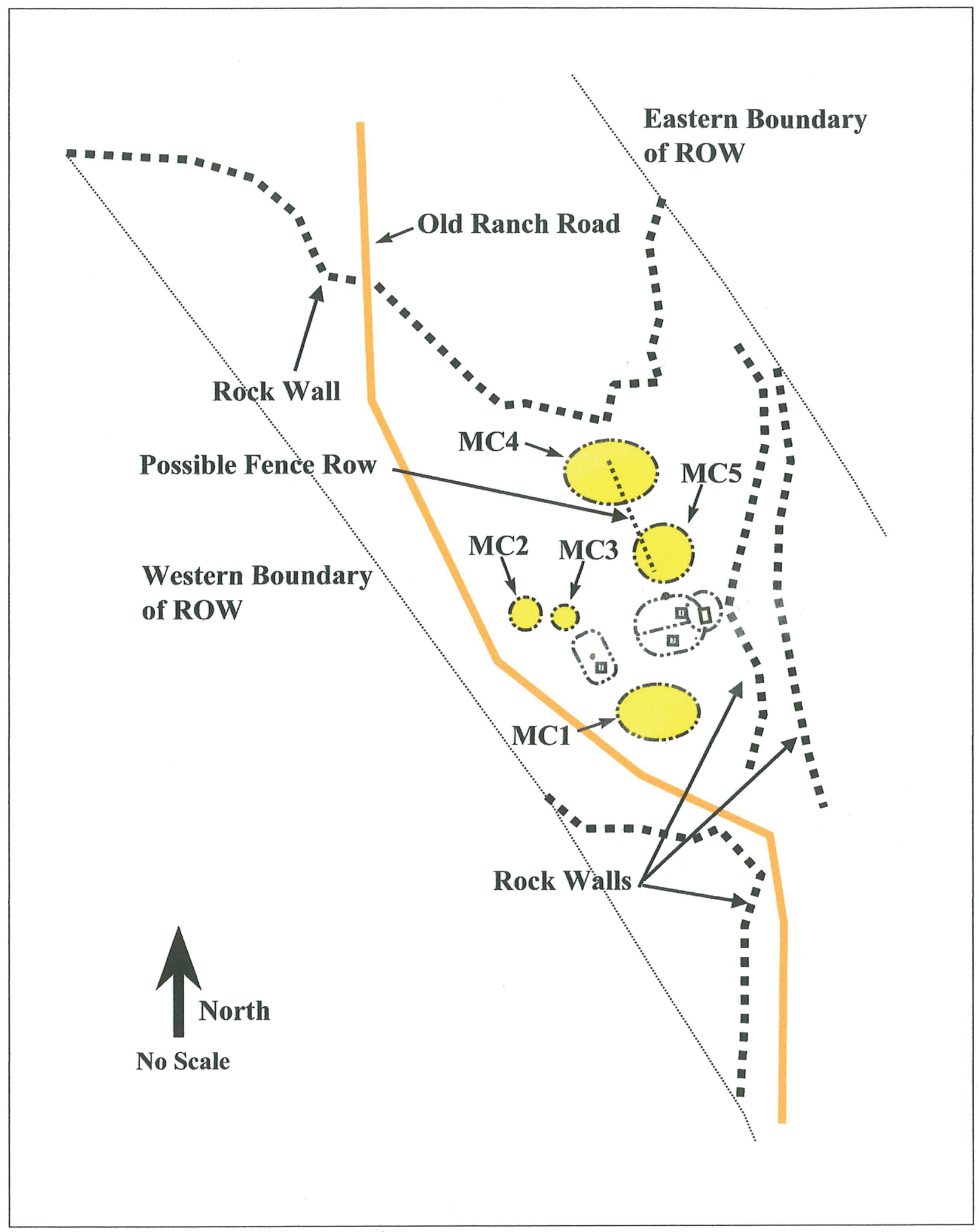

Figure 2.1. Map of the farmstead features and areas where buried metal artifacts were identified at 41 TV1051 by ACSG in 2003 (reproduced from Staples and Nash 2003b:Figure 20). 


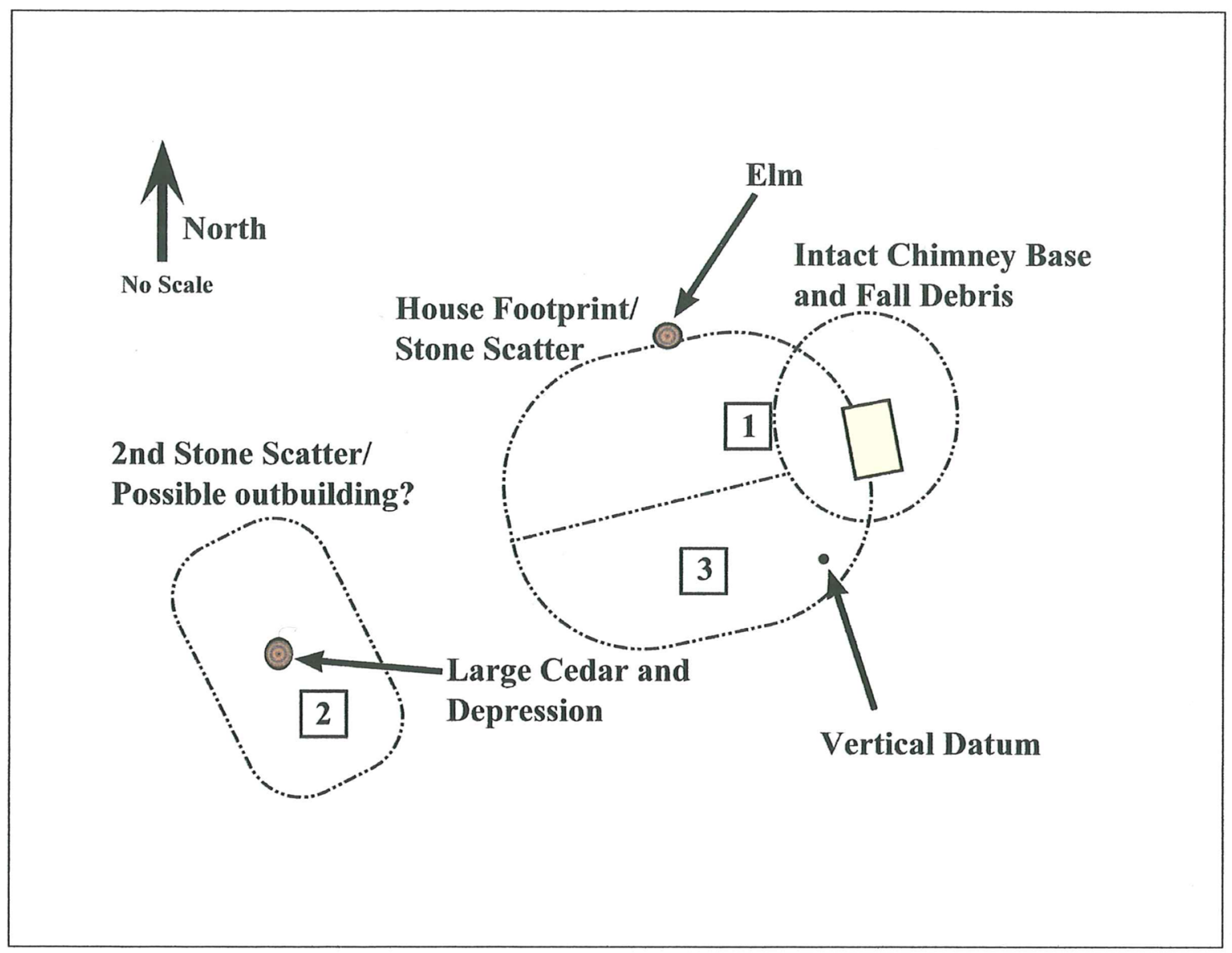

Figure 2.2. Map of archeological features and excavations in the main portion of 41 TV1051 by ACSG in 2003 (reproduced from Staples and Nash 2003b:Figure 4).

about this time that Prewitt and Associates, Inc. got involved with the project.

\section{INVESTIGATIONS BY PREWITT AND ASSOCIATES, INC.}

\section{Initial Historic Research}

TxDOT, Prewitt and Associates, Inc. (PAI), and Myers conducted the next round of research beginning in late 2005. Using the GPS coordinates for the site, an effort was made to rectify a series of modern aerial photographs and maps with historic aerial photographs and maps. One of the most important tasks was to plot the site location relative to the georectified 1871 McGehee League subdivision map and modern Travis County Appraisal District maps. Once this was accomplished, it confirmed something
Myers had suspected: that the homestead site features were indeed on Lot 11 of the 1871 subdivision of the John G. McGehee league.

Based on this information, Myers (2005) conducted follow-up research focusing on Lot 11 of the McGehee survey. Deed records revealed that the lot was part of a 45 -acre farmstead comprised of the 40-acre Lot 11 plus an additional 5 acres, and that Ransom Williams purchased this property in 1871. Research also showed that Ransom and his heirs owned the land up through the 1930s. Consequently, it became clear that the late-nineteenth and early-twentieth-century house site at 41TV1051 was the homestead of Ransom Williams. During the course of this research, Myers also discovered that Ransom Williams was an African American, but that most of his neighbors living in the McGehee Survey along Bear Creek were Euro-Americans. 
As of April 2006, TxDOT and Texas Historical Commission archeologists agreed that the Ransom Williams farmstead component of 41TV1051 was probably eligible for listing in the National Register of Historic Places (Jon Budd, personal communication 2006). TxDOT archeologist Jon Budd recognized the site's research potential but knew that more historical information and archeological data were needed to fully evaluate the site.

\section{Historic Context Development}

The next step was to conduct a more rigorous evaluation of the farmstead's eligibility listing in the National Register of Historic Places. Toward this goal, PAI and Myers collaborated to develop a historic context document. Rural Community Development in Southern Travis and Northern Hays Counties, Texas, 1865-1905: A Historic Context for the Ransom Williams Homestead (41TV1051) was completed in December 2006. In this report, Myers and Boyd (2006) provided the historic contextual background needed to evaluate the Ransom Williams farmstead relative to other historic properties in Travis and Hays Counties. It was recommended that the Ransom Williams farmstead was eligible for listing in the National Register and for designation as a State Archeological Landmark. The research revealed that Ransom Williams lived on and farmed the property, along with his wife, Sarah, and several children, for about 30 years. Historic documents also identified the Williams family as African Americans living along Bear Creek within a predominantly white rural community. Thus, the farmstead was somewhat of a historic anomaly, and the research reported by Myers and Boyd (2006) raised far more questions than it answered. It is rare in Texas that a historical site with good archeological integrity is identified as an African American-owned farmstead during the last quarter of the nineteenth century. Based on this fact and the previous archeological findings, Myers and Boyd (2006) recommended more extensive archeological test excavations and additional archival research.

The historic context document not only defined the registration requirements for eligibility for farmsteads in southern Travis and northern Hays Counties between 1865 and 1905, but it also presented a series of four general research topics for historic archeology and iden- tified numerous research questions pertaining specifically to the Williams farmstead (Myers and Boyd 2006:40-44).

\section{Archeological Testing and Data Recovery}

The next phase of work was the archeological testing conducted in 2007 and 2008. This resulted in an interim report (Myers and Boyd 2008) that recommended the site was eligible for listing in the National Register of Historic Places and for designation as a State Archeological Landmark (SAL). TxDOT and THC agreed with the recommendation, and the project moved into the archeological data recovery phase. Planning and additional research began in 2008, and field archeological investigations were conducted in 2009. The archeological work completed during these phases is described in more detail in Chapter 3.

\section{Planning the Williams Farmstead Archeological Project: An Integrated Approach to Public Archeology}

By the time the testing work was completed, it was clear that the Ransom Williams farmstead was a rare historic archeological site in Texas. Because of its high archeological integrity and its association with, and ownership by, an African American family, the site had a great deal of research value. It was clear that the site's importance was tied to its potential to yield important information on African American history.

During the testing phase, PAI was essentially on a fact-finding mission to gather historical and archeological evidence. Once the basic history of the site and its African American connection were recognized, it was certain there would be many living people who had a vested interest in the history and archeology of the farmstead. It became clear that the archeological project would need a substantial effort to seek out and involve the "descendant community." As the data recovery phase unfolded, the project was transformed into a collaborative effort that had three separate but well-integrated tasks: archeological field investigations, archival research, and public outreach and oral history.

The first step in planning the data recovery effort involved a simple phone call to Dr. 
Maria Franklin, an associate professor at the University of Texas at Austin in the Department of Anthropology and the African and African Diaspora Studies Departments. I asked Franklin if she would be interested in meeting to discuss collaborating on the project. We met for breakfast on October 29, 2008, and Franklin tentatively agreed to work as a consultant with PAI. That meeting transformed what started as a simple archeological investigation into a multidisciplinary project much richer and more meaningful that I could have imagined. Franklin's knowledge of African American archeology and history, as well as her insights as an African American and her skills as an oral history researcher, would add tremendously to the project. As an added bonus, Franklin also suggested that one of her anthropology doctoral students, Nedra Lee, might be interested in this project for her dissertation research and that other African American studies students might be able to help in the archeological investigations. It turned out that Lee was interested, and she agreed to join PAI, working full time during the field investigations and part time during the data analysis phase. ${ }^{5}$ Several other students interested in African American archeology were hired to assist in the field investigations.

With TxDOT providing project oversight, the Ransom Williams farmstead data recovery became a truly collaborative effort among PAI, the University of Texas Anthropology and African and African Diaspora Studies Departments, and historian Terri Myers. The project benefited greatly from this collaboration and from the varying perspectives and talents of the many individuals involved.

\section{African Diaspora Archeology and Research Issues}

The historical archeological investigations presented in this publication address a variety of research questions related to broad themes such as Settlement Patterns, Socioeconomics, and Ethnicity; Consumer Behavior; Technology, Modernization, and Industrialization; and Landscape History. While these and other topics are indeed relevant research issues, historical

${ }^{5}$ Lee has completed her doctoral dissertation focusing on the material culture from the Williams farmstead (Lee 2014). and archeological data often have even more value when examined from a broader thematic perspective. In African American archeology, an organizing theme that is often used to guide research is African American Transitions in the African Diaspora. For this project, we selected a variation on this theme: Post-Emancipation Transitions in the African Diaspora. ${ }^{6}$

We did not create this title or the concept, however. Our chosen theme was the title of a symposium at the Society for Historical Archaeology's annual meeting held in Albuquerque, New Mexico, in January 2008. Dr. Terry Weik (University of South Carolina) organized the symposium, and the two discussants were Dr. Theresa Singleton (Syracuse University) and Carol McDavid (Yates Community Archaeology Project, Rutherford B. H. Yates Museum, Houston). Each of the 11 papers in this session, all presented by African Americanist archeologists, focused on some aspect of the post-emancipation period to examine the slow transition from African slavery to African American citizenship. Although considerable attention has been paid to the centuries of African enslavement in the Americas, and rightfully so, historical archeologists have only recently begun the difficult task of documenting and interpreting the transitional experiences of African Americans in the post-emancipation period.

\section{Community Involvement and Public Outreach}

Because they are intimately intertwined, the community involvement and public outreach for the Ransom and Sarah Williams farmstead project are discussed together. But they are, in fact, different things. All publicly funded archeological research that is carried out in compliance with federal and state laws is done "in the public interest." What this means in practical terms is that our findings from publicly funded archeological research projects should be shared with the general public. This is the broad concept of public outreach, and it is different from the narrower concept of descendant community

\footnotetext{
${ }^{6}$ African diaspora refers to the historical movements of people out of Africa to all other parts of the globe. The African diaspora includes the forced movements of west and central Africans who were captured, shipped across the Atlantic, and enslaved in the Americas.
} 
involvement. The latter narrows the focus from the general public to those people who have a specific interest in, and connection with, a specific archeological project because of shared history and ancestry.

One significant goal for the overall Ransom and Sarah Williams Farmstead Archeological Project was to involve any "interested party" in this "public archeology" project in which the African American community would be actively involved. The local African American community represents the major "interested party" in our project, following the legal terminology from Section 106 of the National Historic Preservation Act. In effect, the interested parties are the public stakeholders who have a legitimate interest in the planning, execution, and outcome of the publicly funded archeological work being conducted on an African American farmstead. The descendant community would, of course, include any people who were direct descendants or close relatives of Ransom and Sarah Williams, but it also includes all those people who live or once lived in the same area and share or once shared a common history and ancestry. In this case, our descendant community includes African American peoples from the Manchaca area of southern Travis County and the Antioch Colony area of northern Hays County. These people all share a common bond of being descended from former enslaved African Americans and having come from rural agricultural backgrounds. For our project, we specifically sought to identify, involve, and integrate these communities, particularly people with rural agricultural roots. In doing so, we found that the life stories of the descendant community members parallel those of the Williams family descendants and relatives.

In 2008 and 2009, we planned and initiated a major oral history component of the project. This work resulted in the publication of a two-volume book of oral history transcripts that documented early-twentieth-century farm and ranch life in southern Travis and northern Hays Counties, as well as the transition to urban life in Austin (Franklin 2012). The oral histories bridge the gap between the late-nineteenth-century Williams family, their descendants, and the larger descendant community living in the area today. In effect, the oral histories enhance the archival and archeological records, adding immensely to the stories of African American life in central Texas after emancipation.

While we focused on identifying and seeking out the African American descendant communities, this does not mean that they are the only legitimate interested parties for the project. Early on in our research, we discovered an organization called the Manchaca Onion Creek Historical Association (MOCHA). Their members are predominately white, and they are descended from the farmers and ranchers who lived in the same area as the Williams family for many decades. We first learned of MOCHA through Marilyn McLeod, the great-granddaughter of Daniel Labenski, the man had owned the property adjacent to the Williams farmstead for more than 30 years. Ms. McLeod remembered hearing about her great-grandfather's neighbor, Ransom Williams, but she did not know that Williams was black. Like McLeod, all of the MOCHA members are interested parties in the Ransom and Sarah Williams farmstead project, and they share a common agricultural lifestyle with the African Americans from Manchaca and Antioch Colony and are likewise actively working to preserve the history and protect the resources of a large area that includes the Williams farmstead.

Once we had begun interacting with the descendant community and MOCHA members, the public involvement aspect of the project took on a life of its own. Word spread about the Williams farmstead project, and this increased our opportunities to do public outreach. To capture video footage of our archeological work that could be used in the future, we arranged for a camera crew from Liberal Arts Instructional Technology Services at the University of Texas at Austin to visit the archeological dig in progress. We invited several members of the descendant community to visit that day, and Franklin conducted onsite videotaped interviews with them. Interviews were also conducted with the project historian and archeologists, as well as archeologists from TxDOT and THC.

News of our project continued to spread, and Michael Emery, a producer for the KLRU television (the Public Broadcasting Service affiliate for central Texas), contacted us. He was interested in talking with us about the Williams farmstead project as a possible addition to the Juneteenth Jamboree program, a series that he started producing in 2008 to explore African 
American history and culture. Emery liked the Ransom Williams story, and KLRU followed up with several days of videotaping at the PAI office and laboratory and other locations in Austin. The Juneteenth Jamboree 2010 program, which aired on June 17, 2010, included a segment titled: "Once Upon a Time Ransom Williams Crossed State Highway 45 Southwest" (Emery 2010). The 28.5-minute-long segment featured the story of Ransom and Sarah Williams as it was revealed by archeological and historical data in conjunction with interviews with the project archeologists, historian, MOCHA members, and people from the descendant community.

When UT's College of Liberal Arts found out about our project, they were interested in the involvement of the UT anthropologists as research consults. This led to an eight-page story in the Fall 2010 edition of Life and Letters (a magazine published by the UT College of Liberal Arts). This article, titled "Digging Up the Past, Close to Home: Artifacts, Descendants Tell Story of Freed Slaves in Texas" (Wahlberg 2010a), highlighted the work of Franklin and Lee. The College of Liberal Arts followed up with a more extensive version of the article that was posted online after the print version was published (Wahlberg 2010b).

At the annual meeting of the Society for Historical Archeology, held in Austin in January 2011, the Williams farmstead project team participated in one-day public archeology event called "Crossroads in Texas History and Archeology Expo.” For this event, PAI prepared display posters, an artifact exhibit focused on the farming and carpentry tools from the Williams farmstead, and even a short lesson plan on how archeologists use spatial analyses of historic artifacts to identify activity areas. Along with PAI and TxDOT personnel, volunteer Joe Rogers from Hereford, Texas, also participated in this event. In period dress and using real period tools, Rogers portrayed an 1880s carpenter, giving hands-on demonstrations of how the tools found at the Williams farmstead were used.

Over the past few years, key project personnel have been invited to present programs on the Williams farmstead to a variety of public and professional groups, including the Texas Archeological Society, Travis County Archeological Society, Houston Archeological Society, MOCHA, Learning Activities for Mature People at the University of Texas at Austin, the
Travis County Historical Commission, and the Society for Historical Archaeology. Key personnel have published a popular article about the project called "From Slave to Landowner: Historic Archeology at the Ransom and Sarah Williams Farmstead" (Boyd et al. 2011). Franklin continued working with current and former Antioch Colony residents on other research. She helped arrange for a remote sensing survey of the Antioch cemetery, and she has initiated an archeological project for UT anthropology students to assist in documenting historic sites associated with the colony, including the locations of the original Antioch school and church.

This series of events highlights one important observation about public archeology: When you make a real commitment to involve the descendant community in a project, the community involvement and public outreach take on a life of their own. This is a positive outcome, of course, but it can make it difficult to plan for these unexpected events, and outreach efforts can become time-consuming. While the oral history component was planned and funded by TxDOT, most of the other descendant community and public outreach activities described above were not planned in advance and were accomplished without any state funding or involvement. The community involvement and public outreach for the Ransom and Sarah Williams Farmstead Archeological Project have been extremely rewarding and mutually beneficial for all parties. The project team is currently working on plans for a museum exhibit at the George Washington Carver Museum and Cultural Center in East Austin and on creating an online exhibit for the Ransom Williams farmstead project on the website www.texasbeyondhistory.net. The Texas Beyond History exhibit will include four lesson plans, two for the 4th grade and two for the 7th grade, that meet Texas's school curriculum requirements and can be downloaded by teachers. Part of the funding for these public outreach products was provided by a grant from the Travis County Archeological Society and a Certified Local Government grant through the Travis County Historical Commission and THC.

For CRM archeology on African American sites, there are five important lessons that may be gleaned from the Williams Farmstead Archeological Project. (1) The community involvement and public outreach were well funded, and planning began as soon as the 
site was determined eligible for the National Register. (2) The involvement of the descendant community and the oral history component were integrated aspects of the historical research for the project. (3) The oral history interviews were a legitimate form of data recovery in which the collection of people's memories salvaged important historical information that would have been lost otherwise. (4) The descendant community and other interested parties had a voice in the development of the historical and archeological research and the direction the public outreach efforts would take. And finally, (5) as the lead and funding agency in the CRM process, TxDOT had the critical role in determining the extent to which the descendant community would be involved and the extent of the public outreach efforts. 



\title{
WORK ACCOMPLISHED AND METHODS OF INVESTIGATION
}

\author{
Douglas K. Boyd, Aaron R. Norment, and Terri Myers
}

\section{3}

The multidisciplinary testing and data recovery investigations at the Ransom and Sarah Williams farmstead span from 2007 to 2014. For discussion purposes, the work can be divided into four major tasks: (1) the archival research; (2) descendant community outreach and oral history research; (3) the archeological investigations, including a landscape analysis; and (4) the public outreach activities. This chapter describes the methods of investigation used and briefly summarizes the work accomplished.

\section{BRIEF SUMMARY OF THE INVESTIGATIONS}

\section{National Register Testing}

Prewitt and Associates, Inc. (PAI) archeologists conducted National Register testing in December 2007 and April 2008. The work focused only on the Williams farmstead, which is only one component of the larger site 41TV1051. The work consisted of:

- A pedestrian survey of the site area within the proposed State Highway 45 Southwest right of way to identify aboveground features;

- A nonsystematic metal detector survey of selected areas and targeted anomaly testing to recover metal artifacts and identify concentrations of artifacts;

- Limited site mapping of the landscape and cultural features;

- Archeological testing in front of the chimney base and limestone rubble pile (four 1x1-m units) to sample the household artifacts and determine their integrity;

- Excavation of four backhoe trenches to examine foundations of rock walls, the suspected location of a livestock pond, and a possible outbuilding location;

- Intensive archival research to define the history of the farmstead property and the Williams family.

The PAI testing excavations included 4 backhoe trenches and 11 test units, bringing the total number of test units at the site to 14 when the 3 Archaeological and Cultural Sciences Group (ACSG) units (see Figure 2.2) are included. These excavations are summarized in Tables 3.1 and 3.2. Four of the $1 \times 1-m$ test units (TUs 4-7) were located in a north-south row immediately in front of the chimney base, and one 1x1-m unit (TU 14) was excavated in the chimney firebox down to the top of the rubble fill that lined the bottom. The other six test units were 50x50-cm units excavated where metal detector hits were recorded in the vicinity of the "metal concentrations" previously identified by ACSG archeologists (see Figure 2.1).

The testing phase provided unequivocal evidence of a late-nineteenth-century farmstead that was owned and occupied by an African American family. The work demonstrated that this farmstead component had a high degree of archeological integrity, and that additional excavations would probably yield a substantial artifact assemblage. Based on the testing phase data, the Williams farmstead component was deemed to be eligible for listing in the National Register 
Table 3.1. Backhoe trenches excavated during the 2007-2008 testing phase at the Williams farmstead

\begin{tabular}{c|c|c|l|l}
\hline $\begin{array}{c}\text { Backhoe } \\
\text { Trench }\end{array}$ & $\begin{array}{c}\text { Length } \\
(\mathrm{m})\end{array}$ & $\begin{array}{c}\text { Depth } \\
(\mathrm{cm}) *\end{array}$ & $\begin{array}{c}\text { Trench Location } \\
\text { and Association }\end{array}$ & \multicolumn{1}{c}{ Deposits Observed } \\
\hline BHT 1 & 7 & 60 & $\begin{array}{l}\text { Adjacent to west side } \\
\text { of prominent rock } \\
\text { wall, 75 m north of } \\
\text { house. Trench placed } \\
\text { in hypothesized pond } \\
\text { area. }\end{array}$ & $\begin{array}{l}\text { Black } 7.5 \text { YR 2.5/1) clay loam to clay from } \\
\text { 0 to 60 cm. Abundant roots in upper 30 cm } \\
\text { but no inclusions. Trench ended on sharp } \\
\text { contact with weathered limestone bedrock } \\
\text { at 60 cm. }\end{array}$ \\
\hline BHT 2 & 4 & 50 & $\begin{array}{l}\text { In open area between } \\
\text { prominent rock walls, } \\
\text { ca. 65 m north of } \\
\text { house. }\end{array}$ & $\begin{array}{l}\text { Black }(7.5 \text { YR 2.5/1) clay loam from 0 to 15 } \\
\text { cm. Weathered limestone bedrock from 30 } \\
\text { to 50 cm. Trench ended on hard bedrock } \\
\text { layer at 50 cm. }\end{array}$ \\
\hline BHT 3 & 4 & 40 & $\begin{array}{l}\text { Between prominent } \\
\text { rock walls ca. 50 m } \\
\text { northwest of house. }\end{array}$ & $\begin{array}{l}\text { Black (7.5 YR 2.5/1) clay loam from 0 to 25 } \\
\text { cm. Weathered limestone bedrock from 25 } \\
\text { to 40 cm. Trench ended on hard bedrock } \\
\text { layer at 40 cm. }\end{array}$ \\
\hline BHT 4 & 4 & 40 & $\begin{array}{l}\text { West of house and } \\
\text { south of possible } \\
\text { outbuilding area. } \\
\text { Trench is located } 3 \mathrm{~m} \\
\text { west of ACSG Test } \\
\text { Unit 2. }\end{array}$ & $\begin{array}{l}\text { Very dark gray (7.5 YR 3/1) clay loam } \\
\text { from 0 to 25 cm. Reddish brown (5 YR 4/4) } \\
\text { clay from 25 to 40 cm. Trench ended on } \\
\text { weathered limestone layer at 40 cm. }\end{array}$ \\
\hline
\end{tabular}

*Maximum depth of excavation (below surface).

of Historic Places and for designation as a State Archeological Landmark by the Texas Department of Transportation (TxDOT) and the Texas Historical Commission (THC). The project immediately moved into planning of a data recovery effort in the winter of 2008. A final data recovery logistical plan was completed by Boyd and Franklin (2009) in May 2009 and was subsequently approved by TxDOT and THC.

\section{Data Recovery Investigations}

Data recovery fieldwork began on June 3 , 2009, and continued through August 28, 2009. In many ways, the kinds of archeological features and artifacts that were present on the site and the goals of the data recovery effort dictated the planning of the fieldwork. The data recovery effort consisted of the following tasks:

- Intensive archival research to detail the history of the Williams family in Travis County, their ownership and occupation of the farmstead, their associations with white neighbors in the rural Bear Creek community, and their associations with the nearby black communities at Antioch Colony and Manchaca.

- A comprehensive community outreach effort and oral history interviews to gather historical evidence of twentieth-century life in southern Travis and northern Hays Counties, focusing on people with ties to the freedmen communities of Antioch Colony, Manchaca, and East Austin.

- A comprehensive landscape analysis and detailed site mapping to document site topography, vegetation, and soils along with the large-scale cultural features to provide evidence of the farm layout and organization.

- Additional backhoe trenching to learn more about the linear rock wall and rock mound features.

- Intensive archeological excavations focusing on the Williams house, the yard area, the nearby trash midden, and a suspected outbuilding location.

- Public outreach efforts to disseminate the significant historic archeological findings from the Williams farmstead project. 
Table 3.2. Test units excavated at the Williams farmstead

\begin{tabular}{|c|c|c|c|c|}
\hline $\begin{array}{l}\text { Test } \\
\text { Unit }\end{array}$ & Unit Size & $\begin{array}{l}\text { Depth (cm below } \\
\text { ground surface) }\end{array}$ & Provenience & Cultural Materials Recovered \\
\hline $\mathrm{TU} 1^{*}$ & $1 \mathrm{x} 1 \mathrm{~m}$ & 24 & Inside house, north central area & Abundant historic artifacts \\
\hline TU $2 *$ & $1 \mathrm{x} 1 \mathrm{~m}$ & 13 & Isolated unit west of house & Abundant historic artifacts \\
\hline TU $3 *$ & $1 \mathrm{x} 1 \mathrm{~m}$ & 20 & Inside house, southwest area & Abundant historic artifacts \\
\hline TU 4 & $1 \mathrm{x} 1 \mathrm{~m}$ & 63 & Inside house in front of chimney & Abundant historic artifacts \\
\hline TU 5 & $1 \mathrm{x} 1 \mathrm{~m}$ & 61 & Inside house in front of chimney & Abundant historic artifacts \\
\hline TU 6 & $1 \mathrm{x} 1 \mathrm{~m}$ & 48 & Inside house in front of chimney & Abundant historic artifacts \\
\hline TU 7 & $1 \mathrm{x} 1 \mathrm{~m}$ & 38 & Inside house in front of chimney & Abundant historic artifacts \\
\hline TU 8 & $50 \times 50 \mathrm{~cm}$ & 15 & $\begin{array}{l}\text { At detector hit in ACSG Metal } \\
\text { Concentration No. } 5\end{array}$ & 1 large cast-iron fragment \\
\hline TU 9 & $50 \times 50 \mathrm{~cm}$ & 17 & $\begin{array}{l}\text { At detector hit in ACSG Metal } \\
\text { Concentration No. } 5\end{array}$ & 2 cast-iron fragments \\
\hline TU 10 & $50 \times 50 \mathrm{~cm}$ & 15 & $\begin{array}{l}\text { At detector hit in ACSG Metal } \\
\text { Concentration No. } 4\end{array}$ & $\begin{array}{l}1 \text { cut nail fragment, } 2 \text { can } \\
\text { fragments, } 1 \text { brown glass } \\
\text { fragment }\end{array}$ \\
\hline TU 11 & $50 \times 50 \mathrm{~cm}$ & 15 & $\begin{array}{l}\text { At detector hit in ACSG Metal } \\
\text { Concentration No. } 4\end{array}$ & $\begin{array}{l}3 \text { small iron (probably can) } \\
\text { fragments }\end{array}$ \\
\hline TU 12 & $50 \times 50 \mathrm{~cm}$ & 15 & $\begin{array}{l}\text { At detector hit in ACSG Metal } \\
\text { Concentration No. } 1\end{array}$ & $\begin{array}{l}1 \text { unidentified iron fragment, } 1 \\
\text { iron cotter pin }\end{array}$ \\
\hline TU 13 & $50 \times 50 \mathrm{~cm}$ & 22 & $\begin{array}{l}\text { At detector hit in ACSG Metal } \\
\text { Concentration No. } 2 / 3\end{array}$ & $\begin{array}{l}1 \text { cut nail fragment, } 1 \text { cast-iron } \\
\text { fragment, } 2 \text { unidentified iron } \\
\text { fragments } * *\end{array}$ \\
\hline TU 14 & $1 \mathrm{x} 1 \mathrm{~m}$ & 75 & Interior of chimney firebox & Abundant historic artifacts \\
\hline
\end{tabular}

* Test Units 1-3 were excavated by ACGS archeologists in 2003 (Staples and Nash 2003b).

** Three chert flakes also were observed in TU 13. They are associated with an ephemeral prehistoric lithic scatter that is a component of $41 \mathrm{TV} 1015$.

\section{METHODS AND WORK ACCOMPLISHED}

\section{Archival Research}

Several phases of archival research have been conducted for the Williams farmstead project with PAI consultant Terri Myers (Preservation Central, Inc., Austin) serving as project historian. Myers conducted some research prior to PAI becoming involved in the project (Myers 2004), and she later conducted research for PAI. Intensive research in 2005 identified the correct location of the farmstead on old Travis County plat maps and revealed that the property had belonged to Ransom Williams (Myers 2005; Myers et al. 2005). This information was then used as the basis for developing a historic context that defined the site history and presented a series of archeological and historical research topics pertinent to the Williams farmstead (Myers and Boyd 2006). Additional archival research was done in conjunction with the 2007-2008 site testing; this was presented in an interim report on the testing (Myers and Boyd 2008). Once the data recovery phase began, the archival research shifted to developing a comprehensive history of the Williams family and their history on their farmstead, as well as a history of the nearby Antioch Colony freedmen community. Myers (2009) completed a preliminary report on this research. The results of all previous phases of the archival research are incorporated into the historical narratives in Chapters 4 and 5.

Near the end of 2005, it became apparent that the nineteenth-century farmstead component of 41TV1051 was on land purchased by Ransom Williams in 1871 and that Williams had a direct familial connection to the community 
of Antioch Colony, established about 1870 in northern Hays County. This African American freedman's community lies about 4 miles south of the Williams homestead, near the HaysTravis county line. Subsequent efforts focused a substantial amount of research on the Williams family, of course, but also on Antioch Colony, the lifeways of its inhabitants, and their agricultural practices. The research sought to find any evidence of connections, genetic or social, between the Williams family and the people of Antioch Colony. Later the archival research was expanded to include researching the African American community at Manchaca, located only about 3 miles east of the Williams property. In addition, a fairly substantial effort was aimed at reconstructing the Williams family genealogy and finding direct lineal descendants of Ransom and Sarah Williams.

The project historian consulted many archival repositories and reviewed a wide range of primary records and secondary references in an attempt to gather historical evidence pertaining to these topics. The repositories and primary records examined for this project include: ${ }^{7}$

1. Austin History Center: slave narratives, oversized maps, plat maps, 1875 Schedule of Inhabitants in the City of Austin (independent city census), Hays County independent school district records and maps, Travis County independent school district records and maps, Travis County road maps

2. Hays County Clerk's Office (San Marcos): deed records, Register of Marks and Brands, and indexes to maps and plats, file registers, records of private surveys and applications, and records of original Survey No. 2

3. Hays County Tax Appraisal Office (San Marcos): modern plat maps

4. San Marcos Public Library: vertical files of the Tula Townsend Wyatt Collection, including these files-Labenski Cabin, African Americans, Bunton Family, John Wheeler Bunton, Dunbar High School, Ku Klux Klan, Land Grants in Hays County, and Old Mountain City

${ }^{7}$ Some of the records listed here are housed at the repositories, but others are available in digital format online.
5. Texas Historic Overlay: A Geographic Information System of Historic Map Images for Planning Transportation Projects in Texas (available from the Texas Department of Transportation, Austin): various historic maps

6. Texas General Land Office (Austin): county maps

7. Texas State Library and Archives (Austin): population census and agricultural census records, ad valorem tax records for Hays and Travis Counties, rural school records for Hays and Travis Counties, voter registration lists for Hays and Travis Counties, school district records for Hays and Travis Counties, Texas Department of Education records

8. Travis County Clerk's Office (Austin): deed records, Register of Marks and Brands, plat maps, survey maps, Commissioner's Court Minutes, Probate Court Records, various

9. Travis County Tax Appraisal Office (Austin): modern plat maps

\section{Request for Public Input and MOCHA Involvement}

In conjunction with the oral history program conducted under the guidance of Dr. Franklin (discussed below), the project historian sought additional public input to augment the historiography of this project. In May 2009, flyers requesting historical information were created and posted in public places in Manchaca, Buda, and Creedmoor. After seeing these flyer, members of the Manchaca Onion Creek Historical Association (MOCHA) contacted the historian and supplied information about the Labenski family, who were neighbors to the Williams family for the last three decades of the nineteenth century. Franklin and Myers then made a presentation to the MOCHA group on June 6, 2009. Subsequently, members of the organization were invited to the Williams farmstead to tour the site and observe the archeological investigations, and they later visited the PAI laboratory to see the artifact assemblage (see Public Outreach Activities below). The MOCHA members took a great interest in the Williams farmstead project, and one of them 
helped identify one of the problematic historic artifacts. MOCHA member Marilyn McLeod, a descendant of Ransom Williams's neighbor Daniel Labenski, provided the project historian with her research notes and several of her written papers on local history.

\section{Use of Secondary Sources}

Several secondary sources were found to be extremely important and provided names, dates, and basic information on Antioch Colony and the Bear Creek area. These include many articles in The Handbook of Texas Online, including: "Antioch Colony" (Jasinski 2008); "Bluff Springs" (Smyrl 2006a); "Buda" (Greene 2006a); "Elm Grove" (Armbruster 2008); "John Wheeler Bunton" (Strom 2008); "Cedar Valley" (Smyrl 2006b); "Creedmoor" (Parker 2006); "Driftwood (Greene 2006b); "Hays County" (Cecil and Greene 2006); "Kyle" (Strom 2006); "Manchaca" (Smyrl 2006c); "Thomas Gilmer McGehee" (Swift 2006); "Mountain City" (Greene 2006c); "Freedmen's Bureau" (Harper 2009); "San Marcos (Greene 2006d); "Slavery" (Campbell 2011); "Travis County" (Smyrl 2006d); "Turnerville" (Smyrl 2006e); and "Wimberley" (Kerbow 2006). The historian also studied sections of Wilbert L. Jenkins's (2002) book, Climbing Up to Glory: A Short History of African Americans During the Civil War and Reconstruction. The book presents a good overview of the African American experience during Reconstruction and the role the Freedmen's Bureau played in their resettlement.

Other secondary sources include general histories of Hays County such as Clear Springs and Limestone Ledges: A History of San Marcos and Hays County (Stovall et al. 1986); People and Places In and Around Historic Buda (Giberson and Younts 2003); and Kyle: The Prairie City (Strom 1981). A section in Freedom Colonies: Independent Black Texans in the Time of Jim Crow (Sitton and Conrad, 2005) and an article in the Austin American-Statesman in September 2000 (Gee 2000) directly addressed the Antioch Colony. Both selections were based largely on interviews with descendants of the original community, some of whom still live in the area. Another important reference is Bonnie Carpenter's (1939) thesis titled Old Mountain City: An Early Settlement in Hays County, which was published as a book in 1970. Based on interviews conducted in the 1930s, Carpenter's (1970) book is useful in understanding the Southern culture of northern Hays County before and after the Civil War. Several references were made to slavery, individual slaves, and places, including mentions of Ransom Bunton Sr. and the "Negro Colony" (referring to Antioch Colony).

The historian traced the names of many key individuals listed in the sources above. Principal among the freedmen were Dave and Mary Bunton, Elias (Lias) and Clarisa (Claracy) Bunton, Ransom Bunton Sr., and a white man named Joseph F. Rowley. According to these secondary sources, the Buntons were instrumental in establishing the Antioch community and donated the land for establishing the community church and school. Brothers Dave and Elias Bunton were former slaves of James M. Bunton, who brought them from Kentucky to Texas in the 1850s. Another resident of Antioch Colony, Ransom Bunton Sr., was a slave of John Wheeler Bunton, who brought him to Texas as early as the 1830 s.

These secondary sources also contained information about several white families connected to the community. Most sources agree that Joseph F. Rowley was a white man who sold the land that became Antioch Colony to the freedmen. They also suggest that Rowley was a missionary and perhaps had some religious motives for establishing a freedman's colony. Unfortunately, no primary evidence has been found to confirm or dispute this claim.

Finally, the historian used many secondary sources to research the activities of the white Buntons, the prominent family that settled in northern Hays County in the 1850s. Virtually all of the secondary sources agree-and primary sources confirm - that John Wheeler Bunton and his brothers, Desha and James, were among the largest slaveowners in northern Hays County. They are of interest because the former slaves of their Mountain City plantation were among the first settlers in the Antioch community. Secondary sources indicate a direct connection between James M. Bunton and Dave and Elias Bunton, and between John Wheeler Bunton and another former slave, Ransom Bunton, Sr. The purpose of researching the white Bunton family was to learn more about the lives and occupations of their slaves before emancipation, and to consider how the relationships between 
these white and black families may have affected their ability to make a living and establish a community after emancipation.

\section{Use of Primary Sources}

Considerable research was done using primary sources, with the focus on official state and county records. The primary sources examined for the Williams farmstead project include U.S. census records, county deed and ad valorem tax records, marriage and death certificates, county court records, county school records, county registers of brands and marks, and the oral histories recorded in slave narratives.

\section{Census Records}

The primary records from the U.S. Bureau of the Census that were consulted for this project include the population census records for 1870 , $1880,1900,1910,1920$, and 1930 (the 1890 census records burned); the agricultural census records for 1870 and 1880; and the slave schedules from the 1860 census. It is notable that Ransom Williams family is absent from all of the census records from 1870 through 1900, both population and agricultural. Despite this, his farm ownership and activities were amply documented via deed and tax records (see Chapter 5).

The census records proved useful in many ways. They helped identify the families living in the Bear Creek, Antioch Colony, and Rose Colony communities and helped establish relationships among the families living in these communities. The census and deed records supplied information on the members of the white Bunton family from their origins in Tennessee and Kentucky to northern Hays County, where they established the Mountain City plantation. The census records also document the movement of Joseph F. Rowley and his family before they arrived in northern Hays County.

\section{County Deed Records}

County deed records housed at the Travis County courthouse were used to trace the property chain-of-title for the Williams farmstead, from the initial land grant to McGehee in 1835 to the purchase of 45 acres by Ransom Williams in 1871 . The deed records also document the purchase of 12 acres of adjacent lands by his sons in 1900 and the family estate's sale of the properties in the 1930s and 1940s. Deed records were also examined for many people in the Bear Creek community, some of whom were Williams's neighbors for more than 30 years.

Deed records for Hays County are on file at the Hays County Records Annex in San Marcos. Considerable time was spent at this facility, and the deed records were used to establish the history of Antioch Colony. The deed records show that Joseph F. Rowley began buying land in Hays County in 1859 (secondary sources indicate that he moved to Hays County from California in that year). About five years after emancipation, Rowley began selling land to black and white buyers alike. Between December 1870 and February 1871, he sold several adjacent farms in the southeast quarter of the P. J. Allen League to the freedmen. The people who bought the land-the Beards, Buntons, Cavanaughs (also spelled Kavanaugh), Champs, Smiths, and Southwoods-would become the core families of Antioch Colony. Finding these names in the deed records opened up new avenues of research for the Antioch community.

\section{County Ad Valorem Tax Records}

Counties in Texas assess and collect taxes annually on an ad valorem basis, meaning "according to value." The historical tax records for Hays and Travis Counties were reviewed to define the property (land, livestock, etc.) owned by Ransom Williams in Hays County from 1870 to 1873 and in Travis County from 1873 through 1910. Tax records were also reviewed for the 12-acre adjacent property owned by Ransom and Sarah's sons, Will and Charley. These tax records provide the best evidence documenting the financial stability and changes to the Williams farmstead over the 40-year period. These records also document the shift when Ransom Williams went from paying taxes only on the livestock he owned to paying taxes on his land as well.

\section{Marriage Records}

Few African Americans are listed in the early Hays County Marriage Records, and only the index 
covering $1867-1887$ is available to researchers. Using this index, the following married couples were identified as possible residents of Antioch Colony: J. Bunton m. G. Kavanaugh; E. Bunton m. P. Friend; G. Bunton m. Hamilton; L. Bunton m. F. Darcy; F. or T. Bunton m E. Friend (likely Tonny Bunton and Emma Friend); and R. Kavanaugh m. L. Beard. The Buntons, Kavanaughs, Beards, Friends, and Hamiltons are all known residents of the Antioch/Mountain City area.

Notably, no marriage record was found for Ransom and Sarah Williams in either Hays or Travis County. This may be because their marriage occurred in the early 1870s, before recordkeeping became standardized, or it may reflect the fact that they were married in an informal ceremony that never got recorded. In contrast, a marriage certificate was found for the union between their oldest son, Will, and Clara Franklin of Creedmoor in 1901.

\section{Death Certificates}

Online searches for death certificates using the FamilySearch.org website proved useful, with one major exception. Ransom Williams died around 1901, but no death certificate has been found. Death certificates did not become a mandatory requirement in the state of Texas until 1903, and it is quite possible that no death certificate exists for him. Death certificates were located for his wife, Sarah, and many of their children who died after 1903. The children's death certificates are the only primary documents that identify Sarah's maiden name as Houston. This discovery was not made until 2013 (when the death certificate search capabilities came online), and it led to some speculation that Sarah could have been a slave belonging to Sam Houston, who lived in Austin when he served as governor of Texas. Additional archival research was conducted to follow up on this revelation (see Chapter 5).

\section{Travis County District Court Records}

At one point, the project historian determined that the man named Ransom Williams could have been the same man who appeared in earlier records as Ransom Bunton. The project historian conducted research in the Travis County District Court to see if Ransom Williams might have changed his name from
Ransom Bunton. No evidence of such a name change was found in the court minutes. The lack of evidence does not mean that this name change did not occur, but an exhaustive search failed to find any definitive evidence that it did.

\section{Travis County School District Records}

Once it became clear that there had been a freedmen school at Manchaca, the historian turned to the Travis County School District Records (housed at the Texas State Library and Archives in Austin) to find more detailed information. These records revealed the existence of a "Rose Colony School" near Manchaca, and they identified all of the prominent people who served as school trustees. Since this school was closer to the Williams farm than was the school at Antioch Colony, it is likely that this is the school the Williams children attended. Unfortunately, none of the county school records document the names of the students who attended.

\section{County Registers of Brands and Marks}

Registers of Brands and Marks were found in the county clerk's offices for both Hays and Travis Counties. The Hays County register lists the brands assigned to the Buntons of Antioch Colony in 1868 and 1870, while the Travis County book identifies the mark registered to Ransom Williams as a "horse brand" in April 1872. This was one of the more important public documents discovered during all of the archival research. It suggests that Williams was a resident of Travis County that year and indicates that he had a special interest in horses. Interestingly, the brand registry does not classify Williams as "colored" as it does for other African Americans at the time. This suggests that Ransom Williams was a light-skinned mulatto man who was sometimes mistaken for white.

\section{Slave Narratives}

The WPA Slave Narratives, compiled as part of the Federal Writer' Project for the Works Progress Administration, are an excellent source of primary oral history pertaining to African American life during and after slavery. Unfortunately, the project historian found no 
listings for Hays or Travis Counties, and no WPA slave narratives were found to contain any information directly relevant to the Mountain City plantation or local freedmen communities such as Antioch Colony.

However, the project historian discovered a rare slave interview from Hays County that proved very useful. In 1941, Austin folklorist John Henry Faulk interviewed Mrs. Harriet Smith, who was born as a slave on the Mountain City plantation owned by John Wheeler Bunton and his brothers. Harriet's maiden name was Bunton, and she was the daughter of Elias and Clarisa Bunton, a prominent family in Antioch Colony. The original interview tape is archived at the Library of Congress and is transcribed online (Smith 1941), and the full transcript was also published, along with background information to provide historical context, in the oral history report for the Williams farmstead project (Smith 2012).

\section{Community Outreach and Oral History Research}

The community outreach and oral history components of the Williams farmstead project were planned in late 2008 and early 2009, before the onsite data recovery investigations began. The plans for this oral history research were first described in a management document called a "Logistical Plan for Archeological Data Recovery Investigations at the Ransom Williams Farmstead" (Boyd and Franklin 2009). The stated goal of this work was "to involve African Americans in the archeological project," including "members of the descendant community" (p. 6). For this project, the descendant community was not limited to people directly related to the Williams family. Rather, this group was defined in the broader sense as including any African Americans in the local area who have a shared heritage and have expressed an interest in the project. The involvement of the descendant community was viewed as a collaborative effort with three specific goals (Boyd and Franklin 2009:7-8):

- Goal No. 1. "To form a mutually beneficial working relationship with African American stakeholders whereby researchers and descendants can collectively define and guide the project's goals." The intent was that "through a shared commitment and decision-making process" the Williams farmstead project would become "significant to individuals who are historically connected to and heavily invested in this project."

- Goal No. 2. "To provide African Americans with opportunities to visit the Ransom Williams Farmstead site." This was considered to be one important way to "help facilitate more interactions between researchers and the community" to give the descendents "a better sense of the roles they can play in this project." Perhaps most importantly, site visitations were an important mechanism that would "increase the [descendant] community's knowledge regarding the importance of preserving historical and archeological resources pertaining to their heritage."

- Goal No. 3. To provide an opportunity to "train African American students in archaeological fieldwork" and engage these students "in research related to their own history." This goal was considered to be beneficial not only to the students but also to the anthropology profession in general and the Williams farmstead project in particular.

To meet the first goal, we developed a comprehensive oral history project that was tied to the Williams farmstead research. The initial step was to contact people who had historic connections with the Bear Creek area, Antioch Colony, or the black communities in Manchaca and East Austin. Myers had already identified some of these people, and others came forward after seeing information-request flyers that she had posted in public places. Following the leads from Myers' research, Dr. Franklin began calling and meeting people, slowly building a list of knowledgeable people who had grown up in the area in the early to mid-twentieth century. As word spread about our project, people began contacting Dr. Franklin. We soon realized that there were too many potential informants and that we could not interview them all.

The oral history project had four objectives of its own, the first of which was to use the project as a vehicle for engaging with the local African American community. This aspect turned out to be more successful than we could have imagined, opening up new avenues of research and outreach opportunities at every 
turn. As she met with each potential informant, Franklin would fill out an information sheet and describe the oral history project (its process and goals) to that person. She would then ask the informant why they felt this research was important and what they would like to see come out of our project. These initial meetings blossomed into an ongoing dialogue with the descendant community. ${ }^{8}$

The second objective of the oral history project was to conduct interviews, with available time and resources being the factors that would limit how much could be accomplished. From 2009 to 2011, Franklin (assisted by Nedra Lee) conducted interviews with 27 people, resulting in over 46 hours of audiotape that were then fully transcribed into written form. The interview questions were designed to elicit firsthand recollections of what life was like for black families and communities living in rural central Texas in the early to mid-twentieth century. Based on what we learned from the interviews and the ongoing dialogue with the descendant community, we were able to modify the directions of our oral history research and follow leads wherever they took us. For example, the initial interviews involved people with connections to the Antioch Colony, but we soon learned that the African American community at Manchaca played an equally important role and that many people from Antioch and Manchaca had direct connections to East Austin. Word of our project spread well beyond our circle of informants and led to many other public outreach opportunities (discussed below).

A third objective was to use these oral histories to help construct a historical context for the Ransom and Sarah Williams farmstead site. Many of the interview questions related to the material culture and the daily activities of farm life, and people's responses to those questions provide another important line of evidence for interpreting the archeological data. The results of this effort, presented in Chapter 12, again exceeded our expectations. The links between the oral recollections and the archeological remains are amazing, and the oral histories allow for a much richer and more accurate

\footnotetext{
${ }^{8}$ Communication with the descendant community continued throughout the project, but it also spawned other research. Franklin has been currently conducting historic archeological investigations at Antioch Colony and held University of Texas archeological field schools there in the summers of 2013 and 2014 .
}

interpretation of the post-emancipation life on the Williams farmstead.

Our fourth objective of the oral history project was to discover information about the Williams family through interviews, and if possible to identify and interview living descendants of the Williams family. Through a series of fortuitous events, Myers discovered the names of some of Ransom and Sarah's great-grandchildren, and she found out that several of them were living in Austin. We ended up interviewing three great-granddaughters, and their memories provide a tangible link between the nineteenth-century archeological remains at the Williams farmstead and the family's history through the twentieth century.

The oral history component of the Williams Farmstead Archeological Project culminated in 2012 with the publication of I'm Proud to Know What I Know: Oral Narratives of Travis and Hays Counties, Texas, ca. 1920s-1960s (Franklin 2012). This two-volume, 1,035-page book contains the full transcripts of oral history interviews with 27 people, along with introductory chapters that provide historical background on the African American communities in southern Travis and northern Hays Counties. Copies of the book were distributed in a public book-release event on July 19, 2013, hosted by the George Washington Carver Museum and Cultural Center in East Austin (Figure 3.1). This well-attended event honored all of the people who participated in the oral history project and their families.

The second goal of the descendant community outreach was to give people an opportunity to visit the excavations at the Williams farmstead. The informants and their families, as well as other groups such as the Manchaca Onion Creek Historical Association (MOCHA) were invited to visit the site in the summer of 2009 and later to visit the PAI laboratory to see the material remains that were recovered. Nine of the 27 oral history informants (with some other family members) and many members of the MOCHA group were able to visit and see the archeological work in progress. In July 2009 a film crew from the University of Texas (Liberal Arts Instructional Technology Services) conducted onsite interviews with descendant community members, PAI archeologists, and project reviewers from TxDOT's Archeological Studies Branch and THC. Once the fieldwork 


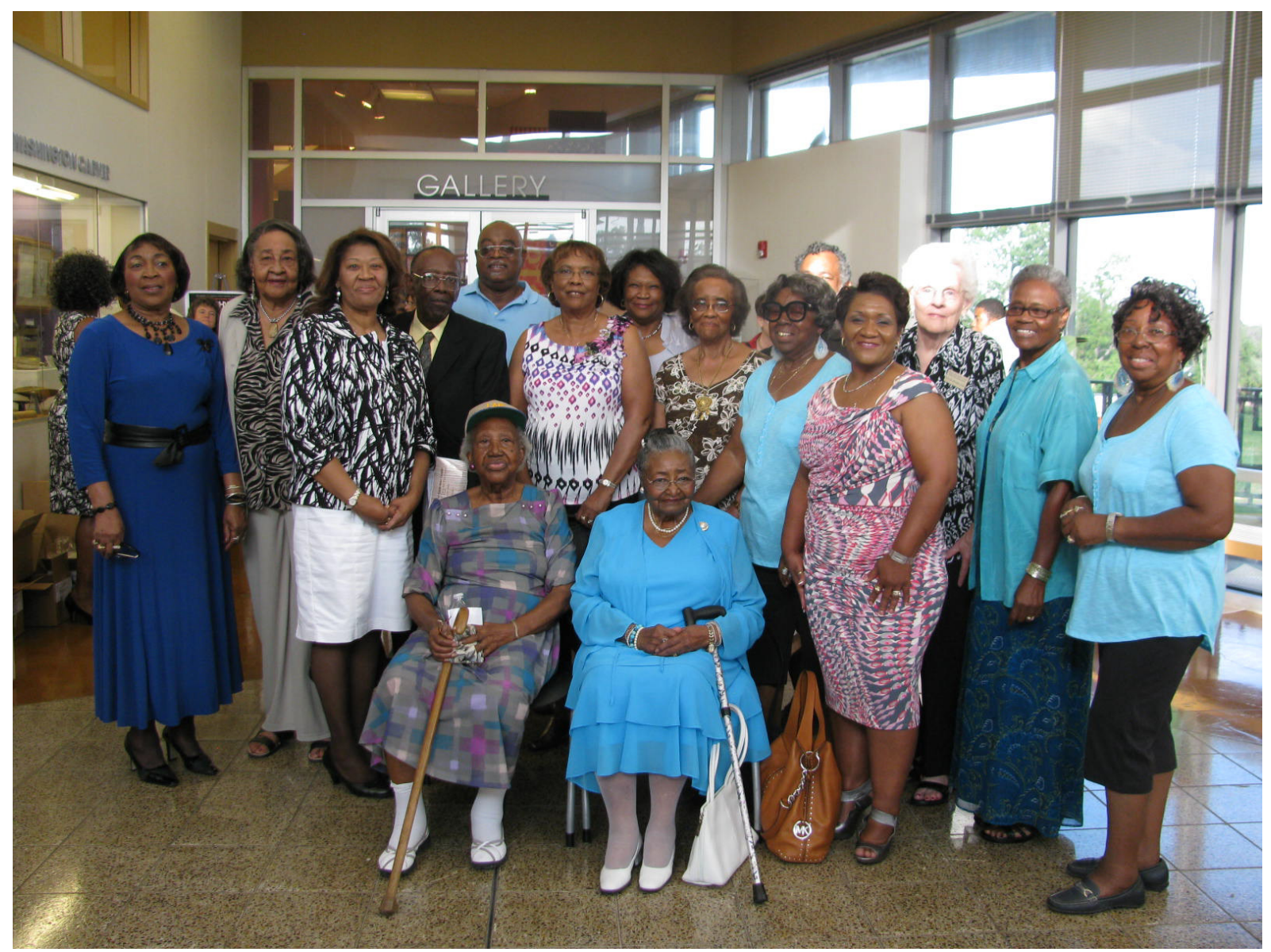

Figure 3.1. Photograph of many of the people who gave oral history interviews for the Williams Farmstead Archeological Project. This photo was taken at a book release event hosted by the George Washington Carver Museum and Cultural Center in Austin, Texas.

was over and the analyses began, the MOCHA group and many of the informants and their families visited the PAI laboratory. A film crew from KLRU-TV came to the PAI laboratory in January 2010 to conduct interviews and shoot scenes for a documentary. ${ }^{9}$

The third goal of the community outreach was to involve African American college students in the archeological fieldwork. To accomplish this, Dr. Maria Franklin helped select students to work as field crew members during the summer 2009 data recovery investigations, and if possible involve them in the subsequent analytical research. Two African American students (Felton Pierre and Ishan Gordon) who partici-

${ }^{9}$ The video footage shot by the UT-LAITS and KLRUTV are archived at their offices for future use. pated in the fieldwork were not anthropology majors, but one Hispanic student (Valera Prado) and two other African American students (Nedra Lee and Jodi Skipper) were. In particular, Nedra Lee became an important player in this project since she was looking for an archeological collection to analyze for her anthropology dissertation research. In 2009, Lee conducted a few of the oral history interviews, and she spent the whole summer working on the data recovery field crew. In 2010, she worked part time in the PAI laboratory doing the analysis of the glass containers from the Williams farmstead. In 2012, she conducted research focused on the historic African American newspapers in Austin, analyzing the articles and advertisements to reveal many facets of post-emancipation life in central Texas from the African American perspective. 
The results of this study, presented in Chapter 13 , provide another important link between primary historical documents and the archeological remains at the Williams farmstead. Since 2010 Lee has been engaged in her anthropology dissertation research, which involves an analysis of the Williams farmstead material culture to examine race, space, and identity in the rural Bear Creek community where the farm was located. Completed in 2014, her dissertation is titled "Freedom's Paradox: Negotiating Race and Class in Jim Crow Texas" (Lee 2014).

\section{Archeological Landscape Analysis}

The work accomplished and methods used for the landscape analysis are discussed in detail in Chapter 6. The work included an intensive pedestrian examination of the site area within the State Highway 45 Southwest right of way, metal detecting in selected areas, mapping and description of large rock features (including rock walls, rock alignments, and rock mounds), and description and mapping of large trees and tree features. As described in Chapter 6, the locational information derived from GPS and total station mapping was crucial for examining spatial relationships between many environmental and cultural variables. Environmental variables-such as geology, topography, soils, hydrology, and modern vegetation patterns-were examined and compared with a wide range of cultural variables. The latter includes the locations of large trees (estimated to be 150 to 300 years old), stacked rock walls and stone alignments, rock mounds, barbed-wire fence posts and fencelines, the house chimney and footprint, trash dumps, and surface artifacts. A big part of the study was tracing the evolution of the historic vegetation patterns, evident on historic aerial photographs, to define areas cultivated in the late nineteenth century.

When the data recovery work began, PAI researchers felt there were many ways in which the landscape analysis might contribute to a greater understanding of the Williams farmstead, but the extent to which the data might be useful was not clear. As it turns out, the landscape analysis became a critical source of data that corroborates and corresponds with the archival, oral history, and archeological evidence.

\section{Archeological Excavations}

The ultimate goal of the Williams farmstead project is to reveal the history of the Williams family by interpreting the archeological remains in light of the archival and oral history data. But it is important for the reader to understand the nature and geographic layout of the site so that the methods chosen to investigate the features and material remains will make sense. A series of maps is presented below to illustrate the cultural features and archeological excavations at different scales across the site. Figure 3.2 is an overview of the excavations and features across the entire site area within the Stateowned right of way. Figure 3.3 shows the main house area, and Figure 3.4 shows the unit numbers assigned to the $1 \mathrm{x} 1-\mathrm{m}$ units. Figure 3.5 shows the numbers of all the shovel tests excavated within the $20 \times 24-m$ grid around the house block. Figure 3.6 shows the excavations and cultural features in the northern portion of the farmstead site.

The excavations at the Williams farmstead were conducted to investigate various features, including the house area, the large trash midden, and the rock mounds and walls. They consisted of 113 shovel tests, 142 excavation units (1x1$\mathrm{m}$ ), and 6 quarter-units (50x50-cm), 9 backhoe trenches, and 3 backhoe scrapes (Table 3.3).

The mechanical excavations were all done with a backhoe to expose the soil stratigraphy profiles and determine the depth to the bedrock substrate. Nine trenches were excavated, four during the testing phase and five during data recovery. None of the backhoe trench fill was screened, and only a few selected artifacts were collected from the trenches.

Two of the trenches were excavated close to the house block: Backhoe Trench 4 west of the house and Backhoe Trench 8 northeast of the house (see Figures 3.2 and 3.3). These trenches showed that the thin layer of clayey soils overlying weathered bedrock was relatively consistent, although the soils were a little thicker in Trench 8. Backhoe Trench 8 also exposed large limestone rocks associated with a parallel set of rock alignments. The evidence suggests that the parallel rock alignments delineate an old north-south road that ran east of the house down past the east side of the corral complex (see Chapter 6). 


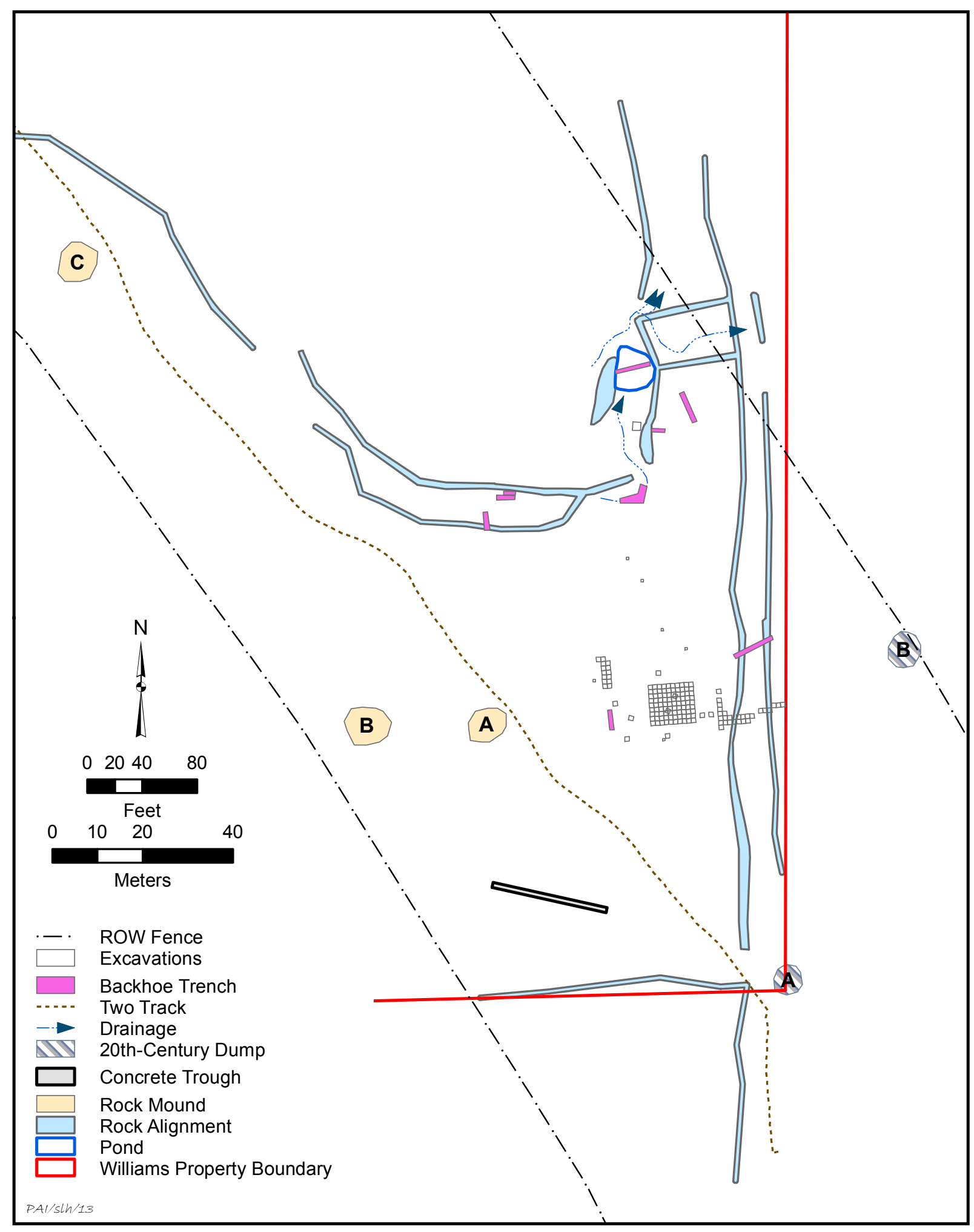

Figure 3.2. Overview map of excavations and landscape features inside the State-owned right of way at the Williams farmstead. 


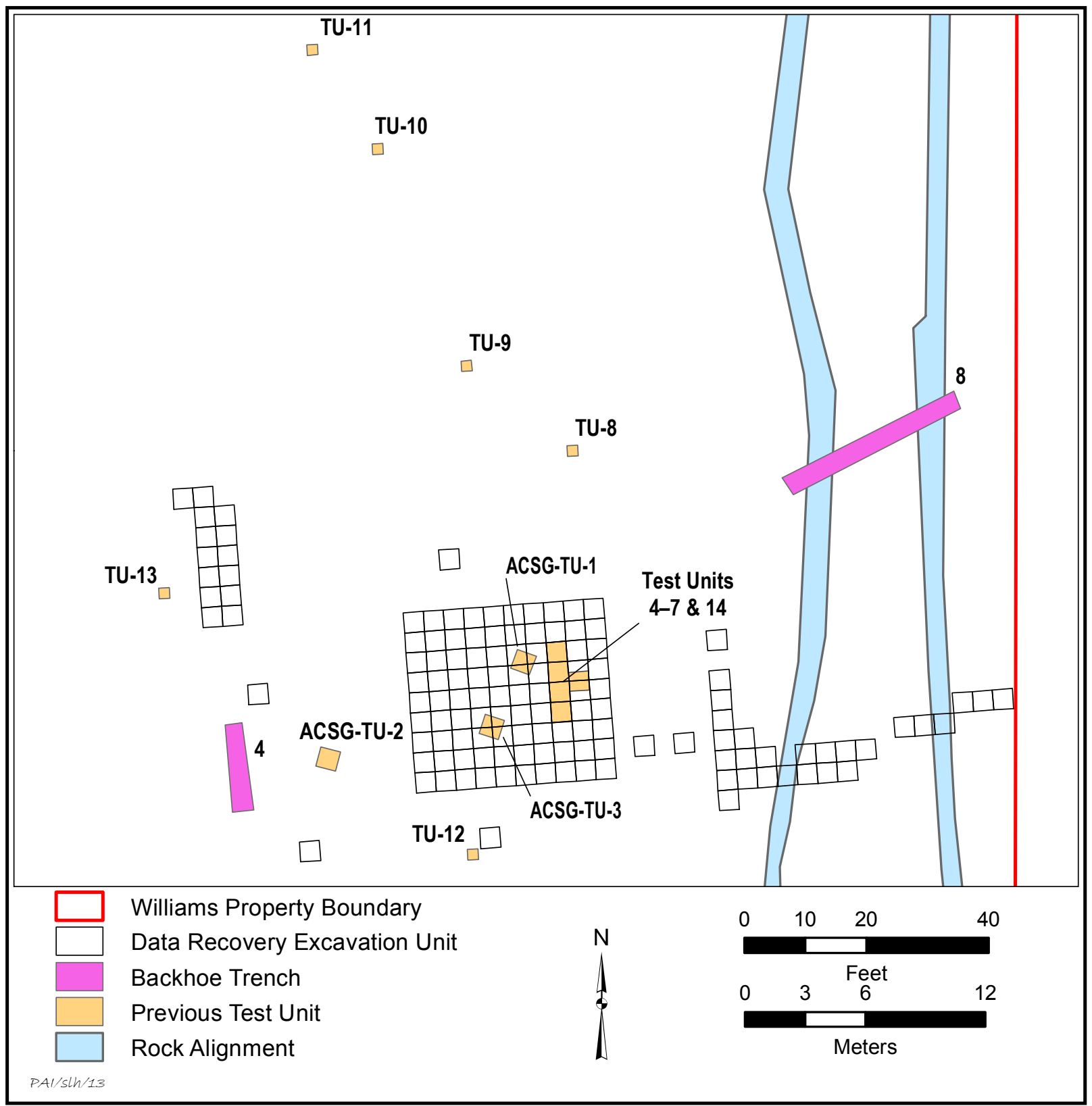

Figure 3.3. Map of the excavations in the main house area. The backhoe trenches and original test units are labeled. Test Units 1-3 were dug by ACSG archeologists in 2003. Test Units 4-13 were dug by PAI archeologists in 2007-2008.

Seven backhoe trenches were dug downslope from the house block in the area designated as the corral complex (see Figure 3.2). Backhoe Trench 1 was excavated at the location of a suspected pond, and the trench indeed revealed stratigraphic evidence to support the inference of a manmade livestock pond. Backhoe Trench 2 was excavated to examine the sediments in a suspected corral area, and Backhoe Trenches 3, 5,6 , and 7 were dug to expose the bases of the rock walls that formed the livestock fences and corrals. Trench 2 revealed thin soils above the rubified clay and weathered bedrock. Backhoe Trenches 3, 5, 6, and 7 were dug well below the bottom layer of rocks, revealing that the rock walls were built directly on top of the natural 


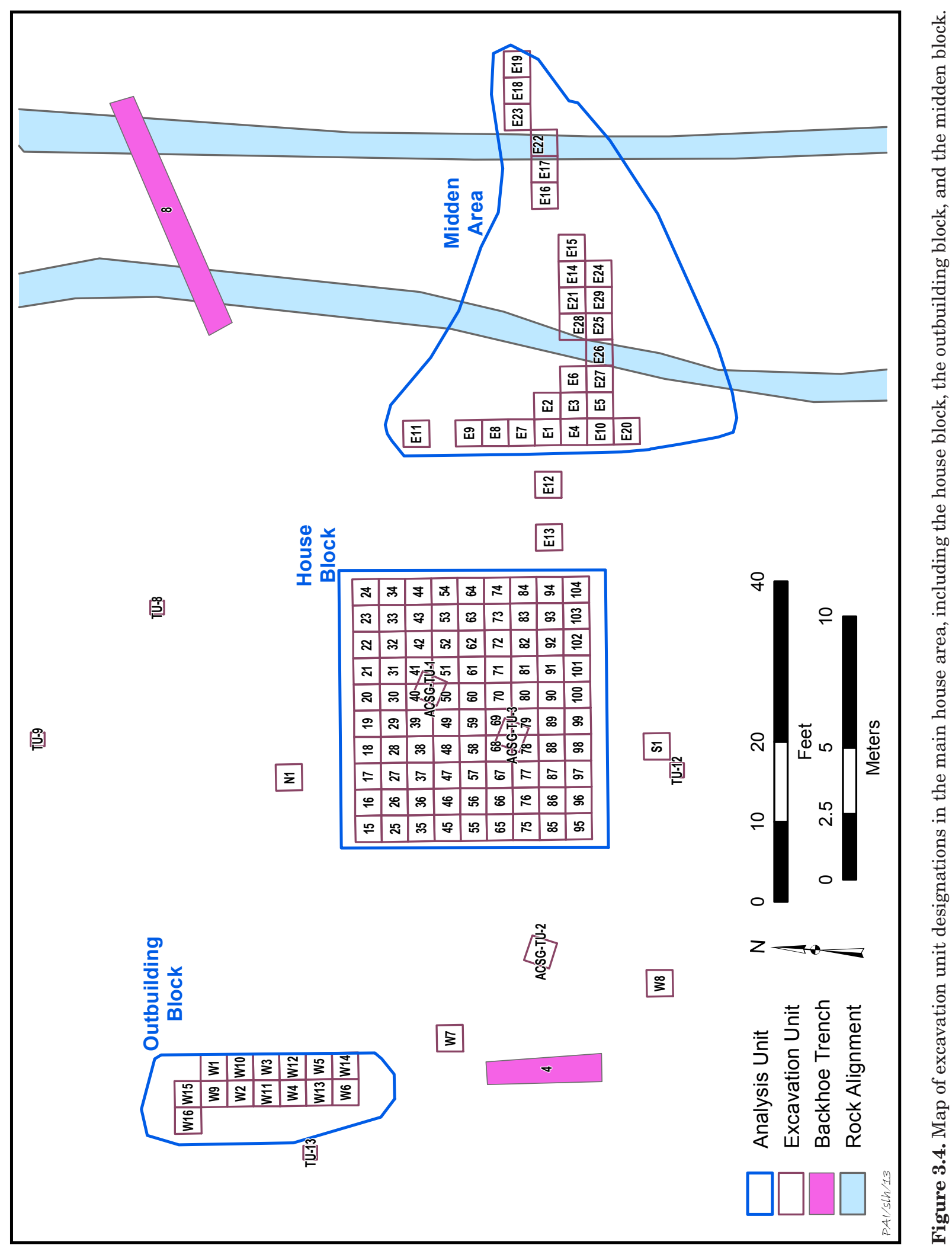




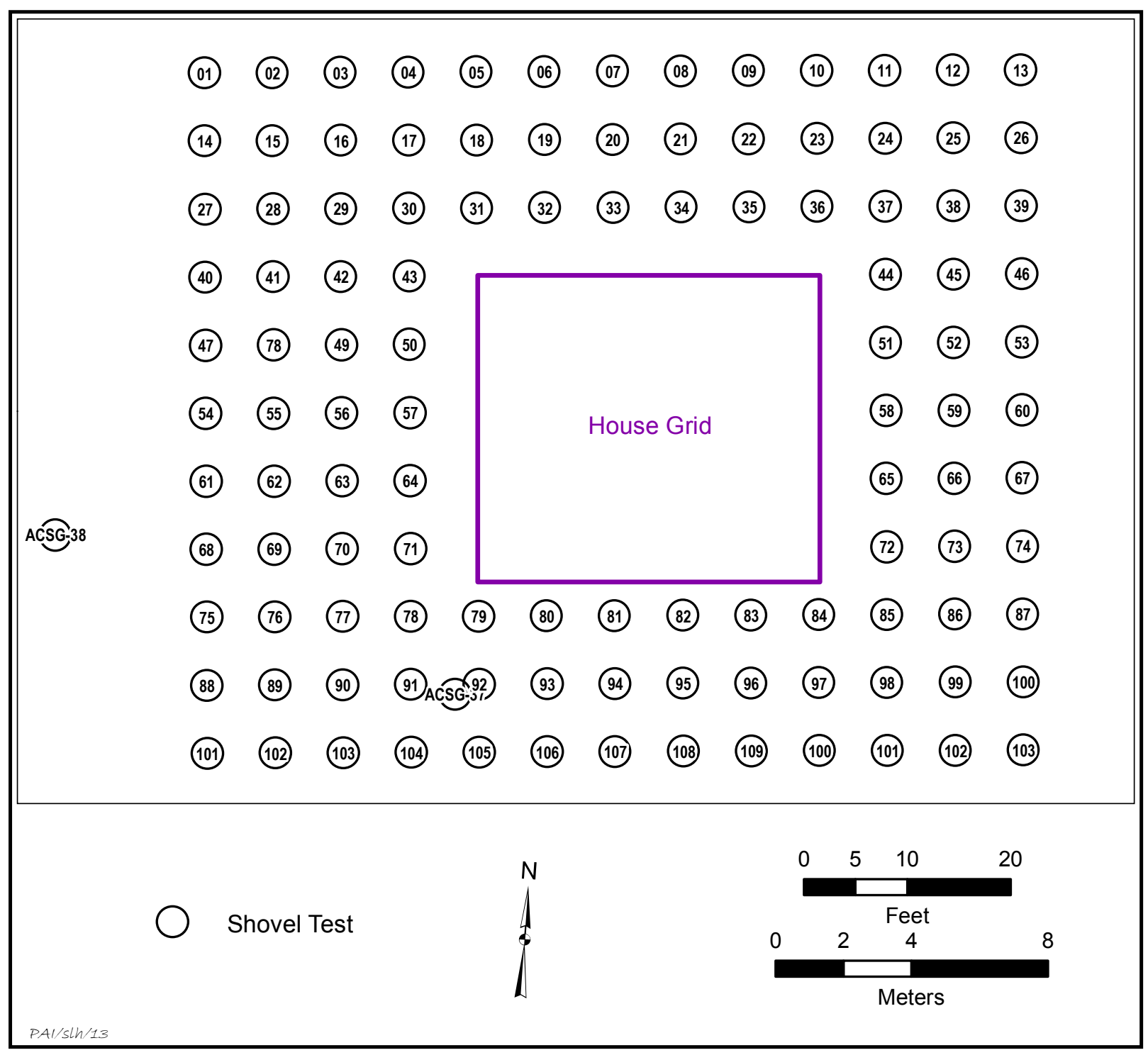

Figure 3.5. Map of the shovel test designation within the 20x24-m shovel testing grid around the house excavation block.

soil, with no attempt to remove the fill and place the base stones directly on the bedrock.

The final machine excavation, Backhoe Trench 9, was an irregular L-shaped trench at the location where wet sediments observed in 2007-2008 suggested a natural spring or seep might be. The tested area was a water-worn depression within a distinct drainage located where two prominent rock walls come together. Several wooden fence posts with attached barbed wire were found on either side of this depression, suggesting a possible gate. The vegetation was cleared using chain saws, and the area was photographed before and after the mechanical excavation. The backhoe was used to dig a broad-area scrape down to hard bedrock, and it revealed no evidence of there having been a spring at this location.

In addition to the backhoe trenches, three backhoe scrapes were excavated to investigate three rock mound features (see Figure 3.2). Designated as Rock Mounds A, B, and C, these features were roughly circular mounds of rock covered in dense vegetation. Given their isolated 


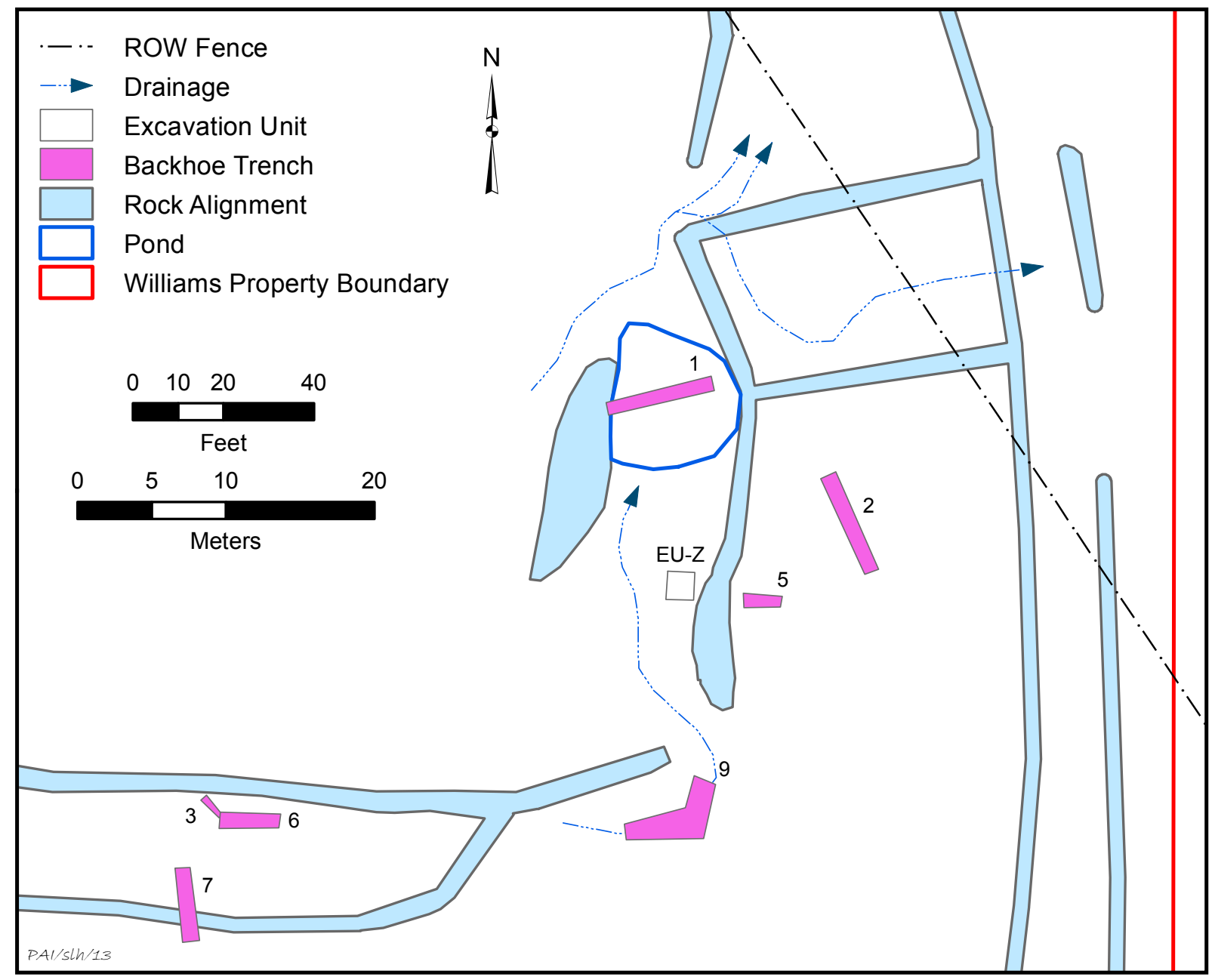

Figure 3.6. Overview map of the excavations and cultural features in the northern portion of the farmstead.

locations in the old cultivated field to the west and northwest of the house area, they were presumed to be locations where people would pile limestone cobbles and boulders that they encountered while plowing the fields. Each feature was investigated with a large horizontal scrape, covering an area of at least $6 \mathrm{~m}$ long and $2 \mathrm{~m}$ wide, that was dug directly into the rock mound. These scrapes revealed that all three features were indeed low-relief piles of random limestone cobbles, and this evidence supports the hypothesis that they are mounds of discarded fieldstones accumulated over many years of cultivation (see Chapter 6).

The hand excavations were concentrated in and around the location of the farmhouse, which was indicated by the intact chimney base and large scatter of chimney fall and foundation stones. The 113 shovel tests were spaced on at 2-m intervals within a 20x24-m area around the house block (see Figure 3.4). The results of the shovel tests were plotted on grid maps to show the relative locations of positive and negative shovel tests and the quantities of recovered artifact by material type (e.g., glass, ceramics, metal). After examining the shovel test results, some metal detecting was done in selected parts of the shovel test grid and beyond. This technique allowed identification of concentrations of metal artifacts and of areas that warranted additional testing with $1 \mathrm{x} 1-\mathrm{m}$ units.

Hand excavations in the vicinity of the house consisted of 138 1x1-m units (see Figure 
Table 3.3. Excavations at the Williams farmstead by area and type

\begin{tabular}{|c|c|c|c|c|c|}
\hline Site Area & $\begin{array}{l}\text { Shovel } \\
\text { Tests* }\end{array}$ & $\begin{array}{l}\text { 50x50-cm } \\
\text { Quarter } \\
\text { Units** }\end{array}$ & $\begin{array}{c}\text { 1x1-m } \\
\text { Excavation } \\
\text { Units }\end{array}$ & $\begin{array}{l}\text { Backhoe } \\
\text { Trenches }\end{array}$ & $\begin{array}{l}\text { Backhoe } \\
\text { Scrapes }\end{array}$ \\
\hline House block ${ }^{* * * *}$ & - & - & 90 & - & - \\
\hline North of house block & - & - & 1 & - & - \\
\hline Northeast of house block & - & - & - & 1 & - \\
\hline East of house block & - & - & 2 & - & - \\
\hline South of house block & - & 1 & 1 & - & - \\
\hline West of house block ${ }^{* * * * *}$ & - & - & 3 & 1 & - \\
\hline Northwest of house block & - & 1 & - & - & - \\
\hline $\begin{array}{l}\text { Possible outbuilding } \\
\text { (northwest of house block) }\end{array}$ & - & 4 & 14 & - & - \\
\hline Yard area & 113 & - & - & - & - \\
\hline $\begin{array}{l}\text { Midden } \\
\text { (east of house block) }\end{array}$ & - & - & 27 & - & - \\
\hline Isolated rock mounds & - & - & - & - & 3 \\
\hline Corral complex & - & - & 4 & 7 & - \\
\hline Total & 113 & 6 & 142 & 9 & 3 \\
\hline \multicolumn{6}{|c|}{ * The shovel tests were excavated at 2-m intervals within a 20x24-m area around the house block. } \\
\hline \multicolumn{6}{|c|}{$\begin{array}{l}\text { The 50x50-cm units were used to test possible metal concentration areas as indicated by metal detector } \\
\text { hits. These are Test Units } 8-13 \text { excavated by PAI in 2007-2008. } \\
\text { The house block subsumes Test Units } 1 \text { and } 3 \text { excavated by ACSG in } 2003 \text { and Test Units } 4-7 \text { and } 14 \\
\text { excavated by PAI in } 2007-2008 \text {. }\end{array}$} \\
\hline
\end{tabular}

3.4). Units previously dug by ACSG in 2003 were designated Test Units 1-3, and units dug by PAI during the testing phase were designated Test Units 4-14. For the data recovery effort, the units in the house block were numbered Excavation Units 15-104. Two of the ACSG test units are subsumed within the house block, but they are not oriented the same as PAI's data recovery grid, but most of each unit was subsumed within one of the data recovery units. Consequently, the cultural materials from Test Unit 1 were assigned to Excavation Unit 40 and the cultural materials from Test Unit 3 were assigned to Excavation Unit 69. Five of the PAI test units excavated by PAI during testing are also subsumed in the house block, but these units were assigned new designations to simplify the numbering in the house block. For analysis purposes, Test Units 4, 5, 6, and 7 were renumbered as Excavation Units 42, 52, 62, and 72, respectively. Test Unit 14 was the excavation of the upper deposits in the chimney firebox, and these cultural materials were assigned to the chimney feature. All other excavation units were numbered by areas relative to their direction from the house block. As described below, these units are designated with $\mathrm{N}, \mathrm{E}, \mathrm{S}$, or $\mathrm{W}$ followed by a sequential number.

The 90 units in the house block constitute the sample associated with the farmhouse, and the exposed chimney foundation and scattered foundation stones were used to define the house block area. The original house block was slated to cover an 8x10-m area, but the block was expanded on the south side due to high artifact recovery. When this row of 10 units was added, the final block size was $9 \times 10 \mathrm{~m}$ with its long axis oriented east to west (see Figure 3.4). This south row of units was added because it was hypothesized that an open porch was once located along the south side of the house. The recovery of artifacts and placement of large rocks within the house 
block undoubtedly defines the location where a wooden structure once stood. The house block subsumed two previous test units excavated by ACSG (see Test Units 1 and 3 in Figures 2.2 and 3.4), the chimney foundation (and a PAI test unit in the chimney firebox), and a subfloor pit that extended over parts of four excavation units in front of the fireplace (see Chapters 7 and 11).

The shovel grid around the house block encompassed an area of $20 \mathrm{~m}$ north-south by 24 m east-west (see Figure 3.5). The grid encompassed 103 shovel tests that provided important information on the yard area. Seven isolated units were excavated on all four sides of the house block but within the shovel test grid: one on the north side (Unit N1), two on the east side (Units E12 and E13), one on the south side (Unit S1), and three on the west side (Units W7 and W8 and a unit previously excavated by ACSG; see Test Unit 3 in Figure 2.2). These isolated units are all within $2-8 \mathrm{~m}$ of the house block, and their relatively low artifact yields confirm that they are located in a yard area that was kept relatively free of debris.

The 14 units excavated northwest of the house probably represent an outbuilding area and are numbered $\mathrm{W} 1$ to $\mathrm{W} 6$ and $\mathrm{W} 9$ to $\mathrm{W} 16$ (see Figure 3.4). The initial units in this area were excavated because a concentration of metal detector hits was observed, and the block excavation was expanded until an adequate sample was obtained. The artifact recovery in this area suggests that an outbuilding in this location is likely (see Chapter 11).

The 27 units located between 5 and $20 \mathrm{~m}$ east of the house block were located in a hypothesized midden area and include units E1 to E11 and E14 to E29 (see Figure 3.4). Relative to the other excavation units, the high density, extreme diversity, and nature of the material culture leaves little doubt that this was the area where the Williams family discarded their household trash (see Chapter 11). These midden units extend east to west across the parallel set of rock alignments that delineate an old roadway. Thirteen are located west of this hypothesized roadway and comprise the east midden, and the other 14 units are east of the hypothesized roadway and comprise the slope midden (see Chapters 7 and 11).

Four units are grouped in a single $2 \times 2-m$ block excavated in the corral complex more than $50 \mathrm{~m}$ north and downslope from the house block (see Figures 3.2 and 3.6). This 2x2-m block is designated as Unit Z1, and the excavation recovered sparse artifacts and demonstrated that the overall density of nineteenth-century materials in the corral complex area was very low. The artifacts from this unit, along with some surface-collected artifacts and items found with a metal detector, constitute the entire sample from the corral complex. Relative to the excavations in and around the farmhouse, the corral complex contains a very different type of artifact assemblage that appears to have been functionally specialized and related to livestock raising and agriculture (see Chapter 11).

\section{The Artifact Assemblage}

The archeological investigations recovered 26,172 artifacts during the testing and data recovery phases. An additional 513 artifacts previously recovered in the 2003 site testing by ACSG (Staples and Nash 2003) are included in the analysis reported here, bringing the total artifact assemblage from the Williams farmstead to 26,685 . The master database is provided in Appendix B (in electronic format only), along with 52 tables that provide provenience and identification data. Four of these tables contain information on ceramic vessels, glass containers, pressed glass objects, and temporally diagnostic specimens. The other 48 tables provide information on various artifact types within the five main functional groups.

\section{Analysis of Material Culture and Features}

The data recovery investigations recovered an impressive assemblage of functionally and temporally diagnostic artifacts associated with the occupation of the farmstead by Ransom Williams and his family. With few exceptions, the temporally diagnostic specimens in the assemblage date to the period of occupation, ca. 1871 to ca. 1905. There is little evidence of overprinting or mixing with later twentieth-century artifacts.

Following the data recovery investigation, the artifacts were taken to the PAI laboratory, where they were washed and cataloged. Then the focus was shifted to artifact identification and analysis. But before the artifact analysis could begin, PAI archeologists had to create a comprehensive artifact classification scheme 
that could accommodate an extremely diverse assemblage of more than 26,000 artifacts.

\section{Artifact Classification}

For the Williams farmstead analysis, PAI chose a functional classification that is essentially a modified version South's (1977:95-96) well-known material culture classification. The final classification scheme incorporates some changes based on reviews of the Sonoma Historic Artifact Research Database (Sonoma State University 2008) and the historic classification schemes by Horn (2005), Sprague (19801981), Stone (1970), the University of Utah (2001), and others. In the PAI artifact classification scheme, the 10 primary functional categories are: Architecture; Kitchen/Household; Activities; Clothing/Adornment; Personal; Faunal; Botanical; Lithics; Unknown, Possibly Identifiable; and Unknown, Unidentifiable. Within these main groups, there are numerous subgroups and specific artifact identifications. The complete classification scheme (as outlined in Appendix B) is as follows:

\section{1) Architecture}

Structural

Square Nails

Wire Nails

Screws

Spikes

Bricks

Wood Samples

Mortar Samples

Flat Glass

Miscellaneous Hardware (e.g., lightFencing ning rod, strap hinge, door plate
Wire
Staples

\section{2) Kitchen and Household}

Food Storage and Preparation

Stoneware Containers

Cast-Iron Vessels

Metal Cans

Container Glass (various bottles)

Other

Food Service and Consumption

Whiteware Dishes

Porcelain Dishes
Tableware (noncontainer glassware and such as goblets, glasses, dishes)

Cutlery

Knives

Forks

Spoons

Utensils (fragmentary and unidentifiable)

Other

Furnishings

Furniture (e.g., castors, hinges, knobs, and pulls)

Lamp Parts (all parts associated with oil-burning lamps)

Stove Parts (cast iron)

Other

Locks and Keys (except door hardware)

Miscellaneous Hardware

Unidentifiable Glass Fragments

\section{3) Activities}

Horse Tack and Harness

Hardware (various nails, buckles, rings, etc.)

Carriage and Wagon

Hardware (various wagon parts)

Construction

Hand Tools (e.g., draw knife, auger bits, hammer, axe, chisel)

Toys (e.g., marbles, tops, doll parts, cap gun)

Firearms/Hunting

Munitions

Gun Parts

Gun Tools

Fishing (e.g., hooks)

Miscellaneous Hardware

Construction Hardware

Other Hardware

Farming

Hand Implements (e.g., hoe, mattock)

Machinery (e.g., plow blade, clevis and pins)

Sewing (e.g., needles, pins, safety pins, thimble)

Music (e.g., Jew's harp, harmonicas)

Water Storage (e.g., barrel hoops)

Writing (e.g., pencils and slate)

Collectibles (e.g., commemorative spoon, dart point, geofacts) 
4) Clothing and Adornment

Fasteners

Buttons

Cufflinks

Buckles

Hook and Eye Fasteners

Grommets/Eyelets

Suspender Buckles

Jewelry

Brooch

Accessories

Other

5) Personal

Grooming

Combs

Toiletries

Cosmetics

Health/Medicine

Medicine Bottles and Stoppers

Syringe

Accoutrements

Coins

Eyeglass/Monocle

Pocket Knives

Tobacco

Snuff Bottles

Alcohol

Smoking Pipes

Wine Bottles

Liquor Bottles

Beer Bottles

\section{6) Faunal}

Bone

Shell

\section{7) Botanical}

Food

Peach Pits

Fuel

Other

Charcoal Samples

Seeds

\section{8) Lithics}

\section{9) Unknown - Possibly Identifiable}

\section{0) Unknown - Unidentifiable}

That there are limitations in using a purely functional classification scheme is explicitly acknowledged, and the importance of context was considered in the classification of specific artifacts. In cases in which an artifact's context clearly showed that its last function was quite different from its original function, the specimen was classified by its final inferred function. The best example of this is a dart point that was found in the construction fill in the bottom of the chimney firebox. In a strict functional classification, it would have been put into the Lithics category and considered to be largely irrelevant to the Williams occupation because the farmstead is located on a large, ephemeral prehistoric artifact scatter. But because of its spatial context, there is little doubt that the dart point was placed at the bottom of the firepit when the chimney base was constructed. In this case, it is clear that the item's spatial context indicates a unique function for the object and suggests it had special meaning for the Williams family. Consequently, this dart point was more appropriately classified in the Activities group under Collectibles.

To organize and manage the large amount of data, PAI created a master database for the Williams farmstead artifacts using Microsoft Access. The database consists of three linked data tables. The first is the provenience data table that has specific provenience information for each of the 470 lot numbers assigned. The second is an artifact data table that includes precise artifact identifications following the functional classification scheme (functional group, subgroup, and specific artifact identification), along with comments and notations about diagnostic markings, dates of manufacture, and published references. The provenience and artifact tables are linked by the "Lot Number" variable, which enables analysts to generate all types of queries, forms, and reports in the Access program. The third data table provides realworld UTM coordinates for each specific provenience (including individual surface collected items, metal detector collections, wire samples from trees, shovel tests, test units, excavation units, and backhoe trenches). This table links to the provenience table using the "UnitLabel" variable, allowing complex database queries that include locational data to be imported into ArcGIS software (by ESRI) and other GIS programs for quick and easy spatial displays.

One of the more useful tools for the spatial analysis of the artifacts recovered from the excavations is a multilayered GeoPDF (created 
using TerraGo software) that includes a main layer for each functional category of artifacts and sublayers for each functional subgroup. Layers can be turned on and off individually, enabling the analyst to quickly visualize the horizontal distribution patterns for each type of artifact. Many of the artifact distribution figures that appear in Chapter 11 were generated in this manner, beginning with data queries from the master Access database that were then transferred to create individual layers in the GeoPDF.

\section{Definition of Analysis Units and Spatial Analyses}

As the field investigations progressed, the spatial distributions of features and artifacts dictated where and how the investigations should continue. These distributions were used to define structure locations and activity areas within the farmstead. Back in the laboratory, they became the analytical units used to compare material culture during the artifact analysis phase.

The analysis units are defined primarily based on horizontal provenience, since there is little or no meaning to the vertical proveniences of artifacts except in some rare cases. During the testing and data recovery excavations, it became increasingly clear that the typical unit yielded artifacts only from the upper 15 to $25 \mathrm{~cm}$, and most units had only one excavation level. The dark brown loamy and clayey sediments where most artifacts were found constitute an extensively bioturbated A horizon resting on top of a sterile red (rubified) clay found just above the weathered bedrock. Consequently, there was no potential for meaningful vertical separation of cultural materials within this single-component historic occupation, and most units were dug in one excavation level.

However, vertical separation of materials was recorded in three cases. (1) Artifacts were collected from different levels in the chimney firebox excavation, but it appears that the cultural materials in the upper deposits were probably dragged there by denning animals (see Chapters 7 and 11). (2) Artifacts were collected from different levels inside the subfloor storage pit. An analysis was conducted to see if the vertical separation had any significance, but this appears unlikely. Rather, the evidence suggests that this pit was backfilled with midden debris in a single episode (see Chapters 7 and 11). (3)
The excavation units near the chimney base had much thicker deposits because the chimney fall rubble created a prominent mound around the intact chimney base. But it appears that the collapse of the chimney stack came down on top of the artifacts at ground level, effectively sealing in the cultural materials. While some artifacts were found higher up in the sediments between the upper rocks, it appears that these materials were most likely introduced by bioturbation.

The analysis units defined for the Williams farmstead artifact assemblage are:

- House block. Consists of materials recovered from 90 contiguous excavation units.

- Chimney base. A feature subset within the house block (portions of Excavation Units $53,54,63$, and 64).

- Subfloor pit (Feature 1). A feature subset within the subfloor pit deposits of the house block (the lower levels of Excavation Units 61, 62, 71, and 72).

- Trash midden. Consists of materials recovered from 27 units in the midden blocks, along with some surface-collected artifacts.

- Outbuilding. Consists of materials recovered from the 14 units in the block excavation northwest of the house block, along with some surface-collected artifacts from this area.

- Yard area. Includes materials from all of the shovel tests around the house and the seven isolated 1x1-m units (Units N1, E12, E13, S1, W7, W8, and ACSG Test Unit 2).

These analysis units are used as the primary groupings for discussions of the features and artifacts in the remainder of this book. More importantly, they provide the organizational structure for the detailed spatial analyses and interpretations of the entire Williams farmstead artifact assemblage. More details on the specific methods used to analyze the spatial distributions of the features and material culture are provided in Chapters 7 and 11.

\section{Artifact Conservation}

After most of the artifact analysis was completed, a sample of artifacts was submitted 
to the Conservation Research Laboratory at Texas A\&M University. The selected artifacts are 1,086 specimens from 620 proveniences (lot numbers). Most are metal objects (primarily iron, but some brass, composite, and other metals) that have deteriorated to some extent by natural corrosive processes. The selected artifacts are in the process of undergoing conservation treatment to stabilize and protect them from further deterioration. This work will also improve the aesthetic qualities of these items for display and public interpretation in the future. At the time of this publication, these artifacts were still undergoing conservation. 


\section{ALLEN'S PRAIRIE, MOUNTAIN CITY, AND ANTIOCH COLONY: AFRICAN AMERICAN PIONEERS IN SLAVERY AND FREEDOM}

Terri Myers

John Henry Faulk, interviewer: "And you just had a colony of colored folks?"

Harriet Smith, former slave and resident of Antioch Colony: "Yes, that colony, where we, where I come from, has got homes out there.... It wasn't nothing but woods when we bought it."

-Interview with Harriet [Bunton] Smith by John Henry Faulk, 1941

Antioch Colony was a rural freedmen community that formed in northern Hays County within a few years after the close of the Civil War. Early census and deed records dating to the 1870 s and 1880 s show that many of the original Antioch Colony settlers-among them the Buntons, the Rectors, and the Breedlovestook the surnames of the white landowners who had come to northern Hays County in the late $1840 \mathrm{~s}$ and $1850 \mathrm{~s}$. The white landowners claimed acreage and established farms and ranches that stretched in a crescent-shaped ribbon of land from the Kyle bluff on the Blanco River on the southwest to Manchaca Springs on the northeast (Figure 4.1). Though the region became known as Mountain City, it was far from urban: Only a few businesses developed, and most of the land remained in agricultural use throughout its history. After the war, some former slaves from Mountain City moved a few miles to the north, near the Travis County line. There they founded a small farming community that became known as Antioch Colony..

Long after Mountain City faded from the Hays County landscape in the 1880s, Antioch remained a haven for freedmen and their descen- dants. Completely surrounded by farms and ranches owned by white landowners, the community thrived for over 70 years, from the late 1860 s to the 1940s. Hard times during the Great Depression, however, prompted many families to leave Antioch in search of work, and by the mid-1950s, the colony was virtually abandoned. In the 1970s, however, a few descendants of the early pioneers moved back to the area, where they purchased land first settled by their ancestors 100 years earlier. Today, about 20 members of three extended families live in the community.

\section{WHITE SETTLERS OF NORTHERN HAYS COUNTY}

The history of Antioch Colony began with an influx of Southern settlers into central Texas in the mid-nineteenth century. Land grants in present Hays County were issued in the 1830 s and 1840s. Although the land was beautiful, with vast, game-rich prairies and numerous cypress-lined creeks and permanent springs, few Anglos ventured into the territory because it was also an attractive hunting and camping ground for the various Indian tribes who ranged through central Texas during that period. As late as 1835, Thomas McGehee, who established a farm on the San Marcos River, was the only known Anglo settler in present Hays County. That year, one of Ben Milam's colonists from Tennessee, Phillip J. Allen, received a large land grant on Onion Creek, in the northern part of present Hays County. ${ }^{10}$ Allen made repeated

\footnotetext{
${ }^{10}$ The Philip J. Allen League lies at the northern boundary of present Hays County with a small portion spilling over into southern Travis County.
} 


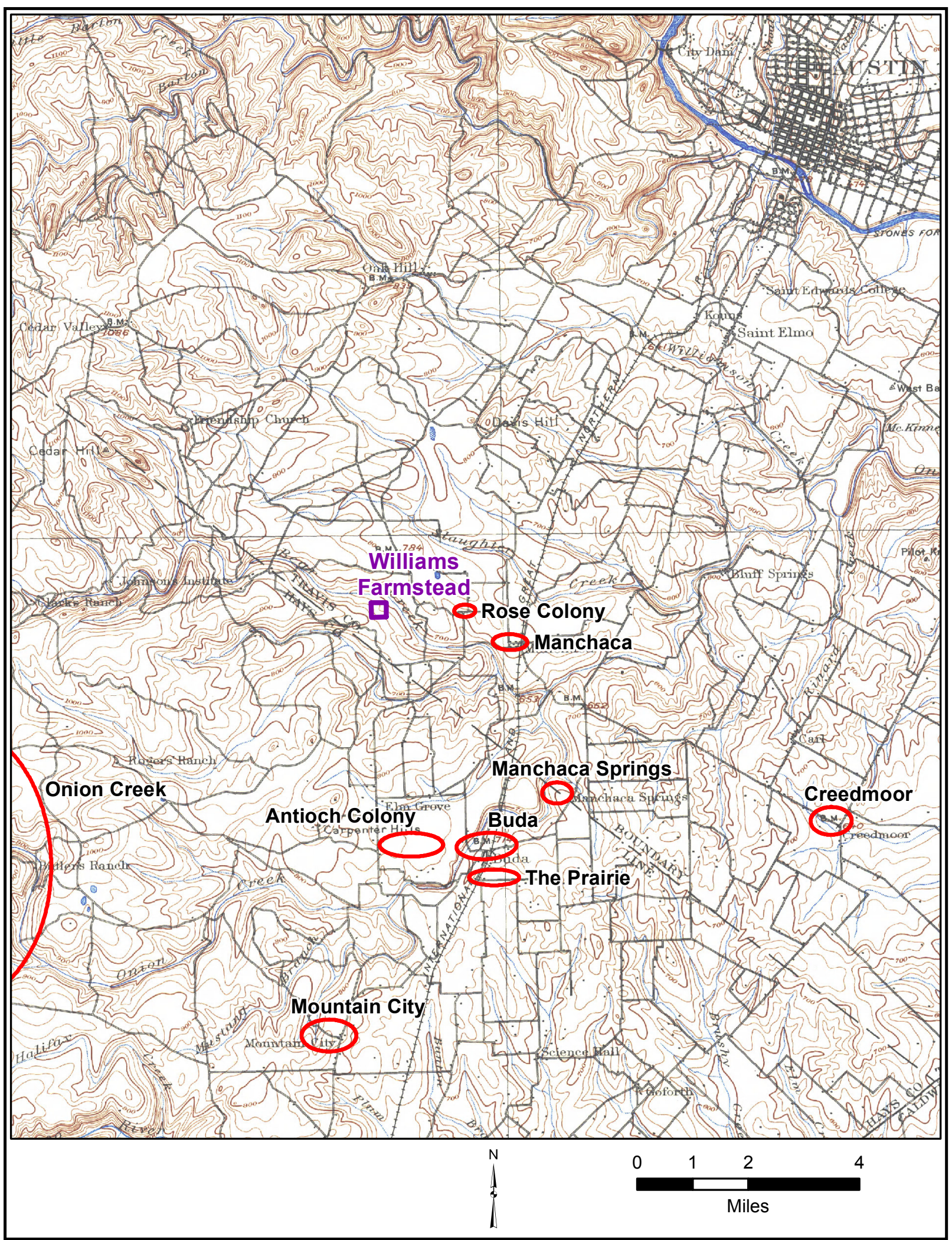

Figure 4.1. Map of the Mountain City area in northern Hays County in relation to Austin and surrounding communities. The outline of the rural Onion Creek community is from Roberson (1972:Figure 6). Base map is the USGS 1896 Austin Quadrangle. 
attempts to locate his family on the grant, but frequent Indian raids in the area prevented his settlement for about 10 years. Allen finally established a permanent homestead in northern Hays County, northwest of present Buda, about 1846 or $1847 .{ }^{11}$ Allen and his family were likely the first Anglo inhabitants of the region that became known as Allen's Prairie (Figure 4.2). ${ }^{12}$

\section{ALLEN'S PRAIRIE}

Relative safety drew more settlers to the area in the late 1840 s, and by 1848 , the population between the San Marcos River and Allen's Prairie had grown sufficiently to warrant the designation of a new county. Hays County was carved out of adjacent Travis County to the north. Although several families lived on Allen's Prairie by that time, most of the county's population clustered in the southern section, along the San Marcos River. The small riverside settlement of San Marcos was named the Hays County seat. It lay about 12 miles south of Allen's Prairie. Despite the general increase in population during the 1840 s, very few residents actually occupied the new county according to the 1850 census. That year, only 259 white residents and 128 slave inhabitants were counted in the entire county (U.S. Bureau of the Census, Hays County, Population and Slave Schedules, 1850). Most lived in or around San Marcos in southern Hays County.

Many who arrived in northern Hays County in the first wave of immigration came from Kentucky, Tennessee, Arkansas, and Missouri. Later groups came from Virginia, Alabama, Georgia, and the Carolinas. Most traveled overland in wagon trains filled with multigenerational families and friends from back home. Others hauled their belongings to New Orleans where they sailed to Indianola and resumed their trek from the Gulf Coast to the Texas interior.

Allen's Prairie eventually developed into a dispersed agricultural community comprised of farms and ranches in northern Hays County, north and west of Onion Creek (Giberson

\footnotetext{
${ }^{11}$ Sources differ as to the exact year.

${ }^{12}$ General Land Office maps show that the Eggleston, Wilson, McGehee, and Allen Leagues in the Mountain City area (Morriss and Armstrong 1946; Walsh 1880). These leagues were patented between March and May 1835.
}

2003:3). Among its early settlers was Victor Labenski, a Polish immigrant who entered Texas through Indianola about 1838. After a sojourn in Bastrop County, Labenski moved his family to a spot on the west side of Onion Creek, northwest of present Buda in 1850. There, they lived in a wagon until their log house was completed (Figure 4.3). The "wet weather" stagecoach route between Austin, San Marcos, and San Antonio passed by the Labenski place, where drivers dropped off mail and watered their horses. A blacksmith by trade, Labenski also repaired wagons and shoed horses. The Labenskis occupied the land well into the twentieth century (Giberson 2003:197-198).

Far-flung neighbors in the region included William Cannon, a farmer from Tennessee, W. A. Young and J. C. Stevenson, farmers from Kentucky, Hickerson Burnham, a farmer from Tennessee and Henry Cheatham, a farmer from Virginia. A Methodist minister named Rev. Zively lived in the Labenski household in 1850. At the western end of the region, Cheatham owned the largest number of slaves in the area; he reported 23 slaves to the Census Bureau, 6 of whom were mulattos (U.S. Bureau of the Census, Hays County, Population Schedule, 1850). While these men listed their occupations as farmers, later census records show that most landowners in northern Hays County were actually more accurately occupied as stock raisers or breeders, likely due to the shallow topsoil and rocky land. Jesse Day, who lived along Onion Creek in northern Hays County, led one of the first Texas cattle drives north to market in 1856 (Greene 2006c).

P. J. Allen died in the late 1850 s but his wife, Jane, and their children continued to farm his headright (U.S. Bureau of the Census, Hays County, Population Schedules, 1860). About 1857, David Crews, a well-to-do farmer from Missouri, moved to Allen's Prairie, where he purchased 277 acres of land in the western part of the S. V. R. Eggleston League. His property lay just east of the Allen league. There he built a house and a mule-drawn cotton gin. About 1869, Crews bought 541 acres in the adjacent P. J. Allen League and built a large, two-story house on the property. The big house and surrounding property remained in the Crews family until 1939, when the Giberson family purchased it. The house survives today on its original site (Giberson 2003:120-122). 
The Ransom and Sarah Williams Farmstead

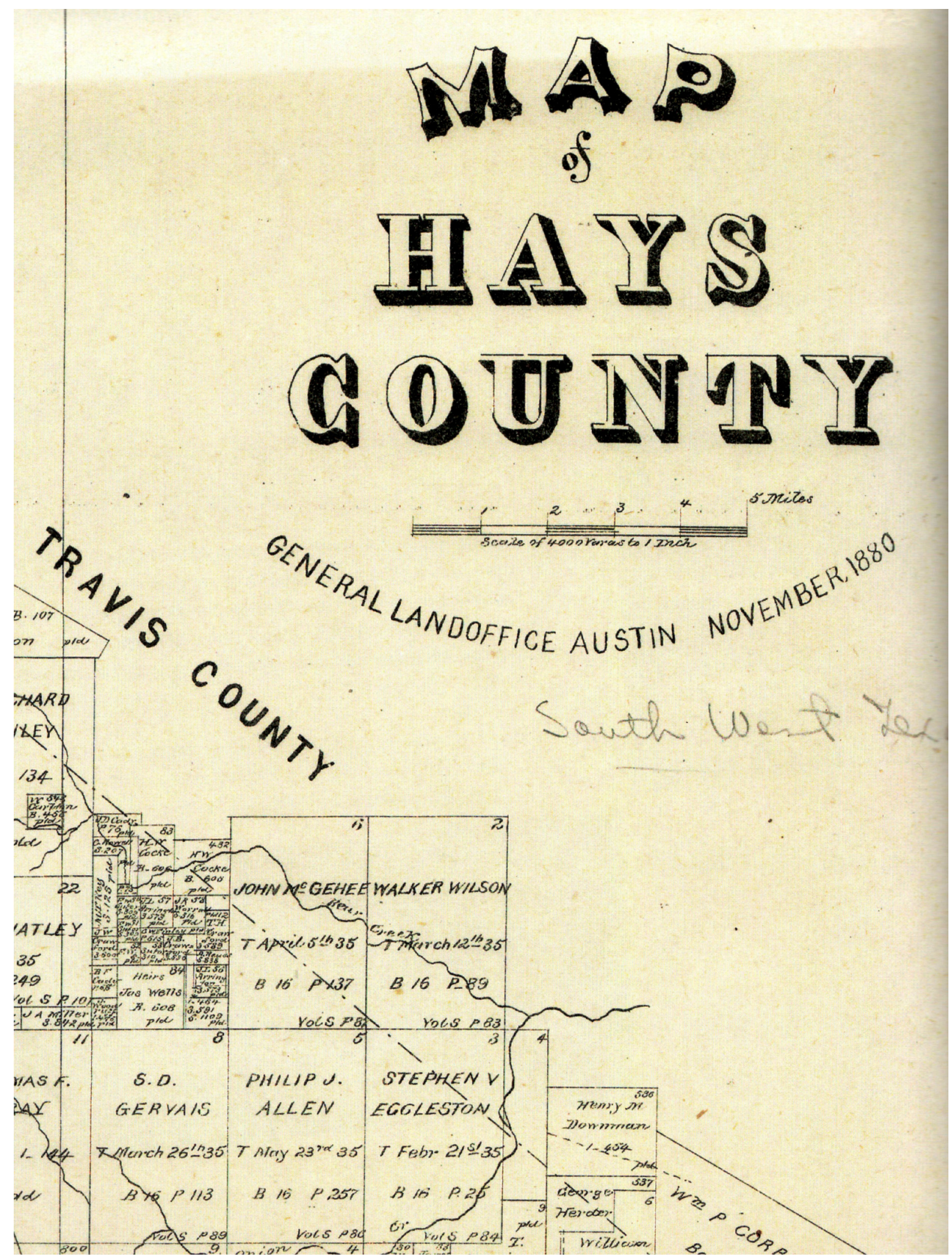

Figure 4.2. Section of an 1880 General Land Office map showing the 1835 leagues in the Mountain City area of northeastern Hays County (Walsh 1880). The Allen League later became known as Allen's Prairie. 


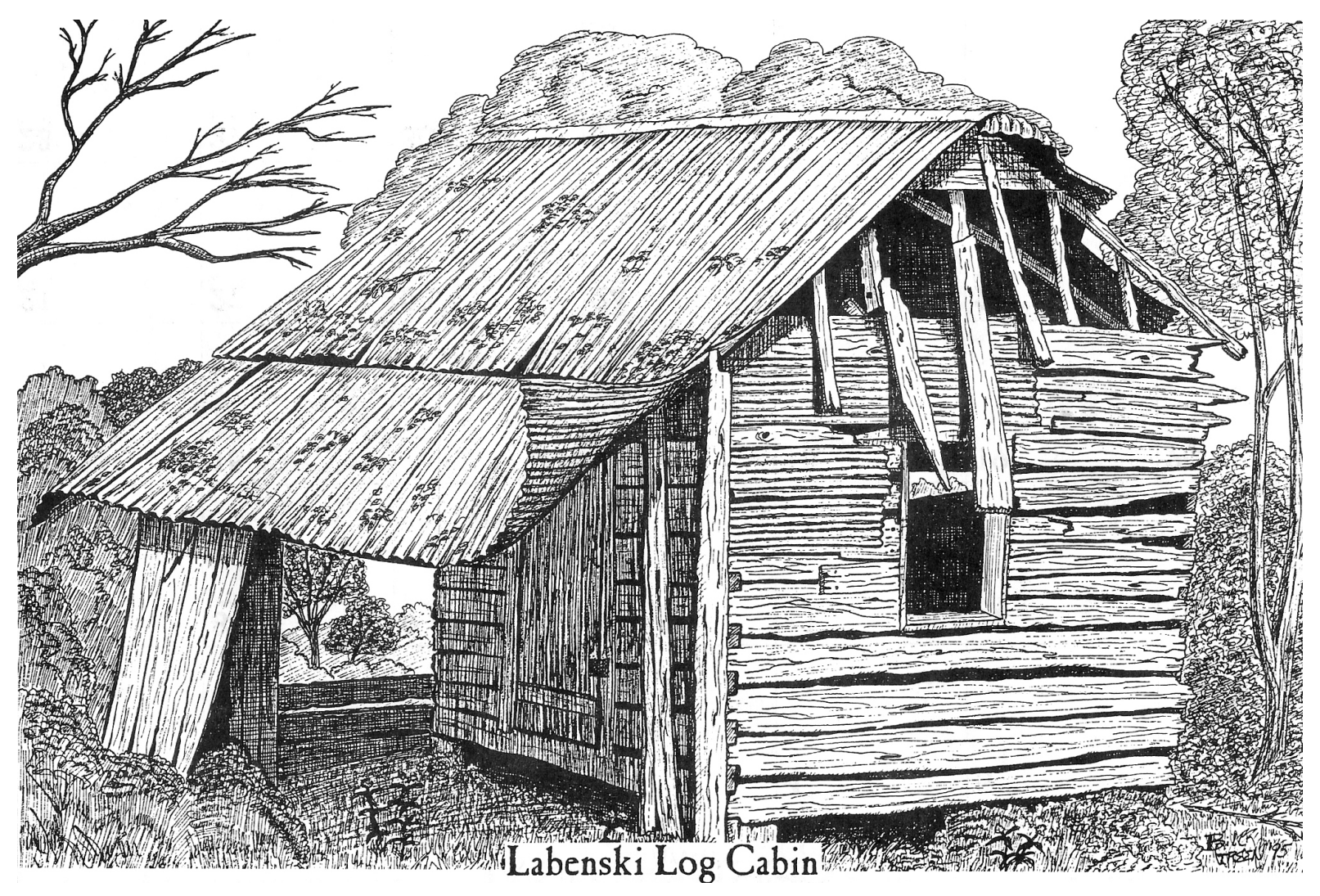

Figure 4.3. Sketch of the remains of the Victor Labenski log cabin by Bill Green (1996; also in Giberson 2003:198). The cabin was built in the 1850 s, and the sketch is based on a 1996 photograph by Mary Giberson.

Settlement increased in the area throughout the 1850s until the loosely organized community of farms and ranches curved across northern Hays County from the Kyle Bluff on the Blanco River to Manchaca Springs, about 2 miles northeast of present Buda (Stovall et al. 1986:205). A postal station was established on the stage route at William Haupt's general store, a few miles southwest of present Buda. About 1858, Haupt reportedly named the post office "Mountain City" and the term took hold, eventually supplanting "Allen's Prairie." Despite its name, the place was neither a mountain nor a city, but rather a chain of ranches and farms with a few general stores, a gin, and a blacksmith's shop scattered among them (Strom 1981:13). In the mid-1800s, however, Mountain City was home to the largest concentration of people in Hays County outside the county seat of San Marcos. Early census records grouped the people of northern Hays County in the "Manchaca P.O." district (at Manchaca Springs), but by 1870, they were enumerated as part of "Mountain City," which by then had taken on an identity of its own.

\section{THE BUNTON COLONIZATION EFFORT}

As early as the 1830 s, and certainly by the 1840 s, the rising generation of men in the Upper South-largely Kentucky, Tennessee, Arkansas, and Missouri-began picking up stakes and striking out for the Republic, then state, of Texas. Their fathers and grandfathers had come through the Cumberland Gap and tamed the wilderness they found on the other side. Now the dense woods and vast, unbroken prairies of Texas lay before the younger generation as the new frontier. Indeed, some had already ventured into the new land, lending their efforts to Texas's struggle for independence. Among 
them were John Wheeler Bunton, a native of Tennessee who studied law at Princeton College in Kentucky. Bunton first ventured into Texas in $1832 .{ }^{13} \mathrm{He}$ came to Texas just as rebellion was brewing between the Mexican government and the Texians. Bunton's law education proved a boon to the nascent Republic. He signed the Texas Declaration of Independence and helped craft the legal foundation for the Republic of Texas. Bunton engaged in several battles. Later, he served the Republic as a representative from Mina (Bastrop) in the First and Third Texas legislatures (Carpenter 1970:6; Greene 2006c). For some, like Bunton, the Texas experiment was both an adventure and a reconnaissance mission to survey the land and opportunities for friends and families back home.

The War for Texas Independence was scarcely over when Bunton returned to Gallatin, Sumner County, Tennessee, and married his sweetheart, Mary Howell, in 1836. Within a year of their marriage, he convinced his wife, his brother and sisters, their spouses, and several neighbors to leave their homes in Kentucky and Tennessee and make the trek to Texas. The Bunton party joined a veritable wave of immigration from the Upper South to Texas in the years between the Republic and the Civil War. The great attraction was land; vast, unbroken acres of virgin land were virtually free for the taking, for farming, stock grazing, and town building. Texas's status as a slave state offered another incentive. While the men of the Upper South were not plantation farmers whose livelihoods were entirely dependent on slave labor, they nonetheless expected their slaves to ease their transition to the frontier by felling trees; cutting stone; building houses, mills, and barns; clearing land and planting crops and gardens; and herding cattle and breeding horses. Their masters' desire for land was not lost on the slaves, thousands of whom would seek their own farms after emancipation.

Bunton's first foray was doomed to failure. In early 1837 , he led a wagon train of about 140 people-100 of whom were reportedly slaves-from Tennessee and Kentucky to New Orleans. The wagons followed one another out of the hills and through the forests in close

${ }^{13}$ The Headright Certificate issued to John Wheeler Bunton on January 13, 1838, states that he came to Texas in 1833, but other sources claim 1832. formation. Typically, men rode ahead or behind the train, scouting as they went; women, small children, and the elderly rode in the wagons; and able-bodied slaves and older children walked beside them (Menn 1937d). Herds of cattle, horses, and pigs followed close behind. Slave children herded hogs, goats, and sheep. One former slave remembered "encouraging" hogs with an "eight-plaited rawhide whoop on a long stick" to keep them in line (Menn 1937d). At New Orleans, the travelers embarked on a ship called the Julius Caesar, bound for Indianola on the Texas Coast. The Mexican Navy seized the vessel and held the passengers in a Matamoros jail for three months. Mary Howell Bunton reportedly secured their release, and the troupe returned to Tennessee to regroup. During their imprisonment, however, all of their slaves were set free. One of the slaves was a 33-year-old man named Rance, who made his way from Veracruz back to Kentucky and eventually found his master. Reportedly, Rance Bunton returned to voluntary servitude with John Wheeler Bunton and stayed with his master until well after emancipation (Carpenter 1970:6). Rance Bunton later became affiliated with the Antioch freedmen colony, which included a number of former Bunton slaves and their families. ${ }^{14}$

\section{Bastrop Settlement on Cedar Creek}

Back in Tennessee and undaunted by his dismal journey, John Wheeler Bunton redoubled his colonization efforts and succeeded in bringing a large group of pioneers to the Texas Republic in 1837. Bunton briefly lived in Austin County, but then moved to a ranch on Cedar Creek in Bastrop County in about 1840. Others from his original party joined him including his younger brother Desha, Fielding, Ludwig, and Thomas Rector, all of Tennessee, and Cicero R. Perry, a native of Alabama (U.S. Bureau of the Census, Hays County, 1850). The Bunton brothers established plantations near one another in the vicinity of Cedar Creek. Many of the new arrivals to Bastrop County raised Durham cattle in the Cedar Creek area, and many of their slaves became adept "cowboys" (Barkley

\footnotetext{
${ }^{14}$ The name Rance appears in earlier records, but records pertaining to Antioch Colony refer to him as Ransom Bunton, Sr.
} 
1970:63). Finally, the youngest Bunton brother, James, brought his family, including the matriarch, Phoebe Desha Bunton, to join the clan in Bastrop County. All of these settlers would later push on to Mountain City by the mid- to late-1850s (Carpenter 1970:6-19; Johnson and Simon 1986:206-207; U.S. Bureau of the Census, Hays County, 1850 and 1860).

\section{MOUNTAIN CITY IN HAYS COUNTY}

\section{First Settlers of Mountain City}

After several years along Cedar Creek, John Wheeler Bunton moved his family farther west into Hays County. ${ }^{15} \mathrm{He}$ had purchased land there in the 1840s, before anyone lived in the area (Carpenter 1970:14), but did not move there until the 1850s. For years after the Texas War for Independence, the territory west of Bastrop County had remained an unsettled wilderness due to the ever-present threat of Indian attack. Phillip Allen, who obtained an early land grant in northern Hays County in 1835, was unable to occupy his land for more than 10 years due to persistent Indian attacks. By the late 1840s, however, the activities of the Texas Rangers and civilian militias discouraged-though they did not stop-Indian hostilities in the territory.

In 1848, the state legislature carved Hays County out of Travis County. The combination of relative peace and recognition by the state reassured would-be settlers. Pioneers joined Allen in northern Hays County, settling along Onion Creek and the Blanco River. A swath of loosely affiliated farms and ranches stretched between Manchaca Springs on the northeast to the Kyle Bluff on the Blanco River on the southwest. At first, the widespread community was known as Allen's Prairie (see Figure 4.2), but sometime in the 1850 s, the crescent-shaped ribbon of ranches and farms became known as Mountain City,

\footnotetext{
${ }^{15}$ According to historian Mary Starr Barkley, Bastrop was the "mother" county for many coming to central Texas. Some stayed and contributed to the county's growth while others only passed a while before moving on to the interior. Many of the first settlers in Bastrop who moved on to Hays County were slaveowners, including the Bunton brothers (Desha, James, and John Wheeler), the Rector brothers (Fielding and Thomas), Bartholomew Manlove, and Cicero R. Perry.
}

though it possessed neither mountains nor cities (see Figure 4.1). ${ }^{16}$

Despite an influx of settlers in the late 1840 s, very few people lived in rural Hays County by the time the census was taken in 1850. Most residents lived in the county seat of San Marcos, to the south. In fact, only 259 white residents in 41 families and 128 slaves were recorded in the entire county that year. ${ }^{17}$ Among the residents of "Mountain City" in 1850 were Phillip J. Allen, a farmer from Tennessee, William Cannon, another farmer from Tennessee, Henry Cheatham, a farmer from Virginia, and Victor Labenski, ${ }^{18}$ a farmer from Poland (see Figure 4.2). While these men listed their occupations as farmers, later census records show that most landowners in northern Hays County were stock raisers or breeders, likely due to shallow topsoil and rocky land. Raising livestock became an important economic mainstay to those who lived along Onion Creek.

After a tentative start, settlers flooded into northern Hays County in the 1850s. Most hailed from the South, especially the Upper South states of Kentucky and Tennessee. The area boasted clear, spring-fed Onion Creek and the Blanco River, both attractive locations for homesteads. Besides Phillip Allen, others who arrived in Mountain City by 1860 were D. A. Porter, W. H. H. Carpenter, James U. Barton, brothers Fielding and Thomas Rector, Ira Breedlove, Jesse Day, Haupts, Dr. Robert and Margaret Manlove, Judge David E. Moore, Drs. Thomas and Fielding Rector, James Stephenson, William A. Vaughn, David W. Crews, Jesse Day, John Hughs, S. H. Burnham, Col. W. W. Haupt, and brothers William and Cicero R. Perry (Johnson and Simon 1986:205-210).

\footnotetext{
${ }^{16} \mathrm{~A}$ lack of historical information makes it difficult to map out exactly what constituted the original Allen's Prairie, but it probably included the area from Manchaca south to Mountain City. The original Mountain City area would have included all of the property owned by the Buntons. A small area southwest of Buda is still known as Mountain City, and a much smaller area south of Buda later became known as "The Prairie" (Franklin 2012:33-45, Figure 1).

${ }^{17}$ Some people may have been missed in the census count, especially if they lived in isolated places.

${ }^{18}$ Various sources list the family name as Labenski, Labenske, Labensky, and Labinski. Labenski is used throughout this chapter.
} 
Like the first settlers in the area, most of the adults in these families were from the Upper South states of Tennessee, Kentucky, Missouri, and Virginia. Only C. R. and William Perry, Hickerson Burnham, and W. W. Haupt hailed from Alabama, considered part of the Deep South. Most households owned slaves and brought them with them on their trek to Texas. By 1860, the average household had between seven and fourteen slaves. James and Mary Ann Stephenson were the exception; they were from Kentucky but owned no slaves. Henry Cheatham was still the largest slaveowner in the postal district, with 36 slaves (U.S. Bureau of the Census, Hays County Population and Slave Schedules, 1860).

\section{Mountain City Families}

The Bunton brothers were among the most noteworthy of the Mountain City settlers, mainly because of John Wheeler Bunton's role in the War for Texas Independence. All three were born in Tennessee but spent time in Kentucky, ${ }^{19}$ and all three had originally settled in Bastrop County before moving west to Hays County. John Wheeler Bunton may have come to the Mountain City area as early as 1851, and he was certainly there by $1857 .{ }^{20}$ His younger brothers, Desha and James, soon followed with their families. The Buntons were primarily stock raisers and though they occasionally stated their occupation as "farmer" on the census rolls, they were better known for their large herds of cattle and good horses. All three brothers owned slaves who worked the cattle and tended the horses. John Wheeler Bunton's "Turkey Foot" brand was well-known in the county (Greene 2006c; Strom 2008). Others in the area were known primarily as stock raisers, as well. Jesse Day was renowned for leading one of the first Texas cattle drives north to market in 1856 (Greene 2006c). Depending on their ages, the Bunton slaves were born in Tennessee, where the Bunton brothers grew up, or in Kentucky, where Desha and

\footnotetext{
${ }^{19} \mathrm{John}$ Wheeler Bunton studied law at Princeton College in Kentucky and Desha and James Bunton both moved to Kentucky where they met and married their wives. This may explain why so many of their slaves were born in Kentucky.
}

${ }^{20}$ Other sources claim that he came in 1856 or 1857. All concede that he was in Mountain City by 1857 .
James married and started their families (U.S. Bureau of the Census, Hays County, Population Schedules, 1870 and 1880).

The Manloves had come to Texas from Tennessee, settling first in Bastrop about 1850. Like many others, they then moved on to establish a permanent home in Mountain City as early as 1852 (Barkley 1970:140). Their daughter Mary eventually married John Wheeler Bunton's son, Desha (Carpenter 1970:14). The couple built a ranch in the southwestern portion of Mountain City, near present-day Kyle, on land that John Wheeler Bunton had purchased in the 1840s (Carpenter 1970:14). The ranch lay at the southwestern end of Mountain City. That same year, the Barton family arrived in Hays County after stopping awhile in Bastrop County (Barkley 1970:140).

About 1852, Adolphus Weir moved his family and about 50 slaves from Mississippi to Manchaca Springs, on the old Austin to San Antonio Road. He built a large house on top of the hill overlooking the springs. On the level plain below, he grew corn on his 500-acre farm. $\mathrm{He}$ is primarily noteworthy for establishing a well-equipped stagecoach stop on the Austin-San Antonio Road. The springs supplied water for travelers and horses, and Weir's sons became experienced horse wranglers and blacksmiths. When necessary, the Weirs supplied the coaches with fresh horses, and in inclement weather, they offered their house as a hostel. Manchaca Springs is generally considered to be the northeastern corner of Mountain City (Carpenter 1970:7).

Also in 1852, the James and Mary Ann Stephenson family came to Mountain City from Kentucky. Stephenson was a cabinetmaker as well as a farmer. Their neighbors, Ira and Patience Breedlove, were born in Virginia and Tennessee, respectively, but came to Texas from Kentucky, where they had lived for many years. The couple owned many slaves, some of whom later settled in the Antioch and Bear Creek communities. Ira Breedlove built the first cotton gin in the area and was the overseer for the Bunton slaves at one time (Smith 1941). Also that year, Hickerson Burnham and wife Sarah moved to Mountain City from Alabama. They established a cotton plantation and had 12 slaves to operate it. Burnham was also a cabinetmaker, fashioning furniture from local cedar. After the Civil War, several of Burnham's former slaves bought property and operated farms in the nearby Antioch community (Carpenter 1970:10). 
In 1854 , W. H. H. Carpenter arrived from Kentucky. He chose a spot at the mouth of Bear Creek, where it empties into Onion Creek, to build a log house. He later built a more substantial dwelling nearby in the Slaughter League, about 4 miles west of the present town of Buda. Known as Carpenter's Hill, the farm was considered the northeastern boundary of the old Mountain City community. Carpenter contributed to his community in numerous ways; he built the Kellyville School on the north bank of Onion Creek, about 1 mile from Buda. As his farm duties called him, Carpenter had to discontinue the school. Area children then attended Live Oak School (Carpenter 1970:12; Johnson and Simon 1986:207).

In 1855, Tennessee natives Thomas Blackstone Rector and his brother Fielding arrived in Mountain City after a sojourn in Bastrop County. Both Thomas and Fielding purchased land and built log homes near the central part of Mountain City. Col. W. W. Haupt, a native Alabama, was another who settled first in Bastrop before bringing his family to Mountain City in 1857. Haupt purchased Fielding Rector's home and operated the post office from his place for many years. He is credited with giving Mountain City its name. Haupt was an innovator in a wide variety of fields; he brought one of the first steam cotton gins to the area and was the first to bring Essex hogs, Brahma cattle, and Angora goats to the region. He also cultivated new varieties of plants; the "Haupt berry" is named for him (Carpenter 1970:18).

\section{Slave Pioneers}

In addition to its white families, Mountain City was home to hundreds of black and mulatto slaves on the eve of the Civil War. Most had come with their masters from Kentucky, Tennessee, and other Upper South states, where slave ownership was common but practiced on a much smaller scale than in the cotton-growing states of the Deep South. Former slaves recalled that they traveled with their masters in wagon trains, generally walking alongside or behind the formation to herd goats and hogs. Some elderly and very young slaves rode in the wagons, but sturdy children and adults typically walked the distance. At night, the slaves tended to tasks around the campsite, and in the mornings, they hitched up the horses or oxen to begin a new day on the trail (Menn 1937a, 1937b, 1937c, and $1937 \mathrm{~d})$.

Once the wagon trains reached their destinations, the slaves performed many of the duties usually attributed to the pioneer landowners. In some cases masters worked alongside their slaves. More often, it was the slaves who performed the hard labor of building houses, slave cabins, fences, and outbuildings, clearing fields for crops and pastures, herding cattle and breeding horses, and generally easing their masters' transition to the new land (Menn 1937a, 1937b, $1937 \mathrm{c}$, and 1937d).

The slave population in Mountain City grew significantly between 1850 , just after the start of immigration in that area, and 1860. The 1850 census counted only 128 slaves in all of Hays County, but the slave population in the county had soared to 797 bondsmen by 1860. Among known residents of Mountain City in 1860, 30 settlers owned 270 slaves of all ages. More than half of the slaves counted-142-were children under the age of 14 . Only a few households claimed one or two slaves, while most owned between 7 and 14. A few of the Mountain City men owned more, like Fielding Rector (owned 20 slaves), John Tinnen (owned 22 slaves), Nancy Brown (owned 20 slaves), and Henry Cheatham (owned 36 slaves). Nearly a third (85) of the Mountain City slaves were listed as "mulatto" or "yellow" (U.S. Bureau of the Census, Hays County, Slave Schedule, 1860), indicating mixed white and African American ancestry. Very little is known about how the slaves lived, but the 1860 slave census shows that there were about five slaves per slave household (U.S. Bureau of the Census, Slave Schedule, 1860).

\section{Mountain City on the Eve of the Civil War}

By 1860 , the population of Mountain City had grown considerably, although it is hard to say how much since there were no firm boundaries and residency was somewhat dependent on one's perspective. For example, several residents of Hays County in 1860 were enumerated in the San Marcos district though secondary sources often claim them as Mountain City pioneers. There was no separate Mountain City district, and the 1860 census for Hays County divides the enumeration districts into five categories: (1) San Marcos, which included the San Marcos town 
limits and surrounding land; (2) Cannonville, a tiny enclave on the Travis County line to the north; (3) Capts Mill, a collection of farmsteads on Onion Creek in the northwestern part of the county; (4) Dripping Springs, a hamlet at the western edge of the county; and (5) Manchaca [Springs] P.O., the stagecoach stop and post office at the northeastern corner of Hays County. ${ }^{21}$ The Manchaca P.O. district covered the north-central part of the county, which included much-but not all—of Mountain City.

On the eve of the Civil War, Mountain City was entirely rural, with the minor exceptions of a few gins, a molasses mill, a stagecoach stop, and a blacksmith shed. These few commercial enterprises had sprang up right before the Civil War. About 1858, W. W. Haupt, who is credited with naming the area, built his dry goods store and served the community as its first postmaster (Barkley 1970:139). Ira Breedlove built the first horse-drawn cotton gin in Mountain City (Carpenter 1970:8), Victor Labenski ran a blacksmith shop in Allens Prairie, and Adolphus Weir had a livery stable (Schwartz 1986: 360-361).

In 1860, the Manchaca P.O. district consisted only of farms and ranches, and only two roads passed through the district. The San Antonio Road skirted its easternmost boundary and contained the stagecoach stop, and an all-weather road that crossed Allen's Prairie went past Victor Labenski's blacksmith shed. Most adult men listed their occupation as "farmer." Out of the 45 heads of household in the district, 40 were farmers, one was a stock raiser, three considered themselves stock breeders, and one was a teamster. Despite the fact that most regarded farming as their primary occupation, nearly all raised beef cattle as well. Other adult men, most of whom were boarders or unmarried kin, worked as carpenters, teamsters, and mechanics.

The 1860 census shows all three Bunton brothers and their families enumerated at Manchaca P.O. The brothers stated their occupations as "farmers," despite their well-known rep-

\footnotetext{
${ }^{21}$ The Manchaca P.O. (post office) referred to the stage and postal stop at Manchaca Springs, at the northwestern edge of Mountain City, and not the later town of Manchaca, which lies in Travis County and was formed in 1881 when the railroad pushed through from Austin to San Antonio.
}

utations as stock raisers. ${ }^{22}$ One of Desha's sons, John, gave his occupation as a stock breeder (U.S. Bureau of the Census, Hays County 1860).

Several churches and schools organized in the 1850s served only the white residents of the Mountain City area. Presbyterian minister J. H. Zivley conducted services from the home of Jesse Day, and Reverend George Golden started the Cumberland Presbyterian Church in 1855. Methodist and Baptist churches followed. The Kellyville School may have been the first school in the community but it was short-lived. Shortly afterward, about 1855, the Live Oak Academy was organized (Barkley 1970:139). Under the tutelage of Professor John Edgar, the Live Oak Academy gained renown as the best school in the region. Children in outlying areas boarded with families that lived near the school. Finally, the Elm Grove School was established about 1871 on 4 acres of land donated by David Crews. The school lay about 4 miles west of present Buda. With 63 students, it was reportedly the largest school in Hays County in the late 1870s (Armbruster 2008). A Masonic Lodge formed in Mountain City as well, but its location is unknown.

For a rural community, Mountain City had an abundance of doctors in its early years. Both Thomas and Fielding Rector served the community as physicians, but after the Civil War, they moved to Travis County. Dr. R. C. Manlove remained to care for the rural patients in Mountain City. He was often paid in goods such as "eleven pounds of ham at $12 \frac{1}{2} 2$ cents a pound" or a "bottle of bitters" for a $\$ 2.00$ charge. Manlove made house calls but charged $\$ 10.00$ for a night call. His ledger identified patients who included African American residents of the Antioch community such as Dave Bunton, Brown Bunton, Rance Bunton, George Kavanaugh, and Henry Burnham. Manlove also operated a store that sold everything from bacon, tobacco, bonnets, and flour to coffins and shrouds (Barkley 1970:141-142).

The outbreak of the Civil War disrupted the growth of the community. As Southerners and slaveowners, nearly all of Mountain City's citizens supported the Confederate cause. Many young men responded to the call, with the

\footnotetext{
${ }^{22}$ John Wheeler Bunton had described himself as a "stock raiser" in the earlier 1850 census (U.S. Bureau of the Census, Bastrop County, Population Schedule, 1850).
} 
majority serving in the 32nd Cavalry Regiment under Col. P. C. Woods and Capt. J. G. Story (Johnson and Simon 1986:210). They enlisted for the duration of the war and furnished their own horses and arms (Stovall 1986:114). Thomas Harrison served as second sergeant of Captain McCullough's Company and Bell's Regiment of Texas Mountain Volunteers. Young Steve Burnham died at the Second Battle of Manassas (Bull Run) in 1862 (Carpenter 1970:9-10). Two Mountain City men, John C. Carpenter and Lee Ewing, participated in the Battle of Palmito Ranch, the last land engagement of the Civil War and a bittersweet victory for the Confederates who soon learned that General Robert E. Lee had surrendered a month earlier (Carpenter 1970:92). Many of the rebel soldiers from the Mountain City area never returned home, and those who did returned to a different world than the one they had left.

\section{"THE PECULIAR INSTITUTION" IN TEXAS AND HAYS COUNTY}

To the residents of Mountain City, the emancipation of their slaves amounted to robbery on a grand scale. Most of their personal wealth was invested in slaves, and with their departure went their field hands, skilled craftsmen, cowboys, wranglers, cooks, seamstresses, and nannies. Mountain City families, like many throughout the South, depended on slave labor to support their way of life.

Slavery in Texas was institutionalized in Stephen F. Austin's commission to establish a colony on Spanish soil in 1821. The agreement between Austin and the Spanish Crown tacitly encouraged the practice as it granted settlers 80 acres of land for each slave they brought to Texas. Austin's original 300 settlers brought so many slaves with them that an 1825 census counted 443 slaves out of a total population of approximately 1,800 , or approximately 25 percent. When Mexico won its independence from Spain and assumed sovereignty over Texas, it promptly forbade slavery, though it did little to enforce the prohibition. The Mexican law did, however, cause considerable concern among existing slaveowners in Texas and likely stalled further immigration from the American South. The antislavery law may have contributed to the relative drop in slaves as a percentage of the Texas population; in 1836, Texas had an estimated population of 38,470 , only $5,000-$ 13 percent-of whom were slaves. The Texas Revolution that year nullified the law, and the Constitution ensured the future of slavery in the new Republic (Campbell 2011).

The institution of slavery expanded greatly in the 1840s and 1850s. Slavery was concentrated in the eastern two-fifths of the state, where it thrived along rivers that provided rich soil and relatively inexpensive transportation. The greatest concentration of large slave plantations were found along the lower Brazos and Colorado Rivers in Brazoria, Matagorda, Fort Bend, and Wharton counties, the region known as the "sugar bowl" for its labor-intensive cane production. The slave population in those counties far exceeded that of whites in the antebellum period. In 1860, slaves accounted for 72 percent of Brazoria County's population (Campbell 2011).

On the eve of the Civil War, slaves made up a quarter of the state's total population (Mears 2009:6), with one in four families owning 20 or more bondsmen (Campbell 2011). Again, slaves were concentrated in the southeastern part of the state where the soil was good for cotton and sugar cane, the major cash crops. Fewer slaves lived in the north-central and southern parts of the state (Mears 2009:6), neither of which had been developed for plantation-style agriculture by that time. The central Texas counties of Bastrop, Hays, and Travis had been largely settled by Southern whites who brought slaves with them. At the end of the antebellum era, slaves constituted nearly a third of the population of Bastrop County, 37 percent of the population of Hays County, and 39 percent of the population of Travis County. ${ }^{23}$

Some discussion of slavery in Hays County is necessary to understand why and where freedman's communities formed. Before emancipation, slaves in Hays County were generally concentrated in the county seat of San Marcos, near the southern county line, and in the dispersed agricultural settlement of Mountain City (Roberson 1972:95). Residents of the town of San Marcos generally had few slaves, only enough to do domestic chores and assist in the workplace. Farmers and ranchers in areas like Mountain

\footnotetext{
${ }^{23}$ In 1860, Bastrop County had a population of 7,006 with 2,248 slaves; Hays County had a population of 2,126 with 797 slaves; and Travis County had a population of 8,080 with 3,136 slaves and 13 free blacks.
} 
City typically had more slaves in response to the greater workload presented by large ranches and agricultural operations.

By the Civil War, most landowners in Mountain City claimed at least a few slaves. Of 18 known landowners in Mountain City, 12 had fewer than 10 slaves and the remaining six counted between 12 and 22 slaves. The average household in the community owned between eight and nine slaves, according to the 1860 slave census (U.S. Bureau of the Census, Slave and Population Schedules, 1860). Because they had come from the hills of Kentucky, Tennessee, Alabama, and Missouri, few of the early homesteaders had experience with large-scale cotton culture requiring abundant slave labor. Nevertheless, several Mountain City farmers did plant some cotton, though few actual plantations developed, possibly because the land was thin and rocky and generally not suited to cotton cultivation.

Most Mountain City landowners used slaves to run their complex households and extensive stock operations. Each spread contained the owner's residence and outbuildings, slave quarters, barns, sheds, corrals, gardens, fields, and fences. Slaves cleared land and built houses, leveled and planted fields, built timber and stone fences, cared for the horses, livestock, and barnyard animals, and tended to their masters' domestic needs including cooking, cleaning, laundry, and childcare. Among the largest slaveowners in the area were Thomas Breedlove $(\mathrm{n}=8)$, James M. Bunton $(\mathrm{n}=13)$, Hickerson Burnham $(\mathrm{n}=12)$, Fielding Rector $(\mathrm{n}=20)$, John Hughs ( $\mathrm{n}=12)$, and John Tinnon $(\mathrm{n}=22)$ (U.S. Bureau of the Census, Hays County, Slave Schedules, 1860). ${ }^{24}$ All had slaves who later contributed to the population of the Antioch freedmen colony (U.S. Bureau of the Census, Population Schedules, Hays County, 1870, 1880, and 1900).

\section{Slavery in the Bunton Family}

The history of Antioch Colony is closely tied to the Bunton brothers of Mountain City, since their former slaves were among the founders of

\footnotetext{
${ }^{24}$ It is known that former slaves of the Bunton brothers, Hickerson Burnham, the Rectors, and John Hughs settled in or around the Antioch Colony after emancipation. Their names are represented in late-nineteenth-century census records (U.S. Bureau of the Census, Population Schedules, 1870 and 1880).
}

the freedmen community. According to several local historians, John Wheeler Bunton started out with as many as 100 slaves in his first, unsuccessful trek to central Texas (Giberson and Younts 2003:15). Although it is unknown how many slaves the Buntons ultimately brought to Texas, the number was far short of 100 . According to the 1860 Hays County Slave Schedule (Table 4.1), John Wheeler Bunton claimed ownership only of a middle-aged woman and three teenagers. One was a 14-year-old mulatto boy who may have been Ransom Williams. John's brother, Desha, owned six slaves: a man, a woman, and four children - three girls and a boy between the ages of one and seven. By their ages and later documents, they appear to have been the children of Rance Bunton Sr. and his wife, Jane. The three girls were most certainly Jane's daughters, Narcissa, Mandy, and Rachel (Bunton 1867; U.S. Bureau of Census, Hays County, Population Schedule, 1870; Hays County Deed Records $\mathrm{D}: 453)$. The boy's name is unknown.

The Buntons' youngest brother, James, owned 13 slaves in 1860; seven adults 17 and older and six children under the age of 17. Among them were a young man of 23 and another man aged 31 (U.S. Bureau of the Census, Slave Schedule, 1860). Based on their ages and primary sources in which they are mentioned, they appear to have been brothers Dave and Elias Bunton, their wives Mary and Clarisa (probably unknown females in Table 4.1), and Clarisa's mother, Rachel (Bunton Family n.d.a and n.d.b; Smith 1941, 2012). They were among the founders of the Antioch freedmen colony after emancipation (Smith 1941, 2012; U.S. Bureau of the Census, Population Schedules, 1870).

\section{Quality of Life}

Despite the scant evidence in slave schedules and a few anecdotal stories, little is known about the lives of slaves in Mountain City during the antebellum period. The area's early settlers hoped to settle a raw, wholly undeveloped land in central Texas and undoubtedly looked to their slaves to clear land, build houses, construct barns, and erect corrals and rock fences to contain livestock and define property boundaries (Carpenter 1970:15). Eventually, the chores separated into domestic work, with slave women cooking, cleaning, making clothes, and tending children, while men tended fields, worked live- 
Table 4.1. The Bunton brothers' slaves who later founded Antioch Colony*

\begin{tabular}{|c|c|c|c|c|}
\hline & $\begin{array}{c}\text { Sex } \\
(1860)\end{array}$ & $\begin{array}{l}\text { Age** } \\
(1860)\end{array}$ & $\begin{array}{l}\text { Name } \\
(1870 \text { or } \\
1880)\end{array}$ & $\begin{array}{c}\text { Notes } \\
\text { (from } 1870 \text { or } 1880 \text { Censuses and other records as listed) }\end{array}$ \\
\hline \multirow{6}{*}{$\begin{array}{l}\text { Slaves of } \\
\text { Desha Bunton }\end{array}$} & M & 45 & Rance Sr. & He was 65 in 1880 Census \\
\hline & $\mathrm{F}$ & 32 & Jane & She was 55 in 1880 Census \\
\hline & $\mathrm{F}$ & 7 & Narcissa & Jane’s daughter (Freedmen's Bureau) \\
\hline & $\mathrm{F}$ & 5 & Mandy & Jane's daughter (Freedmen's Bureau) \\
\hline & $\mathrm{F}$ & 3 & Rachel & Jane's daughter (Hays County Deed Records) \\
\hline & M & 1 & Unknown & Jane's son? \\
\hline \multirow{13}{*}{$\begin{array}{l}\text { Slaves of } \\
\text { James Bunton }\end{array}$} & M & 31 & Dave & He was 40 in 1870 Census \\
\hline & M & 23 & Elias & He was 33 in 1870 Census \\
\hline & $\mathrm{M}$ & 18 & Brown & He was 40 in 1880 Census \\
\hline & M & 12 & Tony & Dave and Mary's son \\
\hline & M & 4 & Louis & Dave and Mary's son (Census records) \\
\hline & $\mathrm{F}$ & 41 & Rachel & Clarisa's mother (Harriet Smith interview) \\
\hline & $\mathrm{F}$ & 39 & Unknown & Not identified in 1870 or 1880 Census Records \\
\hline & $\mathrm{F}$ & 18 & Unknown & Not identified in 1870 or 1880 Census Records \\
\hline & $\mathrm{F}$ & 17 & Unknown & Not identified in 1870 or 1880 Census Records \\
\hline & $\mathrm{F}$ & 12 & Unknown & Not identified in 1870 or 1880 Census Records \\
\hline & $\mathrm{F}$ & 7 & Unknown & Not identified in 1870 or 1880 Census Records \\
\hline & $\mathrm{F}$ & 1 & Harriet & Elias and Clarisa's daughter (Census records) \\
\hline & $\mathrm{F}$ & 1 & Sarah & Dave and Mary's daughter (Census records) \\
\hline \multirow{4}{*}{$\begin{array}{l}\text { Slaves of } \\
\text { John Wheeler } \\
\text { Bunton }\end{array}$} & $\mathrm{F}$ & 42 & Unknown & Not identified in 1870 or 1880 Census Records \\
\hline & $\mathrm{M}$ & 19 & Unknown & Not identified in 1870 or 1880 Census Records \\
\hline & M & 14 & Unknown ${ }^{* * *}$ & Mulatto. This boy may be Ransom Williams \\
\hline & $\mathrm{F}$ & 14 & Unknown & $\begin{array}{l}\text { Mulatto. This girl may be Clarisa. She was } 24 \text { in } 1870 \\
\text { Census }\end{array}$ \\
\hline
\end{tabular}

*Table compiled by comparing the 1860 Slave Schedule, 1870 Population Schedule, and 1880 Population Schedule (U.S. Bureau of the Census, Hays County, Texas).

**Identifying slaves by age is complicated by discrepancies in the slave schedules and later census records. Slaves often didn't know their own age because no one had told them. After Emancipation, former slaves often approximated their ages when the information was required by the census and other official records.

***This 14-year-old boy would have been born about 1846 . This boy may be Ransom Williams, who was born in or before 1846 and was a mulatto.

stock, hunted game, and maintained infrastructure. Nevertheless, many women spent their labor in the plowing and cultivating the fields (Smith 1941, 2012).

In 1860, 18 known residents of Mountain City owned a total of 153 slaves, who lived in 31 slave houses (U.S. Bureau of the Census, Hays County, Slave Schedules, 1860). The houses were generally square or rectangular log structures chinked with mud and covered by a gabled, wood-shingled roof. They were usually set at a distance from the master's residence. On average, the houses sheltered five or six slaves, but in at least one case in Mountain City, nine people were crowded into a single, undoubtedly small, house (U.S. Bureau of the Census, Hays County, Slave Schedules, 1860). In a few cases, slaves lived in the "big houses" with their 
masters. Harriet Bunton Smith (1941, 2012) recalled that she and her mother, grandmother, brother, and sister were living in "Master" Jim Bunton's two-story house when "the break up came." Accounts from Mountain City freedmen confirm that most slaves lived in family groups, though they could be hired out to other farmers or even sold away from their families. Generally, slaveowners provided adequate food, shelter, clothing, and medical attention-basic amenities to keep a healthy workforce. The degree to which they supplied anything further depended on the beneficence of the individual slaveholder.

A Texas law based on a Hays County case made it a crime for any slave to own property or any type of animal that they could sell or trade. Nevertheless, some Mountain City slaves worked for wages or barter to buy their own livestock. According to his daughter, Elias Bunton owned his own horses and chickens while still a slave under Jim Bunton (Smith 1941, 2012:1015). At the same time, the children learned and mastered valuable skills such as saddling and bridling horses on the ranch.

In contrast to the educational and religious opportunities for whites, there were no formal schools and relatively few formal churches for the enslaved community before emancipation. As a state, Texas did not officially ban the education of slaves, but most slaveowners did not allow the practice. It is estimated that 95 percent of slaves in Texas were illiterate as of 1865 (Barr 1996:64). Some slaveowners encouraged Christian religious practices, but dedicated church buildings were rare within slave communities in Texas. Slave congregations would meet in churches provided by their owners, in old buildings, or in simple brush arbors (Montgomery 2013). Information on the Mountain City plantation comes from Harriet Bunton Smith, who had been enslaved in the Buntons and was interviewed in 1941. Smith recalled that the Bunton slaves did not read or write, but the Buntons did allow their slaves to attend the white Methodist church in Mountain City on Sunday nights. They also met in various houses in the community, but there was no separate church buildings for the slaves (Smith 1941, 2012:1010-1011).

\section{Master and Slave}

One white writer recalled that "the masters as a rule were kind and the negroes happy"
(Manlove 1936). Adolphus Weir reportedly planted all his land in corn because he didn't want his slaves to be overworked in cotton fields (Carpenter 1970:7). Former slave Harriet Bunton Smith (1941, 2012: 1011) offered a firsthand account of her treatment in the James Bunton household: "They was good to us. They never whipped none of their colored people, our colored people." She also noted that Mrs. Bunton let her grandmother, Rachel, ride a horse to church rather than have her walk the two-mile distance. At the same time, Smith remembered hearing about slaves who were whipped "till they had to grease their back to take the holes from the back" (Smith 2012:1012). Such cruelty was either rare or went unreported in Mountain City, however.

Perhaps the most extraordinary account of the bond between slave and master among the residents of Mountain City was the tale of "Uncle" Rance Bunton who, when freed by the Mexican government, made his way back to Kentucky and on to Texas to rejoin his master, Col. John Wheeler Bunton. When the two were united, Rance Bunton reportedly put himself back into slavery under Col. Bunton (Carpenter 1970:6). Rance Bunton was likely Ransom Bunton Sr., who appears as an 65-year-old farmer married to Jane Bunton in the 1880 census. Deed records show that Rance Bunton owned a small farm in the Antioch community. According to some sources, the Colonel gave his former slave the land to reward him for his loyalty (Carpenter 1970:6), but the deed records do not support this claim.

Despite instances of kindness, masters in Mountain City clearly considered their slaves as property to be disposed of as they saw fit. Desha Bunton's actions illustrate the point; in 1863, he deeded his three "Negro" girls to his sons: he gave a child named Narcissa, who was about nine years old, to his son John; one named Mandy, who was about seven years old, to his son Joel; and a third named Rachel, who was only about five years old, to his son Robert (Hays County Deed Record D:453). These little girls appear in Bunton's 1860 slave schedule and were most likely the daughters of his slave Jane. In a separate transaction recorded on the same page of the deed record, Desha Bunton gave each of his sons a number of cattle (Hays County Deed Record D:543). In essence, sending three little girls away from their mother was on par with giving cattle away. 


\section{CIVIL WAR AND EMANCIPATION}

The Civil War had a sobering effect on Mountain City. Most young men above the age of 18-and some younger-went to war, and a number were killed. Among the area troops were Pvt. Charles Labenski (Stovall 1986:360) and brothers Arthur and Gilley Barton, who enlisted under Col. P. C. Wood of the 32nd Texas Volunteer Cavalry C.S.A. Gilley was killed on April 12 or 13, 1864, at the Blair's Landing campaign (Stovall 1986:367). After his brother's death, 16-year-old Robert C. Barton enlisted in Col. Wood's regiment (Stovall 1986:369). In all, 18 Mountain City families contributed their loved ones, men and boys, to the Confederate cause. Among them were the Breedloves $(\mathrm{n}=3)$, Burnhams ( $n=5)$, Stephensons $(n=5)$, Buntons $(\mathrm{n}=6)$, and Days $(\mathrm{n}=3)$ (Strom 1981:21). At least some slaves went to war as well. Steve Burnham took his slave, Sherod, to wait on him and care for his saddle horse. Sherod witnessed the death of his young master at the Second Battle of Manassas (August 29-30, 1862), but reportedly remained with the troops until the war closed (Carpenter 1970:10).

Those left at home lived in a heightened state of anxiety throughout the war. The conflagration seemed to produce an abundance of transient strangers, thieves, and general "ne'r do wells" who wandered about the countryside looking to take advantage of the women and children left behind. Old men and boys formed a "Home Guard" to patrol the dispersed Mountain City community on the lookout for these unwanted vagrants. In addition, the lack of news was unbearable. When a stagecoach carrying newspapers and letters from the front was scheduled to arrive at Haupt's store and post office, neighbors gathered from miles around to hear war news. Newspapers carried accounts of various battles and often named those killed in action. In this way, Gilley Barton's parents learned of his death (Anonymous 1936; Schwartz 1869:365).

Toward the end of the war, Mountain City residents knew the Confederate effort was doomed, but how much they conveyed to their slaves is unknown. Surely slaves overheard conversations and rumors about the coming defeat of the South and its way of life. Some, no doubt, were elated about freedom, but they must have had concerns about how they would make their way in the world and what would happen to their families. When General Gordon Granger proclaimed the slaves of Texas to be free men and women on June 19, 1865, he altered their destinies, and those of their former masters, forever.

A few accounts have been found that describe how slaves were informed of their freedom in northern Hays County. Henry Burnham remembered that his mistress called all the slaves out and had them line up in front of her as she stood on the front porch. She told them that "they were free now and would have to look after themselves" (Carpenter 1970:10). William Vaughn, in Mountain City, gathered his slaves, told them they were free, and that they could go and do what they wanted (Clarissa Scales interview; Menn 1937c). Henry Burnham and Clarissa Scales's experiences were shared by many ex-slaves who told similar accounts of being called together in the yard to hear their masters explain their new status.

At the "the break up," as some called emancipation, former masters often asked ex-bondsmen to work through the harvest for a share of the crop or foodstuffs. Mary Dodson, a slave in Fayette County, described her former master, Jim Dodson, telling the collected slaves, 'I'm goin' to tell yo' dis mawnin' dat yo' slaves is free yo' is free to go where yo' want to, but yo' all don't have to leave" (Mary Dodson interview; Menn 1937a). Having nothing more promising on the horizon, some freed slaves stayed on the farms where they at least had minimal shelter and food. According to Mary Dodson, all of the Dodson slaves stayed on the plantation until the crops were harvested. When it was time for them to go out on their own, Jim Dodson gave each adult seventeen dollars to get started in their new lives (Mary Dodson interview; Menn 1937a).

The Freedmen's Bureau, which had been established to ease the transition from slavery to freedom, encouraged former slaves to remain on their home plantations and work for wages. In fact, ex-slaves were immediately required to enter into work contracts either with their old masters or a new employer, to discourage vagrancy, farm abandonment, and a wholesale exodus to the cities, which had few employment opportunities for the newly freed men and women.

Mountain City freedmen tended to stay and work for their former masters for some time after emancipation. Harriet Bunton Smith recalled that her family worked for their ex-mas- 
ter, Jim Bunton, for two or three years after "the break up." She said they "stayed on the place, and rented on the half" (Smith 1941, 2012), a 50-50 split of the crop production. Other freedmen in the area likely did the same. Still others may have found employment as cowboys and horse trainers in a region known for its cattle and horse flesh. For some of those who stayed, the extra time on the homeplace allowed them to save a little money for a small farm of their own. Clarissa Scales said her parents left the William Vaughn plantation to rent a place of their own, probably on a sharecrop basis. The family rented a farm and cabin from a Mrs. Black before moving to Travis County (Clarissa Scales interview; Menn 1937c).

Still others couldn't wait to shed their pasts. Harriet (Bunton) Smith (1941, 2012) recalled a young girl who grabbed a horse and rode off after a column of African American soldiers passing by the Jim Bunton place. She only knew that the men were bound for San Antonio. The girl had no family in the community, and she never returned.

\section{SEEDS OF ANTIOCH COLONY}

\section{The Freedmen's Bureau}

Emancipation left more than four million freed slaves in the South homeless with no means of support. Out of necessity, many stayed with their former masters for a time, but some white landowners could not keep themselves afloat, let alone house and feed their former bondsmen. The war had taken a toll in the South that was unmatched in the North. Homes were ransacked and burned, fields destroyed, and slaves set free, leaving Southern farmers and plantation owners scrambling to rebuild their lives. Many sold out to land speculators, who set upon them from both the North and the South. Some hapless Southerners migrated to Texas, a state that had survived largely intact from the ravages that beset the Deep South.

Congress recognized that it had a duty to assist ex-slaves in adjusting to freedom and become contributing members of society. They were equally aware that their homelessness, unemployment, and, in many cases, lack of familial ties, threatened the newly won peace and fragile social fabric in the postwar era. To address these issues, Congress established the Freedmen's Bureau in March 1865. Headed by
Major General Oliver O. Howard, the agency operated under the direction of the U.S. War Department. Its principal purpose was to provide relief and security to refugees, both black and white. To accomplish these goals, the agency sought to provide rations, set up schools, obtain land for the resettlement of freedmen, achieve equality of opportunity, and settle disputes between white and black citizens (Crouch 1992; Harper 2009). In Texas, the bureau's administrators stressed the importance of establishing a fair system of labor relations and providing an educational program that would serve both children and adults who had never learned to read and write. Its leaders believed that hard work in a free agricultural labor system would help foster peace and goodwill between whites and blacks, and that education would help former slaves function in the larger society. To those ends, they established a system to review labor contracts and monitor court cases, to organize schools, and to find missing relatives (Harper 2009).

\section{The Role of Freedmen Colonies}

At first, many slaves set out on the roads and eventually found themselves in cities where they generally experienced a hardscrabble life; they found shelter in sheds, barns, alleys, and vacant buildings. Others stayed on their home farms and plantations, sometimes for several years. After that, they often wandered from one farm to another, looking for work and often sharecropping, living in slave cabins left on the place. This type of life must have seemed like an extension of slavery, and after a few years in the fields, many rural blacks were drawn to towns and cities, where work possibilities were more diverse. Austin, where the Freedmen's Bureau was headquartered, drew former slaves from all over central Texas. The presence of the Freedmen's Bureau offered them a greater degree of safety than in the countryside, where they were outnumbered and isolated. Within a few years, clusters of freedmen settled in areas throughout the city, usually in places shunned by whites due to frequent flooding or distance from the central city (Mears 2009).

Under these circumstances, many former slaves throughout the South, including Texas, banded together in small, independent settlements often on the periphery of established towns but also in rural settings at some distance 
from white communities. Called freedmen colonies, or freedom colonies, such enclaves offered support and defense for many freed slaves in the years following emancipation. Historian David Williams explained, "One great protection they found was gathering in groups and farming communities, which in many cases grew into stable communities" ${ }^{\prime 25}$ (David Williams quoted in Gee 2000).

In the country, freedmen colonies were often settled by the former slaves of a common master. As a result, the members were often related to one another by blood or marriage and had existing familial and societal bonds. These ties strengthened the community and furthered its common goals, such as establishing churches and schools.

Rural colonies such as these consisted of small, adjacent parcels of land with one or two log houses to shelter extended families. Virtually all adults who had grown up in rural communities were experienced farmers and stock raisers, and in these new communities they typically practiced subsistence-level farming and animal husbandry, augmented by growing cotton as a cash crop.

Permanent, stable freedmen colonies were based on landownership within the community. Land represented self-determination and an ability to provide for themselves and their families rather than return to virtual servitude as sharecroppers under their former slave masters (Sitton and Conrad 2005:9-42). The mere acquisition of land by men and women who could not read or write and who had few possessions beyond the clothes on their backs was no small achievement. Some were assisted by their former masters, but most worked at odd jobs or as farm laborers for several years before they saved enough money to buy small parcels of land. In Hays County, some were hampered by laws that prevented land sales to blacks (Palomo and Giles 2001).

Despite such obstacles, nearly one-fourth of African American farmers in the South succeeded in buying their own land between 1870 and 1880. In Texas, the increase in landownership among freedmen was extraordinary; in 1870 , five years out of slavery, only 1.8 percent of the state's black farmers owned land, but by 1890 ,

${ }^{25}$ David A. Williams is a history professor at HustonTillotson College in Austin and founder of the Texas African American Heritage Association. an amazing 26 percent achieved landownership. Black landownership in Texas continued to increase and peaked at 31 percent just after the turn of the century (Sitton and Conrad 2005:2).

\section{Antioch in the Context of Freedmen Colonies}

The Antioch Colony largely fits the model outlined above for rural freedmen communities. Many freed slaves in the Mountain City area remained on their masters' farms for several years after emancipation. Harriet Bunton Smith (1941, 2012) remembered that her family stayed on the Jim Bunton place for two or three years after emancipation. Perhaps they decided to strike out on their own after awhile, or possibly their masters couldn't afford to keep them any longer. Whatever the reason, the former slaves began to drift away. Those who started the Antioch Colony didn't stray too far from their former homes, however. They migrated to a piece of land that lay a only a few miles north of Mountain City, near the Travis County border. The undeveloped tract was part of a 541-acre parcel in the P. J. Allen League (Hays County Deed Record F:550).

\section{Antioch Predates Land Sales}

The Hays County Clerk's Office has a spate of deed records filed by freedmen beginning in December 1870, but there is good evidence to show that the Antioch Colony had already taken shape by that time. Registered livestock brands (Hays County Register of Marks and Brands, 1868, 1870, and 1872) provide some of this evidence (Figure 4.4). Elias Bunton registered his livestock brand in Hays County on June 11,1868 , nearly two years before his deed was recorded (February 1871). David Bunton registered his brand on November 29, 1870 , several months before his deed was recorded. ${ }^{26}$ Population census records compiled four months before the first deed records to freedmen were filed clearly indicate the presence of an established African American community

\footnotetext{
${ }^{26}$ Brands were also registered to Joe M. Bunton (No. 87, December 19, 1870) and S. D. Bunton (No. 99, February 8,1872 ), but it not known whether these Buntons were white or black (Hays County Register of Brands and Marks, 1870 and 1872).
} 
near Mountain City. ${ }^{27}$ Among the members clustered together in the census tract were Elias Bunton, Dave Bunton, Peter Beard, and George Kavanaugh, all of whom were farmers without clear title to their land. Elias Bunton is a case in point: He did not own his land until February 1871 , but he registered his livestock brand in June of 1868 , cleared and farmed 30 acres of land before June 1, 1870, and appeared in the Antioch area census in August 1870-all before his deed cleared. Furthermore, the deed record mentioned his existing house on the land. Clearly Elias Bunton and others occupied their land, built houses, and farmed crops several years before the official records were filed. They must have entered into some type of agreement with the property owner, then moved onto and worked the land for some time before making the official purchase.

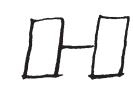

Ransom Bunton

Entry No. 62

May 18,1868

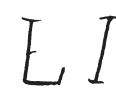

Elias Bunton Entry No. 66 June 11,1868

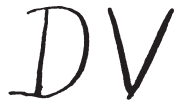

David Bunton Entry No. 83 November 29, 1870
Figure 4.4. Livestock brands registered to Bunton freedmen in Hays County. Data and images from the Hays County Register of Brands and Marks, 1868 and 1870 .

Thus, a sizable community of freedmen had settled north of Onion Creek by the summer of 1870 (Figure 4.5; Table 4.2). Peter Beard, Dave Bunton, Elias Bunton, James Hamilton, George Rector, George Kavanaugh, Harris Watson, John Hughs, and their extended families lived at the site for some time according to the 1870 Census population and agricultural schedules. Ransom Bunton, a former slave of John Wheeler Bunton, lived nearby to the east. Jack Friend, his wife, Elizabeth, and their nine children may have been living in the area by 1870 but were not recorded in the census. The core group was joined soon afterward by George Champ and William

${ }^{27}$ The Antioch Colony was separate from Mountain City but near enough to be counted with that community in the census.
Smith and their families. These 13 families living in 12 households were the founders of the Antioch Colony.

\section{How Antioch Colony Came About}

The story of Antioch Colony would not be complete without a discussion of Joseph Freeborn Rowley (Goodspeed 1888:188-189). Rowley was a relative latecomer in the pioneer history of Hays County, arriving in 1859. Unlike most Mountain City residents, he was not a Southerner, and he owned no slaves. Although born in Virginia in 1828, he grew up in Iowa, married a New Yorker, started his family in Illinois, and lived in California for a while before moving to Hays County, Texas, on the eve of the Civil War. Four of his eight children-Isabella, Joseph, Caroline, and Napoleon-were born in Illinois. Ann and Columbus were born in California, and the seventh child, Perry, was born in Texas in 1860 . He was followed by another son, William, in 1863.

The 1860 census shows that the family was listed in the Manchaca [Springs] Post Office district, which included Mountain City. Northern Hays County was known for stock raising, and he reportedly came to Texas to make his fortune in real estate and livestock. However, Rowley's lack of sympathy for the South and his refusal to fight forced him to abandon his family and move to Mexico for the duration of the war. On a trip back to Texas to visit his sick wife, Rowley was attacked and wounded by Confederate soldiers, who impressed him into service in the artillery corps at Galveston. Determined to escape, he made his way to the Rio Grande and swam across the river back into Mexico (Goodspeed 1888:188). When the war concluded, Rowley returned to Hays County and resumed his real estate ventures. In 1869, he bought the south half of the southeast quarter of the P. J. Allen League from A. C. Crawford for $\$ 1,500$ (Hays County Deed Record F:550). It was the first of many land deals that Rowley would be involved in over the following years, but this parcel was significant to the newly freed ex-slaves of Mountain City.

Within two months of his purchase, Rowley sold tracts in the northern section of the P. J. Allen League to white buyers; he sold 150 acres to Joseph Carbaugh and 75 acres each to James 




Figure 4.5. Map of initial landowners in the core area of Antioch Colony, 1870-1871. The original settlers were George Cavanaugh (Kavanaugh), Griffiths Southwood, George Champ, Peter Beard, Elias Bunton, David Bunton, and Will Smith. Base is 1946 General Land Office map (Morriss and Armstrong 1946). 
Table 4.2. People in the Antioch community, 1870 (U.S. Bureau of the Census, Hays County, Texas, Population Schedule, 1870)

\begin{tabular}{|c|c|c|c|c|}
\hline Name and Relationship & Race & Age & Occupation & Birthplace \\
\hline PETER BEARD, head of household & Black & 35 & Farmer & Kentucky \\
\hline Georgiana, wife & Black & 22 & Keeps house & Arkansas \\
\hline Louisa, daughter & Black & 8 & At home & Texas \\
\hline Leathy?, Lottie? Daughter & Black & 1 & At home & Texas \\
\hline DAVE BUNTON, head of household & Black & 40 & Farmer & Tennessee \\
\hline Mary, wife & Black & 22 & Keeps house & Kentucky \\
\hline Louis, son & Black & 12 & At home & Texas \\
\hline Sarah, daughter & Black & 10 & At home & Texas \\
\hline Tonny, son & Black & 7 & At home & Texas \\
\hline James, son & Black & 4 & At home & Texas \\
\hline Rosa, daughter & Black & 5 & At home & Texas \\
\hline Desha, son & Black & 1 & At home & Texas \\
\hline ELIAS BUNTON, head of household & Black & 33 & Farmer & Kentucky \\
\hline Clarissa, wife & Black & 24 & Keeps house & Kentucky \\
\hline Harriet, daughter & Black & 12 & At home & Texas \\
\hline Ida, daughter & Black & 10 & At home & Texas \\
\hline George, son & Black & 8 & At home & Texas \\
\hline John, son & Black & 6 & At home & Texas \\
\hline Adelade, daughter & Black & 3 & At home & Texas \\
\hline Julia, daughter & Black & $8 \mathrm{mo}$. & At home & Texas \\
\hline Rachall, mother-in-law? & Black & 40 & At home & Kentucky \\
\hline JAMES HAMILTON, head of household & Mulatto & 26 & Farmer & Kentucky \\
\hline Georgiana, wife & Mulatto & 24 & Keeps house & Kentucky \\
\hline Harriet, daughter & Mulatto & 9 & At home & Texas \\
\hline James, son & Mulatto & 6 & At home & Texas \\
\hline Henry, son & Mulatto & 5 & At home & Texas \\
\hline General?, son & Mulatto & 3 & At home & Texas \\
\hline Lula?, Julia? Daughter & Mulatto & $9 \mathrm{mo}$. & At home & Texas \\
\hline Dick, unknown & Black & 13 & At home & Kentucky \\
\hline GEORGE RECTOR, head of household & Mulatto & 35 & Farmer & Arkansas \\
\hline Caroline, wife & Mulatto & 36 & Keeps house & Kentucky \\
\hline Harriet, daughter & Mulatto & 15 & Farmhand & Texas \\
\hline
\end{tabular}


Table 4.2, continued

\begin{tabular}{|c|c|c|c|c|}
\hline Name and Relationship & Race & Age & Occupation & Birthplace \\
\hline Nancy, unknown & Mulatto & 30 & Farmhand & Arkansas \\
\hline Susana, daugher of Nancy? & Mulatto & 13 & Farmhand & Texas \\
\hline Malinda, daughter of Nancy? & Mulatto & 10 & Farmhand & Texas \\
\hline Harriet, daughter of Nancy? & Mulatto & $6 \mathrm{mo}$ & & Texas \\
\hline Susan Breedlove, unknown & Black & 70 & Keeps house & Kentucky \\
\hline Nancy Watson, unknown & Mulatto & 18 & Domestic Servant & Louisiana \\
\hline Louisa Rector, unknown & Black & 70 & Keeps house & Virginia \\
\hline Joseph Rector, unknown & Mulatto & 16 & Farm labor & Texas \\
\hline Mart Breedlove, unknown & Black & 22 & Farmer & Kentucky \\
\hline HARRIS WATSON, head of household & Mulatto & 46 & Farmer & North Carolina \\
\hline Elizabeth, wife & Mulatto & 40 & Keeps house & Virginia \\
\hline ? Girl, Emma?, daughter & Mulatto & 13 & At home & Texas \\
\hline Clarissa, daughter & Mulatto & 9 & At home & Texas \\
\hline JOHN HUGHS, head of household & Black & 45 & Farmer & Kentucky \\
\hline Betsy, wife & Black & 46 & Keeps house & Mississippi \\
\hline John, son & Black & 15 & Farmhand & Texas \\
\hline James, son & Black & 13 & Farmhand & Texas \\
\hline William, son & Black & 11 & At home & Texas \\
\hline GEORGE KAVANAUGH, head of household & Mulatto & 40 & Farmer & South Carolina \\
\hline Missouri, wife & Mulatto & 41 & Keeps house & Georgia \\
\hline George, son & Mulatto & 13 & At home & Missouri \\
\hline Lidia, daughter & Mulatto & 10 & At home & Texas \\
\hline Louis W., son & Mulatto & 7 & At home & Texas \\
\hline Oliver, son & Mulatto & 5 & At home & Texas \\
\hline Sarah, daughter & Mulatto & 2 & At home & Texas \\
\hline Adeline, unknown & Black & 22 & Farmhand & Mississippi \\
\hline Claiborn, unknown & Mulatto & 17 & Farmhand & Mississippi \\
\hline Ella, daughter of Adeline? & Black & 2 & At home & Texas \\
\hline
\end{tabular}

and Ebin Leadenham (Hays County Deed Records F:298, F:288), Rowley's sons-in-law. Some secondary sources have theorized that Rowley used the money he received in these transactions to subsidize sales to freedmen, but that is not supported by deed records (Hays
County Deed Records, various). The following year, in the fall of 1870, Rowley began selling small farms in the southeast quarter of the Allen League and the southwest quarter of the Eggleston League to ex-slaves. These adjacent farms became the nucleus of the Antioch Colony. 
Rumors have long persisted that Rowley was an agent of the Freedmen Bureau or a philanthropist bound to help freedmen. No firm evidence supports the theory that he worked in any official capacity on behalf of the freedmen, but it is known that he obtained his large tract of land in the adjoining P. J. Allen and S. V. R. Eggleston leagues in 1869, the last year the Freedmen's Bureau operated in Texas. This land purchase coincided closely with the establishment of Antioch Colony in the Allen League that fall. ${ }^{28}$ Within a few months, Rowley sold half a dozen farms to freedmen at a time when there was widespread prejudice against selling land to them. ${ }^{29} \mathrm{He}$ appeared to have a paternal attitude toward the recent freedmen; to protect them from losing their land to unscrupulous speculators, Rowley insisted on deed restrictions that required his permission before a sale could be legal. Each deed carried a caveat like this one to Lias (aka Elias) Bunton:

[this sale is made]...on condition that the said [Lias Bunton] shall not have the right to sell or cause to be sold this tract of land or any part thereof, without the consent of the said Rowley or his heirs, if the said Lias Bunton should sell or cause to be sold, this deed is without force or value..." (Hays County Deed Record G:153).

\section{Land Sales and Other Theories}

The possibility of becoming legal owners of their farms had to be utterly enticing to the freedmen of Mountain City. Joseph F. Rowley, the agent of change, made quite an impression on people in the area. After 70 years, Harriet Smith $(1941,2012)$ remembered that "a man

${ }^{28}$ This jibes with Harriet Bunton Smith's recollection that her folks worked on the Bunton place for two or three years after slavery before starting their own farm (Smith 1941, 2012). Rowley purchased the land on October 19, 1869.

${ }^{29}$ In 1859, a group of 20 slaveowners in Hays County had petitioned the General Assembly of the State Legislature to ask for a legislative act "to forbid Negro slaves the right to hold in their own name and for their own use, as property, Horses, Cattle, Land, and Stock of every description, as we see daily the baneful influence and effects on the slave population" (Schweniger 1997:54). named Rowley" began selling land "across the creek" to freedmen. And that land sold quickly. Harriet Smith's father, Elias, bought one of the farms, as did her uncle Dave and Pete Beard, another former slave. Within two or three months, the land set aside for freedmen had sold out. Deed records show that the original inhabitants paid between $\$ 150$ and $\$ 250$ for their 28- to 65-acre parcels in northern Hays County. It is not known whether they worked and saved for the land in the few years since the abolition of slavery, whether the land was purchased for them by others, or whether they received assistance from the Freedmen's Bureau or another agency.

Some have suggested that their slave masters purchased the land for them. Indeed, former slaveowners, some of whom were directly related to their emancipated slaves, did help fund and establish "freedmen's colonies" in the rural South (Sitton and Conrad 2005:35-40). According to Bonnie Carpenter, a descendant of early Mountain City settlers, the "Negroes of Mountain City gave little trouble [after freedom]" because of strong bonds forged between masters and slaves during the antebellum period. She stated that some freedmen chose to stay with their former masters rather than strike out on their own. As an example, she recounted that John Wheeler Bunton gave his former slave, "Uncle Rance" (Ransom Bunton, Sr.), a 160-acre farm but that the freedman declined the offer (Carpenter 1970:6). Later census records show that Ransom Bunton Sr. ultimately moved to the Antioch area, where he worked his own farm.

While some former slaves in the Mountain City area may have remained with their onetime masters for a time, Carpenter stated that the majority were placed in a colony in a section along Onion Creek, just west of the present town of Buda. This is the site of Antioch Colony. The location of the land north of Mountain City and beyond the established white settlement, the similar size of the parcels, and the timing of the land sales within a few months of one another suggests a planned settlement. Carpenter's account implies that white men continued to control the destinies of their former slaves, even after freedom, by buying or giving land or providing a place for them to live within the original household (Carpenter 1970:97). There is no evidence of this in official records. 


\section{LIFE IN ANTIOCH COLONY}

One of the attractions of the Antioch site may have been its very isolation. In the early postwar years, lawlessness reigned in both the cities and the countryside of the South. Some vigilante groups formed to terrorize freedmen and keep them "in their place." The Ku Klux Klan organized a klavern in Hays County. Altercations between freedmen and whites were common in the county, especially in San Marcos (Dobie 1932:81). Harriet Bunton Smith (1941, 2012:1020-1021) recounted how her husband, James, was killed by whites for his political activities. Sitton and Conrad found that ex-slaves tended to form communities in outof-the-way places because they felt safer than in the cities, where reports of violence against African Americans made the daily news. Sitton and Conrad explained, "Freedmen's settlements were communities of avoidance and self-segregation, where black people adapted to Jim Crow restrictions... by withdrawing from whites and by maintaining what Deborah J. Hoskins called 'a culture of dissemblance" (Sitton and Conrad 2005:4).

Antioch may have been such a community. In the early years, few whites lived within miles of the community. Mountain City, where many of the freedmen had lived in bondage for a decade or more, lay several miles to the south and west. The land to the north was virtually vacant for 5 miles or more, and only a handful of white farmsteads were scattered along Onion Creek, to the west. As time passed, more white, Hispanic, and black settlers moved closer to the community, but Antioch remained a rather remote and insular enclave.

While the Antioch settlers may have established their settlement for protection and mutual support, they also forged strong personal bonds based on a common history. First and foremost, they had been born into slavery and lived to see its end. Second, they shared the pioneer experience of traveling overland from Kentucky, Tennessee, and elsewhere in the South, to build new homes in an untamed land. Though born in the Southeast, the Antioch colonists apparently adopted Texas as their permanent home; according to the 1870 census records, most of the adults had lived in Texas for 15 years or more, and virtually all of their children were born in the state (U.S. Bureau of the Census, 1870 Hays County Population Schedule). ${ }^{30}$

Furthermore, most of the Antioch freedmen had established relationships with one another as slaves. The Bunton brothers, Rectors, Haupts, Hughes, Watsons, and Breedloves had all lived in nearby Mountain City for a decade or more before emancipation. They likely worked together on projects like house building and barn raising for their various masters. Unofficial marriages between slaves of different masters in the area further connected the Antioch freedmen, as did the children that were born of these unions. Even during slavery, they worshipped together at the white church in Mountain City and socialized at dances (Smith 1941, 2012). From their shared heritage and experiences, they almost certainly had similar folk and work traditions. In a very real way, the Antioch freedmen had established a community of sorts even before they found a home west of Onion Creek.

\section{The Wilderness}

According to Harriet Bunton Smith (1941, 2012), who came to the Antioch Colony with her parents, Elias and Clarisa ${ }^{31}$ Bunton, the land was entirely woods, unbroken by a plow. It must have been a daunting task to create farmsteads out of raw, rock-pocked land. They probably built temporary lean-to shelters followed by one- or two-room log houses. They likely felled the huge cypress trees that grew along the creeks, as well as upland oak and juniper (cedar) trees, for building timbers and shingles. At the same time, their survival depended on clearing the rocky soil and getting a good crop as soon as possible. Judging by the 1870 Agricultural Census, all of the Antioch settlers engaged in subsistence farming and stock raising, and they planted enough cotton to produce three or four bales for cash.

In fact, the freedmen had already endured such conditions when their masters brought them to Bastrop County, and later to Hays

\footnotetext{
${ }^{30}$ There are some discrepancies in people's ages as listed in the various census tables in this chapter. It was not uncommon for people to either not know their precise age or to state an incorrect age that added or subtracted years.

${ }^{31}$ Her name is listed as Claracy in the 1880 census but Clarisa in all other records.
} 
County. In each case, they had cleared and planted fields, built shelters, and planted and harvested crops from raw land. Both the men and women of Antioch had spent their lives at hard labor on other people's farms and ranches, so they were well equipped to do it again on their own land. Writing about the nearby Onion Creek community, Wayne Roberson observed, "it is assumed that their existence [freed slaves in Hays County] before the Civil War was miserable and that they lives after manumission were only slightly less miserable" (Roberson 1970:72). While the freedmen chores at Antioch were backbreaking and the work relentless, the hardships had to have been mitigated by working for oneself and owning one's own land.

\section{Early Agriculture}

While it is almost certain that a number of freedmen families lived at Antioch in the late 1860 s, the only residents who appeared in the 1870 Hays County tax rolls were Peter Beard and George Kavanaugh. They were among the first to own land in the community, filing their deeds in December 1870. The tax records did not give their acreage, but other notations in the document showed that they were farming their land. Beard owned seven horses, valued at $\$ 100$, and nine head of cattle valued at $\$ 100$. His total worth was listed as $\$ 1,900$. Kavanaugh owned only one horse valued at $\$ 25$ but had six head of cattle valued at $\$ 75$. Kavanaugh also owned miscellaneous property, likely farm equipment, tools, and a wagon or buggy, valued at $\$ 95$. His total worth was calculated at $\$ 195$ (Hays County Tax Rolls, 1870). At the same time, Ransom Williams, possibly a former Bunton slave, ${ }^{32}$ owned between six and nine horses in the Antioch area in the period spanning 1870 to 1873 (Hays County Tax Rolls, 1870-1873).

Although they didn't appear in the 1870 tax rolls, a number of freedmen occupied land and were actively farming it by the summer of 1870 , according to the agricultural census that year (Table 4.3). Seven property owners in the Antioch area were included in the agricultural census: Peter Beard, Dave Bunton, Elias ("Lias") Bunton, James Hamilton, George Kavanaugh, George Rector, and Harris Watson. The record

\footnotetext{
${ }^{32}$ Ransom Williams may have been Ransom Bunton, Jr.
}

shows that the men worked 15 - to 90 -acre farms valued between $\$ 150$ and $\$ 500$. Each owned at least one horse or mule; Elias (Lias) Bunton owned six horses or mules. Six of the seven owned dairy cattle, while six had working oxen, and four owned other cattle, probably for slaughter. All of the farmers owned swine, a staple of the pioneer diet along with corn; George Kavanaugh claimed 18 hogs, and three men each owned eight hogs apiece. The value of all their livestock ranged from $\$ 118$ to $\$ 270$ per farmer (U.S. Bureau of the Census, Hays County, Agricultural Schedule, 1870).

In 1870, the Antioch freedmen were basically subsistence farmers, growing crops and raising livestock to feed their families. Most of their land was planted in corn, both for personal use and to feed their livestock. However, they were able to realize some cash for their work. Each of the seven farmers recorded in the 1870 Agricultural Census planted some cotton for cash. On average, they yielded 3.4 bales each; George Kavanaugh had the most with 6 bales. The farmers may have sold excess butter and molasses. Most of the farmers kept milch (milk) cows that produced between 30 and 100 pounds of butter; according to the 1870 census, John Hughs didn't own any milch cows but somehow made 50 pounds of butter. Most of the farmers made molasses from cane, with yields ranging between 8 and 40 gallons per farmer. Indian corn was the only grain product, and the farmers typically raised between 150 and 300 bushels of corn. All but George Kavanaugh slaughtered livestock for sale; the farmers made between $\$ 50$ and $\$ 150$ from butchered beef and hogs. Kavanaugh produced 75 bushels of sweet potatoes but none of the other farmers raised potatoes as a cash crop. The farms themselves ranged in value from $\$ 330$ to $\$ 570$, with George Kavanaugh, George Rector, and John Hughs at the high end of the scale (U.S. Bureau of the Census, Agricultural Schedule, Hays County, 1870).

By 1875, the Antioch Colony had expanded to include land in the J. Brown League to the northeast (Table 4.4). Elias and Dave Bunton, George Kavanaugh, Peter Beard, William Smith, George Champ, and Rance Bunton Sr. declared property and values for that year. The tax rolls indicate that the pioneers lived on improved farms in the P. J. Allen and Eggleston leagues. Land in the Brown League was less valuable, indicating that it was unimproved at that time. 
Table 4.3. Agricultural statistics for seven freedmen in Antioch community, 1870 (U.S. Bureau of the Census, Hays County, Texas, Agricultural Schedule, 1870)*

\begin{tabular}{|c|c|c|c|c|c|c|c|c|}
\hline \multirow[b]{2}{*}{ Statistic } & \multicolumn{7}{|c|}{ Antioch Resident } & \multirow[b]{2}{*}{ Average } \\
\hline & $\begin{array}{l}\text { Peter } \\
\text { Beard }\end{array}$ & $\begin{array}{c}\text { Dave } \\
\text { Bunton }\end{array}$ & $\begin{array}{c}\text { Elias } \\
\text { Bunton }\end{array}$ & $\begin{array}{c}\text { James } \\
\text { Hamilton }\end{array}$ & $\begin{array}{c}\text { George } \\
\text { Kavanaugh }\end{array}$ & $\begin{array}{l}\text { George } \\
\text { Rector }\end{array}$ & $\begin{array}{l}\text { Harris } \\
\text { Watson }\end{array}$ & \\
\hline $\begin{array}{l}\text { Acres - } \\
\text { improved }\end{array}$ & 25 & 30 & 30 & 30 & 40 & 50 & 15 & 31.4 \\
\hline $\begin{array}{l}\text { Acres - } \\
\text { unimproved }\end{array}$ & 30 & 60 & 0 & 0 & 0 & 0 & 0 & 12.9 \\
\hline Total acreage & 55 & 90 & 30 & 30 & 40 & 50 & 15 & 44.3 \\
\hline Farm value & $\$ 250$ & $\$ 300$ & $\$ 300$ & $\$ 300$ & $\$ 200$ & $\$ 500$ & $\$ 150$ & $\$ 285.71$ \\
\hline $\begin{array}{l}\text { Implements } \\
\text { and machinery } \\
\text { (value) }\end{array}$ & $\$ 15$ & $\$ 15$ & $\$ 15$ & $\$ 10$ & $\$ 10$ & $\$ 20$ & $\$ 10$ & $\$ 13.57$ \\
\hline Horses & 2 & 2 & 6 & 2 & 1 & 3 & 2 & 2.6 \\
\hline $\begin{array}{l}\text { Mules and } \\
\text { asses** }\end{array}$ & 0 & 0 & 0 & 0 & 0 & 0 & 0 & 0.0 \\
\hline Milch cows & 2 & 0 & 3 & 2 & 3 & 8 & 2 & 2.9 \\
\hline Working oxen & 5 & 4 & 0 & 4 & 4 & 4 & 4 & 3.6 \\
\hline Other cattle & 8 & 0 & 0 & 0 & 5 & 11 & 3 & 3.9 \\
\hline Swine & 8 & 4 & 5 & 5 & 18 & 8 & 8 & 8.0 \\
\hline $\begin{array}{l}\text { Value of all } \\
\text { livestock }\end{array}$ & $\$ 211$ & $\$ 118$ & $\$ 200$ & $\$ 120$ & $\$ 150$ & $\$ 270$ & $\$ 170$ & $\$ 177.00$ \\
\hline $\begin{array}{l}\text { Indian corn, } \\
\text { bushels }\end{array}$ & 150 & 170 & 300 & 250 & $* * *$ & 300 & 300 & 245.0 \\
\hline Cotton, bales & 3 & 3 & 3 & 3 & 6 & 4 & 2 & 3.4 \\
\hline $\begin{array}{l}\text { Sweet potatoes, } \\
\text { bushels }\end{array}$ & 0 & 0 & 0 & 0 & 75 & 0 & 0 & 10.7 \\
\hline Butter, lbs. & 30 & 40 & 60 & 30 & 100 & 70 & 70 & 57.1 \\
\hline $\begin{array}{l}\text { Molasses, } \\
\text { gallons }\end{array}$ & 8 & 10 & 15 & 10 & 30 & 40 & 0 & 16.1 \\
\hline $\begin{array}{l}\text { Value of animals } \\
\text { slaughtered }\end{array}$ & $\$ 50$ & $\$ 50$ & $\$ 50$ & $\$ 60$ & $\$ 0$ & $\$ 150$ & $\$ 50$ & $\$ 58.57$ \\
\hline $\begin{array}{l}\text { Value of all farm } \\
\text { production }\end{array}$ & $\$ 340$ & $\$ 340$ & $\$ 410$ & $\$ 395$ & $\$ 570$ & $\$ 570$ & $\$ 330$ & $\$ 422.14$ \\
\hline
\end{tabular}

* Data are entered as presented in the agricultural schedule. Three freedmen farmers listed in the Mountain City area are excluded because they were not part of the core Antioch Colony area: John Hughs, Ben and Elijah Kinchen (or Kincheon), and Harris Watson.

** Mules and asses were not itemized separately and are probably included under horses.

*** The data entered for Kavanaugh's corn production was 1,000 over 200. Since it is unclear what this notation meant, the data are excluded here.

\section{Household Composition and Demographics of the Early Settlement}

According to the 1870 census, the Antioch Colony was composed of fairly homogenous family groups. Most of the adults were born in the Upper South, in the states of Kentucky, Tennessee, Arkansas, or Missouri, while children were almost universally born in Texas. Although slave marriages were unofficial unions, the Antioch colonists quickly formed households consisting of husband, wife, their children, and sometimes in-laws and grandchildren. Several 
The Ransom and Sarah Williams Farmstead

Table 4.4. The Antioch Colony in the 1875 tax records (Hays County ad valorem tax rolls, 1875)

\begin{tabular}{|c|c|c|c|c|c|c|}
\hline Name & Total Worth & Abstract & Acres & Value & $\begin{array}{c}\text { No. and Value } \\
\text { of Horses and } \\
\text { Mules }\end{array}$ & $\begin{array}{c}\text { No. and Value } \\
\text { of Cattle }\end{array}$ \\
\hline \multirow{2}{*}{ Elias Bunton } & \multirow{2}{*}{$\$ 940$} & P.J. Allen & 50 & $\$ 400$ & $7 / \$ 220$ & $14 / \$ 120$ \\
\hline & & J. Brown & 60 & $\$ 120$ & & \\
\hline \multirow{2}{*}{ Peter Beard } & \multirow{2}{*}{$\$ 1,080$} & P.J. Allen & 55 & $\$ 550$ & $8 / \$ 220$ & $8 / \$ 90$ \\
\hline & & J. Brown & 60 & $\$ 120$ & & \\
\hline David Bunton & $\$ 360$ & P.J. Allen & 45 & $\$ 220$ & $4 / \$ 110$ & $2 / \$ 30$ \\
\hline Rance Bunton & $\$ 140$ & Eggleston & 15 & $\$ 70$ & 0 & $4 / \$ 20$ \\
\hline George Champ & $\$ 300$ & P.J. Allen & 23 & $\$ 220$ & $3 / \$ 60$ & $3 / \$ 20$ \\
\hline \multirow{2}{*}{ George Kavanaugh } & \multirow{2}{*}{$\$ 880$} & P.J. Allen & 60 & $\$ 500$ & $4 / \$ 100$ & $10 / \$ 110$ \\
\hline & & J. Brown & 64 & $\$ 100$ & & \\
\hline \multirow{2}{*}{ William Smith } & \multirow{2}{*}{$\$ 620$} & P.J. Allen & 28 & $\$ 300$ & $5 / \$ 150$ & $6 / \$ 40$ \\
\hline & & J. Brown & 60 & $\$ 60$ & & \\
\hline
\end{tabular}

older women lived in households with their adult children. No single people were enumerated as living on their own that year.

Male heads of household ranged in age from 26 to 45 . All of the adult men were farmers, and all of their wives were housekeepers. Other household members, including children under the age of 18, worked as farmhands or farm laborers. One young woman worked as a domestic servant. All families had children; couples typically had between five and six children.

Shortly after the 1870 census was taken, George Champ, William Smith, and their families moved to the community and bought farms adjacent to the Buntons (Hays County Deed Records G:46, G:152). Smith followed the pattern established by the community pioneers. By 1880, Smith was 45 years old, from Tennessee, and a farmer. His wife, Ellen, was 43 , from Mississippi, and a homemaker. Their eight children were all born in Texas, and three of them were under 10 years old. At 54, Champ was somewhat older than the other men in the community, and he hailed from Virginia, rather than the Upper South. His wife, Rose, was born in Alabama. They had no children of their own but invited local children to live with them (Smith 1941, 2012). Like the others, Champ was a farmer, while Rose was a homemaker (U.S. Bureau of the Census, Hays County, Population Schedules, 1870, 1880). By 1875, Ransom Bunton Sr., his wife Jane, and his family had joined the community (Hays County Tax Rolls, 1875). Bunton and Jane had been slaves of Desha Bunton.

\section{The Community}

The Antioch Colony was more than a collection of farms and closely related families: It was a community of like-minded freedmen who shared a past and a vision for the future. Its inhabitants possessed a strong sense of common purpose; they believed in God, education, and civic duty. As time passed, their children tended to marry within the group, further strengthening the community bonds (U.S. Bureau of the Census, Hays County, Population Schedules, 1880, 1900). Roberson defined a community as "a social group of any size whose members reside in a specific locality, share government, and have a common cultural and historical heritage" (Roberson 1972:44). Michelle Mears is more specific in her definition of a freedmen community as "a named area, settled initially by freedmen and their families before 1900, and including a church or school organized by or for African Americans" (Mears 2009:25). By either definition, Antioch Colony met the criteria as a community almost from its inception.

In the late 1860 s and early $1870 \mathrm{~s}$, the Antioch freedmen were consumed with building shelters, clearing fields, and starting their farms. The 1870 census shows that none of the adults 
could read or write, and none of the children attended school. Within a few years, however, the community took steps to correct that situation. In 1874, Elias and Clarisa Bunton donated land for a community school. The deeded property was specifically for the establishment of a "Public School House for the Colored People [in Precinct 5]" and it offered the school house to be used as a "house of public worship by the Colored People" (Hays County Deed Record I:243 in Schwartz 1986:352). Men of the community built a two-story frame building just south of the present Antioch Cemetery. School trustees were Antioch residents Elias Bunton and George Kavanaugh, and a white farmer and Methodist preacher, Cyrus M. Carpenter, ${ }^{33}$ who lived to the west of the community (Schwartz 1986:207, 352 ). By 1880, most of the children between the ages of 7 and 18 attended school and could read and write. At one time, Antioch School District 5 served as many as 57 students.

Church services were probably held in the school building until 1881, when Elias and Clarisa Bunton sold a quarter-acre out of their original 45-acre tract "for use of the African Methodist Church" for the nominal price of $\$ 10.00$. Trustees for the church were George Kavanaugh, William Smith, Louis White, and Ed Lawson (Hays County Deed Record P:22). A church building was erected and a cemetery established nearby. In addition to church and school activities, the Antioch community supported a Masonic Lodge and an Eastern Star organization, both of which met in the second floor of the school building (Schwartz 1986:352).

It is not known when the community began to be called Antioch Colony, but the residents apparently gave it that name. Descendants today confirm that the community was named for the Turkish city where the Apostle Paul preached the Gospel, and followers of Jesus were first called Christians. Numerous early African American churches bear the name "Antioch," especially African Methodist Episcopal and Baptist congregations. The church may have been called Antioch Methodist Church, and the name became associated with the community. In her 1939 thesis on Mountain City, Carpenter observed that the place was called the "Negro

\footnotetext{
${ }^{33}$ In the 1880 census, Carpenter and two of his brothers are identified as schoolteachers. Perhaps one or more taught at the Antioch school.
}

Colony"34 (Carpenter 1970:97), a name that whites undoubtedly imposed on the community. The 1880 population census shows that most of the original settlers, including Peter Beard, George Kavanaugh, William Smith, Elias Bunton, Dave Bunton, and George Champ remained in the community (Table 4.5; see Figure 4.5). Ransom Bunton, Sr. had arrived before 1870, though he didn't appear in the census for that year. Berry Burnham and his wife, Em, set up housekeeping in the area shortly after 1870 . Burnham was a relative outsider, having come from South Carolina. Em was only 16 and a member of the extended Bunton family. By 1880, John Hughs moved his family near Ransom Bunton Sr:; Martha Pelham and Jack Friend lived nearby. A Jimmy Porter, his wife, Narcisa, their two children and a boarder lived near George Kavanaugh, and Ed and Lucy Lawson and their son Willie lived near Peter Beard. Newton Peoples and his family lived near George Champ. In all, more than 80 people lived in or around the Antioch Colony in 1880. A mulatto man named Brown Bunton boarded with Dave Bunton. From his name, age, and association with Dave Bunton, he had probably been the slave of James M. Bunton or John Wheeler Bunton and a close relative of Dave Bunton (U.S. Bureau of the Census, Hays County, Population Schedule, 1880).

Demographics for 1880 show that 14 of the men were farmers, and six others listed their occupations as laborers. Several of the laborers were grown sons of farmers who lived in their parents' household. Almost all of the wives were identified as "keeping house" but one woman worked as a servant. No other occupations were listed for 1880. The biggest change from 1870 was school attendance; in 1870, none of the residents, adult or child, could read or write, but in 1880, 16 children in the community were attending school and many were literate (U.S. Bureau of the Census, Hays County, Population Schedule, 1880). By that time, the Antioch School had been in existence for about five years. Students in the community were probably joined by other African American students from the surrounding territory.

As in the previous census, most of the Antioch inhabitants were born in the Upper South, with a majority born in Kentucky and Tennessee. In 1880, 10 adults were born in

\footnotetext{
${ }^{34}$ The 1920 Census identified the community as "Negro Colony" (U.S. Bureau of the Census, Hays County, Population Schedule, 1920).
} 
Table 4.5. People in the Antioch community, 1880 (U.S. Bureau of the Census, Hays County, Texas, Population Schedule, 1880)

\begin{tabular}{|c|c|c|c|c|}
\hline Name and Relationship & Race & Age & Occupation & Birthplace \\
\hline MARTHA PELHAM, head of household & Black & 45 & Servant & \\
\hline JACK FRIEND, head of household & Black & 60 & Laborer & Arkansas \\
\hline Elizabeth, wife & Black & 45 & Keeps house & Mississippi \\
\hline Charity, daughter & Black & 16 & In school & Texas \\
\hline Dan, son & Black & 13 & In school & Texas \\
\hline Emma, daughter & Black & 12 & & Texas \\
\hline George, son & Black & 10 & & Texas \\
\hline Kate, daughter & Black & 8 & & Texas \\
\hline Martha, daughter & Black & 6 & & Texas \\
\hline Ed, son & Black & 4 & & Texas \\
\hline PLES FRIEND, head of household & Black & 22 & Laborer & Texas \\
\hline Ella, wife of Theo & Black & 18 & & Texas \\
\hline JOHN HUGHES, head of household & Mulatto & 55 & Laborer & Kentucky \\
\hline Betsy, wife & Black & 45 & Keeps house & Kentucky \\
\hline William, son & Mulatto & 21 & At home & Texas \\
\hline Silla, daughter & Black & 21 & & Texas \\
\hline William, grandson? & Black & $7 \mathrm{mo}$. & & Texas \\
\hline RANSOM BUNTON, head of household & Black & 65 & Farmer & Kentucky \\
\hline Jane & Black & 55 & Keeps house & Virginia \\
\hline Anna & Black & 17 & At home & Texas \\
\hline Elizabeth & Black & 15 & At home & Texas \\
\hline William & Black & 14 & & Texas \\
\hline Joel & Black & 11 & & Texas \\
\hline Birdy & Black & 4 or 9 & & Texas \\
\hline JIMMY PORTER, head of household & Black & 35 & Farmer & Kentucky \\
\hline Narcisa & Black & 25 & Keeps house & Texas \\
\hline Robert & Black & 10 & At home & Texas \\
\hline William & Black & 7 or 2 & & Texas \\
\hline Sam Bunton, nephew? stepson? & Black & 5 & & Texas \\
\hline GEORGE KAVANAUGH, head of household & Black & 50 & Farmer & Missouri \\
\hline Missouri & Black & 51 & Keeps house & Georgia \\
\hline Lewis & Black & 26 & Laborer/School & Texas \\
\hline
\end{tabular}


Table 4.5, continued

\begin{tabular}{|c|c|c|c|c|}
\hline Name and Relationship & Race & Age & Occupation & Birthplace \\
\hline Laura, daughter & Black & 18 & In school & Texas \\
\hline Oliver, son & Black & 15 & In school & Texas \\
\hline Sarah, daughter & Black & 12 & In school & Texas \\
\hline George Kinchen, grandson & Black & 5 & & Texas \\
\hline George Kavanaugh, son & Black & 23 & Farmer & Texas \\
\hline Ida, wife of son & Black & 18 & Keeps house & Texas \\
\hline Cordelia, granddaughter & Black & baby & & Texas \\
\hline ED LAWSON, head of household & Black & 25 & Farmer & Texas \\
\hline Lucy, wife & Black & 20 & Keeps house & Texas \\
\hline Willie, son & Black & 2 & & Texas \\
\hline PETER BEARD, head of household & Black & 45 & Farmer & Kentucky \\
\hline Georgian, wife & Black & 37 & Keeps house & Arkansas \\
\hline Lottie, daughter & Black & 10 & In school & \\
\hline WILLIAM SMITH, head of household & Black & 45 & Farmer & Tennessee \\
\hline Ellen, wife & Black & 43 & Keeps house & Mississippi \\
\hline Emma, daughter & Black & 21 & At home & Texas \\
\hline Margaret, daughter & Black & 16 & At home & Texas \\
\hline Clement, son & Black & 14 & In school & Texas \\
\hline Frank, son & Black & 12 & In school & Texas \\
\hline Kitty, daughter & Black & 10 & In school & Texas \\
\hline Betsy, daughter & Black & 8 & In school & Texas \\
\hline Willie, son & Black & 6 & & Texas \\
\hline Mattie, daughter & Black & 4 & & Texas \\
\hline SAM SMITH, head of household & Black & 29 & Farmer & Texas \\
\hline Ester, wife & Black & 19 & Keeps house & Texas \\
\hline Alipa?, daughter & Black & 3 & & Texas \\
\hline ELIAS BUNTON, head of household & Black & 40 & Farmer & Texas \\
\hline Clarracy, wife & Black & 38 & & Kentucky \\
\hline George & Black & 16 & & Texas \\
\hline Adeline & Black & 13 & In school & Texas \\
\hline Julia & Black & 11 & In school & Texas \\
\hline Mary & Black & 8 & In school & Texas \\
\hline Peter & Black & 5 & & Texas \\
\hline
\end{tabular}


Table 4.5, continued

\begin{tabular}{l|l|c|l|l}
\hline \multicolumn{1}{c|}{ Name and Relationship } & \multicolumn{1}{|c|}{ Race } & Age & \multicolumn{1}{|c}{ Occupation } & \multicolumn{1}{|c}{ Birthplace } \\
\hline BERRY BURNHAM, head of household & Black & 35 & Farmer & South Carolina \\
\hline Em, wife & Black & 25 & Keeps house & Kentucky \\
\hline Washington, son & Black & 10 & In school & Texas \\
\hline Caracy, daughter & Black & 9 & & Texas \\
\hline Willie, son & Black & 8 & & Texas \\
\hline Ellen, daughter & Black & 7 & & Texas \\
\hline Eliza, daughter & Black & 5 & & Texas \\
\hline Mary, daughter & Black & 2 & & Texas \\
\hline Hannah Bunton, mother-in-law & Mulatto & 50 & At home & Texas \\
\hline & & & & \\
\hline DAVE BUNTON, head of household & Black & 54 & Farmer & Kentucky \\
\hline Mary, wife & Black & 50 & Keeps house & Kentucky \\
\hline Tonny & Black & 18 & Laborer/School & Texas \\
\hline Jim & Black & 17 & Laborer & Texas \\
\hline Desha & Black & 12 & In school & Texas \\
\hline Willie & Black & 8 & In school & Texas \\
\hline Francine & Black & 5 & At home & Texas \\
\hline Brown Bunton, boarder & Mulatto & 48 & Farmer & Kentucky \\
\hline & & & & \\
\hline NEWTON PEOPLES, head of household & Mulatto & 25 & Farmer & Tennessee \\
\hline Sallie, wife & Black & 21 & Keeps house & Texas \\
\hline Dora, daughter & Black & 7 & & Texas \\
\hline GEORGE CHAMP, head of household & & & & \\
\hline Rose, wife & Black & 54 & Farmer & Virginia \\
\hline & & $48 ?$ & Keeps house & Alabama \\
\hline
\end{tabular}

Kentucky, two each in Virginia, Arkansas, Tennessee, and Mississippi, and one each in Missouri, Georgia, South Carolina, and Alabama (see Table 4.5). Four young adults who headed their own households had been born in Texas. These results were similar to records for whites in the surrounding farms. It was the first year in which some of the adults were native Texans rather than immigrants from other states.

\section{Landholdings}

The Smith, Beard, Kavanaugh, Champ, Elias Bunton, and Dave Bunton farms lay at the heart of the community (Table 4.6). According to various 1870 s deed records, these adjacent farms formed a tight cluster, with the Bunton and Champ farms at the center. The original farms ranged in size from William Smith's 28 acres to George Kavanaugh's 65-acre farm. ${ }^{35}$ Peter Beard initially purchased a 50-acre tract, and George Champ and Elias and Dave Bunton each owned 45-acre farms. A fourth 45-acre tract was owned by a man named Griffith Southwood; Southwood was a white man who lived near Driftwood. He may have leased the farm to James Hamilton, who lived next to the Buntons according to the 1870 census (Hays County Deed Records, various 1869-1871; U.S. Bureau of the Census, Hays

${ }^{35}$ The deed record data does not precisely match the data in the 1870 Agricultural Census in Table 4.3. 
Table 4.6. The Antioch Colony landholdings in the 1880 tax records (Hays County ad valorem tax rolls, 1880)

\begin{tabular}{l|c|l|c|c|c|c}
\hline \multirow{2}{*}{ Name } & Total Worth & \multicolumn{1}{|c|}{ Abstract } & Acres & Value & $\begin{array}{c}\text { No. and Value } \\
\text { of Horses and } \\
\text { Mules }\end{array}$ & $\begin{array}{c}\text { No. and Value of } \\
\text { Cattle }\end{array}$ \\
\hline \multirow{2}{*}{ Elias Bunton } & \multirow{2}{*}{$\$ 560$} & Allen & 55 & $\$ 330$ & $7 / \$ 100$ & $12 / \$ 60$ \\
\cline { 3 - 7 } & & Wells (Brown) & 50 & $\$ 30$ & & \\
\hline \multirow{2}{*}{ Peter Beard } & \multirow{2}{*}{$\$ 480$} & Allen & 55 & $\$ 350$ & $2 / \$ 30$ & $8 / \$ 40$ \\
\cline { 3 - 7 } & & Wells (Brown) & 30 & $\$ 30$ & & \\
\hline David Bunton & $\$ 320$ & Allen & 45 & $\$ 240$ & $3 / \$ 60$ & 0 \\
\hline Rance Bunton & No entry & & & & & \\
\hline George Champ & $\$ 200$ & Allen & 22 & $\$ 150$ & $2 / \$ 30$ & $4 / \$ 20$ \\
\hline \multirow{2}{*}{ George Kavanaugh } & \multirow{2}{*}{$\$ 440$} & Allen & 60 & $\$ 250$ & $2 / \$ 30$ & $8 / \$ 40$ \\
\cline { 3 - 7 } & & Wells (Brown) & 64 & $\$ 60$ & & \\
\hline \multirow{2}{*}{ William Smith } & \multirow{2}{*}{$\$ 360$} & Allen & 30 & $\$ 200$ & $3 / \$ 80$ & 0 \\
\cline { 3 - 7 } & Wells (Brown) & 60 & $\$ 60$ & & \\
\hline
\end{tabular}

County, Population Schedule, 1870). Ransom Bunton Sr. apparently lived a little northeast of the settlement and owned land in the S. V. R. Eggleston League. It may have been given to him or purchased for him by John Wheeler Bunton, his former slave master (Carpenter 1970:6).

Within a few years, farmers began acquiring additional land, indicating that they had achieved an element of success with their farms. By 1875, Elias Bunton, Peter Beard, George Kavanaugh, and William Smith each bought 60 -acre tracts of land in the J. Brown League, which lay northeast of the Allen League and just south of present Manchaca. They remained on their farmsteads but probably used the extra acreage to graze stock. The 1880 agricultural census indicates that Peter Beard's 60-acre tract in the Brown League was unimproved woodland. In 1882, Ransom Bunton purchased 10 acres of land in the Antioch Colony, just east of Elias Bunton and George Kavanaugh in the Eggleston League (Hays County Deed Record N:598).

The Antioch settlers continued to buy land in the P. J. Allen League during the 1870 s and 1880 s. Additional tracts were generally between 20 and 30 acres in size and lay adjacent to the original farms, thus expanding the range of the community. Shortly after his initial purchase, Elias Bunton bought a 12-acre tract adjacent to William Smith's farm (Hays County Deed Record
G:620). ${ }^{36}$ In September 1873, Bunton bought another 24-acre tract from B. B. Garth (Hays County Deed Record H:60-7). In 1880, Bunton bought 30 acres on the northern edge of the colony from Joseph Carbaugh, and in 1883, he purchased 9 acres from Lewis and Aurelia Heep on the east side of the colony (Hays County Deed Record $\mathrm{N}: 601)$. In 1886, Bunton bought his largest parcel, a tract of 120 acres, from Susan Ann Cole (Hays County Deed Record U:463). All of this land was adjacent to or very near Bunton's home farm but beyond the original core of the Antioch Colony.

Peter Beard and George Kavanaugh also bought additional acreage. James and Martha Allen sold a 25-acre tract to Peter Beard in 1883 (Hays County Deed Record R:445). Sometime after 1880, George Kavanaugh purchased 20 acres of land that Rowley originally sold to a white farmer (Hays County Deed Record R:293). Kavanaugh also acquired another 64-acre tract from B. B. Garth about the same time (Hays County Deed Record H:607). As a result, the Antioch community grew to encompass about 500 acres in the Allen and Eggleston leagues, with at least four of the men owning farms that

\footnotetext{
${ }^{36}$ Deed records at this time identified Elias Bunton and his neighbor William Smith as FMOC (Free Men of Color) (HCDR R:293).
} 
together totaled 240 acres in the J. Brown tract, to the northeast.

Most of the settlers owned some livestock that required brands. Dave Bunton, Elias Bunton, and Ransom Bunton, Sr., all registered brands for their livestock. David Bunton registered his cattle brand as "DV" in the Hays County Register of Marks and Brands (1870). Ransom Williams, who lived north of Antioch Colony in Travis County, registered a horse brand as "RA" for his nine horses or mules listed in the Travis County Register of Marks and Brands (1872) and paid taxes on horses in the early 1870s (Hays County Tax Rolls 1870-1873; Travis County Tax Rolls, 1874).

\section{Railroad Bypasses Mountain City and Antioch}

When the railroad from Austin to San Marcos was built in 1880, its tracks bypassed the rural communities of Mountain City and Antioch. Many of the white residents of Mountain City moved to the new towns of Buda and Kyle that cropped up on the railroad line, where there were more opportunities for economic advancement as merchants or cotton brokers. Some built homes in the new towns but continued to operate their farms and ranches in the Mountain City area. At the same time, the new town of Manchaca was platted on the railroad line in southern Travis County. Manchaca, Buda, and Kyle formed a string of small towns that ran in a straight line along the railroad route between Austin and San Marcos.

The demise of Mountain City probably didn't affect Antioch Colony to a significant degree. The Antioch Colony was largely self-sufficient, and any services or goods the residents may have purchased in the scattered stores of Mountain City could be readily found in the new towns of Buda and Manchaca. And, while white landowners moved into town, Antioch residents may have stayed in the country because of Joseph Rowley's deed restrictions against selling property without his permission. Although he lifted the restrictions in 1893, the document wasn't filed in Hays County until 1913 (Hays County Deed Record 63:556; Schwartz 1986:353). This impediment may have been a factor in Antioch's persistence long after Mountain City was abandoned.
Because there are no population or agricultural census records available for 1890 , it is difficult to know how the composition of the Antioch Colony changed during the twenty-year period between 1880 and 1900. However, the number of land purchases made by Antioch residents in the 1880 s seems to indicate that the community was thriving and that agriculture remained the basis of the economy. Antioch School District No. 5 continued to serve African American students across northern Hays County, and the construction of the African Methodist Church is further evidence of the colony's viability and long-term commitment to the land.

\section{The Twentieth Century}

By the turn of the twentieth century, the tight-knit Antioch community had about 17 households with 90 members (Table 4.7) ${ }^{37}$ Thirteen heads of household were farmers, though some operated small businesses as well. Three heads of household had no occupations listed; two of these were women, Estella Bunton and Elizabeth Friend. One family head was listed as a farm laborer. Older children worked as farm laborers. Only six heads of household were listed as property owners; they were Berry Burnham, George Champ, James Smith, Peter Beard, George Kavanaugh and George W. Kavanaugh (U.S. Bureau of the Census, Hays County, Population Schedule, 1900). Others who were listed as renters are known to have owned their own property from deed records; they included Charley Bunkley and Tony Bunton (Hays County Deed Records, various).

The Antioch farmers primarily grew grains, particularly Indian corn, and sorghum cane for molasses. Families raised their own food. They had large vegetable gardens and fruit orchards and raised chickens and other poultry, hogs, dairy cows, and beef cattle. Most supplemented their diets with game, including rabbits, squirrel, doves, and quail. Women and children picked wild grapes and berries, and families fished in Onion Creek (Gee 2000; Schwartz 1986:353). Most grew cotton for cash, and some share-

\footnotetext{
${ }^{37}$ It is difficult to know exactly how many families lived in the area known as Antioch Colony as the census taker did not identify it as such. The families noted lived in the country near one another in 1900 .
} 
Table 4.7. People in the Antioch community, 1900 (U.S. Bureau of the Census, Hays County, Texas, Population Schedule, 1900)

\begin{tabular}{|c|c|c|c|c|c|c|}
\hline Name and Relationship & Race & Age & Occupation & Birthplace & \begin{tabular}{|c} 
Rents \\
or Owns \\
Farm \\
\end{tabular} & $\begin{array}{l}\text { Reads / } \\
\text { Writes } \\
\end{array}$ \\
\hline STILMAN SARPER, head of household & Black & 49 & Farmer & Texas & Rents & Yes \\
\hline Nancy, wife & Black & 33 & & Texas & & Yes \\
\hline Ada, daughter & Black & 14 & At school & Texas & & Yes \\
\hline Jon, Jim? Son & Black & 8 & & Texas & & \\
\hline Samuel, son & Black & 6 & & Texas & & \\
\hline Sarah A., daughter & Black & 4 & & Texas & & \\
\hline Ellen, daughter & Black & 2 & & Texas & & \\
\hline $\begin{array}{l}\text { CHARLES BUNKLEY, head of } \\
\text { household }\end{array}$ & Black & 51 & Farmer & Louisiana & Rents & No \\
\hline Adaline & Black & unkn. & & & & No \\
\hline ESTELLA BUNTON, head of household & Black & 27 & & Texas & $*$ & Yes \\
\hline Eva & Black & 7 & & Texas & & \\
\hline BERRY BURNHAM, head of household & Black & 54 & Farmer & $\begin{array}{l}\text { South } \\
\text { Carolina } \\
\end{array}$ & Mortgage & No \\
\hline Emiline, wife & Black & 50 & & Kentucky & & No \\
\hline Henry, son & Black & 24 & & Texas & & Yes \\
\hline GEORGE CHAMP, head of household & Black & 77 & Farmer & Virginia & Owns & No \\
\hline Rosella & Black & 61 & & Alabama & & No \\
\hline JAMES SMITH, head of household & Black & 46 & Farmer & Texas & Owns & Yes \\
\hline Harriet, wife & Black & 40 & & Texas & & Yes \\
\hline Louis, son & Black & 22 & $\begin{array}{l}\text { Laborer/ } \\
\text { School }\end{array}$ & Texas & & Yes \\
\hline Henry, son & Black & 16 & $\begin{array}{l}\text { Laborer/ } \\
\text { School }\end{array}$ & Texas & & Yes \\
\hline Florence, daughter & Black & 12 & In school & Texas & & Yes \\
\hline Emily, daughter & Black & 10 & In school & Texas & & Yes \\
\hline Albert, son & Black & 8 & & Texas & & \\
\hline Alma, daughter & Black & 4 & & Texas & & \\
\hline James, son & Black & 3 & & Texas & & \\
\hline Julius, son & Black & 1 & & Texas & & \\
\hline
\end{tabular}


Table 4.7, continued

\begin{tabular}{|c|c|c|c|c|c|c|}
\hline Name and Relationship & Race & Age & Occupation & Birthplace & $\begin{array}{c}\text { Rents } \\
\text { or Owns } \\
\text { Farm } \\
\end{array}$ & $\begin{array}{l}\text { Reads / } \\
\text { Writes }\end{array}$ \\
\hline DANIEL FRIEND, head of household & Black & 34 & $\begin{array}{l}\text { Farm } \\
\text { laborer }\end{array}$ & Texas & $*$ & Yes \\
\hline Sallie, wife & Black & 40 & & Texas & & No \\
\hline Jim, son & Black & 11 & & Texas & & Yes \\
\hline Lidia, daughter & Black & 8 & & Texas & & \\
\hline ELIAS BUNTON, head of household & Black & 56 & Farmer & Kentucky & $*$ & No \\
\hline TONY BUNTON, head of household & Black & 35 & Farmer & Texas & Rents & \\
\hline Emma, wife & Black & 34 & & Texas & & \\
\hline Thomas, son & Black & 16 & $\begin{array}{l}\text { Farm } \\
\text { Laborer }\end{array}$ & Texas & & No \\
\hline Ola, daughter & Black & 14 & & Texas & & Yes \\
\hline Cora, daughter & Black & 12 & & Texas & & Yes \\
\hline Girian?, daughter & Black & 9 & & Texas & & Yes \\
\hline Longue, son & Black & 7 & & Texas & & Yes \\
\hline Jefferson, son & Black & 5 & & Texas & & \\
\hline Eliline, son & Black & 3 & & Texas & & \\
\hline JAMES BUNTON, head of household & Black & 24 & Farmer & Texas & Rents & Yes \\
\hline Mary, wife & Black & 25 & & Texas & & Yes \\
\hline Maud, daughter & Black & 4 & & Texas & & \\
\hline Jane, daughter & Black & 3 & & Texas & & \\
\hline Alard, son & Black & 1 & & Texas & & \\
\hline ELIZABETH FRIEND, head of houshold & Black & 64 & & Mississippi & $*$ & No \\
\hline Lenora Bunton, granddaughter & Black & 17 & & & & Yes \\
\hline Lavinia Bunton, granddaughter & Black & 16 & & & & Yes \\
\hline Howell Bunton, grandson & Black & 15 & & & & Yes \\
\hline WILLIAM BUNTON, head of household & Black & 24 & & Texas & $*$ & Yes \\
\hline Kate, wife & Black & 28 & & Texas & & Yes \\
\hline Ada, daughter & Black & 10 & & Texas & & \\
\hline Rosa, daughter & Black & 9 & & Texas & & \\
\hline Fred, son & Black & 7 & & Texas & & \\
\hline Walter, son & Black & 6 & & Texas & & \\
\hline Hester, daughter & Black & 3 & & Texas & & \\
\hline
\end{tabular}


Table 4.7, continued

\begin{tabular}{|c|c|c|c|c|c|c|}
\hline Name and Relationship & Race & Age & Occupation & Birthplace & $\begin{array}{c}\text { Rents } \\
\text { or Owns } \\
\text { Farm }\end{array}$ & $\begin{array}{l}\text { Reads / } \\
\text { Writes }\end{array}$ \\
\hline PETER BEARD, head of household & Black & 60 & Farmer & Kentucky & Owns & No \\
\hline Betti, wife & Black & 40 & & Tennessee & & No \\
\hline Arnold, son & Black & 22 & & Tennessee & & No \\
\hline JOHN DAVIS, head of household & Black & 28 & Farmer & Texas & Rents & No \\
\hline $\begin{array}{l}\text { GEORGE KAVANAUGH, head of } \\
\text { household }\end{array}$ & Black & 43 & Farmer & Texas & Owns & Yes \\
\hline Ida, wife & Black & 46 & & Texas & & Yes \\
\hline Cordelia, daughter & Black & 20 & & Texas & & Yes \\
\hline Geneva, daughter & Black & 18 & & Texas & & Yes \\
\hline Harvey, son & Black & 16 & $\begin{array}{l}\text { Laborer/ } \\
\text { School }\end{array}$ & Texas & & Yes \\
\hline Loris, daughter & Black & 14 & In school & Texas & & Yes \\
\hline John W., son & Black & 12 & In school & Texas & & Yes \\
\hline Milton, son & Black & 10 & In school & Texas & & Yes \\
\hline Pollie, daughter & Black & 8 & In school & Texas & & Yes \\
\hline Claricy, daughter & Black & 5 & & Texas & & \\
\hline Annie, daughter & Black & $3 \mathrm{mo.}$ & & Texas & & \\
\hline $\begin{array}{l}\text { GEORGE W. KAVANAUGH, head of } \\
\text { household }\end{array}$ & Black & 70 & Farmer & $\begin{array}{l}\text { South } \\
\text { Carolina }\end{array}$ & Owns & Yes \\
\hline Elizabeth, wife & Black & 44 & & Alabama & & No \\
\hline Sydney, grandson & Black & 15 & $\begin{array}{l}\text { Farm } \\
\text { laborer }\end{array}$ & Texas & & Yes \\
\hline $\begin{array}{l}\text { FRANCISCO REVADA, head of } \\
\text { household }\end{array}$ & White & 49 & Farmer & Texas & Rents & No \\
\hline Termisa, wife & Black & 45 & & Texas & & No \\
\hline Ceona, daughter & Black & 21 & & Texas & & No \\
\hline Andress, son & Black & 18 & $\begin{array}{l}\text { Farm } \\
\text { laborer }\end{array}$ & Texas & & No \\
\hline Maryo, son & Black & 17 & $\begin{array}{l}\text { Farm } \\
\text { laborer }\end{array}$ & Texas & & No \\
\hline Pablo, daughter & Black & 15 & & Texas & & No \\
\hline James, son & Black & 13 & & Texas & & No \\
\hline Delia, daughter & Black & 8 & & Texas & & \\
\hline Walter, son & Black & 7 & & Texas & & \\
\hline Anstacio, son & Black & 6 & & Texas & & \\
\hline Ada, daughter & Black & 4 & & Texas & & \\
\hline
\end{tabular}

*No data entered. 
cropped on nearby farms (Sitton and Conrad 2005:188)

Some Antioch residents performed services or sold goods to people in the surrounding territory. Berry Burnham collected water from George Taylor's well or from Kelley Springs and sold it to people in nearby Buda for 25 cents a barrel. Oliver Kavanaugh ran a mule-powered mill where he processed grains for bran and corn meal. John Taylor built a mule-powered machine that crushed sorghum for processing into molasses. George Harper assisted him as a youth. Maggie Revada and Pinky Varner served their community as midwives and delivered most of the babies in the colony (Schwartz 1986:352). Others built fences, dug ditches, and built stone structures (Sitton and Conrad 2005:188).

Many of the children attended school during the year. Antioch School District 5 drew students from across northern Hays County as there were no other African American schools in the region. At one time, more than $50 \mathrm{stu}-$ dents attended the country school. The school went through the seventh grade, and students who wished to further their education moved to Austin, where they attended Anderson High School. Among the early students who attended the Antioch school were the Bunton and Kavanaugh children (Schwartz 1986:352). In 1900, the school had been in operation for more than 25 years, and most of the adults under the age of 50 could read and write (U.S. Bureau of the Census, Hays County, Population Schedule, 1900).

Community life centered around school and church. The Masonic Lodge and Eastern Star organizations continued to hold meetings on the second floor of the school. Dansy, Lemuel, and Ivron Harper and their wives were among those active in the Masonic organizations. Holidays and special events, including Juneteenth and the Fourth of July, were celebrated in the community (Schwartz 1986:352-353).

\section{Antioch Community in 1910}

It is hard to tell from the census record the families who lived in Antioch Colony in 1910 (Table 4.8). Some families known to have lived on the east side of Onion Creek were listed with the Antioch community, which lay on the west side of the creek. About 18 families with 93 residents appear to have lived in or very near the Antioch Colony. Among those known to have been part of the colony were Berry Burnham, John Davis, Harriet Smith, John W. Taylor, Tonnie ${ }^{38}$ Bunton, Peter Beard, Lias Bunton, Charley Bunkley, Henry Burnham, and Ida Kavanaugh.

The 1910 census showed a substantial amount of home and farm ownership. Emma Bunton, Berry Burnham, John Davis, Harriet Smith, Rose Cary, John W. Taylor, Tonnie Bunton, Peter Beard, Lias Bunton, and Ida Kavanaugh owned their own farms. As in earlier census records, the members of Antioch Colony worked primarily as farmers or farm laborers. Several women were listed as farmers but more worked as laundresses. At least four women-including Emma Bunton, Harriet Smith, Ella Harper, and Ida Kavanaugh-headed their own households, which included a number of sons and daughters living at home; three women appear to have been widowed, and one, Emma Bunton, appears to have been separated from her husband (U.S. Bureau of the Census, Hays County, Population Schedule, 1910), Tonnie Bunton.

People over the age of 50, including Tonnie Bunton, Peter Beard, Lias Bunton, and Charley Bunkley, typically did not read or write. Almost all younger adults were literate, and virtually all of the children attended school. Fifty-seven children in the communities on both sides of Onion Creek were noted as attending school within the past year (1909). The older children worked as farm laborers or at odd jobs (U.S. Bureau of the Census, Hays County, Population Schedule, 1910).

Some members of the community were listed as mulattos rather than black or white. This is interesting since the 1900 census did not make this distinction. Among those counted as mulattos in 1910 were Emma Bunton and family, Henry Burnham and family, Harriet Smith and family, Rose Cary, John Taylor and family, Lou Goodrich and family, and Charley Bunkley and family. Others in the area near Antioch were counted as mulattos, including Charlie Grant and his family on the east side of Onion Creek and the Timmons and Mullins families (U.S. Bureau of the Census, Hays County, Population Schedule, 1910).

\footnotetext{
${ }^{38}$ Also known as Tonny or Tony in earlier records.
} 
Table 4.8. People in the Antioch community, 1910 (U.S. Bureau of the Census, Hays County, Texas, Population Schedule, 1910)

\begin{tabular}{|c|c|c|c|c|c|c|}
\hline Name and Relationship & Race & Age & Occupation & Birthplace & $\begin{array}{l}\text { Rents } \\
\text { or Owns } \\
\text { Farm }\end{array}$ & $\begin{array}{l}\text { Reads / } \\
\text { Writes }\end{array}$ \\
\hline $\begin{array}{l}\text { STELLA BUNTON, head of } \\
\text { household }\end{array}$ & Black & 37 & Laundress & Texas & Rents & yes \\
\hline Eddie Sorrels, daughter & Black & 17 & Farm labor & Texas & & yes \\
\hline EARLY LOMAX, head of household & Mulatto & 40 & Farmer & Texas & Rents & Yes \\
\hline Letha, wife & Mulatto & 29 & & Texas & & Yes \\
\hline Laura, daughter & Mulatto & 20 & In school & Texas & & Yes \\
\hline Lola, daughter & Mulatto & 19 & In school & Texas & & Yes \\
\hline Minnie,daughter & Mulatto & 10 & In school & Texas & & Yes \\
\hline Bessie, daughter & Mulatto & 9 & In school & Texas & & Yes \\
\hline Wilma, daughter & Mulatto & 3 & & Texas & & \\
\hline Freddie Bunton, boarder & Black & 17 & Farm labor & Texas & & Yes \\
\hline DAN FRIEND, head of household & Black & 44 & Farmer & Texas & Rents & Yes \\
\hline Unknown name, wife & Black & 47 & & Texas & & No \\
\hline Jimmie, son & Black & 20 & Farm labor & Texas & & Yes \\
\hline Emma,daughter & Black & 8 & & Texas & & Yes \\
\hline SAM STOVAL, head of household & Mulatto & 48 & Farmer & Texas & Rents & Yes \\
\hline Alice, wife & Mulatto & 38 & & Texas & & Yes \\
\hline Isbela, daughter & Mulatto & 15 & In school & Texas & & Yes \\
\hline Harvey, son & Mulatto & 13 & $\begin{array}{l}\text { Laborer/ } \\
\text { School }\end{array}$ & Texas & & Yes \\
\hline Maud, daughter & Mulatto & 10 & In school & Texas & & Yes \\
\hline Lillian, daughter & Mulatto & 8 & In school & Texas & & Yes \\
\hline Lotta, daughter & Mulatto & 7 & In school & Texas & & Yes \\
\hline $\begin{array}{l}\text { CHARLIE GRANT, head of } \\
\text { household }\end{array}$ & Mulatto & 57 & Farmer & Mississippi & Rents & Yes \\
\hline Texana, wife & Mulatto & 48 & & Texas & & Yes \\
\hline May, daughter & Mulatto & 27 & & Texas & & Yes \\
\hline Tonnie, son & Mulatto & 26 & $\begin{array}{l}\text { Laborer/ } \\
\text { School }\end{array}$ & Texas & & Yes \\
\hline Lucy, daughter & Mulatto & 22 & In school & Texas & & Yes \\
\hline Carrie, daughter & Mulatto & 19 & In school & Texas & & Yes \\
\hline Viola, daughter & Mulatto & 17 & In school & Texas & & Yes \\
\hline
\end{tabular}


Table 4.8, continued

\begin{tabular}{|c|c|c|c|c|c|c|}
\hline Name and Relationship & Race & Age & Occupation & Birthplace & $\begin{array}{c}\text { Rents } \\
\text { or Owns } \\
\text { Farm }\end{array}$ & $\begin{array}{l}\text { Reads / } \\
\text { Writes }\end{array}$ \\
\hline ANN SNEED, head of household & Black & 70 & Farmer & US & Rents & No \\
\hline Lucy, daughter & Black & 35 & Farm labor & US & & No \\
\hline Alice, daughter & Black & 33 & Farm labor & US & & No \\
\hline West, son & Black & 30 & Farm labor & US & & No \\
\hline Henry, son & Black & 28 & Farm labor & US & & No \\
\hline Giles, son & Black & 20 & Farm labor & US & & No \\
\hline Lennie, granddaughter & Mulatto & 12 & & Texas & & No \\
\hline May, granddaughter & Black & 14 & Farm labor & Texas & & No \\
\hline Rine, grandson & Mulatto & 10 & & Texas & & No \\
\hline Walter, grandson & Mulatto & 8 & & Texas & & \\
\hline Robert, grandson & Mulatto & $6 \mathrm{mo.}$ & & Texas & & \\
\hline Novella, granddaughter & Mulatto & 3 & & Texas & & \\
\hline Sid, granddaughter & Mulatto & 22 & Farm labor & Texas & & No \\
\hline Bula, granddaughter & Mulatto & 6 & & Texas & & \\
\hline $\begin{array}{l}\text { EMMA BUNTON, head of } \\
\text { household }\end{array}$ & Mulatto & 43 & Laundress & Texas & Owns & Yes \\
\hline Georgia, daughter & Mulatto & 29 & $\begin{array}{l}\text { Labor/Odd } \\
\text { jobs }\end{array}$ & Texas & & Yes \\
\hline Lugene, son & Mulatto & 16 & $\begin{array}{l}\text { Odd jobs/ } \\
\text { School }\end{array}$ & Texas & & Yes \\
\hline Jeffie, daughter & Mulatto & 14 & $\begin{array}{l}\text { Odd jobs/ } \\
\text { School }\end{array}$ & Texas & & Yes \\
\hline Minnie, daughter & Mulatto & 12 & In school & Texas & & Yes \\
\hline Mattie, daughter & Mulatto & 9 & In school & Texas & & Yes \\
\hline Lizzie Friend, mother & Mulatto & 74 & & Mississippi & & No \\
\hline SAM GEOAF, head of household & Black & 47 & Farmer & Texas & Rents & Yes \\
\hline Sarah, wife & Black & 28 & & Texas & & Yes \\
\hline Roy, son & Black & 12 & $\begin{array}{l}\text { Laborer/ } \\
\text { School }\end{array}$ & Texas & & Yes \\
\hline George, son & Black & 10 & $\begin{array}{l}\text { Laborer/ } \\
\text { School }\end{array}$ & Texas & & Yes \\
\hline Earnest, son & Black & 9 & In school & Texas & & Yes \\
\hline Jessie, son & Black & 8 & In school & Texas & & Yes \\
\hline Daisy, daughter & Black & 6 & In school & Texas & & \\
\hline Mary, daughter & Black & 4 & & Texas & & \\
\hline Taft, son & Black & $4 \mathrm{mo.}$ & & Texas & & \\
\hline
\end{tabular}


Table 4.8, continued

\begin{tabular}{|c|c|c|c|c|c|c|}
\hline Name and Relationship & Race & Age & Occupation & Birthplace & $\begin{array}{c}\text { Rents } \\
\text { or Owns } \\
\text { Farm }\end{array}$ & $\begin{array}{l}\text { Reads / } \\
\text { Writes }\end{array}$ \\
\hline $\begin{array}{l}\text { BERRY BYNUM (Burnham), head } \\
\text { of household }\end{array}$ & Black & 61 & Farmer & $\begin{array}{l}\text { South } \\
\text { Carolina }\end{array}$ & Owns & No \\
\hline Henry, son & Black & 28 & $\begin{array}{l}\text { Farm } \\
\text { laborer }\end{array}$ & Texas & & Yes \\
\hline Susie, daughter-in-law & Black & 24 & & Texas & & Yes \\
\hline Hattie, granddaughter & Black & 3 & & Texas & & \\
\hline George, grandson & Black & 1.5 & & Texas & & \\
\hline JOHN DAVIS, head of household & Black & 38 & Farmer & Texas & Owns & Yes \\
\hline Martha, wife & Black & 21 & & Texas & & Yes \\
\hline Velma & Mulatto & 3 & & Texas & & \\
\hline Hannibal & Black & $6 \mathrm{mo.}$ & & Texas & & \\
\hline $\begin{array}{l}\text { HARRIET SMITH, head of } \\
\text { household }\end{array}$ & Mulatto & 54 & Farmer & Texas & Owns & No \\
\hline Albert, son & Mulatto & 18 & $\begin{array}{l}\text { Laborer/ } \\
\text { School }\end{array}$ & Texas & & Yes \\
\hline Alma, daughter & Mulatto & 14 & $\begin{array}{l}\text { Laborer/ } \\
\text { School }\end{array}$ & Texas & & Yes \\
\hline Jimmie, son & Mulatto & 11 & $\begin{array}{l}\text { Laborer/ } \\
\text { School }\end{array}$ & Texas & & Yes \\
\hline Julius, son & Mulatto & 10 & $\begin{array}{l}\text { Laborer/ } \\
\text { School }\end{array}$ & Texas & & Yes \\
\hline ROSE CARY, head of household & Mulatto & 72 & & Alabama & Owns & No \\
\hline $\begin{array}{l}\text { JOHN W. TAYLOR, head of } \\
\text { household }\end{array}$ & Mulatto & 49 & Farmer & Texas & Owns & Yes \\
\hline Sallie, wife & Mulatto & 42 & & Texas & & Yes \\
\hline Lencun?, son & Mulatto & 21 & $\begin{array}{l}\text { Farm } \\
\text { laborer }\end{array}$ & Texas & & Yes \\
\hline Roberta, daughter & Mulatto & 20 & $\begin{array}{l}\text { Farm } \\
\text { laborer }\end{array}$ & Texas & & Yes \\
\hline Nina, daughter & Mulatto & 18 & $\begin{array}{l}\text { Laborer/ } \\
\text { School }\end{array}$ & Texas & & Yes \\
\hline Earnest, son & Mulatto & 15 & $\begin{array}{l}\text { Laborer/ } \\
\text { School }\end{array}$ & Texas & & Yes \\
\hline Inez, daughter & Mulatto & 12 & $\begin{array}{l}\text { Laborer/ } \\
\text { School }\end{array}$ & Texas & & Yes \\
\hline Myrtle, daughter & Mulatto & 7 & In school & Texas & & Yes \\
\hline
\end{tabular}


Table 4.8, continued

\begin{tabular}{|c|c|c|c|c|c|c|}
\hline Name and Relationship & Race & Age & Occupation & Birthplace & $\begin{array}{c}\text { Rents } \\
\text { or Owns } \\
\text { Farm }\end{array}$ & $\begin{array}{l}\text { Reads / } \\
\text { Writes }\end{array}$ \\
\hline $\begin{array}{l}\text { PETER ROBERTSON, head of } \\
\text { household }\end{array}$ & Mulatto & 55 & $\begin{array}{l}\text { Farm } \\
\text { laborer }\end{array}$ & Tennessee & Rents & No \\
\hline Katie, wife & Mulatto & 50 & Laundress & Texas & & No \\
\hline $\begin{array}{l}\text { TONNIE BUNTON, head of } \\
\text { household }\end{array}$ & Black & 54 & Farmer & Texas & Owns & No \\
\hline PETER BEARD, head of household & Black & 57 & Farmer & Kentucky & Owns & No \\
\hline $\begin{array}{l}\text { LIAS (Elias) BUNTON, head of } \\
\text { household }\end{array}$ & Black & 75 & Farmer & Kentucky & Owns & No \\
\hline Peter, son & Black & 40 & Farmer & Texas & & Yes \\
\hline Mary, daughter-in-law & Black & 36 & & Texas & & Yes \\
\hline Mary, granddaughter & Black & 14 & In school & Texas & & Yes \\
\hline Idell, granddaughter & Black & 13 & In school & Texas & & Yes \\
\hline Claud, grandson & Black & 12 & In school & Texas & & Yes \\
\hline L.D., grandson & Black & 10 & In school & Texas & & Yes \\
\hline Daisy, granddaughter & Black & 8 & In school & Texas & & Yes \\
\hline $\begin{array}{l}\text { LOU GOODRICH, head of } \\
\text { household (female) }\end{array}$ & Mulatto & 52 & & Texas & Rents & Yes \\
\hline Josie, daughter & Mulatto & 32 & $\begin{array}{l}\text { Farm } \\
\text { laborer }\end{array}$ & Texas & & Yes \\
\hline Henry, son & Mulatto & 18 & $\begin{array}{l}\text { Laborer/ } \\
\text { School }\end{array}$ & Texas & & Yes \\
\hline John, son & Mulatto & 15 & $\begin{array}{l}\text { Laborer/ } \\
\text { School }\end{array}$ & Texas & & Yes \\
\hline Lou Ellen, granddaughter & Mulatto & 12 & In school & Texas & & Yes \\
\hline Wallace, grandson & Mulatto & 9 & In school & Texas & & Yes \\
\hline A.C. Massey, grandson & Mulatto & 8 & In school & Texas & & Yes \\
\hline R.C. (Massey?), grandson & Mulatto & 7 & In school & Texas & & Yes \\
\hline Sallie (Massey?), granddaughter & Mulatto & 5 & & Texas & & \\
\hline ELLA HARPER, head of household & Black & 42 & Farmer & Texas & Rents & Yes \\
\hline Ada, daughter & Black & 24 & $\begin{array}{l}\text { Farm } \\
\text { laborer }\end{array}$ & Texas & & Yes \\
\hline Jason, son & Black & 18 & $\begin{array}{l}\text { Farm } \\
\text { laborer }\end{array}$ & Texas & & Yes \\
\hline Lemuel?, son & Black & 16 & $\begin{array}{l}\text { Laborer/ } \\
\text { School }\end{array}$ & Texas & & Yes \\
\hline Sarah, daughter & Black & 14 & In school & Texas & & Yes \\
\hline Ella, daughter & Black & 12 & In school & Texas & & Yes \\
\hline
\end{tabular}


Table 4.8, continued

\begin{tabular}{|c|c|c|c|c|c|c|}
\hline Name and Relationship & Race & Age & Occupation & Birthplace & $\begin{array}{c}\text { Rents } \\
\text { or Owns } \\
\text { Farm }\end{array}$ & $\begin{array}{l}\text { Reads / } \\
\text { Writes }\end{array}$ \\
\hline George, son & Black & 9 & In school & Texas & & Yes \\
\hline Melvin, son & Black & 7 & In school & Texas & & Yes \\
\hline Danzy, son & Black & 1.5 & & Texas & & \\
\hline $\begin{array}{l}\text { CHARLY BUNKLEY, head of } \\
\text { household }\end{array}$ & Mulatto & 62 & Farmer & Louisiana & Rents & No \\
\hline Adaline, wife & Mulatto & 65 & & Mississippi & & No \\
\hline $\begin{array}{l}\text { OLLIE HARPER, head of } \\
\text { household }\end{array}$ & Black & 28 & Farmer & Texas & Rents & Yes \\
\hline Mackie, wife & Black & 17 & & Texas & & Yes \\
\hline $\begin{array}{l}\text { HENRY BURNHAM, head of } \\
\text { household }\end{array}$ & Mulatto & 48 & $\begin{array}{l}\text { Farm } \\
\text { laborer }\end{array}$ & & Rents & No \\
\hline Henrietta, wife & Mulatto & 28 & & & & Yes \\
\hline Willie G., son & Mulatto & $6 \mathrm{mo.}$ & & & & \\
\hline Julius White, boarder & Mulatto & 18 & $\begin{array}{l}\text { Farm } \\
\text { laborer }\end{array}$ & & & Yes \\
\hline $\begin{array}{l}\text { WILL SHANNON, head of } \\
\text { household }\end{array}$ & Black & 40 & $\begin{array}{l}\text { Farm } \\
\text { laborer }\end{array}$ & Texas & Rents & No \\
\hline Kate, wife & Black & 36 & Laundress & Texas & & Yes \\
\hline Ada, stepdaughter & Black & 20 & & Texas & & Yes \\
\hline Rosa, stepdaughter & Black & 19 & Laundress & Texas & & Yes \\
\hline Walter, stepson & Black & 12 & $\begin{array}{l}\text { Laborer/ } \\
\text { School }\end{array}$ & Texas & & Yes \\
\hline Hester, stepdaughter & Black & 11 & In school & Texas & & Yes \\
\hline Pearlie, daughter & Black & 14 & In school & Texas & & Yes \\
\hline MACK SMITH, head of household & Black & 28 & Farmer & Texas & Rents & Yes \\
\hline Retta (Bertha?) & Black & 20 & & Texas & & Yes \\
\hline Mell Williams, stepson & Black & 3 & & Texas & & \\
\hline $\begin{array}{l}\text { IDA KAVANAUGH, head of } \\
\text { household }\end{array}$ & Black & 50 & Farmer & Texas & Owns & No \\
\hline Harvey, son & Black & 26 & Farmer & Texas & & Yes \\
\hline Milton, son & Black & 20 & Farmer & Texas & & Yes \\
\hline Lottie, daughter & Black & 18 & $\begin{array}{l}\text { Laborer/ } \\
\text { School }\end{array}$ & Texas & & Yes \\
\hline Clarise, daughter & Black & 15 & $\begin{array}{l}\text { Laborer/ } \\
\text { School }\end{array}$ & Texas & & Yes \\
\hline Annie & Black & 10 & In school & Texas & & Yes \\
\hline
\end{tabular}


Table 4.8, continued

\begin{tabular}{|c|c|c|c|c|c|c|}
\hline Name and Relationship & Race & Age & Occupation & Birthplace & $\begin{array}{c}\text { Rents } \\
\text { or Owns } \\
\text { Farm }\end{array}$ & $\begin{array}{l}\text { Reads / } \\
\text { Writes }\end{array}$ \\
\hline $\begin{array}{l}\text { SARAH STEO[...]?, head of } \\
\text { household }\end{array}$ & Mulatto & 39 & Laundress & Texas & Rents & Yes \\
\hline Rosella, daughter & Mulatto & 16 & In school & Texas & & Yes \\
\hline Nellie, daughter & Mulatto & 14 & In school & Texas & & Yes \\
\hline Laura, daughter & Mulatto & 12 & In school & Texas & & Yes \\
\hline Otha Friend, son & Mulatto & unkn. & & Texas & & \\
\hline D.J. Friend, son & Mulatto & 8 & In school & Texas & & \\
\hline $\begin{array}{l}\text { ROSA TIMMONS, head of } \\
\text { household }\end{array}$ & Mulatto & 33 & Laundress & Texas & Rents & No \\
\hline Myrtle, daughter & Mulatto & 9 & & Texas & & Yes \\
\hline Mary, daughter & Mulatto & 8 & & Texas & & No \\
\hline $\begin{array}{l}\text { MATTIE MULLINS, head of } \\
\text { household }\end{array}$ & Mulatto & 37 & Laundress & Texas & Rents & Yes \\
\hline Lee, daughter & Mulatto & 20 & Laundress & Texas & & Yes \\
\hline Callie, daughter & Mulatto & 17 & $\begin{array}{l}\text { Laundry/ } \\
\text { School }\end{array}$ & Texas & & Yes \\
\hline Lucy, daughter & Mulatto & 14 & In school & Texas & & Yes \\
\hline Lizzie, daughter & Mulatto & 11 & In school & Texas & & Yes \\
\hline Mary, daughter & Mulatto & 9 & In school & Texas & & Yes \\
\hline Birdie, daughter & Mulatto & 8 & In school & Texas & & Yes \\
\hline Mattie, daughter & Mulatto & 7 & In school & Texas & & No \\
\hline
\end{tabular}

\section{Antioch Community in 1920}

According to the census, the community appears to have had more individual households but fewer people in 1920 (Table 4.9). Seventyeight people lived in 19 family units. By 1920, almost all of the original settlers, including Lias and Clarracy Bunton, Dave and Mary Bunton, George W., Peter and Betti Beard, and George and Rose Champ, had passed from the scene. Ida Kavanaugh was one of the only original members of the community still alive. She headed a household that included her son Milton, daughter Annie, and grandsons Leslie and Howell Bunton. ${ }^{39}$ Descendants of the original settlers ${ }^{39}$ Howell was the family name of the wife of slave-
owner John Wheeler Bunton. who remained in the community included Pete Bunton, Harry (Harvey?) Kavanaugh, James Kavanaugh, Daniel Friend, and Henry Burnham. Although John L. Taylor, Tennessee Revada, and Charley Bunkley were not among the first settlers, they were early residents who had lived with their families in the community for several decades (U.S. Bureau of the Census, Hays County, Population Schedules, 1900, 1910, 1920).

Antioch Colony had a fair degree of home and farm ownership in the 1920s. Of the 21 heads of household, 10 owned their own farms or homes. Typically, early settlers and their descendants owned their property, while newer members of the community worked as farm laborers. Among the early settlers and their adult children who owned farms were John W. Taylor, Pete Bunton, Tennessee Revada, Daniel Friend, 
Table 4.9. People in the Antioch community, 1920 (U.S. Bureau of the Census, Hays County, Texas, Population Schedule, 1920)

\begin{tabular}{|c|c|c|c|c|c|c|}
\hline Name and Relationship & Race & Age & Occupation & Birthplace & \begin{tabular}{|c}
$\begin{array}{c}\text { Rents } \\
\text { or Owns } \\
\text { Farm }\end{array}$ \\
\end{tabular} & $\begin{array}{l}\text { Reads / } \\
\text { Writes } \\
\end{array}$ \\
\hline $\begin{array}{l}\text { JOHN W. TAYLOR, head of } \\
\text { household }\end{array}$ & Black & 58 & Farmer & Texas & Owns & Yes \\
\hline Stella, wife & Black & 51 & & Texas & & Yes \\
\hline Nina, daughter & Black & 27 & & Texas & & Yes \\
\hline Earnest, son & Black & 24 & $\begin{array}{l}\text { Farm } \\
\text { Manager }\end{array}$ & Texas & & Yes \\
\hline Inez or Irene, daughter & Black & 22 & & Texas & & Yes \\
\hline Myrtle, daughter & Black & 17 & & Texas & & Yes \\
\hline Rachel Grant, granddaughter & Black & 5 & & Texas & & Yes \\
\hline Bruce Grant, grandson & Black & 3 & & Texas & & Yes \\
\hline $\begin{array}{l}\text { ANTHONY WATTS, head of } \\
\text { household }\end{array}$ & Black & 51 & Minister & Texas & Rents & Yes \\
\hline Lucy, wife & Black & 49 & & Texas & & Yes \\
\hline $\begin{array}{l}\text { JOHN L. TAYLOR, head of } \\
\text { household }\end{array}$ & Black & 31 & Farmer & Texas & Rents & Yes \\
\hline Myrtle, wife & Black & 29 & & Texas & & Yes \\
\hline Carlton, son & Black & 5 & & Texas & & \\
\hline PETE BUNTON, head of household & Black & 47 & Farmer & Texas & Owns & Yes \\
\hline Mary, wife & Black & 45 & & Texas & & Yes \\
\hline Dave or Dane, son & Black & 21 & Laborer & Texas & & Yes \\
\hline L.D., son & Black & 15 & & Texas & & Yes \\
\hline $\begin{array}{l}\text { HARRY L. KAVANAUGH, head of } \\
\text { household }\end{array}$ & Black & 36 & Farmer & Texas & Rents & Yes \\
\hline Cora, wife & Black & 31 & & Mississippi & & Yes \\
\hline TENNESSEE REVADA & Mexican & 70 & Farmer & Texas & Owns & No \\
\hline Lucy, daughter & Mexican & 45 & & Texas & & Yes \\
\hline Lela, son & Mexican & 20 & Laborer & Texas & & Yes \\
\hline Ada, daughter & Mexican & 18 & & Texas & & Yes \\
\hline Iza Katrina, (?) daughter & Black & 18 & & Texas & & Yes \\
\hline Odie Revada, grandson & Mexican & 15 & In school & Texas & & Yes \\
\hline Joyes Reyes, grandson & Mexican & 12 & In school & Texas & & Yes \\
\hline Christian Reyes, grandson & Mexican & 5 & & Texas & & \\
\hline
\end{tabular}


Table 4.9, continued

\begin{tabular}{|c|c|c|c|c|c|c|}
\hline Name and Relationship & Race & Age & Occupation & Birthplace & $\begin{array}{c}\text { Rents } \\
\text { or Owns } \\
\text { Farm }\end{array}$ & $\begin{array}{l}\text { Reads / } \\
\text { Writes }\end{array}$ \\
\hline $\begin{array}{l}\text { JAMES KAVANAUGH, head of } \\
\text { household }\end{array}$ & Black & 22 & Farmer & Texas & Rents & Yes \\
\hline Odell, wife & Black & 22 & & Texas & & Yes \\
\hline J.B., son & Black & 2 & & Texas & & \\
\hline Katie, daughter & Black & $2 \mathrm{mo.}$ & & Texas & & \\
\hline $\begin{array}{l}\text { WALLACE SIMPSON, head of } \\
\text { household }\end{array}$ & Black & 20 & Laborer & Texas & Rents & Yes \\
\hline Elenora, wife & Black & 19 & Cook & Texas & & Yes \\
\hline A.C. MASSEY, head of household & Black & 18 & Farmer & Texas & Rents & Yes \\
\hline Johanna, wife & Black & 18 & & Texas & & Yes \\
\hline DANIEL FRIEND, head of household & Black & 53 & Farmer & Texas & Owns & Yes \\
\hline Sallie, wife & Black & 50 & & Texas & & No \\
\hline Hattie Burnham, granddaughter & Black & 13 & In school & Texas & & Yes \\
\hline George Burnham?, grandson & Black & 12 & In school & Texas & & Yes \\
\hline $\begin{array}{l}\text { GEORGE ANDERSON, head of } \\
\text { household }\end{array}$ & Mulatto & 47 & Farmer & Texas & Rents & No \\
\hline Mary, wife & Mulatto & 37 & & Texas & & Yes \\
\hline $\begin{array}{l}\text { HENRY BURNHAM, head of } \\
\text { household }\end{array}$ & Mulatto & 62 & Farmer & Texas & Owns & Yes \\
\hline Henrietta, wife & Mulatto & 30 & & Texas & & Yes \\
\hline Willie G., son & Mulatto & 9 & In school & Texas & & Yes \\
\hline Robert H., son & Mulatto & 4 & & Texas & & \\
\hline Julius Sneed, servant & Black & 23 & Laborer & Texas & & No \\
\hline Henry Sneed, servant & Black & 30 & Laborer & Texas & & No \\
\hline KATE BUNTON, head of household & Black & 48 & Farmer & Texas & Owns & No \\
\hline Ada, daughter & Black & 32 & & Texas & & No \\
\hline Rosa, daughter & Black & 28 & & Texas & & No \\
\hline Walter, son & Black & 24 & \begin{tabular}{|l} 
Farm \\
Manager \\
\end{tabular} & Texas & & No \\
\hline $\begin{array}{l}\text { AMANDA WILLIAMS, head of } \\
\text { household }\end{array}$ & Black & 62 & Wash Woman & & Owns & No \\
\hline Tennessee Crawford, daughter & Black & 34 & Wash Woman & & & Yes \\
\hline Willie Crawford, grandson & Black & 15 & In school & & & Yes \\
\hline
\end{tabular}


Table 4.9, continued

\begin{tabular}{|c|c|c|c|c|c|c|}
\hline Name and Relationship & Race & Age & Occupation & Birthplace & $\begin{array}{c}\text { Rents } \\
\text { or Owns } \\
\text { Farm }\end{array}$ & $\begin{array}{l}\text { Reads / } \\
\text { Writes }\end{array}$ \\
\hline $\begin{array}{l}\text { PAYTON ROBINSON, head of } \\
\text { household }\end{array}$ & Black & 60 & Farmer & Texas & Rents & Yes \\
\hline Kate, wife & Black & 50 & & Texas & & No \\
\hline Willie, granddaughter & Black & 16 & In school & Texas & & Yes \\
\hline Payton Randolph, grandson & Black & 10 & In school & Texas & & Yes \\
\hline Charlie Randolf, grandson & Black & 8 & In school & Texas & & Yes \\
\hline Ida Kavanaugh, head of household & Black & 25 & Laborer & Texas & Rents & Yes \\
\hline Daisy, wife & Black & 17 & & Texas & & Yes \\
\hline Rober, son & Black & 2 & & Texas & & \\
\hline ELLA HARPER, head of household & Black & 51 & Farmer & Texas & Rents & Yes \\
\hline Melvin, son & Black & 16 & In school & Texas & & Yes \\
\hline Dansay?, son & Black & 11 & In school & Texas & & Yes \\
\hline Abner, grandson & Black & 3 & & Texas & & \\
\hline $\begin{array}{l}\text { CHARLEY BUNKLEY, head of } \\
\text { household }\end{array}$ & Black & 70 & Farmer & Louisiana & Owns & No \\
\hline Adaline, wife & Black & 71 & & Mississippi & & No \\
\hline STAN COLEMAN, head of household & Black & 52 & Farmer & Texas & Owns & Yes \\
\hline Malinda, wife & Black & 40 & & Texas & & Yes \\
\hline Eula, daughter & Black & 21 & & Texas & & Yes \\
\hline Ollie, son & Black & 20 & & Texas & & Yes \\
\hline Fredrick, son & Black & 18 & & Texas & & Yes \\
\hline $\begin{array}{l}\text { IDA KAVANAUGH, head of } \\
\text { household (female) }\end{array}$ & Black & 57 & Farmer & Texas & Owns & Yes \\
\hline Milton, son & Black & 30 & $\begin{array}{l}\text { Farm } \\
\text { Manager }\end{array}$ & Texas & & Yes \\
\hline Annie, daughter & Black & 20 & & Texas & & Yes \\
\hline Leslie Bunton, grandson & Black & 13 & & Texas & & Yes \\
\hline Howell Bunton, grandson & Black & 10 & & Texas & & Yes \\
\hline
\end{tabular}

Henry Burnham, Charley Bunkley, and Ida Kavanaugh. Newcomers who owned their own land were Stan Coleman and Amanda Williams. They may have been related to members of the original families (U.S. Bureau of the Census, Hays County, Population Schedule, 1920).
As in other years, members of the Antioch Colony tended to be farmers or farm laborers. Sixteen heads of household were listed as farmers, including some women, such as Ella Harper, Kate Bunton, and Ida Kavanaugh. Three older children living with their families worked as 
farm managers. Other were occupied as general laborers or farm laborers. Two women worked as laundresses and one as a cook. One man, Anthony Watts, was employed as a minister; and Charlie Smith's daughter Willie was a schoolteacher. These were the first professional jobs in the community. The school population in the immediate Antioch area appeared to decline from 1910, and only 11 students were shown to be attending school. This could be due, in part, to the absence of farms from the east side of Onion Creek in the district. It can also be attributed to a decline in school-age children in the community in general. Only 25 children under the age of 18 lived in Antioch in 1920 compared with 77 in 1910 (U.S. Bureau of the Census, Hays County, Population Schedules, 1910, 1920).

\section{Antioch Community in 1930}

By 1930, the Antioch Colony had been in existence for a little over 60 years (Figure 4.6). Descendants of some of the original families, including Pete Bunton, Tonnie Bunton, Milton Kavanaugh, and Daniel Friend, still lived in the settlement. Many children married from within the community. For instance, marriage certificates in the early twentieth century show that E. Bunton married P. Friend, G. Bunton married M. Hamilton, J. Bunton married G. Kavanaugh, and R. Kavanaugh married L. Beard. Some outsiders married into the old families but stayed in the community. As a result, Antioch Colony came to be characterized as a group of several extended families (Table 4.10).

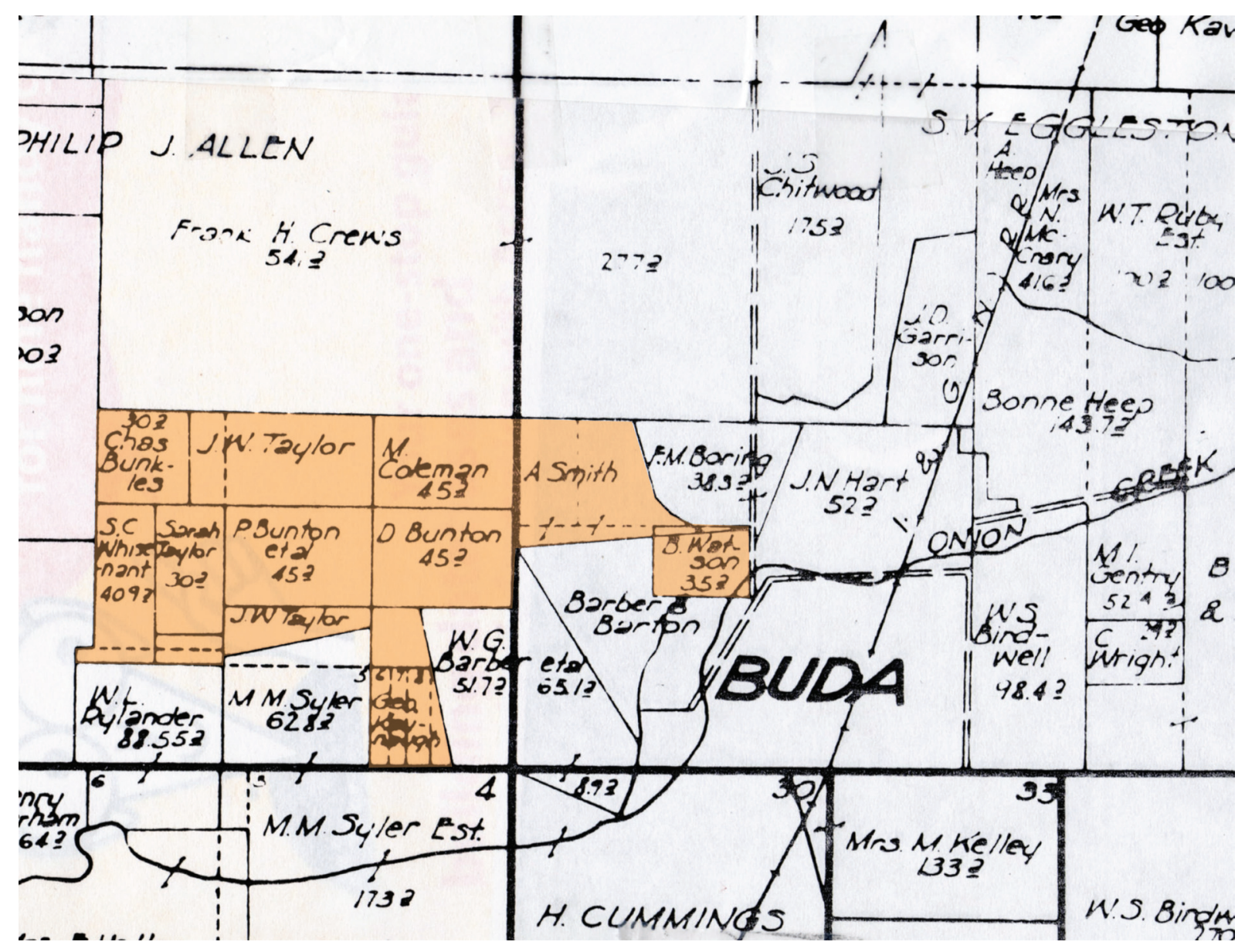

Figure 4.6. Map of Antioch Colony landowners, ca. 1925. Base is an undated plot map of Travis County that dates to around 1925 (Anonymous n.d.). 
Table 4.10. People in the Antioch community, 1930 (U.S. Bureau of the Census, Hays County, Texas, Population Schedule, 1930)

\begin{tabular}{|c|c|c|c|c|c|c|}
\hline Name and Relationship & Race & Age & Occupation & Birthplace & \begin{tabular}{|c}
$\begin{array}{c}\text { Rents } \\
\text { or Owns } \\
\text { Farm }\end{array}$ \\
\end{tabular} & $\begin{array}{l}\text { Reads / } \\
\text { Writes }\end{array}$ \\
\hline HENRY BURNHAM, head of household & Black & 70 & Farmer & Texas & Owns & No \\
\hline Henrietta,wife & Black & 38 & & Texas & & Yes \\
\hline Robert, son & Black & 14 & In school & Texas & & Yes \\
\hline Henrietta, daughter & Black & 4 & & Texas & & \\
\hline Henry Sneed, boarder & Black & 40 & Laborer & & & No \\
\hline ALBERT SMITH, head of household & Black & 38 & Farmer & Texas & Owns & Yes \\
\hline Alma, wife & Black & 36 & & Texas & & Yes \\
\hline Lois, daughter & Black & 16 & In school & Texas & & Yes \\
\hline Anna, daughter & Black & 14 & In school & Texas & & Yes \\
\hline A.J., son & Black & 11 & In school & Texas & & Yes \\
\hline Fred W., son & Black & 9 & In school & Texas & & \\
\hline George, son & Black & 7 & & Texas & & \\
\hline Robert, son & Black & 5 & & Texas & & \\
\hline Wilbert, son & Black & 2 & & Texas & & \\
\hline STELLA SANDERS, head of household & Black & 22 & Laundress & Texas & Owns & Yes \\
\hline $\begin{array}{l}\text { ELDRIDGE SEARCY, head of } \\
\text { household }\end{array}$ & Black & 19 & Laborer & Texas & Rents & Yes \\
\hline Mary Lou, wife & Black & 19 & & Texas & & Yes \\
\hline $\begin{array}{l}\text { GEORGE ANDERSON, head of } \\
\text { household }\end{array}$ & Black & 51 & Farmer & Texas & Owns & Yes \\
\hline Mary, wife & Black & 46 & & Texas & & Yes \\
\hline Louis, son & Black & 9 & In school & Texas & & Yes \\
\hline WILL SHANNON, head of household & Black & 68 & Farmer & Texas & Owns & No \\
\hline Katie, wife & Black & 57 & & Texas & & No \\
\hline Ada, stepdaughter (widow) & Black & 41 & & Texas & & No \\
\hline Hunter, stepdaughter (divorced) & Black & 33 & & Texas & & Yes \\
\hline Willie, granddaughter & Black & 10 & In school & Texas & & No \\
\hline Plear, grandson & Black & 5 & & Texas & & \\
\hline Augustus, grandson & Black & 3 & & Texas & & \\
\hline Daisy Mae, granddaughter & Black & $10 \mathrm{mo.}$ & & Texas & & \\
\hline
\end{tabular}


Table 4.10, continued

\begin{tabular}{|c|c|c|c|c|c|c|}
\hline Name and Relationship & Race & Age & Occupation & Birthplace & $\begin{array}{c}\text { Rents } \\
\text { or Owns } \\
\text { Farm }\end{array}$ & $\begin{array}{l}\text { Reads / } \\
\text { Writes }\end{array}$ \\
\hline TONNIE BUNTON, head of household & Black & 80 & Farmer & Texas & Owns & No \\
\hline PETER ROBINSON, head of household & Black & 72 & Farmer & Texas & Rents & Yes \\
\hline Katie, wife & Black & 66 & & Texas & & Yes \\
\hline ADDIE REVADA, head of household & Black & 28 & Farmer & Texas & Rents & No \\
\hline Maggie, wife & Black & 34 & & Texas & & Yes \\
\hline Raline, daughter & Black & 8 & & Texas & & \\
\hline Hattie, daughter & Black & 6 & & Texas & & \\
\hline Wilbert, son & Black & 13 & In school & Texas & & Yes \\
\hline Velma, daughter & Black & 5 & & Texas & & \\
\hline Jennie, daughter & Black & 1.2 & & Texas & & \\
\hline $\begin{array}{l}\text { MILTON KAVANAUGH, head of } \\
\text { household }\end{array}$ & Black & 38 & Farmer & Texas & Owns & Yes \\
\hline Ida, mother & Black & 75 & & Texas & & No \\
\hline Harvey, brother & Black & 46 & Farmer & Texas & & Yes \\
\hline JOHN W. TAYLOR, head of household & Black & 68 & Farmer & Texas & Owns & Yes \\
\hline Sallie A., wife & Black & 61 & & Texas & & Yes \\
\hline Nina D., daughter & Black & 38 & Teacher & Texas & & Yes \\
\hline Myrtle, daughter & Black & 27 & & Texas & & Yes \\
\hline Ethel Grant, granddaughter & Black & 11 & In school & Texas & & Yes \\
\hline Bruce Grant, grandson & Black & 13 & In school & Texas & & Yes \\
\hline ELLA HARPER, head of household & Black & 63 & & Texas & Rents & Yes \\
\hline Danzy, son & Black & 21 & $\begin{array}{l}\text { Farm } \\
\text { laborer }\end{array}$ & Texas & & Yes \\
\hline MILTON HARPER, head of household & Black & 26 & $\begin{array}{l}\text { Farm } \\
\text { laborer }\end{array}$ & Texas & Rents & Yes \\
\hline Elsie, wife & Black & 23 & & Texas & & Yes \\
\hline EULINE TAYLOR, head of household & Black & 38 & Farmer & Texas & Rents & Yes \\
\hline Irene, wife & Black & 37 & & Texas & & Yes \\
\hline PETE BUNTON, head of household & Black & 55 & Farmer & Texas & Owns & Yes \\
\hline Mary, wife & Black & 54 & & Texas & & Yes \\
\hline
\end{tabular}


Table 4.10, continued

\begin{tabular}{|c|c|c|c|c|c|c|}
\hline Name and Relationship & Race & Age & Occupation & Birthplace & $\begin{array}{c}\text { Rents } \\
\text { or Owns } \\
\text { Farm }\end{array}$ & $\begin{array}{l}\text { Reads / } \\
\text { Writes }\end{array}$ \\
\hline D.J. FRIEND, head of household & Black & 32 & $\begin{array}{l}\text { Farm } \\
\text { laborer }\end{array}$ & Texas & Rents & Yes \\
\hline Ella, wife & Black & 32 & & Texas & & Yes \\
\hline Dorthy, daughter & Black & 11 & In school & Texas & & Yes \\
\hline Arthur, son & Black & 10 & In school & Texas & & Yes \\
\hline Ara Lee, daughter & Black & 9 & In school & Texas & & \\
\hline Hope, daughter & Black & 6 & & Texas & & \\
\hline D.J., Jr., son & Black & 3 & & Texas & & \\
\hline L.B., son & Black & 1.5 & & Texas & & \\
\hline $\begin{array}{l}\text { CHARLIE BUNKLEY, head of } \\
\text { household }\end{array}$ & Black & 82 & Farmer & Louisiana & Owns & No \\
\hline Adeline, wife & Black & 88 & & & & No \\
\hline Abner Kavanaugh, grandson & Black & 11 & In school & Texas & & Yes \\
\hline JIM BUNTON, head of household & Black & 62 & Farmer & Texas & Rents & No \\
\hline Mattie, wife & Black & 65 & & Texas & & Yes \\
\hline Fairy, daughter & Black & 24 & Laborer & Texas & & Yes \\
\hline Francis, daughter & Black & 24 & Laborer & Texas & & Yes \\
\hline Jarfue Walker, grandson & Black & 16 & In school & Texas & & Yes \\
\hline Arelius Walker, grandson & Black & 14 & In school & Texas & & Yes \\
\hline Luerata Walker, grandson & Black & 12 & In school & Texas & & Yes \\
\hline ALLIE SEARCY, head of household & Black & 41 & Farmer & Texas & Rents & Yes \\
\hline Nannie, wife & Black & 38 & & Texas & & Yes \\
\hline Sam, son & Black & 16 & In school & Texas & & Yes \\
\hline Mildred, daughter & Black & 14 & In school & Texas & & Yes \\
\hline Allie Jr., son & Black & 12 & In school & Texas & & Yes \\
\hline Gus, son & Black & 10 & In school & Texas & & Yes \\
\hline Mabel, daughter & Black & 7 & In school & Texas & & \\
\hline George, son & Black & 4 & & Texas & & \\
\hline Daniel, son & Black & 2 & & Texas & & \\
\hline LONNIE GRANT, head of household & Black & 45 & Farmer & Texas & Rents & Yes \\
\hline Ola Bunton Grant, wife & Black & 45 & & Texas & & Yes \\
\hline Cora, daughter & Black & 20 & & Texas & & Yes \\
\hline Ronnie, daughter & Black & 18 & & Texas & & Yes \\
\hline Leroy, son & Black & 16 & In school & Texas & & Yes \\
\hline Willie B., son & Black & 14 & In school & Texas & & Yes \\
\hline
\end{tabular}


Table 4.10, continued

\begin{tabular}{l|l|l|l|l|l|l}
\hline \multicolumn{1}{c|}{ Name and Relationship } & & & & & $\begin{array}{c}\text { Rents } \\
\text { or Owns } \\
\text { Farm }\end{array}$ & $\begin{array}{c}\text { Reads / } \\
\text { Writes }\end{array}$ \\
\hline Annie, daughter & Race & Age & Occupation & Birthplace & Yes \\
\hline Gladys, daughter & Black & 12 & In school & Texas & Yes \\
\hline Mary Ella, daughter & Black & 10 & In school & Texas & Yes \\
\hline Lorane, daughter & Black & 8 & In school & Texas & Yes \\
\hline Oscar, son & Black & 8 & In school & Texas & Yes \\
\hline Arthur, son & Black & 7 & In school & Texas & Yes \\
\hline Lila, daughter & Black & 7 & In school & Texas & & Yes \\
\hline Lola, daughter & Black & 6 & In school & Texas & & \\
\hline $\begin{array}{l}\text { EMMETT WILLIAMS, head of } \\
\text { household }\end{array}$ & Black & 3 & & Texas & & \\
\hline Laurie, wife & Black & 38 & Farmer & Texas & Rents & Yes \\
\hline Imogene, son & Black & 35 & & Texas & & Yes \\
\hline Maurice, son & Black & 16 & In school & Texas & & Yes \\
\hline
\end{tabular}

It is difficult to say where the community stopped and started, geographically speaking (see Figure 4.6). Family farms associated with Antioch spread from Charley Bunkley's farm on the west side of the colony, to the Fred Heep farm, where Ola Bunton and Lonnie Grant lived, east of Onion Creek. As in previous years, the community was comprised of about 21 families. Some were quite large, and the overall population-about 100 people-was larger than that recorded in 1920. Among the families represented were those of Henry Burnham, Albert Smith, Will Shannon, Addie Revada, Milton Kavanaugh, John W. Taylor, Charley Bunkley, Ella Harper, and Lonnie Grant. Pete Bunton and Tonnie Bunton, sons of original settlers, still lived in the community (U.S. Bureau of the Census, Hays County, Population Schedule, 1930).

Most of the men, representing 17 households, were listed as farmers in the 1930 census. To be listed as a farmer, rather than a farm laborer, generally meant that they owned, operated, or managed their own farms. Three heads of household were farm laborers, and one, Stella Sanders, a woman who lived on her own, was a laundress. One woman, Nina Taylor, lived with her parents, John and Sallie Taylor, and worked as a teacher. Older children living in their parents' households worked as farm laborers. Children between the ages of about 9 and 16 were typically in school. The school-age population of the community was about 33 , a substantial increase from 1920 (U.S. Bureau of the Census, Hays County, Population Schedules, 1920, 1930).

The population of Antioch Colony reached its height in 1930 and began to decline in the ensuing decade. Since the mid-1920s, the farmers of central Texas had suffered a multitude of trials that ended in crop failures. A drought in 1925, and again in the $1930 \mathrm{~s}$, combined with periodic boll weevil infestations that decimated the cotton crop, forced farmers to mortgage their land and crops. Some farmers who gambled on next year's crops lost their farms and ended up as renters on their former property. Tenant farming increased in the twentieth century until two-thirds of farms in nearby Travis County were operated under this system by 1930 (Smyrl 2006d).

Despite these hardships, the Antioch community remained viable into the $1940 \mathrm{~s}$, with 70 to 80 members attending the African Methodist Church on a regular basis. After World War II, however, many people left the farming community for better work in industry and business. The colony's population dwindled in the late 
1940s and early 1950s. By 1955, when the community finally received electricity and telephone service, the rural hamlet was virtually deserted, with vacant frame houses and abandoned farms (Jasinski 2009). Over the years, much of the property was sold or lost to back taxes (Gee 2000).

\section{Antioch Colony Today}

After two decades of inactivity, several descendants returned to the Antioch area and began buying back portions of their family land. In the late 1970s, Winnie Martha Moyer, a descendant of the Harper family, was one of the first to arrive; she was soon joined by other family members. Another descendant, LeeDell Bunton, lives in Arizona but bought part of the land settled by his great-great-grandparents, Dave and Mary Bunton. He frequently visits the area, particularly for special events.

In 1997, the small band of residents founded a new Antioch Community Church. As in past generations, the church is the center of religious services and community identity. In 1999, Bunton and Moyer organized an Antioch Colony reunion, which drew about 300 people to the old settlement. By 2000, some 20 people, all descendants of the early settlers, lived in Antioch Colony. They are dedicated to keeping the community and the memories of their ancestors alive. Antioch is one of the few original freedmen colonies in Texas still occupied by descendants of the emancipated slaves who founded them (Gee 2000). On Saturday, January 22, 2011, descendants of the Antioch pioneers and Joseph Freeborn Rowley, along with members of the Hays County Historical Commission and other well-wishers, gathered in the community to dedicate a Texas State Historical Marker to commemorate the lives and achievements of the people of Antioch Colony (Figure 4.7). The marker, located along Old Black Colony Road near the newly constructed Antioch Community Church, reads:

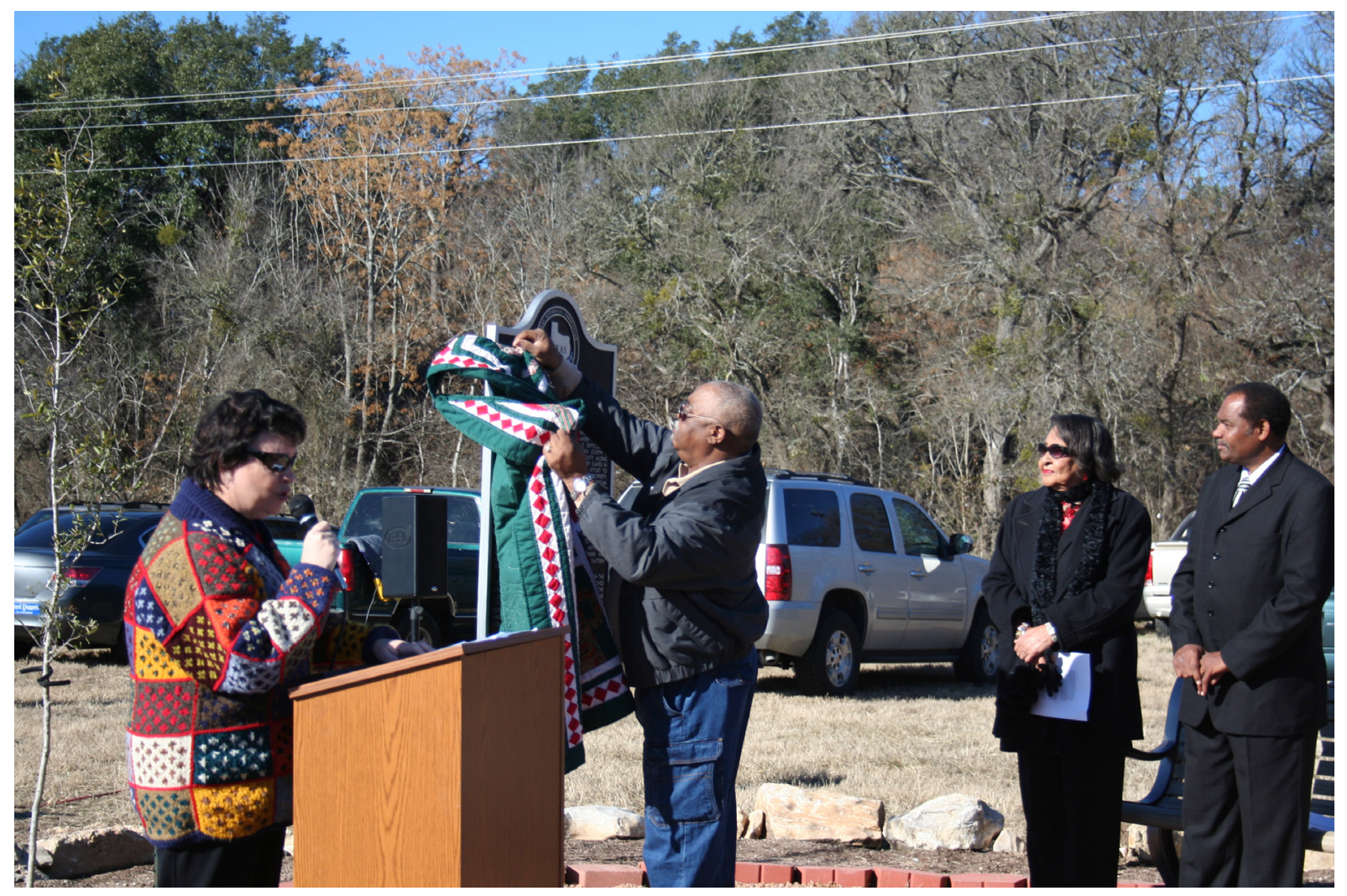

Figure 4.7. LeeDell Bunton, a descendant of the original Antioch Colony settlers who grew up in the freedmen community, unveils a Texas Historical Marker at a dedication ceremony on January 22, 2011. 


\section{ANTIOCH COLONY}

Antioch Colony was a rural farming community formed during reconstruction by a group of formerly enslaved African Americans. Although freed from slavery after the Civil War, African Americans still found it difficult to purchase land. In 1859, Anglo Businessman Joseph F. Rowley purchased 490 acres in north Hays County, along Onion Creek. He began selling parcels to former slaves in 1870 at $\$ 5.00$ per acre. Rowley, perhaps in an effort to protect the new landowners from losing their property, indicated in many of the deeds that the African American owners could not sell the property without Rowley's consent. After moving to Missouri, Rowley rescinded the stipulation in 1893, but the document was not filed in Hays County until 1913.

Community residents Elias and Clarisa Bunton donated property for a community school and church in 1874 , and the building served as the school until 1939. The following year, the school was relocated to Black Colony Road and served Antioch until students were integrated in the Buda School system in 1961. A Baptist church and a Methodist church were organized in the community, and there was also an active Masonic lodge and Order of the Eastern Star chapter in Antioch.

Antioch remained an active farm community through the $1930 \mathrm{~s}$ and 1940 s. By the 1950 s, many residents had moved away in search of better employment opportunities and the community was virtually abandoned. Beginning in the 1970s former residents and their descendants began returning to Antioch, some purchasing the land that the ancestors had previously owned, and the community continues to grow. 


\section{RANSOM AND SARAH WILLIAMS: FREEDMAN FARMERS IN TRAVIS COUNTY}

Terri Myers

5

Ransom Williams was one of the first inhabitants in the John G. McGehee League approximately 12 miles south of the state capital at Austin. The league remained a virtual wilderness-the land was unbroken and inaccessible by road - until after the Civil War, when brothers Charles and David Word subdivided the land into 40-acre parcels and advertised them for sale (Figure 5.1). The postwar era was ripe for land sales in central Texas as the state attracted thousands of people, particularly Southerners, displaced by the war. In 1871, Ransom Williams was one of the first to buy a lot in the McGehee League, on the south side of Bear Creek in Travis County near the Hays County line. He spent the next 30 years there raising his family and working the land.

Williams is intriguing for a number of reasons. He appears to have been an emancipated slave and possibly a mulatto who on occasion passed for white. He could neither read nor write but managed to buy and improve his own property, build a house, take a wife, make a living, and raise nine children, at least four of whom (Will, Mary, John, and Emma) attended school and gained literacy (U.S. Bureau of the Census, Travis County, Population Schedule, 1910). Little else is known about Williams's pedigree or heritage; the man left no written records and managed to avoid the census taker his entire life.

What we do know about Williams and his family stems from archeological investigations and a handful of historical documents, including deed, tax, brand, and voter registration records. In short, Williams was born in Kentucky before 1846 and arrived in Texas by 1866 . He was identified as "colored" in the 1867 Hays County Voter Registration rolls and was almost certainly a freed slave (Hays County 1867). In the late $1860 \mathrm{~s}$, Ransom lived in or near a community of freed slaves called Antioch Colony in northern Hays County (Jasinski 2008; Sitton and Conrad 2005). Some of the founders of this community were former slaves of the Bunton brothers who came to Texas from Tennessee and Kentucky in the 1840s and 1850s. Williams's first name suggests that he may have been related to one of the Bunton slaves, Ransom Bunton Sr., who lived near Antioch after emancipation. Williams's association with the Bunton freedmen, his first name, his Kentucky origins, and his residency in northern Hays County after the war suggest that Williams may have been one of the Bunton slaves.

Many questions remain unanswered about Williams and his family, but archival and secondary research, archeological investigations, and oral histories recorded from descendants of Antioch residents suggest probable scenarios about his life, both as a slave and as a free man.

\section{THE ENIGMATIC RANSOM WILLIAMS}

Little is written about the freedmen farmers who settled in northern Hays and southern Travis counties after the Civil War. Most were hardworking farmers of humble means. They left little evidence of their accomplishments, and many of their children eventually left the farms for towns and cities, cutting their ties to the land. Of the many yeoman farmers who broke land, planted fields, raised families, and eked out an existence in southern Travis and northern Hays County, Ransom Williams is one of the most enigmatic. His race, heritage, and association with other settlers in Hays and Travis counties 


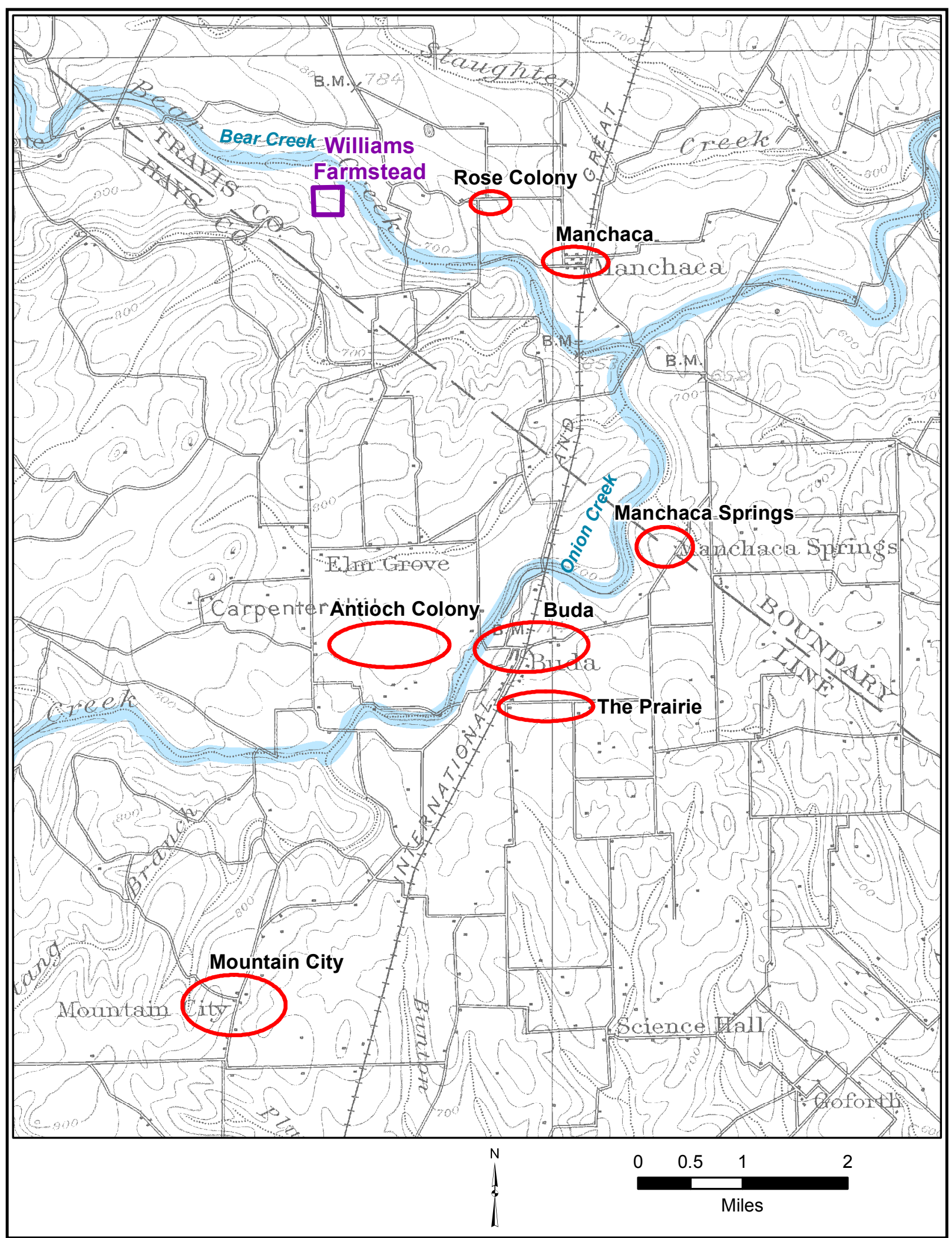

Figure 5.1. Map of the Ransom Williams farmstead in relation to Bear Creek, Onion Creek, and surrounding communities in northern Hays and southern Travis Counties. Base map is the USGS 1896 Austin Quadrangle, 125,000:1 scale, from the Texas Department of Transportation, Texas Historic Overlay: austin1896usgs125k. 
remain clouded by missing documentation or conflicting records. His name was absent from census records his entire life. His parentage and early life remain a mystery; he was born in Kentucky sometime before 1846 and was living in Hays County, Texas, by 1866. Like many former slaves, he never learned to read or write but rather used an " $\mathrm{X}$ " to mark his name on legal papers..$^{40}$ Despite his lack of education, former condition of servitude, and prevailing racial attitudes among ex-Confederate soldiers and citizens, Williams managed to purchase and improve a small, 45-acre farm, engage in skilled labor, send his children to school, and earn a living for his family in an isolated corner of Travis County during the last quarter of the nineteenth century.

\section{RANSOM WILLIAMS'S WORLD}

Ransom Williams's exodus from Kentucky to central Texas is likely linked to the great migration of men and women from the Upper South who abandoned their homes to forge new lives in the vast, undeveloped land of Texas in the 1830s, 1840s, and 1850s. Like hundreds of other slaves who followed their masters out of the Bluegrass country of Kentucky or the hills of Tennessee, Williams learned to plow the virgin prairie, raise barns and build houses or cabins, handle livestock, and train horses. All of these skills would serve him well in freedom.

Ransom Williams may have lived in the Antioch Colony in the years following the Civil War. In 1867, Hays County voter registration rolls showed that he lived in Precinct 2, which encompassed all of Mountain City and Antioch (Hays County 1867). ${ }^{41}$ Before emancipation, Mountain City claimed the second-largest concentration of slaves in Hays County, after the county seat of San Marcos, and many

\footnotetext{
${ }^{40}$ The 1867 Hays County voter registration rolls stated that he was born in Kentucky, was at least 21 years old, and a resident of the county for more than a year. He signed with an " $X$ ", his mark, indicating that he was illiterate.

${ }^{41}$ The Freedmen's Bureau was officially established in March 1865. In 1867, Congress passed the reconstruction acts that allowed the Freedmen's Bureau to launch a massive effort to register former slaves as voters. The bureau immediately sent agents to all parts of Texas to establish polling places and register freedmen and Union loyalists.
}

freedmen remained in the area after the war. Among them were Ransom Bunton, Sr., and his wife, Jane, both of whom were former slaves of the Buntons. ${ }^{42}$ Family lore indicates that John Wheeler Bunton gave Ransom Bunton, Sr., 160 acres of land for his loyalty in the Matamoros incident, but no evidence has been found to verify this claim. ${ }^{43}$ Ransom Williams may have been the son of Ransom Bunton, Sr., or possibly one of the white Bunton brothers. ${ }^{44}$ Many freedmen changed their "slave" names after emancipation, seeking to distance themselves from their former bondage.

Archival evidence indicates that Ransom Williams was born into slavery in the state of Kentucky sometime before 1846. Inconsistencies in deed and tax records for Williams suggest that he may have been a light-skinned man, possibly the son of a slave mother and a white man. ${ }^{45}$ Such relations were not unusual between masters and their slaves as evidenced by the large number of "yellow" and "mulatto" children listed in Texas slave schedules of the 1850s and 1860s. Fully one-third of the slaves enumerated in Mountain City for the 1860 census were identified as yellow or mulatto. Typically, a mixed-race child would have been raised by his mother in the slave quarters along with her other children. Depending on the master's character, he might show some favor to his son or daughter, but the child remained a slave nonetheless.

As a boy in Kentucky, Ransom probably played near his mother with other young children, but as he grew older, he would have taken on chores such as herding hogs, carrying dinner pails to adult workers in the fields, and tending fires. Education was prohibited for slave children, and Ransom remained illiterate

\footnotetext{
${ }^{42}$ Jane may have been a slave of Desha Bunton. He wrote a letter to the Freedmen's Bureau on her behalf on May 29, 1867. Ransom Sr. was reportedly a slave of John Wheeler Bunton.

${ }^{43}$ In 1880, "Ranse" and Jane Bunton purchased a 20 acre farm tract near Antioch Colony (HCDR Q:99).

${ }^{44}$ Although Ransom Williams is shown as "colored" in Hays County records, Travis County records do not identify his color or race, possibly because he was very light-skinned.

${ }^{45}$ Later census records show that Ransom's wife and children were "black " or "negro." These facts indicate that Williams was probably a mulatto in an era that prohibited mixed marriage.
} 
throughout his life. Girls were tasked with caring for younger children, including the master's children, washing and mending clothes, and preparing food (Menn 1937a, 1937b, 1937c, and 1937d). As he grew older, Ransom probably worked in the fields and tended livestock. Kentucky was not part of the cotton belt, and crops primarily consisted of corn, tobacco, and hemp, but the Bluegrass Country, in particular, prided itself on its high-quality horses and cattle.

Ransom was probably a boy or young man when he left Kentucky for Texas. Following the model for Mountain City settlement, he may have moved to Bastrop County with his master's family in the 1840s and then relocated with them to Mountain City in the $1850 \mathrm{~s}$. He may be listed as a 14-year-old mulatto boy owned by John Wheeler Bunton in the 1860 Hays County slave schedule (see Table 4.1). He was a resident of Hays County by July 1866 and lived in Mountain City by 1867 (Hays County Voters Registration 1867:Entry 278). As a resident of Precinct 2 and a "colored" man, Ransom Williams likely had family or friends among the Mountain City freedmen. He was most likely a recently freed slave as there were very few "free men of color" in central Texas before the war's end.

Ransom Williams apparently lived in Mountain City for several years after emancipation. Like other recently freed slaves, he probably worked for wages or a share of the crop on his former master's land or a neighboring farm or ranch. Most of the Southerners who settled in central Texas were farmers and stock raisers, and Ransom probably gained experience tending his master's crops and livestock during his youth. Although most of the white men in Mountain City identified themselves as farmers in the 1860 and 1870 census rolls, they depended largely on stock raising for a living. John Wheeler Bunton, in particular, is said to have had an extensive cattle raising business (Kemp 2010; Strom 2008). The Bunton brothers were also known for their fine horses. As a young man who likely grew up surrounded by horses and cattle, Ransom could have acquired animal husbandry skills that would serve him well in freedom.

\section{Horseman and Taxpayer in Hays County}

Ransom Williams remained in northern Hays County through the early 1870s. According to Travis County deed records, he was still a resident of Hays County as late as December 1871 (Travis County Deed Record ${ }^{46}$ V:686), and possibly longer, since he remained on the Hays County tax rolls for several more years. Although he was not a landowner in Hays County, Williams owned a number of horses. The 1870 and 1873 tax records show that he had six horses or mules worth $\$ 120$, while the 1871 and 1872 tax records show that he had nine horses or mules worth between $\$ 180$ and $\$ 190$ (Hays County Tax Records, various dates). This was a significant amount of horseflesh for a freedman in northern Hays County. While white farmers in the area owned as many as 50 or 100 horses or mules, African American landowners typically claimed one or two. With the exception of Elias Bunton, who owned six horses, Williams's holdings surpassed all other freedmen farmers in northern Hays County in 1870 (Hays County tax rolls, 1870-1873; U.S. Bureau of the Census, Hays County, Agricultural Schedule 1870). Elias Bunton had almost certainly been a slave of the white Buntons, who were known for raising and training horses. Desha Bunton, in particular, was known as a horse trainer and trader. He raised polo ponies, cavalry horses, and race horses on his Mountain City farm (Strom 1981:87). It is possible that one of the Buntons gave Elias some horses in exchange for his work with the animals or some other service. Ransom Williams may have received his horses in the same way, as payment from a former master. Williams's wealth seemed to be entirely vested in his horses; he owned no land, cattle, hogs, or carriages while living in Hays County in the early 1870s (Hays County Tax Rolls, various dates).

Like many landless freedmen in the postwar era, Williams probably worked on local farms or ranches ${ }^{47}$ for low wages, a share of the crops, or, as previously stated, livestock or trade goods. He may have found room in barns or sheds on various farms and ranches in northern Hays County. When Antioch Colony began to take shape in the late 1860s, he may have found shelter among the residents there. Williams's exact occupation at this time is unknown, but

\footnotetext{
${ }^{46}$ Hereafter, Travis County Deed Records are cited as TCDR.

${ }^{47}$ The 1870 census shows that more white farmers paid wages to hired help than African Americans did.
} 
the fact that he owned a number of horses and mules suggests that he had skills as a horse trainer or breeder. If he had mules, he may have rented them out to clear land or build roads. Another possibility may be that he worked as a teamster hauling goods and livestock for local farmers. There is no evidence that he bought land in Hays County during this period.

\section{Landownership}

In 1871, the John G. McGehee League, due north of the Antioch Colony, was subdivided for sale as farm lots. The league spanned the Hays-Travis county line. John G. McGehee died in the War for Texas Independence in 1835, and the land was eventually deeded to his youngest brother, W. B. McGehee. In the $1850 \mathrm{~s}$, W. B. McGehee reportedly built a house and lived on Onion Creek in the southwestern portion of the league, in present Hays County until 1856, when he left the site for good (Barkley 1970:128; Giberson 2003:314). He later died at the Battle of Crowley's Ridge, Arkansas, during the Civil War on May 14, 1863. Fifteen years after McGehee abandoned his homestead, brothers Charles and David Word, who were related to the McGehees by marriage, subdivided the league for sale. When they did, a number of would-be settlers scrambled for the chance to start their own farms.

Charles Word was a resident of Guadalupe County in June 1871, when he filed a plat map for the McGehee League in the Travis County Clerk's office. He subdivided the property into 36 tracts of between 37 and 40 acres, with one lone 20 -acre tract. A wide swath of open land through the middle of the map represented the path of Bear Creek, which ran on an eastwest course through the league. Charles and David Word were land speculators who hoped to profit from the population increase in central Texas after the Civil War. The brothers apparently divided the lots between them and immediately began selling the tracts. The early landowners in the league were primarily newly arrived Southerners who left their war-torn homelands and moved to Texas for a new start. Of 17 original landowners along Bear Creek, 11 were born in Southern states; four were Texas natives. In addition, a number of foreign-born families bought land in the league. Two were Irish, one was Canadian, one Bavarian, and one
Prussian. One Texan was a generation removed from Holland, and another was a second-generation Pole (U.S. Bureau of the Census, Hays County, 1880). Only one, Ransom Williams, was an African American and he, too, was born in the South.

Williams may have been influenced to buy land by the Antioch colonists, many of whom bought small, 40- to 65-acre farms in northern Hays County. Although he may have had ties to the Antioch Colony, it could be that no land was left for sale in the small corner of the Allen League apparently reserved for freedmen. As a result, Williams may have been forced to move away from the colony if he wanted to buy land. On December 5, 1871, Williams purchased a 45-acre tract of land known as Lot 11 from David Word (Travis County Deed Record V:685-686). ${ }^{48}$

Williams paid Word $\$ 160$ in cash and a promissory note for $\$ 20$ (Travis County Deed Record V:686). It is unknown how Williams, a freedman just six years out of slavery, obtained enough money to buy a farm. There is no evidence that he was assisted by the Freedmen's Bureau or anyone else. It is probable that Williams sold some of his horses to obtain cash for the land. In 1871 and 1872, he owned nine horses and mules worth $\$ 190$ and $\$ 180$, respectively. He had only $\$ 32$ in cash. By 1873 , just after he bought his land, Williams's taxable property dropped considerably. He had no cash on hand and only six horses worth $\$ 120$ (Hays County Tax Rolls, 1870-1873). By 1874, Williams was living in Travis County but only owned two horses worth $\$ 100,00$. Thus, he may have sold many of his horses to cobble together the money to buy his land.

Lot 11 was platted as a square parcel containing 40 acres and measuring $1,320 \mathrm{ft}$ on each side. The additional 5 acres undoubtedly adjoined the main tract, probably on the northern edge near Bear Creek. Deed records show that other farmers ultimately purchased land to the east and south of Williams's tract. In 1900,

\footnotetext{
${ }^{48}$ Inconsistencies exist in deed records as to the size of Lot 11. The deed from Word to Williams referred to a plat filed in Travis County (V:201-202), which shows the McGehee League carved into parcels, most of which contained 40 acres. The map shows Lot 11 to be one of the 40-acre tracts, but the actual deed from Word to Williams clearly states that the Lot 11 contains 45 acres "more or less." All tax records from 1873 through 1897 report that Williams owned a total of 45 acres.
} 
Williams's sons purchased 12 acres in a strip along the east side of Lot 12 and adjacent to Lot 11 (Travis County Deed Record 163:472). It appears that the additional 5 acres in Ransom's original purchase lay to the north of Lot 11. Most likely, it was a $165 \times 1,320$-ft strip that ran along the entire northern edge of Lot 11.

The parcel was about 4.5 miles north of the Antioch community and about 12 miles south of the city of Austin. In between lay a few scattered settlements surrounded by undeveloped land; a cluster of families lived at Williamson and Barton creeks, just south of Austin and the Colorado River, and a small enclave had developed around Adolphus Weir's place at Manchaca Springs, to the southeast. Williams had chosen a parcel of land not far south of Bear Creek. Except for his neighbor, John Wilkins, Williams was entirely isolated in 1871 ; there were no roads, no bridges, no farms, and no access to dry goods or mills.

\section{Property Improvements}

Williams's whereabouts between December 1871 and 1875 are unknown. According to his deed record, he was a resident of Hays County as late as December 1871 (Travis County Deed Record V:686). Although he owned land in Travis County, he may have remained in Hays County, where he paid taxes on his horses through 1873. In April 1872, however, he registered a horse brand in Travis County (Figure 5.2), suggesting that he had moved to his land (Travis County Clerk's Office, Register of Marks and Brands 1872). These discrepancies may be attributed to

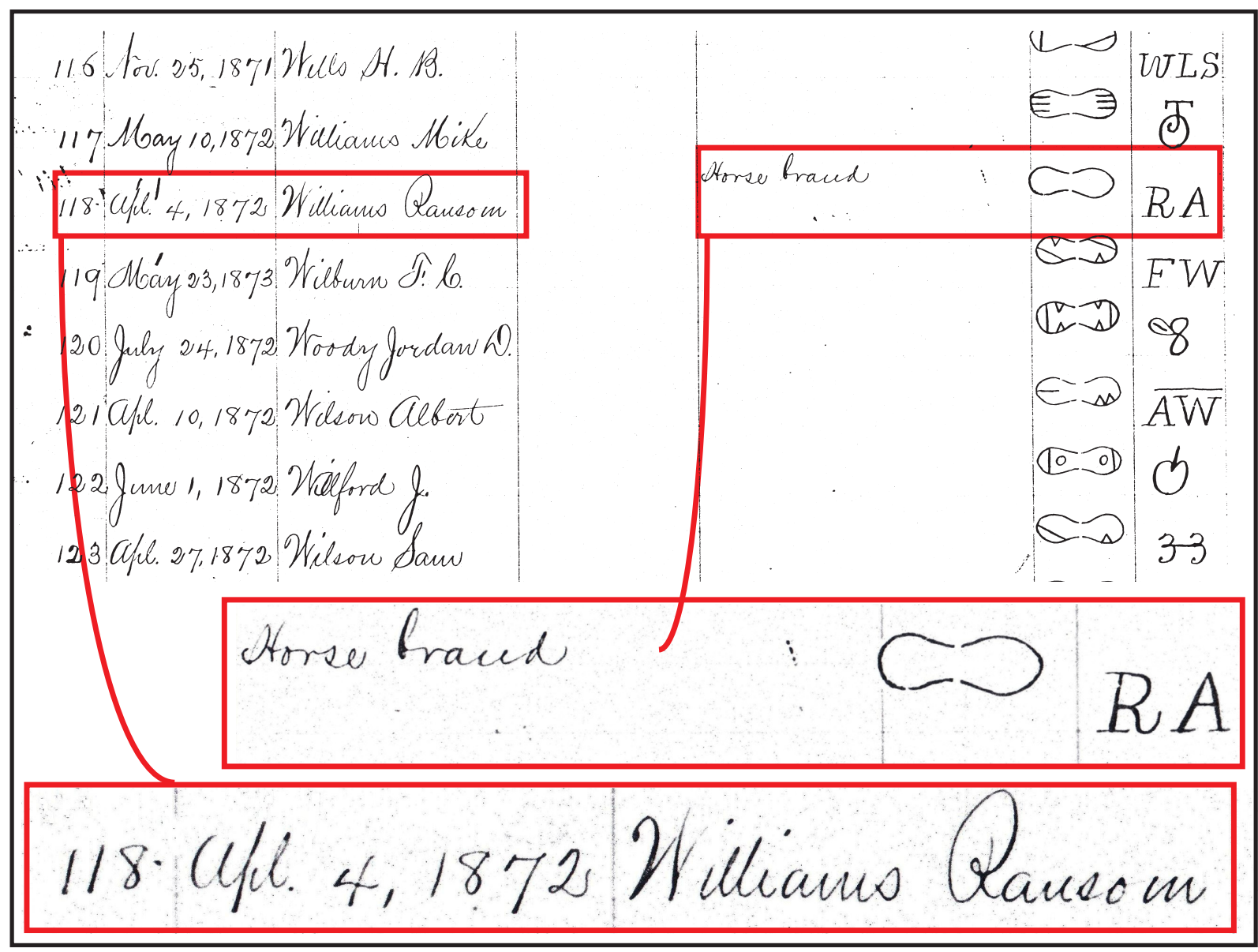

Figure 5.2. Ransom Williams registered his "horse brand" in April 1872. It was the 118th brand registered in Travis County. These images are copies of the original handwritten entries in the Travis County Register of Marks and Brands (1872). 
bureaucratic errors or the imperfect survey of the Hays-Travis county line at that time. Most likely, Williams lived among friends and relatives in northern Hays County from 1866 to 1872 , when he moved to his land in the McGehee League.

Still, Williams may not have had a house on the property for several years. In 1873, Travis County assessed Williams's 40 -acre tract at $\$ 80$. Its value strongly suggests that the property remained unimproved at the time of the assessment. Unimproved land in the area was valued at between $\$ 1$ and $\$ 2$ per acre at that time. Williams may have built a house and moved to the site by 1874, when his horses were listed in the Travis County tax records. By then, he owned only two horses, one a work horse, worth $\$ 50$ apiece (Travis County Tax Rolls, 1874). The fact that he owned a work horse suggests that he was clearing and/or farming his land by that time.

Ransom Williams's name doesn't appear in the Travis County tax records between 1875 and 1877 but neither does it show up in Hays County records. By 1878, he resurfaced in Travis County tax rolls, and the record signals that he was occupying his farm by that time. The tax value had greatly increased from $\$ 80$ to $\$ 200$, or $\$ 5$ per acre, indicating that it had been substantially improved, most likely by the addition of a house and outbuildings. Other improved farms in the area were valued at between $\$ 4.50$ and $\$ 5$ that year (Travis County Tax Rolls, 1878).

\section{Establishing a Home}

Shelter was usually the first and most important improvement on pioneer farmsteads. Upon taking possession of his property, Williams cleared a home site where he probably built a log house with a stone chimney and fireplace. Because building a log house was so labor-intensive, usually a lot of thought, skill, and planning went into the project. Some early settlers lived in brush shelters or covered wagons for a time before undertaking a house. Williams may have camped on his land, but it is more likely that he lived with relatives or friends in northern Hays County until he could make the effort to erect his permanent house. He also likely called on friends or family from the Antioch Colony to help with the construction.

Williams had probably participated in other house building endeavors, both on his master's land and at Antioch, so he was familiar with the process and techniques. First, he had to locate a good site for the house, one with good drainage. Rainfall would provide some water for household use, and no evidence of a cistern or well has been found on Williams's property. Although the house site was some distance from Bear Creek, water could have been collected in barrels and hauled back to the homestead by wagon.

Williams may have selected the foundation and chimney stones and cut thick, long timbers for the walls before his helpers arrived on the scene. The men laid out the foundation for a one-room log house, setting large limestone slabs where the walls would go. The house was a rectangular-shaped log house of about 15 by $16 \mathrm{ft},{ }^{49}$ probably built of oak timbers chinked with mud. It may have had a medium-high pitched roof framed with cedar poles and laid with cedar shake shingles. It likely had a shedroofed porch along the south side, and the door opened onto the porch. One end was almost entirely comprised of the limestone chimney with a large hearth for cooking and heating. It may have had a dirt floor to be covered with deer skins or the like, or he may have had a puncheon or board floor. Later, as his family grew, Williams could easily have added a sleeping loft or a small shed-roofed addition off the back.

It probably took several days of hard labor for the men to fell trees, dig out and move foundation stones into place, lay and chink the timbers, and erect the roof and cover it with shingles. Stonework for the foundation, chimney, and hearth probably took the most skill. Williams may have been left to erect accessory buildings and structures such as privies, work sheds, and barns over time. Because the land was unimproved when he bought it, Ransom would have had to clear the vegetation from the level portions of his property and till the thin, rocky soils to create a garden plot and crop fields. He collected stones from throughout his property, using them to build extensive rock walls that served as boundary lines and livestock corrals.

\section{Working the Farm}

Because Williams did not appear in the 1870 or 1880 agricultural census for the Bear

\footnotetext{
${ }^{49}$ This estimate is based on the archeological evidence in Chapter 11. Single pen log cabins were commonly about $16 \mathrm{ft}$ square (Jordan 1978:111).
} 
Creek area, we do not know for certain what crops he grew or what types of livestock he raised. However, he may have followed examples from farmers he knew in the Antioch Colony. They would have had similar soil types and conditions, rainfall amounts, and climate. Furthermore, the Antioch farmers generally owned between 40 and 65 acres of land in 1870-amounts comparable with Williams's 45-acre tract on Bear Creek. As an ex-slave who lived in a rural setting, Williams probably had considerable experience working in the fields and tending livestock. Thus, he likely grew crops and raised livestock similar to farmers in the Antioch Colony. As summarized in Table 5.1, seven known freedmen farmers who lived in Antioch in 1870 had farms ranging from 15 to 90 acres in size, with the land valued at $\$ 150$ to $\$ 300$. They owned a variety of large animals (horses, oxen, beef cattle, milk cows, and pigs), raised cotton and corn, and made butter and molasses. Although Ransom Williams does not appear in the population or agricultural schedules in the 1870 or 1880 censuses, it is likely that Ransom William was raising the same kinds of livestock and crops and producing the same farm products as his freedmen neighbors, whose agricultural statistics are listed in Table 5.1. The Hays and Travis Counties ad valorem tax records were examined for Ransom Williams and his sons for the period 1870 through 1910. As shown in Tables 5.2 and 5.3, the compiled data confirm that the Williams family had an active farm and regularly paid taxes on their land, horses, cattle, wagons, and farm equipment.

Out of the seven Antioch Colony farms, the five that are most similar in size to Ransom Williams 45 -acre farm were owned by Peter Beard (55 acres), Elias Bunton (30 acres), James Hamilton (30 acres), George Kavanaugh (40 acres), and George Rector (50 acres). The main difference between these five farms is that two had unimproved land (pasture) and improved land (cultivated cropland) while three consisted only of improved land. Based solely on the agricultural census data for freedmen in Antioch Colony, a small freedmen farmer in the 1870s would be expected to have: owned a few horses (or mules); owned a few beef cattle; owned a few milk cows and produced butter; owned a wagon and some simple farming implements; owned a few pigs; grown some crop to produce molasses or syrup; $;^{50}$ and grown some corn and cotton. The five Antioch Colony farms that are between 30 and 55 acres in size share many important attributes, and they are probably a good proxy for the types of agricultural activities that occurred on the Williams farmstead in the 1870s. Most of the characteristics that these farms have in common are also evident for the Williams farmstead:

- Each farm had a small amount of value in agricultural implements and machinery, most likely a wagon and simple single-row plows or cultivators. Williams paid taxes on a wagon, and wagon, harness, and plow parts were recovered from the site.

- Each farm had a number of horses, milk cows, and/or beef cattle. Williams paid taxes on horses and cattle, and butchered cow bones were recovered from the site.

- Each farm had a number of pigs. Williams paid taxes on swine in some years, but most likely owned pigs at all times. Pig remains were well represented on the farmstead.

- Each farm raised a substantial amount of corn that would have been used for human and livestock consumption or as a cash crop. Archeological evidence (charred corn remains and a corn sheller) indicated that the Williams family produced corn.

- Each farm produced a small amount of cotton for commercial sale. There is no historical or archeological evidence for cotton production at the Williams farmstead. ${ }^{51}$

- Each farm produced a fair amount of butter, even the one farm that reportedly did not

\footnotetext{
${ }^{50}$ Molasses is produced from sugar cane or sugar beets, while sorghum and corn were used to produce syrup. The agricultural census appears to have lumped all molasses and syrup products together under the heading of molasses.

\begin{abstract}
${ }^{51}$ Three pieces of a balance scale were found at the farmstead. Although these were often called cotton-scales and were used to weight cotton, they were also used to weight many other types of farm produce and do not, by themselves, constitute archeological evidence of cotton production. However, two artifacts were identified as cotton-related items just as this report was in final production. These artifacts are cotton-bale ties, and they do strongly suggest that Williams was producing cotton (see Chapters 8, 11, and 14).
\end{abstract}




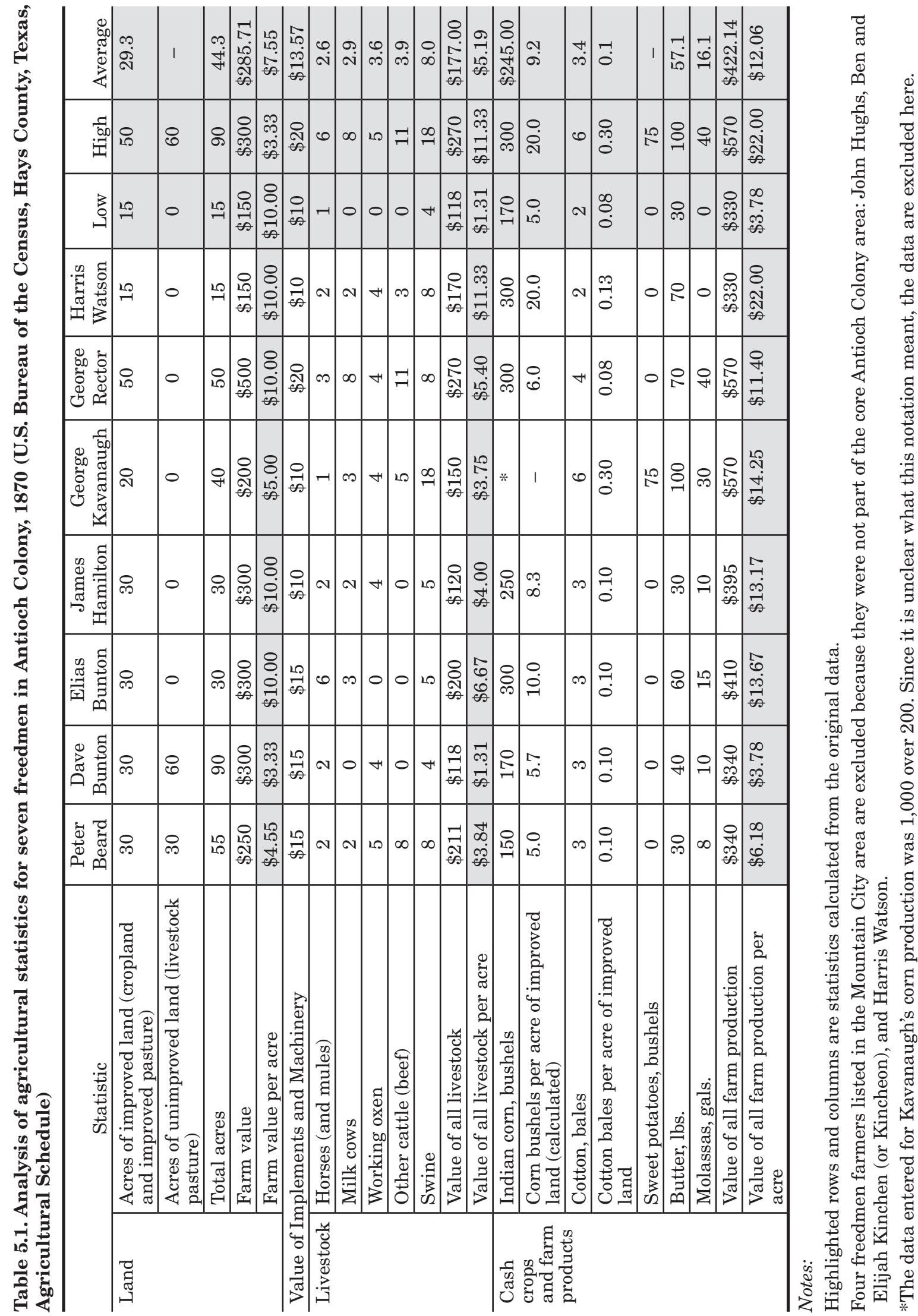




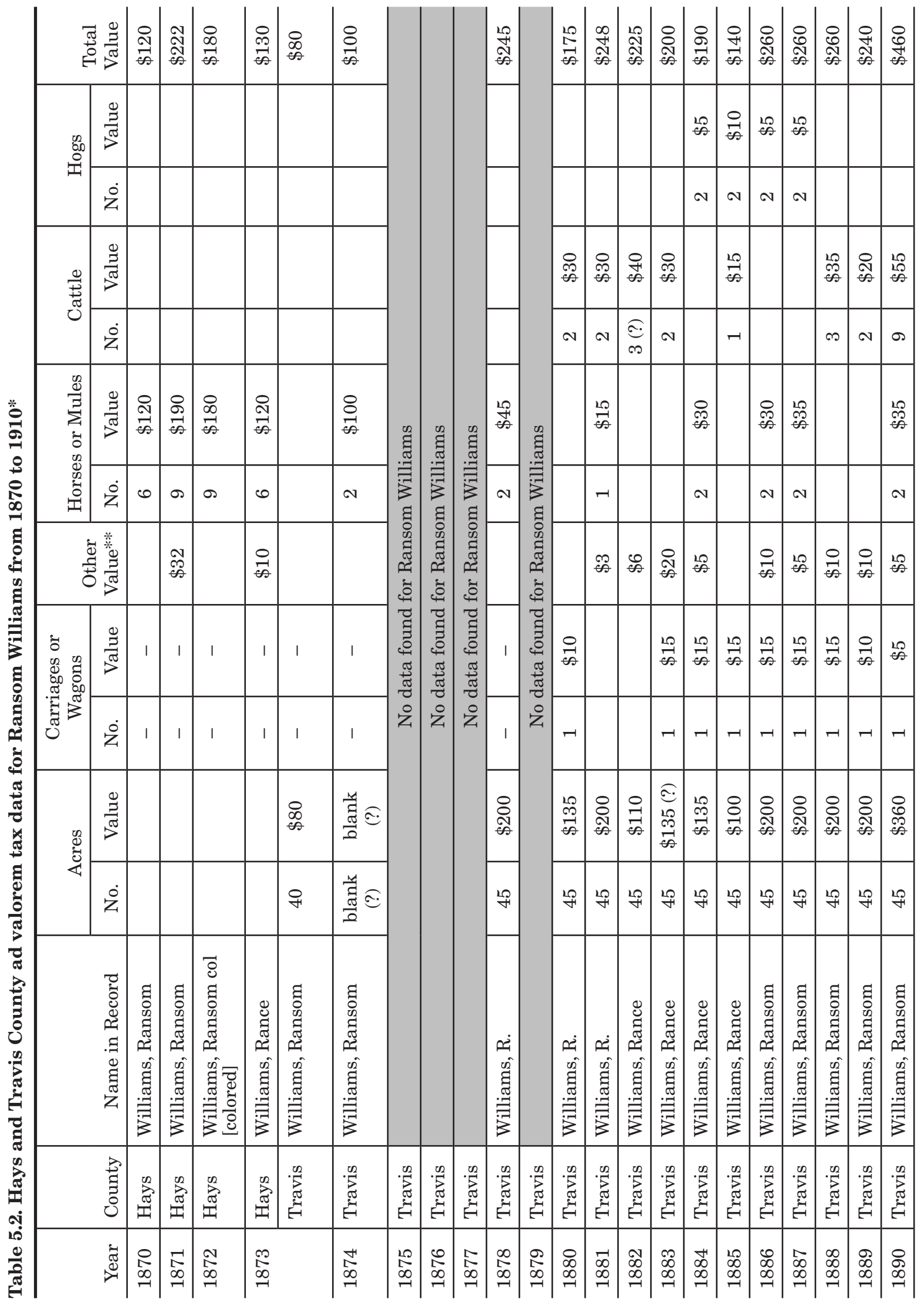




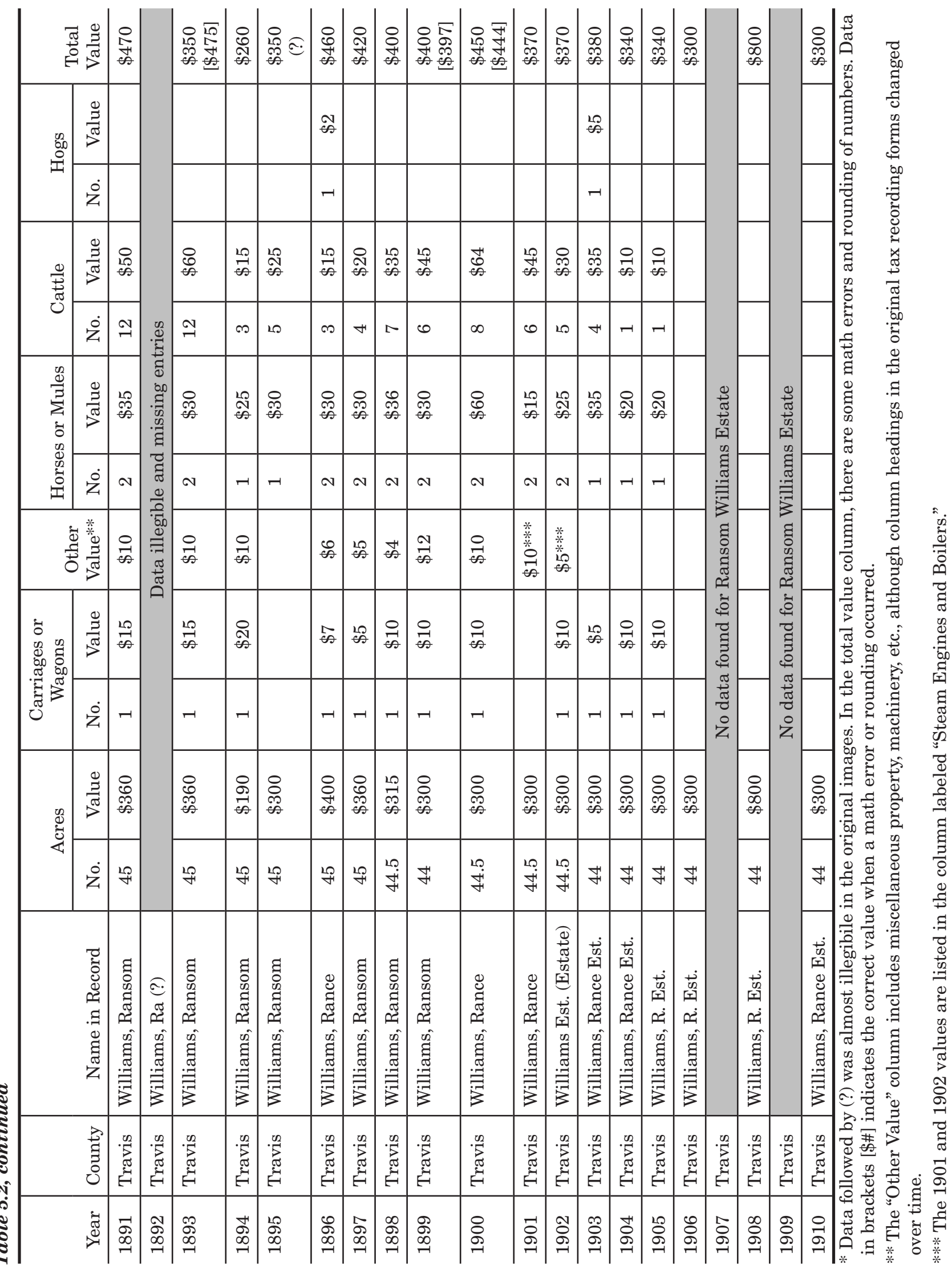


Table 5.3. Travis County ad valorem tax data for Will and Charley Williams from 1902 to 1910

\begin{tabular}{|c|c|c|c|c|c|c|c|c|c|c|c|c|c|}
\hline \multirow[b]{2}{*}{ Year } & \multirow[b]{2}{*}{ Name in Record } & \multicolumn{2}{|c|}{ Acres } & \multicolumn{2}{|c|}{$\begin{array}{c}\text { Carriages } \\
\text { or Wagons } \\
\end{array}$} & \multirow{2}{*}{$\begin{array}{l}\text { Other } \\
\text { Value }\end{array}$} & \multicolumn{2}{|c|}{$\begin{array}{l}\text { Horses or } \\
\text { Mules }\end{array}$} & \multicolumn{2}{|c|}{ Cattle } & \multicolumn{2}{|c|}{ Hogs } & \multirow[t]{2}{*}{$\begin{array}{l}\text { Total } \\
\text { Value }\end{array}$} \\
\hline & & No. & Value & No. & Value & & No. & Value & No. & Value & No. & Value & \\
\hline 1902 & Williams, Chas. & 12.5 & $\$ 40$ & & & & 1 & $\$ 40$ & & & & & $\$ 81$ \\
\hline 1903 & $\begin{array}{c}\text { Williams, R. } \\
\text { [Estate?] Charlie }\end{array}$ & 12 & $\$ 40$ & & & & & & & & & & $\$ 40$ \\
\hline 1904 & $\begin{array}{c}\text { Williams, Will and } \\
\text { Chas. }\end{array}$ & 12 & $\$ 40$ & & & & & & & & & & $\$ 40$ \\
\hline 1905 & Williams, Will & 6 & $\$ 30$ & 2 & $\$ 10$ & $\$ 10$ & 2 & $\$ 40$ & 1 & $\$ 20$ & & & $\$ 110$ \\
\hline 1906 & Williams, Will & & & 2 & $\$ 75$ & $\$ 30$ & 3 & $\$ 140$ & 1 & $\$ 20$ & 9 & $\$ 15$ & $\$ 280$ \\
\hline 1907 & $\begin{array}{l}\text { Williams, Will } \\
\text { [Ransom's son] }\end{array}$ & & & 1 & $\$ 50$ & & 3 & $\$ 100$ & 2 & & 2 & $\$ 5$ & $\$ 190$ \\
\hline 1908 & Williams, Will & \multicolumn{12}{|c|}{ Poll tax assessment only; no property values listed } \\
\hline 1909 & \multicolumn{13}{|c|}{ No data found for Will Williams } \\
\hline 1910 & Williams, Will & & & 2 & $\$ 100$ & $\$ 30$ & 3 & $\$ 350$ & 2 & $\$ 20$ & & & $\$ 500$ \\
\hline
\end{tabular}

have a milk cow. There is no definitive historical or archeological evidence for butter production at the Williams farmstead, but some of the large vessel stoneware sherds could have been from butter churns (the diagnostic lids were absent).

- All but one of the farms produced molasses (or sorghum syrup), indicating that they grew some type of sugar cane, sugar beets, or sorghum. There is no definitive historical or archeological evidence for molasses or syrup production at the Williams farmstead, but it is likely that this activity occurred there.

- Only one of the five farms (Kavanaugh's) produced enough sweet potatoes for commercial sale. It is likely that all of the Antioch farmers grew some sweet potatoes, and production of small quantities for personal consumption would not have been recorded in the agricultural census. Charred sweet potato remains were recovered from the Williams farmstead, and the house had a subfloor "potato cellar."

Based on the historical and archeological evidence, the agricultural characteristics of the Williams farmstead fit well with the historical farm production evidence for the Antioch Colony farms, especially those of similar size. What is less certain is whether the Williams family farming endeavors were geared mainly toward self-sufficiency (producing livestock and crops for their own use) or if they regularly produced a surplus of livestock, crops, or farm products for commercial sale in the Bear Creek area or nearby communities. The Antioch Colony evidence would suggest that Ransom Williams probably did make extra income at times, perhaps by growing and selling cotton and Indian corn or by producing extra farm products such as butter and molasses. If we use the average value of farm production of $\$ 12.06$ per acre for the 45-acre farmstead, Ransom Williams might have been able to reap about $\$ 542$ annually from his farm products by the mid-1870s. One can imagine, however, that making a significant amount of extra income would have been possible only in good years. It is likely that Williams sold livestock, crops, and farm products in any years when he had a surplus, but kept most or all of his farm products for family use when hard times hit (e.g., drought or economic depression).

\section{Marriage and Family}

Deed, tax, marriage, death, and twentiethcentury census records offer some information 
about the Williams family, but it is difficult to pin down many facts and dates (Tables 5.4 and 5.5). It is not known when Ransom and Sarah Williams got married since no marriage certificate has been found for the couple in either Hays or Travis counties. However, archival evidence does reveal some important details about Sarah and when she probably met and married Ransom Williams.

A 15-year-old African American woman named Sarah Houston appeared in the 1870 census record for Austin, Travis County, and she was probably the young woman who married Ransom Williams. From later records, it is known that Sarah's maiden name was Houston and, as no other Sarah Houstons were recorded in the entire state of Texas at that time, it is highly likely that this girl became Ransom's wife. According to the census, Sarah was single, born in Texas, and worked as a live-in servant for the white Albert Roberts household. Roberts was a merchant and grocer from Virginia, and he had five other black servants named Tisdale residing at his address. A family of black Houstons lived only four doors away from the Roberts family, and it is possible that Sarah was related to them in some way (Morrison and Fourny 1872; U.S. Bureau of the Census, 1870). Notably, no other Houstons were listed in Hays County or southern Travis County at the time.

Sarah Houston also appeared in the 1875 Austin census. Again, she was the only Sarah Houston recorded in the Austin census that year (City of Austin Census 1875; Sage n.d.). Almost certainly she was the same Sarah Houston counted in the 1870 census. According to the 1875 census, Sarah was 21 years old, "colored," living on Cypress Street (Third Street) and working as a cook. That was the last year the name "Sarah Houston" appeared in Austin records, most likely because she married Ransom Williams and moved out of the city soon after the 1875 census.

Since Ransom lived in the country south of Austin, either in southern Travis County or in the Antioch Colony of northern Hays County, it is not known how he met Sarah, a resident of Austin. He may have made her acquaintance in an African American church, at a gathering such as Juneteenth, or during a shopping expedition to Austin. However they met, they married after the 1875 census showed her as a single woman and before 1876, when their first child was born.
It is almost certain that Sarah left the Texas capital and moved to her husband's farm by late 1876, when she gave birth to the first of her nine children, Will (U.S. Bureau of the Census, 1910). Will was followed by Charley (date unknown, ca. 1878), Mary (1882), Henry (1883), Mattie (1885), John (1889), and Emma (ca. 1893). Two other children died before reaching adulthood (U.S. Census, 1910; Death Certificates, various dates). Sarah was a young woman in her early twenties when her first child was born and a woman of 41 when she gave birth to Emma, her youngest child (U.S. Census, 1910, 1920, 1930; Death Certificates, various dates). Sarah spent her young adulthood-a span of about 25 years-bearing, nursing, raising, and burying her children.

Ransom Williams was apparently living on his land for some time before he met Sarah. He may have completed the house on his property in preparation for the arrival of his bride, and within a few years, it was filled with children. The little cabin must have been abuzz with activity with a single room serving as kitchen, dining room, bedroom, and family room.

\section{Chores and Play Time}

In addition to caring for her children, Sarah kept house, canned food, tended the garden and raised chickens, hogs, and milch cows. Ransom likely did most of the heavy labor of breaking ground, removing rocks from fields, carrying water from the creek to the house, building and repairing fences, and maintaining the log house. In the tradition of many pioneer women, Sarah probably helped her husband clear and plow fields, and plant and harvest crops. Most likely, the children worked alongside their parents, as was common in the area at that time. As they got older, the children may have helped their parents clear and level land for crops and build stone fences and livestock corrals with the rocks they removed from the fields. Agricultural census records for surrounding farms suggest the types of duties the children may have performed on the farm in the late 1800s. Their days were probably spent performing chores such as feeding livestock, milking cows, building fences, plowing fields, planting, and harvesting crops, and gathering wood. The girls would have helped their mother cook and clean, can and store food, and sew the family clothes. Boys might have hunted for squirrels, rabbits, or deer with their father. 
The Ransom and Sarah Williams Farmstead

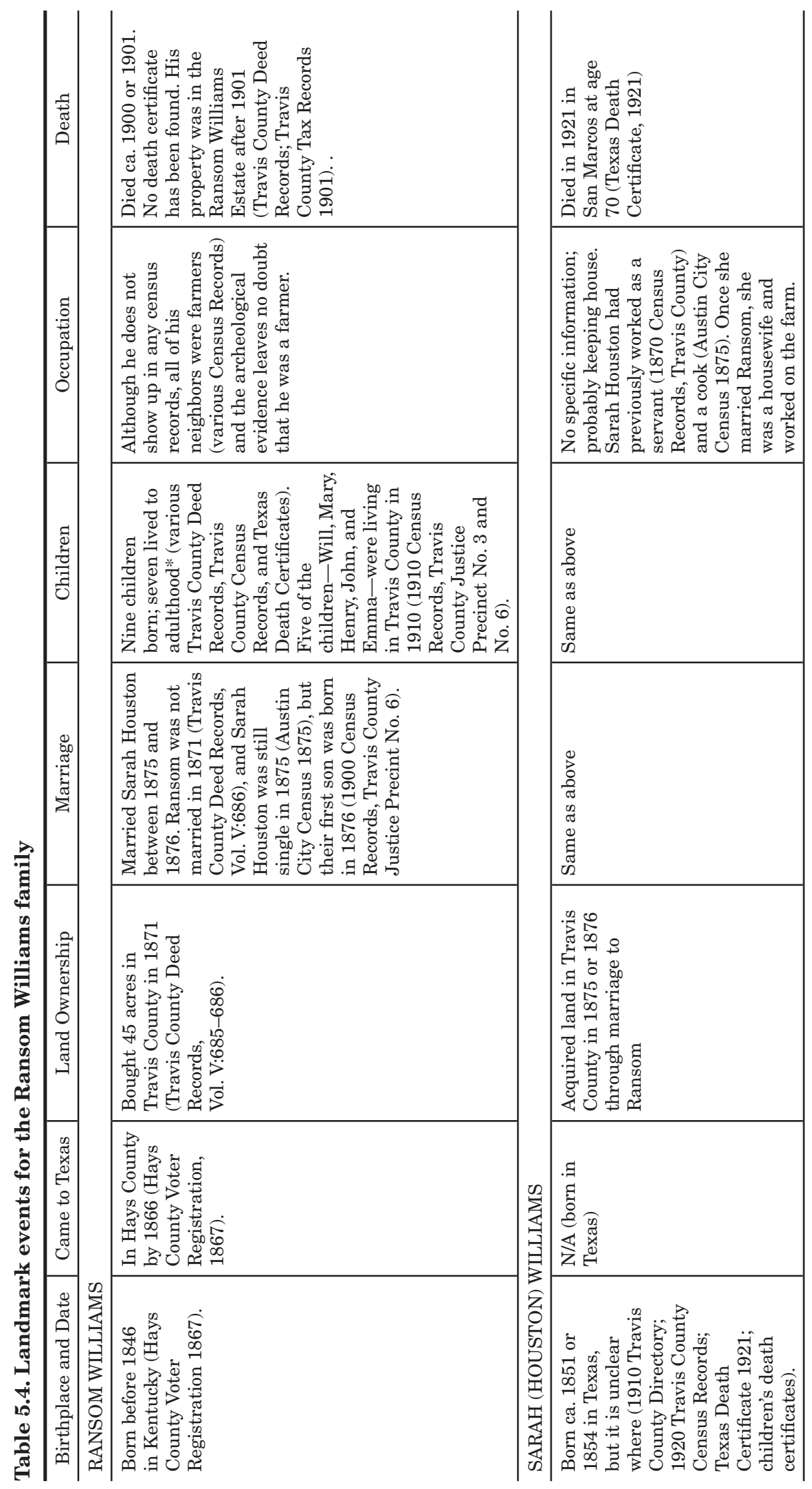


Chapter 5: Ransom and Sarah Williams: Freedman Farmers

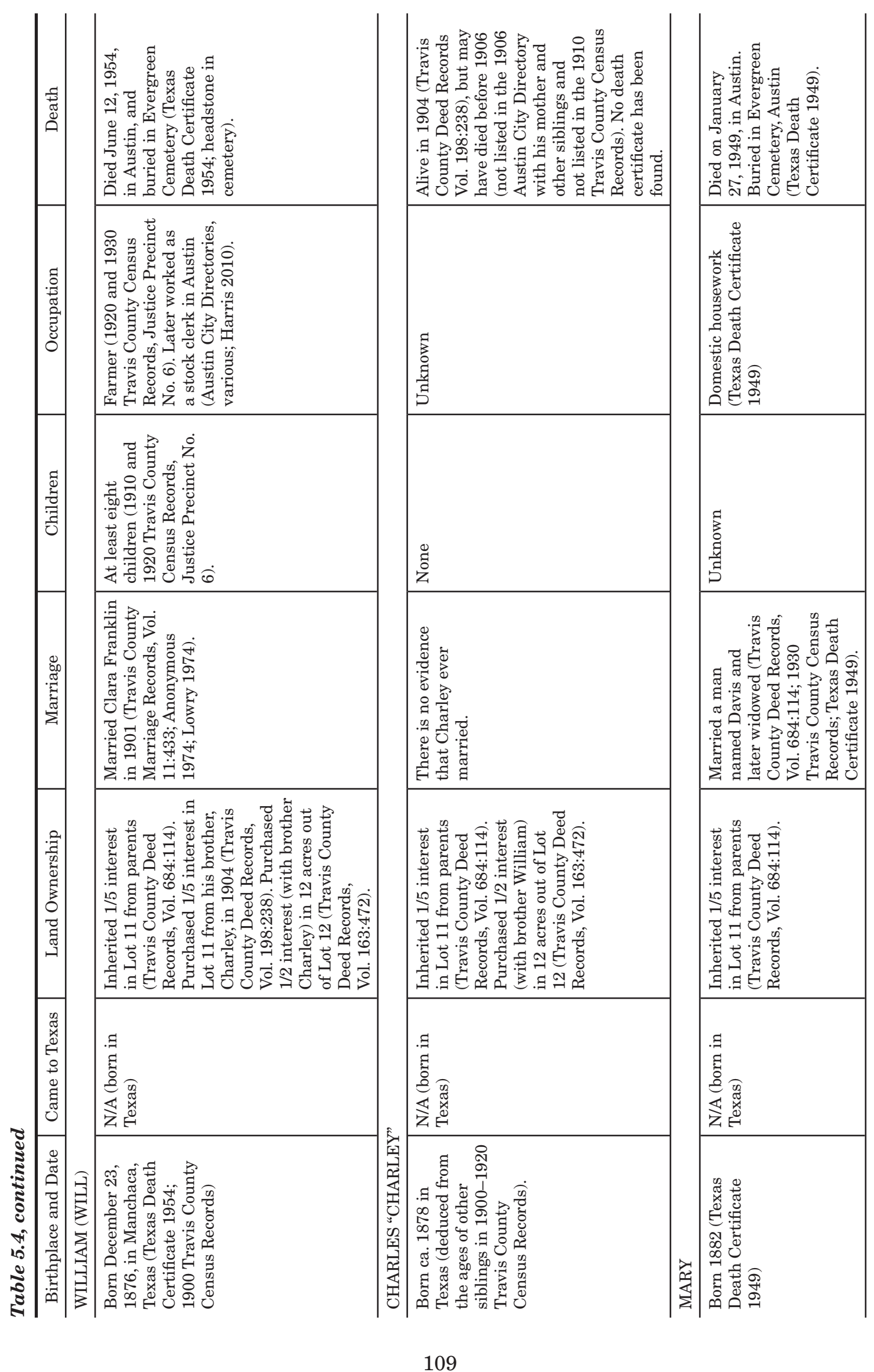


The Ransom and Sarah Williams Farmstead

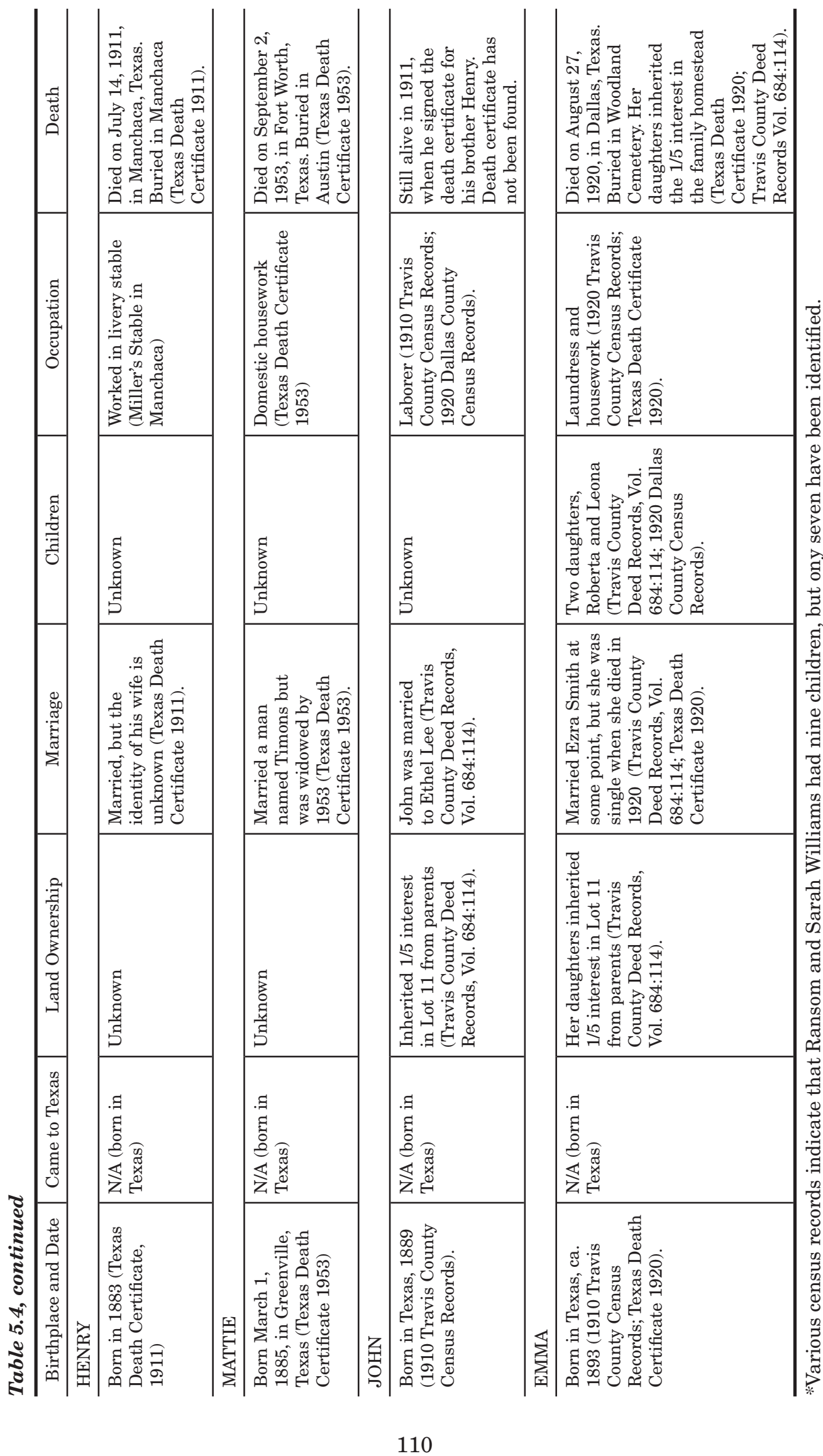


Table 5.5. Timeline of the Williams family in the McGehee League, southern Travis County

\begin{tabular}{|c|c|c|}
\hline Date & Event & Data Source and Notes \\
\hline \multicolumn{3}{|c|}{ RANSOM AND SARAH WILLIAMS FAMILY* } \\
\hline before 1854 & Ransom Williams born in Kentucky & $\begin{array}{l}\text { Age deduced from } 1867 \text { Voter Registration. } \\
\text { Birth state is mentioned on children's death } \\
\text { certificates. }\end{array}$ \\
\hline ca. 1854 & Sarah Houston born in Texas & $\begin{array}{l}\text { Age stated in Travis County Census Records } \\
\text { and in the } 1875 \text { Austin City Census. Maiden } \\
\text { name, approximate age, and birth state are } \\
\text { listed on children's death certificates. }\end{array}$ \\
\hline 1866 & Ransom Williams living in Hays County & 1867 Voter Registration \\
\hline 1871 & $\begin{array}{l}\text { Ransom Williams acquires } 45 \text { acre tract (the } \\
40 \text {-acre Lot } 11 \text { plus } 5 \text { acres) from D. A. Word }\end{array}$ & Travis County Deed Record \\
\hline 1872 & $\begin{array}{l}\text { Ransom Williams registers his horse brand } \\
\text { with Travis County }\end{array}$ & Travis County Register of Marks and Brands \\
\hline $\begin{array}{l}1875 \text { or } \\
1876\end{array}$ & Ransom Williams marries Sarah Houston & $\begin{array}{l}\text { Deduced from Travis County Deed and } \\
\text { Census Record, children's death certificates, } \\
\text { and the } 1875 \text { Austin City Census }\end{array}$ \\
\hline 1876 & William Williams born & Death Certificate and census records \\
\hline ca. 1878 & Charley Williams born & Census records \\
\hline 1882 & Mary Williams born & Texas Death Certificate (for Mary Davis) \\
\hline 1883 & Henry Williams born & Texas Death Certificate \\
\hline 1885 & $\begin{array}{l}\text { Mattie Williams born in Greenville, Texas, } \\
\text { but her parents were Ransom Williams and } \\
\text { Sarah Houston. }\end{array}$ & Texas Death Certificate (for Mattie Timons) \\
\hline 1889 & John Williams born & Travis County Census Records \\
\hline ca. 1893 & Emma Williams born & $\begin{array}{l}\text { Texas Death Certificate and Travis County } \\
\text { Census Records }\end{array}$ \\
\hline $\begin{array}{l}1880 \text { s and } \\
1890 \text { s }\end{array}$ & $\begin{array}{l}\text { The Williams children attend school, } \\
\text { probably the Rose Colony School }\end{array}$ & $\begin{array}{l}\text { Deduced from various records, including } \\
\text { Travis County Deed Record P:22, which } \\
\text { established a school for "colored" children }\end{array}$ \\
\hline 1894-1899 & $\begin{array}{l}\text { Ransom Williams is living in Manchaca area } \\
\text { (on 45-acre farm) }\end{array}$ & Rural Directory \\
\hline 1900 & $\begin{array}{l}\text { William and Charley Williams acquire } 12 \\
\text { acres (east side of Lot } 12 \text { and adjacent to } \\
\text { west side of Ransom Williams's farm) from } \\
\text { G. R. Whiteside }\end{array}$ & Travis County Deed Records \\
\hline ca. 1901 & Ransom Williams dies & Travis County Tax Records and Plat Maps \\
\hline 1902 & $\begin{array}{l}\text { Charley Williams sells } 1 / 2 \text { interest in } 12 \text {-acre } \\
\text { tract to W. H. Thaxton }\end{array}$ & Travis County Deed Records \\
\hline 1904 & $\begin{array}{l}\text { Charles Williams conveys } 1 / 5 \text { interest in } \\
\text { the Ransom Williams Estate to his brother } \\
\text { William Williams }\end{array}$ & Travis County Deed Records \\
\hline 1904 & $\begin{array}{l}\text { Sarah and Charles Williams living on } \\
\text { Ransom Williams Estate }\end{array}$ & Travis County Deed Records \\
\hline $\begin{array}{l}\text { After } 1904 \\
\text { (possibly } \\
\text { before 1906) }\end{array}$ & Charley dies & $\begin{array}{l}\text { Deduced from absence in records; no death } \\
\text { certificate found. }\end{array}$ \\
\hline 1905 & $\begin{array}{l}\text { William and Clara Williams sell 1/2 interest } \\
\text { in } 12 \text {-acre tract to D. W. Labenski }\end{array}$ & Travis County Deed Records \\
\hline
\end{tabular}


Table 5.5, continued

\begin{tabular}{|c|c|c|}
\hline Date & Event & Data Source and Notes \\
\hline ca. 1906 & Sarah, John, and Emma move to Austin & Austin City Directory \\
\hline 1910 & $\begin{array}{l}\text { Sarah, John, and Emma Williams living at } \\
706 \text { E. 8th Street in Austin }\end{array}$ & Travis County Census Records \\
\hline 1911 & Henry Williams dies (July 14) in Manchaca & Texas Death certificate \\
\hline ca. 1916 & $\begin{array}{l}\text { Sarah, John, and Emma move from Austin } \\
\text { to Dallas }\end{array}$ & $\begin{array}{l}\text { Austin City Directory, Travis and Dallas } \\
\text { County Census Records }\end{array}$ \\
\hline 1918 & $\begin{array}{l}\text { Leona Smith born to Emma Williams and } \\
\text { Ezra Smith }\end{array}$ & Travis County Census Records \\
\hline 1920 & $\begin{array}{l}\text { John, Sarah, and Emma Williams are living } \\
\text { with lodger Ezra Smith and daughter Leona } \\
\text { on Maple Avenue in Dallas }\end{array}$ & Dallas County Census Records \\
\hline 1920 & $\begin{array}{l}\text { Emma Williams dies at Parkland Hospital in } \\
\text { Dallas (August 27) at age } 27\end{array}$ & Texas Death Certificate \\
\hline 1921 & $\begin{array}{l}\text { Sarah (Houston) Williams dies (March 11) in } \\
\text { San Marcos at age } 70 \text {. She was buried in San } \\
\text { Marcos }\end{array}$ & Texas Death Certificate \\
\hline 1930 & $\begin{array}{l}\text { Mary (Williams) Davis is living in Austin } \\
\text { with her cousin, Emma Bunton }\end{array}$ & Texas Death Census Records \\
\hline 1949 & $\begin{array}{l}\text { Mary (Williams) Davis dies at King's } \\
\text { Daughter's Home for the Aged in Austin } \\
\text { (January 25) }\end{array}$ & Texas Death Certificate \\
\hline 1953 & $\begin{array}{l}\text { Mattie (Williams) Timons died in Fort Worth, } \\
\text { Texas (September 2) }\end{array}$ & Texas Death Certificate \\
\hline \multicolumn{3}{|c|}{ WILLIAM (WILL) WILLIAMS FAMILY } \\
\hline 1874 & $\begin{array}{l}\text { Clara Franklin born to Richard and Jane } \\
\text { Franklin }\end{array}$ & $\begin{array}{l}\text { Travis County Census Records; Anonymous } \\
\text { (1974); Lowry (1974) }\end{array}$ \\
\hline 1876 & $\begin{array}{l}\text { William Williams born to Ransom and Sarah } \\
\text { Williams }\end{array}$ & $\begin{array}{l}\text { Texas Death Certificate, Travis County } \\
\text { Census Records }\end{array}$ \\
\hline 1900 & $\begin{array}{l}\text { William Williams lodging in Justice of the } \\
\text { Peace Precinct } 6 \text { of Travis County, farmer/ } \\
\text { laborer }\end{array}$ & Travis County Census Records \\
\hline 1900 & $\begin{array}{l}\text { Richard and Jane Franklin and their } \\
\text { children living in Justice of the Peace } 6 \text {, } \\
\text { Travis County }\end{array}$ & Travis County Census Records \\
\hline 1901 & $\begin{array}{l}\text { William Williams and Clara Franklin } \\
\text { Williams marry }\end{array}$ & $\begin{array}{l}\text { Travis County Marriage Records; } \\
\text { Anonymous (1974); Lowry (1974) }\end{array}$ \\
\hline 1903 & $\begin{array}{l}\text { Arnold Williams born to William and Clara } \\
\text { Williams }\end{array}$ & Travis County Census Records \\
\hline 1905 & $\begin{array}{l}\text { William and Clara Williams sell } 1 / 2 \text { interest } \\
\text { in } 12 \text {-acre tract (east side of Lot } 12 \text { ) to D. W. } \\
\text { Labenski }\end{array}$ & Travis County Deed Record \\
\hline 1910 & $\begin{array}{l}\text { William and Clara Williams living on Buda } \\
\text { Route 1, Justice of the Peace } 6 \text {, Travis } \\
\text { County, with children Arnold, Freddie, } \\
\text { Jannie, and Ella }\end{array}$ & Travis County Census Records \\
\hline 1920 & $\begin{array}{l}\text { William and Clara Williams living in } \\
\text { Creedmoor Village, Justice of the Peace } \\
\text { Precinct 6, Travis County, with children } \\
\text { Arnold, Jannie, Eloise, Mabel, Syola, Willie, } \\
\text { and Earl }\end{array}$ & Travis County Census Records \\
\hline
\end{tabular}


Table 5.5, continued

\begin{tabular}{l|l|l}
\hline Date & Event & Data Source and Notes \\
\hline 1930 & $\begin{array}{l}\text { William and Clara Williams living next to } \\
\text { son Arnold, his wife Novella, granddaughter } \\
\text { Corrine, and children Janie, Mabel, Syola, } \\
\text { Willie, and Earl on Austin Route \#7/Colton } \\
\text { and Del Valle Road in Justice of the Peace } \\
\text { Precinct 6, Travis County }\end{array}$ & Travis County Census Records \\
\hline 1954 & $\begin{array}{l}\text { Will Williams dies in Austin (while living at } \\
\text { 2929 East 19th Street) }\end{array}$ & $\begin{array}{l}\text { Texas Death Certificate; Austin Genealogical } \\
\text { Society (2013) }\end{array}$ \\
\hline 1974 & $\begin{array}{l}\text { Clara (Franklin) Williams turned 100 years } \\
\text { old while living in Austin }\end{array}$ & Anonymous (1974); Lowry (1974) \\
\hline 1977 & $\begin{array}{l}\text { Clara (Franklin) Williams died in Austin } \\
\text { FINAL DISPOSITION OF THE RANSOM AND SARAH WILLIAMS HOMESTEAD }\end{array}$ & $\begin{array}{l}\text { Anonymous (1974); Lowry (1974); Austin } \\
\text { Genealogical Society (2013) }\end{array}$ \\
\hline 1934 & $\begin{array}{l}\text { William and Clara Williams convey 2/5 } \\
\text { interest in Ransom Williams Estate to Daisy } \\
\text { Rowell (daughter of Hugh Cunningham) }\end{array}$ & Travis County Deed Record \\
\hline 1941 & $\begin{array}{l}\text { John and Ethel Williams, Mary Williams } \\
\text { Davis, and Emma Williams Smith's children, } \\
\text { Roberta Hill and Leola Johnson, convey } \\
\text { remaining 3/5 interest in estate to W. L. } \\
\text { Wilkins (grandson of Hugh Cunningham) }\end{array}$ & Travis County Deed Record \\
\hline
\end{tabular}

*The Travis County ad valorem tax records for Ransom Williams are not listed separately. Collectively, they indicate that Williams paid taxes on his 45-acre farm and the livestock and machinery he owned from 1871 through his death about 1901. After that, the taxes were paid by the Ransom Williams Estate.

They probably played games with one another. The children had many toys including marbles, porcelain dolls, and a cap pistol. In addition to their family chores and play time, they attended school and learned to read and write (U.S. Bureau of the Census, Dallas and Travis Counties, 1910-1930). ${ }^{52}$

\section{Who Was Sarah Houston?}

It may be impossible to know Sarah's family of origin. Many freedmen had been separated from their families at a young age and raised in households of slaves from various backgrounds. At emancipation, a large number kept the surnames of their white masters, although it was also common for freedmen to abandon their "slave" names and adopt new ones. Sarah's "Houston" surname is intriguing for its possible link to Sam Houston, twice governor of Texas

${ }^{52}$ Later census and deed records show that several of the Williams children were literate, including Will, Mary, John, and Emma (U.S. Bureau of the Census 1910, 1920). and a leader of the Texas War for Independence. Attempts were made to see if she was one of Sam Houston's many slaves, but no direct link could be found. Houston lived in Austin as governor until 1862, when Sarah would have been a child of eight or nine. Sarah first appears in Austin records as a 15-year-old girl in 1870, after emancipation. It is possible that Houston left her with an Austin family when he returned to Huntsville, but no evidence of this has been found. Her name did not appear in books about Houston and his slaves or in his property lists on file at the Sam Houston Memorial Museum in Huntsville. Census records almost all agree that Sarah Houston was born in Texas, and it may be that she was the slave of one of the other white Houstons who lived in the state when she was born in the 1850s. By comparing her census data (1870, 1910, and 1920), her death certificate, and those of her children, the following facts are known: her maiden name was Houston, she was almost certainly born into slavery in Texas in the early 1850 s (conflicting records suggest 1851 or 1854), and she spent her childhood in bondage to her white masters. After emancipation, she 
lived in Austin, where she continued to work as a servant or a cook before getting married and moving to her husband's farm on Bear Creek.

\section{BEAR CREEK COMMUNITY}

Ransom and Sarah Williams were the only African Americans on Bear Creek Road for a decade. Their immediate neighbor to the south was John S. Wilkins, who may have been the first to settle in the subdivided land. He purchased two lots, numbers 15 and 19, aggregating 80 acres, on July 26, 1871 (Travis County Deed Record V:339-340). Wilkins soon built a house on the land; it was known as his homestead by the end of 1871 . Shortly after Wilkins came to the area, William M. and Elizabeth Murphy purchased 275 acres in the southeast section of the league, in present Hays County, on August 15, 1871 (Travis County Deed Record X:204). By the end of the year (December 5, 1871), Ransom Williams bought his Lot 11 just north of John Wilkins (Travis County Deed Record V:686). Wilkins, the Murphys, and Ransom Williams were the only occupants of the McGehee League until the following spring, when Daniel Labenski arrived.

When Daniel W. Labenski purchased a 120-acre farm north of the Murphys and east of Williams and Wilkins, the larger parcels were filled, leaving 10 and 20-acre farms here and there throughout the league. Labenski was the son of Victor Labenski, a Polish immigrant and one of the first settlers in Hays County. Labenski was an American-born man who was raised in northern Hays County but went a little farther north to unbroken land to purchase his farm on March 23, 1872 (Travis County Deed Record Z:133). In December 1873, W. A. Townsley and his wife, Susan, took possession of "lots 16, 17, 18, 20, 23, and the north half of blocks Nos. 21 and 22" (Travis County Deed Record Z:232). The combined tracts equaled 238 acres that surrounded the Wilkins farm on the south and west. Wilkins, Williams, Labenski, the Murphys, and the Townsleys were pioneers on the south side of Bear Creek (Figure 5.3). ${ }^{53} \mathrm{~A}$ series of maps presented in Appendix A traces the history of these properties through time.

${ }^{53}$ In fact, John Wilkins and the Townsleys were living in the nearby Onion Creek postal district in 1870, according to the census. It is possible that they occupied their land prior to the actual sale.

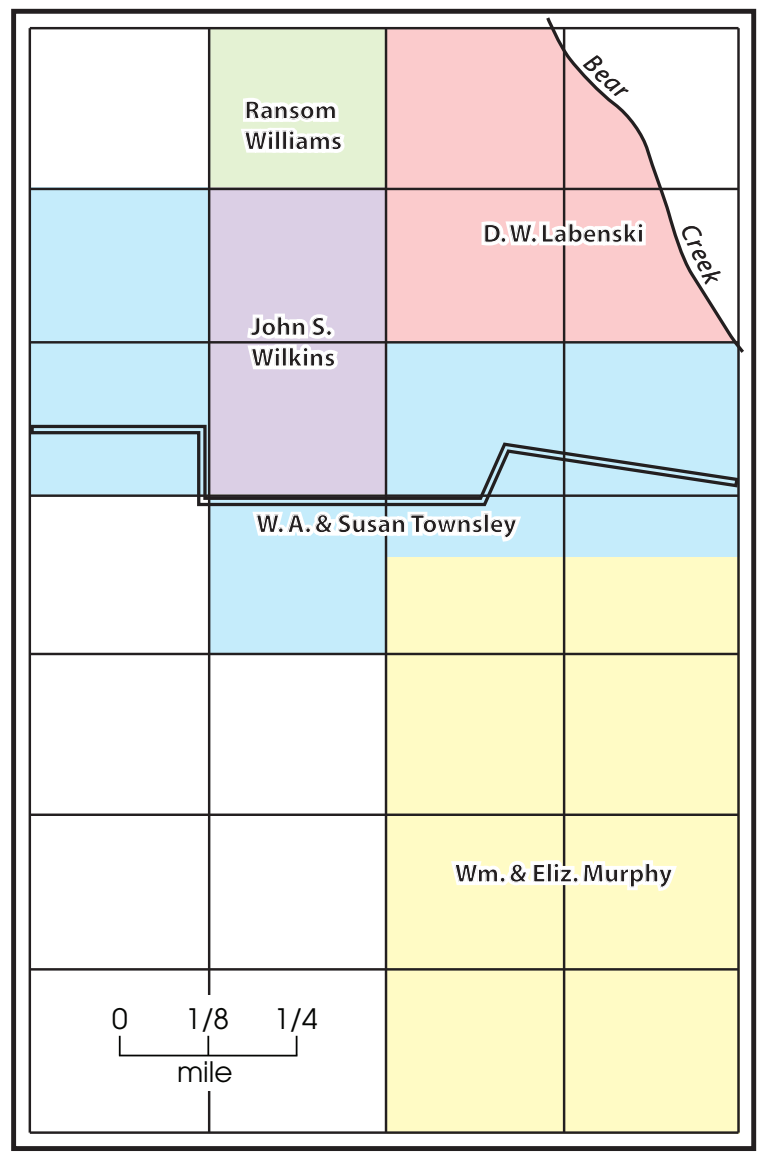

Figure 5.3. Map of lots and landowners along Bear Creek, ca. 1873. Williams's immediate neighbors were Daniel W. Labenski on the east and John S. Wilkins on the south. Map data are taken from the 1871 subdivision map of the southeast portion of the John G. McGehee League.

\section{School, Church, and Community Center on Bear Creek}

These earliest settlers in the McGehee League had no easy access to stores, blacksmiths, machinists, doctors, schools, or churches, the basic amenities that defined communities at that time (Table 5.6). ${ }^{54}$ The city of Austin lay about 12 miles to the north, and the rural community of Mountain City,

\footnotetext{
${ }^{54}$ It was a decade before the extension of the International and Great Northern Railroad extended through the area connecting Austin to San Antonio and creating the town of Manchaca with its stores and services.
} 
Chapter 5: Ransom and Sarah Williams: Freedman Farmers

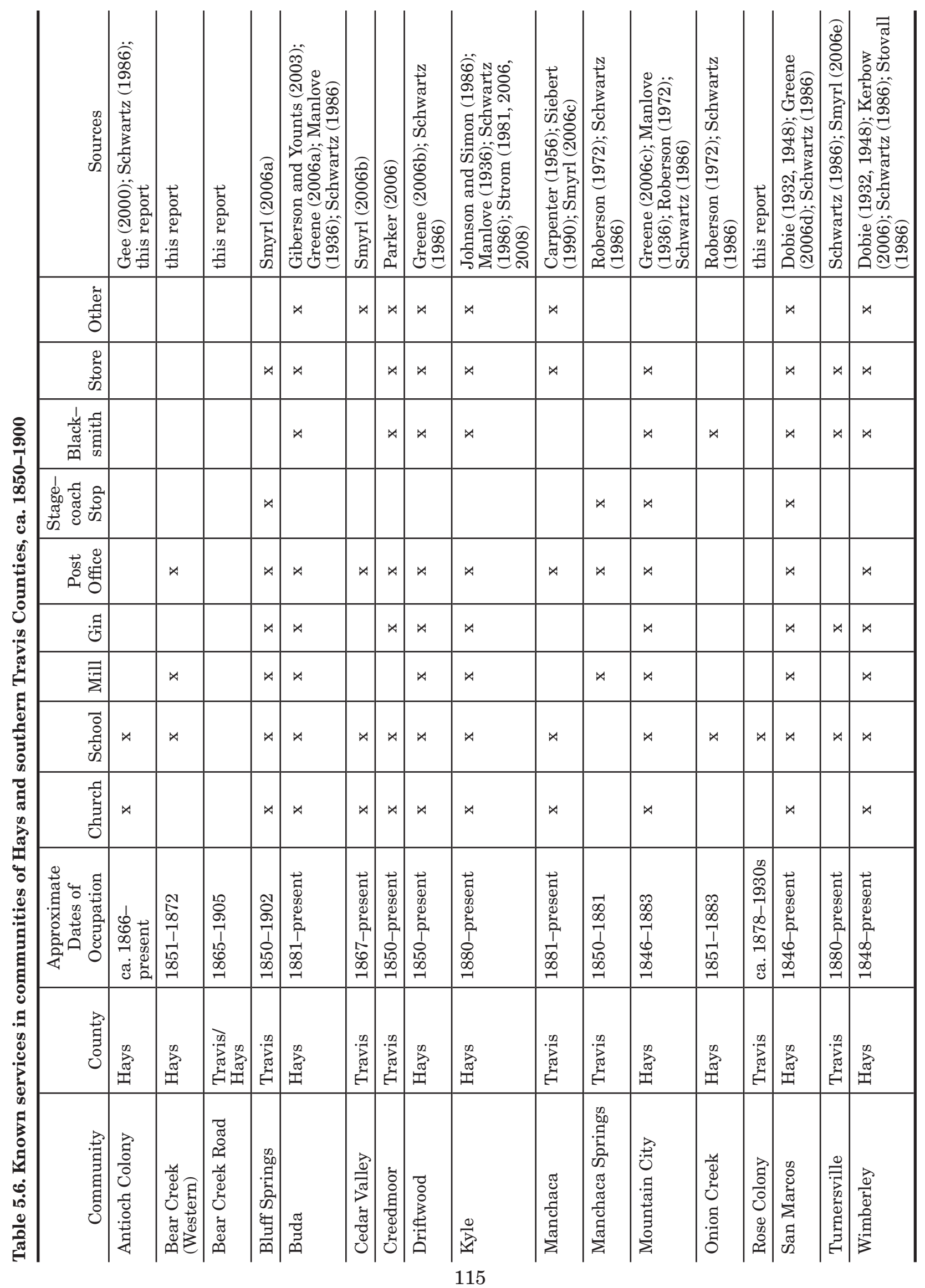


in northern Hays County, lay about 6 miles to the south. No established roads led to either place. Nevertheless, the pioneers endeavored to form a community of like-minded farmers (Figure 5.4). Shortly after the first settlers built their homes and set plow to land, they took steps to establish a community school and church, possibly in the same building. When Ed Burleson deeded land to the Townsleys, he reserved "two acres heretofore given and conveyed by us to W. A. Townsley, John F. Pruitt, and J. H. Hodge as trustees for school and church purposes." Burleson signed the document on December 4, 1873, but its wording suggests that the school and church might have been built by that time (Travis County Deed Records Z:232; 32:298).

Susan Townsley may have been the driving force behind the donation of school land, since she stood to gain considerably from the deal. In 1870 , she had five children attending school, with three younger ones coming up..$^{55}$ The closest school may have been one on Onion Creek, miles away to the east. Shortly after the Townsleys purchased their relatively large 238 -acre farm, Mr. Townsley passed away. ${ }^{56}$ His death left Susan with a large household to manage, a farm to run, and a hefty mortgage to pay. She sold about 80 acres of land to a man named Menard Gagnon, but the proceeds were insufficient to pay her debts. Burleson repossessed most of her remaining property and obtained a judgment against her from the Hays County District Court in the amount of $\$ 328.67$ (Travis County Cause 691). When the dust settled, Susan Townsley retained parts of the north half of Lots 21 and 22, except for the 2 acres set aside for the school and church. She likely farmed the remaining acreage but augmented her income by establishing a store, known as Townsley's Store (Figure 5.5), near the church and school. As the only commercial enterprise for miles around, the store was almost certainly a community gathering place. Mrs. Townsley probably sold dry goods, tools, seed, and staple items. In 1873, the county used the store as a voting precinct for a special election.

\footnotetext{
${ }^{55}$ The location of the school is unknown. It was in the Onion Creek postal district.
}

${ }^{56}$ Between December 1873 and March 1875.
The school at "Townsley's Store" was likely built and in use by $1873 .^{57}$ Families like the Townsleys, whose children had previously attended school, would have encouraged its rapid construction. The school's existence shows that the children of Bear Creek had access to rudimentary education for nearly a decade before the town of Manchaca formed nearby in 1881 (Smyrl 2006c). ${ }^{58}$ From at least 1879 forward, the Townsley Store school operated under the auspices of the Travis County school system, and regulators tracked its quarterly progress. Such registers listed trustees, teachers, their salaries, and school repairs for each of about 90 rural schools in the county (Travis County School District 1879-1888).

John Pruitt served as trustee from 1873 until the school closed about 1883 . He, too, had a vested interest in its well-being as he had four school-age children by 1880 . In 1881, Sam J. Nichols and Jacob T. Swank, neighbors in the Bear Creek community,joined Pruitt as trustees. Like Pruitt and Townsley, they had children in school. The 1881 Travis County School District register shows that the Townsley Store school had 21 students that year, but the 1880 census shows that 33 children between Pruitt's farm and Swanks' farm, all in the Bear Creek area, attended school. Susan F. Dickenson was the first known teacher according to the 1879 school register. ${ }^{59}$ Her salary, at $\$ 25.85$ per month, was on par with that of teachers at other Travis County rural schools at the time. Later teachers included Belle Thompson in 1881 and J. W. Miller in 1882 (Travis County School District 1879-1888). With 20 or more children at the school, traffic at the store, and services in the church, this little node near the crossroads of Bear Creek Road and the San Antonio Road was likely the hub of the community until the town of Manchaca emerged.

\footnotetext{
${ }^{57}$ Travis County school registers confirm that a school existed at Townsley's Store by 1879 , but no earlier records have been found for rural schools. The Townsley deed record suggests that the school opened as early as 1873 .

${ }^{58} \mathrm{~A}$ Bear Creek school existed during the same period but it was further west, close to Dripping Springs.

${ }^{59}$ Although the school was probably older, the first register on record was compiled in 1879 .
} 


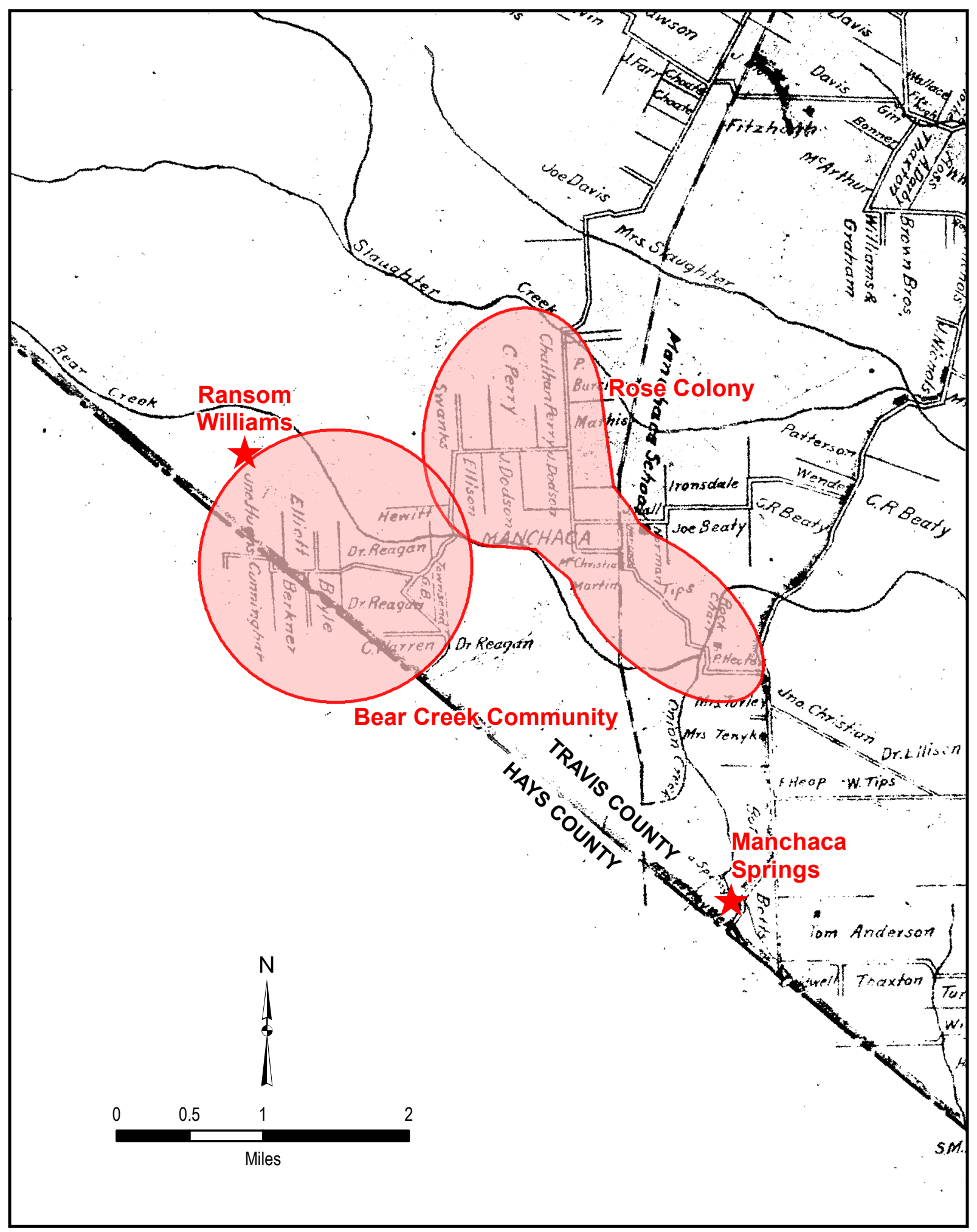

Figure 5.4. A 1914 school district map showing the relative approximate locations of the Bear Creek community, Rose Colony, and Manchaca Springs. Base map is from Travis County School District (1914). 


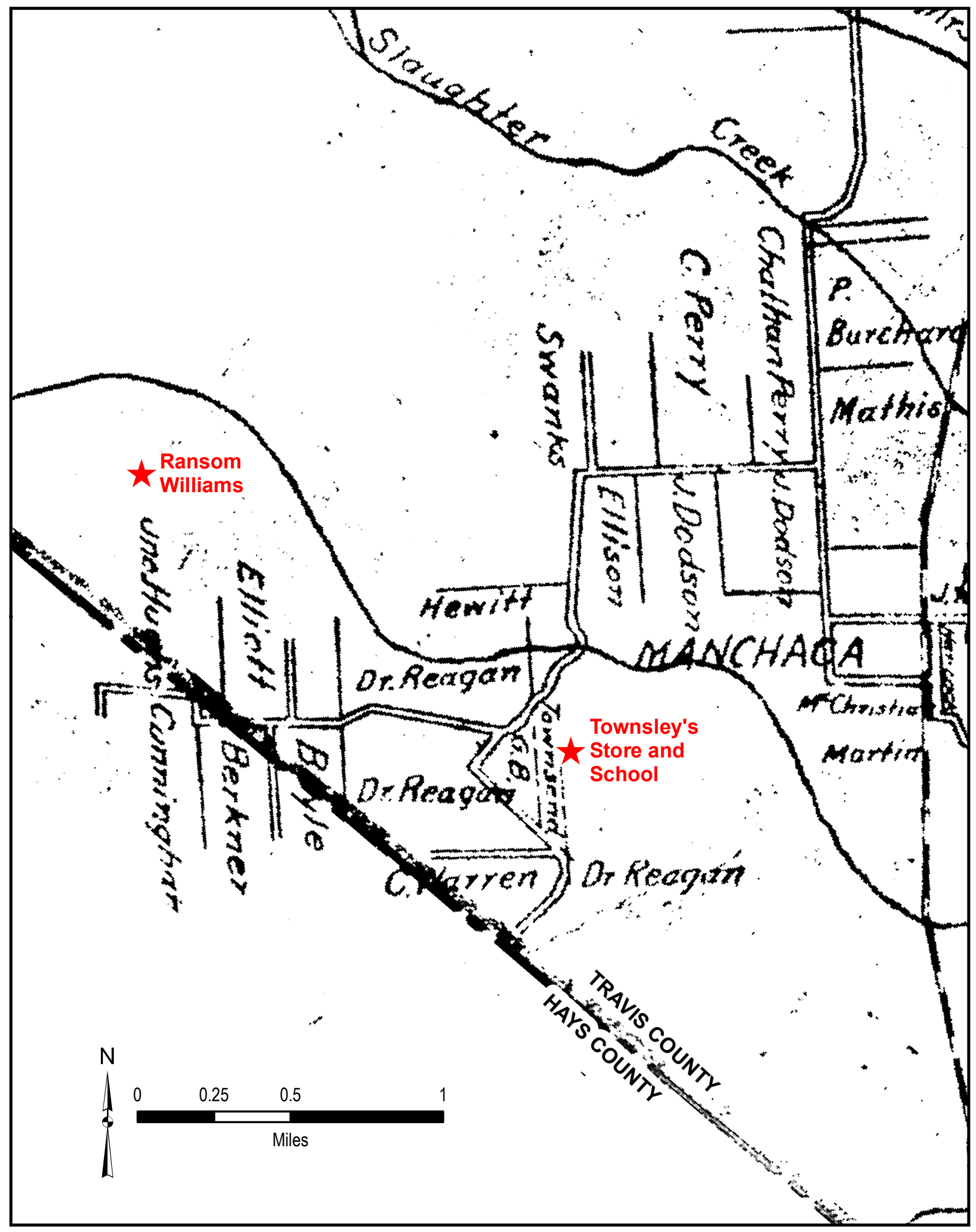

Figure 5.5. A 1914 school district map showing the approximate location of the Townsley Store about 2 miles east of the Williams farmstead. Established in 1873, this was one of the first stores available to residents of the Bear Creek community. There was also a school at this location, but it was not available for African American children. Base map is from Travis County School District (1914). 


\section{Freedman on Bear Creek}

Because of his race, Ransom Williams stood out from the rest of the Bear Creek community, but records vary as to his race or color. Hays County records, including the 1867 Voter Registration rolls and all tax rolls, show him as "colored" (Hays County Voter Registration 1867:Entry 278), but Travis County records did not identify him as such even when it was customary to do so (Table 5.7). ${ }^{60}$ For instance, in the 1870s, the Travis County Register of Marks and Brands carefully identified each and every person of African descent as "colored" even if census records showed them to be mulattos. Ransom Williams, though listed as "colored" in numerous Hays County records, was not listed as "colored" in the Register of Marks and Brands. Despite the lack of racial identification in some Travis County records, this suggests Williams was a mulatto, and he married a "Negro" woman, Sarah, in the 1870s. At this time it was illegal for whites and blacks to marry. ${ }^{61}$ Ransom was almost certainly a slave before emancipation. ${ }^{62}$ But it is impossible to know more about Ransom because slaves were enumerated in census records (slave schedules) only by sex, age, and color, ${ }^{63}$ and not by name. However, all later census records and death certificates clearly identify Sarah and their children as "black" or "Negro."

\begin{abstract}
${ }^{60}$ In other legal documents such as deed records, which frequently identified African Americans as "FMOC or FMC" for "Free Man of Color" in the nineteenth century, Williams's race is not indicated. In census records from 1910 forward, Williams's wife, Sarah, and his children are all shown as "black" or "Negro," indicating that Williams himself was at least mulatto since marriage between mixed couples was illegal in
\end{abstract} Texas at that time.

${ }^{61}$ Texas passed a law against intermarriage in 1858 and confirmed the law by state statute in 1879 .

${ }^{62}$ From a statistical viewpoint, the probability that Ransom Williams was a "free man of color" is extremely low. The 1850 census records show that only 397 out of 58,558 African American in Texas were free (Montgomery 2013). In 1860, there were still only about 400 free blacks in the state, although the actual number may have been higher (Hales 2013).

${ }^{63}$ Slaves were identified as "b" for black, "y" for yellow, or "m" for mulatto.

\section{WILLIAMS FAMILY TIES TO ANTIOCH COLONY}

The Williams family was probably excluded from the Bear Creek community. In the 1870s, Ransom and Sarah Williams and their small children probably socialized with residents of the Antioch Colony, the freedmen settlement that had emerged in the Mountain City area during the late 1860s (see Chapter 4 for a detailed discussion of Antioch Colony). The heart of the colony was due south of the Williams property, in northern Hays County. While some other African Americans lived on the east side of Onion Creek, the Antioch settlement was the only established freedmen community in northern Hays and southern Travis counties in the early 1870s, when Ransom and Sarah Williams first came to the farm. Comprised of 12 or 15 extended families, the community provided a church, a school, and social opportunities that were unavailable to the Williams family in the Bear Creek community in the early years.

There is evidence to suggest that Ransom Williams had familial ties to the Bunton families of Antioch Colony. His age, birthplace, probable light skin, and residence in Mountain City at the end of the Civil War suggest that Ransom Williams may have been one of the 14-year-old mulatto boys listed in Desha Bunton's 1860 slave schedules. In fact, he may have been related to Ransom Bunton, Sr., a freedman and former slave of John Wheeler Bunton. The fact that there existed a Ransom Bunton Sr. presupposes that there was a Ransom Bunton $J r$., but no person by that name has been found in deed, tax, or marriage records. Williams may have been born a Bunton but changed his name to Williams after emancipation. It was not uncommon for former slaves to divest themselves of their slave names. Another example in the Bear Creek area is Richard Washington, who changed his surname from "Luckett" after the war. Because such name changes were usually unofficial, they are difficult to find or prove. If Ransom Williams was originally a Bunton, the African American Buntons of Antioch Colony would have been related to him.

The 1930 census records offer a clue to the relationship between the Buntons and the Williams family. The record for Travis County show that one of Williams's children, Mary Williams Davis, was living with her cousin, 
The Ransom and Sarah Williams Farmstead

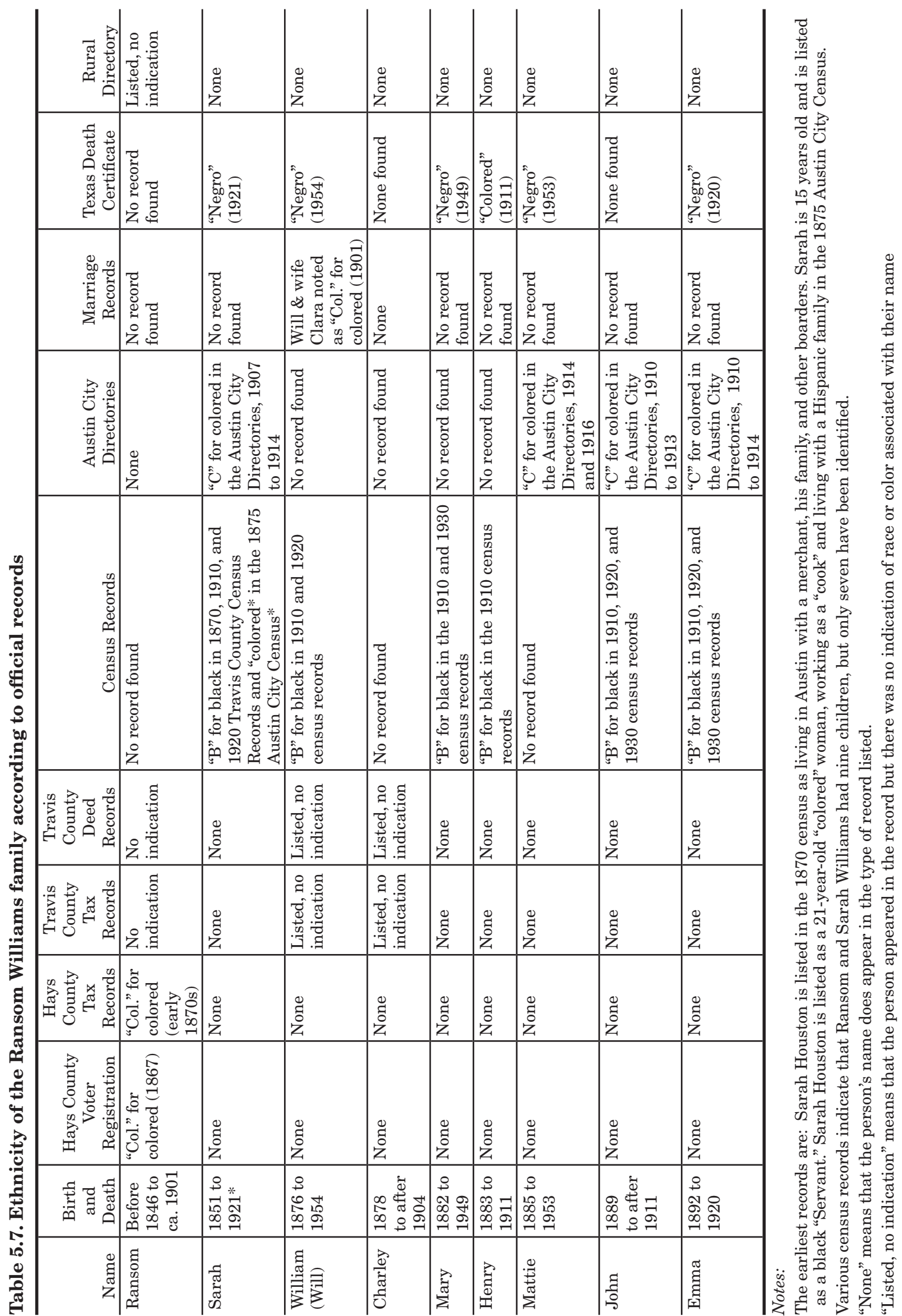


Emma Bunton, in Austin. Emma Bunton was the daughter of Elizabeth (aka Lizzie) and Jack Friend, and wife of Tony Bunton. That made her the daughter-in-law of Dave and Mary Bunton, former slaves of James M. Bunton and among the original settlers of the Antioch Colony. The Friends were also former slaves who lived on the periphery of the Antioch community. If Mary was Emma's cousin, one of her parents was a blood relative of the Friends or Buntons.

In any case, it is highly likely the Williams family associated with residents in the Antioch Colony for school, church, and social reasons, as well as support in times of need. In the first years on Bear Creek, the Antioch Colony was the only African American community accessible to the Williams family. Because they were isolated by their race and may have had familial ties to Antioch, Williams and his family may have traveled south about $41 / 2$ miles to the community for fellowship and worship during their earliest years on Bear Creek. It is unlikely that they regularly traveled the 10 or 12 miles north to Austin, where several freedmen communities had sprung up after the war. While most of these freedmen colonies, such as Wheatville and Clarksville, lay on the periphery of the city, a few small settlements emerged just south of the Colorado River, including one at Barton Creek and one on Williamson Creek, but these, too, were quite a distance from Bear Creek. Within a few years of Ransom Williams's arrival on Bear Creek, however, several other African Americans moved to the Walker Wilson League and the S. F. Slaughter League, just east of the Williamses' McGehee League.

By the time the first of the Williams children were of school age, beginning about 1882, the Rose Colony School for African American children had been in operation for nearly seven years. From deed records, it appears to have been about 2 miles to the east of the farm. As shown in Figure 5.6, Manchaca had three segregated schools for the Colored, White, and Mexican students. ${ }^{64}$ The Williams children could have attended school there. It is also possible that they attended classes at the Antioch school, which lay about 5 miles south of their home. Established in 1874, it was the closest

${ }^{64} \mathrm{~A}$ "Manchaca School" is also shown on a 1914 school district map, but this probably depicts only the white school (Travis County School District 1914).
African American school to the Bear Creek community before the Rose Colony School was built about 1877 .

\section{ROSE COLONY}

Ransom Williams and his family may have been the only African Americans who lived in the McGehee League the 1870s, but others settled in the adjacent Walker Wilson League and nearby S. F. Slaughter League in the 1870 s and 1880 s (Figure 5.7; see Figure 5.6). By 1878, the freedmen population in far-south Travis County was large enough to support a community school (Travis County Deed Record 41:528). ${ }^{65}$ Residents chose trustees Chatham Perry, John Scroggins, and Frank Slaughter to purchase land for the school.

Originally called Union Grove, it was recorded as Rose Colony School in 1880 in the Travis County School District registers. The school and the community may have been named for John Rose, an early farmer in the area. ${ }^{66}$ The exact location of the school is unknown, but the grounds occupied an acre of land in the S. F. Slaughter League, just east of present Manchaca (see Figure 5.6). The school was likely the focal point of African American life in southern Travis County, drawing students from throughout County Precinct 5, in the Bear Creek, Onion Creek, and Slaughter Creek watersheds. For the parents, few of whom could read or write, education represented an opportunity for their children to get ahead in the world. Participation in school affairs also gave adults the chance to serve their own community after a lifetime of working for others. John Rose, John Coats, Chatham Perry, and Gil Stevenson, all African Americans, were the most active trustees in the nineteenth century. Their duties included buying land, constructing the school, hiring teachers, and providing desks, books, and other educational materials (Travis County School District 1879-1888).

\footnotetext{
${ }^{65}$ The deed granted the land for "Union Grove School" in 1878 (Travis County Deed Record 41:528).

${ }^{66}$ Several African Americans with the surname "Rose" lived in the Onion Creek area of southeast Travis County after the Civil War, including John Rose (U.S. Bureau of the Census, Hays County 1870). John Rose moved his family to the Bear Creek area about 1877 (Travis County Deed Record 40:87).
} 


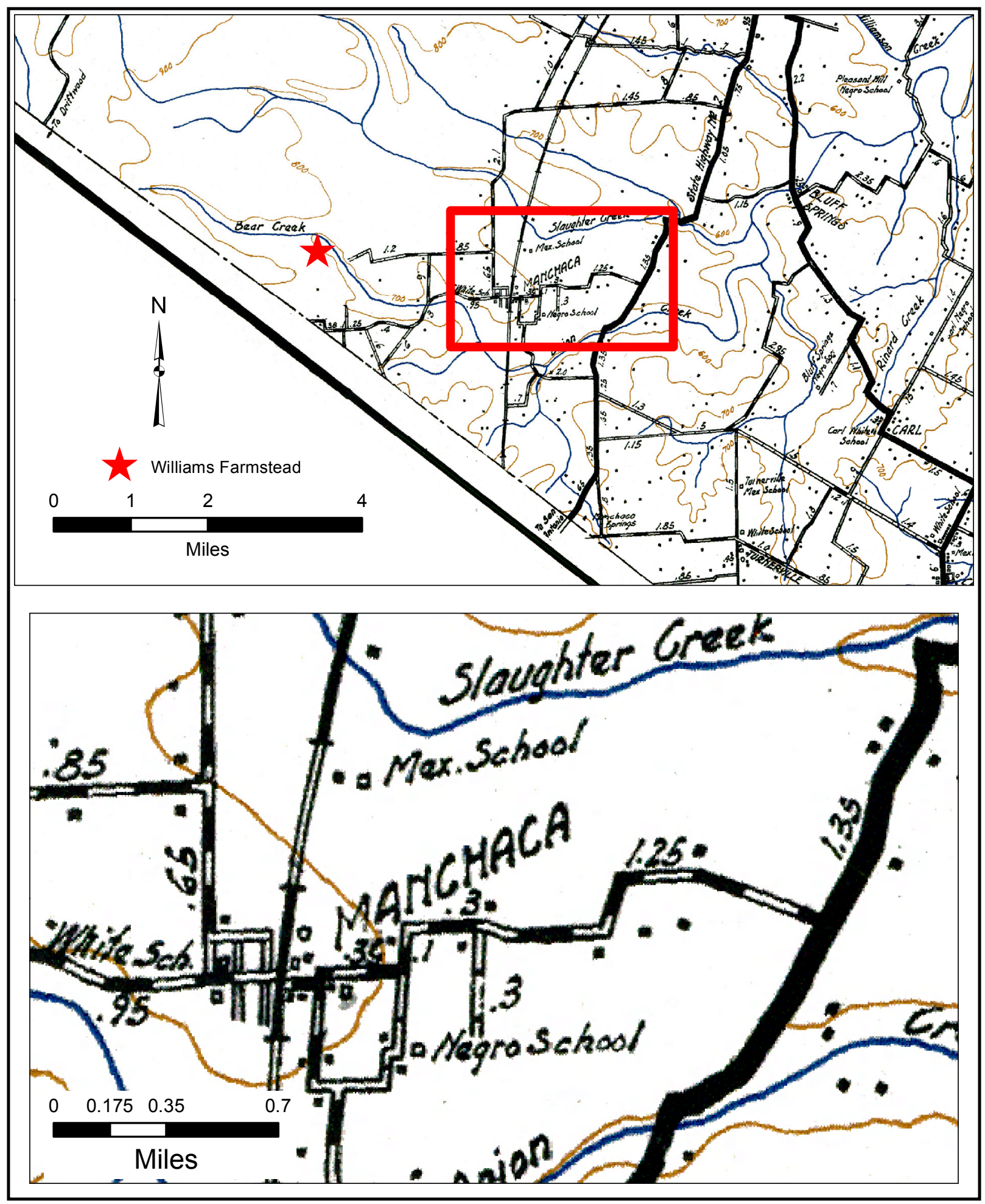

Figure 5.6. Travis County road map, 1932, showing locations of three schools at Manchaca. The schools are labeled as "White," "Negro," and "Mex." The Negro school east of town is probably the Rose Colony School. Base map is from Travis County Engineer Department (1932). 


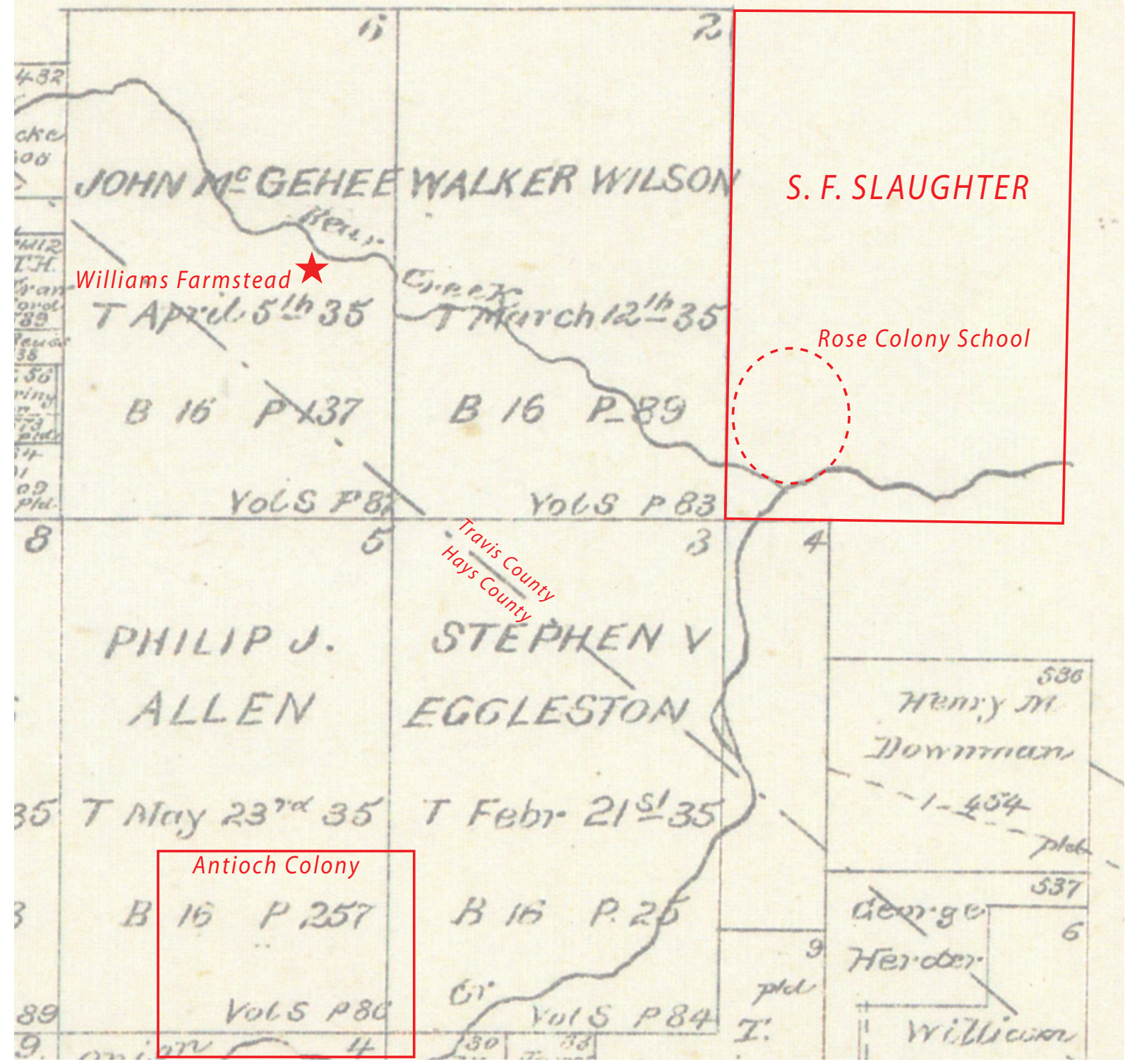

Figure 5.7. Land map of Hays County, 1880, showing relative locations of the Williams farmstead, Antioch Colony, and the Rose Colony School. The latter is an approximate location, and each league is approximately 2 miles wide. Base map is from Walsh (1880).

How or why the community was identified by the Travis County School District as a "colony" is unknown. The word "colony" was a term commonly used to identify freedmen communities, possibly because they were tight-knit groups of people with similar histories who settled adjacent tracts of land and followed a common purpose. Some freedmen established all-black towns in Nebraska and Oklahoma to escape discrimination and harassment. Others formed communities on the periphery of cities to take advantage of job opportunities and amenities in town but live at a safe distance from potential trouble. Clarksville, Wheatville, and Gregory 
Town formed in this manner around Austin (Mears 2009). Other freedmen enclaves like Antioch Colony in northern Hays County and Rose Colony in southern Travis County, were self-sustaining agricultural communities that encouraged landownership, religious assembly, and education. When applied to African Americans in the postwar era, the term "colony" most often referred to an area exclusively occupied by freed slaves and their descendants. This was not entirely true of Rose Colony, however, as many white families owned land between and among the freedmen farms (U.S. Bureau of the Census, Travis County 1880).

Unlike the Antioch Colony, the families who lived in Rose Colony did not appear inter-connected by blood or marriage. Rather, they seemed to be unrelated families drawn to the region by the availability of unbroken upland tracts, and therefore relatively inexpensive, land. Where most of the Antioch adults came from the upper South states of Kentucky, Tennessee, and Missouri, and had lived together for many years in the Mountain City region of Hays County, the Rose Colony residents came from throughout the South. They do not appear to have a common history before moving to southern Travis County. While households didn't seem to have familial ties, they shared common values: most were farmers, many owned their own land, their children attended the same school, and they probably worshipped together. Rose Colony consisted almost entirely of nuclear families with a mother, father, children, and occasionally another relative such as a mother-in-law.

\section{Freedmen Families of Rose Colony}

\section{Ransom Williams}

Ransom Williams was the first known freedman to buy and occupy land in the McGehee League. He and his wife, Sarah, lived a fairly isolated existence for several years following their 1871 land purchase. His farm predates the formation of Rose Colony as a defined community by about half a decade. Williams's first neighbors were a handful of white farmers who plucked up the undeveloped parcels around him, south of Bear Creek. Although he may have originally been associated with the Antioch Colony that formed in northern Hays County by the late 1860 s, Williams and his wife found themselves in the midst of a sparsely developed agricultural community of white pioneers. When other freedmen started moving into the nearby Walker Wilson and S. F. Slaughter leagues in the 1870s (Travis County Deed Records various dates), Williams and his family likely associated with them.

Even before Williams arrived in the McGehee League, several other freedmen had purchased farmland north and east of his parcel below Bear Creek. By the mid- to late 1870 s, a community of black farmers began to coalesce between Bear Creek and Slaughter Creek. Among the pioneers were Ben Van Zandt, Chatham Perry, Richard Washington, and John Rose.

\section{Ben Van Zandt}

Ben Van Zandt was one of the first African American landowners in south Travis County. On January 5, 1870, he purchased 30 acres of land out of the S. F. Slaughter League for $\$ 180.00$ (Travis County Deed Record T:89-90). The land lay on Slaughter Creek just east of the Walker Wilson survey line. ${ }^{67}$ Van Zandt was designated as a "Freedman" in the deed from Nichols. He was a native of Tennessee, born about 1835, and probably came to Texas with his master before the Civil War, according to the ages of his children. Little is known about Van Zandt except that he sold the land to trustees for the Union Grove School in 1878 (Rose Colony School, 1878) and for the adjacent A.M.E. Church in 1889 (Travis County Deed Record 104:137).

\section{Chatham Perry}

Chatham Perry was the first to arrive after Williams. Perry was born in Texas in 1835 . He was probably a slave of Cicero Rufus (C. R.) Perry, who moved from Alabama to Texas in 1832, at the age of thirteen and fought in the War for Texas Independence (Stovall 1986:341). According to the 1850 Bastrop County Slave Schedule, Cicero R. Perry owned four slaves, three of them mulattos (U.S. Bureau of the Census, Bastrop County,

\footnotetext{
${ }^{67}$ The deed record states that Van Zandt's land lay north of Jackson Hammett's land; Hammett had a larger farm that lay in both the Slaughter and Walker Wilson leagues (TCDR T89-90; TCDR R:494).
} 
Slave Schedule, 1850). In 1856, Perry moved to northern Hays County, in the vicinity of Mountain City, where he remained until after the Civil War (Stovall 1986). Chatham Perry probably knew other slaves in the Mountain City area and likely associated with those who later settled the Antioch Colony. It is even possible that Ransom Williams knew him before they both moved to Travis County in the early 1870 s.

Chatham Perry moved to the Bear Creek region in January 1873, when he bought a 40 -acre tract of land for $\$ 75$ in coin and a promissory note for $\$ 168$ in gold. The note was to be paid with 12 percent interest by the following year. The tract was identified in deed records as Lot 9, and according to later maps, it was located in the Walker Wilson League (Travis County Deed Record X:348), between Slaughter Creek and Bear Creek. It lay about a mile northeast of the Ransom Williams farmstead. Perry was about 38 years old, and his wife, Ann, was about 35 when they moved to their property with four daughters and a baby boy. The 1880 census shows that Perry could read and write, an unusual skill for rural freedmen at that time (U.S. Bureau of the Census, Travis County, 1880). It is possible that he learned from his master, but it is more likely that he attended night classes for adults in one of the freedmen schools established by the Freedmen's Bureau during Reconstruction.

Perry became something of an agricultural entrepreneur in the Manchaca area; he bought several other area farms and amassed more than 300 acres of land over the next 20 years. In 1881, right after the International and Great Northern (I \& GN) Railroad was completed from Austin to San Antonio, Perry purchased a town lot in the newly platted city of Manchaca, which lay northeast of the McGehee League (Travis County Deed Record 52:466). Despite his purchase of a town lot, Perry focused most of his efforts on agricultural land. On December 3, 1889, he purchased a 63-acre tract from Travis County Sheriff George Zimpelman, a well-known land dealer of the period. ${ }^{68}$ The tract cost $\$ 725$ and lay adjacent to his original farm on the east. Perry's deed identified him as an F.M.C.-free man of color (Travis County Deed Record 86:638). While

${ }^{68}$ Lot 13 of the Walker Wilson League contained 40 acres, and Lot 16 of the same league contained 23 acres. not universally used in Travis County, F.M.C. (or F.M.O.C.) was a common moniker for African Americans throughout the South.

By 1880 , Perry and his family were well-established on their home farm. At 45, Perry was one of the older African American farmers in the area. His wife kept house for her husband and large family. Nine children, ranging in age from 2 to 19, lived at home. The two oldest girls, Mary and Margaret, were 19 and 16, respectively. Neither could read or write, possibly because school had not been available to them as children. Sisters Ida and Jane Perry, who were 11 and 9, were attending school at the time of the census (U.S. Bureau of the Census, Travis County, 1880). They were probably among the 42 students then enrolled at the Rose Colony School. As they grew older, the younger five children likely joined their sisters at the schoolhouse.

\section{Richard Washington}

Two years after the Perrys moved to the area, another African American, Richard Washington, formerly Richard Luckett, bought 40 acres in the Walker Wilson League (Travis County Deed Record X:422). His property lay near Chatham Perry's and within walking distance of Ransom Williams. According to the 1880 census, Washington was a middle-aged farmer who was born in Kentucky. Along with Chatham Perry, he was one of the few Rose Colony citizens who could read and write. His wife, Caroline, 35, was also from Kentucky. They had probably come to Texas with their masters before the Civil War and may have been part of the Bunton settlement of Mountain City. In fact, Richard may have had a brother named George Washington in Mountain City. They were both born in Kentucky and brought to Hays County before the Civil War. George named one of his sons Richard, possibly in honor of his brother. Richard Washington had two children, John 14, and Ida, 12, both of whom were born in Texas. Both attended school. Like Williams and Perry, Washington was a farmer (U.S. Bureau of the Census, Travis County, 1880).

Ransom Williams, Chatham Perry, and Richard Washington appear to have been the first African American landowners in the McGehee and adjacent Walker Wilson leagues. Although separated by vacant land, Bear Creek, and white-owned farms, the Williams, 
Washington, and Perry families may have felt some kinship and support in the presence of other African American families in this fairly isolated, rural landscape.

\section{John Rose}

John Rose lived to the east of Williams, Perry, and Washington, but he was influential in establishing the African American community in southern Travis County. Born in Mississippi, Rose likely came to Texas with his master before the Civil War. Shortly after emancipation, he married Jane, a young woman from Tennessee. The couple may have lived with or near some other Rose families in the vicinity of Onion Creek, in the southeast part of the county, before purchasing 60 acres of land in the Slaughter League in 1877 (Travis County Deed Record 40:87). The farm lay just east of the Wilson/ Slaughter league boundary line and may have had a house, barn, outbuildings, and land already in cultivation because it cost $\$ 1,000$, a princely sum for land in the area (Travis County Deed Record 40:87). A house was mentioned in the property description but it is not clear whether it lay on the parcel or across from it. Like Chatham Perry, Rose and his wife Jane increased their acreage over the years, eventually owning nearly 200 acres of land in the Slaughter and Wilson leagues. ${ }^{69}$ Rose may have been the source of the name "Rose Colony" attributed to the African American community. He served as a Rose Colony school trustee in the late 1870 s and early 1880s (Anonymous 1884; Travis County Judge 1884). In 1880, John and Jane Rose had three children; their 11-year old son, Houston, attended school, no doubt at the Rose Colony School.

\section{Later Families}

Other African American families followed Ransom Williams, Chatham Perry, and John

\footnotetext{
${ }^{69}$ Rose may have owned other parcels; several deed records are illegible. In 1877, Rose purchased 60 acres of land in the southern part of the Slaughter League. In 1882, he bought Lots 6 and 7 for a total of 80 acres out of the Walker Wilson League. The property extended from Slaughter Creek to the center of the newly built International and Great Northern Railroad track (TCDR 53 263). Two years later, Rose bought adjoining Lots 14 and 15, totaling 47 acres in the Walker Wilson League. These lots abutted Rose's existing Lots 6 and 7 (TCDR 72:300; 60:344). By 1884, Rose owned 187 acres of land.
}

Rose to Bear Creek in the late 1870s and throughout the $1880 \mathrm{~s}$. By the 1880 census, an African American enclave existed near the juncture of Bear Creek and the Manchaca Road, in the vicinity of the Townsley Store School. They included neighbors Rafe Alexander, John Coats, and David Phenig (also known as Pfinney). According to their relative positions to one another in the 1880 census records, all lived close to Ransom Williams, near the boundary line between the McGehee and Walker Wilson leagues (U.S. Bureau of the Census, Travis County, 1880).

Most of the adults in the Bear Creek area were born in various parts of the South but had lived in Texas for 10 years or more according to their children's ages in the 1880 census. At 25 and 18, respectively, John Coats and his wife Catherine were among the youngest couples in the area. The couple married in Travis County in December $1877 .{ }^{70}$ Coats was born in Virginia and worked as a laborer in 1880 . He and Catherine had a two-year-old daughter named Rilla. Rafe Alexander, 35, was from Virginia and also worked as a laborer. He and his wife, Melinda, had three children in school and a two-year-old at home. Daniel Pfinney, 45, was a farmer from Arkansas. He and his wife, Eliza, had a 13-yearold son, Louis, who attended school (U.S. Bureau of the Census, Travis County, 1880). Ransom and Sarah Williams's children were too young to attend school by the 1880 census, but the oldest surely went to Rose Colony School in the following decade.

About 1884, John Hughs and his wife Betsy moved to Lot 20 in the McGehee League. When Bear Creek Road was carved through the McGehee League, the Hughs' 20-acre farm lot fronted the road about a half-mile southeast of Ransom Williams's house (Figure 5.8). John, a native of Kentucky, lived in Mountain City in 1870. He was a neighbor of Elias Bunton, one of the founders of the Antioch Colony, and probably knew Ransom Williams before he moved to the McGehee League. Hughs may have been a slave of the white John Hugh(e)s in Mountain City, who was also from Kentucky (U.S. Bureau of the Census, Hays County, 1870). Until John Hughs

\footnotetext{
${ }^{70}$ Catherine was identified as Kittie Hawes with no race listed. John Coats was identified as "col" for "colored." It was common to list only one member of an African American couple by race.
} 


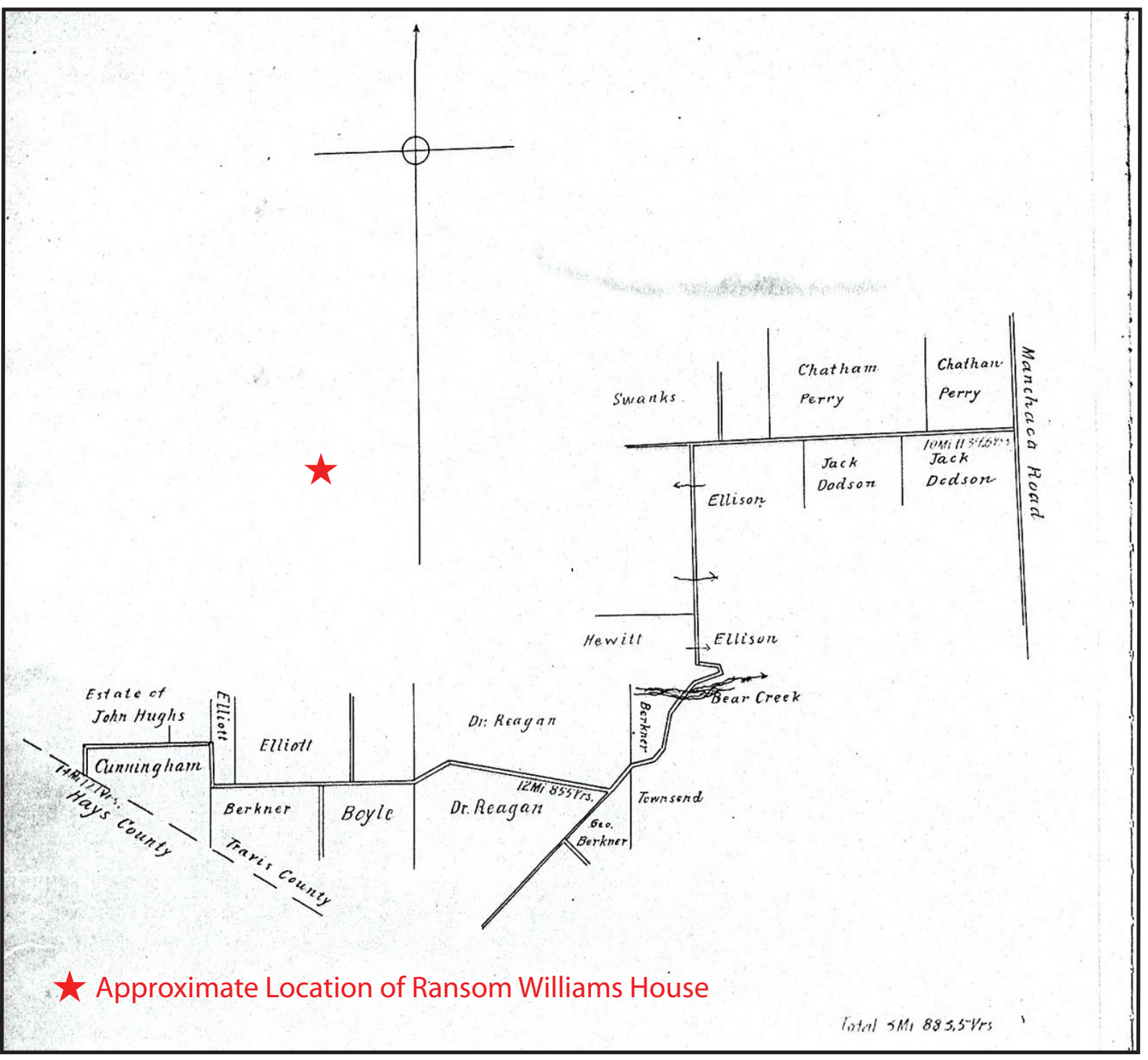

Figure 5.8. Travis County survey map of Bear Creek Road, ca. 1898-1902, showing the "Estate of John Hughs" along the Travis-Hays county line. The approximate location of the Ransom Williams farmhouse has been added. Bear Creek Road was later renamed Bliss Spillar Road. Base map is Wallace (1892-1902).

moved to the area in 1884, Williams and his family were the only African Americans living on the south side of Bear Creek.

\section{Characteristics of the Bear Creek/Rose Colony Community}

African American and white families in the Bear Creek area and Rose Colony shared many traits in the early 1880s. Most lived in nuclear families headed by two parents who were in their
30 s or 40 s. Couples married 10 years or more typically had four to seven children. In-laws and grandchildren commonly lived in the household as well. Based on the numbers of farmers vs. farm laborers, about half of African American and white heads of household appeared to own their own farms. ${ }^{71}$ Adults of both races typically hailed from elsewhere in the South and had

\footnotetext{
${ }^{71} \mathrm{~A}$ survey of deed records for these areas tends to corroborate this claim.
} 
moved to Texas before the Civil War. Most of the children in this vicinity, however, were Texas natives. Southern heritage was so pervasive that European and Mexican settlers were more common than Northerners. Regardless of race or nationality, adult men in southern Travis County generally worked as farmers or farm laborers, and their wives kept house. Some single women, often widows, were occupied as laundresses or cooks, especially in areas along the railroad then being built through southern Travis County. In nearly all households in the Bear Creek area in 1880-African American and white families alike-older children worked on their parents' farms and attended school (U.S. Bureau of the Census, Travis County, 1880).

Changes in African American life since the 1870 census included a rise in landownership, the formation of nuclear family groups, and a drop in women and children working as farm laborers. In 1880 there was almost universal school attendance for children between the ages of about 9 and 15. In the previous census, African American children in rural areas typically did not attend school, likely because there were few schools available to them.

Ransom Williams and his family remained the sole freedmen in the McGehee League in 1880. When John Hughs and his wife, Betsy, bought the 20 -acre Lot 20 in the McGehee League in about 1884, he had African American neighbors for the first time since moving to the area (Travis County tax rolls, 1884). Regardless of their small numbers in the McGehee League, African Americans in the Walker Wilson and Slaughter leagues made noticeable inroads in the larger community, now centered on the railroad town of Manchaca. The town drew a number of African Americans who worked at businesses and as laborers.

\section{Rose Colony School}

John Rose may have been instrumental in bringing the African American school to the area. ${ }^{72}$ Much of the impetus for freedmen schools started in the five years after emancipation when the Freedmen's Bureau set about estab-

${ }^{72}$ Many members of the Rose family were enumerated in the 1870 census from the Onion Creek postal district. This area lay east of the Bear Creek enclave, close to the McKinney and Sneed plantations. lishing schools for both children and adults who never had the opportunity to learn. The agency built and supplied their own schools but also supported self-initiated schools established by existing enclaves of freedmen. Many of the schools were church-sponsored, and a frame building typically served as a classroom for children by day, for adults by night, and for church services on Sunday. The Freedmen's Bureau generally built schools in towns or communities with large numbers of ex-slaves, but their example may have fostered the proliferation of schools in rural communities as well (Mears 2009:25, 113).

By the time Rose arrived in the area, in November 1877, several African American farmers in the McGehee and Walker Wilson leagues had school-aged children and more were moving to the area. Within a year of Rose's arrival, freedmen families joined together to form a school. In 1878, they selected Chatham Perry, Frank Slaughter, and John Scroggins as trustees of "Union Grove School." As trustees, the men purchased an acre of land out of the Slaughter League for the construction of a schoolhouse. The school's exact location is unknown but it lay on Ben Van Zandt's land east of present Manchaca. It almost certainly was a one-story frame or log building with a gabled roof covered in wood shingles. Most contemporaneous rural schools in Travis County had only one room but the large student population in the Bear Creek area during the mid-to late-1880s may have warranted the addition of a second room. The school likely had a wood-burning stove for heat and possibly double-hung sash windows for ventilation and light. Children shared desks and books and wrote their lessons on slate boards, and the school community was expected to "chip in" to supply firewood, a teacher's desk, and any amenities for their students' education. By the 1880 s, the county contributed to the construction of schools and their upkeep. A 1906 report on the "colored" school at Manchaca described it as a wood building in fair condition. By then, it was more than 25 years old (Texas Department of Education 1906).

In 1880, two years after the deed was filed, Travis County School District records referred to the institution as "Rose Colony School," probably named for John Rose. That year, 42 students attended classes taught by a full-time teacher (Travis County School District 1879-1888). By that time, more African American families had 
moved to the Bear Creek area, and scores of children attended Rose Colony School. Mary Mason, a 21-year-old mulatto woman, was employed as the school's only teacher that year. The county paid her salary of $\$ 25.00$ per month, which was about on par with other rural teachers at the time (Travis County School District 18791888; U.S. Bureau of the Census, Travis County, 1880). She boarded with the Allen family who lived near Ransom Williams (U.S. Bureau of the Census, Travis County, 1880). Miss Mason was replaced by a series of male teachers, all of whom made more money than she had. For most of the 1880s, W. R. Lewis, an Ohio-born mulatto man, taught classes at the Rose Colony school. Unlike Miss Mason, Lewis and his wife, Mary, lived in Central Austin, on Lavaca Street (U.S. Bureau of the Census, Travis County, 1880 and 1900). Lewis would have had to cross the Colorado River on a ferry and then travel by horse or buggy about 12 miles south to teach at Rose Colony School each day. In the mid-1880s, the school had grown so large that a second teacher appeared on the payroll, at least part time (Travis County School District 1879-1888).

Throughout the 1880 s, the school population of Rose Colony grew significantly. Attendance dropped slightly to 37 pupils in 1882 , rebounded to 74 students in 1884, and jumped into the 90 s by 1886 , reaching a high of 98 in 1887. Ransom and Sarah Williams's children were sure to have been among these students. Trustees rotated on a yearly basis and included Chatham Perry, Gil Stevenson, Tony Wallace, Daniel Tinnen, John Coats, John Hall, Charlie Douglas, John Rose, and A. W. Peoples. These men would have been considered honest and thoughtful guardians of the community school. All but Tinnen and Douglas lived in the area as early as 1880 . While Ransom Williams was one of the first, if not the first, African Americans in the district, he apparently did not participate in the school operations.

Rose Colony School was well attended by the African American children living near Ransom Williams. His close neighbors in 1880 included Chatham Perry, Richard Washington, and Rafe Alexander, each of whom had two children in school, and Daniel Phenig and John Rose, whose sons attended school. Most of the African American farmers who lived within a couple of miles of Rose Colony School sent their children to school when they were eight or nine. They generally completed their educations by the age of fifteen or sixteen. Successful graduates could read a newspaper, write a letter, add and subtract, and recite selected poetry and prose. They might also learn a little geography and American history. Farmers who owned their own land almost universally sent their children to school, while farmhands or laborers were more apt to keep their children home, probably to help in the fields. Many African American adults took night school to gain basic reading skills after emancipation, but it is not known if such classes were available to families in this area. According to the 1880 census, few African American adults could read and write in rural Travis County, but most of their children attended three to six years at the Rose Colony School and gained a basic education that would serve them well in life (U.S. Bureau of the Census, Travis County, 1880).

From twentieth-century census records, we know that at least four of Ransom and Sarah Williams's children (Will, Mary, John, and Emma) learned to read and write. Their oldest son, William, was probably about eight or nine when he joined the students at Rose Colony School in 1884 or $1885 .{ }^{73}$ William's younger siblings, Charley, Mary, Henry, Mattie, John, and Emma, likely followed their older brother to the community school in the 1880 s and 1890 s. It is also possibly that they traveled to Antioch Colony to attend school, though it would have been several miles farther away and would have cost their parents three or four dollars per child to transfer into Hays County. The Williamses' neighbor, John Wilkins, spent the extra money to send his children to Elm Grove School in northern Hays County rather than have them attend the new Manchaca School (Travis County School District 1879-1888).

\section{African Methodist Episcopal Church}

Schools and churches often define communities. It is not known whether the African American community established a church in the early years, but small prayer groups probably met in private homes with summer

\footnotetext{
${ }^{73}$ By that time, the town of Manchaca had begun to take shape. Rose Colony School served as the Manchaca "colored" school (Travis County school registers, 1877-1888).
} 
church services held under brush arbors. The first known church building in the Rose Colony area was the African Methodist Episcopal (AME) Church. On September 17, 1889, Ben Van Zandt sold a half acre of land to church trustees James Haswell, Jack Dodson, and Robert Green to build an African Methodist Church next to the Rose Colony School (Travis County Deed Record 104:189). Haswell, Dodson, and Green represent the growth of the African American farming community in the Manchaca area. The addition of more freedmen and an AME church helped strengthen the common identity of farmers recently released from bondage. Rose Colony, with its school and church, may have supplanted Antioch Colony as the base community for Ransom Williams and his family by the 1880 s.

\section{A Case Study: The Dodson Family in Slavery and Freedom}

One of the later families who came to Rose Colony was that of Jack Dodson and his wife, Mary. They established a farm along Manchaca Road in the $1880 \mathrm{~s}$, and Mary remained in the house until at least 1937. The Dodsons were a large, extended family who lived next to Chatham Perry, one of the colony's founders. Jack Dodson participated in community matters and served as a trustee for the construction of the AME church in the Manchaca area. By the 1930s, Mary was a widow who still lived on the family farm. In 1937, as part of the Slave Narrative project, ${ }^{74}$ Alfred Menn found Mary at her farm, where she recounted her childhood as a slave and her life after emancipation. Much of the Dodson history that follows is taken from Mary Dodson's slave narrative (Menn 1937a).

Mary recalled that she was born May 1 , 1848 , on the Jim (James W.) Dodson cotton plantation near La Grange, Fayette County. Her mother was Rose Dodson, and she was told that her father was a white man named Lige Higgins (Menn 1937a). According to the 1860 slave schedule for Fayette County, James Dodson owned 12 slaves, all listed as "black" in color with the exception of a 15-year-old female who was listed as a mulatto (U.S. Bureau of the Census,

\footnotetext{
${ }^{74}$ In the $1930 \mathrm{~s}$, hundreds of interviewers employed under the Works Progress Administration (WPA) recorded the recollections of more than 1,000 ex-slaves to preserve their memories before the generation passed.
}

Fayette County, Slave Schedule, 1860). This could have been Mary, since she was listed as a mulatto in the 1880 census. ${ }^{75}$ The slave schedule shows that Dodson owned two adult men over the age of 40 and two 24-year-old women. The rest of his slaves were children (U.S. Bureau of the Census, 1860 Slave Schedule, M653, Roll 1310 , page 321 ). Mary remembered that her mother worked as a cook on some occasions but had to toil in the cotton fields when her help was need. Mary herself cared for her masters' young children (Menn 1937a).

When news of their emancipation arrived, the Dodson slaves didn't know what to do or where to go, according to Mary. They quickly chose to remain on the Dodson place until they brought in the harvest. After that, Dodson apparently couldn't keep them on but gave each of the adults $\$ 17$, which was considered to be generous and was well received. Mary's mother, Rose, married Sam Dodson, another slave on Jim Dodson's place, and the couple set about getting work. Some ex-slaves rented farms, while others hired out their services (Menn 1937a). The Freedmen's Bureau encouraged former slaves to enter into labor contracts as soon as possible to return to normalcy. ${ }^{76}$ Sam and Rose Dodson rented a farm in Fayette County. Mary was a teenager by then, and she worked on her stepfather's farm or hired out to other nearby farmers to supplement the family's income (Menn 1937a).

At the age of 21, Mary wed Jack Dodson, yet another of the Dodson slaves. The young couple worked as hired hands on other farms in Fayette County. They were enumerated in the 1870

\footnotetext{
${ }^{75}$ Census records for slaves and freedmen are rife with errors. The two-year age discrepancy between the 15-year old mulatto slave girl in 1860 and Mary Dodson, who should have been listed as 12 or 13 at that time, is not uncommon. Ages in slave schedules rarely matched later census records, partly because few slaves knew their exact ages. Also, although Mary was shown as a mulatto in the 1880 census, both she and her husband Jack were listed as "black" in the 1910 and 1920 census, despite the fact that their children were listed as mulattos in those years (U.S. Bureau of the Census, Fayette County, 1880; Travis County, 1910 and 1920).

${ }^{76}$ The Bureau wanted to keep freedmen from "a life of idleness " and ensure crop production. Understandably, many freedmen balked at returning to the fields and expressed their fear of re-enslavement. At the same time, planters were warned to maintain the "fair and just treatment of freedmen" or face arrest and punishment (National Archives and Records Administration 2011).
} 
Fayette County census, which listed her age as 21 and Jack's as 27. The census taker listed their birthplace as Georgia, though Mary indicated that she was born in Texas in later census records. According to the 1870 census, Jack worked as a tenant farmer and Mary as a homemaker. The couple had a three-year-old daughter named Annie and a baby boy named Thomas (U.S. Bureau of the Census, Fayette County, 1870).

After a few years, Mary and Jack Dodson moved to Austin, where Jack ran a horse-drawn delivery wagon. Jack enjoyed city life and working for himself, but the Dodsons had little money for food, rent, or wood. At the same time, their family was increasing in size. To help make ends meet, Mary took in washing. Although Jack was disinclined to leave the city, Mary convinced him to buy land and return to farming, where they could at least grow some of their own food. At first, the family rented a little farm south of Austin, and they struggled to make a living with the help of their landlord. The following year they made a good cotton crop and moved to a farm on Onion Creek (Menn 1937a). The family was in the Onion Creek area in 1880 (U.S. Bureau of the Census, Travis County 1880).

After nearly a decade on Onion Creek, the Dodsons moved to Rose Colony, where they rented a relatively large, 100 -acre farm on Manchaca Road in the 1880s. They were likely living on the rented farm by 1889, when Jack became a trustee for the AME Church. He and two other men assumed responsibility for a half acre of land in the Slaughter League, east of Manchaca. The land, on a tract adjacent to "Union Grove School," was specifically dedicated for the construction of an AME church (Travis County Deed Record 104:137-141).

After several years of renting the farm, Jack and Mary finally saved $\$ 1,000$ in cash for a down payment on the land in 1891. The 115acre farm ${ }^{77}$ cost about $\$ 26$ an acre for a total of $\$ 3,000$ (Menn 1937a), a princely sum for the time and region. The remaining $\$ 2,000$ was to be paid off over time (Travis County Deed Records 113:177), and the couple eventually cleared their note (Menn 1937a). The land lay in the Walker Wilson League, just east of Ransom Williams and directly south of Chatham Perry. Other

${ }^{77}$ Mary Dodson stated that their farm had 100 acres, but the Travis County deed records clearly describe a 115-acre parcel.
African Americans lived in the vicinity, and both school and church were about a mile away.

At 115 acres, the Dodson farm was considerably larger than the early 40 -acre pioneer plots most African Americans purchased just after emancipation. It was two and half times as large as Ransom Williams's 45-acre plot and nearly three times as large as the 28- to-40-acre Bunton farms in Antioch Colony. At the time, however, several freedmen in the area owned considerable farmland, including Chatham Perry, who owned more than 300 acres at one time, and John Rose, who owned some 200 acres of land. Large farms and large families contributed to the household income, and those who could save some extra money often put it into more land. This appears to have been the case with the Dodsons, Perrys, and Roses.

The location of the Dodson farm was also fortuitous. In 1898, the county began improving and realigning the Austin-to-Manchaca Road. When finished, the road ran along the Dodson's eastern boundary, giving the family easy access to Manchaca, about a mile to the west (Menn 1937a). There they could purchase essential goods and ship their crops to market on the railroad. At the same time, the improved road made travel to Austin much easier.

Despite their relatively good fortune, the Dodson children still had to hire out as farm laborers to help with family expenses. Despite their outside work, the children attended school regularly, and though they didn't succeed in teaching their mother to read-she said she was too tired at the end of the day-several of the Dodson girls attended Tillotson College and became teachers (Menn 1937a).

By 1900, Jack and Mary Dodson presided over a large household that included grown children, grandchildren, boarders, daughters-in-law, and a son-in-law. All of the adult Dodson children could read and write, though a son-in-law remained illiterate. Jack Dodson was a farmer who owned his land but mortgaged his farm. His sons worked as farm laborers or laborers. The household was enumerated along with the white Labenski, Elliot, and Cunningham families, all longtime residents of Bear Creek Road in Precinct 5.

Jack Dodson remained on his land until Bright's disease claimed him, about 1925. Mary continued to live on the farm until at least 1937, when Alfred Menn interviewed her for the WPA 
project. At the time, she was about 89 and looking forward to her 90th birthday (Menn 1937a).

\section{Reflections on Rose Colony}

The first African American farmers in the Bear Creek/Rose Colony area were true pioneers. They were newly freed from bondage and somehow managed to buy their own land, albeit in an unsettled wilderness. For the first time, they were able to make life decisions and govern themselves: they married with the assurance that their families would not be sold away; they owned their own land and labor; and they formed their own associations-churches, schools, and fraternal organizations-for inspiration, education, and the betterment of their created community. During the 20 years between Ransom Williams's first farmstead (purchased 1871) and the arrival of the Dodsons (1891), the pioneers of Bear Creek/Rose Colony joined many other rural freedmen who "formed remote, scattered, informal, and unofficial communities in the country" throughout the state by the last years of the nineteenth century (Mears 2009:22; see also Sitton and Conrad 2005). This pioneer generation succeeded in establishing a fledgling community for later African Americans who came to live in south Travis County.

Although Jack and Mary Dodsons were themselves freedmen, they represented the second generation of African American settlers in the Bear Creek/Rose Colony area. They did not have to break ground in an almost unpopulated wilderness but assumed a working farm. They probably moved into an existing farmhouse, and their children attended an established school. The town of Manchaca, formed in 1881 after the arrival of the railroad but before the Dodsons arrived, offered dry goods, a blacksmith shop, and other services. They could ship agricultural products from the railroad and even ride the train to Austin or San Antonio. Though they worked hard all their lives and enlisted their children to work outside the home, the Dodsons enjoyed many amenities that were beyond the reach of an earlier generation of wilderness farmers. In this, they represent the passing of the pioneer era.

By the time Mary Dodson told her story to Alfred Menn in 1937, the distinct identity of Rose Colony was diluted somewhat (Menn 1937a). More and more white families had moved to the area, and many African American farmers had moved elsewhere due to boll weevil infestation and a sustained period of drought during the Great Depression. Some of the institutions established by the pioneer generation remained long after the originators passed, however. The Manchaca "colored" school remained a focal point for the African American community. Schools were segregated until 1974. Today, the AME Church is represented by the New Bethel AME Church on Manchaca Road. The congregation dates its origins to Jack Dodson's 1891 African Methodist Episcopal Church.

\section{RANSOM WILLIAMS'S DESCENDANTS}

\section{The End of an Era on Bear Creek}

Ransom Williams and his wife, Sarah, occupied their farm for 30 years, through the end of the nineteenth century. They probably tended to their crops and livestock much as they had when they first moved to Bear Creek. All of their children-Will, Charley, Mary, John, and Emma-attended school, likely the Rose Colony School, ${ }^{78}$ or possibly the Antioch School in northern Hays County. The children were spread out in age; by the time Emma was born, in 1892 or 1893 , the oldest child, Will, was 16 . He was close to finishing his education by then. Charley, John, and Mary were likely in school with Emma soon to follow. Ransom was at least 54 years old and Sarah 49 at the turn of the twentieth century. That next year, however, Ransom Williams died.

The cause and exact date of his death are unknown. The 1901 Travis County Tax Rolls list him as an individual, "Rance Williams," but in 1902 the listing is for the "Ransom Williams Estate," indicating that he had died by then (Figure 5.9). The 1901 Travis County Rural Directory (Von Boeckmann, Schuetz \& Company 1901) does not list Williams, although he had been included in earlier editions of the booklet. From these clues, it seems that Ransom Williams died about 1901, after the tax rolls were prepared but before the directory was published. ${ }^{79}$ No cemetery

\footnotetext{
${ }^{78}$ The school may have been renamed the Manchaca Colored School by then.

${ }^{79}$ Ransom Williams may have been dead as early as 1900 since it was Charley and Will, rather than Ransom, who purchased land adjoining their father's farm in 1900 .
} 


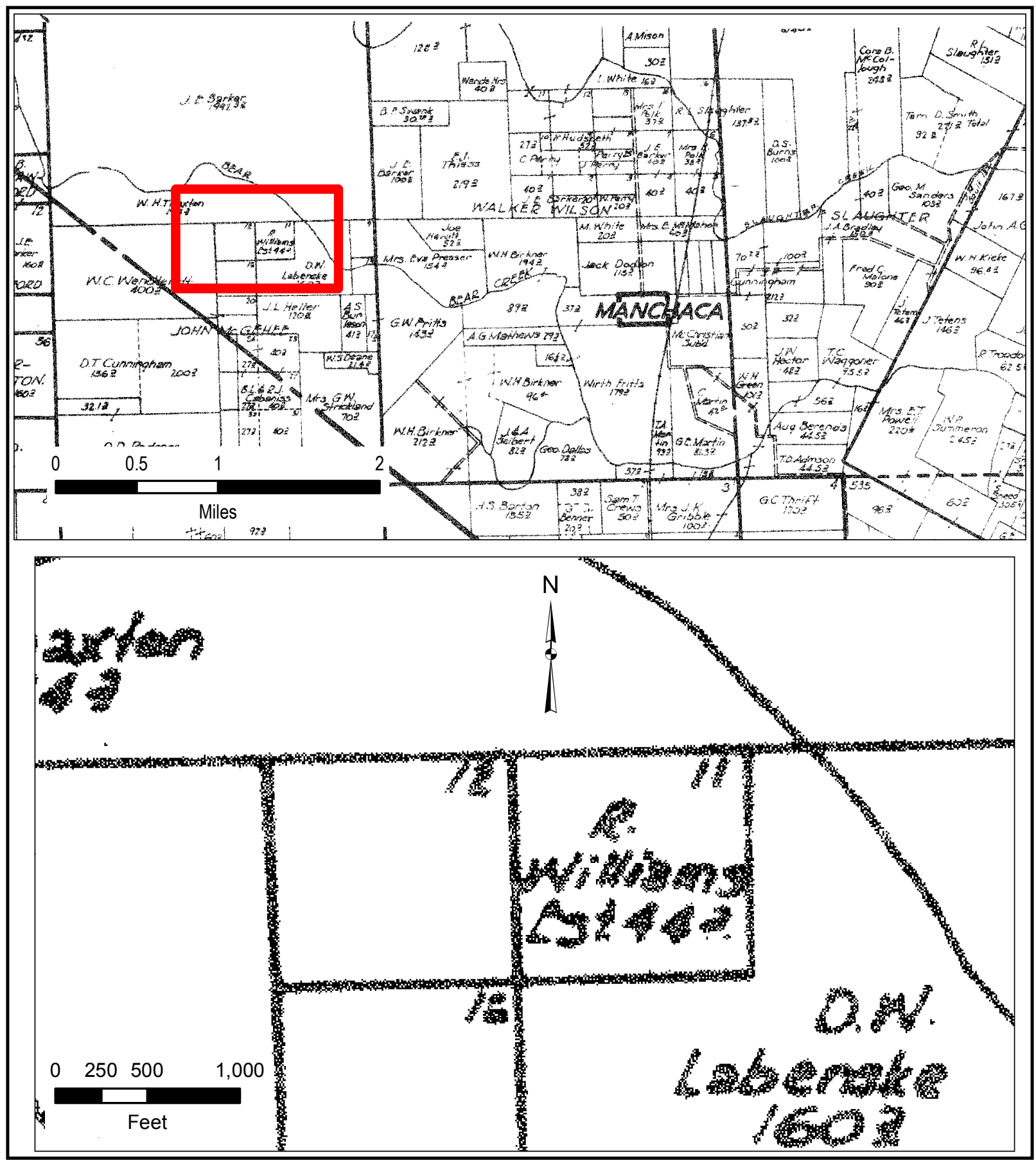

Figure 5.9. A section of a ca. 1925 map showing the subdivision of the John McGehee, Walker Wilson, and Slaughter leagues (Anonymous n.d.). Note that the Williams tract in the McGehee league was owned by the "R. Williams Est." (Estate). Lot 11 is shown as a 40-acre square tract, but Ransom actually owned 45 acres. His sons owned a 12-acre tract immediately to the west, the eastern portion of Lot 12 . 
or death records have been found for Williams. Travis County did not require death certificates until 1903, and his case did not appear in county inquest journals. As a result, we do not know where or how he died, whether it was due to an accident, an illness, or other happenstance. His burial place is also unknown. If he maintained ties to the Antioch Colony, he might have been buried in their community cemetery there, but no headstone exists to mark his grave. Ransom Williams is likely buried in a now-unmarked grave, perhaps at Antioch Cemetery, in a different cemetery in the Manchaca area, or even somewhere on his farmstead. ${ }^{80}$

Williams left some unfinished business for his family to manage. He died intestate, a fact that would later complicate his deed (Travis County Deed Record 507:187). He may have had an interest in land to the west of his Lot 11. On September 17, 1900, Ransom's sons, Charley and Will, bought 12 acres adjacent to the west end on his lot, possibly to prove up the title to land their father was already farming. The brothers owned the small parcel jointly and it remained separate from the homestead in all subsequent transactions (Travis County Deed Record 163:472).

Ransom Williams's death heralded major changes for his family. According to the census, the oldest son, Will, had moved off the home farm by 1900 . The census that year indicates that he boarded with a family in the Creedmoor area, in southeast Travis County (U.S. Bureau of the Census, Travis County, 1900). Jas. (James) Smith owned the farm, and Will may have been a sharecropper or tenant farmer on the property. According to the census record, Will could read and write English. His appearance in the 1900 record was the first time any member of the Ransom Williams family was recorded in the census (U.S. Bureau of the Census, Travis County, 1900).

At that time, Will Williams was a young man of 24 and worked as a farm laborer. Will met Clara Franklin in the Pilot Knob area, close to the Creedmoor community, and in 1901, the couple got married (Figure 5.10). They remained

\footnotetext{
${ }^{80}$ The gravesite of his wife, Sarah Williams, was recently discovered at the San Marcos-Blanco Cemetery in Hays County, and circumstantial evidence suggests that Ransom might be buried there beside her (see the "Postscript" section at the end of this chapter).
}

in Pilot Knob where they farmed and raised a family. About 1935, Will and Clara and their younger children moved to E. 19th Street in East Austin. Their oldest son, Arnold, and his wife, Novella, moved next door (Figure 5.11). Will, Clara, Arnold, and Novella lived in East Austin the rest of their lives, and some of Arnold and Novella's children still live there (Figures 5.12 and 5.13).

Less is known about the rest of the family. When Ransom died in 1901, Sarah was left with at least four of her children at home-Charley was 23 years old, Mary was 19, John was about 12, and Emma was only 9. Twenty-five-year-old Will was engaged and got married that year. It is not known if the others-18-year-old Henry and 16-year-old Mattie-lived at home with their mother and younger siblings. Charley may have become seriously ill around this time. In 1902, he sold his half-interest in the 12-acre parcel to W. H. Thaxton (Travis County Deed Record 174:174). Two years later, he sold his share of the family homestead to his brother Will for $\$ 125.00$ (Travis County Deed Record 238:198). He seemed to be getting his affairs in order for an untimely death, and his name disappeared from public records by 1906 .

Charley's death may have prompted the rest of the family to leave the farm and search for jobs in nearby Austin. By 1906, Sarah, John, and Emma rented a house at 706 E. Eighth Street, but Mary's name is not shown with the family in the 1906 City Directory (Morrison and Fourmy 1906). She may have married young and moved away. Only the last name of her husband, Davis, is known. The name "Mary Davis," a 39-year-old widow, appeared in the 1930 census ${ }^{81}$ as living with her 55-year-old cousin, Emma Bunton, also a widow, in Austin. Emma may have been Tony Bunton's wife, from the Antioch Colony (U.S. Bureau of the Census, Travis County, Texas, 1930).

The 1910 census shows Sarah (age 59) as head of household living on East Eighth Avenue in Austin with John (age 21), Emma (age 18), and two lodgers. Emma and both lodgers worked as laundresses and John worked as a laborer. No occupation was listed for Sarah (U.S. Bureau of the Census, Travis County, Texas, 1910).

\footnotetext{
${ }^{81}$ Mary's age in the 1930 census is incorrect; she should be about 48 years old. She may have intentionally misstated her age.
} 


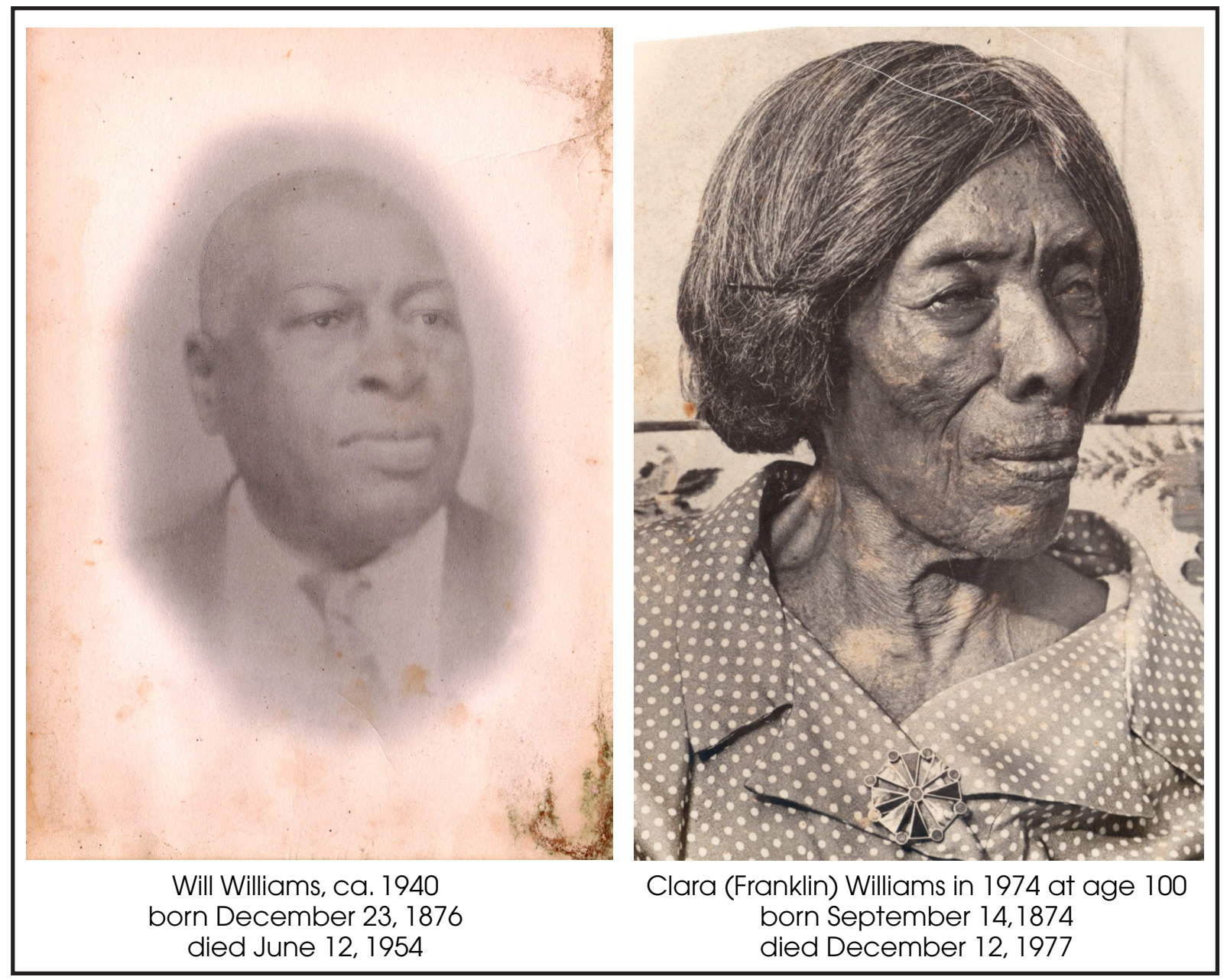

Figure 5.10. Photographs of Will and Clara (Franklin) Williams. The son of Ransom and Sarah Williams, Will (William) Williams was born December 23, 1876, and died June 12, 1954. Photographs courtesy of Mrs. Corrine Harris.

About 1916, Sarah, John, and Emma moved to Dallas. By 1920, they lived with lodger Ezra Smith on Maple Street (U.S. Bureau of the Census, Dallas County, Texas, 1920). Emma and Ezra Smith later married and had two daughters, Leola or Leona and Roberta (Travis County Deed Record 684:114). According to her death certificate, Sarah (Houston) Williams died on March 11, 1921, in San Marcos, Texas. It is not known when she went to San Marcos, but she may have traveled there to spend the last months of her life with relatives. ${ }^{82}$

${ }^{82} \mathrm{As}$ the final editing of this book was in progress, we discovered Sarah Williams's gravesite (see the "Postscript" section at the end of this chapter).

\section{Disposition of the Land: 1934 and 1941}

After Sarah and her children left the 45-acre farm in the McGehee tract about 1904 or 1905 , no one in the family returned to live on the property. They may have leased the land to their neighbors, but there is no evidence that anyone occupied the site again. On September 1, 1905, William and Clara Williams sold half of the 12-acre tract he shared with his brother, Charley, to D. W. Labenski for $\$ 25.00$ (Travis County Deed Record 218:179). In 1934, nearly 30 years later, the couple conveyed their $2 / 5$ interest in the Ransom Williams estate (Lot 11) to Daisy Rowell, daughter of Hugh Cunningham, one of the area's first settlers. Their $2 / 5$ undivided interest in Lot 11 was valued at $\$ 150.00$ at 


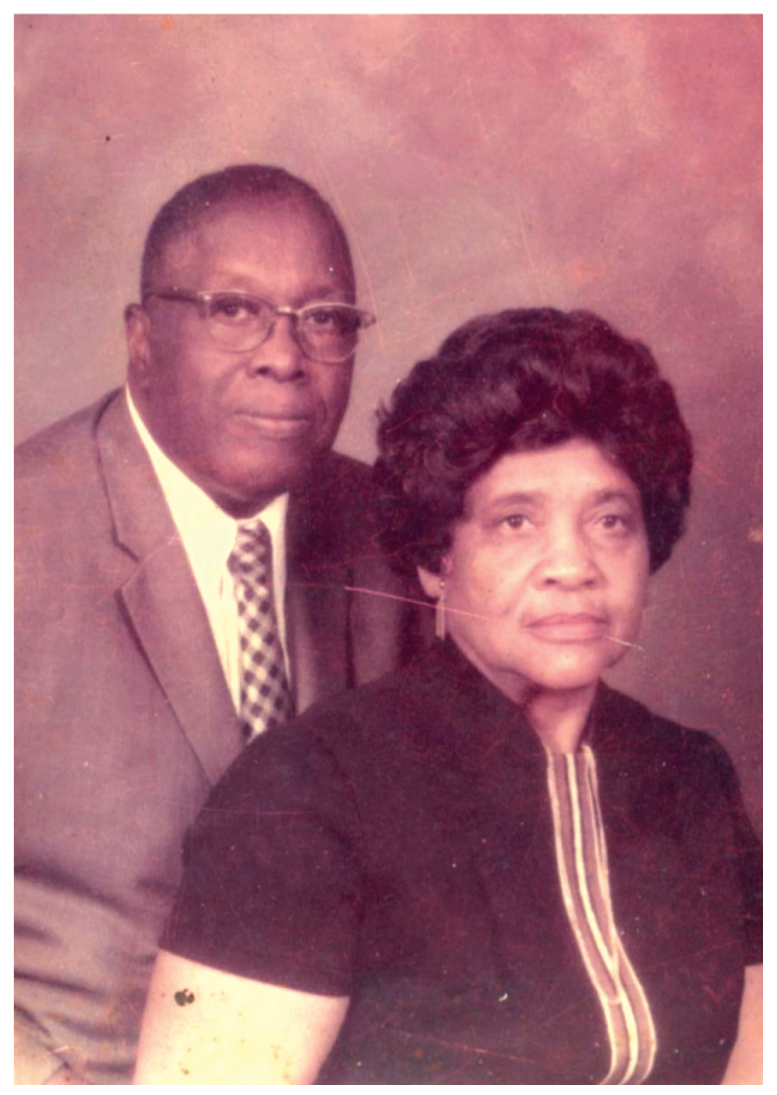

Figure 5.11. Arnold and Novella (Harris) Williams, ca. 1977. The son of Will and Clara Williams, Arnold David Williams was born October 3, 1902, and died December 15, 1981. Photographs courtesy of Mrs. Corrine Harris.

the time (Travis County Deed Record 507:187), but by 1940, when Daisy Rowell Owen died, it was listed in her will as being worth only $\$ 100$ (Travis County Probate Court 96:30).

In 1941, the remaining Williams heirs, John, his sister, Mary Davis, and Emma Williams Smith's daughters, Roberta Hill and Leola Johnson, sold the remaining $3 / 5$ interest in the original farmstead (Travis County Deed Record 684:114). Roberta Hill and Leola Johnson had inherited their mother's share after her death. W. L. Wilkins, Daisy Rowell's nephew, purchased the land, which was adjacent to his own farm. W. L. Wilkins was the grandson of Hugh Cunningham and John Wilkins, two of Ransom Williams's earliest neighbors. While Lot 11 remained in the Williams family for 60 years (from 1871 to 1941), they only occupied it for half that time-the length of Ransom's tenure on the land.

\section{Will and Clara (Franklin) Williams}

The only child of Ransom and Sarah Williams to remain in Travis County was their oldest son, William. ${ }^{83}$ Will Williams married Clara L. Franklin on September 4, 1901. The couple was denoted as "colored" on their marriage license. Will may have met Clara while working as a farm laborer in the Creedmoor area in southeastern Travis County. Clara's parents, Richard and Jane Franklin, and their children lived near Creedmoor in the same justice precinct, according to the 1900 census. Clara was the oldest of 11 children and grew up knowing that hard work was essential to keep a large family clothed and fed (Lowry 1974). The family sharecropped on a farm around the community of Creedmoor. In a 1974 interview, Mrs. Williams recalled that she "did everything a man could do on that farm... I plowed, I picked cotton, I stripped cane and I cut tufts too. I was only 16 years old then and I was the hardest-working kid in the family." The entire family worked the farm six days a week, but on Sunday they all attended a nearby Baptist church (Lowry 1974).

When Clara and Will decided to marry, she told him she liked the "noise" of a big family. Will agreed, and the couple married and settled in "Creedmoor Village." Will and Clara lived on the Buda Route, near Creedmoor, in 1910. They had four children, Arnold, Freddy, Jannie, and Eloise, all under the age of seven. Will was a farmer who rented his land. Arnold (age seven) and Freddy (age six) attended school (U.S. Bureau of the Census, Travis County, Texas, 1910).

By 1920, Will and Clara had added four more children to their family: Mabel, Siola, Willie and Earl C. (for Clara), and by 1930, their oldest son, Arnold, had his own farm and family next to his parents. Both the Arnold Williams and Will Williams families lived on the Colton and Del Valle Road, near Creedmoor, and both owned their own farms (U.S. Bureau of the Census, Travis County, Texas, 1920, 1930).

\footnotetext{
${ }^{83}$ Will's middle name started with an "M" according to the deed from William to Charley (238:198), but relatives have stated that his name was Will "E." Williams.
} 


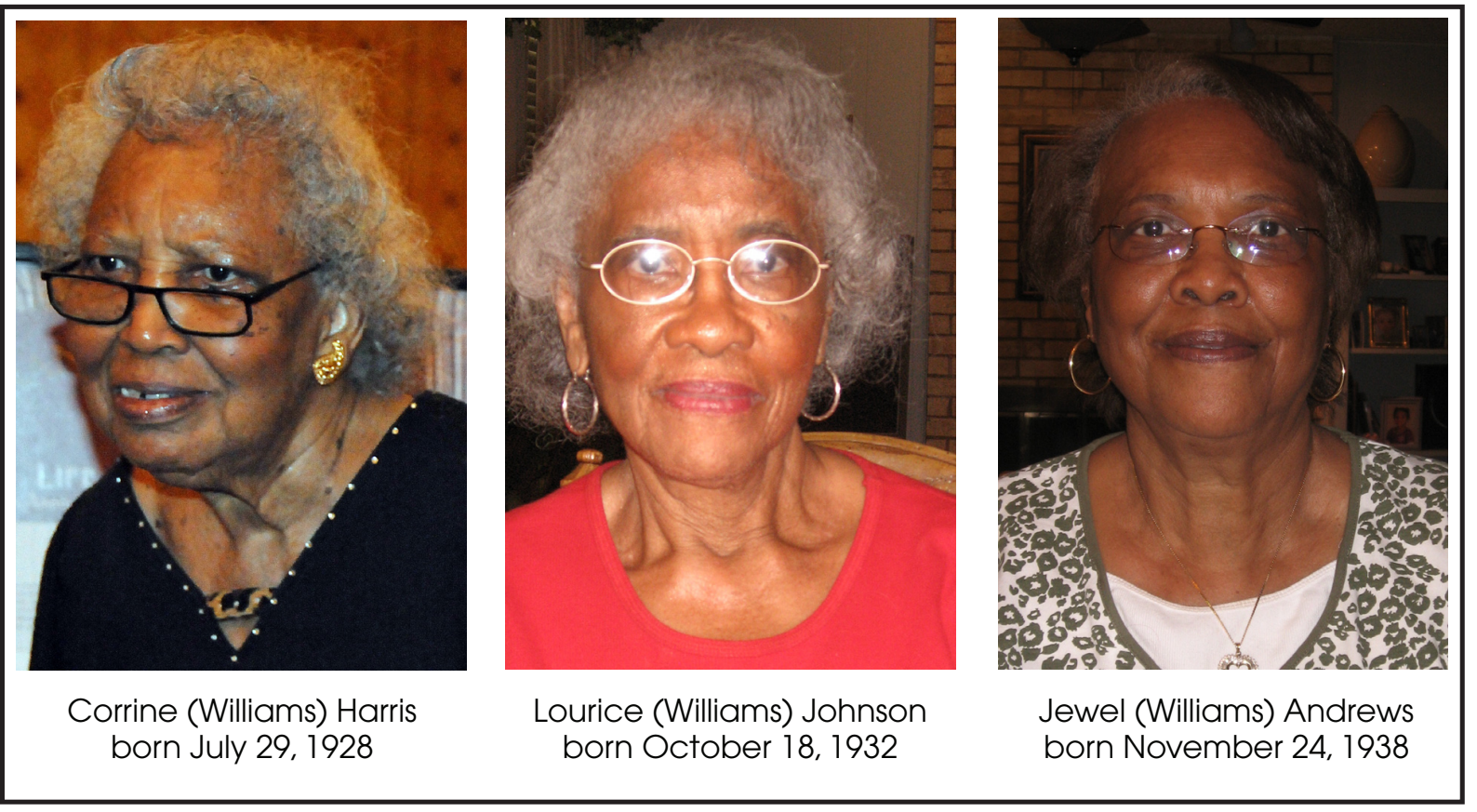

Figure 5.12. Three great-granddaughters of Ransom and Sarah Williams. Photographs taken in 2011 and 2012 by Maria Franklin and Doug Boyd.

About 1935, Will and Clara gave up farming and moved into Austin where they bought a house on E. 19th Street (now Martin Luther King Boulevard, or MLK). The couple lived in the front-gabled frame bungalow at $2929 \mathrm{E}$. MLK for the rest of their lives (Franklin 2012:57). According to their granddaughter, Mrs. Corrine Harris, that part of E. 19th Street had not yet been built up and was considered to be "out in the country" (Harris 2010). Even in town, the couple had cows, chickens, and hogs, which they slaughtered each winter in the yard (Lowry 1974). Clara Williams was a member of Zion Hill Baptist Church (The Tribune, September 19, 1974:1). Will and Clara's Craftsman-style bungalow remains in the family (Harris 2010).

Arnold and his wife Novella followed Will and Clara to Austin later in 1935 and bought a lot next to his parents. Arnold was a good carpenter and built most of the house himself (Harris 2010). They lived at 2727 E. 19th Street (MLK) for the rest of their lives (Morrison \& Fourmy 1935). Their children grew up knowing their grandparents well. Arnold worked at Sam Slaughter's Store for decades. In addition to his employment, Arnold built two small rent houses near the rear of their home to make extra money. The original house is still standing but has been modified significantly by more recent owners (Harris 2010).

Will passed away in 1954 (Certificate of Death, Texas Department of Health). His wife, Clara Franklin Williams, lived to be 103 years old, all of them spent in Travis County. Many friends and family members celebrated her 100th birthday in September 1974. Seven of her eight children were alive. They were Mrs. Jannie E. Carter, Mrs. Clara McCarthy, Arnold Williams, Willie E. Williams, Jr., Mrs. Eloise Sneed, Mrs. Mabel Medlock, and Mrs. Syola Turner (Freddy is not mentioned and may have died before 1974). Clara Williams also had 10 grandchildren and 14 great-grandchildren, some of whom attended college (Anonymous 1974). Two Austin newspapers, the Austin American Statesman (Lowry 1974) and the Tribune (Anonymous 1974), covered the event. Three years later, Clara Williams died at the age of 103 on December 13, 1977. Services were held at David Chapel Baptist Church (Austin American Statesman, December 17, 1977:B8). Will and Clara are buried together in the Evergreen 


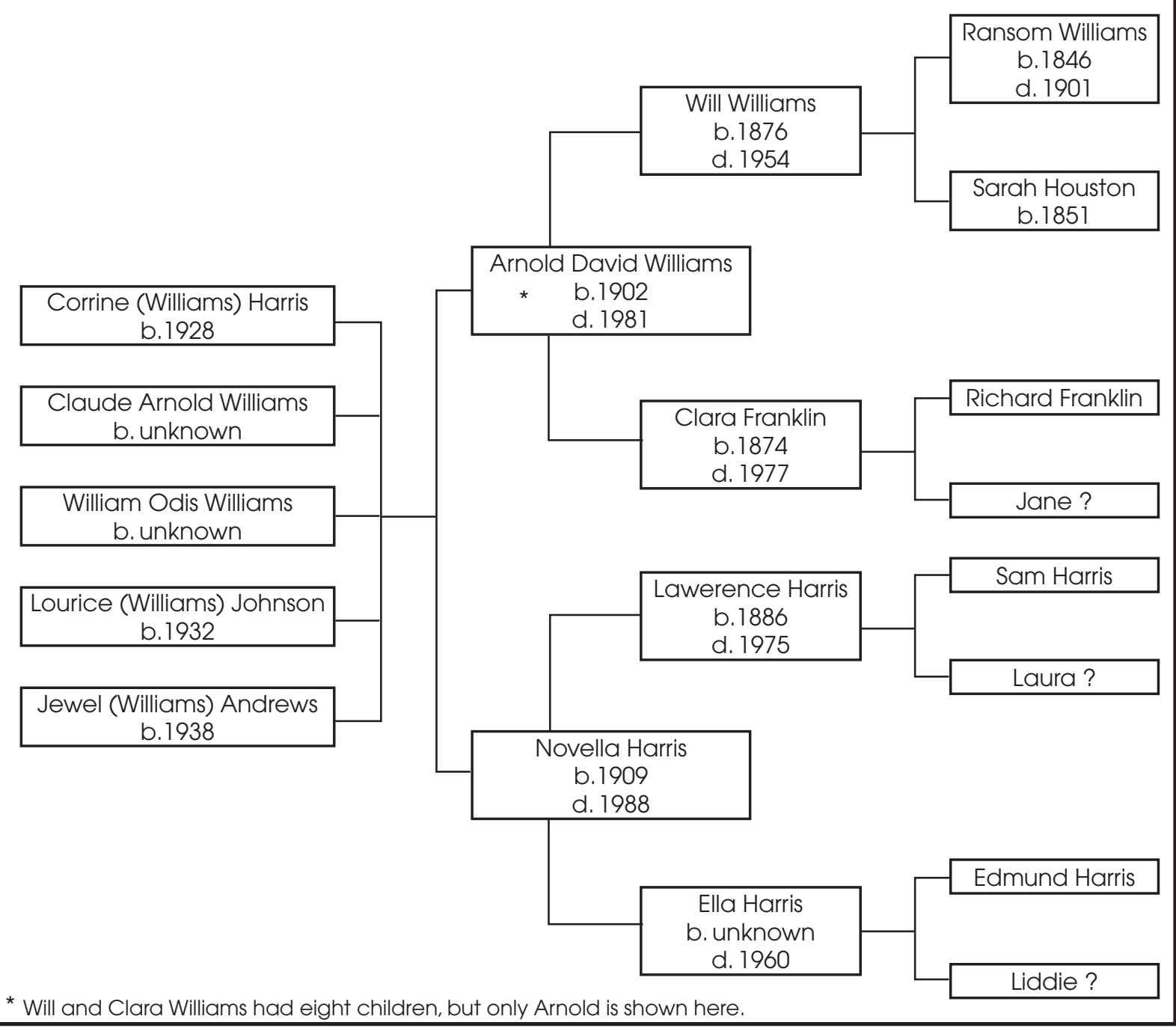

Figure 5.13. Family tree of the three great-granddaughters of Ransom and Sarah Williams.

Cemetery in East Austin (Section CB2, Plot 41; Austin Genealogical Society 2013).

Arnold died on December 15, 1981. Services were held at Ebenezer Baptist Church (Austin American Statesman, December 16, 1981:B17). Arnold's wife, Novella, continued to live in their house until her death on March 5, 1988. Her services were also at Ebenezer Baptist Church (Austin American Statesman, March 8, 1988:B-8). Four of Arnold and Novella's children still live in Austin: Corrine (Williams) Harris, Jewel (Williams) Andrews, Lourice (Williams) Johnson, and Claude Williams, while a fifth, Odis Williams, lives in Houston.

\section{JONESTOWN TRAGEDY: THE RANSOM WILLIAMS CONNECTION}

A tragic postscript to Ransom Williams's history involves the mass murder/suicide of more than 900 men, women, and children at Jonestown, Guyana, on November 18, 1978. Two of Williams's granddaughters, a great-granddaughter, and four of her children, met their deaths that day in a makeshift village founded by cult leader Jim Jones (Department of Religious Studies, San Diego State University 2010). According to family members, Will and 
Clara Williams's daughters Eloise and Syola followed Eloise's daughter Clara to California, where they joined the People's Temple (Franklin 2012:851; Harris 2010).

Although Jim Jones was white, approximately 70 percent of his followers were African Americans who may have been drawn to his church by his teachings on racial equality and social justice. In California, he practiced what he preached; he set up soup kitchens and helped the homeless. He organized a system to care for handicapped and ill church members. He fashioned his sermons after popular African American church practices; they typically lasted several hours, featured rousing call and response sessions, and incorporated music throughout the service. Jones's services would have been familiar to many African American congregants.

Jones's teachings gradually became more socialistic and revolutionary. He appealed to many African Americans who had become disillusioned by the assassination of the Reverend Martin Luther King and a stalled Civil Rights movement. At the same time, his message became more and more apocalyptic in tone. $\mathrm{He}$ preached that the end of the world was imminent but a few places would survive as sanctuaries for his congregation. He looked for a new home for his flock, one that would be safe from outside influences and protect them from nuclear holocaust. In August 1977, a magazine article published the complaints of former members about beatings and drug use in the church. The article hinted of inquiries about his finances and radical message. Jones took the negative publicity and prospect of investigation as a sign that the congregation should relocate to an untainted and isolated place. Later that month, he packed up his congregation and moved to Guyana. There he set out to build a utopian community in the jungles of South America. Hundreds of parishioners left with Jones, and more trickled in over the following year (Department of Religious Studies, San Diego State University 2011).

\section{Ransom Williams's Descendants at Jonestown}

Jim Jones did not attract disaffected youth, like those drawn to Charles Manson. Rather, he recruited entire families to his peculiar brand of Communist dogma and religion. Many of his colonists came with extended families that included parents, grandparents, children, and cousins. Ransom Williams's descendants constituted such an extended family. Clara LaNue Johnson, Williams's great-granddaughter, was reportedly the first member of her family to come under Jones's spell in the early 1970s. She probably influenced her mother, Eloise, and aunt, Syola, to hear Jim Jones, who, by all accounts, was a charismatic and forceful speaker. Clara probably arrived in Guyana with or shortly after Jim Jones, in August 1977. Her mother, four children, and aunt moved to Guyana on August 14, 1977.

Eloise Williams Sneed and Syola Williams Turner were the daughters of Will and Clara Williams and the granddaughters of Ransom and Sarah Williams. The sisters were born near Pilot Knob, a farming region southeast of Austin, Texas. The large, tight-knit family moved to Austin about 1935. Eloise married a man named Sneed, and the couple had a daughter, Clara, in 1932. Eloise worked as a domestic before joining the People's Temple. Syola married a man named Turner and moved to Los Angeles, where she attended beauty school and became a hairdresser. The sisters were probably introduced to the People's Temple by Clara. They were likely attracted to the church because Jones seemed sincere in his beliefs regarding racial and social equality and because of the large number of African Americans members (Garza 2002; Department of Religious Studies, San Diego State University 2011; Washington Review \& Commentary 2008).

Whatever their reasons, Eloise and Syola accompanied Clara's four children, Thomas (age 22), Willa (age 19), Janice (age 18), and Gwendolyn (age 16) to Guyana. ${ }^{84}$ At the compound, which consisted of many manufactured buildings and barracks-type dormitories, they were separated into work and study groups, depending on their ages and capabilities. At the age of 66 , Syola was considered a "senior" and therefore not subject to hard labor. Instead, she worked as a lab technician in the Pathology and Laboratory section of the community health clinic. Eloise, who was five years older than her sister, was also a "senior" and probably worked at making crafts for sales to benefit the church.

\footnotetext{
${ }^{84}$ Memorial sites on the Internet claim that Clara LaNue herself didn't arrive until March 1978 but journals and other written records kept by Jonestown residents prove that she lived and worked on the compound before that date.
} 
Clara, who had been a teacher on the outside, served as both an elementary and junior high school teacher and school administrator for the People's Temple.

Jim Jones's religious, social, and political philosophies were based on the Communist manifesto to work according to one's ability and take according to one's need. He demanded that members turn over their money-including child support and social security checks-to the church coffers. FBI records show that Eloise and many other seniors contributed their social security checks to the cause.

As time wore on, Jones's messages became more paranoid and sinister. He kept his people in a state of constant fear and vigilance against phantom forces and encouraged them to "go out fighting" and kill as many "enemies" as they could. All temple members, young and old, took courses in "Revolutionary Training" where they wrote papers describing how they would defeat their enemies. Church enemies included capitalists, defectors from the compound, and anyone who opposed Jones's teachings or investigated his church. In one such paper, Clara Johnson stated, "I would like to give my life in the name of freedom. I do not mind dying as a communist. I plan to kill a few capitalist [sic] before I die. I have begun to come to terms with death" (Lenin 1978). Hers was one of the least violent of the papers written for Jones; many went into great detail about decapitation, evisceration, and extreme torture.

\section{Revolutionary Suicide}

As early as February 16, 1978, Jones lectured on the concept of "Revolutionary Suicide," in which everyone in the compound would be given a potion made of juice combined with a potent poison. He assured his flock that it would be a painless death lasting only about 45 minutes (Edith Roller, February 16, 1978, February Journal). Jones orchestrated at least five "White Night" 85 events between February 16 and November 1978. Participants were given fruit juice in paper cups and told that they contained poison. Those who refused to drink the juice were physically punished in the pavilion and then assigned particularly difficult work duties.

${ }^{85} \mathrm{He}$ enacted an attack on the compound or impending doom leading to Revolutionary Suicide.
News of Jones's erratic behavior and unsavory conditions at the camp trickled back to the United States. By November 1978, friends and relatives of the Jonestown disciples convinced California Congressman Leo Ryan to undertake a fact-finding mission to the isolated compound. His arrival in the remote hamlet prompted the already-paranoid Jones to take extreme measures to protect his flock from what he considered an increasingly hostile world. $\mathrm{He}$ ordered the execution of Ryan and his entourage, including aides, journalists, and several "defectors" who wished to return to the states with Ryan. As the group was preparing to board the plane, a truckload of armed men drove up and open-fired on them. The attack was swift and bloody. Congressman Ryan, two journalists, one of the "defectors," and others of Ryan's entourage were gunned down by Jones's soldiers. Survivors, some of whom were seriously wounded, crawled into the jungle where they waited for help.

Later that night, November 18, 1978, Jones ordered his people to participate in yet another "White Night." He encouraged them to take their own lives rather than die at the hands of enemies who would surely come to avenge Ryan. He decreed that they should all embark on a mass suicide in which everyone would drink a concoction of potassium cyanide and tranquilizers dissolved in a fruit-flavored soft drink, widely thought to be "Kool-Aid." Many followed the procedure as they had practiced, some no doubt believing it to be just another show of faith like the previous "White Nights." As the first converts began dropping to the ground, however, others began to realize that it was the real thing. Some tried to run or hide, but Jones's armed and loyal security guards surrounded the crowd and forced them into a compact group near the central pavilion. Guards held back the heads of reluctant converts and poured the liquid down their throats. Ultimately, more than 900 of Jones's followers "drank the Kool-Aid" and died an agonizing death. Of the total, more than a third were children, some only infants. Their mothers and caretakers administered the doses as Jones urged them on. Jones himself supervised the massacre and encouraged the faithful to finish the job. At the end, Jones declined the poison and had one of his henchmen shoot him in the head. Only six people survived.

Among the 908 who lost their lives that night were Ransom Williams's granddaughters, 
Syola and Eloise, his great-granddaughter, Clara LaNue Johnson, and his four great-great-grandchildren, Thomas, Willa JoAnn, Janice Arlette, and Gwendolyn Joyce (Department of Religious Studies, San Diego State University 2010). No doubt, they were originally captivated by Jones's promises of racial and social equality, justice and basic welfare. They sought the very thing their ancestors believed would be theirs with emancipation 113 years earlier.

\section{POSTSCRIPT: SEARCHING FOR RANSOM AND SARAH'S GRAVES}

Throughout the course of this project, the archeological team wondered where Ransom and Sarah were buried. But we ran into many roadblocks in the effort to locate their graves, right up until the last quarter of 2014 as this book was going through final editing. At that point, we made a breakthrough and discovered where Sarah (Houston) Williams was buried, and we can now speculate on the location of Ransom's grave. This section was appended to this volume when this discovery was made.

Historical evidence indicates that Ransom Williams died around 1901, which is before the use of death certificates became standard practice in Texas. No death certificate has ever been found for Ransom, perhaps because none exists. There is no definitive evidence that shows where Ransom was buried, although we speculated he could have been buried on his farmstead or in one of the African American cemeteries associated with the nearby communities of Antioch or Manchaca. But new evidence regarding the gravesite of his wife, Sarah, adds another possibility.

Once Sarah Williams's death certificate was discovered, we knew that she died on March 11, 1921, and was buried in San Marcos. Online searches of numerous online cemetery databases turned up several Sarah Williamses buried in various cemeteries in and around San Marcos, but all of them were discounted because none had the correct death year. In late November 2014 , one final search was made to look at all of the Sarah Williams gravesites regardless of death dates. The logic here was that perhaps some online listing contained a tombstone transcription error. Although this was a long shot, this hunch proved to be correct. The online information on the Find A Grave website lists 389 interments in the San Marcos-Blanco Cemetery, an African American burial ground with the earliest known grave dating to 1886 (Findagrave.com 2014a). One of the interments listed for this cemetery is Sarah Williams, born in 1832 and died in March 1902 (Findagrave. com 2014b). But this transcribed data appeared to be an error because the photograph of the headstone (Findagrave.com 2014c), which was somewhat blurry and partially obscured by vegetation, appeared to show a death date of "MAR...921." It also showed the words "AGE 70 ," which was the age at death listed on Sarah (Houston) Williams's death certificate.

On November 2, 2014, a trip to the San Marcos-Blanco Cemetery confirmed that this headstone inscription matches all of the death certificate information for Sarah (Houston) Williams. This grave is oriented southwest (head end) to northeast (foot end), and the cast concrete headstone (Figure 5.14) is inscribed:

\author{
SARAH \\ WILLIAMS \\ DIED \\ MAR 11, 1921 \\ AGE 70 \\ AT REST
}

Sarah's grave marker is somewhat isolated from other marked graves, but there is surface evidence of other unmarked graves nearby and throughout this large cemetery. Immediately adjacent to and parallel with Sarah's grave is a slight linear depression filled with greener grass than the surrounding area. Just offset from its head end there is a rusted iron stakeand-plaque marker that was bent down flush with the ground. Although it had no lettering of any kind, this is the temporary type of grave marker commonly used by funeral homes and cemetery associations (i.e., with a metal nameplate attached to a stake). It could have been placed there at any time to denote the presence of an unmarked grave. Beside this unmarked grave, there is ample room and additional surface evidence suggesting many more unmarked graves in the immediate area.

It is not known whose remains are buried in the grave adjacent to Sarah's, but it is certainly possible that this is the burial site of Ransom 


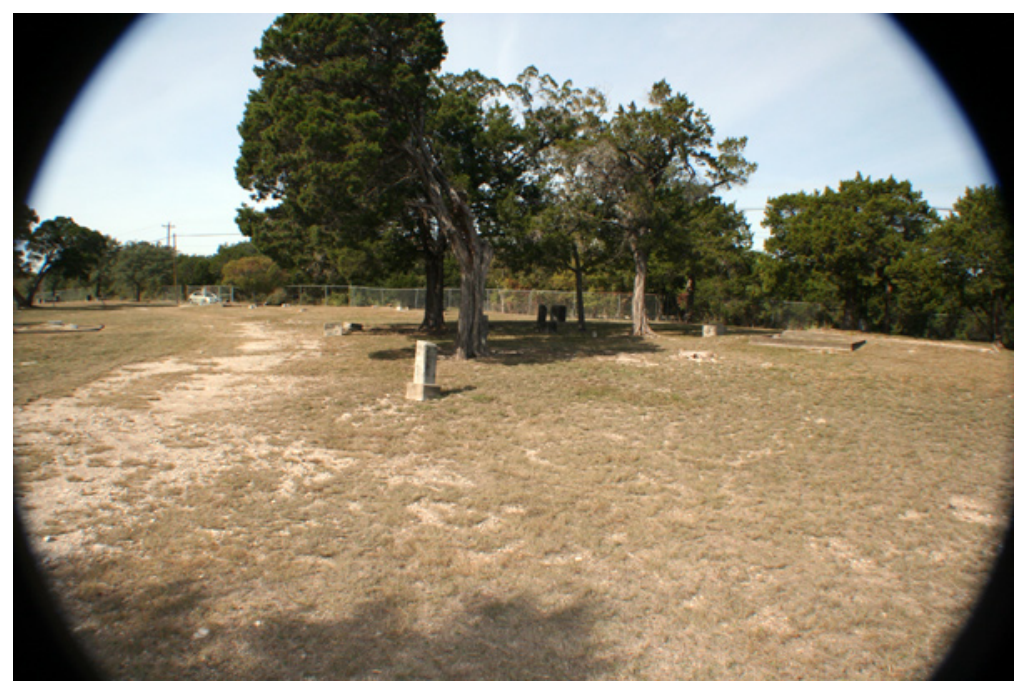

a

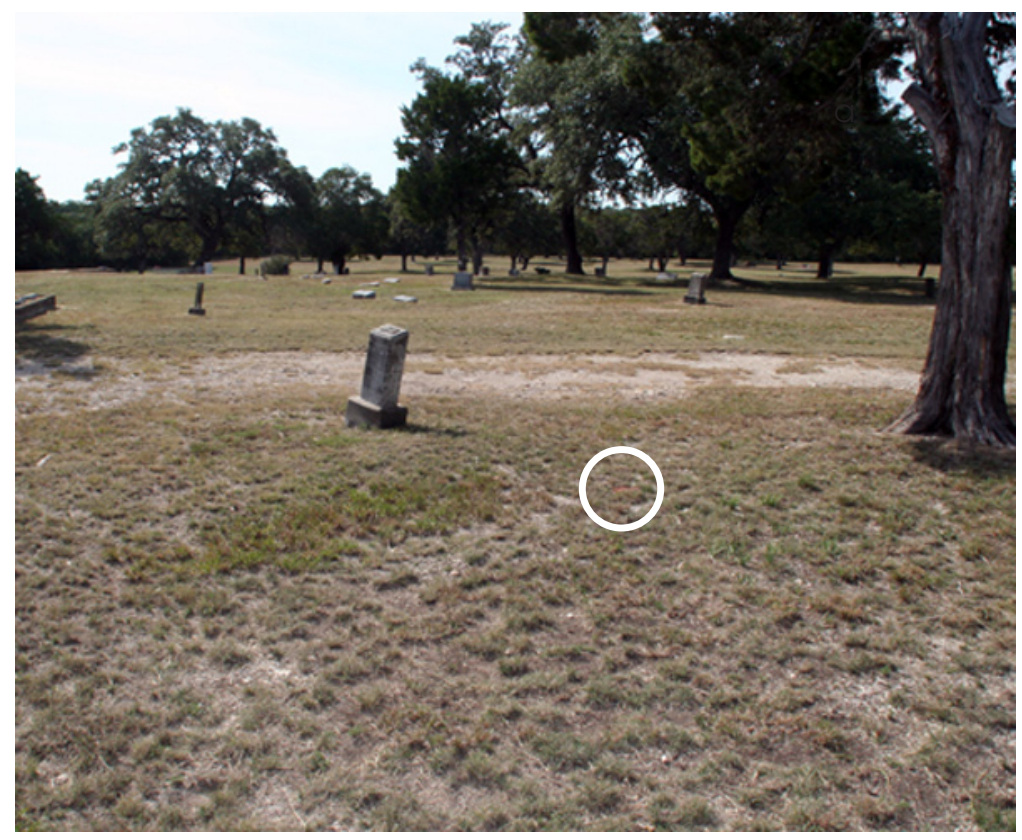

b

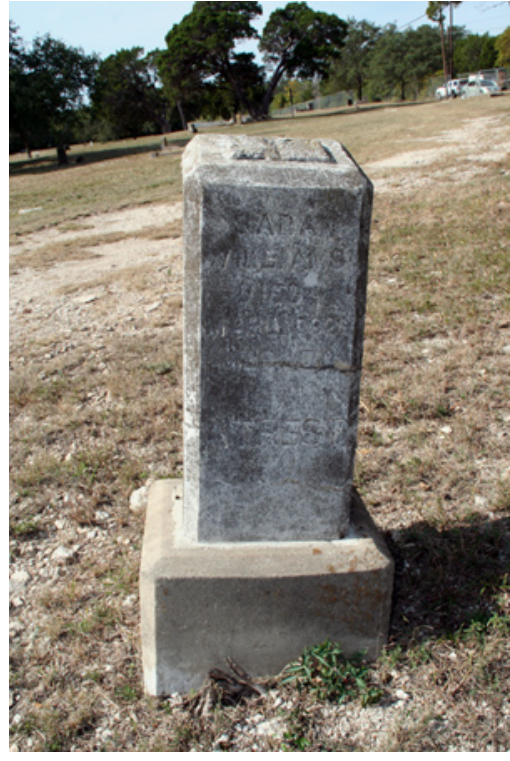

C

Figure 5.14. Photographs of Sarah Williams's grave and headstone at the San Marcos-Blanco Cemetery in Hays County, Texas. (a) Overview of Sarah's grave marked by the tall headstone in the center of photo, looking west. (b) View of Sarah's grave and an adjacent grave indicated by greener grass in a depression and a metal marker (in circle), looking south. (c) Closeup of headstone of Sarah's headstone, looking southwest.

Williams. Other relatives and family members might also be buried nearby, perhaps even some of Ransom and Sarah's children who never appeared in official records and are presumed to have died young. The San Marcos-Blanco Cemetery seems to make sense as a burial place for Ransom and Sarah because many people buried there are associated with prominent African American families from Mountain City and northern Hays County (Findagrave.com 2014a). 


\title{
LANDSCAPE ANALYSIS OF THE WILLIAMS FARMSTEAD
}

\author{
Douglas K. Boyd
}

Limestone rock walls, a livestock pond, ancient oaks embedded with barbed wire-more than 100 years after Ransom Williams shaped this piece of rugged wilderness into a family farm, the landscape still bears evidence of his labors. To try to understand the agricultural system that he put in place to best utilize his small upland farm, we conducted a landscape analysis as part of the data recovery work in 2009 . The objective was to look at the entire 45 -acre farm, examine the spatial relationships between its components, and identify the logic behind the farm's layout and operation. This type of landscape approach is needed because, as Adams writes in Landscape Archaeology, Landscape History, and the American Farmstead, "The farm is a higher-order subsystem, containing many other subsystems. It must be studied in its entirety, not in pieces"(Adams 1990:93). Similarly, Beaudry (2002) argues in her article "Trying to Think Progressively About 19th-Century Farms" that a farmstead is a complex system that can only be understood when viewed from a landscape perspective, one that looks at the relationships between all of the natural and manmade components that comprise the system. She stresses that most farmsteads do not represent a snapshot in time but are systems that evolved over time in response to many factors, including local, state, and national events. In this analysis, we examine the landscape and archeological evidence together with archival evidence to reveal a rich story of a small hardscrabble farm on the edge of the Texas Hill Country.

\section{METHODOLOGY}

The research began with an examination of historic and modern maps, aerial photographs, and small- and large-scale topographical maps. They were extremely useful in defining the site setting in a meaningful way, correlating the natural topography and current vegetation patterns with manmade features and activities. Next, detailed maps were created of all natural and manmade features on the site. But since the investigation was primarily limited to the state-owned right of way for State Highway 45 Southwest ${ }^{86}$ - an area of 16.8 acres that accounts for 37 percent of the 45-acre farm (Figure 6.1) proxy evidence such as historic maps and aerial photos was used to infer historic land use in the portions of the property outside of the right of way. The greatest effort was focused on the southern half of the farm, where the house and the landscape features were. The area north of all the mapped rock walls was completely wooded, but intensive survey there found no landscape features.

Two types of site maps were created and used for the landscape analysis: maps of the archeological excavations and large-scale maps depicting landscape features. During the intensive excavations in and around the house area, shovel tests and 1x1-m excavation units were laid out on one continuous site grid and were plotted on graph paper maps as the excavations progressed. Ultimately, these maps covered an area of $50 \mathrm{~m}$ (east-west) by $25 \mathrm{~m}$ (north-south) and depicted the locations of 90 hand-dug units in the house excavation block, 113 shovel tests, 29 units, and 2 backhoe

\footnotetext{
${ }^{86}$ The one exception was that PAI archeologists were allowed to map the rock walls and alignments in the LCRA transmission line corridor immediately east of the TxDOT right of way.
} 


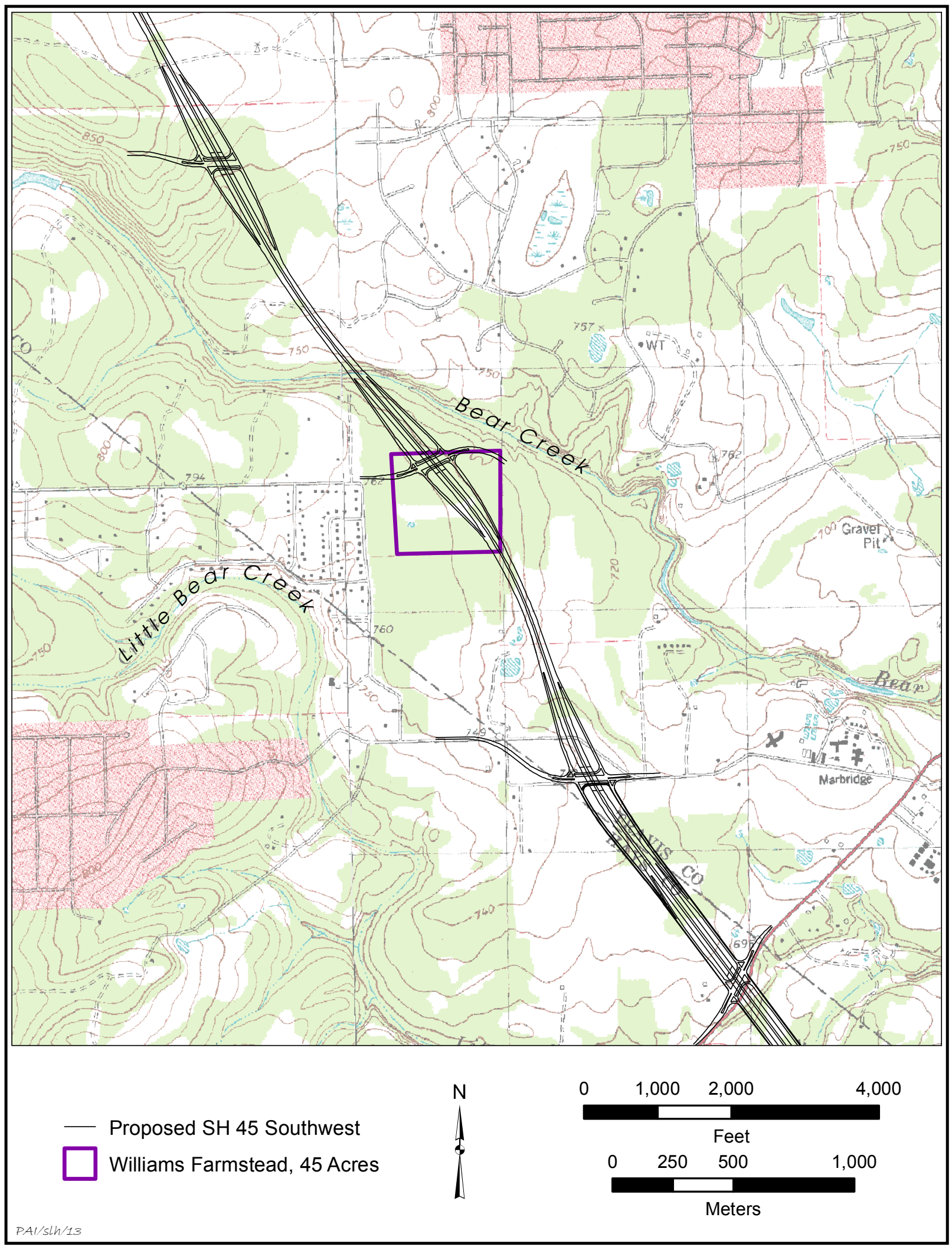

Figure 6.1. Map showing the relationship of the 45-acre Williams farmstead property to the proposed State Highway 45. Base map is the 1988 USGS Oak Hill 7.5-minute quadrangle. 
trenches in close proximity to the house block. In addition, detailed sketch maps were made of the hand excavations (a 2x2-m hand-dug unit), several backhoe trenches, and features in the corral complex, where the rock walls converge near the location of a former pond. Later, largescale features and surface artifacts were mapped using a Trimble GeoXH (2005 Series) global positioning system with submeter accuracy (except in some locations under heavy tree cover) and a Sokkia Set $5 \mathrm{~F}$ total station. The GPS data consisted of 4,324 positions taken as points, lines, and polygons. The total station mapping documented 674 points, concentrating on the features in and around the house excavation block, the major rock walls, and alignments in the corral complex. Table 6.1 summarizes the natural, manmade, and archeological excavations that were mapped as part of the landscape analysis.

\section{SITE SETTING}

The Williams farmstead is in an upland setting a few hundred feet south of Bear Creek, a tributary of Onion Creek and the Colorado River. The property is on an upland ridge between Bear Creek and Little Bear Creek. The farm is relatively flat in the highest southwestern portion; the rest of the property slopes gently to the northeast. The farmstead is in the limestone-dominated Texas Hill Country about 2.5 miles west of topographic breaks marking the Balcones Fault Zone. Geologically, the entire property is covered by large exposures of Cretaceous-age Fredericksburg Group limestones (Bureau of Economic Geology 1974). This group consists of a broad range of limestones and marls, including Edwards limestone, Comanche Peak limestone, Keys Valley marl, Cedar Park limestone, and Bee Cave marl. On the Williams property, limestone outcrops occur in linear bands following the topographic contours, and much of the exposed bedrock consists of hard, fine-grained tabular limestone that is naturally broken into blocky sections. On top of the limestone is a thin veneer of soil across the whole 45 -acre property. The Travis County soil survey identifies it as a shallow, well-drained upland soil called the Speck stony clay loam (USDA 1974:37-38, Sheet 73). It is generally less than 6 to 11 inches thick and contains a significant percentage (5-30 percent) of chert pebbles and cobbles. The soil tends to be thicker on the flat areas and eroded on the slopes.

Figure 6.2 shows the location of the Williams farmstead relative to the Onion Creek watershed and the area geology. Figure 6.3 shows the location of the Williams farmstead in relation to the topography along Bear Creek.

Many important facts regarding the Williams farmstead may be gleaned from the geological, topographic, hydrologic, and soils data. Clay loam soils were thin to nonexistent across the 45-acre farm, and the entire area was underlain by limestone. The soils may have been somewhat thicker during Ransom Williams's occupation, but they were still thin, stony upland soils. Situated on an upland ridge, the property essentially had no surface water except when it rained. These facts had significant implications for Ransom Williams as he endeavored to convert this rough and rocky landscape into a working farm in the early 1870s.

The abundance of limestone was both a curse and a blessing for Williams. The underlying bedrock meant that it was difficult to dig very deep, and creating hand-dug features-such as a root cellar, cistern, or water well-would have been labor-intensive and expensive. The modern soil survey notes that "This soil is not suitable for cultivation. It is well suited to native grass range" (USDA 1974:38). It is not that this land couldn't be farmed-we know that it was-but its productivity would have been rather limited for certain crops. With its thin rocky soils, Williams's land was certainly marginal for farming. On the positive side, the abundant large limestone rocks were well suited for building because they were naturally blocky. The rocks were used to build fences and as foundation stones for the house. The house chimney was also built of these limestone blocks.

Today the cleared and wooded areas of the farmstead remain much the same as they did a few decades after Williams occupied the land. A comparison of 2005 and 1937 aerial photographs was particularly helpful in revealing these patterns (Figures 6.4 and 6.5). They show vegetation patterns that help define the farm layout and identify the functions of the linear rock walls and alignments and isolated rock piles. Both images have a topographic overlay showing that the highest part of the property was the southwestern portion and the lowest area was in the northeast corner. The total relief is about 
Table 6.1. Natural and manmade features and archeological excavations documented for the landscape analysis

\begin{tabular}{|c|c|c|}
\hline Type of Feature & Feature & Comments \\
\hline \multirow[t]{4}{*}{$\begin{array}{l}\text { NATURAL } \\
\text { FEATURES }\end{array}$} & Drainages & $\begin{array}{l}\text { Emphemeral drainages that follow natural } \\
\text { topography. }\end{array}$ \\
\hline & Limestone ridges and slopes & $\begin{array}{l}\text { Natural topographic breaks on the eroded } \\
\text { limestone landscape. }\end{array}$ \\
\hline & Extremely large trees & $\begin{array}{l}\text { Trees estimated to be } 150 \text { to } 300 \text { years old } \\
\text { (some are tree features described below). }\end{array}$ \\
\hline & $\begin{array}{l}\text { Moderate to large trees growing } \\
\text { out of rock walls }\end{array}$ & $\begin{array}{l}\text { Trees that were incorporated into rock walls or } \\
\text { subsequently grew out of them. }\end{array}$ \\
\hline \multirow[t]{9}{*}{$\begin{array}{l}\text { MANMADE } \\
\text { FEATURES }\end{array}$} & Modified drainages & $\begin{array}{l}\text { One natural drainage was modified to follow } \\
\text { rock alignments and channeled water to the } \\
\text { livestock pond. }\end{array}$ \\
\hline & Location of former pond & $\begin{array}{l}\text { An old pond near corral complex, now filled in } \\
\text { with sediment. }\end{array}$ \\
\hline & Trees features & $\begin{array}{l}\text { Most are trees with barbed or smooth wire } \\
\text { embedded in trunks and used as fence posts. } \\
\text { One tree has a natural cavity modified so } \\
\text { people could access beehive honeycombs. }\end{array}$ \\
\hline & Rock walls and alignments & $\begin{array}{l}\text { Intentionally stacked rocks in corral complex } \\
\text { and on property boundaries. Irregular rock } \\
\text { alignments (not stacked) along roads or edges } \\
\text { of cultivated fields. The latter are fieldstones } \\
\text { discard along fencelines. }\end{array}$ \\
\hline & Rock mounds & $\begin{array}{l}\text { Isolated mounds of fieldstones removed from } \\
\text { cultivated fields and discarded. }\end{array}$ \\
\hline & Wooden fence posts & $\begin{array}{l}\text { Isolated and grouped wooden fence posts, } \\
\text { mainly associated with rock walls and old } \\
\text { fencelines. }\end{array}$ \\
\hline & Twentieth-century trash dumps & $\begin{array}{l}\text { Isolated dumps on edges of farmstead property. } \\
\text { These are not associated with Williams family } \\
\text { occupation. }\end{array}$ \\
\hline & Concrete trough & $\begin{array}{l}\text { An isolated concrete trough for water or feed. It } \\
\text { was built after } 1937 \text { and is not associated with } \\
\text { the Williams family occupation. }\end{array}$ \\
\hline & Right-of-way fences & $\begin{array}{l}\text { Iron T-post fences installed by Texas } \\
\text { Department of Transportation to identify } \\
\text { modern property boundary for the State } \\
\text { Highway } 45 \text { right of way. }\end{array}$ \\
\hline \multirow[t]{3}{*}{$\begin{array}{l}\text { ARCHEOLOGICAL } \\
\text { EXCAVATIONS }\end{array}$} & Backhoe trenches & $\begin{array}{l}\text { Most were dug to investigate landscape } \\
\text { features. }\end{array}$ \\
\hline & Excavation blocks and units & $\begin{array}{l}\text { Concentrated in the house area and corral } \\
\text { complex. }\end{array}$ \\
\hline & Shovel tests & Concentrated around the house block. \\
\hline \multirow[t]{2}{*}{$\begin{array}{l}\text { ISOLATED } \\
\text { ARTIFACTS AND } \\
\text { CLUSTERS }\end{array}$} & Surface-collected artifacts & $\begin{array}{l}\text { Items were mapped individually, but clusters } \\
\text { of artifacts provide evidence of activities away } \\
\text { from the main farmhouse. }\end{array}$ \\
\hline & Metal detector-collected artifacts & $\begin{array}{l}\text { Items were found and mapped individually, } \\
\text { but clusters of artifacts provide evidence of } \\
\text { activities away from the main farmhouse. }\end{array}$ \\
\hline
\end{tabular}



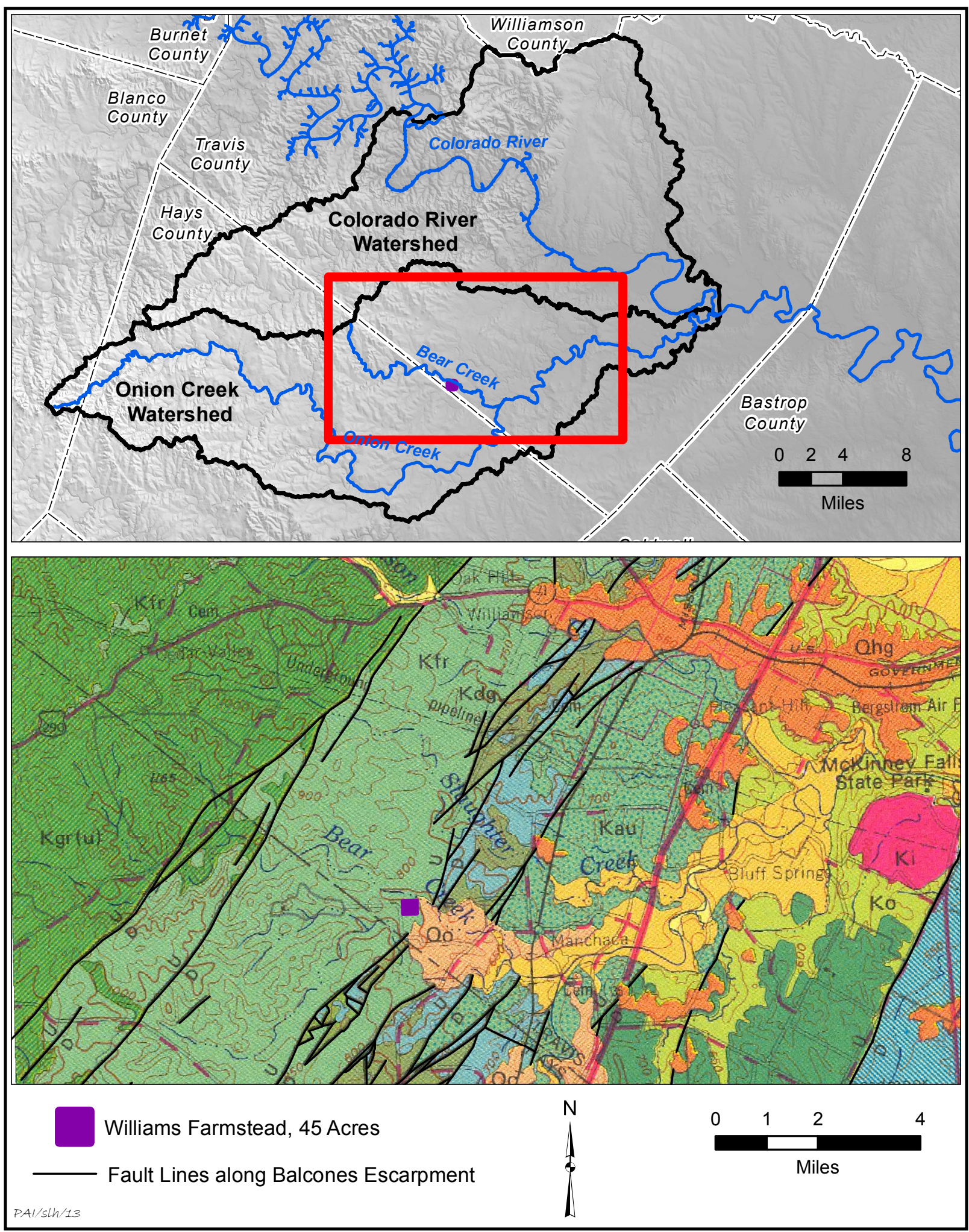

Figure 6.2. Maps showing the location of the Williams farmstead. (a) Relief map of the Onion Creek watershed in Travis and Hays Counties (modified from Austin Watershed Map by the Lower Colorado River Authority 2008). (b) Map of the surface geology showing the Balcones Escarpment, which divides the Edwards Plateau to the west from the Blackland Prairies to the east (Bureau of Economic Geology 1974). 


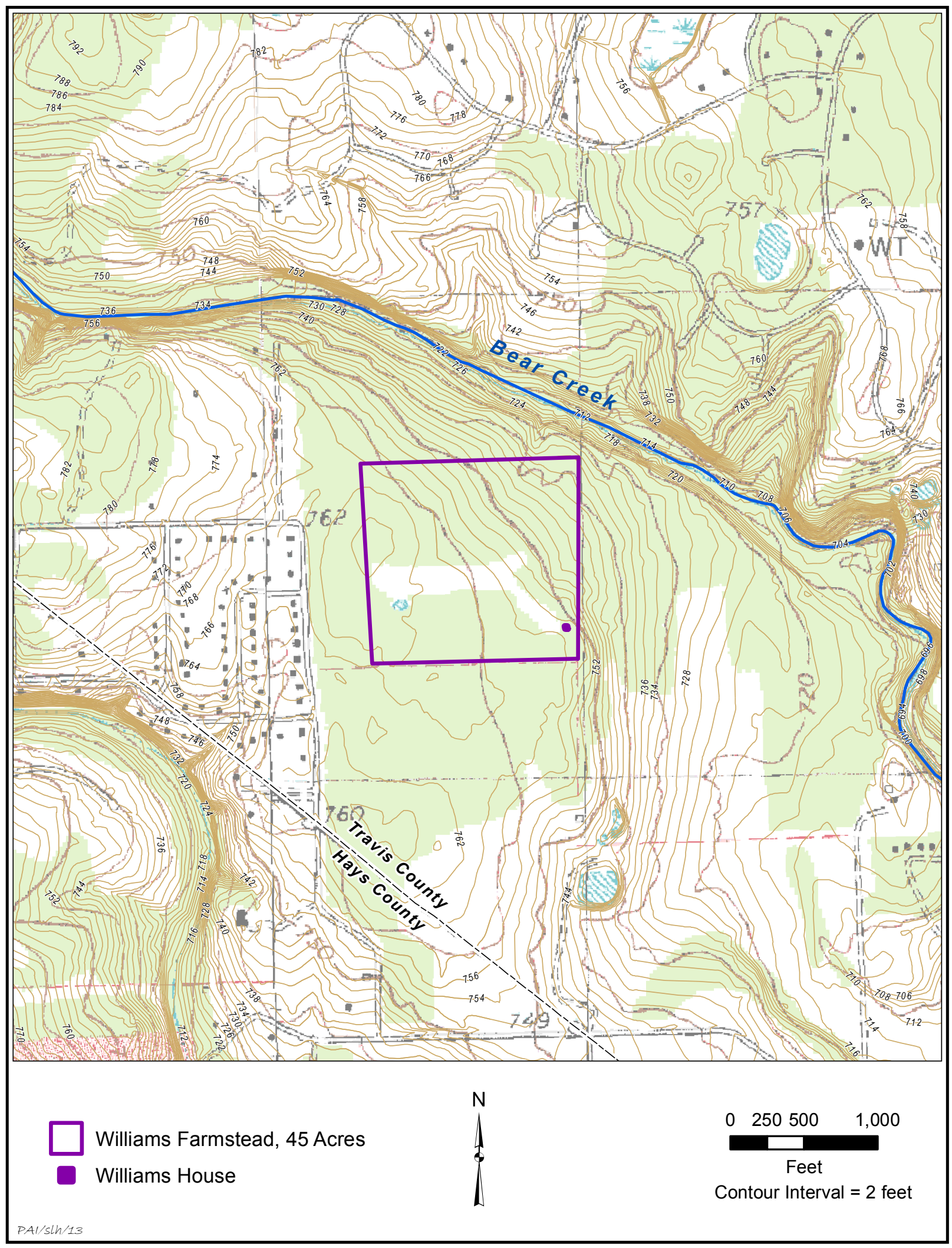

Figure 6.3. Map showing the 45-acre Williams farmstead and farmhouse location in relation to Bear Creek and the area topography. Base map is 1988 USGS Oak Hill 7.5-minute quadrangle. 


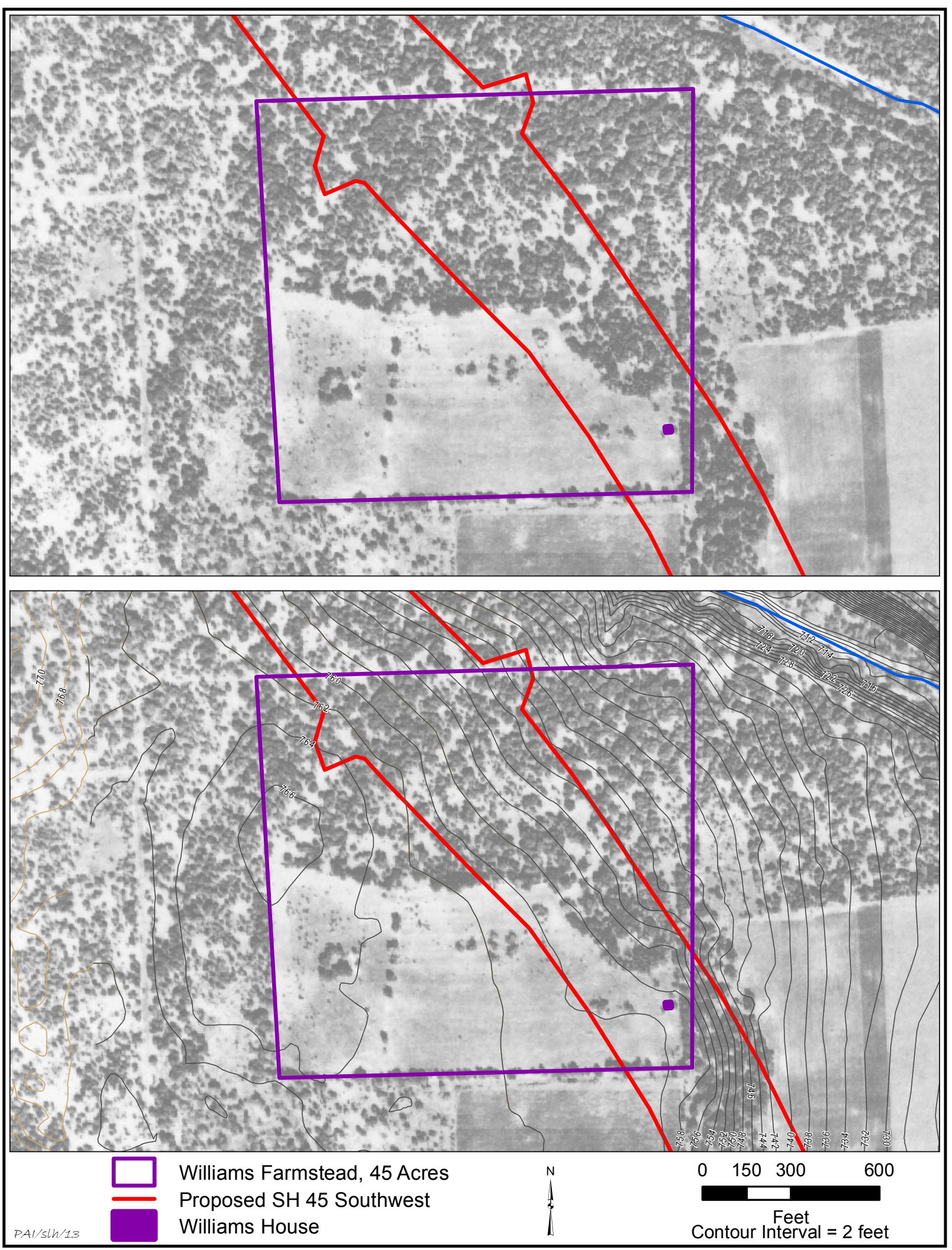

Figure 6.4. The Williams farmstead landscape and topography in 1937. The historic aerial photograph is from Tobin International (1937). 




Figure 6.5. The Williams farmstead landscape and topography in 2005. The modern aerial photograph is from the National Agricultural Imagery Program (2006). 
$28 \mathrm{ft}$ from the high point in the west edge of the property at $766 \mathrm{ft}$ above mean sea level to the lowest point in the northeast corner at $738 \mathrm{ft}$. The 1937 image reveals that about half of the property-the flattest portion in the south and west-had been cleared for cultivation, and all of the trees had been left in the sloping areas to the north and east. The 2005 image shows a great deal of continuity with the earlier photograph. The old cultivated field was still visible in 2005 , and the old property fencelines can still be identified. While the old cultivated field is now covered in trees and shrubs, the careful observer will note that the trees are smaller there, and that the only really large trees are in the areas that were left wooded.

The 1937 aerial photograph provides a snapshot of what the farmstead looked like three decades after the family stopped living on the property (ca. 1905) and just after the family sold the last of the old farmstead in 1934 (45 acres) and 1941 (the adjacent 12 acres). While this view of the property is 66 years after Ransom Williams bought the land, it is only 32 years after the family moved off the farm. For a variety of reasons discussed later in this chapter, the 1937 aerial photograph does indeed represent how the farmstead looked during most of the Williams family tenure in the late nineteenth century. In order to make his farm a viable operation after he acquired the land, Ransom would have had to clear the trees from the flattest part of his land to obtain lumber to build his home (probably a log cabin; see Chapter 11) and provide an area for cultivation. He also would have left some large wooded areas intact as livestock pasture, and gathered the large limestone rocks to build the rock fences and a corral. Indeed this is what the 1937 aerial photograph shows: the flattest area with the thickest soil was cleared for cultivation, and the wooded sloping areas were left intact. The modern aerial photographs from 1970 (U.S. Department of Agriculture 1974:Sheet 73), 1995 (Vargas LLC 1996), 2004, and 2005 (National Agricultural Imagery Program 2005, 2006) all show vegetation patterns that reflect this historic distinction between the cleared and wooded areas. These vegetation patterns are still visible, although less obvious, on the aerial imagery from August 2012 on Google Earth.

As is demonstrated in the descriptions that follow, there is a strong correlation between the landscape features and the vegetation patterns depicted in the 1937 aerial photograph and all subsequent aerial images. There is nothing coincidental about this: the modern landscape simply reflects how Ransom Williams modified and used his land more than a century earlier.

\section{DESCRIPTIONS OF THE LANDSCAPE FEATURES}

A landscape analysis to define the layout of the late-nineteenth-century Williams farmstead depended on accurately identifying and mapping the manmade features that represent components of the farmstead. A substantial effort was expended to accomplish this, and many significant features were identified and documented. The picture is not totally complete, however; it is certain that other farmstead components were once present but left little or no detectable archeological signature. Ransom Williams probably had a smokehouse, for example, but no evidence of such a structure was found, and it was probably nothing more than an ephemeral wooden shed. Scattered surface and metal-detected artifacts in the corral complex hint at the presence of former structures, such as a livestock barn or tack room, but undoubtedly some important farmstead components were missed. Despite this acknowledged gap, enough large-scale features were found to make it possible to develop a fairly precise reconstruction of this late-nineteenth-century farmstead in central Texas.

While the house, yard, and midden were the focus of much archeological attention, they are discussed elsewhere (see Chapters 7 and 11). The features that are considered part of the landscape analysis and are discussed in this chapter are the linear rock features; the livestock pond and associated rock alignment; rock mounds; and large trees. Also discussed in this chapter are the investigation of a possible spring location, the artifacts (surface and subsurface) in the corral complex, and twentieth-century features that are not associated with the Williams family occupation.

\section{Linear Rock Features}

The large linear rock features are an important component of the Williams farmstead, and these features were examined closely and thoroughly documented. The linear features were 
classified either as rock walls or rock alignments. Each linear rock feature was described and assigned a letter or letter and number combination. The distinction between rock walls and rock alignments is one of scale and relates to their original function. Rock walls were intentionally constructed of large tabular limestone rocks to serve as fences. When intact, the rock walls are characterized by multiple layers of stacked rocks at least two feet tall. When disturbed, rock wall segments appeared as linear piles of rock, but they still had substantial relief. When some of the fallen rocks were removed, it generally revealed basal segments with two or more courses of stacked tabular rocks still in place. In contrast, the rock alignments are low-relief linear features that appear to be haphazard arrangements of limestone rocks (some tabular pieces but many irregular cobbles) and rounded chert cobbles. Investigations of these features revealed no hint of intact bases or aligned basal slabs like those used in the rock walls. These rock alignments appear to be ephemeral borders created by removing rocks from fields and roads and piling them along the edges.

Characteristics observed include length; direction/orientation; nature of the rocks; construction details; and associations with other rock alignments, large trees, and topography. Each feature was photographed, and selected portions of the rock walls were profiled using vertical stakes and a level string line. Four backhoe trenches (BHTs 5-8) were excavated alongside or across linear rock features to examine the techniques used in constructing the massive rock walls and to define the nature of the rock alignments, which were comprised of smaller limestone and flint cobbles.

The locations of the rock features are shown in Figure 6.6, and the attributes of these features are summarized in Table 6.2. In the discussions below, the reader should bear in mind two facts. First, rock walls used as livestock fences did not have to be very tall, especially if they were wide and constructed of boulders with angular edges. The most elaborate and intact sections of rock wall in the corral complex (see Rock Wall $\mathrm{F}$, for example) were as wide as they were tall. Second, the distinction between the rock walls and rock alignment may reflect, at least in part, a difference in preservation rather than original construction or function. In many areas, the rock wall had intact sections, collapsed sections, and sections where only the basal rocks were present. In these cases, it is obvious that the rock wall had once been intact but that many of the limestone rocks were removed from some sections. Presumably, this occurred in the mid- to late-twentieth century when subsequent owners reused the rocks for other purposes elsewhere. Notably, most areas where rocks have been removed are close to the two-track roads on the property or in relatively open areas where vehicle access was easy. The most intact sections of rock walls are in the corral complex, where dense trees and vegetation made vehicle access difficult.

\section{Rock Wall A}

Rock Wall A runs east to west along the southern boundary of the Williams property for a total length of approximately $195 \mathrm{ft}$ (Figure 6.7; see Figure 6.6). Wall sections vary in width from about 30 to 78 inches and in height from 0 to 24 inches. The eastern section, called Rock Wall A1, has only one or two courses of stacked rocks that were generally less than 12 inches high. It appears that many of the original rocks were removed from the walls in this area. The western section, designated as Rock Wall A2, is much more intact and has segments with three or four courses of rocks that are more than 24 inches tall. The most intact segment includes a mass of partially collapsed rock wall that is about 78 inches wide, but the average width is about 3 to $4 \mathrm{ft}$. In this area, some fairly large limestone boulders (up to 20 inches in maximum length) are present.

The location of Rock Wall A coincides with an old treeline shown on the 1937 aerial photograph, which suggests it probably functioned as a livestock fence and a property boundary. Compared with some of the other rock walls (especially Rock Wall F, described below), it appears to be very haphazardly built, and it also contains fewer large tabular boulders and more small blocky and odd-shaped rocks that were difficult to stack neatly. In many places, concentrations of cobbles, mainly chert, are piled along the north side of Rock Wall A. These are undoubtedly places where field stones were plowed up and discarded along the fenceline (Figure 6.8).

Rock Wall A appears to end at the twotrack road through the site area, but a closer inspection revealed that it did continue eastward to the approximate southeast corner of the property. Although an attempt was made 


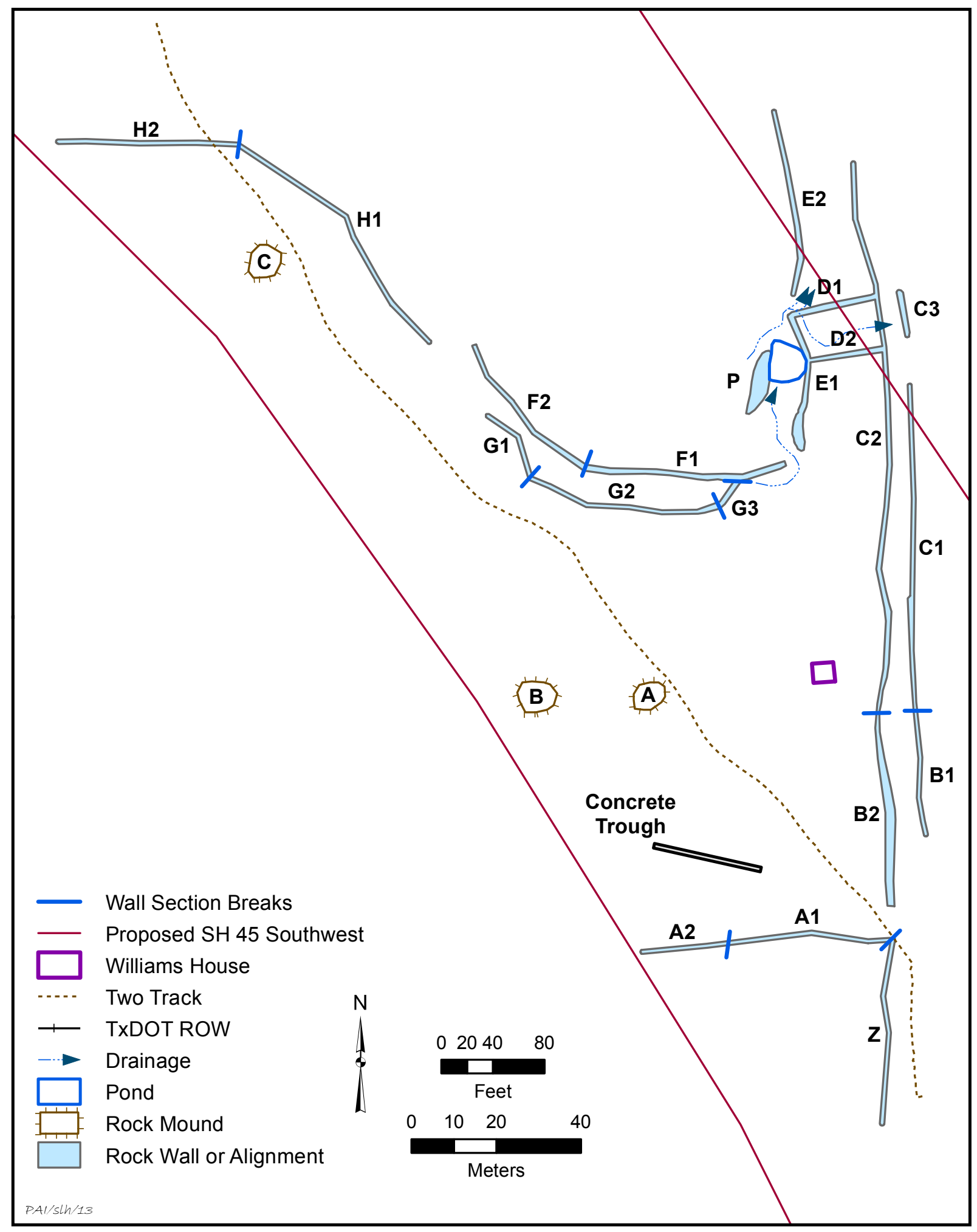

Figure 6.6. Map of the linear rock features at the Williams farmstead. Note that the wall breaks are for descriptive purposes only. 
Table 6.2. Linear rock features

\begin{tabular}{|c|c|c|c|c|c|}
\hline Designation & $\begin{array}{l}\text { Direction and } \\
\text { Configuration }\end{array}$ & $\begin{array}{l}\text { Total } \\
\text { Length } \\
(\mathrm{ft})\end{array}$ & $\begin{array}{l}\text { Maximum } \\
\text { Height } \\
\text { (inches) }\end{array}$ & $\begin{array}{l}\text { Maximum } \\
\text { Width } \\
\text { (inches) }\end{array}$ & Functional Interpretation \\
\hline Rock Wall A1 & $\begin{array}{l}\text { East-west, } \\
\text { straight }\end{array}$ & 127 & 12 & 50 & $\begin{array}{l}\text { Livestock fence and property } \\
\text { boundary marker }\end{array}$ \\
\hline Rock Wall A2 & $\begin{array}{l}\text { East-west, } \\
\text { straight }\end{array}$ & 68 & 28 & 78 & $\begin{array}{l}\text { Livestock fence and property } \\
\text { boundary marker }\end{array}$ \\
\hline Rock Alignment B1 & $\begin{array}{l}\text { North-south, } \\
\text { straight }\end{array}$ & 95 & 10 & 55 & $\begin{array}{l}\text { Road edge and property boundary } \\
\text { marker }\end{array}$ \\
\hline Rock Alignment B2 & $\begin{array}{l}\text { North-south, } \\
\text { straight }\end{array}$ & 148 & 10 & 55 & Road edge and livestock fence \\
\hline Rock Wall C1 & $\begin{array}{l}\text { North-south, } \\
\text { straight }\end{array}$ & 253 & 24 & 35 & $\begin{array}{l}\text { Road edge and property boundary } \\
\text { marker }\end{array}$ \\
\hline Rock Wall C2 & $\begin{array}{l}\text { North-south, } \\
\text { straight }\end{array}$ & 432 & 16 & 33 & Road edge and livestock fence \\
\hline Rock Wall C3 & $\begin{array}{l}\text { North-south, } \\
\text { straight }\end{array}$ & 36 & 16 & 30 & $\begin{array}{l}\text { Probable extension and north end of } \\
\text { Rock Wall C1. This short segment may } \\
\text { have also served as an erosion control } \\
\text { feature near the livestock corral. }\end{array}$ \\
\hline Rock Wall D1 & $\begin{array}{l}\text { East-west, } \\
\text { straight }\end{array}$ & 67 & 20 & 78 & Livestock corral \\
\hline Rock Wall D2 & $\begin{array}{l}\text { East-west, } \\
\text { straight }\end{array}$ & 60 & 12 & 24 & Livestock corral \\
\hline Rock Wall E1 & $\begin{array}{l}\text { North-south, } \\
\text { slightly curved }\end{array}$ & 108 & 36 & 39 & Livestock corral \\
\hline Rock Wall E2 & $\begin{array}{l}\text { North-south, } \\
\text { slightly curved }\end{array}$ & 147 & 12 & $60+$ & Livestock fence \\
\hline Rock Wall F1 & $\begin{array}{l}\text { East-west, } \\
\text { slightly curved }\end{array}$ & 156 & 33 & 57 & Livestock fence \\
\hline Rock Wall F2 & $\begin{array}{l}\text { Northwest- } \\
\text { southeast, } \\
\text { slightly curved }\end{array}$ & 131 & 28 & 72 & Livestock fence \\
\hline Rock Alignment G1 & $\begin{array}{l}\text { Northwest- } \\
\text { southeast, with } \\
\text { bend }\end{array}$ & 60 & 18 & 30 & Field border \\
\hline Rock Alignment G2 & $\begin{array}{l}\text { East-west, } \\
\text { slightly curved }\end{array}$ & 151 & 18 & $84+$ & Field border \\
\hline Rock Alignment G3 & $\begin{array}{l}\text { Northeast- } \\
\text { southwest, } \\
\text { straight }\end{array}$ & 23 & $\mathrm{n} / \mathrm{a}$ & $\mathrm{n} / \mathrm{a}$ & Uncertain; could be displaced rocks \\
\hline Rock Alignment H1 & $\begin{array}{l}\text { Northwest- } \\
\text { southeast, } \\
\text { with bend }\end{array}$ & 216 & 30 & 118 & $\begin{array}{l}\text { Field border and possible livestock } \\
\text { fence }\end{array}$ \\
\hline Rock Alignment H2 & $\begin{array}{l}\text { East-west, } \\
\text { straight }\end{array}$ & 139 & 16 & 118 & $\begin{array}{l}\text { Field border and possible livestock } \\
\text { fence }\end{array}$ \\
\hline Rock Alignment P & $\begin{array}{l}\text { North-south, } \\
\text { irregular oval }\end{array}$ & 50 & 12 & $96+$ & $\begin{array}{l}\text { Natural cobbles removed from pond } \\
\text { excavation. The cobbles form the west } \\
\text { edge of the pond, but an alignment of } \\
\text { limestone rocks to the west may be a } \\
\text { natural ridge outcrop. }\end{array}$ \\
\hline Rock Wall Z & $\begin{array}{l}\text { North-south, } \\
\text { straight }\end{array}$ & 144 & 16 & 48 & $\begin{array}{l}\text { Property boundary south of the } \\
\text { Williams farm. Southern extension of } \\
\text { Rock Alignment B2. }\end{array}$ \\
\hline
\end{tabular}




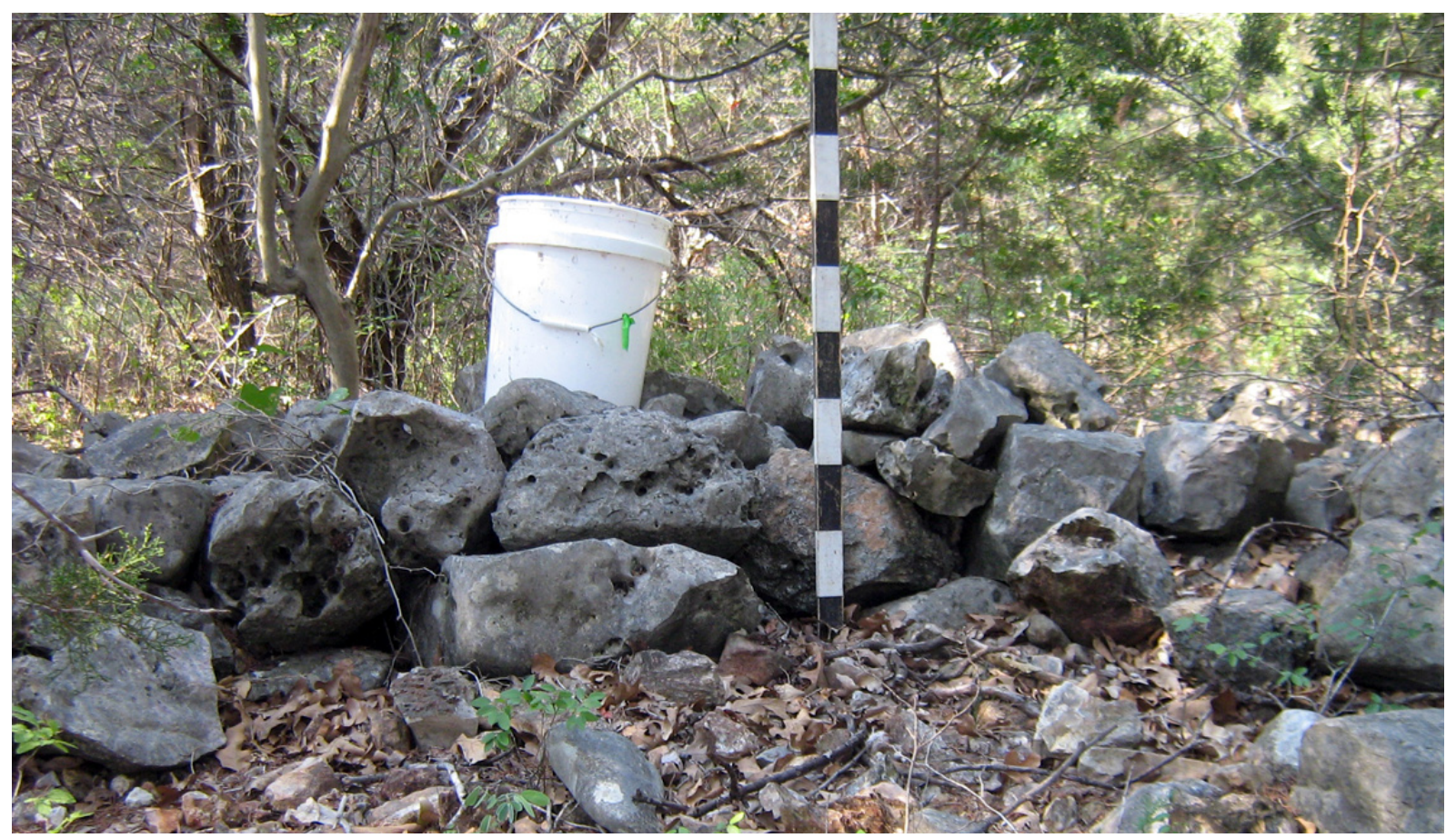

a

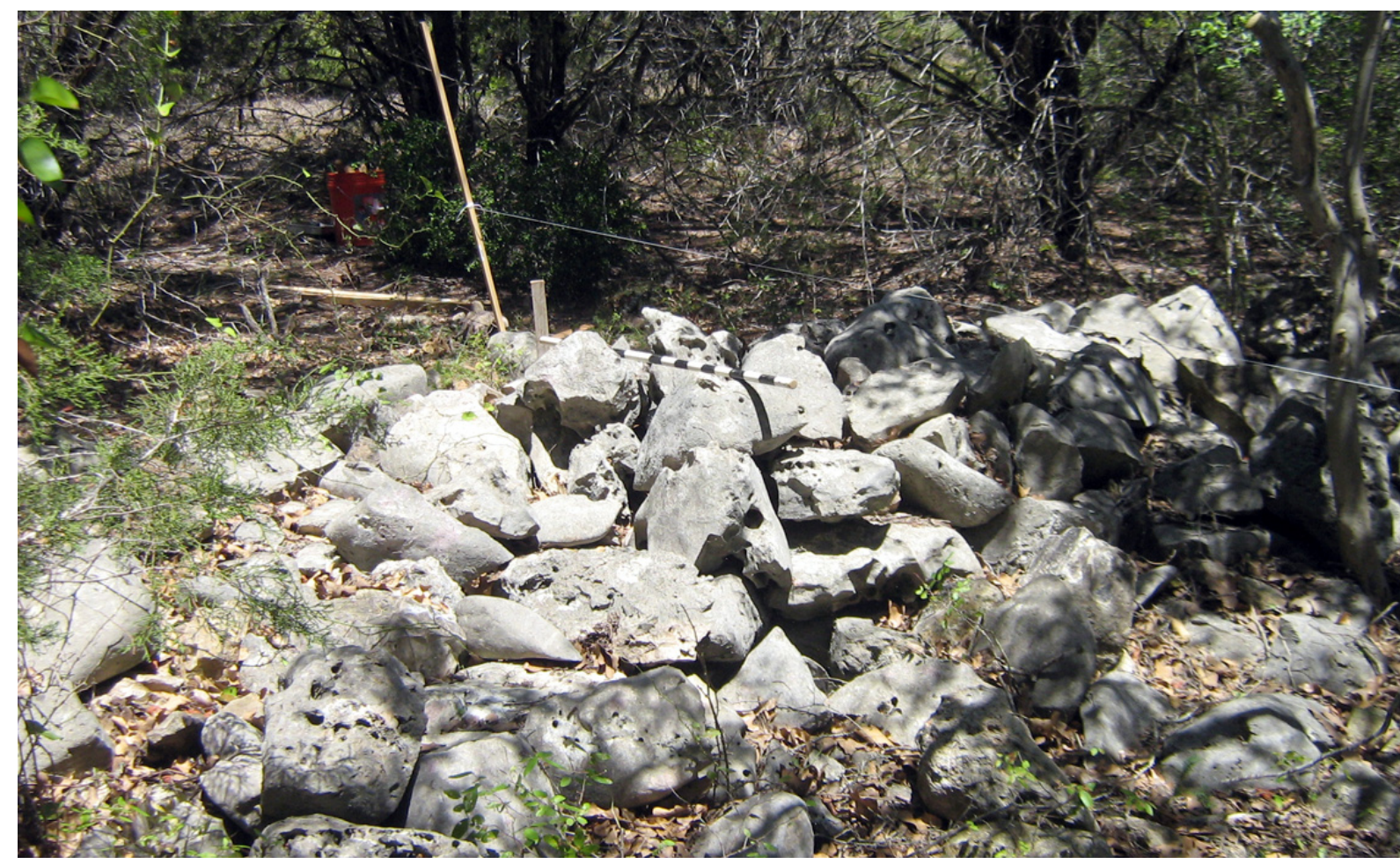

$\mathrm{b}$

Figure 6.7. Photographs of relatively intact sections of Rock Wall A. (a) View of Rock Wall A1 looking north (b) View of Rock Wall A2 looking south. Photo scale is $1 \mathrm{~m}$ (39 inches). 
North

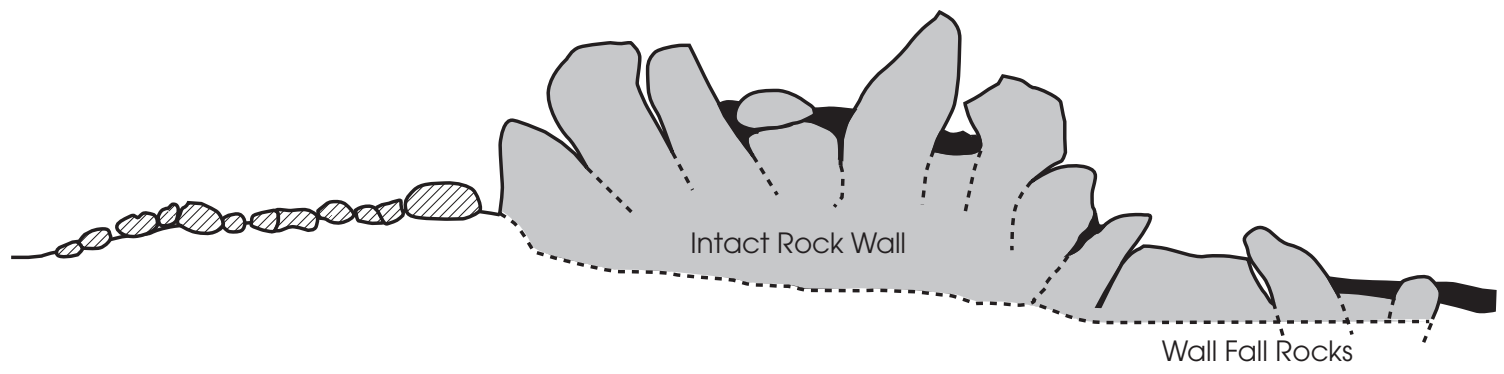

LEGEND

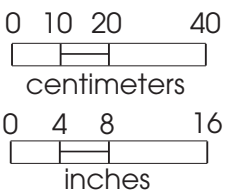

Flint Cobbles

Rock

Figure 6.8. Profile of Rock Wall A2 near its east end. Note the concentration of chert and limestone cobbles on the north side of the rock wall.

to locate the exact corner where Rock Walls $\mathrm{A} 1$ and B1 would meet, this corner is no longer evident. It is presumed that many rocks were removed from this area, which is located close to a twentieth-century dump location (see Rock Alignment B1 below).

\section{Rock Alignments B1 and B2}

Rock Alignments B1 and B2, located southeast of the Williams house, were originally documented as isolated parallel segments that measured 95 and $184 \mathrm{ft}$ long, respectively. But later investigations showed that these segments align perfectly with Rock Walls C1 and C2 (see Figure 6.6) and are continuations of those rock walls. But B1 and B2 are more appropriately classified as alignments rather than walls because it appears that they are simply irregular concentrations of limestone slabs and flint cobbles rather than intentionally stacked walls (Figure 6.9a). Unlike Rock Walls C1 and C2, they contain no hints of rock wall bases in the alignments.

Rock Alignments B1 and B2 are less than 10 inches high, and at any given point they consist of a few limestone rocks or chert cobbles dispersed over an area 20 to 55 inches wide. The density of rocks varies considerably, with some sections easily discerned and others ephemeral. After the leaf litter was brushed away, the rocks were concentrated enough to follow the alignments over their full lengths. 


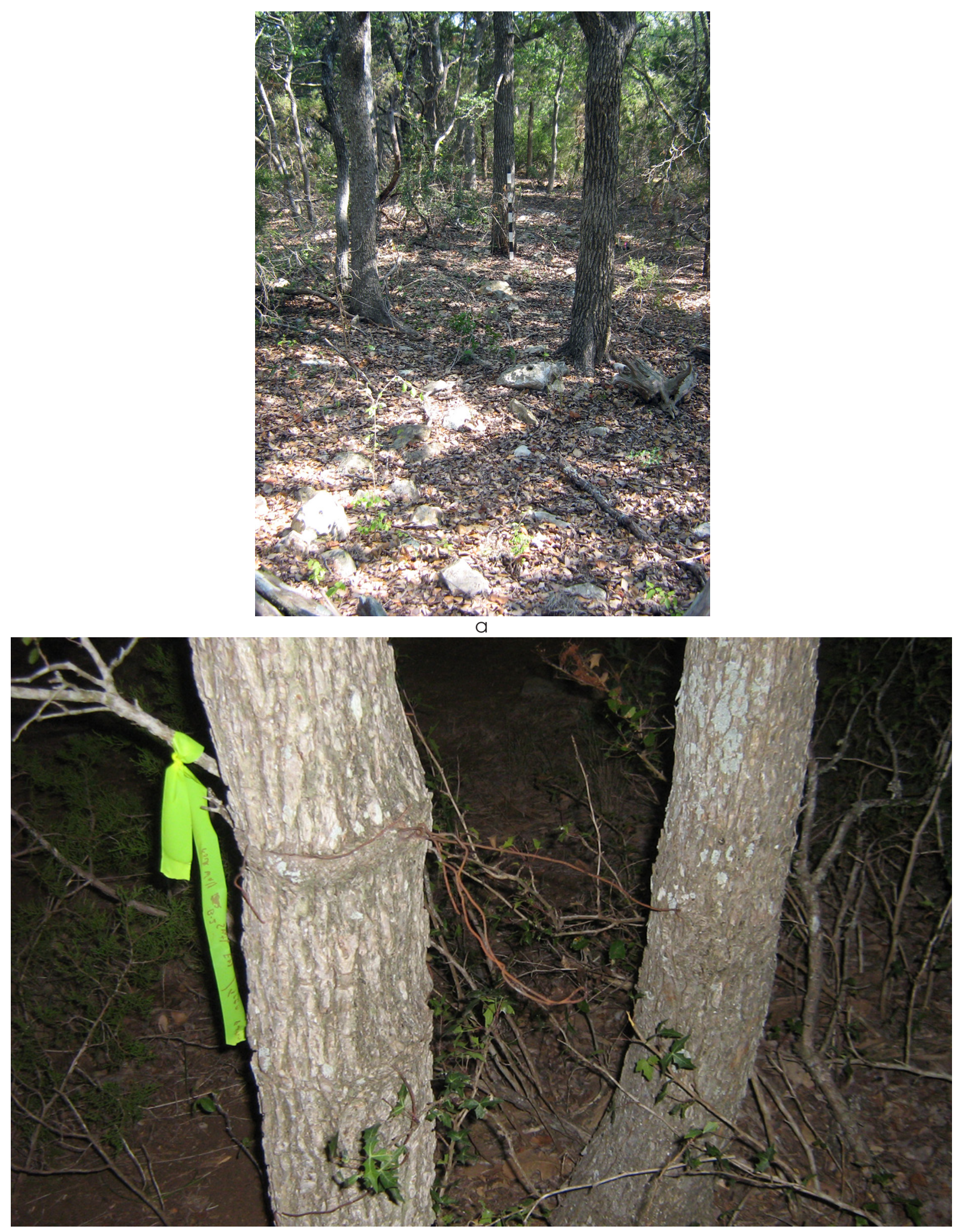

$\mathrm{b}$

Figure 6.9. Photographs of Rock Alignment B2. (a) View of the ephemeral rock alignment, looking north. Scale is $1 \mathrm{~m}$ (39 inches); (b) closeup of young trees with smooth wire embedded in their trunks, located at the southern end of Rock Alignment B2. 
The most notable characteristic of Rock Alignments B1 and B2 is a distinct swale between them, as shown in Figure 6.10. This swale was subtle in some areas but rather prominent in others. It is hypothesized that it represents an old roadway. According to this scenario, Rock Alignments B1 and B2 were made with the natural cobbles that were removed from the roadway and tossed down along its edges. It is believed that this road is quite old, because it does not appear on the 1937 aerial photograph. It was probably abandoned and overgrown well before then, and it may not have been used after ca. 1905, when the Williams family left the property. Notably, Rock Alignment B2 continues south of the Williams property (as Rock Alignment Z, discussed below; see Figure 6.6). The location of Alignment $\mathrm{Z}$ corresponds with the edge of a cultivated field and a probable roadway on the 1937 aerial photograph, supporting the idea that Alignments B1 and B2 bordered a road.

\section{Rock Walls C1, C2, and C3}

As mentioned above, Rock Walls $\mathrm{C} 1$ and C2 are in line with Rock Alignments B1 and $\mathrm{B} 2$, respectively. These rock walls run parallel to each other, between 8 and $12 \mathrm{ft}$ apart, from east of the house northward and downslope to the corral complex (see Figure 6.6). While some wall sections are relatively intact, it is likely that rocks were removed from both walls in the twentieth century, particularly in the area just east and northeast of the house.

Rock Wall C1 (Figure 6.11) runs northsouth for a distance of approximately $253 \mathrm{ft}$ from the house area to the corral complex, and it aligns with Rock Wall C3. Rock Wall C1 is more ephemeral than $\mathrm{C} 2$-little more than a concentration of boulders or cobbles in some places. It is surmised that it was never as substantial as Rock Wall C2 because it probably served primarily as a border along the

West

East

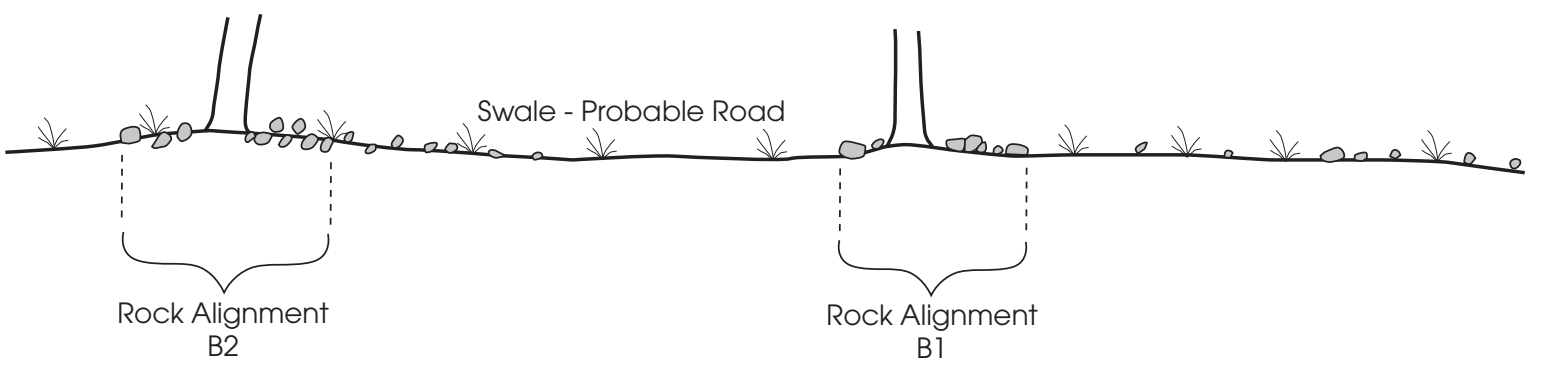

$L E G E N D$

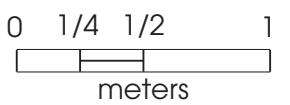

Rock

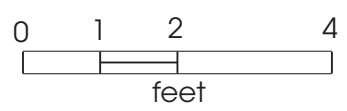

PAI/13/BW

Figure 6.10. Schematic profile of Rock Alignments B1 and B2 showing the swale between them. 


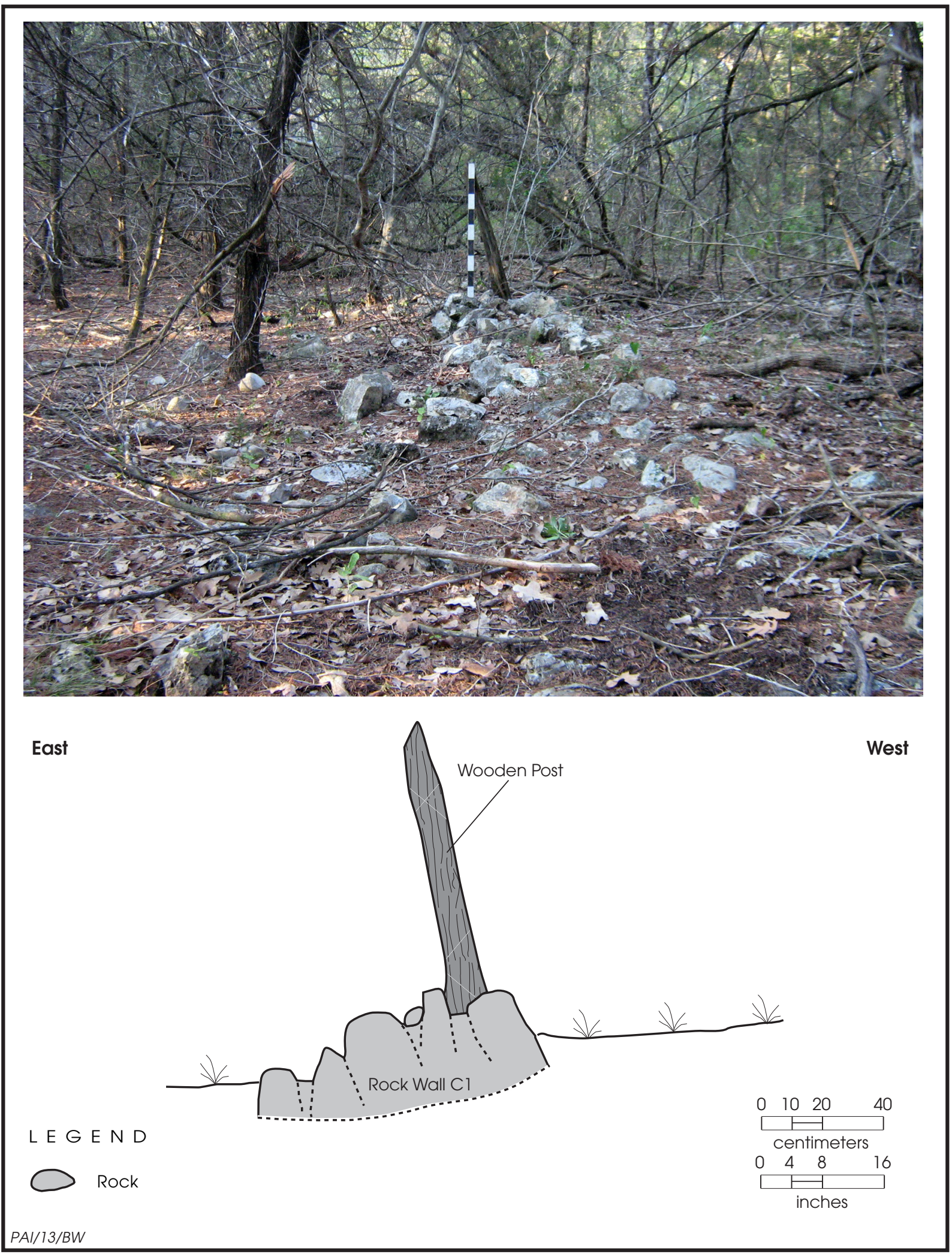

Figure 6.11. Photograph and profile of Rock Wall C1, looking south. The photo view is south and shows a vertical wooden post in the rock wall. Scale is $1 \mathrm{~m}$ (39 inches). 
north-south roadway and a property boundary rather than as a livestock fence. Old vertical cedar posts were found along Rock Wall C1 in two locations, indicating that a wire fence may have been incorporated into this wall at one time, most likely in the twentieth century. Several strands of barbed wire were observed in this general area, but none were attached to the posts associated with this rock wall.

Rock Wall C1 appears to end abruptly at its north end, and a 35-ft-wide gap between it and Rock Wall C3 might have been the location of a wooden gate (note that a large tree, Tree 8 , is almost centered in this gap). Rock Wall C3, which was clearly exposed in the vegetation-cleared LCRA easement (Figure 6.12), is an isolated segment that is only $36 \mathrm{ft}$ long, with no hint that the wall ever continued farther to the north. Rock Wall C3 is more substantial than most of Rock Wall C1, and it spans across a natural swale that ran east-west through the corral area. A short section (ca. $5 \mathrm{ft}$ ) of completely collapsed wall is present in Rock Wall C2, just west of Rock Wall C3. A broad scatter of limestone rocks a few feet east of this collapsed section indicates that this damage was caused by erosion undercutting the wall and dispersing the rocks. This occurred because of the natural drainage that runs eastward through the rectangular enclosure. It is surmised that Rock Wall C3 was intentionally built up to stop the erosion at the east end of this natural drainage. If so, it seems to have worked well, because the east-flowing drainage ends at Rock Wall C3, which functioned as a dam to trap sediment and disperse runoff.

Rock Wall C2 runs north-south for a distance of $432 \mathrm{ft}$ (Figure 6.13). At the lower end of the site Rock Wall C2 becomes the east wall of the corral complex, where it abuts Rock Walls D1 and D2 to form a rectangular enclosure. The southern and far northern ends of this wall are ephemeral, with most sections being totally collapsed and dispersed. In contrast, the portion of Rock Wall C2 along the corral complex was once a substantial rock wall, but it has largely collapsed and been dispersed. The section of Rock Wall C2 along the corral is only about 16 inches high but about 33 inches wide. Given its width and its association with other walls, it seems likely that some rocks were robbed from Rock Wall C2 in this area (see Rock Wall D2 below).

\section{Rock Walls D1 and D2}

Rock Walls D1 and D2 are located near the stock pond in the corral complex (see Figure 6.6). They are parallel walls that run east-west for approximately 67 and $60 \mathrm{ft}$, respectively. They are 38 to $40 \mathrm{ft}$ apart, and they abut Rock Walls $\mathrm{E} 1$ (on the west) and C2 (on the east) to form a rectangular enclosure that was almost certainly a livestock corral located adjacent to the pond.

Rock Wall D1 is the most substantial of the two (Figure 6.14). While it is relatively intact, some parts are partially collapsed. It is 20 inches high and as much as 70 inches wide, although its original width varies from 40 to 50 inches. There is a noticeable gap in the western end of the wall where it abuts Rock Wall E1; this is a likely location where a wooden gate would have been (see Figure 6.14a).

Rock Wall D2 is more ephemeral than Wall D1. It consisted of an intermittent line of jumbled rocks not more than 12 inches tall and 24 inches wide, with limestone rocks from the collapsed wall widely dispersed. Many of the scattered rocks were partially or completely buried by sediments that accumulated because runoff collected in this low-lying spot. It is likely that Rock Wall D2 was once as substantial as Rock Wall D1 but that most of the rocks were subsequently removed from this area long after the farmstead was abandoned. Vehicle access would have been relatively easy from the north because the slope is gentle and there are no large trees blocking access.

\section{Rock Walls E1 and E2}

Rock Walls E1 and E2 are aligned with each other, running north-south in the corral complex (see Figure 6.6). Rock Wall E1 is one of the best-preserved rock wall sections on the Williams farmstead over most of its 108 -ft length (Figures 6.15 and 6.16). Its southernmost end is mostly collapsed, but the rest of the wall is nearly intact. Rock Wall E1 forms the west wall of the rectangular enclosure (see Rock Walls D1 and D2 above) as well as the east side of the livestock pond (discussed below). The wall is over 24 inches high everywhere, and some sections are 36 inches high. It is consistently between 30 and 39 inches wide. In many places, the east and west sides are nearly vertical, and the rocks have been intentionally faced to form 


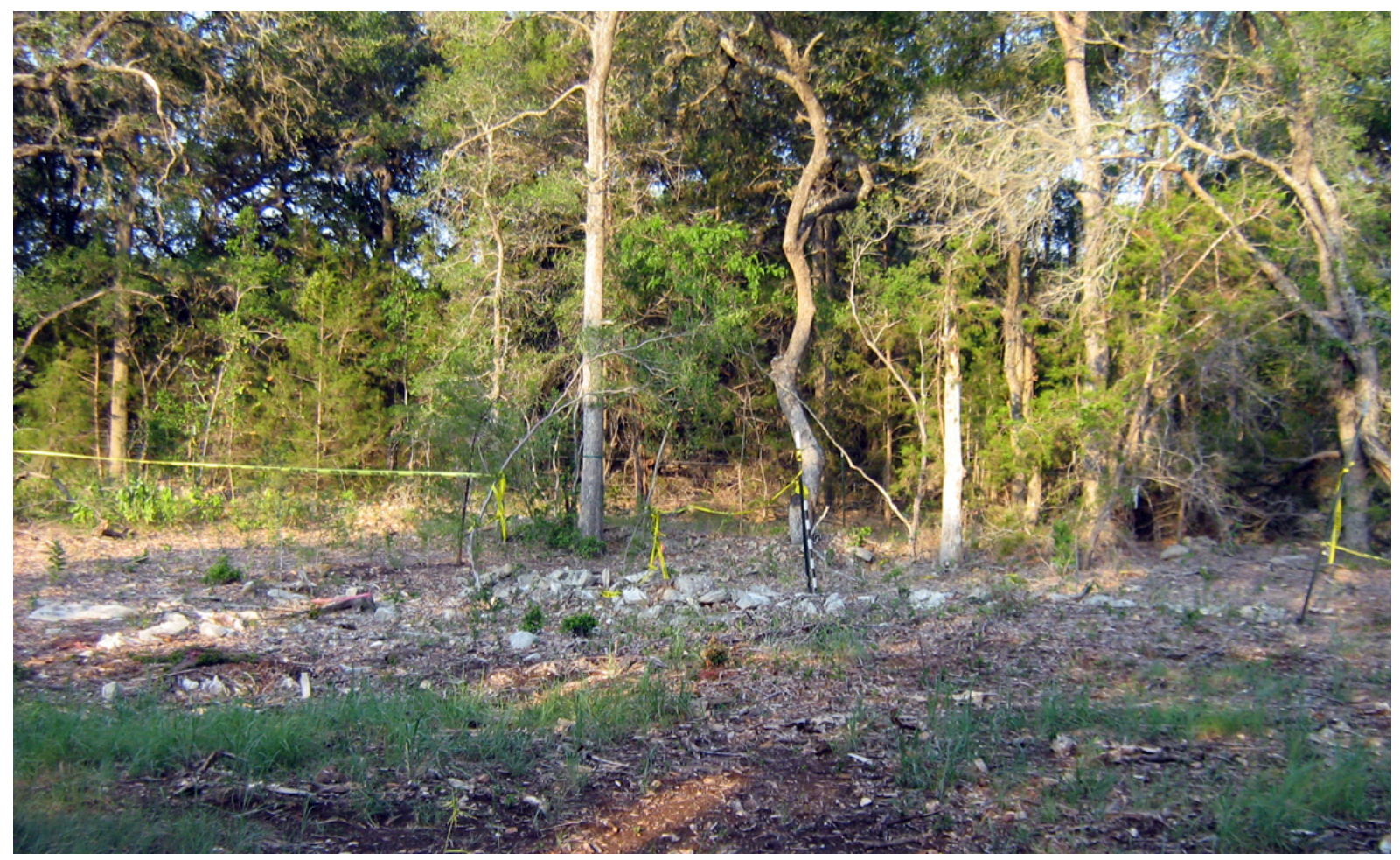

a

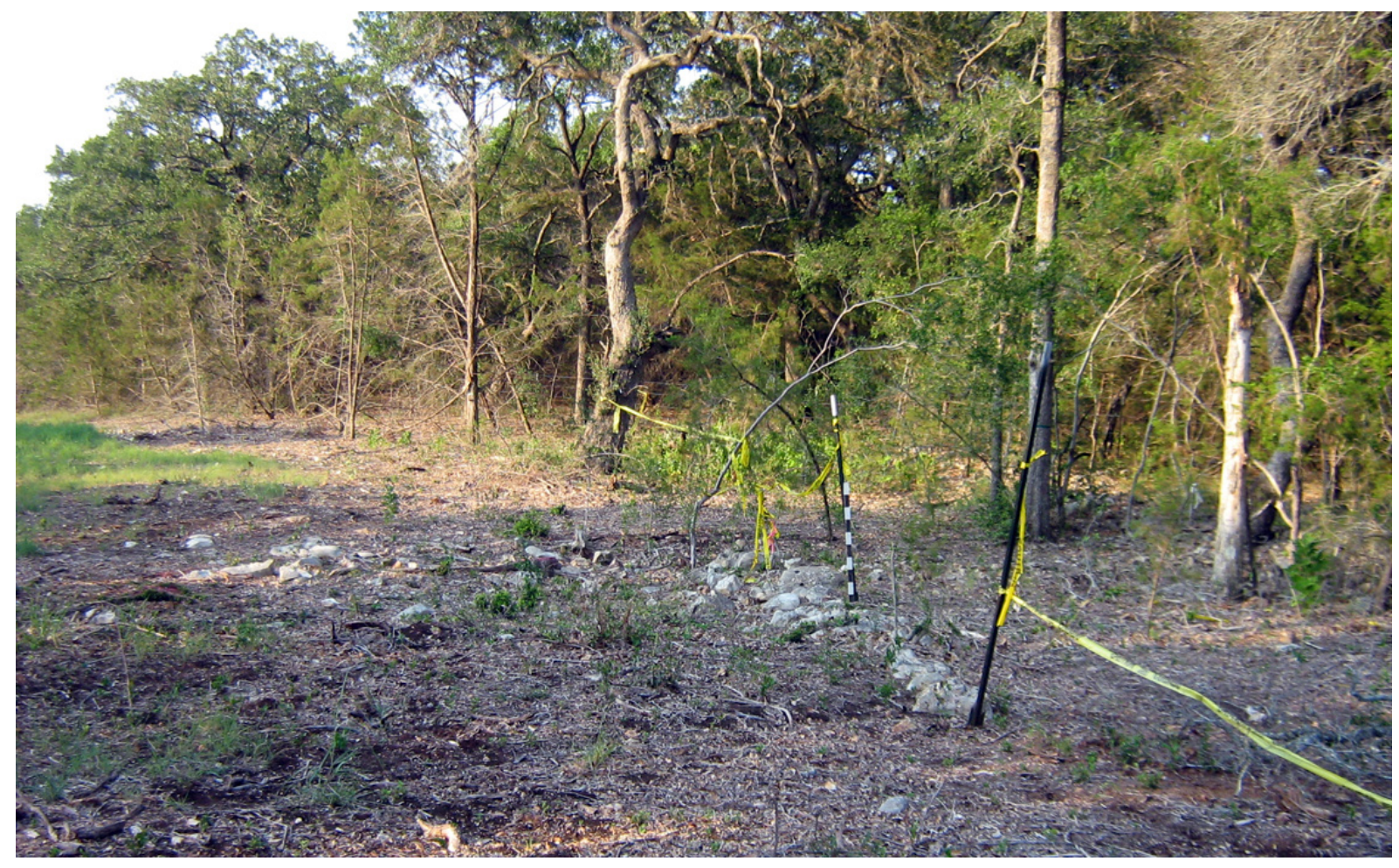

b

Figure 6.12. Photographs of Rock Wall C3 in the LCRA easement. (a) View to the west perpendicular to the wall. (b) View to the south-southwest looking down the wall. Note the scatter of limestone rocks to the left of the far end of the wall. Vertical scale is $1 \mathrm{~m}$ (39 inches), and the T-posts and flagging tape were placed by LRCA to protect the wall during vegetation clearing. 


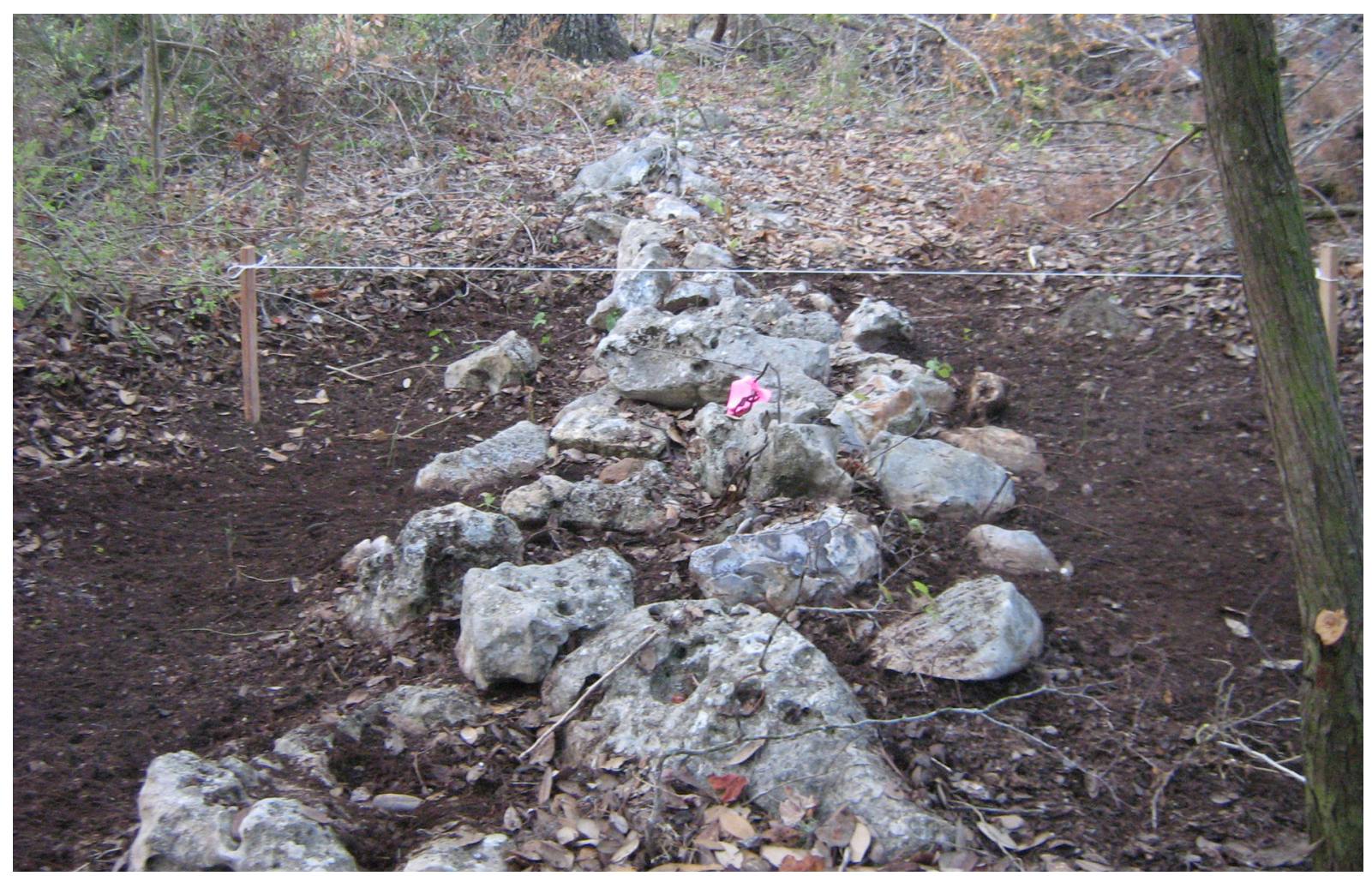

a

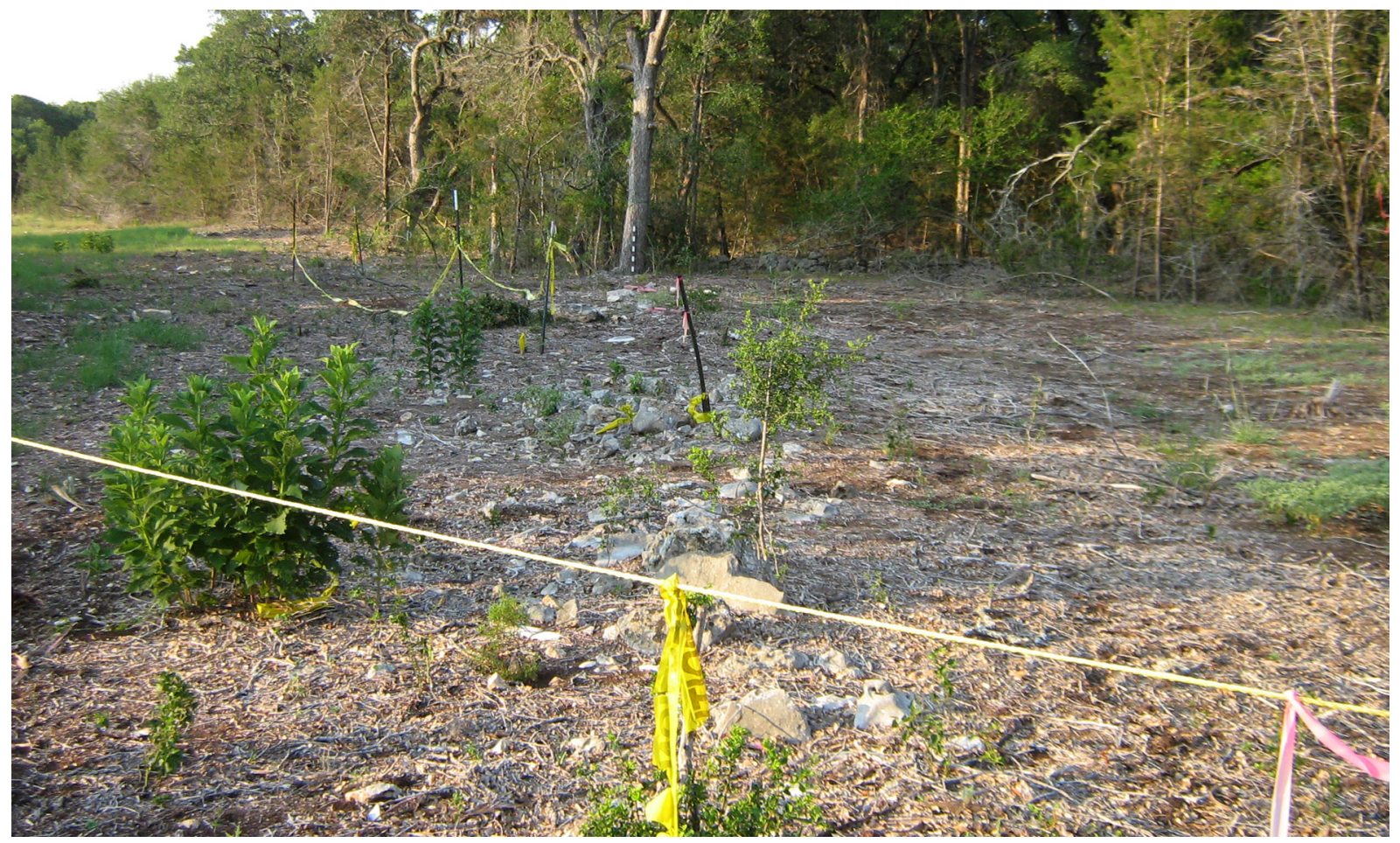

b

Figure 6.13. Photographs of Rock Wall C2. (a) View south of the rock wall just east of the Williams house. (b) View south of the northern end of the rock wall in the cleared LCRA transmission line corridor. Note that Tree 10 is in the background at the corral complex. Scale is $1 \mathrm{~m}$ (39 inches). 


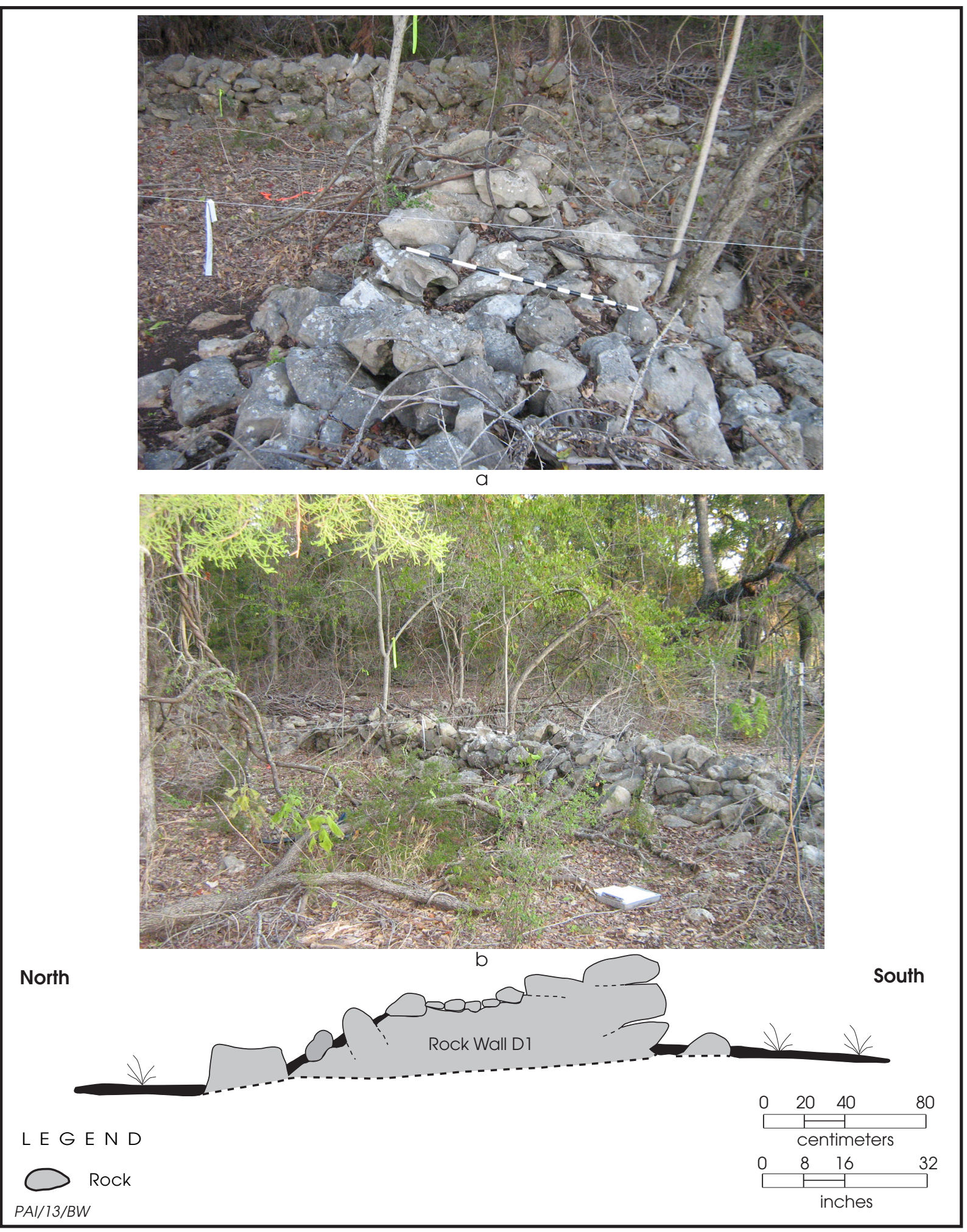

Figure 6.14. Photographs and profile of Rock Wall D1. (a) View west with Rock Wall D1 on the right and Rock Wall E1 in the background. (b) View northeast of the rock wall. Note that the wall extends beyond the SH 45 Southwest right of way (fence at right edge of photo) into the LCRA easement. Scale in both photos is $1 \mathrm{~m}$ (39 inches). (c) Profile of section of the rock wall. 


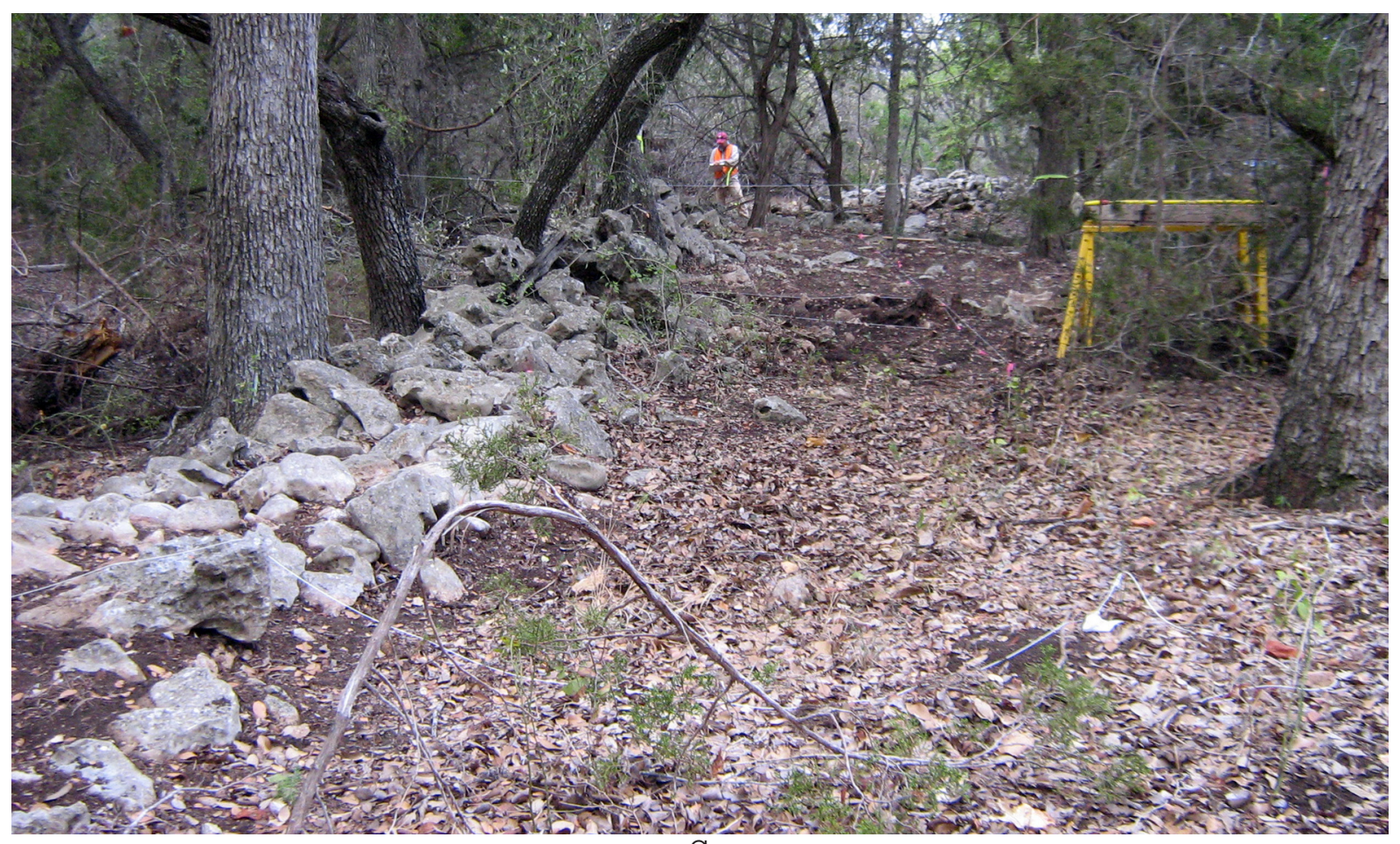

a

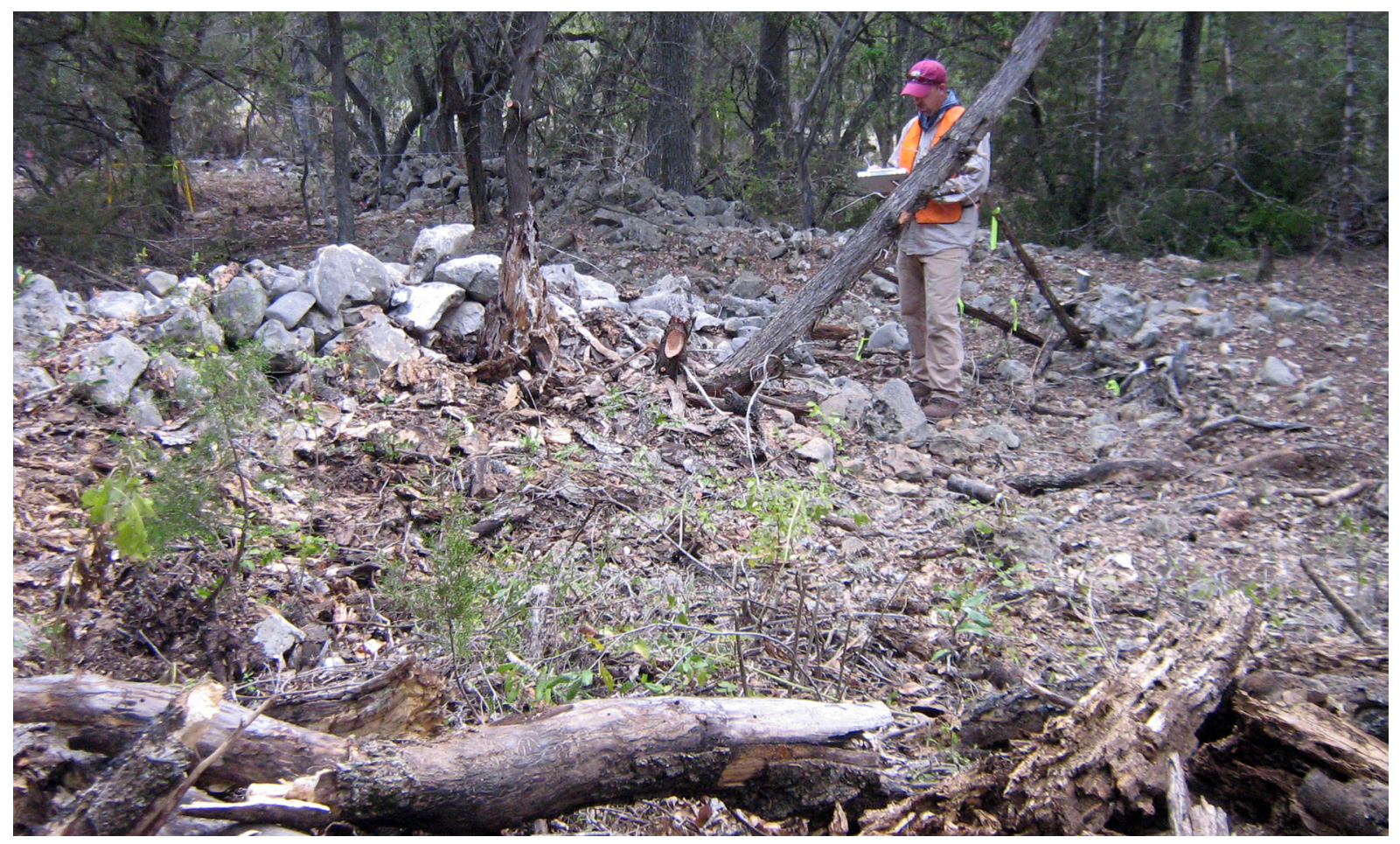

b

Figure 6.15. Overview photographs of Rock Wall E1. (a) View south of the west side of Rock Wall E1, taken from the pond location. The archeologist is standing at the point where Rock Wall E1 abuts Rock Wall F1 (to his right). Note that Excavation Unit Z is being dug in the center of the photo. (b) View northeast showing the confluence of Rock Wall E1 (in the background) with Rock Wall F1 (in the foreground). The archeologist is standing in the drainage gap where the two walls come together and in front of the wooden fence posts. 


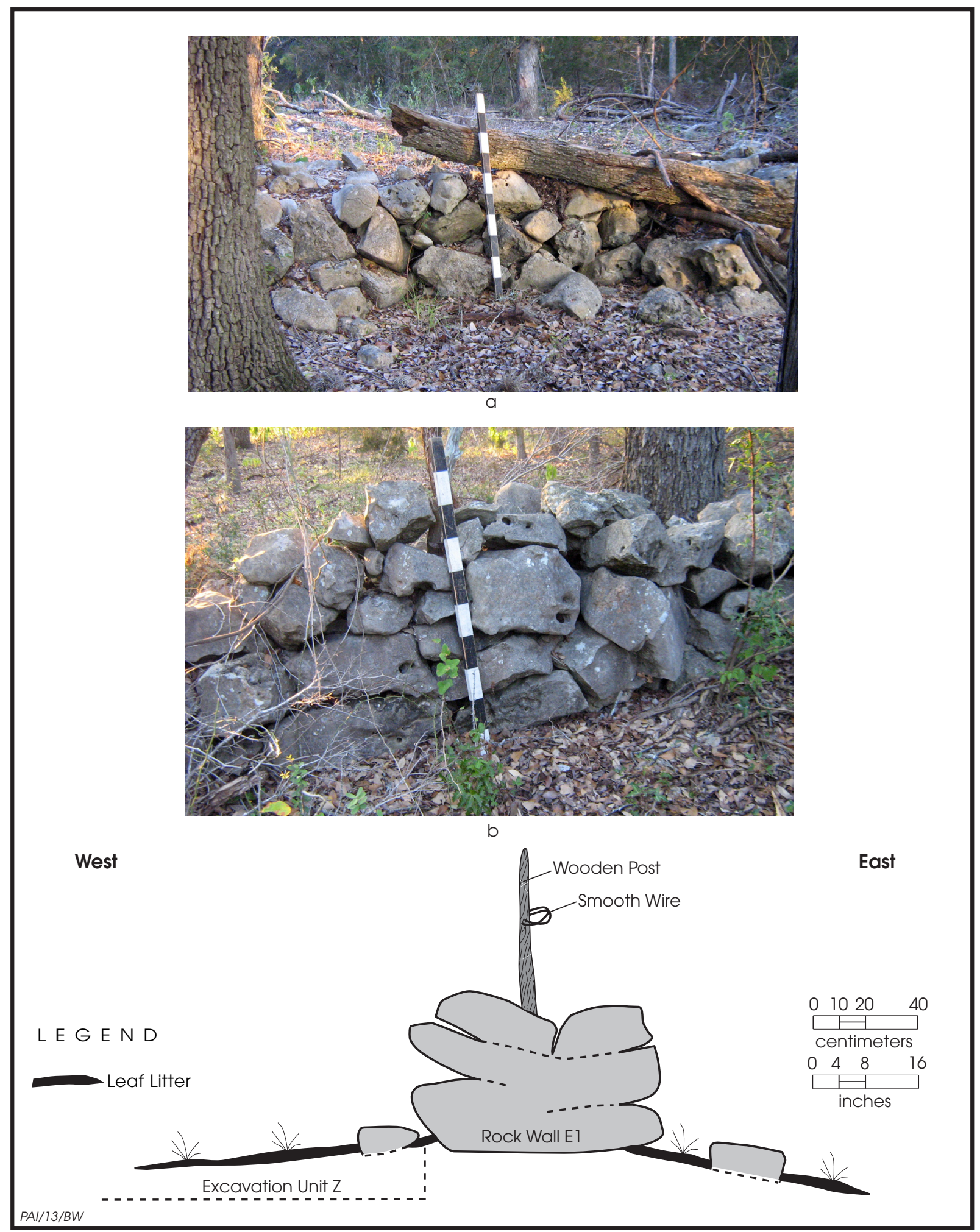

Figure 6.16. Photographs and profile of intact sections of Rock Wall E1. (a) Looking west-northwest at the east face of the rock wall with the pond area behind the wall. (b) Looking west at the east face of the rock wall, with vertical wooden post behind the scale. Scale is $1 \mathrm{~m}$ (39 inches). (c) Profile of rock wall at location of Excavation Unit Z. 
relatively flat edges. Vertical cedar posts are present in four places within the wall; they were obviously placed there to add a wire fence above the wall. Segments of smooth wire were observed wrapped around two of the posts, but no fence staples or barbed wire were observed. The posts appear to be set down into the lower rocks (not into the ground), and it is likely that they are an early- to mid-twentieth-century addition to the rock wall.

The southern end of Rock Wall E1 terminates at the east end of Rock Wall F1, and the two walls form a right angle with a small gap (about $6 \mathrm{ft}$ ) between them. An ephemeral drainage runs eastward along the north edge of Rock Wall F1, and it then turns and flows northward through this gap toward the pond location downslope. Three wooden (cedar?) posts in the gap were originally set vertically into the ground or in holes dug into the bedrock, but they now lean prominently to the west (see Figure $6.15 \mathrm{~b}$ ). Several strands of barbed wire (Types 1 and 5) are attached to these posts with fence staples, and one of these strands extended west on top of Rock Wall F1 and connected to Tree 38 (see Tree Feature 38 below). These posts indicate that a section of barbed-wire fence was used to span the gap between the rock walls, which allowed rainfall runoff from the uplands to flow through.

Rock Wall E2 appears to be a continuation of Rock Wall E1, but there is a distinct gap between the two (see Figure 6.6). Rock Wall E2 extends north-south for $147 \mathrm{ft}$, and most of it is located in the LCRA easement outside the proposed highway right of way (Figure 6.17). The wall is entirely collapsed and is less than 12 inches high. The original rock wall was probably about $3 \mathrm{ft}$ wide, but the rocks are now widely dispersed (as much as 60 inches). Rock Wall E2 was probably part of a livestock pen along with Rock Walls C2 and D1.

\section{Rock Wall F}

Rock Wall $\mathrm{F}$ is the most intact and impressive manmade feature to have survived on the Williams farmstead, and it represents a tremendous amount of hard labor (see Figure 6.6). Beginning at the gap confluence with Rock Wall E1, Rock Wall F is $287 \mathrm{ft}$ long and extends west and then northwest following the natural contours of the slope. For discussion purposes, the wall was divided into the eastern half, called
Rock Wall F1, and the western half, called Rock Wall F2. But it is a single rock wall, and the differentiation is based on the post-abandonment alterations and current conditions of the two sections. The main difference is that the F1 section is much more intact (Figure 6.18), while the F2 section is collapsed (Figure 6.19). Relative to most of the other rock walls on the Williams property, it is clear that relatively few rocks were removed from Rock Wall $\mathrm{F}$ after the farmstead was abandoned.

Several intact sections of Rock Wall F1 were profiled and documented, and hand excavations were conducted in several places to find the bottom of the wall (i.e., the bottom course of laid stones). This evidence reveals the construction details and formal design elements incorporated into this wall. Figure 6.20 shows a segment in the center of Rock Wall F1 where the wall is 33 inches tall and 48 inches wide. Figure 6.21 shows a segment at the west end of Rock Wall F1 where the wall is 28 inches tall and 57 inches wide. As these illustrations show, the north and south faces of Rock Wall F1 were neatly arranged, with the north face being particularly flat and tall in all areas where it was undisturbed. It is clear that some effort was expended to select large flat rocks and align their surfaces on the north wall face. Somewhat less attention was paid to neatly facing the rock surfaces on the south edge, suggesting that the main livestock pen was on the north side of the wall. Although the intact sections of Rock Wall F1 are not particularly tall (generally 24 to 33 inches), they are very wide (generally 36 to 57 inches). Rock walls of this size are more than sufficient to contain large livestock because horses and cattle cannot step over such barriers.

Another observation made in many places along Rock Wall F1 (particularly in the eastern half) is that the ground surface was higher on the south side than the north. Excavations in several locations revealed that 8 to 20 inches of fine-grained sediment had washed in, effectively burying the bottom layers of rock on the south face (see Figure 6.20b). Rock Wall F1 acted as a dam and trapped slopewash sediments along its south face over an extended period of time. It is likely that Ransom Williams would have kept the south side of Rock Wall F1 cleaned out so that water would flow east and end up in his pond. If so, then the sediment accumulation 


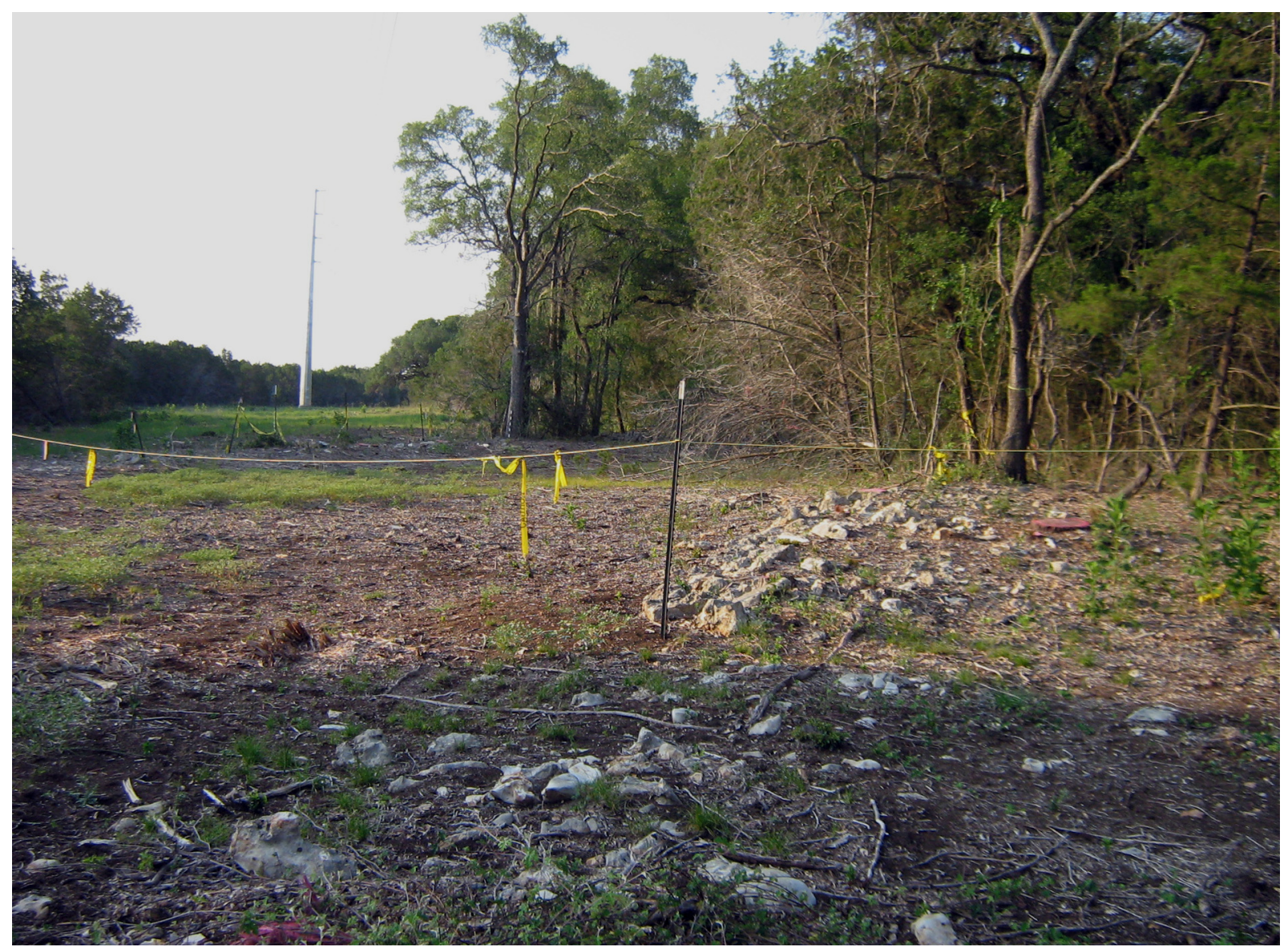

Figure 6.17. View of the north end of Rock Wall E2 in the LCRA easement, looking southeast. Note the dispersed nature of the limestone rocks.

did not begin until the Williams family stopped using the pond, which may have occurred when they left the property about 1905 or possibly when they sold the land in the 1930s and 1940s.

As mentioned above, Rock Wall F2 is essentially collapsed. In almost all areas, the uppermost rocks have fallen down from the top of the wall or were pushed off. The result is a long linear jumble of rocks dispersed as much as 5 to 6 feet in most areas (see Figure 6.19). The most intact section is only 28 inches tall, and most sections are less than 18 inches tall. The lower courses of rocks, which are intact in several areas (Figure 6.22), make it is clear that the original wall was about 30 to 36 inches wide. The rather consistent dispersal of the stones over most of Rock Wall F2 appears to have been intentional. A later owner could have pushed down this long wall section so that animals could walk over it, or perhaps local children facilitated its destruction.

\section{Rock Alignment G}

Rock Alignment $\mathrm{G}$ is a discontinuous rock alignment that extends horizontally for $234 \mathrm{ft}$ and follows the boundary between the cleared upland fields to the south and the wooded area to the north (see Figure 6.6). This rock alignment more or less parallels Rock Wall F, but it is much more ephemeral and extensively disturbed. In fact, Rock Alignment G is only a scatter of limestone boulders and cobbles in most places, and in some places it is little more than a cluster of rounded cobbles of chert and limestone. The rocks form a line that can be traced across a long distance, but there are no hints in any areas that it was once a wall of stacked rocks. Shallow 
excavations were made in several areas to look for large in situ rocks that might represent an intentionally laid bottom wall layer, but no such evidence was observed.

Rock Alignment $\mathrm{G}$ is not a constructed wall but is probably a line of fieldstones that were removed from the cultivated field to the south (Figures 6.23 and 6.24). Two main lines of evidence support this conclusion. First, when compared with the large tabular limestone rocks in Rock Wall F, the rocks in Alignment $\mathrm{G}$ are more variable in size. In some places, limestone boulders predominate; in others, many small rounded chert and limestone nodules of the kind that are typically found in the stony clay upland sediments are more prevalent.

Second, Rock Alignment G follows the natural topographic break where the flat upland ends and drops off to the north and east along an exposed bedrock ledge. The topographic break is subtle, only 10 to 18 inches, but the rock alignment undoubtedly follows it and represents an accumulation of rocks on top of the ledge. Therefore, it is likely that Rock Wall G was built up over many years as the Williams family members plowed the field, picked out the stones, and discarded them at the edge of the woods. It was probably intended to serve as a field border rather than a livestock fence, although this does not preclude the possibility that a wood-rail or barbed-wire fence was present at this location. Rock Wall G shares many characteristics with Rock Alignment $\mathrm{H}$ and the large rock mounds discussed below.

The rock accumulations in Alignment $\mathrm{G}$ are less than 18 inches above the original surface in all locations. Rock Alignments G1 and G2 are essentially the same, although Rock Alignment

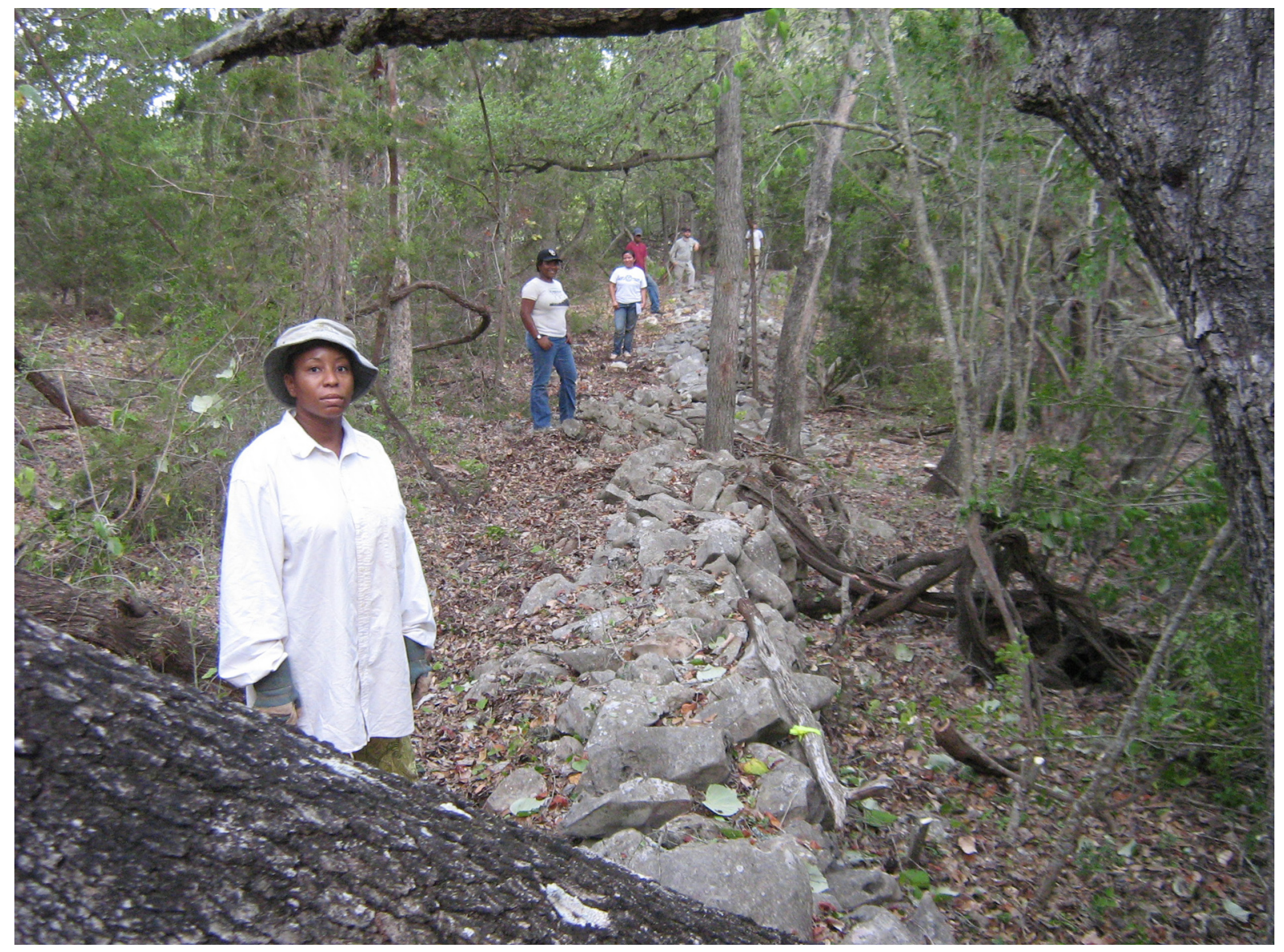

Figure 6.18. Overview photograph of Rock Wall F1, looking west from the location of Tree 38 (branches in foreground). The archeologists standing on the wall provide scale and depth perspective. Note that the ground surface to the left is higher than the ground surface to the right. 


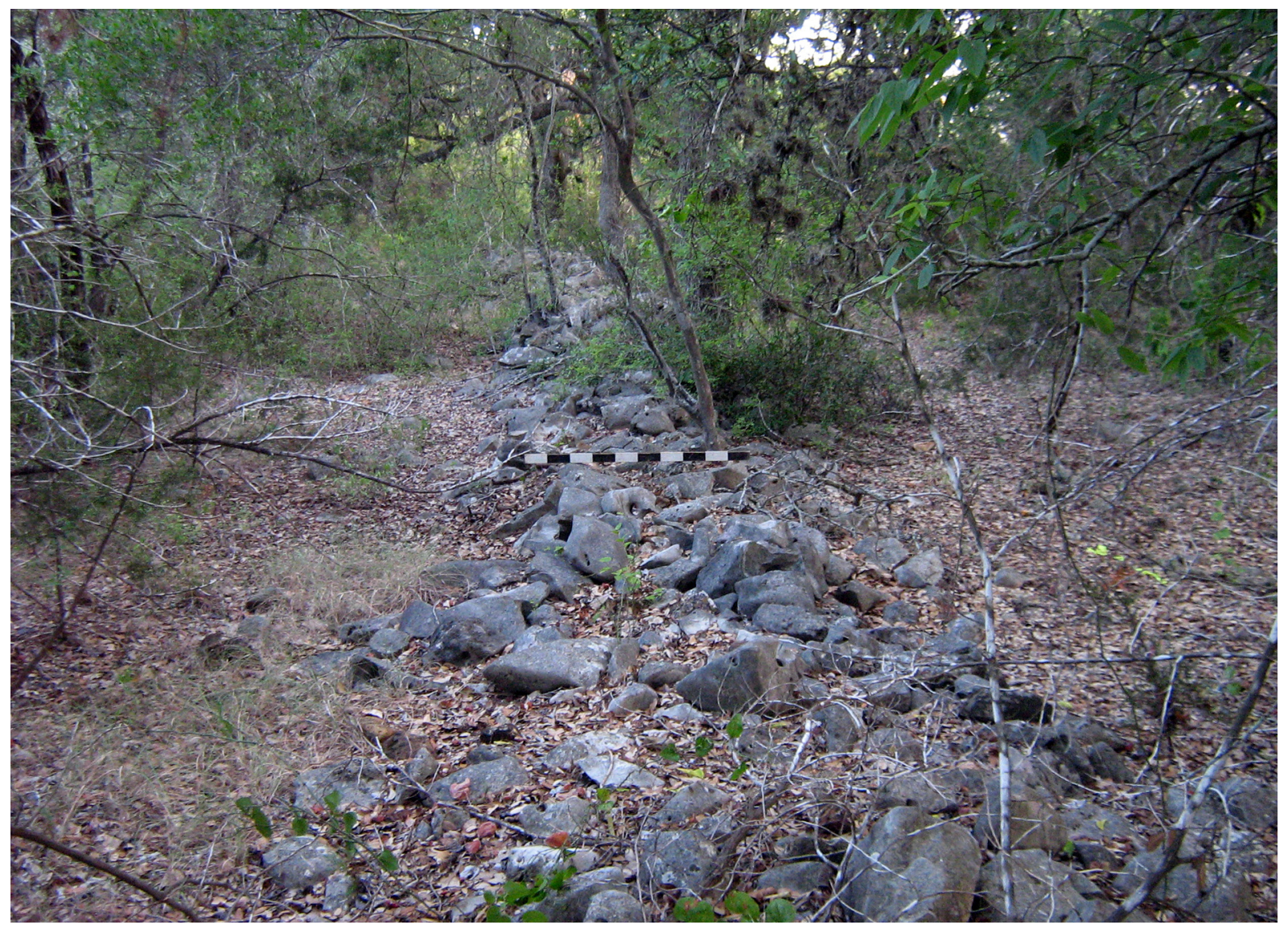

Figure 6.19. Overview photograph of the northwestern end of Rock Wall F2, looking northwest. The large tree at the end of the wall is Tree 53. Scale is $1 \mathrm{~m}$ (39 inches).

G2 tends to have more small cobbles associated. In one area where modern vehicles have crossed over Alignment G2 and Wall F2, the cobbles in Alignment $\mathrm{G} 2$ are dispersed as much as $7 \mathrm{ft}$ wide (see Figure 6.23a).

Rock Wall F and Rock Alignment G run generally parallel about $25 \mathrm{ft}$ apart, narrowing in one section (Alignment G2 to Wall F2) to about $10 \mathrm{ft}$ apart. One of the most notable characteristics is a swale that runs between them (see Figure 6.23b). It appears that this swale may have been an old road that ran along the edge of the fields and the wooded pasture. In some areas it is subtle, perhaps having been backfilled with slopewash sediment after the farmstead was abandoned. But in other areas, the swale is still quite prominent, with local relief of 12 inches or more.

While Rock Alignments G1 and G2 are unmistakably in the locations where they were originally deposited, the rocks mapped as Rock Alignment G3 may not be in their original place. Rock Alignment G3 is a very short segment, being only $23 \mathrm{ft}$ long. Several large limestone boulders and cobbles are present in this area, but they do not form a perfect linear arrangement. Even more problematic is the fact that they are all in the swale area between Wall $\mathrm{F}$ and Alignment G, meaning that they are where an old road used to be. It is possible that these rocks were once a continuation of the east end of Rock Alignment G2 but that they got moved and scattered in the old road swale. It is not known if they were moved by people or as a result of natural processes. Many large iron barrel hoops (complete and fragments) were found in the general vicinity of Rock Alignment G3, suggesting that wooden barrels and perhaps water may have been stored in this location (Figure 6.25). 


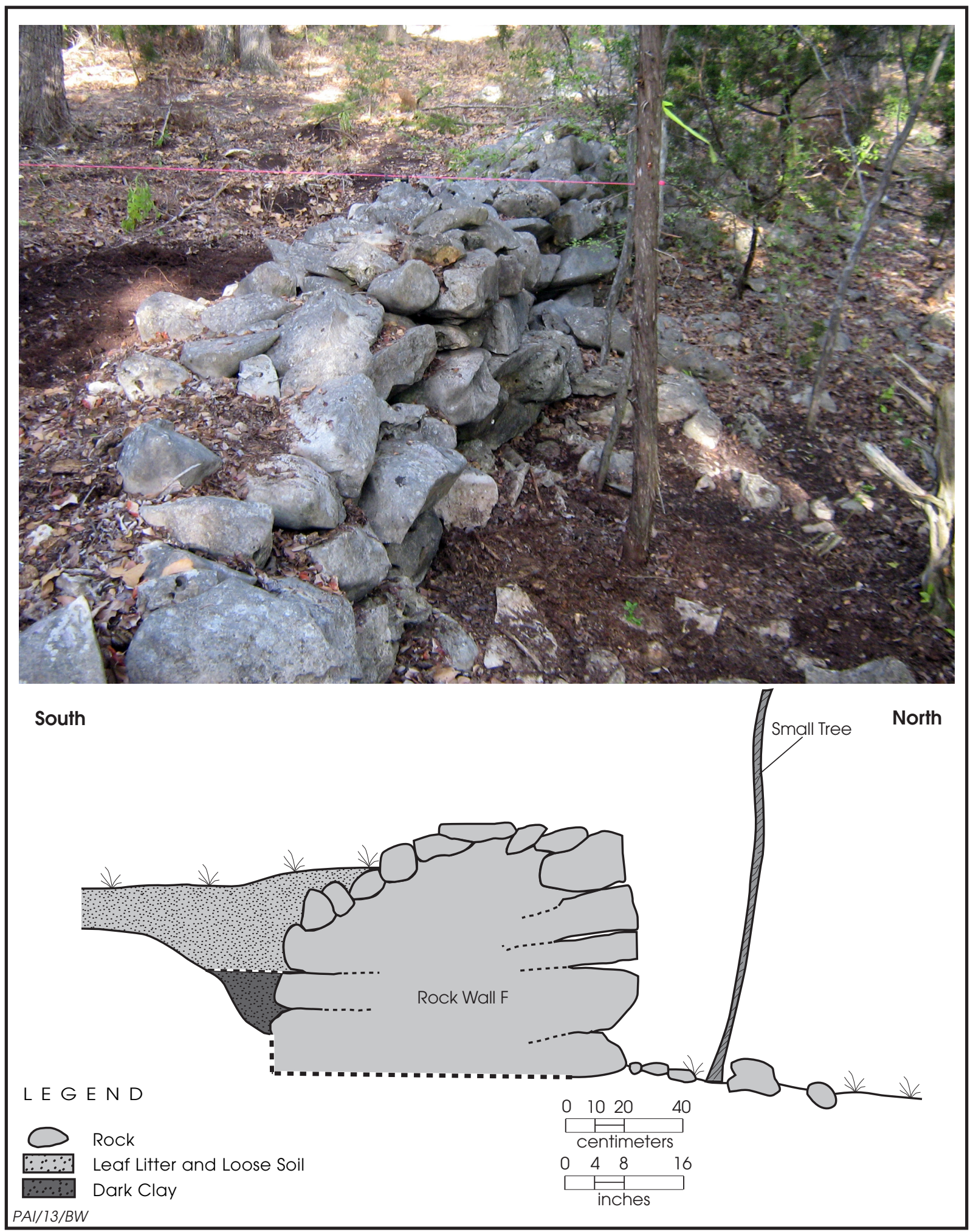

Figure 6.20. Photograph and profile of Rock Wall F1 at the center of the wall. (a) View looking west showing the north face of the wall and the hand-excavated area on the south side of the wall. (b) South-north profile of the rock wall. Note that the higher ground surface on the south side represents sediment and leaf litter deposited after the wall was built. 


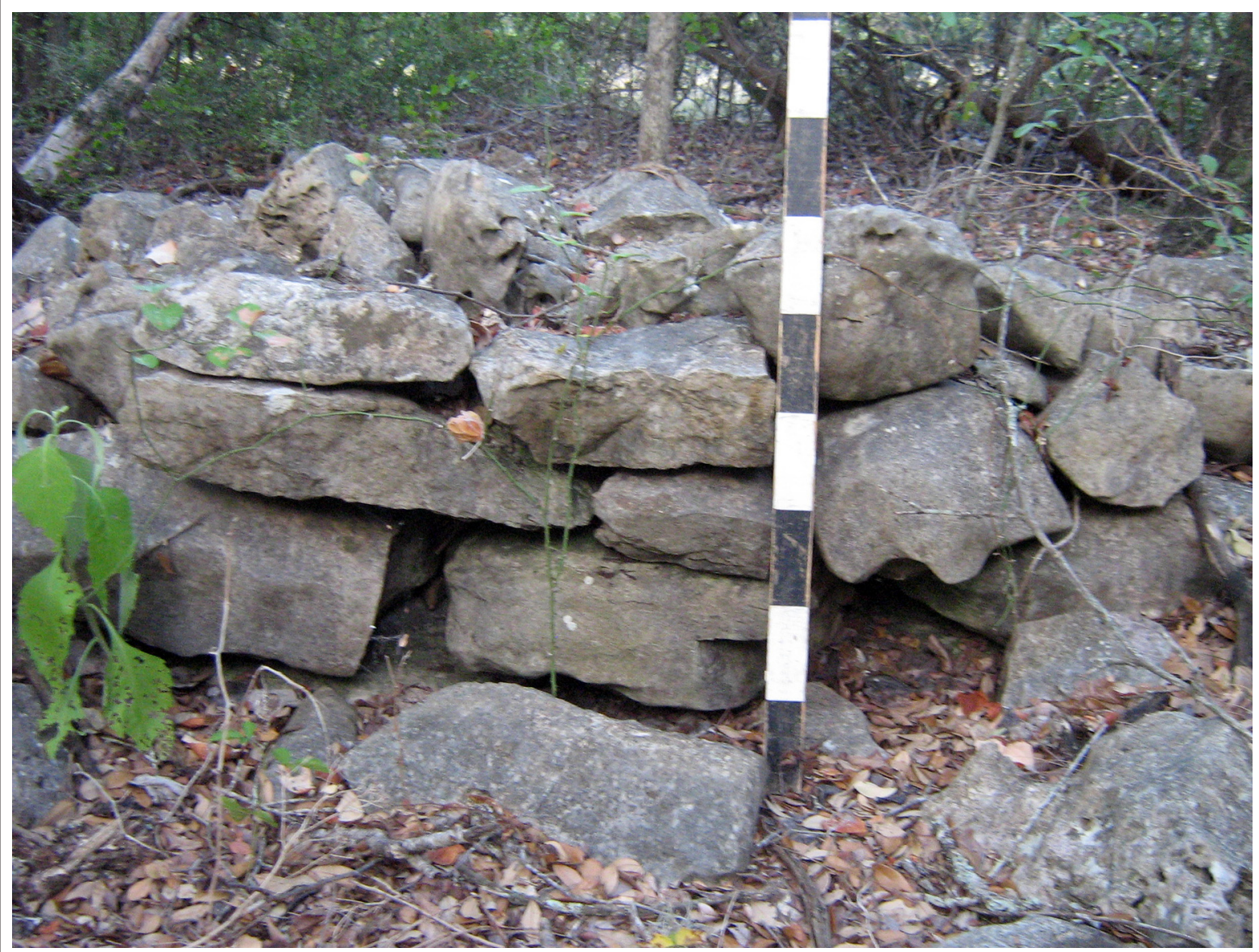

South

North

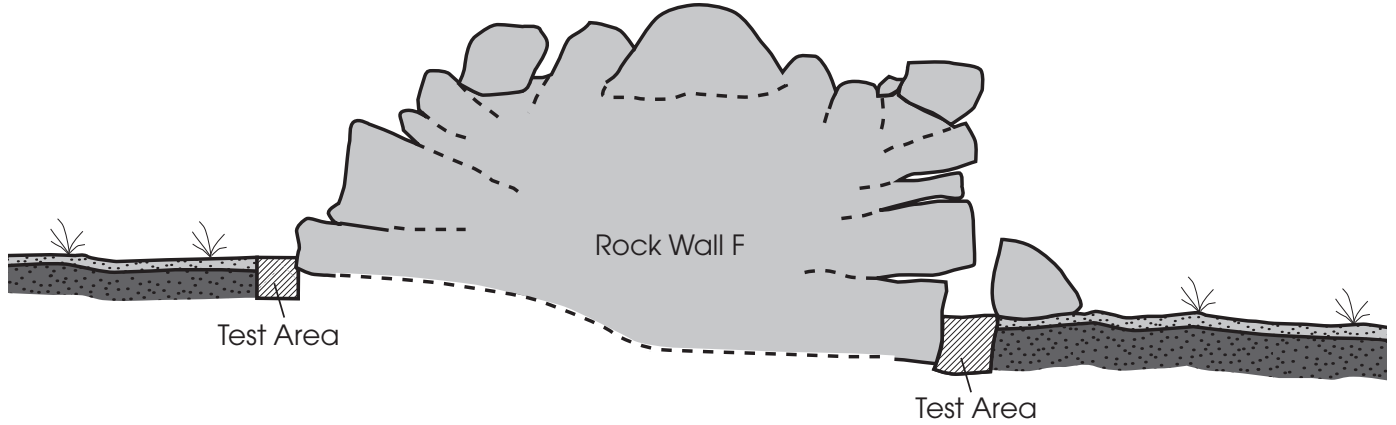

$L E G E N D$

\section{Rock}

Leaf Litter and Loose Soil

Dark Clay

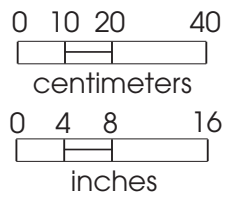

PAI/13/BW

Figure 6.21. Photograph and profile of Rock Wall F1 at the west end of the wall. (a) View of the north face, looking south. (b) South-north profile of the rock wall. Note that the ground surface on the south side is slightly higher than on the north side. 


\section{Rock Alignment $\mathrm{H}$}

Rock Alignment $\mathrm{H}$ extends for $355 \mathrm{ft}$ (see Figure 6.6), with its eastern half running southeast to northwest (called Alignment H1) and its western half running generally east to west (called Alignment H2). It shares many characteristics with Rock Alignment G, and it most likely represents an accumulation of fieldstones removed from the cultivated field to the south and piled up along the edge of the wooded area (Figure 6.26). Rock Alignments $\mathrm{H} 1$ and $\mathrm{H} 2$ are generally very low and widely dispersed, with rock often scattered laterally between 6 and $10 \mathrm{ft}$. One section of Rock Alignment $\mathrm{H} 1$ has jumbled rocks 30 inches high, but all other areas of both alignments are less than 16 inches high.

In some places, there are hints that Rock Alignment $\mathrm{H}$ might have once been a rock wall.
Two or three layers of stacked limestone rocks were observed in a few short segments, but no definite intact wall bases could be identified. Given the location of this alignment at the north end of the cultivated field, modern vehicle access would have been easy in this location. It is possible that Rock Alignment $\mathrm{H}$ was actually a rock wall livestock fence but that virtually all of the stones were carried away in the twentieth century.

\section{Rock Wall Z}

Rock Wall Z is located just outside Ransom Williams's 45-acre farm. It runs north-south in line with Rock Walls C2 and B2 and is essentially a continuation of those walls. The wall was only mapped for $144 \mathrm{ft}$ south of Williams's property line, but it probably extends much farther. There

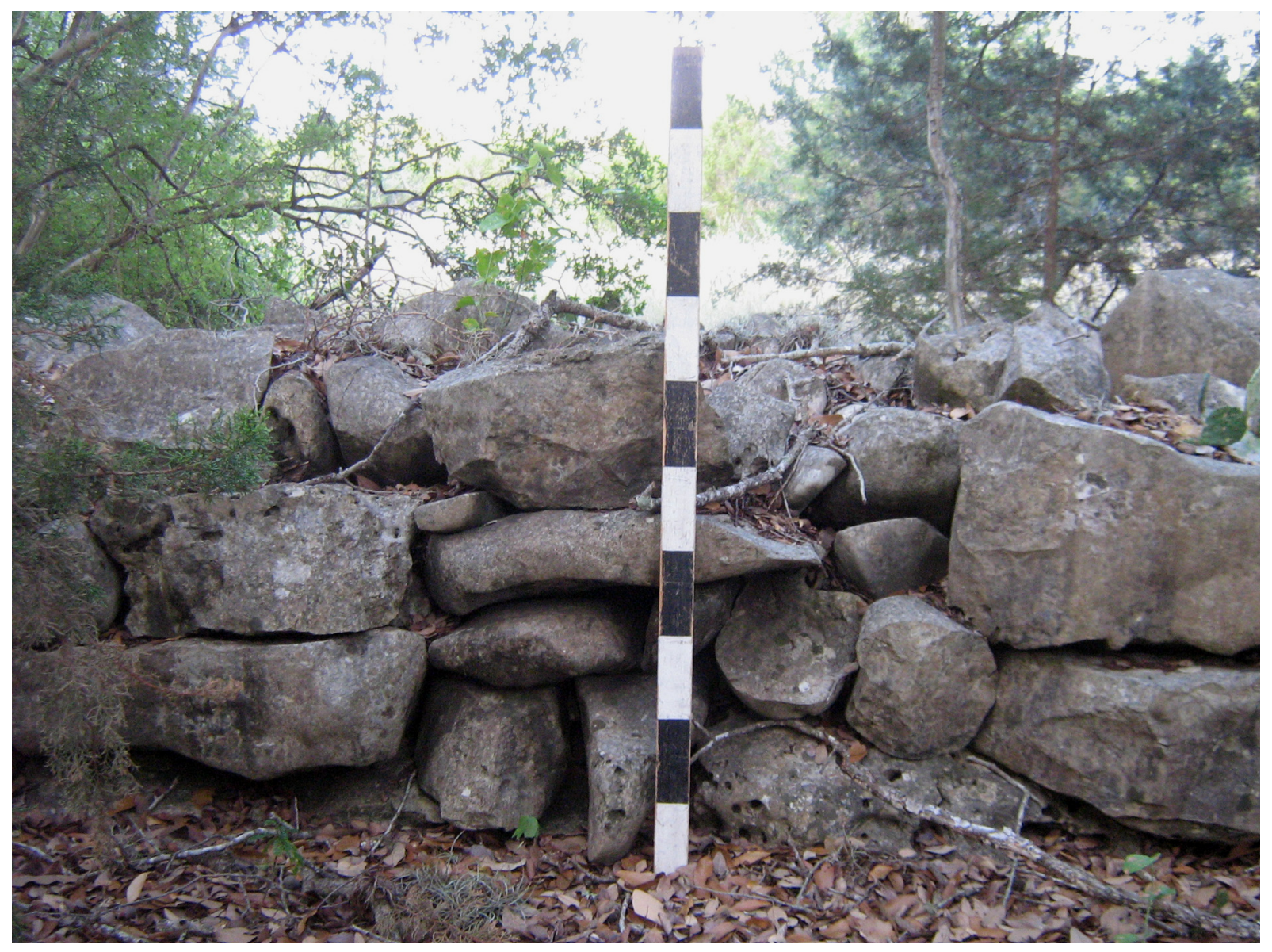

Figure 6.22. Photograph of the best-preserved section of Rock Wall F2. View is of the north face looking southwest. Scale is $1 \mathrm{~m}$ (39 inches). 


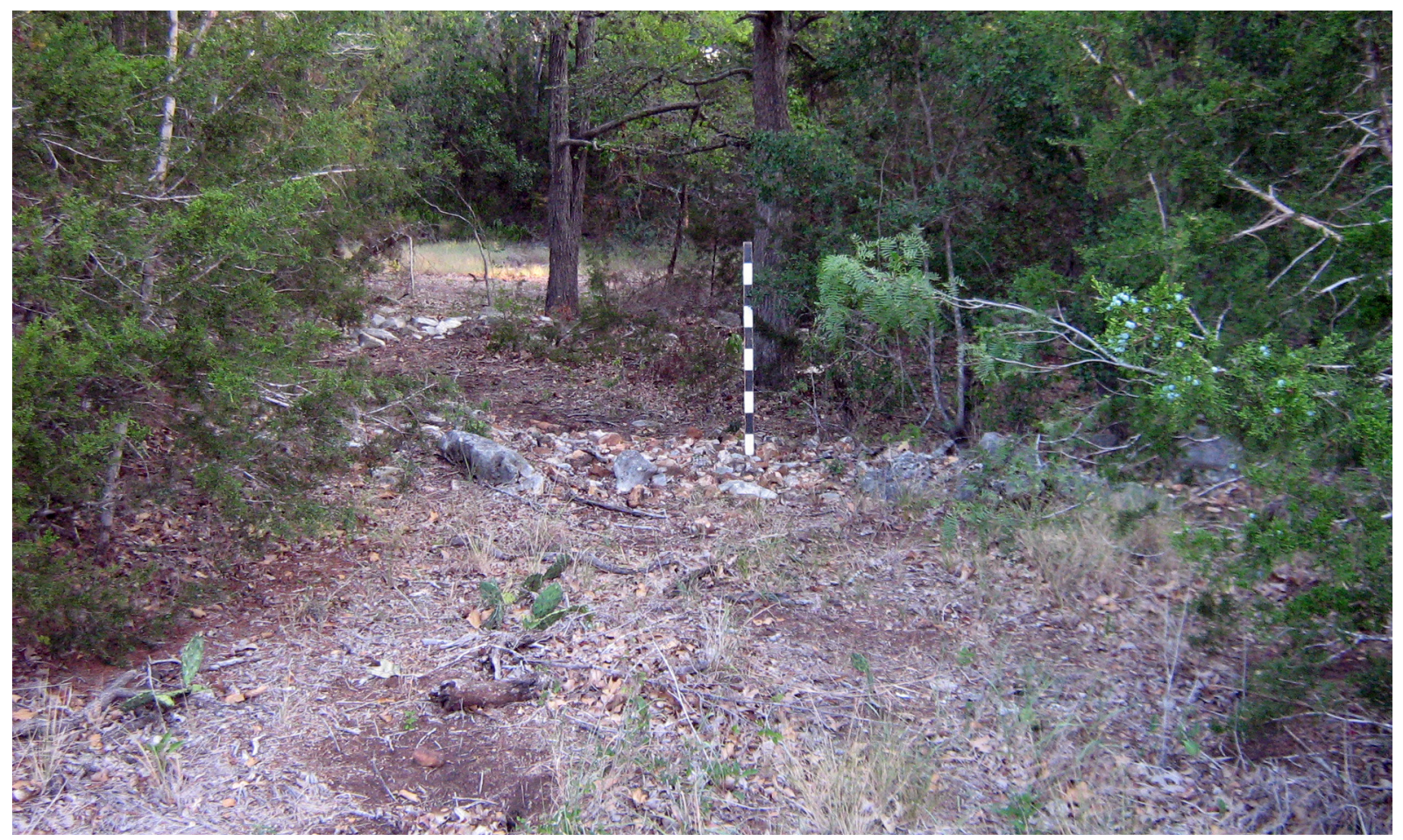

a

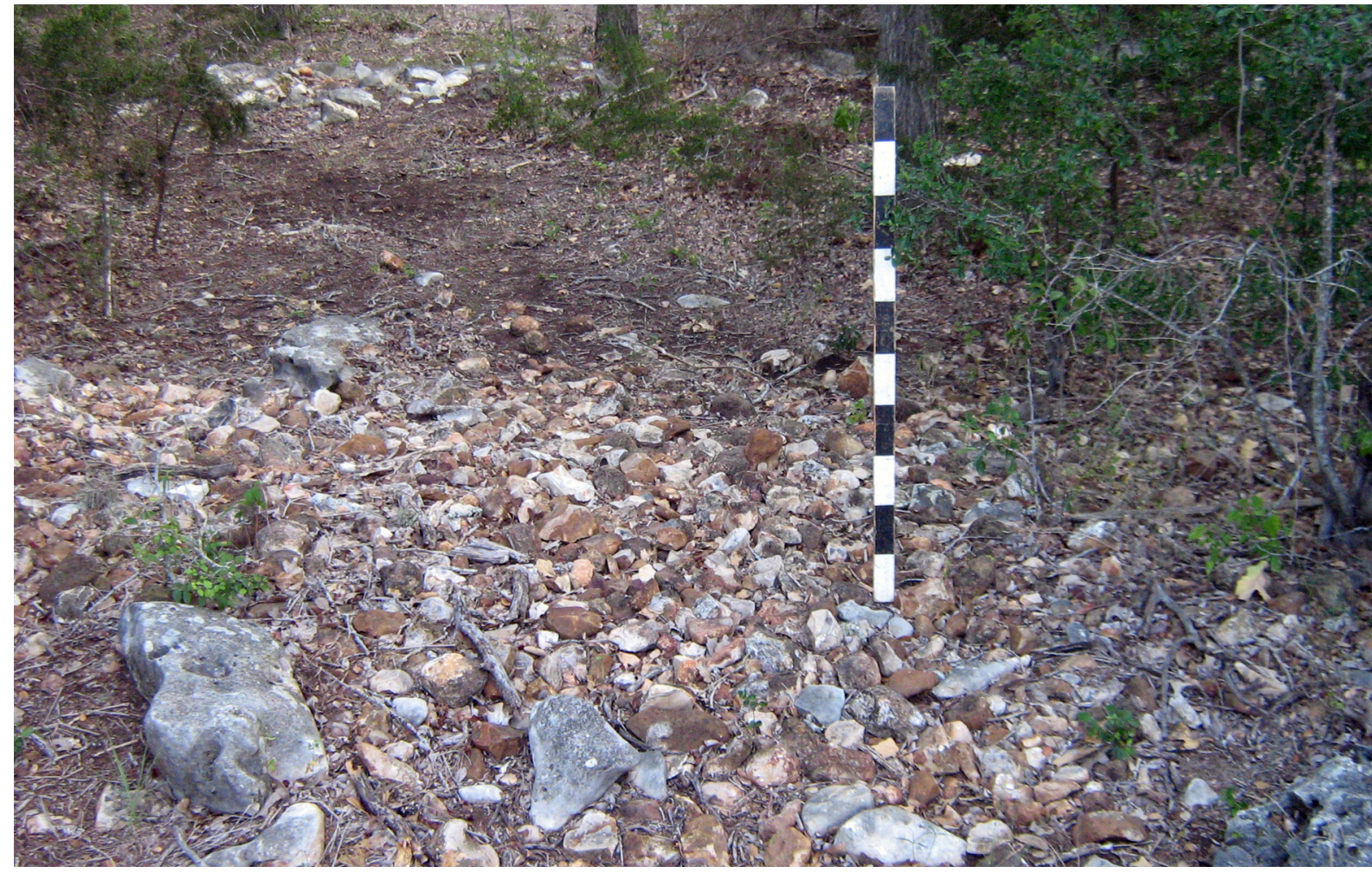

b

Figure 6.23. Photographs showing the relationship between Rock Wall F and Rock Alignment G. (a) Overview looking north with Rock Alignment G2 in the foreground and Rock Wall F2 behind. (b) Closeup view looking north at the cobble and boulder concentration of Rock Alignment G2 with Rock Wall F2 in the background. Scale is $1 \mathrm{~m}$ (39 inches). 


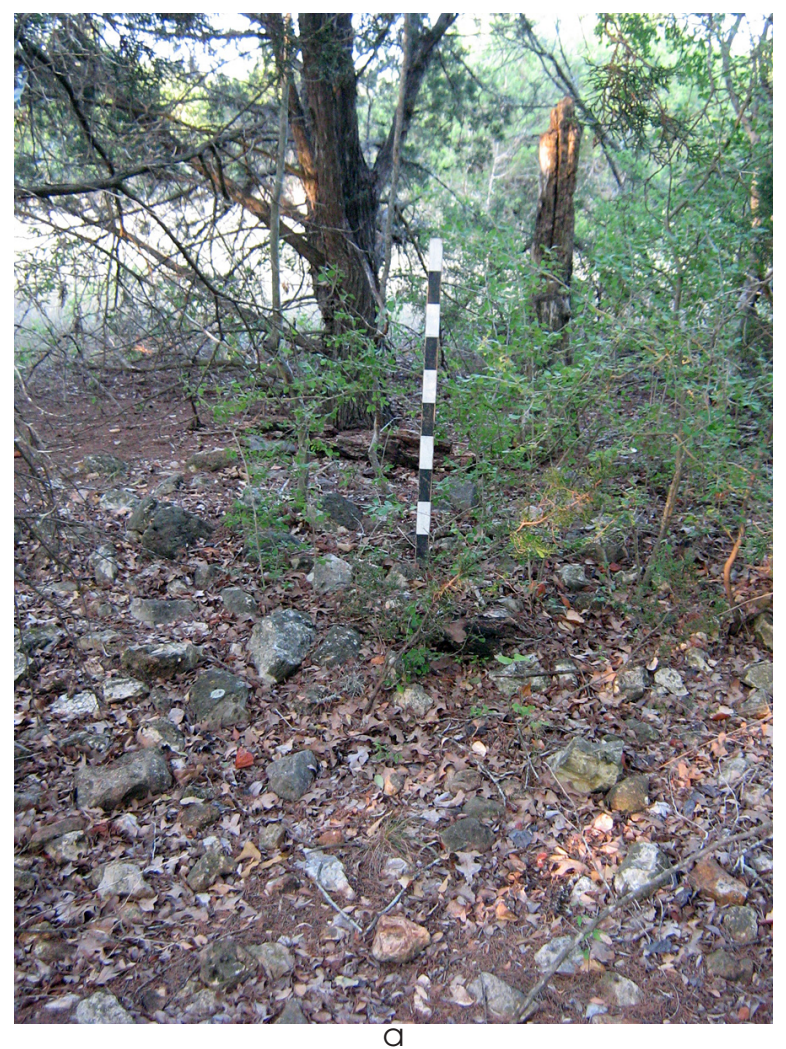

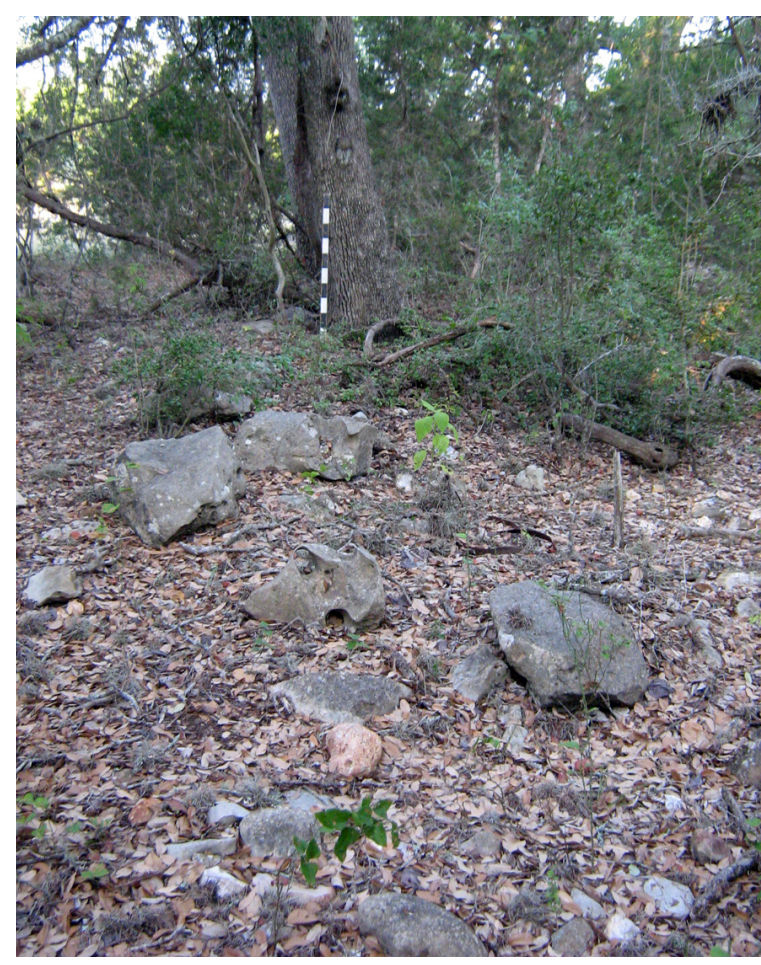

b

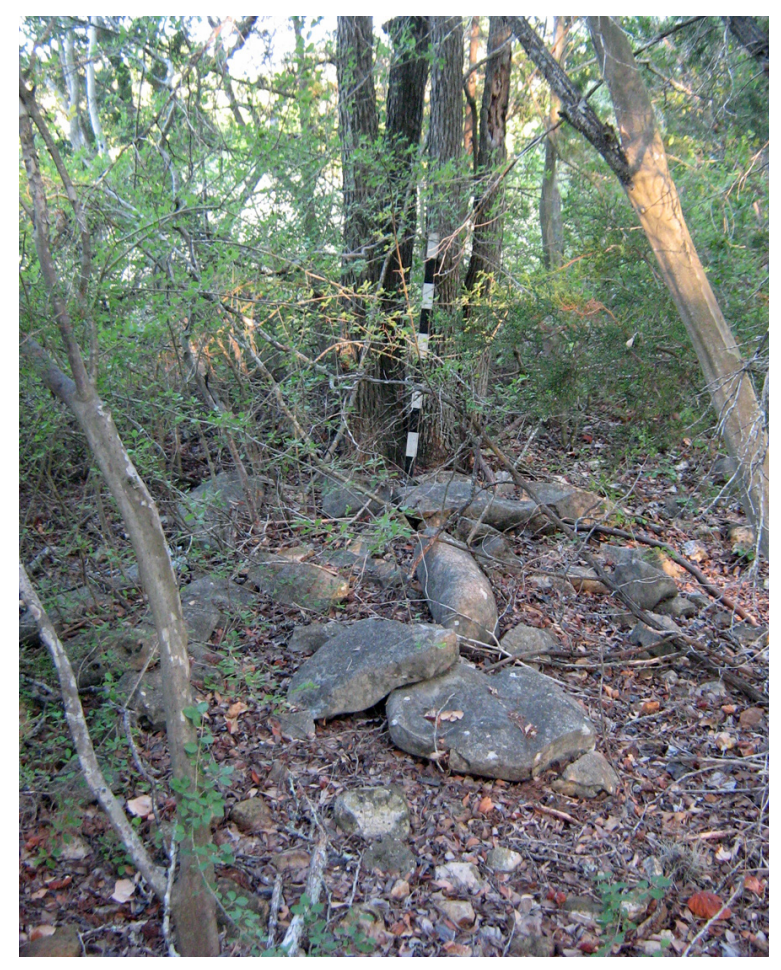

C

Figure 6.24. Photographs of limestone rocks in Rock Alignment G2. (a) View of scattered limestone boulders and limestone and chert cobbles with Tree 57 in the background. (b) View of scattered chert and limestone cobbles just west of Tree 57. (c) View of scattered limestone boulders near the west end of Rock Alignment G2. Scale is $1 \mathrm{~m}$ (39 inches). 


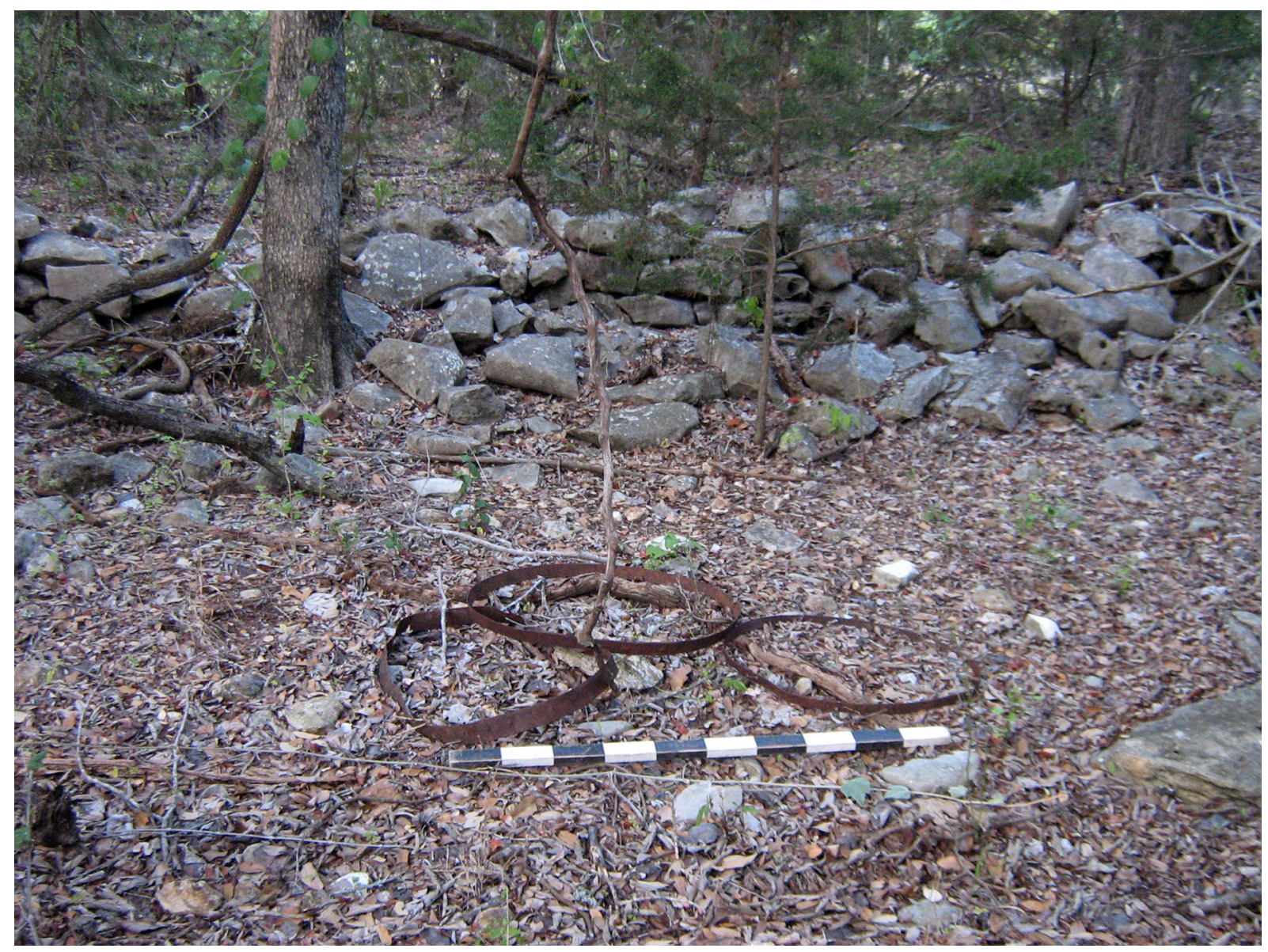

Figure 6.25. Complete iron barrel hoops found just north of Rock Wall F1 in the vicinity of Rock Alignment G3. View is south and scale is $1 \mathrm{~m}$ (39 inches).

are hints that a north-south alignment of rocks may run parallel to, and ca. $15 \mathrm{ft}$ east of, Rock Wall Z. No attempt was made to trace and map this ephemeral rock alignment, but it appears to represent an accumulation of fieldstones piled along the edge of an old road (much like Rock Wall B1). It is clear from the 1937 aerial photograph that Rock Wall Z runs along an old property fenceline, with a probable road along its east side. One tree feature (see Tree 84 below) was found south of, but close to, Rock Wall Z.

One isolated artifact was found on the surface near Rock Wall Z, about $50 \mathrm{ft}$ west of the two-track road. This specimen is a large curved iron mechanical part with the words "HURLBUT MAFG CO PATD MAY 21 1872" and "CALDWELL WAGON" in raised letters (see Figure 8.21). The piece precisely matches the drawing of Part A of the "Improvement in Wagon-Brake Lock" patented by Sidney Hurlbut 1872 (U.S. Patent No. 126,964; Hurlbut 1872). Part A is described as the "a segment-rack having ratchet teeth on its lower edge." No other artifacts were found in this area despite an intensive search and metal detector scans.

\section{The Livestock Pond and Rock Alignment $\mathbf{P}$}

Rock Alignment $\mathrm{P}$ is discussed in conjunction with the livestock pond because it is in close proximity, and its origin is related to the pond (see Figures 6.6 and 6.16a). During the testing phase, Backhoe Trench 1 was excavated to test the idea that Ransom Williams had removed sediment from a low-lying area near the corral complex to create a stock pond. As shown in Figures 6.27 and 6.28, the 22-ft-long backhoe 


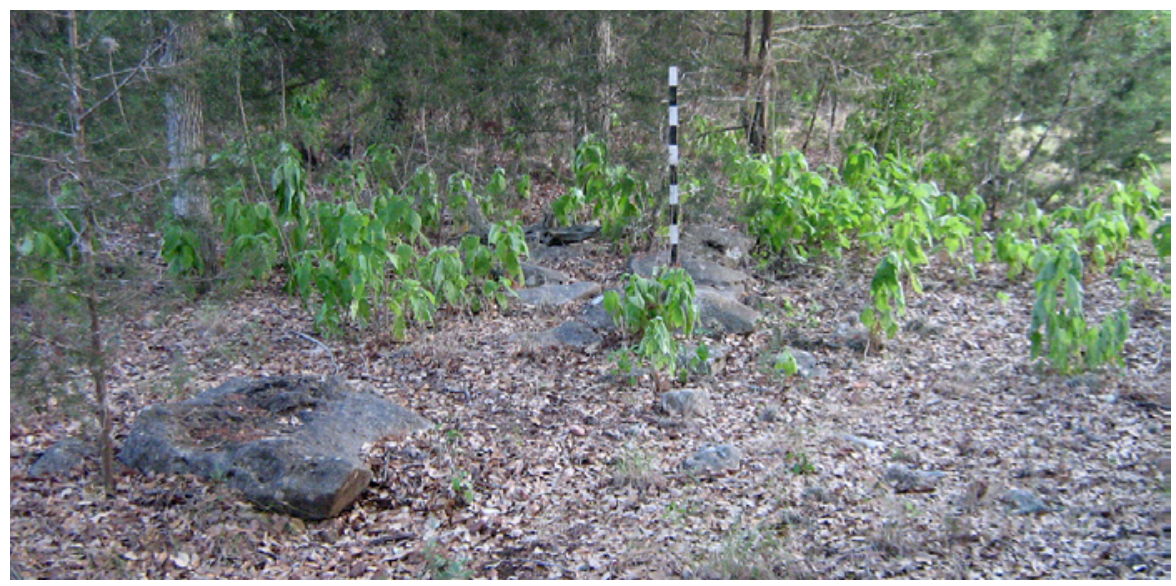

a

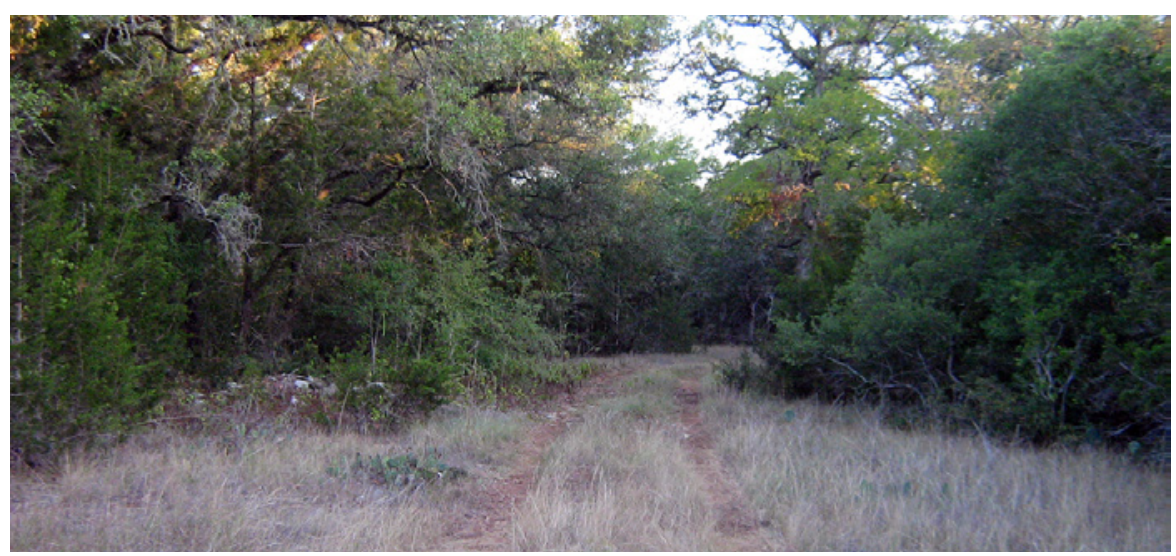

$\mathrm{b}$

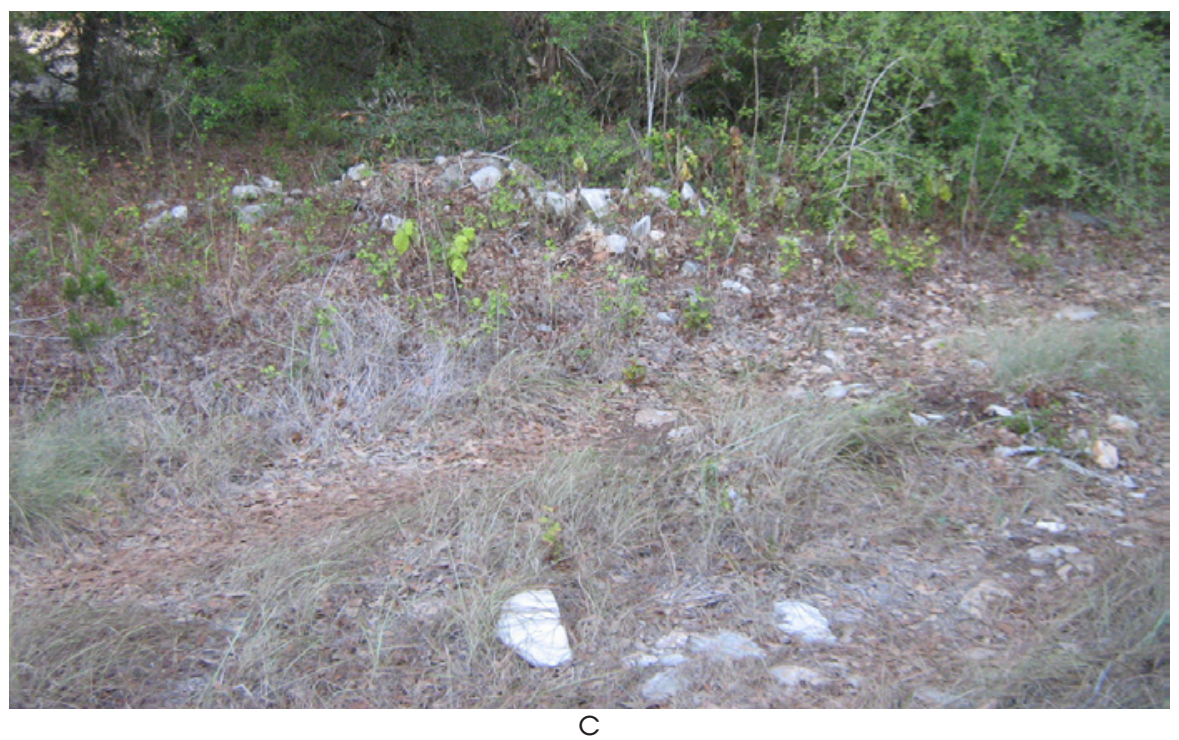

Figure 6.26. Photographs of Rock Alignment H. (a) View northwest of limestone boulders and cobbles at the southeast end of Rock Alignment H1. Scale is $1 \mathrm{~m}$ (39 inches). (b) Overview looking north at the east end of Rock Alignment H2 where the two-track road crosses over the rocks. (c) Closeup view of b, looking northeast and showing the rocks and two-track road. It is likely that rocks were removed from the two-track road and pushed or piled in the area to the left. 
Chapter 6: Landscape Analysis

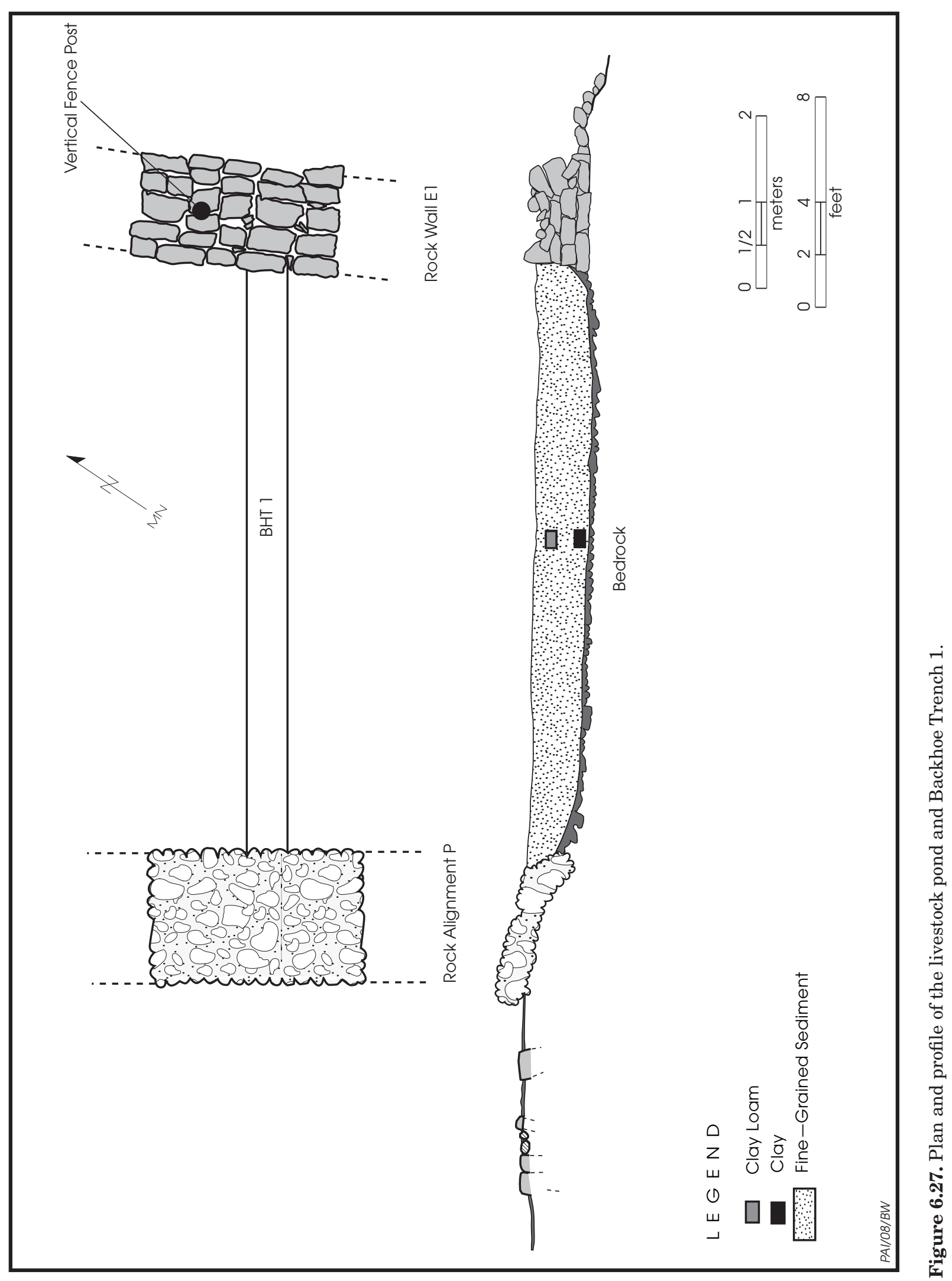




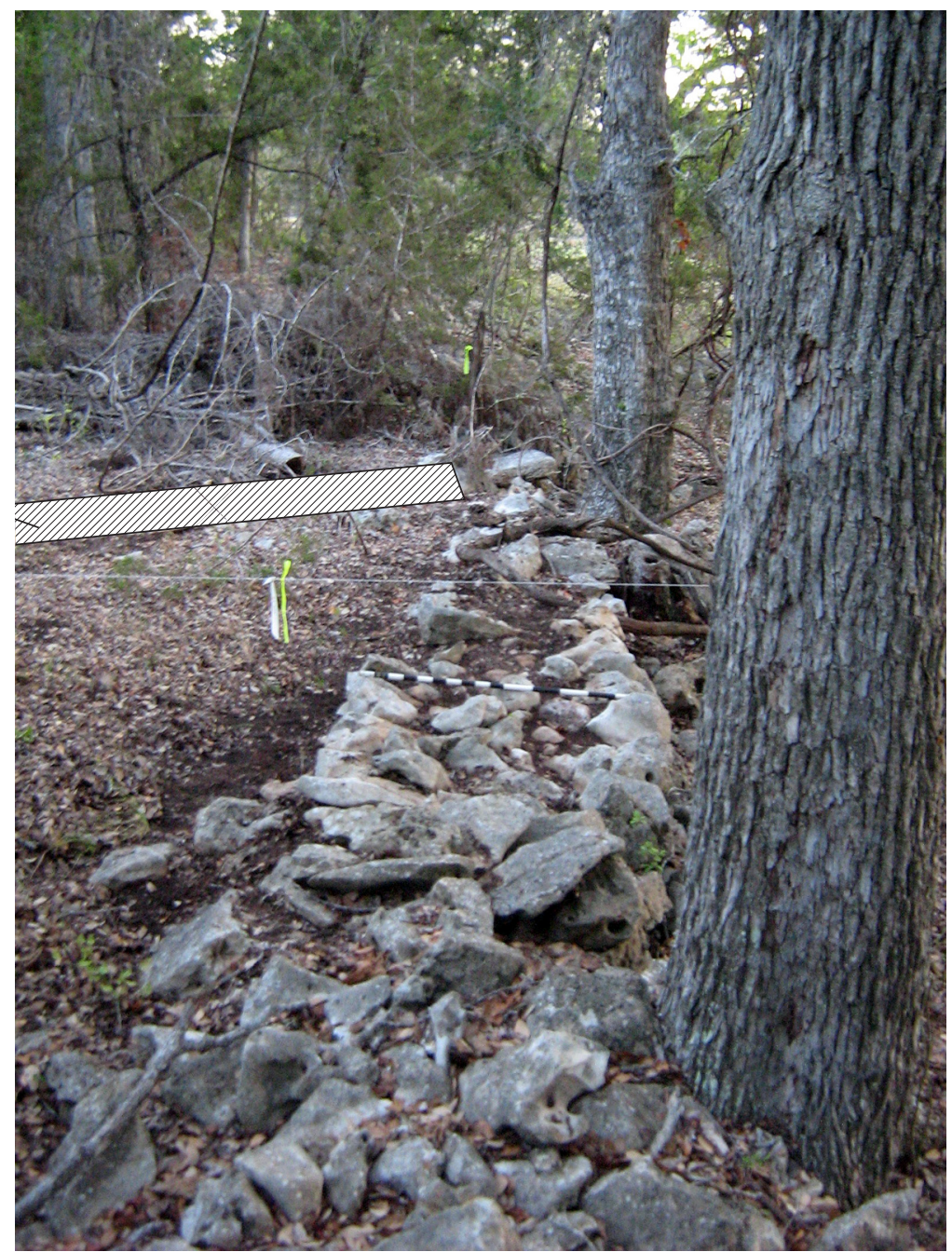

Figure 6.28. Photograph of Rock Wall E1 showing the pond location to the left of the rock wall. Note that the sediment to the left is level with the top of the wall. Location of Backhoe Trench 1 added.

Located on the west side of the livestock pond, Rock Alignment $\mathrm{P}$ is composed of a concentration of rounded cobbles, including chert and limestone, and some scattered larger limestone slabs and boulders. It covers an ovate area of approximately $50 \mathrm{ft}$ north-south by 10 to $15 \mathrm{ft}$ east-west and is definitely an unnatural accumulation (Figure 6.29). The absence of any cobbles in the pond area sediments (see profile in Figure 6.27) strongly suggests that the cobble cluster on the west side of the pond represents an accumulation of natural stones derived from the stony clay fill excavated from the pond area. Once the pond was built, it would have started to fill in with fine sediment. Some of the fine-grained clayey sediment that washed back in may have been from the stony fill that was removed. The subsequent erosional process left behind a lag gravel deposit along the edge of the pond, which is the irregular alignment of cobbles described as Rock Alignment P.

Ransom Williams certainly would have had to maintain the pond by periodically removing any fine sediment that washed in. It is not clear when the pond was finally abandoned, but it began to fill in for the last time as soon as it was no longer used and maintained. By the time of

trench was dug in the slight depression west of Rock Wall E1. The trench profile revealed that the original stony rubified clay sediments had been removed and that the area had been filled in with homogenous dense clayey sediment containing no rocks or pebbles. In the center of the trench, the sediment at 6 to 18 inches below surface was very dark gray (10 YR 3.1) to very dark grayish brown (10 YR 3/2) clay loam. This fine-grained upland sediment was slopewash that was deposited in the depression formed by digging out the fill between the Rock Wall E1 on the east and the natural bedrock slopes on the north, south, and west. the archeological investigations, the pond area had become a barely perceptible swale bounded by the rock wall, the limestone slopes, and the lag gravel deposit.

The southern and western portions of Rock Alignment $\mathrm{P}$ are characterized by a concentration of limestone slabs and boulders (see Figure $16.29 \mathrm{~b})$. At first it was thought that this was a remnant of a manmade rock wall, but more careful inspection revealed that most of the rocks are associated with a natural ridgeline outcrop that runs north-south perpendicular to the eastward slope. Some of the limestone rocks were undoubtedly placed there after being dug 


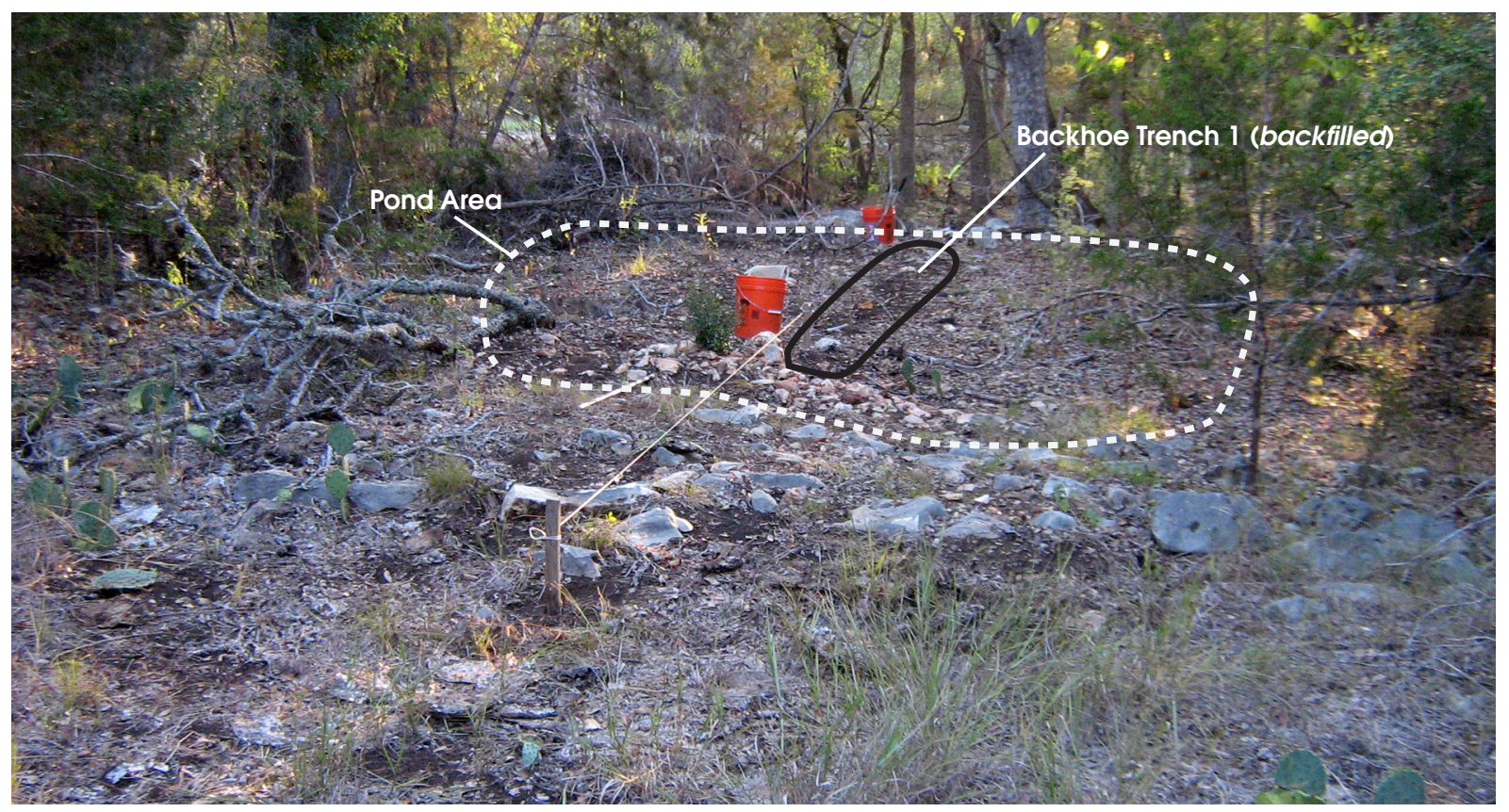

a

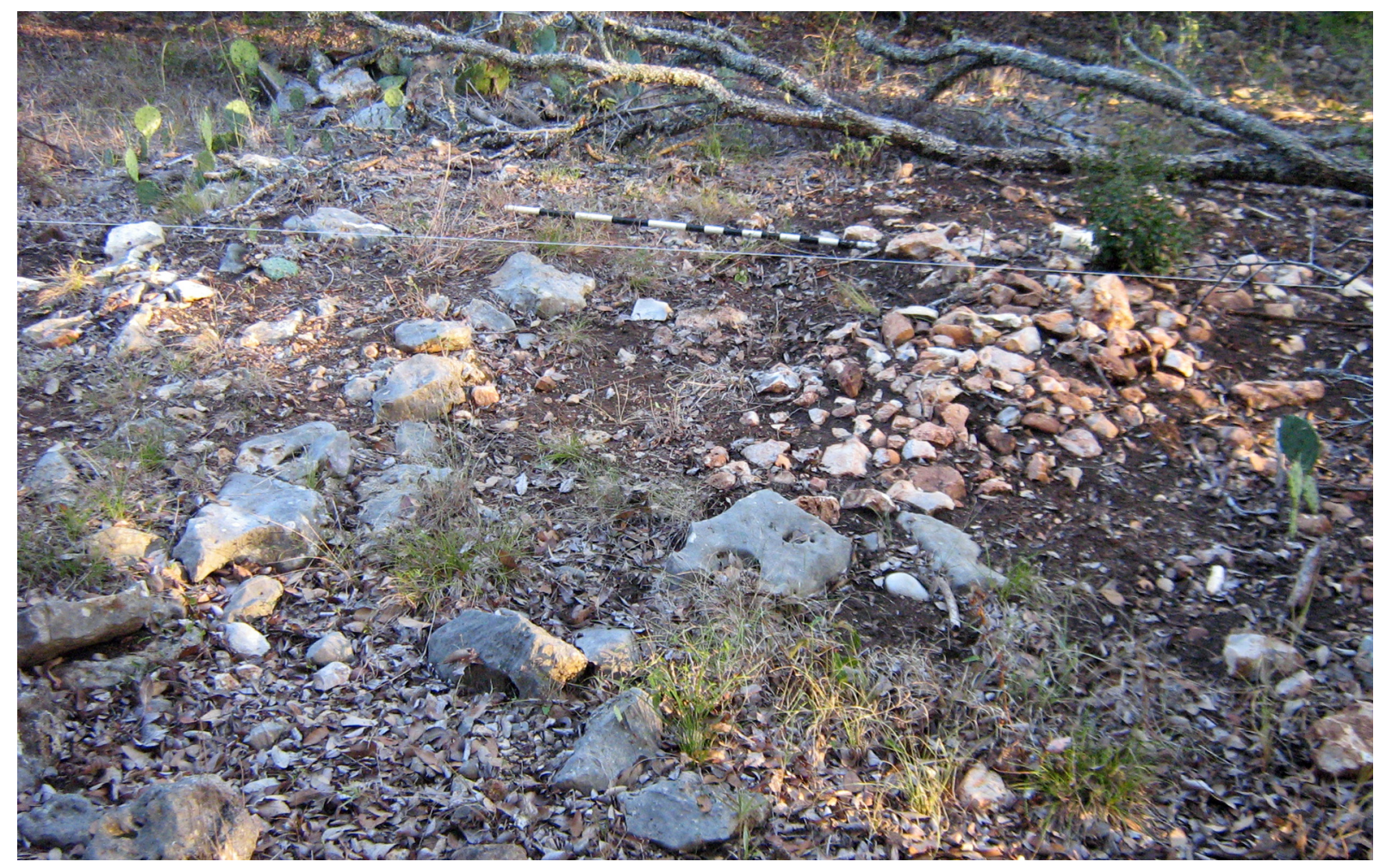

$\mathrm{b}$

Figure 6.29. Photographs of the livestock pond area and Rock Alignment P. (a) Overview looking northeast of the livestock pond area with Rock Alignment $\mathrm{P}$ in the foreground. The orange buckets are on either end of the backfilled Backhoe Trench 1, and the string line extends over Rock Alignment P. (b) Closeup view of Rock Alignment $\mathrm{P}$ on the west side of the pond. The cluster of smaller cobbles on the right comprises the bulk of the rock alignment. While some of the limestone rocks in the foreground and on the right are natural manuports dug out of the pond, most are part of a natural rock outcrop. Scale is $1 \mathrm{~m}$ (39 inches). 
out of the pond area, but these are scattered rocks over the natural bedrock ridge and slope. The configuration of the ridgeline and the underlying bedrock ultimately provided horizontal and vertical barriers that limited the size of the pond that could be constructed at this location. The importance of the livestock pond is discussed more in Chapter 14.

\section{Rock Mounds}

Three rock mounds designated as Mounds $\mathrm{A}, \mathrm{B}$, and $\mathrm{C}$ were documented in the state-owned right of way (see Figure 6.6). They were covered by dense vegetation, and their locations correspond with three tree clusters in the cultivated field in the 1937 aerial photograph (see Figure 6.6). This indicates that the tree clusters survived because there were large rock piles and the areas could not be cultivated. Backhoe scraping revealed that all three are composed of various sizes and shapes of limestone cobbles and boulders, along with many smaller rounded chert cobbles. The mounds rest on bedrock limestone with very little clay soil, and they are only 12 to 24 inches higher than the surrounding surface. Metal detector sweeps found a few small rusted fragments, but no identifiable artifacts. The rocks composing each mound are completely jumbled.

The evidence indicates that these mounds are artificial accumulations. They were probably created when Ransom Williams piled up rocks that were found while plowing the surrounding fields in and around trees or clusters of trees. Limestone rocks and chert cobbles are natural in the thin stony upland soils, but they are a frustrating nuisance in a plowed field. Williams would have removed these rocks whenever they were encountered. These mound locations appear to be places where large bedrock slabs were shallow or already exposed, and they would have had too little soil to be cultivated. The 1937 aerial photograph shows that there were other isolated tree clusters in the cultivated portion of Williams property, but these areas could not be examined because they were west of the TxDOT right of way.

\section{Large Trees}

Many large trees observed on the Ransom Williams farmstead, including elm, live oak, post oak, mulberry, and juniper, were probably present during the Williams family's occupation from ca. 1871 to ca. 1905 . These trees, especially the very big ones, undoubtedly were an integral part of the farmstead landscape during the Williamses' occupation. Therefore, they were studied as part of the landscape analysis.

All trees with a circumference of about $3 \mathrm{ft}$ or larger were assigned a unique tree number, and their locations were mapped. The type of tree and its circumference were recorded. For consistency, tree circumference was measured at about 39 inches $(1 \mathrm{~m})$ above the ground surface. Many of the large trees displayed some type of human modification. Data from the Morton Arboretum (2009) were used to estimate the ages of the large trees in the white oak family (includes live and post oaks) based on the trunk diameter as summarized in Table 6.3. ${ }^{87}$

As summarized in Table 6.4, this effort documented 85 large trees, ${ }^{88}$ many of which were also classified as tree features. It is notable that none of the trees in the old cultivated field area had a circumference of over $3 \mathrm{ft}$; all 85 of the documented large trees were in areas that were wooded in 1937. The estimated ages of the large oak trees in the wooded area range from 100 to more than 300 years old, and it is likely that many of them were fairly large when the Williams family lived on the property between ca. 1871 and ca. 1905. The locations of these large trees are depicted in Figure 6.30. It is worth mentioning that there are also many large live oak and post oak trees within the TxDOT right of way that would be worth study using dendrochronology to identify ages and to reconstruct climatic data for the nineteenth and twentieth centuries. ${ }^{89}$

\footnotetext{
${ }^{87}$ The growth rate of oak trees can vary considerably, and there are many different methods for estimating a tree's age based on its size. Other methods yield younger and older age estimates than those presented in Table 6.3. These age estimates could easily be off by several years either direction (especially considering the highly variable rainfall in central Texas), but the data provide a useful general guide.

${ }^{88}$ Table 6.4 has 85 trees, but Tree 9 is a duplicate
number, and two trees are designated as Tree 19a and Tree $19 \mathrm{~b}$.

${ }^{89}$ In particular, extremely large live oaks (Trees 1 , 38,53 , and 76) and two large post oaks (Trees 7 and 57) are associated with landscape features at the Williams farmstead. Most of the trees at the site will be destroyed when State Highway 45 Southwest is built, so it is recommended that these large live oaks and post oaks be cut down before road construction
} 


\section{Tree Features}

Trees that were modified by people were designated tree features, and three types were documented (Table 6.5, Figure 6.31). All trees that had barbed or smooth wire embedded in their trunks were mapped and documented regardless of the size of the tree because these trees had been used as fence posts for stringing wire fences. In most cases, these fence trees were quite large and old, and some were integrated into the rock walls and alignments. But in other cases (see Rock Alignment B1 and B2), the smaller trees with embedded wire probably represent fences added in the twentieth century after the Williams family left the farm in ca. 1905 and possibly after they sold the property in 1934 .

\section{Tree 1 with Modified Cavity}

The first tree feature is a single large live oak that has a hollow cavity that was modified by people (Figure 6.32). Tree 1 was $35 \mathrm{ft}$ southeast of the southeast corner of the Williams house and in line with the westernmost of two parallel rock alignments along the edges of an old northsouth road (Rock Wall B2). This tree was also on the eastern edge of the inferred yard area. This massive live oak, with a 10-ft 8-inch trunk circumference and a canopy of more than $30 \mathrm{ft}$, is undoubtedly several hundred years old. In this location, this large tree would have provided shade in the southwest part of the yard during the Williams occupation. In fact, the presence of this large tree was probably one of the important factors in selecting the house location.

Tree 1 has a prominent cavity in the north side of its trunk about 20 to 44 inches above the ground (see Figure 6.32b). The cavity opening

begins to obtain slabs of their trunks (ca. 3 inches thick). The slabs should then be sent to a laboratory for tree ring analysis (e.g., the University of Arkansas Tree Ring Laboratory or the Laboratory of Tree Ring Research at University of Arizona). The tree sections would be very useful tools for precise climatic reconstruction during the last 200 to 300 years, and they could provide a robust data set for central Texas. Stahle and Cleaveland (1988) reported on a previous tree ring study that looked at climate and droughts in Texas from 1698 to 1980, but their tree sample for central and south Texas was limited to five post oaks. Using dendrochonology, it may also be possible to get a fairly accurate date on when the barbed wire was stapled to these trees (Tree 38 is a good example) by counting the subsequent growth rings.
Table 6.3. Estimated age of white oak trees by trunk diameter*

\begin{tabular}{|c|c|}
\hline $\begin{array}{l}\text { Trunk Diameter } \\
\quad \text { (inches) }\end{array}$ & $\begin{array}{c}\text { Estimated Age } \\
\text { of White Oak }\end{array}$ \\
\hline 10 & 84 \\
\hline $11^{* *}$ & 92 \\
\hline 12 & 100 \\
\hline $13^{* * *}$ & 108 \\
\hline 14 & 115 \\
\hline $15^{* *}$ & 122 \\
\hline 16 & 129 \\
\hline $17 * *$ & 137 \\
\hline 18 & 144 \\
\hline $19 * *$ & 152 \\
\hline 20 & 159 \\
\hline $21^{* *}$ & 166 \\
\hline 22 & 173 \\
\hline $23^{* *}$ & 180 \\
\hline 24 & 187 \\
\hline $25^{* *}$ & 194 \\
\hline 26 & 201 \\
\hline $27 * *$ & 208 \\
\hline 28 & 215 \\
\hline $29 * *$ & 222 \\
\hline 30 & 229 \\
\hline 31 & 243 \\
\hline $32^{* * *}$ & 249 \\
\hline $33^{* *}$ & 254 \\
\hline 34 & 260 \\
\hline 35 & 271 \\
\hline $36 * *$ & 278 \\
\hline 37 & 285 \\
\hline $38^{* *}$ & 292 \\
\hline 39 & 298 \\
\hline $40 * *$ & $>300$ \\
\hline
\end{tabular}

* Data are from the Morton Arboretum (2009), with tree circumference measured at 39 inches above the ground and converted to trunk diameter.

** Age is extrapolated because the trunk diameter was not in original data set. 
The Ransom and Sarah Williams Farmstead

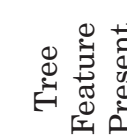

\begin{tabular}{|c|c|c|c|c|c|c|c|c|c|}
\hline 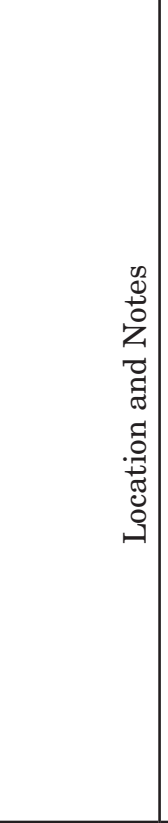 & 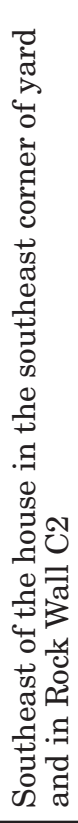 & 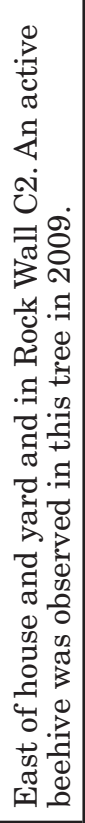 & 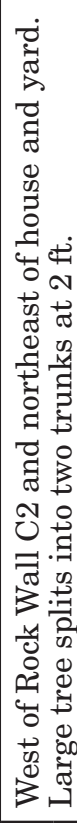 & & 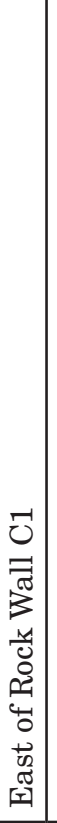 & 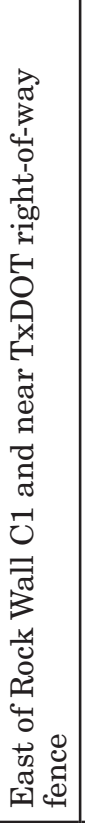 & 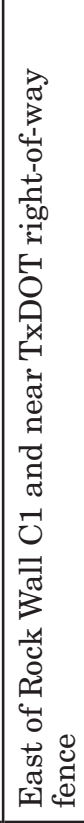 & 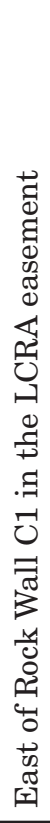 & 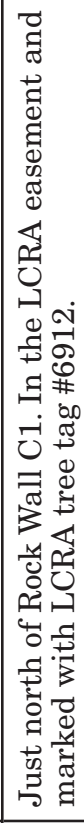 \\
\hline 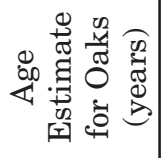 & $\begin{array}{l}\stackrel{8}{\infty} \\
\text { N }\end{array}$ & 岕 & 1 & 1 & 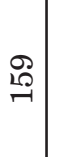 & 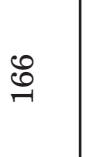 & 10 & స్ & $\stackrel{\infty}{\infty}$ \\
\hline 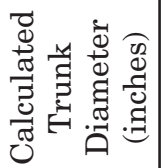 & $\dot{\leftrightarrow}$ & ח. & $\begin{array}{l}\stackrel{N}{\sim} \\
\stackrel{-}{\sim}\end{array}$ & $\stackrel{-}{\beth}$ & ¿ே. & $\overrightarrow{\mathrm{N}}$ & 몀 & $\dot{\vec{d}}$ & ฯ? \\
\hline
\end{tabular}

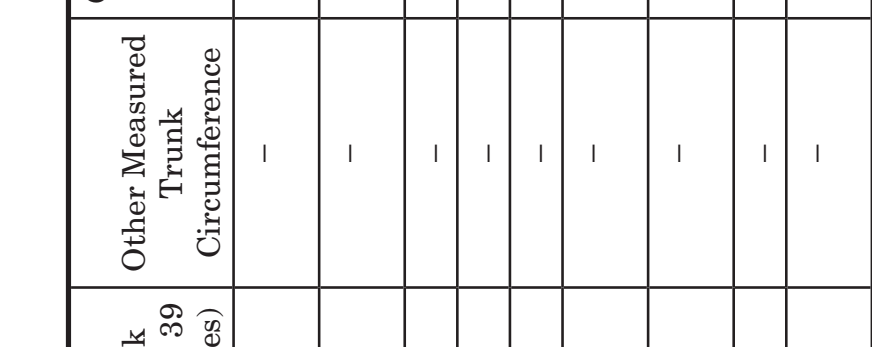

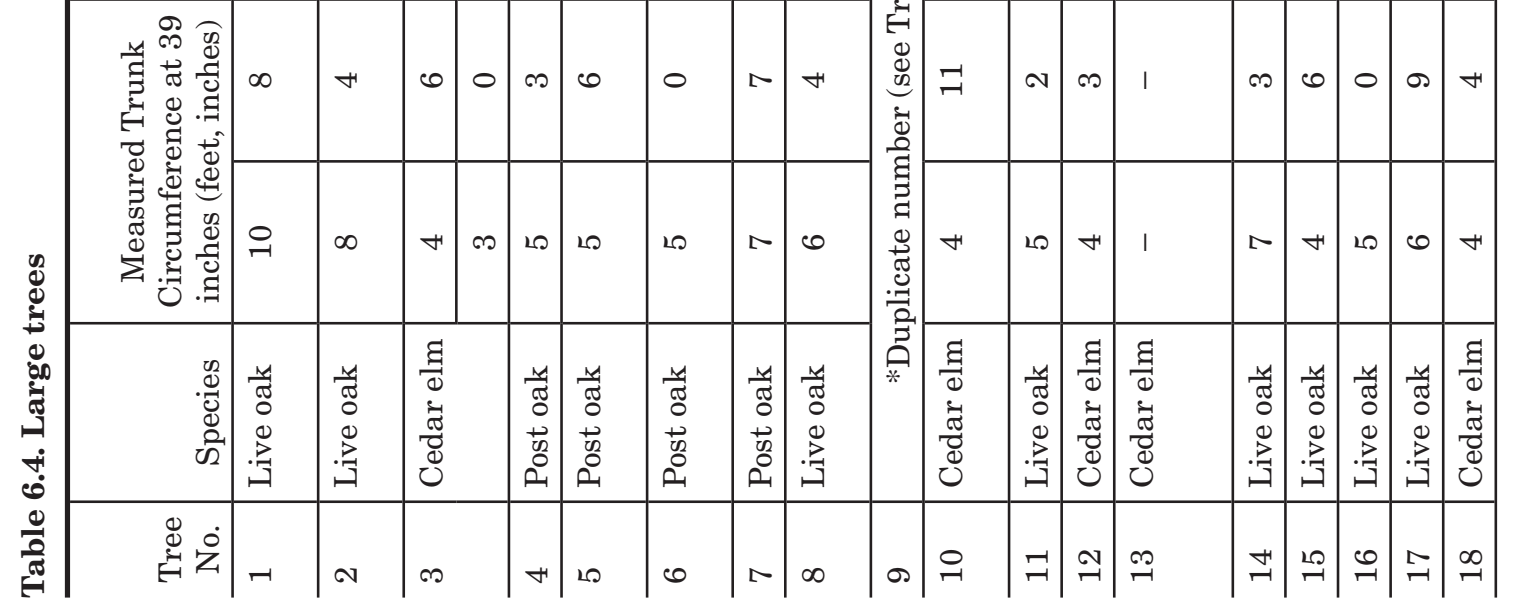

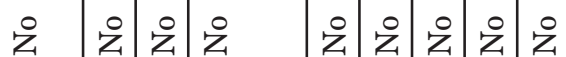

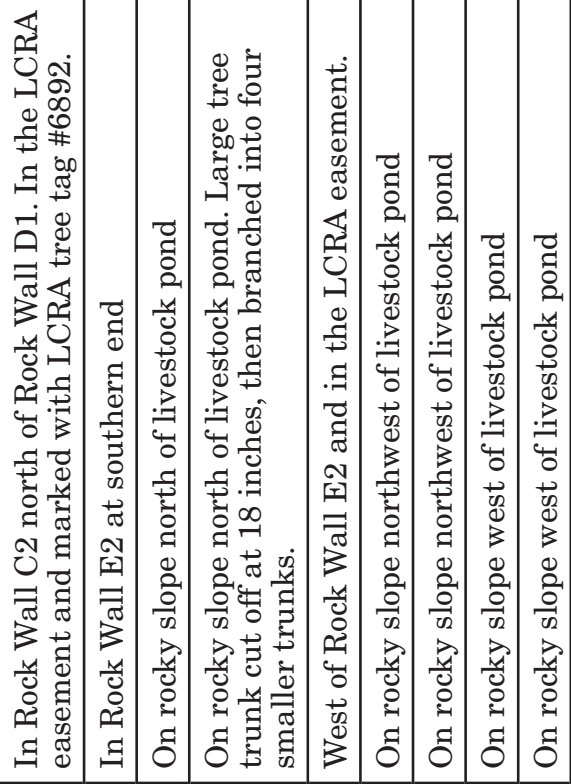

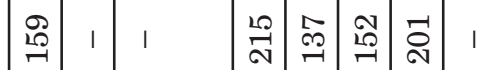

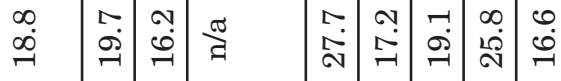

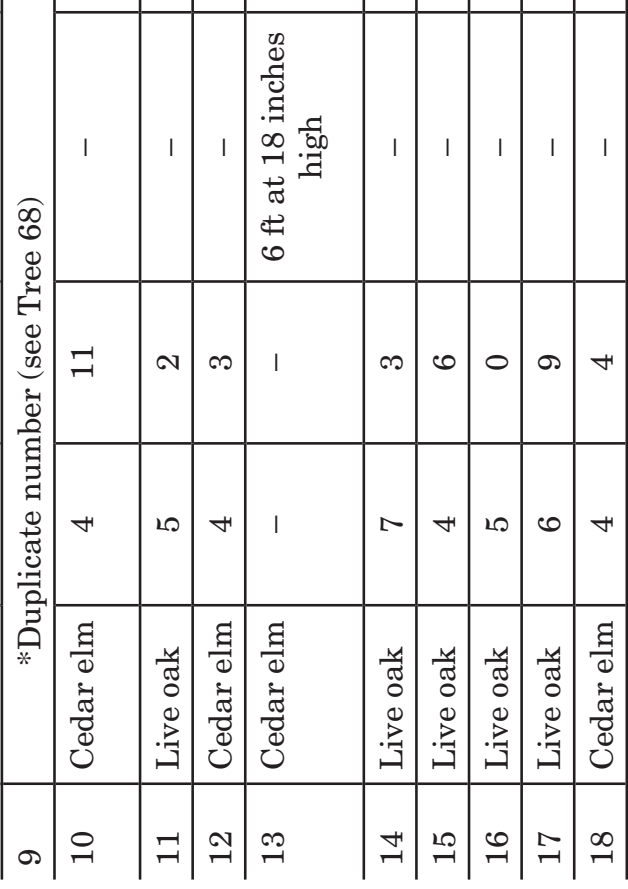




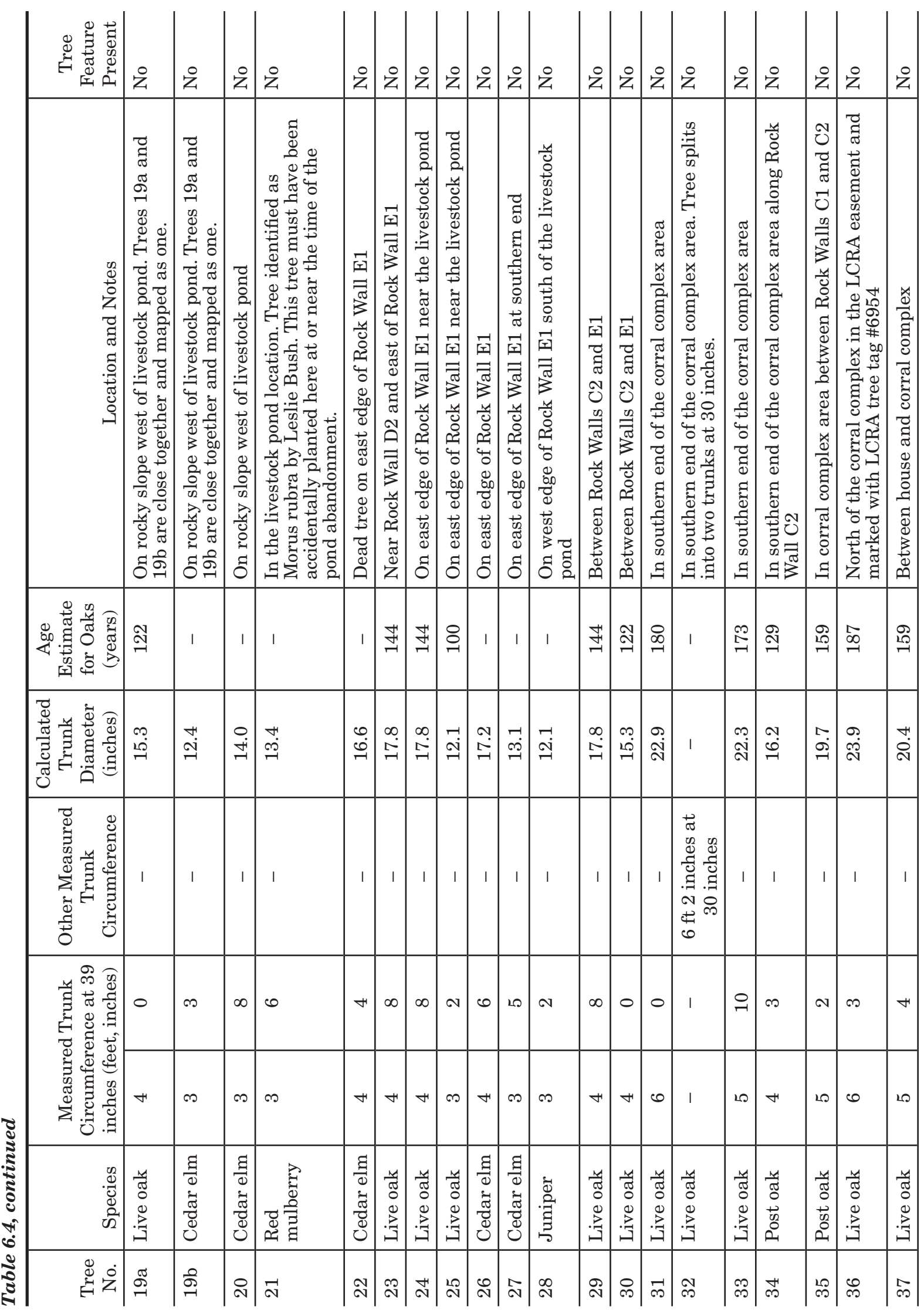




\begin{tabular}{|c|c|c|c|c|c|c|c|c|c|c|c|c|c|c|c|c|c|c|c|c|c|}
\hline E & \multicolumn{4}{|l|}{$\underset{\nu}{\mathscr{D}}$} & $\stackrel{\circ}{z}$ & $\stackrel{\circ}{z}$ & z & $\stackrel{\circ}{z}$ & $\stackrel{\circ}{z}$ & ż & $\stackrel{\circ}{z}$ & $\stackrel{0}{z}$ & $\stackrel{\circ}{z}$ & ż & $\stackrel{\circ}{z}$ & $\underset{\sim}{\infty}$ & $\overbrace{i=1}^{\infty}$ & $\stackrel{\circ}{z}$ & $\stackrel{\circ}{z}$ & $\stackrel{0}{Z}$ & $\stackrel{\circ}{z}$ \\
\hline 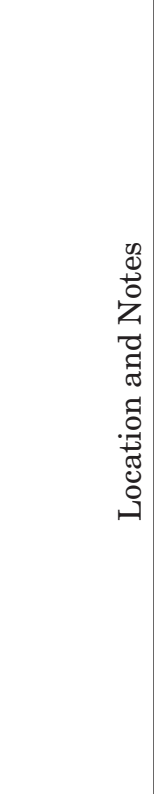 & 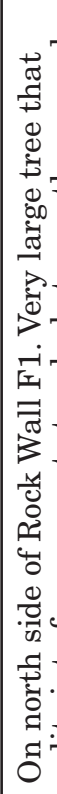 & 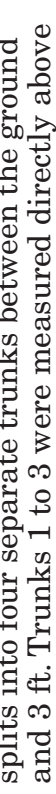 & 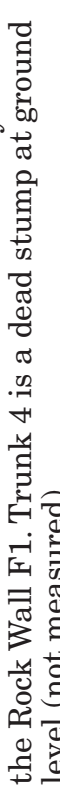 & & 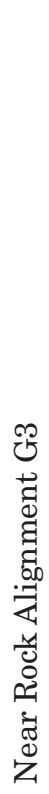 & 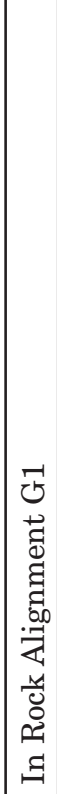 & 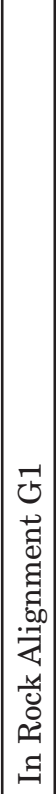 & 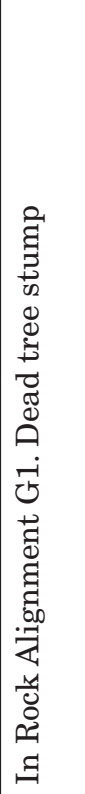 & 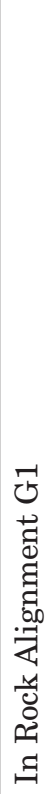 & 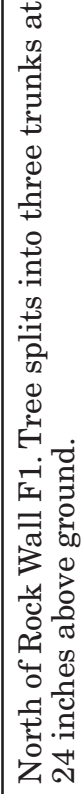 & 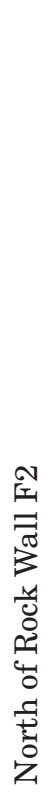 & 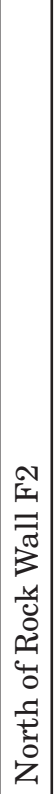 & 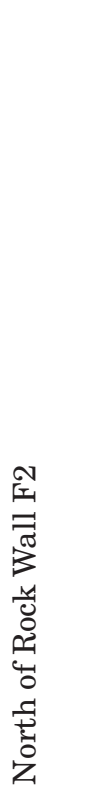 & 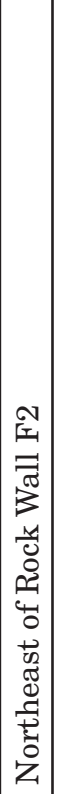 & 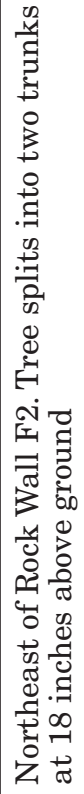 & 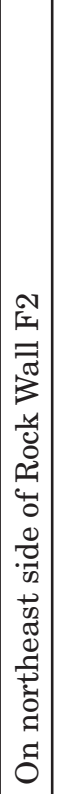 & 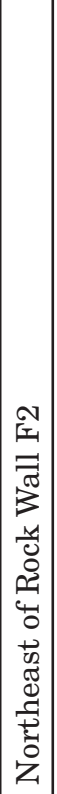 & 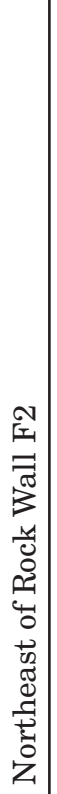 & 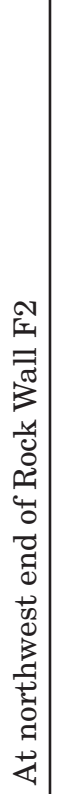 & 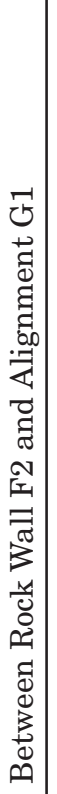 & 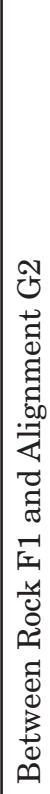 \\
\hline 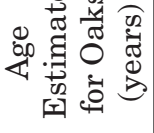 & : & $\begin{array}{l}0 \\
\vdots \\
-1\end{array}$ & $\underset{⿱}{\stackrel{4}{二}}$ & 1 & $\stackrel{\widehat{\omega}}{\stackrel{9}{9}}$ & 䞄 & $\mid \begin{array}{l}1 \\
\text { id } \\
-1\end{array}$ & 1 & $\stackrel{\infty}{\infty}$ & 1 & 1 & 1 & 1 & 1 & 1 & 1 & 1 & $\begin{array}{l}\infty \\
\infty \\
\sim\end{array}$ & $\stackrel{\substack{\infty \\
\sim}}{\sim}$ & $\stackrel{\sim}{9}$ & 1 \\
\hline 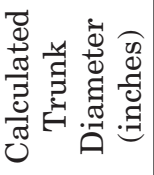 & \begin{tabular}{|c|}
0 \\
1 \\
\\
-1 \\
\end{tabular} & $\stackrel{n}{\vec{N}}$ & 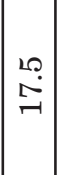 & $\frac{\pi}{a}$ & Nִ & \begin{tabular}{|l}
10 \\
$\infty$ \\
-1
\end{tabular} & $\mid \begin{array}{l}10 \\
\infty 0 \\
0\end{array}$ & å & $\vec{m}$ & $\frac{\pi}{a}$ & $\begin{array}{c}0 \\
20 \\
10\end{array}$ & $\mid \begin{array}{l}20 \\
\infty \\
-1\end{array}$ & $\stackrel{\pi}{a}$ & $\begin{array}{l}0 \\
\stackrel{N}{N} \\
\end{array}$ & $\stackrel{\pi}{a}$ & 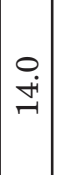 & $\mid \begin{array}{l}10 \\
0 \\
0\end{array}$ & $\begin{array}{l}0 \\
\stackrel{\text { N }}{\text { N }}\end{array}$ & $\begin{array}{c}\stackrel{\sim}{+} \\
\stackrel{i}{\sim}\end{array}$ & $\begin{array}{l}\stackrel{N}{\sim} \\
\stackrel{-}{\sim}\end{array}$ & $\begin{array}{l}0 \\
\dot{H}\end{array}$ \\
\hline 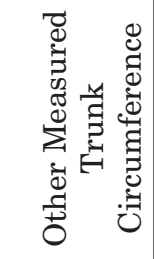 & 1 & 1 & 1 & 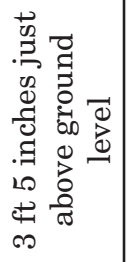 & 1 & 1 & 1 & 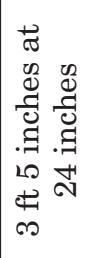 & 1 & 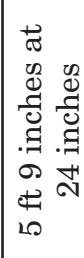 & 1 & 1 & 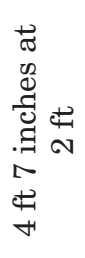 & 1 & 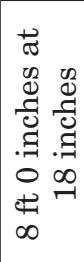 & 1 & 1 & I & 1 & 1 & 1 \\
\hline 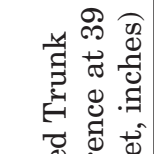 & -1 & $\sim$ & $\sim$ & 1 & 0 & $\stackrel{0}{-}$ & 윽 & 1 & 10 & 1 & -1 & 으 & 1 & 0 & 1 & $\infty$ & $\infty$ & 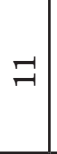 & $H$ & 0 & $\stackrel{2}{\circ}$ \\
\hline 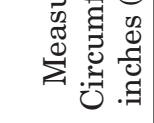 & +4 & 10 & +1 & 1 & 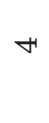 & $r$ & $H$ & 1 & $\infty$ & 1 & 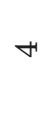 & $H$ & 1 & $H$ & 1 & $\infty$ & $\infty$ & 10 & 0 & $H$ & $\infty$ \\
\hline 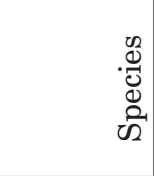 & 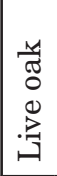 & & & & 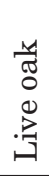 & 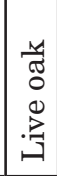 & 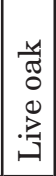 & 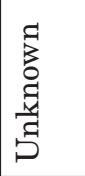 & $\begin{array}{l}\text { సี } \\
0 \\
0 \\
0 \\
. \\
0\end{array}$ & 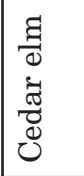 & $\begin{array}{l}\text { g } \\
0 \\
\tilde{\sigma} \\
\text { ర్ } \\
0 \\
0\end{array}$ & 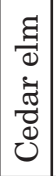 & 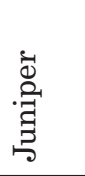 & 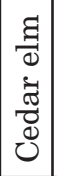 & 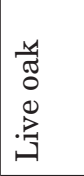 & 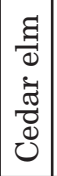 & 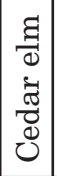 & 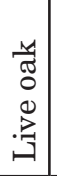 & 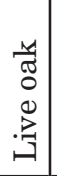 & 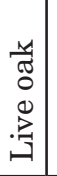 & 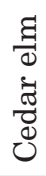 \\
\hline 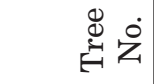 & $\infty$ & & & & ले & 아 운 & $\vec{F}$ & F & H & 出 & 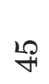 & $\begin{array}{l}0 \\
y \\
1\end{array}$ & 年 & $\stackrel{\infty}{+}$ & \& & 10 & 210 & î & దొ & 䘮 & مी \\
\hline
\end{tabular}


Chapter 6: Landscape Analysis

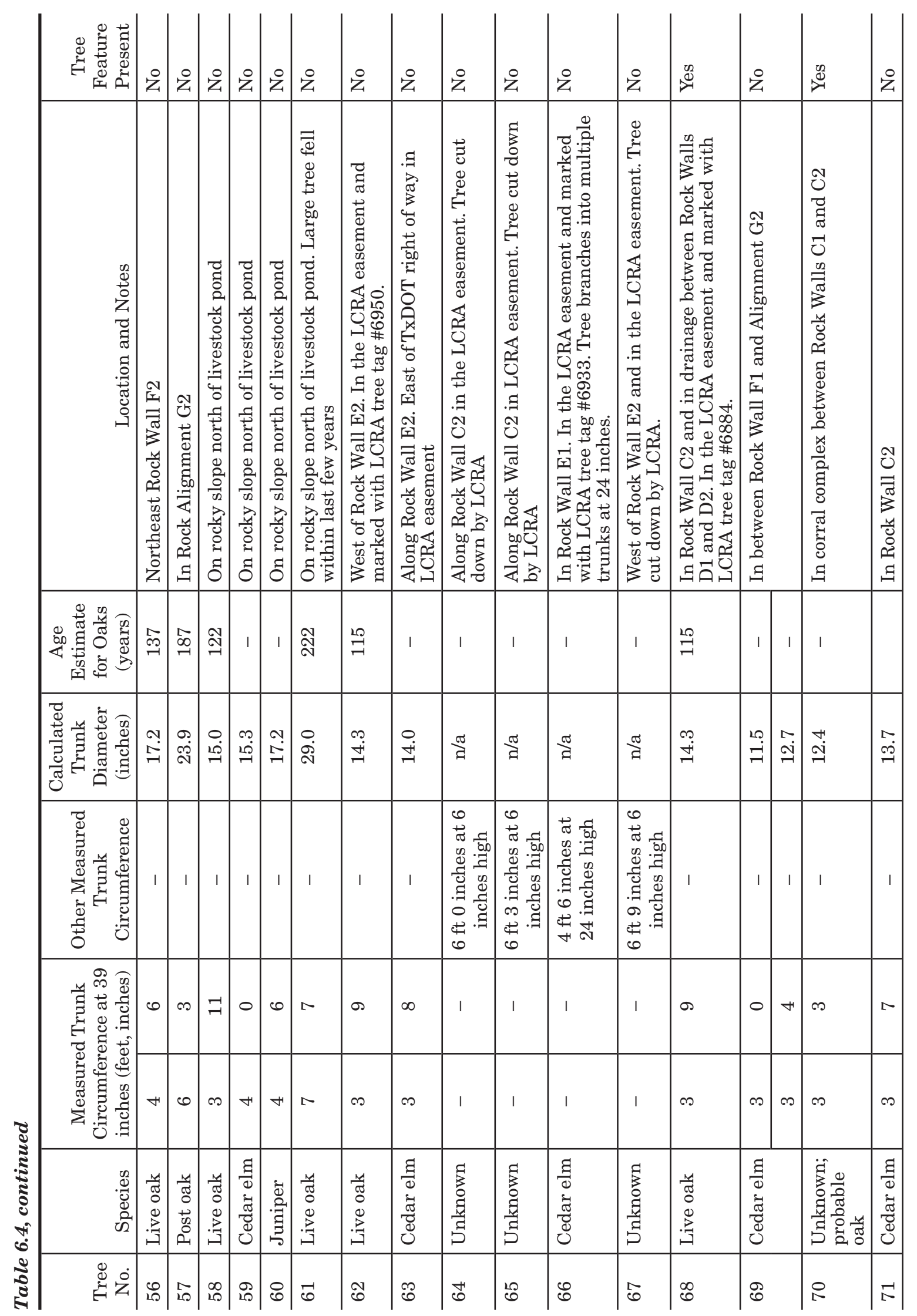


The Ransom and Sarah Williams Farmstead

\begin{tabular}{|c|c|c|c|c|c|c|c|c|c|c|c|c|c|c|c|}
\hline 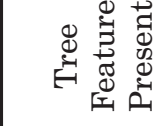 & $\underbrace{\infty}_{>-1}$ & $\stackrel{\circ}{z}$ & $\stackrel{0}{z}$ & $\stackrel{\circ}{z}$ & $\stackrel{\infty}{\infty}$ & $\stackrel{0}{z}$ & z & $\stackrel{2}{z}$ & $\stackrel{2}{z}$ & $\stackrel{\circ}{z}$ & $\underbrace{\infty}_{\approx}$ & $\stackrel{\circ}{z}$ & $\sum_{\star=1}^{\infty}$ & z & 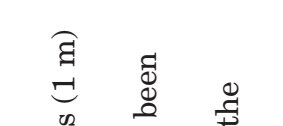 \\
\hline 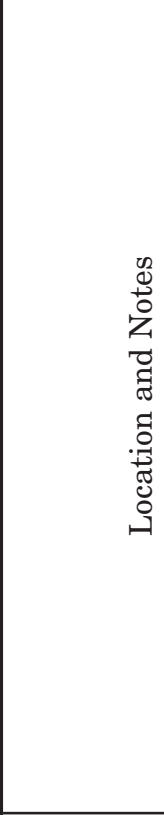 & 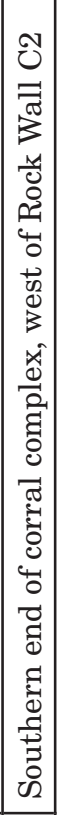 & 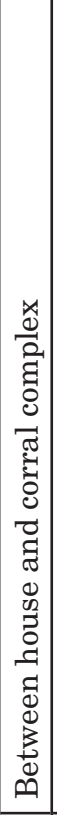 & 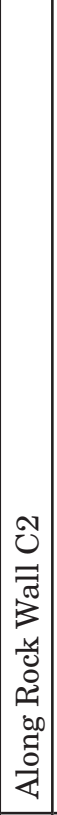 & 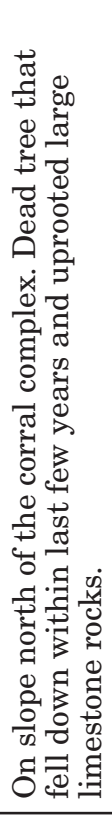 & 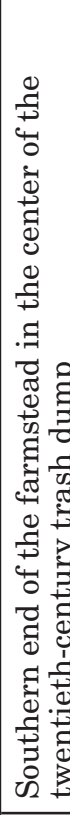 & 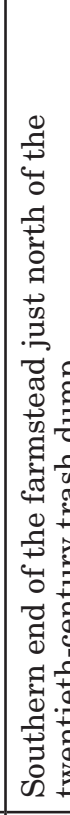 & 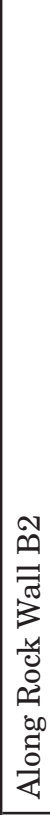 & 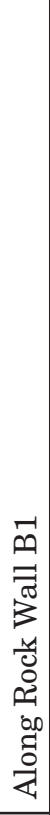 & 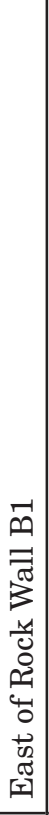 & 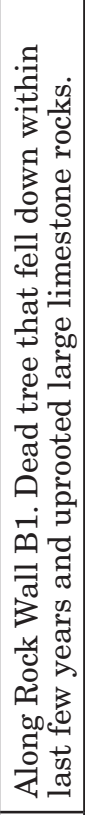 & 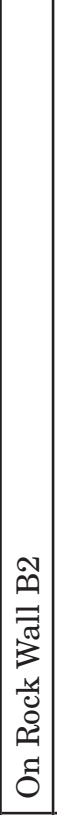 & 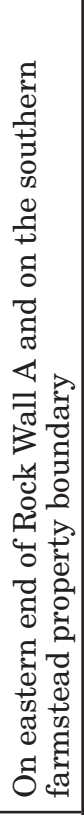 & 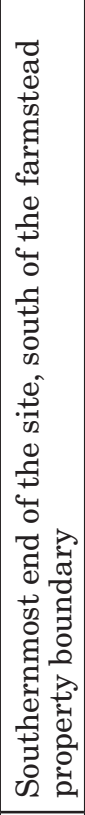 & 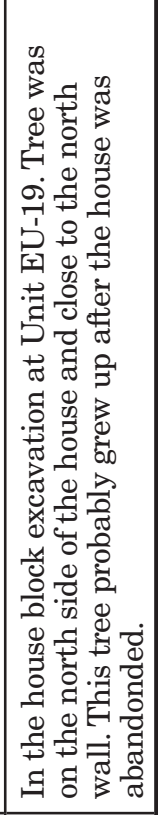 & 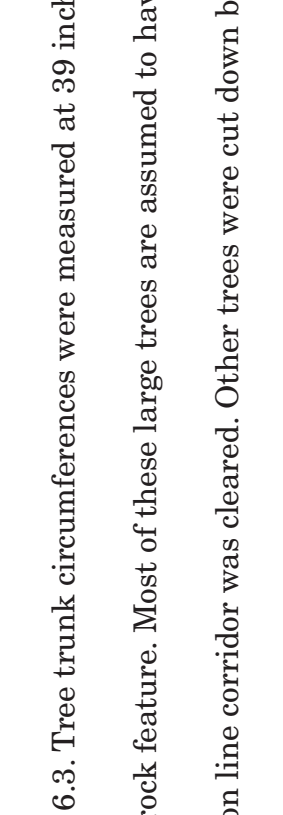 \\
\hline 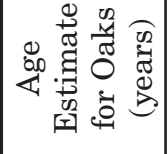 & 1 & 1 & 1 & 1 & ลิ & 兽 & 兽 & 1 & 党 & 1 & 1 & 党 & \&্ট & 1 & 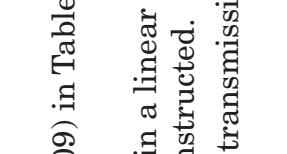 \\
\hline 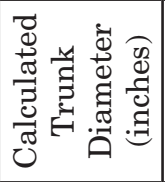 & 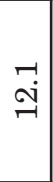 & 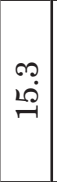 & $\begin{array}{ll}\infty \\
\stackrel{n}{\sim} \\
\sim\end{array}$ & 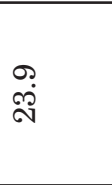 & $\stackrel{0}{\stackrel{N}{N}}$ & 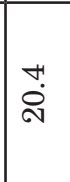 & $\ddot{r}$ & 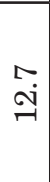 & $\ddot{\circ}$ & $\begin{array}{l}\infty \\
\stackrel{+}{+}\end{array}$ & $\begin{array}{l}\stackrel{H}{4} \\
\stackrel{\leftrightarrow}{\sim}\end{array}$ & 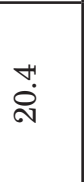 & $\stackrel{\sim}{\infty}$ & $\begin{array}{l}0 \\
0 \\
0 \\
-1\end{array}$ & 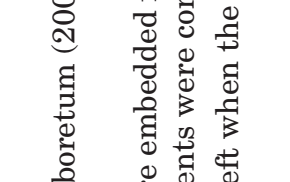 \\
\hline 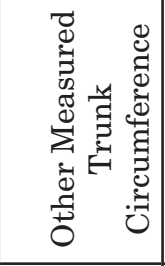 & 1 & 1 & 1 & 1 & 1 & 1 & 1 & 1 & 1 & 1 & 1 & 1 & 1 & 1 & 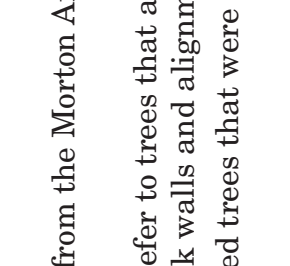 \\
\hline 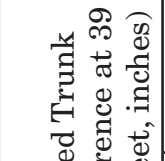 & N & 0 & $\infty$ & $\infty$ & $\sim$ & + & $N$ & $\sigma^{\prime}$ & $\infty$ & 0 & $\infty$ & + & 으 & $\infty$ & 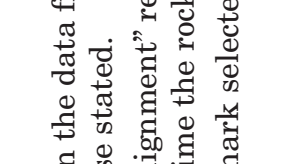 \\
\hline 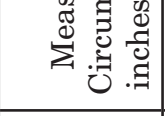 & $\infty$ & 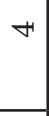 & $\infty$ & 0 & $\sim$ & ما & 10 & $\infty$ & 10 & 0 & $\infty$ & 10 & $\infty$ & ${ }^{\prime}$ & 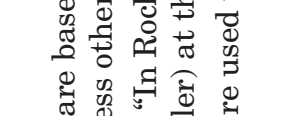 \\
\hline 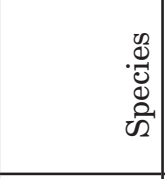 & 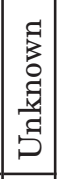 & 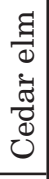 & 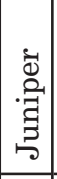 & 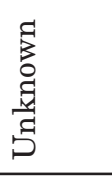 & 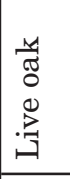 & 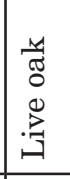 & 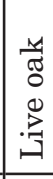 & 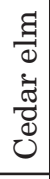 & 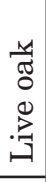 & 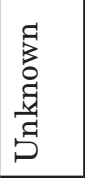 & 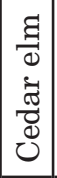 & $\begin{array}{l}\text { त्र } \\
\text { त् } \\
+\overrightarrow{0} \\
0 \\
0\end{array}$ & 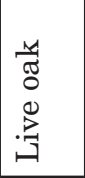 & 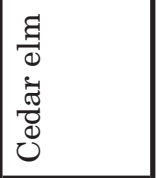 & 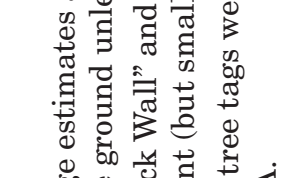 \\
\hline 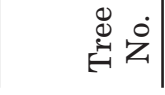 & $\mathbb{N}$ & $\pi$ & $|2|$ & - & 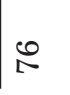 & 依 & 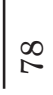 & L & $\infty$ & $\infty$ & $\mid \begin{array}{l}\infty \\
\infty\end{array}$ & $\infty$ & $\varpi_{\infty}$ & 10 & 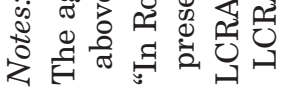 \\
\hline
\end{tabular}




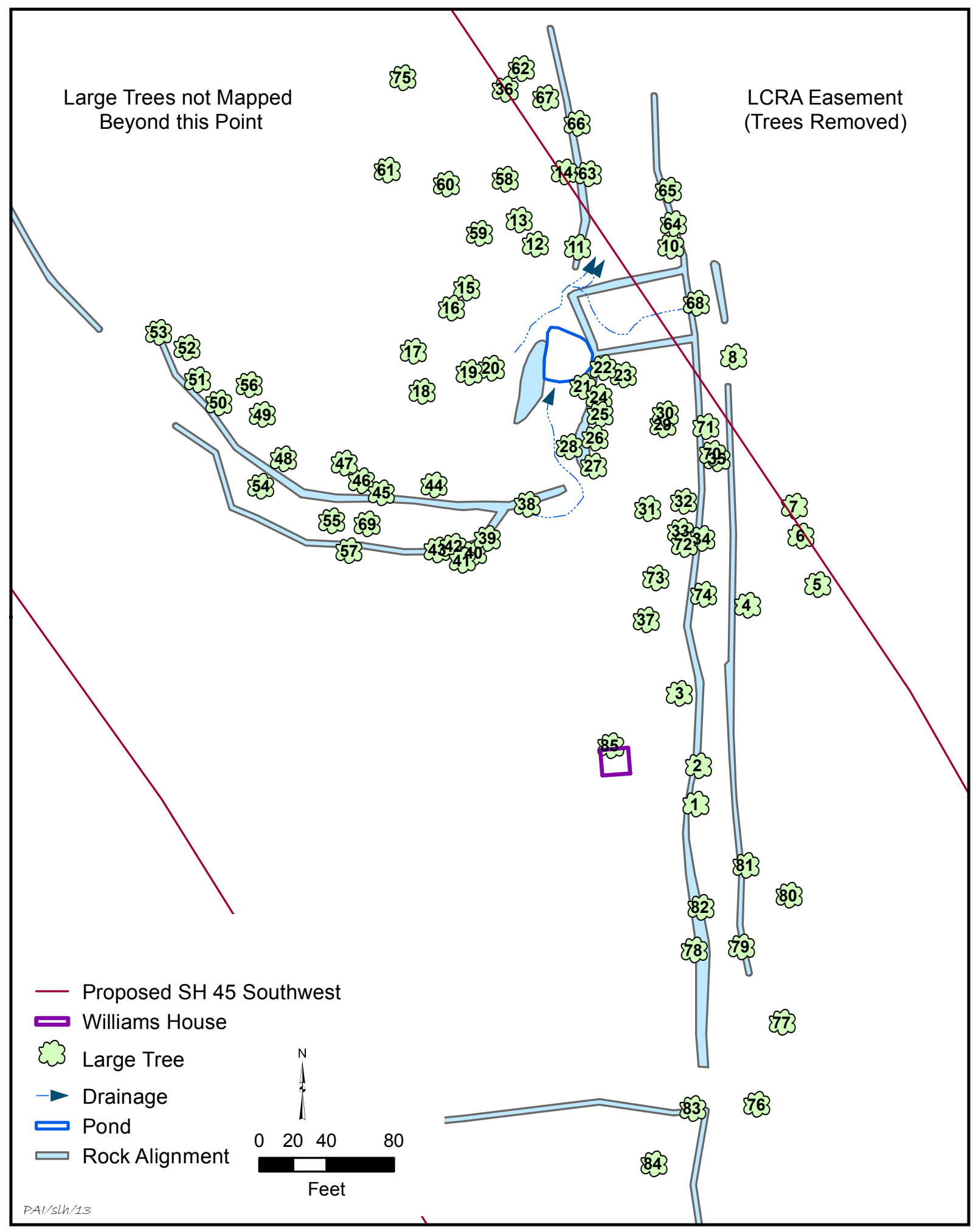

Figure 6.30. Map of large trees. 


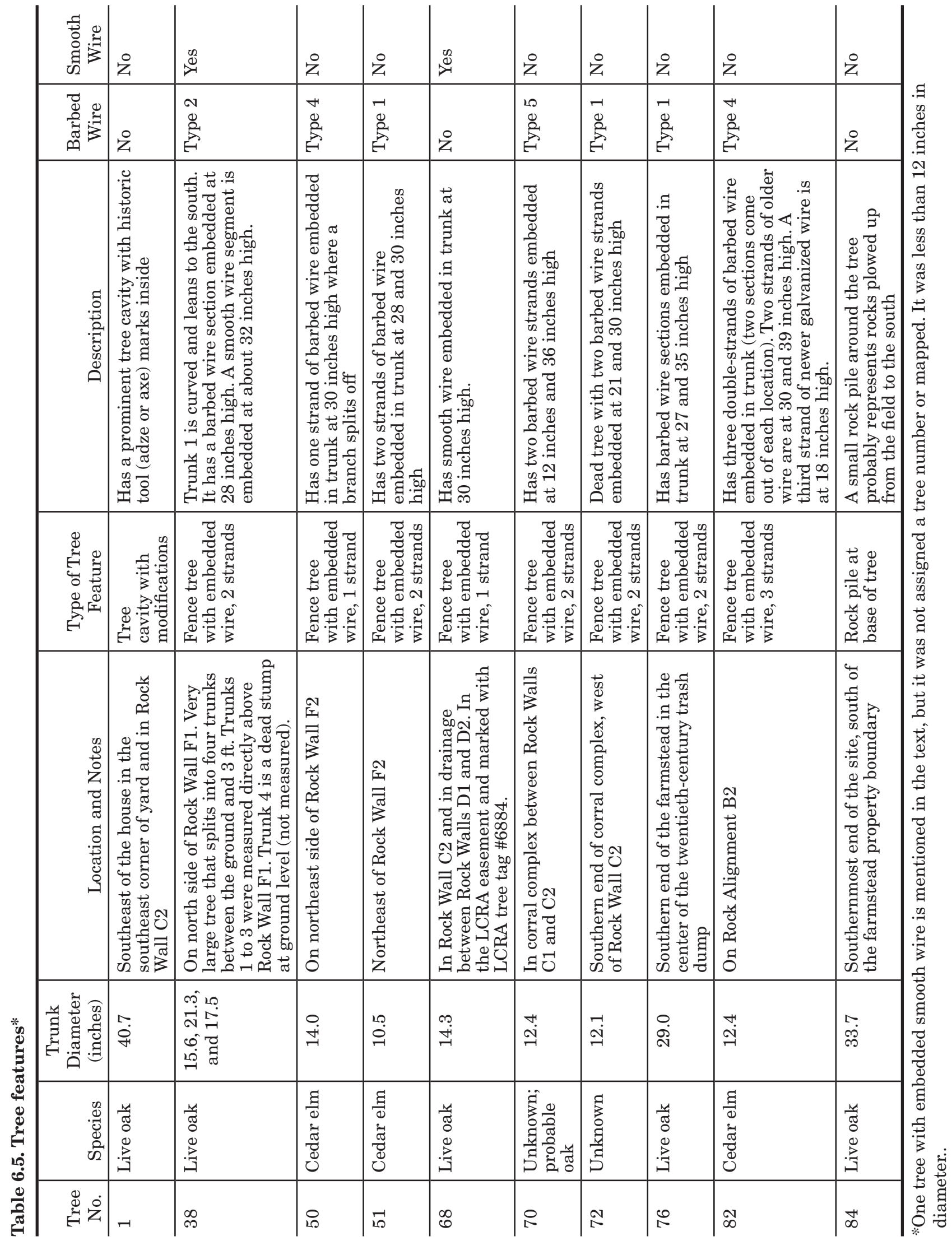




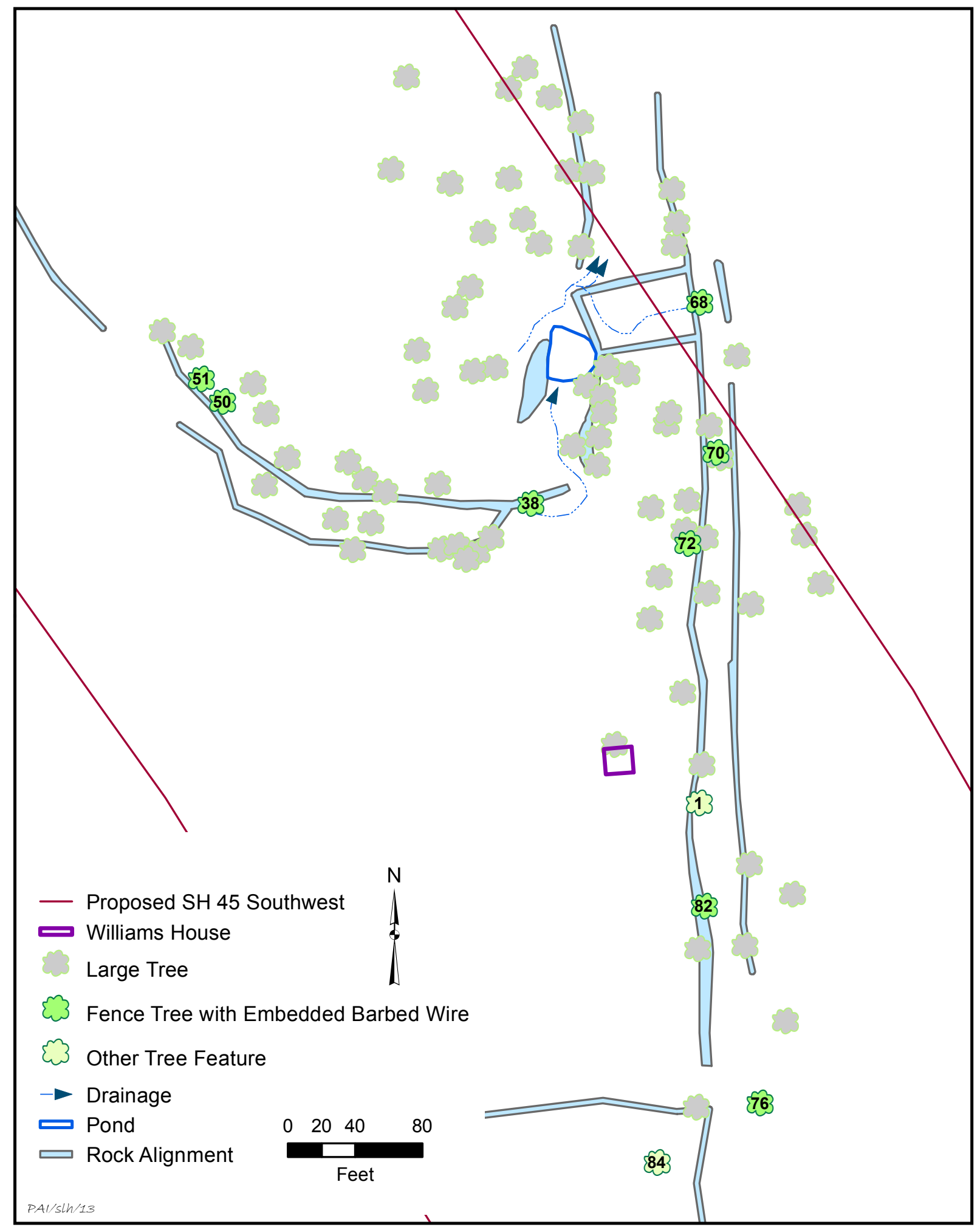

Figure 6.31. Map of tree features. 

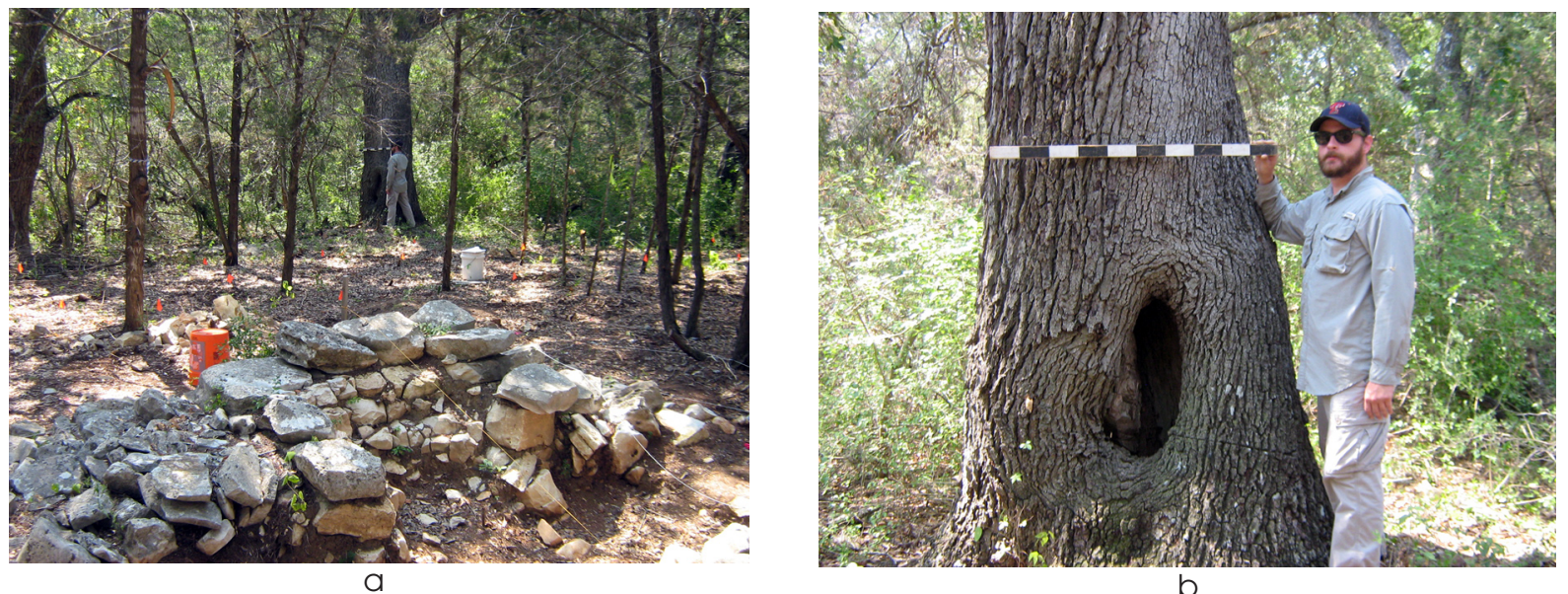

b
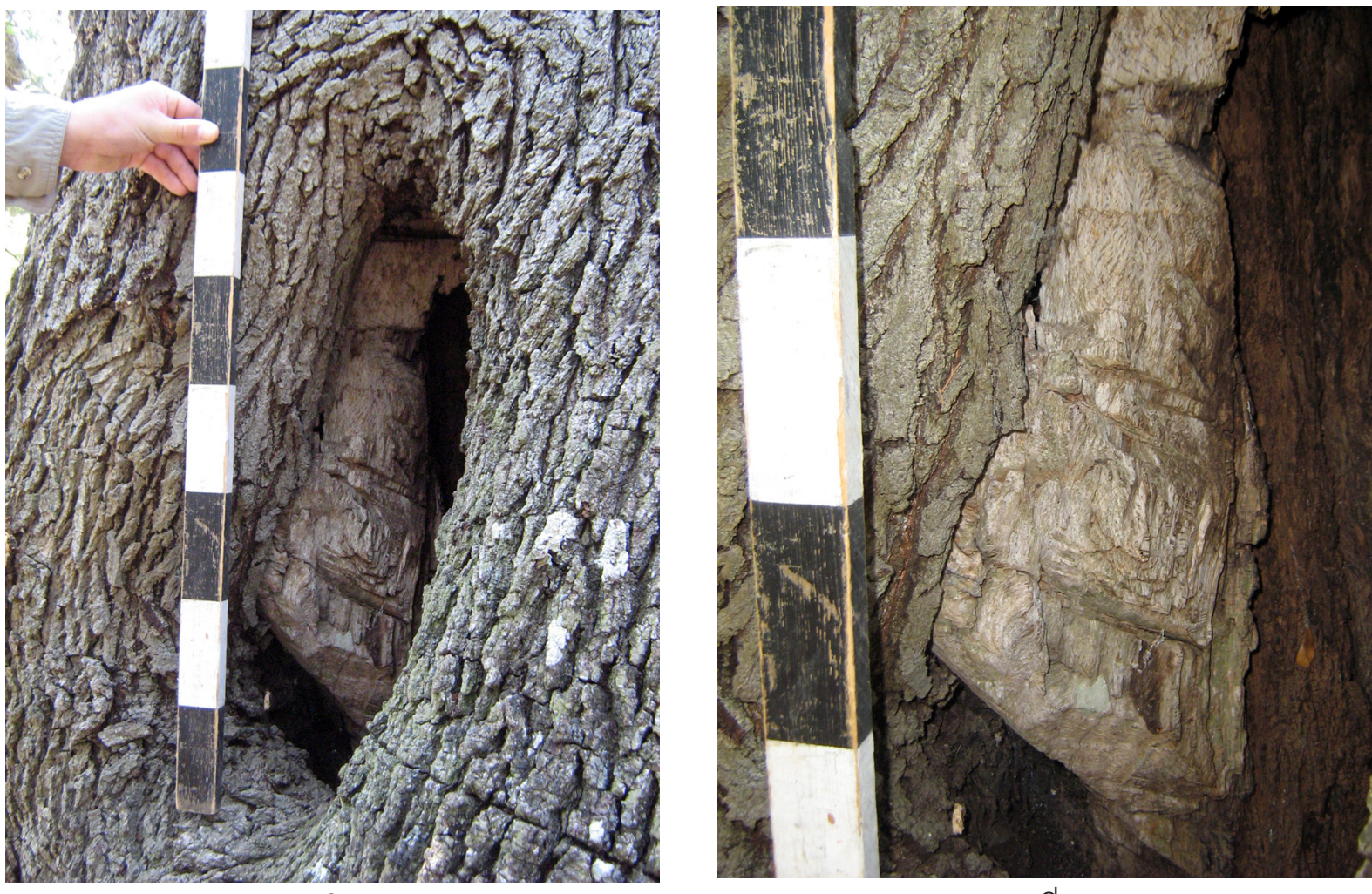

d

Figure 6.32. Photographs of Tree 1 near the Williams house. (a) Looking southeast at the rock chimney base with the large live oak tree in the background. (b) Looking south at the tree cavity in the trunk. (c) Closeup view of the tree cavity. (d) Closeup view of the metal tool marks on the knot inside the tree cavity. The scale is $1 \mathrm{~m}$ (39 inches).

is a $24 \times 10$-inch oval, with its long axis running vertical, that extends up and down inside the tree. In forestry terminology, this is a classic den tree. During the archeological investigations, honeybees and daddy longlegs spiders occupied the cavity, and there were probably other creatures living inside as well (a fresh snake skin was found nearby). 
But the feature that makes this tree so unique is that some of the wood of a large knot inside the cavity was hacked away with a flat-bladed metal tool, probable an adze or an axe. Figures $6.32 \mathrm{c}$ and $\mathrm{d}$ show the probable adze or axe marks on the knot inside. This tree may have been modified in an effort to collect honey. During the summer 2009 archeological investigations, an active honeybee hive was observed in Tree 2, about $20 \mathrm{ft}$ to the north. Bees were also occasionally observed entering and leaving the trunk cavity of Tree 1 . Although there was no active beehive in the Tree 1 cavity, it is not unusual for wild honeybees to live in one area for a long time, and a large tree cavity would have been an ideal spot for a colony. ${ }^{90}$ Since the tree cavity is obviously quite old, it is speculated that it could have been occupied by honeybees and that people altered the tree cavity using a metal adze or axe to get to at the honeycombs inside. Although there is no way to determine how long ago this modification occurred, it is likely that one of the Williams family members altered the cavity, hacking away to remove a portion of the knot inside and enlarge the opening to retrieve the honey inside.

\section{Fence Trees with Embedded Wire}

Trees that have barbed or smooth wire embedded in their trunks represent manmade features, and they provide information on the locations of fencelines on the farm. Eight of the large trees documented at the Williams farmstead had embedded wire and are described separately below (see Table 6.5). The barbed wire types are described in Chapter 8.

Tree 38 is a large live oak located near the east end of Rock Wall F1, and it splits into three live trunks with circumferences of $4 \mathrm{ft} 1$ inches, $5 \mathrm{ft} 7$ inches, and $4 \mathrm{ft} 7$ inches. The tree is growing along the north side of the rock wall, and the

\footnotetext{
${ }^{90}$ Entomologist William Meikle (personal communication 2012) with the USDA's Carl Hayden Bee Research Center notes that native honeybee colonies only survive for two or three years with the same queen, but new colonies might come back to nest in a particularly suitable tree cavity repeatedly over many years. Entomologist Dr. Scott Fleenor (personal communication 2012), with the University of Texas at Austin, agrees that the lineal descendant colonies of a single honeybee colony could inhabit a suitable site, such as a tree cavity, indefinitely.
}

smallest of its trunks curves over the top of the wall. This curved trunk has two strands of wire embedded in it. Type 2 barbed wire is embedded in the center of the trunk at 28 inches high and directly over the north edge of Rock Wall F1 (Figure 6.33). A short segment of the barbed wire protrudes out on the west side of the trunk, but the section coming out on the east side is more than $25 \mathrm{ft}$ long and runs to the east end of Rock Wall F1. This long barbed-wire strand is attached to the fence posts in the drainage between Walls F1 and E1 (see Rock Walls E1 and E2 above). Since the barbed wire is deeply embedded and protrudes from near the center of Tree 38's curved trunk, it appears that the barbed-wire fence over Rock Wall F1 is quite old.

Besides the barbed wire, a short segment of smooth wire protrudes only 1 inch out of the same curved trunk at 32 inches high and directly over the center of Rock Wall F1. This wire runs east-west on the top of the trunk and is very shallowly embedded. This smooth wire was obviously added to Tree 38 long after the barbed wire was attached to the tree.

Trees 50 and 51 are cedar elms on the north side of Rock Wall F2. A section of Type 4 barbed wire is embedded in the trunk of Tree 50 at the point where a large branch comes of the main trunk (Figure 6.34). This wire is about 30 inches high. Tree 51 is about $15 \mathrm{ft}$ northwest of Tree 50 , and it has two sections of barbed wire embedded at 28 and 30 inches high on its trunk (Figure 6.35). Both strands are Type 1 barbed wire, and the upper strand is only a few inches long, while the other (lower strand) is about $15 \mathrm{ft}$ long. Both Trees 50 and 51 were used as fence posts in the same fence, with the barbed-wire strands running parallel to and above Rock Wall F2.

Tree 68 is a live oak located along Rock Wall $\mathrm{C} 2$ adjacent to the rectangular corral enclosure east of the livestock pond. It has a section of smooth wire coming out of its trunk at 30 inches high. The wire would have run parallel to and above Rock Wall C2.

Tree 70 is an unknown type of tree located in the southeastern end of the corral complex between Rock Walls $\mathrm{C} 1$ and $\mathrm{C} 2$. It has two strands of wire embedded in its trunk, both Type 5 barbed wire (Figure 6.36). One long strand comes out of the trunk at 12 inches high, and the second strand at 36 inches high comes out in two places about 5 inches apart. These strands would have run parallel to Rock Wall 


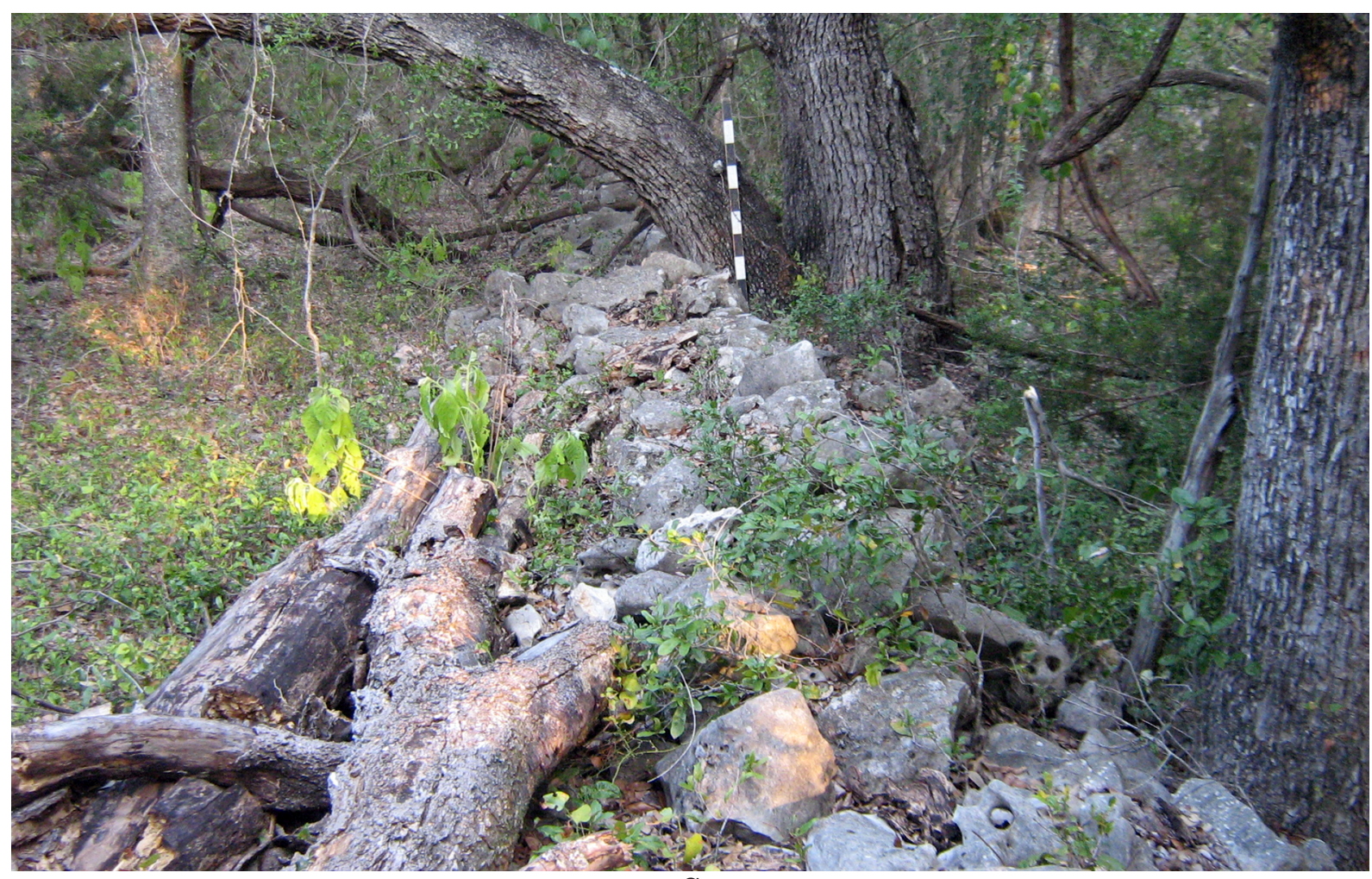

a

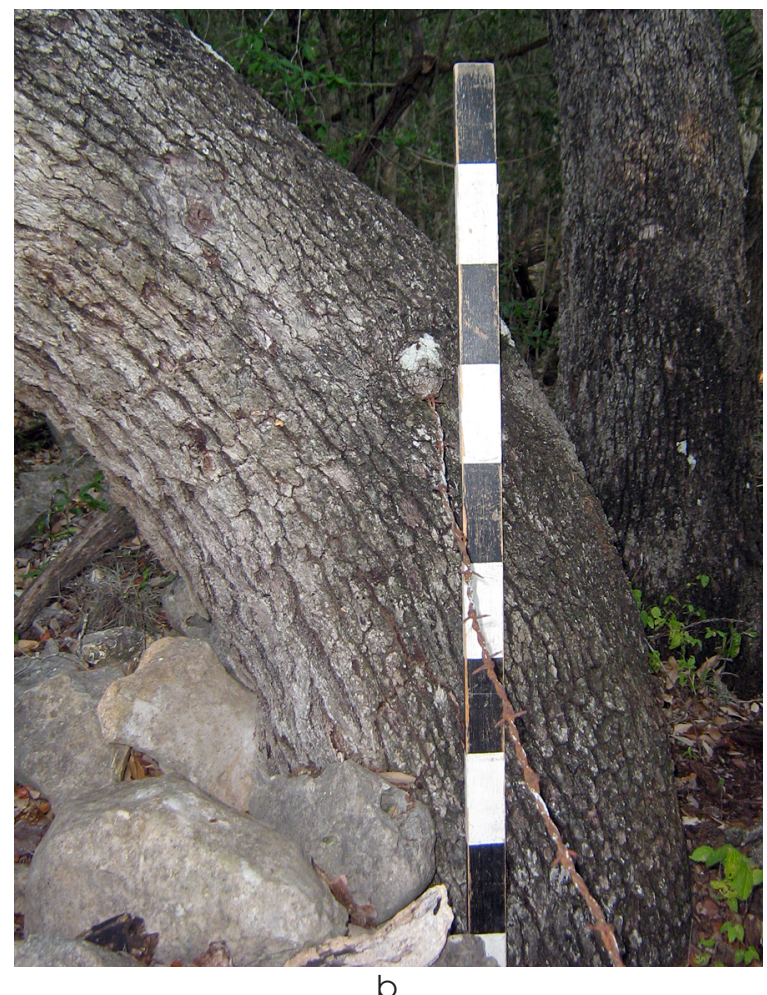

$\mathrm{b}$

Figure 6.33. Photographs of embedded barbed wire in Tree 38 at Rock Wall F1. (a) View south of the multiple trunks growing on the north side of Rock Wall F1. (b) Closeup view of the barbed wire coming out of the east side of the tree trunk that curves over Rock Wall F1. Scale is $1 \mathrm{~m}$ ( 39 inches). 


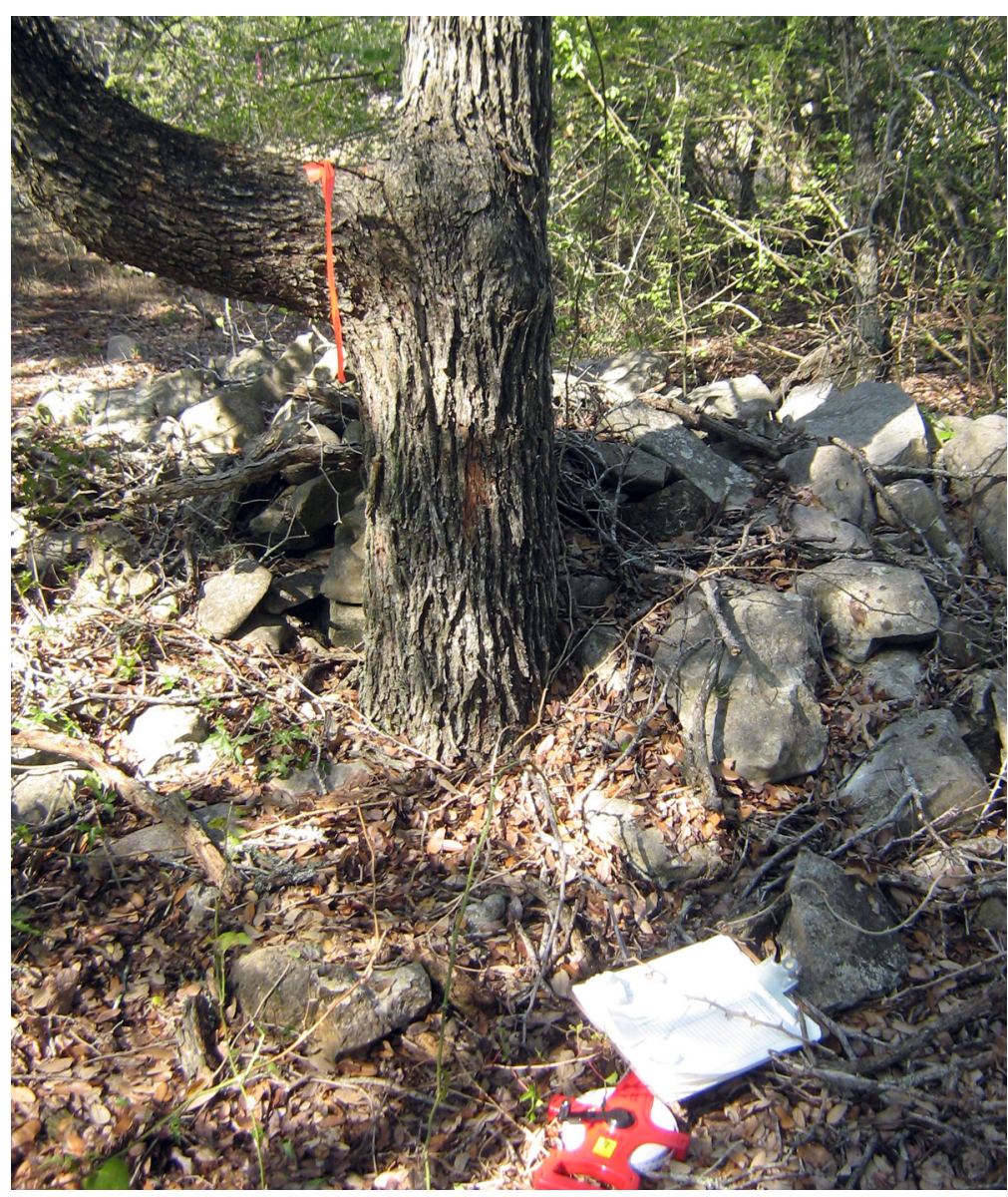

a

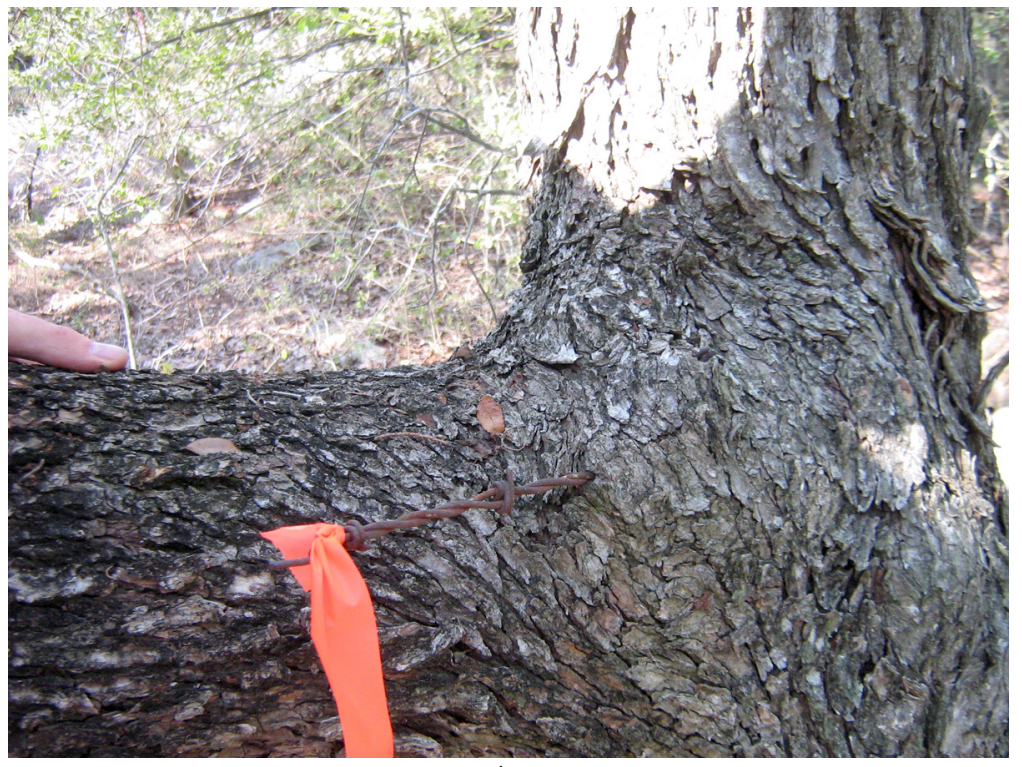

$\mathrm{b}$

Figure 6.34. Photographs of embedded barbed wire in Tree 50. (a) View south of tree beside Rock Wall F2. Orange flagging tape marks the barbed wire embedded in the trunk. (b) Closeup view of the barbed wire coming out of the tree trunk. 


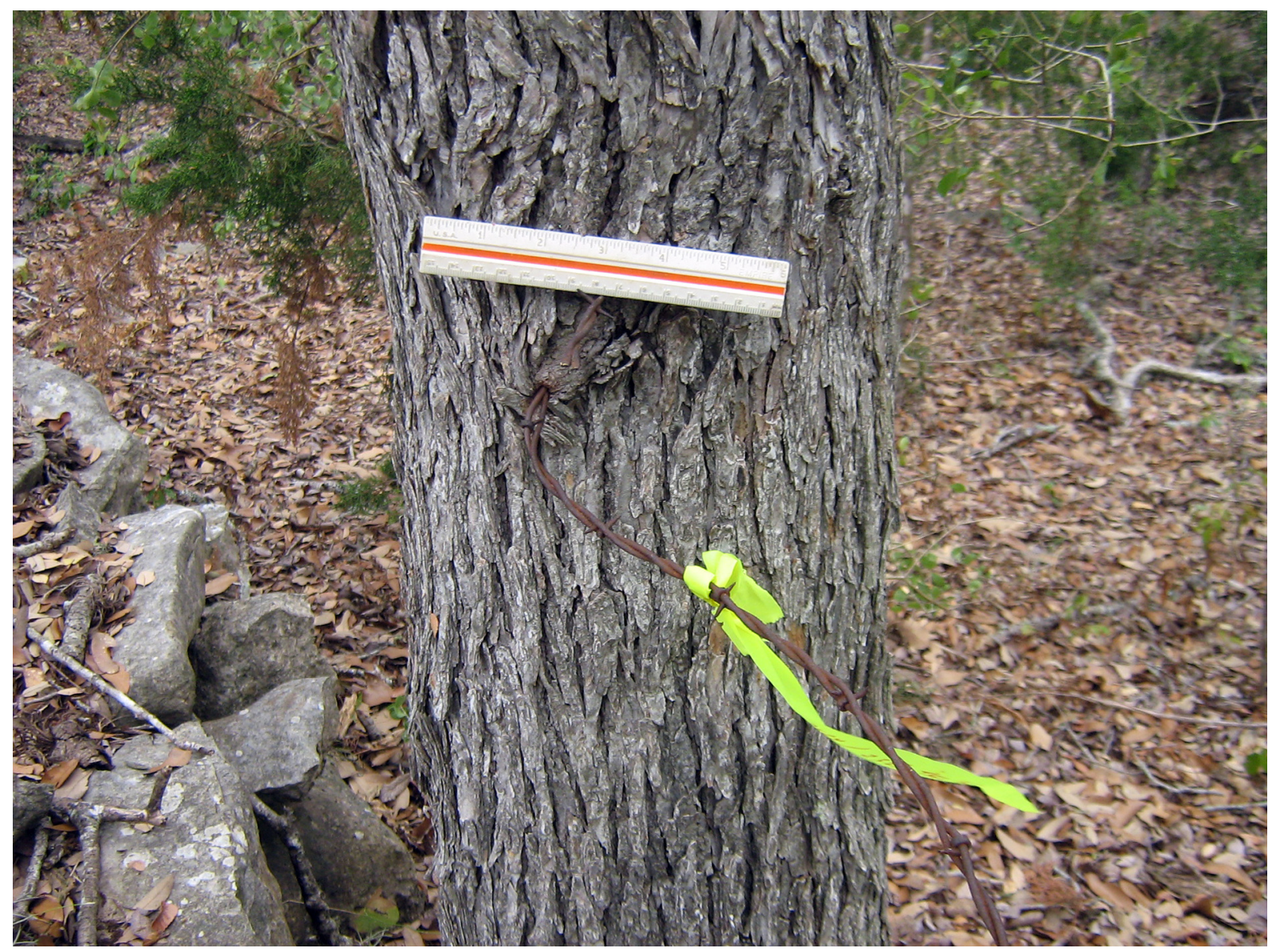

Figure 6.35. Photograph of barbed wire embedded in Tree 51. View is northwest with Rock Wall F2 on the left. Scale is 6 inches.

C2, and the upper strand on one side end in a loop that is linked to a long section of smooth wire. The upper strand also appears to be embedded only a few inches into the tree, which is not particularly large, suggesting that this section of wire fence is not very old and could postdate the Williams occupation.

Tree 72 is a dead tree (type unknown) lying on the ground in the south end of the corral complex and just west of Rock Wall C2. Like Tree 70, Tree 72 also has two strands of barbed wire embedded in it. The wire is Type 1 barbed wire, and one strand is at 21 inches from the bottom of the tree and the other is at 30 inches. The upper strand is not deeply embedded and protrudes in two places about 3 inches apart on the same side of the trunk. This suggests that this wire fence is not particularly old and could postdate the Williams occupation.
Tree 76 is a very large live oak with a trunk diameter of 29 inches, located south of the Williams house and in the southeastern corner of the Williams property. A twentieth-century trash dump is all around the tree. Two short sections of barbed wire (both Type 1) are embedded at 27 and 35 inches high (Figure 6.37). Both strands are very short (from 1 to 3 inches long), and they protrude from the center of the trunk on the east side. These wires are oriented east-west, but no wire sections protrude on the west side of the tree. These wires would have been part of a fenceline that ran east-west along the southern boundary of the Williams farm, in line with Rock Wall A. Because they are deeply embedded in the trunk of a very large tree, it appears that this fence section is quite old. A wooden post with attached barbed wire (also Type 1) lay on the 

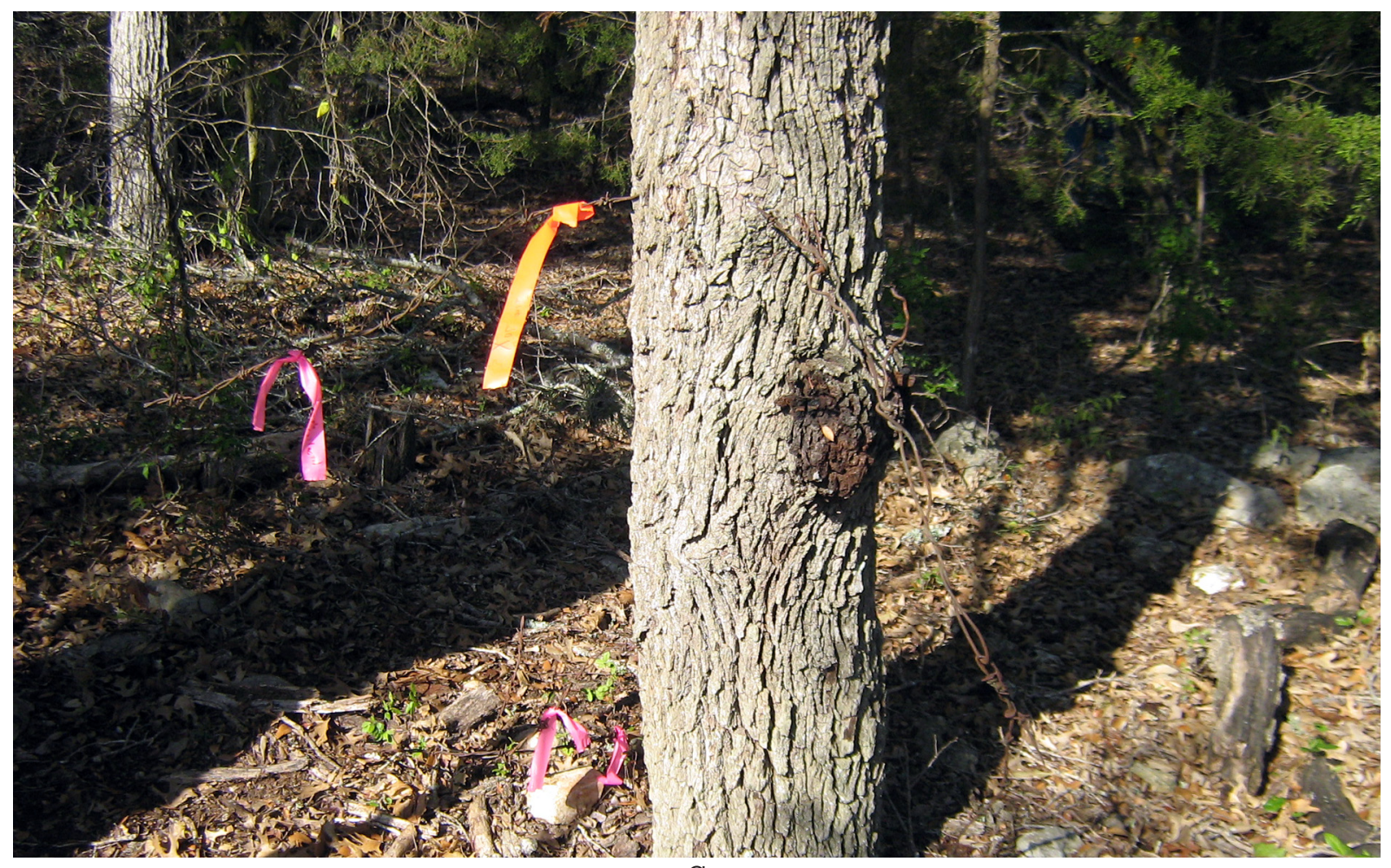

a
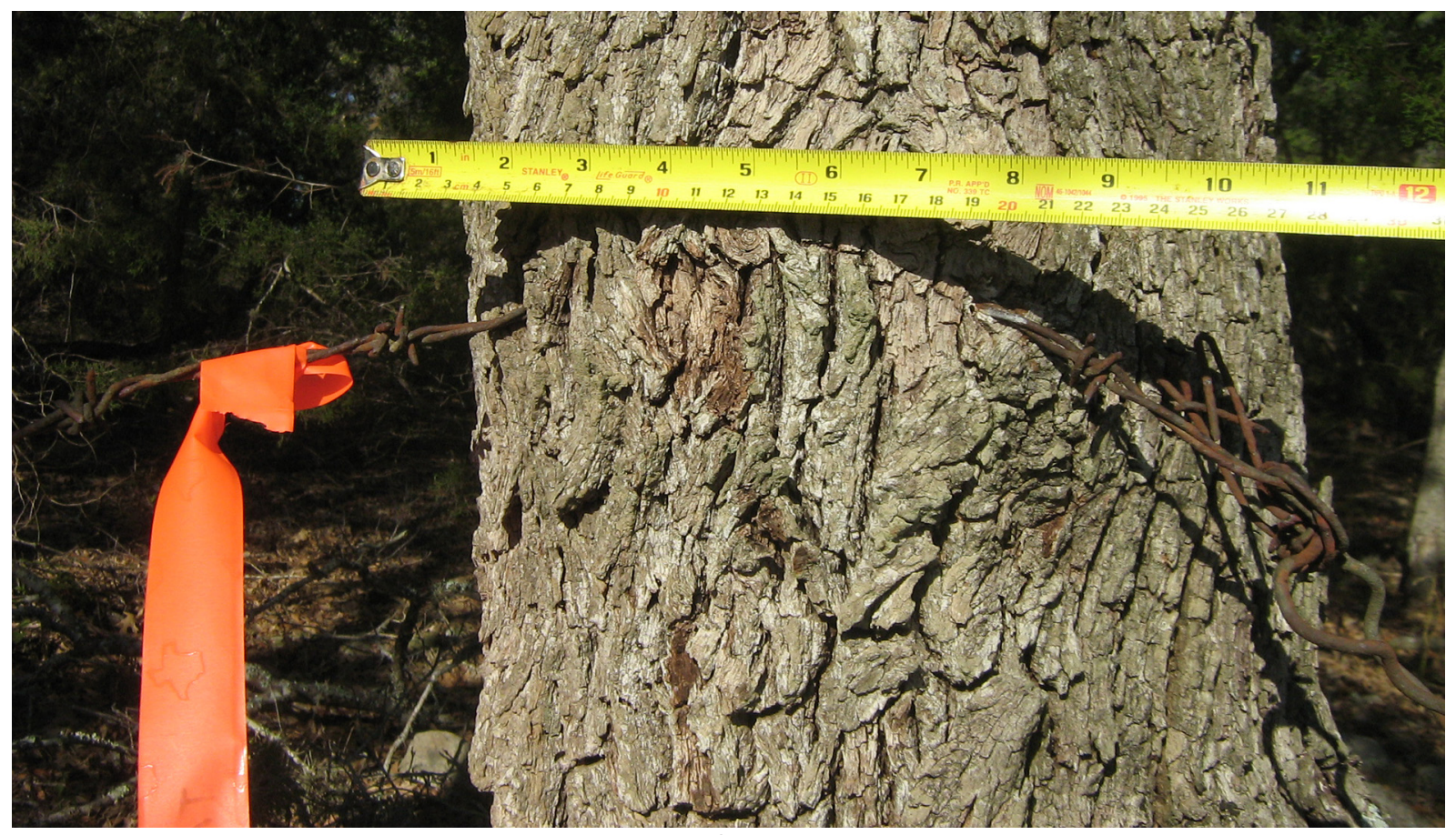

$\mathrm{b}$

Figure 6.36. Photographs of Tree Feature 70. (a) Overview looking southwest at the tree with Rock Wall C2 in the background. Note colored flagging tape on the upper and lower strands. (b) Closeup of the upper strand of barbed wire at 36 inches high on the trunk. Horizontal scale is in inches (top) and centimeters (bottom). 
ground a few feet east of the tree. No other evidence of fencing materials was observed, but a twentieth-century trash dump is present around Tree 76 (discussed below).

Tree Feature 82 is a cedar elm located along Rock Alignment B2 about 90 southeast of the Williams house. It has three strands of barbed wire (all Type 4) embedded in its trunk at 18, 30, and 39 inches high (Figure 6.38). The strands all run north-south, and the barbedwire sections are several feet long. The upper two strands are older and completely oxidized, while the lower strand is newer galvanized wire, and only its barbs are oxidized. The tree is relatively small, and the wires are not deeply embedded, suggesting that this section of wire fence is not particularly old and could postdate the Williams occupation.

The embedded wire strands in Trees 68,70 , 72 , and 82 all indicates that a barbed-wire fence ran north-south following Rock Walls B2 and C2. The evidence suggests that this fence could easily be over 50 years old, but it is certainly not as old as the barbed-wire fence strands attached to the other trees. This fence was probably built in the first half of the twentieth century, after the Williams family left the land in ca. 1905, but perhaps before they sold the land in the 1930s and 1940s.

Two trees at the far southern end of Rock Wall B2 offer proof of human use of this area after 1950. These relatively small cedar elms growing only 1 to $2 \mathrm{ft}$ apart had smooth wire embedded in their trunks (see Figure 6.9b). These trees are not recorded as historic tree features and are probably not more than 40 years old; the larger one has a trunk diameter of about 12 inches, and the smaller is about 10 inches. ${ }^{91}$ Multiple strands of heavy smooth gauge (heavier than any of the barbed wire)

\footnotetext{
${ }^{91}$ These trees were not assigned feature numbers because they are obviously young and postdate the Williams occupation.
}

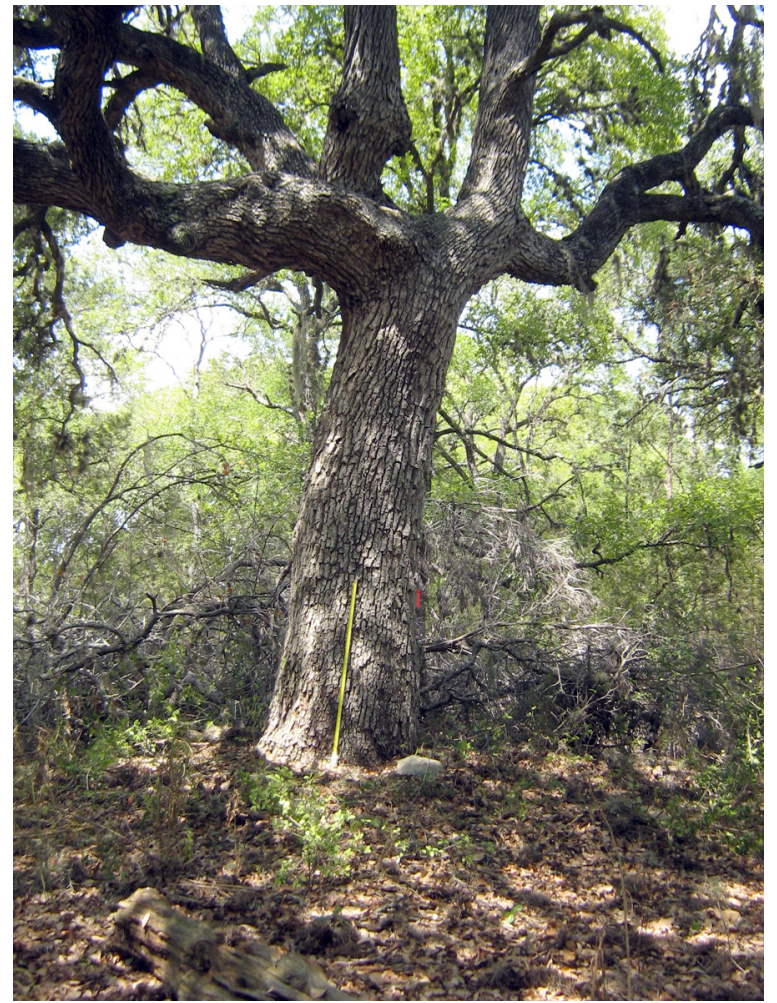

a

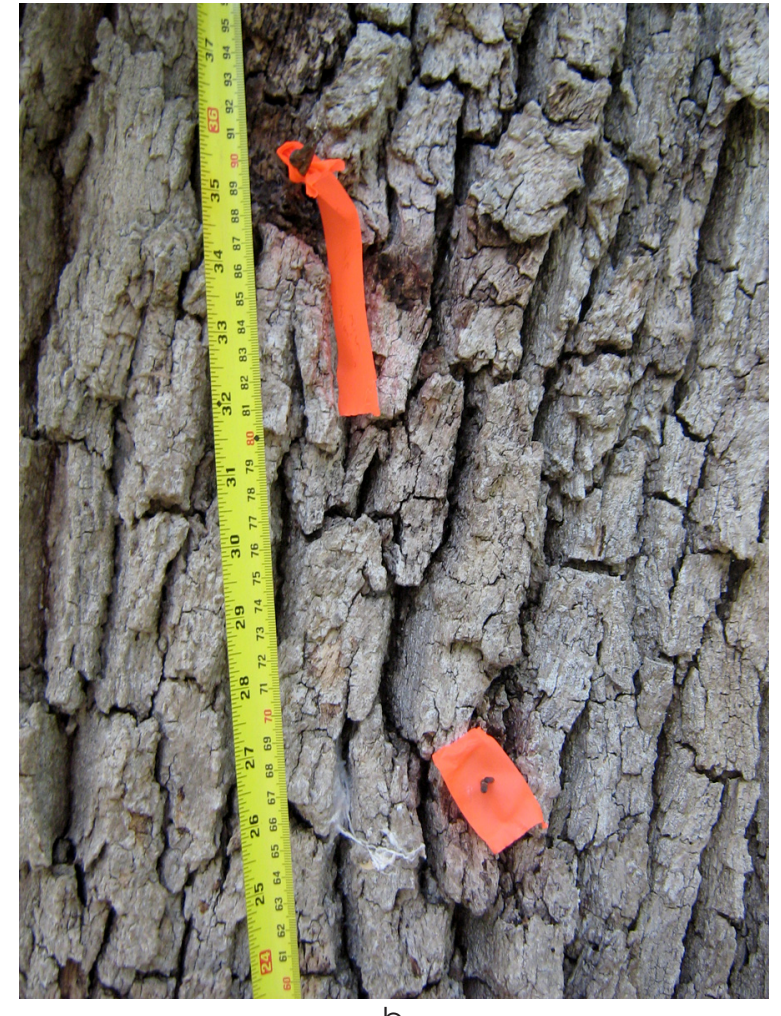

b

Figure 6.37. Photographs of Tree Feature 76. (a) Overview of the tree looking north with orange flagging marking the top strand of barbed wire. The tape measure is extended to 36 inches. (b) Closeup of the barbedwire strands that are 8 inches apart and centered on the east side of tree trunk. Vertical scale in inches (left) and centimeters (right). 
had been wrapped completely around the larger tree at ca. 40 inches above ground, and its trunk has grown around the wire. Three stands of smooth wire protruded from the larger tree, and one strand extended horizontally and was embedded in the trunk of the second tree. These two trees are near the southern end of the Williams property and only ca. $70 \mathrm{ft}$ north of one of the twentieth-century trash dumps, indicating that mid- to late-twentieth-century activities occurred in this general area.

\section{Tree with Rock Pile}

Tree 84 is an isolated very large live oak about $40 \mathrm{ft}$ south of the Williams property line. Around the tree is a small rock pile, giving the appearance that the rocks were placed there around the tree. The 1937 aerial photograph shows a large tree appears at this location (compare Figures 6.5 and 6.31). It appears to be along an east-west fenceline and south of an old road that ran parallel to the southern boundary of the Williams property. Consequently, it is not associated with the Williams family occupation. Notably, the field to the south was cultivated, and it is likely that the rock piled around Tree 84 represent stones plowed up in the field and discarded along the old fence row.

\section{INVESTIGATION OF POSSIBLE SPRING LOCATION}

In the 2008 testing phase, a possible spring location was identified in the lower area of the farmstead (Boyd and Franklin 2009:4). The location was an eroded cut, shallow but quite distinctive, in the bottom of a natural drainage that occurred at the precise location where two prominent rock walls (F1 and E1) converged and old wooden posts with barbed wire were present (see Figure 6.15b). During the 2009 data recovery investigations, no moisture was

observed in this area, but that summer was one of the driest recorded in central Texas for many decades. Because wet sediments were observed in previous years, it was thought that there might have been a small spring or groundwater seep at this location. As part of the landscape study, Backhoe Trench 9 was excavated to test this hypothesis. The L-shaped excavation (see Figure 3.6) measured 3 to $4 \mathrm{ft}$ wide and extended $6 \mathrm{~m}$ east-west and $6 \mathrm{~m}$ north-south. It exposed only upland clay soils over weathered limestone bedrock. No evidence of a groundwater seep or spring was observed (e.g., no gley sediments, unusual discoloration of the clay soils or bedrock limestone, or hint of travertine or other spring-associated deposits). 


\section{TWENTIETH-CENTURY FEATURES}

Three of the features documented at the Williams farmstead date to the twentieth century and postdate the Williams family occupation (Figure 6.39). Two are trash dumps and one is a concrete trough.

Trash Dump A is located in the southeast corner of the Ransom Williams property-and in fact may not even be on the original Williams property. Debris is scattered over a 23 -ft-diameter area around Tree 76, a large live oak with barbed wire embedded in it (see Tree Feature 76 above).

The historic artifacts observed in this dump area are summarized in Table 6.6. They all appear to date from the first half of the twentieth century. Many of the cans are the "flat-top" style beverage (probably beer) cans with church key holes in the top. The flat-top beer can was patented in 1936 (Robison 1936), and the church key was patented in 1935 (Sampson and Hothersall 1935). Flat-top beverage cans were later replaced with pull-tab cans, which were invented in 1959 but not patented until 1967 (Fraze 1967; Ohio History Central 2006). The clear glass wide mouth jar is a variation of the "Mason jar" or "fruit jar" used for food canning; it has a "J-in-a-Keystone" mark on its base. This mark was used by the Knox Glass Bottle Company of Jackson, Mississippi, from the inception of the plant in 1932 until it changed marks in 1952 (Lockhart et al. 2008:7; Toulouse 1971:271). The many wine bottles in this dump are all the same: clear glass with mold seams over the lip of the screw-cap finish. This indicates that they were made on an automatic bottle machine after ca. 1905 (Lindsey 2013a, 2013b). These bottles also have a diamond enclosing the "O" and "I" letters-a distinctive mark used by the Owens-Illinois Glass Company from its 1929 inception until 1954, when the company changed the mark (Toulouse 1971:403). These bottles are embossed with the words "WINE" and "4/5 Quart" on the sides.

Trash Dump B is next to the TxDOT right-of-way fence more than $150 \mathrm{ft}$ east of the Williams house and at least $70 \mathrm{ft}$ east of the Williams property line. Because it was so far from the nineteenth-century farmstead features and off Williams's land, it was not examined closely. But the materials observed in Dump B were all twentieth-century artifacts similar to those documented in Dump A. Among the artifacts were several iron beer cans with church key holes punched in the top and several clear glass wine bottle fragments. Like the bottles in Dump A, the specimens in Dump B included machinemade necks with screw caps and bottle sides embossed with the words "WINE" and "3/4 Quart."

The concrete trough is a rectangular feature measuring $85 \mathrm{ft}$ long, $2 \mathrm{ft}$ wide, and 10 to 12 inches high. It is constructed of wire meshreinforced concrete that was poured in place on the ground, presumably inside a wooden frame. The interior of the trough is about 8 inches deep, and the surface was smoothed with a trowel. The trough is made of poor-quality concrete, and it has weathered and broken in many places, exposing in some places a high density of poorly mixed sandy gravel and the wire mesh. Long horizontal sections of rebar, used to reinforce the top edges of the trough, were also exposed in many places. It appears that this trough was constructed in five separate sections, each about $17 \mathrm{ft}$ long.

The possibility that this was a water trough was considered, but this is unlikely given the fact that it was built in sections. The surrounding area was examined to look for a vertical pipe and footings of a windmill, but none were found. Consequently, it is more likely that this feature was a feed trough. It does not appear in the 1937 aerial photograph, but it does appear in an aerial photograph from the early 1970s (USDA 1974). This clearly indicates that the feature postdates 1937 and was not associated with the Williams family occupation.

\section{ARTIFACTS IN THE CORRAL COMPLEX}

As the landscape analysis progressed, it became increasingly obvious that many of the rock walls were part of a livestock corral complex, and trenching confirmed the presence of a former pond in this area. This led to a more intensive surface survey and metal detector searching, and 113 artifacts were found (Table 6.7). Figure 6.40 is a map of the corral complex area showing the locations of these artifacts. These findings led, in turn, to the excavation of a $2 \times 2-m$ unit south of the pond, along Rock Wall E1. Designated Excavation Unit Z, it yielded more artifacts associated with the corral complex (Table 6.8). These surface and excavated 


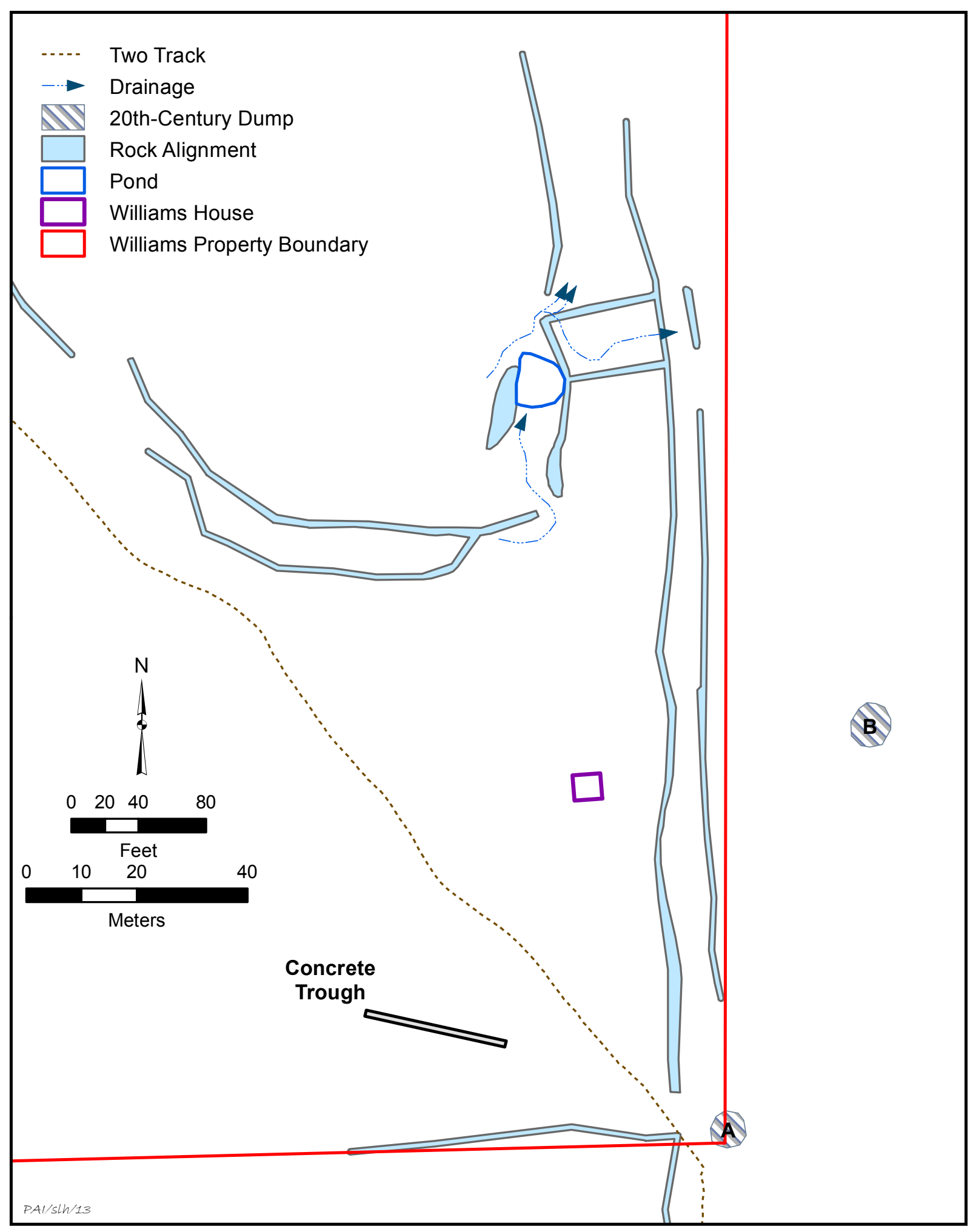

Figure 6.39. Map of twentieth-century features. 
Table 6.6. Artifacts observed in Trash Dump A

\begin{tabular}{|c|c|c|}
\hline Group & Artifact Description & Diagnostic Markings \\
\hline \multirow[t]{10}{*}{ Metal } & Three one-gallon paint cans and lids & \\
\hline & $\begin{array}{l}\text { A tin enamelware wash basin, 14-inch } \\
\text { diameter }\end{array}$ & \\
\hline & $\begin{array}{l}\text { Three thin metal shelves from prefabricated } \\
\text { shelf unit }\end{array}$ & \\
\hline & $\begin{array}{l}\text { Flat iron pieces and a leg, probably from a } \\
\text { metal kitchen cabinet }\end{array}$ & \\
\hline & $\begin{array}{l}\text { Various sizes of modern sanitary tin cans; } \\
\text { one medium-sized can had a remnant of the } \\
\text { painted label }\end{array}$ & $\begin{array}{l}\text { Faded painted label with "MAXWELL } \\
\text { HOUSE COFFEE." The Maxwell House } \\
\text { brand began in 1892, but this can probably } \\
\text { dates to the mid-twentieth century }\end{array}$ \\
\hline & $\begin{array}{l}\text { A large modern tin can with horizontal ridges, } \\
\text { probably a one-gallon coffee can }\end{array}$ & \\
\hline & $\begin{array}{l}\text { Seven 12-ounce iron "flat top" style beer cans } \\
\text { with two church key holes in the top. }\end{array}$ & \\
\hline & $\begin{array}{l}\text { Twelve } 12 \text {-ounce iron cans with lids cut out } \\
\text { using can opener, probably food cans }\end{array}$ & \\
\hline & $\begin{array}{l}\text { Seven } 6 \text {-ounce cans with a drop of solder } \\
\text { on centered on one top. These are modern } \\
\text { evaporated milk cans rather than "hole-in-top" } \\
\text { cans. }\end{array}$ & \\
\hline & A flat rectangular, sardine-type can & \\
\hline \multirow[t]{7}{*}{ Glass } & $\begin{array}{l}\text { A white milk glass jar base, probably a cold } \\
\text { cream jar }\end{array}$ & \\
\hline & $\begin{array}{l}\text { A one-gallon clear glass jug neck fragment } \\
\text { with a loop finger handle }\end{array}$ & \\
\hline & Two clear glass large jug necks & \\
\hline & $\begin{array}{l}\text { Many complete and fragmentary wine glass } \\
\text { bottles (estimated } 56 \text { bottles). They are all the } \\
\text { same type and were made on an automatic } \\
\text { bottle machine. Bottle necks have screw-cap } \\
\text { tops, and some have metal caps attached. } \\
\text { Many bottles have diagnostic markings }\end{array}$ & $\begin{array}{l}\text { Bottle bases have the diamond-circle and } \\
\text { "I" maker's mark of the Owens-Illinois } \\
\text { Glass Company. "WINE" and "4/5 QUART" } \\
\text { are embossed on sides }\end{array}$ \\
\hline & $\begin{array}{l}\text { A clear glass, wide-mouth, pint-size jar with a } \\
\text { diagnostic maker's mark }\end{array}$ & $\begin{array}{l}\text { Base has the "J-in-a-Keystone" maker's } \\
\text { mark of the Knox Glass Bottling Company } \\
\text { that operated in Jackson, Mississippi, from } \\
\text { 1832-1953 (Toulouse 1971:271-272) }\end{array}$ \\
\hline & $\begin{array}{l}\text { Small clear glass spice bottle, probably Tabasco } \\
\text { sauce }\end{array}$ & \\
\hline & $\begin{array}{l}\text { A brown glass bottle neck with a crown finish, } \\
\text { probably a beer bottle }\end{array}$ & \\
\hline \multirow[t]{2}{*}{ Ceramic } & Three plain whiteware sherds & \\
\hline & A red transfer-printed sherd & \\
\hline
\end{tabular}

artifacts are significant because of their contextual association with the rock walls and what they reveal about the corral complex.

Of the 113 surface and metal-detected artifacts found in the corral complex, 64 could be assigned to functional groups. Artifacts associated with activities include wagon hardware, horse harness parts, and hand tools. Many iron hoops from large barrels were found; these are presumably associated with water storage. 
Chapter 6: Landscape Analysis

Table 6.7. Surface-collected and metal-detected artifacts recovered from the corral complex

\begin{tabular}{|c|c|c|c|c|}
\hline $\begin{array}{l}\text { Functional } \\
\text { Group }\end{array}$ & Artifact Category & Identification & $\begin{array}{l}\text { Number of } \\
\text { Specimens }\end{array}$ & $\begin{array}{c}\text { Functional } \\
\text { Group } \\
\text { Subtotal }\end{array}$ \\
\hline \multirow[t]{5}{*}{ Activities } & Carriage and Wagon & $\begin{array}{l}\text { Hardware, wagon wheel } \\
\text { rough lock }\end{array}$ & 1 & \multirow[t]{5}{*}{23} \\
\hline & Construction & $\begin{array}{l}\text { Hand tools, draw knife } \\
\text { blade fragments (both refit) }\end{array}$ & 2 & \\
\hline & Horse Tack and Harness & $\begin{array}{l}\text { Hardware, 3.5-inch cinch } \\
\text { ring }\end{array}$ & 2 & \\
\hline & Horse Tack and Harness & $\begin{array}{l}\text { Hardware, chain segment } \\
\text { with ring }\end{array}$ & 1 & \\
\hline & Water Storage & Barrel Band & 17 & \\
\hline \multirow[t]{6}{*}{ Architectural } & Fencing, wire & Barbed wire Type 1 & 5 & \multirow[t]{6}{*}{16} \\
\hline & Fencing, wire & Barbed wire Type 2 & 2 & \\
\hline & Fencing, wire & Barbed wire Type 5 & 2 & \\
\hline & Fencing, wire & Barbed wire, untyped & 4 & \\
\hline & Fencing, wire & Smooth wire & 1 & \\
\hline & Structural & Cut nails & 2 & \\
\hline \multirow{3}{*}{$\begin{array}{l}\text { Kitchen/ } \\
\text { Household }\end{array}$} & Food Storage and Preparation & Container glass & 17 & \multirow[t]{3}{*}{21} \\
\hline & Food Storage and Preparation & Metal screw cap* & 3 & \\
\hline & Food Storage and Preparation & Metal crown cap & 1 & \\
\hline \multirow[t]{2}{*}{ Personal } & Accoutrements & Pocket knife, complete & 1 & \multirow[t]{2}{*}{4} \\
\hline & Alcohol & $\begin{array}{l}\text { Wine bottle, base } \\
\text { fragments* }\end{array}$ & 3 & \\
\hline $\begin{array}{l}\text { Clothing/ } \\
\text { Adornment }\end{array}$ & - & - & 0 & 0 \\
\hline $\begin{array}{l}\text { Unknown or } \\
\text { Unidentifiable }\end{array}$ & - & - & 49 & 49 \\
\hline \multicolumn{3}{|l|}{ Total } & 113 & 113 \\
\hline
\end{tabular}

*The metal screw caps probably went with the wine bottle bases, which match the wine bottles found in the twentieth-century Trash Dump A. These bottle bases have the Owens-Illinois Glass Company maker's marks dating between 1929 and 1959 (Toulouse 1971:403). They were collected from among the rocks near the top of Rock Wall E1 south of the livestock pond.

The architectural artifacts are dominated by barbed-wire fragments, which is not unexpected since barbed-wire fences were present in the corral complex. Only two nails were found, both cut nails that probably were used before the turn of the century. Collectively, these activities and architectural artifacts are typical of the kinds of objects commonly used in areas where livestock was kept.

The personal artifacts from the corral complex include a pocketknife that was probably lost by someone working in the corral area, as well as four broken wine bottle bases (see Tables 6.7 and 6.8). The metal screw caps and clear glass found in Unit Z and on the surface nearby were assigned to the kitchen household group, but they probably came from the same wine bottles as the bases. Notably, all of the wine bottle bases have diagnostic maker's marks that date between 1929 and 1959, which indicates that they postdate the Williams occupation. Three of the bottle bases were found among the upper and mid-level rocks of Rock Wall E1 near the pond area, and it is surmised that these bottles were placed on the rock wall and used for target shooting, probably by people who owned the land 


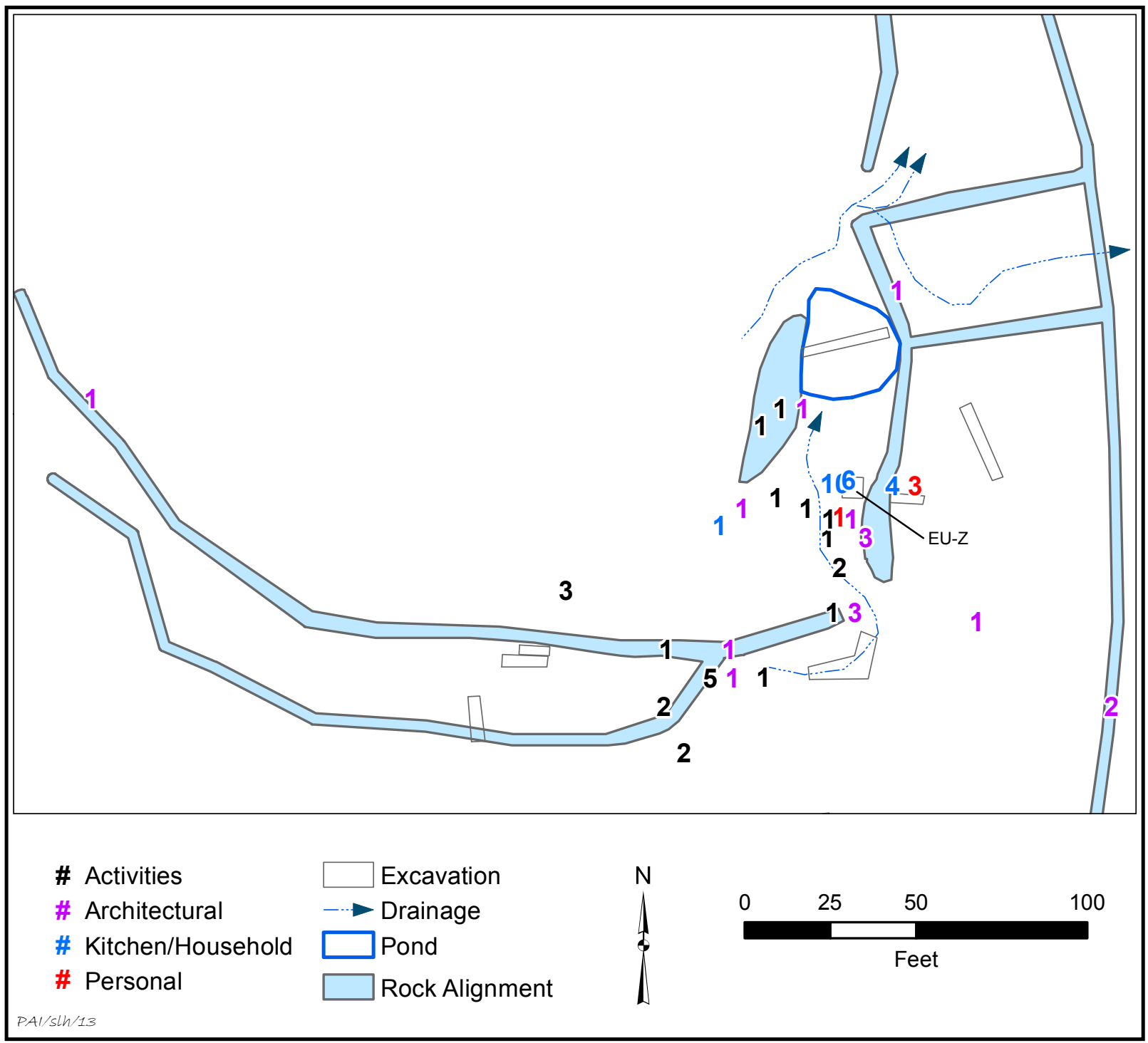

Figure 6.40. Map of surface-collected and metal-detected artifacts found in the corral complex. The map shows 64 artifacts grouped by functional class; 49 corroded specimens (mostly unidentifiable iron) are not shown.

Table 6.8. Artifacts recovered from Excavation Unit $Z$ in the corral complex

\begin{tabular}{l|l|l|r}
\hline \multicolumn{1}{c|}{ Functional Group } & \multicolumn{1}{|c|}{ Artifact Category } & \multicolumn{1}{c}{ Identification } & Quantity \\
\hline Kitchen/Household & Food Storage and Preparation & Metal screw cap & 7 \\
\hline Kitchen/Household & Food Storage and Preparation & Container glass, clear fragments & 92 \\
\hline Personal & Alcohol & Wine bottle, base fragment & 1 \\
\hline Faunal & - & $\begin{array}{l}\text { Medium to large mammal, unidentifiable } \\
\text { fragment }\end{array}$ & 1 \\
\hline Unknown & - & Corroded iron, unidentifiable fragments & 72 \\
\hline \multicolumn{2}{l|}{ Total number of specimens } & & 173 \\
\hline
\end{tabular}


or lived on a nearby farm after the Williams family sold the farm in 1934 .

Nails and other architectural artifacts can provide evidence of former structures, but there is no definitive evidence that wooden structures once stood anywhere in the corral complex. However, this possibility cannot be ruled out. Williams could have built a small structure (e.g., a barn, storage shed, or tack room) of logs, which would have left few nails. Another possibility is that Williams built one or more wood-frame structures held together with nails but that the nails are too deteriorated (i.e., oxidized) to produce a metal detector signal. In fact, many of the small, corroded iron artifacts recovered from Excavation Unit Z produced only a weak metal detector signal or none at all. So although some type of wooden structures could have existed in the corral complex, we can never know for sure if this was the case.

The final observation regarding the corral complex does not pertain to the artifacts that were found there but to the things that were not found there. Despite an intensive surface survey, metal detector searching, and backhoe trenching in the area, many types of common artifacts found in the house block and trash midden were not found in the corral complex. These include items associated with food preparation and serving, (especially ceramics and kitchen utensils), children's toys, and clothing. Collectively, the sparse quantity of materials recovered from the corral complex, and the types of artifacts that were found, are indicative of an area where specialized activities occurred.

\section{SUMIMARY OF THE LANDSCAPE ANALYSIS}

Many lines of evidence were used to examine the landscape features associated with the Ransom and Sarah Williams farmstead. Historic and modern aerial photographs were studied, and all of the rock features were mapped and documented, including linear rock walls and alignments and rock mounds. Backhoe trenches were used to investigate some of the landscape features, and one of the trench excavations helped identify the location of an old livestock pond. The location of the Williams farmhouse, with its rock chimney base intact, was obvious. Excavations around the house revealed the presence of a defined yard area, a possible farm-related outbuilding west of the house, and a household trash dump east of the house. While the farmhouse and yard area were the central focus of most of the archeological work (see Chapters 7 and 11), they were spatially separated from the main livestock corrals and pastures.

One of the most interesting facts is that the landscape analysis revealed is the vegetation patterns and the locations of rock walls, alignments, and mounds seen in the 1937 aerial photograph correspond perfectly with those observed at the site in 2009 (see Figures 6.5 and 6.6). The wooded area in the old photograph is still wooded today, and those woods conceal the pond location and the rock walls and alignments that comprise the corral complex. Many old trees are present in this area, and some are old oaks (many in the 150- to 300-year-old range) that were undoubtedly big trees when the Williams family lived on the farm. Several of these trees have barbed wire embedded in their trunks, indicating that they once served as fence posts along the rock walls and alignments. The 1937 aerial photograph also shows cleared fields, and these areas are still identifiable on the ground today. Although trees have grown back in the old field locations, they are obviously smaller and younger trees. The property boundaries evident in the 1937 photograph also are evident in the vegetation patterns today, and some of these boundaries are still marked by rock walls and alignments.

In their classic study of fences and farms, Cotton Mather and John Hart (1954:201) state that "the fence is a feature of functional importance in American agriculture, in the rural scene, and the rural economy, and, hence, in the geography of this country." They note that stone fences are relatively rare across the United States and that they are "restricted to livestock areas with stony soils: the surface stones removed from the field as hazards are used to build a substantial and durable fence" (Mather and Hart 1954:212). Thus, the widespread use of limestone rocks to build farm fences was quite common in the Texas Hill Country before the invention and widespread adoption of barbed wire in the 1870s (Freeman et al. 2001:131; Taylor 1979). This phenomenon is easily predictable based on the character of the Hill Country landscape.

Extensive archeological surveys of more than 300 square miles of land on the Fort Hood military reservation provide ample evidence of the importance of dry-laid rock walls in 
the Texas Hill Country. Fences are one of the feature types associated with farm and ranch properties (Freeman et al. 2001:143-144), and a review of 710 historic sites on Fort Hood reveals that stone fences are ubiquitous (Blake 2001). More than 20 percent of these sites have "rock wall," "stone wall," or "limestone wall" sections, and some have extensive systems. Oral histories with former residents of the Fort Hood lands also record rock or stone fences (Dase et al. 2003a:57, 63, 328, 339; Dase et al. 2003b:1074, 1267). Relatively speaking, rock or stone fences are well documented archeologically because they have survived well, while most barbed-wire fences were systematically removed from the Fort Hood lands and only sparse remnants are documented. In contrast, the oral history recollections, all of which relate to the early twentieth century, show the opposite pattern. Only a few people mentioned the existence of rock and stone fences, while many people recalled building and maintaining barbed-wire fences. This evidence suggests two historical trends. First, most of the rock fences were probably built in the nineteenth century prior to the widespread use of barbed wire. And second, by the turn of the century, barbed wire had replaced rock as the preferred type of fence in the rocky Fort Hood landscape. Notably, the Fort Hood archeological record has many cases where barbed-wire fences were placed on or adjacent to stone fences, as was observed at the Williams farmstead.
It is important to remember that the landscape features documented on the Williams farmstead do not represent all of the farm structures and features that existed. Many common and important components of rural nineteenth-century farms were not found, but that does not mean that they were not there. It simply means that if they were there, they are below the threshold of archeological visibility. Investigations of the Fort Hood historic sites reveal the types of structures and features most commonly associated with central Texas farm and ranch properties (Blake 2001:10-11,Figure 10; Freeman et al. 2001:128-133). Components commonly found on nineteenth-century central Texas farmsteads are listed in Table 6.9, and those present on the Williams farmstead are noted.

Collectively, the landscape analysis evidence indicates that the placement of the large-scale features was anything but random. Ransom Williams planned the layout of his farm in a way that made perfect sense given the characteristics of his property. The spatial evidence, including the locations of permanent improvements and activity areas, reflect the integrated systemic nature of a small, single-family farmstead. The spatial evidence also demonstrates that Williams was a knowledgeable farmer who had a good understanding of the topography, hydrology, soils, and biotic resources of the central Texas Hill Country. The layout of the Williams farmstead as revealed through the landscape analysis is discussed further in Chapter 14. 


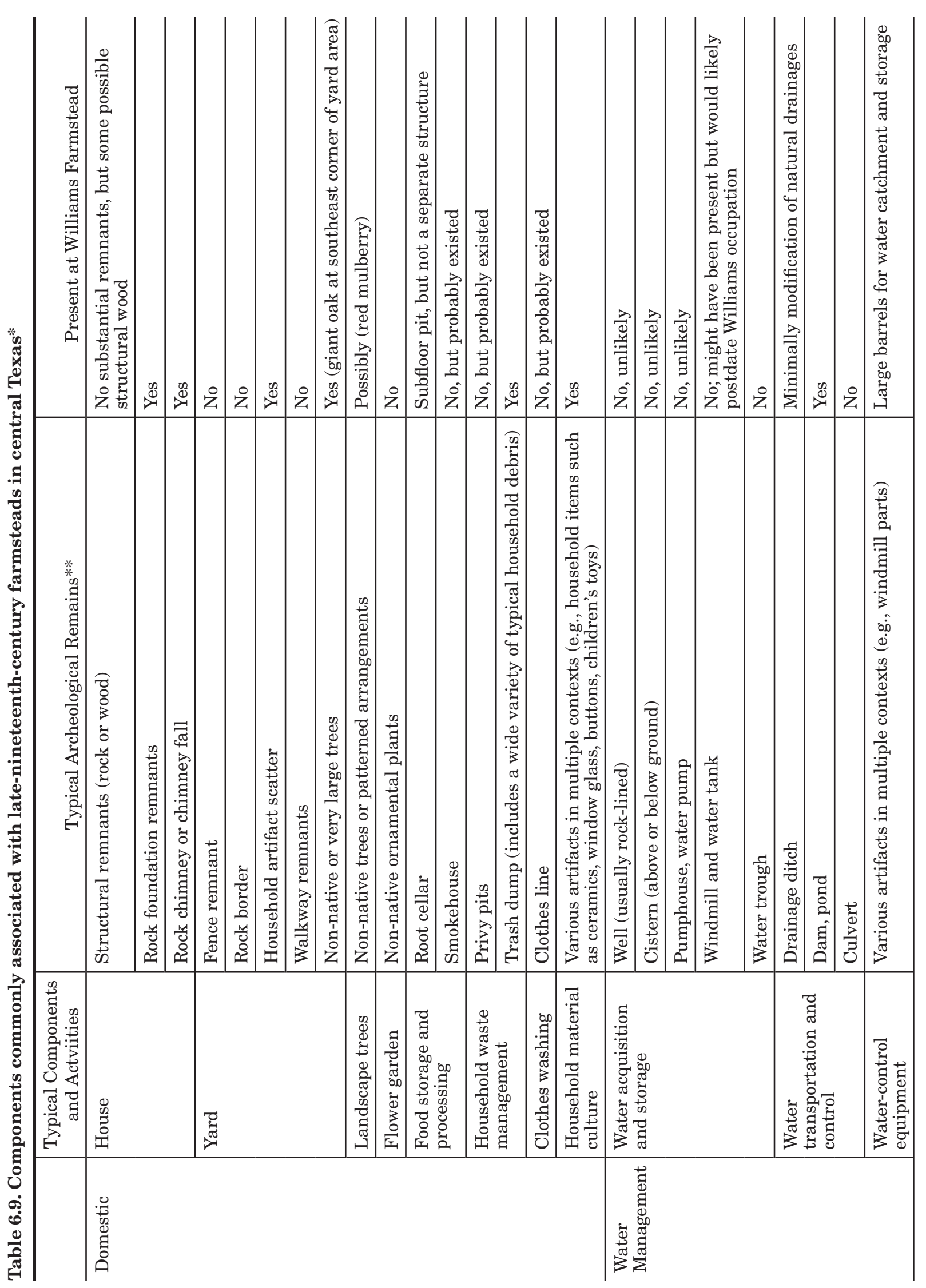


The Ransom and Sarah Williams Farmstead

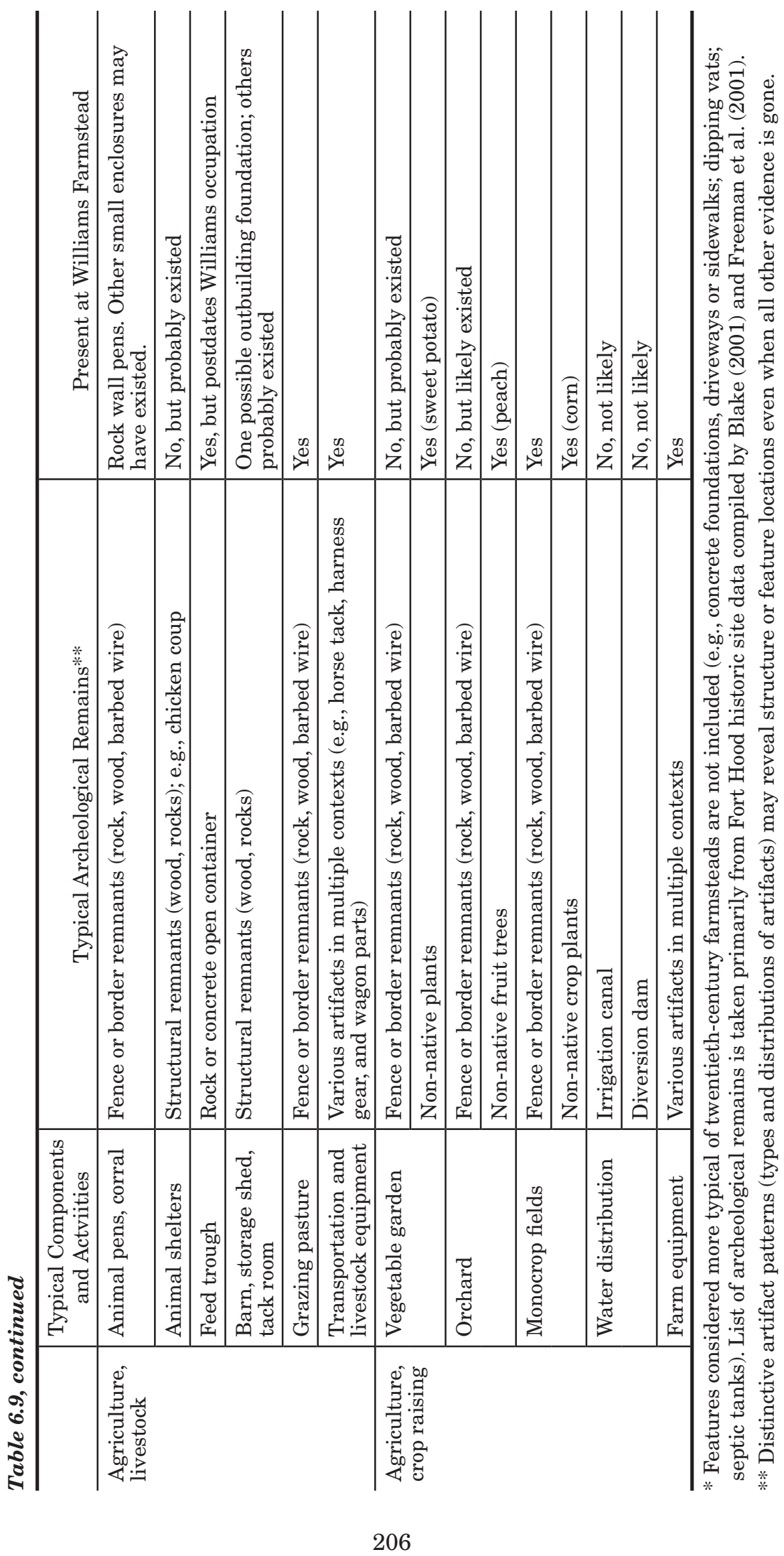




\title{
CULTURAL FEATURES ASSOCIATED WITH THE WILLIAMS FARMHOUSE
}

\author{
Aaron R. Norment and Douglas K. Boyd
}

The most intensive archeological work at the Williams farmstead took place at the historic house and the area immediately around it. Archeological excavations there documented three household features: the house foundation, the chimney firebox, and a subfloor storage pit inside the house area. Two other large features were documented nearby: a large trash midden east of the house and a possible outbuilding northwest of the house (Figure 7.1). Each of these features is an integral part of the house and yard complex where most of the Williams family's daily activities occurred.

\section{HOUSEHOLD FEATURES}

The three household features discussed in this section are the house foundation, which is composed of scattered limestone rocks concentrated in a roughly rectangular area; the chimney firebox, including the chimney base and the mound of collapsed chimney rocks around it; and a subfloor pit that was found a few feet in front of the fireplace.

\section{House Foundation}

Once the house block excavations were completed, the area was swept clean and all of the exposed large rocks were left in place (Figure 7.2). A series of overhead photographs was then taken, one for each $1 \mathrm{x} 1-\mathrm{m}$ unit. These 90 overhead images were later stitched together to create a mosaic plan-view photograph of the entire excavated house block. This composite photograph was used to construct a plan drawing used to study the rock patterns with the goal of identifying foundation stones to reveal the house outline (Figure 7.3). This process of defining the house foundation by interpreting the spatial patterning of structural rocks and artifacts worked well; it is discussed in more detail in Chapter 11.

Many of the rocks in the eastern half of the house block were obviously rubble from the collapse of the chimney, but many other stones in the block are likely foundation stones. Four large tabular limestone boulders were observed in areas inferred to be the house corners, and other large and medium-sized stones were generally concentrated along lines between these cornerstones. As a result, a fairly accurate outline of the house foundation was inferred from the locations of the in situ (and displaced) foundation stones.

The four largest limestone slabs were relatively equidistant from one another, and they are interpreted as the foundation stones for the house corners. If this interpretation is correct, the relative placement of these stones indicates that the house was a roughly square structure that measured approximately $16 \times 16 \mathrm{ft}$. This estimate is approximate because it appears that the southeast cornerstone and some wall stones were displaced from their original location over the years. Any of the foundation stones could have been moved by livestock, wildlife, burrowing animals, or tree roots. It is also likely that the collapse of the wooden structure and the chimney caused some foundation stones to be shifted from their original settings. Nevertheless, the estimated size appears to be quite reasonable if the structure was a log cabin, as is suggested in Chapter 11 . It conforms to the most common pattern for single-pen log cabins in Texas. In Texas Log Buildings, Jordan (1978:111) writes: 


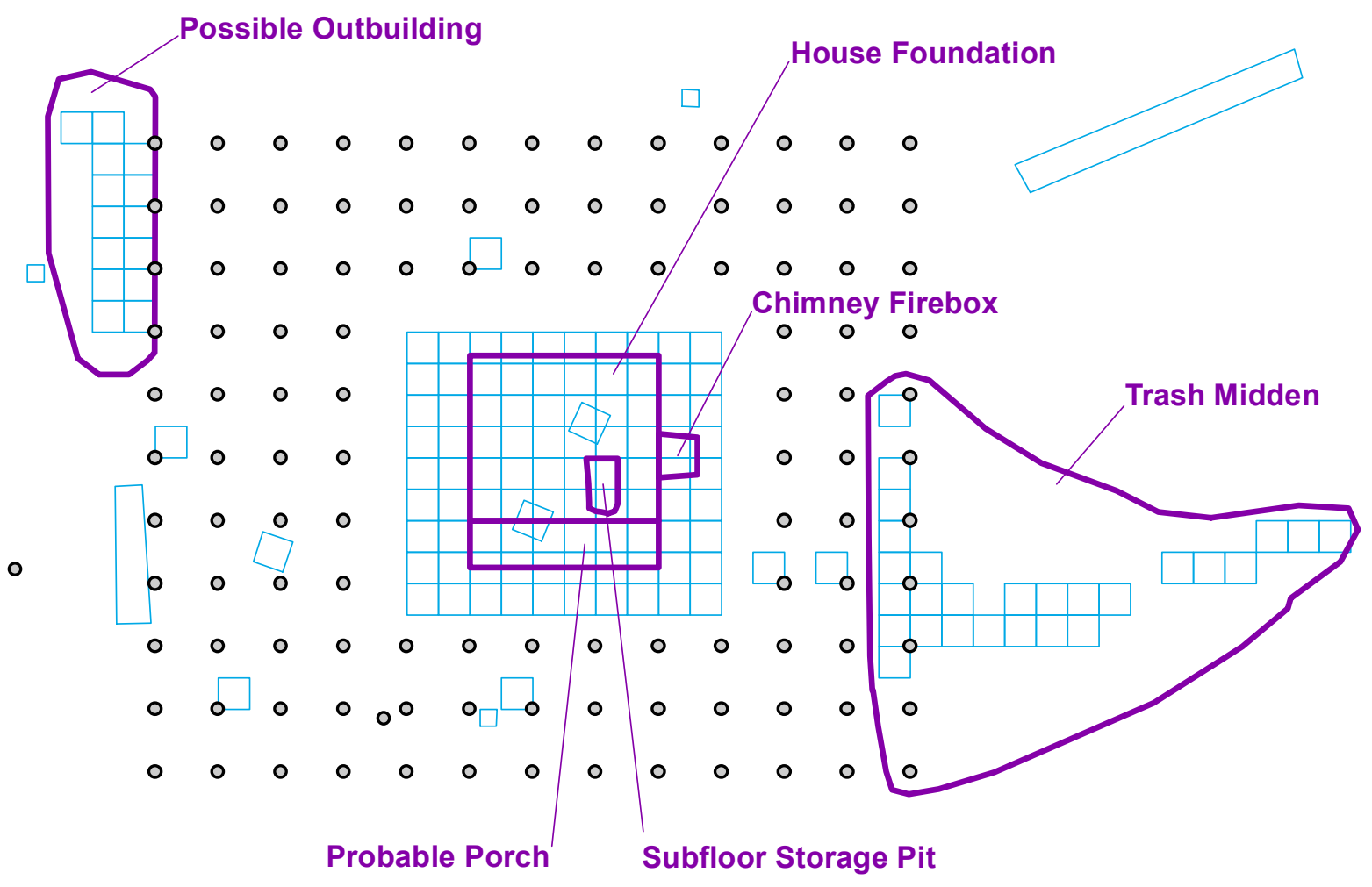

\begin{tabular}{ll}
\multicolumn{1}{c}{ Shovel Test } \\
$\square$ & Feature \\
$\square$ & Excavations
\end{tabular}

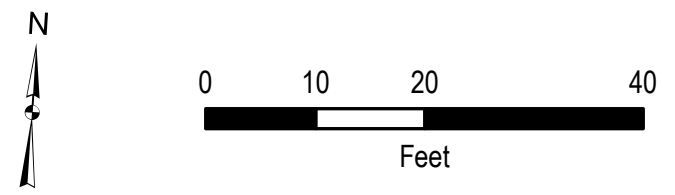

Figure 7.1. Map of cultural features associated with the Williams farmhouse.

The other basic type of single pen, the type dominant in Texas, has a square or roughly square floor plan....The majority of such pens measure about $16^{\prime}$ x $16^{\prime}$ to $18^{\prime}$ x $18^{\prime}$, though smaller and larger examples can be found.... the overwhelming majority of singlepen log dwellings in the state are square or roughly square, and the $16^{\prime}$ $\mathrm{x} 16$ ' pen is very common. ${ }^{92}$

${ }^{92}$ The square single-pen $\log$ cabin is a variation of the "one-bay house of Old England." In this region, "a bay is sixteen feet square in British terminology" (Jordan 1978:111). 


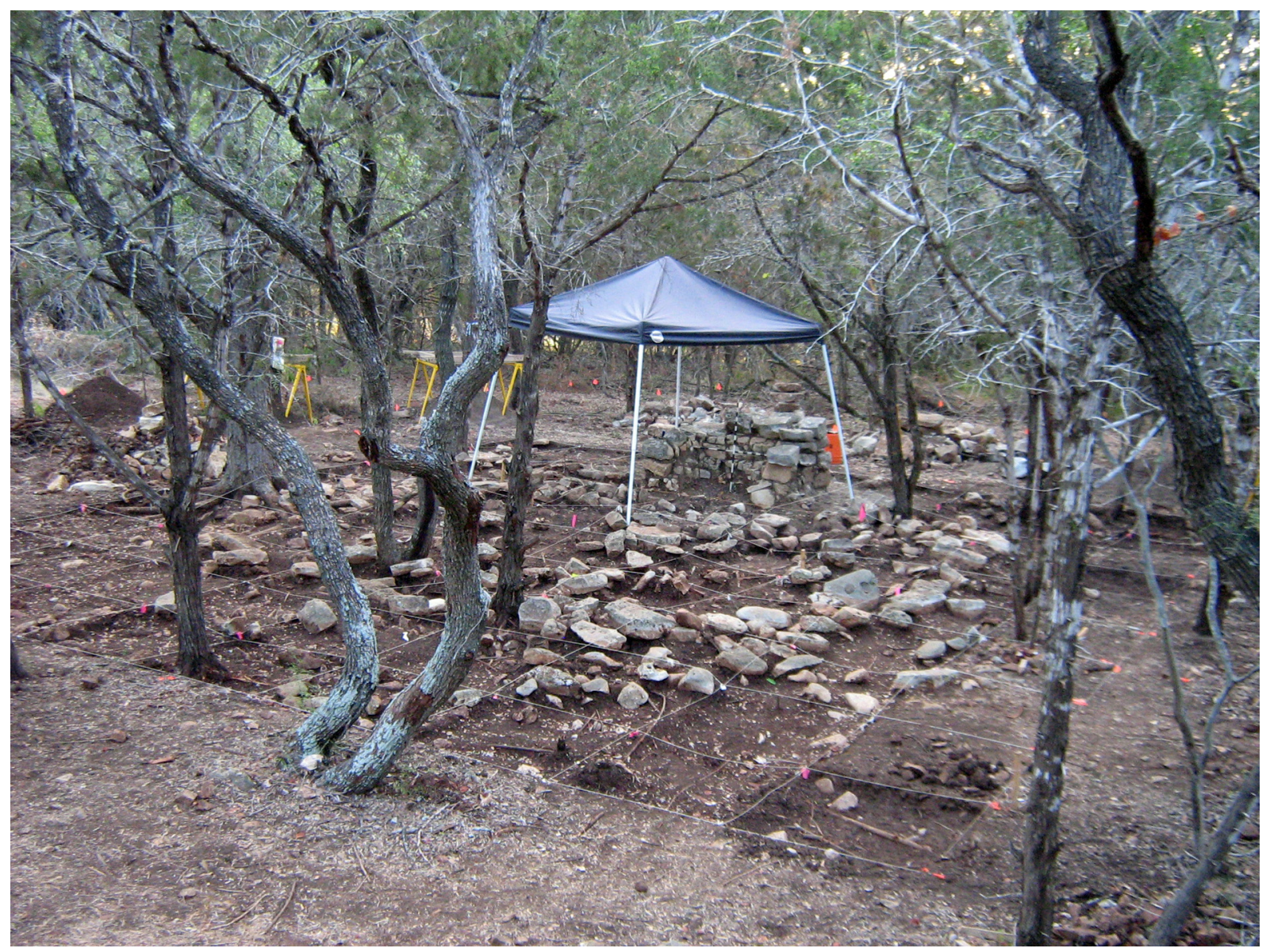

Figure 7.2. Overview of the house excavation block with the intact chimney base and in situ rocks exposed. View is to the northeast. A 1-m vertical scale is in the center of the chimney firebox under the tent.

Scattered among the large cornerstones of the Williams house were limestone rocks of various sizes and shapes. Some were faced with minimal to moderate modifications (i.e., broken and chipped to form flat edges), but most had no evidence of being modified from their natural tabular forms. Quite a few of the rocks observed in the eastern half of the house block represent rubble from the chimney after it had collapsed. It is uncertain whether parts of the chimney collapsed onto or behind the house while the wooden structure was still standing, but the patterning of rock rubble suggests that the chimney stood until the house had deteriorated and then collapsed. The rock distribution pattern suggests that the upper part of the chimney toppled westward, scattering rocks across the east end of the house area where the house once stood, while the lower part of the chimney fell into a large pile all around the chimney's base. The collapse of the rock chimney created a substantial mound pile of rubble that sealed in and helped preserve some of the material culture underneath it.

Many of the larger rocks across the house block, especially those in the western half, probably represent in situ or slightly displaced foundation stones. Once the chimney fall rubble was removed, a noticeable distribution pattern appeared for the remaining rocks. Two linear alignments of large stones were observed running east-west in the approximate locations where the north and south walls of the structure would have been. The most reasonable interpretation of this patterning is that some of the large rocks served as foundation stones (i.e., supporting the structure walls) and perhaps skirting around the base of the house. Stone skirting would have closed off the open area 


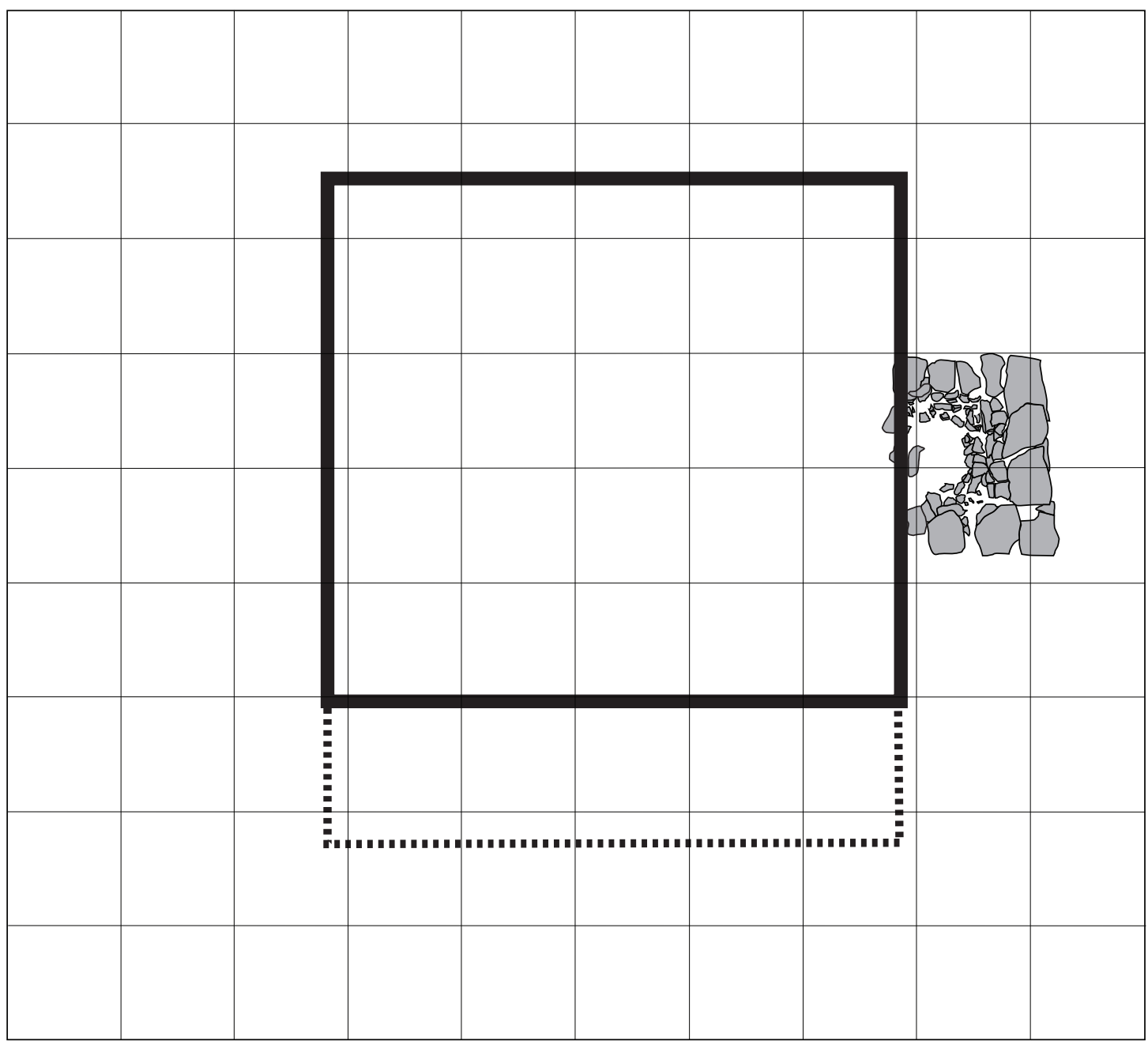

House Block

$(10 \times 9 m)$

$L E G E N D$

$\square$ Rock

House Wall (hypothesized)

IIIIII Porch (hypothesized)
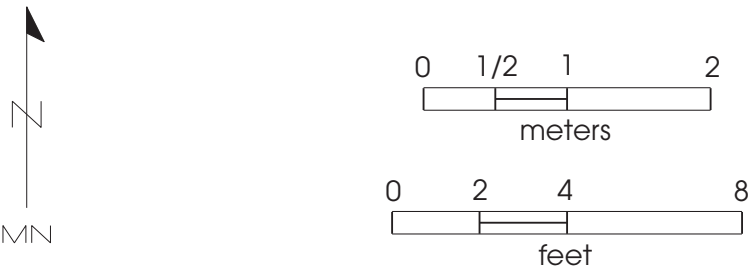

Figure 7.3. Plan map of house excavation block showing the intact chimney base and the inferred house outline. 
underneath the house between the floorboards and the ground. By doing this, it reduced the likelihood that rodents or other large burrowing critters would move into the empty space.

\section{Chimney Firebox}

The most recognizable architectural feature remaining at the house site was the chimney base. It was a large mound of limestone surrounded by a very dense scatter of hand-hewn white limestone rocks (Figure 7.4). On the east side of the rock pile, a line of neatly faced stacked rocks clearly represented an intact remnant of the chimney base. The larger rock rubble mound represented the remains of the chimney, which had collapsed as the house deteriorated.

During excavation and disassembly, it became evident how the chimney base had likely been constructed. Because so little of the chimney remained, construction details and information were gleaned from what remained of the base (Figures 7.5 and 7.6). All measurements regarding the chimney base are approximate due to inconsistency in the sizes and shapes of the limestone rock. The chimney rocks vary greatly in size and shape, but those used in the chimney base were carefully selected and placed to create relatively uniform layers and flat exterior wall faces. Many of the in situ chimney base rocks had been modified, with flakes hammered off to form flatter edges. Because of this, it is likely that most of the modified rocks scattered around the house area came from the chimney rather than being foundation stones.

The chimney base remnant stood ca. $3 \mathrm{ft}$ 3 inches tall and consisted of up to five solid courses of hand-hewn and natural limestone blocks. The back wall of the chimney, which is the easternmost part that would have been outside the house, measured ca. $5 \mathrm{ft} 2$ inches wide at the base. Each of the side walls measured ca. $4.5 \mathrm{ft}$ wide. After the rubble and debris were removed from around the chimney base to take these basal measurements, it became obvious that the chimney base was constructed wide at the bottom and tapered upward. This observation is most evident when looking at the back wall of the chimney base (see Figure 7.6b). Both the north and south walls of the chimney base also appear to taper slightly on the east side (exterior) as they ascend. The chimney would be widest at the bottom to provide a firm foundation of support, and its base may have tapered gradually up to a point 4 or $5 \mathrm{ft}$ above the ground. It is assumed the chimney would have tapered significantly at about one-third to one-half of its height, and that the upper portion would have been a much narrower rectangular or square flue (for variations in rock chimneys on log structures, see Jordan [1978:Figures 1-4, 5-3, 5-8, 5-12 to 5-14]).

The interior dimensions of the firebox within the chimney base were ca. $2 \mathrm{ft} 9$ inches wide by $3 \mathrm{ft} 4$ inches deep. The thickness of the chimney walls varied slightly. The north wall measured ca. $1 \mathrm{ft}$ thick, while the east and south walls each measured ca. $1 \mathrm{ft} 3$ inches thick.

During excavation of the firebox interior, the relatively loose rubble fill was cleaned out to reveal a flat surface of thin tabular limestone rocks. This was encountered at about the hypothesized level of the house floor, leading to the interpretation that this platform was probably the firebox floor (see Figure 7.5b). To reveal additional construction details, these stones were removed. Below this floor layer, many smaller angular rocks were found skirting the interior walls (see Figure 7.6a). Many of these limestone blocks were heavily fractured, likely from the weight of the structure and/or intense heat from many fires. These rocks may have served as added support for the chimney walls, and they also provided a heat barrier between the firebox and the large rocks that supported the immense pressure of the chimney.

Angular limestone rocks were also found across the entire firebox enclosure, mixed among the red and gray mottled clay with abundant charcoal flecks. It appears that many of these rock fragments were flakes knocked off of larger stones during the shaping of the large chimney base blocks. Because charcoal is mixed in this layer, it is evidence of a disturbed context below the firebox floor. It probably indicates that the bottom of the firebox was removed and relined at some point during the house occupation. This type of fireplace maintenance probably occurred many times, but the excavated remains only document the last episode before the final abandonment of the house.

The overall chimney construction was relatively straightforward in terms of design, with the largest and thickest stones on the bottom. Each course was composed in a manner in which one rock would overlap multiple rocks under- 


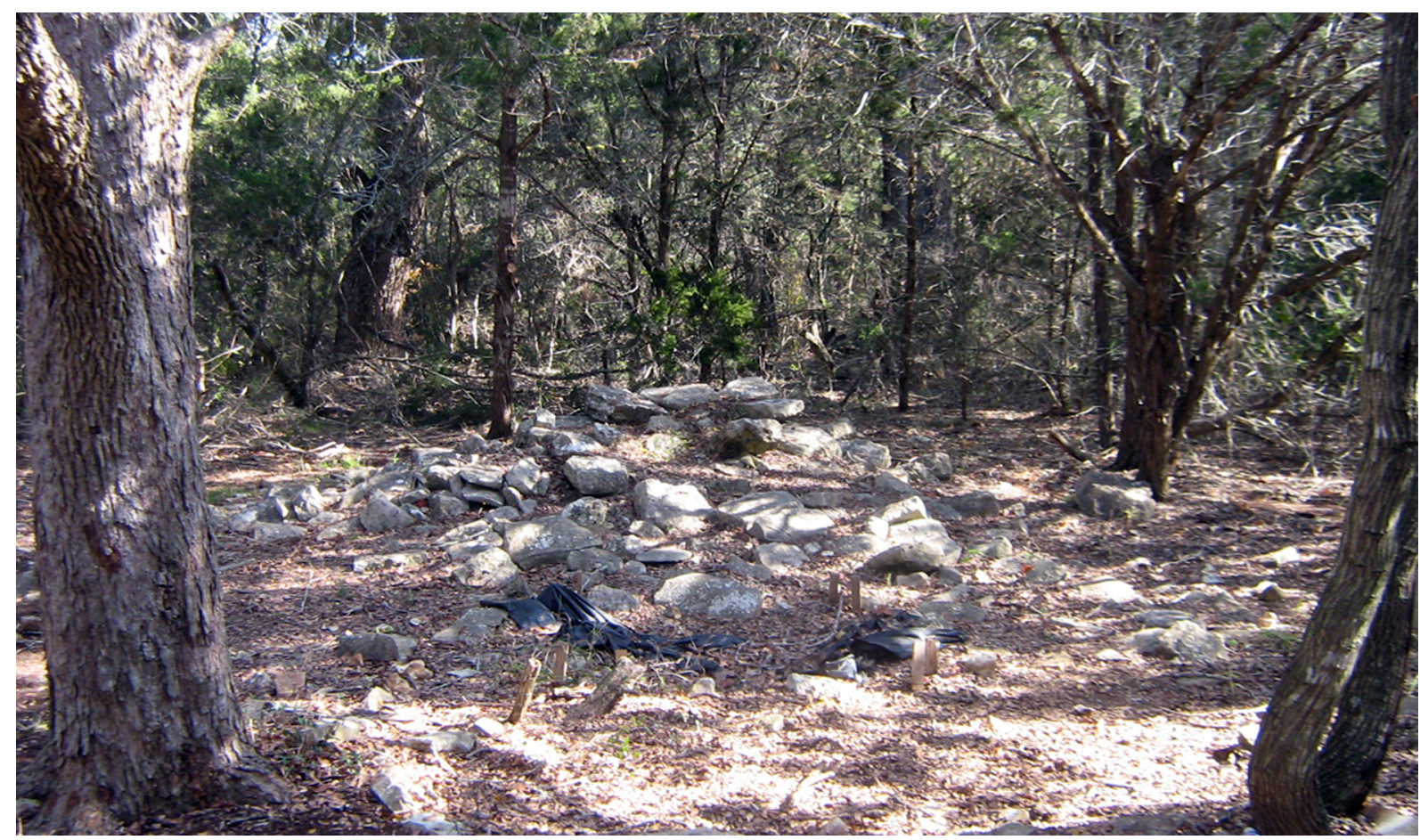

a

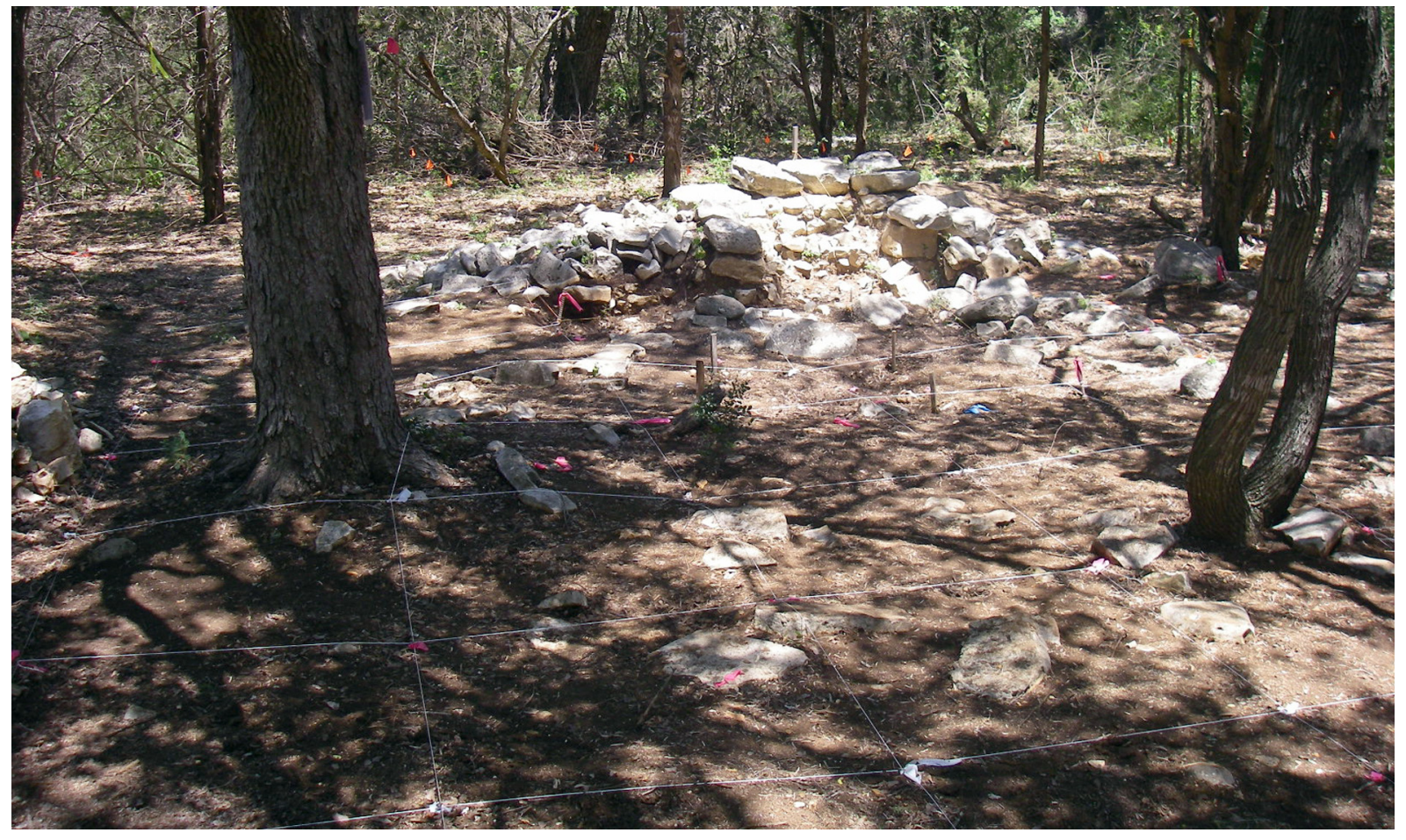

b

Figure 7.4. Photographs of the rock pile and chimney base at the Williams house, looking east. (a) The rock pile in 2007 before the PAI site testing began. The black plastic marks backfilled test units dug in 2003. (b) The rock pile exposed by testing at the beginning of the data recovery investigations in 2009. Vegetation had been cleared from the house area and the 1-m grid had been laid out. The chimney firebox is in the center of the mound, and some chimney rubble had been removed from the front of the chimney base. 


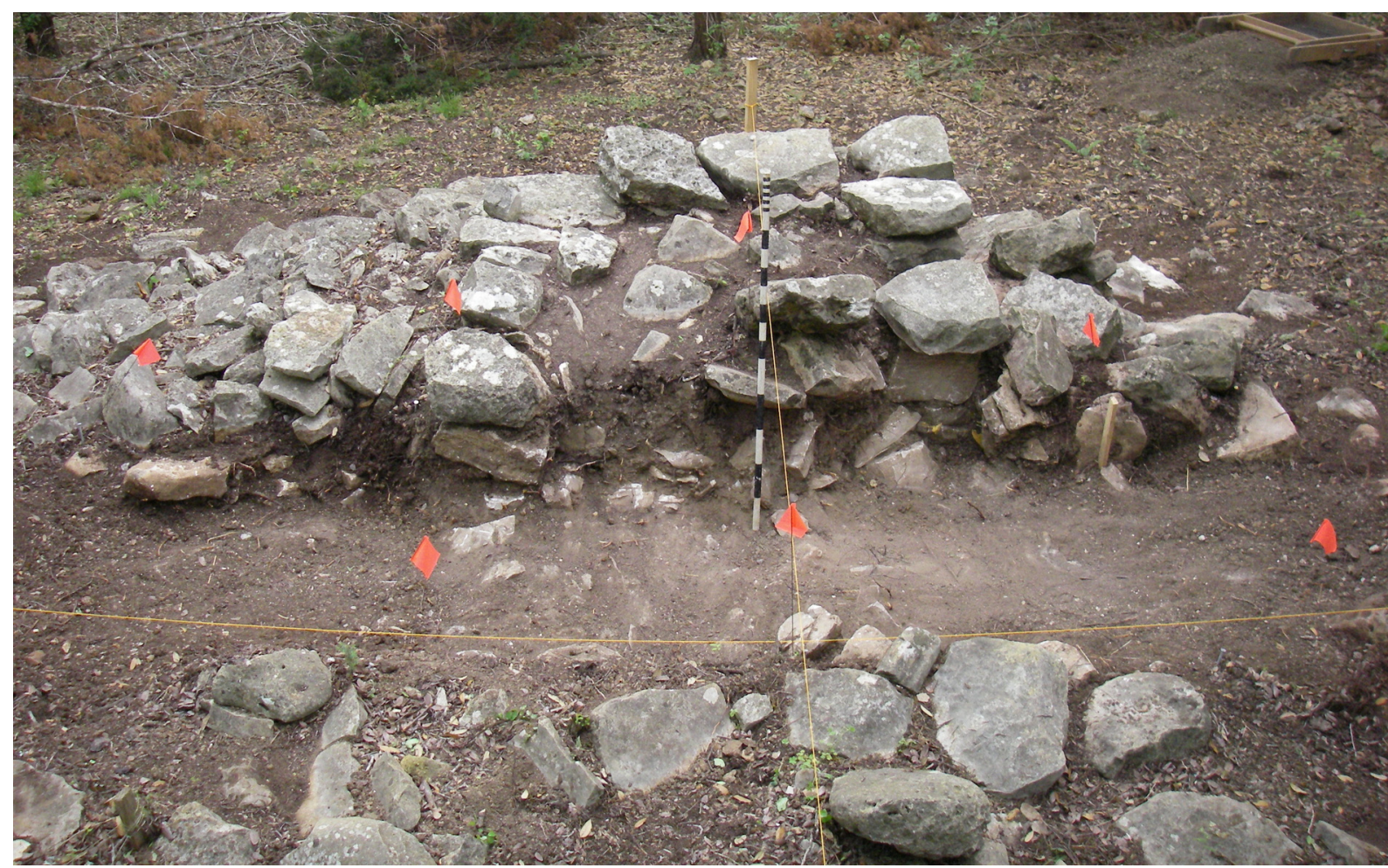

a

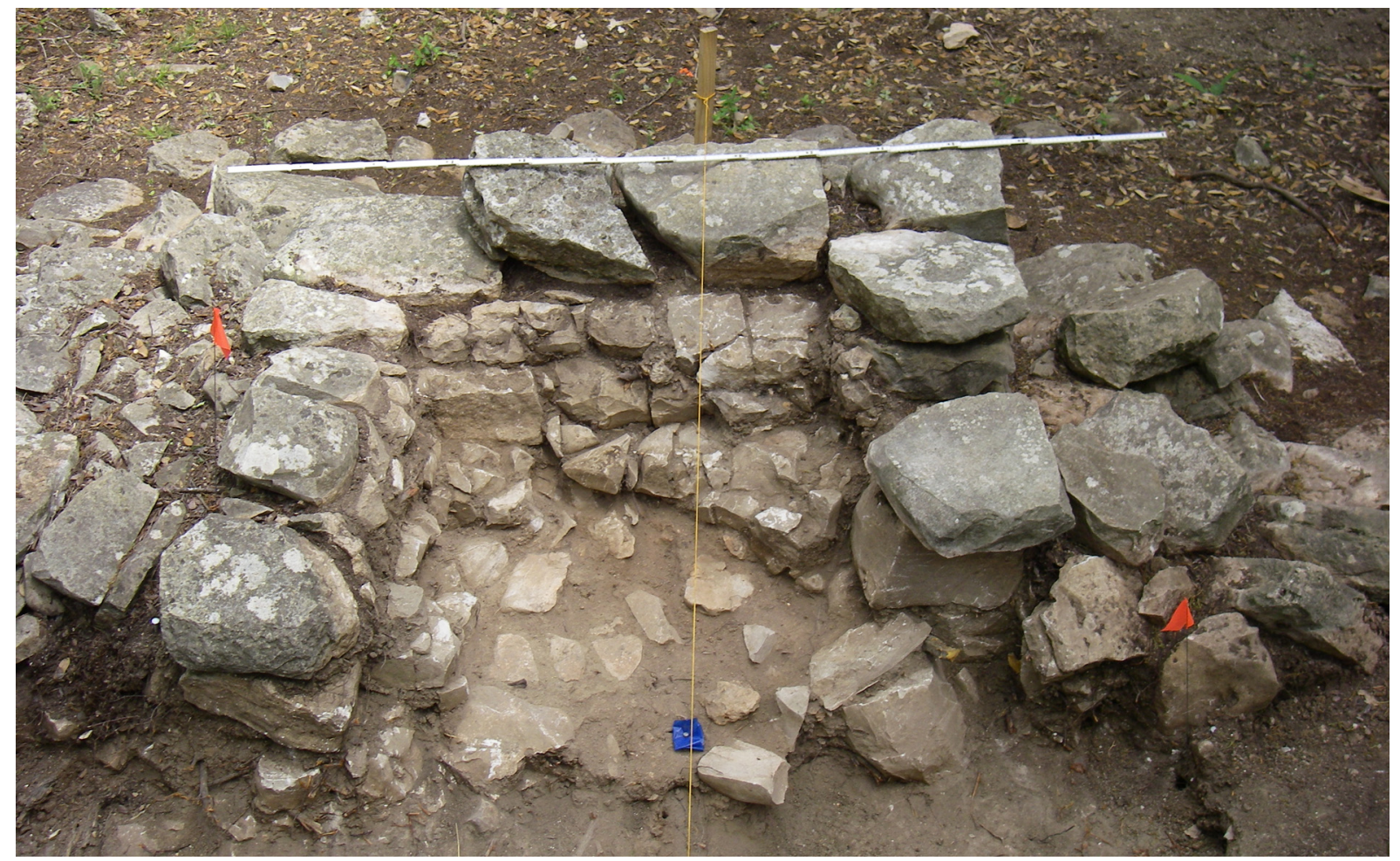

$\mathrm{b}$

Figure 7.5. Views of the chimney base and firebox at different stages of excavation, looking east. (a) The chimney base and rubble pile in 2008, exposed by the excavation of a 1-m-wide trench in front of the firebox. Vertical scale is $1 \mathrm{~m}$. (b) The exposed chimney firebox interior in 2008. Note the layer of mottled fill and smaller angular rocks at the base of the firebox. Horizontal scale is $2 \mathrm{~m}$. 


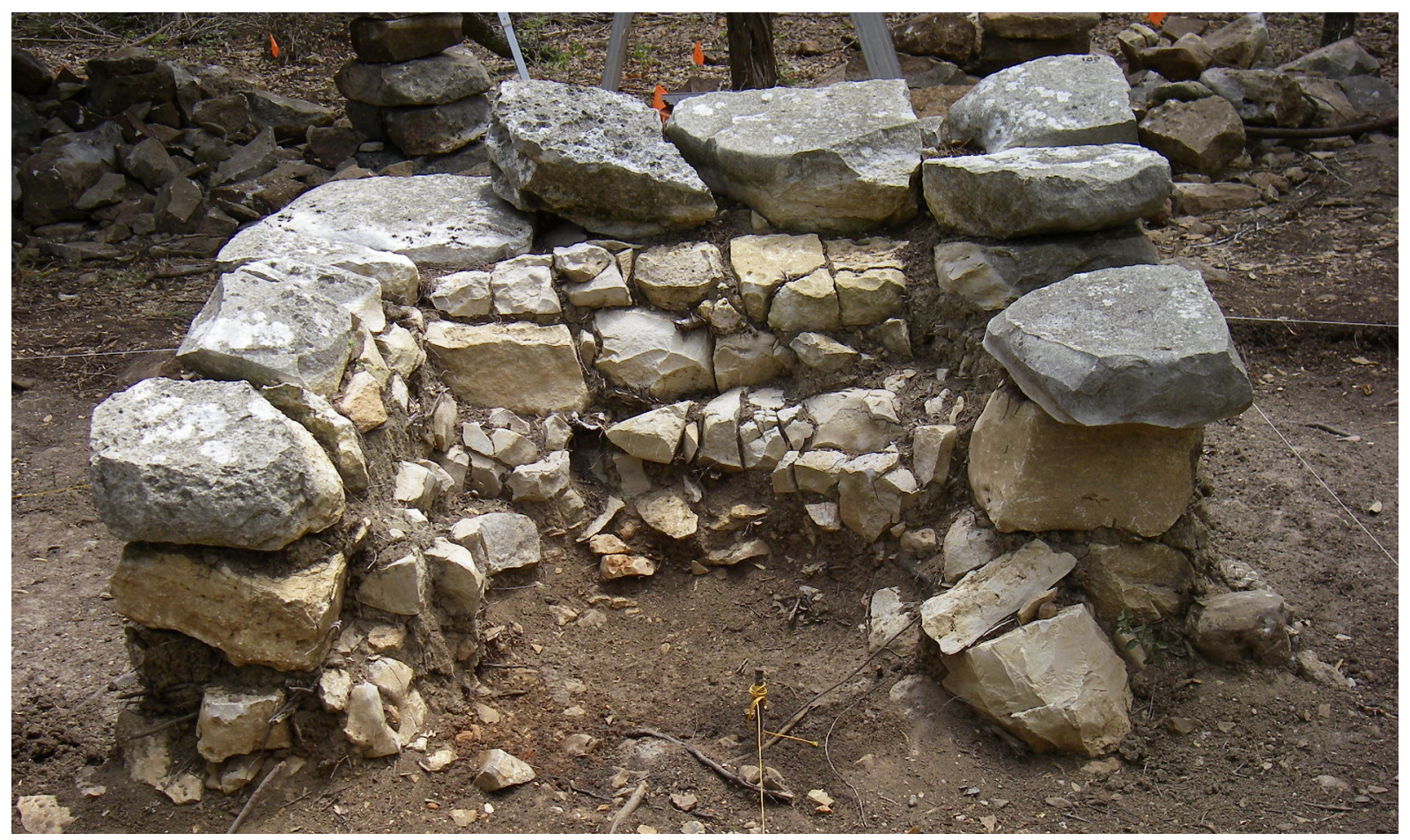

a

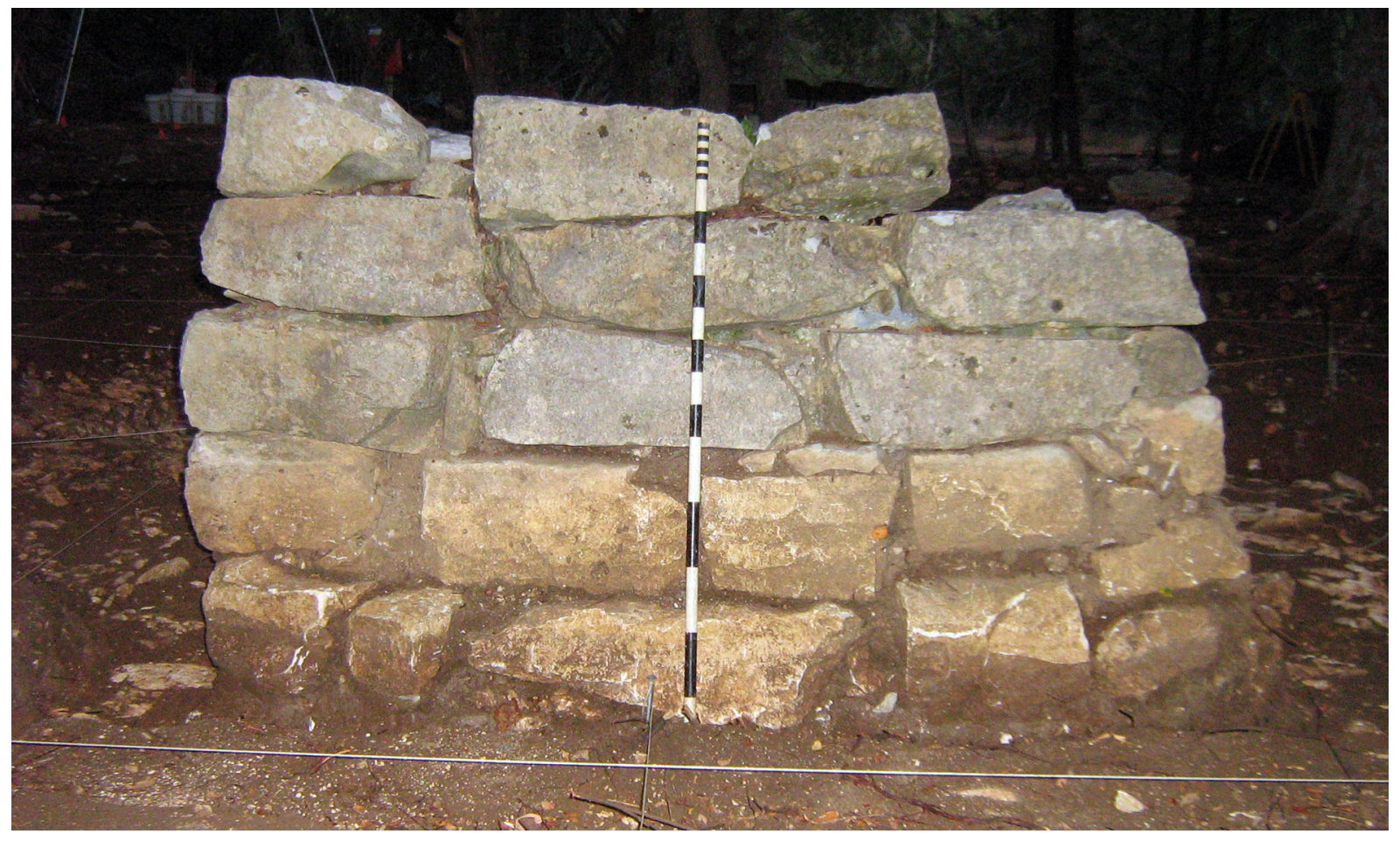

b

Figure 7.6. Views of the fully exposed chimney base and firebox. (a) View east of the firebox interior. Note that many of the limestone rocks have angular fractures from heating. (b) View west of the back (exterior) side of the chimney base. The lower two courses of rocks were below ground level. Vertical scale is $1 \mathrm{~m}$. 
neath, with each successive course creating an interlocking design. All of the chimney rock was once held in place with what appears to be a simple lime mortar. Some remnants of this mortar were still in place in the lower courses of rocks when the chimney was disassembled. The mortar was completely eroded away in the upper courses, and the mortar that was preserved was in poor condition. The wet mortar appeared to harbor some type of fungus. Constant exposure to the elements for the last 130 years took its toll on the structure. But despite the weathering and near absence of mortar, the chimney base was quite solid, with most of the rocks anchored by gravity and the interlocking design.

One of the eventual goals of the fieldwork was to disassemble the remaining intact portion of the chimney to determine how it was constructed. The plan was to completely expose the chimney base, excavate and clean out all the fill within its firebox, then remove each limestone rock individually, layer by layer, down to the last stone. First, the fill and rubble covering the outside walls of the chimney base were removed to expose the intact walls. After the exact dimensions and shape of the chimney base were determined, the firebox interior was excavated down to bedrock. Much of the fill within the firebox was a mix of various clay soils and rock, with small quantities of artifacts and bone. The previous excavations that took place during the 2007-2008 testing phase revealed several areas of loose, ashy soil mixed with flecks of charcoal. Pockets of organic nesting material were observed, indicting that these disturbances were the result of rodent activities. Most of the artifacts recovered from the chimney were found in the rodent-disturbed areas in the uppermost portions of the firebox.

After the firebox interior was removed, the final step was to completely disassemble the chimney base itself. This process revealed the bottom layers of large limestone blocks, which provided a strong and well-built foundation (see Figure 7.6b). After the last stone block was removed, it became clear that the chimney was built directly on top of the bedrock substrate. The only barrier between the first layer of stone and bedrock was a thin layer of mottled red and gray clay that provided a stable base on which the chimney stones would rest. This layer of clay also contained several small limestone flakes that appear to have been used as chink- ing wedges or shims to help level the chimney rocks. Additional clay was packed around the basal chimney stones to help lock them in place. This construction method obviously worked well, because the lowest two courses of foundation stones were still in their original place after 130 years.

In relation to other areas of the site, relatively few artifacts $(n=280)$ were recovered from the chimney firebox excavation (Table 7.1), the majority being animal bones. Many of the bones were small and fragmentary, leading to the interpretation that they could have been introduced by rodents following the occupation. Some of the bones could be from various animals consumed at the farmhouse, but the former seems more likely. Although small amounts of charcoal were encountered during excavation, no botanical specimens were recovered from flotation of the firebox fill.

Only 146 recovered artifacts could be classified by functional group (see Table 7.1), but all five of the major categories were represented. Of this assemblage, Architectural items made up 47.3 percent $(n=69)$ of the artifacts, with nearly all of them being cut nails. Only 7 architectural items were not cut nails: 3 wire nails, 2 staples, a wire fragment, and a mortar sample. The presence of so many nails might be explained by the eventual collapse of the house, which could have filled the chimney firebox with shattered roof wood containing nails. An alternate explanation is that old lumber with nails in it was being burned in the fireplace during one of the last use episodes.

Only 53 Kitchen/Household artifacts were recovered, primarily consisting of container glass fragments $(n=41)$. A few fragments of stoneware, whiteware, and cutlery were also found. In the Clothing/Adornment category, 10 buttons were found, along with 2 clothing buckles and 3 eyelets. Only six Activities artifacts were found: a wagon skein, a marble, an ink bottle, a .44-caliber Webley cartridge casing, a pencil eraser end, and a Darl dart point. The only other identifiable objects were 3 Personal artifacts: 2 snuff bottle fragments and a clear medicine bottle. The latter is a neck fragment of a wide mouth bottle; it has a tooled lip indicating that it was made prior to the advent of the automatic bottle machine in ca. 1904 (Glass Container 22 in Appendix B). The remaining items were a single lithic artifact (a chert flake) 
Table 7.1. Artifacts from the chimney firebox excavation

\begin{tabular}{l|c|c|c}
\hline \multicolumn{1}{c|}{ Functional Group } & $\begin{array}{c}\text { No. of } \\
\text { Specimens }\end{array}$ & $\begin{array}{c}\text { Percent } \\
\text { (excluding Unknown) }\end{array}$ & $\begin{array}{c}\text { Percent } \\
\text { (five main categories only) }\end{array}$ \\
\hline Activities & 6 & 2.44 & 4.11 \\
\hline Architectural & 69 & 28.05 & 47.26 \\
\hline Clothing/Adornment & 15 & 6.10 & 10.27 \\
\hline Kitchen/Household & 53 & 21.54 & 36.30 \\
\hline Personal & 3 & 1.22 & 2.05 \\
\hline Lithics & 1 & 0.41 & - \\
\hline Faunal & 99 & 40.24 & - \\
\hline Unknown* & 34 & - & - \\
\hline Total & 280 & - & 100.00 \\
\hline Total (excluding Unknown) & 246 & 100.00 & - \\
\hline Total (five main categories only) & 146 & - & - \\
\hline
\end{tabular}

* Unidentifiable metal fragments

and 34 unknown specimens (unidentifiable metal fragments).

The most intriguing artifact is the nearly complete dart point found in the lower firebox fill along the back (east) wall of the chimney firebox. The stratigraphic evidence for how the chimney base was constructed leaves little doubt that this Native American artifact was intentionally placed at the bottom of the firebox when it was built. In this context, the dart point likely has symbolic meaning (see discussion in Chapter 11).

The following scenario is offered as a hypothesized construction sequence for the chimney base that would have been built on the gabled east end of the Williams house, which is presumed to have been a log cabin (see Chapter 11). ${ }^{93}$ The central area just outside the east wall was prepared, and a square opening was cut out of the wall for the firebox. A variety of tabular limestone blocks were hauled in, either by hand or using a mule-drawn skid. The rocks were probably sorted by size and piled around the work area. Hammers and chisels were then used to face some of larger slabs that would be used in the chimney base, chipping away flakes to create solid right-angle edges. The ground

${ }^{93}$ In this scenario, it is assumed the log cabin was built before the chimney. Very late in the project, we discovered evidence confirming that this house was indeed a long cabin (see Chapter 14). surface at the chimney location was dug out down to the bedrock, probably using a pick mattock, shovel, and hoe. Part of the excavated clay was sifted to remove the small rocks, and a thin layer of this clay was reapplied over newly exposed bedrock surface. This layer was leveled as a platform for the first course of rocks. An appropriate number of large limestone blocks were selected, and the stones set in place to form the "U" shape of the firebox, with the base measuring just over 5 feet north-south and 4.5 feet east-west (exterior dimensions). Once the base layer was completed and leveled, additional courses of partially faced stone were added. In order for the all the stones to sit level, facing flakes and other limestone fragments were used as shims and wedges, and smaller rocks were used to fill large gaps. Natural clay was packed in and around the bases of the stones to create a basal layer inside the firebox. A dart point was placed in the clay along the back wall of the firebox, perhaps as part of a ritual (see Chapter 11). Smaller limestone blocks were placed on top of the clay layer to line the back and sides of the interior firebox. Then a mixture of clay and small angular limestone fragments and facing flakes was used to fill in the bottom of the firebox up to the approximate house floor level. On top of this layer, a layer of rocks was laid out to create a flat fireplace floor. This floor consisted of flat pieces of limestone that were mortared together 
with a crude lime mixture. As the chimney base was being constructed, the west wall (with the firebox opening into the house) would have been kept vertical, and the chimney stack would be flush with the house wall. The other three exterior chimney base walls were constructed in a tapered fashion. The chimney base width became a little narrower with each consecutive course of rocks, and it continued to taper gradually up to about 5 or $6 \mathrm{ft}$ above the ground. At this point, which was a foot or two above the top of the firebox, the chimney would have had a prominent shoulder, and the remainder of the chimney was a smaller square stack, probably no more than $2 \mathrm{ft}$ wide. All the rocks were laid and anchored with mortar, course after course, until the chimney reached the desired height a few feet above the house roofline. The gap between the chimney and the house wall was also filled with mortar ${ }^{94} \mathrm{~A}$ capping stone, possibly a single flat rock with a square hole cut out of its center, was placed on top to anchor the structure.

\section{Subfloor Storage Pit (Potato Cellar)}

During the excavation of the main house block, an inconsistency in soil color and texture was noticed just a few feet west of the chimney base. Further excavation revealed the top of a small rectangular pit that measured approximately 2.5 to $3.5 \mathrm{ft}$ wide by $5.6 \mathrm{ft}$ long, which first appeared at about 4 to 6 inches below the modern ground surface. Once the excavation was completed, it revealed that the pit had been dug from the old ground surface about 4 inches through the rubified clay to the limestone substrate, then an additional 6 to 10 inches into the solid bedrock. The pit bottom was rectangular at approximately 18 inches below the modern ground surface.

The subfloor pit, designated as Feature 1 , spans over parts of four excavation units. It was first observed in EU 61. After further excavations to determine the its horizontal limits, the pit covered almost all of EU 61. Continued excavations revealed that it also extended into EU 62, EU 71, and EU 72, but more than 90 percent of the pit was contained in EU 61

${ }^{94}$ The chimney stack could be freestanding (Jordan 1978:99), but it is more likely that it was filled in with mortar or clay. and EU 71. The top of the pit feature was at an elevation of $99.15 \mathrm{~m}$ where the pit outline was first observed. The contrast between the mottled brown silty clay of the pit fill and the reddish brown rubified clay was subtle at first but became quite pronounced within a few $\mathrm{cm}$. The pit bottom was at a maximum depth of $98.80 \mathrm{~m}$. Thus, the pit was originally dug to $35 \mathrm{~cm}$, or 14 inches, from the old ground surface. Due to the undulating limestone surface of the pit bottom, the overall depth varied across the pit. When the pit was originally constructed, the amount of fill removed is estimated to have been about 5 cubic feet of clay and about 12 cubic feet of hard limestone bedrock.

Feature fill consisted of a mix of local sediment and small limestone rock fragments, as well as a mix of ash, mortar, charcoal, and a variety of artifacts. During excavation, the feature fill was examined to look for layering that might indicate individual backfill episodes or other evidence of chronological patterning. The feature profiles were photographed and examined, but no distinct breaks or layers of deposition that would indicate different backfilling episodes were discerned (Figure 7.7). Based on the mottled nature of the feature fill, the presence of various sizes of charcoal fragments scattered throughout the matrix, and the variety and abundance of artifacts, it is likely that the pit was backfilled in a single episode after the Williamses determined they no longer needed the pit for storage.

The density and diversity of the artifacts recovered from the subfloor pit fill are informative (Table 7.2). Of the 2,729 artifacts recovered, 1,158 are bones or bone fragments. Another 528 are unidentifiable metal fragments, most of them appear to be from tin cans. The 80 lithic artifacts (mostly unmodified chert flakes) are not associated with the Williams occupation (see below). Fifteen charred botanical specimens were recovered from the pit, including peach pits, corn kernels, sweet potato, and seeds. This leaves 948 artifacts (34.7 percent) assigned to the five main functional categories. When the major functional categories are broken down further into artifact subgroups and types, the diversity of items is impressive (Tables 7.3 and 7.4).

Of the 948 artifacts assigned to the five functional categories, the Architectural group has the most artifacts with 338 (35.7 percent). Artifacts associated with the Kitchen/ 


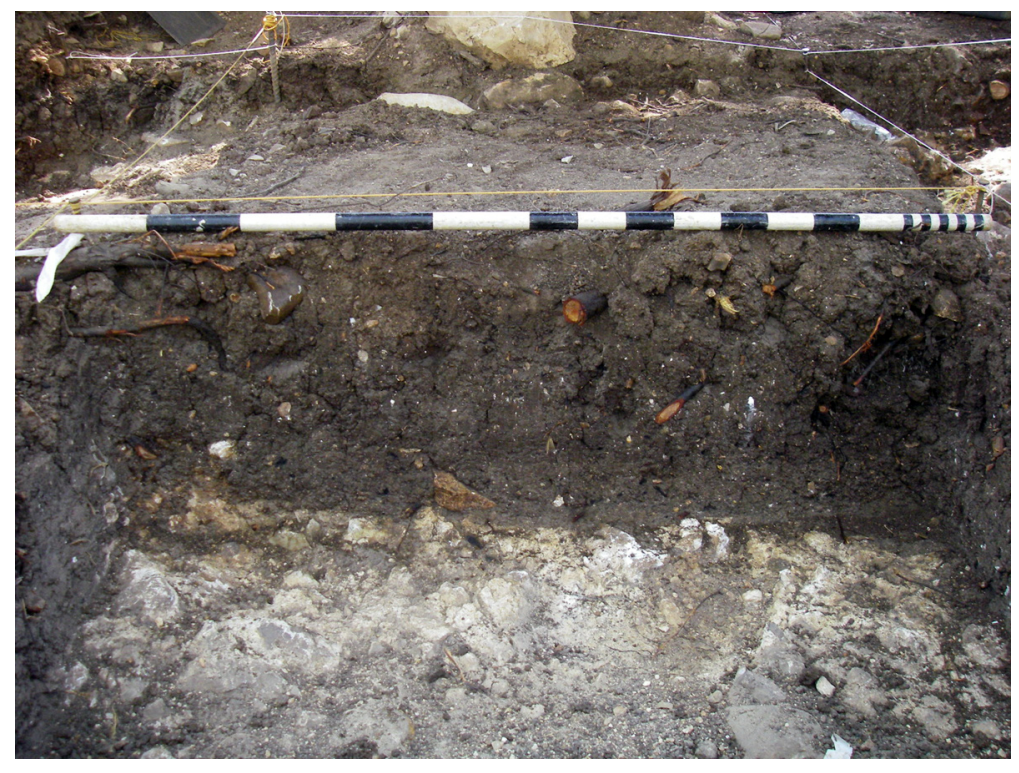

a

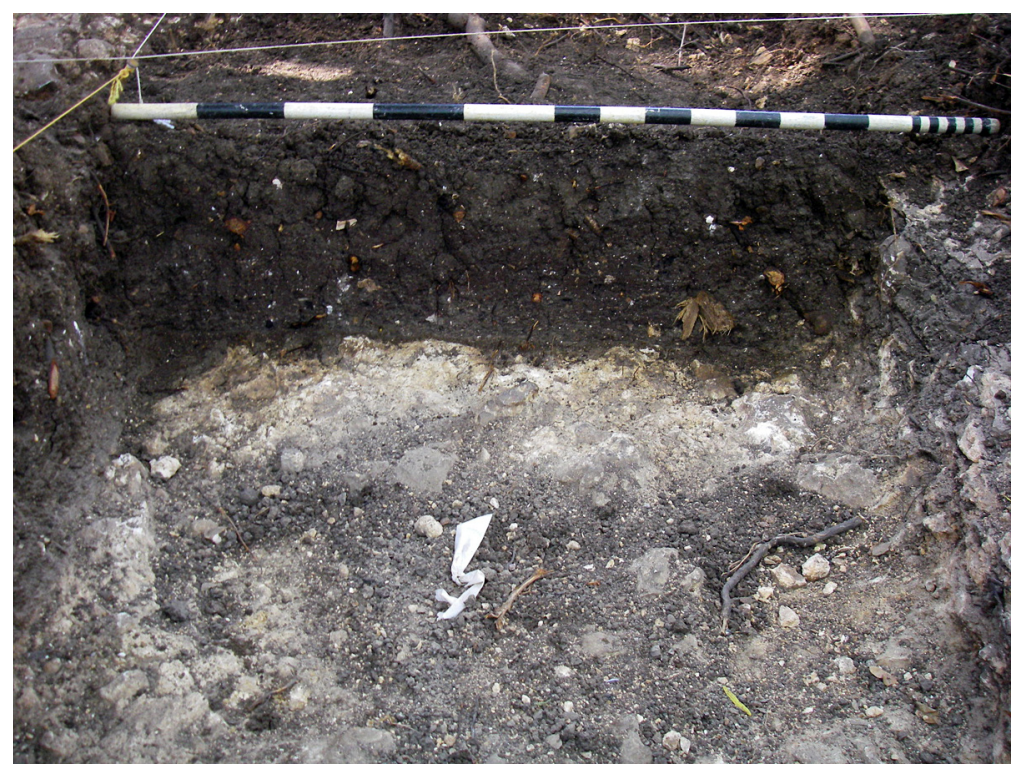

b

Figure 7.7. Profile views of fill in the subfloor storage pit (Feature 1). (a) East wall profile of EU 61; (b) South wall profile of EU 61. are represented (see Tables 7.2 and 7.3). Cut nails are the most common single artifact, with 180 recovered. In addition, 108 wire nails were found; as discussed later in this section, these nails provide chronological clues as to when the pit backfilling may have occurred. The next most common artifact type is container glass, with 172 fragments in the assemblage.

One of the most interesting aspects of the storage pit assemblage is that 136 buttons were recovered. This is an astounding number of buttons to be found in one small area, and no similar concentrations occur anywhere else on the site. One possible scenario could be related to backfilling of the pit. When the Williams family abandoned the pit, perhaps they discarded a collection of buttons, gathered over many years, into it.

All evidence suggests that the backfilling of the storage pit happened in a single episode. No patterns were observed in the artifacts or sediments (e.g., layering of deposits) that would indicate different depositional events at different times. The most likely scenario is that once the family decided that the pit was no longer needed, they quickly filled it with household refuse and sediment. Floor sweepings, firebox cleanout, and hearth sweepings may have been thrown in, along with debris-filled midden soil from outside the home. Backfilling with midden debris would help explain the abundant charcoal flecks scattered throughout the pit fill. It is notable that most of the artifacts recovered from the pit are small and fragmentary, suggesting they were already broken into small pieces before they were placed in the pit. This evidence, along with the sheer diversity of artifact types representing a wide range of functions and activities, would seem to indicate that the storage pit was indeed backfilled with 
Table 7.2. Artifacts recovered from the subfloor storage pit

\begin{tabular}{l|c|c|c}
\hline Functional Group & $\begin{array}{c}\text { No. of } \\
\text { Specimens }\end{array}$ & $\begin{array}{c}\text { Percent } \\
\text { (excluding Unknown) }\end{array}$ & $\begin{array}{c}\text { Percent } \\
\text { (five main categories only) }\end{array}$ \\
\hline Activities & 80 & 3.63 & 8.44 \\
\hline Architectural & 338 & 15.36 & 35.65 \\
\hline Clothing/Adornment & 158 & 7.18 & 16.67 \\
\hline Kitchen/Household & 289 & 13.13 & 30.49 \\
\hline Personal & 83 & 3.77 & - \\
\hline Lithics & 80 & 3.63 & - \\
\hline Botanical & 15 & 0.68 & - \\
\hline Faunal & 1,158 & 52.61 & - \\
\hline Unknown* & 528 & - & - \\
\hline Total & 2,729 & - & 100.00 \\
\hline Total (excluding Unknown) & 2,201 & 100.00 & - \\
\hline Total (five main categories only) & 948 & - & - \\
\hline
\end{tabular}

* Unidentifiable metal fragments

midden trash. Aside from the house block excavations, the trash midden is the only other location where such a range of artifact types was observed. In addition, the density of artifacts in the storage pit fill is equaled only by the density in a few parts of the trash midden.

Further evidence that midden trash was used to backfill the subfloor pit comes in the form of lithic artifacts (i.e., 80 specimens, dominated by unmodified chert flakes). Excavations in various parts of the site indicate that lithic artifacts are associated with an ephemeral prehistoric Native American occupation that occurs over a broad area. A few lithic artifacts were found in almost every unit in the house block and midden excavations. When the subfloor pit was first created, any lithic artifacts in the sediment there would have been removed. Therefore, the only way lithic artifacts could be introduced back into the pit was for outside sediment to be brought in. Because the yard seems to have been a maintained surface or swept yard (Heath and Bennett 2000:43; see Chapter 11), there might have been fewer lithic artifacts in any yard soil that was used as backfill. The most logical conclusion, then, given all the evidence, is that a substantial amount of midden trash was used to backfill the storage pit when it was abandoned.

After the feature excavation was completed and the fill was removed, the archeological evidence suggested how the pit was constructed. Digging out the upper 4 to 6 inches of clay sediment was relatively easy, but digging 6 to 10 inches deep into the bedrock limestone would not have been an easy feat. Using hand tools such as a pick mattock or a hammer and chisel (all of which are represented in the artifact assemblage), the limestone bedrock could be slowly chipped away, piece by piece. It is not clear if they intended the pit to be only 14 inches deep, or if they simply stopped at this depth because it became too difficult to dig. Regardless, the floor of the pit is a pockmarked, undulating surface showing signs of having been struck with a pick to dislodge chunks of limestone. The pit was not lined with sand, and there are no hints (i.e., soil staining) that it might have been lined with grass, wood, or other organic materials. It is likely that the environment inside the limestone pit provided the correct humidity and temperature for food storage.

The spatial relationship between the chimney firebox and subfloor storage pit (Figures 7.8 and 7.9) are important for understanding how the two features are interrelated. The pit's east edge was about $3 \mathrm{ft}$ west of the chimney firebox, and its north edge was almost in line with the center of the firebox. Thus, the entire pit was located less than $6 \mathrm{ft}$ southwest of the fireplace. 
Table 7.3. Artifacts recovered from the subfloor pit

\begin{tabular}{l|c}
\hline \multicolumn{2}{c}{ Architecture Artifacts } \\
\hline Bricks & No. of Specimens \\
\hline Cut nails & 1 \\
\hline Mortar samples & 180 \\
\hline Screws & 2 \\
\hline Staples & 6 \\
\hline Wire & 12 \\
\hline Wire nails & 29 \\
\hline Total & 108 \\
\hline
\end{tabular}

\begin{tabular}{l|c}
\hline \multicolumn{2}{c}{ Kitchen/Household Artifacts } \\
\hline Cast iron vessel & No. of Specimens \\
\hline Container glass & 1 \\
\hline Cork & 12 \\
\hline Cutlery & 14 \\
\hline Furniture & 3 \\
\hline Grate fragments & 5 \\
\hline Non-container glass & 6 \\
\hline Padlock & 1 \\
\hline S-hook & 1 \\
\hline Stoneware & 20 \\
\hline Stove part & 1 \\
\hline Tableware & 2 \\
\hline Unidentifiable glass fragment & 1 \\
\hline Unidentifiable glass fragments & 38 \\
\hline Whiteware & 23 \\
\hline Total & 289 \\
\hline
\end{tabular}

\begin{tabular}{l|c}
\hline \multicolumn{2}{c}{ Clothing/Adornment Artifacts } \\
\hline Buckles & No. of Specimens \\
\hline Button hooks & 1 \\
\hline Buttons & 136 \\
\hline Clasp & 1 \\
\hline Collar studs & 3 \\
\hline Grommets/eyelets & 7 \\
\hline Pendant fragment & 1 \\
\hline Pin & 1 \\
\hline Shoe nails & 5 \\
\hline Suspender buckle & 1 \\
\hline Total & 158 \\
\hline
\end{tabular}

\begin{tabular}{l|c}
\hline \multicolumn{2}{c}{ Personal Artifacts } \\
\hline Clay pipe fragment & No. of Specimens \\
\hline Combs & 1 \\
\hline Eyeglass/monocle & 16 \\
\hline Liquor bottles & 1 \\
\hline Medicine bottles & 20 \\
\hline Pocket knife & 2 \\
\hline Snuff bottles & 1 \\
\hline Snuff bottle fragments & 21 \\
\hline Total & 21 \\
\hline
\end{tabular}

Assuming that the pit functioned as a subfloor food storage compartment, often called a potato cellar in the South, two factors may have dictated its location. One is that this is the logical area for easy access to a subfloor pit. The area in front of the fireplace was a communal area where the family gathered to eat meals and socialize. Except perhaps for a table and chairs, this central area would have been kept clear and maintained regularly. More permanent furniture

(such as cabinets, beds, etc.) would have been along the walls and toward the back of the house, opposite the fireplace. The second factor is that heat provided by the fireplace may have been an important consideration for the underground storage of perishable food items such as sweet potatoes and dried corn. In the coldest winter months, keeping food from freezing would have been a concern. If the pit were close enough to the chimney, the heat from the fireplace would 
Table 7.4. Activities artifacts recovered from the subfloor storage pit

\begin{tabular}{|c|c|c|}
\hline Artifact Category & Identification & No. of Specimens \\
\hline Carriage and Wagon & Hardware & 2 \\
\hline Collectibles & Geofact (rock with quartz crystals) & 1 \\
\hline Construction & Hand tools & 6 \\
\hline Firearms/Hunting & Munitions & 11 \\
\hline Horse Tack and Harness & Hardware & 5 \\
\hline Horse Tack and Harness & Spur & 1 \\
\hline Miscellaneous Hardware & Bolts & 7 \\
\hline Miscellaneous Hardware & Chain & 2 \\
\hline Miscellaneous Hardware & Hinge & 1 \\
\hline Miscellaneous Hardware & Nuts & 2 \\
\hline Miscellaneous Hardware & Other hardware & 12 \\
\hline Sewing & Safety pins & 4 \\
\hline Sewing & Straight pins & 2 \\
\hline Toys & Marble & 1 \\
\hline Water Storage & Barrel bands & 2 \\
\hline Writing & Pencils & 1 \\
\hline Writing & Slate fragments & 16 \\
\hline Writing & Slate writing utensils & 4 \\
\hline \multicolumn{2}{|l|}{ Total } & 80 \\
\hline
\end{tabular}

warm the enclosed house and probably have kept the centrally located potato cellar from freezing during severe cold spells.

Subfloor pits like this one are common in dwellings that housed plantation slaves. They served a variety of purposes. Samford (2007) published a treatise on subfloor pits at plantation sites in colonial Virginia, and she discusses the multiple functions they served. First, she describes their use as root cellars and supports this functional inference with ethnographic accounts and archeological examples (Samford 2007:123-137). The subfloor pits near hearths were ideal for storing sweet potatoes (Samford 2007:136-137), although other vegetables such as corn, white potatoes, and squash were sometimes stored. Echoing the use of the pit as a storage cellar for perishable food items, Maria Franklin's (2012) oral history research with members of the communities near the Williams farmstead documents the use of potato cellars. Lillie Grant, who was born and raised on "The
Prairie" near Buda, Texas, mentions how potatoes were stored in a cellar-like area under the floorboards of the pantry because it was cooler there (Franklin 2012:498).

According to Samford (2007:138-148), pits were also used as storage areas for keeping one's personal possessions, similar to the function of soldiers' footlockers in a barracks. When many people were living in one crowded dwelling, personal space inside the house would have been hard to come by. As a result, subfloor pits were excavated into the house floor as places for storing personal possessions or valuables. Identifying this function for archeological subfloor pits is often difficult, especially when the pit's original contents have been removed and the hole has been backfilled.

The third function identified by Samford (2007:149-173) is that subfloor pits were used as shrines for hiding sacred objects used in ritual activities. Because slaves usually could not openly practice their religion, they created ways to hide 


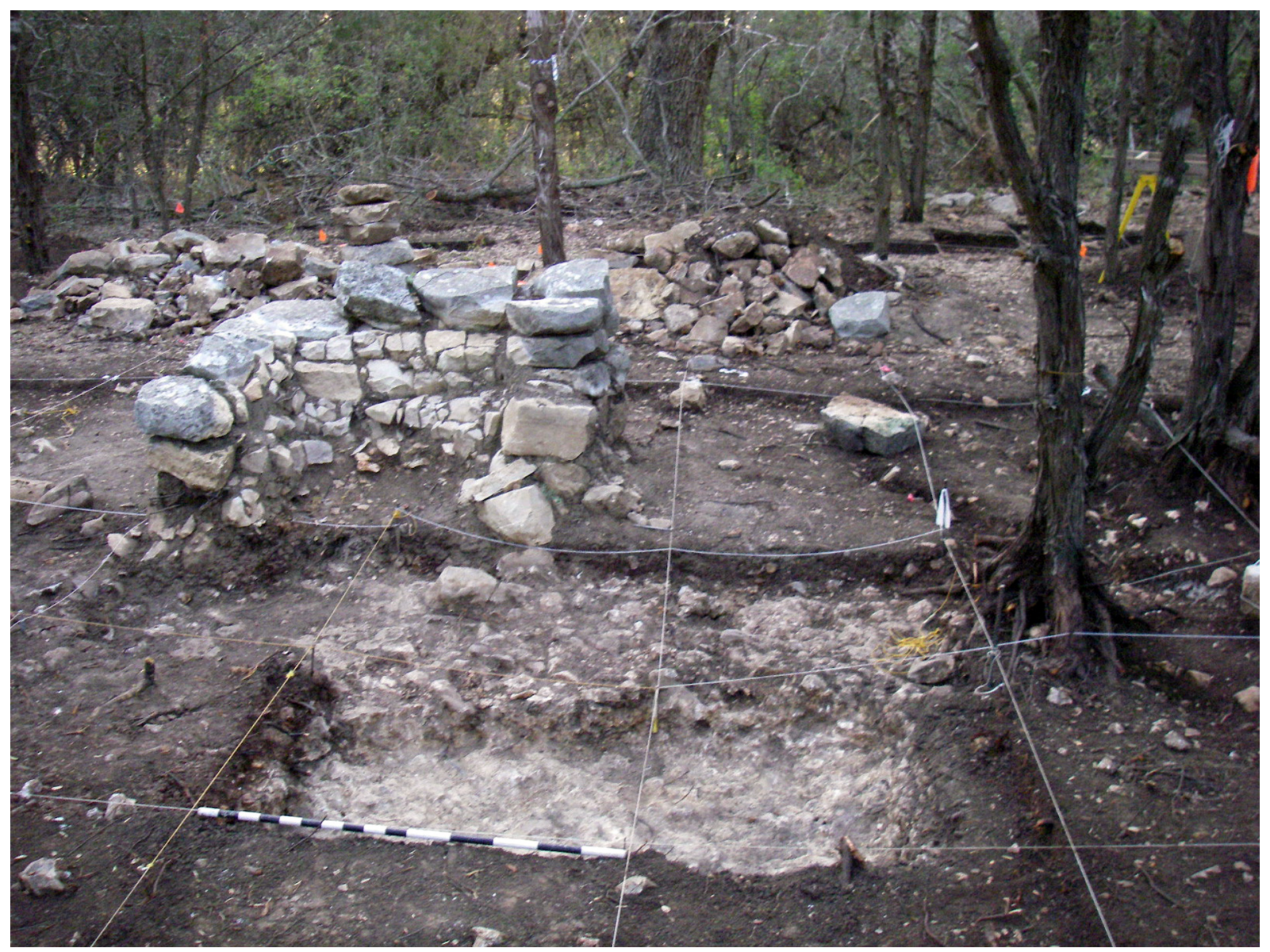

Figure 7.8. View east of the subfloor pit in relation to chimney firebox. The string lines mark the $1 x 1-m$ units, and the 1-m scale is laying along the west edge of the pit feature. Note that the pile of rocks behind the chimney consists entirely of rocks removed from the house block excavations.

such practices. The material objects associated with these unauthorized practices and belief systems were kept secret from their white owners and overseers. Subfloor pits were easy to create and conceal, so they were ideal spaces for storing objects associated with spiritual beliefs.

The Williams family owned their own property outright and could run their farm the way they thought best. Since it was their own property, keeping ritual objects and activities secret may not have been necessary. ${ }^{95}$ Similarly, the pit

\footnotetext{
${ }^{95}$ This statement cannot be applied to all post-emancipation situations. In many areas of the South, free blacks were still suspicious of whites and wanted to keep a low profile. They might have chosen to continue their old practices of hiding religious beliefs that would not be acceptable to most whites at the time. This may have included hiding ritual objects in subfloor pits.
}

under the Williams house floor was probably not intended to serve as a storage area for personal belongings or valuables. There is no definitive archeological or historical evidence to suggest that this type of activity occurred there. The most likely scenario, then, is that the pit was used for storage of perishable foods, most likely sweet potatoes and other vegetables. The interpretation is discussed in more detail in Chapter 11. In this sense, it was a potato cellar of the type that was commonly used by rural peoples throughout the South, whites and blacks alike. Many ethnographic accounts and archeological examples of potato cellars exist (e.g., Dunnahoo 1982; Gross et al. 1993; Jurgelski et al. 1996; Kimmel 1993). Additional evidence is in the form of charred plant remains recovered from flotation of the pit fill, including sweet potato 


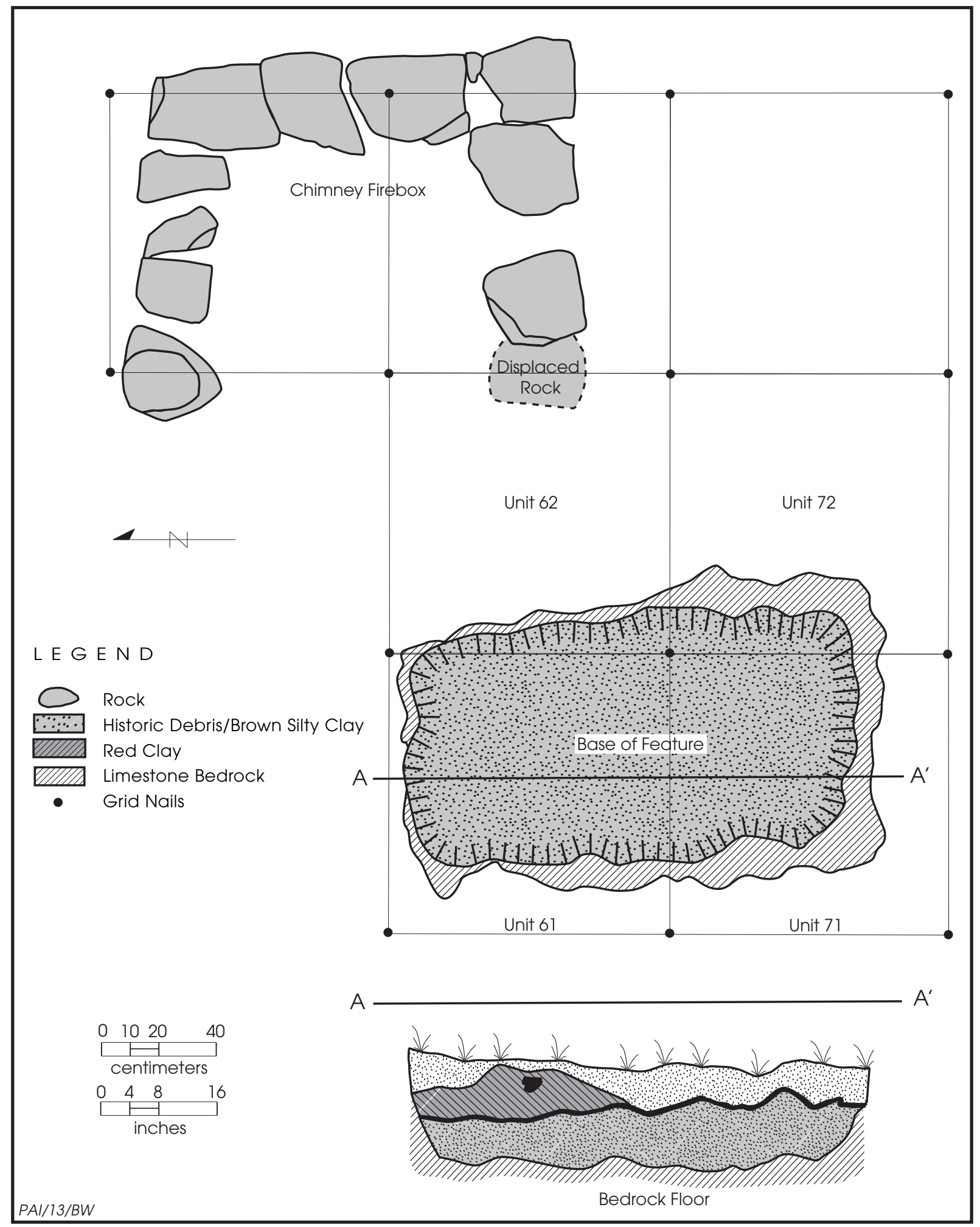

Figure 7.9. Plan map showing the spatial relationship between the chimney firebox and the storage pit and a profile of the storage pit. 
fragments and corn kernels (see Chapter 10). Both of these plants were grown on the Williams farm to supplement their diet.

Trying to date the precise time when the subfloor storage pit was backfilled became a major goal during the analysis. A few temporally diagnostic artifacts provide good evidence of the earliest possible backfill date. Two transfer-printed whiteware vessels, a dinner plate (CV-33) and one saucer (CV-38), had identifiable maker's marks located on the underside of the vessels. The marks indicate that the pottery was made by Alfred Meakin Ltd., of Tunstall, England, and the floral-design transfer pattern is called the Kenwood (Figure 7.10). These vessels from the pit fill match the Kenwood-pattern and Meakin logos on vessels recovered from the house excavation block. The distinctive mark consists of a banner with the name Kenwood inside it, over a globe and banner enclosing the name "ALFRED MEAKIN." The word "ENGLAND" appears under the globe.

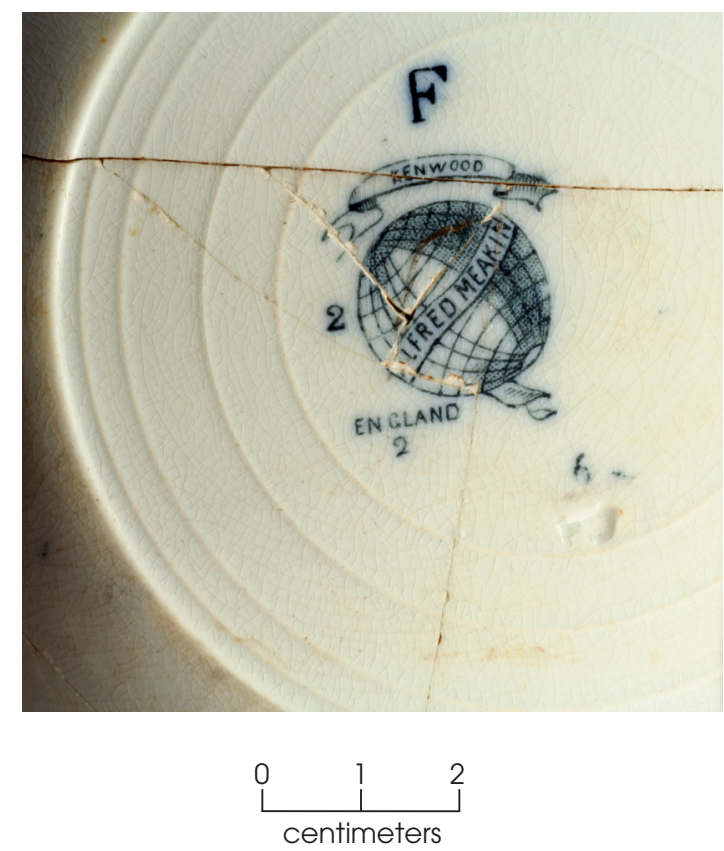

Figure 7.10. The globe and banner maker's mark used by the Alfred Meakin company between 1891 and 1897. This mark is on a blue (or gray) transferprinted saucer (CV-38). The word "KENWOOD" is the name of the specific floral pattern. The scale at left is in centimeters.
Additional printed markings include the number " 3 " on the plate and number " 2 " and letter "F" on the saucer. The saucer also had the letter "P" stamped into the base near the maker's mark. This specific globe mark was used by the Alfred Meakin pottery company only between the years 1891 and 1897 (VanBuskirk 2002), meaning that the subfloor pit could not have been backfilled before 1891 because this particular mark was not yet in production. Additional evidence for a backfill date came from the recovery of a single glass jar lid in the pit fill. On its surface, the embossed markings indicate a patent date of January 11, 1898, and this was identified as Patent No. 597,299 issued to John Schies for his "Design for a Jar-Fastening Bar" (Schies 1898). The distinctive feature of these jar lids is the S-shaped indention on the top where the closure wire clamps the lid down (Figure 7.11). Two other Schies jar lids were found in the house excavation block (EU 41), but the specimen found in the storage pit fill pushes the date of the backfilling episode to no earlier than 1898 (i.e., a terminus post quem of 1898). While this specimen indicates that the storage pit was backfilled sometime after 1898 , no other turn-of-the century artifacts were recovered from the pit. Notably absent in the storage pit assemblage are fragments of machinemade bottles that would postdate 1904 .

Evidence from nail types and counts also suggests a backfill date for the pit feature sometime during or just after the 1890s. By the mid1880 s, wire nails were finally entering the market as an alternative to cut nails, with price listings and penny weights finally becoming available for the first time (Fontana and Greenleaf 1962). The transition from cut to wire nails occurred across the United States during the 1890s, and by 1902 , wire nails were the most widely produced and used type of nail. In the subfloor pit of the Williams house, the ratio of cut to wire nails is 1.25 to 1 . Cut nails still outnumbered wire nails, but not in the same ratio as seen in the house block excavations (4 to 1 ) or in the midden area (2.7 to 1 ). This ratio is reflective of the overall trend in nail use and production in the last decade of the nineteenth century, further reinforcing the inference that the storage pit was abandoned and backfilled sometime in the late 1890s.

Having established that the subfloor pit in the Williams house was backfilled after 1898 and probably before 1904, the question then becomes, Why was the storage pit abandoned? There is 


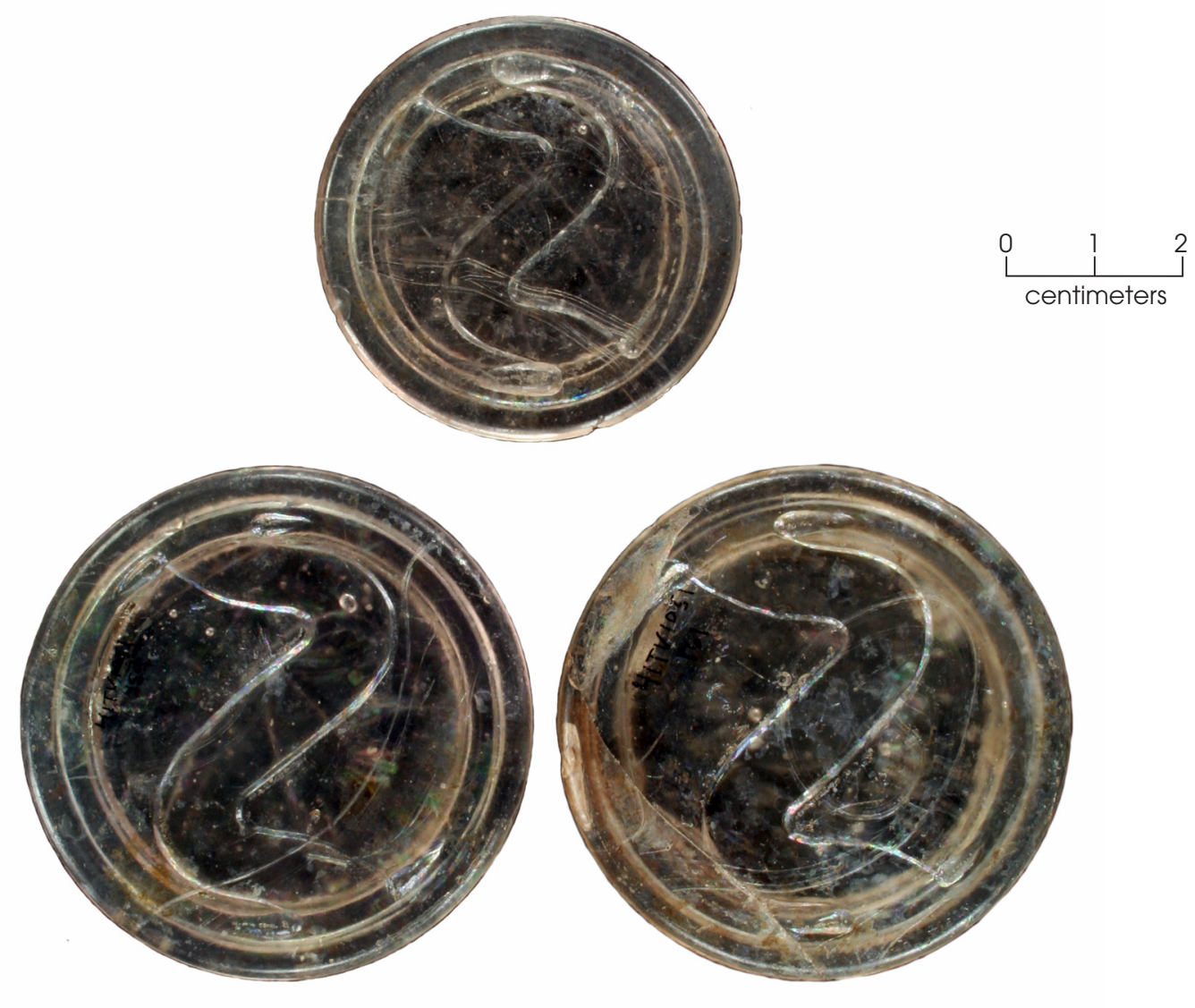

[No Modol.)

J. SCHIES.

JAR GLOSURE.

No. 597,299 .

Patented Jan. 11, 1898.
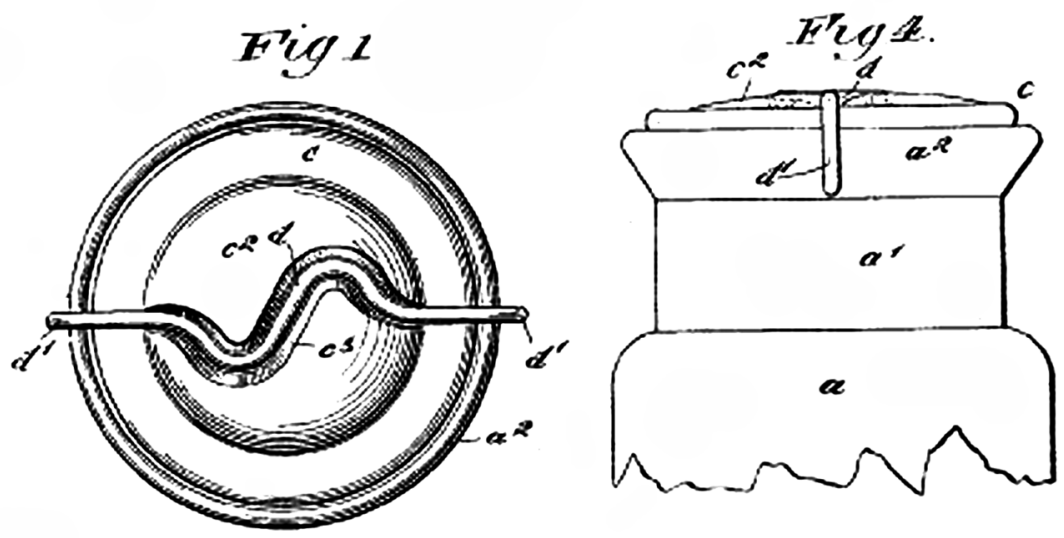

Figure 7.11. Schies glass jar lids from excavations and selected patent drawing for the Schies "JAR CLOSURE." The drawing is from Patent No. 597,229 issued on January 11, 1898 (Schies 1898). 
no known event that can be singled out as the cause for the abandonment but several options can be entertained.

- Block ice became more readily available and affordable around the turn of the century, so the Williams family might have purchased an icebox to store perishable food items. At this point, the pit would not have been needed, and it would have been backfilled to keep animals from living under the house.

- Ransom Williams died sometime between 1900 and 1901, based on county tax records. At some point soon after that, it appears that Sarah and some of the kids decided to relocate to Austin. Knowing that the house would be permanently abandoned as a habitation, it is likely that the storage pit would have been backfilled.

From an archeological perspective, the near absence of machine-made bottles in the entire assemblage indicates that the Williams farmstead was essentially abandoned by ca. 1904 . Since the material culture recovered from the subfloor storage pit indicates that it was filled in after 1898 and sometime around the turn of the century, either of the two scenarios described above could be valid.

The fact that the pit was intentionally backfilled indicates the family no longer needed it for storage by about 1898 . With the changes in technology coming about at a rapid pace during the late-nineteenth and early-twentieth centuries, life on rural farms was changing fast, too (Hanson 1986). Subfloor storage pits generally became obsolete because of the inventions of the icebox, commercially packaged foods, and home canning equipment, all of which made food storage easier and more convenient. And the arrival of national mail-order houses after 1890 made mass-manufactured products widely available to local general stores and consumers (Hanson 1986:70). Peoples' subsistence practices changed as packaged foods and storage vessels became more widely available, cheaper, and convenient. Archeological evidence indicates that the Williams family was tied into the national market economy and consumed many foods packaged in metal cans and glass containers and used large stoneware containers for food storage (see Tables B.3, B.4, and B.8).

\section{TRASH MIDDEN}

The area just east of the house, on a gentle slope heading east toward an ephemeral drainage, was where the Williams family disposed of its household refuse. The trash midden was first observed as a large scatter of surface artifacts. Excavations units were placed throughout the area where artifacts were most concentrated. These investigations helped determine the size and depth of the midden, as well as the nature of the items the Williams family was using.

Most historic farmsteads from this time period had a large refuse midden near the house. This midden location was made obvious by the wide diversity of surface artifacts and the large number of broken and unusable items. The fact that this midden area was downslope from the house is not a coincidence and further reinforces this interpretation.

Initially, the midden was divided into two parts: the east midden being closest to the house (Figure 7.12) and the east slope midden being farther away (Figure 7.13). The boundary between the two was the north-south rock wall nearest to the house (Rock Wall C2). Evidence indicates that this rock wall was in place at the time the midden debris was deposited (i.e., the wall was not constructed on top of the midden deposits) (see Chapter 6). By the end of excavations, however, it became clear that the east and east slope middens were in reality a single trash midden, so it is discussed as such here.

A total of 27 excavation units (E1-E11 and E14-E29) were placed in the midden area. The first units were excavated along the far eastern edge of the shovel test grid due to the high concentrations of fragmented artifacts recovered there. This area was only about $15-17 \mathrm{ft}$ from the southeast corner of the house. Subsequent units were excavated northward and southward from this area and up to the edge of the rock wall that lies east of the house (Rock Wall C2; see Chapter 6). Artifact counts were consistently high in this area, with the highest concentrations of material observed along the east side of the rock wall. As a result of increased artifact counts, additional units were excavated in a staggered pattern heading downslope to the east, and artifact counts remained quite high. The densest concentrations of cultural materials were recorded in Units E25 and E28, just on the west side of the rock alignment, and the presence 


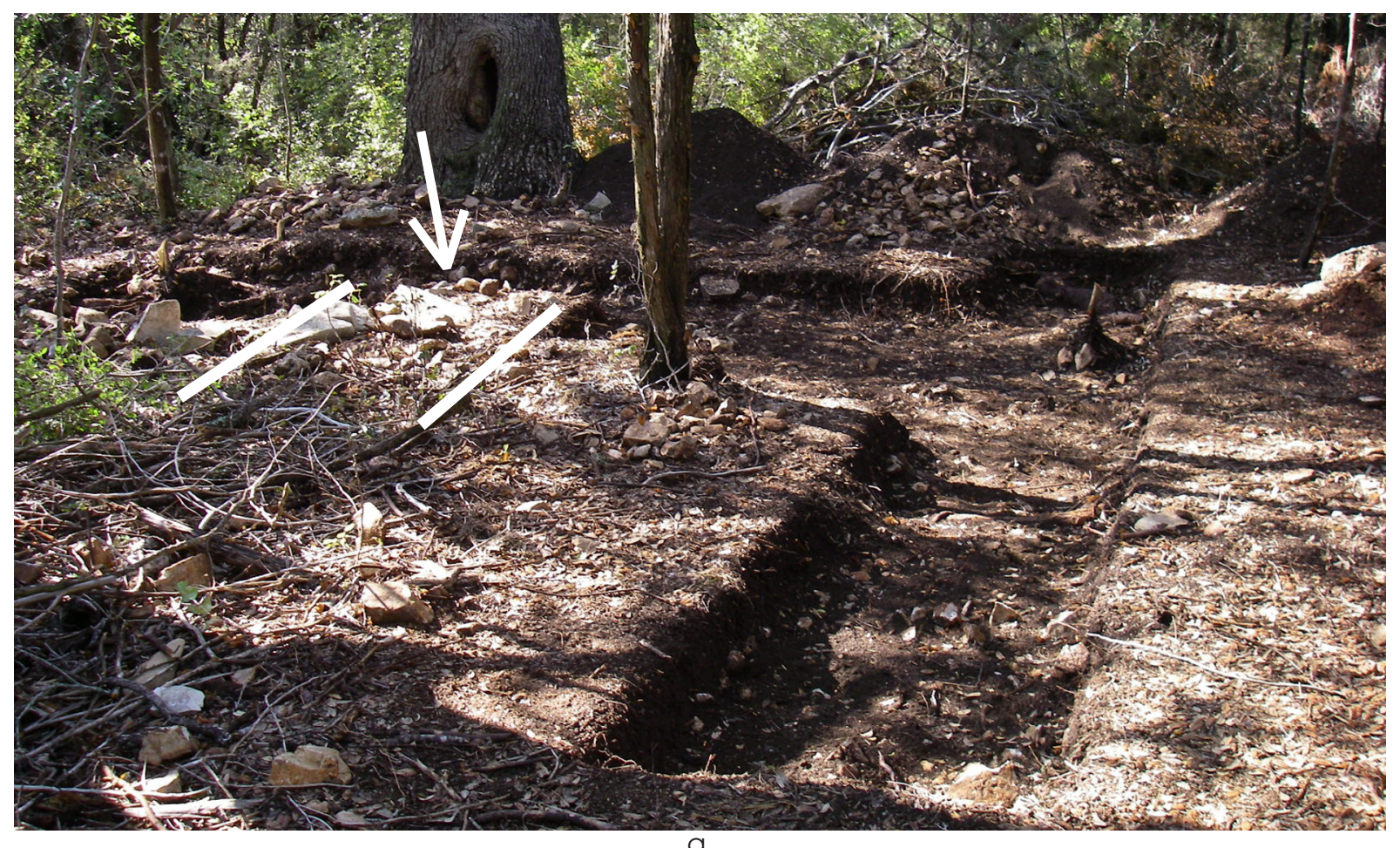

a

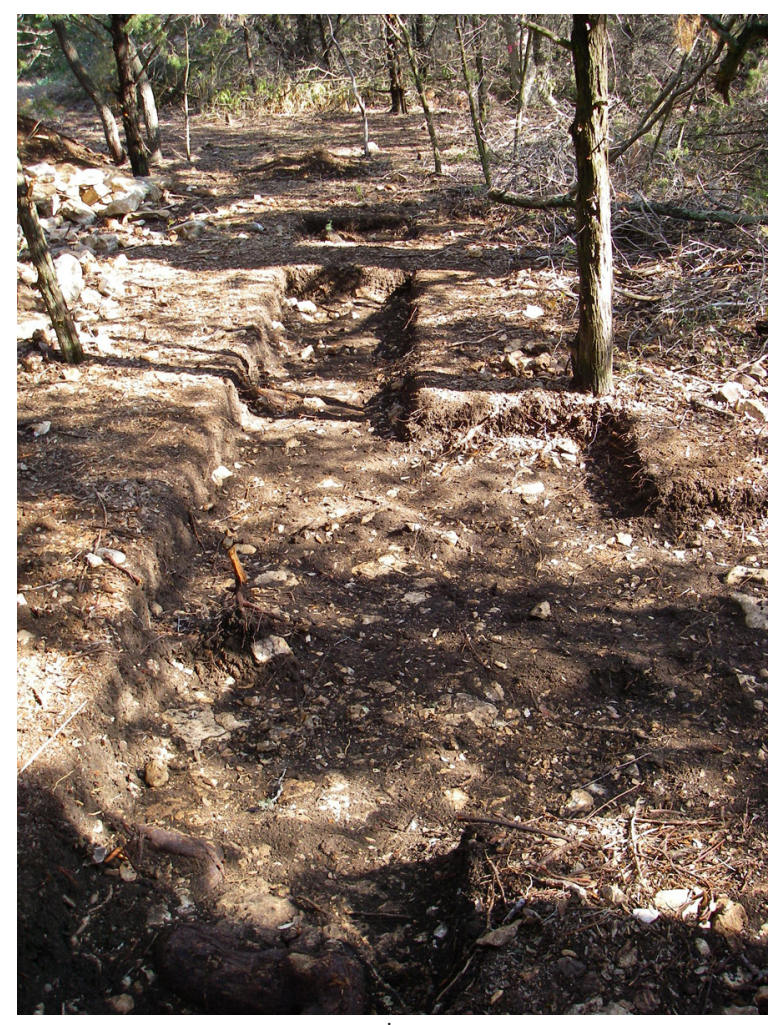

b

Figure 7.12. Views of the east midden located on the west side of Rock Wall C2. (a) View south of the east midden excavations. The white lines and arrow denote the location of a rock alignment. In the background, note the large oak tree with the large oval cavity (Tree Feature 1). (b) View north of the east midden excavations just east of the Williams house. The rock piles on the left are from the house block excavation. 


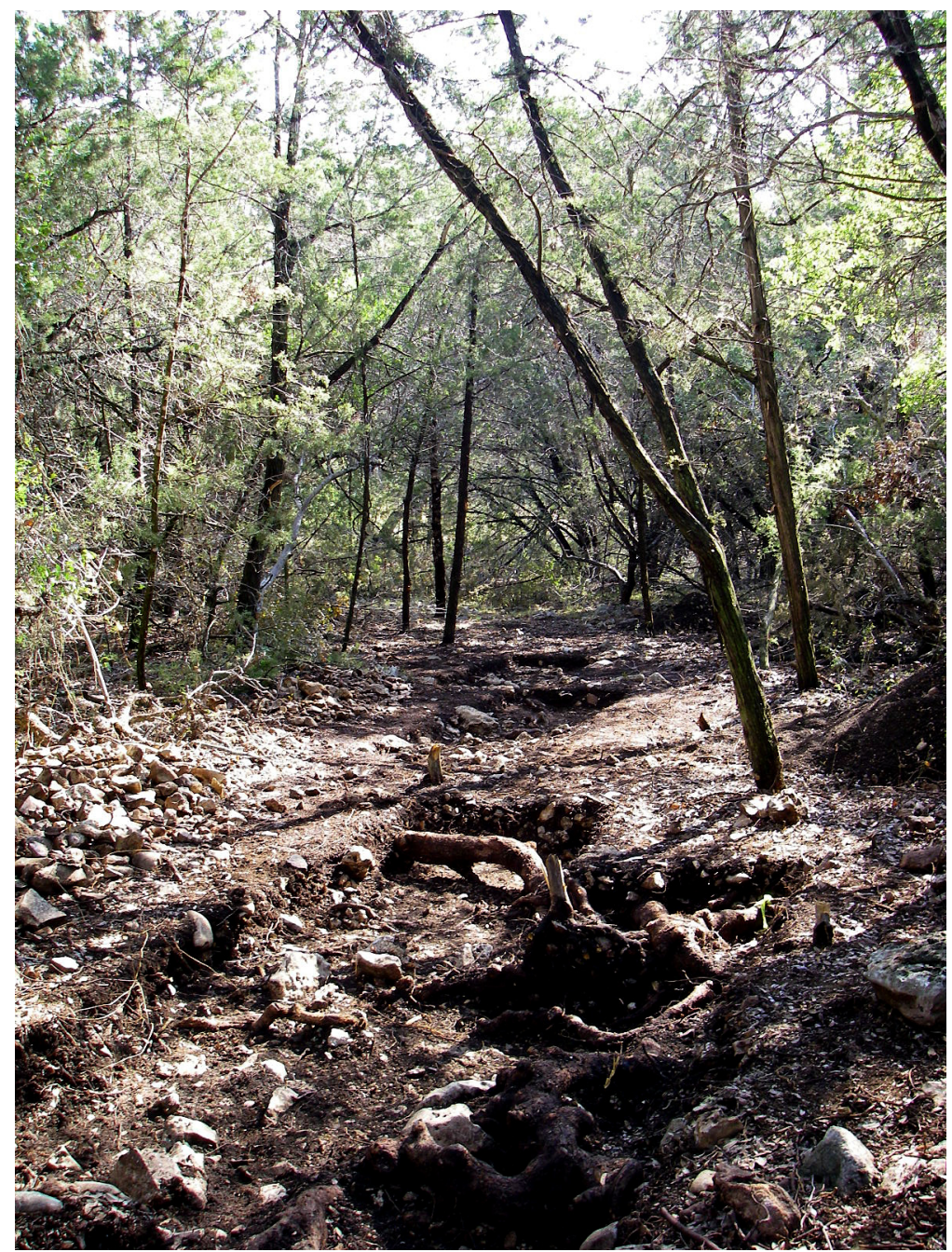

Figure 7.13. View of the east slope midden excavations, looking east and downslope from Rock Wall C2. The rocks piled on the left were removed from the excavation units.

of a few wooden fence posts were farther to the north suggesting that a barbed-wire fence may have been present along this rock alignment. It is likely that this low rock wall and fence served as a boundary to demarcate the yard, and the Williams family members would walk up to and discard refuse over the wall.

Once all the investigations were completed, the dimensions of the midden were estimated to be ca. $32 \times 48 \mathrm{ft}(10 \times 15 \mathrm{~m})$. The deepest deposits were around the rock wall and just east of the house, where artifacts were found to a depth of ca. $15-20 \mathrm{~cm}$ below the surface. The midden deposits were thinner farther downslope, where the artifacts were generally less than $10 \mathrm{~cm}$ deep.
There are hints that the horizontal extent of the midden could be larger than the estimated size. The excavations were limited to selected areas downslope of the house, where artifacts were obviously most concentrated. But occasional surface materials found beyond this area suggest that the midden was somewhat larger. Regardless, the data recovery excavations focused in the heart of the midden, and the large sample of recovered material is more than representative of the Williams family occupation.

The midden excavations recovered 9,420 specimens assigned to the five major functional categories, which account for 52.3 percent of artifacts recovered from all excavations. All of the major functional categories are well represented in the midden assemblage. These cultural materials came from 27 excavation units spread across the midden, with an average density of 348.8 artifacts per unit.

The high number of artifacts in one category admittedly skews the functional breakdown of the midden artifacts. Kitchen/ household artifacts account for 7,766 artifacts from the midden, and 6,853 of these are fragments of broken bottle glass assigned to this category because they most likely represent food bottles. Because glass containers may break into hundreds of fragments, a relatively small number of containers can turn into thousands of artifacts, but there is no way to totally avoid this problem. Architectural artifacts account for 1,245 artifacts, while the remaining 409 artifacts are classified as Personal $(\mathrm{n}=179)$, Activities $(\mathrm{n}=146)$, and Clothing/Adornment artifacts $(\mathrm{n}=84)$. This pattern fits with what might be expected of a household trash midden, where refuse from kitchen activities would likely dominate the assemblage, while reusable items like clothing fasteners would have been recycled for future use. The midden artifacts are discussed further 
as part of the spatial analysis of the Williams farmstead assemblage in Chapter 11.

\section{OUTBUILDING AREA}

Many of the day-to-day operations of the farm required a variety of heavy equipment (such as wagons, horse tack, tools, plows, and other implements and hardware) that needed to be stored and maintained away from the house. For this, it is likely that the Williams family had a storage barn or tool shed nearby where plows, planters, and wagons could be kept and repaired. Near this structure there also would have been a general outdoor workspace for various farm activities. Archeological evidence suggests that there was such an outbuilding northwest of the Williams house. At first this location was called a possible or probable outbuilding location, but the data analysis suggests that there was some type of structure there, so the designation was shortened to outbuilding.

The outbuilding area was first identified by a concentration of surface artifacts observed approximately $30 \mathrm{ft}$ northwest of the house. Many of these artifacts were glass and iron fragments. In addition to the artifacts, many limestone rocks were exposed on the surface, possibly indicating some sort of foundation or stone pavement. A metal detector survey of this area revealed a significant concentration of buried metal artifacts mixed among the rocks.

Excavation units were set up in a $2 \times 6-m$ block in an attempt to locate any architectural features that might reveal the presence of such a structure (Figure 7.14). Eventually, two more units were added just off the north end of the block, bringing the total number of units to 14 (EUs W1-W6 and W9-W16). These excavations went to a maximum depth of $17 \mathrm{~cm}$ below surface in one unit, but averaged $11 \mathrm{~cm}$ below surface across the excavation block. The excavators searched for possible postholes and meaningful patterns in the rocks and artifacts, but no evidence of architectural features was observed. However, the functional patterning of the recovered artifacts suggests that there was indeed an outbuilding in this area. Unfortunately, if there was a storage shed or workshop at this spot, there is no accurate means of estimating its size or the type of structure.

All of the major functional artifact categories are represented from excavations of the northwestern excavation block (14 units) where the outbuilding is inferred. A total of 653 artifacts recovered from this area are classified into the five major functional groups (Table 7.5). These artifacts, ranging from horse gear to kitchen and personal items, represent an array of activities and suggest multiple uses for this area. The most common artifact category represented is the Kitchen/Household category, which is dominated by metal can fragments $(\mathrm{n}=234)$. Because of their fragmentary nature, the metal can fragments inflate the Kitchen/Household group. All can fragments came from five of the 14 excavation units, with a single unit (Unit W2; Lot 291) accounting for about 45 percent of the fragments $(n=105)$. The combined evidence suggest that relatively few cans were deposited at this location, and that they deteriorated where they fell. Sixty-seven glass bottle fragments were found, and these are also classified in the Kitchen/Household group. Consequently, more than half of all the artifacts recovered from the outbuilding area are assigned to the Kitchen/ Household category, due mainly to the fragmentary nature of the metal cans and glass bottles.

More telling about the likely function of the outbuilding are the artifacts in the Activities category. Only 81 Activity-related artifacts were recovered, but these are dominated by artifacts related to farm and ranch activities. Only four of the Activity artifacts are not farm and ranch-related, and they stand apart from the rest of the assemblage. These are a .44-caliber Webley cartridge, a crank handle from an unknown device, a toy gun hammer, and a slate fragment.

Horse tack and harness gear was the most common Activity artifact recovered, suggesting that horse gear and related items were stored here. These 28 artifacts include a mix of harness and roller buckles, harness rivets, a straight bar bit, horseshoe nails, and horseshoe fragments. These suggest that the outbuilding not only served as a storage area but also as a staging point for saddling horses, harnessing horses or mules, and hitching them to the wagons. It is likely that repairing of horse gear and harnesses was also done at this location.

Wagon tools and hardware include whiffletree clips, a wagon strap and hook, as well as a clevis and clevis fragment. A single sideboard bracket and wagon box or bow staple were also found, along with one wagon wheel wrench. These parts certainly do not comprise an entire 


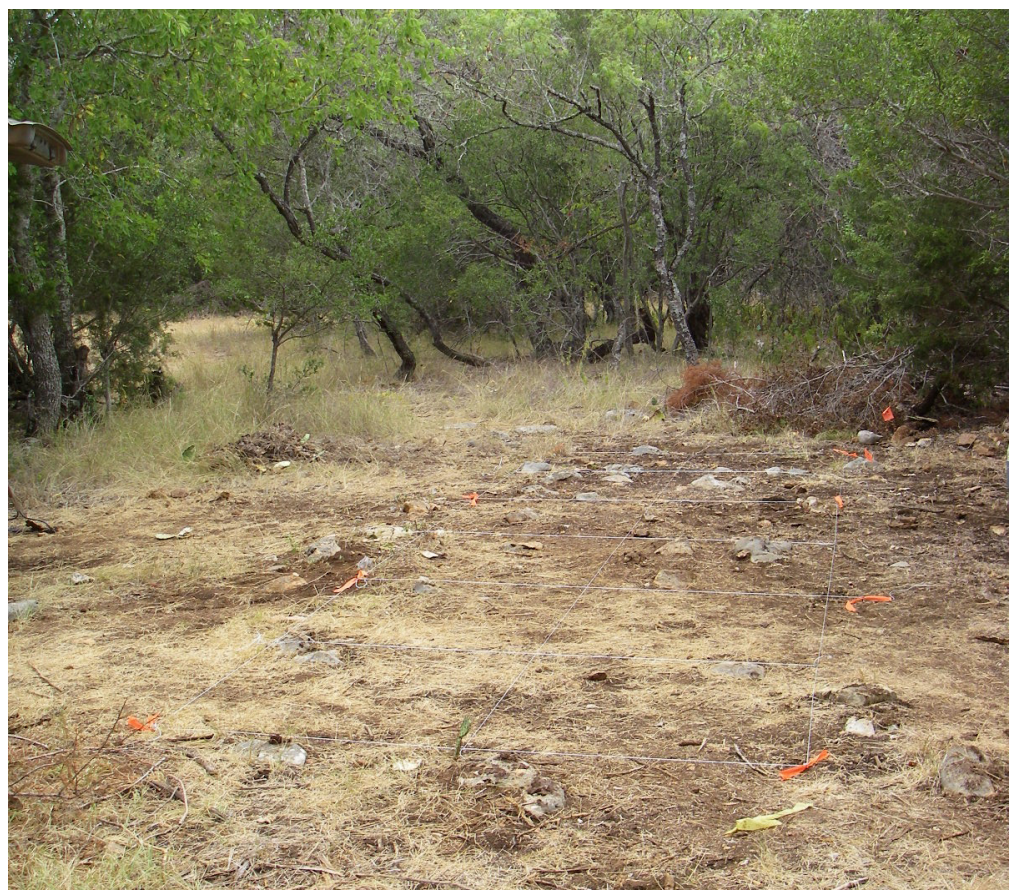

a

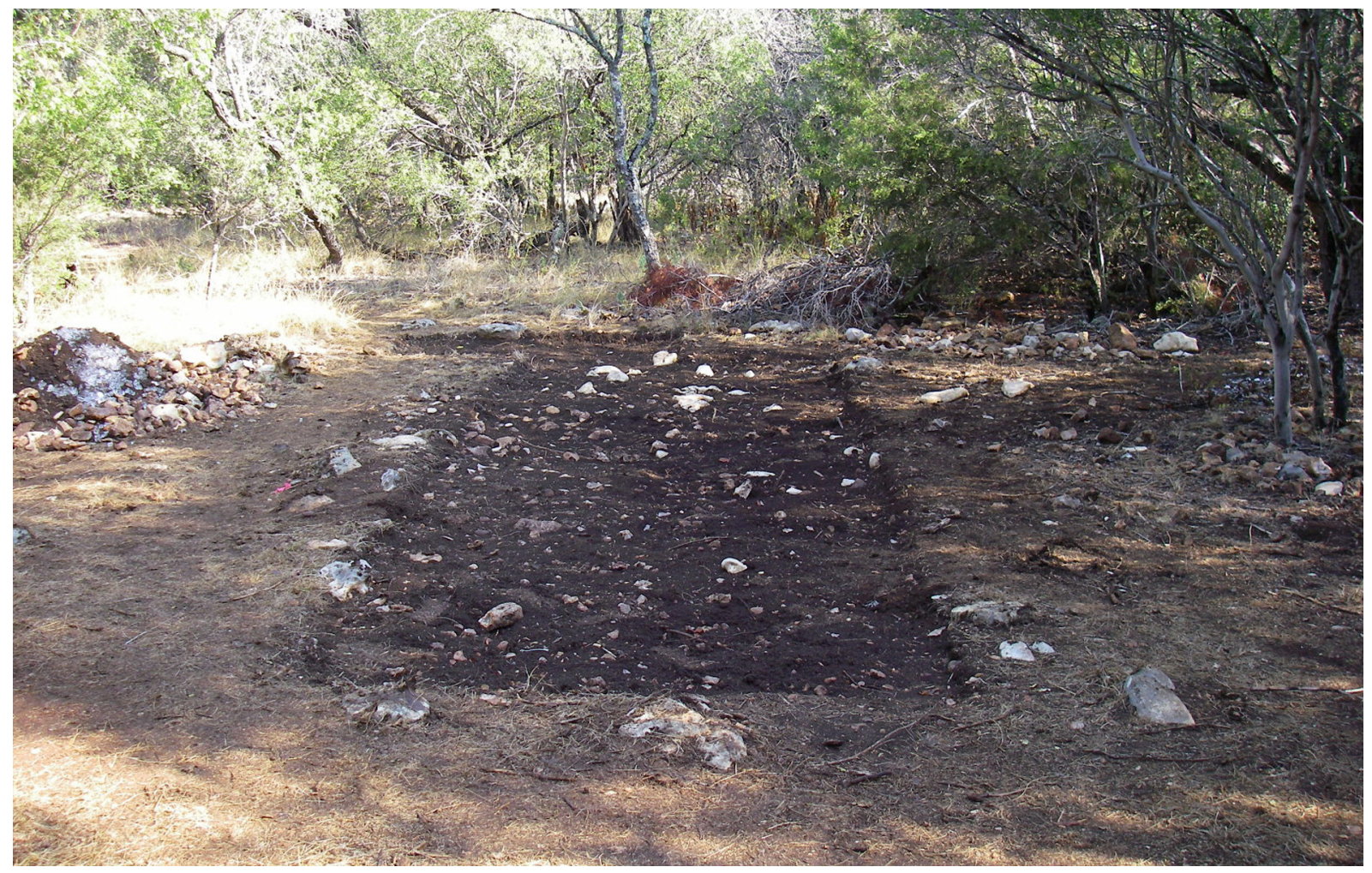

$\mathrm{b}$

Figure 7.14. Photographs of the outbuilding area northwest of the house. (a) View of the area prior to excavation with string line grid laid out. (b) View of the excavation block in progress. 
Table 7.5. Artifacts recovered from the outbuilding area

\begin{tabular}{l|c|c}
\hline \multicolumn{1}{c|}{ Functional Group } & No. of Specimens & Percent for Five Main Functional Groups \\
\hline Activities & 81 & 12.4 \\
\hline Architectural & 132 & 20.2 \\
\hline Clothing/Adornment & 17 & 2.6 \\
\hline Kitchen/Household & 362 & 55.4 \\
\hline Personal & 61 & 9.3 \\
\hline Lithics & 70 & - \\
\hline Botanical & 24 & - \\
\hline Faunal & 0 & - \\
\hline Unknown & 263 & - \\
\hline Total of all groups & 1,010 & - \\
\hline Total of five main functional groups & 653 & 100.0 \\
\hline
\end{tabular}

wagon, but they reveal that Ransom Williams had at least one wagon, a fact confirmed by historical evidence (see Chapter 5). The box/bow staples could indicate that it was some type of covered wagon, similar to the Conestoga variety, and the sideboard brackets demonstrate that it had raised walls to enclose the cargo within the bed. When not in use, the wagon or wagons may have been stored and maintained under cover of this outbuilding.

A variety of miscellaneous hardware would be expected to be found in a work barn or storage shed. In fact, only 12 pieces of hardware were recovered from the outbuilding area, but the wide variety of items-nuts, bolts, chains, pins, rivets, and hinges-may speak to what was being stored or used in the structure or possibly even how the structure was built. The nuts, bolts, and hinges might have been associated with a wagon, or some of them may have been part of the outbuilding construction.

Only 52 cut nails and 15 wire nails were recovered from the outbuilding excavations. This number is quite low when compared with the number of nails recovered from the house block, which seems to rule out the possibility that the outbuilding was a board-and-batten structure with complete vertical walls. The low number of nails would be more consistent with a pole barn-a simple open-sided structure consisting of vertical corner posts (and sometimes a few along the walls) supporting a roof.
Pole barns were common on farms and ranches in many areas, and they were widely used in central Texas. The support posts and roof framework could have been made of tree trunks and branches cut on the farm or of milled lumber. The roof cover could have been made of shakes (i.e., wooden shingles made from split logs), sections of split logs, or even sheet metal or corrugated tin. A pole barn would have been a simple and inexpensive solution for covering the wagon, farm equipment, and other gear to keep them out of the elements.

Sixty-one items in the Personal category were recovered from the outbuilding area. The most common artifact type was snuff bottles and fragments. At least two individual snuff bottles were identified (Glass Containers 87 and 90), along with dozens of other brown glass fragments that probably represent additional snuff bottles. Regardless, their presence indicates that some members of the Williams family were regularly consuming various tobacco products, including snuff. Snuff bottles were found in many excavations across the site, but their presence in the outbuilding might suggest recycling of the jars after their tobacco was used up. Because they have a wide mouth, they could have been used to store smaller items. In old and modern barns, it common to see small containers such as coffee cans and mason jars used to store small hardware such as nails, nuts, and bolts. Other Personal items include fragments of a 
cobalt blue glass bottle (Glass Container 73) with unknown contents, two liquor bottles (Glass Containers 30 and 42), a pocketknife blade, two hair comb fragments, and an umbrella/parasol rib. Other than noting their presence, not much can be inferred from these few personal items.

Seventeen items in the Clothing/Adornment category were recovered, including one buckle, seven buttons, and nine small eyelets, likely from shoes. Button types include four white Prosser buttons, two metal buttons, and one U.S. Army general service button. Buttons were recovered in almost all excavations across the site, so it is not surprising that some buttons were recovered from the outbuilding area. The buttons could indicate that a clothesline was stretched out across this area or that some of the clothes washing was done there.

The total artifact assemblage from the outbuilding area is a relatively small sample, but the high frequency of artifacts related to horses, harnesses, and wagons is notable. This evidence reinforces the idea that some type of building, most likely a combination storage barn and work shed, once existed northwest of the Williams house. The exact size and type of structure cannot be determined from the minimal investigations in this area, but the evidence suggests that it was a large building used for storing and maintaining wagons and horse gear, and perhaps served as a staging point for saddling riding horses and harnessing mules. 


\title{
DESCRIPTIONS OF MATERIAL CULTURE FROM THE WILLIAMS FARMSTEAD
}

\author{
Aaron R. Norment and Douglas K. Boyd
}

More than 26,000 individual items were recovered from the Ransom and Sarah Williams farmstead. These objects reveal many aspects of everyday life on the farm of an African American family in the rural Bear Creek community of southern Travis County. The late nineteenth-century material culture reflects an agricultural household that was economically sound, with a robust diversity of mass-manufactured items, some moderately priced goods, and leisure activities well represented.

The farmhouse and other improvements were left to decay with minimal disturbance, so much of the associated material culture was left intact, providing a wealth of information about the people who once lived there. As a result, 26,685 individual artifacts were recovered during excavations conducted at the site between 2003 and 2009. This includes 513 artifacts previously recovered during the initial site testing by Archaeological and Cultural Sciences Group (ACSG) in 2003 (Staples and Nash 2003) and 26,172 artifacts recovered by Prewitt and Associates, Inc. (PAI) during intensive 2007-2008 site testing and 2009 data recovery.

The assemblage is described following the functional artifact classification scheme presented in Chapter 3. Appendix B contains a master database and tables organized by artifact type. In this chapter, the material culture is often described independently of artifact provenience, but the discussions do take the spatial associations and analysis units into account. The comprehensive spatial analyses and detailed interpretations of the cultural materials recovered from the house, yard, and midden areas are presented in Chapter 11.

\section{8}

The 18,742 recovered artifacts described in this chapter are classified and discussed in this order:

$\begin{array}{lr}\text { Architectural Artifacts } & 4,586 \\ \text { Kitchen/Household Artifacts } & 11,965 \\ \text { Activities Artifacts } & 954 \\ \text { Clothing and Adornment Artifacts } & 638 \\ \text { Personal Artifacts } & 599\end{array}$

The recovered faunal and macrobotanical remains are described in detail in Chapters 9 and 10 respectively. Also not discussed in this chapter (but included in the master artifact database in Appendix B) are the Unidentified items ${ }^{96}$ ( $\mathrm{n}=4,198$, of which 4,112 are too fragmentary or corroded to be identified) and the Lithic items ( $\mathrm{n}=784$; mostly unmodified chert flakes). The latter are associated with an ephemeral prehistoric lithic scatter that covers the entire site area.

\section{ARCHITECTURAL ARTIFACTS}

The architectural artifacts are specimens that would normally be considered structural components of a house or building or are related to fencing. The 4,586 architectural specimens described in this section:

$\begin{array}{lr}\text { Cut nails } & 2,502 \\ \text { Cut nail fragments } & 739 \\ \text { Wire nails } & 614 \\ \text { Wire nail fragments } & 78\end{array}$

${ }^{96}$ Two of the unidentified items were subsequently identified as cotton bale ties and are described at the end of this chapter. 
Spikes 2

Bricks and brick fragments $\quad 11$

Wood screws $\quad 51$

Wood screw fragments $\quad 10$

Miscellaneous hardware 3

Barbed wire 44

Staples and staple fragments $\quad 127$

Smooth wire 367

Wood samples

Mortar fragments

Flat glass is notably absent from that list. When pieces of flat glass are found around a historic house location, archeologists usually assume that they are derived from window panes. This assumption is well founded, and flat window glass constitutes an important type of architectural evidence at many nineteenth-century historic sites. The total absence of flat glass in the Williams farmstead assemblage suggests that the house had no glass windows.

\section{Nails}

Both wire and cut nails, the most common type of architectural artifacts, were recovered from the Williams farmstead. Complete nails and fragments with the nail head present were considered "complete" nails for the purposes of counting the minimum number of nails. Any shaft fragments missing the nail head were classified as nail fragments and were not used in determining the minimum number of nails. Many of the nails were categorized based on the presence of the nail head and a small portion of the nail shaft, so an accurate length could not be determined. Figure 8.1 illustrates an assortment of the cut and wire nails.

\section{Cut Nails}

The cut nails include 3,241 specimens, but 739 of these (22.8 percent) are nail fragments lacking heads. The 2,502 complete cut nails were classified into four types defined by their sizes, with Type 1 being the smallest and Type 4 being the largest. The size ranges for the cut nail types are summarized in Table 8.1. Within each size category, the head and shaft shapes varied somewhat. No attempt was made to classify the cut nails according the types defined in various catalogs and studies (e.g., Edwards
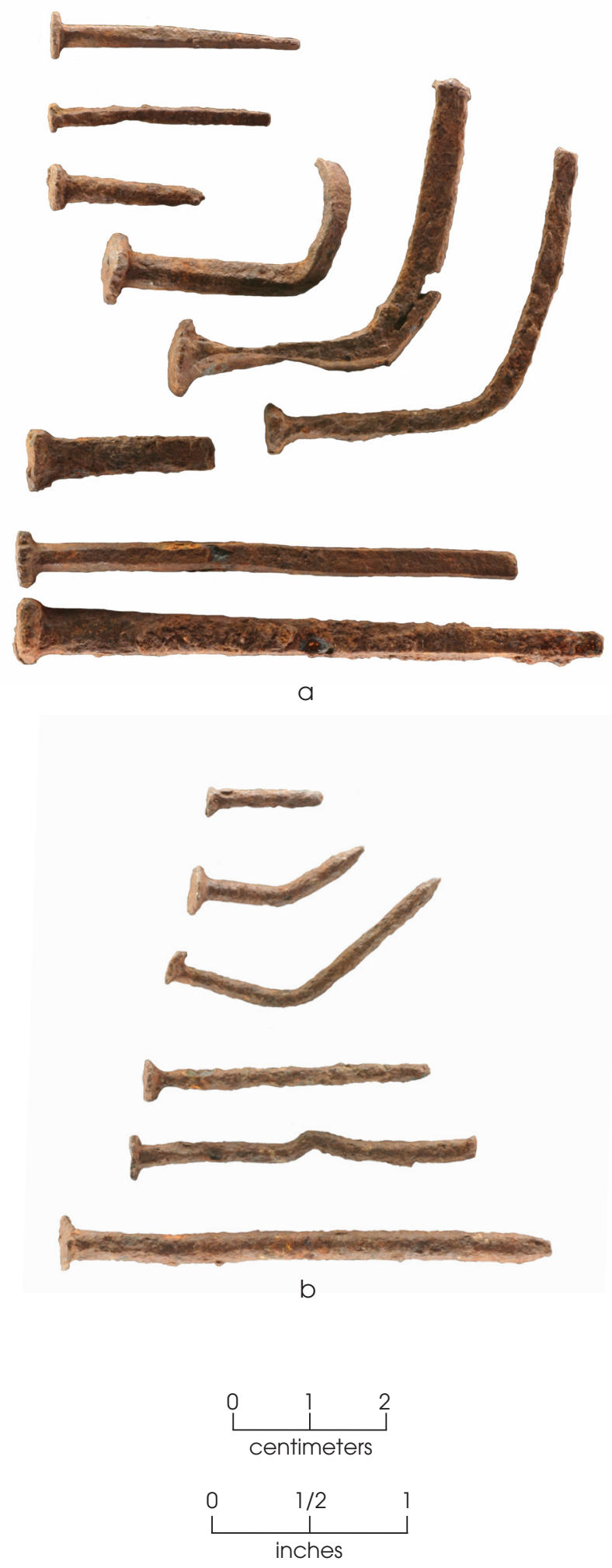

Figure 8.1. Nails. (a) Assorted sizes of cut nails; (b) assorted sizes of wire nails. 
and Wells 1993; Tremont 2012). Most have a flat head and a tapered shaft and are variations of the "Cut Nails" form in the 1865 Illustrated Catalogue of American Hardware (Russell and Erwin 1865:251). This form is illustrated as the "common" cut nail form in the Tremont (2012:4) catalog of modern reproduction cut nails.

Typically, the more corroded and deteriorated nails came from the chimney firebox and midden areas. Nails from the house block excavations were generally in better condition, with less severe corrosion. Since many of the cut nails were missing their tips, accurate length measurements could not always be obtained. Because of this, the standard penny scale for measuring nail sizes was not employed.

Type 1 are the most common cut nails at the site, with 1,384 specimens recovered. Type 1 nails typically measure between 1 inch and 1.75 inches in length. They have small heads and a thin shaft and are notably shorter than the other nails in the collection. Some of the Type 1 nails may actually be small brads or tacks rather than actual nails.

Type 2 nails are slightly larger, measuring between 2.0 and 2.5 inches in length. Overall, their shafts and heads are thicker and more robust than Type 1. A total of 341 Type 2 cut nails were recovered. The Type 3 category is comprised of 420 specimens between 2.75 and 3.0 inches long, and they have larger and heavier shafts and heads than Type 2 nails. Type 4 cut nails are the largest nails found, and 158 specimens were recovered. Several of the larger cut nails may actually be spikes that they may or may not have functioned as nails. Cut nails too deteriorated to accurately determine their type are classified as "other." This category includes 199 specimens. In a few cases, nails with different styles of heads were also classified as other; some of these may be hinge nails (Tremont 2012:6).

\section{Wire Nails}

A total of 692 wire nails were identified in the Williams farmstead collection, but 78 of these are fragments lacking heads (see Figure 8.1). The other 614 wire nails with heads are considered "complete." Provenience data for these 614 wire nails are presented in Table B.22.

To gain a better understanding of the types of wire nails in the assemblage, the individual nails were classified into subcategories using

Table 8.1. Complete cut nails by size group (excludes cut nail fragments)

\begin{tabular}{|c|c|c|c|c|c|c|c|c|c|c|}
\hline \multirow{2}{*}{$\begin{array}{l}\text { Size } \\
\text { Group }\end{array}$} & \multirow[b]{2}{*}{ Size Range } & \multirow{2}{*}{$\begin{array}{l}\text { Penny- } \\
\text { Size } \\
\text { Classes } \\
\end{array}$} & \multicolumn{2}{|c|}{$\begin{array}{l}\text { Cut Nails from } \\
\text { All Contexts }\end{array}$} & \multicolumn{2}{|c|}{$\begin{array}{c}\text { Cut Nails in the } \\
\text { House Block } \\
\text { Only }\end{array}$} & \multicolumn{2}{|c|}{$\begin{array}{c}\text { Cut Nails in } \\
\text { Subfloor Storage } \\
\text { Pit Only }\end{array}$} & \multicolumn{2}{|c|}{$\begin{array}{l}\text { Cut Nails in } \\
\text { the Chimney } \\
\text { Firebox Only }\end{array}$} \\
\hline & & & No. & Percent & No. & Percent & No. & Percent & No. & Percent \\
\hline $\begin{array}{l}\text { Type 1, } \\
\text { Small }\end{array}$ & $\begin{array}{c}1.0 \text { to } 1.75 \\
\text { inches }\end{array}$ & $2 \mathrm{~d}$ to $5 \mathrm{~d}$ & 1,384 & 55.3 & 1,021 & 66.3 & 42 & 35.0 & 5 & 20.8 \\
\hline $\begin{array}{l}\text { Type } 2, \\
\text { Medium }\end{array}$ & $\begin{array}{c}2.0 \text { to } 2.5 \\
\text { inches }\end{array}$ & $6 \mathrm{~d}$ to $8 \mathrm{~d}$ & 341 & 13.6 & 155 & 10.1 & 17 & 14.2 & 1 & 4.2 \\
\hline $\begin{array}{l}\text { Type 3, } \\
\text { Large }\end{array}$ & $\begin{array}{c}2.75 \text { to } 3.0 \\
\text { inches }\end{array}$ & $8 \mathrm{~d}$ to $10 \mathrm{~d}$ & 420 & 16.8 & 171 & 11.1 & 20 & 16.7 & 1 & 4.2 \\
\hline $\begin{array}{l}\text { Type } \\
\text { 4, Very } \\
\text { Large* }\end{array}$ & $\begin{array}{c}3.25 \\
\text { inches and } \\
\text { larger }\end{array}$ & $\begin{array}{l}\text { 10d and } \\
\text { larger }\end{array}$ & 158 & 6.3 & 77 & 5.0 & 5 & 4.2 & 0 & 0.0 \\
\hline $\begin{array}{c}\text { Other } \\
\text { Cut } \\
\text { Nails }{ }^{* *}\end{array}$ & - & - & 199 & 8.0 & 116 & 7.5 & 36 & 30.0 & 17 & 70.8 \\
\hline \multicolumn{3}{|c|}{ Total } & 2,502 & 100.0 & 1,540 & 100.0 & 120 & 100.0 & 24 & 100.0 \\
\hline
\end{tabular}

* This category includes specimens that could be very large nails or spikes. It also includes all of the cut nails recovered in the previous ACSG testing. No attempt was made to classify these by size.

** This category includes all of the cut nails recovered in the previous ACSG testing. No attempt was made to classify these by size. 
the standard historical and modern nail sizing method. Penny-size categories were used to classify the wire nails, with the size groups ranging from $2 \mathrm{~d}$ ( 1 inch long) to 16 ( 3.5 inches long). The individual wire nails are summarized by sizes in Table 8.2.

Shaft thickness varies slightly within each of the categories, but length was the main factor used to size the wire nails. Some nails were too fragmentary or corroded to be categorized by size. These specimens are classified as "other" wire nails. One finishing nail and one roofing nail are the only examples of these types of nails in the assemblage.

\section{Discussion of Cut and Wire Nails}

Of the 3,116 complete nails recovered (excluding 817 fragments without heads), 1,928 specimens (62 percent) were found within the main house block excavations (excluding the nails from the chimney firebox and the subfloor pit). These excavations consisted of ninety $1 \times 1-m$ excavation units in a $9 \times 10-m$ grid that encompassed the house foundation and chimney base. Of the nails recovered from the house block, 1,540 specimens (79.9 percent) are cut nails, while the remaining 388 (20.1 percent) are wire nails, a ratio of cut nails to wire nails is 3.9 to 1 .

Type 1 cut nails are the most common nail recovered from the house block excavations. A total of 1,021 Type 1 nails were recovered, accounting for 66.0 percent of the cut nails. All of the Type 1 cut nails measure less than 1.75 inches long, making them likely candidates to be shake roofing nails. If the estimated house size of $15 \times 16 \mathrm{ft}$ is correct (see Chapter 11), then the density would be 4.3 Type 1 cut nails per square foot for the 240-square-ft house. The relatively large number of these small nails suggests that a shake roof may have covered the original structure. Jurney (1987a:83) describes shake roofing nails as being 3.2 and $3.8 \mathrm{~cm}$ long, or 1.25 and 1.5 inches respectively.

Table 8.2. Complete wire nails by size group (excludes wire nail fragments)

\begin{tabular}{|c|c|c|c|c|c|c|c|c|c|}
\hline \multirow{2}{*}{$\begin{array}{l}\text { Size Group or } \\
\text { Type }\end{array}$} & \multirow{2}{*}{$\begin{array}{l}\text { Penny- } \\
\text { Size } \\
\text { Class }\end{array}$} & \multicolumn{2}{|c|}{$\begin{array}{l}\text { Wire Nails from } \\
\text { All Contexts }\end{array}$} & \multicolumn{2}{|c|}{$\begin{array}{l}\text { Wire Nails in the } \\
\text { House Block Only }\end{array}$} & \multicolumn{2}{|c|}{$\begin{array}{c}\text { Wire Nails in } \\
\text { Subfloor Storage } \\
\text { Pit Only }\end{array}$} & \multicolumn{2}{|c|}{$\begin{array}{l}\text { Wire Nails in the } \\
\text { Chimney Firebox } \\
\text { Only }\end{array}$} \\
\hline & & No. & Percent & No. & Percent & No. & Percent & No. & Percent \\
\hline $1 \mathrm{inch}$ & $2 \mathrm{~d}$ & 4 & 0.7 & 3 & 0.6 & 1 & 1.1 & 0 & 0.0 \\
\hline $11 / 4$ inch & $3 d$ & 95 & 15.5 & 57 & 11.9 & 15 & 16.0 & 0 & 0.0 \\
\hline $11 / 2$ inch & $4 \mathrm{~d}$ & 92 & 15.0 & 55 & 11.5 & 12 & 12.8 & 0 & 0.0 \\
\hline $13 / 4$ inch & $5 d$ & 67 & 10.9 & 51 & 10.7 & 9 & 9.6 & 0 & 0.0 \\
\hline 2 inch & $6 \mathrm{~d}$ & 118 & 19.2 & 75 & 15.7 & 21 & 22.3 & 0 & 0.0 \\
\hline $21 / 4$ inch & $7 d$ & 17 & 2.8 & 13 & 2.7 & 1 & 1.1 & 1 & 33.3 \\
\hline $21 / 2$ inch & $8 d$ & 116 & 18.9 & 70 & 14.6 & 20 & 21.3 & 1 & 33.3 \\
\hline $23 / 4$ inch & $9 \mathrm{~d}$ & 11 & 1.8 & 8 & 1.7 & 0 & 0.0 & 0 & 0.0 \\
\hline 3 inch & $10 \mathrm{~d}$ & 19 & 3.1 & 11 & 2.3 & 2 & 2.1 & 1 & 33.3 \\
\hline $31 / 4$ inch & $12 \mathrm{~d}$ & 6 & 1.0 & 5 & 1.0 & 1 & 1.1 & 0 & 0.0 \\
\hline $31 / 2$ inch & $16 \mathrm{~d}$ & 2 & 0.3 & 2 & 0.4 & 0 & 0.0 & 0 & 0.0 \\
\hline Framing Nail & none & 1 & 0.2 & 1 & 0.2 & 0 & 0.0 & 0 & 0.0 \\
\hline Roofing Nail & none & 1 & 0.2 & 1 & 0.2 & 0 & 0.0 & 0 & 0.0 \\
\hline $\begin{array}{l}\text { Other Wire } \\
\text { Nails* }^{*}\end{array}$ & none & 65 & 10.6 & 36 & 7.5 & 12 & 12.8 & 0 & 0.0 \\
\hline Total & & 614 & 100.0 & 388 & 81.2 & 94 & 100.0 & 3 & 100.0 \\
\hline
\end{tabular}

* This category includes all of the wire nails recovered in the previous ACSG testing. No attempt was made to classify these by size. 
When all 1,540 cut nails from the house block are taken into account, the number is too low to suggest that the original structure was a cut lumber frame house. If the small Type 1 nails are indeed roof nails and we subtract them from the total, this leaves only 519 larger nails that could have been used for fastening the wooden siding of a cut lumber or board-and-batten house. This number is far too low to account for such a structure, assuming there was no scavenging of building materials that removed nails from the site. ${ }^{97}$ The most logical interpretation is that the Williams family's original house was a log cabin that required relatively few nails. ${ }^{98}$ Only 166 small wire nails (1.75 inch or smaller) were recovered from the house block, and the ratio of small cut to wire nails is 6.2 to 1 . Consequently, the small wire nails could represent later repairs to the original shake roof.

Many floors in Texas cabins were typically dirt or rammed earth, but cabins were also known to have used puncheon floors (Connor 1949:114). Puncheon floors were made of roughly split logs with one face smoothed, and they were typically set into a bed of sand or dirt, where they could be set in place and fastened with pegs (Connor 1949:114). It is likely that a dirt floor was present in the original log cabin, but a puncheon floor is also a possibility. However, no archeological evidence was observed to indicate a puncheon floor existed (e.g., log impressions or log remnants in the clay).

Because so many large limestone rocks were found inside the house foundation area, it seems likely that they must have served as supports for a wooden floor (see Chapter 11). In this scenario, floor joists sat on the limestone

\footnotetext{
${ }^{97}$ The potential that scavenging of structural wood could have reduced the number of nails is acknowledged, but there is no evidence to suggest that this occurred. It is more likely that the wooden superstructure, whether it was a log cabin or a cut lumber house, simply deteriorated in place.

${ }^{98}$ Based on the 117 machine-cut nails and 20 wire nails recovered during the 2003 testing by ACSG, Staples and Nash (2003b:60) hypothesized that the house was a log cabin. They stated that: "The large quantity of finishing nails and a corresponding lack of large framing nails suggest that the building was a log structure." They caution that the lack of chinking fragments is problematic, but this observation is not particularly relevant if local upland clays were used for chinking. As the log house deteriorated, the clay chinking would have melted away and become largely indistinguishable from the natural sediment.
}

rocks, and floorboards were nailed onto the joists. Considering only the larger nails (in size $6 \mathrm{~d}$ and above), the density of large nails would be approximately 1.7 nails per square foot for the 240 -square-ft house. These 587 nails ( 403 cut and 184 wire) could be large nails used to anchor floorboards to joists. The ratio of large cut to wire nails is 2.2 to 1 , which is much lower than the 6.2 to 1 ratio of small roofing nails. This suggests that a wooden floor was added some time after wire nails had come into common use but before cut nails dropped out completely.

The wire nails are a likely indicator of repair episodes or additions that occurred at the Williams house. By 1880 , the first American wire nail manufacturer began operating in Kentucky, but wire nails were slow to catch on as a replacement for cut nails (Edwards and Wells 1993:18). By 1892, half of all nails manufactured in the United States were wire, and by 1900 cut nail production was in serious decline (Edwards and Wells 1993:18). Ransom Williams probably started building his house soon after he purchased the land in 1871, and it was probably built by 1875 (see Chapter 6). This early construction date would preclude the use of wire nails. This evidence helps explain the relative paucity of wire nails.

A caveat is that some of the nails, both cut and wire, might have been associated with the construction of a door or window shutters, and the recovery of some clinched cut nails may be evidence of this. The coming of the railroad from Austin to San Marcos in 1880 might have made milled lumber more readily available, and structural repairs or additions would have been easier and more affordable. It was not uncommon for small log cabins to have a second-floor loft opposite the fireplace, and such a loft could have been original or added at a later date (Jurney and Moir 1982:156). It is also possible that a small wood frame structure, such as a porch or a lean-to storage shed, might have been built onto the cabin at some point, but the spatial distribution of nails suggests this is unlikely (see Chapter 11).

\section{Spikes}

Two large spikes are grouped with the architectural artifacts. One specimen is 8 inches long with a 5/8-inch square shaft and a rounded head. It was found on the surface along the north 
wall of the house by Archaeological and Cultural Sciences Group (ACSG) archeologists in 2003. The specimen is identified as a harrow spike and illustrated by Staples and Nash (2003b:Figure 24). Although it could be from an agricultural harrow (a farming tool with many spike-like teeth used to break up clods), this single specimen was probably used in some other manner, perhaps as a punch or a chisel.

The second specimen is a large iron spike that is $61 / 8$ inches long with a $3 / 8$-inch wide square shaft. The distal end of the shaft is broken. Its head is splayed out into an oval that measures $3 / 4 \times 7 / 8$ inch. This spike appears to be hand forged, and it was likely used as a punch or a chisel.

\section{Bricks}

Eleven bricks and brick fragments were found at the Williams farmstead (see Table B.24). Seven specimens are identified as Austin Common brick. They are hand-molded with a frog, or rectangular indentation, on one face (Boyd and McWilliams 2009:49). Of these, two are nearly complete but have chipped corners, and five are half to three-quarter fragments. The second style is represented by three hand-molded brick fragments (each approximately one half) that are a plain version of the Austin Common brick (with no frog indentation). Both styles of Austin Common bricks are light in color (tan or yellow), and they have been found in historic structures throughout the Austin area. They were probably made in the Austin area from Colorado River clays (Boyd and McWilliams 2009:48). The final specimen is a hand-molded brick fragment (approximately one half) of a different style than the Austin Common bricks. It is similar in color to some of the Austin Common bricks but made of a more compact, fine-grained clay. Its struck face has a series of parallel scraping marks where the excess clay was scraped from the mold. On the opposite molded face are wear marks that appear to be the result of pecking, perhaps from using the brick as an anvil. There are also a few iron rust striations on that face, which would be consistent with the use of the brick as an anvil.

Bricks are usually considered to be architectural items, but in this assemblage they probably did not serve that function. None of the bricks was found in a context indicating they served an architectural purpose, and the total number of bricks is far too small for them to have been used to build any architectural features at the farmstead. It is more likely that they were collected as individual items for use on the farm. The 11 brick specimens are scattered about in the yard and house block, and their locations do not suggest any particular use. They could have been brought to the site to serve some practical function, such as an anvil or a doorstop. Or they could have been brought to the farm with no specific function in mind but with the intent that they could be used for many purposes.

\section{Wood Screws}

A total of 51 screws (specimens with heads) were recovered from the farmstead, along with 10 screw shaft fragments (no heads). As summarized in Table 8.3, the specimens are various sizes of gimlets, or wood screws, ranging from $5 / 8$ inch to 2 inches long. All of the wood screws were compared with size (gauge) illustrations and data in period catalogs (Russell and Erwin Illustrated Catalog of American Hardware [1865:126-127], the 1895 Montgomery Ward \& Company catalog [1895:383], and the Sears, Roebuck \& Company [1897:np, Item 143]). Using this information, it was possible to classify all but one of the screws by size linked to the historical size classifications using shaft diameter (gauge) and length. For each screw, the length and shaft diameters were measured (see Table B.23), and each specimen was then placed over a copy of the catalog screw illustrations to confirm the correct sizes.

All of the wood screws are iron, with the exception of one brass screw that could have been a hinge or furniture screw. All of the screws possessed flat, counter-sinking heads except for one that had a raised, oval head. It is unclear how these screws functioned, but they could have been used in furniture or other objects that would have been found on a family farm.

Ten specimens are wood screw shaft fragments that are too incomplete to be classified by size. Seven of these appear to be common wood screws, but three have very fine threads and were probably used for specialized purposes, such as in the construction of fine furniture. 
Table 8.3. Slot-head wood screws*

\begin{tabular}{l|c|c|c|c|c|c}
\hline $\begin{array}{c}\text { Size } \\
\text { Length) }\end{array}$ & $\begin{array}{c}\text { House } \\
\text { Block }\end{array}$ & $\begin{array}{c}\text { House Block, } \\
\text { Subfloor Pit }\end{array}$ & Yard Area & Midden & Total & $\begin{array}{c}\text { Percent of } \\
\text { Total }\end{array}$ \\
\hline $5 / 8$ inch, Brass & 1 & 0 & 0 & 0 & 1 & $2.0 \%$ \\
\hline $3 / 4$ inch & 6 & 0 & 0 & 1 & 7 & $13.7 \%$ \\
\hline 1.0 inch & 4 & 0 & 0 & 5 & 9 & $17.6 \%$ \\
\hline 1.25 inches & 7 & 0 & 0 & 1 & 8 & $15.7 \%$ \\
\hline 1.5 inches & 6 & 4 & 1 & 0 & 11 & $21.6 \%$ \\
\hline 1.75 inches & 3 & 1 & 0 & 0 & 4 & $7.8 \%$ \\
\hline 2.0 inches & 5 & 0 & 0 & 2 & 7 & $13.7 \%$ \\
\hline Undefined** & 4 & 0 & 0 & 0 & 4 & $7.8 \%$ \\
\hline Total & 36 & 5 & 1 & 9 & 51 & $100.0 \%$ \\
\hline
\end{tabular}

* Excludes the 10 wood screw fragments. All specimens are iron unless otherwise noted.

** The undefined wood screws are from the ACSG collection and were not measured.

\section{Miscellaneous Architectural Hardware}

\section{Doorknob Plate}

The doorknob plate is a flat, $3 \times 6$-inch rectangular piece of iron with a 0.81 -inch-diameter hole through its center and four 0.25-inch-diameter screw holes, one in each corner. The plate has no decorations and is an excellent example of a plain doorknob plate. It was recovered from the midden area east of the house, suggesting that it had been discarded.

\section{Iron Strap Hinge}

A single strap hinge is 15.25 inches long. It was hand forged of iron and is very heavy. It is 1.5 inches wide and has four holes down its length where bolts attached it to a door or gate. The end where the hinge pin would be located was made by bending the end of the hinge over on itself and welding it to the main shaft. The folded metal end welded to the backside of the hinge is bifurcated, with a cut of ca. 1.25 inches. The hinge was recovered from Excavation Unit 42 , which was inside the house near the fireplace.

\section{Lightning Rod Segment}

An iron lightning rod measures 20.5 inches long and is twisted down its entire length. It is broken and at one end, with a slight bend in the center. Opposite the broken end, the rod has an attached white metal cap with a threaded male connector protruding from it. The cap is tightly fitted to the rod, and the threaded end would have been used to connect it to another rod section, ball, or pointed spire. It was found along the east side of the house, just north of the chimney in Excavation Unit 34.

This specimen represents part of an ornamental lightning rod that would have sat on a rooftop (along with several others) and been connected to a ground pole by heavy gauge wires. Mohun (2009:Figure 8.2) illustrates several lightning rods from an 1870s catalog, and many of them have a long vertical twisted rod as the main vertical element, with various types of ornamental balls, arrows, and spires attached at the top. Mass-manufacture lightning rods became a popular item peddled by traveling salesmen in the latter half of the nineteenth century (Mohun 2009), and complete lightning rod systems can still be seen on many old houses and barns in central Texas.

It is possible that this specimen was attached to the roof of the Williams house and had once served as a lightning rod there. However, because no other essential lightning rod components (e.g., other twisted rod sections, heavy-gauge ground wire, rod clips, or stand parts) were recovered, it seems unlikely that a full lightning rod system was present on the house. As an alternative explanation, it is possible that this iron rod section was scavenged from 
another location and brought to the Williams farmstead for use as a tool. A heavy iron rod would have made a good pry bar, perhaps explaining the prominent bend in this specimen.

\section{Barbed Wire}

Barbed wire was one of the more common surface artifacts observed. Some barbed-wire sections were observed in almost every setting of the site, but there were no places where intact fence sections and only a few places where strands of barbed wire over $2 \mathrm{ft}$ long were found. Small sections were recovered from the house block and the midden area, and longer sections were observed along rock wall fences of the corral complex. In addition, long strands and short pieces were embedded in many old trees (see Tree Features in Chapter 6).

Five styles of barbed wire were observed at the site, and samples of each were collected for identification. Designated as Types 1 through 5 in the field, four of these types were later identified using the barbed-wire guide by Clifton (1970). The barbed-wire types are defined in Table 8.4, and they are discussed in more detail in Chapter 6. Patents for the four identified types date from 1874 to 1883.

\section{Type 1 - Baker's Barb, Needle- Point Variation}

This form of barbed wire is made of two strands of twisted wire with a two-point, flatwire barb (Clifton 1970:90). The barbs are all on the same piece of wire and are wrapped around the wire only once.

\section{Type 2 - Glidden's Barb, Common Variation}

This type of barbed wire is a two-strand wire with a two-point wire barb (Clifton 1970:99). All barbs are located on the same wire, and the barb is wrapped around the wire twice.

\section{Type 3 - Similar to Glidden's Barb}

Type 3 barbed wire is similar to Type 2 in that it is a two-strand wire with a two-point barb of the same configuration (Clifton 1970:99). But the Type 3 barbs are significantly smaller than the Type 2 barbs. Type 3 could be a variation of the same type, but the Type 3 barbs are twisted in the opposite direction.

\section{Type 4 - Haish's "S", Wrap Variation}

Haish's "S" is also a twisted two-strand wire with a two-pointed wire barb, but the barb is not situated on a single wire (Clifton 1970:110). In this case, each barb is woven in between the twisted wires, then wrapped around both wires.

\section{Type 5 - Burnell's Barb}

Burnell's Barb is the only four-pointed barbed wire recovered from the Williams farmstead. It is a two-strand, twisted wire with a four-pointed wire barb composed of two wire barbs that are woven through and around each other and the two strands of wire (Clifton 1970:150).

\section{Staples}

A total of 121 staples and 6 staple fragments (see Table B.26) were recovered (fence staples found on standing fence posts were observed but not collected). As summarized in Table 8.5, all but five of the specimens are common fence staples. Three are wire cloth staples that are smaller and lighter weight than the fence staples; they were typically used to attach cloth or wire mesh to wood. One is a large staple that likely belonged to some type of hasp or hook fastener. It could have held the hasp in place or could have served as the loop for the hook fastener.

The 1865 Russell and Irwin Illustrated Catalog of American Hardware was the primary reference used to identify the common staple sizes available for purchase. The 1895 Montgomery Ward \& Company catalog and the 1897 Sears Roebuck \& Company catalog were also used. Staples were available in a variety of sizes-in 1/4-inch increments up to 3 inches long, and in $1 / 2$-inch increments up to 5 inches long. The majority of staples from the Williams farmstead were 1.25 inches long, a common size used for fencing.

\section{Smooth Wire}

Smooth (non-barbed) wire segments were found scattered throughout the farmstead in vari- 
Table 8.4. Barbed wire types

\begin{tabular}{l|l|c|c|l}
\hline $\begin{array}{c}\text { Type } \\
\text { No. }\end{array}$ & \multicolumn{1}{|c|}{ Type Name } & Patent & Patent & \\
\hline 1 & Baker's Barb, needle-point variation & Year & \multicolumn{1}{|c}{ Reference } \\
\hline 2 & Glidden's Barb, common variation & 273219 & 1883 & Clifton (1970:90, 372) \\
\hline 3 & $\begin{array}{l}\text { Unidentified but similar to Glidden's Barb and its } \\
\text { variations }\end{array}$ & - & - & Clifton (1970:99, 101) \\
\hline 4 & Haish's “S," wrap variation & 167124 & 1874 & Clifton (1970:99, 365) \\
\hline 5 & Burnell's Barb & 192225 & 1877 & Clifton (1970:150, 368) \\
\hline
\end{tabular}

Table 8.5. Staples*

\begin{tabular}{|c|c|c|c|c|c|c|c|}
\hline Staple Type & $\begin{array}{c}\text { Size } \\
\text { (Length) }\end{array}$ & $\begin{array}{l}\text { House } \\
\text { Block }\end{array}$ & $\begin{array}{c}\text { House Block, } \\
\text { Subfloor Pit }\end{array}$ & $\begin{array}{l}\text { Yard } \\
\text { Area }\end{array}$ & Midden & Total & $\begin{array}{c}\text { Percent of } \\
\text { Total }\end{array}$ \\
\hline \multirow[t]{4}{*}{ Fence staples } & 1.0 inch & 6 & 1 & 1 & 0 & 8 & $6.6 \%$ \\
\hline & 1.25 inches & 40 & 8 & 0 & 32 & 80 & $66.1 \%$ \\
\hline & 1.5 inches & 18 & 1 & 0 & 7 & 26 & $21.5 \%$ \\
\hline & 1.75 inches & 1 & 1 & 0 & 0 & 2 & $1.7 \%$ \\
\hline Wire cloth staples & $0.75 \mathrm{inch}$ & 2 & 1 & 0 & 0 & 3 & $2.5 \%$ \\
\hline Large staple & 2.75 inches & 1 & 0 & 0 & 0 & 1 & $0.8 \%$ \\
\hline Unidentified ${ }^{* *}$ & unknown & 1 & 0 & 0 & 0 & 1 & $0.8 \%$ \\
\hline \multicolumn{2}{|l|}{ Total } & 69 & 12 & 1 & 39 & 121 & $100.0 \%$ \\
\hline
\end{tabular}

* Excludes the six staple fragments.

** The unidentifed staple is from the ACSG collection and was not measured.

ous contexts - in the house, yard area, midden, and corral complex. Smooth wire also was observed in isolated surface contexts, usually associated with tree features (wire embedded in trees) and fence posts (see Chapter 6). For analysis purposes, the wire fragments were examined to see if they were plain or complex wire fragments, the latter having been twisted into various configurations. Only 28 of the 367 recovered wire segments (7.6 percent) were classified as complex (see Table B.25). The simplest form was a single strand of wire with a single loop in one end. Others were two segments, with both twisted and looped and intertwined on the end to connect the segments. These may represent some type of repair or mending of longer strands of wire. Some segments were two strands of wire simply twisted together. Other complex specimens were formed by looping the ends of two or more segments together, essentially connecting the wire segments by joining their loops.

For analysis purposes, all of the smooth wire is classified as architectural fencing material, even though it is acknowledged that multiple uses were likely. The functions of the twisted and looped complex wire specimens are not known, but most appear to have been modified for some specific use. Some may have served as homemade fasteners or used as hangers looped around nails or pegs. The more complex specimens have two segments that swivel at their loop connections, and they could have been used in many different ways. It would be impossible to identify the myriad of uses for smooth wire on a late-nineteenth-century farm. In many ways, smooth wire on a historic farm is analogous to baling wire (i.e., smooth wire removed from hay bales) and duct tape, which are both used to mend and modify almost anything on modern farms.

\section{Wood Samples}

Seven wood samples collected near the stone chimney base and fireplace hearth may represent architectural wood. Most of them are 
of the Quercus genus, or white oak (see Chapter $10)$. There are numerous species in this genus, and the exact species of white oak could not be accurately identified due to poor preservation. Based on where these specimens were found, they could represent pieces of the original house architecture that were partially preserved because the chimney fall rocks protected them. Several were large pieces, suggesting that they could have been logs from the house walls or floor. Others were smaller and could represent interior structural elements such as floorboards or joists, or perhaps remnants of wood furniture.

Two of the smaller wood samples are identified as pine family and juniper family. Since no pine grows in the area, the pine specimen is probably milled lumber that was brought to the site, perhaps a piece of pine furniture. The juniper specimen is partially carbonized and may be a piece of firewood. Juniper trees are common in the area and would have been an excellent source of firewood.

It is not surprising that so little wood was found even though the Williams house was made of wood. Once a house roof falls down, old wooden walls and floors will deteriorate rapidly. Once the wood is on the ground, the insects take over to accelerate the destruction. It is not uncommon for little or no wood to be preserved when houses are abandoned and left untended for decades. In the Williams house, the only place where any structural wood was preserved was under the jumble of chimney fall rocks. This massive rock pile afforded a unique preservation environment, but even there the wood was not in good shape when it was uncovered.

\section{Mortar Samples}

Thirty-one fragments of mortar were found in the house block. Of those, 29 were from excavations units, and all but 5 specimens were found within $3 \mathrm{~m}$ of the chimney base, among and under the mound of collapsed chimney rocks. All of the recovered mortar fragments match a sample of mortar taken from the intact chimney base. This is a very soft, grainy mortar that is light colored (Munsell 10YR 7/2, light gray) and has abundant rounded sand particles. It also has common siliceous grains that are well rounded and up to $5 \mathrm{~mm}$ in size. Small chunks of a white friable material (up to $3 \mathrm{~mm}$ in size) are probably burned limestone or lime. This material is probably a homemade mortar that was mixed onsite using sand from Bear Creek mixed with crushed chalk or soft limestone.

\section{KITCHEN AND HOUSEHOLD ARTIFACTS}

Artifacts in the Kitchen and Household functional category include kitchenware items used in the preparation, serving, and consumption of food as well as household furnishings. Kitchen and Household is the largest functional group, but that is because the numbers in this category are inflated due to the ubiquitous glass fragments recovered. Glass was assigned to this group on the assumption that the majority of the glass fragments are from food containers (i.e., commercial food bottles).

The first step in the analysis of the glass was to identify the minimum number of glass containers, with specimens with a complete or nearly complete bottle mouth and neck constituting one bottle. Then 109 glass containers were identified (see Appendix B) and described. Many of the glass containers are identified as nonfood containers such as medicine bottles, liquor or beer bottles, ink bottles, and tobacco (snuff) bottles. In all of these cases, the functional classification of these glass containers (i.e., the fragments attributed to a specific container) was changed from Kitchen and Household to the appropriate functional category (most were reclassified as Personal artifacts). For descriptive purposes, however, all of the glass containers are discussed in the section below.

The Kitchen and Household functional group contains 11,965 specimens as follows:

\section{CONTAINER GLASS}

Glass fragments from 23 food bottles $\quad 96$

Glass fragments from undefined bottles 9,528

\section{PRESSED GLASS}

Pressed glass from 10 tableware objects 55

Pressed glass from 6 unidentified objects

OTHER GLASS

Noncontainer glass fragments 49

Unidentified glass fragments

CERAMICS

Ceramic sherds from 52 vessels $\quad 778$

Ceramic sherds from unassigned vessels $\quad 660$ 
OTHER KITCHEN AND

HOUSEHOLD ARTIFACTS

Cast-iron vessel fragments

Corn sheller

Cutlery 64

Metal cans fragments from 72 cans

Container bottle caps

Miscellaneous unique items

HOUSEHOLD FURNISHINGS

Cast-iron stove parts

Furniture artifacts

Candle lantern and oil lamp parts

Locks and keys

Other furnishing items

\section{MISCELLANEOUS HARDWARE}

\section{Container Glass}

Thousands of glass shards were recovered from the Williams farmstead, most of them undoubtedly from broken glass containers. Other than the fact that broken containers were present in a limited variety of colors (clear, light green, and amber being most common), the glass fragments have relatively little interpretive value compared to whole or partial glass containers. The glass analysis therefore focused on determining the minimum number of glass containers and examining their contents. This goal was achieved by locating bottle mouth and neck fragments and unique closures that would represent the minimum number of bottles, then assigning each specimen a glass container number (i.e. GC-1, GC-2, etc.). It is likely that many more glass containers actually exist in the assemblage, but these containers are too fragmented to be sure. Further attempts to identify containers from the thousands of glass shards proved to be fruitless. ${ }^{99}$ When this analysis was completed, the 109 glass containers were identified as follows:

Complete closures

Complete bottles

\footnotetext{
${ }^{99} \mathrm{An}$ attempt was made to examine glass bottle bases, but these could not be linked to the mouth and neck fragments. Consequently, only the latter were used to define the glass containers because the neck and mouth fragments are more diagnostic of the bottle manufacturing process and dating.
}

Reconstructed bottle 1

Partially reconstructed bottles $\quad 11$

Fragment groups $\quad 84$

(7)

17


Table 8.6. Glass containers by bottle manufacture type, inferred contents, and functional group $(\mathbf{n}=\mathbf{1 0 9})$

\begin{tabular}{|c|c|c|c|c|c|c|c|}
\hline $\begin{array}{c}\text { Container } \\
\text { Contents }\end{array}$ & $\begin{array}{l}\text { Blown, } \\
\text { Applied } \\
\text { Lip }\end{array}$ & $\begin{array}{c}\text { Blown, } \\
\text { Tooled Lip }\end{array}$ & $\begin{array}{l}\text { Automatic } \\
\text { Bottle } \\
\text { Machine }\end{array}$ & $\begin{array}{c}\text { Unknown } \\
\text { Manufacture }\end{array}$ & $\begin{array}{l}\text { Bottle } \\
\text { Closure } \\
\text { Only }\end{array}$ & $\begin{array}{l}\text { Total No. } \\
\text { of Bottles } \\
\text { and } \\
\text { Closures }\end{array}$ & $\begin{array}{c}\text { Total No. } \\
\text { of Glass } \\
\text { Fragments }\end{array}$ \\
\hline \multicolumn{8}{|c|}{ Kitchen \& Household } \\
\hline Food bottles & - & 6 & - & 1 & - & 7 & 77 \\
\hline $\begin{array}{l}\text { Food bottles } \\
\text { (or medicine) }\end{array}$ & - & 1 & - & - & - & 1 & 1 \\
\hline $\begin{array}{l}\text { Soda water } \\
\text { bottle }\end{array}$ & - & 1 & - & - & - & 1 & 1 \\
\hline $\begin{array}{l}\text { Bottle closure: } \\
\text { glass stoppers }\end{array}$ & - & - & - & - & 2 & 2 & 2 \\
\hline $\begin{array}{l}\text { Bottle closure: } \\
\text { glass lids }\end{array}$ & - & - & - & - & 3 & 3 & 3 \\
\hline \multicolumn{8}{|l|}{ Activities Group } \\
\hline Ink bottles & - & 2 & - & - & - & 2 & 5 \\
\hline \multicolumn{8}{|l|}{ Personal Group } \\
\hline $\begin{array}{l}\text { Grooming: } \\
\text { cosmetic bottles }\end{array}$ & - & 1 & - & - & - & 1 & 11 \\
\hline $\begin{array}{l}\text { Grooming: } \\
\text { toiletry bottles }\end{array}$ & - & 1 & - & - & - & 1 & 20 \\
\hline $\begin{array}{l}\text { Alcohol: liquor } \\
\text { bottles }\end{array}$ & 1 & 8 & - & 1 & - & 10 & 81 \\
\hline $\begin{array}{l}\text { Alcohol: beer } \\
\text { bottles } \\
\text { (amber glass) }\end{array}$ & 1 & 2 & - & - & - & 3 & 3 \\
\hline $\begin{array}{l}\text { Alcohol: wine } \\
\text { bottles } \\
\text { (clear glass) }\end{array}$ & - & - & 3 & - & - & 3 & 4 \\
\hline $\begin{array}{l}\text { Medicine } \\
\text { bottles* }\end{array}$ & 1 & 32 & - & 2 & - & 35 & 83 \\
\hline $\begin{array}{l}\text { Medicine bottles } \\
\text { (or food) }\end{array}$ & 1 & 7 & - & - & - & 8 & 11 \\
\hline $\begin{array}{l}\text { Medicine bottles } \\
\text { (or liquor) }\end{array}$ & - & 8 & - & - & - & 8 & 8 \\
\hline $\begin{array}{l}\text { Medicine bottle } \\
\text { (or toiletry) }\end{array}$ & - & 1 & - & - & - & 1 & 1 \\
\hline $\begin{array}{l}\text { Tobacco: snuff } \\
\text { bottles } \\
\text { (brown glass) }\end{array}$ & - & 23 & - & - & - & 23 & 69 \\
\hline $\begin{array}{l}\text { Total No. } \\
\text { of Glass } \\
\text { Containers }\end{array}$ & 4 & 93 & 3 & 4 & 5 & 109 & 380 \\
\hline
\end{tabular}

\footnotetext{
* One medicine bottle neck has a glass stopper still embedded.
} 


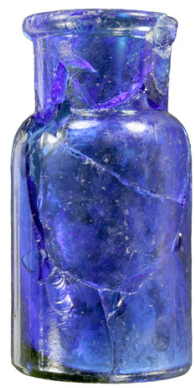

GC-3

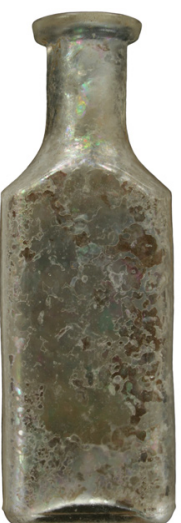

GC-4

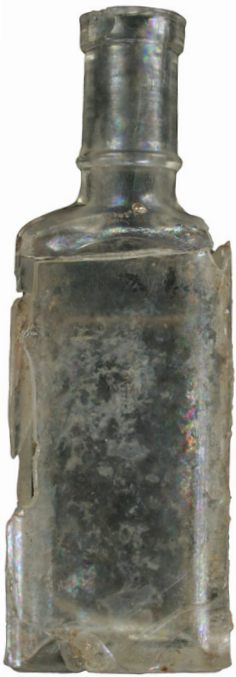

GC-6
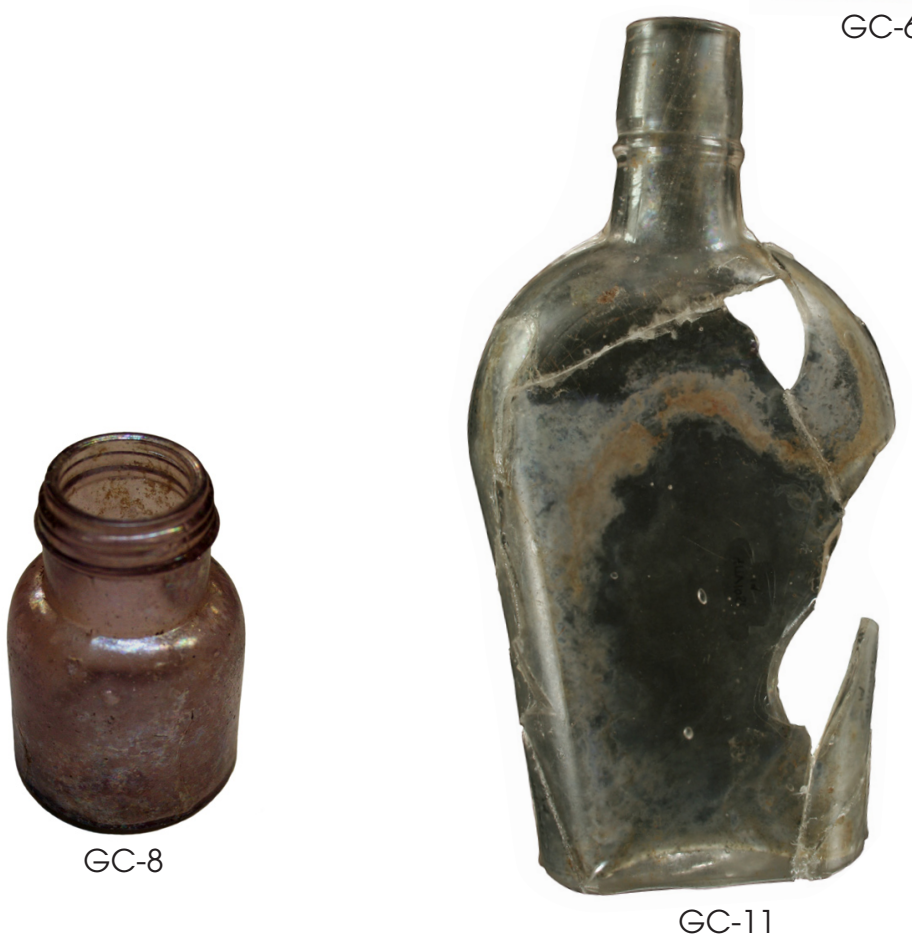

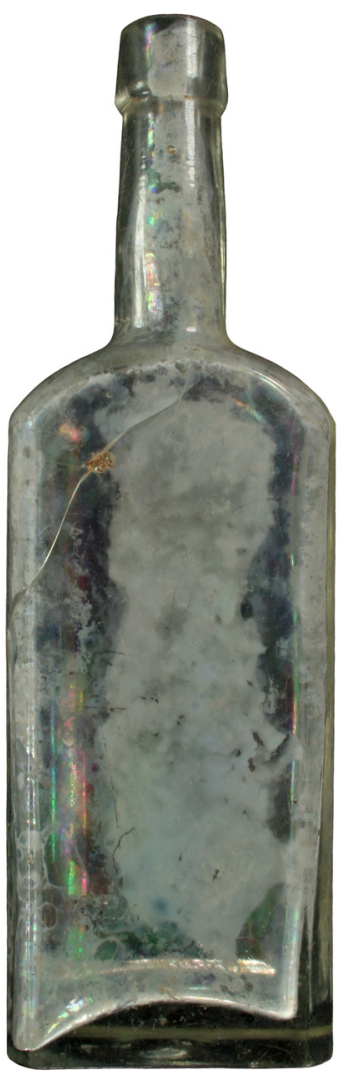

GC-7

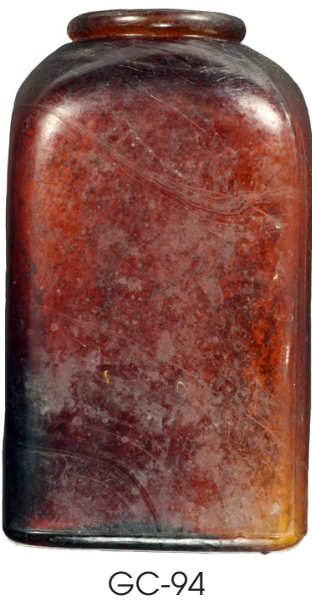

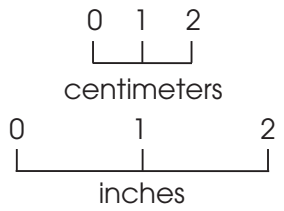

Figure 8.2. Complete glass bottles. GC-3 is a wide mouth medicine bottle; GC-4, GC-6, and GC-7 are panel bottles for patent medicine; GC-8 is an ink bottle with a threaded mouth for a screw cap; GC-11 is a brandy finish liquor bottle; GC-94 is a snuff bottle. 


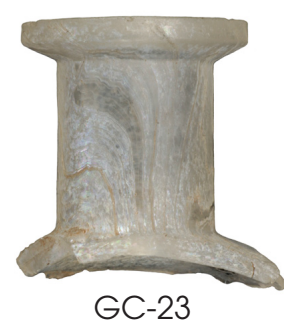

GC-23

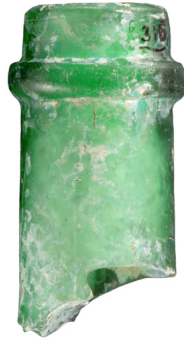

GC-29
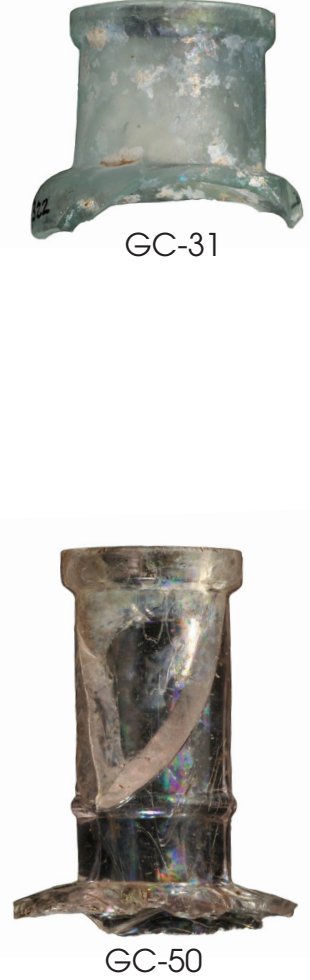

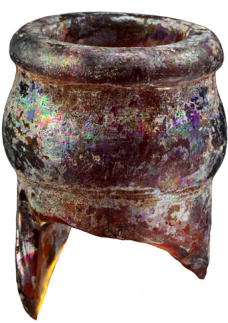

GC-32

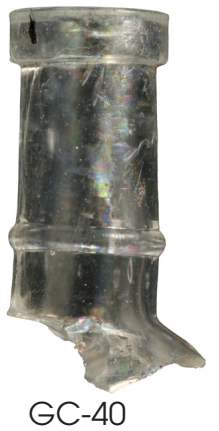

GC-40
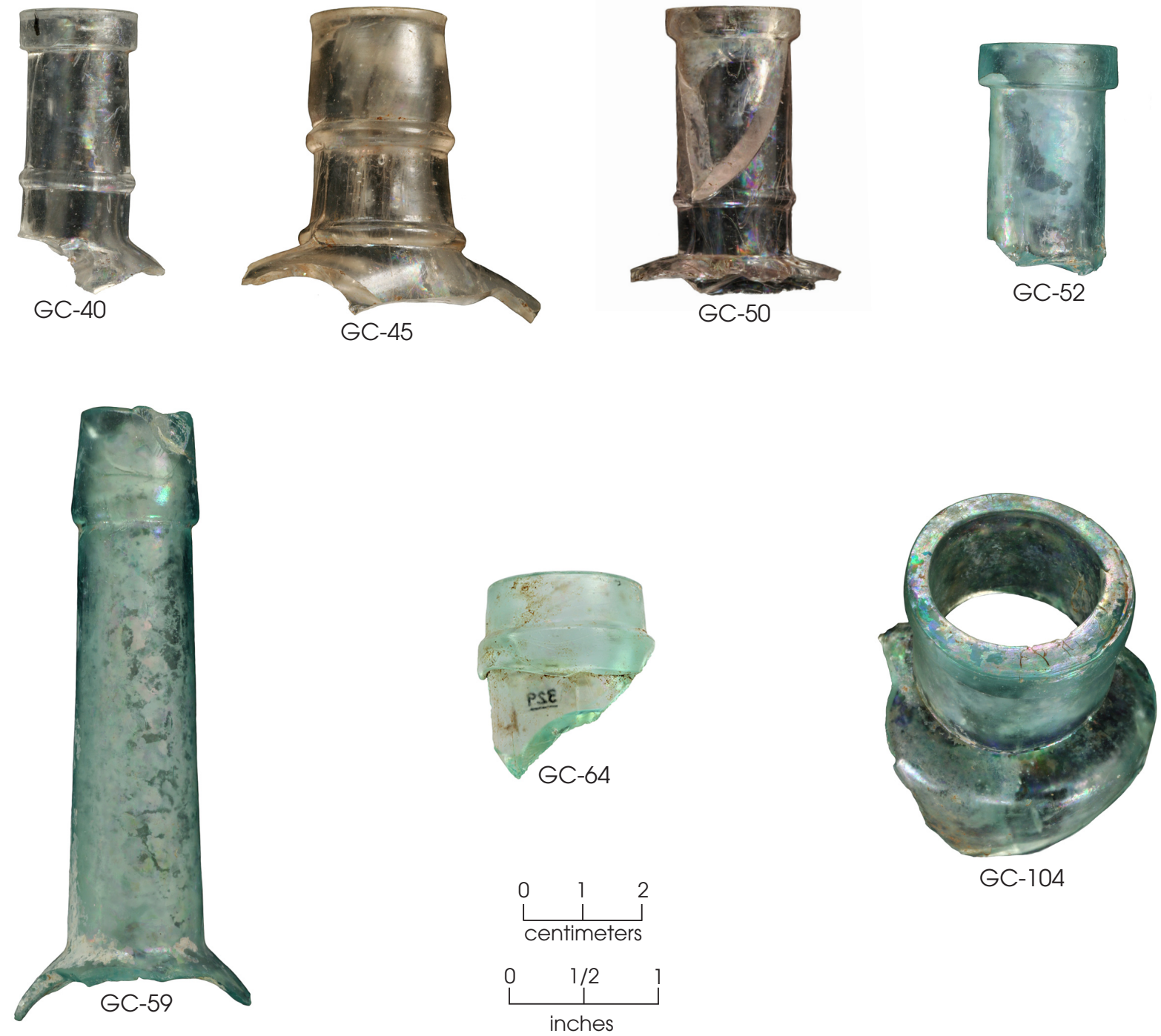

GC-104

Figure 8.3. Glass bottle necks showing a variety of neck and mouth finishes. GC-64 and GC-104 have applied lips, and all the others have tooled lips. 

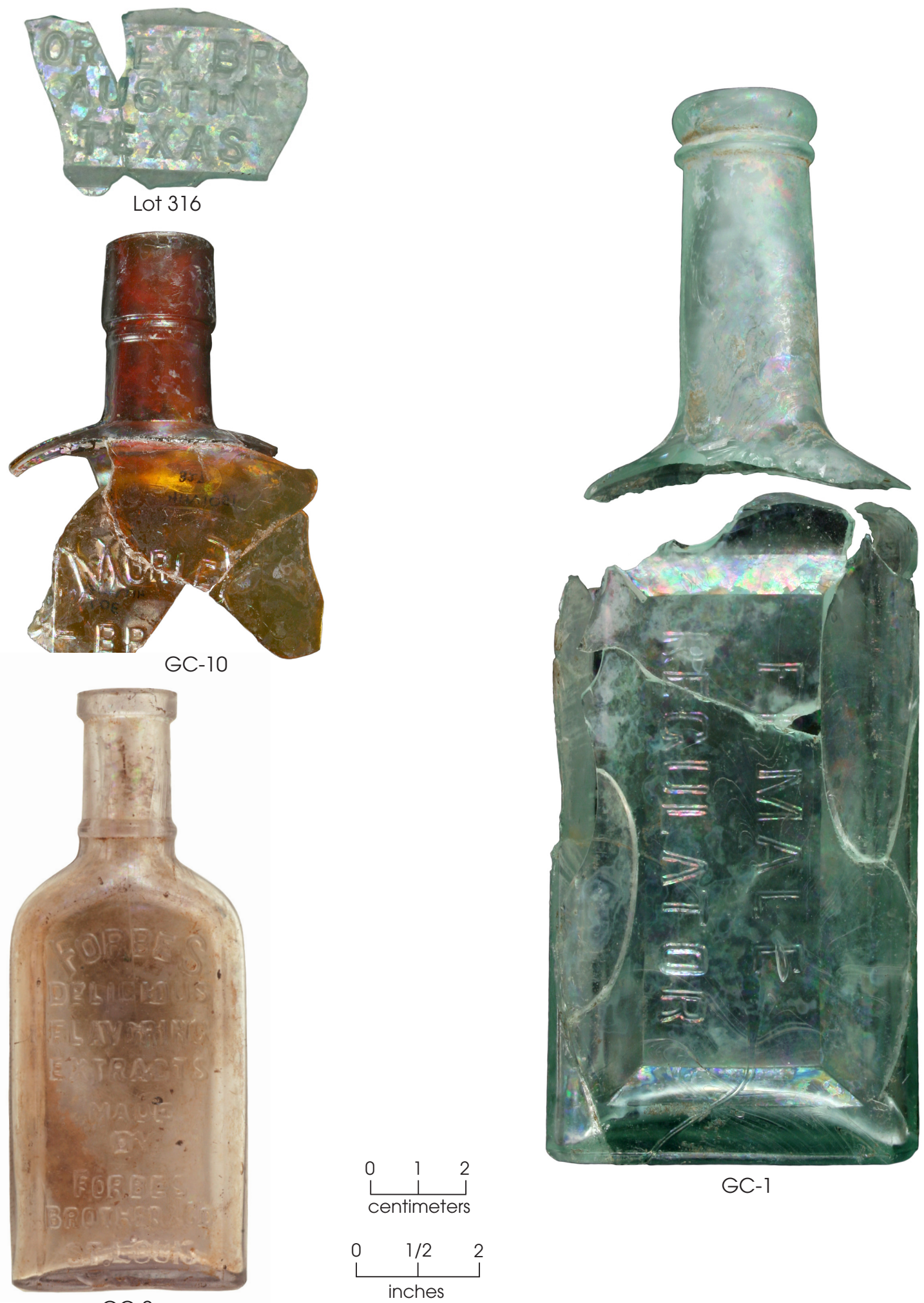

Figure 8.4. Glass bottles with identifying marks. Lot 316 is two refit fragments of a bottle panel that is marked "[M]OR[L]EY BRO[S] / AUSTIN / TEXAS." GC-10 is a panel bottle with a portion of the Morley Brothers' mark. GC-2 is panel bottle with one panel marked: "FORBES DELICIOUS FLAVORING EXTRACTS MADE BY FORBES BROTHER \& CO ST. LOUIS." GC-1 is a panel bottle with four panels marked "FEMALE REGULATOR / WOMANS BEST FRIEND / BRADFIELD’S / ATLANTA, GA." 

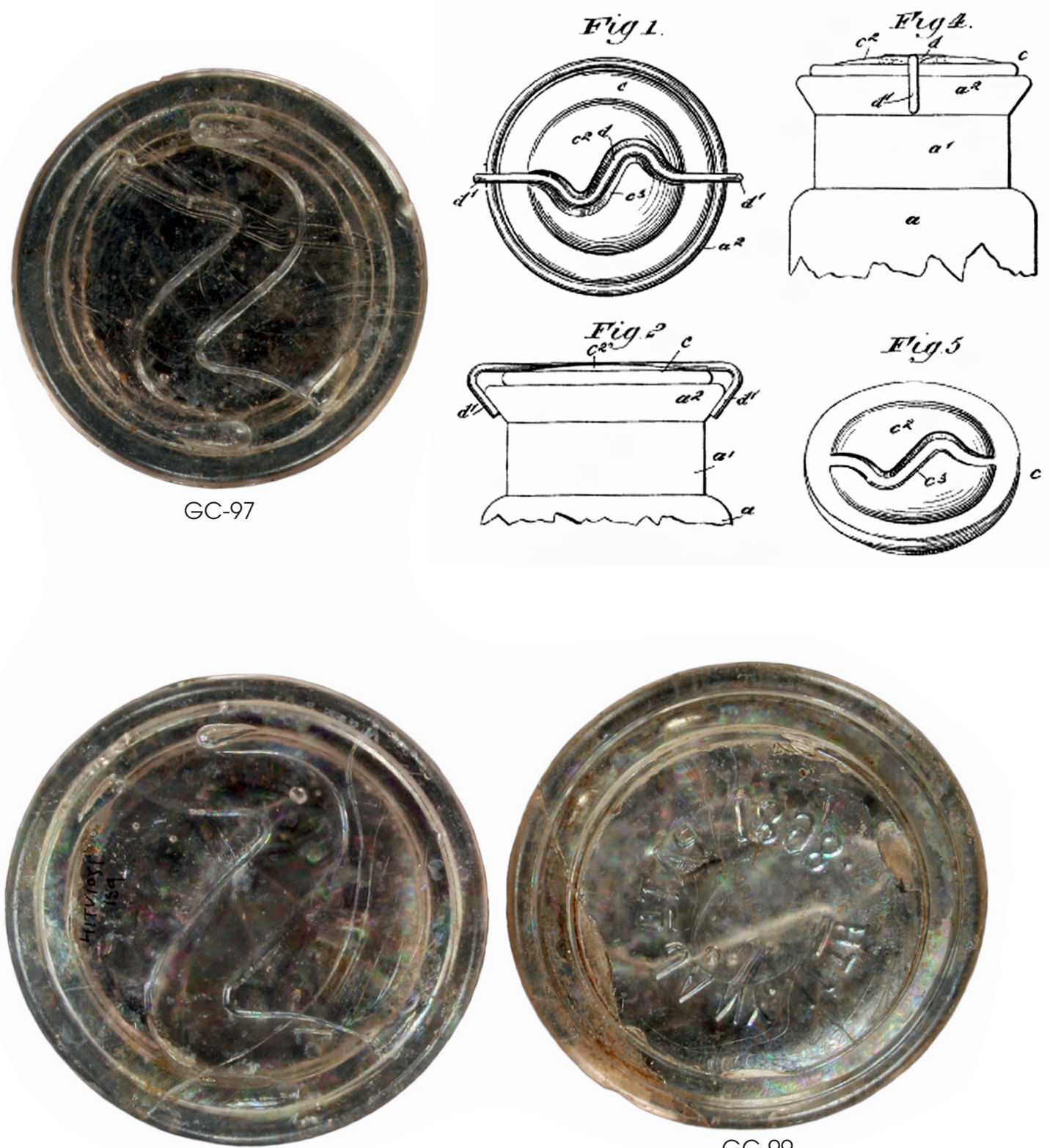

GC-98

GC-99

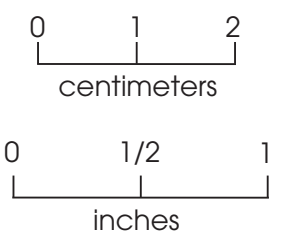

Figure 8.5. Glass bottle closures identified as the Schies jar closures. The specimens from the Williams farmstead are GC-97, GC-98, and GC-99. Two specimens show the distinctive S-shaped indention on the top of the lid, while the third shows the patent date of January 11, 1898 embossed on the bottom side of the lid. The drawings are from J. Schies' 1989 Patent No. 579,299. 
Chapter 8: Descriptions of Material Culture

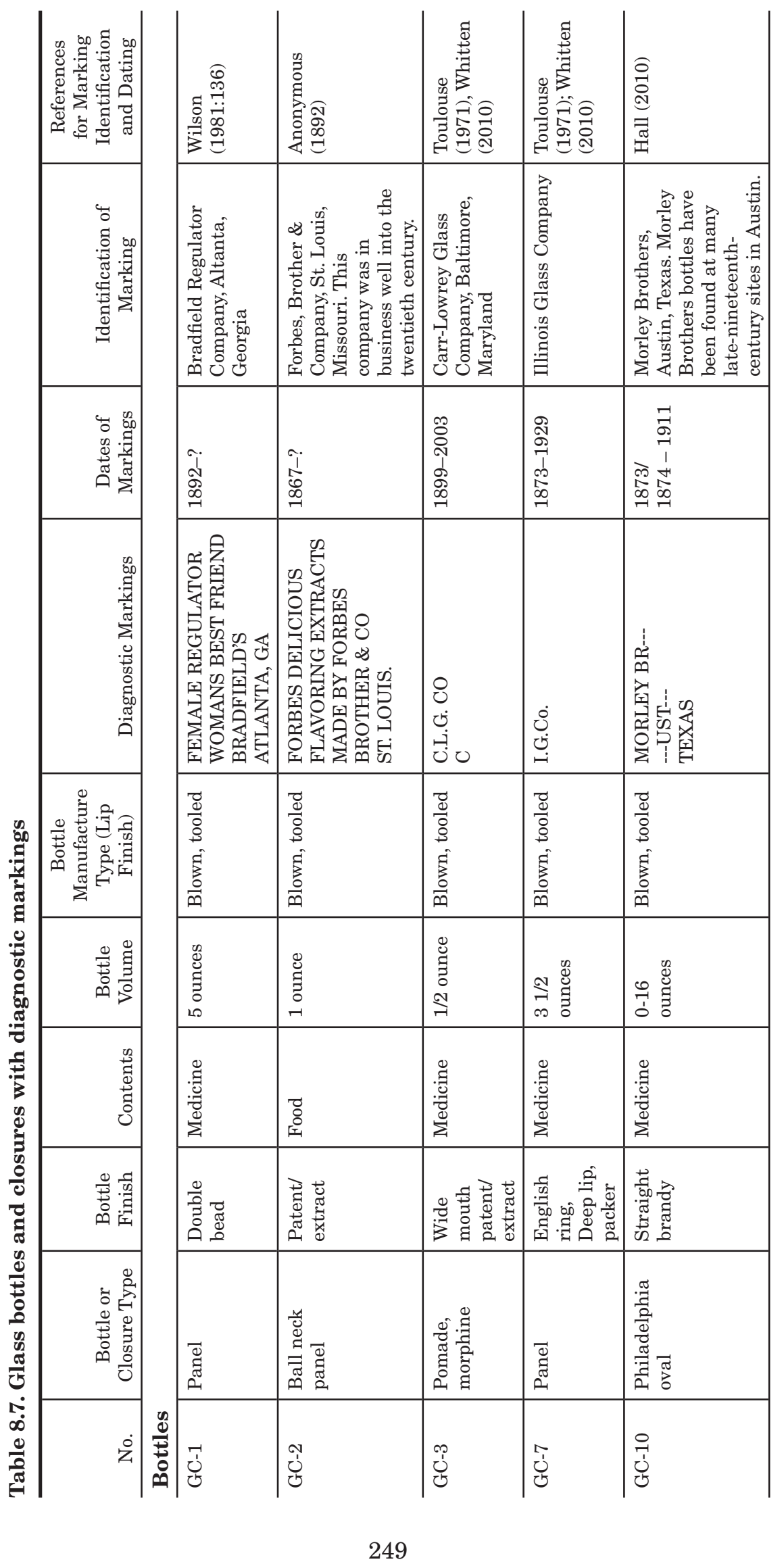


The Ransom and Sarah Williams Farmstead

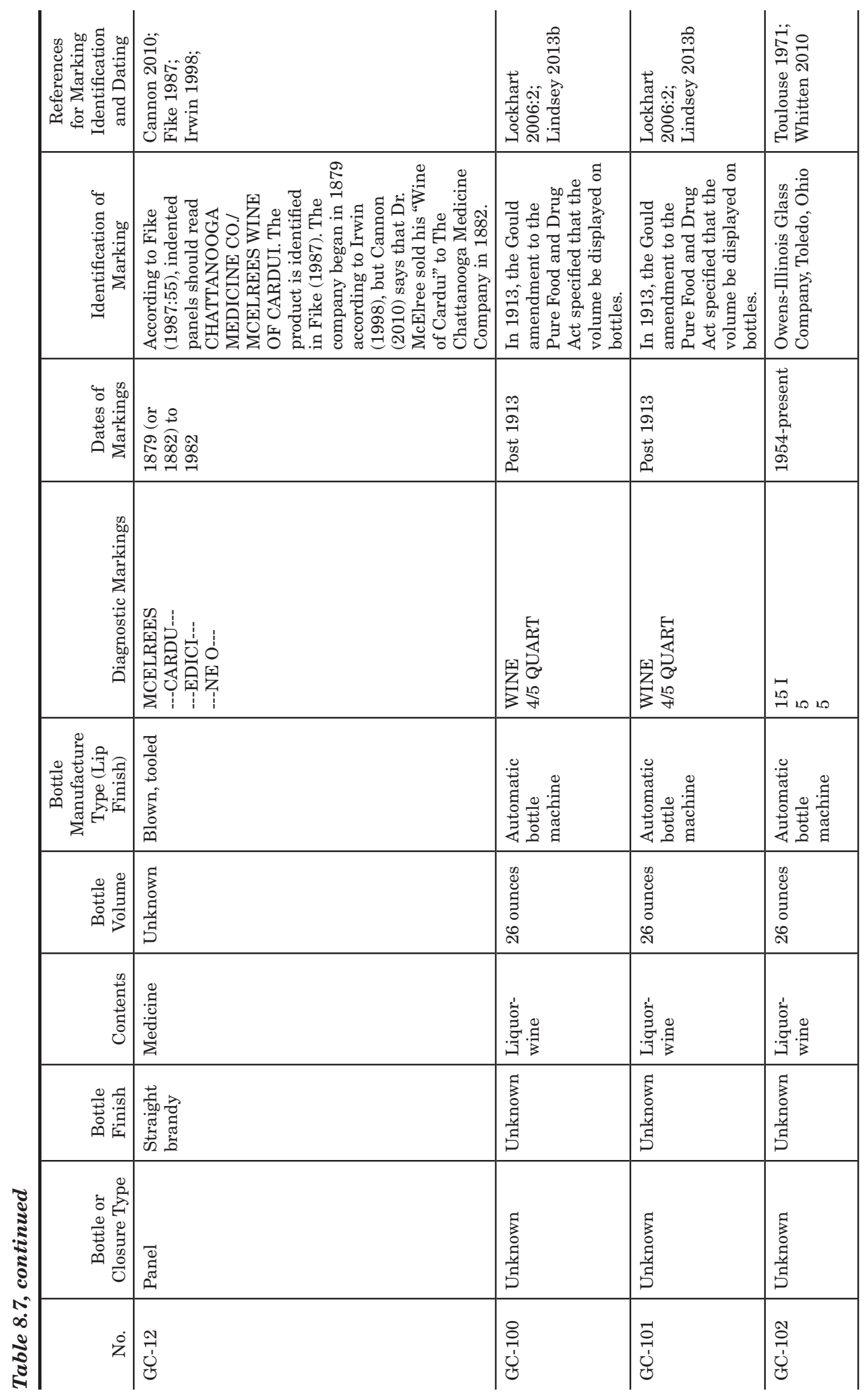


Chapter 8: Descriptions of Material Culture

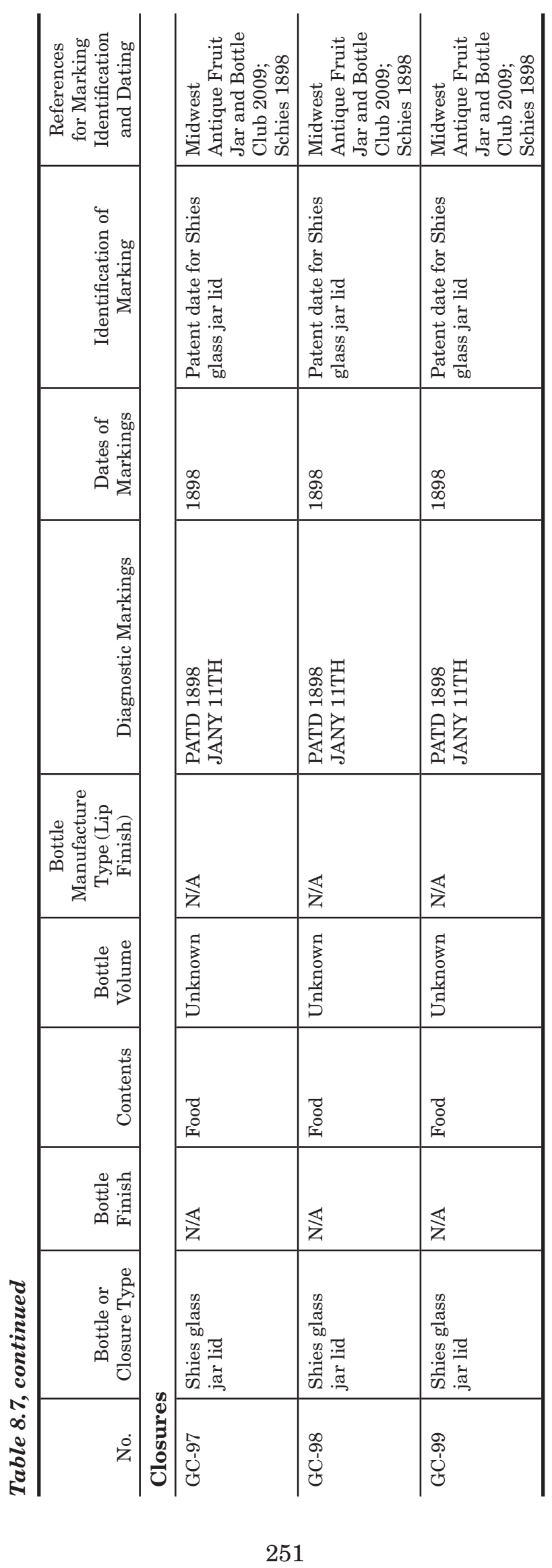


Many fragments in the glass assemblage also have diagnostic markings (see Table B.6). Of these, only one has a maker's mark that postdates the Williams family occupation. A brown glass bottle base, probably from a beer bottle, has an "I" inside and diamond and circle. This is the mark used by the OwensIllinois Glass Company from 1929 through 1954.

Once the analysis of glass containers was completed, 9 bottles (made up of 79 fragments) and 5 closures were identified as being food-related items and left in the Kitchen and Household group (Table 8.8). Relative to the other types of bottles, the specimens in the Kitchen and Household group are relatively incomplete, but they include a soda water bottle with a crown-cap mouth, several screw-lid jars, and a panel extract neck (probably a condiment bottle). The two types of bottle closures are a club sauce stopper (a glass plug with a wide knob handle that fit inside a narrow bottle mouth) typically used for condiments and the 1898 patented Schies jar lid that sealed onto a bottle top with a wire clamping mechanism (see Figure 8.5).

Compared with the 14 food bottles, the 54 medicine bottles in the assemblage seems to be an unusually large number. At face value, it would seem that the majority of small glass fragments that could not be assigned to specific glass containers might have come from medicine bottles. But this is probably not the case, and it is more likely that most of the ubiquitous glass fragments came from food containers that were wide mouth, round-bodied jars (assigned to the Kitchen and Household group). The high frequency of medicine bottles and low frequency of food bottles simply reflects these facts: (1) large wide mouth, round-bodied food jars were more fragile and got broken into many more pieces, making it harder to identify specific containers and refit pieces; (2) the most common types of medicine bottles are flat panel bottles, and their fragments were much easier to sort and refit into specific containers; and (3) the necks and shoulders of narrow mouth panel bottles survived well and were easily identified as separate medicine containers. As an example, many clear glass fragments of wide mouth jar rims with screw tops most likely represent many different food jars, but the pieces are simply too small to do anything with.

\section{Pressed Glass}

As was done for the glass containers, all the pressed glass fragments were sorted and grouped by similar attributes to identify the minimum number. The 21 objects identified in this manner are summarized in Table 8.9 (see Table B.5). The assemblage includes 10 glass tableware items and 6 unidentified items (possibly tablewares). None are complete and only a few are partially reconstructed. All of the pressed glass tablewares are decorated with simple geometric designs, and they are identified according to form and type as defined by Jones and Sullivan (1989:132-145).

Three of the pressed glass items are bases of oil lamps that are described later with the other lamp artifacts. Two of the pressed glass items, a perfume bottle and a syringe plunger, were moved out of the Kitchen and Household group and reclassified into the Personal functional group.

\section{Ceramics}

The Williams farmstead assemblage includes 1,438 ceramic sherds (excluding children's toys) identified as porcelain, whiteware, and stoneware. Once all the ceramic vessel fragments and sherds were cataloged, a rigorous examination was made to define the minimum number of vessels, to refit as many sherds as possible, and to group obvious vessel sherds together even when they did not refit. As each unique vessel was identified, it was assigned a ceramic vessel number (i.e., CV-1, CV-9, etc.), and the attributes of these vessels were documented and entered into the inventory (see Table B.3). Through this process, 52 unique ceramic vessels were identified. All ceramic sherds that could not be positively identified as belonging to a particular vessel were excluded from the vessel inventory.

The ceramic vessels vary from single sherds that are unique (e.g., CV-35 is a single sherd of embossed porcelain or semi-porcelain), to partially reconstructed vessels (e.g., CV-4 is a Rockingham glaze pitcher composed of 123 sherds estimated to be about 20 percent complete), to substantially reconstructed vessels (e.g., CV-1 is a large stoneware jar composed of 79 sherds that is 95 percent complete). The completeness of the 52 ceramic vessels is summarized as follows: 
Table 8.8. Food bottles and closures $(n=14)$

\begin{tabular}{|c|c|c|c|c|c|c|}
\hline $\begin{array}{c}\text { Glass } \\
\text { Container } \\
\text { No. } \\
\end{array}$ & $\begin{array}{c}\text { No. of } \\
\text { Glass } \\
\text { Fragments }\end{array}$ & $\begin{array}{l}\text { Container } \\
\text { Type and } \\
\text { Glass Color }\end{array}$ & $\begin{array}{c}\text { Bottle Contents } \\
\text { and Type }\end{array}$ & Bottle Size & $\begin{array}{c}\text { Bottle } \\
\text { Manufacture Type } \\
\text { (Neck Finish) }\end{array}$ & $\begin{array}{l}\text { Closure } \\
\text { Type }\end{array}$ \\
\hline GC-2 & 1 & Bottle, clear & $\begin{array}{l}\text { Food, panel } \\
\text { extract neck }\end{array}$ & Small & Blown, tooled & - \\
\hline GC-15 & 59 & $\begin{array}{l}\text { Bottle, } \\
\text { amber }\end{array}$ & $\begin{array}{l}\text { Food, screw-lid } \\
\text { jar }\end{array}$ & Indeterminate & Blown, tooled & - \\
\hline GC-17 & 4 & Bottle, clear & Food, unknown & Small (est.) & - & - \\
\hline GC-24 & 1 & Bottle, aqua & $\begin{array}{l}\text { Food (soda } \\
\text { water), crown } \\
\text { cap }\end{array}$ & Small (est.) & Blown, tooled & - \\
\hline GC-61 & 2 & Bottle, clear & Food, screw-lid & Small & Blown, tooled & - \\
\hline GC-62 & 1 & Bottle, clear & Food, screw-lid & Small & Blown, tooled & - \\
\hline GC-63 & 1 & Bottle, clear & Food, screw-lid & Small & Blown, tooled & - \\
\hline GC-71 & 1 & Bottle, clear & $\begin{array}{l}\text { Food (or } \\
\text { medicine), } \\
\text { screw-lid jar }\end{array}$ & Indeterminate & Blown, tooled & - \\
\hline GC-95 & 1 & $\begin{array}{l}\text { Closure, } \\
\text { clear }\end{array}$ & $\begin{array}{l}\text { Food (or } \\
\text { medicine) }\end{array}$ & Indeterminate & - & $\begin{array}{l}\text { Club sauce } \\
\text { stopper }\end{array}$ \\
\hline GC-96 & 1 & $\begin{array}{l}\text { Closure, } \\
\text { clear }\end{array}$ & $\begin{array}{l}\text { Food (or } \\
\text { medicine) }\end{array}$ & Indeterminate & - & $\begin{array}{l}\text { Club sauce } \\
\text { stopper }\end{array}$ \\
\hline GC-97 & 1 & $\begin{array}{l}\text { Closure, } \\
\text { clear }\end{array}$ & Food & Indeterminate & - & $\begin{array}{l}\text { Schies glass } \\
\text { jar lid; } \\
\text { patented } \\
1898\end{array}$ \\
\hline GC-98 & 1 & $\begin{array}{l}\text { Closure, } \\
\text { clear }\end{array}$ & Food & Indeterminate & - & $\begin{array}{l}\text { Schies glass } \\
\text { jar lid; } \\
\text { patented } \\
1899 \\
\end{array}$ \\
\hline GC-99 & 1 & $\begin{array}{l}\text { Closure, } \\
\text { clear }\end{array}$ & Food & Indeterminate & - & $\begin{array}{l}\text { Schies glass } \\
\text { jar lid; } \\
\text { patented } \\
1900\end{array}$ \\
\hline GC-103 & 9 & Bottle, clear & $\begin{array}{l}\text { Food, } \\
\text { horizontal } \\
\text { ribbed body }\end{array}$ & Small (est.) & Blown, Tooled & - \\
\hline Total & 84 & & & & & \\
\hline
\end{tabular}

- 1 nearly whole vessel lid (CV-26, a serving dish lid that is complete except for a broken handle on top)

- 5 substantially reconstructed vessels (CV-1, CV-2, CV-3, CV-9, and CV-38)

- 21 partially reconstructed vessels

- 20 sherd group vessels

- 5 single sherd vessels
Table 8.10 is a summary of the ceramic vessels by ceramic type and vessel form, and Table 8.11 presents basic data for all 52 of the ceramic vessels. The variability in the ceramic vessels is illustrated in Figures 8.6 to 8.9. The Williams farmstead assemblage has only one annular ware vessel and one coarse earthenware vessel, both of unknown form. Four vessels are porcelain or semi-porcelain, and these are all unknown forms as well. Stonewares vessels are the most common $(n=22)$; they account for 42 percent of 
Table 8.9. Pressed glass objects

\begin{tabular}{|c|c|c|c|c|}
\hline $\begin{array}{c}\text { Functional Group: } \\
\text { Subgroup }\end{array}$ & Object Identification & $\begin{array}{l}\text { Pressed Glass } \\
\text { Item No. }\end{array}$ & $\begin{array}{c}\text { No. } \\
\text { Objects }\end{array}$ & $\begin{array}{c}\text { No. of Glass } \\
\text { Fragments }\end{array}$ \\
\hline $\begin{array}{l}\text { Kitchen \& Household: } \\
\text { Lamp Parts }\end{array}$ & Lamp base and stem & $\begin{array}{l}\text { PG-1, PG-2, } \\
\text { PG-3 }\end{array}$ & 3 & 60 \\
\hline \multirow{8}{*}{$\begin{array}{l}\text { Kitchen \& Household: } \\
\text { Tableware }\end{array}$} & Drinking glass (base fragment) & PG-20 & 1 & 1 \\
\hline & Goblet bowl & PG-4 & 1 & 12 \\
\hline & Goblet stem & PG-7 & 1 & 1 \\
\hline & Mug handle & PG-6 & 1 & 1 \\
\hline & Tumbler (fragments) & PG-9 & 1 & 8 \\
\hline & Unknown tableware (finial only) & PG-8 & 1 & 1 \\
\hline & Unknown tableware (possibly covered dish) & PG-5 & 1 & 13 \\
\hline & Unknown tableware (fragments) & $\begin{array}{l}\text { PG-10, PG-11, } \\
\text { PG-12 }\end{array}$ & 3 & 18 \\
\hline $\begin{array}{l}\text { Kitchen \& Household: } \\
\text { Unidentifiable }\end{array}$ & Unknown forms (fragments) & $\begin{array}{l}\text { PG-13 through } \\
\text { PG-18 }\end{array}$ & 6 & 13 \\
\hline $\begin{array}{l}\text { Personal: } \\
\text { Cosmetics }\end{array}$ & Perfume bottle fragments & PG-21 & 1 & 7 \\
\hline $\begin{array}{l}\text { Personal: } \\
\text { Medicine }\end{array}$ & Syringe plunger (medicine) & PG-19 & 1 & 1 \\
\hline \multicolumn{3}{|l|}{ Total } & 21 & 136 \\
\hline
\end{tabular}

the identified vessels and appear in a variety of finishes and forms. The stonewares include vessels with Albany and Albany-like slip, Bristol glaze, salt glaze, and a variety of earth-tone slips, and the forms range from large 2- and 3-gallon cylindrical jars (CV-1 and CV-5) to small-mouth jugs and jars (CV-2, CV-3, CV-6, and CV-10). The assemblage even includes imported mineral water (CV-7) and probably ale bottles (CV-13) with maker's marks, and a colorful Victorian majolica-style cup (CV-39).

All of the ceramic vessels are related to food in some way and are classified in the artifact database as being food storage and preparation or food service and consumption. ${ }^{100}$ All of the stoneware vessels in the collection are considered to be for food storage and preparation. When it came time to serve and eat the

${ }^{100} \mathrm{It}$ is acknowledged that there are exceptions to this general rule. Some ceramics might have been nonfunctional, such as unique ornamental pieces that were displayed in the home and never used. Others might have been for nonculinary purposes, such as a tea cup used as a toothpick holder. Lacking any definitive evidence of such specialized uses, it is assumed that the ceramic vessels were primarily culinary in function. food, the tablewares in the Williams household were whiteware plates, bowls, saucers, and cups. Some items were plain or embossed whiteware, but evidence suggests that the Williams family had a matching set of transfer-printed dishes that had a floral motif and was made in England.

The simple impressed mark on the stoneware lid of CV-9 has not been identified to any particular pottery or pottery-producing region. But it is interesting to note that Oval-X mark is similar to some variations of the "Landrum Cross" mark used by many African American potters working in the Edgefield District of South Carolina (Joseph 2011:Figures 2c and 2d). This possible connection is discussed further in Chapter 14.

There is not much to say about the coarse earthenware vessel or the four porcelain/ semi-porcelain vessels. They consist of only a few small sherds, so the forms and functions of these vessels are unknown. In contrast, several of the stoneware vessels and one yellowware vessel are relatively complete and their forms are well defined. Some of the more complete vessels are as follows: 
Chapter 8: Descriptions of Material Culture

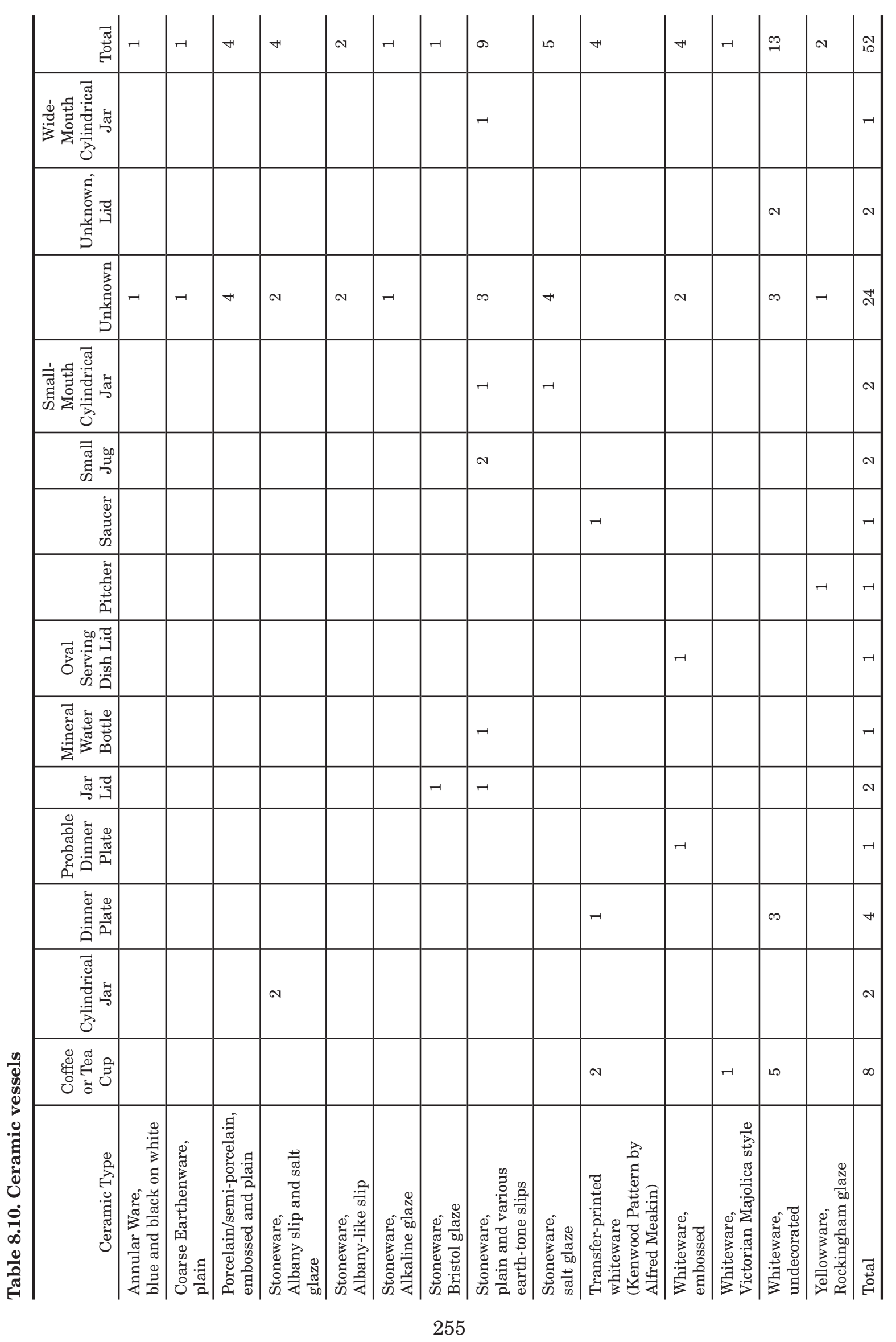


The Ransom and Sarah Williams Farmstead

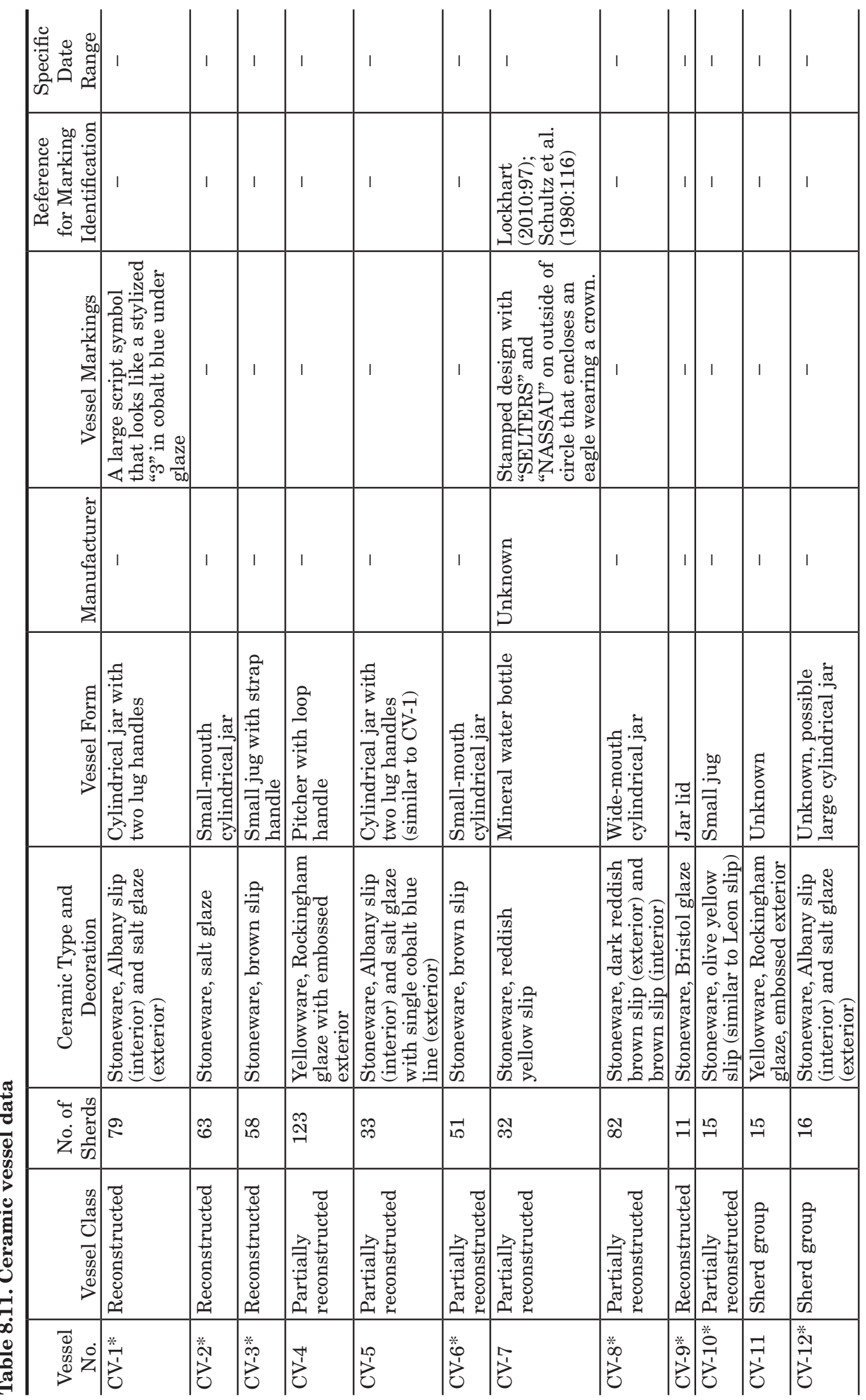




\begin{tabular}{|c|c|c|c|c|c|c|c|c|c|c|c|c|}
\hline 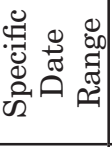 & 1 & 1 & 1 & 1 & 1 & 1 & 1 & 1 & 1 & 1 & 1 & 1 \\
\hline 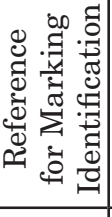 & 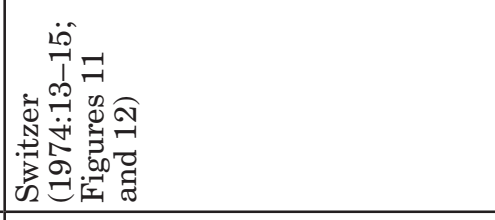 & 1 & 1 & 1 & 1 & 1 & 1 & 1 & 1 & 1 & 1 & 1 \\
\hline 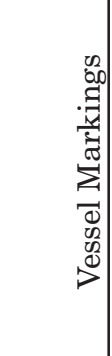 & 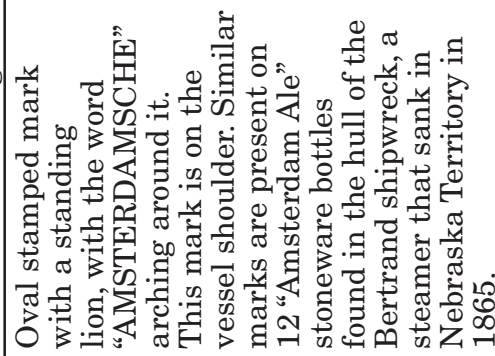 & I & 1 & 1 & 1 & 1 & I & 1 & I & 1 & 1 & 1 \\
\hline 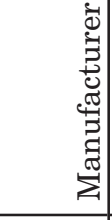 & 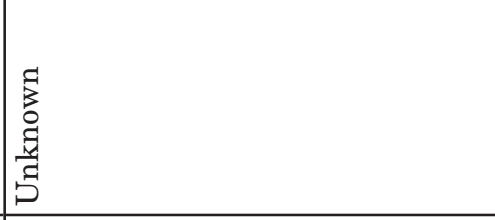 & 1 & 1 & 1 & 1 & 1 & 1 & 1 & 1 & 1 & 1 & 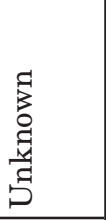 \\
\hline 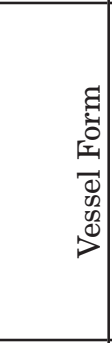 & 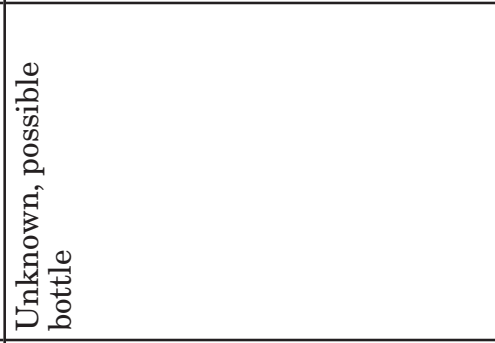 & 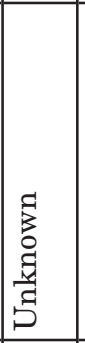 & 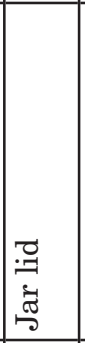 & 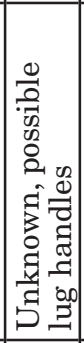 & 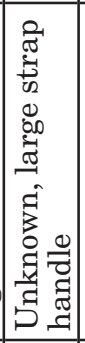 & 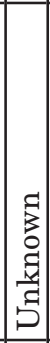 & 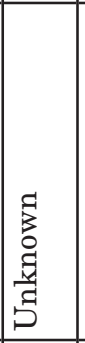 & 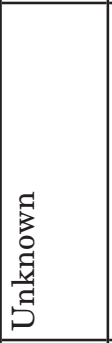 & 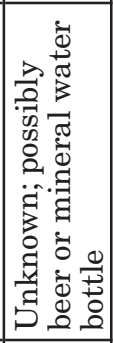 & & 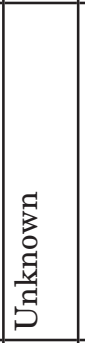 & 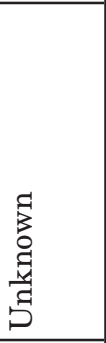 \\
\hline 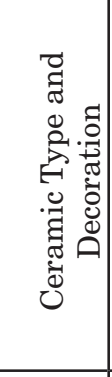 & 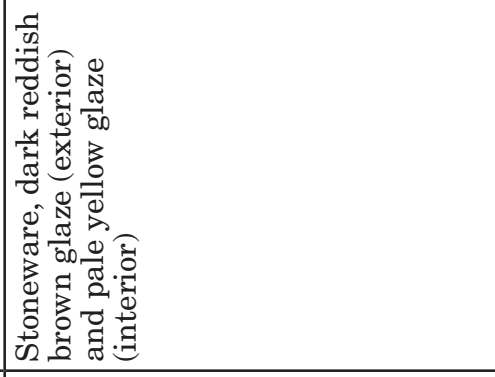 & 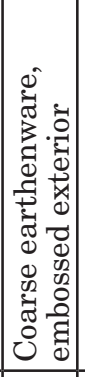 & 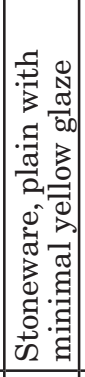 & 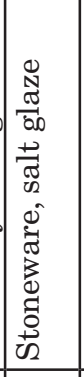 & 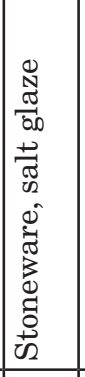 & 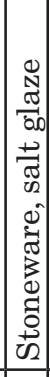 & 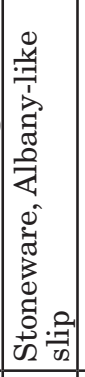 & 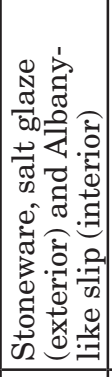 & 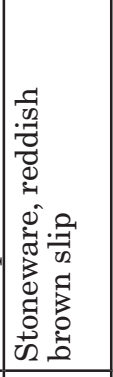 & 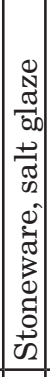 & 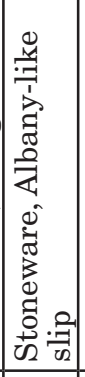 & 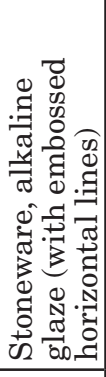 \\
\hline 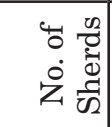 & $\stackrel{\sim}{\sim}$ & 으 & $\infty$ & ๑ึ & N & 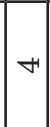 & 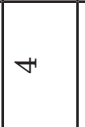 & 10 & o & 든 & -1 & $\forall$ \\
\hline $\begin{array}{c}0 \\
2 \\
0 \\
0 \\
0 \\
0 \\
0 \\
0 \\
0 \\
D\end{array}$ & 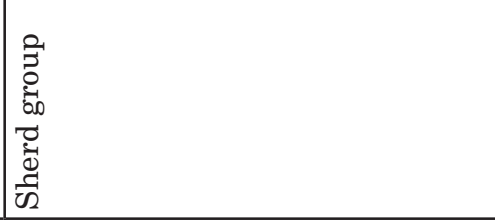 & 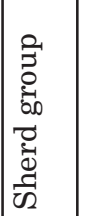 & 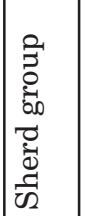 & 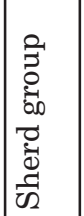 & 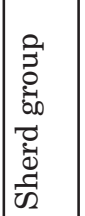 & 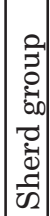 & 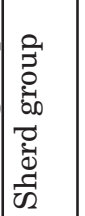 & 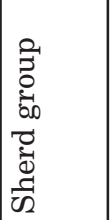 & 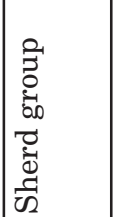 & 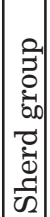 & 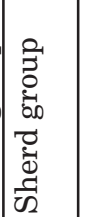 & 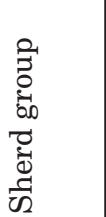 \\
\hline $\begin{array}{l}\vec{D} \\
\bar{v} \\
0 \\
0 \\
0 \\
\vec{p}\end{array}$ & 孚 & 告 & 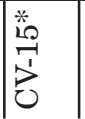 & 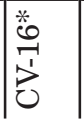 & 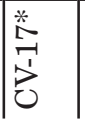 & $\mid$ & 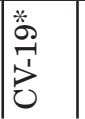 & $\begin{array}{l}\text { o } \\
\text { 交 } \\
\text { 己 }\end{array}$ & $\begin{array}{l}-1 \\
\text { - } \\
\dot{1} \\
\vec{b}\end{array}$ & $\mid \begin{array}{c}\mathbb{N} \\
\stackrel{1}{ } \\
\vec{c}\end{array}$ & 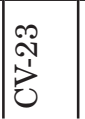 & $\begin{array}{l}\stackrel{H}{N} \\
\stackrel{1}{1} \\
\vec{U}\end{array}$ \\
\hline
\end{tabular}


The Ransom and Sarah Williams Farmstead

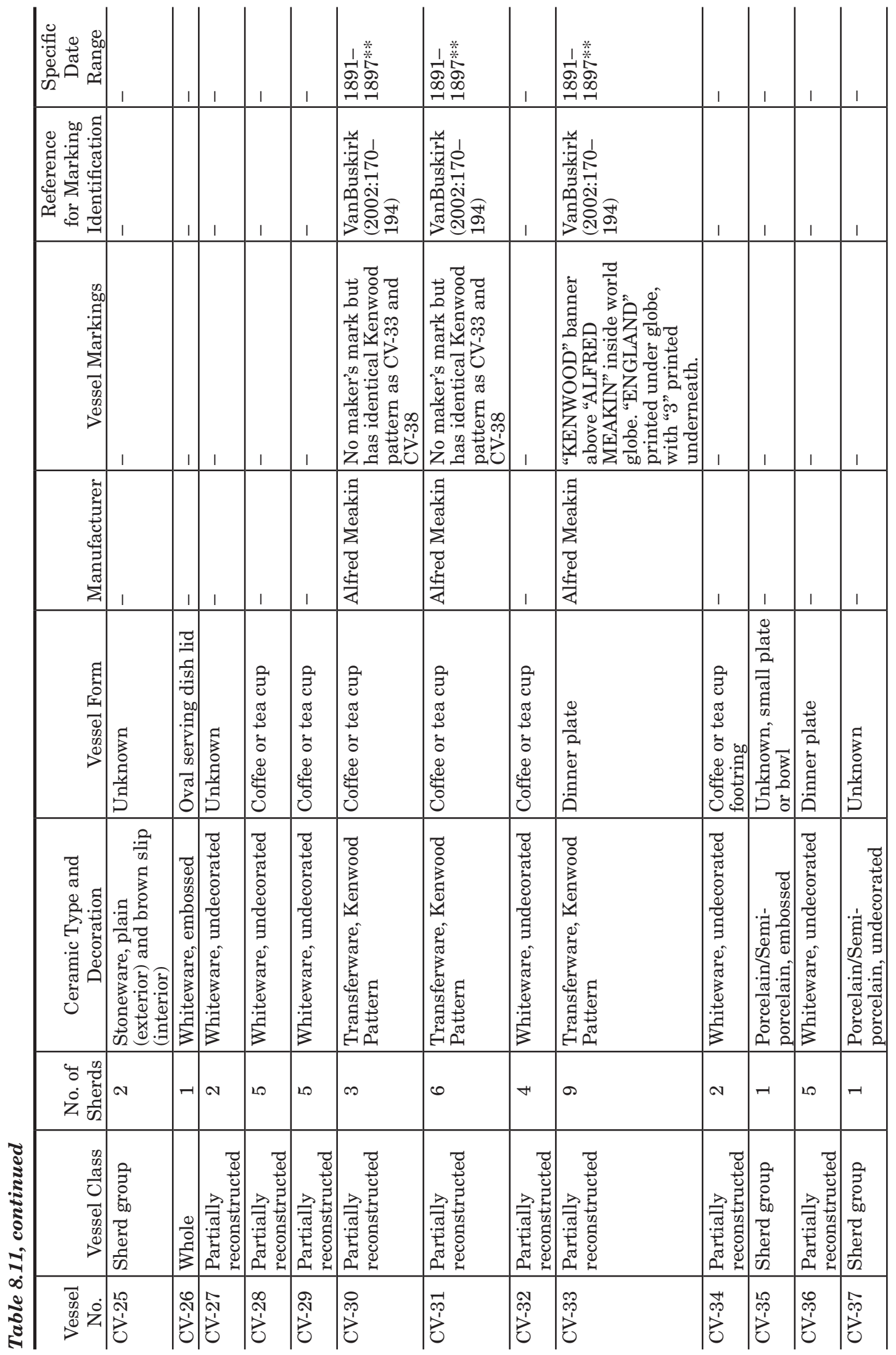




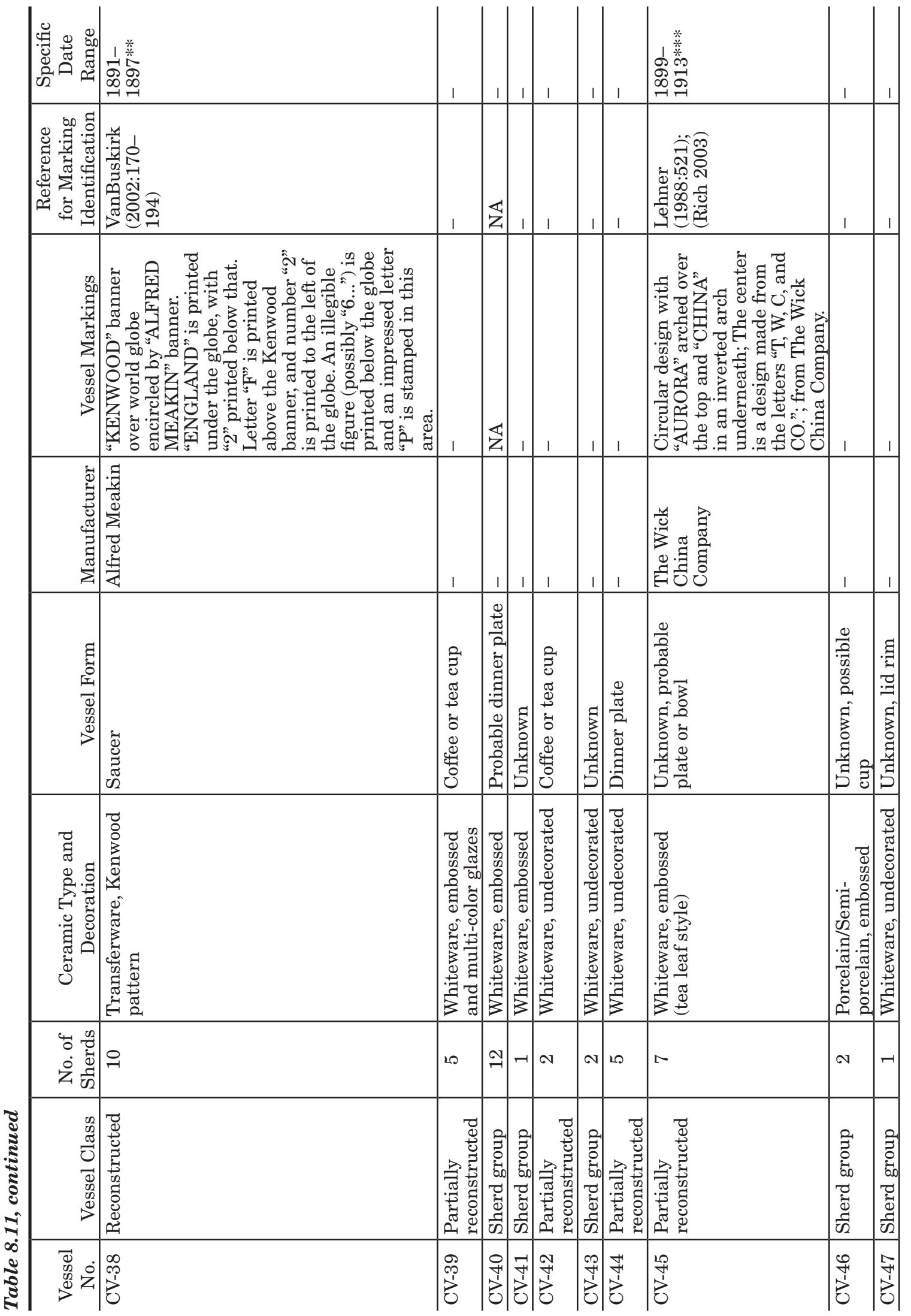


The Ransom and Sarah Williams Farmstead

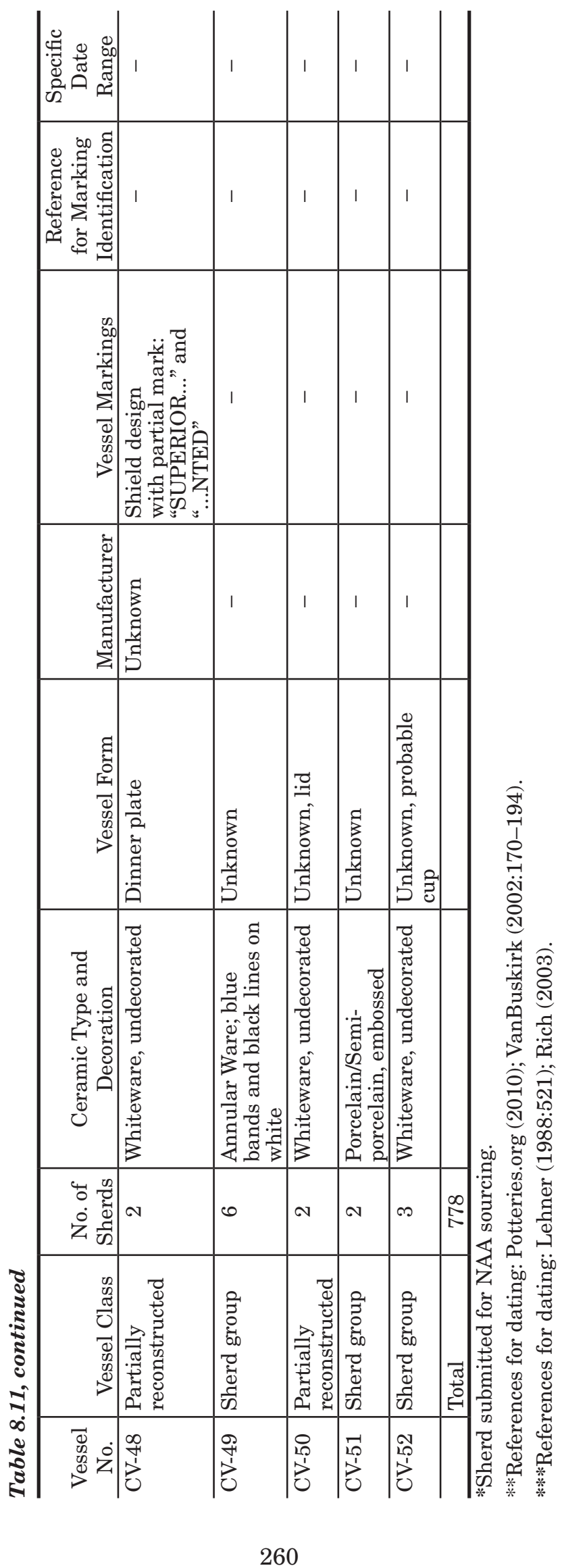



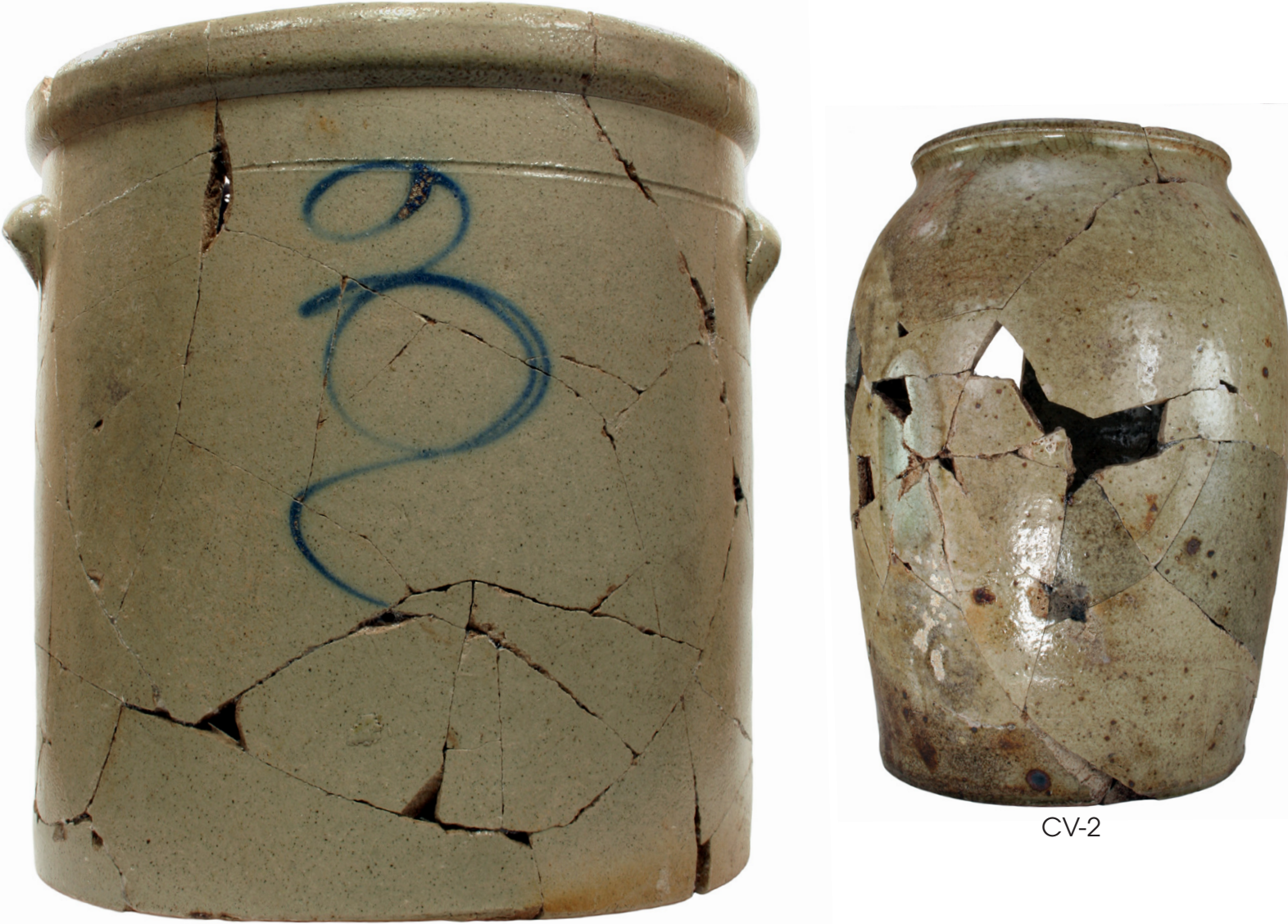

CV-2

CV-1
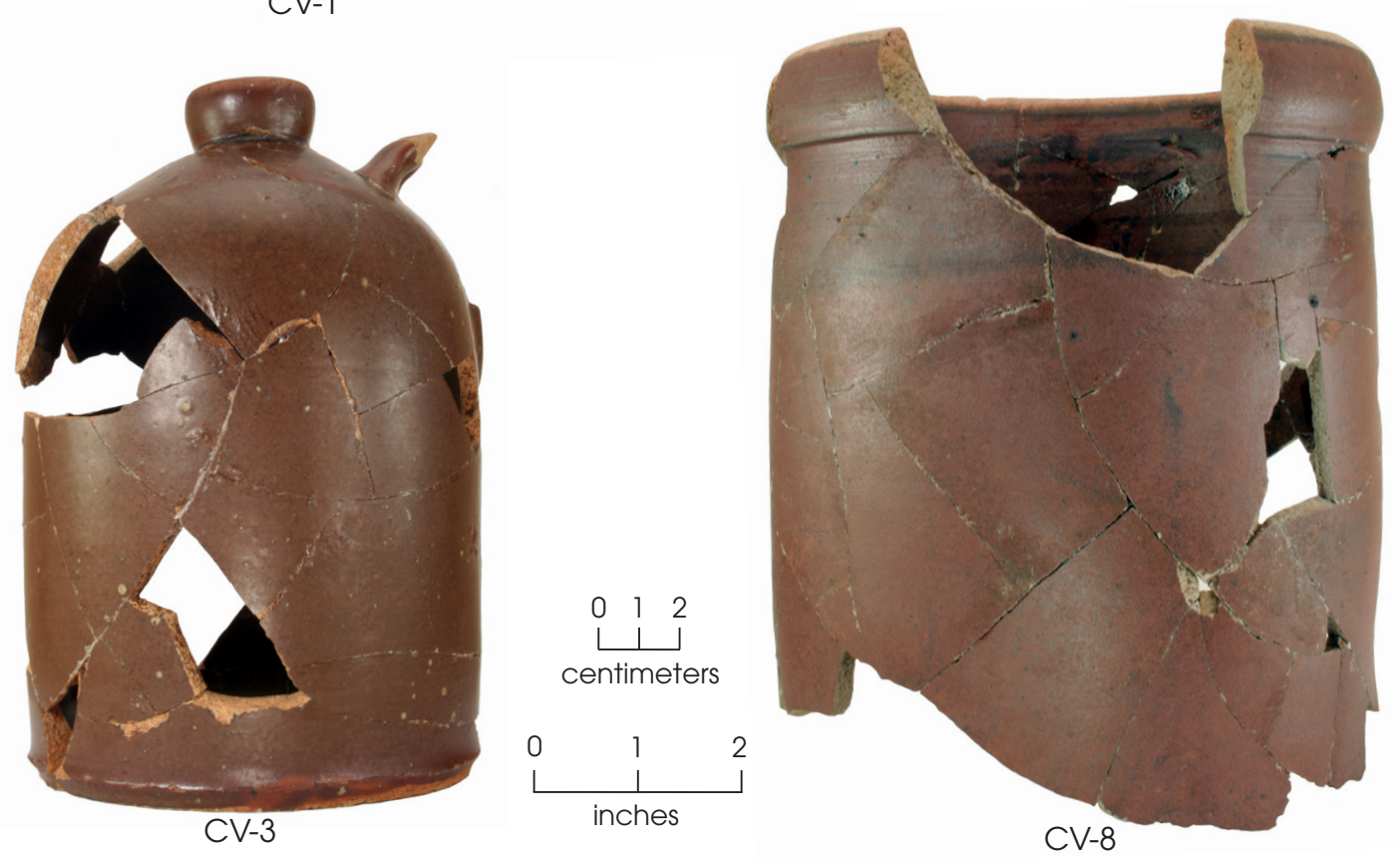

Figure 8.6. Large stoneware vessels. The mark on CV-1 is a stylized " 3 " indicating it is a 3 -gallon container. The other vessels have no markings. 

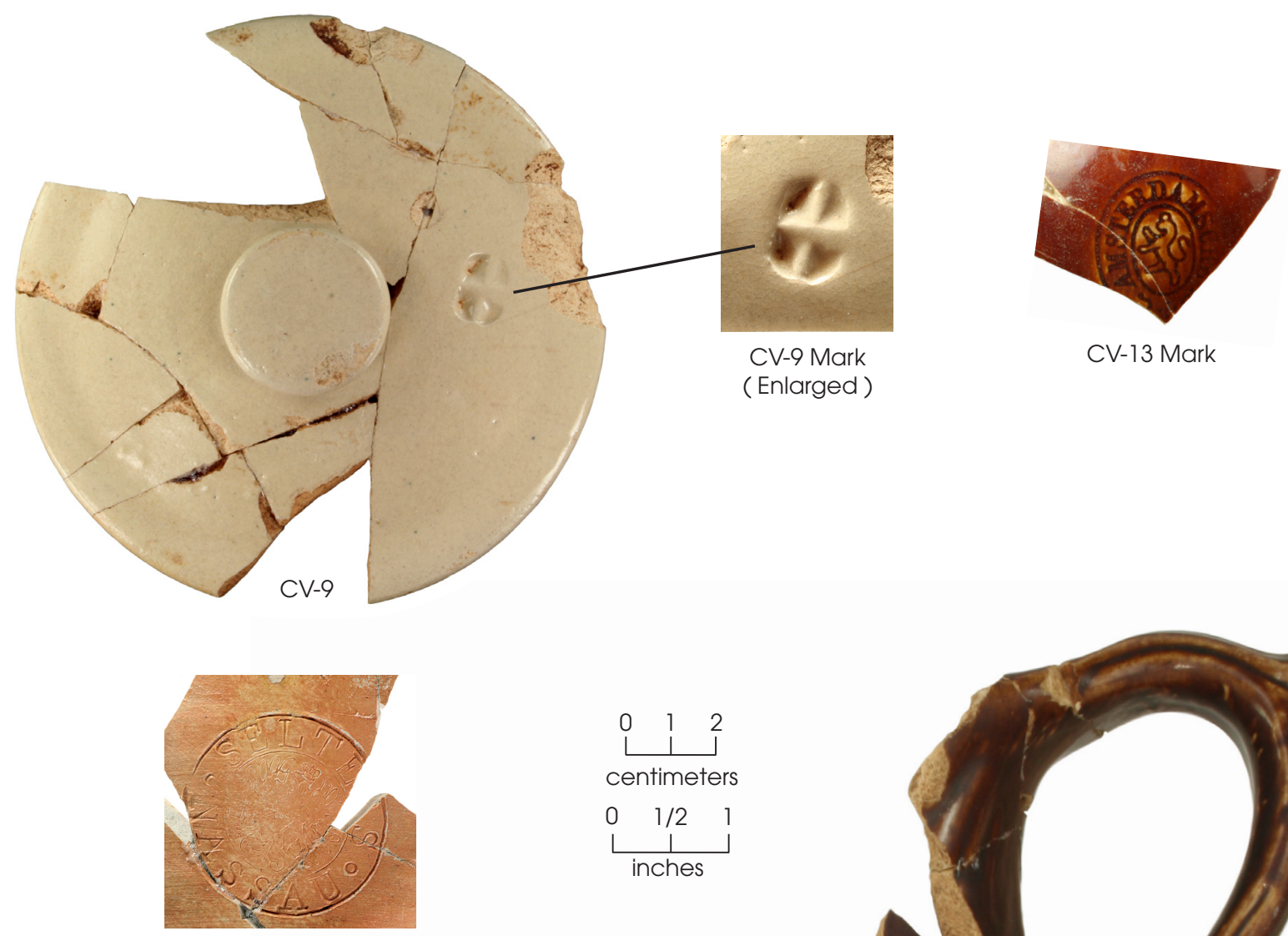

CV-7 Mark
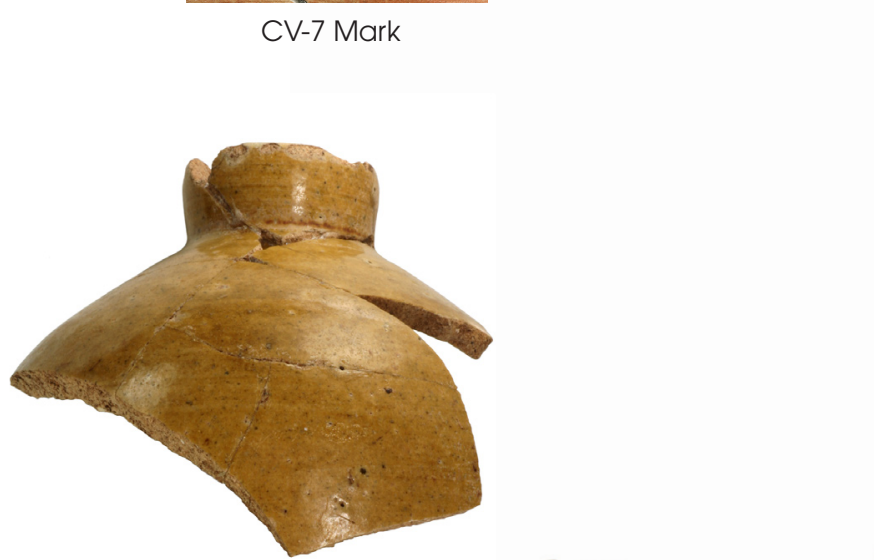

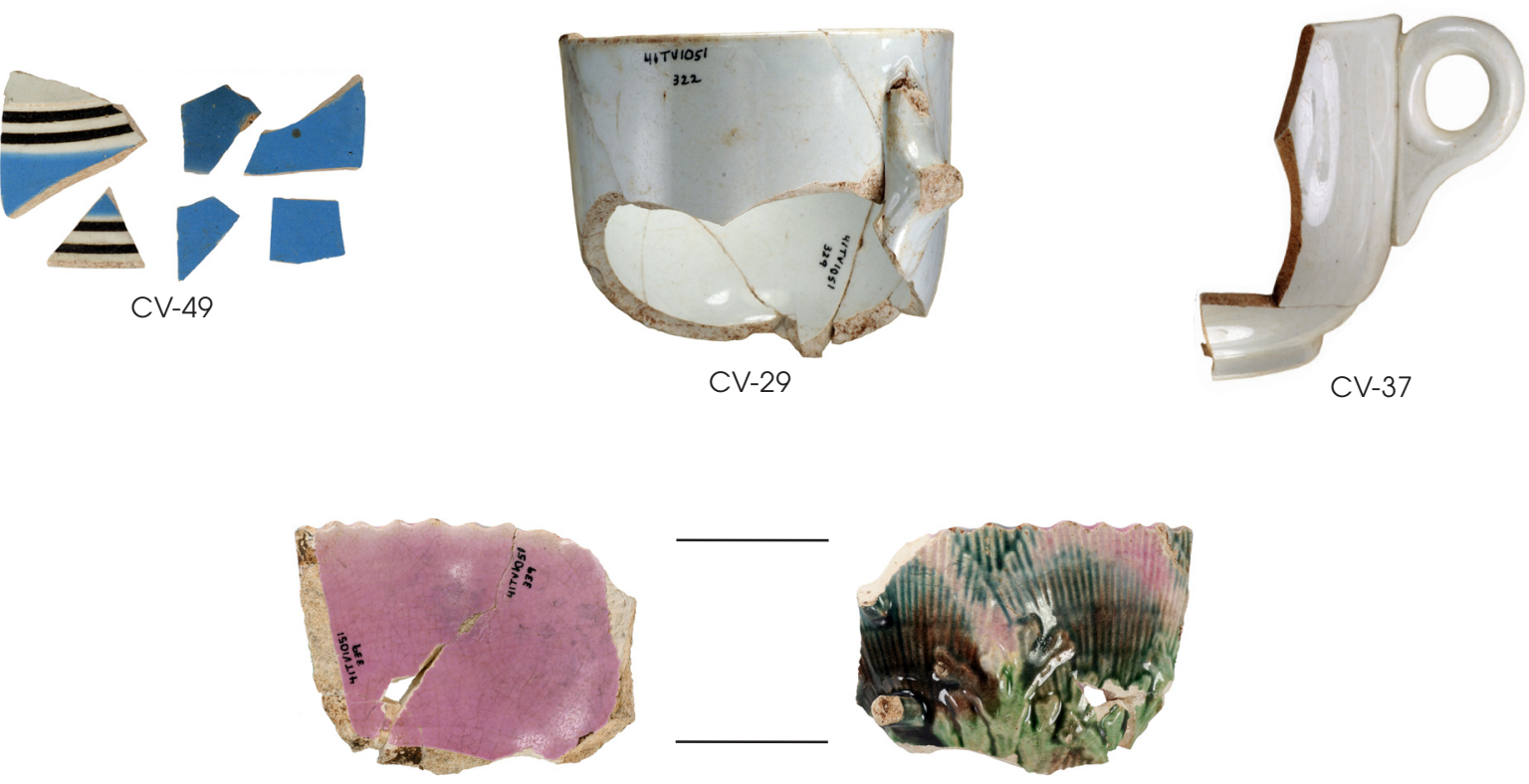

CV-39 Interior

CV-39 Exterior
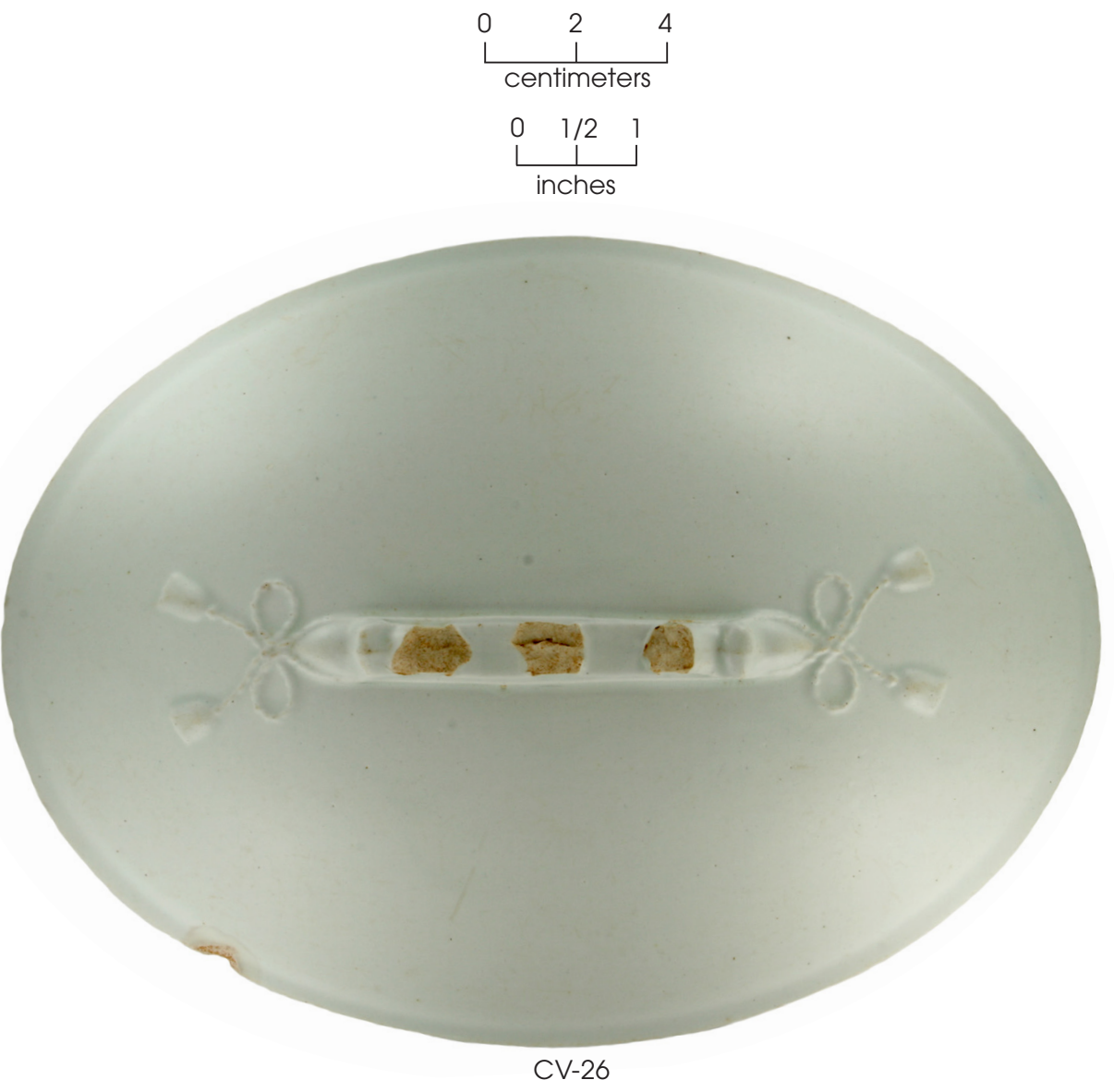

Figure 8.8. Various whiteware vessels, including annular ware (CV-49), undecorated whiteware (CV-29 and CV-37), Victorian majolica (CV-39), and embossed whiteware (CV-26). 

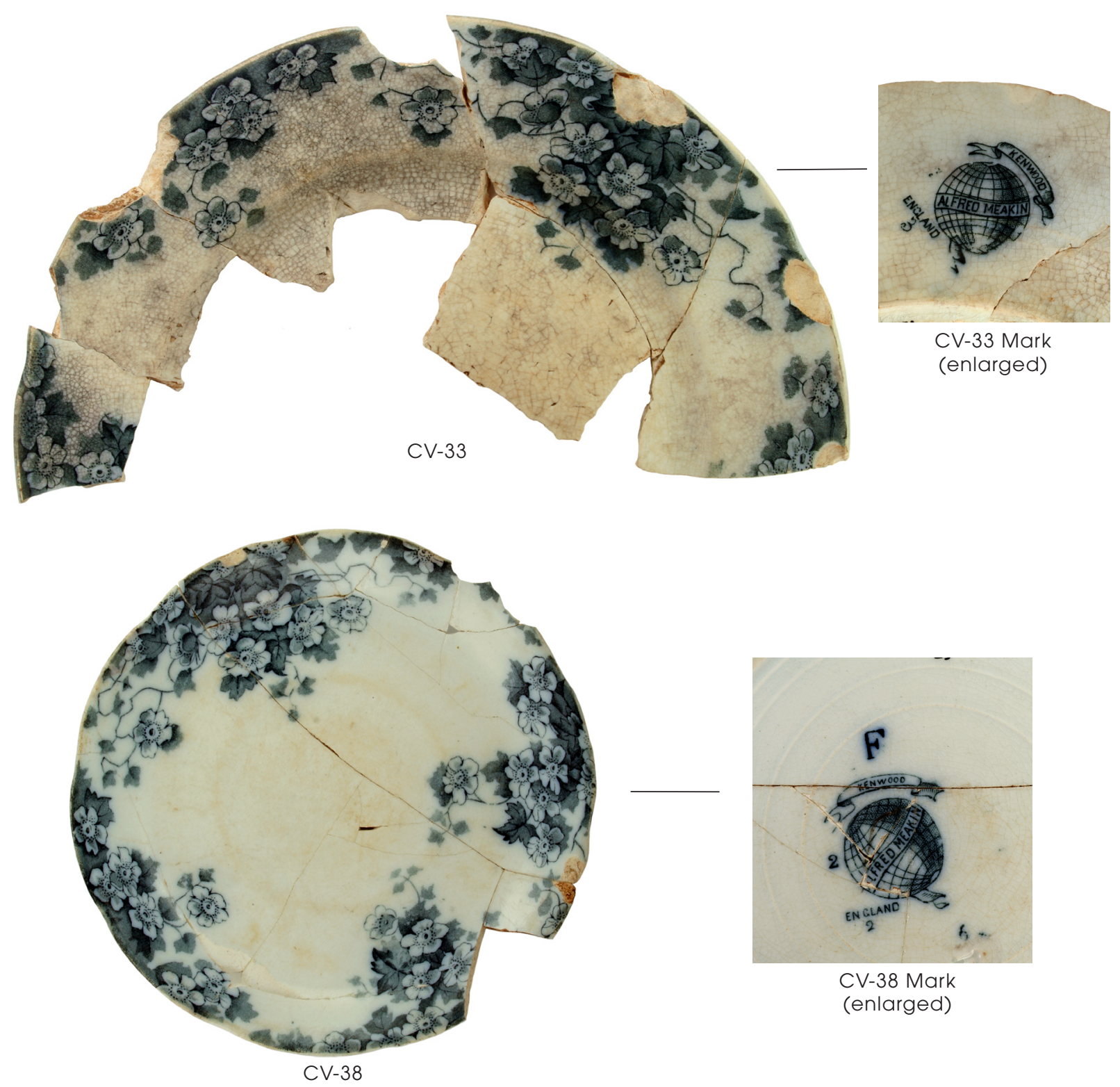

CV-38 Mark

(enlarged)

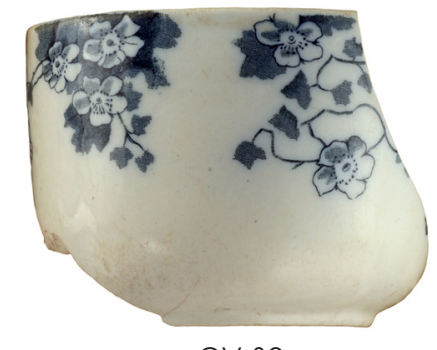

CV-30

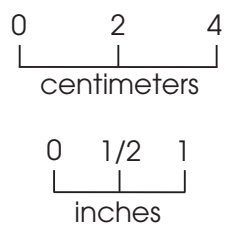

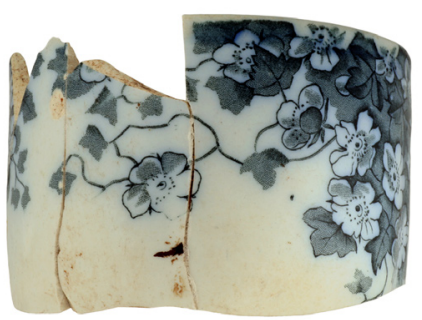

CV-31

Figure 8.9. Transfer-printed whiteware. All four vessels have the floral design identified as the Kenwood pattern made in England by the Alfred Meakin, Ltd. The globe mark was used by the company only from 1875 to 1897 (Potteries.org 2010; VanBuskirk 2002:177). 
- $\mathrm{CV}-1$ is a large 3 -gallon cylindrical jar with two small lug handles just below the rim. It has an Albany slip interior and salt glaze exterior. The vessel is 10.8 inches tall, and its maximum diameter is 10.8 inches.

- $\quad$ CV-2 is a half gallon jar with salt glaze interior and exterior. The vessel is 8 inches tall, and its maximum diameter is 5.9 inches.

- $\quad$ CV-3 is a one-quart jug with a single loop handle on its shoulder. It has a brown slip exterior and interior. The vessel is 7 inches tall, and its maximum diameter is 4.25 inches.

- CV-4 is a small yellowware pitcher (estimated size is one quart) with an embossed design and a single loop handle. It has a dark brown Rockingham glaze finish on interior and exterior. The vessel is estimated to be 6 inches tall with a body diameter of about 6 inches. The handle and body style are similar to the Rockingham pitchers in a D. E. McNichol Pottery Co. catalog illustrated by Leibowitz (1985:52).

- $\mathrm{CV}-7$ is a mineral water bottle with an unidentified marking (impressed circle with "SELTERS" and "NASSAU" around an eagle wearing a crown). Its interior is unfinished, while its exterior has a reddish yellow slip. Its capacity is estimated to be about 40 ounces.

- $\mathrm{CV}-8$ is a cylindrical jar, at least one gallon in size. It has a brown slip interior and a dark reddish brown slip exterior. Maximum vessel diameter is 7 inches; its height cannot be determined but is at least 9 inches.

- CV-9 is a lid from a small jar, with as single knob handle in its center. It has a light Bristol glaze on top and is unfinished on the bottom. Maximum diameter is just over 5 inches.

- CV-10 is a neck and lip from a jug. The olive yellow slip on its interior and exterior is similar to what has been described as a Leon slip (Greer 1981:194, 198).

- CV-13 is a probable ale bottle with an unidentified impressed marking on its shoulder. It has a pale yellow slip on its interior and a dark reddish brown glazed exterior. The oval mark has a standing lion with the word "AMSTERDAMSCHE" arching around it. Similar marks are present on 12 "Amsterdam Ale" stoneware bottles found in the hull of the Bertrand shipwreck, a steamer that sank in the Missouri River in Nebraska Territory in 1865 (Switzer 1974:13-15; Figures 11 and 12).

The plain and embossed whiteware vessels are a relatively inexpensive utilitarian ware that was sometimes marketed as white ironstone (Wetherbee 1980, 1985). Four embossed whiteware vessels are represented, but only two have identifiable forms: a dinner plate and an oval serving dish lid. The 13 plain whiteware vessels include 5 cups, 3 dinner plates, and 2 unknown lids. But it appears that none of these embossed and plain vessels have matching styles that might be evidence of a matched set of tableware.

Four transfer-printed vessels-a 9.5-inch dinner plate, a 6-inch saucer, and two coffee cups-have identical floral patterns and maker's marks, indicating they are from a matched set (see Figure 8.9). It is likely that some similar-patterned sherds in the ceramic assemblage represent additional matching pieces, although they could not be linked to these vessels. The maker's marks on the plate and saucer identify the transfer-print as the Kenwood pattern made by the Alfred Meakin, Ltd. Pottery of Tunstall, England. The globe mark was only used from 1875 to 1897 (Potteries.org 2010; VanBuskirk 2002:177), but the word "England" that appears below the mark suggests that these vessels were produced after 1891, when this word was added to all wares made in English potteries in accordance with the McKinley Tariff Act of 1890 which required that imported items bear the name of the country of manufacture (Potteries. org 2010; VanBuskirk 2002:177). Thus the likely period of manufacture for these Kenwood pattern transfer-printed dishes is 1891-1897.

Identical transfer-printed sherds were found at two other Texas sites: one at an Anglo farmstead (41HY53, the McGee cabin occupied ca. 1870 to 1940) in the Onion Creek area of Hays County (Roberson 1972:Figure 15g, 128-129, 173) and others from two African American households (41HR1010) in Houston's Freedmen's Town (the Fourth Ward; Feit and 
Jones 2007:178, Figure 8-7). For the latter site, Feit and Jones (2007:178) state that the distinctive "blue floral transfer ware print" was found in the Spillman trash pit assemblage (which was sealed by 1925 or earlier) as well as in a tenant house assemblage from the same urban community. They speculate on the significance of the fact that this distinctive floral transfer-printed ware was used in two different households:

The presence of the same pattern in these different household contexts has several implications. First it implies that project area residents shared similar aesthetic tastes. Lucy Spillman, who, as previously noted owned a diverse collection of decorated wares, purchased the same plates as here neighbor Annie Richardson. She was also attracted to the same ceramic pattern as her neighbors in the tenant houses on the same block. It also suggests that different households probably did their shopping at many of the same establishments, and that these ceramics were something available locally, perhaps stocked at one of the local markets. (Feit and Jones 2007:178)

It appears that the Kenwood and other similar floral patterns were very popular in late-nineteenth-century Texas. Alfred Meakin pottery with similar floral designs was offered for sale in period catalogs, including the 1895 Montgomery Ward (Kent Pattern, Montgomery Ward \& Company 1895:529), 1897 Sears (Princess Pattern, Sears, Roebuck \& Company 1897:n.p., Items 9680-9685), and 1902 Sears (Woodland Pattern, Sears, Roebuck \& Company 1902a:794; Green Exeter Dinner Set, Sears, Roebuck \& Company 1902b:635). During this time, American potteries were competing headto-head with the well-established English pottery makers, and VanBuskirk (2002:251) notes that "mail order catalogs were most likely the greatest avenue that the English had in getting their wares to the rural American consumer." He also notes that Alfred Meakin products were made "chiefly for the American market" (VanBuskirk 2002:170), and that English ceramics were often cheaper in the United States than American-made wares in the late nineteenth century (VanBuskirk 2002:18-19). These period catalogs indicate that the English transfer-printed wares (including those by Alfred Meakin) were middle-of-the-road in terms of price. They certainly were not the most expensive, but they cost significantly more than other cheaper wares, especially the embossed and plain utilitarian whitewares. ${ }^{101}$

CV-39 is relatively odd whiteware vessel that has a bright pink interior slip with an embossed exterior brightly painted in green, light blue, and pink. There is no maker's mark, but the vessel matches the "shell and seaweed" designs on many "Victorian majolica" and "Etruscan majolica" wares that were made in Europe and America in the last half of the 1800s. Vessel CV-39 matches many specimens found for sale online at various antique and auction websites (e.g., ebay, Amazon.com, Worthpoint. com). This majolica is a refined earthenware and should not be confused with the earlier tin-glazed majolicas. It became popular in American after the 1876 Centennial Exposition in Philadelphia, but it later fell out of popularity, and production ceased around the turn of the century (Dawes 1990; Jefferson Patterson Park and Museum 2002).

\section{Cast-Iron Vessels}

In addition to the ceramic vessels used in food preparation, 31 cast-iron vessel fragments were recovered from various contexts in and around the house area (Table 8.12; see Table B.7). Based on general shape and curvature, many of the fragments are base, body and rim, and lid fragments from dutch ovens (Figure 8.10), while other fragments cannot be specifically identified to vessel types. The latter appear to be fragments from small pots, cauldrons, or shallow frying pans. Many of the fragments display a high degree of corrosion, making identification difficult.

\footnotetext{
${ }^{101}$ A price comparison of in the 1895 Montgomery Ward \& Co. catalog (pp. 529-530) supports this statement. For example, a dozen handled tea cups and matching saucers in the Alfred Meakin Kent Pattern (a floral design, transfer-printed "semi porcelain") cost $\$ 1.82$. In contrast, the embossed whiteware (a "semi-porcelain" called the "Victoria Pattern") cups and saucers made by the Johnson Brothers of Hanley, England cost $\$ 1.20$, and the plain "Vitreous Hotel China" cups and saucers by an unknown maker cost $\$ 1.38$.
} 
Table 8.12. Cast-iron vessel fragments

\begin{tabular}{l|c|c|c|c|c}
\hline \multicolumn{1}{c|}{ Context } & House Block & House Block, Subfloor Pit & Midden & Outbuilding & Total \\
\hline Base or body fragments & 6 & 1 & 13 & 3 & 23 \\
\hline Foot fragment & 1 & 0 & 0 & 0 & 1 \\
\hline Lid fragments & 2 & 0 & 5 & 0 & 7 \\
\hline Total & 9 & 1 & 18 & 3 & 31 \\
\hline
\end{tabular}

From the number and kind of fragments recovered, it is impossible to determine how many cast-iron cooking vessels may have been used at the farmstead. It appears that there are at least four different dutch ovens represented, with vessel diameters documented as $8,9,10$, and 12.5 inches. The latter is a 12.5 -inch-diameter dutch oven lid fragment that is embossed with the letters "..ETERSON" over "No. 2 1/..." The number would have indicated the size of the vessel, but the size markings were not standardized among various manufacturers (Cast Iron Collector 2013). The name probably identifies it as vessel made by the Stuart, Peterson \& Company of Philadelphia. This company was founded in 1844 and was a major manufacturer of cast-iron cookware in the late nineteenth century (Dawson 1872-1873; Stahl 2004).

\section{Corn Sheller}

One unique cast-iron item was surface collected in 2003 by ACSG archeologists (Staples and Nash 2003b:42; Figure 21). It is one half of a corn sheller that has a stamped name "GRAY \& BROS / PAT 1870 / LOUISVILLE KY" on the outside surface (Figure 8.11). The piece is one-half of a cylindrical hand-held device, and its interior has rows of raised teeth. With only minor differences, this specimen matches the patent drawings for the "Corn Husker" that was patented as No. 110,565 on December 27,1870 , by J. M. Gray (Figure 8.12). This corn sheller consisted of two hinged plates that clamped together to form a tube with "shelling-teeth of different sizes" that were "arranged in rows running lengthwise on each plate." The device was clamped around an ear of corn and was twisted so that the teeth knocked the kernels off the ear. Charred corn kernel fragments were recovered from the house block, subfloor storage pit, and midden areas (see Chapter 10 and Appendix D), reinforcing the notion that this corn sheller would have been an important tool on the Williams farmstead.

\section{Cutlery}

The Williamses had a variety of cutlery utensils (Figure 8.13). The excavations recovered 10 forks, 10 knives, 19 spoons, 26 utensil handle fragments, and a corkscrew from the house and midden areas (Table 8.13; see Table B.9). All of the forks were of the three-prong variety, and several of the spoons were large serving spoons. In some cases, the tableware was plain plated metal with minimal ornamentation and wooden handles (the wood was gone), while other utensils were fancier with bone and white metal handles attached to an iron implement. The unidentifiable handles included iron, bone, and combination materials (bone, iron, and white metal or iron and white metal). One silver plated spoon has a floral motif marked "IMPERIAL PLT CO" on the back of the handle, but this mark has not been identified. A cupreous plated spoon has the name "ROGERS SMITH \& Co" stamped on the back of its handle. Rogers, Smith \& Company, of New Haven and Meriden, Connecticut, was founded in 1857 (or 1862) and operated until 1898 (Online Encyclopedia of Silver Marks 2010; Woodhead 1991:211).

The archeological evidence demonstrates that the Williamses owned a variety of silverware. Some of the specimens appear to be plain eating utensils that may have been from one or more matched sets of silverware, such as the plain iron forks and knives, which probably had wooden handles (see a, e, and f in Figure 8.13). Many of the fancier utensils are unique items in terms of their design or maker, but there is no way of knowing if they were one-of-a-kind items or if they belonged to matched sets. Matched sets of high-quality silverware would have been taken when the Williams family abandoned the 

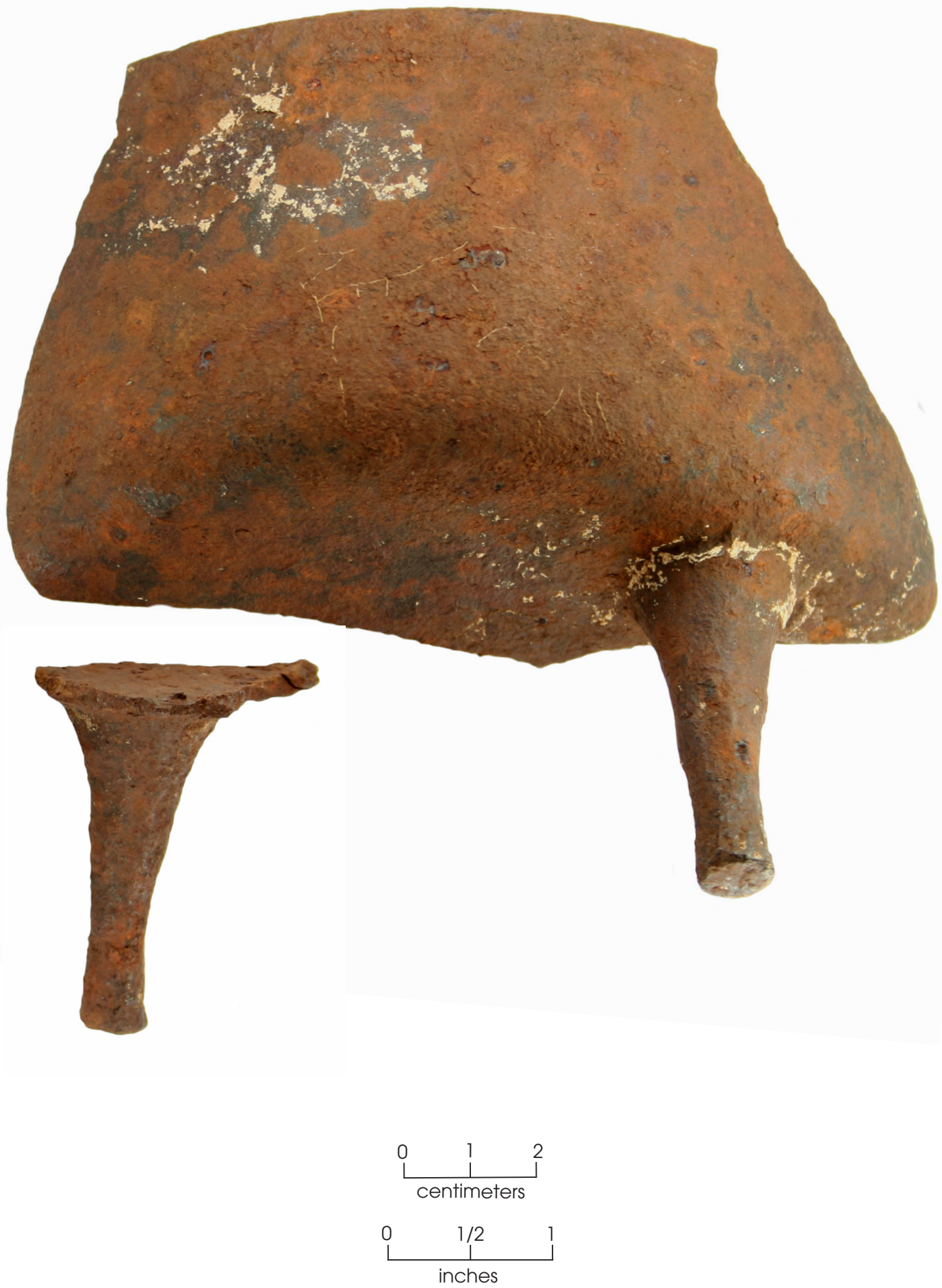

Figure 8.10. Base and body fragment of a large cast-iron dutch oven, approximately 3 inches deep. The variety with long tripod legs was often called a spider oven. 

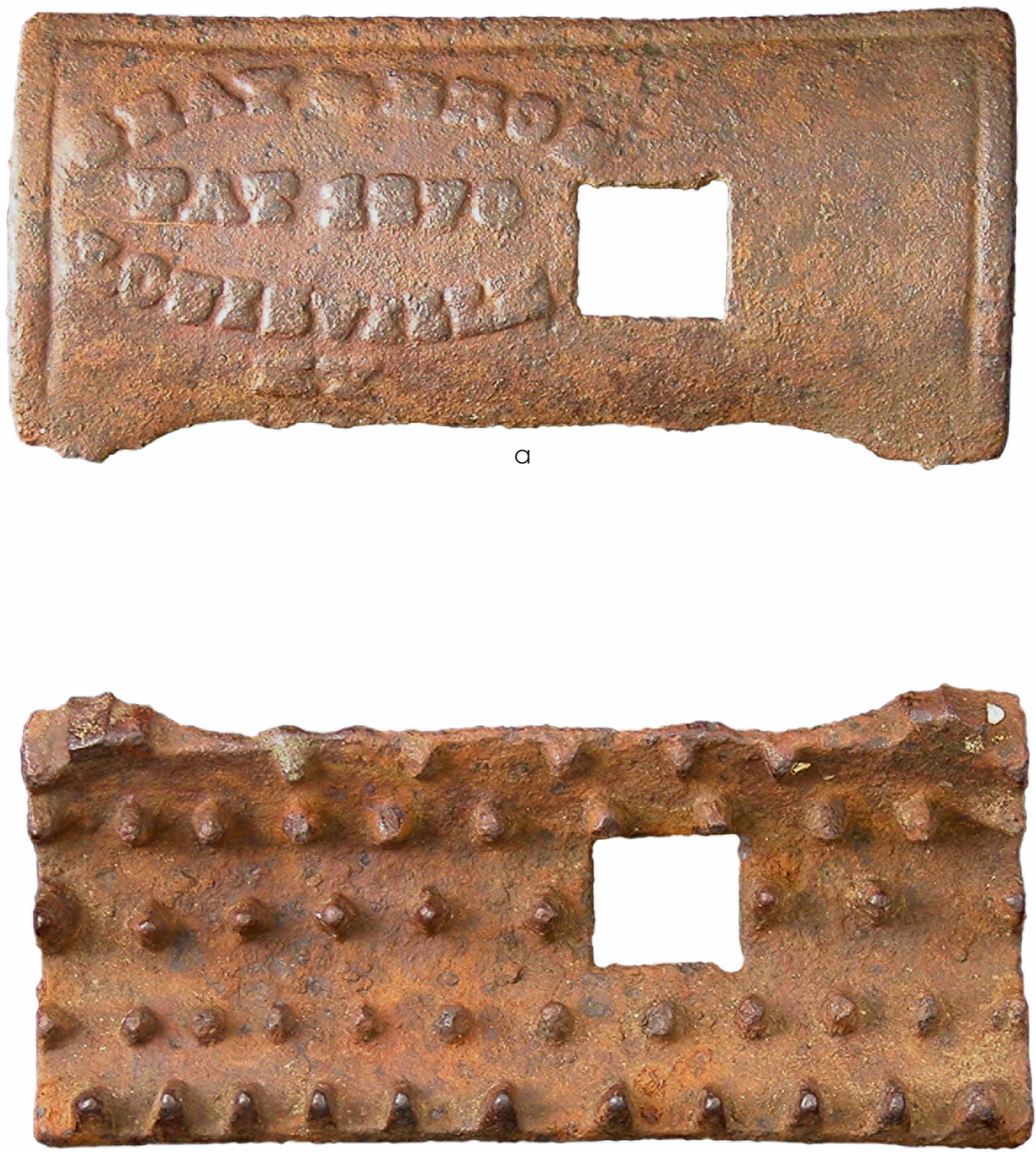

$\mathrm{b}$

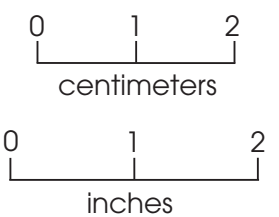

Figure 8.11. Hand corn sheller by Gray \& Brothers. Exterior and interior views of one-half of a hinged iron corn sheller. The outside surface is stamped with the words GRAY \& BROS / PAT 1870 / LOUISVILLE / KY.

property, and only the specimens that were lost or broken would have been left behind.

\section{Metal Cans}

As technology advanced in the nineteenth century, increasing amounts of mass-produced goods became readily available, including canned goods. Canned goods were food items packaged in metal cans for better preservation, and they became easier to produce through a series of technological changes in canning machinery. A variety of metal cans are represented in the Williams farmstead assemblage, all classified 


\section{J. M. GRAY.}

\section{Corn Husker.}

3. 110,565 .

Patented Dec. 27, 1870.
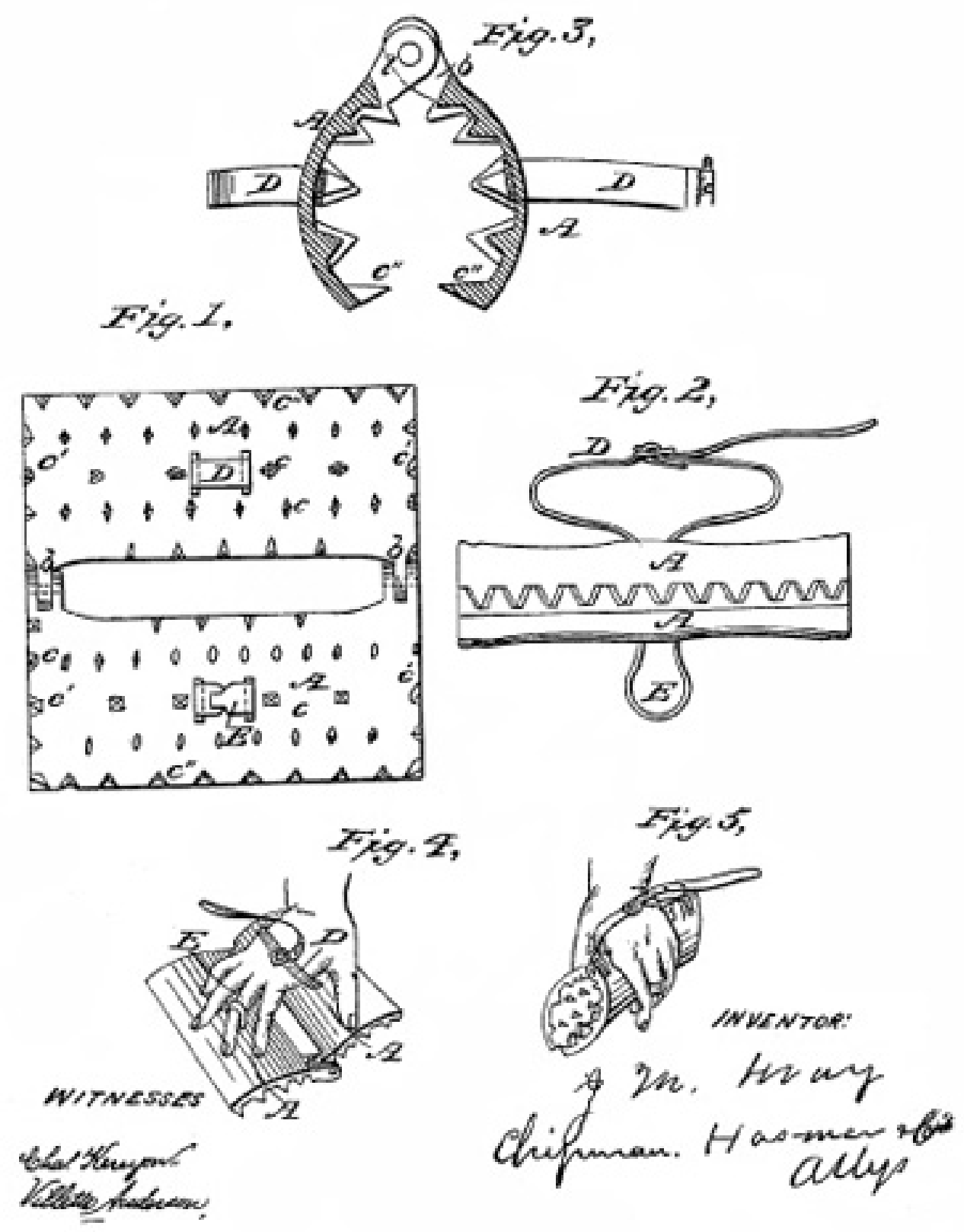

Figure 8.12. Patent drawings for the "Corn Husker" patented on December 27, 1870, by J. M. Gray (Patent No. 110,565; Gray 1870). 


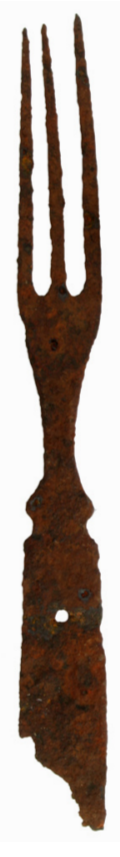

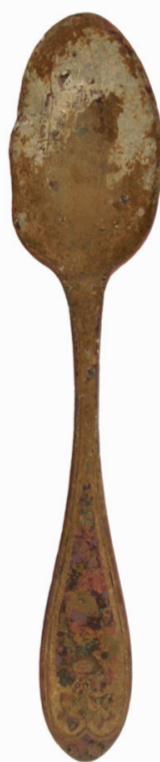

a

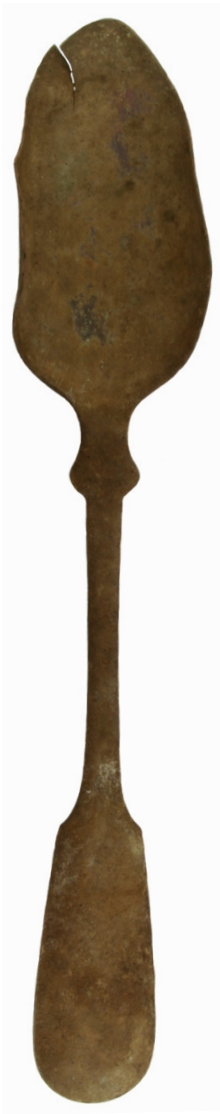

d
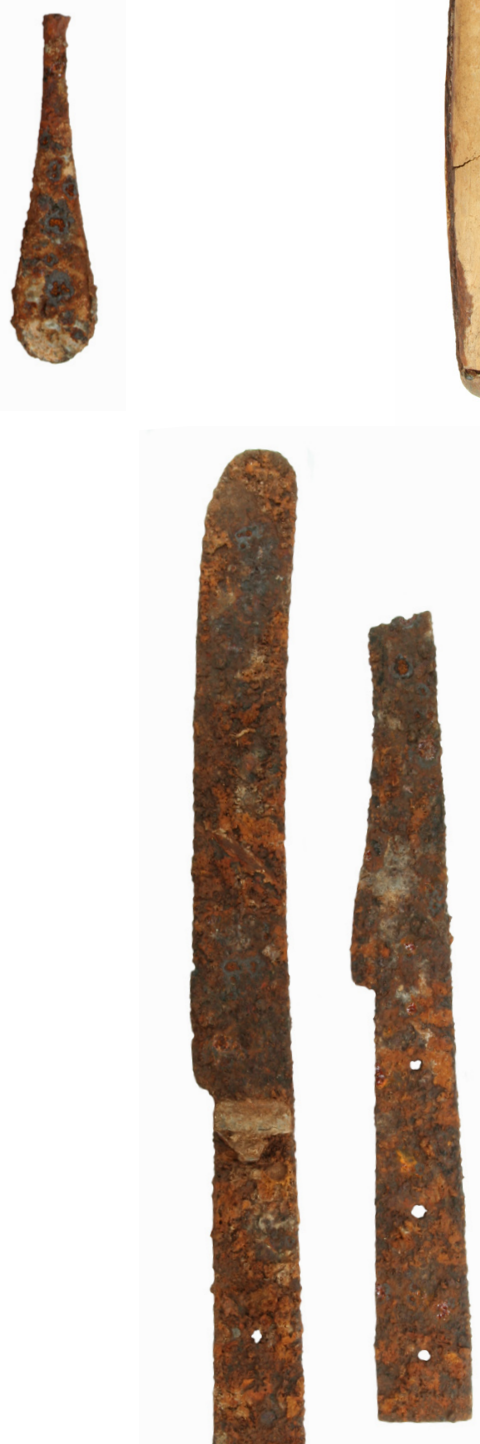

e
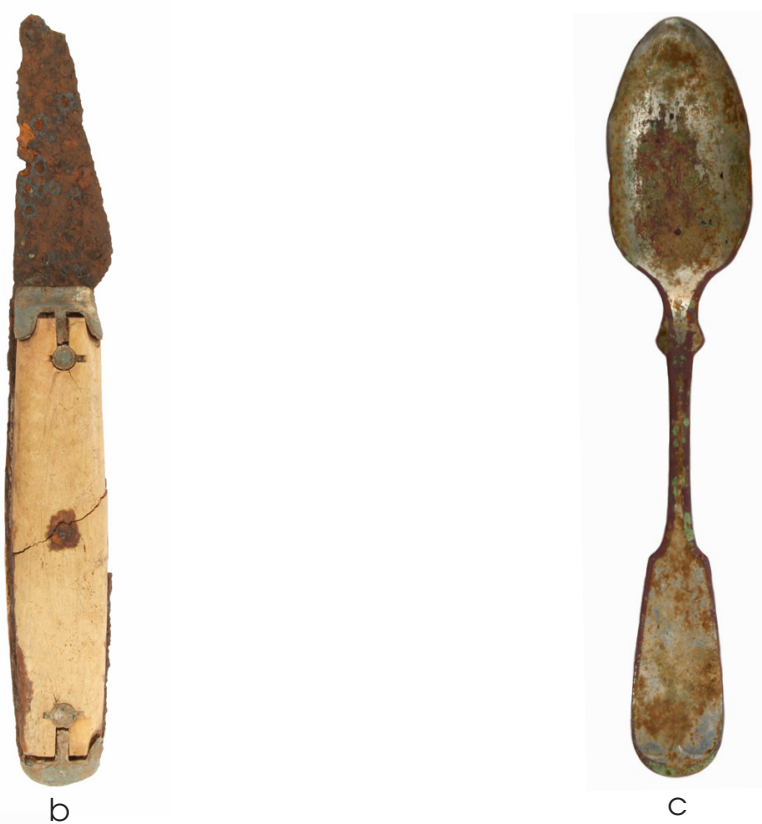

c

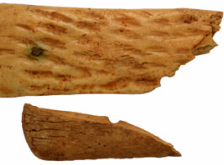

g
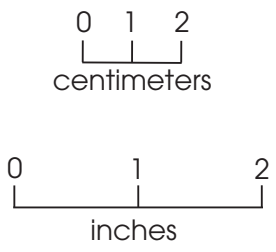

Figure 8.13. Assorted cutlery artifacts. (a) Iron three-prong fork, plated spoon, and spoon handle. (b) iron knife with a bone and white-metal handle; (c) plated spoon with "ROGERS SMITH \& Co" mark; (d) spoon with illegible maker's mark; (e) iron knives; (f) iron fork; (g) engraved bone handle from unknown utensil. 
Table 8.13. Cutlery items

\begin{tabular}{|c|c|c|c|c|c|}
\hline Artifact & $\begin{array}{l}\text { House } \\
\text { Block }\end{array}$ & $\begin{array}{c}\text { House Block, } \\
\text { Subfloor Pit }\end{array}$ & Yard & Midden & Total \\
\hline Forks (iron) & 6 & 1 & - & 1 & 8 \\
\hline Forks (bone, iron, and white metal) & 1 & 1 & - & - & 2 \\
\hline Knives (iron) & 3 & 1 & 1 & 3 & 8 \\
\hline Knife (bone, iron, and white metal) & 1 & - & - & - & 1 \\
\hline Knife (iron and white metal) & - & 1 & - & - & 1 \\
\hline Spoons (iron) & 6 & 2 & 1 & 3 & 12 \\
\hline Spoons (cuprous)* & 2 & 1 & 1 & 1 & 5 \\
\hline Spoons (unknown) & 2 & - & - & - & 2 \\
\hline Unknown handles (iron) & 8 & 5 & - & 4 & 17 \\
\hline Unknown handle (bone) & 3 & 1 & - & - & 4 \\
\hline Unknown handle (iron and white metal) & - & 1 & - & - & 1 \\
\hline Unknown (bone, iron, and white metal) & 1 & - & - & - & 1 \\
\hline Unknown handle (unknown material) & 1 & - & - & - & 1 \\
\hline Corkscrew (iron) & 1 & - & - & - & 1 \\
\hline Total & 35 & 14 & 3 & 12 & 64 \\
\hline
\end{tabular}

*Two spoons have complete maker's marks. One is from the house block and one is from the yard.

in the Kitchen and Household functional group because it is assumed that most (if not all) of them probably contained food products.

A minimum of 72 individual cans were identified within the Williams farmstead assemblage (Table 8.14; see Table B.8). Many are so fragmentary that the can type could not be identified, and these are described as unknown. Identifiable can shapes are cylindrical and rectangular (Figure 8.14), and the most common type is the holein-cap can $(\mathrm{n}=18)$, a can with a circular cap (usually 1 to 1.5 inches in diameter) that fits onto the top of the can. Once the food contents were placed in the can, the cap was attached to the top with solder, but the cap had a pinhole opening in its center. The can was heated to allow steam to escape, and then a small bead of solder was applied to the pinhole to seal the can. Lead solder was typically used to attached the caps and seal the cans.

Other cans found at the farmstead include sanitary cans $(n=8)$, screw top cans $(n=2)$, stamp-end cans $(\mathrm{n}=1)$, and key-wind cans $(\mathrm{n}=4)$. Sanitary cans have crimped metal edges (one vertical on the body and one on each end) sealed with rubber and/or gum seal, thus eliminating the need for lead solder. By 1896, Charles
Ams had patented a rubber and gum seal, making the canning process more effective, and by 1897 the Ams Machine Company created a machine to expedite the manufacture of sanitary cans (Rock 1984:101; University of Utah 2001).

\section{Container and Bottle Caps}

A total of 38 iron container or bottle caps of three different types are in the farmstead assemblage. Most $(n=26)$ are crown caps from soda pop or beer bottles. Screw caps $(\mathrm{n}=10)$ could have come from metal containers or bottles, and two snap-on iron caps probably came from metal containers.

\section{Unique Items}

This group is composed of nine fragments representing seven unique Kitchen and Household items. Two fragments are small pieces of an iron metal plate with embossed (raised) letters along the rim. This was an alphabet plate that was used to help children learn their A, B, Cs. Two iron fragments are from a coffee pot spout. It was probably an enameled tin coffee pot, but the enamel is worn away. One 
Table 8.14. Metal cans

\begin{tabular}{|c|c|c|c|c|c|c|c|c|c|}
\hline Can Shape & Can Type & $\begin{array}{l}\text { House } \\
\text { Block }\end{array}$ & Midden & $\begin{array}{l}\text { Yard } \\
\text { Area }\end{array}$ & Outbuilding & $\begin{array}{c}\text { Total } \\
\text { by } \\
\text { Type }\end{array}$ & $\begin{array}{l}\text { Percent } \\
\text { by Type }\end{array}$ & $\begin{array}{c}\text { Total } \\
\text { by } \\
\text { Shape }\end{array}$ & $\begin{array}{c}\text { Percent } \\
\text { by } \\
\text { Shape }\end{array}$ \\
\hline \multirow[t]{5}{*}{ Cylindrical } & Hole-in-cap & 1 & 11 & 1 & - & 13 & $18.1 \%$ & \multirow[t]{5}{*}{37} & \multirow[t]{5}{*}{$51.4 \%$} \\
\hline & Sanitary & 5 & 2 & 1 & - & 8 & $11.1 \%$ & & \\
\hline & Screw top & 1 & - & - & - & 1 & $1.4 \%$ & & \\
\hline & Stamped end & 1 & - & - & - & 1 & $1.4 \%$ & & \\
\hline & Unknown & 5 & 7 & 1 & 1 & 14 & $19.4 \%$ & & \\
\hline \multirow[t]{4}{*}{ Rectangular } & Hole-in-cap & - & 1 & - & - & 1 & $1.4 \%$ & \multirow[t]{4}{*}{16} & \multirow[t]{4}{*}{$22.2 \%$} \\
\hline & Key wind & 1 & 2 & - & 1 & 4 & $5.6 \%$ & & \\
\hline & Screw top & - & 1 & - & - & 1 & $1.4 \%$ & & \\
\hline & Unknown & 9 & 1 & - & - & 10 & $13.9 \%$ & & \\
\hline $\begin{array}{l}\text { Probably } \\
\text { rectangular }\end{array}$ & Key only & 1 & - & - & - & 1 & $1.4 \%$ & 1 & $1.4 \%$ \\
\hline \multirow{2}{*}{$\begin{array}{l}\text { Unknown } \\
\text { shape }\end{array}$} & Hole-in-cap & - & - & - & 4 & 4 & $5.6 \%$ & \multirow[t]{2}{*}{18} & \multirow[t]{2}{*}{$25.0 \%$} \\
\hline & Unknown & - & 7 & 3 & 4 & 14 & $19.4 \%$ & & \\
\hline \multicolumn{2}{|l|}{ Total } & 24 & 32 & 6 & 10 & 72 & $100.0 \%$ & 72 & $100.0 \%$ \\
\hline
\end{tabular}

iron fragment is part of a shaker top, probably for something like a salt and pepper shaker. An iron fragment appears to be part of a flexible metal band from a spring-like utensil, probably something like tongs for handling food. The last three items are fragments of a pewter cup, an iron handle fragment from a small pot or pan (iron), and a fragment of an iron cork screw. The latter is interesting because a fragment of cork was also recovered (see Miscellaneous Household Hardware below).

\section{Household Furnishings}

Within the home, various furnishings would have made the living space more comfortable and personal. Other furnishings were essential for operating and maintaining the family's daily life. Early on, the only source of heat for cooking, cleaning, and warmth came from the fireplace. At some point, the Williams family acquired a wood-burning stove, and 18 cast-iron stove parts were recovered from excavations in the house block and midden (Table 8.15; see Table B.12). Based on one burner plate recovered from the house block, the implement appears to have been a simple two-burner stove, perhaps something like the "laundry stove" illustrated in the 1895 Montgomery Ward \& Company catalog (p. 422).
Forty artifacts are related to household furniture (Table 8.16; see Table B.10), and some of these items are illustrated in Figures 8.15 and 8.16. One piece of furniture that is well represented is a bed frame, with a bed wheel, casters, and caster inserts being recovered. The inserts are the pieces that fit into the leg of the bed to hold the casters and wheels in place. Two sets of bedstead irons were also found. These are the parts that help hold the frame together. One piece anchors to the bedpost, while the other connects the rail to the bedpost. A single bedfast with a pin rusted in place and three additional bedfast pins also were found. These are another mechanism for attaching the frame rails to the bedposts. It is unclear if all of this bed hardware could have all been from a single bed or if the hardware indicates multiple beds.

Many of the other furnishing artifactssuch as hinges, knobs, escutcheons, hooks, handles, and decorative screws and tacksrepresent pieces of household furniture that cannot be identified, but they hint at a variety of different furniture. The brass, iron, and wood knobs and brass ring pull are probably drawer pulls from several different pieces of furniture. The brass trunk plate is probably from a large storage trunk or foot locker. The marble base fragment has a hole through its center and may 


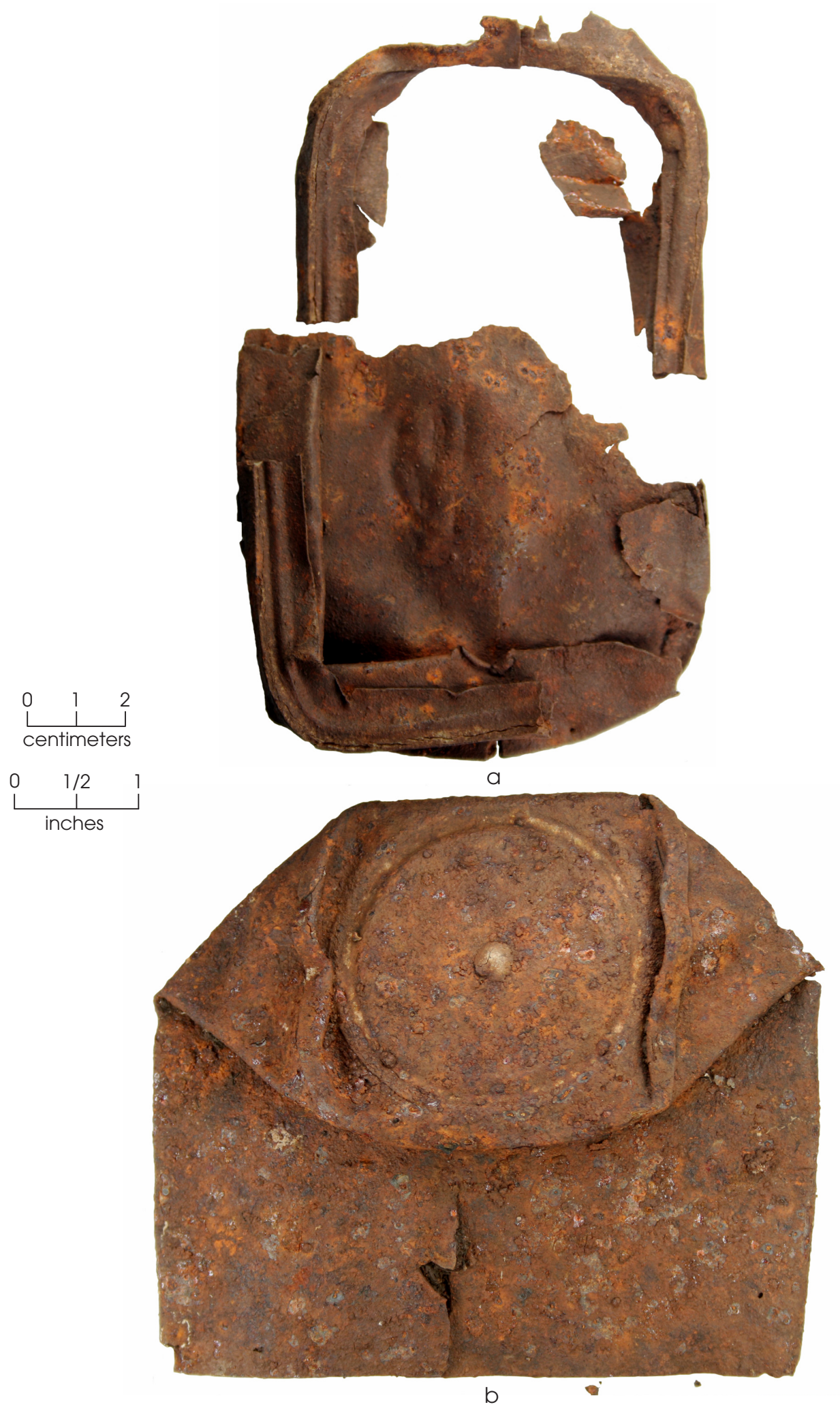

Figure 8.14. Metal (iron) cans. (a) A rectangular sardine-type can; (2) a hole-in-cap can. 
Table 8.15. Cast-iron stove parts

\begin{tabular}{l|c|c|c|c|c}
\hline \multicolumn{1}{c|}{ Artifact } & House Block & Yard Area & Midden & Outbuilding & Total \\
\hline Burner plates & 1 & - & 2 & 1 & 4 \\
\hline Burner plate divider & 1 & - & - & - & 1 \\
\hline Burner rings & 1 & 1 & - & - & 3 \\
\hline Burner lid & 1 & - & - & - & 1 \\
\hline Stove pipe fragment & - & 1 & - & - & 1 \\
\hline Stove feet & - & - & 2 & - & 2 \\
\hline Stove door or body fragments & - & - & 3 & 1 & 4 \\
\hline Undefined body parts & - & - & 9 & 3 & 18 \\
\hline Total & 4 & 2 & & - & 2 \\
\hline
\end{tabular}

Table 8.16. Furnishing artifacts

\begin{tabular}{|c|c|c|c|c|}
\hline Artifact (material) & House Block & $\begin{array}{c}\text { House Block, } \\
\text { Subfloor Pit }\end{array}$ & Midden & Total \\
\hline Bed casters (iron) & - & 1 & 1 & 2 \\
\hline Bed caster inserts (iron) & 3 & 1 & - & 4 \\
\hline Bedfast (iron) & 1 & - & - & 1 \\
\hline Bedfast pins (iron) & 3 & - & - & 3 \\
\hline Bedstead irons (iron) & 2 & - & 2 & 4 \\
\hline Bed wheel (iron) & - & - & 1 & 1 \\
\hline Escutcheons (brass) & - & - & 2 & 2 \\
\hline Furniture button (iron) & 1 & - & - & 1 \\
\hline Handle fragment (iron) & 1 & - & - & 1 \\
\hline Hat and coat hook (iron) & 1 & - & - & 1 \\
\hline Hinges (brass) & 4 & - & - & 4 \\
\hline Knobs (brass) & 3 & - & 1 & 4 \\
\hline Knob (iron) & 1 & - & - & 1 \\
\hline Knob (wood) & 1 & - & - & 1 \\
\hline Marble base & - & 1 & - & 1 \\
\hline Ring pull (brass) & 1 & - & - & 1 \\
\hline Rollers (iron) & - & - & 2 & 2 \\
\hline $\begin{array}{l}\text { Screw, probable hinge } \\
\text { screw (brass) }\end{array}$ & 1 & - & - & 1 \\
\hline Tacks, decorative (brass) & 1 & - & 1 & 2 \\
\hline Tacks, decorative (iron) & 1 & - & 1 & 2 \\
\hline Trunk plate (brass) & 1 & - & - & 1 \\
\hline Total & 26 & 3 & 11 & 40 \\
\hline
\end{tabular}




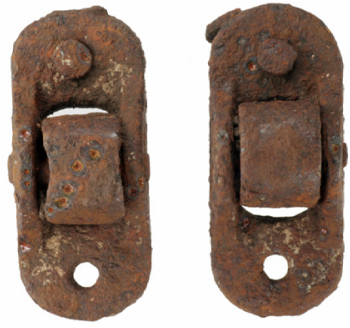

a

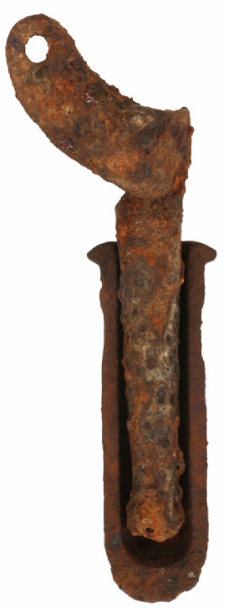

b
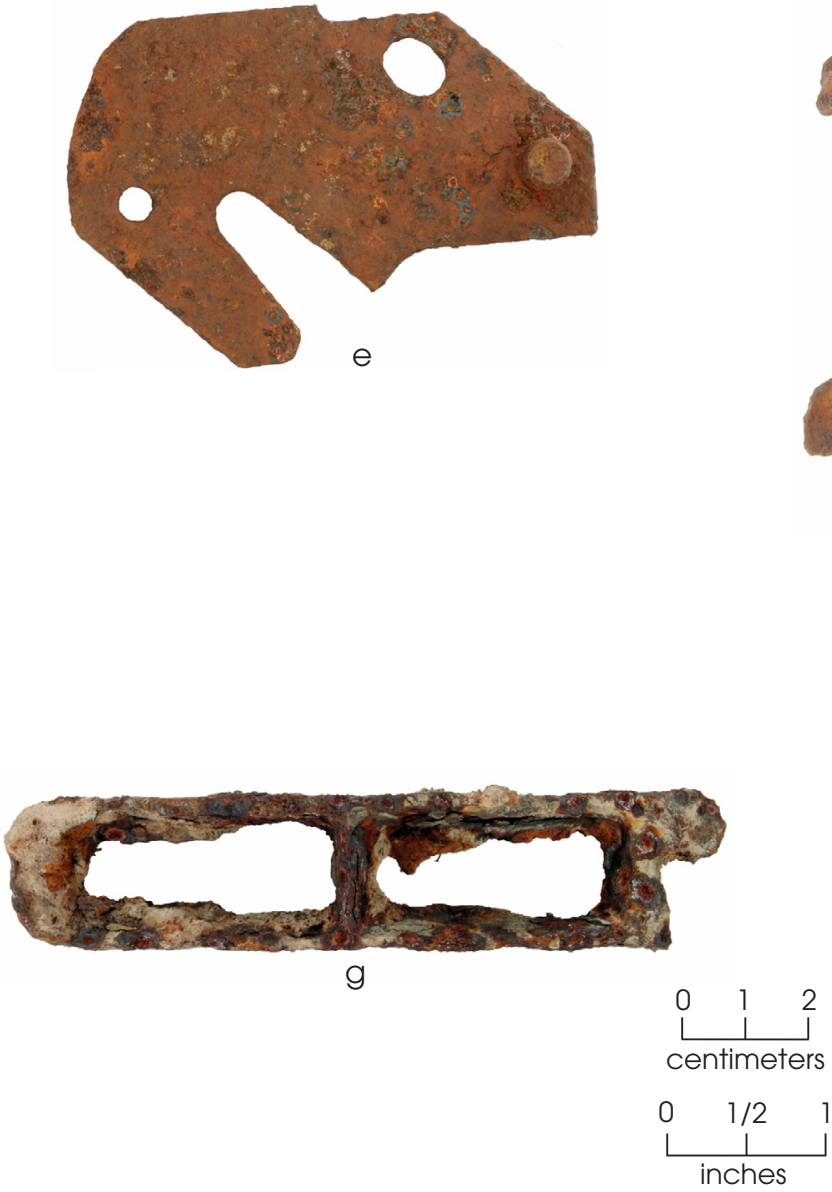
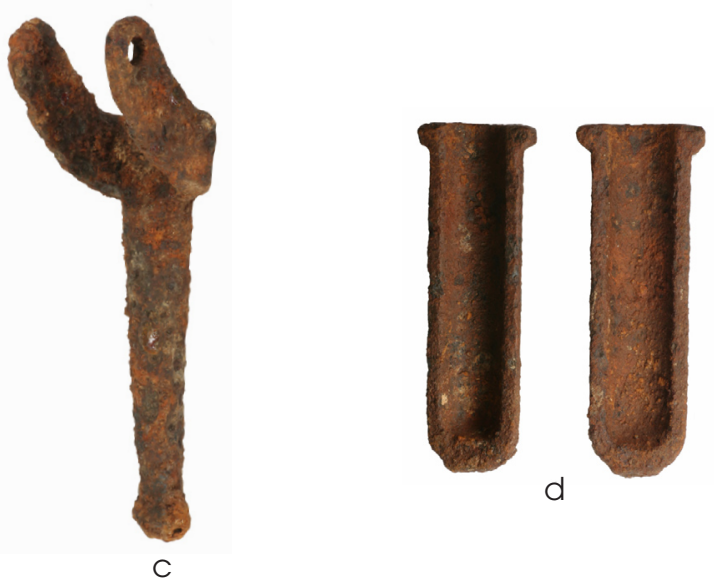

C
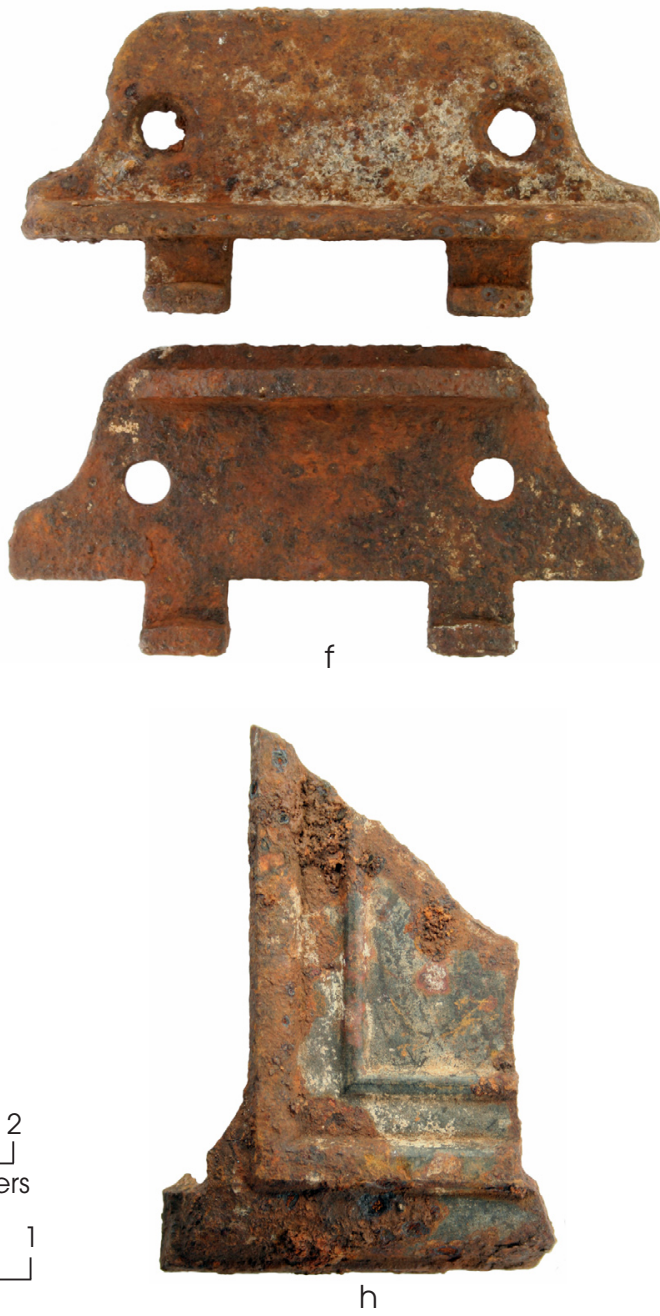

Figure 8.15. Selected furnishing artifacts. (a) Furniture rollers; (b-d) bed casters and caster inserts; (e) bedfast or bedrail hook; (f and g) bedstead irons; (h) stove door fragment with decorative design. 

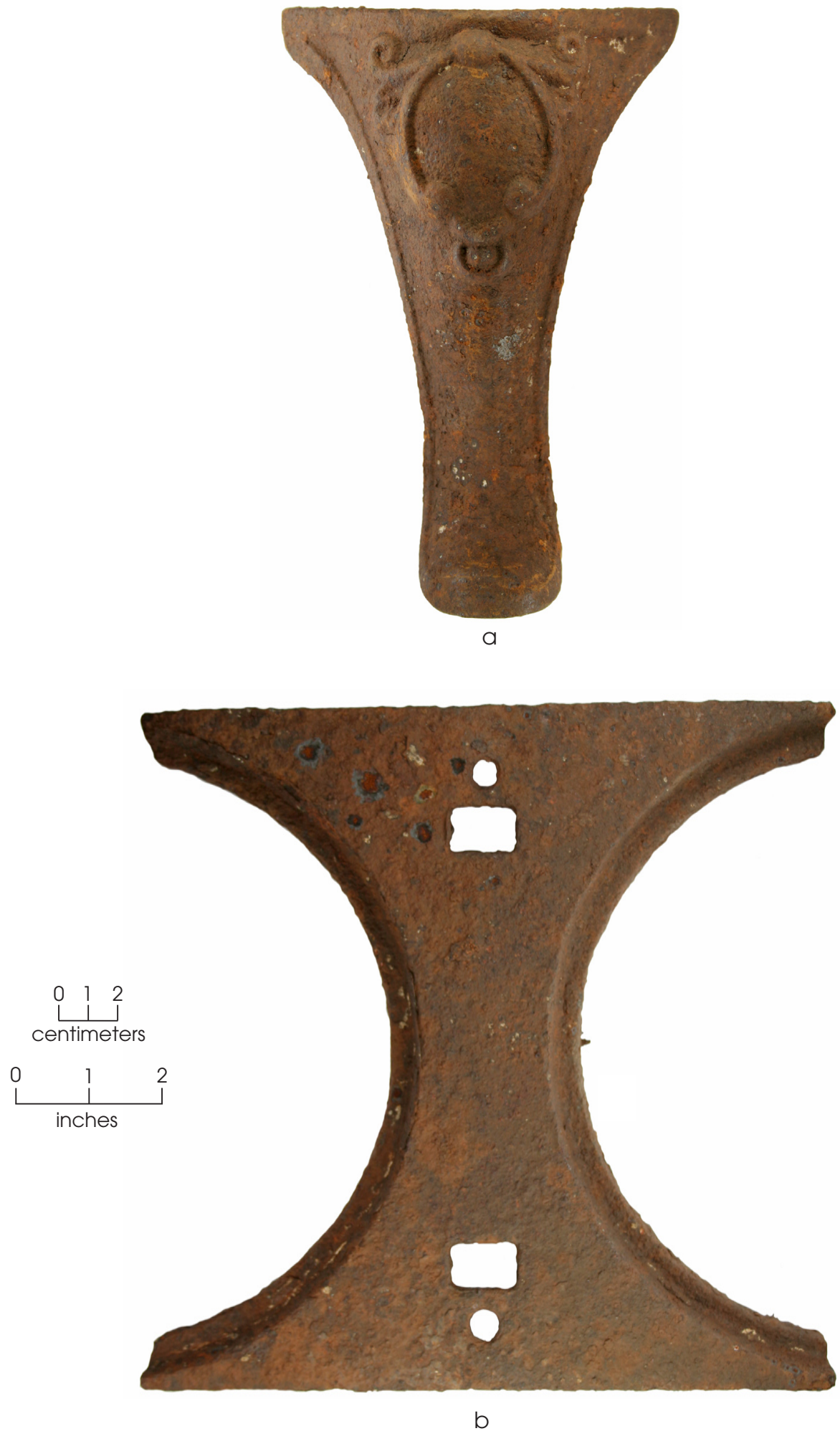

Figure 8.16. Cast-iron stove parts. (a) Stove leg with decorative design; (b) burner plate divider from a two-burner stove. 
have been a base stand for an ornamental oil lamp. The brass hinges and screws are probably from small boxes or furniture pieces. The hat and coat hook is a fragment (hook missing), but it had two screw holes for attaching it. It was probably attached to a wooden coat stand or might have been screwed into the wall by the door.

\section{Candle Lantern and Oil Lamps}

Another common furnishing item is represented by various parts of one candle lantern and several oil lamps (Table 8.17; see Table B.11). Five different oil lamp burner mechanisms were found in the house block (Figure 8.17), along with pressed glass fragments from at least three elaborately decorated lamp bases. Lamp chimney glass was recovered but was quite rare, with only two pieces found during the 2003 ACSG testing. This is not surprising because chimney glass is so fragile.

\section{Locks and Keys}

Three different padlocks, one lock latch, and four keys were recovered from the house block, suggesting that security was an important concern on the Williams farmstead (Figure 8.18; see Table B.13). It is unclear what the padlocks were used for, but they could have been used on storage trunks for privacy. A padlock could also have been to chain a wagon or equipment or added to the door of the house when the family moved to Austin about 1905. All of the padlocks and keys are corroded iron, and none has any identifiable markings.

One of the padlocks was found in the subfloor storage pit and is broken. ASCG archeologists recovered another padlock and the lock latch in 2003. These items were found in the same area and are illustrated by Staples and Nash (2003b:Figure 18). They are probably from the same lock.

\section{Other Furnishing Items}

Seven items are grouped as other furnishing items. Four specimens are fragments of a white-metal frame, probably from a picture or mirror frame. Two specimens are unidentified cast-iron pieces that may be parts of the stove described earlier. The final specimen is a brass escutcheon, essentially a small fragment of a decorative knob from an unknown type of furnishing.

\section{Miscellaneous Household Hardware}

The Kitchen and Household functional group includes one subgroup called miscellaneous household hardware that includes a variety of artifacts (Table 8.18; see Table B.14). Eight

Table 8.17. Candle lantern and oil lamp parts

\begin{tabular}{l|c|c|c|c|c|c}
\hline \multicolumn{1}{c|}{ Artifact } & $\begin{array}{c}\text { House } \\
\text { Block }\end{array}$ & $\begin{array}{c}\text { Yard } \\
\text { Area }\end{array}$ & $\begin{array}{c}\text { House } \\
\text { Block and } \\
\text { Yard Area }\end{array}$ & Midden & Outbuilding & Total \\
\hline Candle lantern fragment (iron) & 1 & - & - & - & - & 1 \\
\hline Lamp burners (brass) & 2 & - & - & - & - & 2 \\
\hline Lamp burner and collar (brass) & 1 & - & - & - & - & 1 \\
\hline Lamp burner and collar (iron) & 1 & - & - & - & - & 1 \\
\hline Lamp burner and cones (brass) & 2 & - & - & - & - & 2 \\
\hline Lamp burner fragments (brass) & 3 & - & - & - & - & 3 \\
\hline $\begin{array}{l}\text { Lamp base fragments (pressed } \\
\text { glass)* }\end{array}$ & 11 & 1 & 21 & - & 27 & 60 \\
\hline Lamp globe fragments (glass) & 2 & - & - & - & - & 2 \\
\hline Lamp wick adjuster (brass) & & - & - & 1 & - & 1 \\
\hline Total & 23 & 1 & 21 & 1 & 27 & 73 \\
\hline
\end{tabular}

* The 60 pressed glass fragments represent a minimum of three lamp bases, designated PG-1, PG-2, and PG-3. 


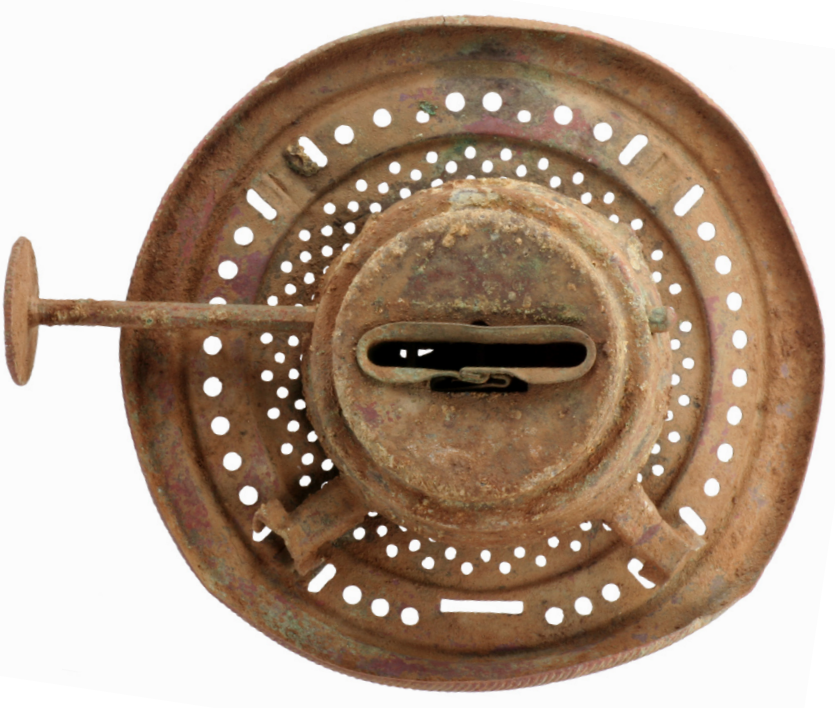

a

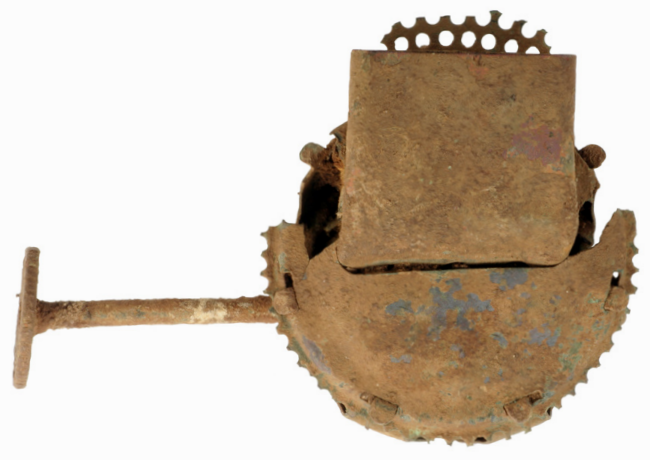

$\mathrm{C}$

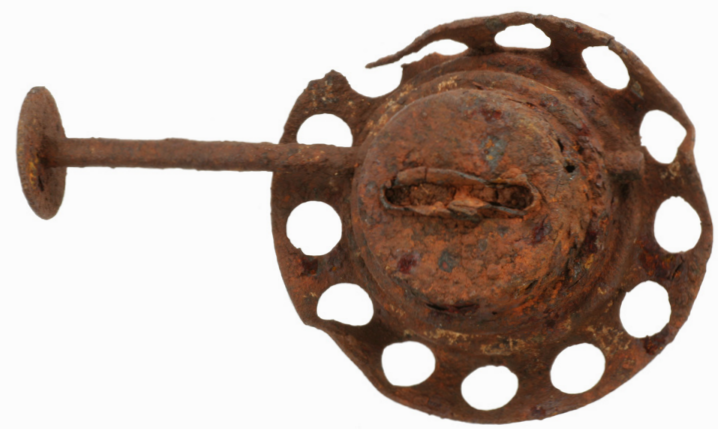

e
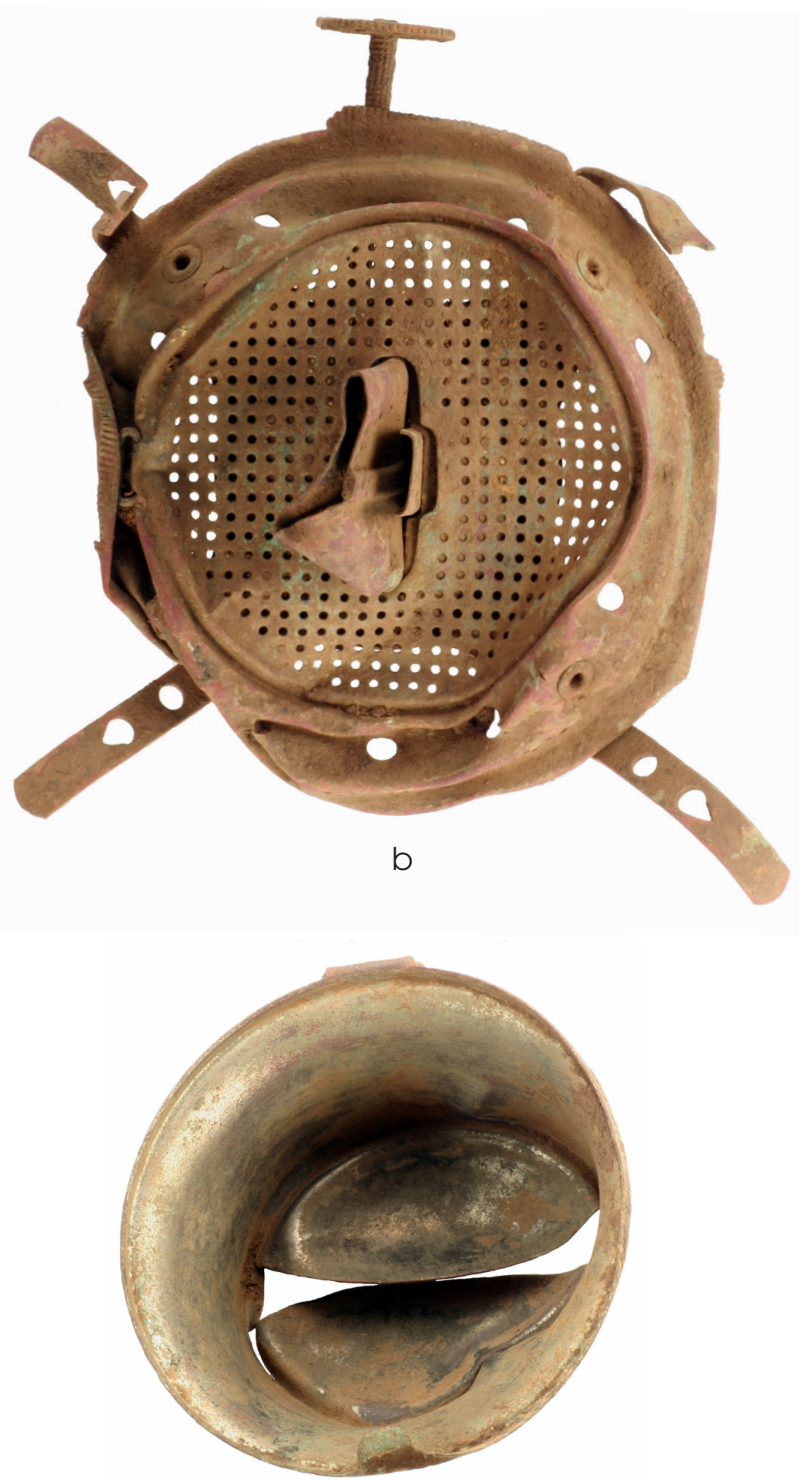

d
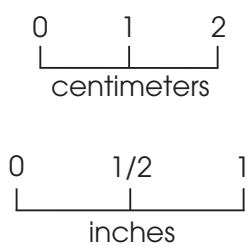

Figure 8.17. Five oil lamp burner mechanisms. (a-d) brass burners; (e) iron burner. 


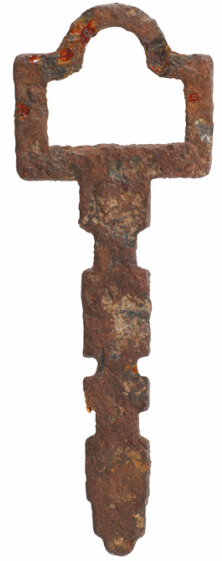

a

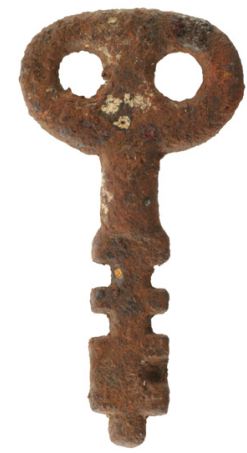

d
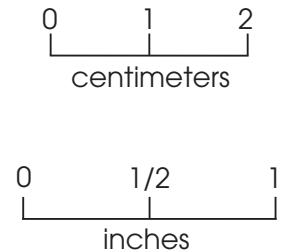
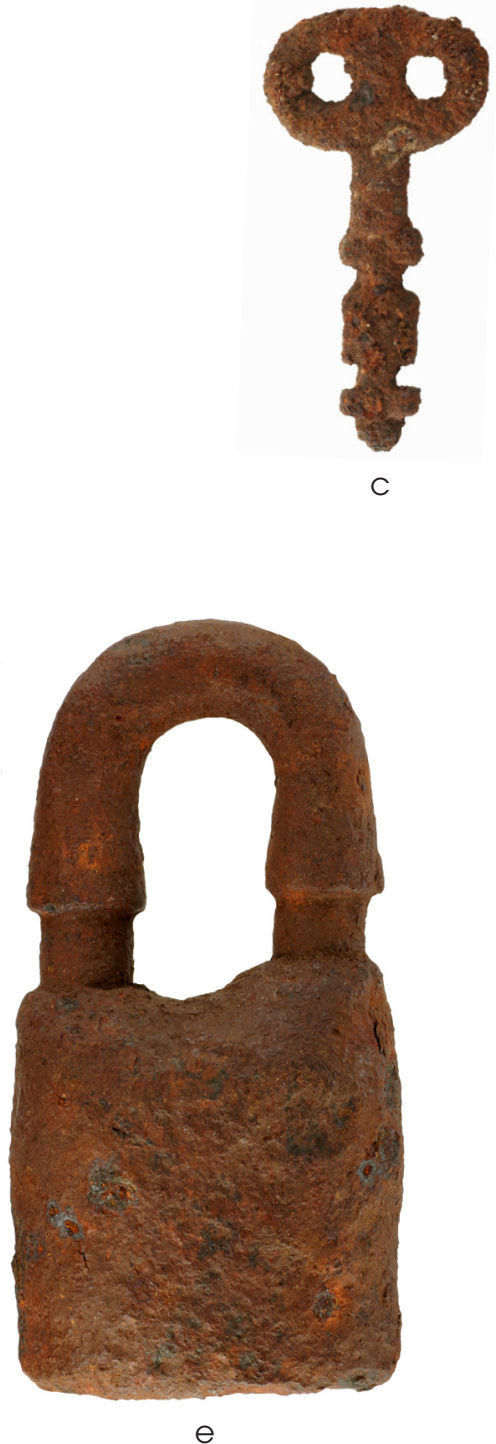

e

Figure 8.18. Assorted keys and a padlock. Note that $b$ and $c$ are matching keys.

of the items are wire handles, body fragments, and ears (tabs for connecting wire handles) from small pails or buckets used in a variety of different tasks. Some plain wire segments are identified as wire handles for pails or buckets due to their sizes and shapes. Similarly, a single body fragment from a bucket or pail was also found. Its size is unknown, but the general shape and location of a rivet indicate that it is likely a pail fragment. Other small, miscellaneous items include a small cork bottle stopper and an S-hook that would have held an object over the fire, most likely a cooking pot. Five fragments of a cast-iron grate form a panel that measures $13 \times 15$ inches and was found in the upper part of the subfloor storage pit. The grate could have been from a wood burning stove or was perhaps used in the fireplace and then discarded in the pit after it was broken. Because it was found in the storage pit below the original house floor, however, this 
Table 8.18. Miscellaneous household hardware*

\begin{tabular}{l|c|c|c|c}
\multicolumn{1}{c|}{ Artifact } & $\begin{array}{c}\text { House } \\
\text { Block }\end{array}$ & $\begin{array}{c}\text { House Block, } \\
\text { Subfloor Pit }\end{array}$ & Midden & Total \\
\hline Burner plate lifter (for wood stove) & 1 & - & - & 1 \\
\hline Cork bottle stopper & - & 1 & - & 1 \\
\hline Grate fragments (cast iron) & - & 5 & - & 5 \\
\hline Iron handle & 1 & - & - & 1 \\
\hline Pail ear (handle attachment for bucket or pail) & - & - & - & 1 \\
\hline S-hook (pot hanger) & - & 1 & - & 1 \\
\hline Vessel fragment (bucket or pail) & 1 & - & 1 & 2 \\
\hline Wire handles with pail ear (for bucket or pail) & 1 & - & 1 & 4 \\
\hline Wire handles (for bucket or pail) & 3 & - & 3 & 17 \\
\hline Total & 7 & 7 & 2 & 2 \\
\hline
\end{tabular}

* All artifacts are iron except for the cork bottle stopper.

grate might have been used as a flat plate to cap the pit (perhaps covered by a blanket) when it was still being used for food storage.

\section{ACTIVITIES ARTIFACTS}

The Activities category is a large group that contains many diverse types of artifacts representing a broad range of activities that occurred around a family farm. The 954 artifacts in the Activities group are classified as follows:

Carriage and wagon hardware

Construction hand tools

Farming

Horse tack and harness equipment

General hardware

168

Water storage 274

Firearms and hunting

Fishing

Music

Toys

Writing

Sewing

Collectibles

\section{Carriage and Wagon Hardware}

Transportation to and from the farm was limited to horses and mules and anything that could be pulled behind them. Being somewhat isolated on a working farm, the Williams family had a need for horse-drawn vehicles and a variety of equipment related to carriages and wagons. It cannot be stated with certainty which of the recovered items came from a wagon, carriage, or buggy, or how many of these types of vehicles might be represented. But most of the artifacts classified as carriage and wagon hardware are unquestionably related to some form of horse-drawn vehicle (Table 8.19; see Table B.34). Selected carriage and wagon hardware specimens are illustrated in Figures 8.19 and 8.20. Most of these items were identified using the illustrations in the reprinted version of the 1909 hardware catalog of the George Worthington Company (Spivey 1979), as well as illustrations in the catalogs of Montgomery Ward \& Company (1895) and Sears, Roebuck \& Company (1897, 1902a). It is notable that automobiles did not become common in central Texas until after the Williams family moved off the farm, and no automotive artifacts were found.

Some of the hardware is related to whiffletrees used for harnessing animals. Whiffletrees were wooden arms used to connect one or more draft animals to the tongue of the implement they were pulling, and they served to evenly distribute the pulling forces. The assemblage includes a whiffletree cockeye (or tongue), two center clips, five end clips (three of the latter have hooks attached), and a single hook. The end clips and hooks were attached to both end of a wooden whiffletree, and these were attached to chains or leather straps connecting the draft 
Table 8.19. Carriage and wagon hardware

\begin{tabular}{|c|c|c|c|c|c|c|c|c|}
\hline Artifact & $\begin{array}{l}\text { House } \\
\text { Block }\end{array}$ & $\begin{array}{c}\text { House } \\
\text { Block, } \\
\text { Subfloor } \\
\text { Pit } \\
\end{array}$ & $\begin{array}{l}\text { Yard } \\
\text { Area }\end{array}$ & Midden & Outbuilding & $\begin{array}{c}\text { Corral } \\
\text { Complex } \\
\end{array}$ & $\begin{array}{l}\text { Isolated } \\
\text { Surface }\end{array}$ & Total \\
\hline Brake shoe iron & - & - & - & 1 & - & - & - & 1 \\
\hline Chain swivels & 2 & - & - & - & - & - & - & 2 \\
\hline Clevises & 3 & - & - & - & 2 & - & - & 5 \\
\hline Clevis pin & 3 & 1 & - & - & - & - & - & 4 \\
\hline Corner iron & 1 & - & - & - & - & - & - & 1 \\
\hline Forged wagon nuts & 2 & - & - & - & - & - & - & 2 \\
\hline Iron straps & 1 & - & - & 2 & 3 & - & - & 6 \\
\hline Malleable ferrule & 1 & - & - & - & - & - & - & 1 \\
\hline Rivets & 2 & - & - & - & - & - & - & 2 \\
\hline $\begin{array}{l}\text { Wagon box side board } \\
\text { brackets }\end{array}$ & 4 & - & 1 & 1 & 1 & - & - & 7 \\
\hline Wagon box rod & 1 & - & - & - & - & - & - & 1 \\
\hline Wagon box rod collars & 2 & - & - & - & - & - & - & 2 \\
\hline Wagon box staples & 5 & - & 2 & - & 1 & - & - & 8 \\
\hline Wagon box straps & 2 & - & 1 & - & - & - & - & 3 \\
\hline Wagon box strap irons & 10 & 1 & 9 & 1 & 2 & - & - & 23 \\
\hline Wagon brake lock & - & - & - & - & - & - & 1 & 1 \\
\hline Wagon brake pawl & 1 & - & - & - & - & - & - & 1 \\
\hline Wagon seat brace & 1 & - & - & - & - & - & - & 1 \\
\hline Wagon seat/corner iron & 1 & - & - & - & - & - & - & 1 \\
\hline Wagon wheel hub & - & - & 1 & - & - & - & - & 1 \\
\hline Wagon wheel nut wrench & - & - & - & - & 1 & - & - & 1 \\
\hline Wagon wheel rough locks & - & - & - & 1 & - & 1 & - & 2 \\
\hline Wagon wheel skein & 1 & - & - & - & - & - & - & 1 \\
\hline Whiffletree center clips & - & - & - & 1 & 1 & - & - & 2 \\
\hline Whiffletree end clips & 3 & - & 1 & - & - & - & - & 4 \\
\hline $\begin{array}{l}\text { Whiffletree end clip and } \\
\text { hooks }\end{array}$ & 2 & - & - & - & 1 & - & - & 3 \\
\hline Whiffletree hook & 1 & - & - & - & - & - & - & 1 \\
\hline Whiffletree strap & - & - & - & - & 1 & - & - & 1 \\
\hline Whiffletree tongue & - & - & 1 & - & - & - & - & 1 \\
\hline Total & 49 & 2 & 16 & 7 & 13 & 1 & 1 & 89 \\
\hline
\end{tabular}

animal to the vehicle. The cockeye serves the same purpose as the end clip and hook; one end of the cockeye is threaded while an offset tab protrudes from the opposite end where the trace would attach. The threaded end was used to secure the cockeye through the whiffletree to replace a clip and hook.

Dominating the carriage and wagon hardware group are fragments of wagon box straps and strap iron, most of the latter with beveled 


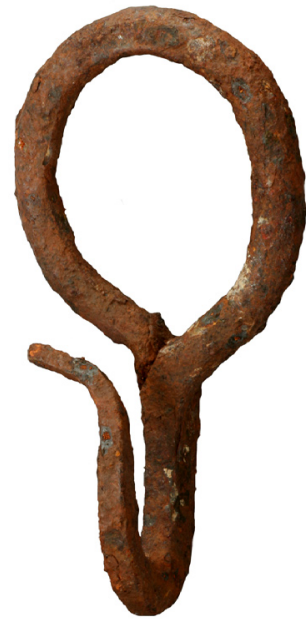

a
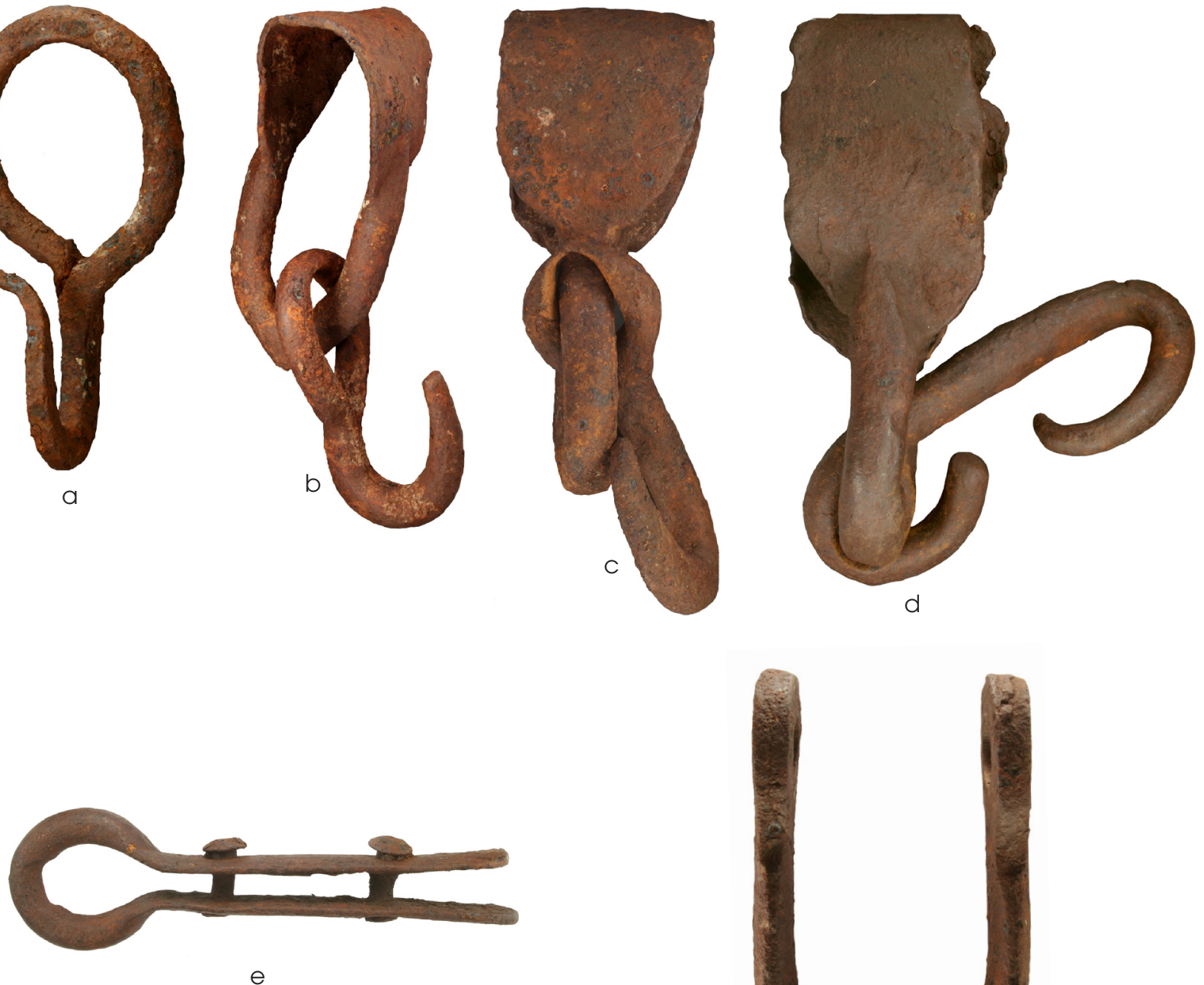

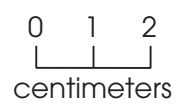

$\underbrace{1 / 2 \quad 1}_{\substack{0 \\ \text { inches }}}$
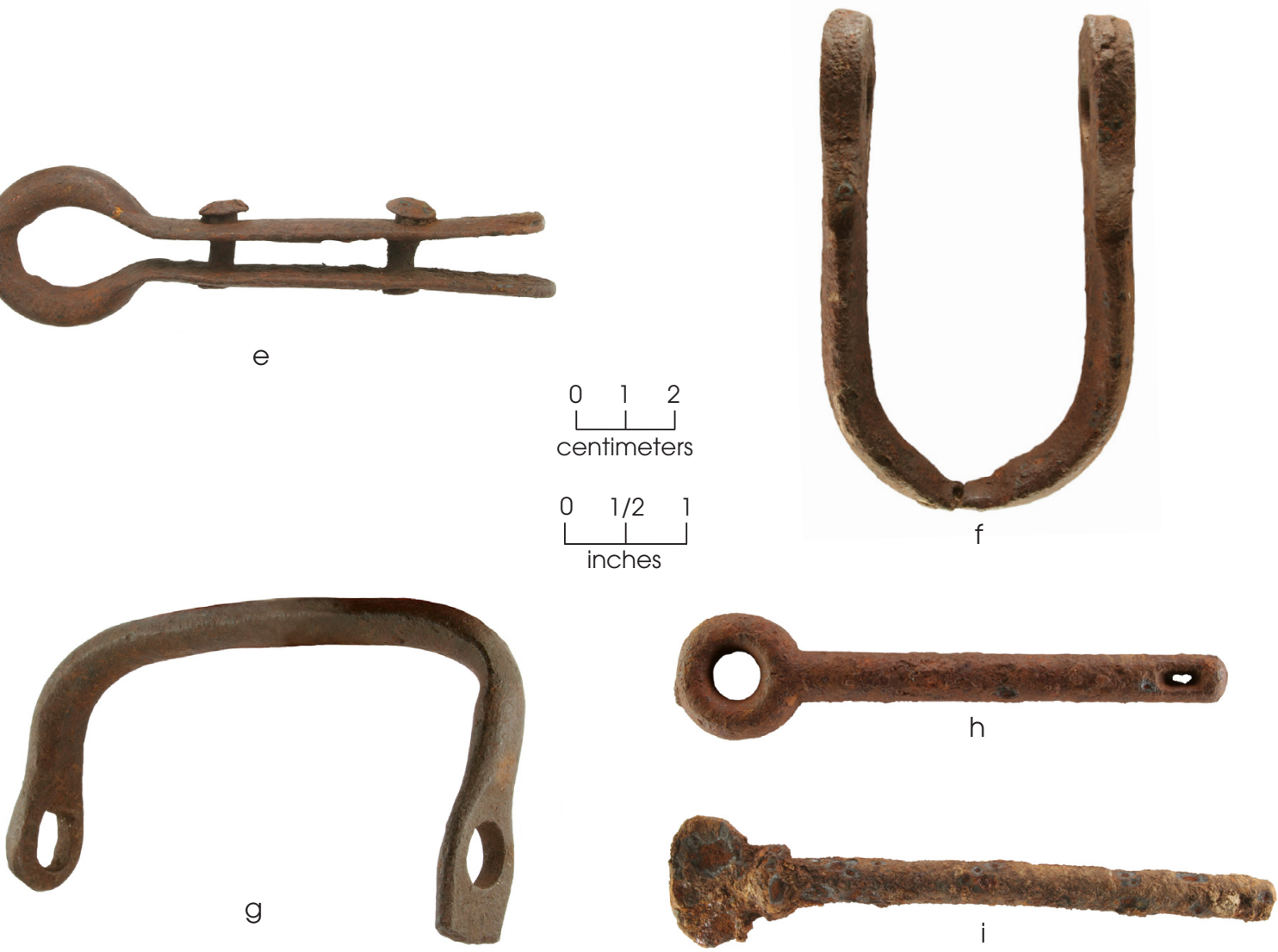

Figure 8.19. Carriage and wagon harness hardware. (a) Whiffletree hook; (b-d) whiffletree clips and hooks; (e) whiffletree end stap; (f and g) clevises; (h) clevis pin with perforated end; and (i) clevis pin with threaded end. 


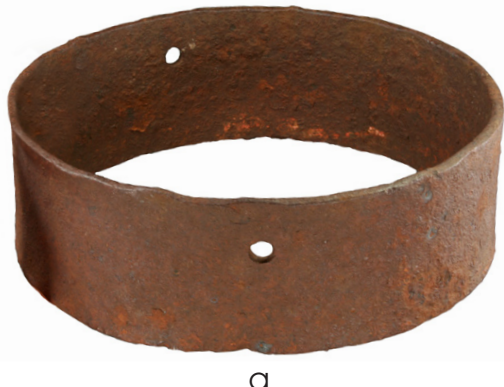

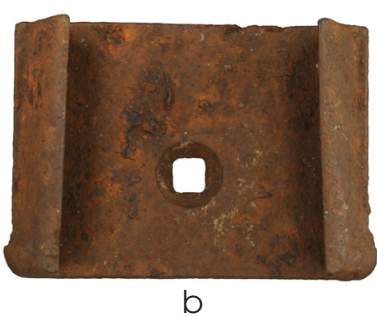

$\mathrm{b}$

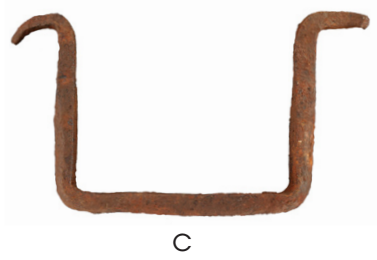

C
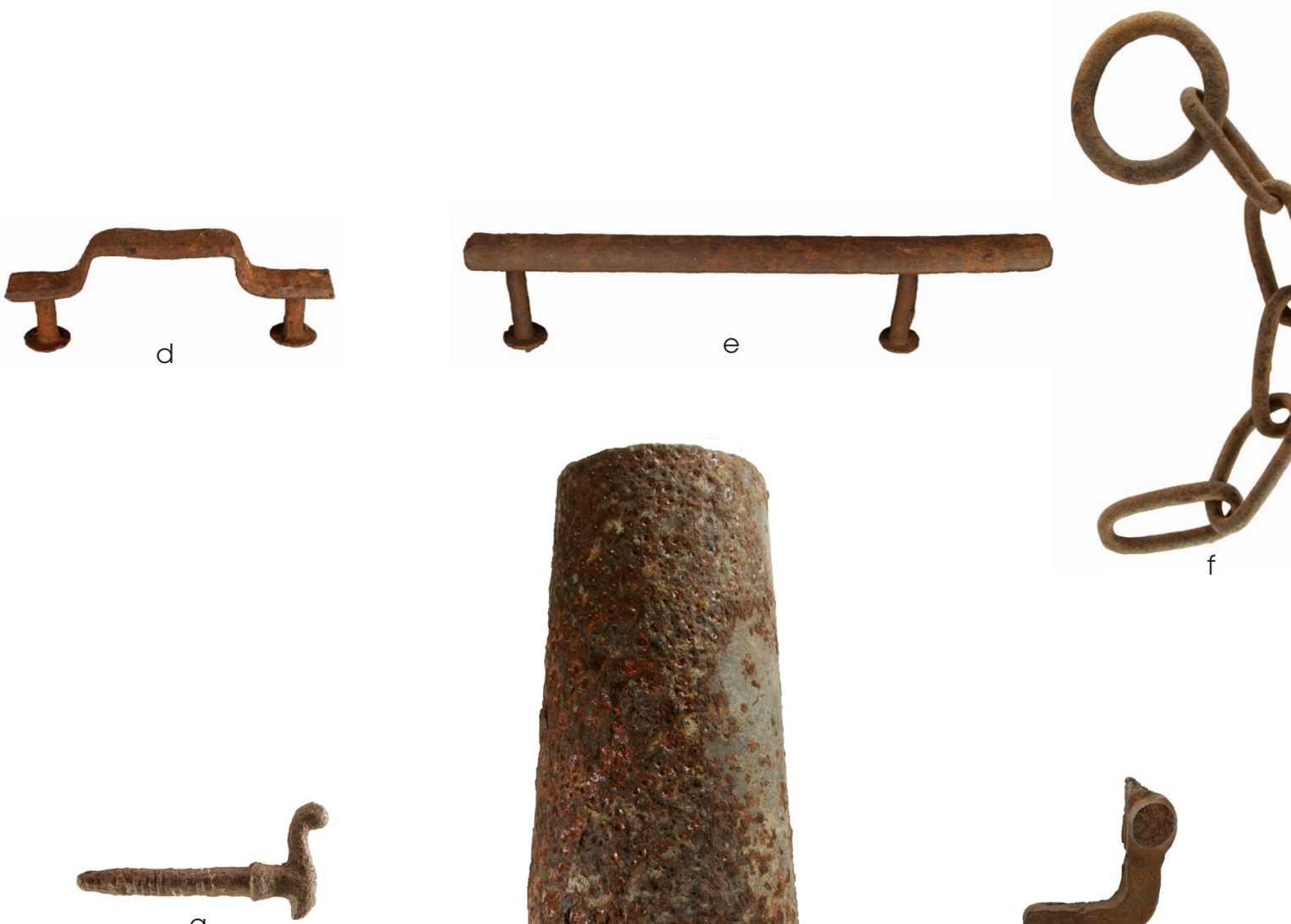

9
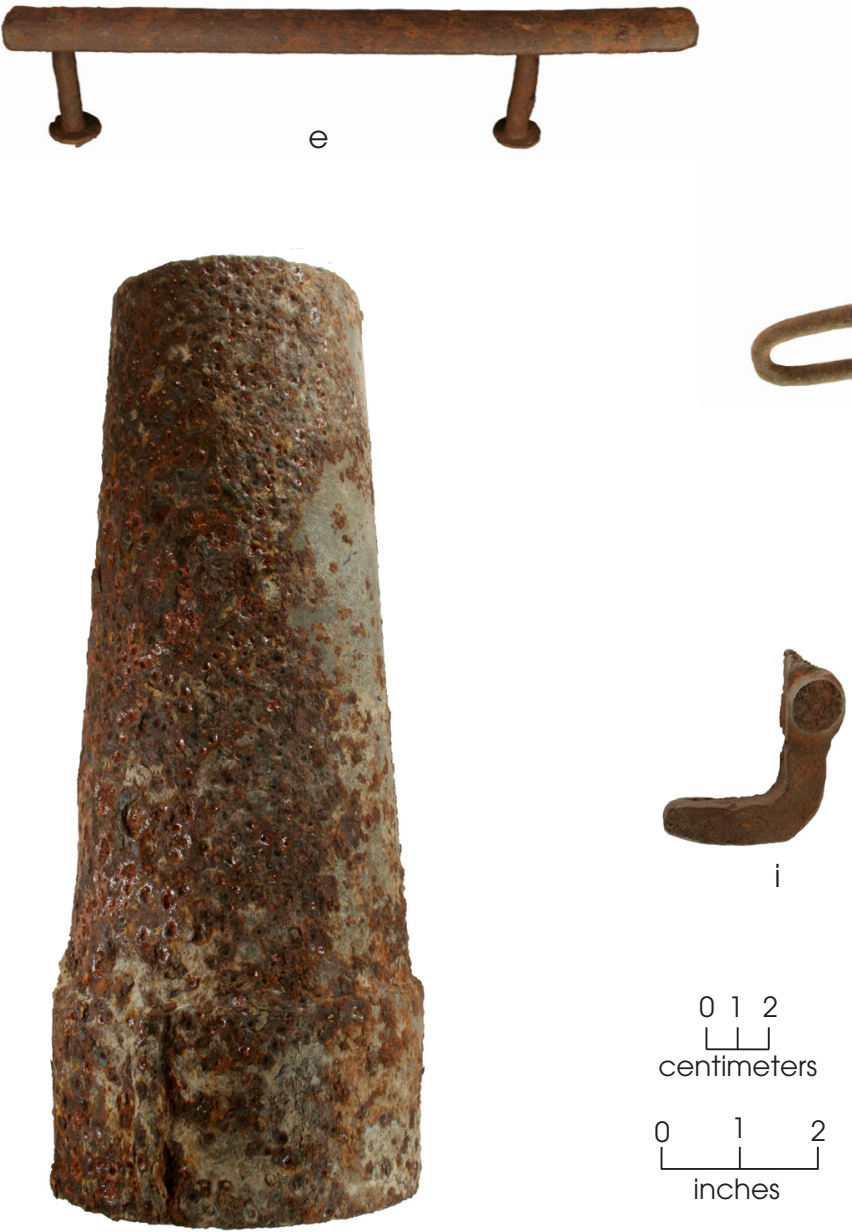

012
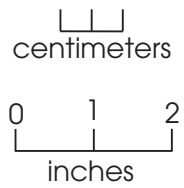

$\mathrm{h}$

Figure 8.20. Carriage and wagon artifacts. (a) Wagon wheel hub; (b) brake shoe iron; (c) wagon box staple; (d) side board bracket; (e) wagon box strap; (f) stay chain segment; (g) cockeye; (h) wagon wheel skein; (i) wagon wheel wrench fragment (box end). 
edges. These iron straps were used on various types of wagon boxes and were attached along the outside edges of the box to secure the wood and to help protect it from wear. With so many tools likely being tossed in and out of the wagon box, wooden box edges took a beating over time, and the use of iron straps helped prolong the life of the box. The iron strap metal was probably reused for a wide array of different tasks on the farm. A few iron strap fragments from the Williams farmstead were stamped with the name "WARRINGTON." Warrington is an industrial town in England, and by the late nineteenth century, it had been transformed into a metalworking town, particularly for manufacturing wire (Lambert 2010). Warrington might have made these straps specifically for use with wagons and other farm machinery. Conversely, these straps could have functioned originally as bands that bound rolls of wire together but were subsequently reused for repairing wagon boxes.

Several clevises and clevis fragments were recovered, along with clevis pins. A clevis is a U-shaped bracket with holes at the ends of the prongs where a clevis pin passed through. Some clevis pins are smooth, and some were held in place by a small cotter pin through a slot on the end. Other clevis pins are threaded and screwed into the bottom arm of the clevis. Clevises were used on many types of farm equipment that were pulled by draft animals, including wagons, carriages, and plows. At a minimum, this indicates that the Williams family owned some types of horse-drawn equipment, but it is uncertain whether these clevises are from wagons, carriages, or plows.

Other artifacts associated with carriages or wagons include side board brackets, box rod, box rod collars, wagon box staples, a wagon wheel hub, a wagon wheel skein, a wagon wheel nut wrench, and a wagon wheel rough lock. The two rough lock pieces are separate but could be from the same wheel lock. One specimen is a stay chain segment with a large iron ring attached and a chain swivel.

The most distinct and diagnostic wagon item is part of wagon brake lock found as an isolated surface artifact south of the house area and near the southern edge of the Williams property. This heavy iron specimen has an arm attached to a ratchet bar with teeth. The ratchet bar is marked "HURLBUT MAFG CO. PAT. MAY 21 1872" while the lower arm has "CALDWELL WAGON" on it (Figure 8.21). Because of the patent date, this artifact was easily identified as being a wagon brake mechanism based on S. S. Hurlbut's Patent No. 126,964 in May 1872 for an "Improvement in Wagon Brake Lock" (Hurlbut 1872). The "Caldwell Wagon" was a type of wagon made by the Kansas Manufacturing Company (whose president was Alexander Caldwell), of Leavenworth, Kansas, from 1874 to 1888 (Connelley 1918). This brake lock would have been equivalent to a parking brake on a car; it was part of a heavy braking mechanism to keep the wagon from rolling or being pulled away by horse before one was ready to depart. A single iron brake shoe bracket was also found.

\section{Construction and Hand Tools}

Various types of construction and hand tools were found across the farmstead, and a sample of these tools is illustrated in Figure 8.22. Many of the recovered items are related to woodworking, a common and important task on any farm. Some were undoubtedly used by Ransom Williams to build his log cabin and other improvements on the farm. The construction tools and hand tools are summarized in Table 8.20 (see Tables B.35, B.36, and B.37).

The most common tool type is the file. Eleven specimens recovered represent a minimum of eight different files based on types and sizes (see Table B.37). The assemblage from the Williams farmstead includes a variety of files suitable for sharpening metal tools. Five specimens are single-cut flat files, meaning that each file has a single set of parallel teeth at an oblique angle to the length of the file (Henry Disston \& Sons, Inc 1921:39). The flat files include three types: bastard, second cut, and smooth. Bastard files are coarse and have teeth that are spaced far apart. Smooth files are fine and have teeth spaced closely together. Second cut files have a number of teeth between bastard and smooth files. The other five specimens are taper files. Each one is triangular in cross section with a very slight rounding to the edges. This edge rounding was done so that when a saw was being sharpened it created a small, rounded gullet in between the saw teeth (Henry Disston \& Sons, Inc. 1921:45). Many of the teeth have long since corroded away, so it could not be determined how fine or coarse these files would have been, but enough segments of the teeth rows are present to determine that each file is single-cut. 


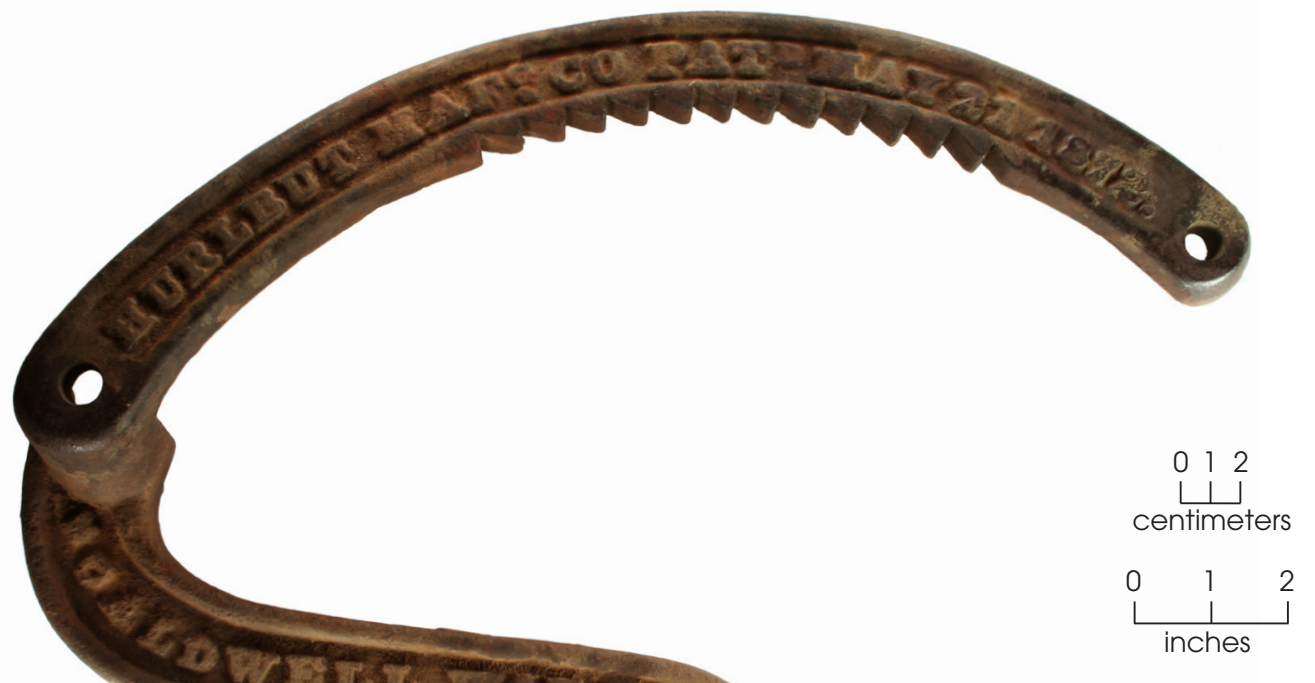

Improvement in Wagon-Brake Lock.
Patented May 21, 1872 .

No. 126,964 .

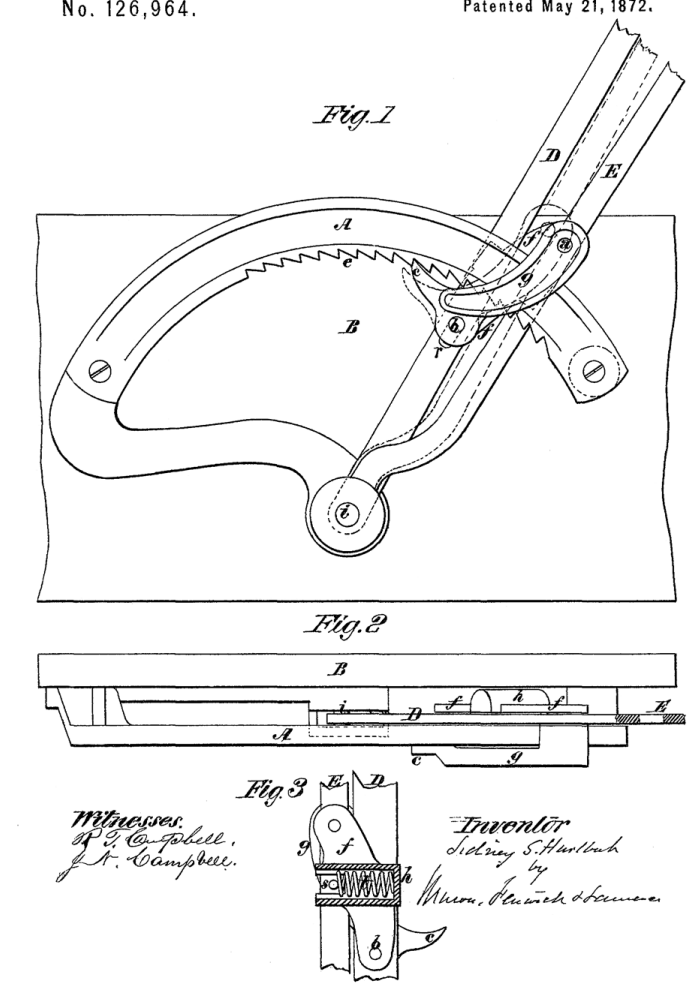

Figure 8.21. Brake ratchet and 1872 patent drawing for an "Improvement in Wagon-Brake Lock" by Hurlbut (1872). 

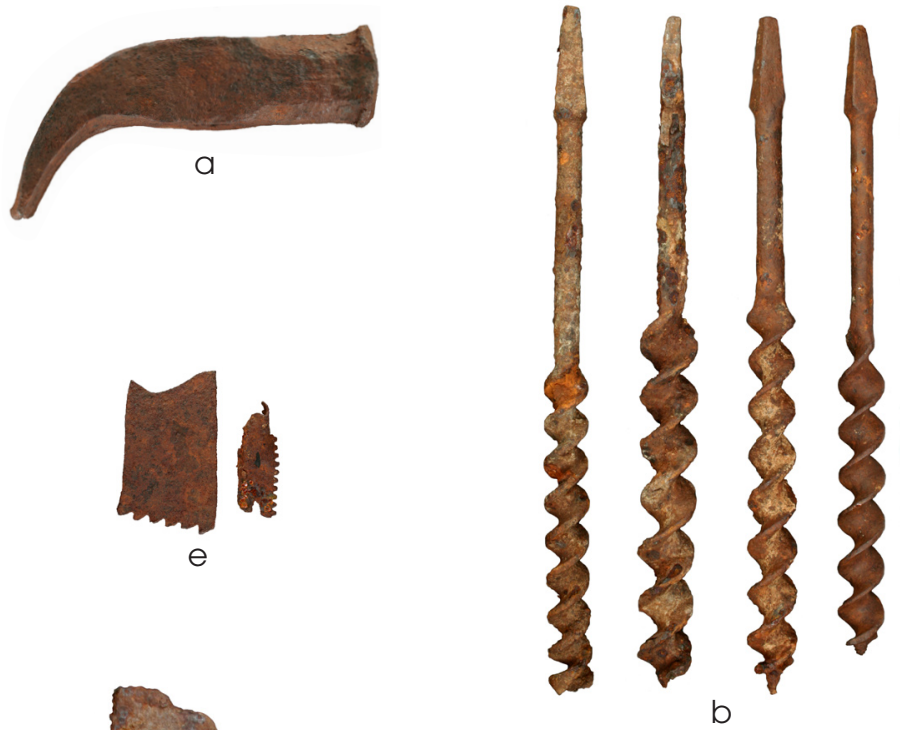

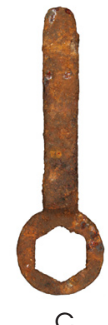

C

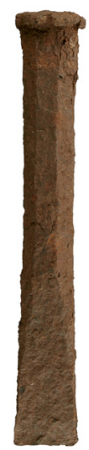

9

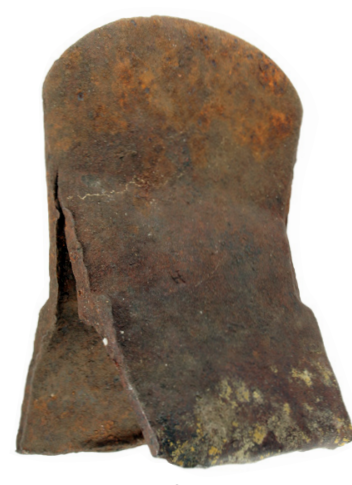

h

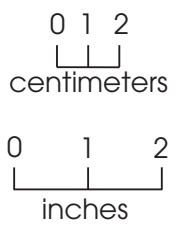

Figure 8.22. Construction and hand tools. (a) Claw hammer head; (b) auger bits; (c) box-end wrench for 11/16 nut; (d) flat and tapered file fragments; (e) saw blade fragments; (f) draw knife blade; (g) rock chisel; and (h) axe head split from use as a wedge. 
Table 8.20. Construction and hand tools

\begin{tabular}{|c|c|c|c|c|c|c|c|}
\hline Artifact & $\begin{array}{l}\text { House } \\
\text { Block }\end{array}$ & $\begin{array}{c}\text { House } \\
\text { Block, } \\
\text { Subfloor } \\
\text { Pit }\end{array}$ & $\begin{array}{l}\text { Yard } \\
\text { Area }\end{array}$ & Midden & Outbuilding & $\begin{array}{c}\text { Corral } \\
\text { Complex }\end{array}$ & Total \\
\hline Auger bits & 2 & 2 & - & - & - & - & 4 \\
\hline Auger bit fragments & 2 & 1 & - & - & - & - & 3 \\
\hline Auger bit shank fragment & 2 & 1 & - & - & - & - & 3 \\
\hline $\begin{array}{l}\text { Axe head, hand forged } \\
\text { (used as a wedge) }\end{array}$ & - & - & 1 & - & - & - & 1 \\
\hline Bench vise jaw & 1 & - & - & - & - & - & 1 \\
\hline Bucksaw turnbuckle & 1 & - & - & - & - & - & 1 \\
\hline Crank handles & 1 & - & - & - & 1 & - & 2 \\
\hline Draw knife (12-inch blade) & - & 1 & - & - & - & - & 1 \\
\hline Draw knife fragments* & - & - & - & - & - & 2 & 2 \\
\hline Files, flat & 4 & - & - & 2 & - & - & 6 \\
\hline Files, tapered & 4 & - & - & - & - & - & 4 \\
\hline File, tapered fragment & 1 & - & - & - & - & - & 1 \\
\hline Grindstone crank handle & 1 & - & - & - & - & - & 1 \\
\hline Grindstone roller wheel bracket & 1 & - & - & - & - & - & 1 \\
\hline Grindstone roller wheel cover & 1 & - & - & - & - & - & 1 \\
\hline $\begin{array}{l}\text { Grindstone roller wheel cover } \\
\text { (fragment) }\end{array}$ & 1 & - & - & - & - & - & 1 \\
\hline Hammer head & 1 & - & - & - & - & - & 1 \\
\hline Rock chisel & 1 & - & - & - & - & - & 1 \\
\hline Saw blade fragments & 1 & - & 2 & 1 & - & - & 4 \\
\hline Screw wrench & - & - & - & 1 & - & - & 1 \\
\hline Screwdriver fragment & 1 & - & - & - & - & - & 1 \\
\hline Wedge & - & - & 1 & - & - & - & 1 \\
\hline Wrench (box end) & - & 1 & - & - & - & - & 1 \\
\hline Total & 26 & 6 & 4 & 4 & 1 & 2 & 43 \\
\hline
\end{tabular}

* The two draw knife fragments refit.

Auger bits are the next most common type of hand tool, and four complete and six fragmentary auger bits were recovered (see Table B.37). The four complete bits closely resemble Russell Jennings auger bits pictured on page 361 of the 1895 Montgomery Ward catalog, with bore size increments of $1 / 16$ of an inch. The recovered bits measure $9 / 16,5 / 8,11 / 16$, and $3 / 4$ inches in bore diameter, and they appear to be part of a graduated set of drill bits. The fragmentary specimens include proximal shank fragments and distal bit sections, and the latter are both $5 / 16$ inches in diameter from two different bits.

In addition to the auger bits and files, an assortment of other hand tools and tool fragments was recovered. These are typical items that one would expect to be found on a late-nineteenth-century farmstead, including a hammer, chisel, screwdriver, and wrenches. Woodworking tools include an axe head, saw blade fragments, and a turnbuckle from a bucksaw. The axe head is hand-forged, but it was broken (split at the butt 
end) from repeated hammering and heavy use as wedge. ${ }^{102}$ Another important woodwork tool is represented by two draw knives, including two refit blade pieces and a nearly complete specimen with a 12-inch cutting blade. This size draw knife could be used for shaving tree bark to prepare logs for building a cabin and trim branches for making all types of wooden furniture.

One of the more interesting sets of artifacts are parts of a hand-cranked grindstone fixture that could be mounted on a homemade wooden frame. The mechanism would have turned a large grinding wheel used to sharpen metal-bladed implements. The 1895 Montgomery Ward \& Company (1895:408, Item 43458) catalog has a grindstone fixtures with parts similar to those found at the Williams farmstead, but the grindstone fixtures illustrated in the 1897 and 1902 Sears, Roebuck catalogs (Sears, Roebuck \& Company 1897:n.p., Item $13145 ; 1902 b: 703$, Item 35T1040) have identical roller wheel covers (Figure 8.23). The prices for these grindstone fixtures were the same in the 1897 and 1902 catalogs, ranging in price from 25 to 35 cents depending on the length of the crank shaft and the weight of the stone it would hold. At these prices, this simple model was much cheaper than the more elaborate self-contained grinding wheels, with some models listed for $\$ 1.60$ to more than $\$ 3.50$. This type of grindstone fixture would have been a relatively inexpensive item, but it was a necessity on the farm.

\section{Farming-Related Artifacts}

Direct evidence of farming is based on the recovery of 21 specific farming-related artifacts (Table 8.21; see Table B.47). ${ }^{103}$ Based on

\footnotetext{
${ }^{102}$ In July 2014, archeologist Matt Carter (personal communication, 2014) was conducting a karst survey for the SH $45 \mathrm{SW}$ roadway and found a similar split axe head. It had been battered so heavily that its butt end was splayed open to form a $\mathrm{T}$ shape. It was found about $100 \mathrm{~m}$ south-southeast of the Williams farmstead, inside the proposed road corridor but south of Williams southern property boundary.

${ }^{103}$ While this final report was being prepared, two identical artifacts in the "Unknown, Possibly Identifiable" category were identified. These specimens are rectangular iron objects found in EU 55 (Lot 186) and EU 61 (Lot 197) of the house block. They have been identified as cotton bale ties, and they closely match the drawings for Patent No. 31,252 for an "Improvement in Iron Ties for Cotton-Bales" (McComb 1861). These artifacts are described and illustrated at the end of this chapter.
}

the low frequency and types of farming tools, along with the conditions of the land (i.e., upland setting with poor soils), many of these tools likely were used for family gardening to produce food for domestic use. But it is also possible that some of the tools were used to produce cash crops that were sold outside the home. Figures 8.24 and 8.25 illustrate some of the farming-related artifacts.

The small farming hand tools include two garden hoes. One is a rectangular blade that retains its original shape but is heavily worn from years of use and resharpening. The other is heavily modified, and much of the blade has been cut away to form a long triangular pointed blade. The exact purpose of this modification is not known, but pointing the blade and shortening the hoe handle could have transformed a broken tool into a one-handed implement that would work well for planting seeds or precision weeding around flowers or vegetable plants. A set of pruning shears also was found. They are extensively corroded but appear to be a very plain general-purpose gardening tool.

The largest of the hand tools is a pick mattock head that is in good condition but heavily worn from years of intensive use (it appears that about half of the length of the original pointed pick end is worn away). The heavy iron blade is stamped with the word "...HUNT" and parts of other words that are virtually illegible due to use wear. Enough of the mark survives, however, to reveal that it originally was "W. HUNT" and the blade was probably also marked with "D.SHARP, MF'D BY DOUGLAS AXE MF'G CO.” The name W. HUNT is a registered trademark of the Douglas Axe Manufacturing Company, and the Douglas Axe Company Illustrated Catalog from 1873 (p. 9) states that W. HUNT was the company's stamp since its inception. Nelson (1999) notes that the company existed from 1836 to 1897 in East Douglas, Massachusetts, and it commonly used the trade name W. HUNT.

Several objects associated with plows and cultivators were recovered (see Figure 8.25). One clevis pin wrench likely came from a small oneor two-row plow. It is about 6 inches long and has an open-end wrench (for 3/4- to 7.8-inch nuts) on one end and bolt threads on the other. Images in the 1909 George Worthington Company catalog of wagon hardware and blacksmith supplies (Spivey 1979:36) shows nearly identical wrench clevis pins attached to elaborate plow clevises. 


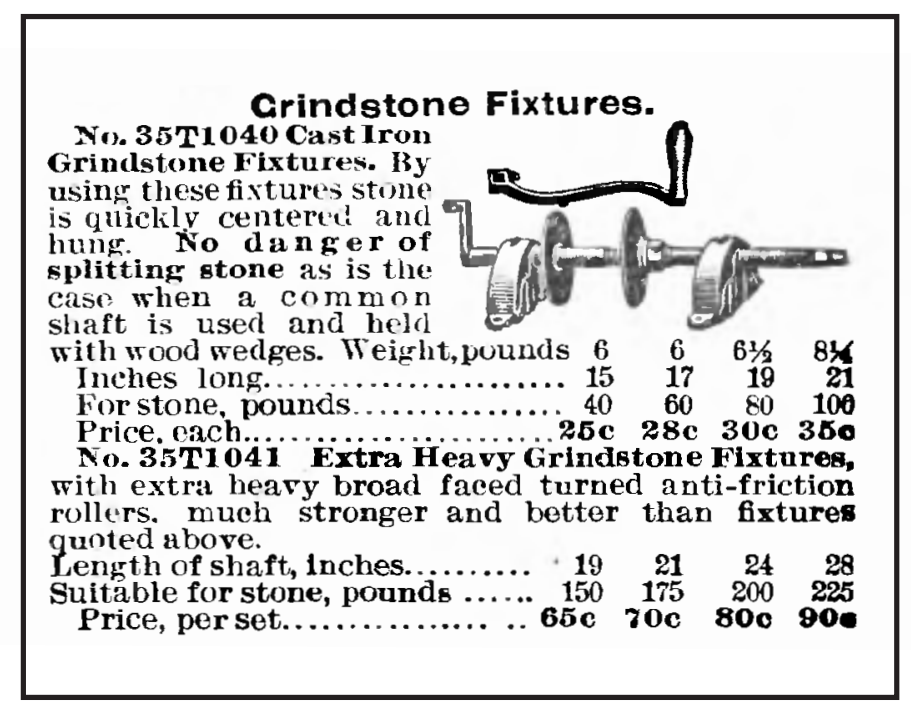

a

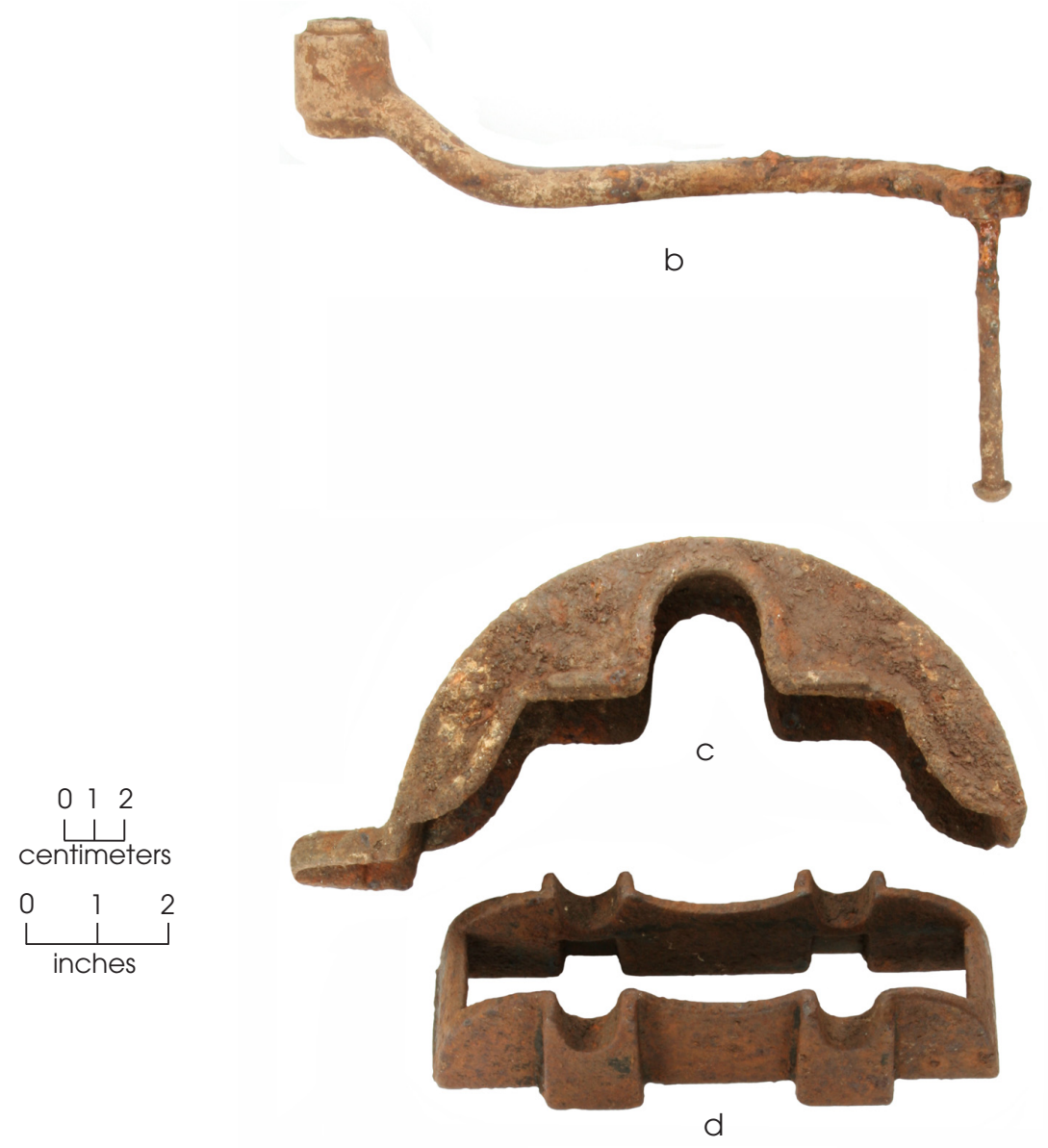

Figure 8.23. Grindstone fixture components. (a) Grindstone fixture as advertised in the 1902 Sears and Roebuck catalogue (Sears, Roebuck \& Company 1902b:703); (b) crank handle; (c) roller wheel assembly cover; (d) roller wheel bracket. 
Table 8.21. Farming-related artifacts*

\begin{tabular}{l|c|c|c|c|c}
\hline \multicolumn{1}{c|}{ Artifact } & House Block & Yard Area & Midden & Outbuilding & Total \\
\hline Clevis pin wrench & - & - & - & 1 & 1 \\
\hline Cultivator chain & 4 & 1 & 1 & 3 & 9 \\
\hline Ferrule (probably from hoe handle) & 1 & - & - & - & 1 \\
\hline Hoe blade & 1 & - & - & 1 & 2 \\
\hline $\begin{array}{l}\text { Pick mattock** (with identifiable maker's } \\
\text { mark) }\end{array}$ & 1 & - & - & - & 1 \\
\hline Plow jointer & 2 & - & - & & - \\
\hline Pruning shears & 1 & - & - & - & 1 \\
\hline Scale hanger hinge & 2 & - & - & - & 2 \\
\hline Scale hanger hook & 1 & - & - & - & 1 \\
\hline Scale counter weight & 1 & - & - & - & 1 \\
\hline Total & 14 & 1 & 1 & 5 & 21 \\
\hline
\end{tabular}

*This table does not include the two cotton bale ties that were identifed during the final preparation of this report. They are described and illustrated at the end of this chapter.

**Mattock head is stamped “...HUNT" and "D.SHARP, MF”D BY DOUGLASS AXE MF'G CO.” W. Hunt is a registered trademark of the Douglas Axe Manufacturing Co., which operated from 1836 to 1897 (Douglas Axe Manufacturing Company 1873; Nelson 1999).

It is notable that the wrench pins are the only style of clevis pin paired with plow clevises.

Several links of cultivator chain were recovered, indicating that the Williamses probably had some types of large farm equipment. All the chain links are rectangular, but there are two different sizes of links that are nearly identical in style: one type of chain has 1-inch-long links and the other has 2-inch-long-links. The smaller 1-inch size is the most common. These chain segments are probably drive chains from some type of one- or two-row farm implement such as a corn planter.

One of the recovered artifacts is certainly from a small plow or cultivator. It is a plow jointer blade that is about 6 inches long and has a square hole with a round beveled edge for a plow bolt on its shank. This type of blade was typically used on a single-horse cultivator, and the jointer blade was attached in front of the main plowshare. The purpose of the jointer is to break the ground ahead of the main plow slice to properly mix the soil (Bacon 1920:162).

Three of the farming-related artifacts are all parts of a balance scale, often called a cotton scale. In period catalogs from 1865 to 1909, they were called steelyards or scale beams (Montgomery Ward \& Company 1895:390;
Russell And Erwin Manufacturing Company 1865:315; Sears, Roebuck \& Company 1897:n.p., Items 1505 and $1506 ; 1902 a: 564 ;)$. Two of the items are hanger hinges; one was used to suspend the scale beam and the other to hang what was being weighed below the scale. The third part is a one-pound counterweight that would have been suspended from one end of the scale beam. Such scales were common on farms that raised cash crops and were used to weigh cotton, corn, vegetables or other crops intended to sell. The presence of these scale parts on the Williams farmstead suggests that the family was producing some type of commercial product.

\section{Horse Tack and Harness Equipment}

The Williams farmstead was powered by human and animal labor, and horses and mules were especially important. The farmstead assemblage includes a wide variety of horse-related tack and harness equipment. Many of the tack items (e.g., saddle and bridle parts) were essential for riding horses, and the horse harness items were used for hitching draft animals to various types of plows, cultivators, and wagons. This diversity of horse tack and harness parts 


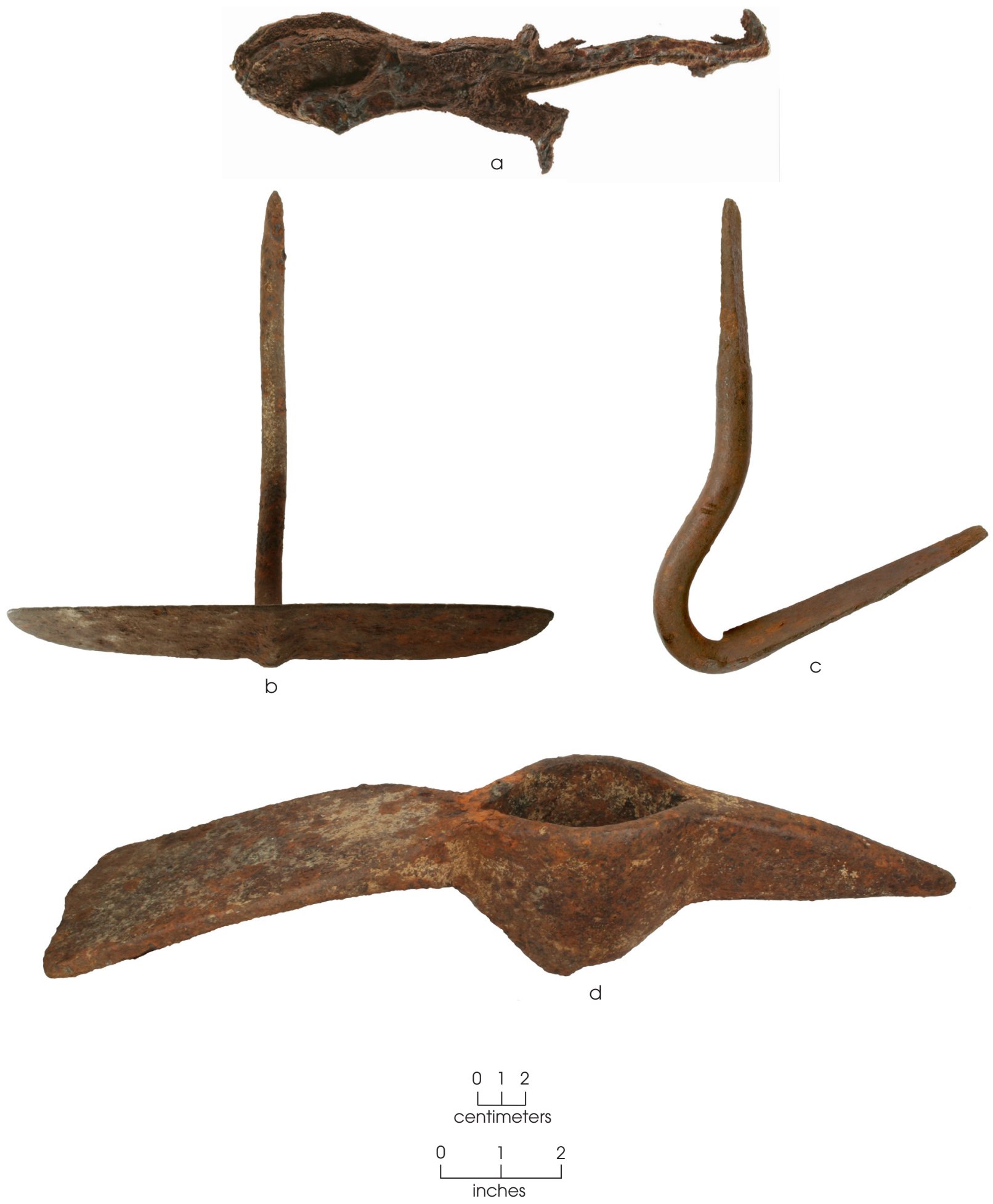

Figure 8.24. Farming-related hand tools. (a) Pruning shears; (b) rectangular hoe blade; (c) hoe blade sharpened to a long triangular point; and (d) pick mattock stamped with the name "...HUNT" and other illegible words. 


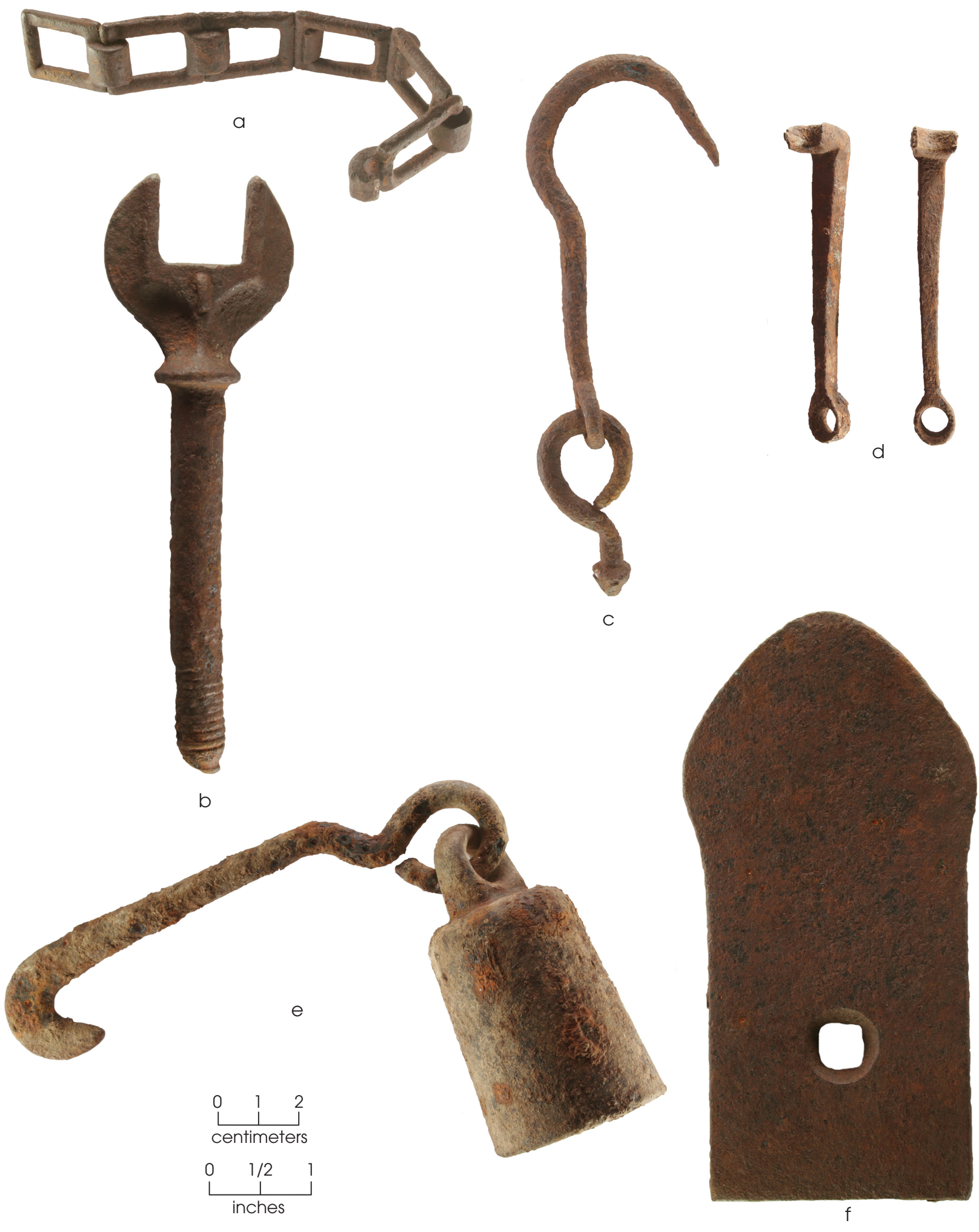

Figure 8.25. Parts of farming-related implements. (a) Cultivator chain segment; (b) cotton scale hanger hinges; (c) plow clevis pin wrench; (d) cotton scale hanger hook; (e) one pound cotton scale counterweight; and (f) plow jointer. 
demonstrates the importance of horses and mules as modes of transportation and labor for the Williams family. In addition, circumstantial evidence suggests that horses and mules could have been a source of outside income as well, perhaps raising animals for sale or by providing commercial hauling using mules and wagons (i.e., teamster services; see Chapter 5). The horse tack and harness equipment found at the farmstead is summarized in Table 8.22 (see Tables B.30, B.31, B.32, and B.33), and selected artifacts are illustrated in Figures 8.26 and 8.27.

Most bridles and harnesses had many buckles of different types and sizes. A total of 47 individual harness buckles were recovered (see Table B.30). Aside from the unidentifiable buckle fragments and specimens in the ACSG collection, 27 specimens are center bar buckles and 10 are roller buckles (Montgomery Ward \& Company 1895:327). Center bar buckles are rectangular frames with a center bar that has a tongue (or prong) looped around it. A harness strap would be looped and sewn around the center bar, with the tongue sticking out of a slot. A second harness strap would be threaded through the buckle and secured by poking the tongue through a hole in the strap. A roller buckles consists of a simple square or rectangular frame with a tongue looped around one end bar and a piece of thin sheet metal rolled into a tube around the other end bar. A leather strap would be looped and sewn around the end bar with the tongue sticking out through a slot, and a second leather strap would be passed through the buckle, slide easily over the roller, and be secured by poking the tongue through a hole in the strap.

Other horse tack includes cinch rings, dee rings, bridle bits, brass rivets, and miscellaneous buckles (see Table B.33). The cinch rings and dee rings are probably from Western-style riding saddles. A cinch strap (made of leather and woven fabric or rope) contains at least two round cinch rings. It served to secure (or cinch) the saddle onto the horse by going underneath the horse's belly just behind the front legs and attaching to the rigging dee (an attached dee ring), located on each side of the saddle, below the horn and in front of the fenders. Some saddles used two cinches, with front cinch attached to the front rigging dee and a rear cinch attached to the rear rigging dee (located below the cantle) and passing around the horse's loin. Other rings and cinch rings might be used to attach a breast strap to the saddle. In addition to the cinch and dee rings, some of the buckles mentioned above (including the simple harness and roller buckles) could have been used on various leather straps attached to the saddle.

Twenty-nine rivets representing four different styles were recovered. Twenty of the rivets measure 1/2 inch in diameter, and 16 of these were found in the outbuilding area, suggesting the presence of a shed or covered area where the horse tack was stored. Seven brass rivets measure $3 / 8$ inches in diameter, and each is marked "HENDRICKS \& BRS" on the underside. These were all found together in the midden area, and they probably came from a single piece of discarded horse tack. The other two styles of rivets are a single iron rivet (7/16-inch diameter) and a single copper (or softer brass) rivet (3/8-inch diameter). The styles are similar to the other horse tack rivets and differ only in material and size.

The maker of some of the 3/8-inch brass rivets is Hendricks and Brothers, a major manufacturer of copper and brass items in New York City. The name "Hendricks \& Brothers" was used from 1830 to 1861, and "Hendricks Brothers" was used from 1861 to 1938 . The earlier mark is on these specimens, perhaps indicating that Ransom Williams bought a piece of horse tack that was made before the Civil War or that he purchased some older rivets that he used to make or repair his own horse tack.

Other horse equipment in the Williams farmstead assemblage are the four bridle bits (the mouth piece). Two are snaffle bits and two are straight bar bits. All are from bridles that would have been used for riding horses or mules. All of these specimens are rather plain except for one half of an ornate snaffle bit that has a swivel cheek plate with a decorative shield-andstar design.

Besides the smaller harness buckles, two large strap buckles with teeth were found. They are similar in style, but one is a solid piece and one has a pivoting bar that served as a clamp to place tension on the strap to keep it from shifting. These buckles were probably attached to and secured large leather straps under great tension, most likely as part of some heavy-duty horse harness. One triangular-shaped specimen is identified as a trace buckle that served as an anchor where three trace straps came together, and adjustments could easily be made to 
Table 8.22. Horse tack and harness equipment

\begin{tabular}{|c|c|c|c|c|c|c|c|}
\hline Artifact & $\begin{array}{l}\text { House } \\
\text { Block }\end{array}$ & $\begin{array}{c}\text { House } \\
\text { Block, } \\
\text { Subfloor } \\
\text { Pit } \\
\end{array}$ & $\begin{array}{l}\text { Yard } \\
\text { Area }\end{array}$ & Midden & Outbuilding & $\begin{array}{c}\text { Corral } \\
\text { Complex } \\
\end{array}$ & Total \\
\hline Bolt snap & 1 & - & - & - & - & - & 1 \\
\hline $\begin{array}{l}\text { Breast strap slides } \\
\text { (fragment) }\end{array}$ & 2 & - & - & - & - & - & 2 \\
\hline $\begin{array}{l}\text { Bridle bit, ornate snaffle (one } \\
\text { half) }\end{array}$ & - & - & - & 1 & - & - & 1 \\
\hline Bridle bit, plain snaffle & 1 & - & - & - & - & - & 1 \\
\hline Bridle bit, straight bar & 1 & - & - & - & 1 & - & 2 \\
\hline Bull snap & 1 & - & - & - & - & - & 1 \\
\hline Cinch rings & 12 & - & 4 & 2 & - & 2 & 20 \\
\hline Dee ring & 1 & - & - & - & - & - & 1 \\
\hline Harness buckles & 25 & 4 & 5 & 5 & 6 & 1 & 46 \\
\hline Harness cockeye & - & - & 1 & - & - & - & 1 \\
\hline Hook and eye fasteners & 1 & - & - & 3 & - & - & 4 \\
\hline Horse brand - "R" & 1 & - & - & - & - & - & 1 \\
\hline Horseshoe nails & 15 & 1 & 4 & 8 & 4 & - & 32 \\
\hline Horseshoes & 3 & - & 3 & 2 & 2 & - & 10 \\
\hline Horseshoes (fragments) & 1 & - & - & 1 & 1 & - & 3 \\
\hline Muleshoes & 2 & - & - & - & - & - & 2 \\
\hline Metal buckle (unidentified) & - & - & 1 & - & - & - & 1 \\
\hline $\begin{array}{l}\text { Metal plate buckle } \\
\text { (unidentified) }\end{array}$ & 1 & - & - & - & - & - & 1 \\
\hline Rivets (brass) & 2 & - & - & 11 & 14 & - & 27 \\
\hline Rivet (copper or soft brass) & - & - & - & 1 & - & - & 1 \\
\hline Rivet (iron) & - & - & - & 1 & - & - & 1 \\
\hline Spur (brass, style 1) & - & - & - & 1 & - & - & 1 \\
\hline Spur (brass, style 2) & 1 & - & - & - & - & - & 1 \\
\hline Spur fragments (iron) & 2 & - & - & - & - & - & 2 \\
\hline $\begin{array}{l}\text { Spur fragment (iron, child's } \\
\text { spur) }\end{array}$ & - & - & - & 1 & - & - & 1 \\
\hline Strap buckles & 1 & - & 1 & - & - & - & 2 \\
\hline Tension strap buckle & - & - & - & 1 & - & - & 1 \\
\hline Trace buckle & 1 & - & - & - & - & - & 1 \\
\hline Total & 75 & 5 & 19 & 38 & 28 & 3 & 168 \\
\hline
\end{tabular}

lengthen or shorten each of the straps. A breast strap slide was found in the earlier testing by ACSG, and it matches a breast strap slide fragment recovered by PAI. The collection also has a harness cockeye that probably attached to a whiffletree tongue. It would have been attached to the end of a leather strap so that the eye pivoted on the end of the strap.

Two different snaps were recovered during excavations. One is a bolt snap, with the spring 

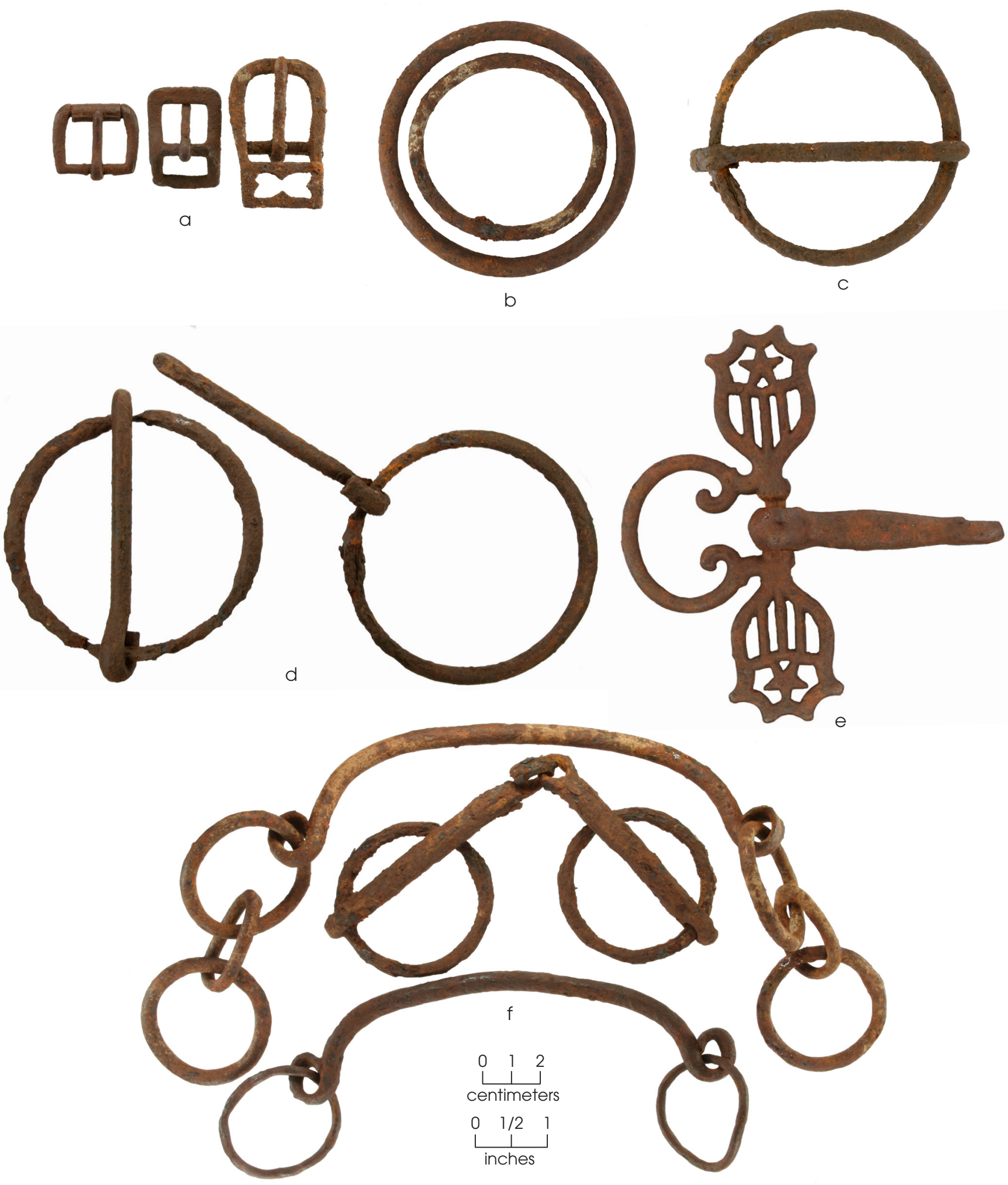

Figure 8.26. Selection of horse tack. (a) Harness buckles (left to right are roller, center bar, and decorative center bar); (b, c, and d) cinch rings (with and without tongues); (e) ornate snaffle bit; (f) bridle bits (top to bottom are large straight bar, simple snaffle, small straight bar). 

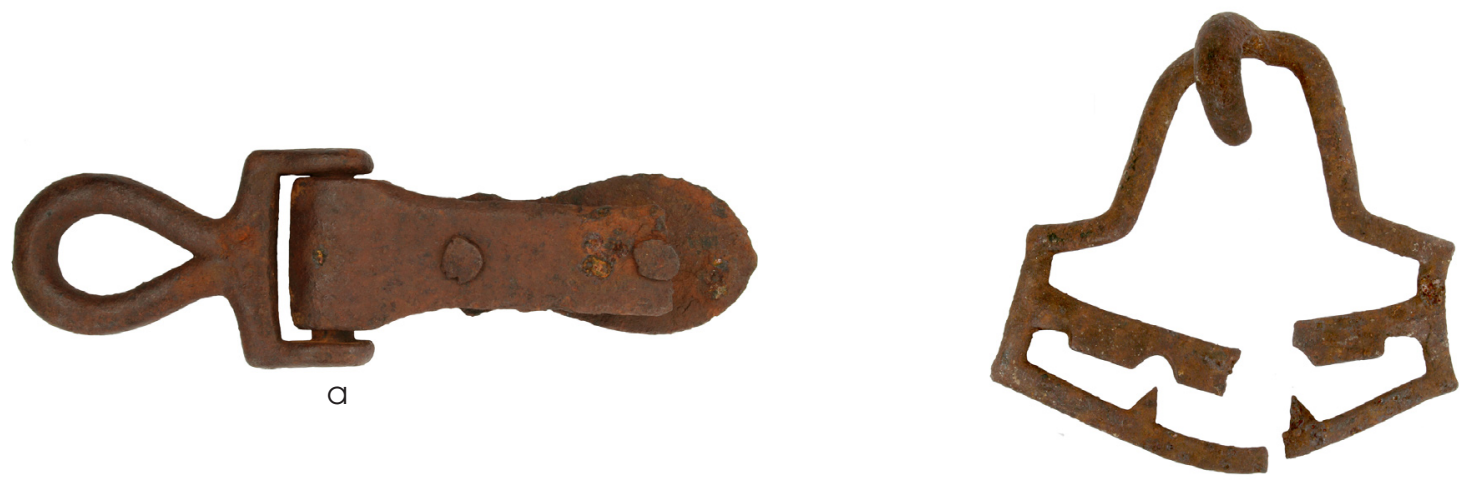

b
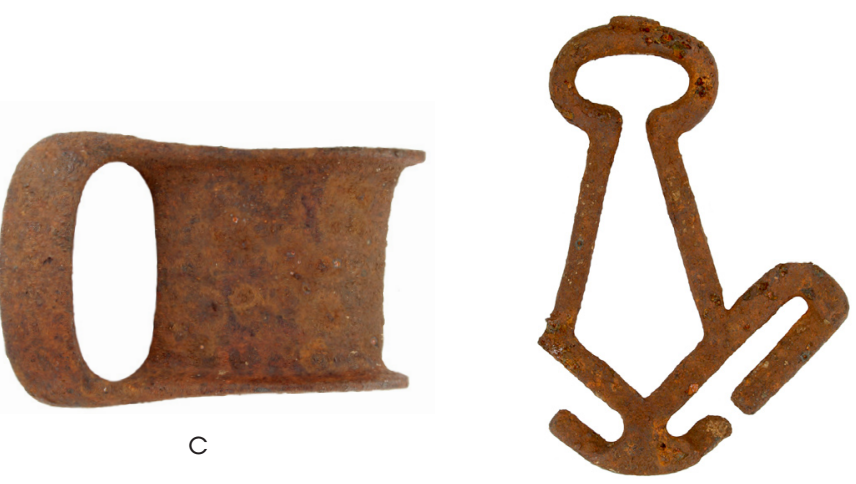

d

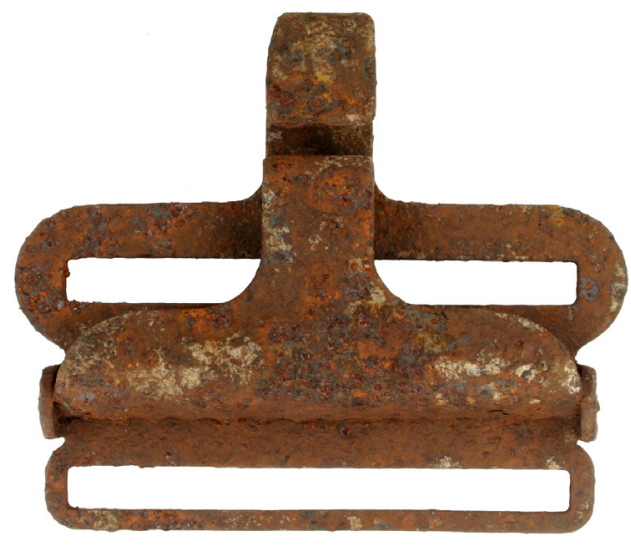

e
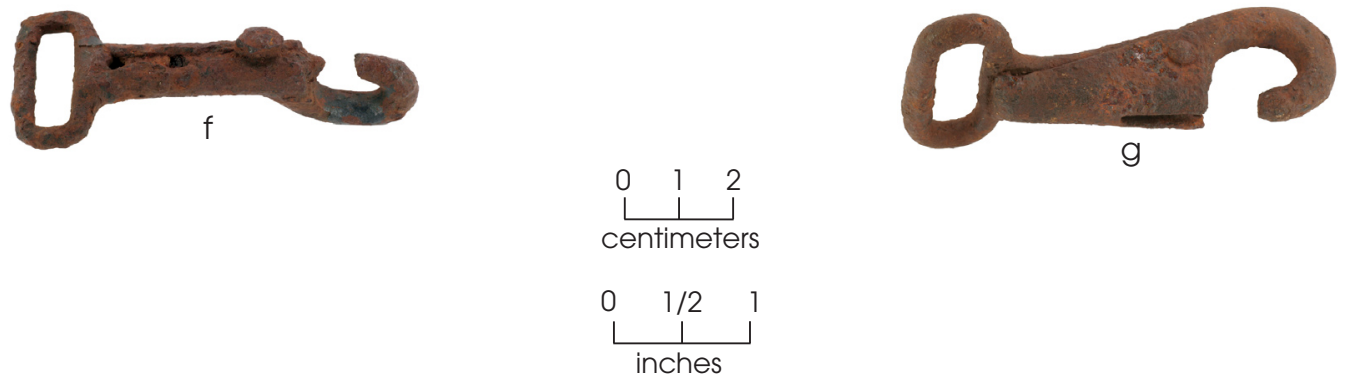

Figure 8.27. Selection of iron harness hardware. (a) Harness cockeye; (b) unidentified buckle; (c) breast strap slide fragment; (d) trace buckle; (e) strap buckle; (f) bolt snap; (g) bull snap. 
that operates the thumb piece still in place. Only a small fragment of the closure is missing. This bolt snap would have been attached to a rope or leather strap, and the snap end could be quickly snapped onto something else. This type of snap was commonly used on the end of a lead rope so it could be attached to a horse halter to lead the animal. The other type of snap is a bull snap. It is similar to the bolt snap and they both functioned in the same way, but the bull snap closure is different. On the bull snap, a small spring-loaded metal tab swivels to open and close the hook. On this specimen the swivel tab is missing, but the closure hook is intact.

Ten horseshoes, 3 horseshoe fragments, and 2 muleshoes were recovered (Figure 8.28; see Table B.31). Some could not be measured because they were broken, but eight horseshoes are size 00 (5 $1 / 4$ inches long by $41 / 2$ inches wide) and one shoe is size 1 ( 6 inches long by $51 / 4$ inches wide). ${ }^{104}$ The two muleshoes are different sizes. One measures 5 $1 / 4$ inches long by $33 / 4$ inches wide, and the other is $41 / 2$ inches long by $31 / 2$ inches wide. To go along with the horseshoes, 33 horseshoe nails were found (see Table B.32). The shoes and nails provide evidence that Williams had horses and mules on the Williams farmstead, corroborating the tax records that indicate that Ransom Williams owned some horses and mules almost every year he lived on the property (see Table 5.2). Although a farrier could have come to his property on occasion, it is likely that Ransom Williams shod his own horses and mules.

Perhaps the most interesting of all the horse-related artifacts is a hand-forged iron letter "R" found near the northwest corner of the house (Figure 8.29). It is part of the working end of a branding iron. Travis County records show that Ransom Williams registered his brand in April 1872 with the letters "RA" with a slight swirl coming off of the bottom of the R. This mark was specifically registered as a "Horse Brand" (Travis County Register of Marks and Brands 1872; see Chapter 5). The artifact has a tab on one side of the $R$ where the shank was once attached. Oddly, the shank is on the wrong side of the letter. If this brand were used, it would have burned a backwards letter $\mathrm{R}$ into a horse's hide. It seems likely that this $\mathrm{R}$ rep-

${ }^{104}$ These sizes are approximate because the size designations are not standardized and vary slightly among manufacturers. resents a mistake by the blacksmith who made the branding iron. After realizing the mistake, the backwards $R$ was probably removed and a new letter was made and attached correctly. The "A" would be the same regardless of the side on which the shank was attached.

The final category of horse-related items are spurs. While spurs were clothing items of a personal nature worn by riders, they are classified as horse tack because of the obvious functional association. Spurs were essentially an extension of someone's boots to make them more functional when riding a horse. The collection has four unique spurs that were found in the house block and midden (Figure 8.30).

A corroded iron spur found south of the chimney is complete, but one separate fragment is a stud broken off the heel band. Its iron rowel is corroded in place. This spur is very plain and has no identifiable markings. The other specimen from the house block is a brass spur with an iron rowel corroded in place and one heel band broken off. It is plain with no identifying marks. One spur from the midden area is an iron heel band fragment and end buckle. Compared with the other spurs, this specimen is thin and light, and it may be a child's spur used by the Williams children when they were learning to ride. The fourth spur was surface-collected from the midden area by ACSG archeologists. It is about one-half of a brass spur, missing its rowel and one heel band. It has a stamped ornate pattern on its rowel shank consisting of a line of small floral stamps and small dots running the length of the shank (Staples and Nash 2003b:Figure 22).

\section{General Hardware}

A variety of items are lumped together in this general hardware group, including nuts and bolts, washers, chain, and hinges-all small hardware items that hold things together (Table 8.23). This miscellaneous hardware category also includes pins, rivets, hooks, bushings, brackets, and an assortment of other items. This hardware would have been used in a variety of repair and construction activities involving farm equipment. When a bolt broke or a nut was lost, having a ready supply of replacement parts would have been important.

Nuts and bolts comprise much of the general hardware group (Figure 8.31). A total of 34 nuts, ranging in size from $1 / 2$ inch to ca. 

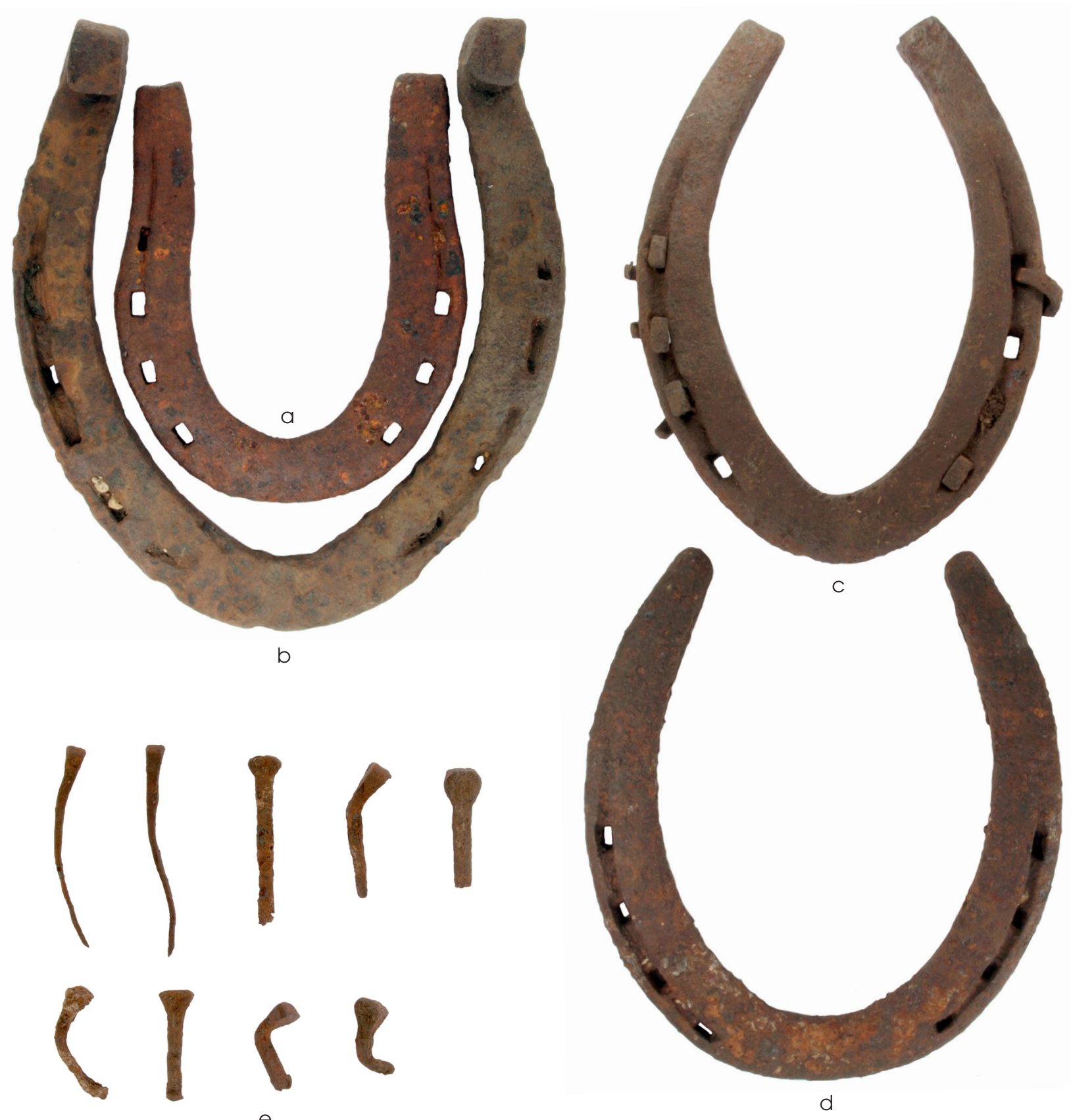

e
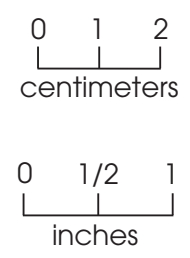

Figure 8.28. Horseshoes, muleshoes, and horseshoe nails. (a) Small mule shoe; (b) large horseshoe; (c) small horse shoe; (d) medium horseshoe; (e) assortment of horseshoe nails. 


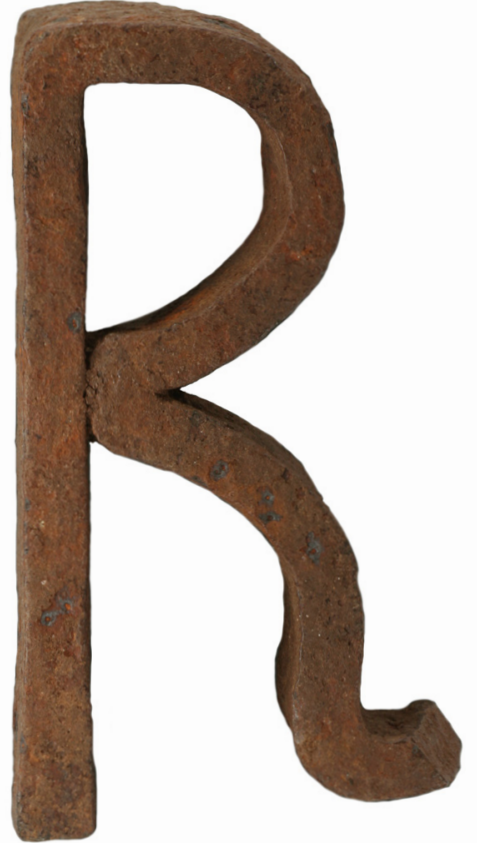

Front

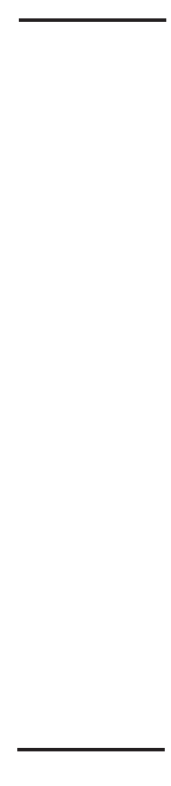

(1)

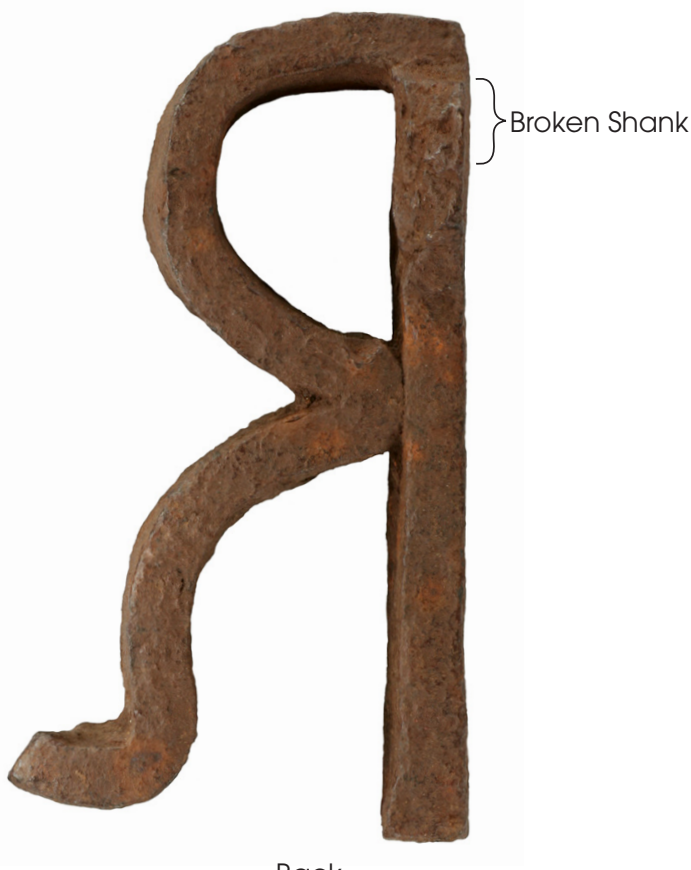

Back
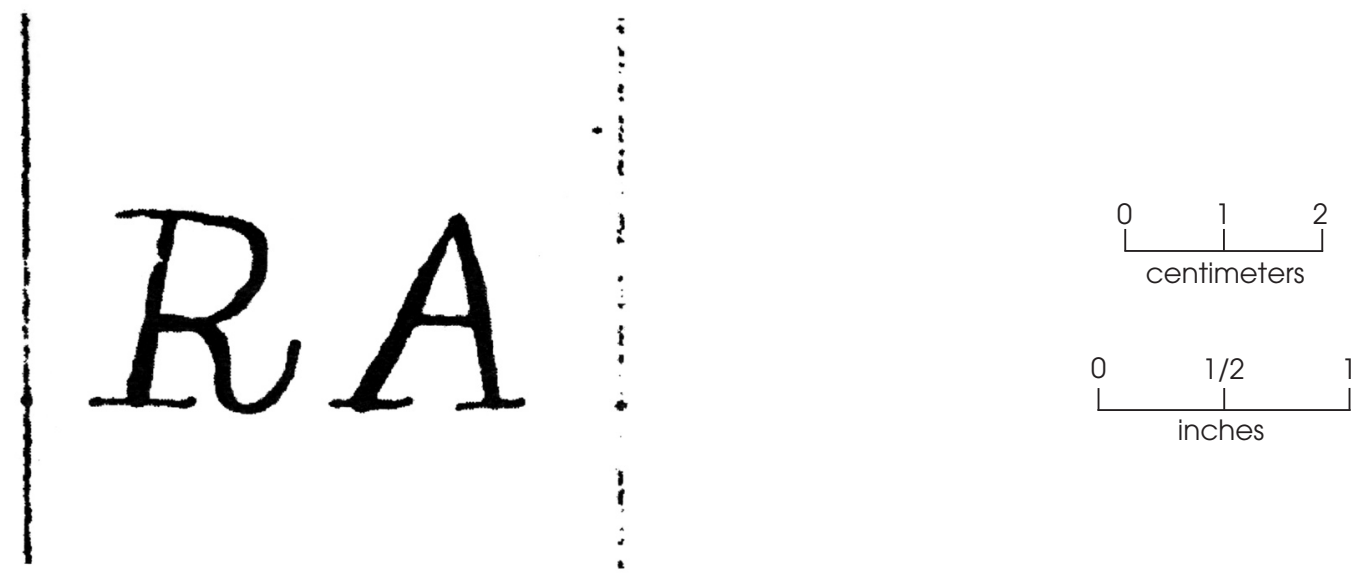

Figure 8.29. Ransom Williams's livestock brand. The iron letter "R" is broken off of a branding iron, and the broken shank is visible on its backside. The letters "RA" were registered to Ransom Williams in April 1872 as his "Horse Brand" (Travis County Register of Marks and Brands 1872).

$1 \frac{1}{2}$ inches, were recovered throughout the farmstead (see Table B.42). Bolt hole diameter ranged from $3 / 16$ inch to 11/16 inch with a variety of sizes in between, the majority measuring $1 / 4$ inch and 5/16 inch. All but two of the nuts were square, with the others being hex nuts.

A total of 95 bolts and bolt fragments were recovered (see Table B.41). Carriage bolts were the most common style, with 49 specimens. Bolt range from $1 / 4$ to $5 / 8$ inch in shaft diameter and from 1.75 to 9.0 inches in length. Carriage bolts have a round head and are typically used for bolting timber together. The distal portion of the shank is threaded, while the proximal portion is smooth. Stove bolts are the second most common type, with 19 specimens found. Diameters range 

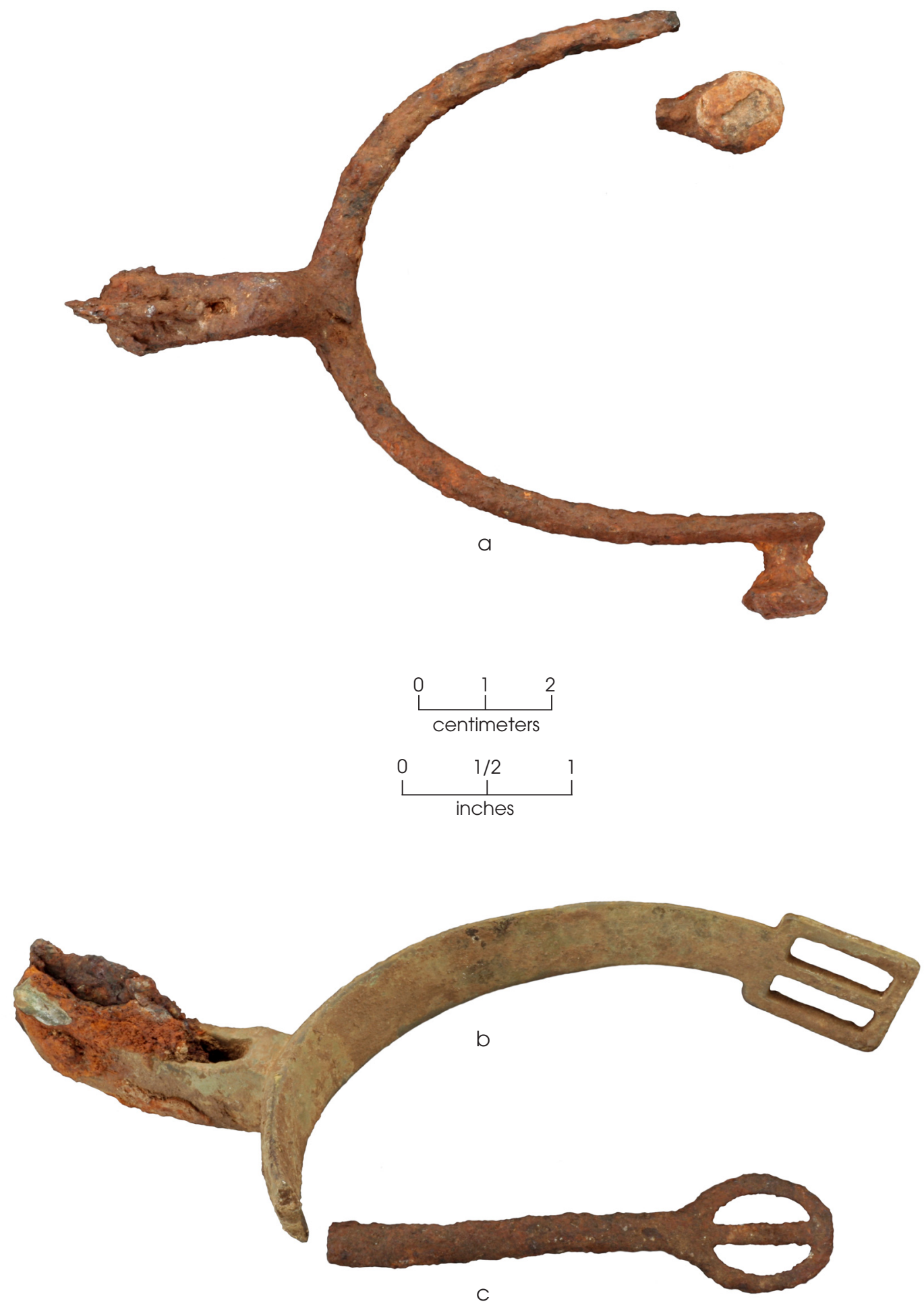

Figure 8.30. Spurs. (a) Complete iron spur (two fragments); (b) brass spur fragment with iron rowel; (c) iron spur heel band, possibly a child's spur. 
from $1 / 4$ to $5 / 8$ inch, and lengths range from 1.0 to 2.75 inches. Stove bolts are typically used for joining metal and often have a round head with a screwdriver slot. Most of the shank is threaded, and the bolt heads are countersunk. Seven machine bolts were also found, ranging in length from 1.75 to 10.75 inches and diameter from $3 / 8$ to $5 / 8$ inches. Machine bolts typically have a square or hexagonal head and have to be tightened with a wrench. The shank is threaded for a nut to attach and help hold things in place. Lastly, a single U-bolt has a 5/16-inch diameter shank and is in the shape of a "U" with threads on both ends. The remaining fragments are a mixture of carriage bolts and unidentifiable bolt fragments whose lengths could not be measured accurately.

Table 8.23. General hardware*

\begin{tabular}{|c|c|c|c|c|c|c|c|}
\hline Artifact Group & Artifact & $\begin{array}{c}\text { House } \\
\text { Block }\end{array}$ & \begin{tabular}{|c|} 
House Block, \\
Subfloor Pit \\
\end{tabular} & $\begin{array}{l}\text { Yard } \\
\text { Area }\end{array}$ & Midden & Outbuilding & Total \\
\hline \multirow{7}{*}{$\begin{array}{l}\text { Bolts } \\
(\mathrm{n}=103)\end{array}$} & Carriage bolts & 41 & 7 & 3 & 2 & 3 & 56 \\
\hline & Carriage bolt (fragments) & 4 & - & - & 1 & 1 & 6 \\
\hline & Machine bolts & 6 & - & 1 & - & - & 7 \\
\hline & Eye bolt & 1 & - & 1 & - & - & 2 \\
\hline & Stove bolts & 17 & - & 1 & 1 & - & 19 \\
\hline & U bolts & 1 & - & - & - & - & 1 \\
\hline & Undefined bolt (fragments) & 8 & - & 1 & 2 & 1 & 12 \\
\hline \multirow{3}{*}{$\begin{array}{l}\text { Nuts } \\
(\mathrm{n}=35)\end{array}$} & Hex nuts & 2 & - & - & - & - & 2 \\
\hline & Square nuts & 21 & 2 & 5 & 3 & 1 & 32 \\
\hline & Undefined nut & 1 & - & - & - & - & 1 \\
\hline \multirow{4}{*}{$\begin{array}{l}\text { Washers } \\
(\mathrm{n}=47)\end{array}$} & Brass washers & 10 & 2 & - & 2 & - & 14 \\
\hline & Lead washer & 1 & - & - & - & - & 1 \\
\hline & Iron washers & 20 & 8 & 2 & 1 & - & 31 \\
\hline & $\begin{array}{l}\text { Brass washer } \\
\text { (with bolt fragment attached) }\end{array}$ & - & - & 1 & - & - & 1 \\
\hline \multirow{4}{*}{$\begin{array}{l}\text { Hinges } \\
(n=10)\end{array}$} & Butt hinges & 1 & 1 & - & - & 1 & 3 \\
\hline & Strap hinges & 2 & - & - & - & - & 2 \\
\hline & Strap hinge (fragments) & 4 & - & - & - & - & 4 \\
\hline & Undefined hinge (fragment) & 1 & - & - & - & - & 1 \\
\hline \multirow{11}{*}{$\begin{array}{l}\text { Chain links } \\
\text { and segments } \\
(\mathrm{n}=26)\end{array}$} & Links, small & 2 & 1 & - & 1 & 1 & 5 \\
\hline & Links, medium & 1 & 1 & - & - & - & 2 \\
\hline & Link, undefined size & - & - & - & 1 & - & 1 \\
\hline & Link fragments, small & 1 & - & 2 & - & - & 3 \\
\hline & Repair link, small & 1 & - & - & - & - & 1 \\
\hline & Repair link, medium & 1 & - & - & - & - & 1 \\
\hline & Chain segments, small & 5 & 1 & - & - & - & 1 \\
\hline & Chain segment, medium & 1 & - & - & - & - & 6 \\
\hline & $\begin{array}{l}\text { Chain segments, undefined } \\
\text { size }\end{array}$ & 2 & - & 1 & 1 & - & 4 \\
\hline & Jack chain link, medium & - & - & - & 1 & - & 1 \\
\hline & Jack chain segment, large & - & - & - & 1 & - & 1 \\
\hline
\end{tabular}


Table 8.23, continued

\begin{tabular}{|c|c|c|c|c|c|c|c|}
\hline Artifact Group & Artifact & $\begin{array}{l}\text { House } \\
\text { Block }\end{array}$ & $\begin{array}{c}\text { House Block, } \\
\text { Subfloor Pit }\end{array}$ & $\begin{array}{l}\text { Yard } \\
\text { Area }\end{array}$ & Midden & Outbuilding & Total \\
\hline \multirow{24}{*}{$\begin{array}{l}\text { Miscellaneous } \\
\text { hardware } \\
(\mathrm{n}=52)\end{array}$} & Bolster (copper) & 1 & - & - & - & - & 1 \\
\hline & Brackets & 2 & - & - & 1 & - & 3 \\
\hline & Copper bushing & 1 & - & - & - & - & 1 \\
\hline & Copper wire & 1 & - & - & - & - & 1 \\
\hline & Hooks & 4 & - & - & - & - & 4 \\
\hline & Iron bands or straps & - & 1 & - & 7 & - & 8 \\
\hline & Grommet & 1 & - & - & - & - & 1 \\
\hline & Lead coupling (for small hose) & 1 & - & - & - & - & 1 \\
\hline & Machine screw & 1 & - & - & - & - & 1 \\
\hline & Metal ferrule & 1 & - & - & - & - & 1 \\
\hline & Metal plate & 1 & - & - & - & - & 1 \\
\hline & Nail (brass) & 1 & - & - & - & - & 1 \\
\hline & Pins & 4 & - & - & - & 1 & 5 \\
\hline & Pipe section (6.7 inches) & - & - & - & 1 & - & 1 \\
\hline & Railroad spike (5.6 inches) & - & - & - & - & 1 & 1 \\
\hline & Ring (1.6-inch diameter) & 1 & - & - & - & - & 1 \\
\hline & Rivets & 4 & - & - & 2 & 1 & 7 \\
\hline & Screw hooks & 2 & 1 & - & - & - & 3 \\
\hline & Spike (8 inch) & 1 & - & - & - & - & 1 \\
\hline & Spring (coiled, 0.6 inch) & - & - & - & 1 & - & 1 \\
\hline & Trim fragment (unidentified) & 1 & - & - & - & - & 1 \\
\hline & Window sash pulleys & 2 & - & - & - & - & 2 \\
\hline & Wire handle & 1 & - & - & 1 & 1 & 3 \\
\hline & Wire loops & 2 & - & - & - & - & 2 \\
\hline \multicolumn{2}{|l|}{ Total } & 188 & 25 & 18 & 30 & 12 & 273 \\
\hline
\end{tabular}

*All artifacts are iron unless otherwise stated. Chain links are divided into small (1/4-inch diameter), medium (1/4- to 7/16-inch diameter), and large (1/2-inch or larger diameter).

A variety of washers were recovered, and they differ in size and material (see Table B.43). Washers were sorted first by material, including iron $(n=31)$, brass $(n=15)$, and lead $(n=1)$. The brass and lead washers were small. The outside diameters of the brass washers range from 0.31 to $0.56 \mathrm{inch}$, and the lead washer is $0.47 \mathrm{inch}$. The iron washers were larger, ranging in outside diameter from 0.5 to 1.65 inches. The precise functions of all the washers are not known, but it is likely that the smaller washers were from household items while the larger iron washers may have been from farm equipment.
Ten iron hinges and hinge fragments are represented in the collection (see Table B.44). Six specimens are identified as strap hinges with triangular plates that were typically used on doors or gates (Figure 8.32). Three are butt hinges typically associated with doors. Butt hinges are composed of two plates (often square) that attach to the abutting surfaces of a door and jamb. The two plates are held together by a vertical pin.

Chains are another type of hardware that would have been used in a variety of tasks around the farm. Heavy chains, for example, 

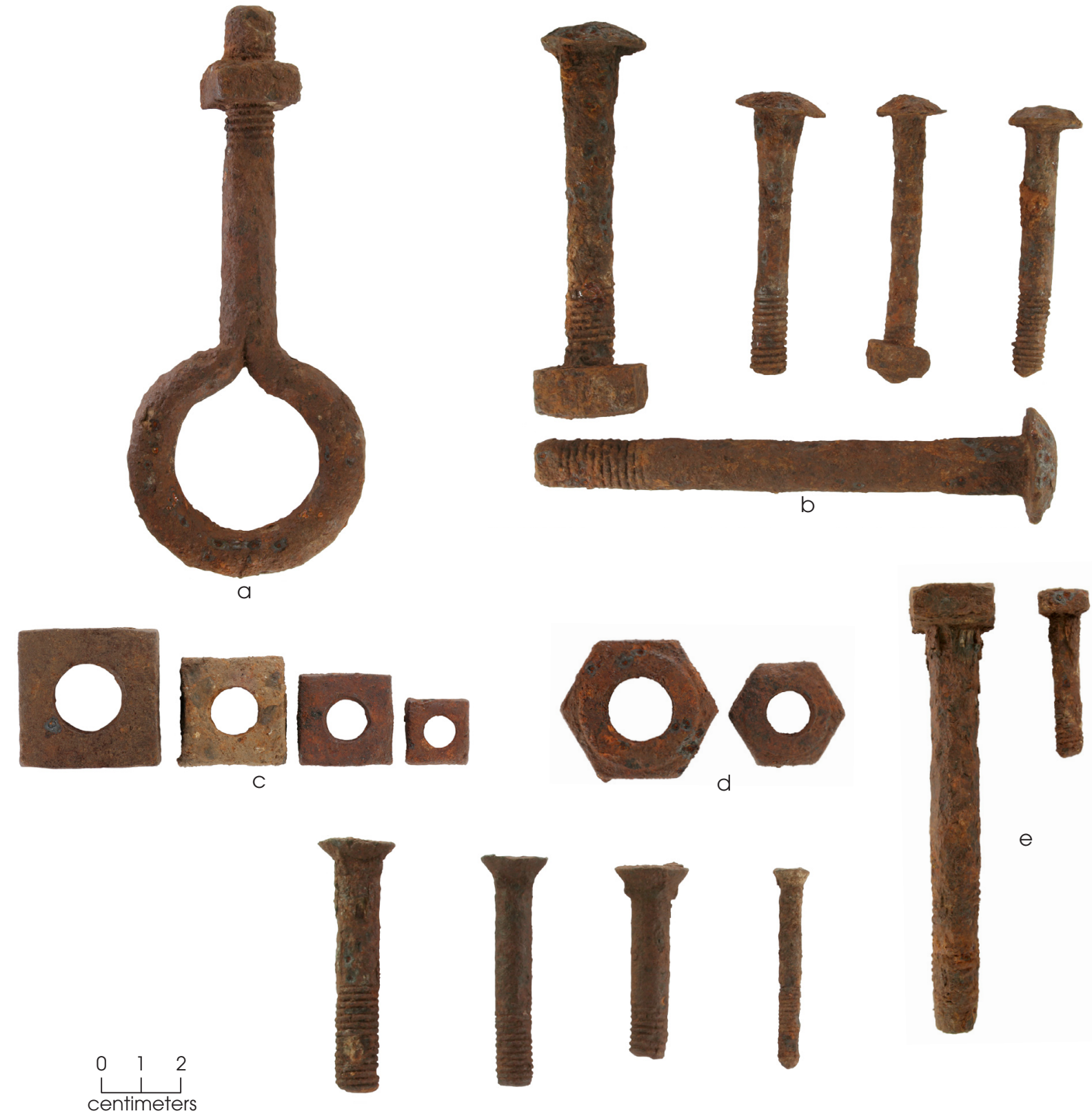

e
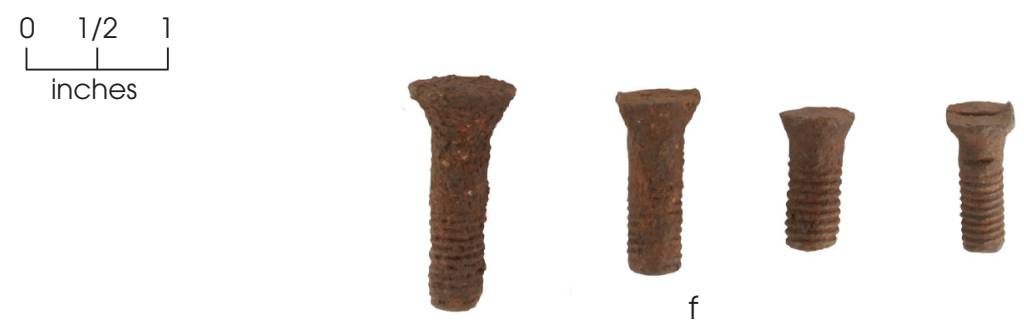

Figure 8.31. Assorted nuts and bolts. (a) Large eye bolt with square nut; (b) assorted carriage bolts, two with square nuts attached; (c) square nuts; (d) hexagonal nuts; (e) machine bolts; (f) assorted stove bolts. 
could have been used to drag things behind a horse, to attach things to or haul behind a wagon, to pull tree stumps or large rocks from the ground, or to tether livestock. Twenty-two links and fragments of chain were recovered from the farmstead (Figure 8.33; see Table B.45). The majority are medium-size links (1/4- to 7/16-inch diameter) representing heavy chains, but some smaller chains are represented as well. Seven chain segments were recovered, five of which are 1/4-inch-diameter chains. Two repair links (with a break in the ring to allow two different segments to be joined) were also recovered, and they are 3/16 and 7/16 inches in diameter. The assemblage includes two segments of jack chain, which was typically used for hanging objects. Jack chain links are a figure-eight shape with a 90-degree bend at the center. The jack chains are both large, one being a No. 16 (9/16-inch-diameter wire) and the other being a No. 14 (11/16-inch-diameter wire).

The remaining items were grouped together as miscellaneous hardware due to the variety of objects and the diverse manners in which they could have been used (see Table B.46). Items in this category include screw hooks, rivets and pins, metal brackets of different types, iron bands, wire handles, and other unique pieces of hardware.

\section{Water Barrels}

The only archeological evidence of water storage was in the form of numerous barrel bands recovered from many areas of the site (Figure 8.34). The farmstead assemblage includes 97 specimens that are classified as complete bands, band segments, and band fragments (Table 8.24; see Table B.50). A complete band is one with no break in the metal and the two ends still riveted together. These bands were presumably intact when the barrel staves rotted away. Some retain their original circular shape, while others are complete but bent and distorted. Barrel band segments are sections that have overlapping ends connected by one or more rivets (usually two), and it is clear that the broken ends do not match to form a complete band. A band fragment is simply a section of a band without overlapping ends and rivets. Complete bands were only found in the midden, corral complex, and yard area. Band segments were common in these areas as well, but one was also found in the house block. Band fragments were found in all locations but were most common in the yard area, midden, and outbuilding location. Most of the barrel bands have original iron rivets, but some specimens have brass rivets that appear to be a homemade repair job (see Figure 8.34b).

The minimum number of barrel bands, which is the number of complete bands and band segments combined, is 40 , and the size data for these specimens is summarized in Table 8.25. Of the nine complete bands, four are probably from small barrels (15-inch diameter or less) and the other five bands have diameters ranging from 22 to 25 inches and are definitely from large barrels.

Unfortunately, the minimum number of barrels cannot be calculated precisely from the band data because wooden barrels came in a variety of sizes and had varying numbers of bands. A large short barrel might have only three bands, while large tall barrels typically had five or six bands, sometimes more. But if the average number of bands per barrel were five or six, the barrel band data would suggest a minimum of six to eight barrels represented in the assemblage, with about half of them being large barrels. This number only reflects barrels that were left at the site, however; many others might have been removed when the farm was abandoned or later. Because many barrel band fragments were not collected, there were likely more than seven barrels on the farm.

\section{Firearms and Hunting}

Rural life in the last quarter of the nineteenth century would have required possession and familiarity with firearms, both for security and hunting. The Williams family apparently felt this way, and the archeological investigations uncovered an array of firearms-related artifacts representing many different types of firearms. The 96 firearms-related artifacts recovered from the farmstead include munitions, gun parts, and tools. These artifacts are summarized in Table 8.26 (see Tables B.39 and B.40). Sixty-nine of the brass cartridges have headstamps linked to specific munitions manufacturers, as summarized in Table 8.27. A sample of munitions, gun parts, and tools is illustrated in Figures 8.35 and 8.36.

The most common type of ammunition casing found is the .44 Webley. All 34 casings were manufactured by the Winchester 

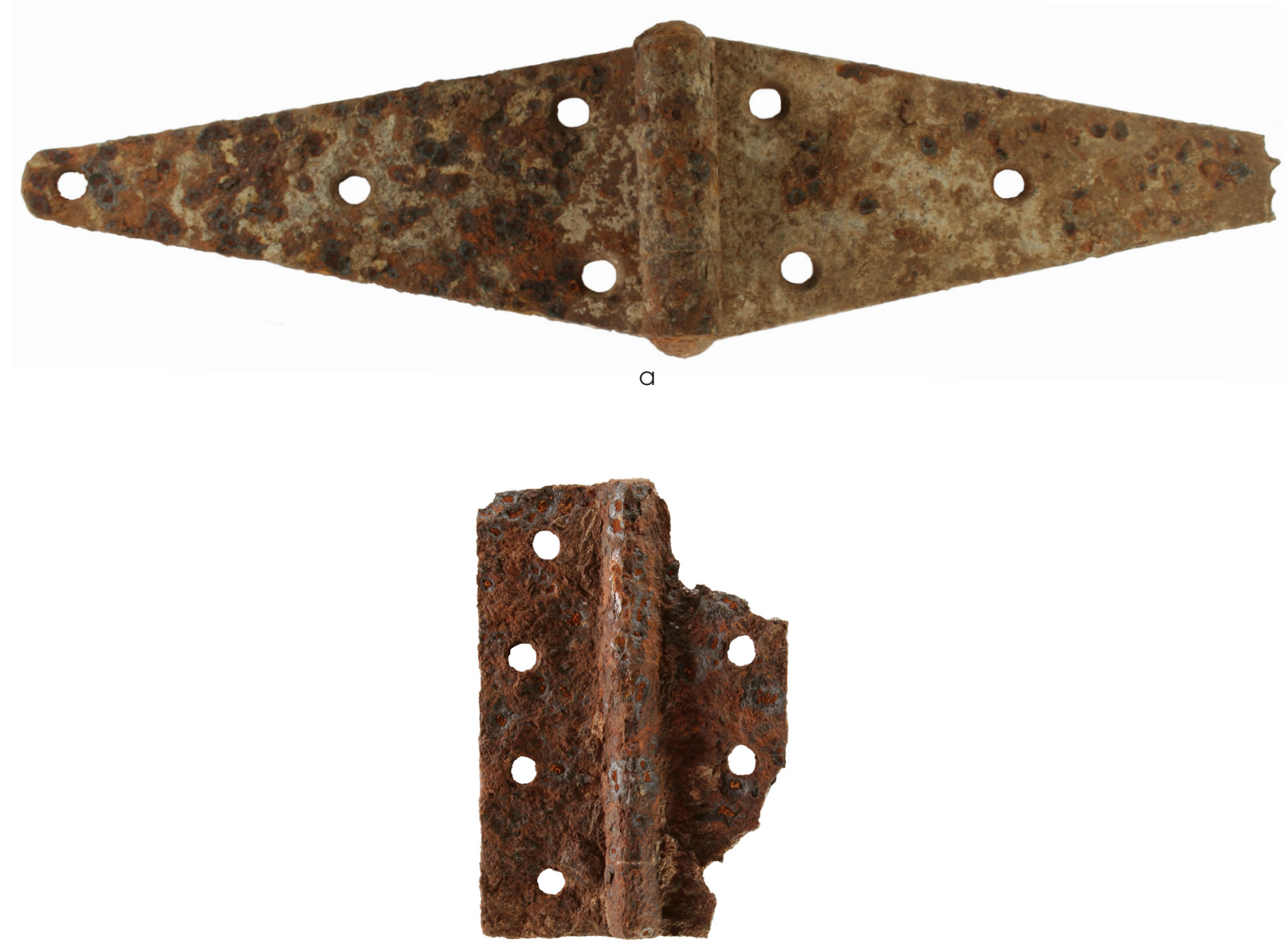

$\mathrm{b}$
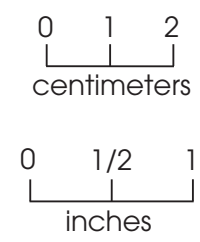

Figure 8.32. Hinges. (a) Large triangular strap hinge; (b) small butt hinge.

Table 8.24. Iron barrel bands

\begin{tabular}{l|c|c|c|c|c|c|c}
\hline \multicolumn{1}{c|}{ Type } & $\begin{array}{c}\text { House } \\
\text { Block }\end{array}$ & $\begin{array}{c}\text { House Block, } \\
\text { Subfloor Pit }\end{array}$ & $\begin{array}{c}\text { Yard } \\
\text { Area }\end{array}$ & Midden & Outbuilding & $\begin{array}{c}\text { Corral } \\
\text { Complex* }\end{array}$ & Total \\
\hline Complete barrel bands & - & - & 2 & 4 & - & 3 & 9 \\
\hline $\begin{array}{l}\text { Barrel band segments } \\
\text { (with connecting rivets) }\end{array}$ & 1 & - & 9 & 6 & 2 & 13 & 31 \\
\hline Barrel band fragments & 2 & 1 & 26 & 12 & 15 & 1 & 57 \\
\hline Total & 3 & 1 & 37 & 22 & 17 & 17 & 97 \\
\hline
\end{tabular}

*Only the complete bands and band segments were collected from the corral complex, so the number of fragments there is underrepresented. 

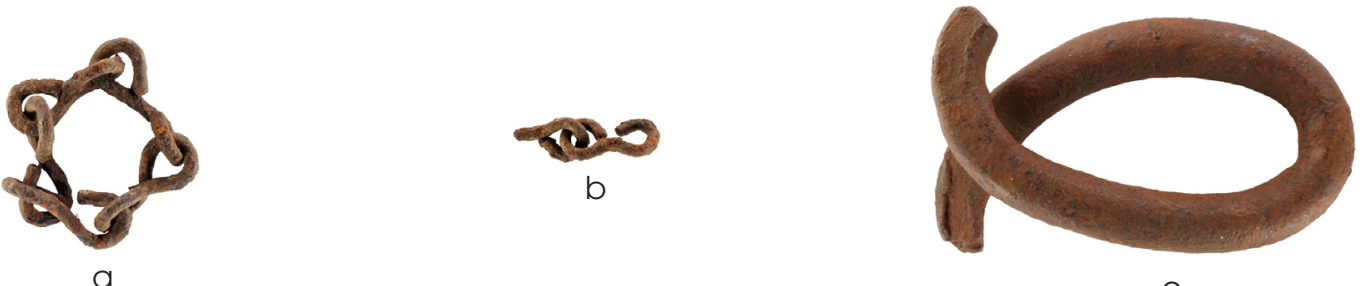

C
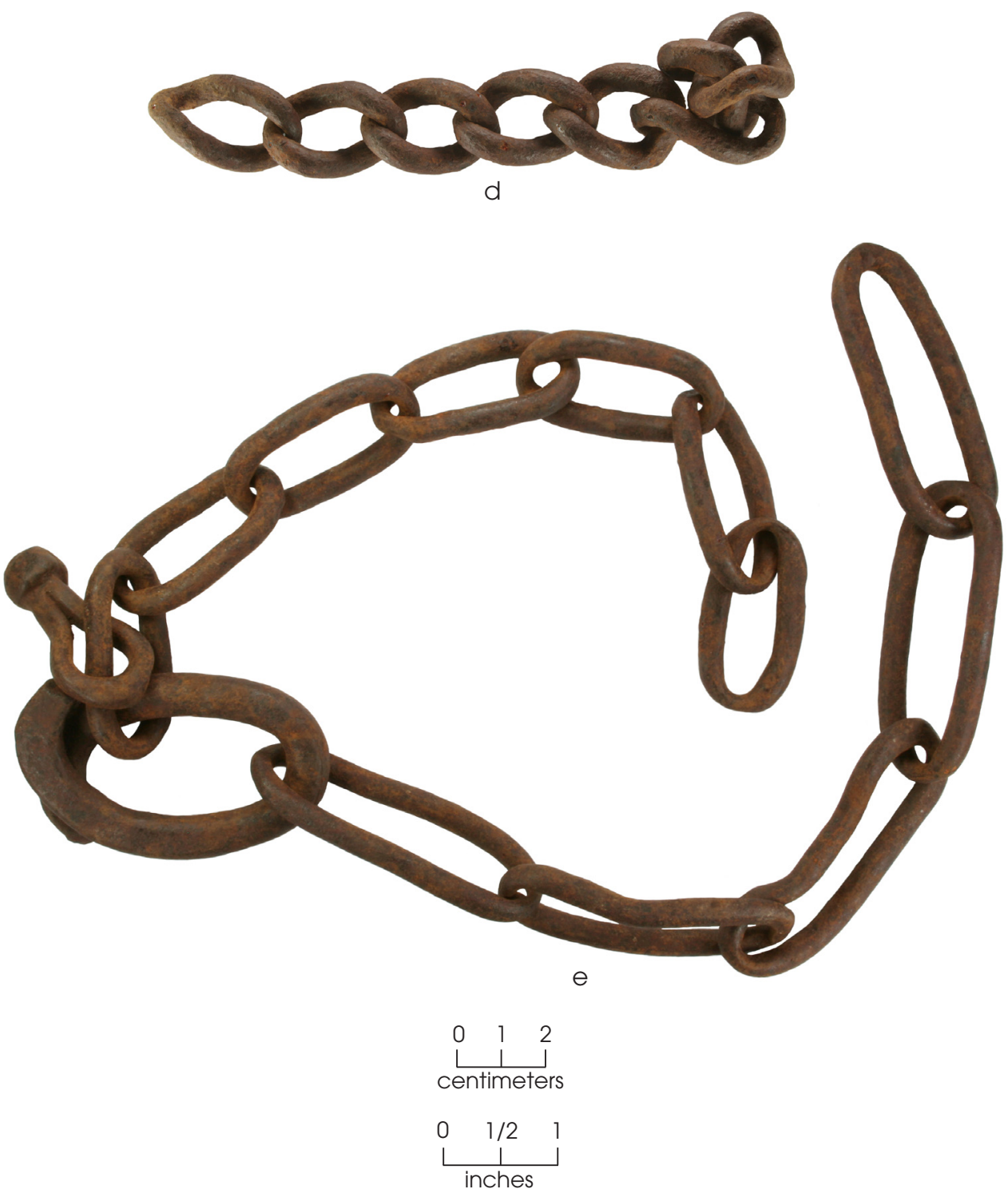

Figure 8.33. Chain links and chain segments. (a, b) Small jack chain segments; (c) large chain repair link; (d, e) long chain segments. 


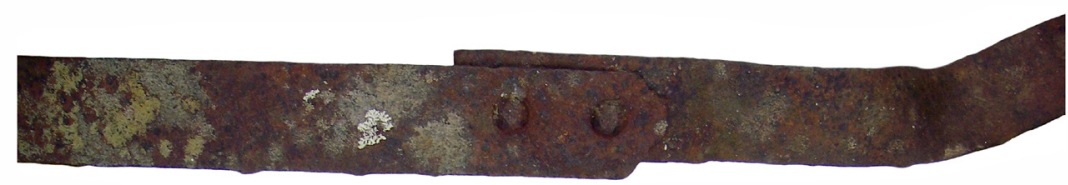

a

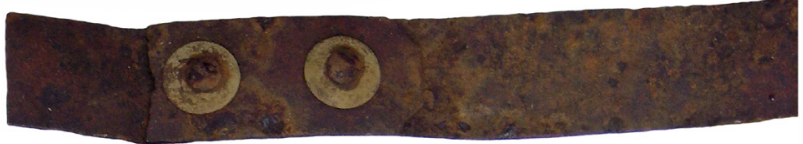

$\mathrm{b}$
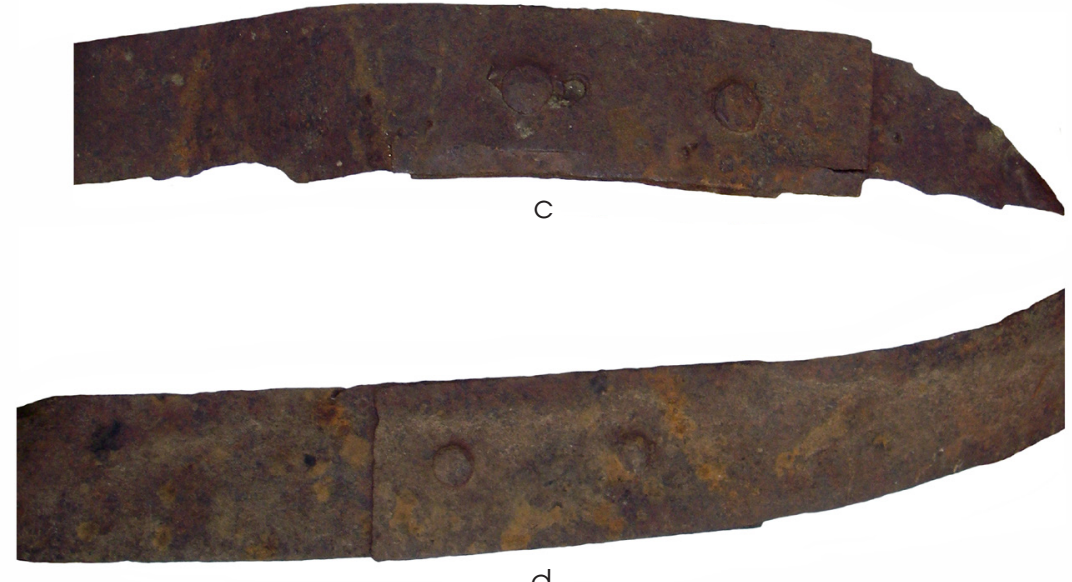

d

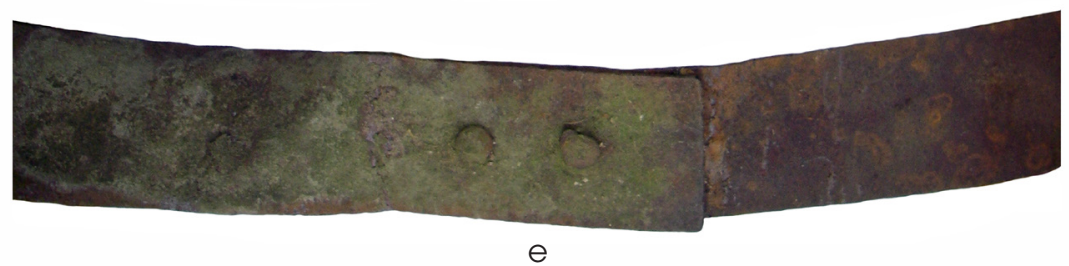

e
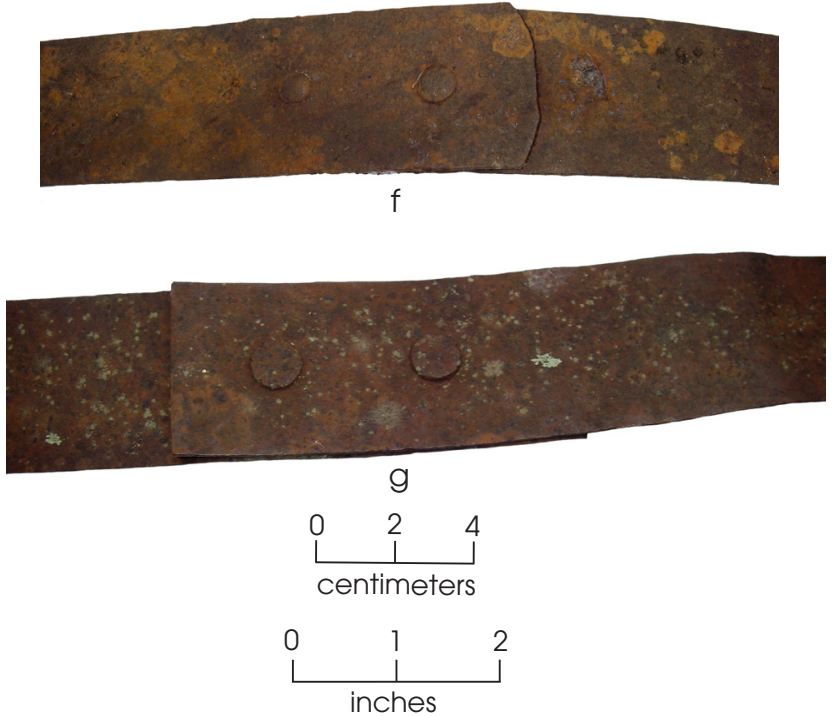

Figure 8.34. Barrel band sections showing the overlapping ends and connecting rivets. While some bands have machine-cut ends and rivets, other are crudely cut with repair rivets added by hand. 
Table 8.25. Minimum number of barrel bands and band sizes*

\begin{tabular}{|c|c|c|c|c|c|}
\hline $\begin{array}{l}\text { Band Width } \\
\text { (inches) }\end{array}$ & $\begin{array}{c}\text { Complete } \\
\text { Barrel } \\
\text { Bands } \\
\end{array}$ & $\begin{array}{c}\text { Barrel } \\
\text { Band } \\
\text { Segments }\end{array}$ & $\begin{array}{l}\text { Total No. } \\
\text { of Bands }\end{array}$ & $\begin{array}{c}\text { Circumferences of } \\
\text { Complete Bands } \\
\text { (inches) }\end{array}$ & $\begin{array}{c}\text { Minimum Barrel Diameters } \\
\text { (inches) }\end{array}$ \\
\hline $3 / 4$ & - & 2 & 2 & - & - \\
\hline $7 / 8$ & - & 1 & 1 & - & - \\
\hline 1 & 2 & 3 & 5 & 33,69 & $10.5,22.0$ \\
\hline $11 / 8$ & - & 1 & 1 & - & - \\
\hline $11 / 4$ & 1 & 4 & 5 & 48 & 15.3 \\
\hline $13 / 8$ & 1 & - & 1 & 75 & 23.8 \\
\hline $17 / 16$ & - & 2 & 2 & - & - \\
\hline 1 15/32 & - & 3 & 3 & - & - \\
\hline $11 / 2$ & 4 & 5 & 9 & $40,46,72,76$ & $12.7,14.6,23.9,24.2$ \\
\hline $15 / 8$ & - & 2 & 2 & - & - \\
\hline $111 / 16$ & - & 5 & 5 & - & - \\
\hline $13 / 4$ & 1 & 1 & 2 & 70 & 22.3 \\
\hline 2 & - & 2 & 2 & - & - \\
\hline Total & 9 & 31 & 40 & & \\
\hline
\end{tabular}

*Circumference was measured only for complete bands. Diameter is calculated from circumference because many bands were bent and misshapen.

Repeating Arms Company (each is marked "W.R.A. Co."). This cartridge originated in 1868 for the Webley Royal Irish Constabulary model revolver (Barnes 1980:181). In the United States it was loaded as .44 Webley until ca. 1940.

The .22 short is the next most common type of cartridge, and three different manufacturers made the .22 cases in the Williams assemblage. The .22 short is the oldest American self-contained, metallic cartridge produced for a commercial purpose (Barnes 1980:289). It was first introduced in 1857 for the Smith \& Wesson First Model revolver and is currently produced around the world for a variety of firearms, from pistols to rifles (Barnes 1980:289). The versatility of a .22 short makes it a good choice for hunting small game, something the Williamses would have likely done on a regular basis. It also could have been used for target practice or close-range protection.

The .22 short cartridges could have been fired in a variety of pistols or rifles, but the recovery of a single trigger guard suggests one possibility. This specimen is from a Flobert rifle, a weapon that was often chambered in .22 caliber, either $.22 \mathrm{BB}, .22$ short, or .22 long (although some were also chambered in .32 short). The Flobert was a single shot rifle, often used as a gallery or parlor gun when shooting indoor targets was a popular hobby. This hobby has long since declined in popularity. But the Flobert was a relatively inexpensive gun that would have been a good choice for a kid's first gun. As a 1895 Montgomery Ward catalog (p. 461) description put it, "Don't expect a Stevens or Winchester in a Flobert." Five different models of Floberts were sold for $\$ 2.25$, $\$ 2.55, \$ 2.80, \$ 3.25$, and $\$ 3.40$. In contrast, similar single-shot .22 rifles made by Stevens, Winchester, and Remington were sold for prices ranging from $\$ 10$ to more than $\$ 20$.

The other self-contained metallic cartridges could have been fired from several different rifles or pistols. The .44 Bulldog cartridge could have been fired from the same revolver as the .44 Webley, because the case length is short, but the bullet diameter would be the same as the .44 Webley. The .32 and .38-.40 cartridges indicate that additional firearms were used, but these were popular calibers, and the cartridges could be fired from a variety of weapons.

Based on cartridge heads, at least three different shotguns are represented. A shotgun is 
Table 8.26. Firearms-related artifacts

\begin{tabular}{|c|c|c|c|c|c|c|c|}
\hline $\begin{array}{l}\text { Artifact } \\
\text { Group }\end{array}$ & Artifact & $\begin{array}{l}\text { House } \\
\text { Block }\end{array}$ & $\begin{array}{l}\text { House Block; } \\
\text { Subfloor Pit }\end{array}$ & $\begin{array}{l}\text { Yard } \\
\text { Area }\end{array}$ & Midden & Outbuilding & Total \\
\hline \multirow{12}{*}{$\begin{array}{l}\text { Brass } \\
\text { Cartridge } \\
\text { Cases }\end{array}$} & Shotgun shell primer & 1 & - & - & - & - & 1 \\
\hline & Shotgun shell head, 10-gauge & 1 & - & - & - & - & 1 \\
\hline & $\begin{array}{l}\text { Shotgun shell head, 10-gauge } \\
\text { pinfire } \\
\text { (Lefaucheux type) }\end{array}$ & 1 & - & - & - & - & 1 \\
\hline & Shotgun shell heads, 12-gauge & 6 & - & - & 1 & - & 7 \\
\hline & Brass cartridge cases, .22 short & 17 & 4 & - & 1 & - & 22 \\
\hline & Brass cartridge cases, .22 long & 1 & - & - & - & - & 1 \\
\hline & Brass cartridge cases, .32 short & - & - & - & 2 & - & 2 \\
\hline & Brass cartridge cases, $.38-40$ & 2 & - & 1 & - & - & 3 \\
\hline & Brass cartridge case, .44 caliber & - & - & - & 1 & - & 1 \\
\hline & $\begin{array}{l}\text { Brass cartridge case, } .44 \\
\text { Bulldog }\end{array}$ & - & 1 & - & - & - & 1 \\
\hline & $\begin{array}{l}\text { Brass cartridge cases, } .44 \\
\text { Webley }\end{array}$ & 21 & 3 & 1 & 8 & 1 & 34 \\
\hline & Brass cartridge cases, $.44-40$ & 2 & - & - & - & - & 2 \\
\hline \multirow{7}{*}{$\begin{array}{l}\text { Other } \\
\text { Munitions }\end{array}$} & Lead ball, 32 caliber & 1 & - & - & - & - & 1 \\
\hline & Lead ball, .44 caliber & - & - & 1 & - & - & 1 \\
\hline & Lead bullet, .44 caliber & - & 1 & - & - & - & 1 \\
\hline & Lead shot (bird shot) & - & - & - & 1 & - & 1 \\
\hline & Lead sprue & 1 & - & - & - & - & 1 \\
\hline & Percussion cap (brass) & 1 & - & - & - & - & 1 \\
\hline & Percussion caps, musket (brass) & 3 & 1 & - & 2 & - & 6 \\
\hline \multirow[t]{6}{*}{ Gun Parts } & Butt plate, Enfield rifle & 1 & - & - & - & - & 1 \\
\hline & Butt plate, unidentified & 1 & - & - & - & - & 1 \\
\hline & $\begin{array}{l}\text { Muzzleloader shotgun breech } \\
\text { plug }\end{array}$ & - & - & - & 1 & - & 1 \\
\hline & Muzzleloader shotgun hammer & 1 & - & - & - & - & 1 \\
\hline & $\begin{array}{l}\text { Muzzleloader shotgun } \\
\text { mainspring }\end{array}$ & 1 & - & - & - & - & 1 \\
\hline & Trigger guard, Flobert rifle & - & - & - & 1 & - & 1 \\
\hline \multirow[t]{2}{*}{ Gun Tools } & Folding pocket screwdriver & 1 & - & - & - & - & 1 \\
\hline & Nipple wrench & 1 & - & - & - & - & 1 \\
\hline \multicolumn{2}{|l|}{ Total } & 64 & 10 & 3 & 18 & 1 & 96 \\
\hline
\end{tabular}

a versatile firearm that can be used for hunting birds and small game (such as quail, dove, squirrels, and rabbits) as well as large game (such as deer). A shotgun could also provide an impressive measure of security and is an excellent close-range weapon for self-defense. Living in an isolated location during the Jim Crow era, the Williamses were certainly aware of the potential for racial violence, and personal protection may have been an important consideration.

One of the shotgun shell heads represents a pinfire shotgun of the Lefaucheux style. The 
Table 8.27. Cartridge headstamp marks and munitions makers

\begin{tabular}{|c|c|c|c|}
\hline Cartridge Type & Headstamp Mark & Manufacturer & No. \\
\hline $\begin{array}{l}\text { Shotgun shell head, } \\
10 \text {-gauge }\end{array}$ & W.R.A. Co. No. 10 & Winchester Repeating Arms Company & 1 \\
\hline $\begin{array}{l}\text { Shotgun shell head, } \\
10 \text {-gauge pinfire }\end{array}$ & E.B. LONDON 10 & Eley Brothers London & 1 \\
\hline \multirow{6}{*}{$\begin{array}{l}\text { Shotgun shell head, } \\
\text { 12-gauge }\end{array}$} & PETERS REFEREE & Peters Cartridge Company & 1 \\
\hline & REM-UMC NO 12 NEW CLUB & Remington Arms Company & 1 \\
\hline & U.M.C. CO. NO 12 NEW CLUB & Union Metallic Cartridge Company & 1 \\
\hline & WINCHESTER NO 12 LEADER & Winchester Repeating Arms Company & 1 \\
\hline & WINCHESTER NO 12 NEW RIVAL & Winchester Repeating Arms Company & 1 \\
\hline & WINCHESTER NO 12 REPEATER & Winchester Repeating Arms Company & 1 \\
\hline \multirow[t]{3}{*}{.22 short } & $\mathrm{D}$ & Dominion Cartridge Company & 2 \\
\hline & $\mathrm{P}$ & Peters Cartridge Company & 14 \\
\hline & $\mathrm{U}$ & Union Metallic Cartridge Company & 5 \\
\hline .22 long & $\mathrm{U}$ & Union Metallic Cartridge Company & 1 \\
\hline .32 short & $\mathrm{H}$ & Winchester Repeating Arms Company & 1 \\
\hline $.38-40$ & U.M.C. $38-40$ & Union Metallic Cartridge Company & 3 \\
\hline .44 Bulldog & U.M.C. 44 B DOG & Union Metallic Cartridge Company & 1 \\
\hline .44 Webley & W.R.A. CO. 44 WEB. & Winchester Repeating Arms Company & 32 \\
\hline \multirow[t]{2}{*}{$.44-40$} & PETERS 44-40 & Peters Cartridge Company & 1 \\
\hline & U.M.C. 44 C.F.W. & Union Metallic Cartridge Company & 1 \\
\hline \multicolumn{3}{|l|}{ Total } & 69 \\
\hline
\end{tabular}

falling hammer would strike the exposed pin, and the pin would then strike the internal primer within the cartridge. This would cause the powder to ignite and propel the projectile out of the barrel. The pinfire shotgun shell recovered at the Williams farmstead is a 10-gauge (casing head only) manufactured by Eley Brothers of London. The pinfire is an older style of self-contained cartridge, which would have been relatively rare in central Texas in the late nineteenth century. However, it is notable that empty paper shot shells with brass pinfire heads were still sold in the 1894 Sears, Roebuck \& Company Catalog (p. 296) for reloading shells in 10, 12, 14,16 , and 20 gauges.

Other shotguns are represented by a single 10-gauge shell head manufactured by the Winchester Repeating Arms Company and numerous 12-gauge shell heads made by four different manufacturers: Winchester Repeating Arms Company, Remington Arms Company, Peters Cartridge Company, and Union Metallic
Cartridge Company. The dating of particular shotgun shell heads is based on the dating of the companies and the periods of manufacture for specific types of shotgun ammunition (designated by names on the headstamps). The dating of the shotgun shells is discussed at the end of this chapter, but it is notable that all but one of them date to the late nineteenth century and certainly before 1905. The one oddball shotgun shell has a "WINCHESTER NO 12 NEW RIVAL" mark that indicates it was made between 1920 and 1929 (Cartridgecorner.com 2012a; Winchester Repeating Arms 2012a, 2012b). It is likely that this shell casing was left behind by someone hunting after the Williams family had left the property around 1905.

The last piece of evidence for shotgun use is the recovery of a hammer, a breech plug, and a mainspring that all came from a black powder, muzzleloading shotgun. The 1895 Montgomery Ward catalog had several models of muzzleloading shotguns for sale ranging in price from $\$ 2.75$ to 

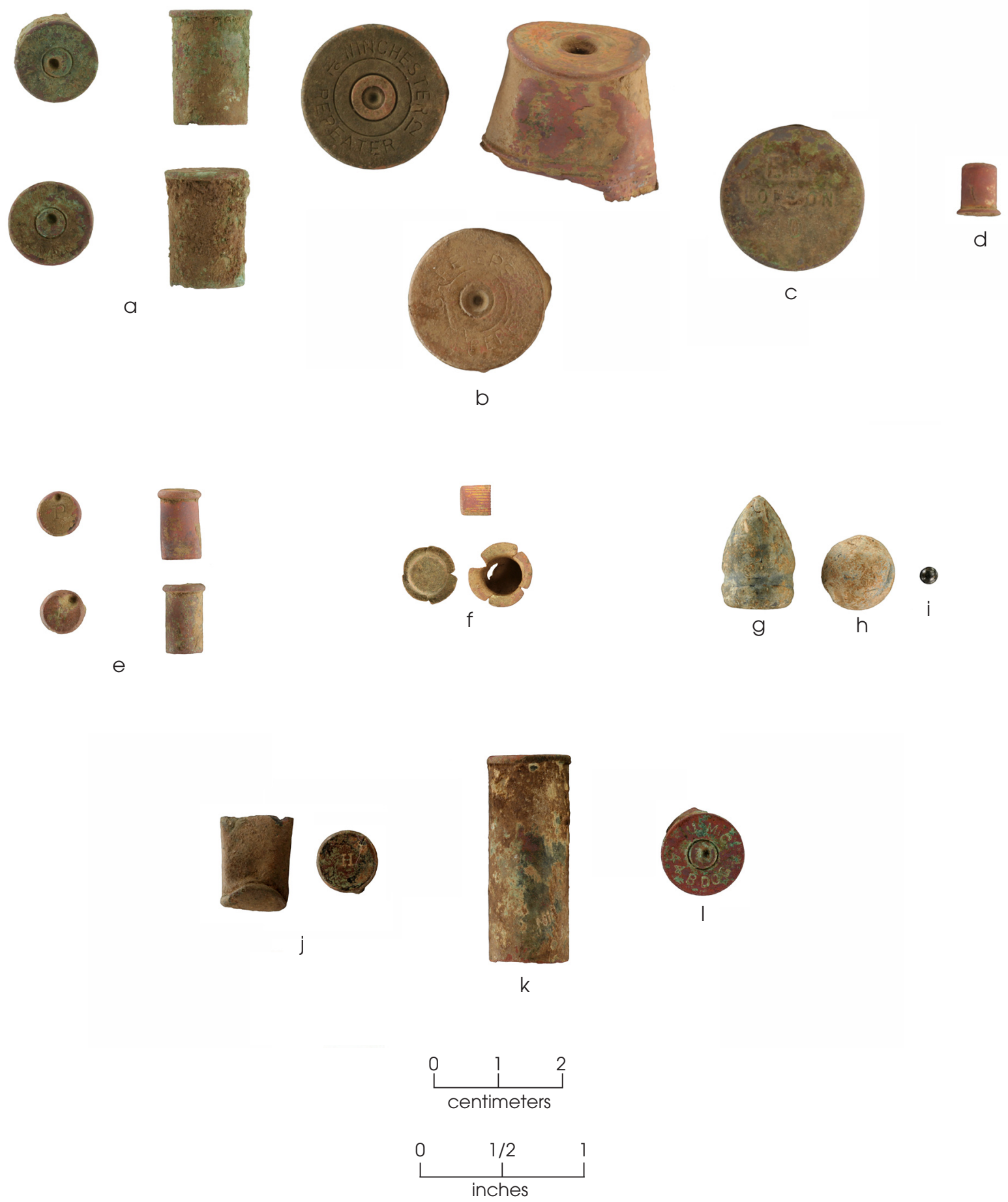

Figure 8.35. Munitions. (a) .44 Webley center-fire cartridge cases (with "WRA" headstamp); (b) 12-gauge shotgun shell heads (one with "WINCHESTER" and one with "PETERS" marks); (c) 10-gauge pinfire shotgun shell head; (d) shotgun shell primer; (e) .22-caliber rim-fire cartridge cases; (f) small and large percussion caps; (g) .44-caliber conical lead bullet; (h) .44-caliber round lead ball; (i) small lead shot; (j) .32 short rim-fire cartridge cases (one has " $\mathrm{H}$ " headstamp); (k) unidentified .44-caliber centerfire cartridge case; (l) .44 Bulldog center-fire cartridge case. 

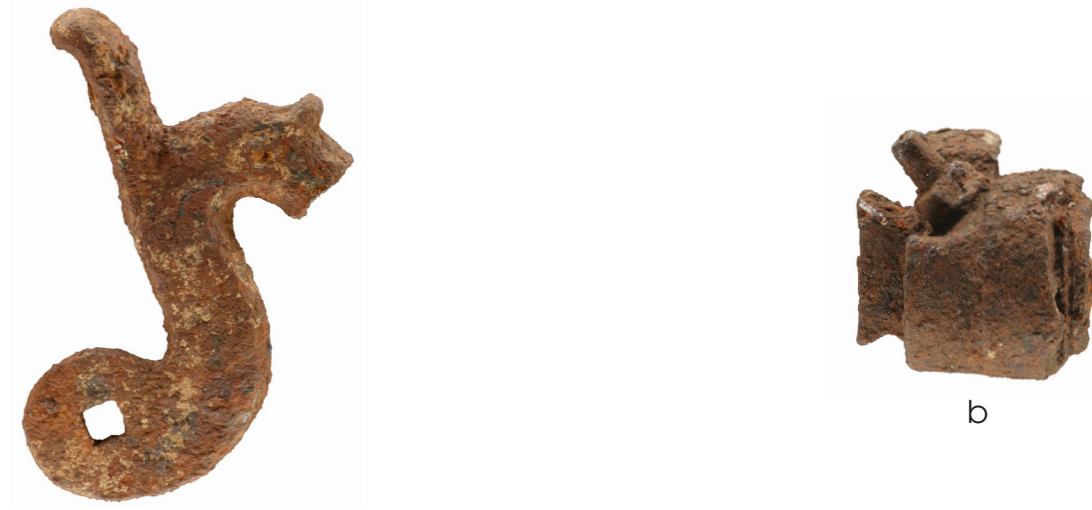

b

a

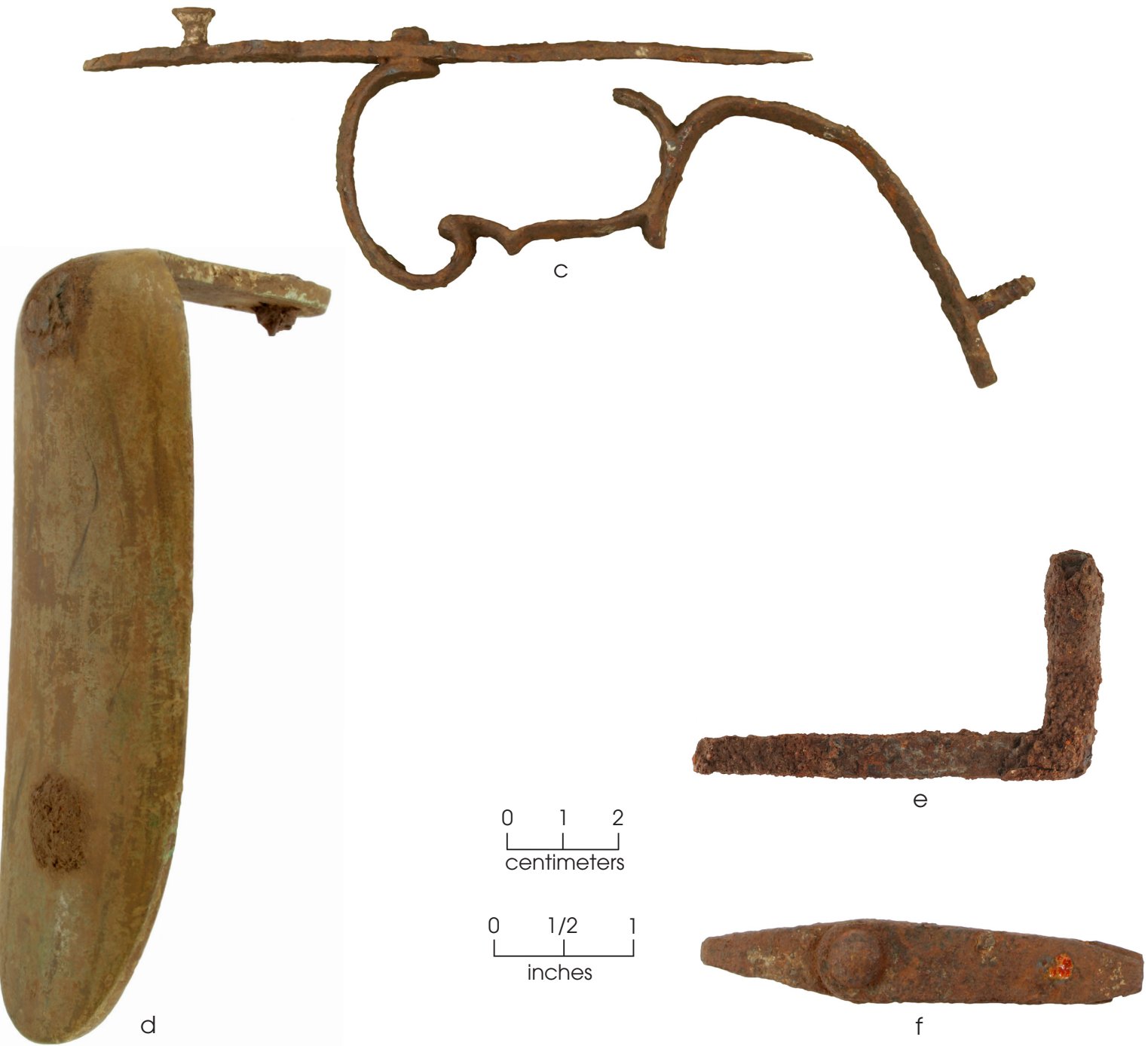

Figure 8.36. Gun parts and firearms tools. (a, b) Hammer and breech plug from a muzzleloading shotgun; (c) rifle trigger guard, possibly from a Flobert rifle; (d) butt plate from an Enfield rifle; (e) nipple wrench; (f) pocket screwdriver. 
$\$ 9.75$ (pp. 455-456). These prices are much lower than that of their side-by-side breachloading single-shot and double-barrel counterparts, many of which cost more than $\$ 20$ (pp. 449-455). Ransom Williams may have preferred the more affordable muzzleloading shotgun not only due to its cost but because the technology was more familiar to him.

Muzzleloading arms are also represented by the six musket caps (large size for rifles) and one percussion cap (small size for a pistol or small rifle lock) and a butt plate that is identified as being from an Enfield rifled musket. It cannot be stated with certainty what model musket this particular butt plate belonged to, but it may have been from a surplus Civil War gun, probably the Model 1853 or 1858 Enfield rifle. Englishmade Enfield rifled muskets, which fired a large .577-caliber conical bullet, saw extensive use during the Civil War. Both sides used them, with more than 428,000 Enfields being purchased for Union troops and at least 400,000 used by Confederate troops (Lord 1982:247). The musket caps could have been used with the Enfield rifled musket or with the muzzleloading shotgun.

Three individual pieces of shot were also recovered. One is a .44-caliber round ball and the other is a .44-caliber conical lead bullet. Both could be fired in various types of black powder pistols or rifles. The final specimen is a very small piece of lead shot, only 0.108 inches in diameter, that represents likely squirrel or bird shot from one of the shotgun shells or loose shot.

Two firearms-related artifacts are tools: a nipple wrench and a pocket screwdriver. The nipple wrench was used to remove nipples from percussion firearms. The nipple is where the explosive percussion or musket cap would be placed, and they easily became fouled with excess burned power residue. Nipples had to be regularly cleaned, and this was easier to accomplish when they were removed. The pocket screwdriver has three flat blades for various sizes of screws, and the blades all pivot on a single pin at the center joint. Screwdrivers were essential firearms tools because many guns have numerous screws that must be removed to clean the gun properly. This small pocket screwdriver was easy to carry and could be used to clean or repair guns in the field if necessary.

Table 8.28 summarizes the minimum number of firearms and possible firearms on the farmstead. Based on the cartridge cases only, there were at least seven guns: three types of shotguns (10 and 12 gauges) and four other guns (could be rifles or pistols) that fired brass cartridges in $.22, .32, .38$, and .44 calibers. Gun parts, percussion caps, and lead balls in the assemblage reveal the presence of at least three muzzleloading guns-a shotgun, an Enfield rifle, and a .44-caliber pistol or rifle. It also is possible that a fourth muzzleloading gun, a .32-caliber pistol, is represented by the smaller lead ball. The only caveat here is that the .32-caliber ball could have been used as buckshot in the muzzleloading shotgun. The collective evidence indicates there were at least 10 different weapons, and possibly 11 , at the Williams farmstead.

It is not clear why so many different firearms are represented or how many types of firearms the Williams family actually possessed. There are certainly many possibilities, but three plausible explanations are offered:

- All of these guns might have been owned and used by various members of the Williams family during the three decades they lived on the farm.

- Some of these guns were owned and used by the Williams family members, but other friends occasionally came to hunt on their land and brought different weapons.

- Ransom Williams or one of his sons might have been in the business of repairing firearms for other people.

\section{Fishing}

Fishing is represented at the Williams farmstead by three hook fragments (Figure 8.37) and one lead weight found in the house block. One large hook fragment is 1.5 inches long, but since it is missing the eye, its exact size cannot be determined. The other two specimens are distal fragments that appear to be medium-sized hooks, but their exact sizes cannot be determined. The fishing weight consists of iron wire with a piece of lead wrapped around it, but the wires that protruded from the lead on both ends are broken off. It weighs 4 grams and measures 1 inch in length. The lead piece is tubular and tapers toward both ends, and it has a mold seam running down its entire length. This weight matches the size and shape of the small lead "Sinkers" illustrated in the 1895 Montgomery 
Table 8.28. Minimum number of guns represented in the assemblage

\begin{tabular}{|c|c|c|c|}
\hline Firearm & Indicated by & $\begin{array}{l}\text { Minimum } \\
\text { No. of Guns }\end{array}$ & $\begin{array}{c}\text { No. of } \\
\text { Possible Guns }\end{array}$ \\
\hline Shotgun, 10-gauge & Cartridge case & 1 & \\
\hline Shotgun, 10-gauge pinfire & Cartridge case & 1 & \\
\hline Shotgun, 12-gauge & Cartridge cases & 1 & \\
\hline Unknown, .22 Caliber & $\begin{array}{l}\text { Cartridge cases (long and short); } \\
\text { possibly Flobert trigger guard }\end{array}$ & 1 & \\
\hline Unknown, .32 Caliber & Cartridge cases (short) & 1 & \\
\hline Unknown, .38 Caliber & Cartridge cases $(.38-40)$ & 1 & \\
\hline Unknown, .44 Caliber & Cartridge cases (Bulldog, Webley, and .44-40) & 1 & \\
\hline Muzzleloading shotgun & Breach plug, hammer, and mainspring & 1 & \\
\hline Muzzleloading rifle & Enfield butt plate, musket caps & 1 & \\
\hline $\begin{array}{l}\text { Muzzleloader, } .32 \text { caliber } \\
\text { (probably a pistol) }\end{array}$ & .32 -caliber lead ball,* percussion cap & & 1 \\
\hline $\begin{array}{l}\text { Muzzleloader, } .44 \text { caliber } \\
\text { (probably a pistol) }\end{array}$ & $\begin{array}{l}.44 \text {-caliber conical bullet and } .44 \text {-caliber lead } \\
\text { ball, musket and percussion caps }\end{array}$ & 1 & \\
\hline \multicolumn{2}{|l|}{ Total } & 10 & 1 \\
\hline
\end{tabular}

*A .32-caliber ball could have been used as buckshot.

Ward catalog (p. 494), which had wire loops on both ends for attaching to the fishing line.

The nearest body of water is Bear Creek, a quarter-mile north-northeast of the Williams farmstead. In dry years (such as the summer of 2009 during the data recovery work), the stream holds very little water. But the water table has certainly been lowered by the intensive development in the area. It is likely that during the late nineteenth century, Bear Creek was usually a flowing stream full of various species of fish. The fact that several small fish scales, likely sunfish, were recovered in flotation samples from the midden and subfloor pit deposits demonstrates that the Williams family consumed fish, and they almost certainly caught the fish locally (see Chapter 10). Although the fishhooks are quite corroded, they suggest that they were going after fairly large fish. But it also is likely that smaller fishhooks were not recovered because they did not survive or were unrecognizable.

\section{Music}

With little to provide entertainment in remote rural areas, life on the farm would have been somewhat slow, repetitive, and monoto-
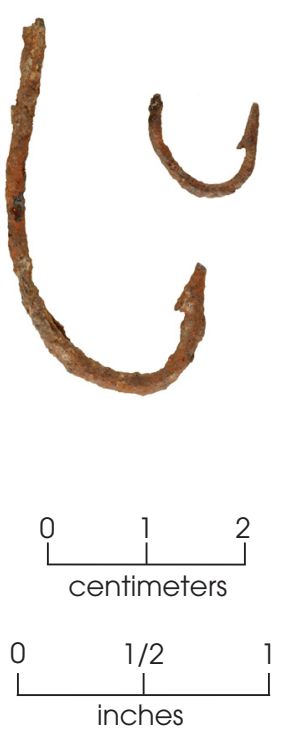

Figure 8.37. Fishhook fragments.

nous at times. People sought out other ways to entertain themselves to combat the boredom of farm life. One affordable and common form of entertainment was playing music. Two types of musical instruments are represented in the 
Williams farmstead assemblage: harmonicas and a Jew's harp (Table 8.29; see Table B.49). Harmonicas were popular musical instruments in the late nineteenth century, and many different models appear in period catalogs (Montgomery Ward \& Company 1895:241; Sears, Roebuck \& Company 1897:n.p.; 1902:207) along with a few types of Jew's harps (Montgomery Ward \& Company 1895:246; Sears, Roebuck \& Company 1902a:208).

A complete harmonica and harmonica parts were found in the house block, yard area, and midden (Figures 8.38 and 8.39). The complete harmonica has two brass cover plates, still screwed together, with the wooden comb and two reed plates still inside. The cover plates are engraved with the words: "The Nightingale" one side and "[G]olden Richter" (first letter is illegible) on the other. It is a richter-tuned, or 10-hole, harmonica, but all attempts identify the maker and date of manufacture were unsuccessful. The other specimens are one reed and 10 reed plates. All of the other reed plates also appear to be from richter-tuned harmonicas. The plates are all roughly the same size (but there are minor differences), and the complete examples all have 10 slots present. Based on the differences between the various reed plates (i.e., material, screw hole placement, and plate sizes), the assemblage appears to represent at least five other harmonicas beside the complete specimen.

The other musical instrument is a Jew's harp (also called a mouth harp) from the house block (see Figure 8.39). It was a much simpler instrument, composed of only a few parts. Its iron frame and arms are complete, but the tongue and trigger are missing. This type of mouth harp was a very popular folk music instrument in the eighteenth and nineteenth centuries. The 1894 Sears, Roebuck catalog (p. 254) lists seven models of Jew's harps. The simpler of the two illustrated models matches the farmstead specimen; these sold for $\$ 0.05$ to $\$ 0.40$ each depending on their size and weight.

\section{Toys}

Toys reflect the presence of children on the farmstead. Since children's toys often mimic adult activities, the Williams children were probably acting out gender roles, both consciously and unconsciously, when they played with many of their toys. While some toys were somewhat gender-neutral, others were ascribed to a specific gender by societal norms. This is not to say that boys and girls did not play together with all the toys at various times, but toy guns were typically associated with boys while dolls and tea sets were considered to be girl toys.

The toy assemblage is summarized in Table 8.30 (see Table B.38), and some specimens are illustrated in Figure 8.40. Toy guns have been a favorite among American boys for many generations, and the Williams boys were no exception. A complete toy cap gun is made of stamped metal and bears the name "CHIEF" on one handle. It has two barrels and one of its two original triggers, but both hammers are broken off. Attempts to identify the manufacturer and age of this toy pistol were unsuccessful, and many different toy makers used the Chief name to invoke the image of cowboys and Indians. Two other gun artifacts are hammers from toy cap guns.

The more gender-neutral toys are six marbles and a rubber ball. The marbles include two glass (diameters 0.76 and 0.82 inch) and

Table 8.29. Musical artifacts

\begin{tabular}{|c|c|c|c|c|}
\hline Artifact & House Block & Yard Area & Midden & Total \\
\hline Harmonica, complete* (brass and wood) & - & - & 1 & 1 \\
\hline Harmonica reed (brass) & 1 & - & - & 1 \\
\hline Harmonica reed plates (brass) & 3 & 2 & 2 & 7 \\
\hline Harmonica reed plates (white metal) & - & - & 3 & 3 \\
\hline Jew's harp (iron) & 1 & - & - & 1 \\
\hline Total & 5 & 2 & 6 & 13 \\
\hline
\end{tabular}

*This specimen has stamped names on the front and back cover plates:"The Nightingale" and "[?]olden Richter" (probably Golden). 

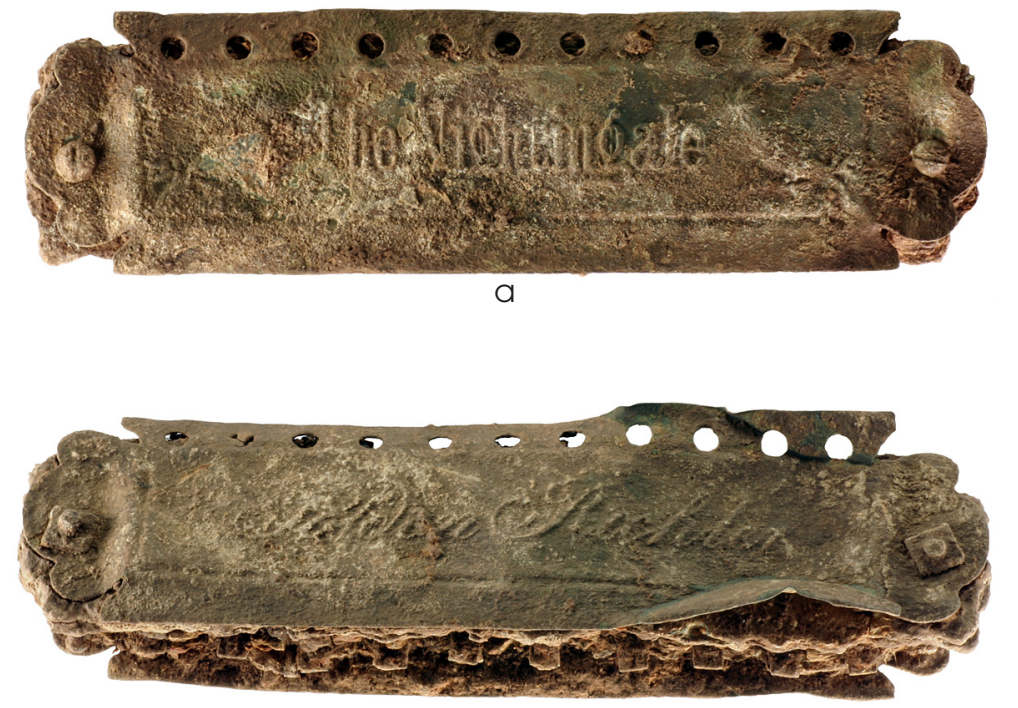

b

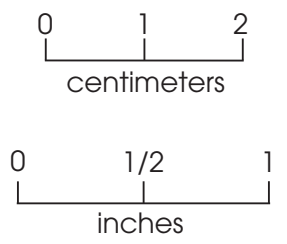

Figure 8.38. Complete harmonica, front and back sides. The brass cover plates are stamped with the words "The Nightingale" and "[?]olden Richter" (probably Golden).

four made of white clay, possibly kaolin (diameters $0.57,0.71,0.82$, and 0.84 inch). Both of the glass marbles are in poor condition, with one being a half marble of blue glass and the other a clear glass with numerous chips on its surface from heavy use. The clay marbles are in better condition, not showing any signs of breaks or chips. The rubber ball is made of a hard black material that has long since dried and cracked. It retains none of its original elastic properties.

The girls' toys include porcelain doll fragments and parts of a tea set. The doll parts are limb fragments, either arm or leg segments, and one head and face fragment. Differences in the porcelain finishes suggest that these fragments came from at least two different dolls. The tea set artifacts are all porcelain and represent one cup, one pitcher, and one saucer. The finish on all three specimens is quite similar, so they probably came from the same tea set.

\section{Writing}

Education would have been an important aspect of the children's lives, especially taking into account Ransom and Sarah's backgrounds. Having been former slaves, a formal education was not an option for them, and there is no evidence to indicate that they were literate. Following the Texas emancipation in 1865, African Americans were allowed access to education, and segregated black schools sprang up across the state. ${ }^{105}$ One of the most important aspects of a child's education was learning how to read and write, and the material culture from the Williams farmstead provides direct evidence of these endeavors (see Table B.51). Ninety-two writing artifacts were found in the house block, midden, and outbuilding area. These are summarized in Table 8.31, and some specimens are illustrated in Figures 8.41 and 8.42. The presence of these writing materials provides circumstantial evidence indicating that Williams children were attending school and that education was a priority for the family.

Ink bottles are represented by one complete ink bottle and seven glass fragments from ink bottles. The complete bottle is Glass Container 8, illustrated in Figure 8.2, and it had a threaded mouth for a metal screw cap lid. Four other fragments are pieces of a similar threaded mouth that are grouped as Glass Container 60 (see Table B.4). No pieces of ink pens were found, but it is likely that they might have had wooden shafts that would deteriorate and thin metal tips that would have been too corroded to identify.

Slate fragments were the most common writing-related item recovered $(n=64)$. These fragments range in size from less than 0.5 inches up to the largest fragment measuring almost $4 \times 7$ inches. Although the exact number of small

\footnotetext{
${ }^{105}$ A Freedmen's Bureau report for 1866 showed that there were 90 bureau schools for freedmen and 4,590 students in Texas (Hornsby 1973:400).
} 
writing slates is not known, it is likely that several are represented. No attempt was made to reconstruct writing slates from the fragments because the broken edges would be difficult or impossible to refit. One specimen has a squared and smooth edge that appears to be a corner that would have been seated into a wooden frame. Several of the larger fragments have many scratches on their surfaces, some of which appear to be etched letters, numbers, and small designs reminiscent of doodling.

Eleven slate pencils fragments were recovered, and these are cyclinders of a soft rock like talc or soapstone. When dragged across the surface of the slate writing table, the slate pencil produces a white line similar to that of chalk on a chalkboard. All of the slate pencil fragments are quite small, and the largest measures only ca. 1.5 inches long.

Graphite pencils are represented by six specimens. Three have measurable lead fragments with diameters of $2.06,2.20$, and $2.47 \mathrm{~mm}$, and three have proximal ends with metal eraser bands or ferrules (probably aluminum). Two of
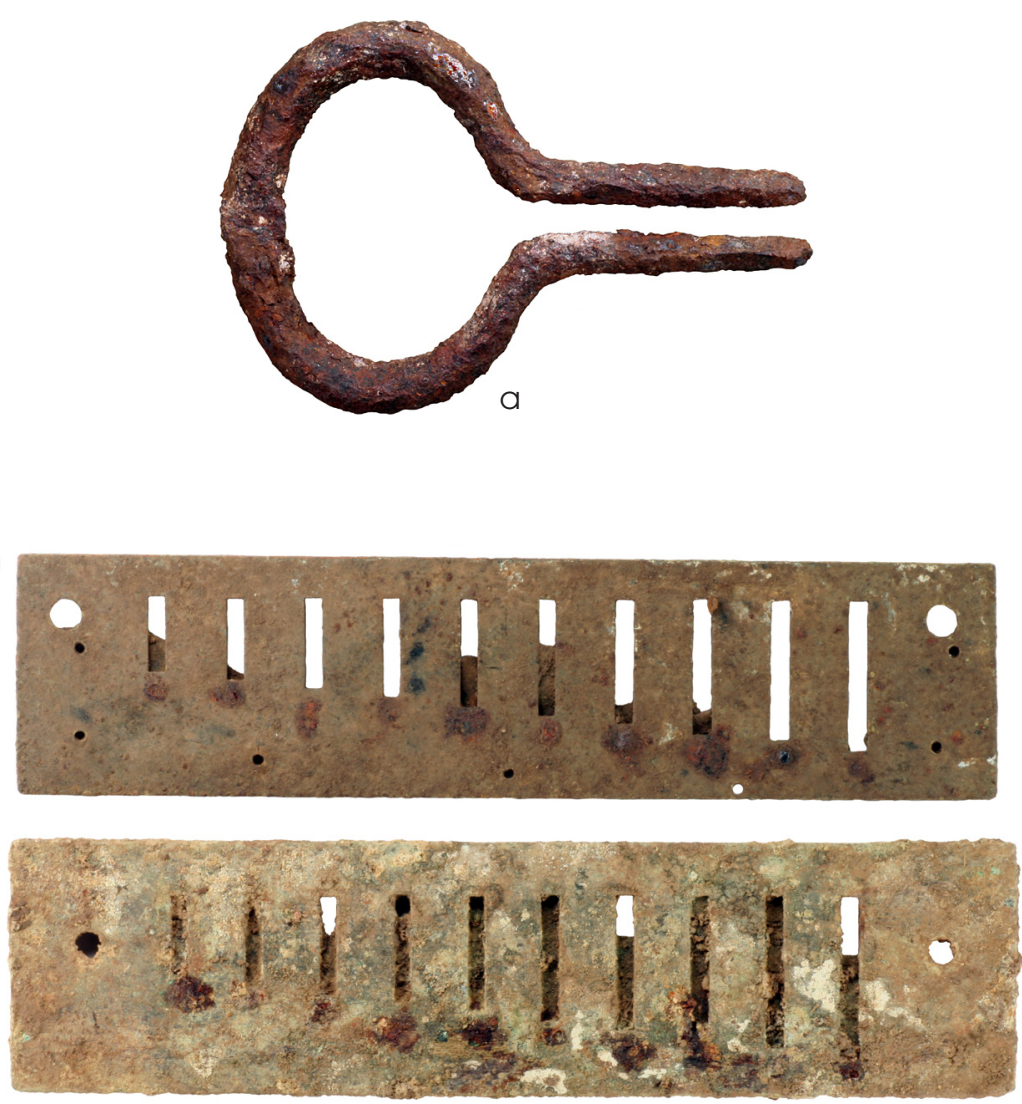

b the latter still have the gum erasers intact. One is worn flush with the eraser band from extensive use. The other specimen has a domed-shape eraser that protrudes beyond the band, as well as a portion of the wood pencil and lead intact.

The first patent for a pencil with an attached eraser was in 1858 (Patent No. 19,783; Lipman 1858), but the classic metal ferrule for attaching erasers was patented 1891 by Eberhard Faber and is still in use today. This patented eraser attachment consisted of a narrow metal tube with parallel indentions that clamped to the wooden pencil and held the eraser in place. This is the same type of eraser ferrule that is

represented by the three specimens found at the Williams farmstead (Patent No. 457,579; Faber 1891). Many variations of this type of pencil were sold in the 1895 Montgomery Ward \& Company catalog (1895:115) under the manufacturer's trade name "Dixon's American Graphite Pencils."

Evidence of recycling is represented in the Williams farmstead artifact assemblage, and two carbon battery cores (three fragments; two pieces that refit) show evidence of modification that may be related to writing (Figure 8.43). One end of each specimen is modified by sharp- 
Table 8.30. Toys

\begin{tabular}{l|l|c|c|c|c|c}
\hline \multicolumn{1}{c|}{ Artifact } & \multicolumn{1}{c|}{$\begin{array}{c}\text { Typical Gender } \\
\text { Association }\end{array}$} & $\begin{array}{c}\text { House } \\
\text { Block }\end{array}$ & $\begin{array}{c}\text { Yard } \\
\text { Area }\end{array}$ & Midden & Outbuilding & Total \\
\hline Toy gun, marked “Chief” & Boys & - & - & 1 & - & 1 \\
\hline Toy gun hammers & Boys & 1 & - & - & 1 & 2 \\
\hline Marbles (clay) & Neutral or boys & 3 & 1 & - & - & 4 \\
\hline Marbles (glass) & Neutral or boys & 2 & - & - & - & 2 \\
\hline Rubber ball & Neutral or boys & 1 & - & - & - & 1 \\
\hline Porcelain doll fragments & Girls & 3 & 1 & - & - & 4 \\
\hline Tea-set cup & Girls & - & - & 1 & - & 1 \\
\hline Tea-set pitcher fragments* & Girls & - & - & 8 & - & 8 \\
\hline Tea-set saucer fragments** & Girls & - & - & 3 & - & 3 \\
\hline Total & & 10 & 2 & 13 & 1 & 26 \\
\hline
\end{tabular}

* All of the pitcher fragments refit to form one pitcher.

** All of the saucer fragments refit to form one saucer.

ening and abrasive use wear, and it appears that someone recycled these battery cores into writing implements. The carbon rods were probably sharpened so they could be used to write on hard surfaces, leaving black marks on sheet iron or limestone rocks, for example.

The two carbon rods are about the same diameter as the carbon rods in modern $\mathrm{D}$ cell batteries, and their presence in the assemblage is interesting. Were they scavenged from somewhere else and brought to the farm, or did the Williamses have some devices that used batteries? Dry-cell batteries were not listed in the 1865 Montgomery Ward \& Company catalog, but "Dry Batteries" appeared in the 1897 Sears catalog and were touted as being greatly improved and now "largely displacing the wet batteries...for nearly all types of work" (Sears, Roebuck \& Company 1897:np; Item No. 6055). Several sizes of dry-cell batteries were advertised in the 1902 Sears catalog, and the same page listed an "Electric Search Light" (Sears, Roebuck \& Company 1902b:253). This battery-powered flashlight cost $\$ 1.72$, and extra batteries cost $\$ 0.39$ each.

\section{Sewing}

Although sewing was likely an important activity at the Williams farmstead, only 19 sewing-related items were recovered. With as many as 9 to 11 people living on the farm at some times, the Williamses probable made some of their own clothes and repaired clothing on a regular basis. They also may have made and repaired quilts, bedsheets, pillowcases, saddle blankets, etc. The sewing-related artifacts consist of straight pins, safety pins, scissors, and a thimble (Table 8.32; Figure 8.44). All of the items are iron, and most were recovered from the house block.

The iron straight pins are corroded and very fragile, suggesting that this artifact type is underrepresented because many specimens were no longer identifiable. The single pair of scissors is incomplete, consisting of only the handle with the blades broken or rusted away. The thimble is complete, but this plain specimen has no obvious decorations. Its outside surface is covered with impressed dimples.

Three styles of safety pins are represented. Seven of the safety pins are identified as the Lindsay type (two specimens on the left and one on the bottom right in Figure 8.44b), patented in 1878 (Patent 198,890; Lindsay 1878). The Lindsay type was of "a wire safety-pin made in one piece, and so bent as to form a shield, composed of two loops arranged side by side, and terminating in another loop, which forms a guard or socket for the point of the pin...."

One specimen is of the Hyatt type (specimen at top right in Figure 8.44b), patented in 


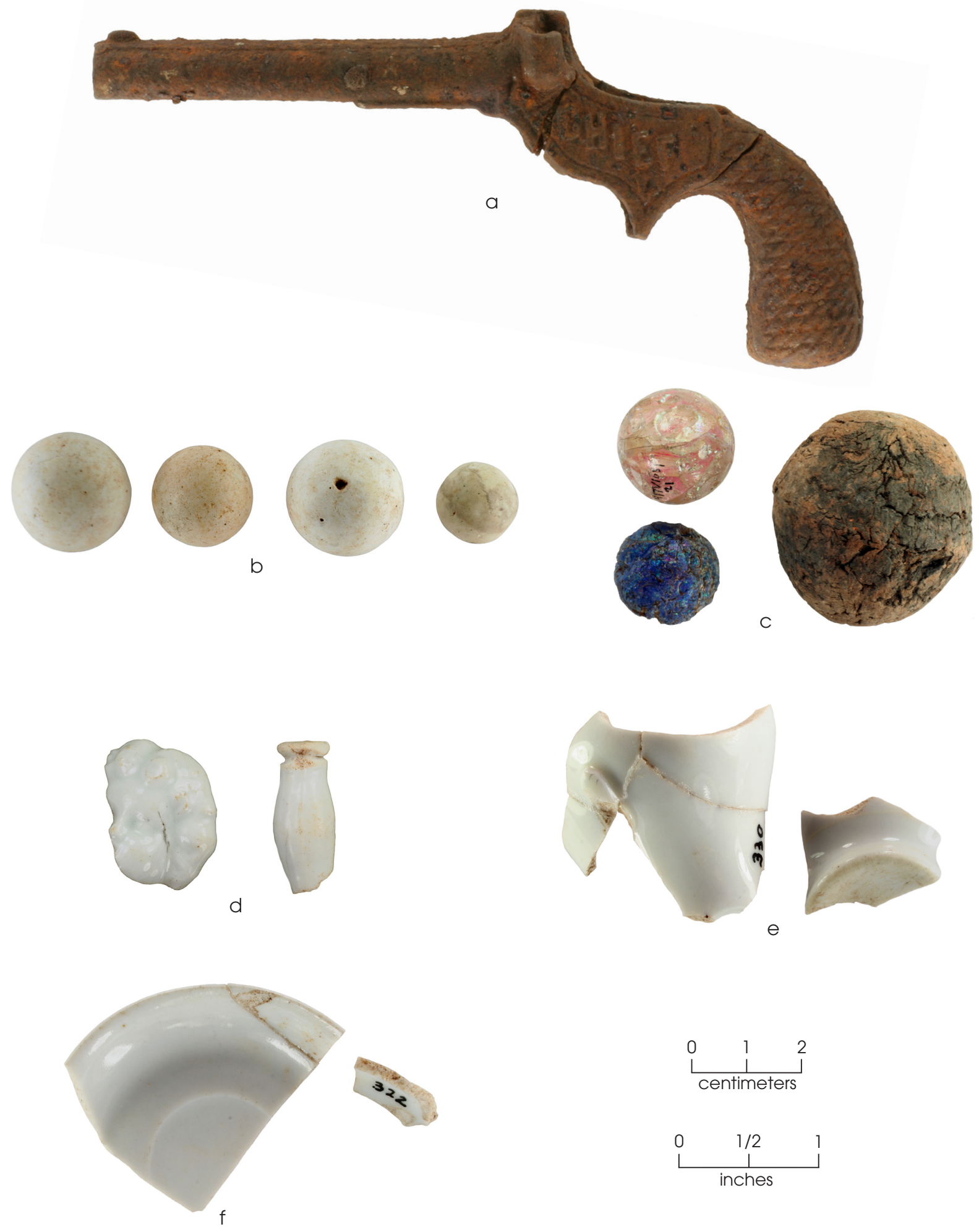

Figure 8.40. Children's toys. (a) Cast-iron "CHIEF" cap pistol; (b) fired clay marbles; (c) glass marbles and a hard rubber ball; (d) porcelain doll parts; (e) pitcher and cup fragments from a porcelain tea set; (f) saucer fragments from a porcelain tea set. 
Table 8.31.Writing artifacts

\begin{tabular}{l|c|c|c|c|c|c}
\hline \multicolumn{1}{c|}{ Artifact } & $\begin{array}{c}\text { House } \\
\text { Block }\end{array}$ & $\begin{array}{c}\text { House Block, } \\
\text { Subfloor Pit }\end{array}$ & $\begin{array}{c}\text { House Block, } \\
\text { Chimney Firebox }\end{array}$ & Midden & Outbuilding & Total \\
\hline $\begin{array}{l}\text { Ink bottle, complete } \\
\text { (GC-8) }\end{array}$ & - & - & - & 1 & - \\
\hline $\begin{array}{l}\text { Ink bottle fragments } \\
\text { (GC-60) }\end{array}$ & 1 & - & 1 & 5 & - & 7 \\
\hline $\begin{array}{l}\text { Modified carbon cores from } \\
\text { dry cell battery* }\end{array}$ & 3 & - & - & - & - & 3 \\
\hline $\begin{array}{l}\text { Pencil fragments with eraser } \\
\text { end }\end{array}$ & 3 & - & - & - & - & 3 \\
\hline Pencil leads & 2 & 1 & - & - & - & 3 \\
\hline Slate pencil fragments & 7 & 4 & - & - & - & 11 \\
\hline Writing slate fragments** & 28 & 16 & - & 17 & 3 & 64 \\
\hline Total & 44 & 21 & 1 & 23 & 3 & 92 \\
\hline
\end{tabular}

* The ends of the three battery carbon rods have been sharpened.

** The number of writing slates represented by these fragments is unknown.

1888 (Patent 375,873; Hyatt 1888). In addition to the bent wire, it has a separate protective shield "which is approximately of $U$ shape and made of sheet metal." The distinctive feature that identifies this specimen as a Hyatt safety pin is the wire that projects upward within the shield. The Hyatt type closely resembles pins illustrated in the 1895 Montgomery Ward \& Company (1895:87) catalog and advertised as "sensible safety and blanket pins."

The last specimen is a fragmentary safety pin (not illustrated) that is most similar to the "Clinton Safety Pin" that was advertised in a 1902 issue of the Woman's Home Companion. The ad, which has an illustration of this safety pin, was reproduced in an online vintage fashion blog (What-I-Found 2010). The Clinton Safety Pin, manufactured by the Oakville Company of Waterbury, Connecticut (Owens 2000:426), is almost identical to safety pins used today. It appears to be a variation of the safety pin with a sheet metal shield patented by Boden in 1900 (Patent 643,261; Boden 1900).

In the Williams farmstead assemblage, the Lindsay and Hyatt types are older styles of safety pins that were in use before the turn of the century. These styles were found associated with many of the burials in the African American Freedman's Cemetery in Dallas (described as Types 1C1, Hyatt, and Type 2, Lindsay; Owens 2000:424-427). The Clinton Safety Pin was very popular around 1900, perhaps earlier, and this style and many similar variations were used throughout the twentieth century. It is notable that the Clinton-style safety pin was recovered from the subfloor pit in the house block, which is thought to have been backfilled with trash after 1898 and before 1904 (see Chapter 7).

\section{Collectibles}

Collectible objects are unusual items that were procured for some intended but now unknown purpose, perhaps for a hobby, for display, or as an investment. Regardless of their original intended purposes, collectible objects were intentionally obtained and curated by people. Archeologically, collectibles are recognized because they are unique items in the assemblage. The collectible artifacts are summarized in Table 8.33 (see Table B.52).

Eight polished hematite nodules were found during excavations, and some of these are shown in Figure 8.45. Hematite does not occur naturally in the vicinity of the Williams farmstead, so these nodules were apparently brought in from somewhere else. Each of these items exhibits some degree of smoothing and polishing. Five of the nodules are mostly round and shiny, another specimen is cylindrical, and two are irregularly shaped. It is unclear if these shapes are natural or the result of intentional 

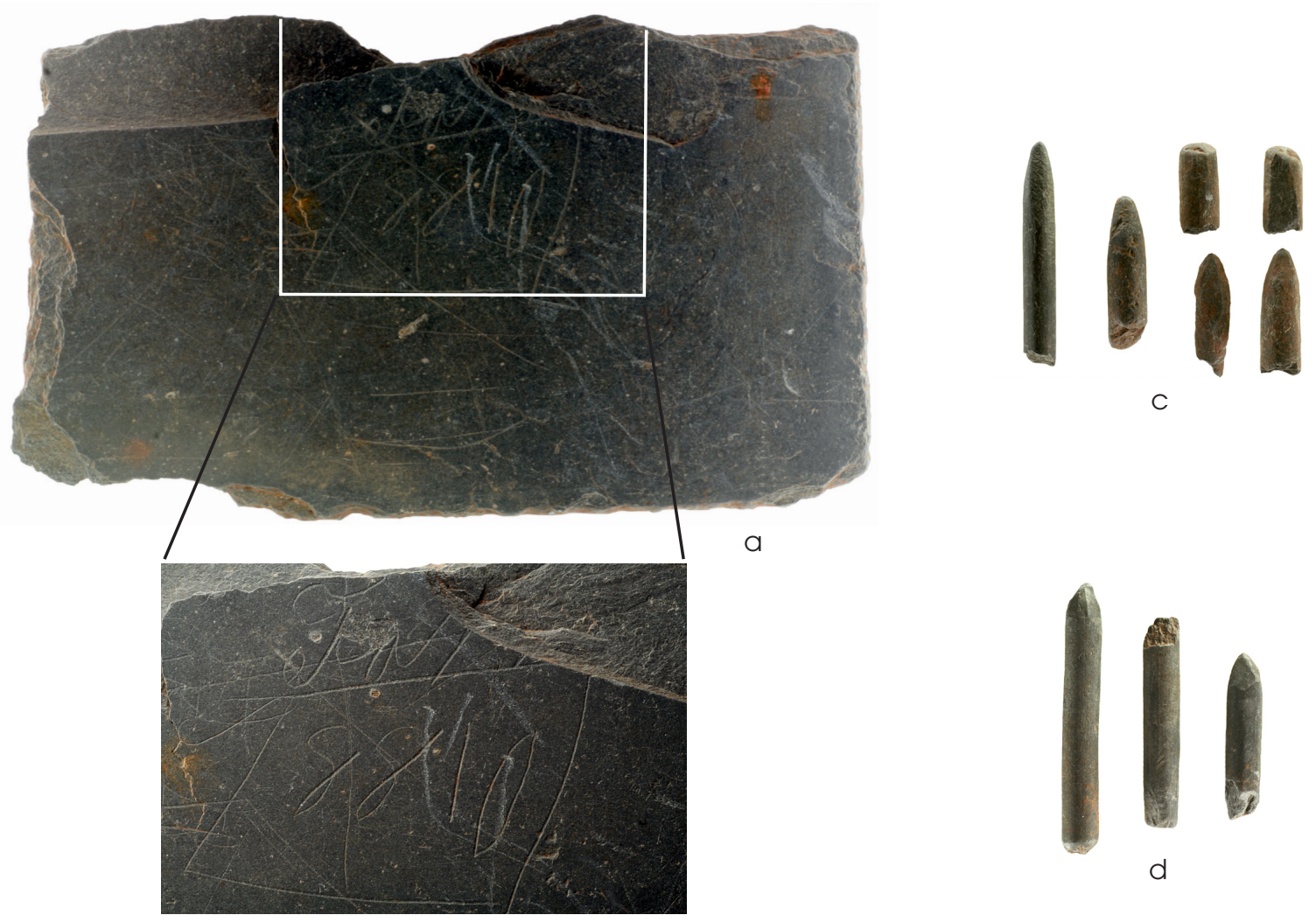

(Enlarged)

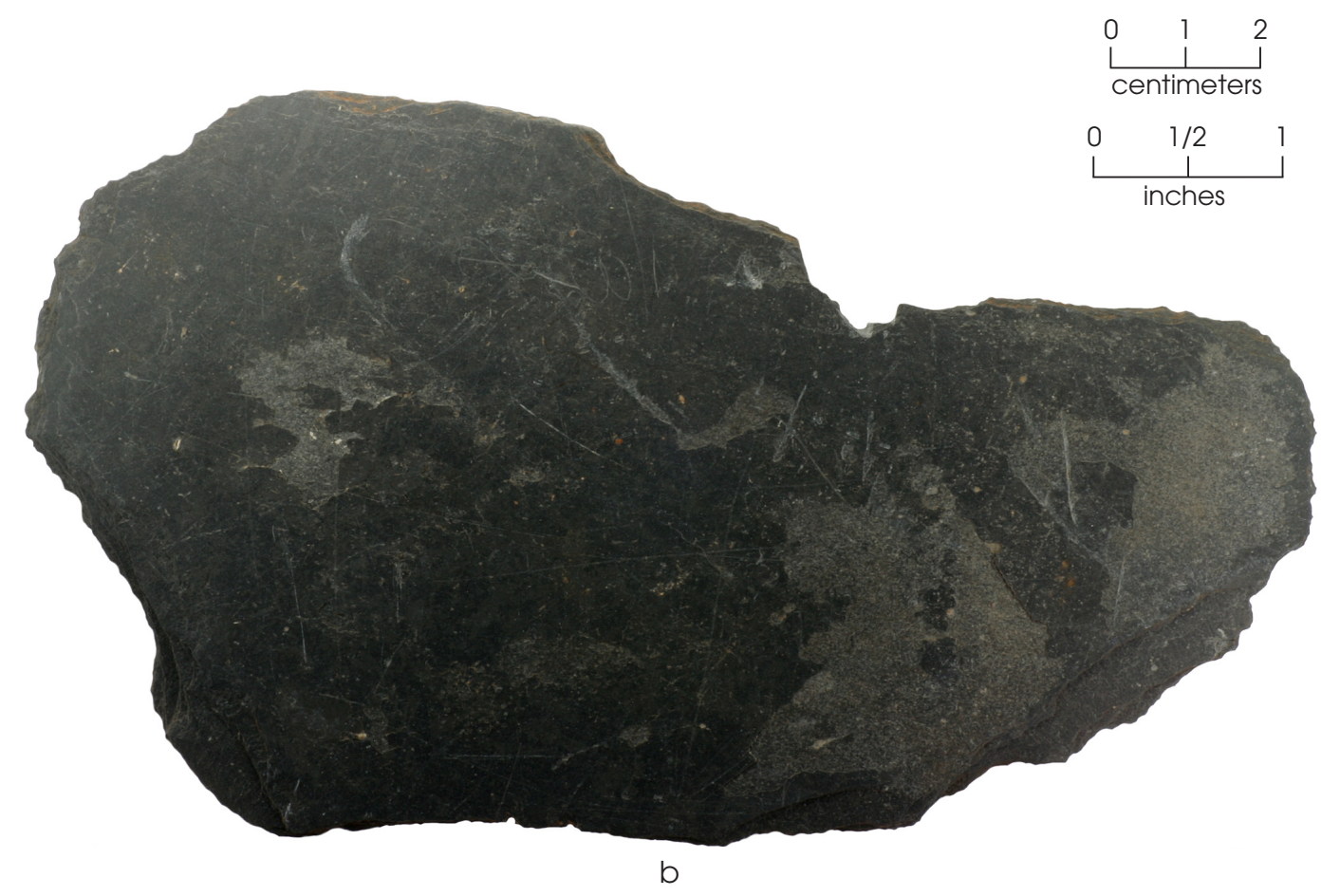

Figure 8.41. Slate fragments and slate writing utensils. (a) Large slate fragment with etching; (b) Closeup of slate fragment with etching; (c) large slate fragment; (d) slate pencil fragments. 

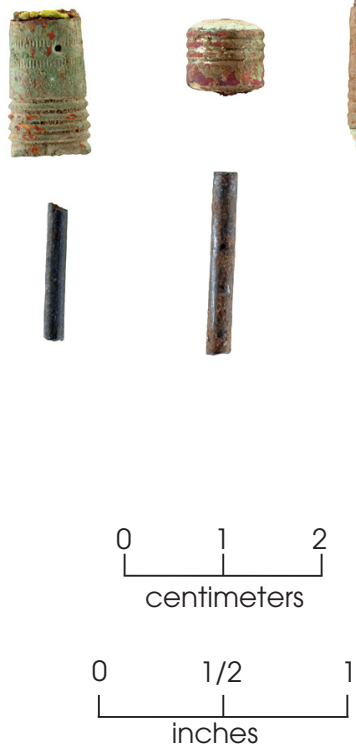

Figure 8.42. Graphite pencil leads and pencil fragments with metal ferrules and erasers.

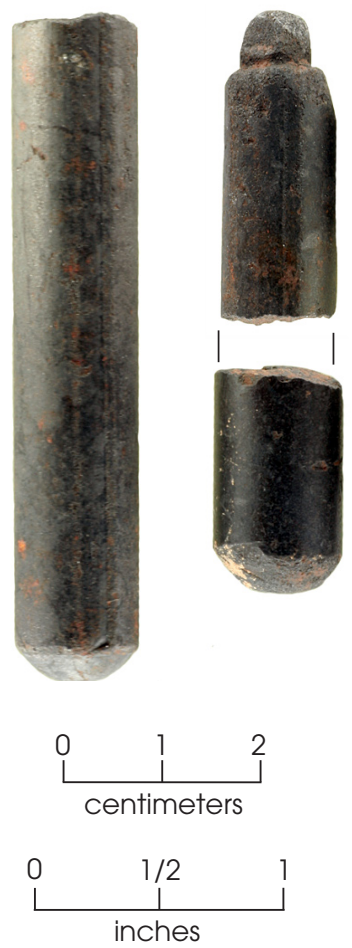

Figure 8.43. Modified carbon battery cores. These recycled items have sharpened and worn ends and were used as writing implements. modification, or if the polish was intentional or incidental as a result of being carried or handled for a long time. These hematite nodules may have been picked up and brought to the farm as curiosities, but the round nodules could have been shaped and used as children's toys (i.e., as marbles).

The other specimen is geofact-a quartz nodule that appears to be unmodified (see Figure $8.45 \mathrm{~b})$. A portion of the rounded nodule is missing, but several quartz crystals are visible on its surface. It is likely that this item was collected as a curiosity.

The collectibles group also includes two chert projectile points (Figure 8.46). One specimen (Figure 846a) is a nearly complete Darl dart point that was found in the rubble-filled sediment layer forming the base below the chimney firebox (see Chapters 7 and 11). It was intentionally placed at the bottom of the fireplace during the construction of the rock chimney. The intentional placement of this dart point within the fireplace has an unusual significance. Similar archeological findings of Native American artifacts at African American sites have been interpreted as representing spiritual offerings. The dart point from the chimney firebox is discussed in more detail in Chapter 11. The other specimen (Figure 8.46b) is a broken Scallorn arrow point found in the yard area west of the house (Unit EU-W8). The distal portion of the point is missing, likely broken long ago, and the chert may have been heat-treated. The context of this specimen suggests it was simply picked up and brought to the site as a curiosity, perhaps by one of the Williams children.

The only manufactured collectible item recovered from the Williams farmstead is a silver-plated commemorative spoon in memory of the sinking of the USS Maine in Havana harbor in 1898 (Figure 8.47). The spoon depicts a cruising battleship along with the words "U.S. BATTLESHIP MAINE" above and "DESTROYED FEB. 15 1898" below. At the top of the handle, the bust of a Navy officer is depicted along with images of a Navy anchor and a U.S. shield (enclosing stars and bars). The name "CAPTAIN SIGSBEE" appears between the bust and the anchor shield. Charles Dwight Sigsbee was the captain of the USS Maine when the incident occurred on February 15, 1898. It was never established that the Spanish forces 
Table 8.32. Sewing artifacts*

\begin{tabular}{l|c|c|c|c}
\hline \multicolumn{1}{c|}{ Artifact } & House Block & House Block, Subfloor Pit & Midden & Total \\
\hline Straight pins & 4 & 2 & 1 & 7 \\
\hline $\begin{array}{l}\text { Safety pins, } \\
\text { Lindsay type }\end{array}$ & 4 & 4 & - & 8 \\
\hline $\begin{array}{l}\text { Safety pin, } \\
\text { Hyatt type }\end{array}$ & 1 & - & - & 1 \\
\hline $\begin{array}{l}\text { Safety pin, } \\
\text { variant of the Clinton type }\end{array}$ & - & 1 & - & 1 \\
\hline Scissors & 1 & - & - & 1 \\
\hline Thimble & 1 & - & - & 1 \\
\hline Total & 11 & 7 & 1 & 19 \\
\hline
\end{tabular}

* All of the sewing artifact are iron except the safety pins, which appear to be plated with a white metal, probably nickel.

attacked and destroyed the Maine, but Spain was blamed, and this was a key incident leading up to the Spanish-American war. This well-publicized incident also galvanized patriotic feelings for the American public, and buying and owning a commemorative spoon was one way of displaying such patriotism.

\section{CLOTHING AND ADORNMENT ARTIFACTS}

Clothing and Adornment is a category that includes a variety of clothing parts, accessories related to clothing, and ornamental jewelry. The 638 specimens in the Clothing and Adornment group are classified into these subcategories:

Clothing fasteners

Clothing buckles

Buttons

Clothing components

Clothing accessories

Jewelry

\section{Clothing Fasteners}

Two types of clothing fasteners recovered from the farmstead are busk fasteners and hook and eye fasteners (Figure 8.48 and Table 8.34; see Table B.17). The busk fasteners are white metal and were typically used to fasten women's corsets. These items demonstrate that the Williams women were abiding by the social fashion norms of the time despite their rural farm setting. Corsets were women's undergarments, and fashionable ladies were expected to wear them underneath their dresses when they went into public social settings. This type of busk fastener was patented in 1880 by Lucian Hill (1880).

The hook and eye is a simple type of fastener consisting of two wire pieces. Hook and eye fasteners were used for a variety of clothing, from overcoats and jackets to ladies' dresses. Hook and eye fasteners were sold in large quantities (by the card, gross, and great gross) in the 1895 Montgomery Ward \& Company (1895:89) catalog. The specimens from the Williams farmstead include pieces that are made of copper wire.

\section{Clothing Buckles}

Thirty-nine buckles and parts of buckles were recovered (see Table 8.34; Table B.16), and some of these specimens are illustrated in Figure 8.49. The most common types are simple two-piece square buckles and two-piece swivel buckles often seen on the adjustment straps on vest backs and on waist adjustment straps in period pants or jeans. These specimens are generically called clothes buckles because it is not possible to accurately determine the exact type of clothing on which they were used. Nine two-piece square clothes buckles were found, and 

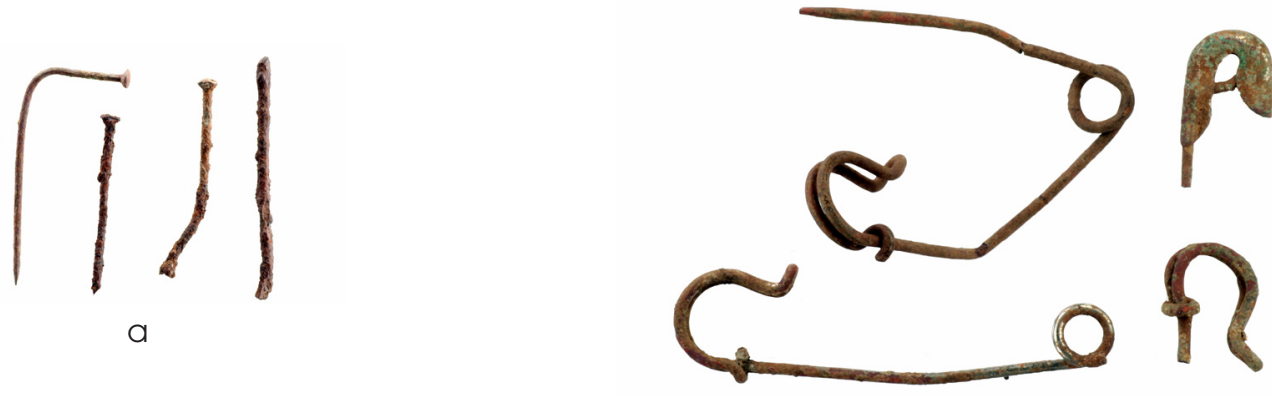

b

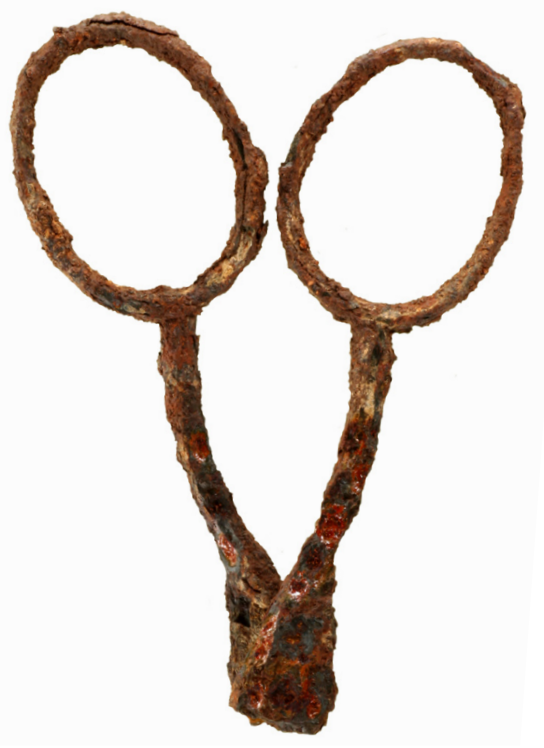

C

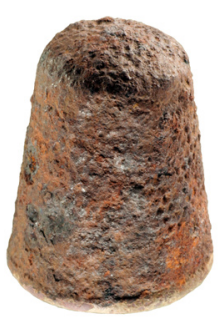

d

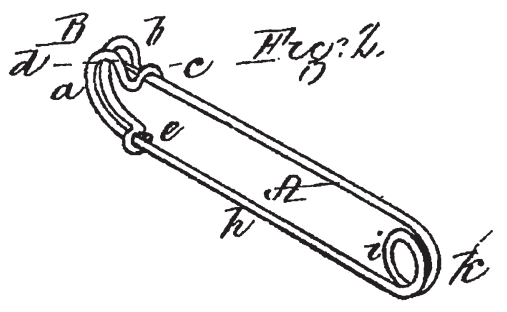

e
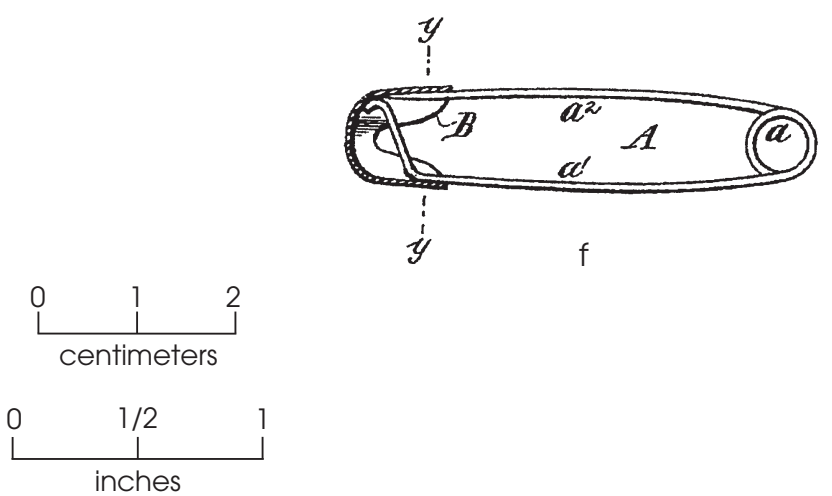

Figure 8.44. Sewing artifacts. (a) Straight pins; (b) safety pins; (c) scissors; (d) thimble; (e) safety pin drawing from Patent No. 198,890 (Lindsay 1878); (f) safety pin drawing from Patent No. 375,873 (Hyatt 1888). 
Table 8.33. Collectibles

\begin{tabular}{l|c|c|c|c|c|c}
\hline \multicolumn{1}{c|}{ Artifact } & $\begin{array}{c}\text { House } \\
\text { Block }\end{array}$ & $\begin{array}{c}\text { House Block, } \\
\text { Subfloor Pit }\end{array}$ & $\begin{array}{c}\text { House Block, } \\
\text { Chimney Base }\end{array}$ & $\begin{array}{c}\text { Yard } \\
\text { Area }\end{array}$ & Midden & Total \\
\hline Commemorative spoon* & 1 & - & - & - & - & 1 \\
\hline Darl dart point & - & - & 1 & - & - & 1 \\
\hline Scallorn arrow point & - & - & - & 1 & - & 1 \\
\hline Geofact, quartz & 1 & - & - & - & - & 1 \\
\hline Polished hematite nodules & 6 & 1 & - & - & 1 & 8 \\
\hline Total & 8 & 1 & 1 & 1 & 1 & 12 \\
\hline
\end{tabular}

*This spoon is engraved with an image of a ship and the words "U.S. BATTLESHIP MAINE" and

"DESTROYED FEB. 15 1898" in the bowl and "CAPTAIN SIGSBEE" on the handle.

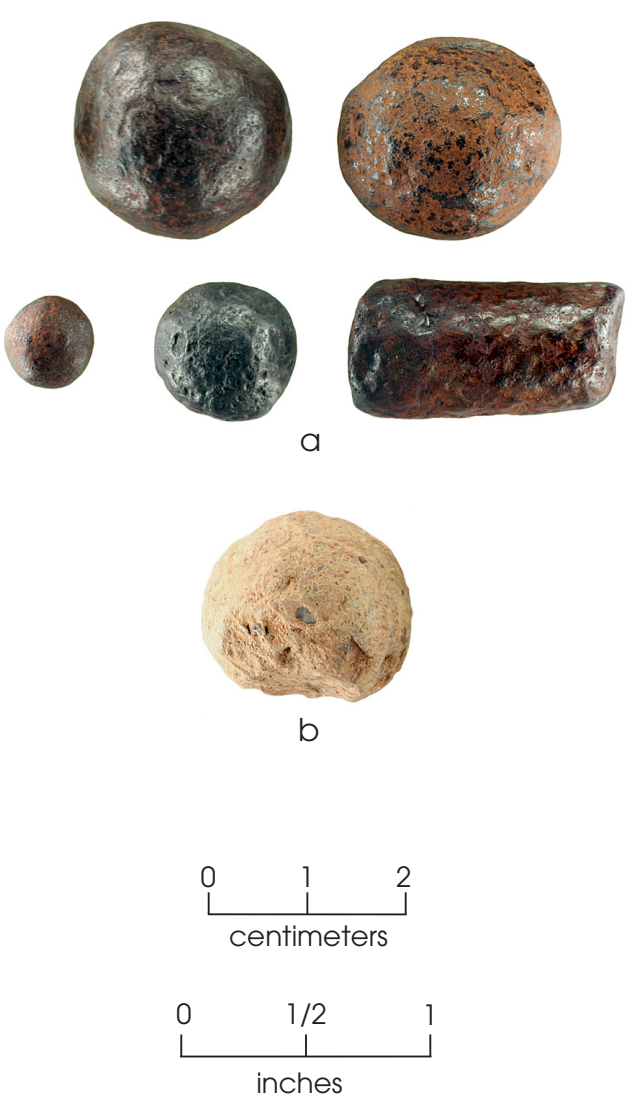

Figure 8.45. Modified hematite nodules and quartz geofact. (a) Hematite nodules; (b) quartz rock geofact.

on average they measure just over 1.2 inches and have two sharp prongs for securing the fabric. The square frames have a pair of small divots opposite each other on the inside of the buckle frame where the tongue bar rotates. Nine speci-
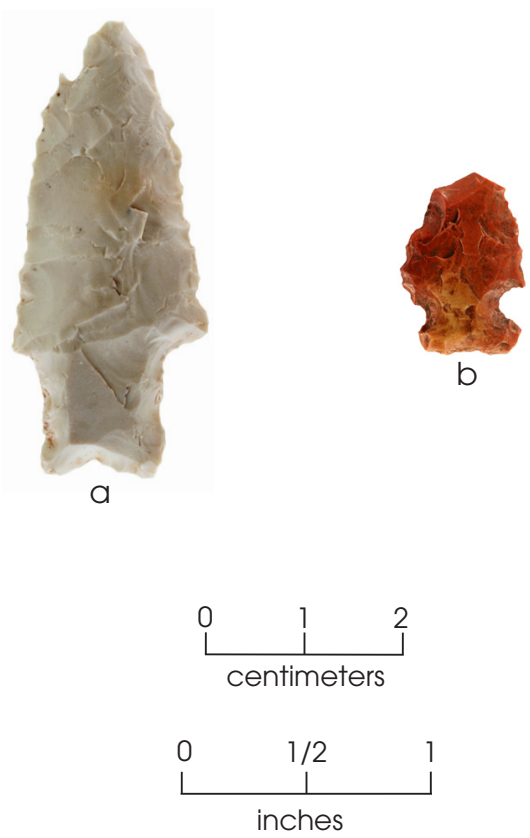

Figure 8.46. Chert projectile points. (a) Nearly complete dart point found in the chimney firebox; (b) arrow point fragment found in the west yard area.

mens are two-piece swivel clothes buckles made of cuprous metal or iron wire and consisting of a tongue and loop part and a frame. The frame piece has two hinge loops that attach to the bent wire tongue and loop where it pivots. Several of the two-piece iron swivel buckles from the farmstead are identical to a buckle design patented on February 3, 1874 (reissued Patent No. 5,755 by Hartshorn 1874). Some others are very similar and clearly based on the same patent. The 


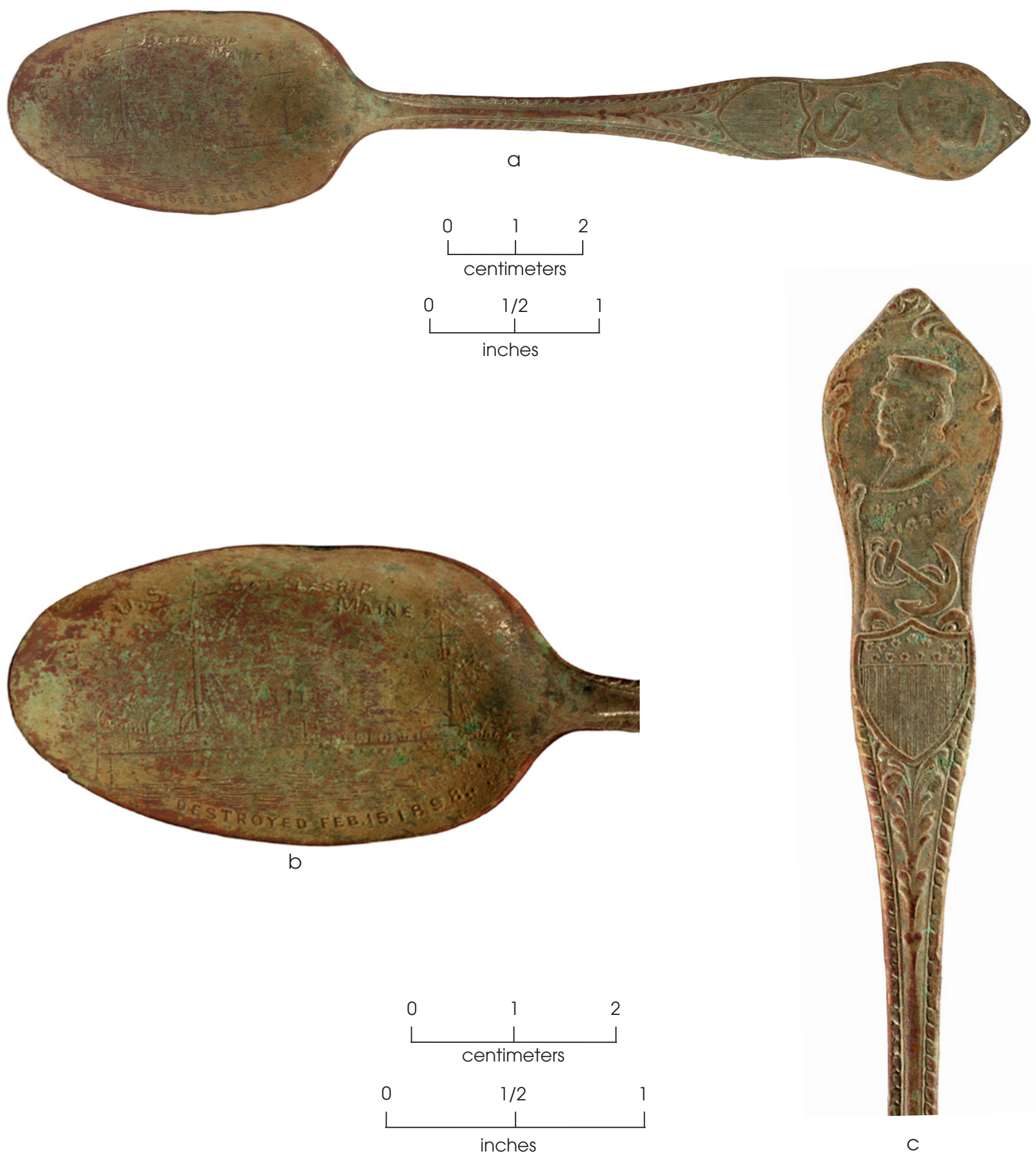

Figure 8.47. Spoon commemorating the sinking of the USS Maine in 1898. (a) Whole spoon; (b) closeup view of the engraved spoon bowl; (c) closeup of the spoon handle.

final two clothing buckles are a nickel-plated safety buckle (rectangular $1 \times 1.6$ inches) and a sliding buckle with teeth (square $0.9 \times 0.9$ inch). Two square iron buckles have stamped marks on them-"SOLIDE" and "PARIS"-but these marks have not been identified.

Three iron buckle fragments are classified as shoe buckles, and they are pieces of a two-part 


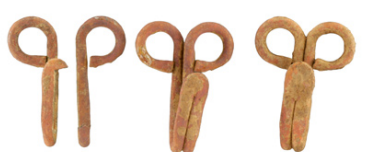

a

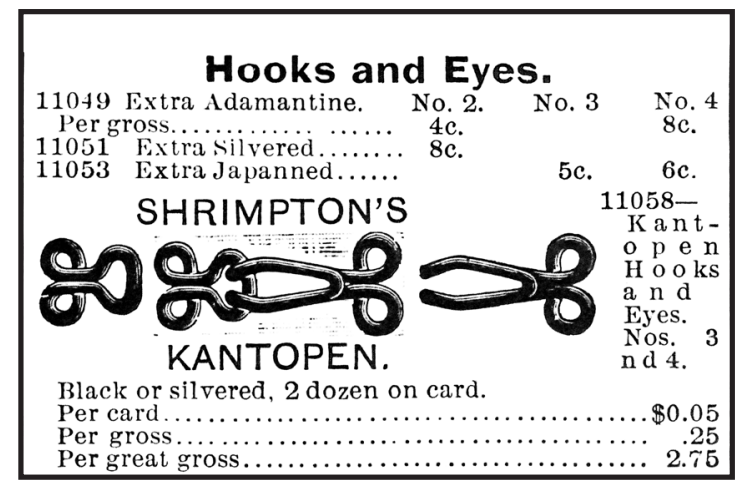

$\mathrm{b}$
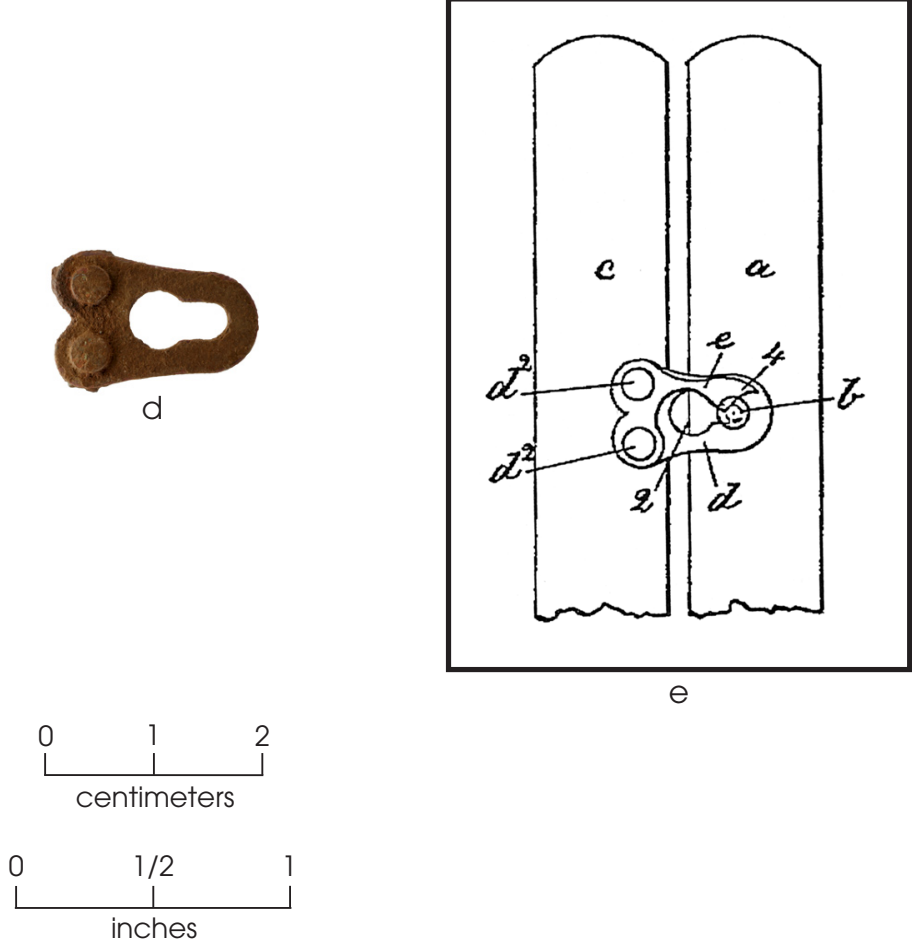

Figure 8.48. Clothing fasteners. (a) Simple hooks from eye-and-hook fasteners; (b) "Hooks and Eyes" illustration from the 1895 Montgomery Ward catalog (p. 89); (c and d) busk fasteners; (e) 1880 drawing for "Corset-Steel Fastening" Patent No. 225,375 by Lucian Hill (1880).

latching mechanisms (see Figures 8.49f, g). One part is a metal band with a series of small parallel slots and the other part is the latch that goes through a slot and clamps down on the band. The latch was attached to one part of the shoe, and the band was attached to the opposite shoe flap. These latches were designed to keep dirt out of shoes when plowing, and to keep out water, mud, or snow. They were often attached to rubberized overshoes that were worn over everyday shoes or boots to keep them from being exposed to the elements. This style of latching mechanism is shown on several varieties of shoes illustrated in the 1895 Montgomery Ward \& Company and 1902 Sears, Roebuck \& Company catalogs, such as "Plow Shoes" (Sears, Roebuck \& Company 1895:518, 1902:1048), "Lumberman's Ankle Boots" (1895:523, 1902:1052), "Rubber Artics" 
Table 8.34. Clothing fasteners and buckles

\begin{tabular}{|c|c|c|c|c|c|c|c|}
\hline $\begin{array}{l}\text { Artifact } \\
\text { Group }\end{array}$ & Artifact & $\begin{array}{l}\text { House } \\
\text { Block }\end{array}$ & $\begin{array}{l}\text { House } \\
\text { Block; } \\
\text { Subfloor } \\
\text { Pit }\end{array}$ & $\begin{array}{l}\text { Yard } \\
\text { Area }\end{array}$ & Midden & Outbuilding & Total \\
\hline \multirow{3}{*}{$\begin{array}{l}\text { Clothing } \\
\text { fasteners } \\
(\mathrm{n}=15)\end{array}$} & $\begin{array}{l}\text { Busk fasteners } \\
\text { (white metal) }\end{array}$ & 8 & - & - & - & - & 8 \\
\hline & $\begin{array}{l}\text { Hook and eye fastener, } \\
\text { eyes } \\
\text { (cuprous metal) }\end{array}$ & 2 & - & - & - & - & 2 \\
\hline & $\begin{array}{l}\text { Hook and eye fastener, } \\
\text { hooks } \\
\text { (cuprous metal) }\end{array}$ & 5 & - & - & - & - & 5 \\
\hline \multirow{6}{*}{$\begin{array}{l}\text { Clothing } \\
\text { buckles } \\
(\mathrm{n}=20)\end{array}$} & $\begin{array}{l}\text { Clothes buckle, safety } \\
\text { (cuprous metal) }\end{array}$ & 1 & - & - & - & - & 1 \\
\hline & $\begin{array}{l}\text { Clothes buckle, sliding } \\
\text { (iron) }\end{array}$ & 1 & - & - & - & - & 1 \\
\hline & $\begin{array}{l}\text { Clothes buckles, square } \\
\text { (cuprous metal) }\end{array}$ & 1 & - & - & - & - & 1 \\
\hline & $\begin{array}{l}\text { Clothes buckles, square } \\
\text { (iron)*** }\end{array}$ & 6 & 1 & - & 1 & - & 8 \\
\hline & $\begin{array}{l}\text { Clothes buckle, swivel } \\
\text { (cuprous metal) }\end{array}$ & 1 & - & - & - & 1 & 1 \\
\hline & $\begin{array}{l}\text { Clothes buckles, swivel } \\
\text { (iron) }\end{array}$ & 4 & - & - & 3 & 1 & 8 \\
\hline $\begin{array}{l}\text { Shoe buckles } \\
(\mathrm{n}=4)\end{array}$ & $\begin{array}{l}\text { Shoe or boot buckles } \\
\text { (iron) }\end{array}$ & - & - & - & 4 & - & 4 \\
\hline \multirow{7}{*}{$\begin{array}{l}\text { Suspender } \\
\text { buckles and } \\
\text { accessories (n } \\
=15)\end{array}$} & $\begin{array}{l}\text { Suspender adjusters* } \\
\text { (cuprous metal) }\end{array}$ & 4 & - & - & 1 & - & 5 \\
\hline & $\begin{array}{l}\text { Suspender adjusters } \\
\text { (iron) }\end{array}$ & 2 & - & - & - & - & 2 \\
\hline & $\begin{array}{l}\text { Suspender buckle } \\
\text { (cuprous metal, nickel } \\
\text { plated) }\end{array}$ & - & - & 1 & - & - & 1 \\
\hline & $\begin{array}{l}\text { Suspender buckles } \\
\text { (iron) }\end{array}$ & 1 & - & - & 1 & - & 2 \\
\hline & $\begin{array}{l}\text { Suspender loop** } \\
\text { (cuprous metal) }\end{array}$ & 1 & - & - & - & - & 1 \\
\hline & $\begin{array}{l}\text { Suspender loops } \\
\text { (iron) }\end{array}$ & 2 & - & - & - & - & 2 \\
\hline & $\begin{array}{l}\text { Suspender slides } \\
\text { (cuprous metal) }\end{array}$ & 2 & - & - & - & - & 2 \\
\hline \multicolumn{2}{|l|}{ Total } & 41 & 1 & 1 & 10 & 1 & 54 \\
\hline
\end{tabular}

*Two suspender adjusters from the house block and the one from the midden are marked with the "CARLSBAD" brand name.

** This suspender loop has "PAT, JULY, 15, 1890" stamped on it. This refers to Patent No. 432,258.

***The iron buckle from the midden has a stamped "SOLIDE" mark. One iron buckle from the house block is stamped with "PARIS." 


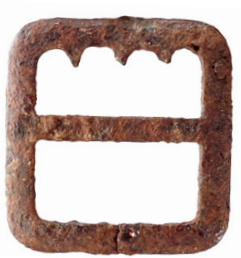

a

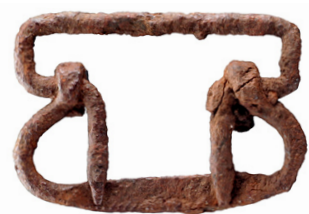

d

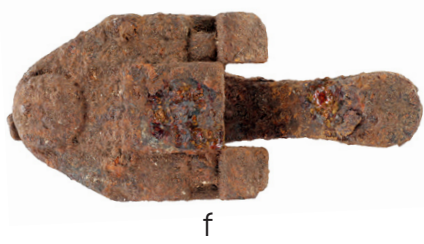

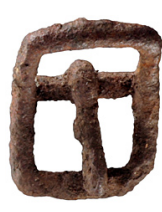

b

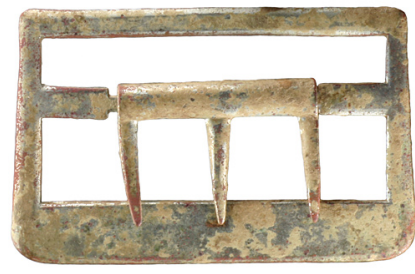

C

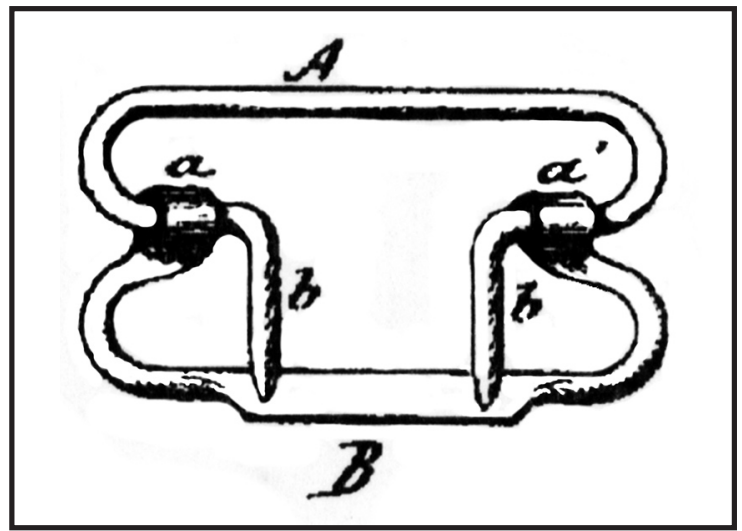

e
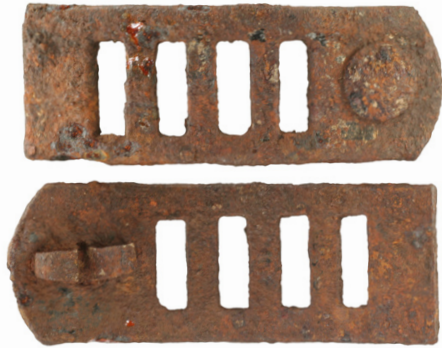

9

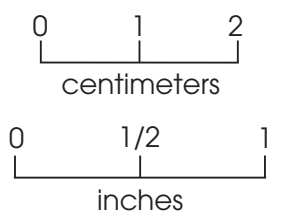

Figure 8.49. Clothing buckles. (a) Simple one-piece iron shoe buckle; (b) two-piece iron buckle with single prong; (c) two-piece, nickle-plated safety buckle with a three-tooth swivel prong; (d) iron two-piece buckle; (e) 1874 drawing of Patent 5,755 buckle by S. S. Hartshorn (1874); (f) iron overshoe buckle latch; (g) iron overshoe buckle straps. 
or "Snow Excluders" (1895:523; 1902:1050), and high-top "Beacon Gaiters" (1902a:1051).

Fifteen specimens are identified as suspender buckles or associated suspender hardware such as adjusters, loops, and slides (Figure 8.50). One buckle is iron with only a small hook remaining; its original shape is unknown. The other is complete and is made of a cuprous metal that appears to be nickel-plated. It is marked with the words "PAT, JULY, 15, 1890." This refers to Patent No. 432,258 issued to S. Baum and V. B. Ulman (1890) for a "Suspender Buckle." The U.S. Patent Office drawings show the buckle and all its working parts. The patent text describes it as a "simple, cheap, and durable buckle that will automatically fasten upon the web of a suspender by the tension of the buckle, so that the greater the strain the closer the buckle will hold" (Baum and Ulman 1890).

Suspender adjusters were the most common suspender part found. These are the tabs found on the front of suspenders that allow the person wearing them to shorten or lengthen the suspenders for a better fit. Each one found has a clamping device with teeth that help to secure the suspender strap when the adjuster is clamped down. Two of the adjusters are likely from the same set of suspenders, and each face is marked with the cursive word "CARLSBAD." They are identical and were found in adjacent excavation units in the house block. A third specimen from the midden also has the Carlsbad name on it. It is not known if Carlsbad is a trade name or a manufacturer's name, and these suspender adjusters have not been identified.

Three suspender loops are all plain iron or cuprous metal. This is the part on the suspender where the strap passes through and heads back to the adjuster, and where the tabs are affixed that attach to the buttons on the pant or jean. Two suspender slides in the assemblage represent another type of suspender adjuster, but one that slides up and down the suspender strap. Slides are simpler in design than the other adjusters, and they lack clamping teeth.

\section{Buttons}

The 440 buttons recovered from the Williams farmstead comprise the largest single category of clothing artifacts (Table 8.35), and selected specimens are illustrated in Figures
8.51, 8.52, and 8.53. Each button was examined individually, and various attributes were recorded (see Table B.15). Recorded information includes count, material, button type, button size, color, and diagnostic markings. Sizing was done using the button chart illustrated in the 1895 Montgomery Ward catalog (Figure 8.54). This is a standardized button sizing scale based on the ligne (line) as a unit of measurement, with 1 ligne equivalent to 1/40 of one inch. Each button was measured using this scale for speed and consistency, and the diameters were then calculated mathematically.

The buttons are made of a wide variety of materials, most commonly of Prosser, a glassy ceramic material.

$\begin{array}{llr}\text { Prosser } & 216 & 49.1 \% \\ \text { Shell } & 94 & 21.4 \% \\ \text { Iron } & 60 & 13.6 \% \\ \text { Cuprous metal } & 35 & 8.0 \% \\ \text { Rubber } & 9 & 2.0 \% \\ \text { Glass } & 7 & 1.6 \% \\ \text { Bone } & 6 & 1.4 \% \\ \text { Jet } & 5 & 1.1 \% \\ \text { White metal } & 4 & 0.9 \% \\ \text { Composite } & 3 & 0.7 \% \\ \text { Unknown } & 1 & 0.2 \%\end{array}$

The high frequency of Prosser buttons speaks to their popularity during the later half of the nineteenth century (see Figure 8.51). Following the advent and patent of the Prosser process in 1840 , these buttons were mass produced quickly and easily by the tens of thousands (Sprague 2002). White is the dominant color of the Prosser buttons in the assemblage, with 196 specimens (90.7 percent); the colored Prossers are black $(\mathrm{n}=14)$, blue $(\mathrm{n}=1)$, brown $(\mathrm{n}=1)$, pink $(\mathrm{n}=2)$, and multiple colors in a calico pattern $(\mathrm{n}=2)$.

Bone buttons are rare at the Williams farmstead; all six specimens are the four-hole dish type (see Figure 8.51). These four-hole machine-made buttons were one of the most common types throughout much of the nineteenth century (Matchen 2006), but they became scarce in historic sites in the last decades of the nineteenth century as other types of buttons became more common and cheaper to manufacture. The 1895 Montgomery Ward catalog had no simple sew-through bone buttons for sale but did advertise these (pp. 85-86): 

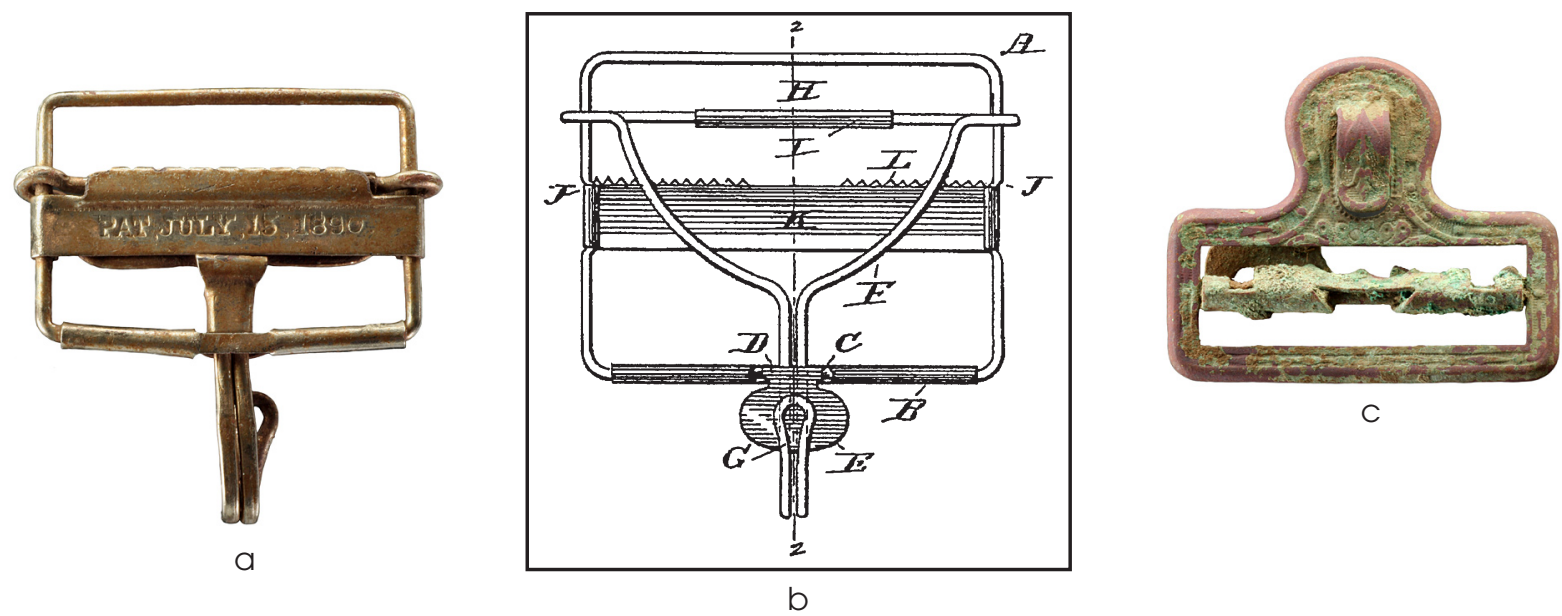

C
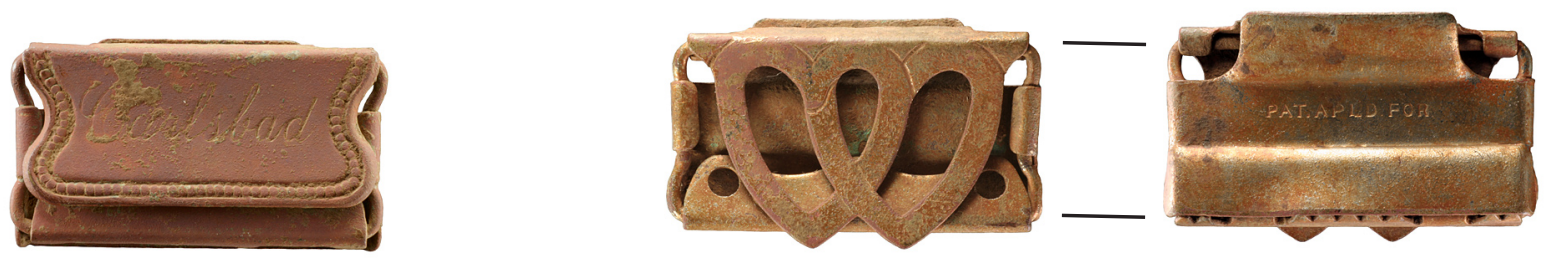

d

e

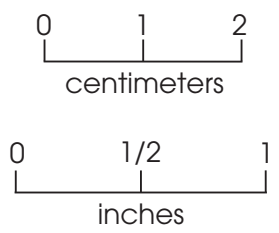

Figure 8.50. Suspender buckles, slides, and adjusters. (a) Nickel-plated buckle with 1890 patent date; (b) 1890 drawing from Patent No. 432,258 by S. Baum and V. B. Ulman (1890); (c) unidentified brass slide; (d) unidentified nickel-plated adjuster with engraved name "Carlsbad"; (e) front and back sides of unidentified adjuster.

- A variety of shell buttons called "Pearl Dress Buttons," "Fancy Pearl Dress Buttons," and "Pearl Shirt Buttons"

- "Imitation Pearl Buttons"

- Ornate women's dress buttons described as "Jet Dress Buttons," "Fancy Metal Dress Buttons," "Silk Dress Buttons" (probably silk over metal frame), and "Black and Colored Crochet Buttons" (probably fabric over metal frame)

- "Fancy Brass Buttons" (metal)

- A large variety of sizes of common Prosser buttons called "Agate Buttons, White and Colored" and "White Fancy Pearl Agates"

- "Full Ball Bone Buttons, self shank" in various colors

- "Plain Vegetable Ivory Buttons" in various colors with "self shank" attachment

- Medium to large rubber buttons described as "Vest, Coat, Ulster and Overcoat Buttons"

- Metal "Pant Buttons"

- Metal "Hand Snap Buttons" (a two-piece button that snaps together through the fabric) 


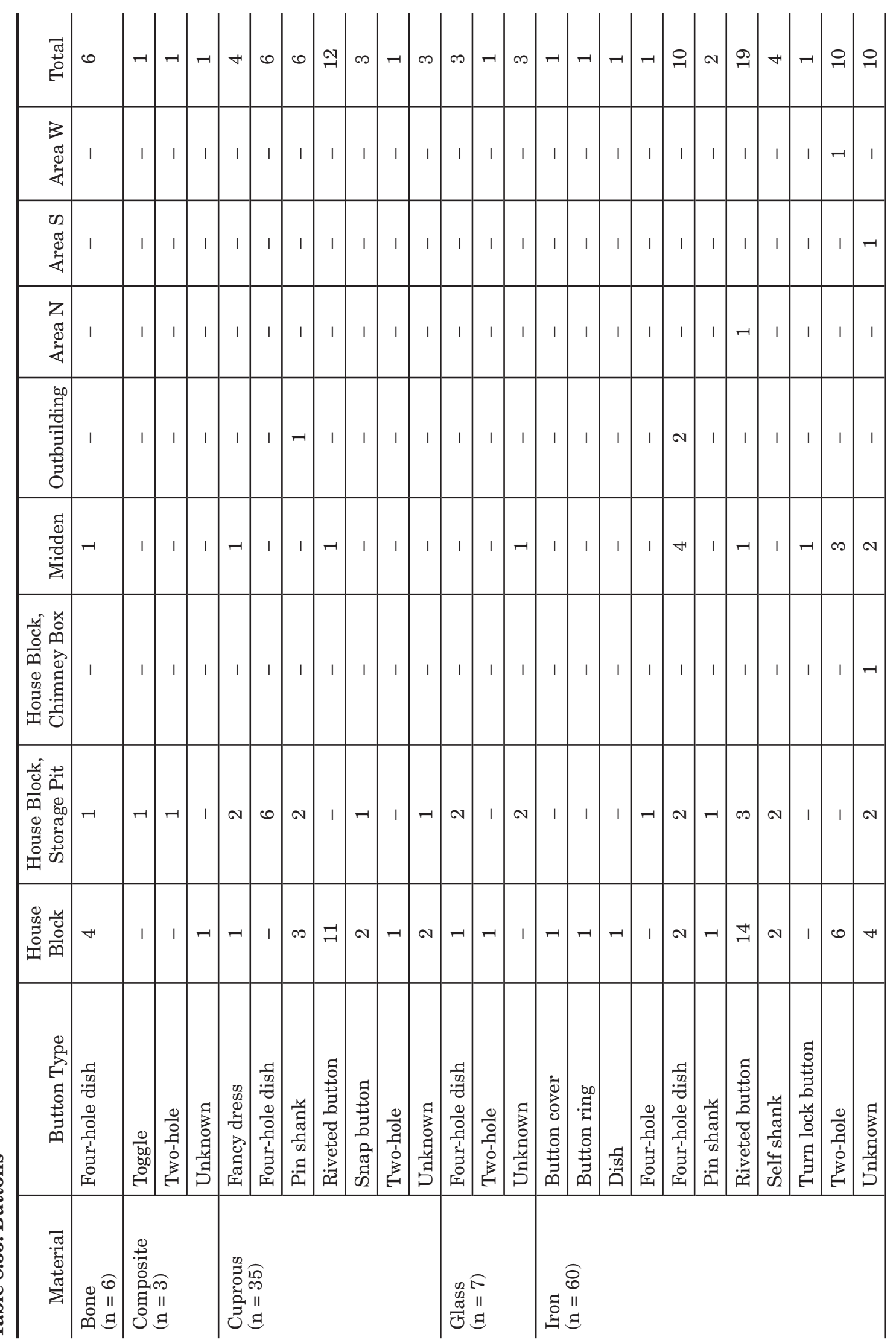


The Ransom and Sarah Williams Farmstead

\begin{tabular}{|c|c|c|c|c|c|c|c|c|c|c|c|c|c|c|c|c|}
\hline 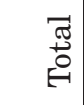 & 10 & 20 & $\stackrel{-}{-}$ & $\rightarrow$ & $\stackrel{\sim}{\sim} \stackrel{\sim}{\sim}$ & 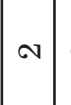 & \begin{tabular}{|l|l|l|}
$\infty$ & 10 \\
\end{tabular} & | & 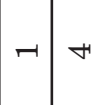 & -1 & \begin{tabular}{l|l}
$\mathbb{N}$ & $\infty$ \\
\hdashline
\end{tabular} & $\forall$ & $\infty$\begin{tabular}{l|l}
$\infty$ & -1
\end{tabular} & -1 & 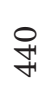 & $\mid \begin{array}{c}0 \\
8 \\
\dot{0} \\
8 \\
-1\end{array}$ \\
\hline 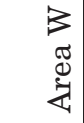 & 1 & 1 & $\neg 1$ & 1 & \begin{tabular}{l|l}
1 & 1
\end{tabular} & 1 & 1 & \begin{tabular}{r|l}
-1 & 1
\end{tabular} & \begin{tabular}{l|l}
1 & 1
\end{tabular} & 1 & 101 & 1 & $1 \mid 1$ & 1 & $\infty$ & $\mid \begin{array}{l}\stackrel{0}{1} \\
\vdots \\
0\end{array}$ \\
\hline $\begin{array}{c}\sigma 2 \\
\sigma \\
0 \\
\stackrel{d}{4}\end{array}$ & 1 & 1 & 1 & 1 & \begin{tabular}{l|l}
1 & 1
\end{tabular} & 1 & \begin{tabular}{l|l}
1 & 1
\end{tabular} & \begin{tabular}{l|l}
1 & 1
\end{tabular} & \begin{tabular}{l|l}
1 & 1
\end{tabular} & 1 & $1-1$ & 1 & 111 & 1 & $N$ & $\mid \begin{array}{c}0 \\
10 \\
0 \\
0\end{array}$ \\
\hline 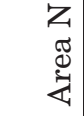 & 1 & 1 & 1 & 1 & \begin{tabular}{l|l}
1 & 1
\end{tabular} & 1 & \begin{tabular}{l|l}
1 & 1
\end{tabular} & \begin{tabular}{l|l}
1 & 1
\end{tabular} & \begin{tabular}{l|l}
1 & 1
\end{tabular} & 1 & \begin{tabular}{l|l}
1 & 1
\end{tabular} & 1 & $1 \mid 1$ & 1 & -1 & $\left|\begin{array}{l}0 \\
o \\
0 \\
0\end{array}\right|$ \\
\hline 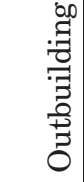 & 1 & 1 & 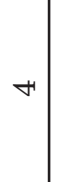 & 1 & \begin{tabular}{l|l}
1 & 1
\end{tabular} & 1 & 1 & \begin{tabular}{l|l}
1 & 1
\end{tabular} & \begin{tabular}{l|l}
1 & 1
\end{tabular} & 1 & \begin{tabular}{l|l}
1 & 1
\end{tabular} & 1 & \begin{tabular}{l|l}
1 & 1
\end{tabular} & 1 & 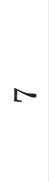 & 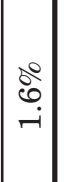 \\
\hline $\begin{array}{l}\frac{\pi}{0} \\
\frac{0}{7} \\
\dot{z}\end{array}$ & 1 & 1 & $\stackrel{10}{\rightarrow}$ & \begin{tabular}{l|l}
1 & 0
\end{tabular} & $\odot \mid-1$ & 1 & \begin{tabular}{l|l}
1 & 1
\end{tabular} & \begin{tabular}{l|l}
1 & 1
\end{tabular} & \begin{tabular}{l|l}
-1 & $\infty$
\end{tabular} & 1 & \begin{tabular}{l|l}
$N$ & -1
\end{tabular} & 1 & \begin{tabular}{l|l}
1 & -1
\end{tabular} & 1 & $F$ & $\left|\begin{array}{l}0 \\
\tilde{\sigma} \\
\sigma\end{array}\right|$ \\
\hline 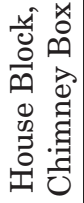 & 1 & 1 & 10 & $\begin{array}{lll}-1 & 1\end{array}$ & $1 \mid-1$ & 1 & \begin{tabular}{l|l}
1 & 1
\end{tabular} & $1-1$ & \begin{tabular}{l|l}
1 & 1
\end{tabular} & 1 & $1-1$ & 1 & \begin{tabular}{l|l}
1 & 1
\end{tabular} & 1 & 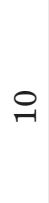 & 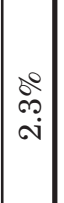 \\
\hline 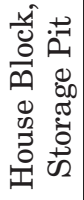 & $\infty$ & 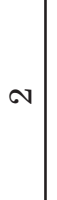 & $\stackrel{\infty}{\rightarrow}$ & 101 & $\begin{array}{lll}-10 & 10\end{array}$ & N & \begin{tabular}{l|l}
-1 & 1
\end{tabular} & \begin{tabular}{l|l}
1 & 1
\end{tabular} & \begin{tabular}{l|l}
1 & 1
\end{tabular} & 1 & ऽ & 1 & \begin{tabular}{l|l}
-1 & 1
\end{tabular} & 1 & مొ & $\left|\begin{array}{l}0 \\
0 \\
0 \\
0 \\
0\end{array}\right|$ \\
\hline 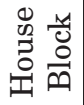 & N & $\infty$ & $\stackrel{\infty}{\infty}$ & $1 \mid \infty$ & \begin{tabular}{l|l}
$\infty$ & 10
\end{tabular} & 1 & 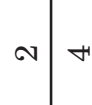 & $+|\propto|$ & $1-1$ & -1 & ๙ิ) & 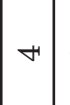 & \begin{tabular}{l|l}
$\infty$ & 1
\end{tabular} & -1 & 암 & 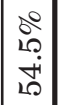 \\
\hline 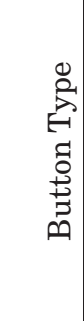 & 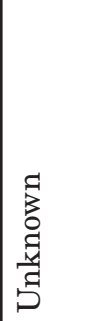 & 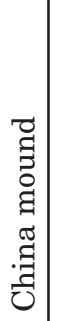 & 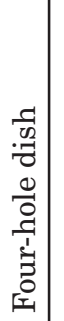 & 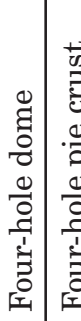 & 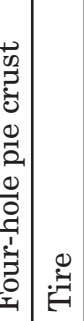 & 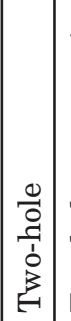 & 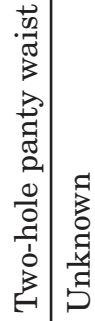 & 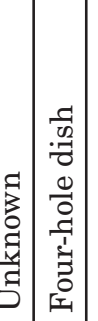 & 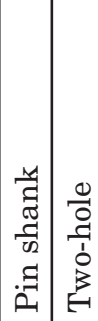 & 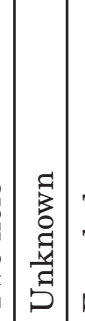 & 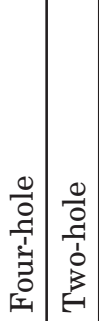 & 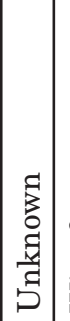 & 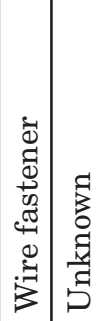 & 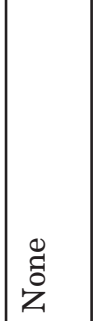 & & 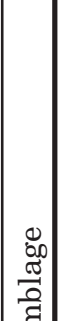 \\
\hline 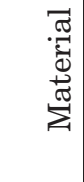 & 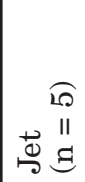 & 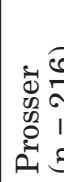 & & & & & & 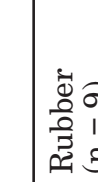 & & & 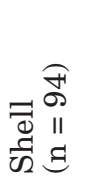 & & 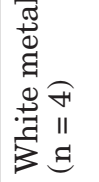 & 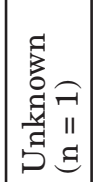 & $\begin{array}{l}\vec{\pi} \\
\stackrel{\pi}{0} \\
\stackrel{\theta}{*}\end{array}$ & 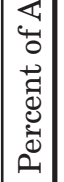 \\
\hline
\end{tabular}




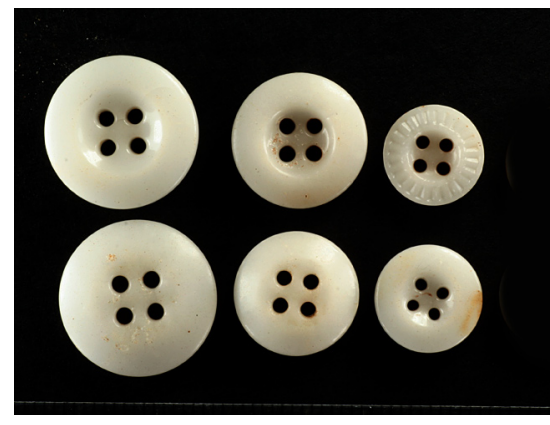

a

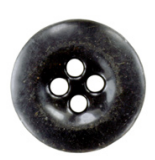

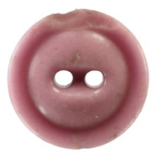

C
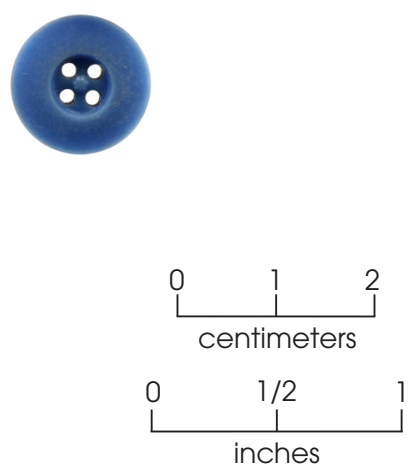

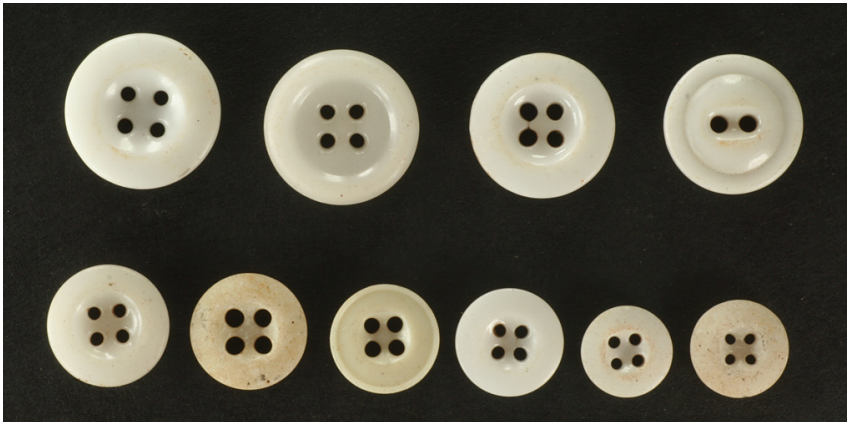

$\mathrm{b}$

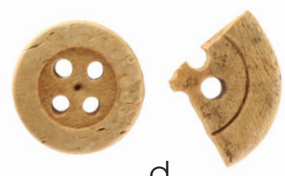

d

Figure 8.51. Buttons. (a and b) Variations of white Prosser buttons; (c) colored Prosser buttons-black, pink, and blue; (d) bone buttons.

- Metal overcoat "Officers' Gold-Plated Buttons" that may have been Civil War surplus (e.g., General Service line eagle buttons) or reproductions of military buttons

Based on the advertising evidence, it appears that the Williamses were simply consuming what was readily available in the late nineteenth century. It is impossible to know how many buttons came with purchased clothing, were bought in quantities and added to homemade clothing, or were salvaged from other clothing. Regardless, the assemblage appears to be quite representative of what was being mass produced and marketed at the time. In some cases, buttons from the farmstead are identical or nearly identical to those advertised for sale in the 1895 Montgomery Ward catalog. For example, one of the fancy metal dress buttons in the catalog shows what looks to be a cornucopia on its face (Item 9883, p. 84), and an identical button was recovered at the Williams farmstead.
Many other decorated metal dress buttons of the same size are quite similar. The jet buttons from the farmstead are not identical but are quite similar in size and design (linear and geometric patterns) to the jet buttons for sale in the catalog (p. 84). Of all the buttons advertised in the 1895 Montgomery Ward catalog, the "Agate Buttons, white, full shirt size" (i.e., small Prosser buttons) were among the least expensive at $\$ 0.03$ per card of 12 dozen buttons (Item 10280, p. 85).

Only a small number of the buttons had potentially identifiable markings; they are summarized in Table 8.36 and illustrated in Figure 8.55. These buttons include two U.S. Army General Service buttons with an eagle on the front and maker's stamps of the Scovill Manufacturing Company of Waterbury, Connecticut, on the back (McGuinn and Bazelon 2001:111; Kearns et al. 1997:14-17). The style of the eagle indicates that these buttons were manufactured between 1855 and 1884 (Brinkerfhoff 1976:3-5), and it is possible that they are pre-1865 buttons from the Civil War or 

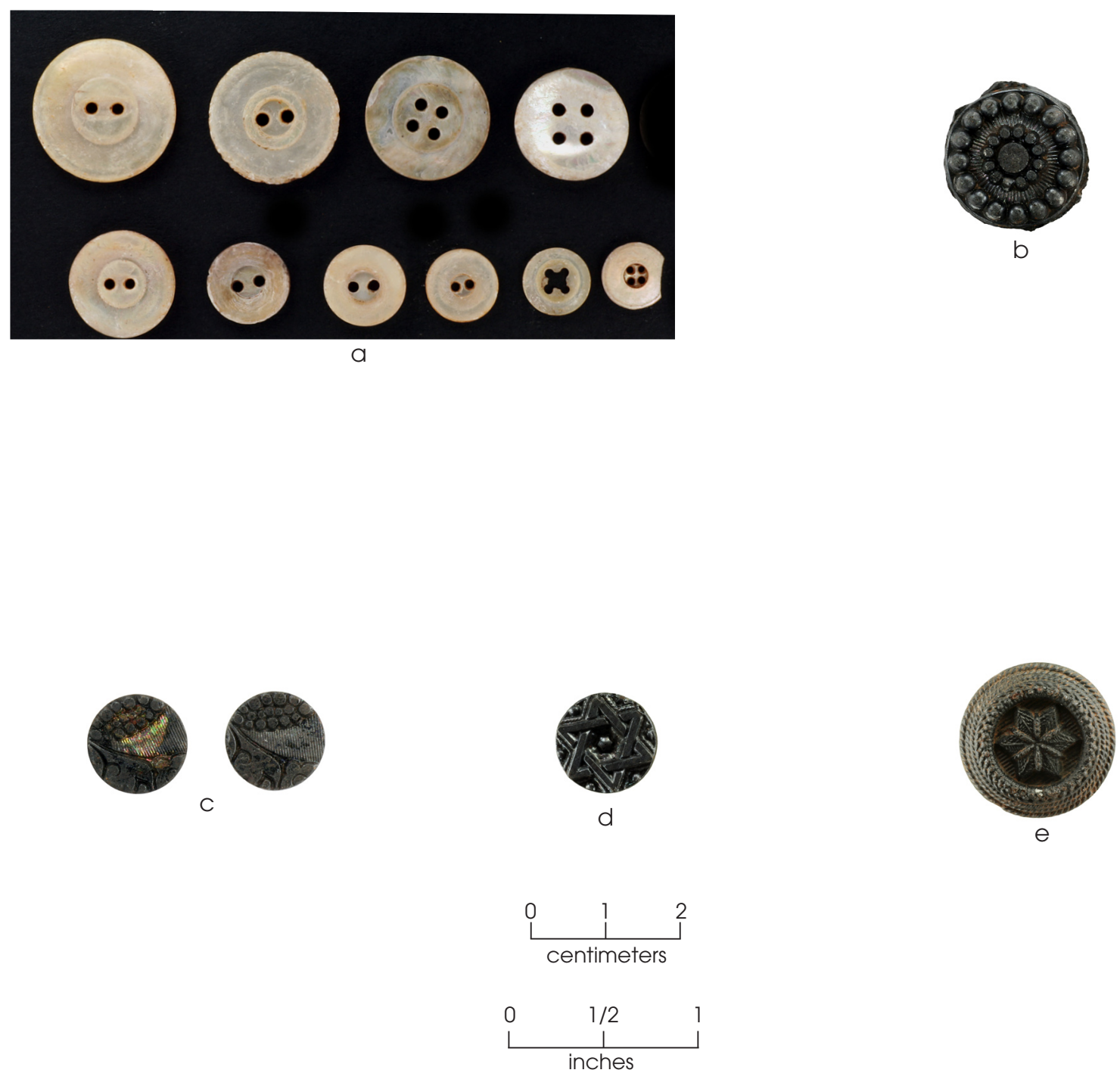

Figure 8.52. Buttons. (a) Variations of shell buttons; (b) black glass button with decorative design; (c) black jet buttons with decorative designs; (d) black jet button with six-pointed star design; (e) black rubber button with six-pointed star design.

surplus sold after the war. Three hard rubber buttons were made after 1854 or 1855 by different companies using Goodyear's 1851 patented production process (Ridgeway 2012; University of Utah 2001:475). One metal snap button has a stamped 1889 patent date that identifies it as a type with a unique snapping mechanism, Patent No. 405,179, by P. A. Raymond (1889). The other 11 specimens have markings that could not be identified.

For the button assemblage, 411 specimens were complete or complete enough to classify by size. Size data are summarized in Table 8.37, and material groups are quantified in Table 8.38. The buttons fall into 14 size groups, ranging from 12 line $(0.3 \mathrm{inch})$ to 40 line $(1.0 \mathrm{inch})$. The size distributions, presented in a graphic display in Figure 8.56, are interesting. The most common size category is 16 line ( 0.4 inch), almost all of which are Prosser and shell, and these are small shirt buttons. A large portion of the assemblage $(\mathrm{n}=254 ; 61.8$ percent $)$ is sizes 18 line $(0.45 \mathrm{inch})$ to 30 line $(0.75$ inch) and is composed of buttons of various materials. These buttons came from a range of different clothing items for men, women, and children. 

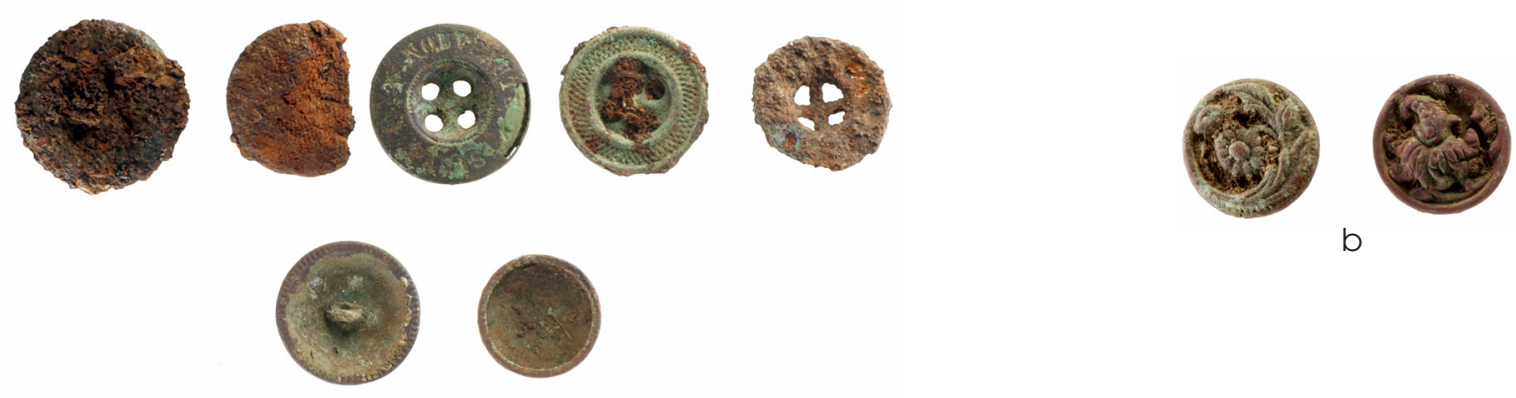

$\mathrm{b}$

a

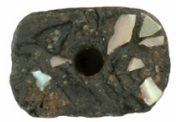

C

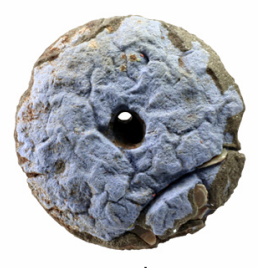

d

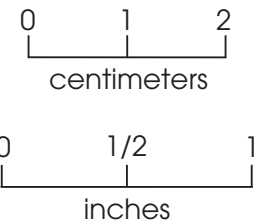

Figure 8.53. Buttons. (a) Variations of metal buttons; (b) metal buttons with stamped designs; (c) composite toggle button, black material (rubber?) with abalone shell inlay; (d) composite button, unknown materials.

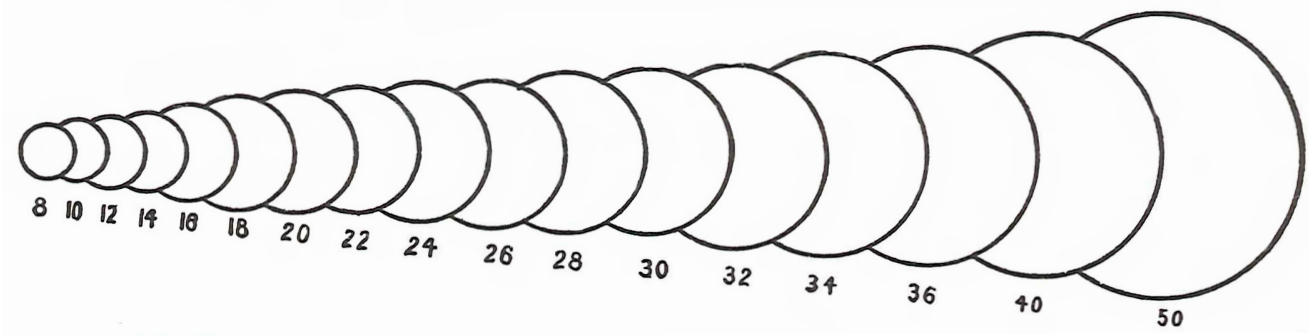

Figure 8.54. Button line size chart from the 1895 Montgomery Ward catalog (p. 85). A line size 40 button is 1 inch in diameter.

Buttons are often the most common dress-related artifact recovered at African American archaeological sites (Orser 2001:83; White and Beaudry 2009:216; Wilkie 1994:257-258, 2000b:154), and the Ransom and Sarah Williams farmstead is no exception. The number of buttons recovered at the farm seems unusually high, and this phenomenon warrants some discussion. High frequencies of buttons found on other African American sites have produced a variety of possible interpretations. William Kelso suggests that such a high number of buttons could reflect the West African tradition of quiltmaking (Orser 2001:84). Enslaved Africans and African Americans used segments of old or worn clothing items to make quilts after removing the buttons from the cloth- 
The Ransom and Sarah Williams Farmstead

\begin{tabular}{|c|c|c|c|c|c|c|c|c|c|c|}
\hline$\stackrel{0}{\Xi}$ & $\begin{array}{l}\tilde{0} \\
\dot{+} \\
\infty \\
\stackrel{2}{\infty} \\
\infty\end{array}$ & $\begin{array}{l}+1 \\
\infty \\
\infty \\
-1 \\
0 \\
+ \\
10 \\
10 \\
\infty \\
-1\end{array}$ & ๙. & a. & $a$. & a. & 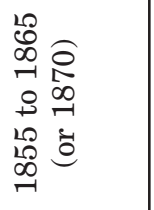 & 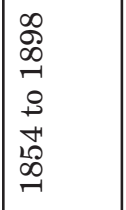 & $\begin{array}{ll}10 \\
0 \\
0 & 0 \\
0 & 0 \\
\sim & 0 \\
0 & 0 \\
0 & 0 \\
10 & 0 \\
0 & 0 \\
0 & 0 \\
-1 & 0\end{array}$ & 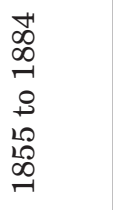 \\
\hline 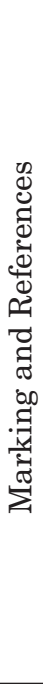 & 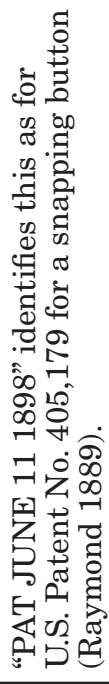 & 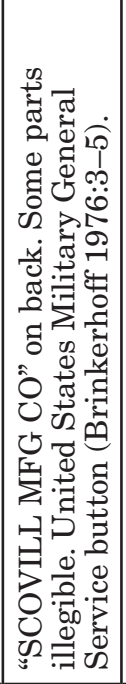 & 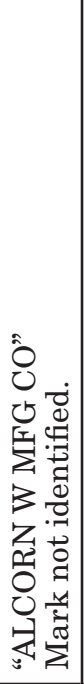 & 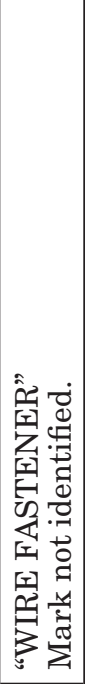 & 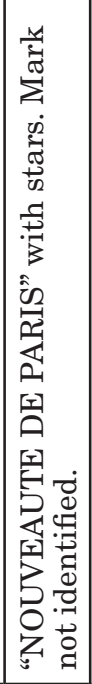 & 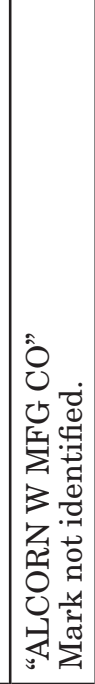 & 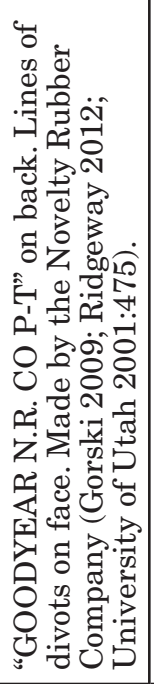 & 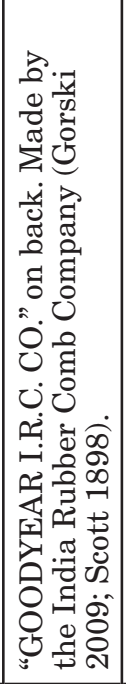 & 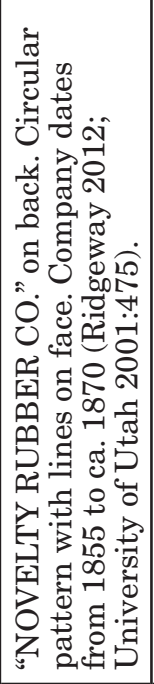 & 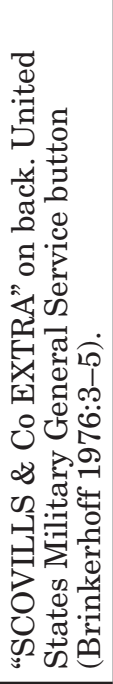 \\
\hline $\begin{array}{l}\frac{0}{0} \\
0\end{array}$ & 1 & 1 & 1 & 1 & 1 & 1 & 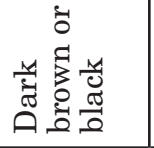 & 苔 & 范 & 1 \\
\hline & $\stackrel{H}{0}$ & $\mid \begin{array}{l}\infty \\
0 \\
0\end{array}$ & $\begin{array}{l}\stackrel{20}{5} \\
0\end{array}$ & $-r$ & $\stackrel{1}{0}$ & $\begin{array}{l}\frac{12}{5} \\
0 \\
0\end{array}$ & $\begin{array}{l}\qquad 0.0 \\
0 \\
0\end{array}$ & \begin{tabular}{|l}
10 \\
0 \\
0 \\
0
\end{tabular} & $\begin{array}{l}10 \\
0 \\
0\end{array}$ & $\stackrel{\varphi}{0}$ \\
\hline ठิ & $\stackrel{0}{-1}$ & ๙ิ & ஓి & 아 & $\stackrel{\infty}{\sim}$ & ిొ & ลิ & $\stackrel{\mathscr{N}}{\mathrm{N}}$ & $\stackrel{\leftrightarrow}{\sim}$ & $\stackrel{\leftrightarrow}{N}$ \\
\hline 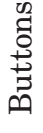 & $\neg$ & -1 & $\sim$ & N & -1 & $\neg$ & -1 & -1 & -1 & -1 \\
\hline 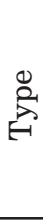 & 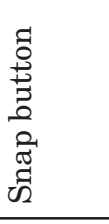 & 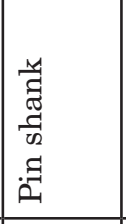 & 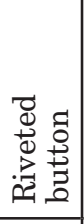 & 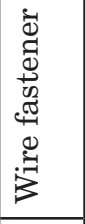 & 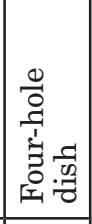 & 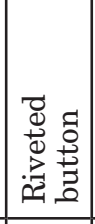 & 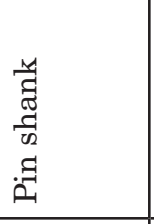 & 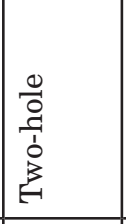 & \begin{tabular}{|c|}
0 \\
0 \\
0 \\
$\vdots$ \\
0 \\
0 \\
3 \\
\\
\end{tabular} & 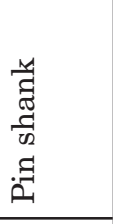 \\
\hline 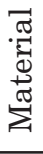 & $\begin{array}{l}\frac{\pi}{2} \\
0 \\
0 \\
\vdots \\
\vdots \\
0\end{array}$ & $\begin{array}{l}\text { n } \\
0 \\
0 \\
\vdots \\
\vdots \\
0\end{array}$ & ฮ્ర & 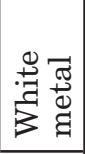 & \begin{tabular}{|l}
0 \\
$\vdots$ \\
0 \\
$\vdots$ \\
$\vdots$ \\
$\vdots$ \\
\end{tabular} & 芯 & 岗 & 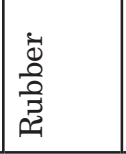 & 离 & 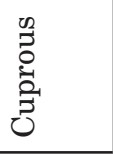 \\
\hline 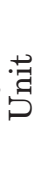 & $\begin{array}{l}\frac{y}{0} \\
0 \\
0 \\
0 \\
0 \\
0 \\
0 \\
0\end{array}$ & $\begin{array}{l}\frac{y}{0} \\
0 \\
0 \\
0 \\
0 \\
0 \\
0 \\
0 \\
0 \\
0\end{array}$ & & & 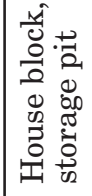 & & 离 & & & 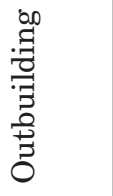 \\
\hline
\end{tabular}



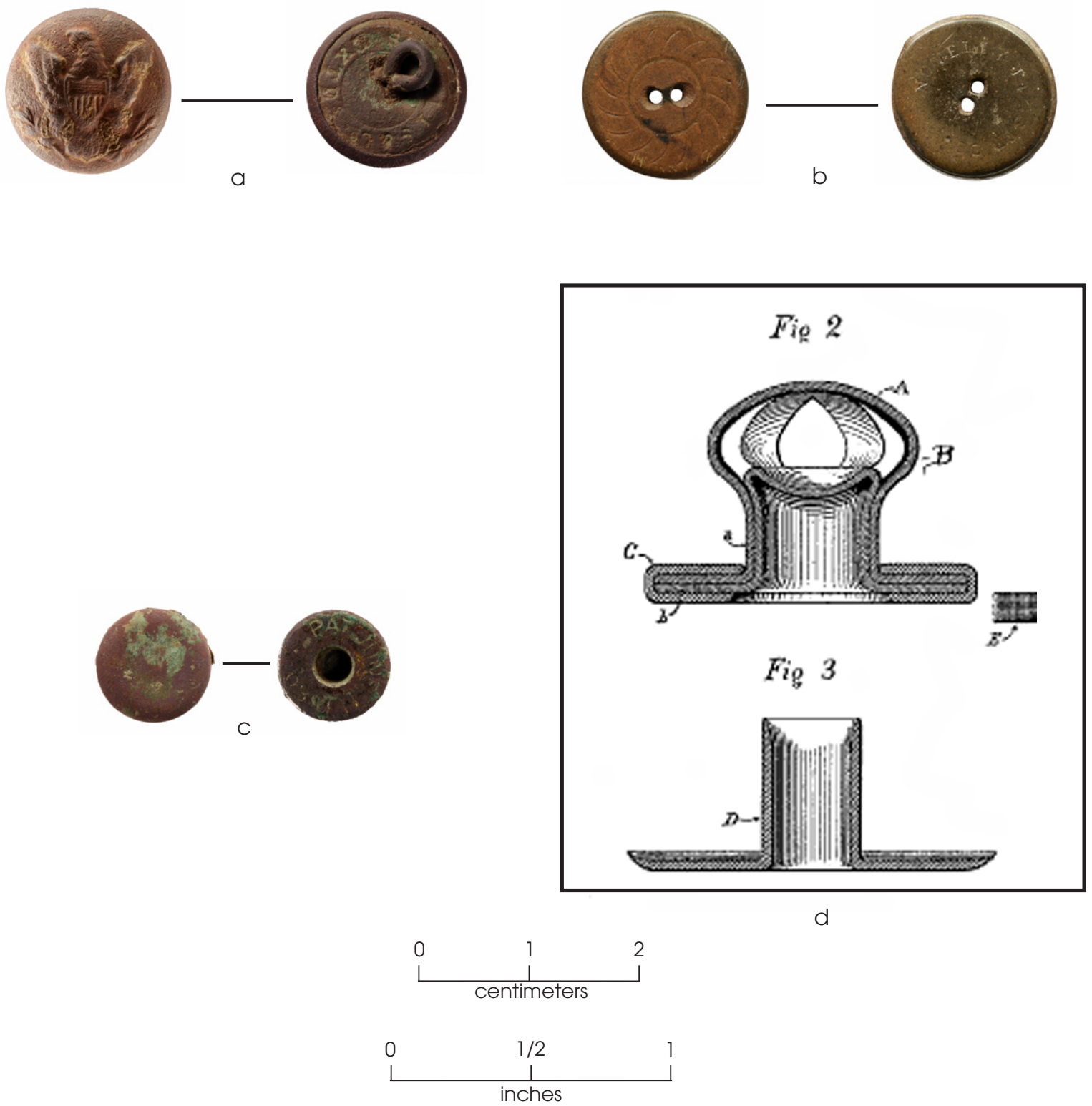

Figure 8.55. Buttons with diagnostic markings. (a) U.S. Army brass button with an eagle design on the front and a maker's stamp "SCOVILLS \& Co EXTRA" on the back; (b) hard rubber button with a geometric design on the front and the maker's mark "NOVELTY RUBBER CO." on the back; (c) metal snap button with stamped "PAT JUNE 11 1898" linked to Patent No. 405,179; (d) drawings showing the two pieces of the snap button patented by P. A. Raymond in 1889 .

ing. Patricia Samford suggests that buttons may have been strung on gourds and used in place of cowrie shells to make musical instruments (Orser 2001:84). Wilkie (2000b:156) notes that buttons could have been used as counters, been parts of religious caches, or accumulated as a result of recycling old clothing. In her study of the Oakley
Plantation in Louisiana, Wilkie (1994:257-258) suggests that "buttons... represent a common and inexpensive means of ornamentation" that was part of African American cultural expression (also see Wilkie 2000b:231-233).

The high number of buttons from the Williams farmstead cannot be specifically 
Table 8.37. Button assemblage by size group

\begin{tabular}{|c|c|c|}
\hline $\begin{array}{c}\text { Size } \\
\text { (lignes) }\end{array}$ & $\begin{array}{c}\text { Diameter } \\
\text { (inches) }\end{array}$ & $\begin{array}{c}\text { No of } \\
\text { Specimens }\end{array}$ \\
\hline 12 & 0.3 & 1 \\
\hline 14 & 0.35 & 12 \\
\hline 16 & 0.4 & 133 \\
\hline 18 & 0.45 & 43 \\
\hline 20 & 0.5 & 25 \\
\hline 22 & 0.55 & 40 \\
\hline 24 & 0.6 & 48 \\
\hline 26 & 0.65 & 34 \\
\hline 28 & 0.7 & 15 \\
\hline 30 & 0.75 & 49 \\
\hline 32 & 0.8 & 2 \\
\hline 34 & 0.85 & 1 \\
\hline 36 & 0.9 & 4 \\
\hline 40 & 1 & 4 \\
\hline \multicolumn{2}{|l|}{ Total } & 411 \\
\hline
\end{tabular}

attributed to any one of the activities mentioned above, but none can be ruled out, either. One other plausible explanation is that clothing was being manufactured or repaired at the Williams homesite, perhaps by Sarah taking in outside seamstress work. In this case, the recovered buttons could represent a normal rate of loss over the three decades the family was on the farm. Alternatively, she could have worked as a laundress. The physical activity involved in hand washing was tough on clothing, and this might have accelerated the rate of button loss over the years. The problem with the latter interpretation is the limited availability of water on the property. Except for rainwater, all clean water had to be brought to the Williams farmstead. In addition to the large number of buttons, it is notable that over 30 percent of the buttons were recovered from the subfloor storage pit (see Table 8.35), which seems like an unusually high number given the small size of the pit. These buttons seem to have been discarded, along with other trash, into the pit in a single episode at the time the storage pit was abandoned. This probably occurred late in the Williams occupation, after 1989 and before ca. 1904. The spatial distribution of buttons, and interpretations of how they ended up where they were found, are discussed in more detail in Chapter 11.

\section{Clothing Components}

Clothing components are objects that helped hold an article of clothing together or were essential to the proper wear and function of the clothing article. Clothing components recovered from the Williams farmstead include leather fragments, boot lace hooks, eyelets, rivets, and shoe/boot nails (Table 8.39; Figure 8.57; see Table B.18).

Eyelets were the most common clothing component, with a total of 71 specimens recovered. They are all cuprous metal and range in size from ca. 0.20 to 0.25 inch in outside diameter. Each specimen does not necessarily represent a complete eyelet because the eyelets were two separate pieces that were pressed together through a hole in the clothing article. Some specimens are a complete eyelet, and some are only one piece. At a minimum, about 31 eyelets could be represented. Due to the deteriorated condition of many specimens, however, an exact minimum number of individual eyelets could not be determined. Based on their sizes, it is likely that these eyelets are from articles of clothing, but the particular articles cannot be identified. Many of the eyelets are probably from footwear, and the 1895 Montgomery Ward catalog illustrates many types of boots and shoes that had numerous eyelets for lacing (pp. 508-522).

In addition to the eyelets, 25 shoe or boot nails (iron and brass) were recovered. These nails are used to attach the sole and heel to the vamp and other parts of the shoe. All of these nails are small, measuring less than 0.5 inch long.

Eight bootlace hooks were recovered. These hooks were attached to the upper portions of shoes and boots and were used to anchor the laces. All these are made of a cuprous metal, most likely brass, and each consists of the hook and the back portion of a rivet where it attached to the shoe or boot. This type of bootlace hook is shown on several types of men's boots in the 1895 Montgomery Ward catalog (pp. 516-520).

Six clothing rivets (brass and iron) and small leather fragments represent the remaining clothing components recovered. It is not certain what type of clothing these rivets are from, but they resemble the rivets used on denim 
Table 8.38. Button sizes by material group

\begin{tabular}{|c|c|c|}
\hline Material & Size (lignes) & No. of Specimens \\
\hline \multirow{3}{*}{$\begin{array}{l}\text { Bone } \\
(n=5)\end{array}$} & 22 & 2 \\
\hline & 28 & 2 \\
\hline & 40 & 1 \\
\hline \multirow{2}{*}{$\begin{array}{l}\text { Composite } \\
(\mathrm{n}=2)\end{array}$} & 22 & 1 \\
\hline & 36 & 1 \\
\hline \multirow{8}{*}{$\begin{array}{l}\text { Cuprous } \\
(\mathrm{n}=32)\end{array}$} & 16 & 1 \\
\hline & 20 & 3 \\
\hline & 22 & 6 \\
\hline & 24 & 11 \\
\hline & 26 & 1 \\
\hline & 28 & 1 \\
\hline & 30 & 8 \\
\hline & 32 & 1 \\
\hline \multirow{4}{*}{$\begin{array}{l}\text { Glass } \\
(\mathrm{n}=5)\end{array}$} & 16 & 2 \\
\hline & 18 & 1 \\
\hline & 26 & 1 \\
\hline & 36 & 1 \\
\hline \multirow{6}{*}{$\begin{array}{l}\text { Iron } \\
(\mathrm{n}=56)\end{array}$} & 20 & 1 \\
\hline & 22 & 5 \\
\hline & 24 & 12 \\
\hline & 26 & 3 \\
\hline & 28 & 2 \\
\hline & 30 & 33 \\
\hline \multirow{2}{*}{$\begin{array}{l}\text { Jet } \\
(\mathrm{n}=5)\end{array}$} & 22 & 4 \\
\hline & 24 & 1 \\
\hline
\end{tabular}

jeans and overalls. The leather fragments are in very poor condition but were probably parts of shoes or boots.

\section{Clothing Accessories}

Ten artifacts were examined and identified as clothing accessories (see Table B.20). They consist of five collar studs or collar buttons, a cufflink, and button hooks, and selected specimens are illustrated in Figure 8.58. The collar

\begin{tabular}{|c|c|c|}
\hline Material & Size (lignes) & No. of Specimens \\
\hline \multirow{9}{*}{$\begin{array}{l}\text { Prosser } \\
(\mathrm{n}=211)\end{array}$} & 14 & 7 \\
\hline & 16 & 100 \\
\hline & 18 & 26 \\
\hline & 20 & 11 \\
\hline & 22 & 15 \\
\hline & 24 & 16 \\
\hline & 26 & 22 \\
\hline & 28 & 8 \\
\hline & 30 & 6 \\
\hline \multirow{8}{*}{$\begin{array}{l}\text { Rubber } \\
(\mathrm{n}=9)\end{array}$} & 22 & 1 \\
\hline & 26 & 2 \\
\hline & 28 & 1 \\
\hline & 30 & 1 \\
\hline & 32 & 1 \\
\hline & 34 & 1 \\
\hline & 36 & 1 \\
\hline & 40 & 1 \\
\hline \multirow{10}{*}{$\begin{array}{l}\text { Shell } \\
(\mathrm{n}=83)\end{array}$} & 12 & 1 \\
\hline & 14 & 5 \\
\hline & 16 & 30 \\
\hline & 18 & 16 \\
\hline & 20 & 10 \\
\hline & 22 & 6 \\
\hline & 24 & 8 \\
\hline & 26 & 5 \\
\hline & 28 & 1 \\
\hline & 30 & 1 \\
\hline \multirow{2}{*}{$\begin{array}{l}\text { White metal } \\
(\mathrm{n}=3)\end{array}$} & 36 & 1 \\
\hline & 40 & 2 \\
\hline \multicolumn{2}{|l|}{ Total } & 411 \\
\hline
\end{tabular}

studs and cufflinks were used to keep the collar and cuff fastened to the shirt, while the button hooks made it easier to button a blouse or shirt.

The five collar studs are simple in design, far more basic than the solid gold and gold-plated items offered in the 1895 Montgomery Ward \& Company catalog. Four of the studs (from the house block) look to be made by the Prosser process resulting in a highly vitrified glass-like material. Two of the Prosser studs are complete, and the other two are stud base and 


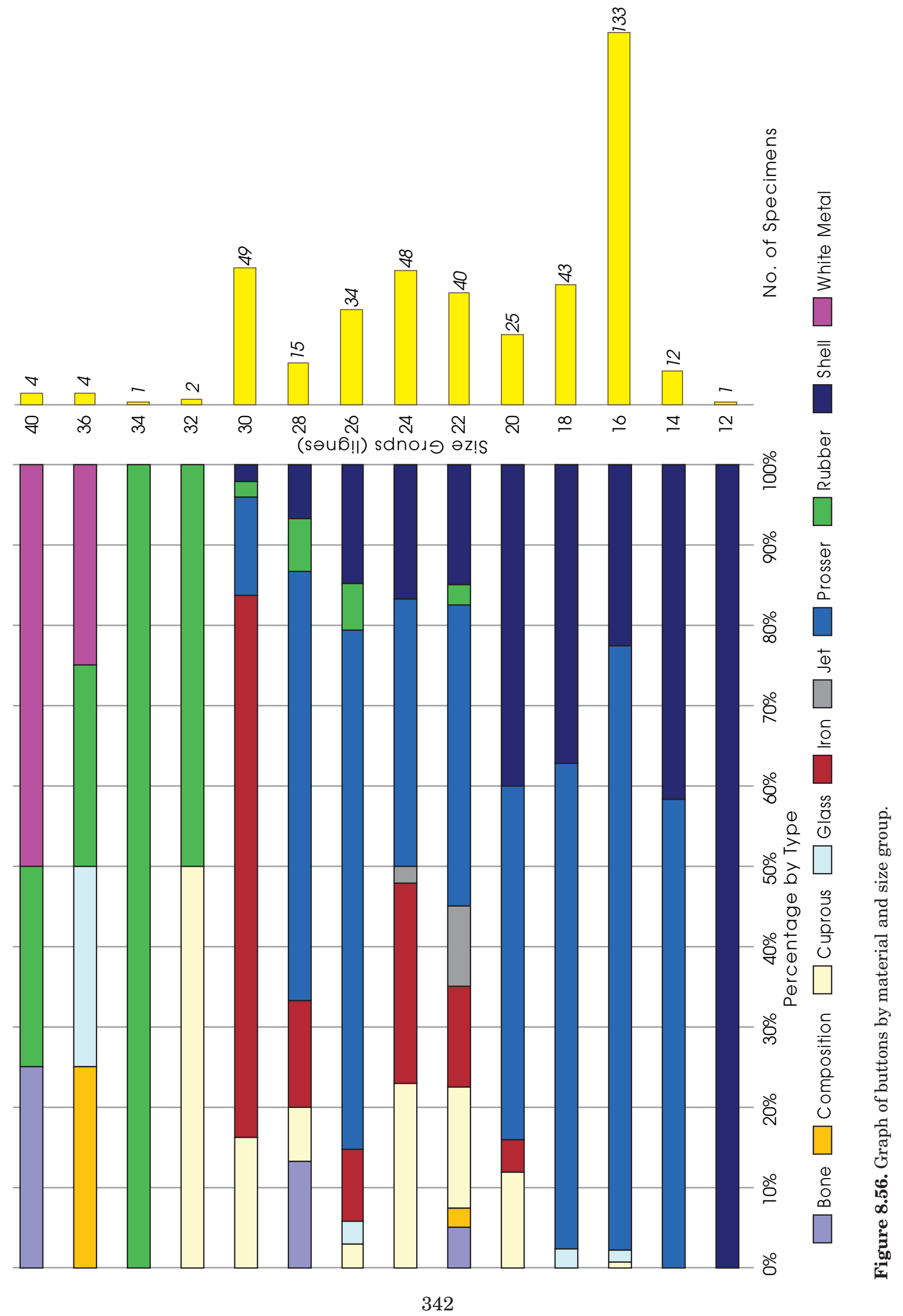


Table 8.39. Clothing components

\begin{tabular}{l|c|c|c|c|c|c}
\hline \multicolumn{1}{c|}{ Artifact } & $\begin{array}{c}\text { House } \\
\text { Block }\end{array}$ & $\begin{array}{c}\text { House Block, } \\
\text { Subfloor Pit }\end{array}$ & $\begin{array}{c}\text { Yard } \\
\text { Area }\end{array}$ & Midden & Outbuilding & Total \\
\hline Boot lace hooks (iron) & 3 & - & - & 5 & - & 8 \\
\hline Eyelets (cuprous metal) & 40 & 6 & - & 16 & 9 & 71 \\
\hline Leather fragments & 13 & - & 1 & - & - & 14 \\
\hline Rivet (brass) & 1 & - & - & 2 & - & 3 \\
\hline Rivets (iron) & 2 & - & - & 1 & - & 3 \\
\hline Shoe/boot nails (brass) & 3 & - & - & - & - & 3 \\
\hline Shoe/boot nails (iron) & 3 & - & - & 12 & - & 15 \\
\hline Shoe/boot nails (unspecified) & 7 & - & - & - & - & 7 \\
\hline Total & 72 & 6 & 1 & 36 & 9 & 124 \\
\hline
\end{tabular}

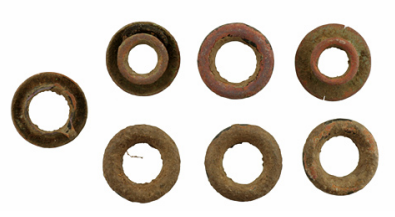

a

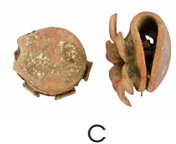

C

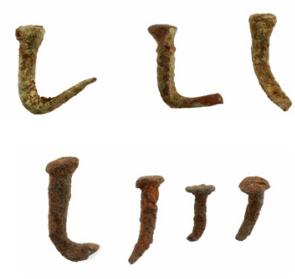

$\mathrm{b}$
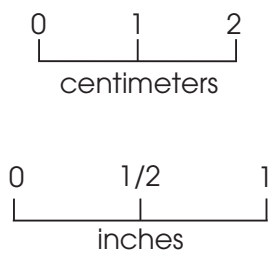

Figure 8.57. Clothing components. (a) Brass eyelets; (b) iron boot or shoe nails; (c) brass bootlace hooks.

stud tip fragments. The other collar stud (from the subfloor pit) is a base fragment made of bone.

The single cufflink (from the house block) is complete and has a rather elaborate floral design with a red glass jewel inset into the face. It is made of a cuprous metal and may have been plated to add to the overall expensive look.

The four metal button hooks (two from the house block and two from the subfloor pit) are also simple in design consisting of a piece of iron wire with a loop at one end and the hook on the opposite end. The hook would pass through the button hole, hook around the button between the button and the shirt fabric, then be pulled back through the button hole, resulting in the garment being buttoned.

\section{Jewelry}

Ten jewelry or jewelry-related items were recovered (see Table B.19). Six specimens were from the house block (a bead, a brooch, a charm, a clear glass jewel, a jump ring, and a pin), three were from the subfloor storage pit (a clasp hook, a pendant, and a pin), and one was from the midden (a clasp eye). Jump rings are small rings used to attach pendants or charms to a necklace or bracelet. Selected specimens are shown in Figure 8.59. 

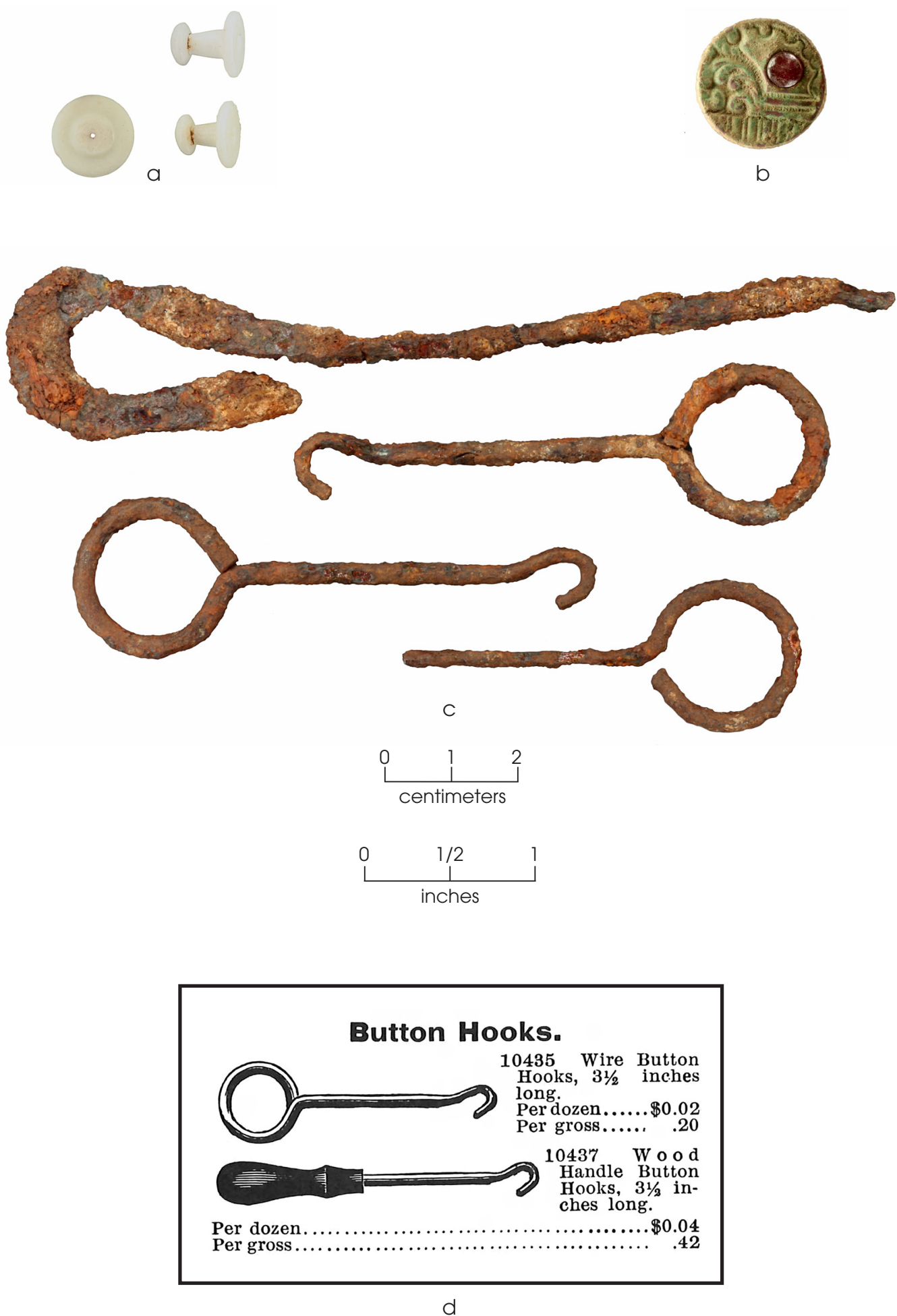

Figure 8.58. Clothing accessories. (a) White glass Prosser collar studs; (b) brass cuff link with elaborate design and inset red glass jewel; (c) iron button hooks; (d) button hooks advertised in the 1895 Montgomery Ward catalog (p. 86). 
The brooch is the most elaborate piece of jewelry, with the molded metal resembling a rope in a figure-eight design. It has settings for six jewels, but only one clear and two green glass jewels remain intact. A small pointed-oval charm is made of shell and is also fairly elaborate. It sits in a cuprous metal frame that could have been attached to another piece of jewelry or hung from a bracelet or necklace. Three parallel lines are engraved into the surface of the shell.

Two pins were found. One elongated pin is somewhat decorative and has a floral design around a setting space for a missing jewel or stone. It appears to have been plated with some gold-colored metal, because gold particles are present in the smallest crevices. The other pin is a simple scarf or stick pin with a domed top. It also may have been gold plated. The 1895 Montgomery Ward catalog has two pages of various scarf and stick pins illustrating the many different styles that were available (pp. 172-173).
The rest of the jewelry pieces are much simpler in design or too fragmented to determine what the original jewelry was like. One specimen is a white metal pendant fragment with an eye still attached. Another is a faceted jewel of clear glass with two holes drilled just off center. It may have been attached to a larger brooch or pin or perhaps was attached to a chain to form a necklace. The final jewelry item is a white glass seed bead, the only bead recovered from the Williams farmstead.

Although some jewelry was found at the Williams farmstead, it is not surprising that such items are relatively rare. The paucity of these items in the assemblage does not mean that the family did not possess other jewelry. With the exception of some types of costume jewelry that might have been worn daily, jewelry would have been considered a luxury item on any late-nineteenth-century rural farm, and would be worn only on special occasions and carefully put away afterwards. Consequently,
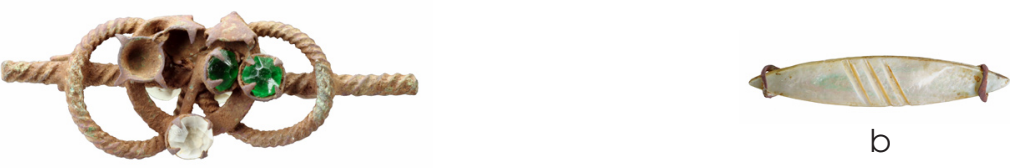

a
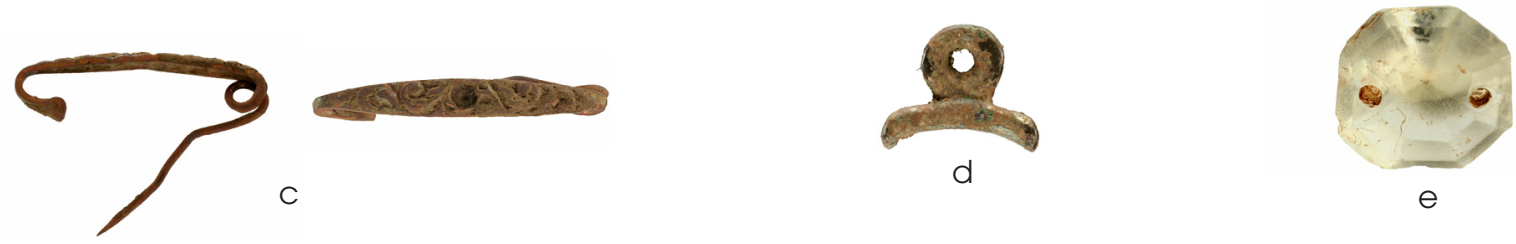

e
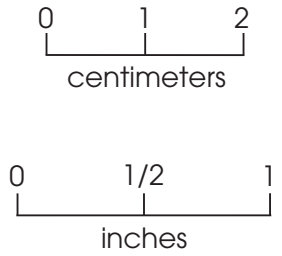

Figure 8.59. Jewelry. (a) Figure-eight brooch with three clear and green glass jewels; (b) Shell charm with engraved lines; (c) side and top views of a simple decorative pin with a floral design and empty jewel setting; (d) white metal pendant fragment; (e) faceted clear glass jewel with drilled holes. 
the most prized jewelry items would enter the archeological record only if they were accidentally lost or broken.

\section{PERSONAL ARTIFACTS}

The personal category contains items typically owned and used by one individual and consumables used by one person. The 599 personal artifacts are classified as follows:

\section{GROOMING}

Glass fragments from 2 cosmetic bottles

(GC-16 and GC-72)

Glass fragments from 1 perfume bottle

(PG-21)

Glass fragment (unassigned)

Comb fragments

Other grooming items

HEALTH AND MEDICINE

Glass fragments from 52 medicine bottles 104

Syringe plunger handle

\section{TOBACCO}

Glass fragments from 23 snuff bottles

Glass fragments from undefined snuff bottles 212

Smoking pipe fragments

Tobacco plug tag

\section{ALCOHOL}

Glass from 16 liquor, beer, and wine bottles 88

Glass from undefined liquor bottle

\section{OTHER}

Personal accoutrements

\section{Grooming}

Grooming items are those objects associated with maintaining one's appearance (Table 8.40; see Table B.27). Three specimens are identified as glass bottles having contained some type of cosmetic or perfume (see Tables B.4 and B.5). One cosmetic bottle is GC-16, a partially reconstructed bottle (11 glass fragments from 9 lots). It is a small jar (1 ounce) of white milk glass with a threaded mouth for a metal screw cap. GC-72 is a small blue glass bottle ( 20 fragments from 8 lots) that probably contained some type of cosmetic product. One pressed glass item, PG-21, is a small perfume bottle of clear glass (7 fragments from 3 lots).
The other 52 grooming artifacts are classified as hair comb fragments, hairpins, a strop buckle, and a straight razor blade (Figure 8.60). Hair maintenance seems to have been a priority for members of the Williams family as evidenced by the number of hard rubber comb spine and teeth fragments $(n=48)$ that represent a variety of fine-tooth combs and coarse-tooth combs found in every part of the site. The more complete comb pieces vary in color, size, and shape, and they represent a minimum of seven different combs. These are probably all hard rubber, and they are different from Bakelite, which was not invented until 1907 or 1909 (American Chemistry Council 2013; Lindsey 2013c), a couple years after the Williams family abandoned the farm. In the 1895 Montgomery Ward catalog (pp. 105, 106), most of the combs available for purchase were made of hard rubber, some were made of horn, and one was made of celluloid. Most of the farmstead specimens are standard hair combs, but at least one specimen is a hard rubber side comb that functioned as a hairpin. Several examples of side combs are illustrated in the 1895 Montgomery Ward catalog (p. 183), and most were made of "Celluloid" and called "Imitation Tortoise Shell."

One unusual attribute was observed on one of the comb fragments. Chew marks are present on the ends of the comb spine. These are not small, rodent-like gnawing marks often seen on bone and other materials. Rather, these impressions resemble chew marks made by human teeth.

Other hair-related objects include two metal hairpins, one made of iron and the other a white metal alloy. The iron hairpin measures just over 3 inches long with a series of ridges near the center of the hairpin shafts. The white metal hairpin measures about 2.5 inches long with a series of divots or dimples along the shafts. Both pins have the same overall shape and were recovered together.

A corroded piece of iron with a loop on one end is identified as a strop buckle. Strop buckles were hung from a hook or nail and held one end of a leather strop that was used for sharpening and honing knives or blades, especially straight razors for shaving. A handle on the hanging end of the strop was held in one hand while the razor was held in the other hand and passed rapidly back and forth over the leather, turning the blade over with each pass. This specimen measures just over 2.3 inches wide and 1.5 inches tall from the top of the eye 
Table 8.40. Grooming artifacts

\begin{tabular}{|c|c|c|c|c|c|c|c|}
\hline Artifact & $\begin{array}{l}\text { House } \\
\text { Block }\end{array}$ & $\begin{array}{c}\text { House Block, } \\
\text { Subfloor Pit }\end{array}$ & $\begin{array}{l}\text { Yard } \\
\text { Area }\end{array}$ & Midden & Outbuilding & $\begin{array}{c}\text { Corral } \\
\text { Complex } \\
\end{array}$ & Total \\
\hline $\begin{array}{l}\text { Cosmetic jar, milk glass } \\
\text { fragments, GC-16 }\end{array}$ & 12 & - & - & - & - & - & 12 \\
\hline $\begin{array}{l}\text { Cosmetic jar, blue glass } \\
\text { fragments, GC- } 72\end{array}$ & - & - & - & 20 & - & - & 20 \\
\hline $\begin{array}{l}\text { Perfume bottle, pressed } \\
\text { glass fragments, PG-21 }\end{array}$ & - & - & - & 7 & - & - & 7 \\
\hline $\begin{array}{l}\text { Milk glass fragment } \\
\text { (unassigned) }\end{array}$ & - & - & - & 1 & - & - & 1 \\
\hline $\begin{array}{l}\text { Hair comb fragments, } \\
\text { spine and teeth } \\
\text { (hard rubber) }\end{array}$ & 21 & 16 & 2 & 7 & 2 & - & 48 \\
\hline $\begin{array}{l}\text { Hairpin } \\
\text { (iron) }\end{array}$ & 1 & - & - & - & - & - & 1 \\
\hline $\begin{array}{l}\text { Hairpin } \\
\text { (white metal) }\end{array}$ & 1 & - & - & - & - & - & 1 \\
\hline $\begin{array}{l}\text { Straight razor blade } \\
\text { (iron) }\end{array}$ & - & - & - & 1 & - & - & 1 \\
\hline $\begin{array}{l}\text { Strop buckle } \\
\text { (iron) }\end{array}$ & 1 & - & - & - & - & - & 1 \\
\hline Total & 36 & 16 & 2 & 36 & 2 & 0 & 92 \\
\hline
\end{tabular}

to the base of the buckle. Its inside width is ca. 2 inches for a 2-inch leather strap. Several types of strop buckle ends are illustrated in the 1895 Montgomery Ward (p. 445) and 1902 Sears, Roebuck (pp. 497-498) catalogs.

The strop buckle was one piece of shaving equipment, and it was probably used with a complete straight razor blade, one of which was found behind the house and just east of the chimney. The blade measures around 5.5 inches long, with a cutting edge of ca. 3 inches long. The blade is made of iron and is wedge-shaped; the blade is 0.25 -inch thick on its flat back edge, while its distal end is pointed. This style of blade is different from the blade styles of the razors for sale in the 1895 Montgomery Ward (pp. 444-445) and 1902 Sears, Roebuck (pp. 406-407) catalogs. The advertised razors had either a rounded end or squared end on the blade, while the end of the Williams farmstead blade comes a sharp point. It is possible that the razor blade from the farmstead is an older style.

\section{Health and Medicine}

Artifacts classified as health and medicine include 44 glass bottles and 1 glass syringe fragment. The latter is the proximal end of a plunger shaft fragment ( 0.75 inch total length), but it has an intact thumb rest (Figure 8.61). It matches the plungers on various glass syringes (general, eye, ear, and rectal) illustrated in the 1880 wholesale catalog of glassware for "Druggists, Chemists, and Perfumers" by the Whitall, Tatum \& Company (1971:58-59). The presence of a glass syringe in the assemblage could be related to medical treatment for someone in the Williams family, but it could also have been used for medical treatments administered to their livestock.

The medicine or probable medicine bottles are summarized and described with the glass containers mentioned earlier in this chapter (see Tables 8.6 and B.4), and the 52 specimens are listed in Table 8.41. In many cases, these were identified because the bottle neck and mouth finishes or bottle body styles are indicative of medicine bottles. In several instances, a bottle's original contents are known because of the product it contained is identified by the embossed labeling on the bottle. In other cases, a bottle is known to have contained a medicine because 

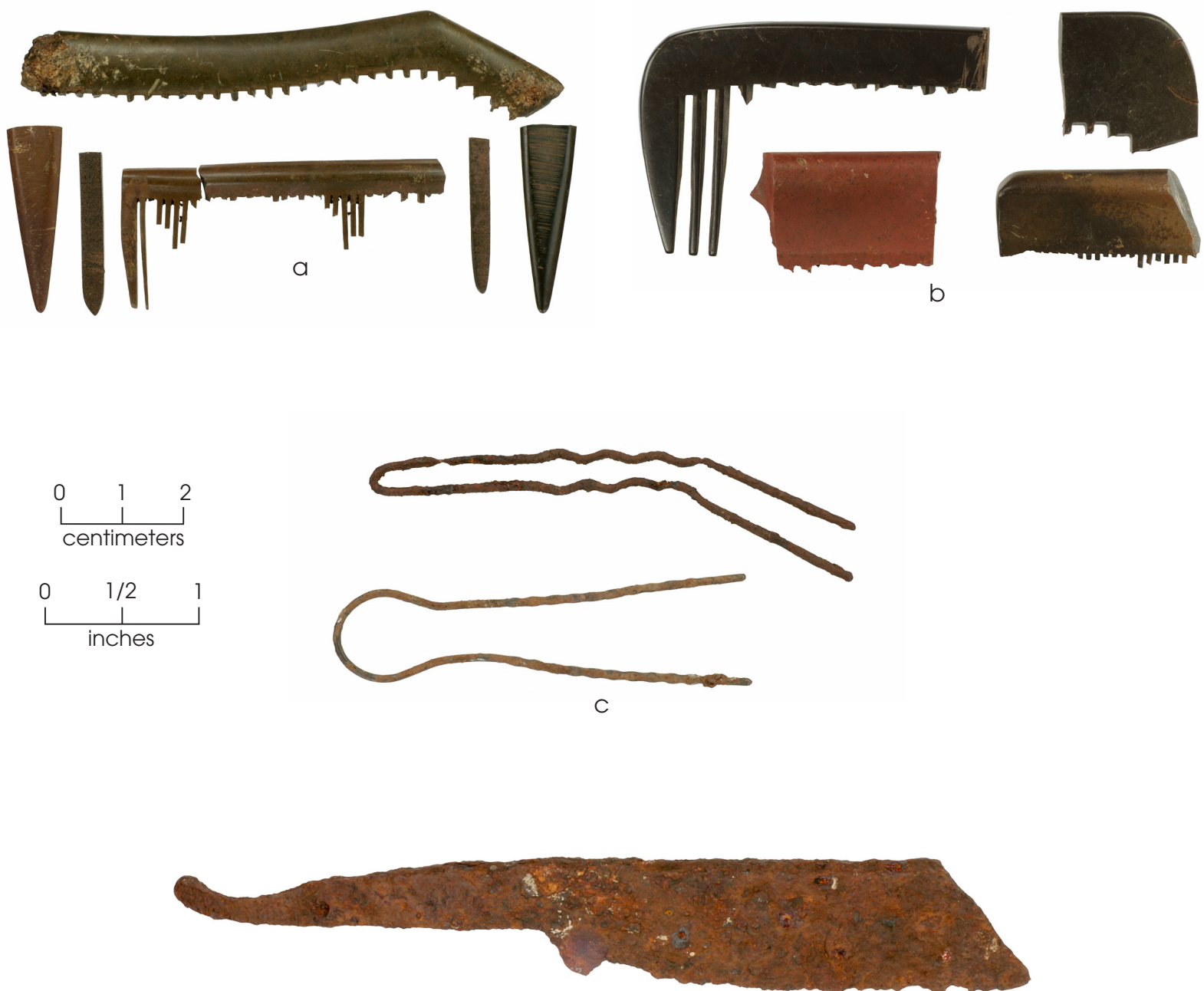

d

\section{RAZORS.}

Razors sent by mail, 3 to 6 cents extra.

Our razors are fully warranted by $u s$, and if properly

used and stropped on a good smooth strop they can be returned at our expense and money refunded or exchanged for unother, if not as represented.

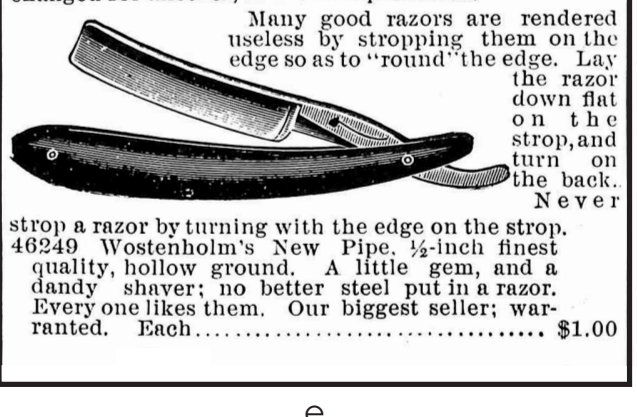

e

Figure 8.60. Grooming artifacts. (a and b) Hard rubber comb fragments; (c) iron and white-metal hairpins; (d) iron straight razor blade; (e) straight razor advertised in the 1895 Montgomery Ward catalog (p. 444). 
the embossed labeling identifies a specific drug manufacturer or drugstore that distributed the medicine. Most of the medicine bottles that were complete enough to estimate their sizes are small bottles that contained less than 6 ounces of liquid. One of the medicine bottles is blown-glass with an applied lip, while the other 43 are blown-glass bottles with tooled lips. One of the latter is a neck fragment with its glass stopper still attached.

Five individual bottles have embossed lettering that provides more information about the medicinal contents or the bottle manufacturer (see Table 8.7). One, found in the house block near the chimney, is a four-sided, rectangular panel bottle (GC-1) with embossed words on all sides (see Figure 8.4). The two narrow panels are marked "BRADFIELD'S" and "ATLANTA, GA" while the two wide panels are marked "FEMALE REGULATOR" and "WOMAN'S BEST FRIEND." Wilson (1981:136) identifies Bradfield's Female Regulator as a patent medical preparation that was first produced in 1892 . The paper label advertised it as:

"a Tonic For Women and a Relief of Irregularities of the Menstrual Functions when not caused by malformation or that do not require surgical treatment, especially for use during the last two months of pregnancy, at puberty and at the change of life" (Fike 1987:53).

Two of Bradfield's products, the "Female Regulator" and "Mother's Friend," were advertised regularly in Austin's black newspapers The Sunday School Herald and The Herald (see Chapter 13). ${ }^{106}$

Besides Bradfield's, another fragmentary bottle (GC-12) is complete enough to know that it was a type of female regulator product called McElree's Wine of Cardui. The Chattanooga Medicine Company began in 1879 , but it purchased and began producing McElree's Wine of Cardui in 1882 (Cannon 2010; Fike 1987; Irwin 1998). One other bottle glass fragment that bears a portion of the name Chattanooga may be from the same bottle, but it could not be

${ }^{106}$ Thirty-two ads for Bradfield Regulator Company products appeared in 1892-1894 issues of The Sunday School Herald and The Herald (see Chapter 13 and Appendix F).

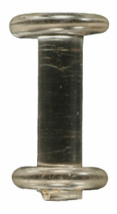

a

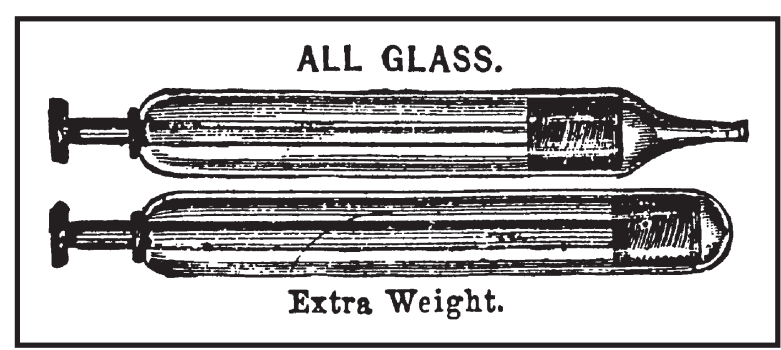

b

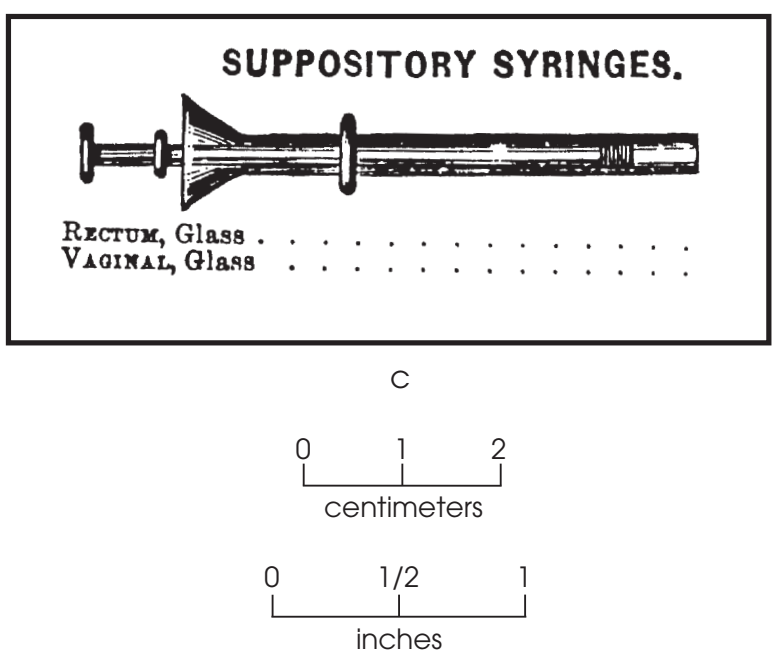

Figure 8.61. Glass syringe plunger. (a) Proximal end of a glass syringe plunger shaft; (b, c) glass syringes sold advertised in the 1880 Whitall, Tatum \& Company (1971:58-59) catalog.

refit. McElree's Wine of Cardui was another one of the medicinal products that was advertised regularly in The Sunday School Herald and The Herald (see Chapter 13). ${ }^{107}$

The presence of the Bradfield's and McElree's products at the Williams farmstead suggest a regular use of "female regulator" medicines by one or more of the women at the Williams farmstead.

${ }^{107}$ Thirty-three ads for McElree's Wine of Cardui appeared in the 1892-1894 issues of The Sunday School Herald and The Herald (see Chapter 13 and Appendix F). 
The Ransom and Sarah Williams Farmstead

Table 8.41. Medicine and probable medicine bottles $(n=52)$

\begin{tabular}{|c|c|c|c|c|c|}
\hline No. & $\begin{array}{l}\text { No. of Glass } \\
\text { Fragments }\end{array}$ & Bottle Contents & Glass Color & Bottle Size & $\begin{array}{c}\text { Bottle Manufacture } \\
\text { Type } \\
\text { (Neck Finish) }\end{array}$ \\
\hline GC-1* & 1 & Medicine & Aqua & Small & Blown, tooled \\
\hline $\mathrm{GC}-3 * *$ & 1 & Medicine & "True" Blue & Small & Blown, tooled \\
\hline GC-4 & 1 & Medicine & Clear & Small & Blown, Applied \\
\hline GC-5 & 1 & Medicine & Clear & Small & Blown, tooled \\
\hline GC-6 & 10 & Medicine & Clear & Small & Blown, tooled \\
\hline GC-7** & 1 & Medicine & Clear & Small & Blown, tooled \\
\hline GC-9 & 10 & Medicine & Aqua & Small (est.) & Blown, tooled \\
\hline GC-10* & 5 & Medicine & Amber & Small (est.) & Blown, tooled \\
\hline GC-12* & 19 & Medicine & Aqua & Small (est.) & Blown, tooled \\
\hline GC-18 & 1 & Medicine & Aqua & Small (est.) & Blown, tooled \\
\hline GC-19 & 1 & Medicine (or food) & Clear & Small (est.) & Blown, tooled \\
\hline GC-20 & 1 & Medicine & Aqua & Small (est.) & Blown, tooled \\
\hline GC-21 & 1 & Medicine & Aqua & Small (est.) & Blown, tooled \\
\hline GC-22 & 1 & Medicine (or food) & Clear & Small (est.) & Blown, tooled \\
\hline GC-23 & 1 & Medicine & Clear & Small (est.) & Blown, tooled \\
\hline GC-25 & 1 & Medicine & Aqua & Small (est.) & Blown, tooled \\
\hline GC-26 & 3 & Medicine (or food) & Aqua & Small (est.) & Blown, tooled \\
\hline GC-27 & 1 & Medicine & Green & Small (est.) & Blown, tooled \\
\hline GC-30 & 1 & Medicine (or liquor) & Clear & Small (est.) & Blown, tooled \\
\hline GC-31 & 1 & Medicine & Aqua & Small (est.) & Blown, tooled \\
\hline GC-33 & 1 & Medicine & Clear & Small (est.) & Blown, tooled \\
\hline GC-34 & 1 & Medicine (or liquor) & Aqua & Small (est.) & Blown, tooled \\
\hline GC-35 & 1 & Medicine & Clear & Small & Blown, tooled \\
\hline GC-36 & 1 & Medicine & Clear & Indeterminate & Blown, tooled \\
\hline GC-37 & 1 & Medicine & Clear & Small & Blown, tooled \\
\hline GC-38 & 1 & Medicine & Aqua & Small (est.) & Blown, tooled \\
\hline GC-39 & 1 & Medicine (or food) & Clear & Indeterminate & Blown, tooled \\
\hline GC-40 & 1 & Medicine & Clear & Small (est.) & Blown, tooled \\
\hline GC-41 & 1 & Medicine (or liquor) & Clear & Small (est.) & Blown, tooled \\
\hline GC-42 & 1 & Medicine (or liquor) & Clear & Medium (est.) & Blown, tooled \\
\hline GC-43 & 1 & Medicine (or liquor) & Clear & Small (est.) & Blown, tooled \\
\hline GC-46 & 1 & Medicine & Clear & Small (est.) & Blown, tooled \\
\hline GC-47 & 1 & Medicine (or liquor) & Clear & Small (est.) & Blown, tooled \\
\hline GC-48 & 1 & Medicine (or food) & Clear & Medium (est.) & Blown, tooled \\
\hline GC-49 & 1 & Medicine (or liquor) & Amber & Small (est.) & Blown, tooled \\
\hline GC-50 & 1 & Medicine & Clear & Small (est.) & Blown, tooled \\
\hline GC-51 & 1 & Medicine & Aqua & Small (est.) & Blown, tooled \\
\hline
\end{tabular}


Table 8.41, continued

\begin{tabular}{|c|c|c|c|c|c|}
\hline No. & $\begin{array}{l}\text { No. of Glass } \\
\text { Fragments }\end{array}$ & Bottle Contents & Glass Color & Bottle Size & $\begin{array}{c}\text { Bottle Manufacture } \\
\text { Type } \\
\text { (Neck Finish) }\end{array}$ \\
\hline GC-52 & 1 & Medicine & Aqua & Small (est.) & Blown, tooled \\
\hline GC-53 & 1 & Medicine & Clear & Small (est.) & Blown, tooled \\
\hline GC-54*** & 1 & Medicine & Clear & Small (est.) & Blown, tooled \\
\hline GC-55 & 1 & Medicine & Aqua & Small (est.) & Blown, tooled \\
\hline GC-58 & 1 & Medicine (or food) & Clear & Small (est.) & Blown, tooled \\
\hline GC-59 & 1 & $\begin{array}{l}\text { Medicine (or } \\
\text { Toiletries) }\end{array}$ & Aqua & Small (est.) & Blown, tooled \\
\hline GC-65 & 1 & Medicine & Aqua & Small (est.) & Blown, tooled \\
\hline GC-68 & 2 & Medicine (or food) & Clear & Small (est.) & Blown, tooled \\
\hline GC-69 & 1 & Medicine & Clear & Small (est.) & Blown, tooled \\
\hline GC-70 & 1 & Medicine (or liquor) & Clear & Indeterminate & Blown, tooled \\
\hline GC-73 & 9 & Medicine & "True" Blue & Small (est.) & Blown, tooled \\
\hline GC-104 & 1 & Medicine (or food) & Aqua & Small (est.) & Blown, applied \\
\hline GC-107 & 1 & Medicine & Clear & Small (est.) & Blown, tooled \\
\hline GC-108 & 2 & Medicine & "True" Blue & Small (est.) & - \\
\hline GC-109 & 1 & Medicine & "True" Blue & Small (est.) & - \\
\hline Total & 104 & & & & \\
\hline
\end{tabular}

*Bottle has diagnostic markings.

**Bottle has markings that are not identified.

***Bottle has a glass stopper in its neck.

These specific products were mass marketed across the country, and advertisements in late-nineteenth-century African American newspapers in the Austin area specifically aimed at selling their products to black women (see Chapter 13). This reinforces the notion that despite living on a rural farm, the Williams family was well integrated into the late-nineteenth-century commercial economy, and they were consuming mass-produced items that were marketed for women.

One of the defined glass containers (GC-10) is a partially reconstructed amber glass medicine bottle (see Figure 8.4) that has the following words embossed on a flat panel along with the apothecary logo:

\section{MORLEY \\ BR[OTHERS] \\ [A]UST[IN] \\ TEXAS}

Although parts of this name are incomplete (and some fragments from the bottle could not be refit), this amber bottle is identical to some bottles recovered from the Austin Convention Center (Anthony and Parsons n.d.; Brown and Anthony n.d.). This was a medicine bottle made for the Morley Brothers Drug Store, which operated in Austin, Texas, from 1873 or 1874 until 1911 (Brown and Anthony n.d.; Hall 2010). After 1912, the company name changed to the Morley Drug Company, and the listings in Austin City Directories before and after 1912 confirm this (Dana Anthony, personal communication 2010).

In addition to the amber bottle, there are many other fragments of clear or light green glass panel bottles that bear parts of the Morley Brothers name (see Figure 8.4). These appear to represent at least six additional bottles from the Morley Brothers' drugstore (see Table 
B.6). ${ }^{108}$ These specimens have nearly identical markings that also match bottles recovered from the Austin Convention Center (Anthony and Parsons n.d.; Brown and Anthony n.d.). In addition, another light green glass fragment with the name "WONDERFUL EIGHT" embossed on it (Lot 335) was a medicine produced and marketed by the Morley Brothers, who had businesses in Austin and St. Louis, Missouri. "Morley's Wonderful Eight" is listed as a product sold by the "Morley Bros." of St. Louis in a 1902 pharmaceutical publication (Kennedy 1902:176). The Morleys moved their patent medicine production from Austin to St. Louis in 1885, but continued to run the store in Austin well into the twentieth century (Leonard 1906). Morley's Wonderful Eight bottles were also found at the Austin Convention Center (Anthony and Parsons, n.d.) and at the Lamar Street Dump site in Austin (Glazener 1981:14).

The presence of so many medicine bottles from the Morley Brothers drugstore in Austin is interesting. ${ }^{109}$ The Morley Brothers regularly ran advertisements in two of Austin's black newspapers, Austin Searchlight and The Herald (see Chapter 13). ${ }^{110}$ The Williams family could have obtained some of these medicines directly

\footnotetext{
${ }^{108}$ The glass fragments are from Lots 219, 316, 325 329,330 , and refits in Lots 307 and 327. They could not be assigned to specific glass containers because they do not refit with any bottle neck and mouth sections.
}

${ }^{109}$ Hall (2010) notes that Morley Brothers was established in 1873 as a drug retail and wholesale store in Austin. Data compiled by Dana Anthony (personal communication 2010) from various Austin city directories from 1877 through 1922 shows that the Morley Brothers store was in downtown Austin on Pecan Street, which became Sixth Street. Most directories list the address as 203, 206, 207, or 209, but these reflect address numbering changes rather than location changes. The Morley Brothers drugstore was in a brick building with a brass front facade that is currently located a $209 \mathrm{E}$. Sixth Street in downtown Austin. The building now serves as the Austin Visitors Center. The words "MORLEY BROS. DRUGGISTS EST'D 1874" appear in large brass letters at the top of the front (south) wall of the building. The words "MORLEY BROS DRUG STORE" are also painted along the top of the two-story brick wall on the east side. This building was known as the Grove Drugstore for many years, and it still has a modified neon sign with the Grove name on it.

${ }^{110}$ Twenty-nine ads for the Morley Brothers Drug Store or Morley Brothers' products appeared in Austin Searchlight and The Herald from 1893 to 1896 (see Chapter 13 and Appendix F). from the Morley Brothers store if they traveled to downtown Austin by horseback or wagon (11 miles from the farm as the crow flies), and it is certain that the Morley Brothers advertised to the African American community. But it also is possible that the Morley Brothers sold their medicinal products to other smaller drugstores and general stores in nearby rural communities. If so, these products would have been easier for the Williamses to obtain.

The farmstead assemblage contains even more medicinal evidence among the glass fragments that cannot be assigned to specific glass containers. The following diagnostic markings (see Table B.6) are found on medicine bottles fragments:

- $\quad[$ MEXICAN] / [MUST]ANG / [LINIM]ENT / [LYO]N MFG CO / [NEW] YORK

Lots 281 and 289; Units W2 and W9 in the outbuilding block. This product has been identified as "Mexican Mustang Liniment" manufactured by Lyon Manufacturing Company of New York. The Lyon Manufacturing Company started in 1871, and they took over the production and sale of Mexican Mustang Liniment that year (Fike 1987:135-136; Lyon Manufacturing Company 2010). Wilson $(1981: 41,55)$ illustrates a bottle of Mexican Mustang Liniment from Fort Laramie, Wyoming, Mexican Mustang Liniment, and advertisements for the product were in the 1872 World Almanac (1872) and the New York Daily Tribune on April 26, 1873 (Wilson 1981:41). The product was advertised as a medicine "for man or beast" (Fike 1987:135), and one color ad stated "Use Mustang Liniment and you will be all right in a day or two, and so will your horse" (Western Bitters News 2010). Mexican Mustang Liniment was also advertised in an 1892 issue of Austin's black newspaper, the Sunday School Herald (see Chapter 13 and Appendix F). The finding of these glass bottle fragments in the outbuilding excavations, rather than the house or midden areas, suggests that Ransom Williams might have used this product as a horse medicine.

- $\quad \mathrm{P}[\mathrm{AT}] \mathrm{NOV} 2667$ / 466

Lot 321; Unit E20 in the midden area. This is a patent date on a glass bottle fragment. 
It refers to Letters Patent No. 71,594 for "Improved Medicine." This patent was issued to Harriet E. Taylor (executrix for Theodore H. Taylor) of Saratoga Springs, New York (Taylor 1867). The medicine for "liver complaints," to "purify the blood," and "regulate the bowels."

\section{- $\quad$ DR KING'S / NEW DISCOVERY}

Lots 316 and 325; Units E15 and E24 in the midden area. This embossed panel bottle fragment contained a medicine manufactured by H. E. Bucklen \& Company of Chicago, Illinois. The product was a cure "For Coughs, Cold and all Bronchial Affections of the Throat, Chest and Lungs" (Fike 1987:109).

The abundance of patent medicines on the Williams farmstead speaks to a general lack of medical knowledge among the late-nineteenth-century population in Texas. Most of these products were actually nostrums-medicines that make false or exaggerated claims but had no demonstrated health benefits. And for many of these products, alcohol was the main ingredient. It was not until after the passage of the Pure Food and Drug Act in 1906 that companies were forced to substantiate their claims and list the ingredients the "medicine" contained. The implications of the patent medicine bottles found on the Williams farmstead are discussed more in Chapter 14.

\section{Tobacco}

One or more people at the Williams farmstead consumed tobacco. The 31 artifacts represent three forms of tobacco: pipe tobacco, chewing or plug tobacco, and snuff (Table 8.42). The evidence suggests that snuff may have been the most common form of tobacco consumed. Snuff is a dry, powdered, smokeless tobacco that was typically ingested by inhaling it through the nostrils (sometimes called nasal snuff). The minimum number of snuff bottles recovered is 23 , a total calculated by counting the number of complete bottles and separate mouth and lip fragments that had more than 50 percent of the mouth present (see Table 8.6 and Figure 8.2). The individual snuff bottles are described in the glass container inventory; only two are complete (see Table B.4). One complete snuff bottle (GC-94) is 4 inches high with a $21 / 4$-inch square body and no diagnostic markings (see Figure 8.2). Its neck height is $3 / 16$ inch, and its round mouth opening is $15 / 16$ inch. The other complete bottle (GC-93) is 4 inches high with a $23 / 8$-inch square body and three raised dots off-center on its base. Its neck height is $3 / 16$ inch, and its round mouth opening is $15 / 16$ inch. These bottles, and all of the other fragmentary snuff bottles, have irregular necks and mouths from rapid finishing with a lipping tool. One other fragment of brown glass, which is not linked to a defined glass container, has an embossed name "PL Co" on it. The Peter Lorillard \& Company used this mark from 1870 to 1910 (Toulouse 1971:422), and this glass fragment is almost certainly from a snuff bottle. The Lorillard Tobacco Company is the oldest continuously operating tobacco company in America, and it is the oldest publicly traded company on the New York Stock Exchange (Lorillard.com 2011).

Smoking tobacco was also used on the farm, and at least four different pipes are represented by an elbow pipe bowl and bowl fragments. Each of the bowl fragments is distinct in clay color, size, and molded decoration, and several have mold seams. The fragments are all rather plain except for one gray clay bowl fragment with molded rounded ridges running parallel at an angle across the bowl. The reconstructed pipe bowl is nearly complete and was reconstructed from fragments from the same excavation unit (Figure 8.62). It is a plain clay pipe with mold seams on opposite sides of the bowl.

Lastly, a single tobacco plug tag from the Lorillard Tobacco Company was found. This specimen is a circular iron tag, measuring 0.5 inches in diameter, with two small prongs coming off the edge opposite each other. These prongs were used to poke into a plug of paper-wrapped tobacco to hold the paper wrapping in place. The name "LORILLARD" is stamped around the margin of the round tag. The P. Lorillard Company was founded in 1760, and the firm was the first to use metal tags on chewing tobacco plugs beginning in the 1870s (Lorillard Company 1960:1, 2, 4, 20-22; Springate 1997:10).

\section{Alcohol}

All of the items related to personal consumption of alcohol are glass bottles, and each is described in the glass container inventory (see 
Table 8.42. Tobacco artifacts

\begin{tabular}{l|c|c|c|c|c}
\hline \multicolumn{1}{c|}{ Artifact } & House Block & Midden & Outbuilding & Corral Complex & Total \\
\hline $\begin{array}{l}\text { Pipe bowl, reconstructed } \\
\text { (gray and brown clay) }\end{array}$ & 1 & - & - & - & 1 \\
\hline $\begin{array}{l}\text { Pipe bowl rim fragments } \\
\text { (brown clay) }\end{array}$ & 1 & 1 & 1 & - & 3 \\
\hline $\begin{array}{l}\text { Pipe bowl rim fragments } \\
\text { (gray clay) }\end{array}$ & 1 & 1 & - & - & 2 \\
\hline $\begin{array}{l}\text { Pipe bowl rim fragment } \\
\text { (reddish-orange clay) }\end{array}$ & - & 1 & - & - & 1 \\
\hline $\begin{array}{l}\text { Snuff bottles* } \\
\text { (brown glass) }\end{array}$ & - & 1 & 20 & - & - \\
\hline $\begin{array}{l}\text { Tobacco plug tag** } \\
\text { (iron) }\end{array}$ & 4 & 24 & 3 & 0 & 23 \\
\hline Total & 0 & 1 & & 31 \\
\hline
\end{tabular}

* The snuff bottle counts are based on the minimum number of containers described in Table B.4. The total number of glass fragments associated with these 23 snuff bottles is 66 .

** This specimen is a round metal tag with "LORILLARD" stamped around its margin.

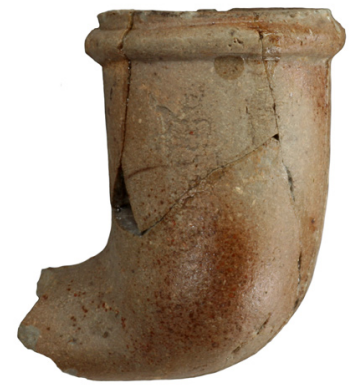

a
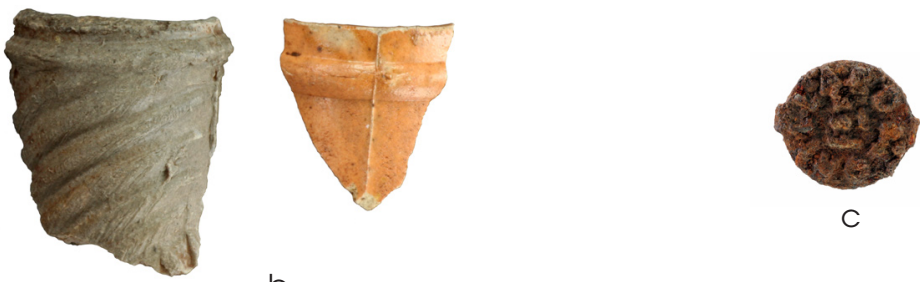

b
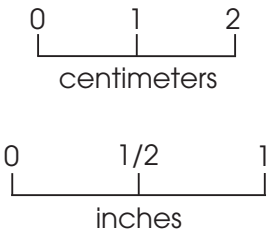

Figure 8.62. Tobacco-related artifacts. (a) Reconstructed elbow pipe bowl; (b) two clay pipe bowl fragments; (b) corroded iron tobacco plug tag with "LORILLARD" mark.

Table B.4). Detailed information pertaining to size, shape, type, color, and other attributes can be found there. Table 8.43 is a summary of the glass alcohol bottles recovered from the farmstead.

A total of 15 glass bottles contained some form of alcoholic beverage, excluding 8 bottles that might have once held medicine or liquor (see Table 8.6). Nine appear to be liquor bottles that held some type of distilled spirit. The exact contents of these bottles are not known because many different types of liquor were packaged in similar styles of bottles. It is impossible to determine the exact liquor contents of a bottle without any markings or a label.

Three specimens are fragments that have neck and mouth finishes characteristic of beer 
bottles. One is an older style of blown bottle with an applied lip, and the other two have tooled lips.

The final three specimens are wine bottle fragments found in Excavation Unit Z, the $2 \times 2-m$ unit in the corral complex (see GC-100, GC-101, and GC102 in Table B.4). Numerous identical bottles were found (but not collected) in a twentieth-century dumpsite just south of the southeast corner of the Williams property (see description of the twentieth-century dump in Chapter 6). The three wine bottles from the corral complex have a distinctive dot pattern on their base with an embossed label denoting the contents as "WINE," a threaded mouth for a metal screw cap lid, and mold seams that extend over the mouth and lip. This indicates that they were made on an automatic bottle machine after ca. 1905 (Lindsey 2013a, 2013b; Lockhart 2006:2). Two specimens have side marks indicating a volume of " $4 / 5$ QUART" that dates the bottles after the 1913 Gould amendment to the Pure Food and Drug Act that required the volume to be shown on bottles (Lindsey 2013b). And the third specimen (GC-101) also has a diamond enclosing the letter "I" inside an oval-a distinctive mark used by the Owens-Illinois Glass Company after 1954 (Toulouse 1971:403; Whitten 2010).

Two of the wine bottle fragments from the corral complex date after 1913 and the third dates after 1954. These bottles definitely postdate the Williams family occupation of the farm, and it is interesting that none of these wine bottle fragments were recovered anywhere from the excavations in or around the house and midden area. It is likely that these bottles were picked from the nearby dumpsite, carried to the corral complex, set up along the wall, and used for pistol or rifle target practice by someone long after the Williams family had moved away.

Table 8.43. Alcohol bottles* $(n=16)$

\begin{tabular}{|c|c|c|c|c|c|}
\hline $\begin{array}{c}\text { Glass } \\
\text { Container No. }\end{array}$ & $\begin{array}{l}\text { No. of Glass } \\
\text { Fragments }\end{array}$ & $\begin{array}{c}\text { Bottle } \\
\text { Contents }\end{array}$ & $\begin{array}{l}\text { Glass } \\
\text { Color }\end{array}$ & Bottle Size & $\begin{array}{l}\text { Bottle Manufacture Type } \\
\text { (Neck Finish) }\end{array}$ \\
\hline GC-11 & 11 & Liquor & Clear & Small & Blown, tooled \\
\hline GC-13 & 43 & Liquor & Clear & Medium & Blown, tooled \\
\hline GC-14 & 20 & Liquor & Clear & Small & Unknown \\
\hline GC-28 & 1 & Liquor & Clear & Small (est.) & Blown, tooled \\
\hline GC-29 & 1 & Liquor & Green & Indeterminate & Blown, tooled \\
\hline GC-32 & 1 & Beer & Amber & Indeterminate & Blown, tooled \\
\hline GC-44 & 1 & Liquor & Clear & Medium (est.) & Blown, tooled \\
\hline GC-45 & 1 & Liquor & Clear & Small (est.) & Blown, tooled \\
\hline GC-56 & 1 & Liquor & Clear & Small (est.) & Blown, tooled \\
\hline GC-57 & 1 & Liquor & Clear & Small (est.) & Blown, tooled \\
\hline GC-64 & 1 & Liquor & Aqua & Medium (est.) & Blown, applied \\
\hline GC-66 & 1 & Beer & Amber & Medium (est.) & Blown, tooled \\
\hline GC-67 & 1 & Beer & Amber & Medium (est.) & Blown, applied \\
\hline GC-100 & 1 & Wine** & Clear & Medium & Automatic bottle machine \\
\hline GC-101 & 1 & Wine** & Clear & Medium & Automatic bottle machine \\
\hline GC-102 & 2 & Wine ${ }^{* *}$ & Clear & Medium & Automatic bottle machine \\
\hline Total & 88 & \multicolumn{4}{|c|}{ ragment has an embossed rye whiskey label, but it could not be identified as } \\
\hline $\begin{array}{l}* \text { One other glas } \\
\text { distinctive ves } \\
\text { **These wine bc } \\
\text { occupation (i.e. } \\
\text { century trash }\end{array}$ & bod & ragment has & embosse & the whiskey labe & $\begin{array}{l}\text { th it could not be identified as } \\
\text { er the Williams family } \\
\text { observed in a twentieth- }\end{array}$ \\
\hline
\end{tabular}


Besides the 15 defined alcohol bottles, a fragment of a bottle shoulder has a round embossed emblem that bears the words: "PAUL JONES / PURE RYE / LOUISVILLE, KY." (Figure 8.63). This specimen is not in the glass container inventory because it is a body fragment without a base or mouth, but it represents a whiskey bottle. This specimen could go with one of the amber glass bottle necks that are assigned glass container numbers (see Tables 8.6 and B.4). Paul Jones \& Company operated in Louisville, Kentucky from 1887 to 1922, and it operated under the name Paul Jones (without the addition of Company) from 1887 to 1893 (Pre-Prohibition Collector.com 2013).

\section{Personal Accoutrements}

The final group of personal artifacts discussed consists of 19 specimens that are classified as personal accoutrements (Table 8.44; Figure 8.64). These are items of a personal nature that were carried or used by an individu$\mathrm{al}$, and the specimens are 8 pocketknives, a small purse (represented by two latch fragments), 2 matching eyeglass lenses, an umbrella or parasol

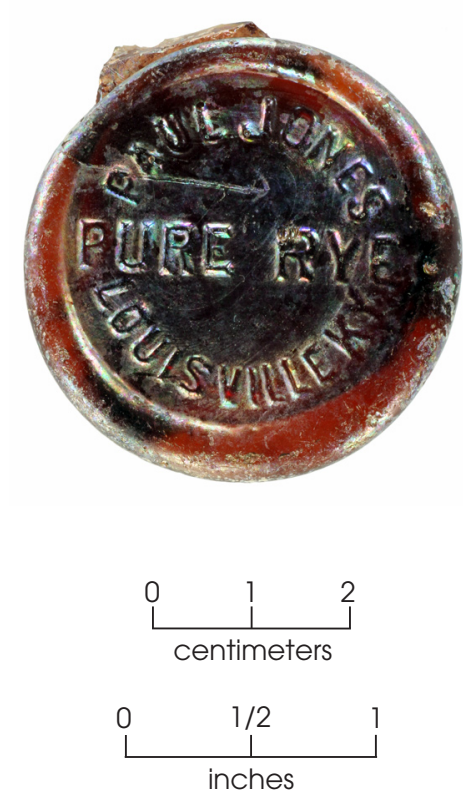

Figure 8.63. Amber glass bottle body fragment with raised circle and embossed label: "PAUL JONES / PURE RYE / LOUISVILLE KY.” (represented by 4 iron rib pieces), a pocket watch (represented by a sprocket gear), and 2 coins.

One pocketknife handle was found by ACSG and is illustrated by Staples and Nash (2003b:Figure 24). Of the seven PAI specimens, five are handle and blade fragments only, and two of the blades have been resharpened many times (blade lengths are ca. 2 1/8 and $31 / 8$ inches). The other two specimens are nearly complete one-blade folding knives. The metal bolsters are present on both, but the handle portions are missing and were probably wooden (and were attached to the bolsters with brads). One has its blade folded into the bolsters (handle length 3 1/2 inches; blade length ca. 2 $1 / 2$ inches), the other has its blade fully extended from the bolsters (handle length 3 inches; blade length $13 / 4$ inches). Pocketknives were a popular item in the 1894 Montgomery Ward (Montgomery Ward \& Company 1895:440-443) catalog and were classified as "Ladies' Knives," "Men's Knives," and "Boy's Knives" depending on size and complexity. Simple one-blade knives were commonly boy's knives, which ranged in price from $\$ 0.08$ to $\$ 0.15$ (Montgomery Ward \& Company 1895:440-443). The number of pages devoted to pocketknives in the Sears and Roebuck catalogs (Sears, Roebuck \& Company 1897:n.p., 1902a:487-495) also attests to the popularity of this all-purpose tool.

The brass pocket watch gear represents a personal luxury item that would have belonged to a single individual. Pocket watches were popular items sold in the late-nineteenth century and early twentieth-century catalogs, including men's and ladies' watches (Montgomery Ward \& Company 1895:135-150; Sears, Roebuck \& Company 1897:n.p., 1902a:29-59).

The two eyeglass lenses are oval and, while not identical, are very close in size and shape. They match the broad oval-shaped lenses illustrated in the Montgomery Ward \& Company (1895:203-204) and Sears, Roebuck \& Company (1897:n.p., 1902a: 125-126) catalogs. The four parasol or umbrella ribs don't allow the item to be further identified, but many varieties of these items were also sold in these catalogs (Montgomery Ward \& Company 1895:297298; Sears, Roebuck \& Company 1897:n.p., 1902a:928-929).

The coins are a 1941 penny that postdates the Williams family occupation and an 1877 Seated Liberty dime. The latter has no mint 
Table 8.44. Personal accoutrements

\begin{tabular}{|c|c|c|c|c|c|c|c|}
\hline Artifact & $\begin{array}{l}\text { House } \\
\text { Block }\end{array}$ & $\begin{array}{l}\text { House Block, } \\
\text { Subfloor Pit }\end{array}$ & $\begin{array}{l}\text { Yard } \\
\text { Area }\end{array}$ & Midden & Outbuilding & $\begin{array}{c}\text { Corral } \\
\text { Complex }\end{array}$ & Total \\
\hline $\begin{array}{l}\text { Coin, } 1877 \text { Seated Liberty } \\
\text { dime }\end{array}$ & 1 & - & - & - & - & - & 1 \\
\hline Coin, 1941 wheat penny & - & - & - & 1 & - & - & 1 \\
\hline Glasses lenses* & 1 & 1 & - & - & - & - & 2 \\
\hline $\begin{array}{l}\text { Pocket knives (iron, blade and } \\
\text { handle fragments) }\end{array}$ & 1 & 1 & - & 3 & 1 & - & 6 \\
\hline $\begin{array}{l}\text { Pocket knives (iron, nearly } \\
\text { complete) }\end{array}$ & 1 & - & - & - & - & 1 & 2 \\
\hline $\begin{array}{l}\text { Purse latch fragments } \\
\text { (cuprous metal) }\end{array}$ & - & - & - & 2 & - & - & 2 \\
\hline Umbrella/parasol parts (iron) & 2 & - & - & 1 & 1 & - & 4 \\
\hline $\begin{array}{l}\text { Watch part, spocket gear } \\
\text { (cuprous metal) }\end{array}$ & - & - & - & 1 & - & - & 1 \\
\hline Total & 6 & 2 & 0 & 8 & 2 & 1 & 19 \\
\hline
\end{tabular}

*Although they were recovered from different contexts, the two lenses match and are probably from the same pair of glasses.

mark, indicating it was minted in Philadelphia. It was found just in front of the fireplace (in Excavation Unit 52). This dime may have been lost or could have been intentionally placed as some type of symbolic or spiritual offering. The context and possible interpretations of this dime are discussed further in Chapter 11.

\section{NEUTRON ACTIVATION ANALYSIS OF STONEWARE POTTERY}

This final section of the material culture chapter present the results of a special study undertaken as part of the ceramic analysis. This was an attempt to use a geochemical analytical technique, specifically neutron activation analysis (NAA), to identify possible production sources of selected stoneware ceramics in the Williams farmstead assemblage. The details of the NAA study are presented in Appendix E, but the study samples and results are summarized here, with an emphasis on the historical significance of the interpretations.

This NAA sourcing study was initiated because of an observation and a hunch. The observation was that one of the stoneware vessels from the farmstead, CV-2 (see Figure 8.6), a reconstructed small-mouth cyclindrical preserve jar with an olive-green salt glaze, looked quite similar to some of the stoneware jars made at the Wilson potteries near Seguin, Texas. ${ }^{111}$ The Wilson potteries is an informal term for three ceramic kiln sites, 41GU4, 41GU5, and 41GU6, located within 2 miles of each other a few miles southeast of Seguin. The three potteries produced stonewares from the late 1850 s to the turn of the century, and they were all owned and operated by African American potters for part or all of their existence. ${ }^{112}$ The hunch was that if given a choice, African American farmers in central Texas might have sought out and purchased ceramics made by African Americans. The obvious research question was: Did the Williams family obtain and use pots made at the African American-owned Wilson pottery?

\footnotetext{
${ }^{111}$ In 1999, Boyd visited the Wilson pottery sites and saw a collection of Wilson pottery in a small museum in downtown Seguin. When the analysis of the Williams farmstead ceramics began, he noticed that one of the stoneware pots resembled the Wilson pots in vessel form and finish. A quick online search for photos confirmed the suspicion that CV-2 from the Williams farmstead was indeed similar to some of the Wilson pots.

${ }^{112}$ Information on the Wilson pottery business enterprises has been published by many researchers, including Blake et al. (1999), Brackner (1981, 1982, 1984), Britt (2005), Brown (2002), and Morgan (2009).
} 


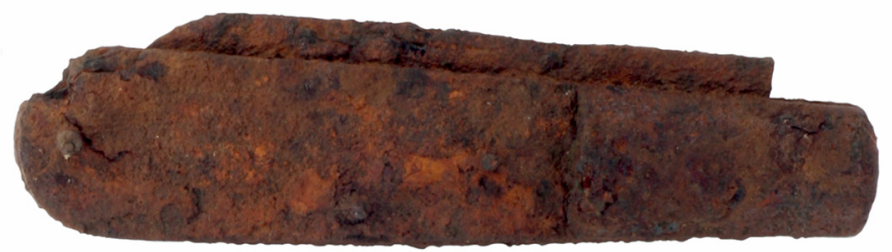

a

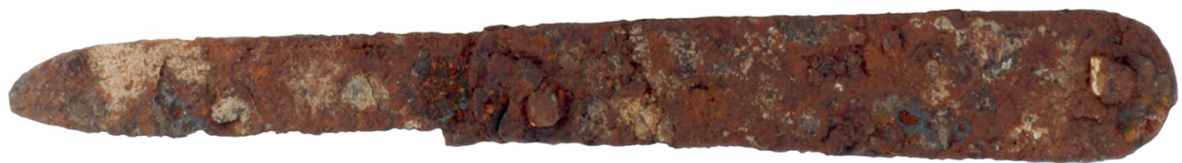

$\mathrm{b}$
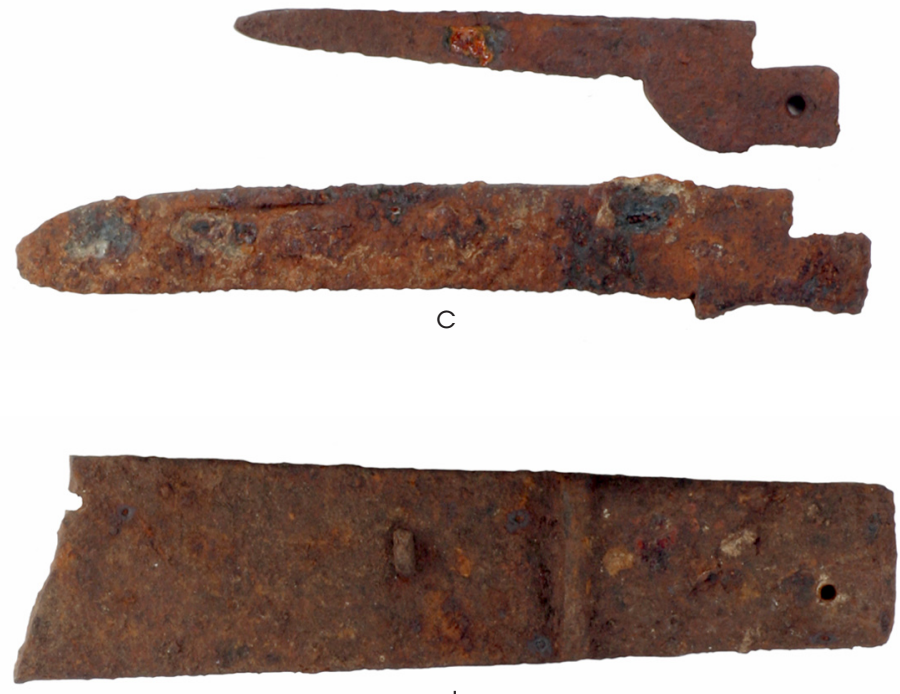

d

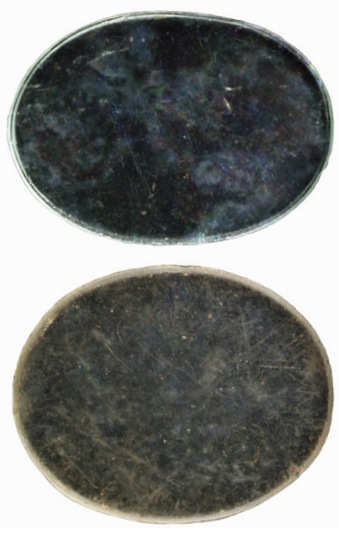

e
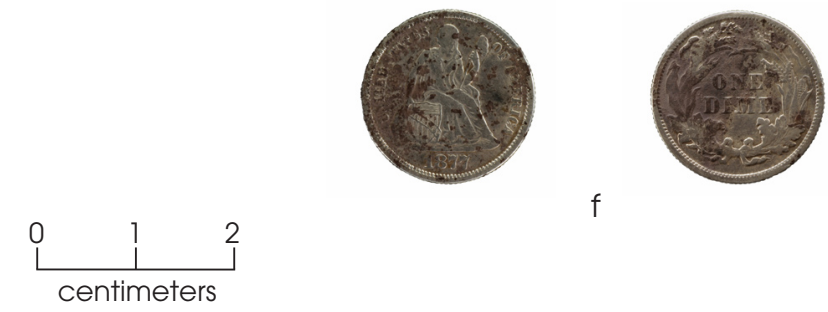

$f$

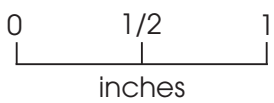

Figure 8.64. Personal accoutrements. (a) Nearly complete pocketknife, blade folded; (b) nearly complete pocketknife, blade open; (c) pocketknife blades; (d) pocketknife bolster; (e) eyeglass lenses; (f) both faces of an 1877 Seated Liberty dime. 
It was determined that the best analytical approach to this problem would be to conduct a pilot NAA study to determine if the Wilson pots have a distinctive geochemical signature (i.e., one unique to their potteries). If the Wilson pottery was found to have a unique geochemical signature, would any of the Williams farmstead stoneware vessels match it? A sample of 50 items was selected for this NAA stoneware: 46 sherds, 2 kiln brick, and 2 clay samples. The analysis compared ceramic sherds from the Williams farmstead to samples from four Texas potteries: Meyer Pottery (near Elemdorf in Bexar County); the Wilson, Durham, Chandler site; the H. Wilson and Company site; and Guadalupe Pottery.

All 13 of the Williams farmstead samples are linked to individual ceramic vessels defined in Table 8.11 and Appendix B. The sherd samples from the Meyer Pottery and the sherd, kiln brick, and clay samples from the three Wilson potteries were all obtained by Molly Morgan in the summer of 2010. These sherds all came from collections in the central Texas area, and samples were obtained for analysis with permission from various owners. The Wilson-Durham-Chandler sherds were donated by the Wilson Pottery Foundation and were originally collected by Richard Kinz in his 1999-2006 pottery kiln excavations. Sherds from the H. Wilson \& Company site are from the Center for Archaeological Research at the University of Texas at San Antonio (UTSA-CAR) collections (eight sherds originally came from the Georgeanna Greer collection and five came from the Elmer Joe Brackner collection). The Wilson pottery sherds are all from waster piles and kilns, meaning that they were pots broken in manufacture, during or after the firing. The Meyer Pottery sherds were donated by UTSA-CAR. The kiln brick fragments and raw clay samples were taken by Morgan during visits to two of the Wilson pottery sites, 41GU4 and 41GU5. The Guadalupe Pottery sherds came from UTSA-CAR (two were originally from the Georgeanna Greer collection) and from the private collection of Jan Anderson (Kerrville, Texas). The latter were collected by Anderson's daughter, Kerry Sagebiel, as part of a high school science project involving the excavation of a groundhog kiln in 1985-1986.

To prepare the ceramic sherd samples, a section was cut from each sherd using a dremel tool. The sherd pieces, fragments of kiln bricks, and raw clay samples were then submitted to the University of Missouri Research Reactor (MURR), where they were analyzed by Jeffrey Ferguson and Michael Glascock. Their report describing the methods and results of this NAA study is presented in Appendix E. The chemical data were analyzed by MURR using principal component analyses, and the interpretive results are summarized in Table 8.45. Figure 8.65 is a bivariate plot of two elements, chromium and cesium. The NAA samples are sorted into four distinct chemical groups, with one pottery sherd and the four brick and clay samples being unassigned outliers. Similar patterns were observed when many of the other trace elements were compared, so the group designations represented in Figure 8.65 are not unique to the chosen elements.

The details of MURR's analyses are in the appendix, but the significant conclusions of the NAA study are as follows:

- A principal components analyses of the NAA data sorted the 50 samples into four geochemical groups (containing 45 samples) and one unassigned group (containing 5 samples).

- Group 1 is a large group that includes all 29 sherds from the three Wilson pottery sites and 4 sherds from Williams farmstead pots. It is a tight chemical group, and the Williams's vessels that match the Wilson pottery chemistry are: CV-2, CV-8, CV-16, and CV-18.

- Group 2 includes all 4 sherds from the Meyer Pottery in Bexar County (Greer and Black 1971), along with 4 of the sherds from Williams farmstead vessels. Chemically speaking, this is a tight group that is quite distinctive from Group 1, and the Williams vessels that match the Meyer Pottery chemistry are: CV-3, CV-6, CV-10, and CV-19. CV-10 is especially notable, since it has a consistent yellowish slip that was tentatively identified as Leon slip, which is one of hallmarks of Meyer pots (Greer and Black 1971).

- Group 3 includes only two sherds from Williams farmstead vessels: CV-15 and CV-17. These cluster by themselves and represent pots from an unknown source.

- Group 4 includes sherds from two Williams farmstead vessels: CV-1 and 
Table 8.45. Neutron activation analysis results for the Williams farmstead study sample

\begin{tabular}{|c|c|c|c|c|c|c|c|c|}
\hline \multirow{2}{*}{$\begin{array}{c}\text { Site } \\
\text { Number }\end{array}$} & \multirow[b]{2}{*}{ Site Name } & \multirow{2}{*}{$\begin{array}{c}\text { No. of } \\
\text { Samples }\end{array}$} & \multicolumn{4}{|c|}{ Chemical Composition Groups } & \multirow[b]{2}{*}{ Unassigned } & \multirow[b]{2}{*}{ Total } \\
\hline & & & Group 1 & Group 2 & Group 3 & Group 4 & & \\
\hline \multirow[t]{2}{*}{$41 T V 1051$} & \multirow{2}{*}{$\begin{array}{l}\text { Ransom and } \\
\text { Sarah Williams } \\
\text { Farmstead }\end{array}$} & 13 sherds & 4 & 4 & 2 & 2 & 1 & 13 \\
\hline & & $\begin{array}{l}\text { Ceramic } \\
\text { vessel nos. }\end{array}$ & $\begin{array}{l}2,8,16 \\
\text { and } 18\end{array}$ & $\begin{array}{l}3,6,10 \\
\text { and } 19\end{array}$ & $\begin{array}{c}15 \text { and } \\
17\end{array}$ & 1 and 12 & 9 & \\
\hline $41 \mathrm{BX} 28$ & Meyer Pottery & 4 sherds & - & 4 & - & - & - & 4 \\
\hline \multirow[t]{3}{*}{$41 \mathrm{GU} 4$} & \multirow{3}{*}{$\begin{array}{l}\text { Wilson, Durham, } \\
\text { Chandler site }\end{array}$} & 10 sherds & 10 & - & - & - & - & 10 \\
\hline & & 1 kiln brick & - & - & - & - & 1 & 1 \\
\hline & & 1 clay sample & - & - & - & - & 1 & 1 \\
\hline \multirow[t]{3}{*}{$41 \mathrm{GU} 5$} & \multirow{3}{*}{$\begin{array}{l}\text { H. Wilson and } \\
\text { Company }\end{array}$} & 10 sherds & 10 & - & - & - & & 10 \\
\hline & & 1 kiln brick & - & - & - & - & 1 & 1 \\
\hline & & 1 clay sample & - & - & - & - & 1 & 1 \\
\hline 41GU6 & $\begin{array}{l}\text { Guadalupe } \\
\text { Pottery site }\end{array}$ & 9 sherds & 9 & - & - & - & - & 9 \\
\hline \multicolumn{3}{|c|}{ Total samples } & 33 & 8 & 2 & 2 & 5 & 50 \\
\hline
\end{tabular}

CV-12. These cluster by themselves and represent pots from an unknown source.

- The two brick kiln and two raw clay samples from the Wilson pottery sites 41GU4 and 41GU5 are unassigned because they do not match anything else in the sample. The fact that that these samples cluster together suggests that the local alluvial clays derived from the Carrizo-Wilcox Formation are homogenous at both sites, which are located only 2 miles apart. ${ }^{113} \mathrm{We}$ intentionally selected raw clay samples that we thought might be from the same clay sources quarried by the potters, but the clay and brick samples are chemically quite different from the pottery. There are two plausible scenarios to account for these significant differences. One is that we did not sample the correct clay sources that were used by the Wilson potters. The other is that the Wilson potters may have been adding something to the raw clay,

${ }^{113}$ Clay samples were taken from sites $41 \mathrm{GU} 4$ and 41GU5, but access could not be obtained to sample clays at the third site, 41GU6. The sample from 41GU4 is alluvial clay from Salt Creek, and the sample from 41GU5 is alluvial clay from Sandy Creek. Both are tributaries to the Guadalupe River, and the parent material for both clay samples is derived from the Carrizo Sands of the Wilcox Formation (Blake et al. 1999; Brackner 1981; Morgan 2009). perhaps a fine-grained tempering material that significantly altered the chemistry of the pottery clay.

- The sherd from the Williams farmstead CV-9 is unassigned because its chemistry does not match anything else in the sample. It is from an unknown source.

This pilot study of only 50 samples from four stoneware manufacturing sites and the Williams farmstead is an admittedly small sample. More NAA studies of Texas-made stonewares are certainly needed, ${ }^{114}$ but the geochemical clusters seen in this analysis are statistically significant. These samples undoubtedly represent a variety of different stoneware sources with distinct chemical compositions, and the data clearly show that the Williams farmstead stonewares came from quite a few sources, including four vessels probably made at the Meyer Pottery in San Antonio. The strong compositional link between four of the Williams pots and all of the Wilson pottery

\footnotetext{
${ }^{114}$ Additional NAA studies are in progress that include many clay sources in central and south Texas as well as early historic ceramics (Darrel Creel, Mike Quigg, and Steve Tomka, personal communication 2011; see Appendix E), but to date no serious effort has been made to focus on the geochemistry of stonewares made in Texas.
} 

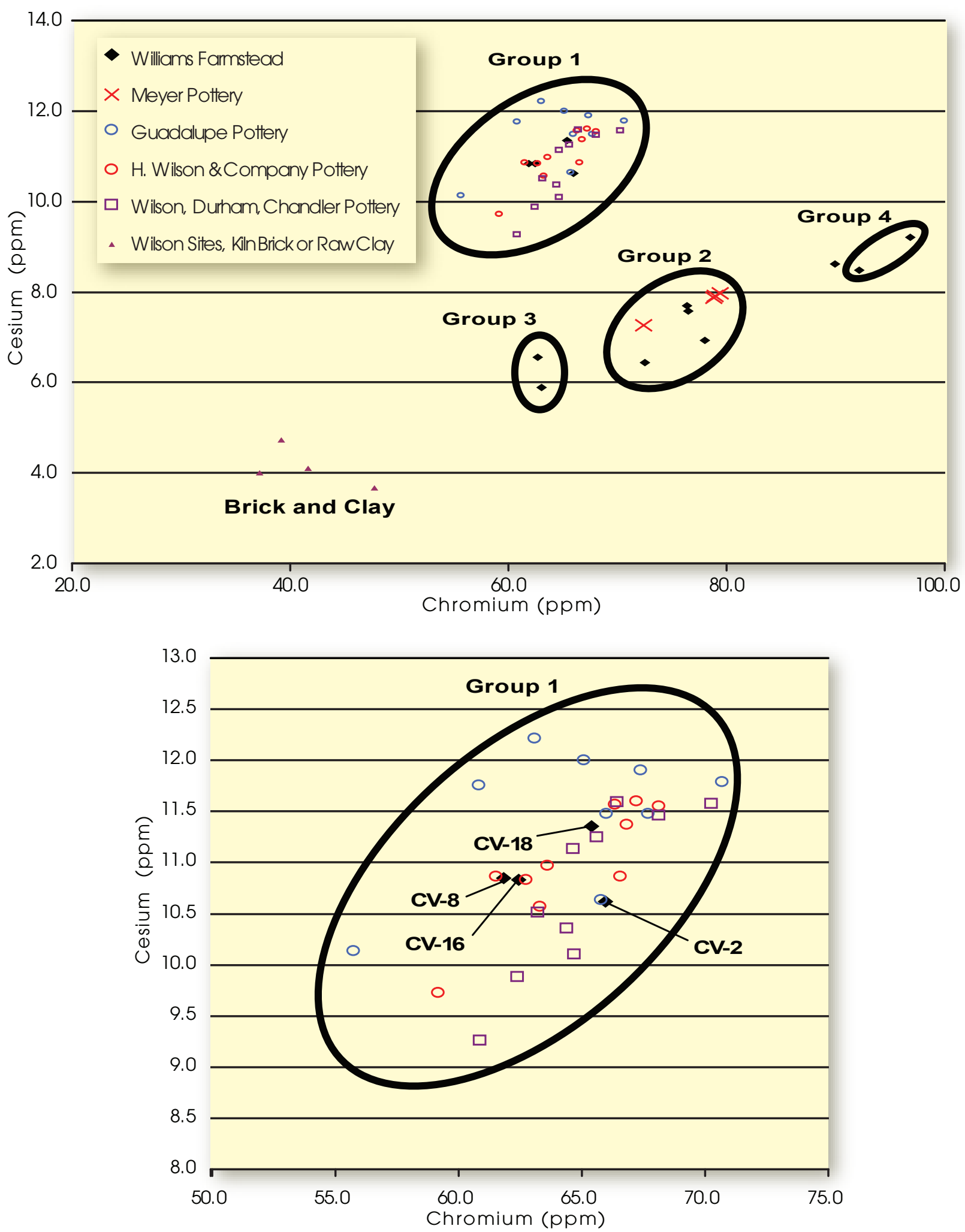

Figure 8.65. (Above) Bivariate plot of chromium and cesium showing the 50 samples in the stoneware analysis and geochemical groups defined by MURR. (Below) Closeup of the Group 1 sample cluster in the bivariate plot of the NAA stoneware samples. The Williams farmstead stoneware vessels that match the chemistry of the Wilson pottery samples are labeled. 
sherds is most intriguing, and the preliminary interpretation of the Group 1 geochemical cluster is obvious. It appears that the Williams family had obtained some stoneware pots made by the African American potters who operated out of the Wilson potteries near Seguin.

Narrowing in on the Wilson pottery, Figure 8.65 depicts a closeup of the bivariate plot for the Group 1 stonewares. An examination of spatial proximity of these samples shows that the four vessels from the Williams farmstead cluster with the sherds from all three of the Wilson potteries. The correlation is strongest with sherds from the H. Wilson \& Company Pottery (41GU5), while the sherds from the Guadalupe Pottery (41GU6) and the Wilson, Durham, Chandler Pottery (41GU4) are more dispersed. This is quite interesting because the Guadalupe Pottery began around 1857 but reportedly closed in 1869, two years before Ransom Williams bought his farm, and the operation was moved to the Wilson, Durham, Chandler Pottery location. This would mean that if the Williamses had pots from the Guadalupe Pottery, they probably got them before they came to the farm or they acquired them second-hand. In contrast, the H. Wilson \& Company operated from 1869/1872 to 1884, and the Wilson, Durham, Chandler Pottery operated from 1869 to ca. 1903 (Brackner 1981; Morgan 2009:13-17). Both of the later potteries were in full production when the Williamses lived on their Travis County farm.

If our preliminary interpretations of the NAA evidence are correct, the Williams family was purchasing stoneware vessels, whether directly or indirectly, that were manufactured at black-owned Wilson potteries located 43 miles south of their farm. Exactly how they obtained these pots is another question that has interesting implications for the existence of an independent African American economic network in central Texas (see Chapter 14).

\section{ADDENDUM: COTTON BALE TIES}

Two unusual artifacts found in the house block (EU 55, Lot 186 and EU 61, Lot 197) remained in the "Unknown, Possibly Identifiable" category when the draft version of this report was completed in November 2013. After the report was reviewed and while the final report was being prepared, PAI archeologists identified these small rectangular iron objects with the help of two informants. ${ }^{115}$ Because this artifact type is rather unique in the farmstead collection, this section has been added to provide a description and illustrations of these specimens. However, no attempt was made to add these specimens into their proper classification groups (i.e., Farming-Related artifacts within the Activities functional group) described earlier in this chapter. The addition of these two specimens to these categories would not alter the comparative spatial analyses or interpretations in any significant way, but it would have required going back to recreate many different tables and graphs in this chapter and in Chapter 11, which time would not permit. Consequently, no changes have been made to the main text of this report, except for the insertion of this section and the addition of footnotes in appropriate places earlier in this chapter (see "Farming-Related Artifacts" and Table 8.21) and in Chapters 11 and 14. The master database in Appendix B and Table B.47 (Farming Artifacts) have been updated with the correct artifact identification for these specimens.

The two Williams farmstead artifacts are identical and size and shape. Each is a thin rectangular piece of iron measuring $2.30 \times 1.53$ inches $(58.4 \times 38.8 \mathrm{~mm})$. Each is 0.2 inches $(0.51 \mathrm{~mm})$ thick on both short ends, but their middle sections are recessed and only 0.14 to 0.15 inches (3.56 to $3.81 \mathrm{~mm}$ ) thick. The specimens have a distinctive arrow-shaped cutout in the center, with a 0.35 -inch-wide $(8.89 \mathrm{~mm})$ slot that opens out onto one of the long sides. The arrow-shaped aperture measures 1.37 inches $(34.80 \mathrm{~mm})$ long and 0.43 to 0.47 inches (10.92 to $11.94 \mathrm{~mm}$ ) wide. The length of the rectangular portion of the arrow aperature is 1.10 inches $(27.94 \mathrm{~mm})$.

The Williams farmstead artifacts closely match the patent drawings for a cotton bale tie from U.S. Patent No. 31,252 (Figure 8.66). This patent was issued in January 1861 to J. J.

\footnotetext{
${ }^{115}$ Credit for identifying this artifact type as a cotton-related item goes to Mr. Loran Pitts. Credit for determining that its function was related to the binding of cotton bales goes to Mr. Pitts and Mr. Kenneth L. Boyd. Both men currently live in Lubbock, Texas, and they each spent much of their lives farming in the Texas Panhandle-Plains region. Once this generic identification was offered, a few hours of internet searching confirmed the identity of this specimen as a cotton bale tie. The search also discovered a nearly exact match among the many U.S. patents issued for cotton bale ties and buckles.
} 
McComb for an "Improvement in Iron Ties for Cotton-Bales." In the patent document, $\mathrm{McComb}$ (1861) stated:

The nature of my invention consists in the use of a peculiarly-shaped buckle as a fastening or tie for the ends of the iron hoops which it is desired to substitute in place of the hemp ropes now made use of in baling cotton, said iron hoops being so much safer in case of fire...

The tie or buckle is a piece of wroughtiron or other metallic substance, about the eighth of an inch thick, an inch and three-quarters wide, and two inches long, (the size being modified to suit the width of the hoop used,) with an oblong hole or aperture cut or punched through the center...

Forming the link or tie with an oblong aperture, one end of which is arrow-shaped, or, rather, presents two sides of an equilateral triangle, the design of this arrow-shaped end being not only to force the hoop or bend of the hoop over the slot, which it does with unerring precision when the bale expands after being released from the press, but also to secure an equal bearing upon the separated parts of the slotted side of the tie...

It is clear from the patent description above that McComb's cotton-bale tie buckles were designed to accommodate metal straps of a standard width, and both of the Williams farmstead specimens were for use with 1-inch-wide metal straps. One notable feature of the farmstead specimens is that the two ends of the slot are slightly offset from each other (when viewed laying flat), and this is especially obvious on the farmstead bale tie that went through conservation treatment (the Lot 186 specimen). This offset is an attribute that is illustrated in the original patent drawings (Figure 2 in $\mathrm{McComb}$ 1861), and it was intended to facilitate the insertion of the looped metal strap into the tie buckle.

Dozens of different types of cotton bale ties and buckles were patented, and an 1892 report titled The Growth of Industrial Art (Butterworth 1892:48) illustrates 19 patents on cotton bail ties issued by the U.S. Patent Office from 1856 to 1894 , including the $1861 \mathrm{McComb}$ 's arrow tie. While all the various tie buckles served the same purpose and are generally similar, they vary widely in their specific design details and how they interlocked with metal bands or wires to bind cotton bales.

Of all the various types of cotton bale tie that were made, the McComb's arrow tie appears to have been a common one that was produced for several decades. McComb's Patent No. 31,252 was involved in a lawsuit that was "brought for the infringement" of three patents on cotton bale ties. The suit was filed in November 1876 and was settled in November 1882. The plaintiff was the American Cotton-Tie Company (1882), which had owned the following three patents for cotton bale ties since March 1876:

10. Patent No. 19,490 , issued to Frederick Cook, March 2, 1858, for an "improvement in metallic ties for cotton bales, and extended for seven years from March 2 , 1872 ;

11. Reissue Letters Patent No. 5,333, issued to James J. McComb as assignee of George Brodie, March 25, 1873, for an "improvement in cotton-bale ties." The original patent was granted to Brodie on March 22, 1859, and reissued April 27, 1869, and extended for seven years from March 22, 1873 ;

12. Patent No. 31,252 , granted to J. J. McCombs, January 29, 1861, for an "improvement in iron ties for cotton-bales."

These were called "the Cook, the Brodie, and the McComb patents," and the company alleged that others "made, used, and sold" these patented inventions without permission.

The style of the McComb's patented bale tie was described in the 1882 lawsuit document as being the "arrow tie," and this document stated:

The corporation plaintiff, since it acquired title to the three patents in March, 1876, has carried on the 

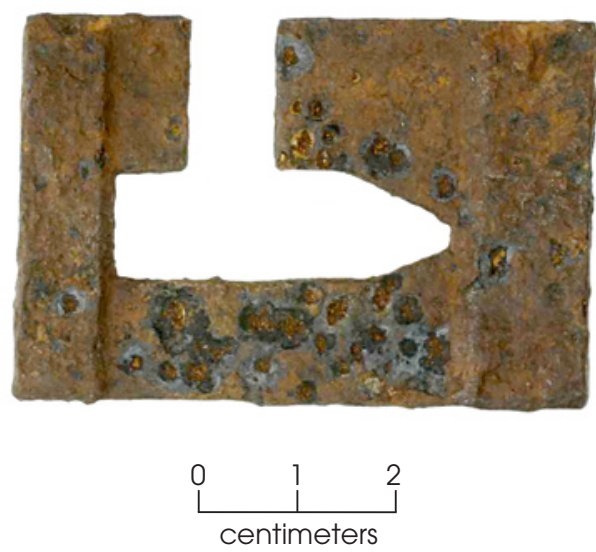

a
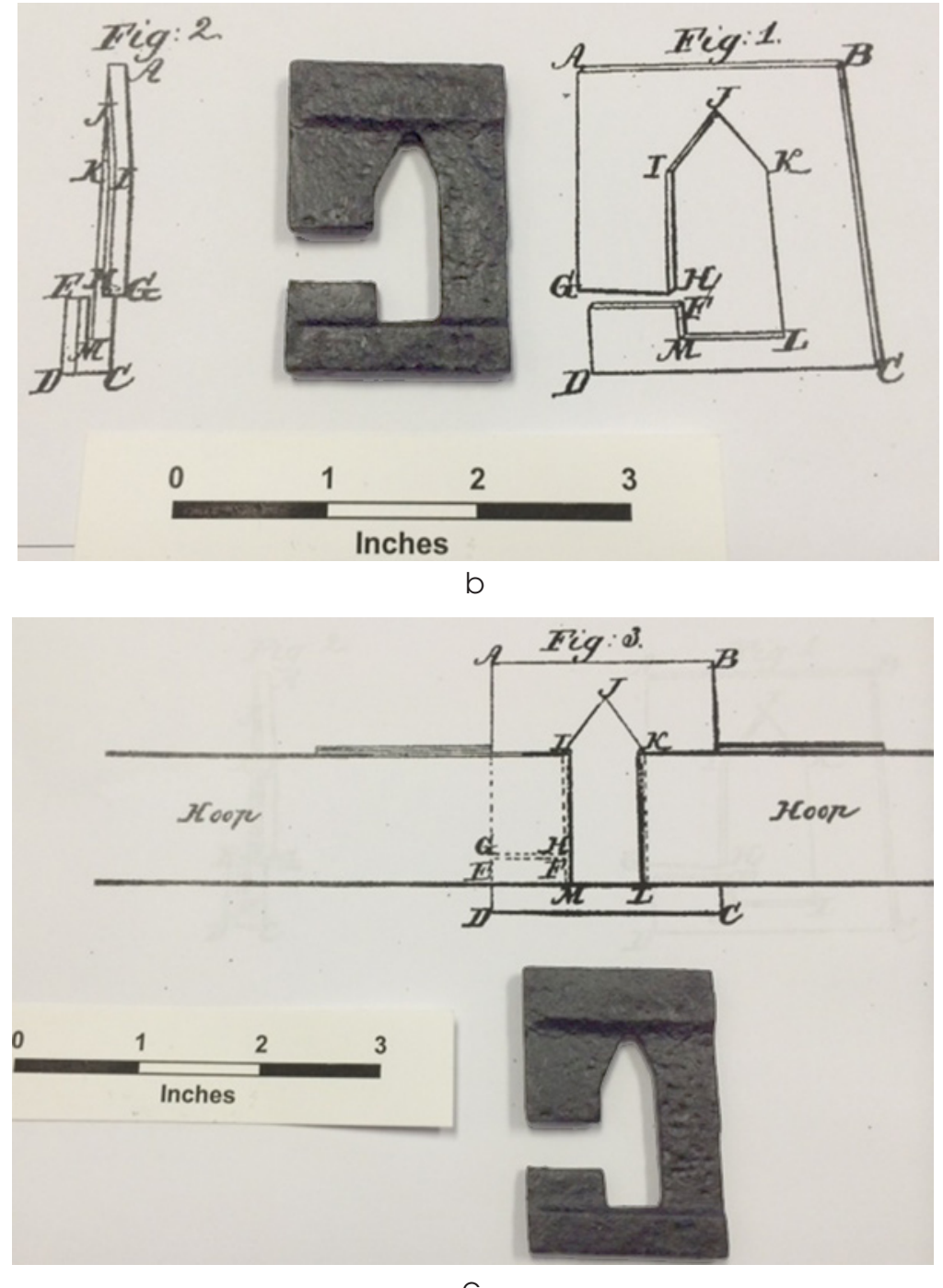

C

Figure 8.66. Cotton bale tie found in the Williams farmhouse (Lot 186) and patent drawings. (a) Photograph of specimen before conservation. (c and d) Photographs of the specimen after conservation with drawings from U.S. Patent No. 31,252 granted to J. J. McComb on January 29, 1861, for an "Improvement in Iron Ties for Cotton-Bales" (McComb 1861). 
business of making cotton bale ties under the patents. The form of tie it has principally made is the form of the McComb patent, which is called the "arrow tie," from the shape of the fivesided hole cut in the plate of the buckle. It has not granted any licenses to make the ties, but has itself supplied the demand for them. The tie consists of a buckle and a band all made of metal. The band goes around the bale, and the two ends of it are confined by means of the buckle. On each of the buckles which the corporation has made and put upon the market it has placed the words "Licensed to use once only," stamped into the body of the metal. This practice was also observed by its predecessor, the copartnership firm (American Cotton-Tie Company 1882).

The fact that the McComb patent and "arrow tie" are specifically mentioned in this 1876-1882 lawsuit indicates that McComb's 1861 cotton bale ties were still a viable commercial product through the $1870 \mathrm{~s}$ and into the 1880s. The defendants in the lawsuit were individuals associated with the Providence Cotton-tie Company, and the court found that the defendants had infringed on the rights of the
Cook, Brodie, and McComb patents when they salvaged and resold the patented tie buckles and binding hoops for baling cotton.

Given all of these historical facts, it is not surprising to find that Ransom Williams would have used the McComb's cotton bale ties on his Travis County farmstead in the last quarter of the nineteenth century. From a historical perspective it is also notable that a number of McComb's cotton bale ties were found, bound together in a mass concretion, among the wreckage of the USS Westfield (Jason Parkoff, personal communication 2014), a Union gunboat that was scuttled during the Battle of Galveston in Galveston Bay on January 1, 1863. Soon after it was built as a ferryboat, the Westfield was purchased by the U.S. Navy in November 1861, and by the fall of 1862 it was the flagship of the West Gulf Blockading Squadron and was patrolling the Texas coast (Borgens and Gearhart 2010). From October through December of 1862, the Westfield was engaged in actions to blockade Galveston Bay and capture Confederate blockade runners. Galveston had become a major shipping point, and most blockade runners were carrying cotton that would be sold to help finance the Confederate war effort. Consequently, it seems likely that Union ships involved in the blockades of Southern ports would have carried some extra cotton bale bands and ties. 



\title{
VERTEBRATE FAUNAL REMAINS
}

\author{
Brian Sawyer Shaffer ${ }^{116}$
}

Excavations at the Ransom and Sarah Williams site (41TV1051) produced 2,916 vertebrate remains (Table 9.1). This assemblage was analyzed to assess what types of animals were present at the site and which were being exploited. Faunal remains were recovered from four main areas and produced an interesting assemblage dominated by pigs, cottontail rabbits, cattle, and chickens, with a variety of other taxa occurring in much lower frequencies.

Remains were identified using the Zooarchaeological Research Collection at the University of North Texas. Identifications were made to the most specific taxon possible given the completeness and condition of the specimens, diagnostic attributes, comparative material available, and analyst skill. For example, cattle were identified as Bos sp. for specimens that could actually be identified to that genus, cf. Bos sp. for specimens most closely matching domestic cattle, and Bos/Bison for very large artiodactyls that could not be discerned as either Bos sp. or Bison Bison. Give the site's historical context, however, it is rather certain that all of the latter group represents bones of domestic cattle.

Data were recorded using a zooarchaeological coding system (Shaffer and Baker 1992). Provenience, taxonomic, anatomical, and taphonomic information were recorded for each specimen along with unique information such as butchery marks and medical disorders. Specimens were quantified based on the number of identified specimens (NISP) and the minimum number of individuals (MNI) by activity area (Tables 9.2 and 9.3).

\footnotetext{
${ }^{116}$ Independent faunal analyst, Denton, Texas.
}

The NISP simply represents the number of specimens identified for each taxon. By comparison, the MNI is the fewest number of individuals potentially represented based on skeletal representation and duplication of elements. For this analysis, aging of skeletal elements was also used. MNI was assessed for the site as a whole and separately for each activity area. In many cases, an MNI of one was assigned due to the presence of a single identified specimen from a given taxon in a given activity area. For the taxa where many elements were present, such as for cottontail, chicken, and pig, element representation and aging criteria had to be used to determine MNI because there were individuals from multiple age classes.

Comparison of the NISP to MNI shows the same basic frequency distribution of taxa, and this is the expected pattern. Marked differences in representation between the two methods of calculation would indicate some form of bias in the composition of the sample affecting quantification.

\section{TAXOMOMIC AND HABITAT REPRESENTATION}

As seen in Tables 9.2 and 9.3, the representation of taxa at the site produced no unexpected taxa for the region and time period, though the representation may be incomplete, as indicated by the limited diversity of indigenous taxa. There are what appear to be a few staple species and then a limited number of ancillary species. The taxa represented can be divided into categories of likely exploited indigenous taxa, domesticated animals, and likely commensal taxa. Others that occur in 
Table 9.1. Bones by analysis unit and recovery method

\begin{tabular}{l|c|c|c}
\hline \multicolumn{1}{c|}{ Analysis Unit } & $\begin{array}{c}\text { Regular Excavation } \\
\text { Recovery* }\end{array}$ & $\begin{array}{c}\text { Flotation Sample } \\
\text { Recovery }\end{array}$ & Total Bones Recovered \\
\hline Area N (north of house) & 1 & - & 1 \\
\hline Area W (west of house) & 3 & - & 3 \\
\hline Corral complex & 1 & - & 447 \\
\hline East midden & 447 & - & 23 \\
\hline East slope midden & 439 & - & 763 \\
\hline Outbuilding block & 23 & $407 * *$ & 155 \\
\hline House block & 763 & - & 84 \\
\hline Feature 1, subfloor pit & 748 & 407 & 2,916 \\
\hline Chimney box & 84 & & \\
\hline Total & 2,509 & - & 2 \\
\hline
\end{tabular}

* Found in situ or in 1/4-inch screen.

** The flotation samples from Feature 1 also include 18 fish scales.

low frequency and are not typically exploited may have entered the site after occupation.

\section{Indigenous Taxa}

Indigenous taxa that were likely exploited are primarily small game, including a variety of birds (quail, dove, turkey, and unidentified quail-sized birds), mammals (rabbit, squirrel, and opossum), and fish (bony fish and something akin to sunfish). Turtle, snake, canid, and raccoon remains certainly may have been exploited as well, or possibly dispatched as varmints, but this is speculative because their frequencies at the site are low, and none have diagnostic taphonomic indicators reflecting human interaction.

Although fish hooks were recovered from the site (see Chapter 8), no fish bones were recovered. But two types of fish scales were recovered from the flotation samples of sediment from the Feature 1 storage pit (Lots 454, 457, 459, 460, 461, and 462 from Units 61 and 71). These samples yielded fish scales of an unidentified type of bony fish and Centrarchidae, the family that includes sunfish, black bass, and crappies. It is likely that the fish scales were found in the sediment from the trash-filled storage pit because this context afforded much better preservation potential than in all the other excavated contexts (see Feature 1 discussion in Chapter 7).
Part of what makes the composition of the Williams farmstead faunal remains so interesting are the taxa that are missing from the assemblage. Several types of animals that one might expect to recover from a historic site in this area were not found. Of the indigenous birds, with the possible exception of turkey, larger birds such as goose and duck are not present. Indigenous mammals exploited apparently are all smaller taxa. Most notably missing from the assemblage is deer, which would have been the largest common indigenous mammal.

\section{Habitat Exploitation}

Indigenous taxa recovered from the site appear to reflect the habitats of the immediate Ransom Williams property area. With the exception of water turtle and fish (as indicated by fish scales and fish hooks in the artifact assemblage), aquatic habitats appear to have been exploited on a limited basis. Quail, dove, turkey, and jackrabbit would have most likely been exploited in upland field or forest edge or open habitats, and cottontail rabbits and raccoons from environs affording shelter such as forest, forest edge, and parklands, though agricultural fields and gardens would also be an attraction to them. Opossums typically would be taken from forest and forest edge environments (Schmidly and Davis 1994). 


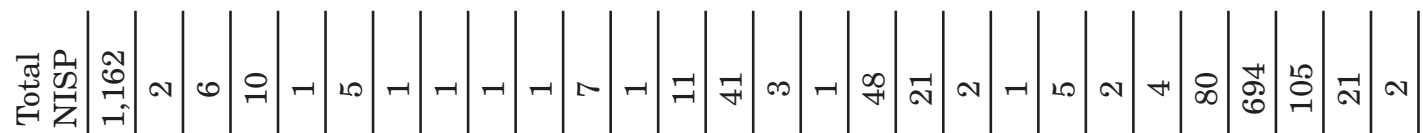
喵

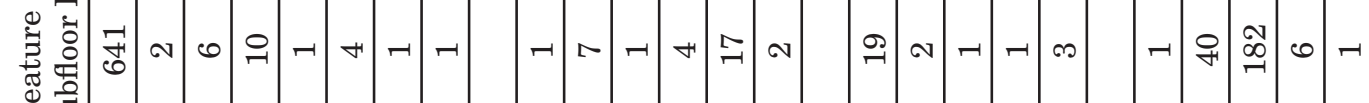
政表

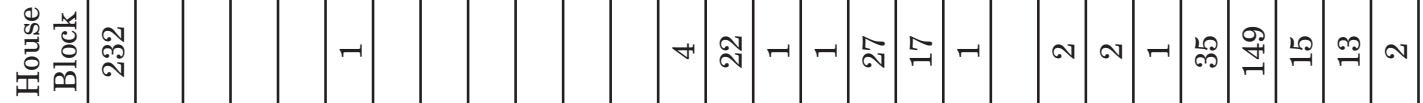

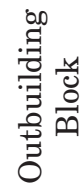

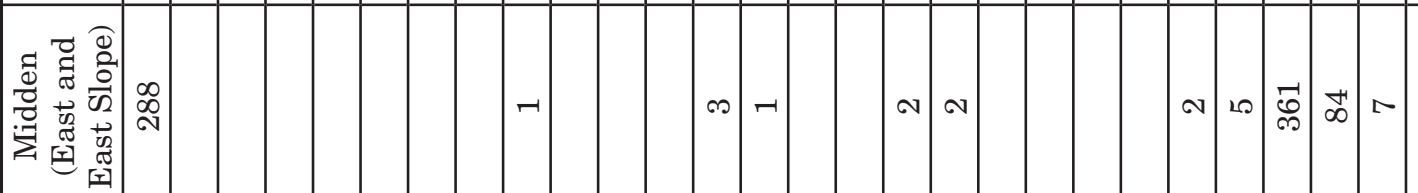

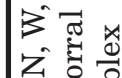

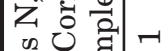

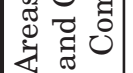

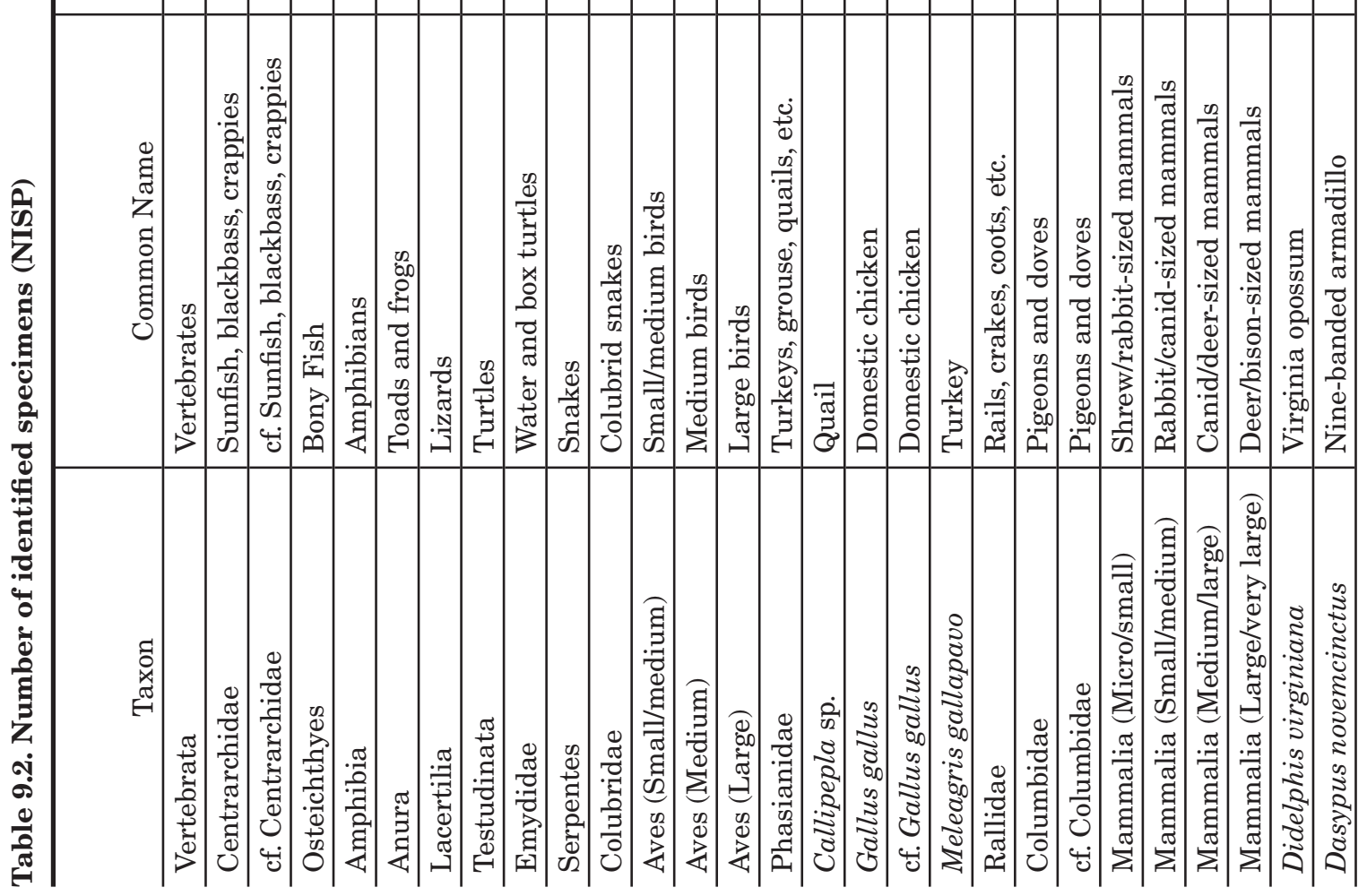


The Ransom and Sarah Williams Farmstead

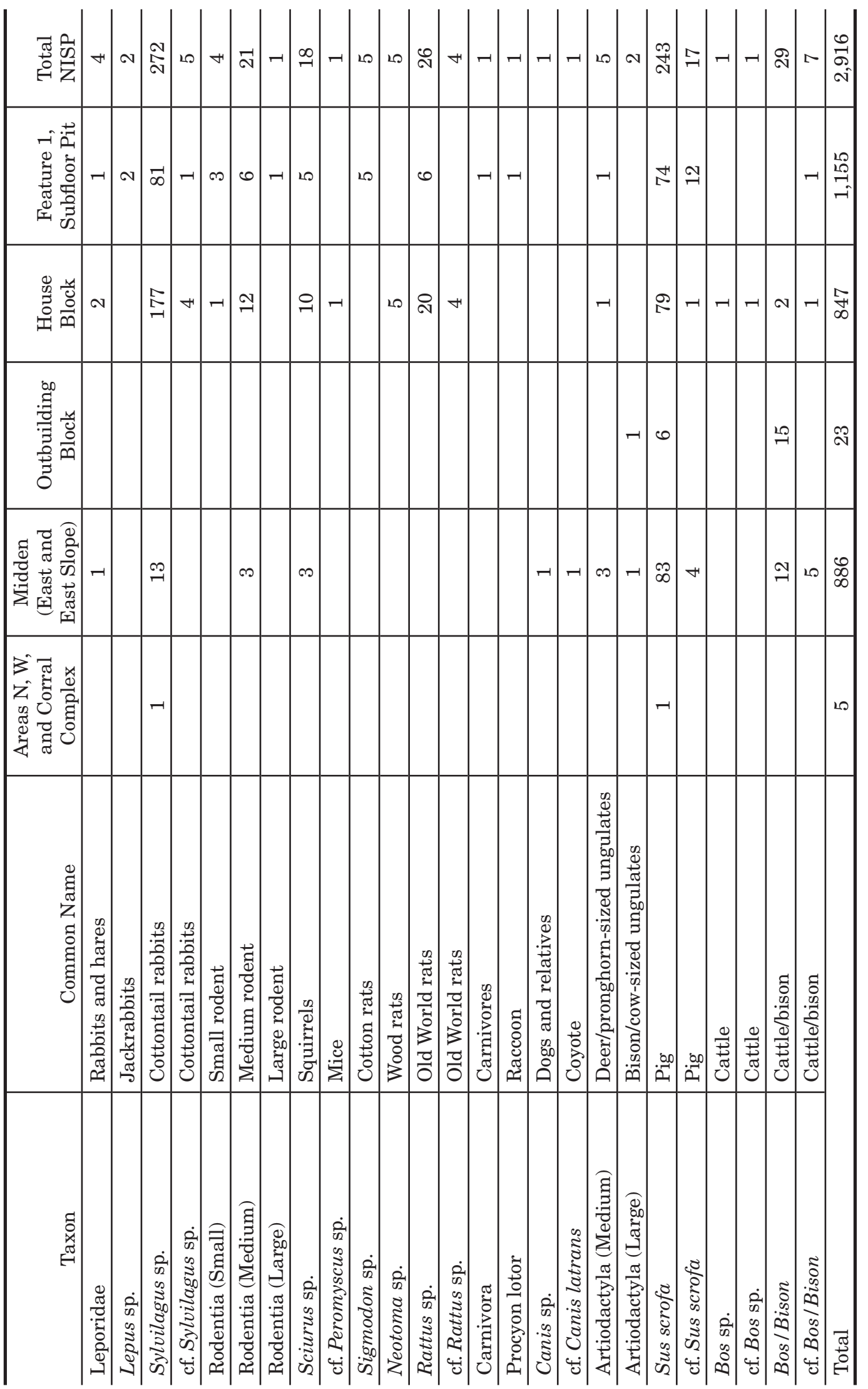


Chapter 9: Vertebrate Faunal Remains

\begin{tabular}{|c|c|c|c|c|c|c|c|c|c|c|c|c|c|c|c|c|c|c|c|c|c|c|}
\hline 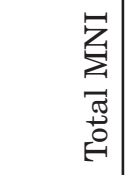 & N & -1 & -1 & -1 & $N$ & $\rightarrow 1$ & $\sim$ & $\infty$ & -1 & N & $\infty$ & -1 & $\neg 1$ & 10 & $H$ & -1 & $\neg 1$ & $\neg$ & + & $-1-$ & $\infty$ & 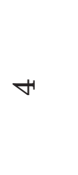 \\
\hline 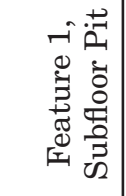 & -1 & -1 & & $\neg 1$ & N & & N & -1 & -1 & -1 & -1 & & -1 & 10 & -1 & & $\neg 1$ & & -1 & -1 & $\sim$ & $\neg$ \\
\hline 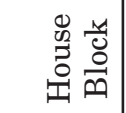 & -1 & & & & & -1 & +1 & -1 & & -1 & -1 & -1 & & $\Sigma$ & $\infty$ & -1 & & -1 & $\infty$ & & $\sim$ & -1 \\
\hline 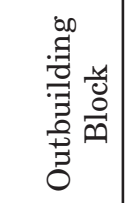 & & & & & & & & & & & & & & & & & & & & & -1 & $\neg$ \\
\hline 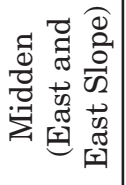 & & & -1 & & & & -1 & & & & -1 & & & N & -1 & & & & & - & $\infty$ & -1 \\
\hline 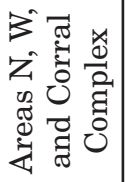 & & & & & & & & & & & & & & -1 & & & & & & & & \\
\hline 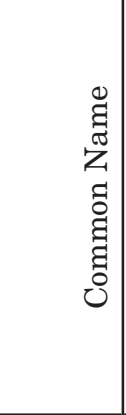 & 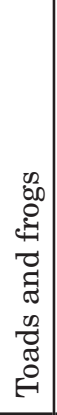 & 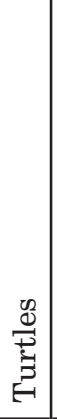 & 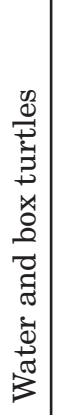 & 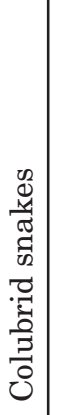 & 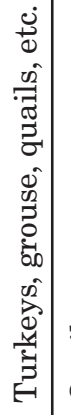 & $\begin{array}{l}\bar{\sigma} \\
\vec{\Xi} \\
\vec{\sigma}\end{array}$ & 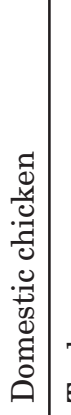 & 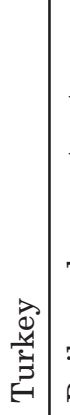 & 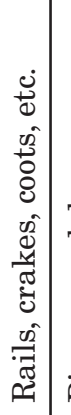 & 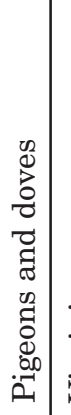 & 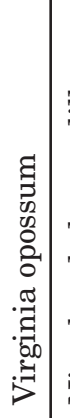 & 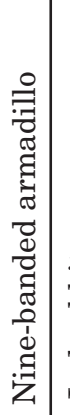 & 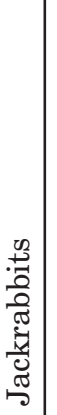 & 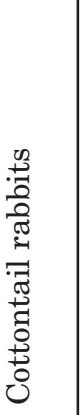 & 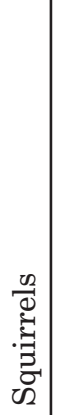 & $\underset{\Sigma}{\stackrel{\Xi}{\Sigma}}$ & 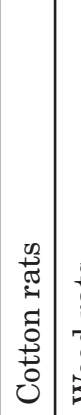 & 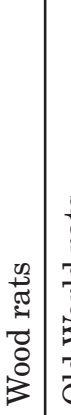 & 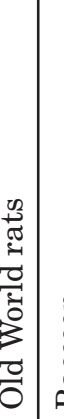 & 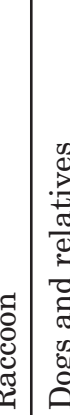 & 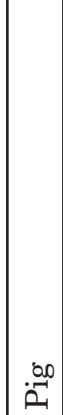 & 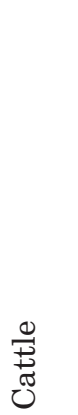 \\
\hline 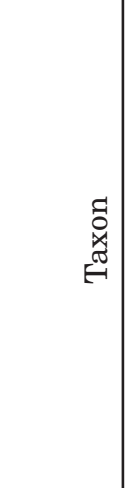 & 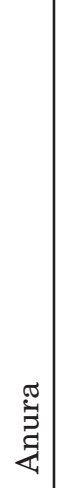 & 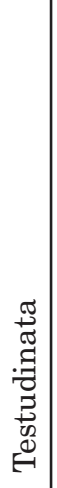 & 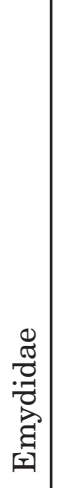 & 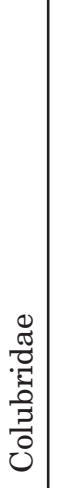 & 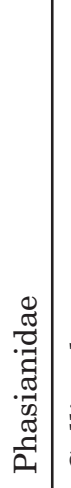 & 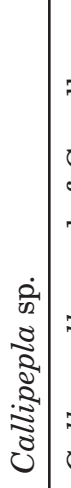 & 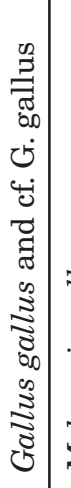 & 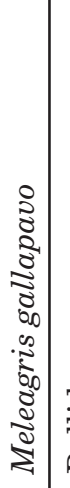 & : & 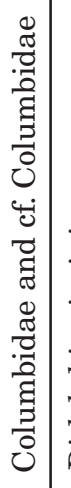 & 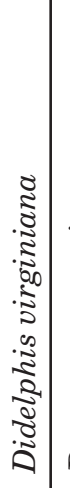 & 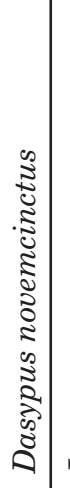 & 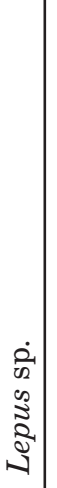 & 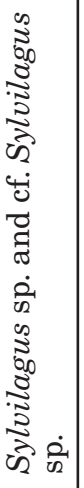 & 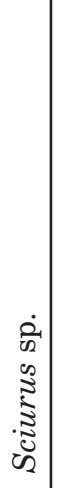 & 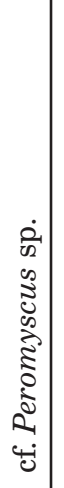 & 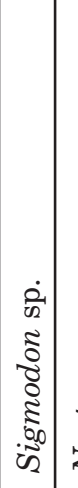 & 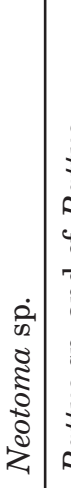 & 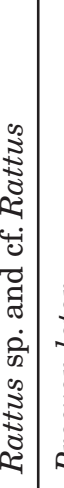 & 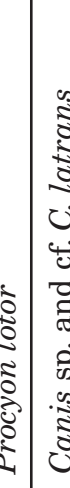 & 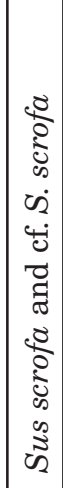 & 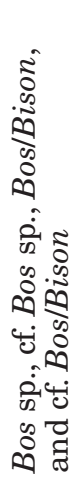 \\
\hline
\end{tabular}




\section{Domesticated Taxa}

Domesticated taxa are dominated by pig, but also include cattle and chicken. The avian assemblage includes both hens $(n=5)$ and roosters $(n=2)$ as indicated by the presence of spurs on the tarsometatarsi recovered (see Table 9.3). While both male and females were identified in the assemblage, no long bones containing medullary bone (indicative of a laying hen) or eggshell were recovered. With the domesticated taxa, the pattern of conspicuous absence continued. There is no evidence of dogs or cats as pets or utilitarian animals (e.g., for security or varmint control). Two specimens from the east midden were identified as canid, but one of them compares most favorably with coyote. Although horse and mule shoes and a variety of horse tack were recovered from the site, no horse remains were recovered. This is not to suggest that horses were being used for food but that their remains were not recovered from the excavated areas despite there being physical and historic evidence of their presence at the site.

\section{Commensal Taxa}

Commensal taxa and those that may have not been part of the original site assemblage include the anuran (likely toads), mouse, and rat remains along with the armadillo, which would have been incorporated in the site no earlier than 1900 based on its range expansion into Texas (Davis and Schmidley 1994:85).

\section{TAPHONOMY}

The general condition of the remains from 41TV1051 is good, with little destruction being caused by typical factors such as weathering (exposure to the elements on the ground surface), burning, animal gnawing, and chemical etching (e.g., from plant roots, gastric acid, or carbonic acid produced from rainwater and limestone) (Table 9.4). Breakage, however, is extensive across the sample, with 92 percent of the specimens being broken, including the 49 specimens that exhibit butchering marks (discussed below).

Several types of breaks were observed. Angularly broken bones usually have either lost their collagen content and hence cannot spirally fracture (Johnson 1985) or are specimens that do not typically spiral fracture, such as teeth $(\mathrm{n}=252)$, some flat bones such as the cranium $(n=57)$, turtle shell $(n=1)$, costal cartilage $(\mathrm{n}=0)$, mammal sternum segments $(\mathrm{n}=1)$, and fish vertebrae $(n=0)$. Such collagen loss may occur due to fire, weathering on the ground surface, leaching, or biodegradation over time. After collagen loss, bones may fracture due to: (1) activities being conducted at the site (e.g., trampling, oven cooking, and boiling); (2) activities occurring after the site was occupied (i.e., plow zone damage, though that is not relevant here); (3) geological activity such as ground compaction; or (4) weather-related activities such as freeze-thaw or wetting and drying. Bones can also be broken during the course of archeological recovery (which often produces visible new fracture surfaces), though that does not appear to be a significant factor in this assemblage. As noted in Table 9.4, marked weathering (producing fine-line cracking, exfoliation of bone layers, flaking in planes) is very infrequent $(\mathrm{n}=14)$. Burning is present in just 30 specimens, of which 18 are charred (incomplete combustion, usually burned brown or black) and 12 are calcined (burned white, more complete combustion). Chemical dissolution processes could have resulted in further destruction of the sample; 4 specimens were noted with light etching, and 70 specimens exhibit marked etching that damaged the majority of the surface of these specimens. These factors do not appear to be leading causes for the angular breakage seen in the majority of the assemblage. Instead, it is probably due to a combination of factors, including ground compaction, weather-related influences, and biodegradation over time.

The faunal assemblage has a fairly high frequency of spirally fractured specimens, which may be indicative of human activity. Removed from consideration are the 310 specimens not apt to spirally fracture (noted above), leaving a sample of 2,606 specimens, of which 487 (19 percent) are spirally fractured. This fairly high percentage indicates that the breaking was possibly intentional-a conclusion supported by the recovery of three specimens that exhibited dynamic loading impact points (Figure 9.1). Such impact points occur when bone is struck with a hard object, resulting in a cone of percussion and fracturing (Johnson 1985). While no doubt some of the bone would be spirally fractured as part of the normal butchering and disarticulation 


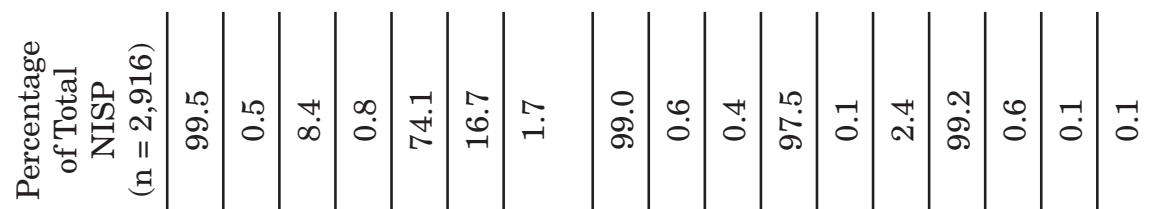

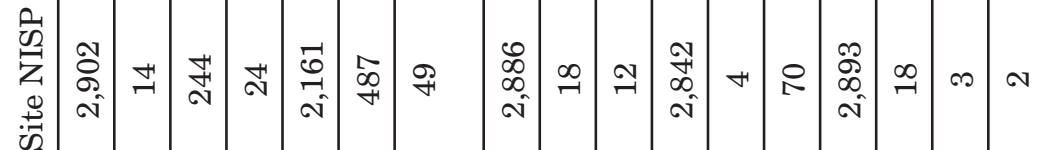

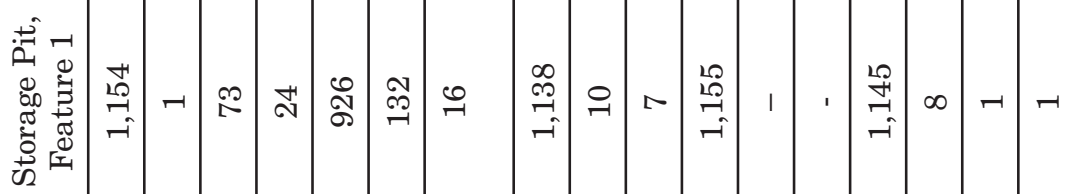

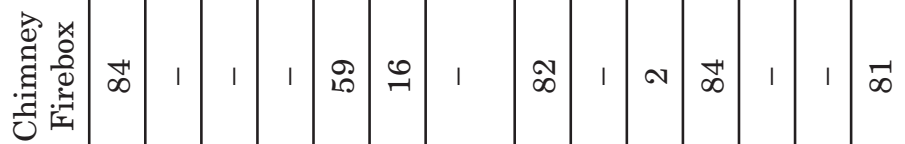

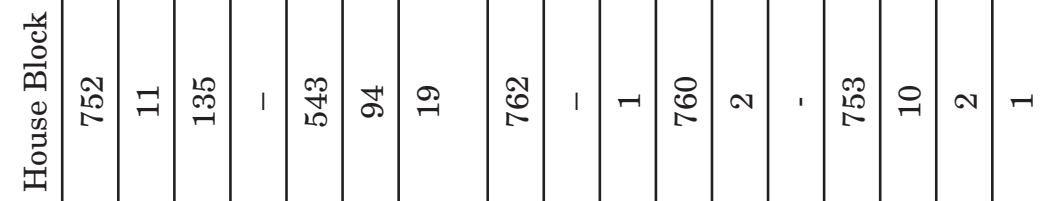

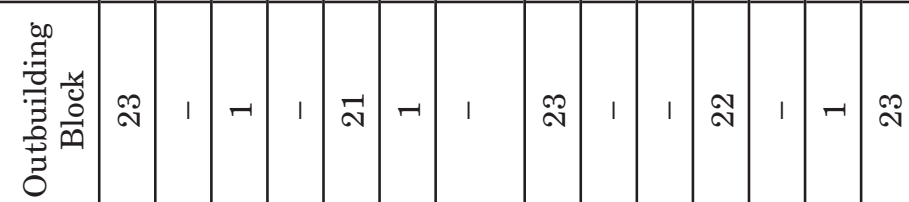

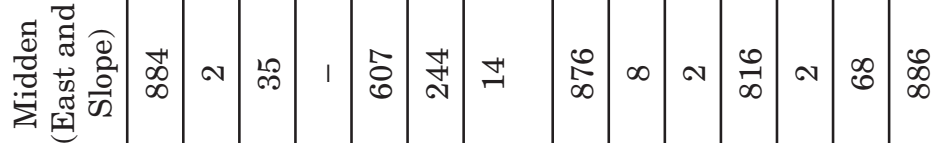

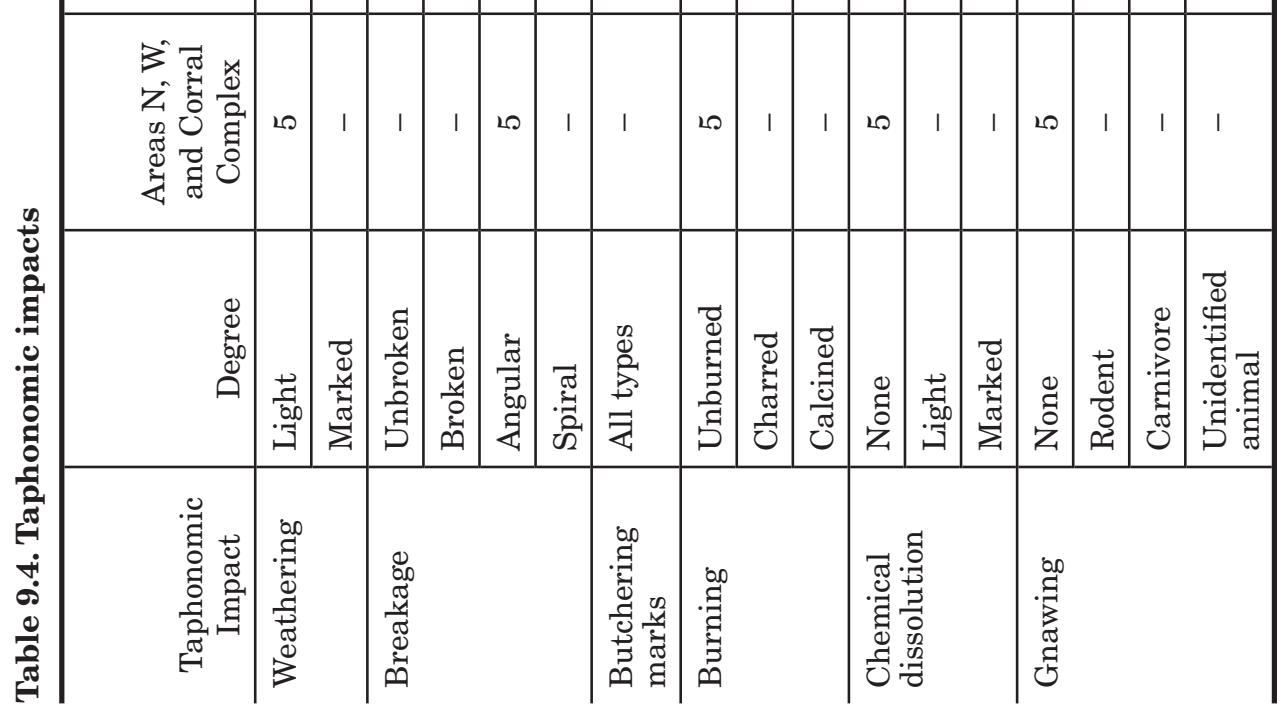



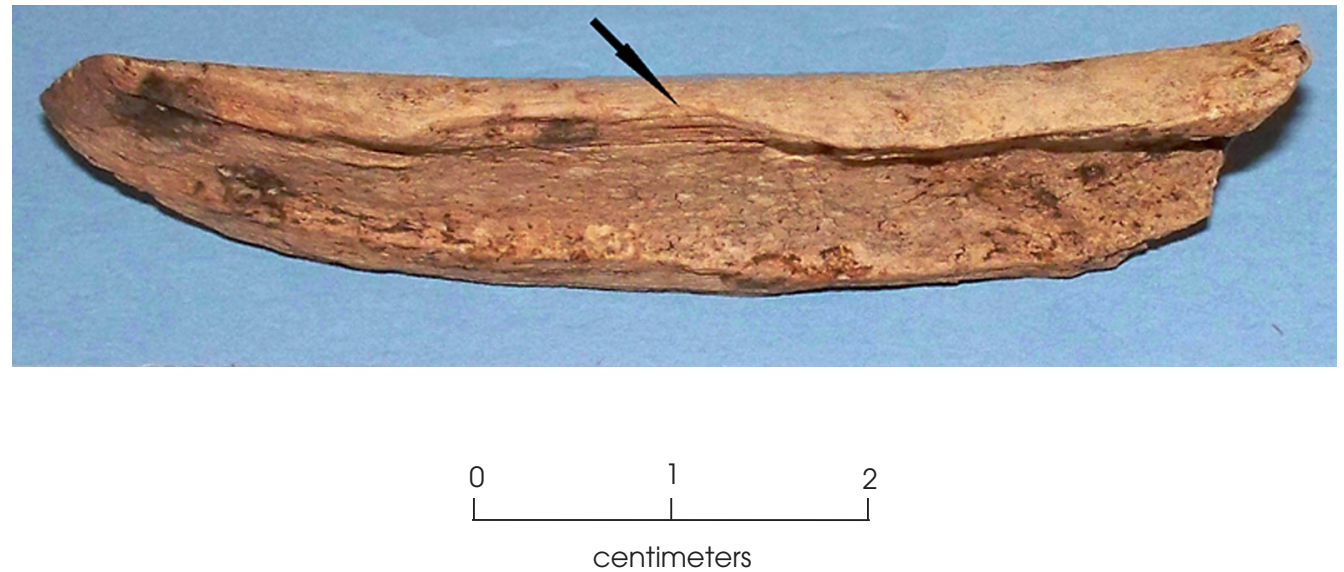

Figure 9.1. Dynamic loading impact point on medium to large mammal long bone fragment (from EU E10; Lot 311).

processes, the impact fractures indicate likely intentional breakage. Such breakage may have been for the rendering of marrow and fat for dietary and utilitarian purposes (e.g., candle and soap manufacture).

\section{AGE OF DEATH FOR DOMESTICATED TAXA}

Assessing the age at death for domesticated animals can be problematic when single specimens are used or when an assemblage is composed of mixed multiple individuals. For many taxa, age may be assessed on the fusion of the epiphyses to the diaphyses or by development of the bone itself. An unfused bone would indicate that the animal died before the age at which the fusion would occur, so the aging of animals from individual bones with these data are limited to being either younger than or older than a given age. Only if the animal died at the time of fusion is the age of death more certainly known based on bone fusion. Dental ages can be more informative based on a combination of known ages of tooth eruption and assessments of tooth wear.

The data are summarized here to address each generalized age class represented for each taxon. As noted above, no egg or chick remains of chickens were recovered. In case chick remains were so undeveloped as to not be recognized as chicken, the unidentified large bird data were examined as well. For unidentified large bird and for chicken, there was only one example of each that was not fully mature. All of the other large bird and chicken remains recovered were skeletally mature. As such, the assemblage appears to be comprised mostly of adults at the time of death.

Pig and cattle remains show a different pattern. Pigs reach long bone skeletal maturity by about 3.5 years of age and cattle at $3.5-4.0$ years of age (Huidekoper 1891; Silver 1969). For the pig remains, 137 specimens were assigned useful ages or age ranges in months, and another 50 were assigned a generic age category (fetal/ neonatal, subadult, adult, or old adult). Not all age data are particularly useful and thus are not included here. For example, an element that fuses before birth is only useful for aging if it is unfused. If said element was recovered fused, that information is not considered here as it provides no useful information about the possible age at death.

All 50 pig specimens assigned a generic age are identified as subadult. Such assessments are made based on size, bone texture, lack of wear on nonspecifically identified tooth eruption or wear, and other similar indicators. Of the elements that can be assigned an age assessment in months, only one pig element in the assemblage represents an adult (at 42 months). Of the 105 specimens that could be assigned a maximum possible age at death, all were 30 months old or less: 81 were $<24$ months; 59 were $<18$ months; 31 were $<12$ months; 2 were $<6$ months; and 1 
was fetal or neonatal. The greatest minimum age of death noted was $>27$ months.

This assemblage of mixed multiple individuals does not give a clear indication of a set butchery pattern of pigs based on age, though some patterning is apparent. Pigs were likely slaughtered around the age of 6 to 30 months, before reaching adulthood. Because the pigs were killed before they reached adulthood, it appears that the timing of the slaughter was not tied to the maximum amount of meat to be garnered but when they would be considered of sufficient size and tenderness.

A similar pattern is found with the cattle remains, though in much less detail. No older adults were identified. Of those that could be identified as to a maximum age of death, there was one example each of $<54$ months, $<36$ months, $<27$ months, and $<18$ months. The greatest minimum age of death was $>24$ months $(n=1)$.

In regard, then, to beef and pork, the site occupants were apparently well enough off to be slaughtering primarily younger animals, not having to wait until the animals reached full size and not having to consume less-desirable older animals. This pattern coincides with other lines of evidence indicating that the Williams family was economically successful.

\section{BUTCHERY}

The faunal remains were examined for butchering marks, which provide evidence of what animals were being consumed. Cut, chop, or saw marks were observed on 49 specimens, primarily pig, cattle, chicken, and rabbit (see Tables 9.4 and 9.5) Cut mark types noted include smooth blade ( $\mathrm{n}=17$; cuts appeared to be slices in the bone and not chops); chops ( $\mathrm{n}=16)$; handsaw cuts $(\mathrm{n}=14)$; unknown implement $(\mathrm{n}=3)$; and serrated blade cut marks $(\mathrm{n}=1)$.

The only indigenous taxon with a cut mark is the rabbit. One smooth-blade cut on a lumbar vertebra was observed along with several smooth-blade cuts on a pelvis os coxa, and several transverse cut marks and a complete chop through the distal end of a femur that severed the lower leg (Figure 9.2). The rest of the butchered remains are from domesticated taxa or from specimens with identifications that cannot be specifically attributed to indigenous or domesticated taxa, though they are likely from domesticated taxa.
Of the identified domestic taxa, cut marks were observed on chicken, pig, and cattle remains. For chickens, smooth-bladed knife cuts were observed on the pectoral girdle in four out of five specimens, all of which were recovered from the house block. These are two complete coracoids, one incomplete coracoid, and one complete scapula. With the possible exception of one coracoid with three cuts on the distal end that indicate the cut was likely for disarticulation (Figure 9.3), the cuts are located along the shafts of the bones and appear to be for meat removal. The last chicken specimen with cut marks was a tibiotarsus. Multiple cuts appear on the distal condyle and are in a location that suggests the cut was for separating the lower leg from the upper leg.

Seven pig elements were butchered, with six being from the house block, though only one cut of meat is identified. It is a $10.7-\mathrm{mm}$-thick hand-sawed shoulder steak of the scapula. The rest of the cuts are either for dismemberment, meat removal, or unknown. One is an occipital condyle exhibiting multiple complete (passing through) and incomplete chop marks and hand sawing. The multiple cuts and cut types appear to represent a difficult decapitation. The humerus from the single adult pig has six smooth-bladed cut marks on the medial side that appear to be for disarticulation of the joint. A humerus shaft fragment exhibits nine or more overlapping chop marks, including one resulting in a hinge snap fracture that finally separated the bone. A calcaneus exhibits a complete chop of the proximal end of the bone, which also appears to be for disarticulation. The final specimen is a lumbar vertebra with two transverse smooth-blade cuts. From the Feature 1 storage pit, an ilium was recovered with more than eight smooth-blade cut marks along the medial edge, which would correspond with removing meat from the bone.

Cattle butchery is less revealing. Only two identified elements have cut marks, a distal humerus with a single smooth-bladed knife cut and a 9.39-mm-thick hand-sawed steak cut from a femur. Both specimens were recovered from the midden.

With limited butchery data, skeletal representation of the four most common taxa (rabbit, chicken, pig, cattle) was examined to ascertain more about what was being consumed. For chicken, 18 of the 69 elements recovered ( 26 percent) are cranial and foot elements, which usually 
The Ransom and Sarah Williams Farmstead

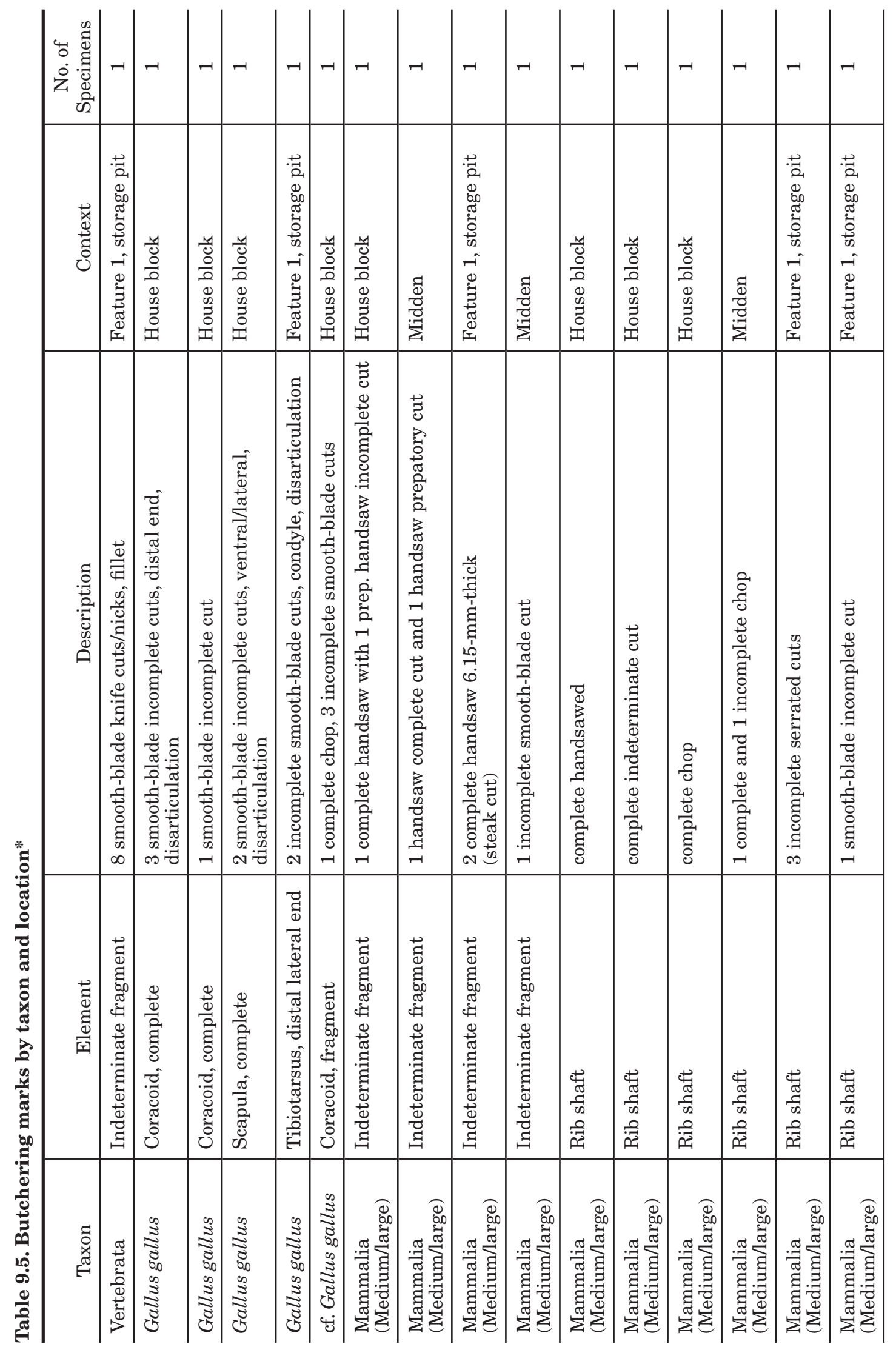


Chapter 9: Vertebrate Faunal Remains

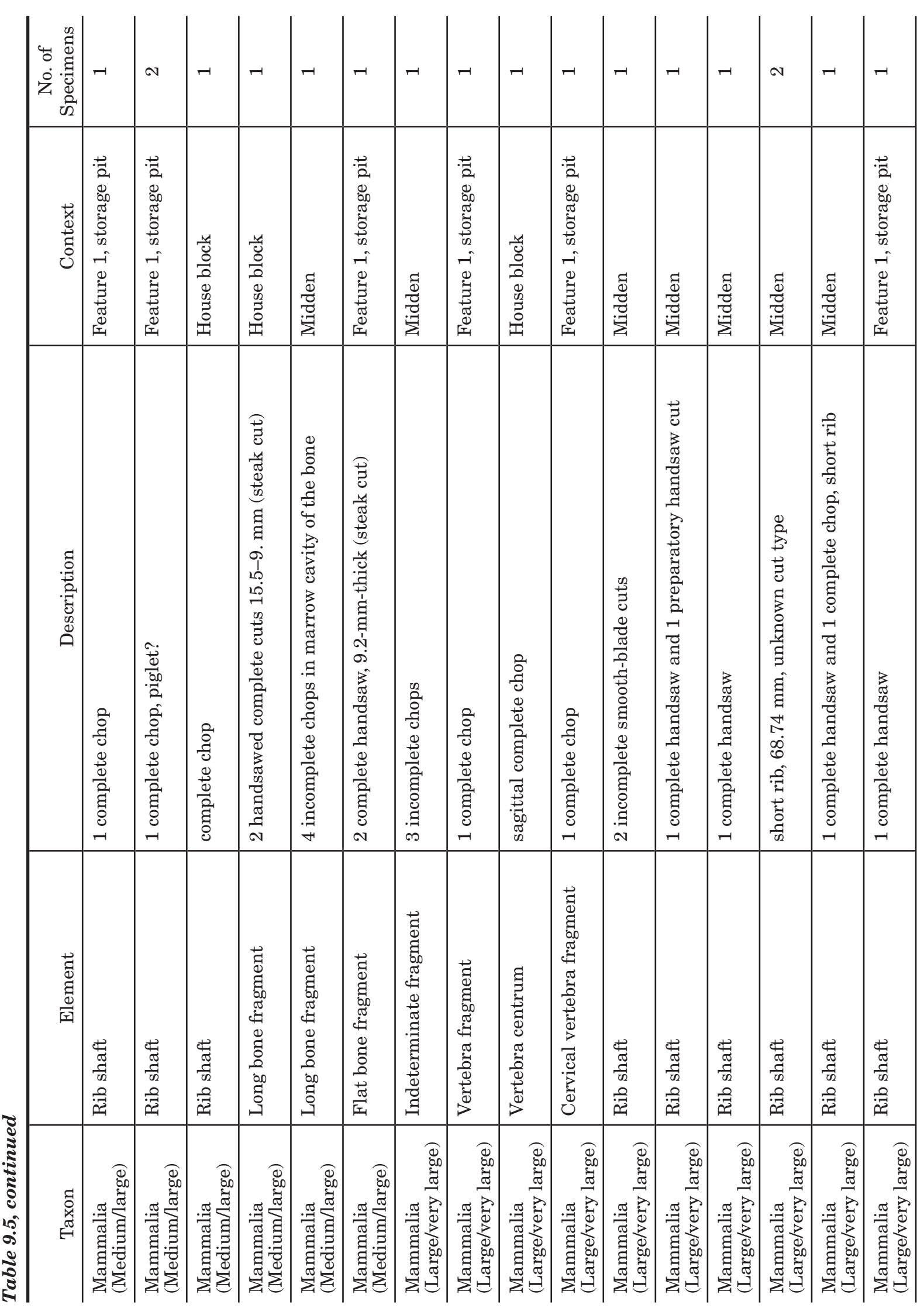


The Ransom and Sarah Williams Farmstead

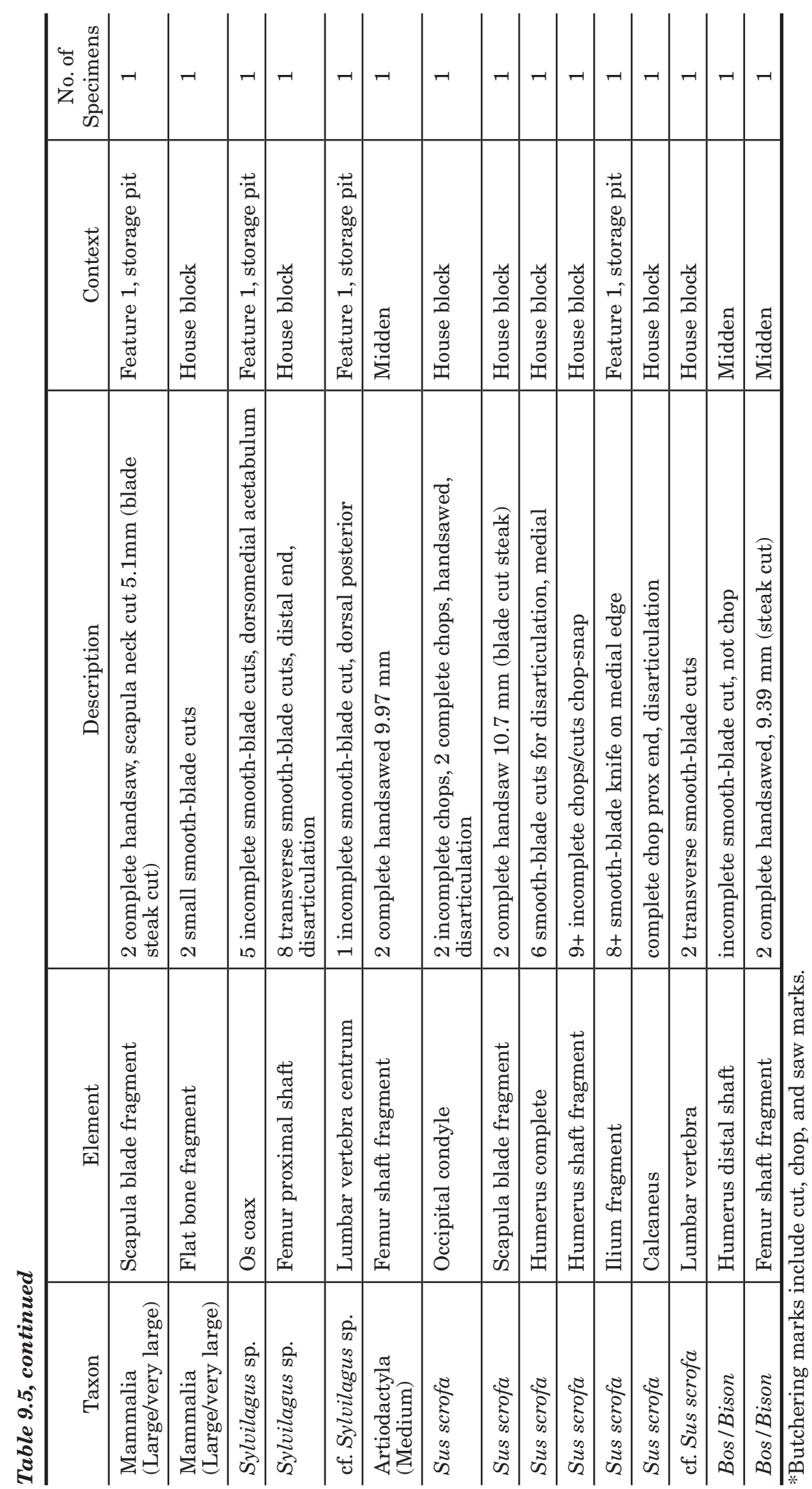




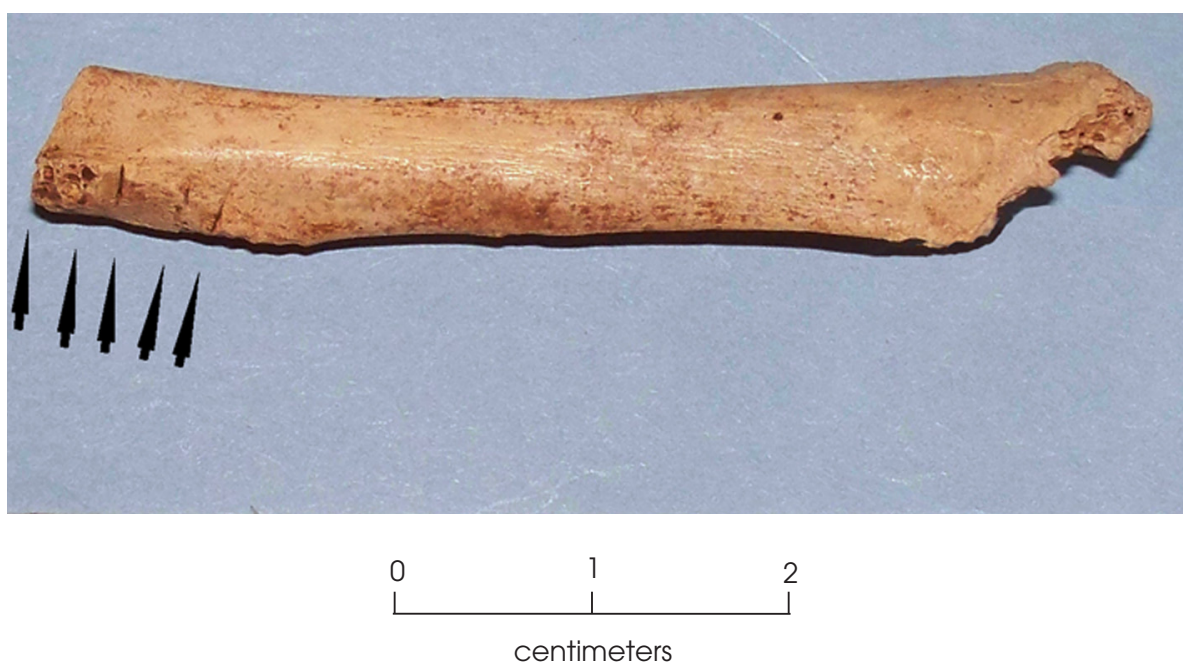

Figure 9.2. Cut and chopped rabbit bone recovered from the house block. Note complete chop mark on far left (from EU 52; Lot 21).

would be considered nondietary. For rabbit, 119 of the elements recovered (43 percent) are cranial, mandibular, dental, and foot bones, which would be considered nondietary. Of the 260 pig specimens recovered, 236 (91 percent) are cranial, mandibular, dental, and foot elements, and for cattle 31 ( 82 percent) of 38 are nondietary. Note that the comparison of chicken with the mammalian taxa does introduce a bias, since chickens do not have teeth. If the teeth are excluded for all species, the number of nondietary elements becomes: rabbit 75 (32 percent); pig 106 (82 percent); and cattle 7 (50 percent). No doubt some of the animals are underrepresented because they were processed more thoroughly, and certain elements would have been discarded in locations other than those excavated. The taxa with the greatest abundance of cut marks are pig and cattle, both types being disproportionately represented by typically nondietary elements that do not bear meat or are not usually cooked with meat. This indicates that most of the meat-bearing elements were deposited elsewhere, or perhaps were transported offsite. What these data suggest is that the loss of dietary bone data does not appear to be the result of butchery practices. However, the amount of non-taxon-specific butchered bone is not high enough to indicate that butchery practices would be the cause.

The loss of dietary bone may be due to nonhuman taphonomic processes. The bones of pig and cattle could have been removed and consumed by pets or scavengers. The problem here is the lack of evidence that this may have occurred. Gnawing is identified on just 23 specimens, 18 of which are identified as rodent and 3 as carnivore (very small carnivore as indicated by the small size of the marks) and so does not appear to be a significant cause for the loss.

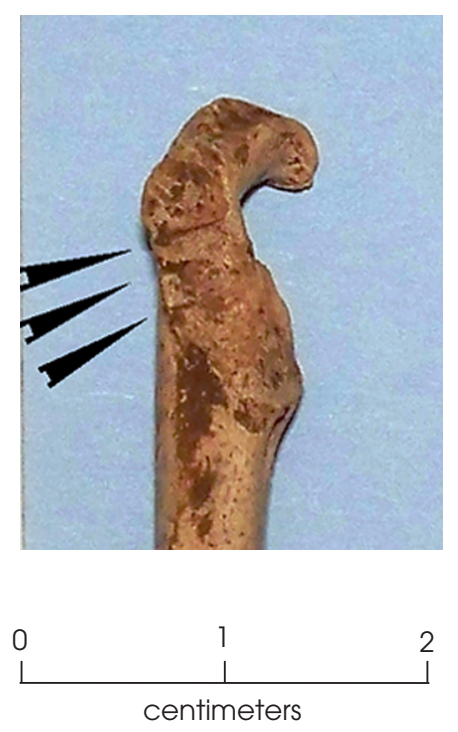

Figure 9.3. Chicken coracoid with three cuts at articulation of pectoral girdle recovered from the house block (from chimney base; Lot 349). 
Carnivores or scavengers could have carried these bone scraps away from the site, but this would not explain all the bone left behind.

Post-consumption dietary bone (table scraps) could have been lost by the burning of garbage. However, only 30 bones from the site were burned, and if burning was a preferred method for disposal of bone rubbish, a much higher percentage of the nondietary bone should be burned.

The most likely explanation is that much of the dietary bone is deposited elsewhere, likely through cultural behavior. It is possible that the post-consumption dietary bone was discarded elsewhere on the site, in areas that were not excavated or even offsite. One possible scenario, admittedly speculative in the absence of evidence, is that the Williams family was supplying meat to other people, which would account for the paucity of dietary bone.

\section{MEDICAL DISORDERS}

Three types of medical disorders are noted in the assemblage from the site. Arthitic lipping is present on a chicken coracoid. An ossified tendon is present on the proximal end of a squirrel tibia. Subperiosteal bone deposition (infection) was observed on 1 chicken tarsometatarsal, 11 medium/large mammal bones, 3 large/very large mammal bones, and $1 \mathrm{cf}$. Bos sp. metacarpal.

\section{DISCUSSION OF THE WILLIAMS FARMSTEAD FAUNAL REMAINS}

Vertebrate remains from the Ransom and Sarah Williams site provide insight into some of the activities conducted at the site, but the assemblage also is enigmatic in its composition. Taxa represented indicate a reliance almost exclusively on terrestrial animals, with indigenous taxa being comprised of primarily smaller animals such as dove, quail, turkey, squirrel, and rabbit and domesticated taxa including chicken, pig, and cattle. Missing from the faunal assemblage are fish and horse bones, despite the artifactual evidence for both. Also missing is the largest indigenous mammal likely to be in the area at the time of the Williamses' occupation: deer.

Animals were processed onsite, and portions of their discarded remains indicate that butchery was accomplished through the use of smooth-bladed implements (likely knives and possibly large knives or cleavers for chopping), serrated knives, and handsaws. The taxa with the greatest abundance of cut marks are pig and cattle, both types being disproportionately represented by typically nondietary elements that do not bear meat or are not usually cooked with meat. This indicates that many of the meat-bearing elements were discarded and deposited elsewhere, potentially transported offsite.

The age at death analysis for the domesticated taxa reveals that pigs and cattle were almost exclusively slaughtered before reaching adulthood, while chickens were almost exclusively killed after adulthood. This indicates that the occupants consumed younger and more tender juveniles rather than maximizing meat production by allowing the animals to reach full maturity.

\section{COMPARISON OF FAUNAL REMAINS FROM FIVE AFRICAN AMERICAN SITES IN TEXAS}

There are relatively few archeological investigations of nineteenth-century African American sites in Texas that have produced faunal assemblages that can be compared directly with the faunal remains recovered from the Williams site. But four African American sites-one urban home in Austin known as the Pennington House and three isolated farmsteads (41NV267, 41NV305, and 41NV306) in Navarro County-have data useful for comparison (Table 9.6).

The Pennington House site (41TV1814, Area B) offers a culturally, geographically, and temporally relevant data set for comparison, though the faunal assemblage is from a more urban setting (Seibel et al. 2000). The site is in downtown Austin, about 12 miles from the Williams site, and it was occupied by an African American family from approximately 1868 to 1921 . There are several notable contrasts between the two sites in regard to vertebrate representation. The first is that fish remains are the single largest class of vertebrate recovered from the Pennington household, while no fish bones were recovered from the Williams site, although there was evidence for use of fish by the Williams family in the form of fish scales found in flotation samples and fish hooks among the 
Chapter 9: Vertebrate Faunal Remains

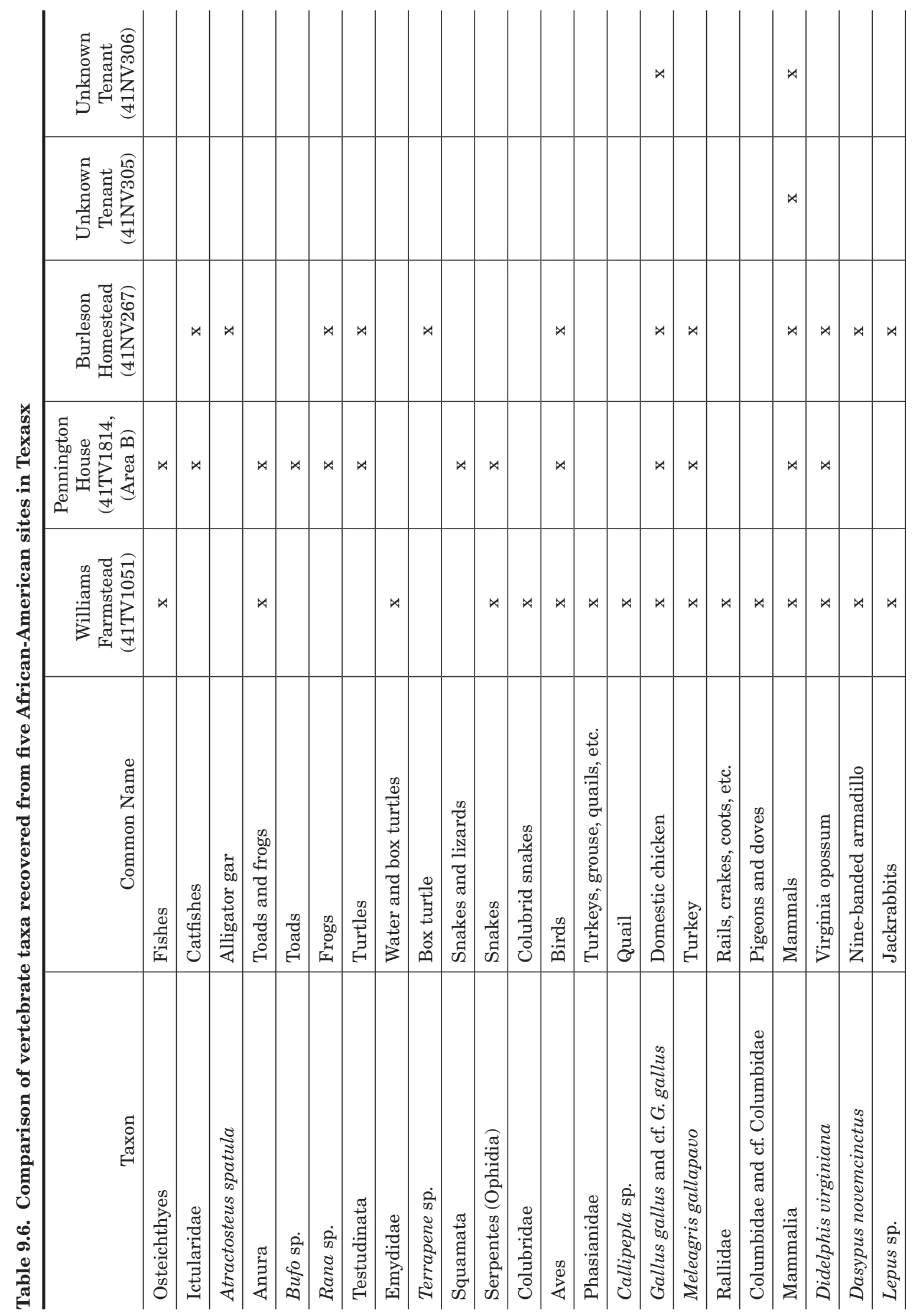


The Ransom and Sarah Williams Farmstead

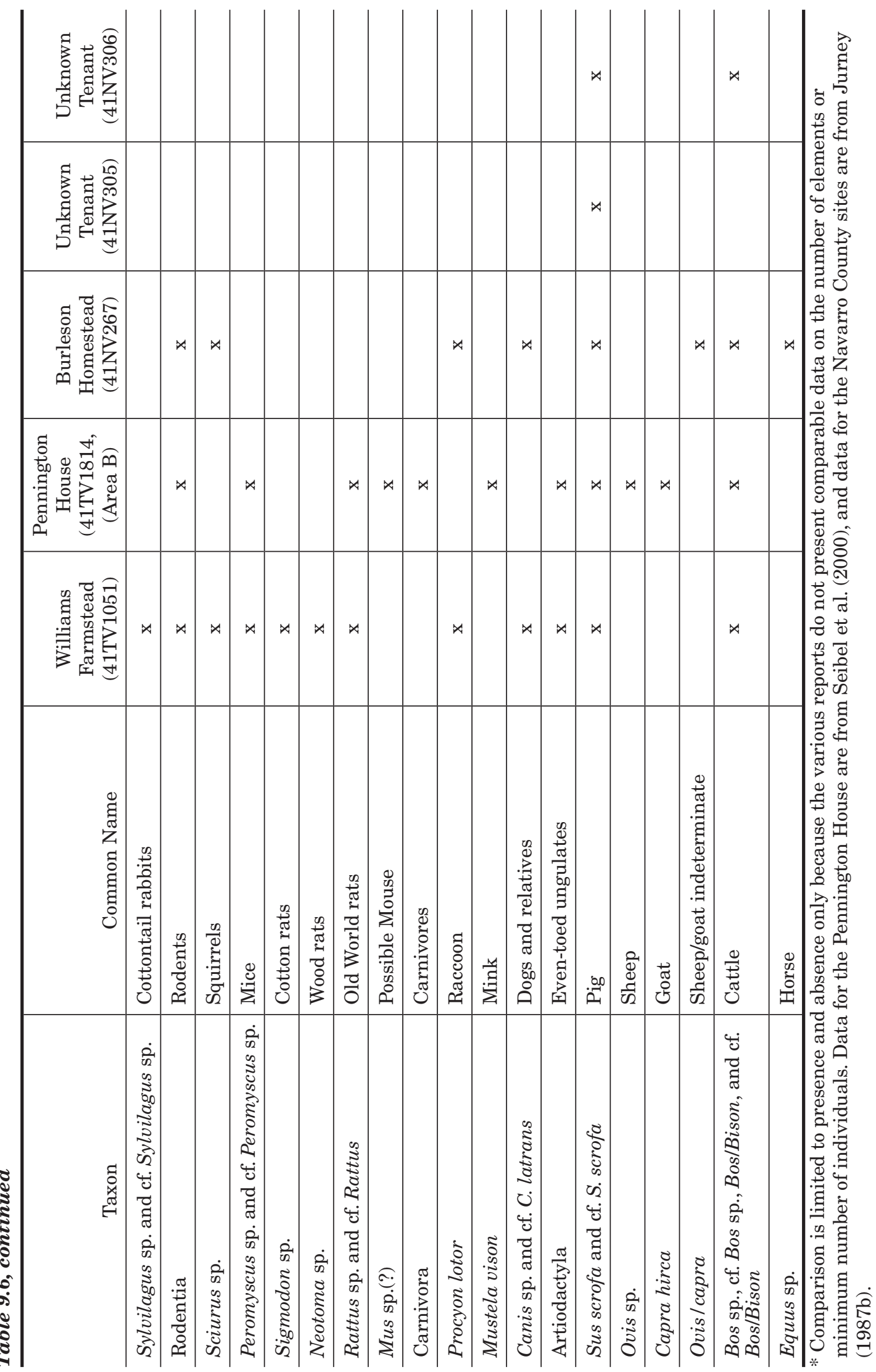


artifacts. Pennington also had a larger number of reptile and amphibian remains than did the Williams site, despite having a vertebrate faunal assemblage less than a quarter of the size. The types of domestic taxa were more numerous as well, with sheep and goat being present. Pigs dominated at the Williams site, but cow was the dominant mammalian taxon at Pennington. Pennington did have chicken and turkey as well, but chicken were only a very small contributor to the Pennington assemblage, which was not the case at Williams. The Williams farmstead had a greater variety of birds.

The other three contemporary assemblages from African American sites are 41NV267, 41NV305, and 41NV306 (Jurney and Moir 1987:94-95, 99-142; Moir and Jurney 1987:7379, 133-138, 141-144, 181-183). The faunal remains are described by Jurney (1987b). The site with the largest faunal assemblage was a homestead owned by freed slaves Mingo and Nancy Burleson (41NV267) and the faunal assemblages at the other two sites, $41 \mathrm{NV} 305$ and 41NV306, occupied by freedmen tenant farmers, are much smaller (Jurney and Moir 1987:100; Moir and Jurney 1987:133-144). Based on the representation of the remains from these five African American sites, three domestic taxapigs, chickens, and cattle-comprise the most common remains recovered as individual species, though their contribution to the diet of the sites' occupants would have been supplemented by a variety of wild taxa.

Taphonomically, the Navarro County assemblages have much higher rates of burned bone (14-33 percent), which Jurney (1987b:149) attributes to refuse disposal. The Williams assemblage has just 30 burned specimens, representing about 1 percent of the assemblage, suggesting that either bone burning was not a significant factor in refuse disposal at Williams or that such deposits were missed in the excavations. No data are available on the Pennington House bone taphonomy.

Comparisons of the taxa from all five assemblages revealed some similarities and differences in the assemblages (see Table 9.6). Most notably, assemblage size affected the number of taxa present, with the smaller assemblages from 41NV305 and 41NV306 producing only two identified taxa: chicken and pig. For the other three sites, the compositions of the identified taxa include both domestic and wild animals, with pigs, cattle, and chickens being the predominant domestic species.

There are notable patterns in the wild taxa recovered from each of these sites as well. Each of the three larger sites included a variety of anuran (frogs and toads), turtle, and small mammals. The Pennington House site and Burleson Homestead both had fewer birds and fewer wild birds than the Williams farmstead, though both had more fish and turtle remains than the Williams farmstead. All three sites included a small number of opossum and small carnivores.

Of the rodent remains recovered, distributions varied. Pennington House did not have squirrels, and the Burleson Homestead is lacking rats and mice. This was unexpected given that rats and mice are commonly found living in conjunction with humans and hence often comprise a portion of archeologically recovered assemblages. Examination of the taxa from all 22 sites examined by Jurney (1987b) revealed that very few rats and no mice were identified in any of the assemblages, and remains identified as rodent occur infrequently. A quick look at the other assemblages also reveals a general lack of smaller taxa such as small birds. The lack of small animal remains may be due to some type of archeological recovery bias such as limited use of sediment flotations.

Deer skeletal elements are the same size ranges as those of larger goats and sheep and moderate-size pigs, though pigs can be highly variable in size and can produce much larger elements. Given the recovery of many other medium-sized wild taxa, deer remains would have been expected in the assemblages, but none were identified. At the Williams farmstead and Pennington House site, recovery methods were such that had deer remains been present, they would have been recovered. In the 22 sites discussed by Jurney (1987b), deer were present in just two site assemblages, and deer bones were not found in any of the three Navarro County African American assemblages being considered here. Given the smaller and comparable-sized taxa recovered, the lack of deer cannot be attributed to recovery methods.

In the oral histories compiled for the Richland Creek area in Navarro and Freestone Counties, hunting is mentioned as an important subsistence activity. In the discussion of "foodways," Jurney and Moir (1987:204) state that "meat was also obtained from hunting 
squirrels, rabbits, and deer. Deer disappeared from the area, the exact time of which could not be ascertained. These animals were restocked late in the second quarter of the twentieth century (Woody Fossard, personal communication 1982). Although frequently mentioned, deer evidently have not provided a significant contribution to area subsistence at any time during the focus period." Rideout (1994:3-4) also reports that deer were seriously overhunted in Texas during the late nineteenth and early twentieth centuries. The low deer populations in the first decades of the twentieth century led to a statewide program of trapping and restocking deer, as well more rigorous hunting regulations. This suggests that deer were sparse in many parts of Texas before the turn of the century. It is quite likely that the absence of deer bones in the Williams farmstead assemblage reflects the scarcity of deer in central Texas in the late nineteenth century due to overhunting. 


\section{MACROBOTANICAL REMAINS}

Leslie L. Bush ${ }^{117}$

10

Ransom Williams purchased a 45 -acre farmstead in southern Travis County west of Manchaca in 1871, and he lived there with and his wife, Sarah, and their children until after the turn of the century. When the data recovery investigations began in 2009, a chimney and firebox were the only structural remains still standing on the property. The hand excavations focused on the house block (which included the chimney), a possible outbuilding, and two midden areas behind the house (see Figure 7.1). The east midden began some $5 \mathrm{~m}$ beyond the house block, and the east slope midden began on the west side of the east midden and continued downslope. A single house-related feature was identified within the house block. Feature 1 was a shallow subfloor storage pit excavated into limestone bedrock in front of the firebox (see Figure 7.2). All of these contexts yielded macrobotonical remains.

Three types of botanical samples were submitted for analysis. Seven samples of architectural wood (unburned) were taken as individual piece-plotted samples from the house block. Thirty-six samples of various botanical materials were collected in situ from four excavation areas (Table 10.1). Fourteen flotation samples were taken from the house block and east midden areas, as detailed in Table 10.2.

\section{METHODS}

Flotation samples from the Ransom Williams site were processed at Prewitt and Associates, Inc., in a Flote-Tech flotation machine with bottom mesh openings of $1.0 \mathrm{~mm}$.

\footnotetext{
${ }^{117}$ Macrobotanical Analysis, Manchaca, Texas.
}

Table 10.1. Location of hand-collected botanical samples

\begin{tabular}{l|c}
\hline \multicolumn{1}{c|}{ Context } & No. of Samples \\
\hline House block & 20 \\
\hline Subfloor pit, Feature 1 & 10 \\
\hline East midden & 5 \\
\hline East slope midden & 1 \\
\hline Total & 36 \\
\hline
\end{tabular}

Table 10.2. Location and volume of flotation samples

\begin{tabular}{l|c|c}
\hline Context & $\begin{array}{c}\text { No. of } \\
\text { Samples }\end{array}$ & $\begin{array}{c}\text { Volume of } \\
\text { Sediment Processed } \\
\text { (cubic decimeters) }\end{array}$ \\
\hline $\begin{array}{l}\text { Subfloor pit, } \\
\text { Feature 1 }\end{array}$ & 7 & 36 \\
\hline East midden & 7 & 33.5 \\
\hline Total & 14 & 69.5 \\
\hline
\end{tabular}

Charcoal remaining in the flotation heavy fractions was removed and added to the light fraction. The flotation samples were sorted according to standard procedures (Pearsall 2000) at the Macrobotanical Analysis laboratory in Manchaca, Texas. Each flotation sample was weighed on an Ohaus Scout II 200x0.01-g electronic balance before being size-sorted through a stack of graduated geologic mesh. Materials that did not pass through the No. 10 mesh (2-mm square openings) were completely sorted, and all carbonized botanical remains were counted, 
weighed, recorded, and labeled. Uncarbonized botanical material that did not pass through the $2-\mathrm{mm}$ mesh (primarily rootlets and leaf litter) was weighed, recorded, and labeled as "contamination." Materials that fell through the 2-mm mesh ("residue") were examined under a stereoscopic microscope at 7-45x magnification for carbonized botanical remains. Identifiable botanical material other than wood was removed from residue and counted, weighed, recorded, and labeled. Uncarbonized macrobotanical remains other than rootlets and leaf litter were recorded on a presence/absence basis on laboratory forms. Because of the recent date of the site, semicarbonized plants were treated in the same manner as carbonized plants, although they are reported and curated separately.

Plant samples that were not flotation-processed were not sieved in the laboratory unless many small fragments and soil particles were present. These samples were placed on a No. 10 mesh (2-mm square openings), and the residue smaller than $2 \mathrm{~mm}$ was scanned for plant parts other than wood. The residue was bagged, weighed, and labeled for curation. Plant material larger than $2 \mathrm{~mm}$ from nonflotation samples was identified, counted, weighed, and labeled in the same manner as material from flotation samples.

Identification was attempted for up to 20 randomly selected wood and wood charcoal specimens from each sample. For fresh wood samples, a clean transverse section was cut with a razor blade. Wood charcoal fragments were snapped to reveal a transverse section. The transverse sections were examined under a stereoscopic microscope at 28-180x magnification. When necessary, tangential or radial sections were examined for ray seriation, presence of spiral thickenings, types and sizes of intervessel pitting, and other minute characteristics that can only be seen at the higher magnifications of this range.

Botanical materials were identified to the lowest possible taxonomic level by comparison to materials in the Macrobotanical Analysis comparative collection and through the use of standard reference works (e.g., Core et al. 1979; Davis 1993; Hoadley 1990; Martin and Barkley 2000; Panshin and de Zeeuw 1980).

\section{RESULTS}

Architectural wood specimens are identified in Table 10.3. Botanical samples recovered in the hand excavations are identified in Table 10.4. Plants identified in the flotation samples are shown in Tables 10.5 (wood) and 10.6 (nonwood). A full list of plant remains, with recovered counts and weights by lot number, is provided in Appendix D.

\section{Summary of Architectural Samples}

Three types of wood were identified in architectural samples from the house block. Six of the seven samples consisted primarily of white group oak. The uncarbonized wood from Unit 43

Table 10.3. Architectural wood samples from the house block*

\begin{tabular}{|c|c|c|c|c|}
\hline Lot No. & Unit No. & Botanical Name & Common Name & Other Material \\
\hline 19 & 42 & Quercus subg. Quercus & White group oak & \\
\hline 25 & 72 & Quercus subg. Quercus & White group oak & $\begin{array}{l}1 \text { fragment oak wood } \\
\text { charcoal }\end{array}$ \\
\hline \multirow[t]{2}{*}{165} & \multirow[t]{2}{*}{43} & Quercus subg. Quercus & White group oak & \\
\hline & & Pinus sp. & Pine & \\
\hline 166 & 43 & Juniperus sp. & Juniper & $\begin{array}{l}27 \text { fragments live oak } \\
\text { wood charcoal }\end{array}$ \\
\hline \multirow[t]{2}{*}{468} & 43 & Quercus subg. Quercus & White group oak & \\
\hline & & Pinus sp. & Pine & \\
\hline 469 & 4 & Quercus subg. Quercus & White group oak & \\
\hline 470 & 4 & Quercus subg. Quercus & White group oak & \\
\hline
\end{tabular}

*All woods are uncarbonized unless otherwise noted. 
Table 10.4. Plants identified in hand-collected botanical samples*

\begin{tabular}{|c|c|c|}
\hline Plant Part & Botanical Name & Common Name \\
\hline \multirow[t]{15}{*}{ Wood } & Carya sp. & Hickory \\
\hline & Celtis sp. & Hackberry \\
\hline & Cornus spp. & Dogwood \\
\hline & Juglans nigra & Black walnut \\
\hline & Juniperus sp. & Juniper \\
\hline & Pinus sp. & Pine \\
\hline & Prosopis sp. & Mesquite \\
\hline & Prunus sp. & Plum/cherry/peach \\
\hline & Quercus fusiformis & Plateau live oak \\
\hline & Quercus sp. & Oak \\
\hline & Quercus subg. Lobatae & Red group oak \\
\hline & Quercus subg. Quercus & White group oak \\
\hline & Sideroxylon lanuginosum & Gum bully \\
\hline & Ulmus sp. & Elm \\
\hline & Viburnum spp. & Viburnum \\
\hline Nutshell & Juglans nigra & Black walnut \\
\hline Rachis & Zea mays & Corn \\
\hline Seed fragments $* *$ & Prunus persica & Peach \\
\hline Tuber & Ipomoea batata & Sweet potato \\
\hline Bark & Unknown & - \\
\hline Indeterminable & Unknown & - \\
\hline
\end{tabular}

*All woods are uncarbonized unless otherwise noted.

**Carbonized, uncarbonized, and semicarbonized.

(Lot 166) was juniper. Unit 43 (Lots 165 and 468) included fragments of pine in addition to white group oak. Two samples, from Units 72 (Lot 25) and 43 (Lot 166), also included fragments of oak wood charcoal. All of these juniper, pine, and oak wood specimens were found close to the chimney base and underneath the mound of fallen chimney rocks. It is likely that they are remnants of the house structure or large pieces of furniture, and that they were protected from deterioration because they were covered by the large rocks when the chimney collapsed.

\section{Summary of Botanical Samples}

Most material in the botanical samples consisted of carbonized wood, probably the remains of fuel wood. The 298 identified fragments are shown in Figure 10.1. Sixty-eight percent of the sample is oak, and 22 percent is juniper. Of the remaining woods, black walnut is the most common at 5 percent of the assemblage. Other woods identified include pine, gum bully, and hackberry. All of these trees are common in southern Travis County today. Pine is not native to this area, however. The pine wood charcoal fragments either represent branches of a cultivated tree or possibly the burning of containers such as wooden boxes or pallets.

The remaining identified botanical samples are interpreted as the remains of food plants. They are peach pit fragments, a corn cob fragment, black walnut shell, and a sweet potato tuber fragment. All occur in carbonized 
form, and the peach pits occur in fresh and semicarbonized forms as well. Because of their durability, all of the peach pits are interpreted as relating to the nineteenth-century occupation of the site (including the noncarbonized pits as identified in Appendix D). No peach trees were noted at the site during excavation. Peach trees are cultivated in central Texas, but they are difficult to grow, prone to pest infestations, and susceptible to spring frosts and drought (Garrett 1996). They do best on sandy, well-drained soils, not the clay loams and stony clays at the Williams site (Sperry 1991).

\section{Summary of Flotation Sample Recovery}

Fourteen flotation samples taken during the data recovery excavations were processed to recover botanical remains. These samples yielded uncarbonized remains that probably represent natural accumulations of plant materials as well as carbonized remains that represent cultural activities and use of various plants. All of the flotation samples are from the midden deposits and the subfloor pit feature (see Table 10.2).

\section{Uncarbonized Plants}

In addition to rootlets and leaf litter, 13 taxa of uncarbonized seeds were recovered from flotation samples (Table 10.7). Although the site is sufficiently recent that some seeds, especially hackberry, could date to the time of site occupation, these seeds are unlikely to represent plants used by the Williams family. Four lines of evidence point to this conclusion. First, there is little difference in uncarbonized plants between the east midden samples and those from the Feature 1 subfloor pit in the house block. Of the seeds that appeared in more than two flotation samples, all appeared in both Feature 1 and east midden contexts, suggesting a common source in seed rain for both contexts. In contrast, the carbonized, nonwood plants differ considerably between east midden and Feature 1 contexts. Second, there is little overlap between carbonized (i.e., archeological) and uncarbonized seeds recovered. Galium, a bur, is the only seed that appears in both forms. Third, the taxon most likely to represent a nineteenth-century economic plant, sunflower, consists of small and
Table 10.5. Wood identified in flotation samples*

\begin{tabular}{l|l}
\hline Botanical Name & Common Name \\
\hline Fraxinus sp. & Ash \\
\hline Hardwood & \multicolumn{1}{|c}{-} \\
\hline Hardwood & Yaupon \\
\hline Ilex sp. & Black walnut \\
\hline Juglans nigra & Juniper \\
\hline Ilex sp.** & Olive family \\
\hline Oleaceae & Pine \\
\hline Pinus sp. & Mesquite \\
\hline Prosopis sp. & Plum/cherry/peach \\
\hline Prunus sp. & Plateau live oak \\
\hline Quercus fusiformis & Oak \\
\hline Quercus sp. & Red group oak \\
\hline Quercus subg. Lobatae & White group oak \\
\hline Quercus subg. Quercus & Elm \\
\hline Ulmus sp. & Viburnum \\
\hline Viburnum spp. &
\end{tabular}

*All woods are uncarbonized unless otherwise noted.

**Carbonized, uncarbonized, and semicarbonized.

thin seeds that are consistent with wild seeds rather than domesticated sunflower. Finally, all seeds represent volunteer plants commonly found in the area today. The trees representedhackberry, juniper, and ligustrum - are common on untended lands near Manchaca, as are the live oak and persimmon trees represented by uncarbonized leaves in the flotation samples. The herbaceous plants are common yard weeds in southern Travis County.

\section{Carbonized Plants}

\section{WOOD}

The wood charcoal recovered by flotation is very similar in composition to that recovered in the hand excavations, as shown in Figure 10.2. Oak makes up 61 percent of fragments identified, with juniper the next most common wood at 34 percent. Like the wood charcoal recovered by hand, flotation wood charcoal is interpreted as fuel. 
Table 10.6. Carbonized nonwood plants identified in flotation samples

\begin{tabular}{|c|c|c|}
\hline Plant Part & Botanical Name & Common Name \\
\hline \multirow[t]{2}{*}{ Nutshell } & Carya sp. & Hickory \\
\hline & Juglans nigra* & Black walnut \\
\hline Rind & Lagenaria siceraria & Bottle gourd \\
\hline \multirow[t]{6}{*}{ Seed } & Galium sp. & Bedstraw \\
\hline & Poaceae & Grass family \\
\hline & Polygonum sp., trigonous & Knotweed \\
\hline & Prunus persica** & Peach \\
\hline & Rubus spp. & Dewberry \\
\hline & Zea mays & Corn \\
\hline Rachis & Zea mays & Corn \\
\hline Bark* $^{*}$ & Unknown & - \\
\hline Bud & Unknown & - \\
\hline Bulb scale & Unknown & - \\
\hline Fruit & Unknown & - \\
\hline Indeterminable & Unknown & - \\
\hline
\end{tabular}

*Carbonized and semicarbonized

**Semicarbonized

\section{Fuel Wood from Hand-Collected Samples $(n=298)$}

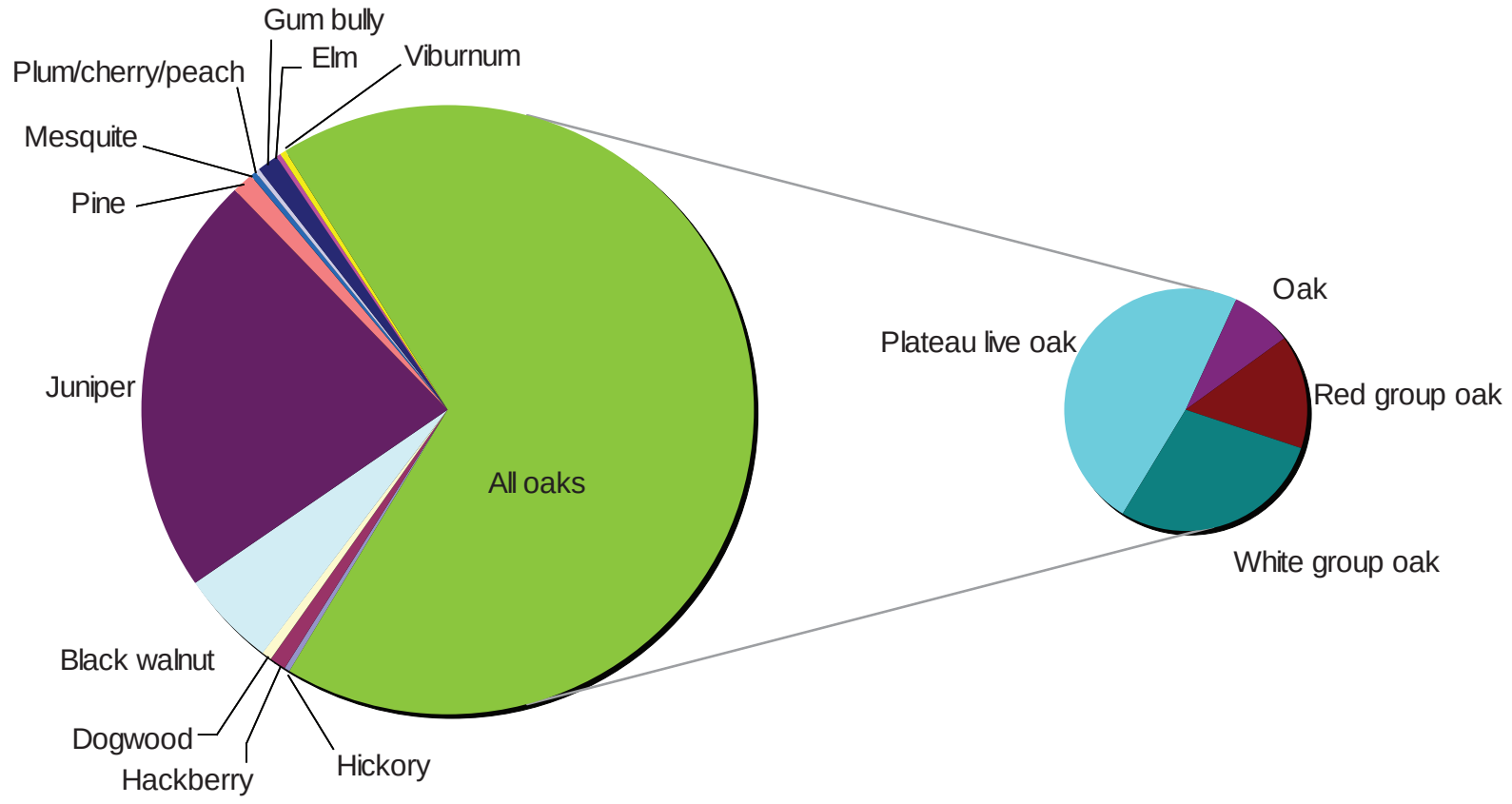

Figure 10.1. Graph of plant taxon representing wood fuel recovered as hand-collected samples. 
The Ransom and Sarah Williams Farmstead

Table 10.7. Uncarbonized seeds recovered from flotation samples

\begin{tabular}{|c|c|c|}
\hline Botanical Name & Common Name & Contexts (Lot Numbers) \\
\hline Oxalis sp. & Woodsorrel & $\begin{array}{l}\text { Feature } 1 \text {, subfloor pit }(454) \text {; } \\
\text { east midden }(455,456,463,464,465,466,467)\end{array}$ \\
\hline Ligustrum sp. & Privet & $\begin{array}{l}\text { Feature } 1 \text {, subfloor pit }(454) \text {; } \\
\text { east midden }(455,456,464,465,466,467)\end{array}$ \\
\hline Celtis sp. & Hackberry & $\begin{array}{l}\text { Feature } 1 \text {, subfloor pit }(459) \\
\text { east midden }(463,464,465,467)\end{array}$ \\
\hline Chamaesyce sp. & Sandmat & $\begin{array}{l}\text { Feature } 1 \text {, subfloor pit }(454,461,462) \\
\text { east midden }(463,466)\end{array}$ \\
\hline Croton spp. & Croton & east midden $(455,463,464,466)$ \\
\hline Chenopodium /Amaranthus spp. & Chenopodium & Feature 1, subfloor pit $(461,462)$ \\
\hline Galium sp. & Bedstraw & east midden $(464,465)$ \\
\hline Phytolacca americana & Pokeweed & $\begin{array}{l}\text { Feature } 1 \text {, subfloor pit ( } 459) \text {; } \\
\text { east midden }(467)\end{array}$ \\
\hline Chenopodium sp. & Goosefoot & east midden (464) \\
\hline Euphorbia sp. & Spurge & east midden (466) \\
\hline Helianthus annuus & Sunflower & Feature 1, subfloor pit (459) \\
\hline Juniperus sp. & Juniper & east midden (464) \\
\hline Smilax sp. & Greenbrier & east midden (455) \\
\hline
\end{tabular}

\section{Fuel Wood from Flotation Samples $(n=272)$}

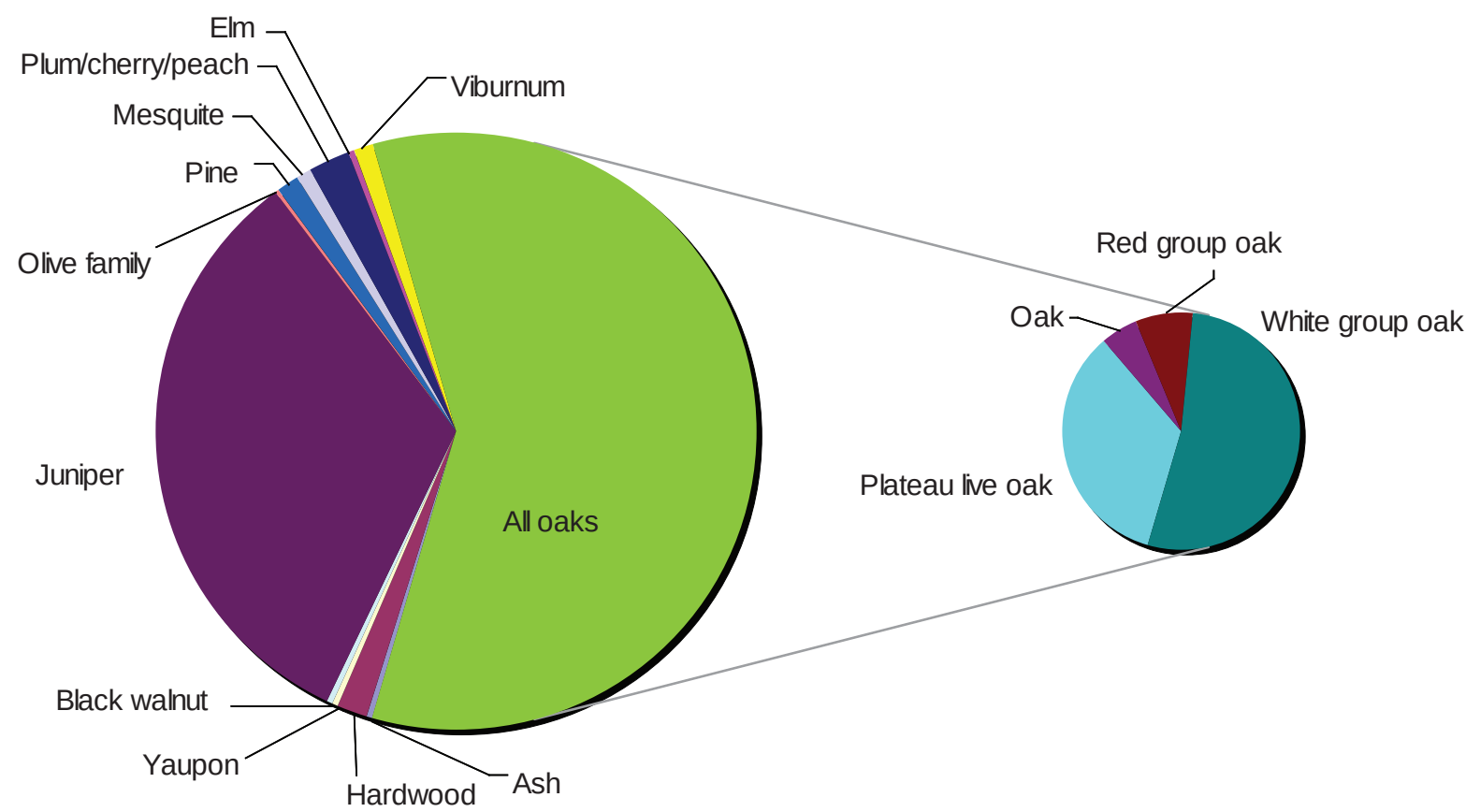

Figure 10.2. Graph of plant taxon representing wood fuel recovered from flotation samples. 


\section{FOOD PLANTS}

Corn kernels and cupules were recovered from four flotation samples. Two of the corn samples were taken from Feature 1 of the house block (Lots 454 and 458), and two were from the east midden (Lots 463 and 467). Other than peach, corn was the most common widely distributed nonwood plant on the site. Hickory and black walnut nutshell fragments were recovered from two flotation samples, and peach pits and dewberry seeds from one flotation sample each. A bulb scale was recovered from the east midden (Lot 467). It could not be identified to genus, but it is probably onion. The great majority of the food plants were recovered from the east midden rather than Feature 1, which produced only wood, bark, corn, and uncarbonized seeds.

\section{OTHER PLANTS}

Two bottle gourd rinds were recovered in east midden flotation samples. They are discussed below. A single knotweed specimen was found in an east midden sample. Knotweed is a member of the same botanical family as buckwheat, but the Williams farmstead specimen is far too small (1.5-mm carbonized) to be the domesticated Fagopyrum, which averages $4.5 \mathrm{~mm}$ long (Martin and Barkley 2000). A badly preserved, carbonized fruit that is probably elbowbush (Forestiera pubescens) was recovered from the east midden. Although the shrub is a member of the olive family, its fruits are bland and not widely consumed by humans. A carbonized bedstraw seed from Lot 455 probably represents disposal by burning of a nuisance bur that clung to hair or clothing. A single, carbonized wild grass seed was also recovered.

\section{NONBOTANICAL ITEMS RECOVERED BY FLOTATION}

Fish scales were recovered from six flotation samples, and they resemble scales of the Centrarchidae or sunfishes (Daniels 1996). Coal was present in two flotation samples, both from the Feature 1 subfloor pit in the house block. The spatial context of Feature 1, immediately in front of the chimney firebox, suggests that coal was used for fuel in the hearth or a wood stove vented by the chimney. Other nonbotanical items include a small piece of metal and small bones.

\section{DISCUSSION OF BOTANICAL REMAINS}

The plant remains recovered from 41TV1051 are an interesting botanical assemblage from a post-emancipation African American farmstead in central Texas. Table 10.8 summarizes the nonwood plants from the Williams farmstead. Many of these plants likely represent food remains, including one staple grain (corn), two fruits (peach and dewberry), two nuts (hickory and walnut), and two geophytes (sweet potato and onion). Other remains represent a domesticated container plant (gourd) and four plants that are probably incidental inclusions.

In addition to the peach pits, wood charcoal from the peach genus was recovered in both botanical and flotation samples. The wood could represent Mexican plum (Prunus mexicana) or escarpment cherry (Prunus serotina var. eximia), both of which are native to central Texas. No cherry or plum pits were recovered during excavation, however, making peach (Prunus persica) the most likely identification. The presence of both (probable) peach wood and peach pits on the site suggests that an orchard, or at least a few fruit trees, were cultivated by the Williams family. Given the difficulty of growing peaches, they may not have produced a good crop every year, but even poor fruits would have provided

Table 10.8. Summary of all nonwood plants recovered from the Williams farmstead

\begin{tabular}{l|l}
\hline Plant Part & Common Name \\
\hline Grain & Corn kernels and cob fragment \\
\hline \multirow{2}{*}{ Fruit seeds } & Dewberry \\
\cline { 2 - 2 } & Peach \\
\hline \multirow{2}{*}{ Nutshell } & Hickory \\
\cline { 2 - 2 } & Black walnut \\
\hline \multirow{2}{*}{ Tuber } & Sweet potato \\
\hline \multirow{2}{*}{ Rind } & Probably onion \\
\hline \multirow{2}{*}{ Incidental } & Bottle gourd \\
\cline { 2 - 2 } & Wild grass seed \\
\cline { 2 - 2 } & Bedstraw seed \\
\cline { 2 - 2 } & Indeterminable fruit \\
\hline
\end{tabular}


welcome treats for their horses. Peach trees typically live only 10 to 20 years in Texas and, as noted above, they do not naturalize in this landscape. It would therefore be unexpected for the peach trees or their descendants to be growing on the site more than a century after the Williams family left the farmstead. The Williamses almost certainly had a vegetable garden, although the rocky soils would have made cultivation of root crops such as sweet potato and onions difficult.

Bottle gourds, also called birdhouse gourds, would have been an easier garden crop, although they could easily have been purchased. Bottle gourds have been used as container plants in North America since the early Holocene. The Williams property had no direct access to Bear Creek, so any containers capable of storing liquids would have been particularly important. Bottle gourds have a wide array of other uses, too, including masks, musical instruments, athletic protection, pottery scrapers, and birdhouses (Heiser 1979; Moerman 1998). The immature gourds can be eaten; they are the "squashes" referred to in early European cookbooks (e.g., Milham 1998). As symbolized by the Big Dipper constellation, the bottle gourd also led enslaved Americans north to freedom (Heiser 1979).

Corn is the only grain represented in the macrobotanical assemblage. Its presence in the house block indicates human consumption, though raw corn may have been fed to the horses as well. No wheat remains were recovered, and there is no evidence that it was grown on the farm. If the Williamses used wheat, it was probably purchased as flour.

Other archaeological finds provide evidence for uses of plants that are not apparent among the macrobotanical remains. Snuff jar fragments, a tobacco plug tin, and smoking pipe fragments all indicate the use of various forms of tobacco obtained as commercial products. Plant extracts, as evidenced by a glass bottle that probably contained vanilla, for example, were used in cooking and probably as medicine. Metal barrel hoops attest to the importance of wooden containers for water storage in a situation where access to water was controlled by an adjacent landowner. 


\title{
SPATIAL ANALYSIS OF MATERIAL CULTURE AND FEATURES
}

\author{
Aaron R. Norment and Douglas K. Boyd
}

The testing and data investigations at the Williams farmstead recovered 26,685 items in surface collections and excavations (see Chapter 8 and Appendix B). Excluding the 744 lithic artifacts that are not associated with the farmstead occupation, the remaining 25,901 specimens comprise the historic material culture of the Williams farmstead. These materials have superb archeological and associational contexts. The artifacts are spatially associated with the main farmhouse location, the adjacent yard area, a trash midden area, a suspected outbuilding, and a large corral complex. The landscape analysis, cultural features, and artifacts have already been described (see Chapters 6, 7, and 8). This chapter provides an in-depth look at the spatial distributions of material culture across the farmstead. The goals of this analysis are to define the activity areas at the site, interpret the activities conducted on the farm, and reveal a more comprehensive history of the Williams family during its 30-year occupation of the farmstead.

\section{NOTES ON ANALYTICAL METHODS}

When all of the cultural materials are considered in conjunction with the layout of all the farm features, they provide a marvelous snapshot of the Williams farmstead occupation from ca. 1871 to ca. 1905. Because of the excellent preservation and minimal amount of postdepositional disturbance, the material culture is well suited for a spatial analysis to interpret where specific activities occurred on the farm. But first, it is important to take a quick look at everything that was recovered and how these materials were recovered to understand the ways in which the material culture assemblage is used in this chapter and how the analytical units are defined. Table 11.1 summarizes all the cultural materials recovered from the Williams farmstead by the type of material, artifact functional group, and the location and type of recovery. But not all of these materials are equally useful for a comparative spatial analysis. In this chapter, the analytical focus is on the five main functional groups because these are the most useful materials for interpreting the activities and behaviors of the farm occupants. The spatial distributions of the faunal and macrobotanical remains are also interpreted, but the unknown and unidentifiable artifacts have only limited utility for the spatial analyses. The latter are most useful when considering the total density of materials per square meter, for example. The lithic artifacts are excluded from any further consideration in this chapter, except for two specimens. ${ }^{118}$

Unless otherwise stated, all references to the "excavated artifacts" refers to a subset of the total assemblage that consists of only the artifacts recovered from excavation units and from two specific excavated features: the storage pit and chimney firebox. In many cases, these feature-related artifacts are included among the excavated artifacts, but in other cases these

\footnotetext{
${ }^{118}$ These are a dart point and an arrow point found in unusual contexts. These specimens are classified as collectible items in the Activities functional group rather than as lithic artifacts. The remaining lithic artifacts are chipped stone items (e.g., crude tools, cores, and unmodified flakes) associated with an ephemeral Native American occupation. These materials are not related to the historic Williams occupation in any way.
} 
The Ransom and Sarah Williams Farmstead

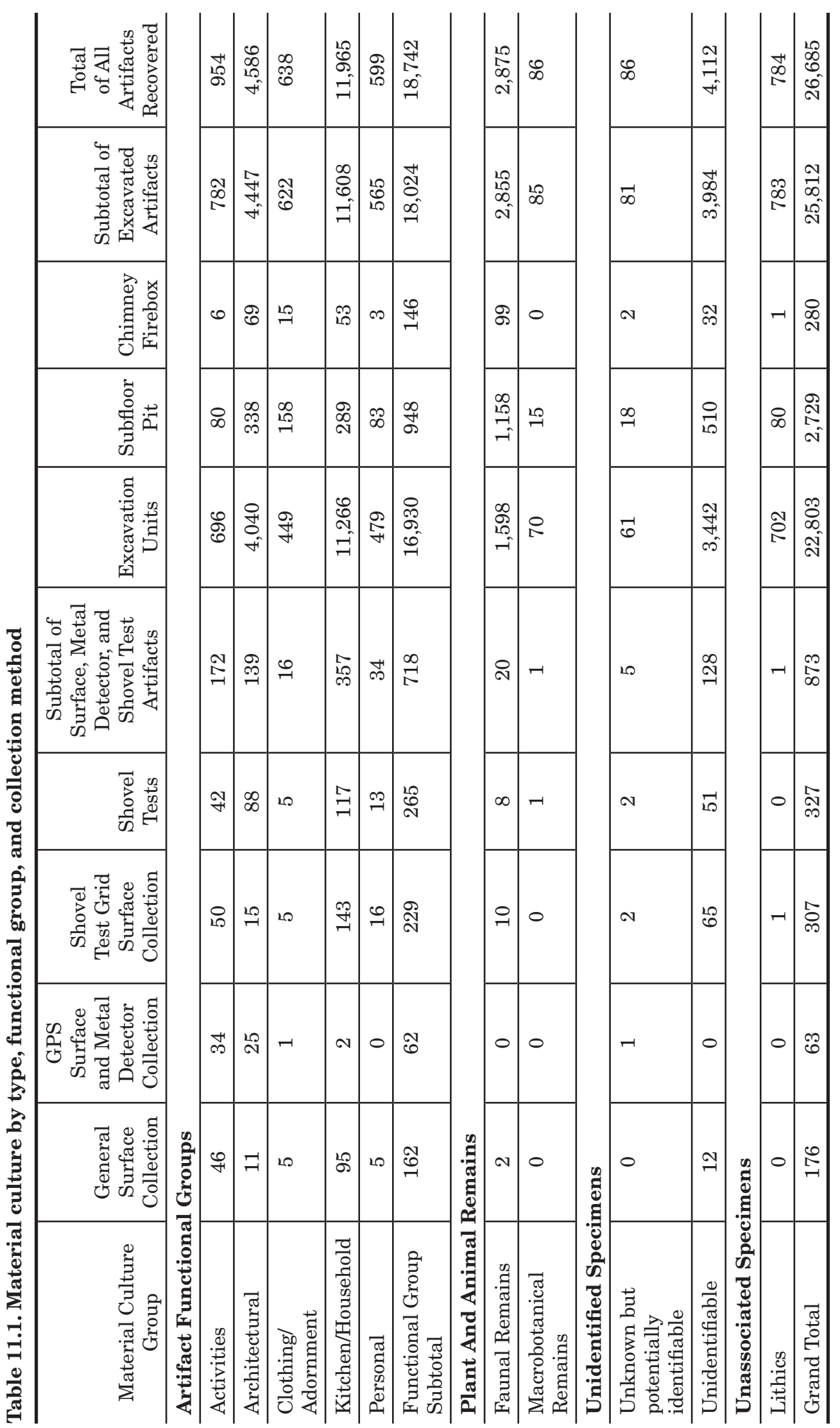


unique proveniences are separated from the excavation unit materials.

In this chapter, several different scales of data analysis are used. At one level, all of the artifacts found anywhere on the farmstead are examined regardless of whether they were surface collected, found shallowly buried with a metal detector, found in the 30x30-cm shovel tests, or found in the 1x1-m excavation units. At another level of analysis, only the cultural materials recovered from the excavation units are considered. Although surface and metal detector collections were made in many parts of the site, the total number of specimens collected is relatively low, and the recovery of these materials was not systematic. Consequently, while these artifacts may be useful for broad comparisons of activities across the farmstead, they cannot be compared directly with the cultural materials recovered from the excavations for examining small-scale activities in and around the farmhouse. When looking specifically at the spatial patterns in the house and immediately surrounding areas, the artifacts recovered from excavation units are comparable in terms of their densities, and the relative frequencies of artifacts per square meter is an important measure. For this type of analysis, artifacts recovered as surface-collected or metal-detected items must be excluded.

The cultural materials recovered from the systematic shovel test grid around the house block are quite useful for one level of spatial analysis. They provide the best evidence for examining the active yard area immediately surrounding the house, and the artifact density per shovel test is comparable and meaningful information. It is impossible to make a direct comparison of the shovel test data with the excavation unit data, but it was possible to mathematically convert the shovel test data to artifact density per square meter so that a gross comparison with excavations could be made. This level of analysis also provides important evidence of activities in the yard area.

\section{DEFINITION OF ANALYTICAL UNITS}

Some distinct spatial patterns of features and artifacts were obvious during the initial surface reconnaissance and testing, and these preliminary patterns dictated in part the locations where metal detecting, shovel testing, and the excavation units were focused during the subsequent data recovery. The feature and artifact patterns became increasingly clear as the investigations proceeded (see Chapter 6), and the field archeologists initially recognized six areas of the site that became distinct localities for archeological investigations. Later on, two of these areas were collapsed into one, thus creating five cohesive spatial groupings that are defined herein as analytical units: house block, yard area, trash midden (originally defined as two areas called the east midden and the slope midden), outbuilding, and corral complex. The locations of the analytical units are depicted in Figure 11.1.

\section{House Block}

The location of the Williams farmhouse was obvious to even a casual observer because of the intact chimney foundation, the large pile of fallen rocks from the middle and upper chimney, and the partially buried foundation stones denoting the location where the structure once stood. The farmhouse was the focus of intensive excavation activities because a large amount of material culture had been discarded or left inside and immediately around the farmhouse. The farmhouse was the center of many of the day-to-day activities for the entire family, and various lines of evidence suggest that the structure deteriorated in place without any significant postdepositional disturbances. Consequently, hand excavations included 90 1x1-m units laid out in a 9x10-m block over the house footprint. This rectangular area is the house block analytical unit (Figure 11.2).

Two features within the house block warrant mention. One is the rock chimney base and firebox made of native limestone, and the other is a subfloor storage pit dug into the bedrock limestone (see Chapter 7). At one level of spatial analysis, the artifacts recovered from these features are lumped together with the house block artifacts for comparisons between the larger analytical units. For the spatial analysis of materials within the house block, however, these features are considered separate archeological contexts.

\section{Yard Area}

The yard area around the farmhouse is defined by the artifacts recovered in 113 shovel 


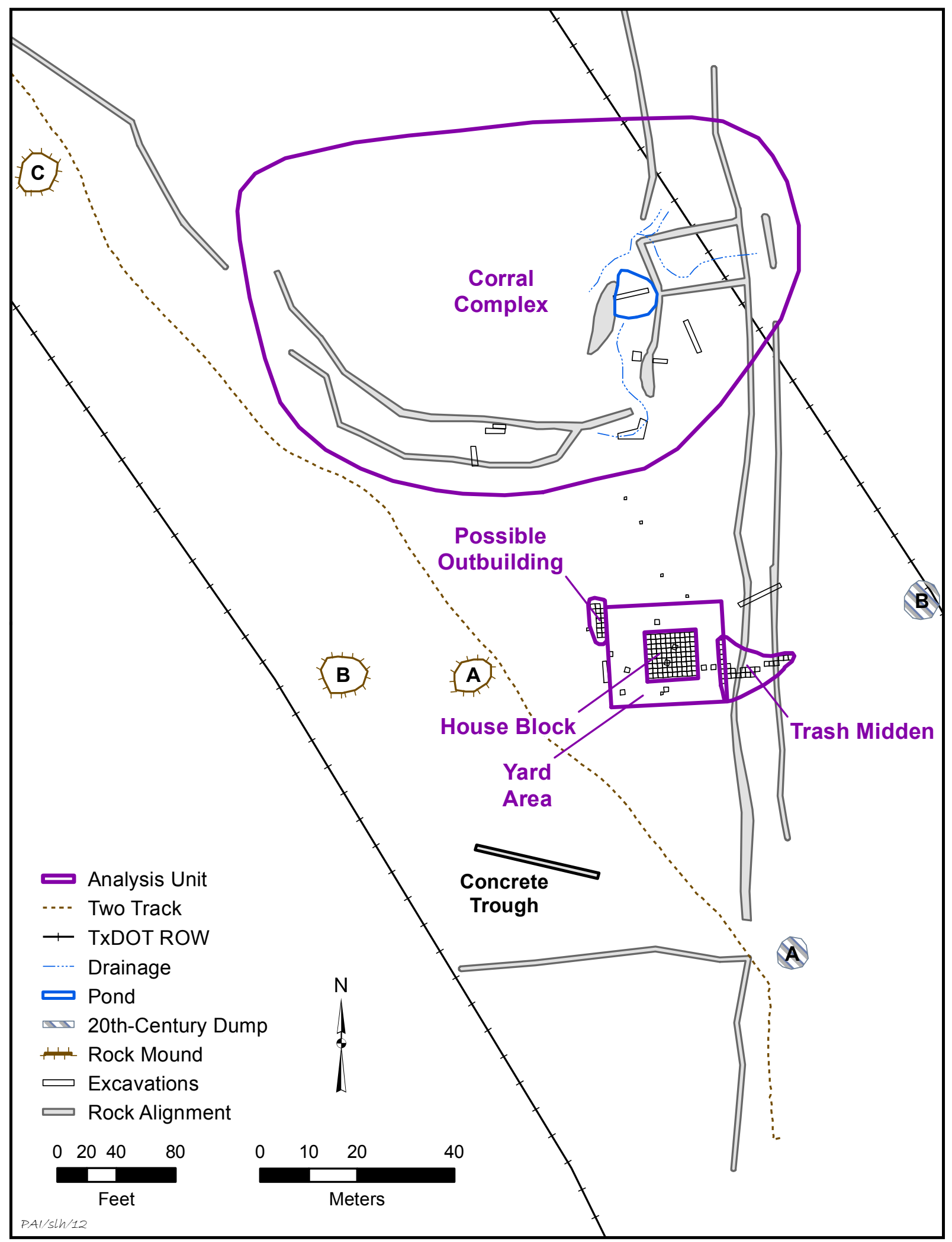

Figure 11.1. Map of the Williams farmstead analysis units for the spatial analysis of material culture. 


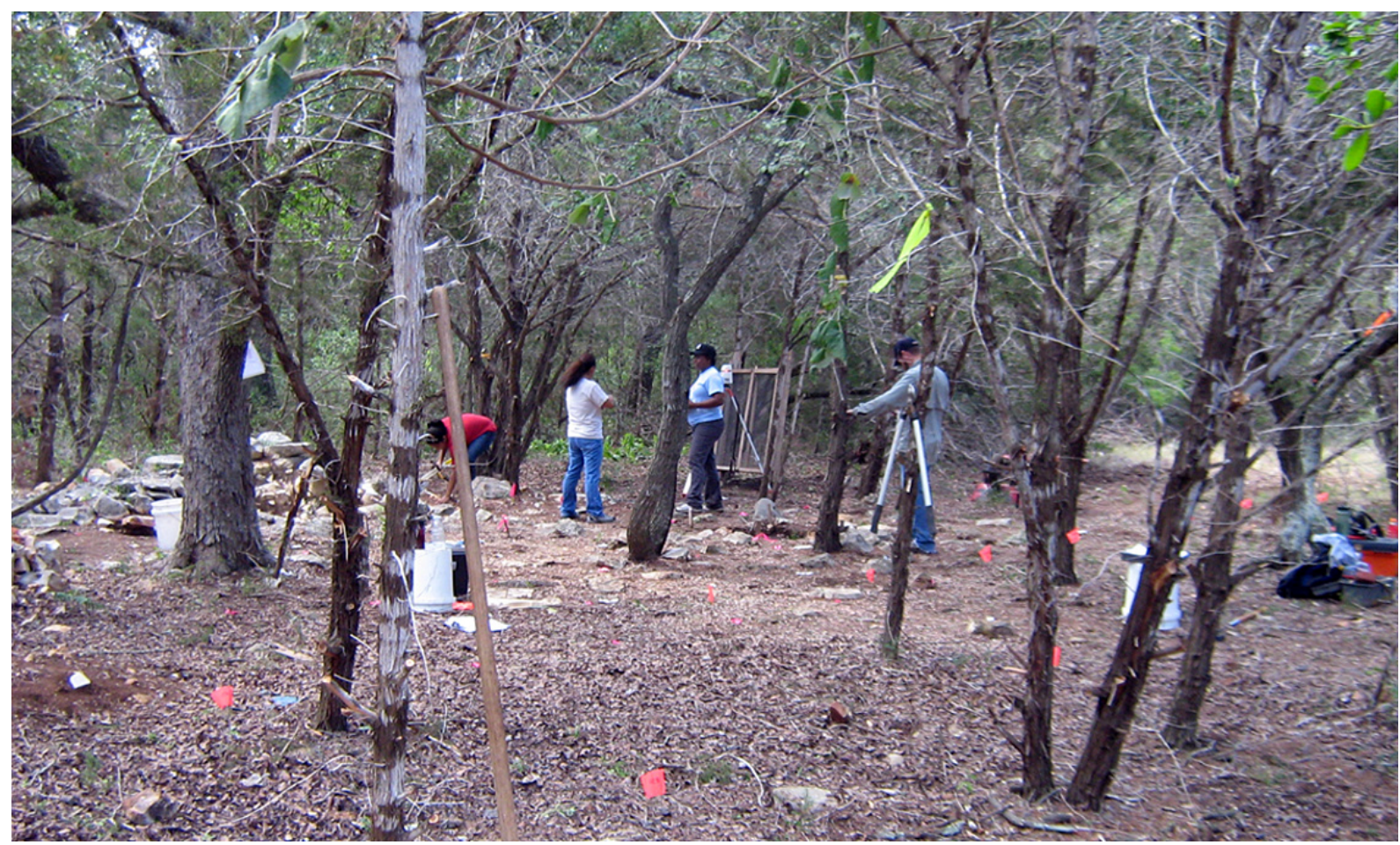

a



b

Figure 11.2. Views of the house area before and during the data recovery excavations. (a) View southeast showing locations of house block and shovel tests (orange pinflags) in the surrounding yard area prior to beginning excavations. The chimney base is at center right, partially hidden behind the large tree. (b) View northwest of the house block excavations in progress. The orange pinflags in the background mark shovel tests in the south yard area. The chimney base is in the lower left corner. 
tests (Figure 11.3) and 7 excavation units. The precise yard boundaries are not known, but it is generally delimited on two sides by the relative locations of the outbuilding to the northwest and the trash midden and two parallel rock alignment to the east. The rock alignments are interpreted as evidence of an old north-south roadway that separated the house and yard area from the wooded slope (see Rock Alignments B1 and B2 in Chapter 6).
The seven isolated $1 \mathrm{x} 1-\mathrm{m}$ excavation units are scattered around the house block and are located to the north $(n=1)$, east $(n=2)$, south $(\mathrm{n}=1)$, and west and southwest $(\mathrm{n}=3)$ of the house. Relatively speaking, the recovery of artifacts in these units was quite low, and it was determined that additional excavation units in the yard would not be very productive. But the combined shovel test and excavation unit data are useful for looking at the densities of various

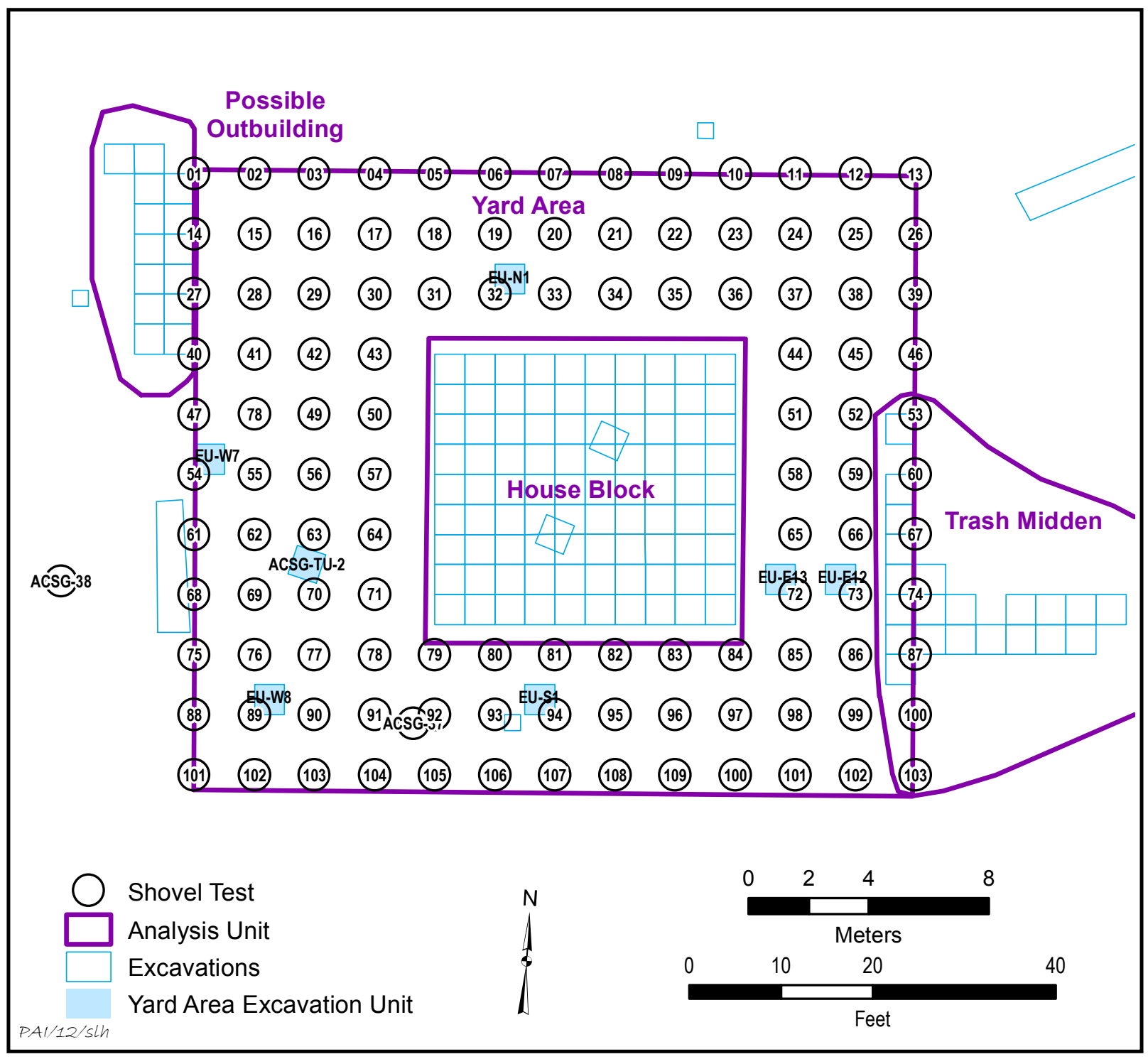

Figure 11.3. Map of the shovel tests and 1x1-m excavation units in the yard area. The map shows the shovel test numbers for 113 shovel tests and 6 excavation units dug by PAI in 2009 and 2 shovel tests and 1 test units dug by ACSG in 2003. Note that the row of eight units just inside the east edge of the shovel test grid is grouped with the trash midden analytical unit. 
artifacts in the yard relative to the artifact densities in other areas.

\section{Trash Midden}

When the site investigations first began, numerous artifacts were observed on the surface about 5 to $8 \mathrm{~m}$ east of the house block, and later high concentrations of broken artifacts were noted in the easternmost shovel tests around the house block. Metal detector sweeps revealed dense concentrations of buried metal artifacts in this location and downslope farther to the east. This area was clearly a logical spot for a household trash dump, and subsequent hand excavations recovered large numbers of artifacts within a dark, organic-rich soil. The evidence led to the conclusion that this extensive cultural deposit was indeed a trash midden.

As the excavations progressed, the field archeologists originally conceived of two separate midden deposits, separated by a prominent north-south rock alignment (see Rock Alignment B2 in Chapter 6). The portion of the midden located in the level area just east of the house, referred to as the east midden, was sampled first. This deposit abutted the rock alignment that ran northward from the giant oak tree and marked the edge of the flat topography. Excavations continued downslope to the east of this rock alignment, exposing more historic debris and dark midden soils. This area was called the slope midden. The lower eastern end of the slope midden excavations crossed an area where a second rock alignment (see Rock Alignment B1 in Chapter 6) was mapped. This alignment was quite ephemeral in this area, and it was not particularly obvious in the excavation (Units E22). Both of these north-south rock alignments ran parallel to the east edge of the house, about 30 to 50 feet east of the chimney, and they were interpreted as evidence of an old roadway (see Figure 6.10). Northwest of the house block, some cedar fence posts with attached barbed wire were found on top of the eastern rock alignment (B2), clearly indicating that a barbed-wire fence had once been present along the alignment.

To better understand these cultural deposits, we had to try to determine when the east midden and slope midden were deposited relative to the construction of the eastern rock alignment. The intersection of the rock alignment and the midden deposits was examined in excavation units E25, E26, and E28 (see Figure 11.1), and these exposures revealed that the midden debris was deposited on top of the rocks of the eastern alignment. No artifacts were found at the level of or below the lowest rocks. Thus, the stratigraphic evidence revealed that the construction of the eastern rock alignment predated the accumulation of the midden deposits.

An attempt was made to determine if there were any differences in the artifacts between the east midden and slope midden. This effort revealed no recognizable functional or temporal differences between these artifact assemblages. For all practical purposes, then, the two areas were found to be parts of the same midden deposit.

Understanding the relationship between the midden deposits and the barbed-wire fence following the rock alignment (B2) was more problematic. It is likely that the remnant posts represent a relatively late barbed-wire fence that dates to the twentieth century. Unfortunately, there is no way of knowing if the fence was rebuilt a few times or if there were other fences (of the same or different ages) in the same area. So we know that there was at least one fence that delineated the eastern edge of the yard in the twentieth century, but the yard boundaries and fences could have changed through time. ${ }^{119}$

For the spatial analyses, the east and slope midden excavations were combined into a single analytical unit- the trash midden - that encompasses 27 hand-dug 1x1-m units located 5 to $20 \mathrm{~m}$ east of the house block. These units are spread out in two directions and extend $9 \mathrm{~m}$ north-south by 15 m east-west. Within this area, 20 units are contiguous in the western half of the midden area, 1 unit is isolated at the north end, and 6 units are contiguous at the downslope eastern end.

Metal detector and surface evidence indicate that the dense midden deposits extend north and south of the excavations. The midden deposits also continue downslope to the east, but the artifact density drops off dramatically beyond the easternmost excavation unit (Unit

\footnotetext{
${ }^{119}$ Oral histories document the variability in yard fencing and changes in yard areas through time. Informants interviewed by Nunley (1987:204) in his study of Navarro County farms recalled a variety of different scenarios regarding yard fences. Some families had fences around their entire yards, some had fences only around the back yard, and some had no yard fences at all. Others recalled having a fence "part of the time."
} 
E19). Based on metal detector hits and surface artifacts, it is estimated that the total midden area is at least $15 \times 15 \mathrm{~m}$ (a minimum of $225 \mathrm{~m}^{2}$ ), perhaps larger. If this estimate is correct, the 27 $\mathrm{m}^{2}$ of hand-dug units represent an approximate 12 percent sample of the larger midden area. The trash midden analytical unit represents a significant sample of the primary discard area used by the Williams family for disposal of their daily household refuse (Figure 11.4).

\section{Possible Outbuilding}

The location of the possible outbuilding was first recognized because a surface concentration of metal artifacts was observed on a flat limestone outcrop with thin soils that was located about 8 to $10 \mathrm{~m}$ northwest of the house block. A metal detector sweep indicated that many more metal artifacts were buried there. Several of the surface artifacts (such as wagon parts) suggested that some sort of transportation- or farming-related activities occurred in this location. It was obvious that this was not a typical trash midden, and based on its proximity to the house, this seemed to be a logical area for a small outbuilding. Excavations were conducted in this area to investigate the possibility of an outbuilding, perhaps a barn or work shed.

The possible outbuilding analytical unit consisted of fourteen 1x1-m excavation units clustered into an elongated block (Figure 11.5). Metal detecting showed that the density of metal artifacts dropped off considerably several feet beyond these units. Although the excavations are limited, and no definitive structural evidence was found (e.g., in situ foundation stones or postholes), the recovered artifacts indicate that this area may well have been the location of an ephemeral structure such as a pole barn or shed.

\section{Corral Complex}

The most obvious manmade features at the site were the massive rock walls used for livestock and water control in the northern part of the farmstead. These walls were composed of local limestone boulders and slabs that were intentionally stacked, often up to 3 feet high and 3 feet wide, in linear arrangements. In some places, large trees or cedar posts with attached sections of barbed wire are evidence that barbed-wire fences once ran on top of some of these rock walls (see
Chapter 6). Additional investigations revealed that a small livestock pond had once existed among the cluster of rock walls and barbed-wire fences. Collectively, this area, which covers more than $60,000 \mathrm{ft}^{2}$, is called the corral complex (see Figure 11.1). While the corral complex is the most horizontally extensive analytical unit, it also has the lowest density of artifacts. During field investigations, an intensive surface collection and metal detector survey was done over the corral complex, and some scattered artifacts were recovered. Artifacts were more common in the eastern portion of the corral complex, but no significant concentrations were found. The finding of many iron hoops (whole and fragments) from large wooden barrels and many transportation- and horse-related artifacts led us to hypothesize that the activities in the corral complex were primarily related to livestock and farming.

A single 2x2-m unit was excavated to investigate a concentration of artifacts found with the metal detector south of the pond (Figure 11.6). The area was selected because it had deeper intact soils than anywhere else in the corral complex, and it was adjacent to one of the best preserved sections of rock wall (see Figure 11.1). Because some of the artifacts found nearby with the metal detector were horse-related items, it was speculated that there might have been a livestock-related structure in this area. But the artifact recovery was minimal in the excavation unit, and no evidence of a possible structure was encountered. It seems likely that some kind of wooden structure-such as a pole barn, a livestock shelter, a storage shed, a tack room, or a workshop-once existed in the corral complex. Since the kinds of structures that might have existed there would have left very minimal archeological signatures, no additional effort was spent looking for structural evidence.

\section{FUNCTIONAL COMPARISONS OF THE ANALYSIS UNITS}

Each of the analysis units defined above was designated based on the subsurface occurrence of artifacts as well as functional considerations relative to surface features, topography, and the layout of the farmstead. The spatial relationships of analysis units are anchored to the main farmhouse, which was the center of farm life, but they are best understood within the context of the large-scale landscape features and 


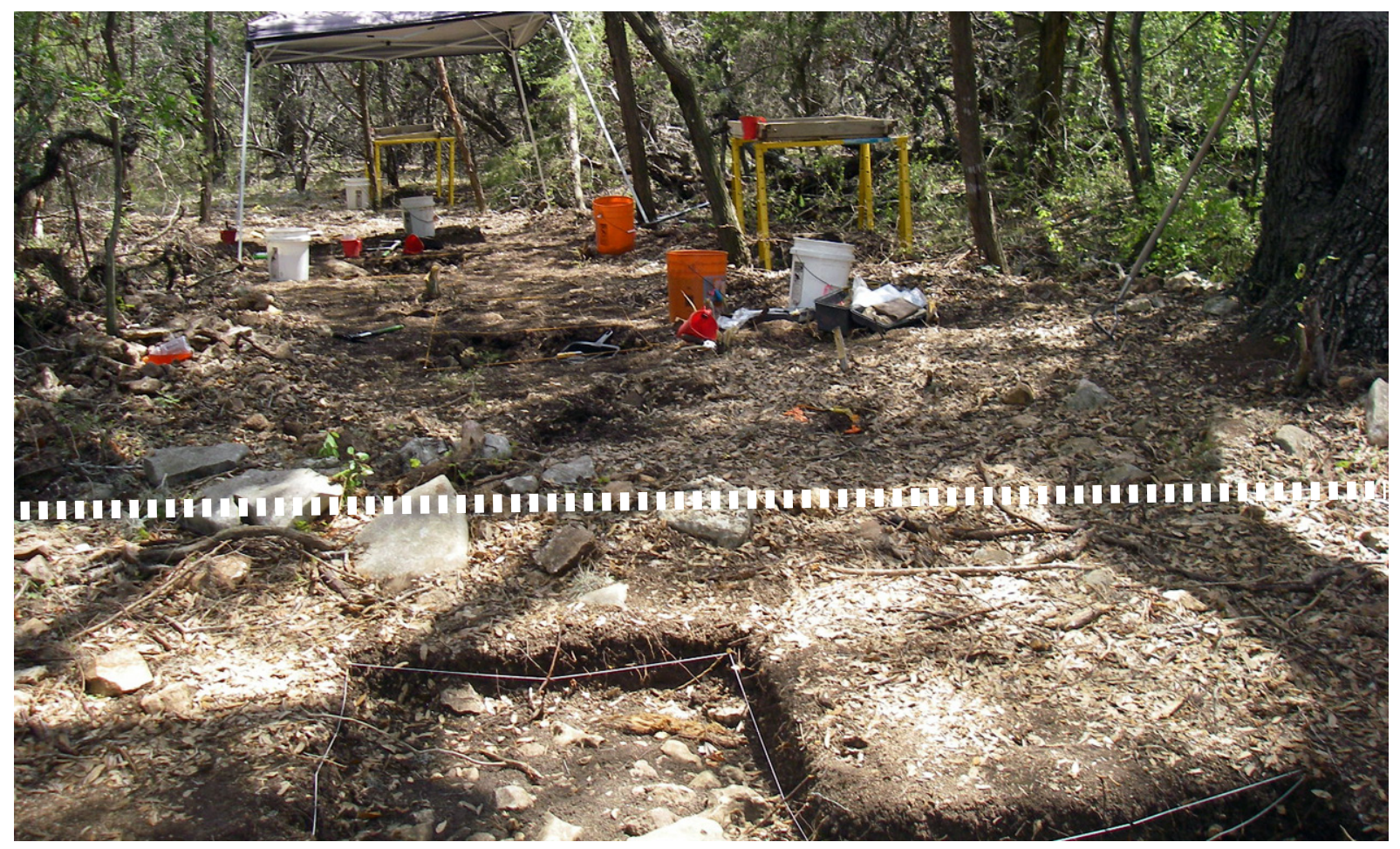

a

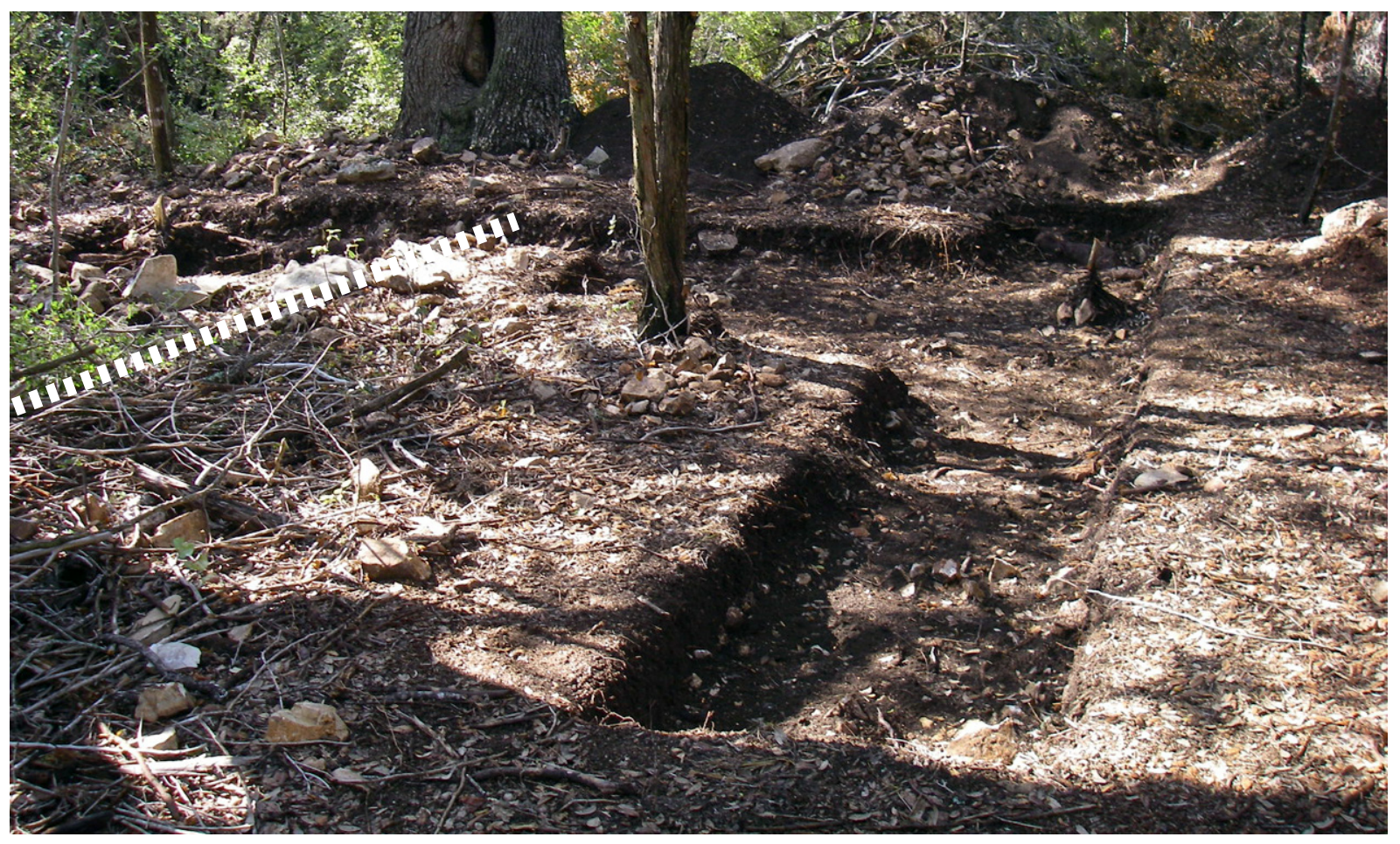

b

Figure 11.4. Views of the trash midden excavations in progress. (a) Photo looking east and downslope from the southeast corner of the house block. The giant oak tree is on the right, and in the foreground is the rock alignment that separates the east midden from the slope midden. The yellow screen stands behind the shade tent mark the eastern extent of the midden excavations. (b) Photo looking south-southeast with a line marking the rock alignment. Dashed line shows location of Rock Alignment C2. 
The Ransom and Sarah Williams Farmstead

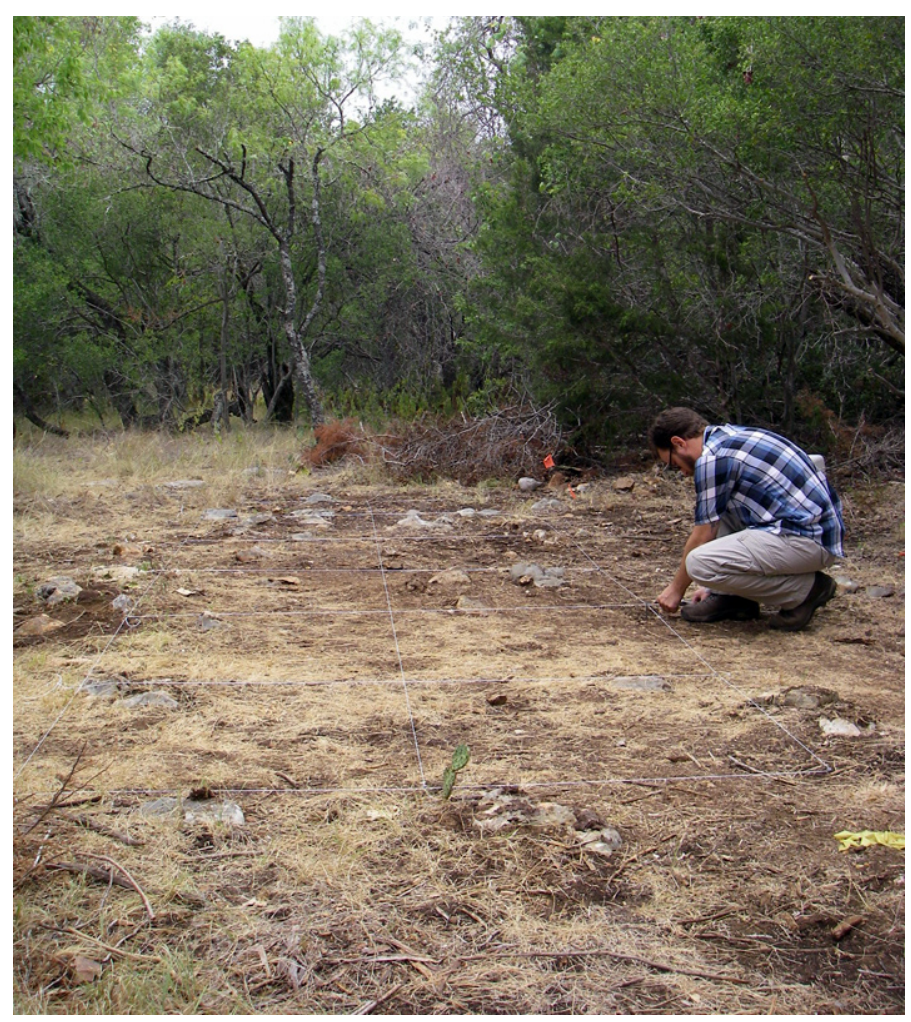

a

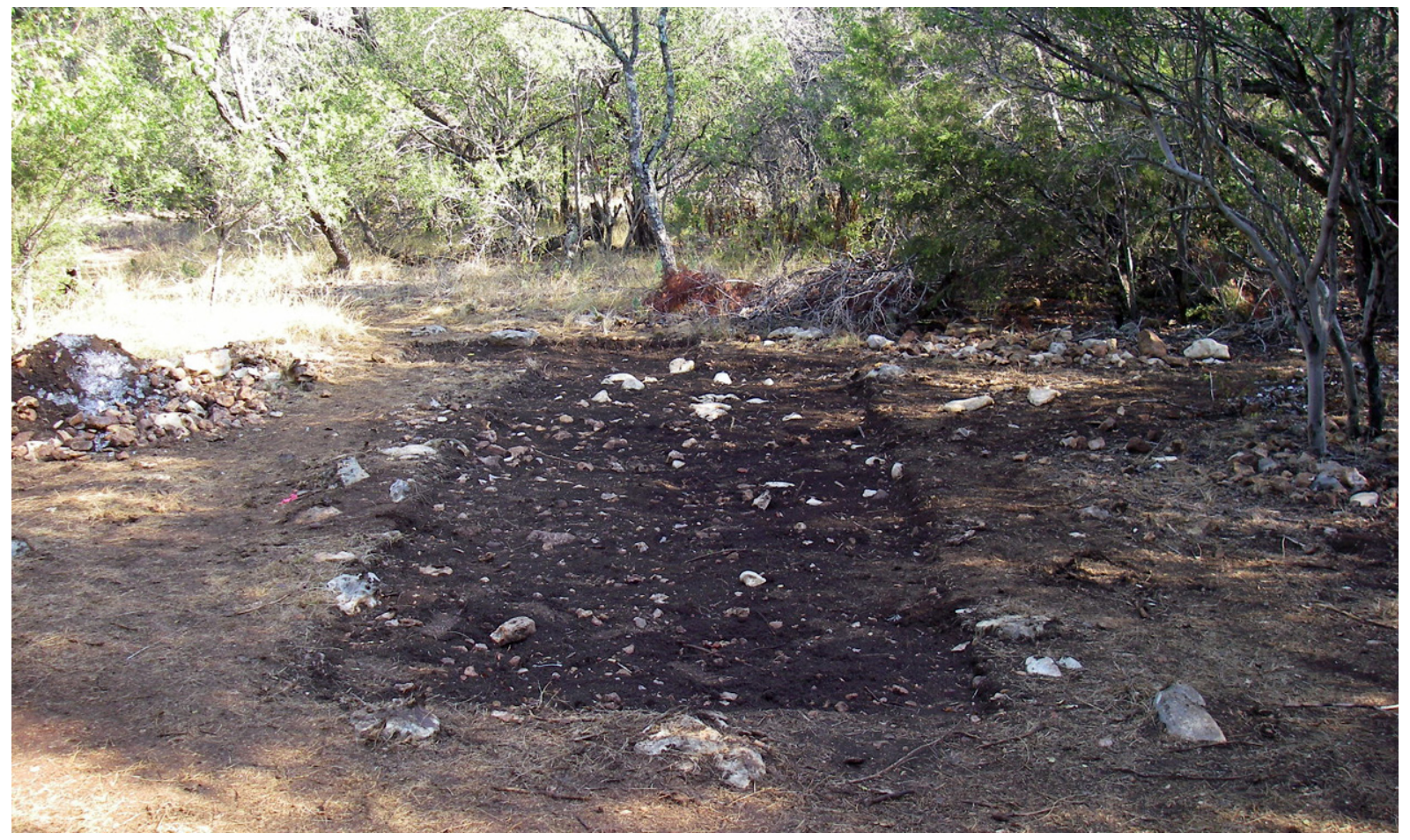

$\mathrm{b}$

Figure 11.5. Views of the possible outbuilding excavations, looking north. (a) Photo of units being laid out before excavation. (b) Photo of units during excavation. 


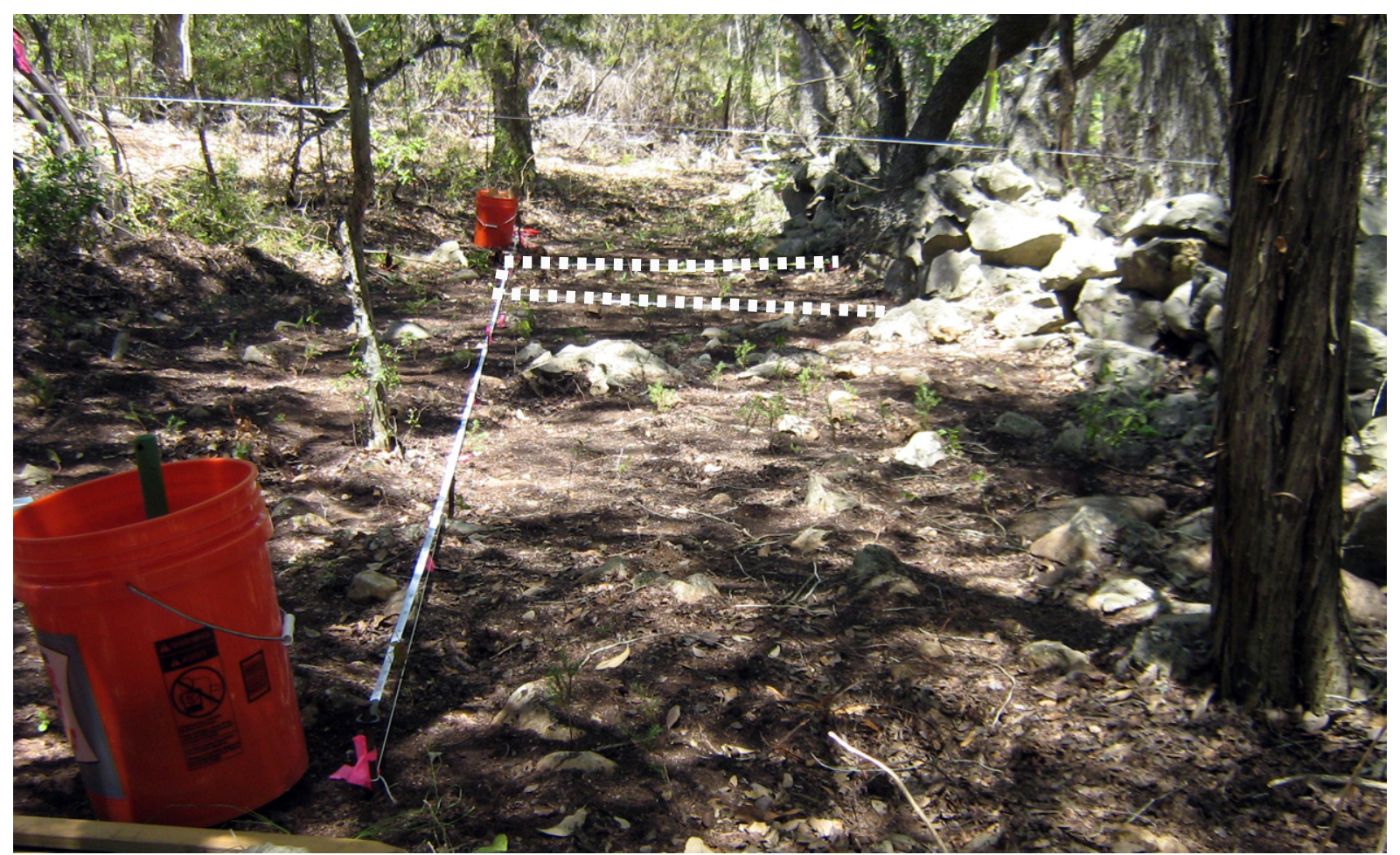

a

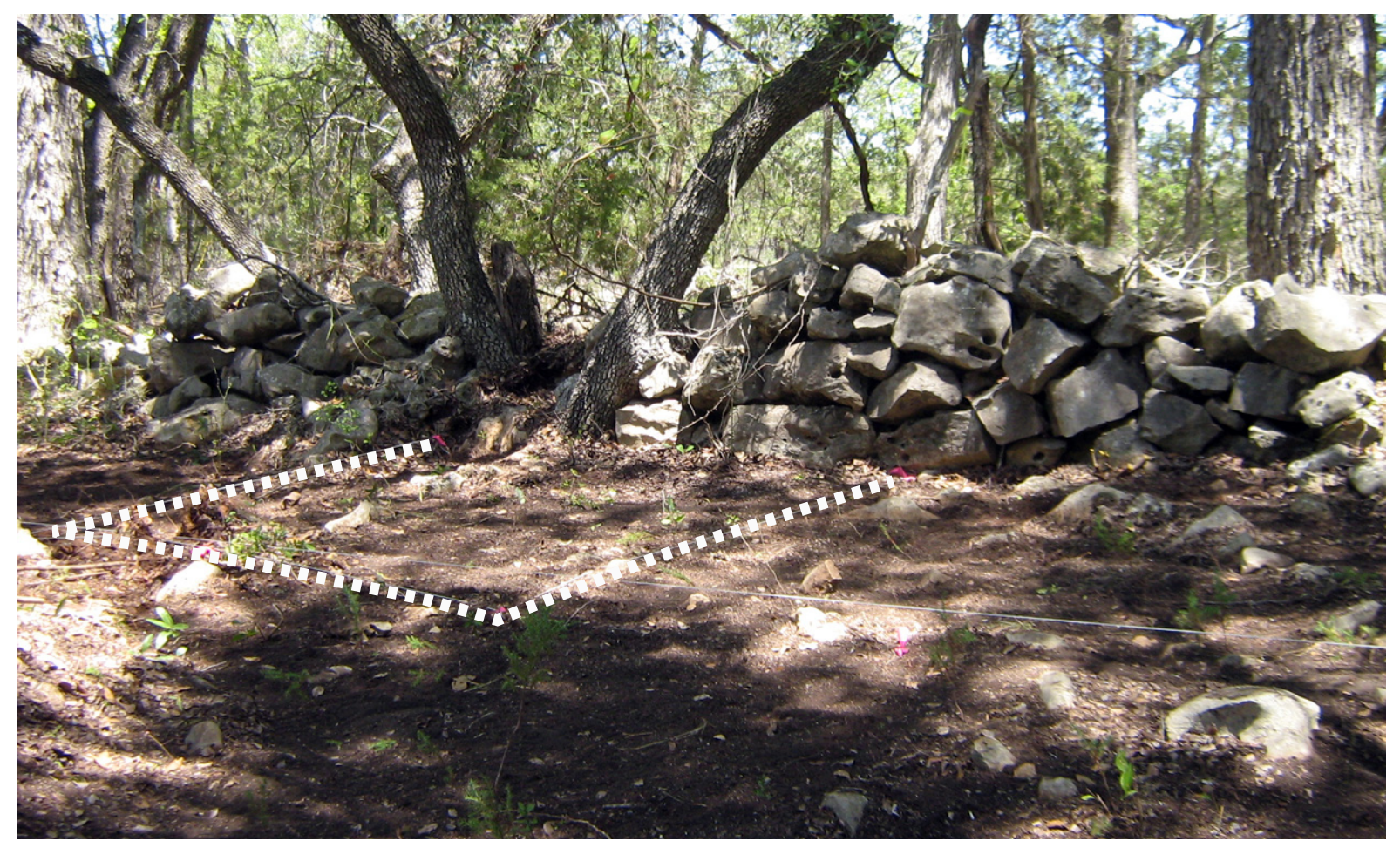

b

Figure 11.6. Views of the 2x2-m excavation in the corral complex. (a) Photo looking south along the north-south rock wall in the corral complex, with the $2 \times 2-m$ unit in the center and the stock pond behind. (b) Photo looking northeast showing the location of the $2 \times 2-m$ unit adjacent to the north-south rock wall. The dashed line has been added to mark the excavation unit. 
the smaller-scale structural and inter-structural features. Table 11.2 summarizes the quantities of historical artifacts associated with these analysis units by functional classification. Figures 11.7 and 11.8 show these quantities presented as raw numbers and as cumulative percentages within each analysis unit.

The house block excavations produced 6,546 artifacts (excluding those recovered from the storage pit and the chimney firebox excavations), and these account for 36.3 percent of all excavated artifacts. The majority are related to the kitchen/household (45 percent) and architecture (39.1 percent) functional groups. The remaining house block artifacts (15.8 percent) represent a wide variety of different activities, clothing, and personal items.

One of the two features within the house block, the subfloor pit, yielded 5.3 percent of all the excavated artifacts and about one-seventh the number of artifacts found in the whole house block. What is notable in the subfloor pit is the high number of clothing artifacts, mostly buttons, relative to the other analysis units. The other feature, the chimney firebox, yielded only 146 artifacts, but they include some specimens in all five functional categories.

Not unexpectedly, the trash midden yielded the highest amount of cultural materials with 9,420 artifacts in the five functional groups, accounting for just over half of all the excavated artifacts (52.3 percent). Midden artifacts are dominated by kitchen/household artifacts (82.4 percent), most of which are broken glass fragments. Our artifact classification followed the common protocol of classifying container glass (excluding flat window glass) into the kitchen/ household category. While this may be true for a significant portion of the glass, some portion of it (such as medicine bottle glass, for example) actually belongs in other functional groups. However, for the purposes of this analysis, it is assumed that the bulk of the broken glass does represent kitchen/household items. The next highest functional group in the midden artifacts is the architectural materials (13.2 percent),

Table 11.2. Artifact quantities for all excavated artifacts by functional group and analysis unit*

\begin{tabular}{|c|c|c|c|c|c|c|c|c|}
\hline $\begin{array}{c}\text { Functional } \\
\text { Group }\end{array}$ & $\begin{array}{l}\text { House } \\
\text { Block }\end{array}$ & $\begin{array}{l}\text { Subfloor } \\
\text { Pit }\end{array}$ & $\begin{array}{c}\text { Chimney } \\
\text { Box }\end{array}$ & Midden & Outbuilding & $\begin{array}{l}\text { Yard } \\
\text { Area }\end{array}$ & $\begin{array}{c}\text { Corral } \\
\text { Complex }\end{array}$ & Total \\
\hline \multicolumn{9}{|c|}{ Numbers of Artifacts } \\
\hline Activities & 454 & 80 & 6 & 146 & 81 & 15 & 0 & 782 \\
\hline Architectural & 2,562 & 338 & 69 & 1,245 & 132 & 101 & 0 & 4,447 \\
\hline $\begin{array}{l}\text { Clothing/ } \\
\text { Adornment }\end{array}$ & 346 & 158 & 15 & 84 & 17 & 2 & 0 & 622 \\
\hline $\begin{array}{l}\text { Kitchen/ } \\
\text { Household }\end{array}$ & 2,946 & 289 & 53 & 7,766 & 362 & 93 & 99 & 11,608 \\
\hline Personal & 238 & 83 & 3 & 179 & 61 & 0 & 1 & 565 \\
\hline Total & 6,546 & 948 & 146 & 9,420 & 653 & 211 & 100 & 18,024 \\
\hline $\begin{array}{l}\text { Percent of } \\
\text { Total }\end{array}$ & $36.3 \%$ & $5.3 \%$ & $0.8 \%$ & $52.3 \%$ & $3.6 \%$ & $1.2 \%$ & $0.6 \%$ & $100.0 \%$ \\
\hline \multicolumn{9}{|c|}{ Percentage of Artifacts } \\
\hline Activities & $6.9 \%$ & $8.4 \%$ & $4.1 \%$ & $1.5 \%$ & $12.4 \%$ & $7.1 \%$ & $0.0 \%$ & $4.3 \%$ \\
\hline Architectural & $39.1 \%$ & $35.7 \%$ & $47.3 \%$ & $13.2 \%$ & $20.2 \%$ & $47.9 \%$ & $0.0 \%$ & $24.7 \%$ \\
\hline $\begin{array}{l}\text { Clothing/ } \\
\text { Adornment }\end{array}$ & $5.3 \%$ & $16.7 \%$ & $10.3 \%$ & $0.9 \%$ & $2.6 \%$ & $0.9 \%$ & $0.0 \%$ & $3.5 \%$ \\
\hline $\begin{array}{l}\text { Kitchen/ } \\
\text { Household }\end{array}$ & $45.0 \%$ & $30.5 \%$ & $36.3 \%$ & $82.4 \%$ & $55.4 \%$ & $44.1 \%$ & $99.0 \%$ & $64.4 \%$ \\
\hline Personal & $3.6 \%$ & $8.8 \%$ & $2.1 \%$ & $1.9 \%$ & $9.3 \%$ & $0.0 \%$ & $1.0 \%$ & $3.1 \%$ \\
\hline Total & $100.0 \%$ & $100.0 \%$ & $100.0 \%$ & $100.0 \%$ & $100.0 \%$ & $100.0 \%$ & $100.0 \%$ & $100.0 \%$ \\
\hline
\end{tabular}

*Data includes only 18,024 artifacts classified into the five main functional groups. 


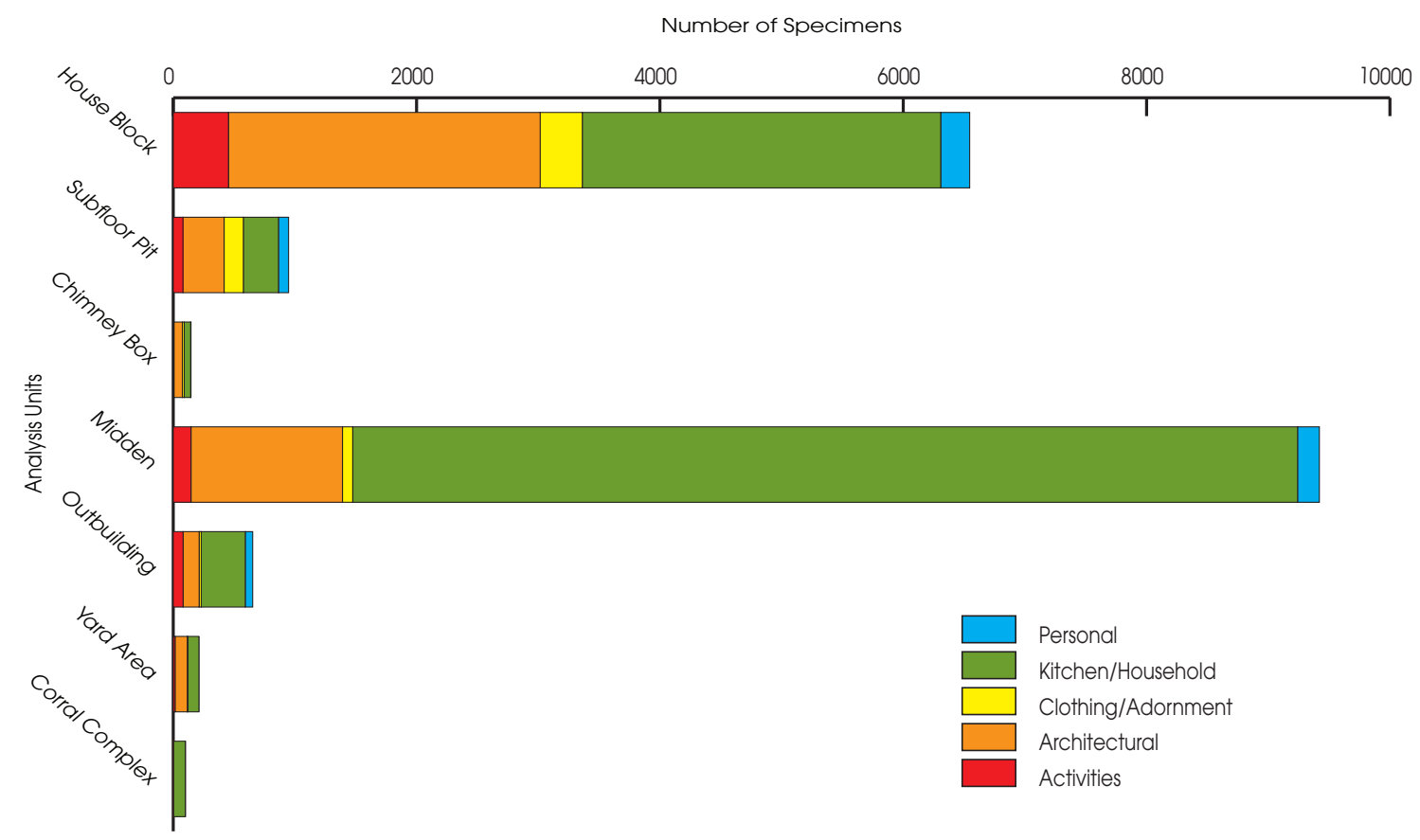

Figure 11.7. Graph of excavated artifacts showing quantity by functional group and analysis unit.

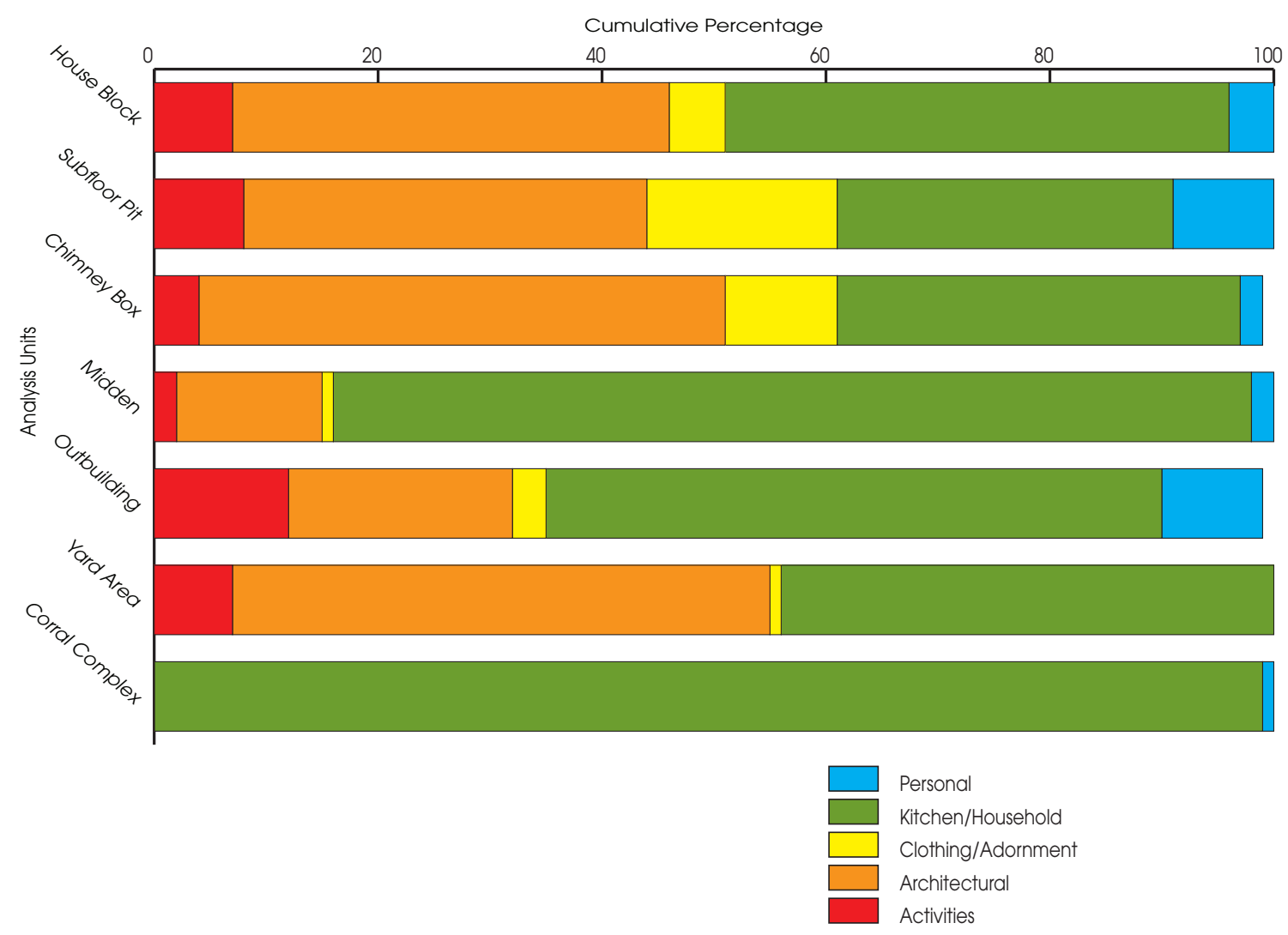

Figure 11.8. Graph of excavated artifacts showing percentage by functional group and analysis unit. 
which are dominated by nails and nail fragments. The other three groups (activities, clothing, and personal) collectively account for only 4.3 percent of the midden artifacts.

The area yielding the next highest amount of cultural materials is the outbuilding, and it produced only 3.6 percent of all the excavated artifacts. The outbuilding has a higher percentage of activities and personal artifacts than any of the other analysis units (see Figure 11.8).

The numbers and percentages of excavated artifacts recovered from the yard area and corral complex are very low (211 and 100, respectively), and combined these assemblages account for only 1.8 percent of the total excavated artifacts. Both of these areas are discussed in more detail later, and they are better understood when the shovel test data are examined for the yard area and when the surface- and metal detector-collected artifacts are considered for the corral complex.

When the raw artifact numbers are converted to artifacts per square meter (Table 11.3), they reveal some broad functional differences between the analysis units. As shown in Figures 11.9 and 11.10 , the artifact density numbers and percentage reveal slightly different patterns. The most striking pattern is the high density of items found in the subfloor storage pit and the trash midden relative to all the other analysis units. The lowest overall densities are in the outbuilding, yard area, and corral complex, while the house block and chimney box fall in the middle. Looking at the density cumulative percentages, the midden and corral complex are dominated by kitchen/household items, a result skewed by the high quantities of broken glass. In the case of the corral complex, broken bottle glass is from containers that were set on the rock wall and shot with guns. Much of this glass is from wine bottles that postdate the Williams farmstead occupation. One interesting pattern is that the outbuilding has a higher relative amount of activities artifacts than the other analysis units. This is significant because many of these items are farming-related artifacts that are indicative of the specialized function of the outbuilding.

\section{SPATIAL DISTRIBUTIONS OF ARTIFACTS}

To begin looking at the spatial distributions of artifacts across the main excavations in the house complex and within analysis units, the raw artifact counts were linked with the site map and plotted across the analysis units, and then the data were converted to density maps. Figure 11.11 shows the raw artifact counts for all of the excavated artifacts in the house block, yard area, midden, and outbuilding analysis units ( $n=16,830$; excludes corral complex). Figure 11.12 is a density map of the same data, and it shows some interesting patterns. The highest overall artifact densities are in the midden, with more than 1,000 artifacts per unit in five units along and east of the north-south rock alignment.

Spatial distribution maps of artifact density are presented in Figures 11.13 to 11.17 for each of the five functional categories. These maps provide a good overall picture of the material culture assemblages associated with the house block, yard area (excluding shovel tests), trash midden, and the outbuilding. They provide much of the data for the general observations and interpretations in the discussions that follow.

\section{THE FARMHOUSE}

As described in Chapter 7, the evidence for the Williams family house consists of the chimney base, the limestone rock pile representing the collapsed middle and upper portion of the chimney, and the large rocks that once served as foundation stones for a wooden structure. There was no evidence of excavated pier holes, and the shallowness of the hard limestone substrate would have prevented the digging of house piers. The lowest level of rocks was mapped throughout the house block (see Figure 7.2), and the distribution of these rocks relative to the chimney base was used to interpret the size and configuration of the Williams house. As shown in Figure 11.18, the estimated house footprint is relatively small, likely no more than $15 \mathrm{ft}$ north-south by $16 \mathrm{ft}$ east-west and totaling about 240 square feet $(4.6 \times 4.9 \mathrm{~m}$ and 22.5 $\mathrm{m}^{2}$ ). This size estimate is based on the location of the chimney firebox relative to the overall distribution of large rocks and the locations of several very large tabular limestone slabs that probably served as cornerstones for the house foundation. It is acknowledged that one or two of the probable cornerstones may have been shifted slightly from their original positions by post-abandonment activities, especially tree 


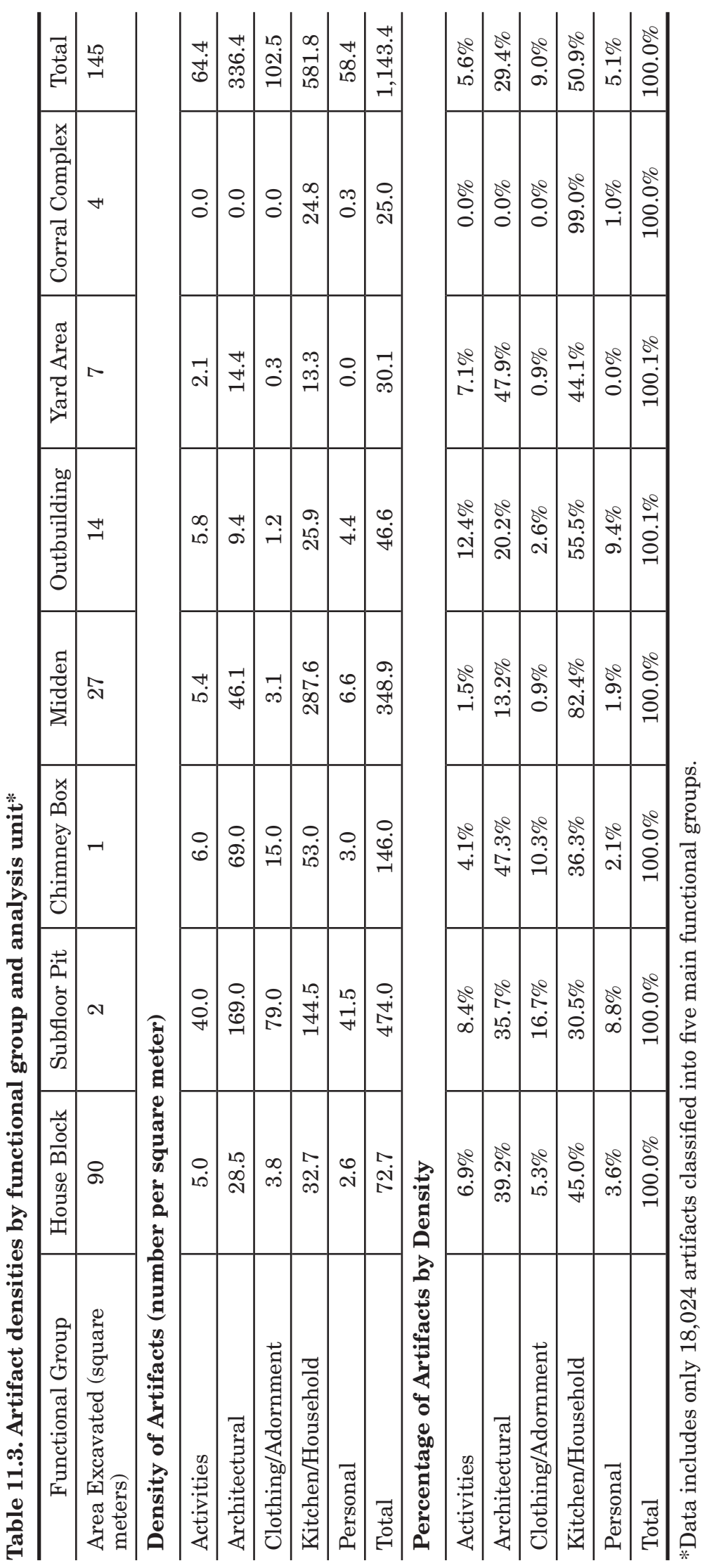




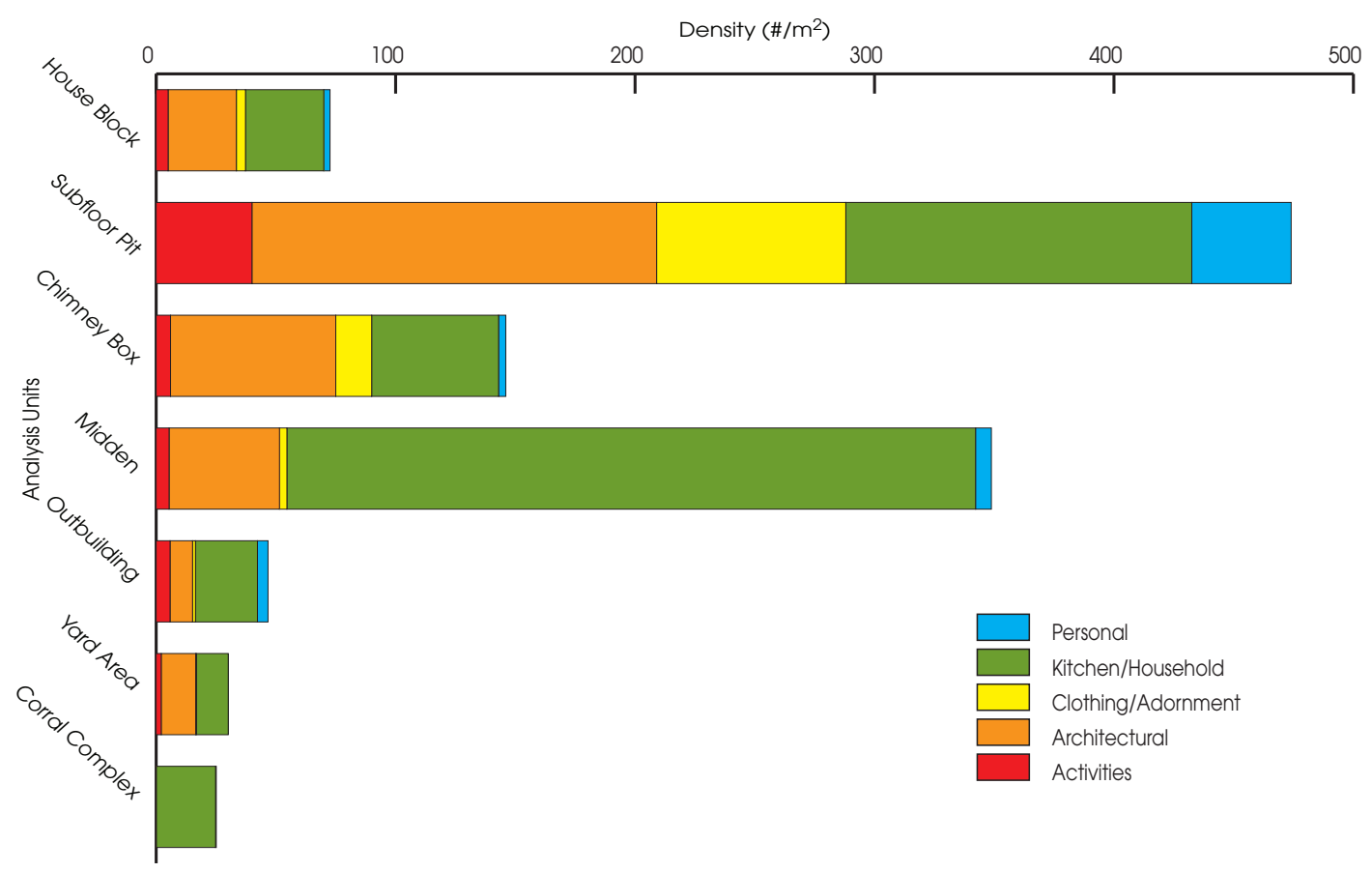

Figure 11.9. Graph of all excavated artifacts showing artifact density numbers by functional group and analysis unit.

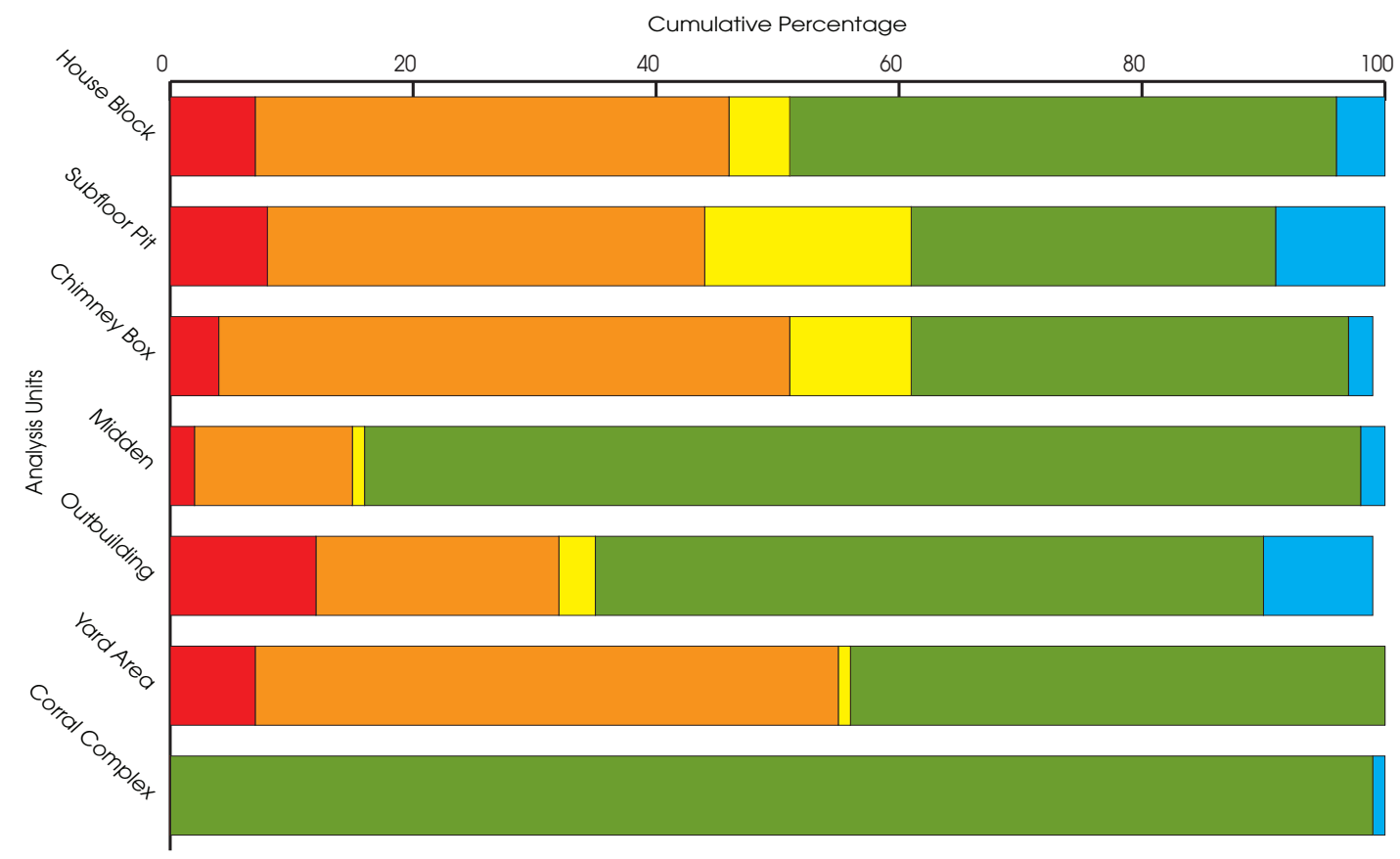

Personal

Kitchen/Household

Clothing/Adornment

Architectural

Activities

Figure 11.10. Graph of the all excavated artifacts showing artifact density cumulative percentage by functional group and analysis unit. 


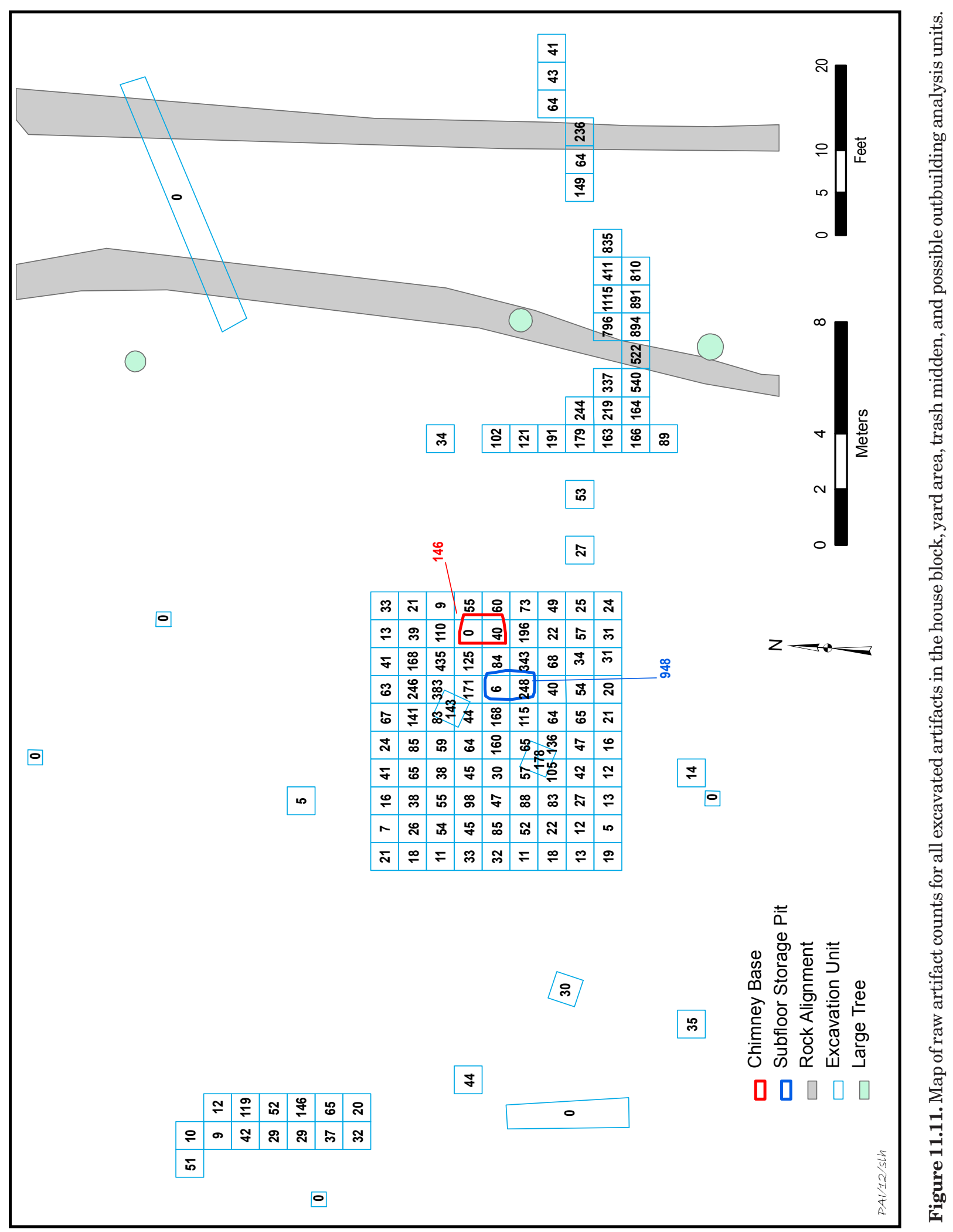


roots growing near the southeast corner. The field archeologists looked carefully for evidence of driplines anywhere in the house block, but no such evidence was found.

At different times during the Williamses' 35-year occupation, the house could have served as the home for many family members, including Ransom and Sarah, plus all five of the children (born between 1876 and 1892) who lived to become adults. Four other children were born and may have lived there for some time, but none of them survived into adulthood. So it is reasonable to assume that five to seven people lived on the farm in the 1880s and perhaps eight or nine people lived there in the 1890s until the children began to leave home. Regardless, it was a small house for a large family, as was typical for many late-nineteenth-century farm households.

The excavations provide no data that would reveal how tall the house may have stood. Unfortunately, even the chimney rubble pile was too scattered and mixed with other rocks to provide an accurate estimate of chimney height. Based on the fact that as many as seven to nine people lived in the house at one time, the house may have been one-and-a-half stories tall. In addition to the ground floor with an estimated 240 square feet of space, it is likely

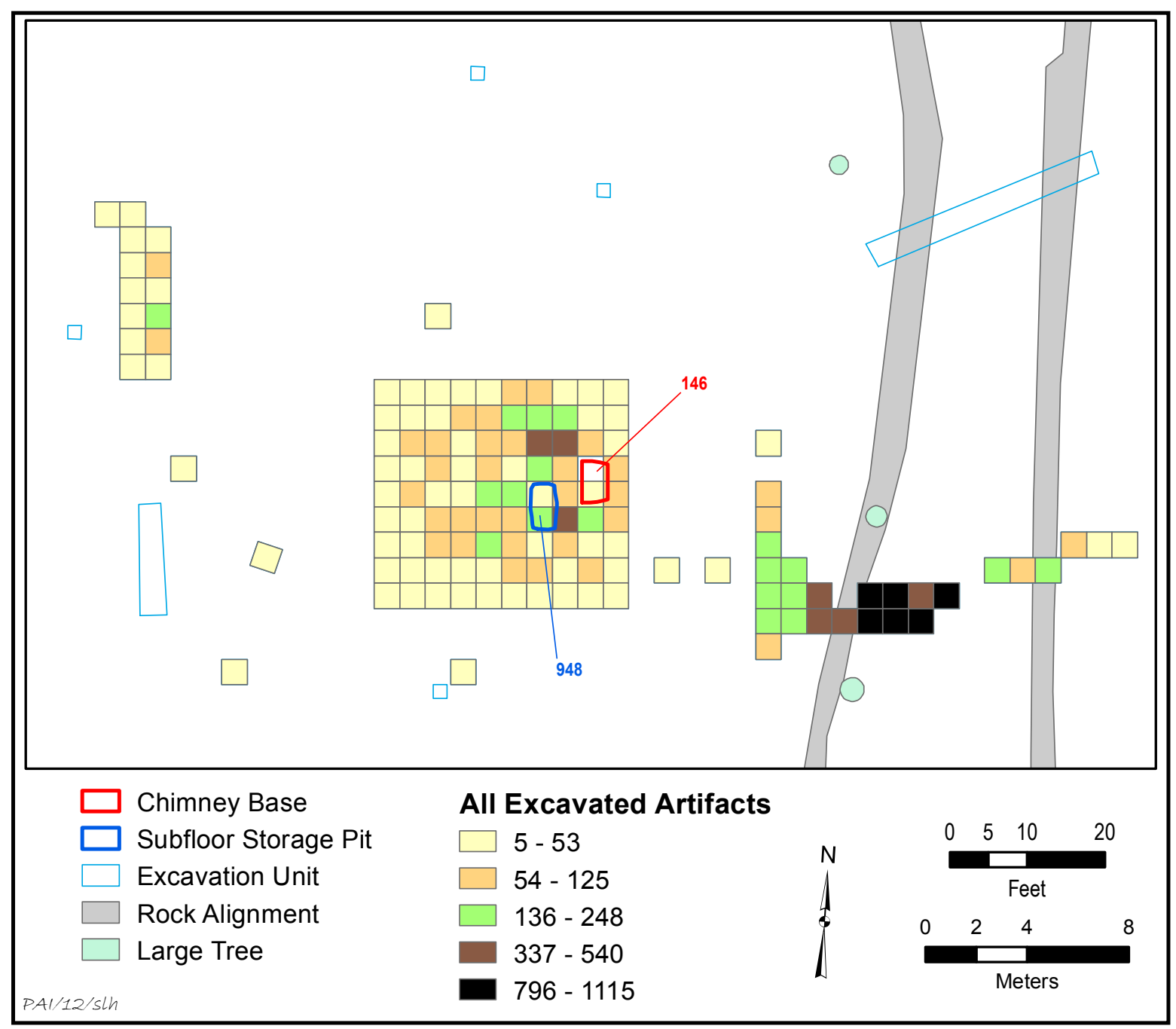

Figure 11.12. Artifact density map showing all excavated artifacts in the house block, yard area, trash midden, and possible outbuildings. 


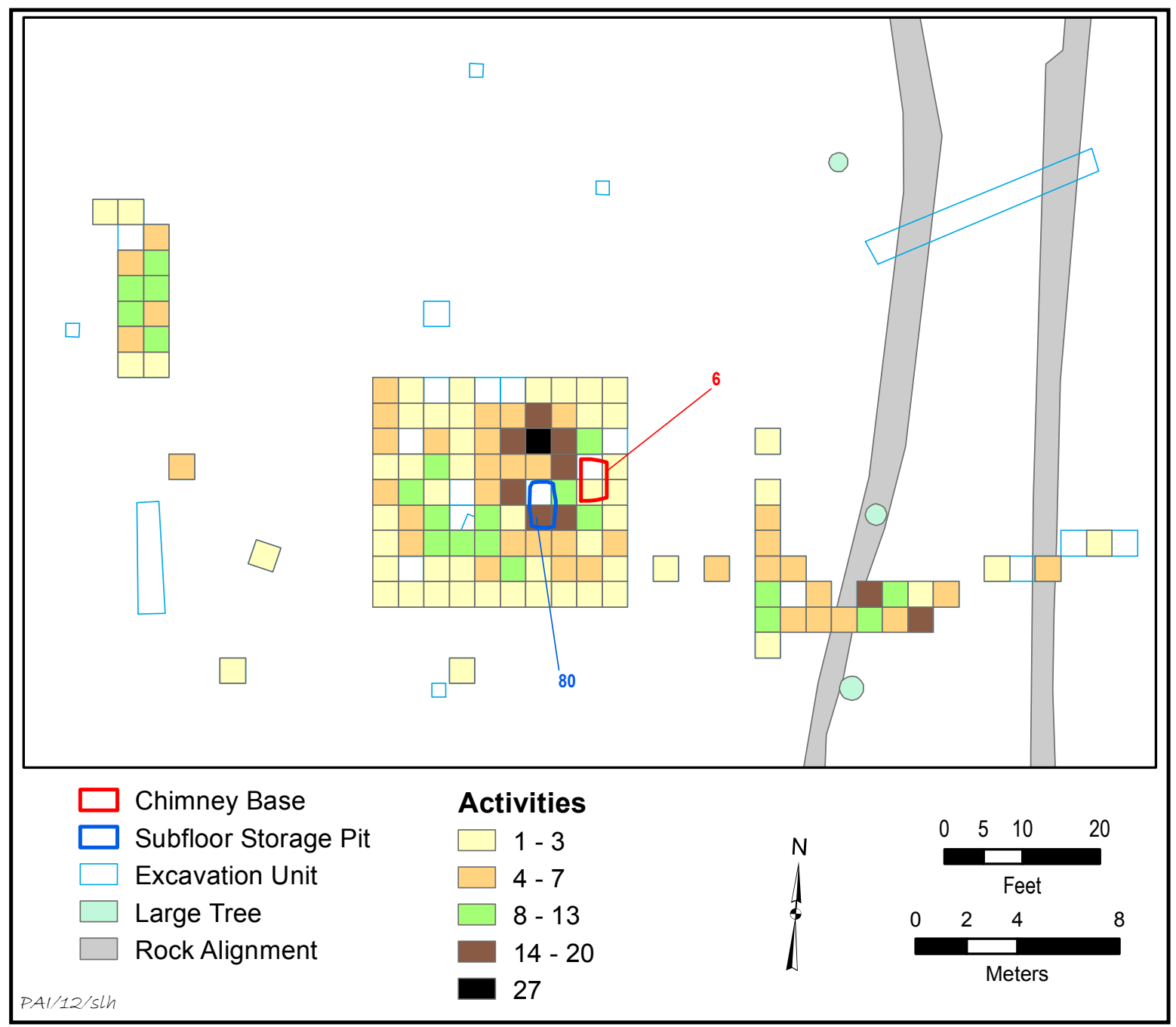

Figure 11.13. Artifact density map for the activities functional group in the house block, yard area, trash midden, and possible outbuilding analysis units. Total number of excavated artifacts in this functional group is 782 .

that a second-level loft provided additional living space over at least half of the house. This type of arrangement was typical for early pioneer log cabins, and Jordan (1978:133 notes) that "Even the smallest single-story cabin usually has at least an open half-attic sleeping loft for children... and access is by means of a ladder."

If the Williams house was a log cabin, ${ }^{120}$ its estimated size is very close to the typical

${ }^{120}$ Throughout this chapter, we present evidence in support of the theory that the Williams farmhouse was a log cabin. In July 2014, long after this report draft was written, Marilyn Dunnahoo McLeod (2014) dimensions of single-pen log cabins in Texas. Jordan (1978:111) notes that as opposed to rectangular log cabins:

The other basic type of single pen, the type dominant in Texas, has a square or roughly square floorplan... Normally, the dimensions of the four

discovered historical evidence in her research files that confirms that the Williams house was indeed a log cabin. This evidence is presented in Chapter 14 in a section called "Addendum: Historical Recollection of the Williams Log Cabin." 


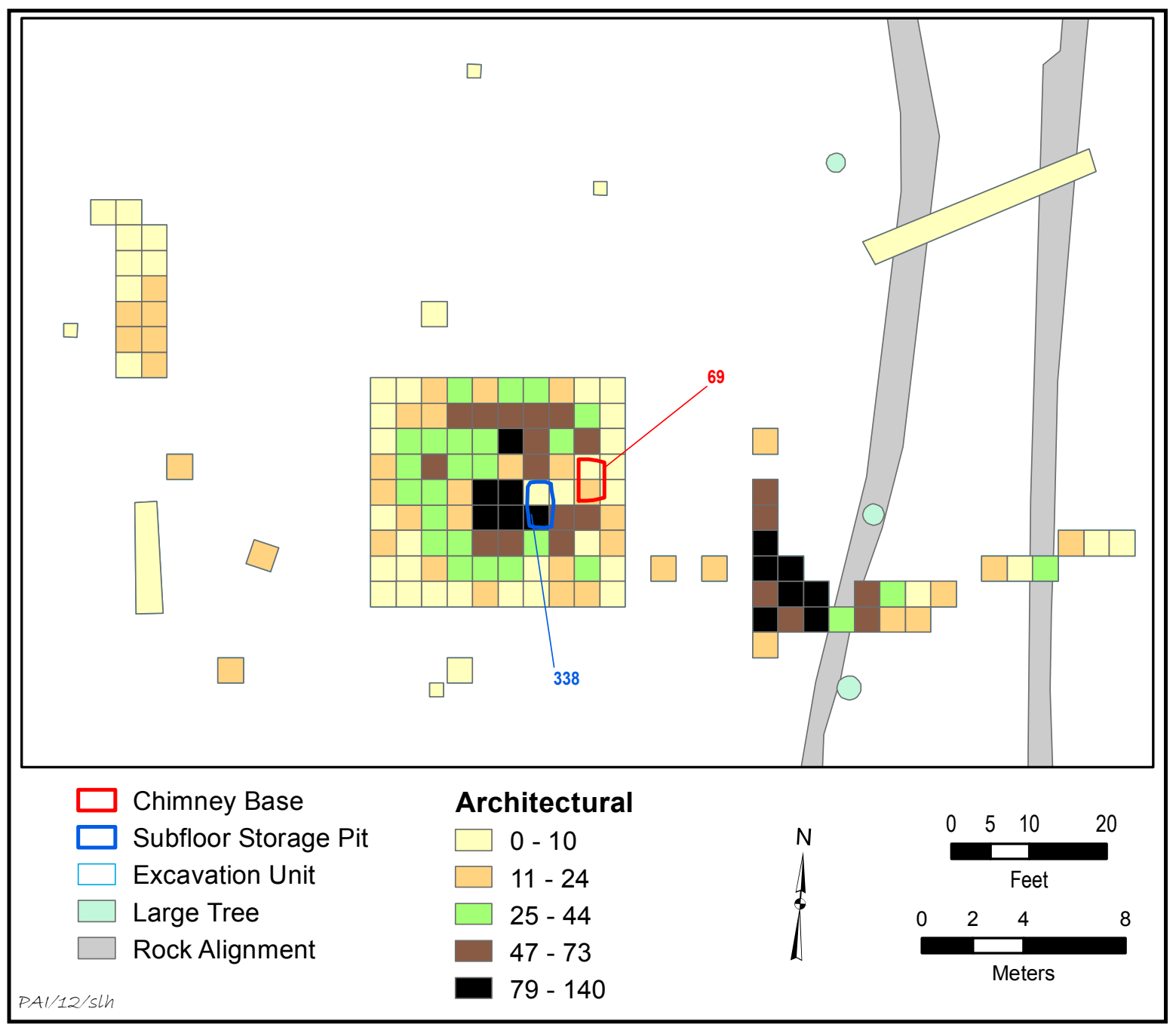

Figure 11.14. Artifact density map for the architectural functional group in the house block, yard area, trash midden, and possible outbuilding analysis units. Total number of excavated artifacts in this functional group is 4,447 .

walls are equal or within two or three feet of being equal. If the plan is not precisely square, the longer dimensions are on the front and back walls. The majority of such pens measure about $16^{\prime}$ ' $16^{\prime}$ to $18^{\prime} \times 18^{\prime}$, though smaller and larger examples can be found. Rarely if ever are square pens subdivided by partitions.

It cannot be stated with absolute certainty where the main entrance to the house was located or how many doors the dwelling may have had, but circumstantial evidence indicates that it probably had only one door on the south side. Jordan (1978:105-113) describes single-pen log homes in detail and provides the evidence for what the Williamses' log house probably looked like. First, the rock chimney was located on the east side of the Williamses' house, and almost all single-pen log houses in Texas had a gabled roof with the chimney on one of the gable ends. Almost all single-pen log houses in Texas also had side-facing gables relative to a single doorway, and front porches with long overhanging eves were common. The single door was a practical matter, because having a second entrance would effectively remove too much of the usable 


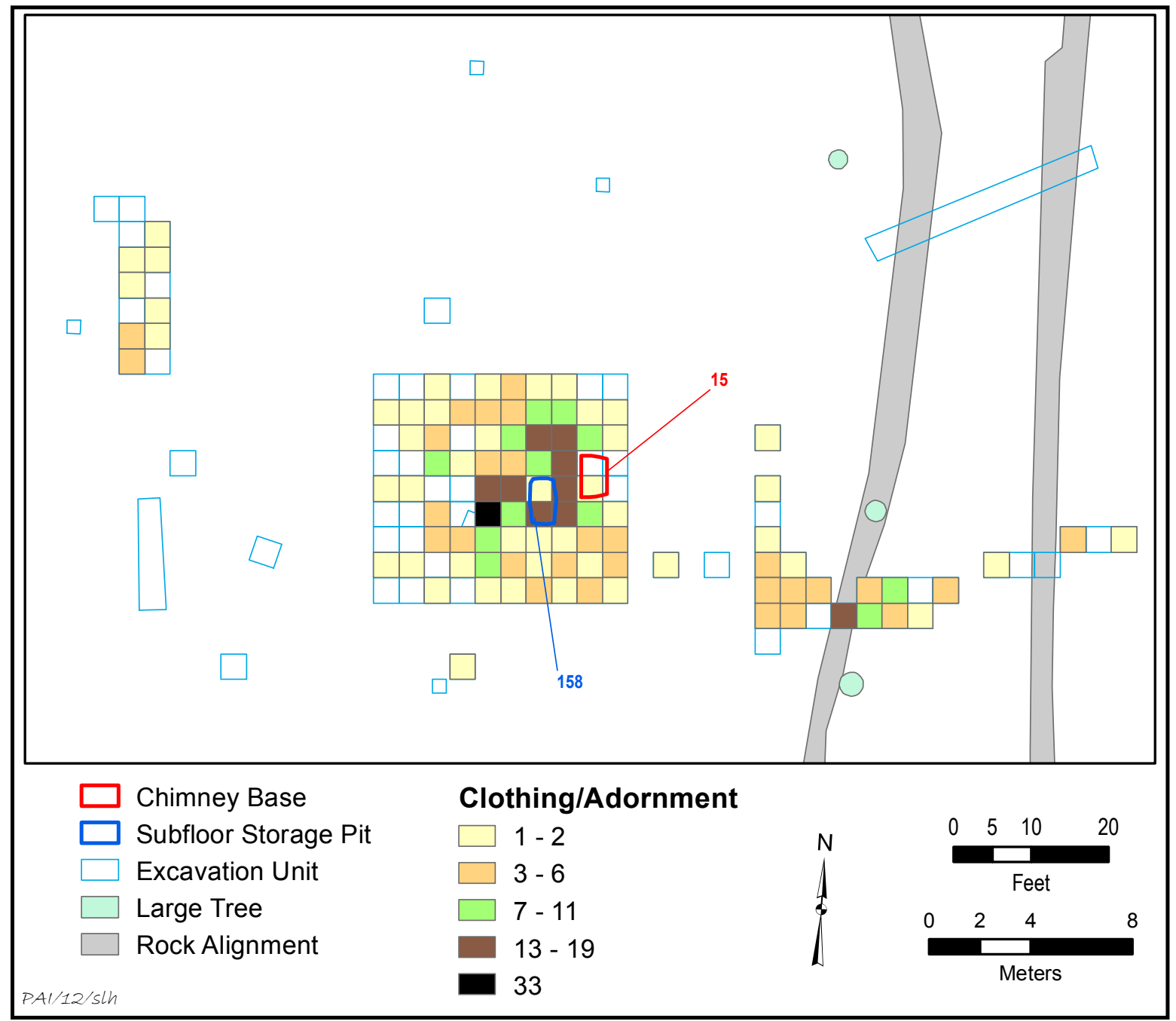

Figure 11.15. Artifact density map for the clothing/adornment functional group in the house block, yard area, trash midden, and possible outbuilding analysis units. Total number of excavated artifacts in this functional group is 622 .

floor space inside a small dwelling. The doorway was generally centered on one wall if the log house was square or nearly square, but the door was often offset on one long wall in rectangular single pens. This means that the Williams log home probably had a single door centered on the north or south side.

Prevailing winds in Travis County are southerly throughout the year (Natural Fibers Information Center 1987:479), and it would have been important to take advantage of the breeze during the hot Texas summers. Conversely, the arctic cold fronts that often hit central Texas in the winter months produce bitterly cold north winds. For these reasons, it is likely that the door of the Williamses' log house would have been on the south side. Additional circumstantial evidence for a southern entrance is that the most concentrated portion of the midden is located only 29 to $43 \mathrm{ft}$ ( 9 to $13 \mathrm{~m}$ ) east of the southeast corner of the house. Rather than walking all the way around the house from the west or north side, it is logical to assume that one would walk out of the south-facing doorway and turn left for the shortest walk to the east edge of the yard to throw out the garbage.

Just west and south of the fireplace, in the southeast corner of the house, was the subfloor 
storage pit that was offset to the right when facing the hearth. It is quite plausible that the south edge of this pit extended to where it met the south wall of the house, but it would not have gone under the wall. Using the southern edge of the storage pit as the approximate location of the south wall, it corresponds with a general east-west line of large rocks that would have been along the south wall. And there are two larger limestone slabs, one at the east end and one at the west end, that probably served as corner foundation stones. Assuming the house was relatively symmetrical in layout, measuring an equal distance to the north of the chimney's centerline there is another general east-west line of large rocks that would correspond with the north wall of the structure. There are also large limestone slabs on the east and west ends that probably served as foundation cornerstones. It is likely that the larger rocks in both of the east-west alignments once served as supports for wooden floor joists that spanned the short distance (north to south) across the house.

From the inferred south wall of the Williamses' log house, it is notable that another east-west line of rocks was present about 4 feet away, south of and parallel to the south wall. If the door was located in the center of the south

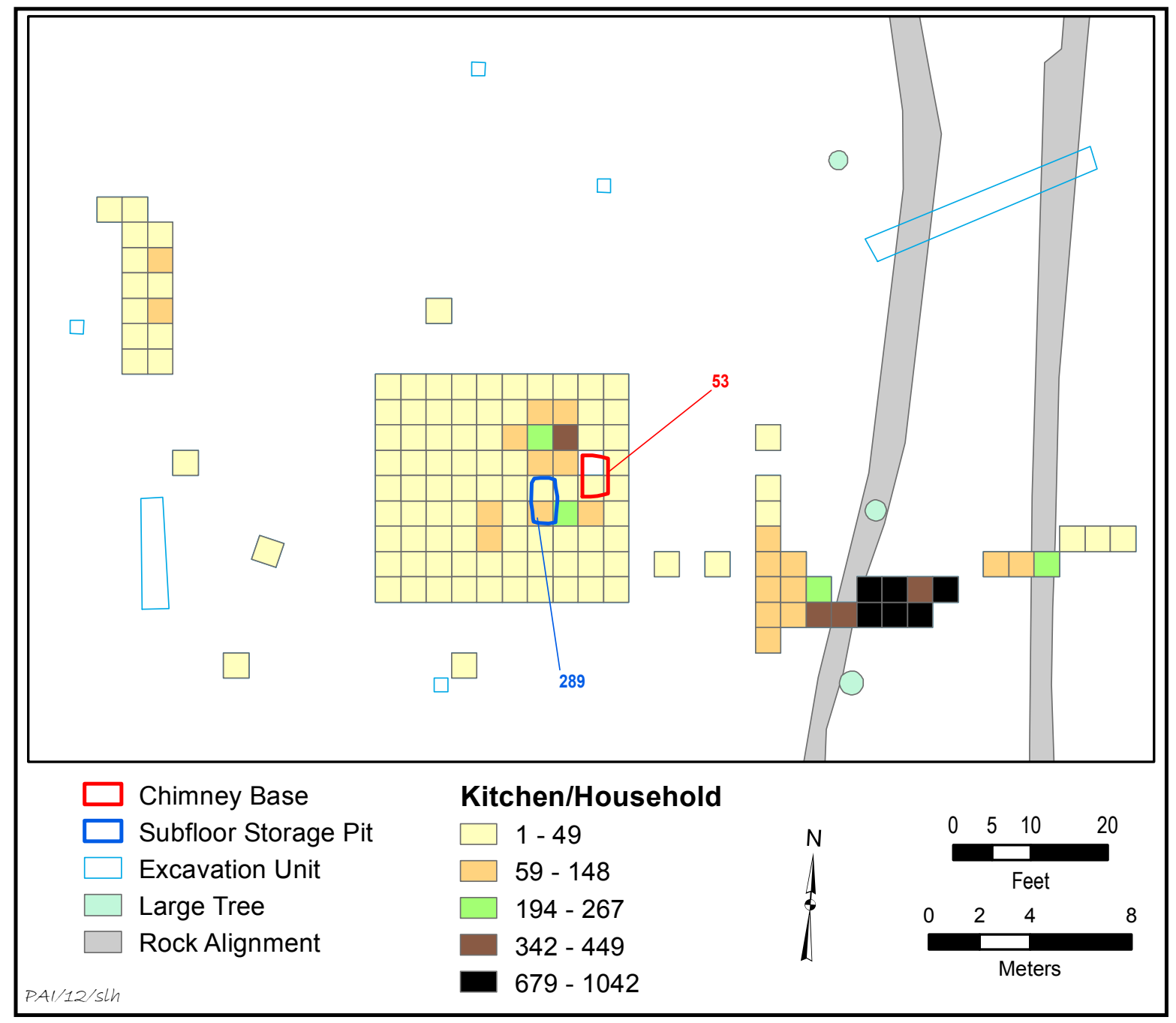

Figure 11.16. Artifact density map for the kitchen/household functional group in the house block, yard area, trash midden, and possible outbuilding analysis units. Total number of excavated artifacts in this functional group is 11,509 (excludes 99 specimens from the corral complex). 


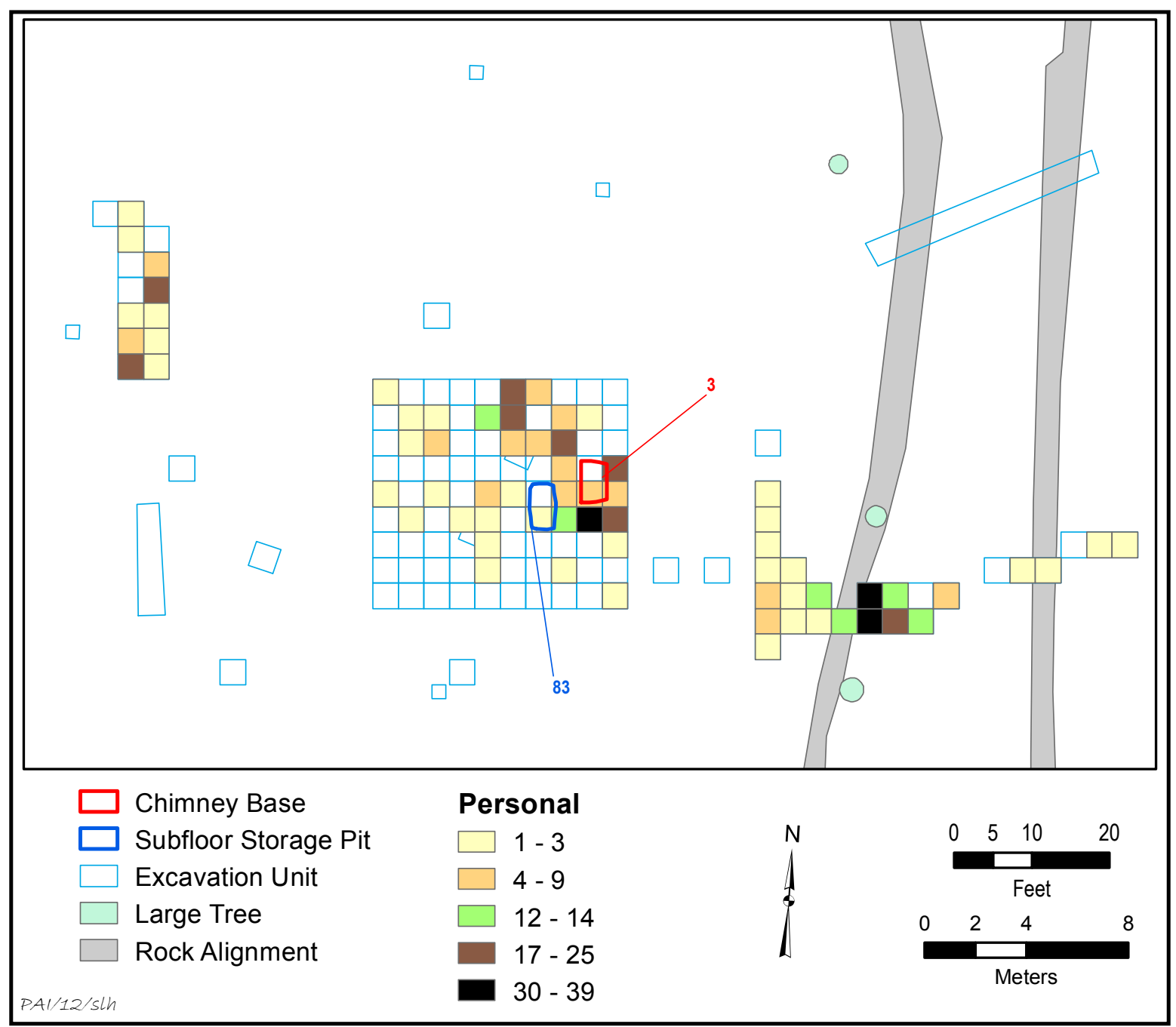

Figure 11.17. Artifact density map for the personal functional group in the house block, yard area, trash midden, and possible outbuilding analysis units. Total number of excavated artifacts in this functional group is 564 (excludes 1 specimen from the corral complex).

wall as suspected, this second alignment of stones probably represents a line of foundation rocks skirting the south edge of a front porch. If the house was a single-pen log cabin and the family lived there for more than 30 years, it seems almost certain that it would have had a long overhanging eve and a front porch on the south side of the dwelling. Most of the small square and rectangular single-pen log cabins in Texas illustrated by Jordan (1978:Figures 1-1, 3-10, 5-3, 5-7, 5-9, 5-12, 5-14, 6-4) had substantial overhanging eves or covered porches. Only one shows a log home with no eves and no porch; a second illustration shows a tall single pen in which the porch had obviously been removed (Jordan 1978:Figures 6-2 and 6-5).

Reconstructing what the Williamses' farmhouse looked like was one of the major goals of the archeological fieldwork and subsequent analysis. One of the important questions was whether it was a log cabin or a cut lumber (woodframe) house. As described above, the historical and structural evidence suggest it was indeed a $\log$ cabin. Figure 11.19 is an illustration of what it may have looked like. This image is a modified version of a drawing by Tammie J. Green (Lebo 1996:Figure 8-6). The original image was a reconstruction drawing of a log cabin at the 


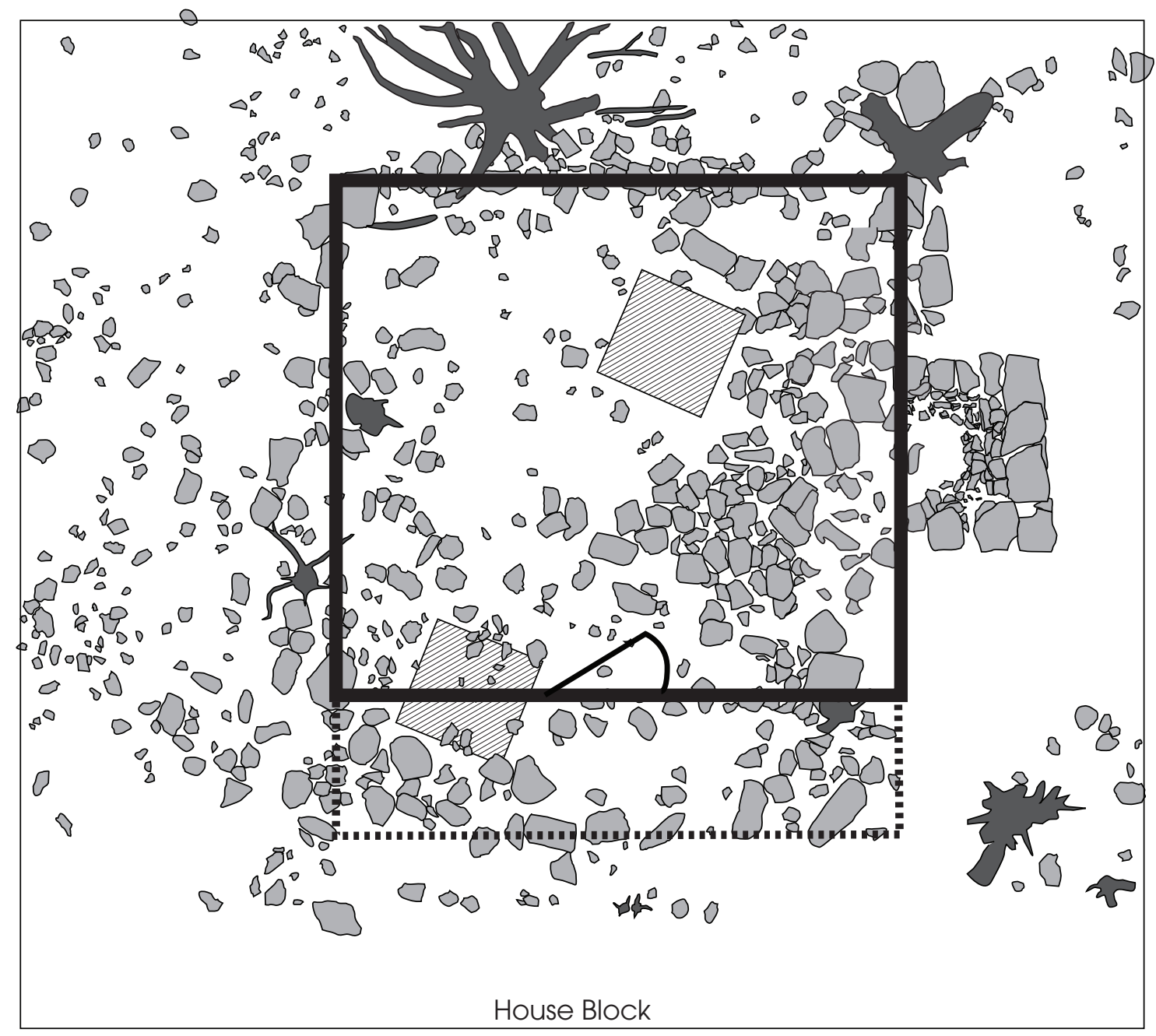

$L E G E N D$

\section{Rock}

House Wall (hypothesized)

uuu Porch (hypothesized)

$\sum_{\text {Tree }}$ Door (hypothesized)
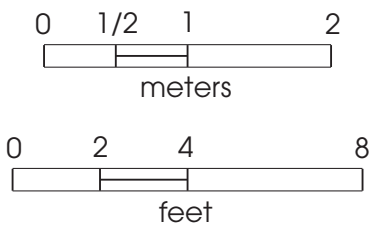

PAI/12/BW

Figure 11.18. Map of the house block showing the hypothesized structure footprint including the locations of the house walls, a porch, and a doorway. 
Jones Farmstead (41DN250), occupied from the late 1850 s to 1984 . The original image was flipped so that the chimney would appear on the right side when facing the front of the house, and a lean-to on the back side was removed from the drawing. This revised Figure 11.19 drawing shows a slightly rectangular, single-pen log home with a rock fireplace on one gabled side and a doorway and covered porch on one long side. Note the foundation stones at ground level in the corners and under the vertical posts along the front porch.

Since the historical and structural evidence suggests that the structure was a log cabin, the next question was: Does the artifactual evidence support the interpretation that the Williams family lived in a single-pen log house? Wood remnants (unburned) were found at the floor level near the fireplace. Bush (see Appendix D) identified four of the wood samples collected
(Lots 19, 25, 165, 468) from around the hearth as being from the white oak group, and two other samples from the same area as being juniper (Lot 166) and pine (Lot 165). Each of the samples is thought to be an architectural remnant based on the context and type of wood. The placement and orientation of two large sections of wood found just northwest of the northwest corner of the fireplace is interesting (Figure 11.20). They were underneath a large mass of fallen chimney rocks, which probably helped preserve them, and they appear to be two parallel logs or branch sections that ran east to west, perpendicular to the chimney. These logs, identified as white oak group (see Appendix D), lay horizontal at the bottom of the artifact zone, and they may represent the only surviving remnants of original floor joists. These logs were also at the same level as the second row of rocks in the chimney base. The pine wood sample could have been from a

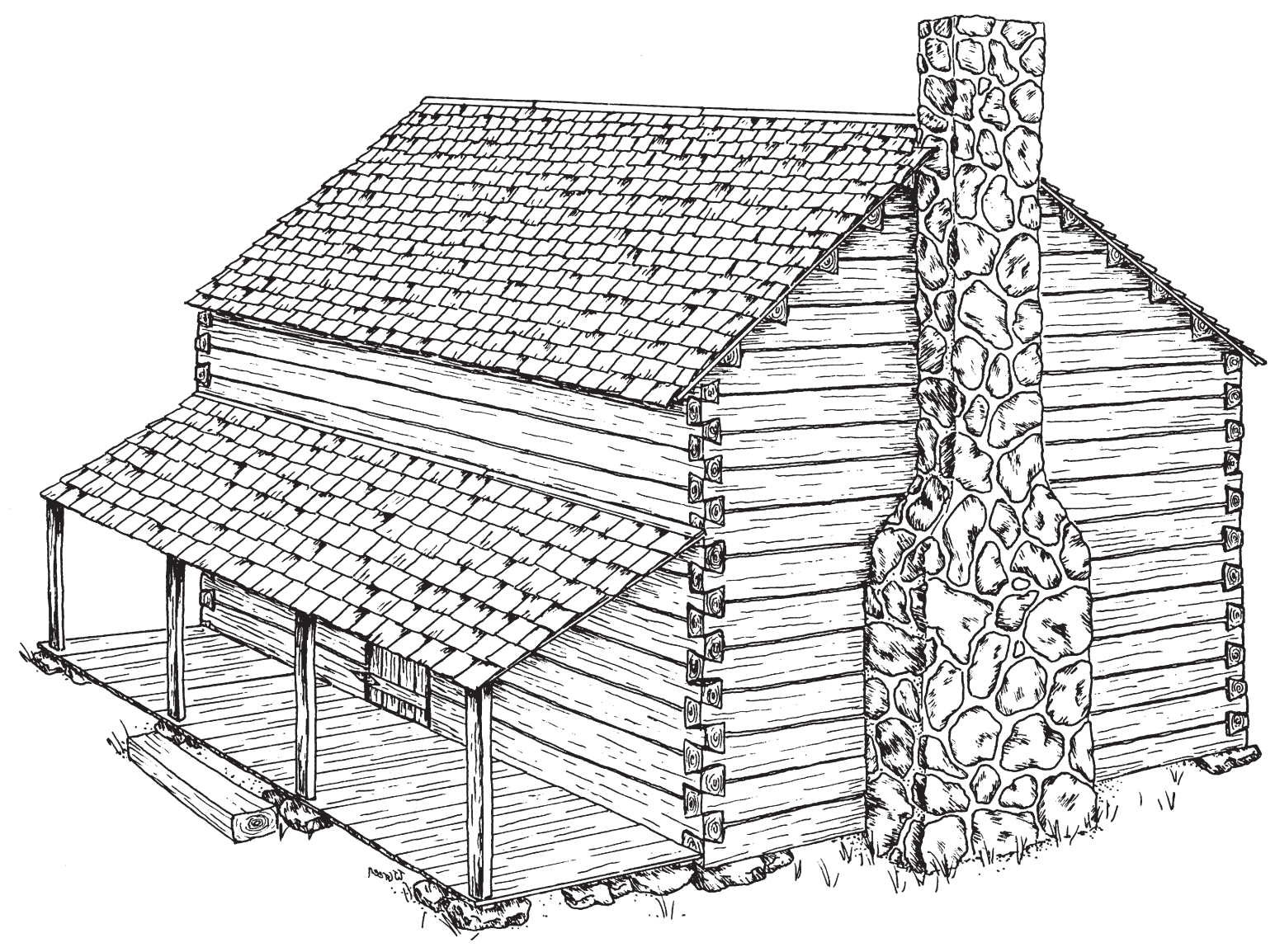

Figure 11.19. Drawing of a single-pen log cabin that approximates what the Williams house may have looked like. Modified from Lebo (1996:Figure 8-6). 


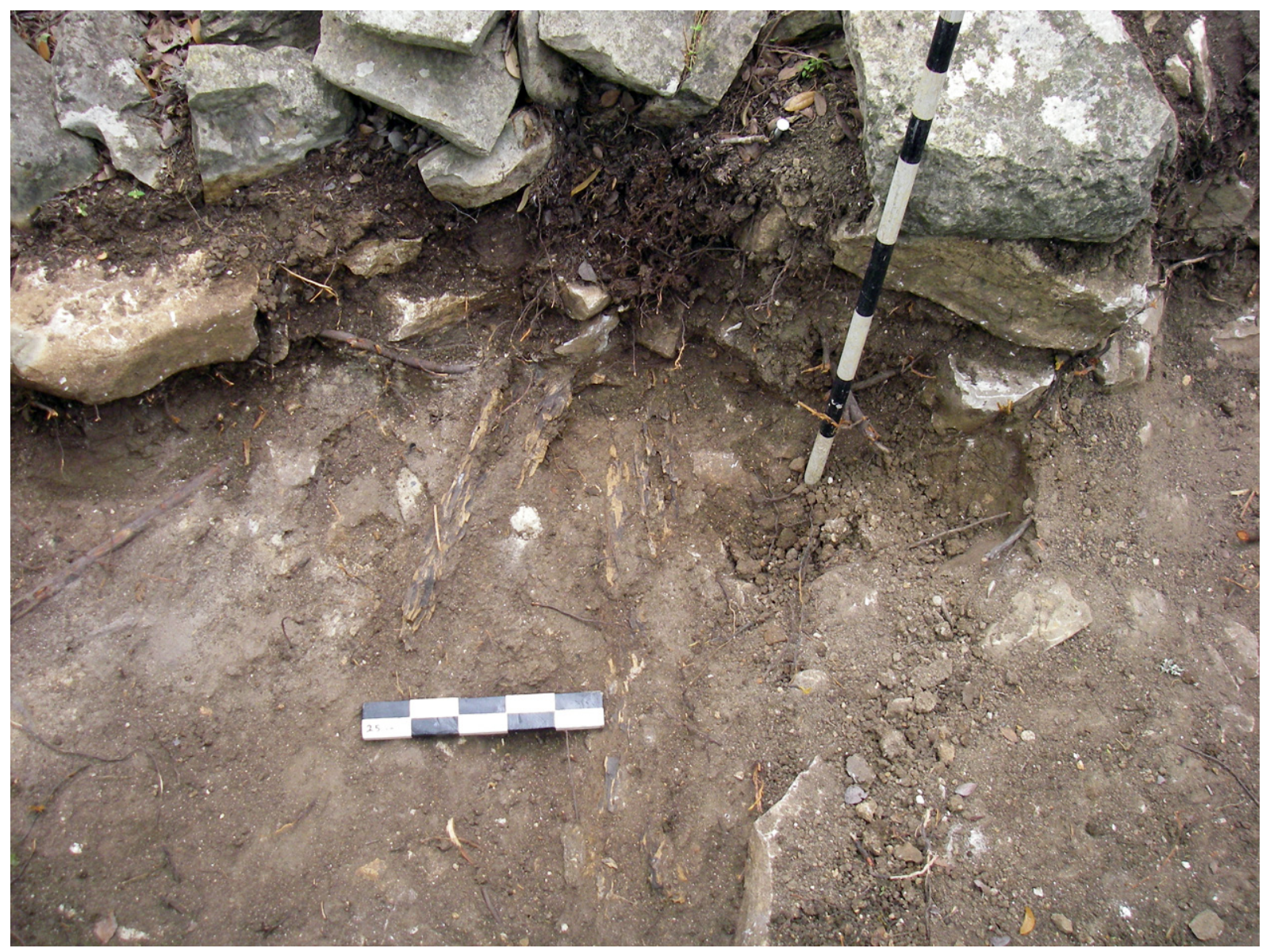

Figure 11.20. Photograph of preserved wooden logs running east to west at the northwest corner of the chimney base. These logs may be original floor joists onto which floorboards were nailed.

floorboard that spanned the area in front of the hearth that was nailed to the oak joists. As for the juniper, it may have also served as a floor joist because juniper is a very durable hardwood. With abundant oak and juniper trees on the property, these wood types would have been an obvious choice for construction material.

Lacking any other significant wood remnants, evidence of the type of house is limited to the spatial data described above, along with any clues that can be gleaned from architectural or household hardware that that might be associated with the dwelling (Figure 11.21). No obvious door butt hinges were found, but two large hinges could have been on a door. ${ }^{121}$ One is half of a long rectangular strap hinge (see Figure

${ }^{121}$ Many other hinges were found, but they are too small to have been used as door hinges. 11.20a), 15 inches long by 1.5 inches wide, found in EU 42 (just in front of the northwest corner of the chimney). It appears to be a hand-forged iron piece and, if it were used as a door hinge, it would have been from a homemade wooden door. The other is a triangular butterfly hinge (see Figure 11.20b), 12 inches long by 3 inches tall, found in EU 54 (just east of the chimney). This hinge could have been used on a wooden door, a window shutter, a piece of furniture (e.g., a large trunk), or something else. But the locations where both of these hinges were found do not make sense because they were not where any door would have been. Consequently, it is uncertain if either of these artifacts was actually a door hinge.

One architectural artifact is probably associated with the dwelling. A plain iron, 3x6-inch, rectangular doorknob plate (see Figure 11.21c) 


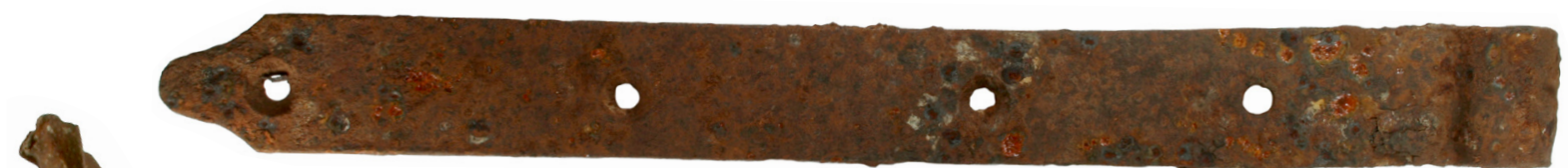

a
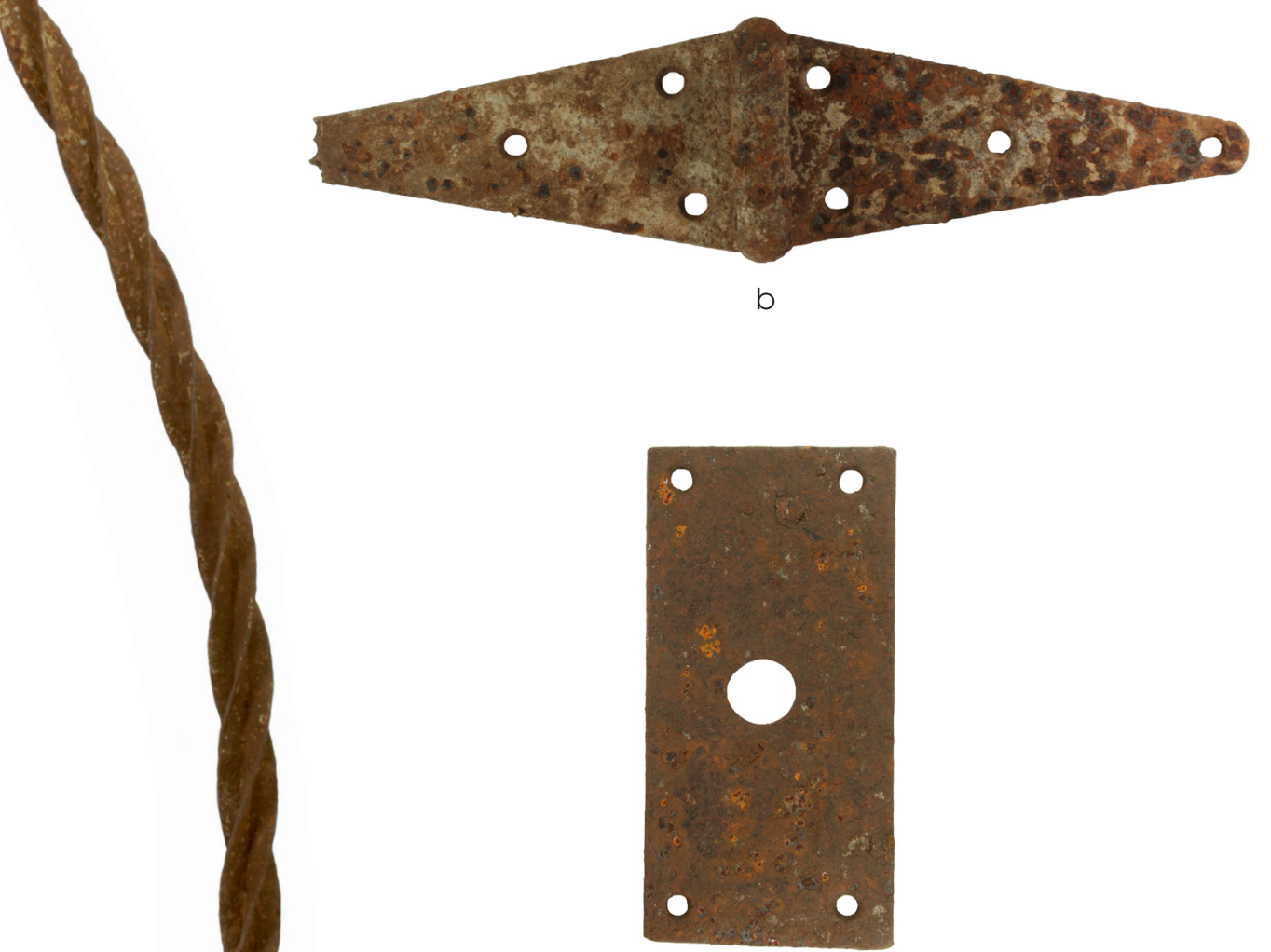

C
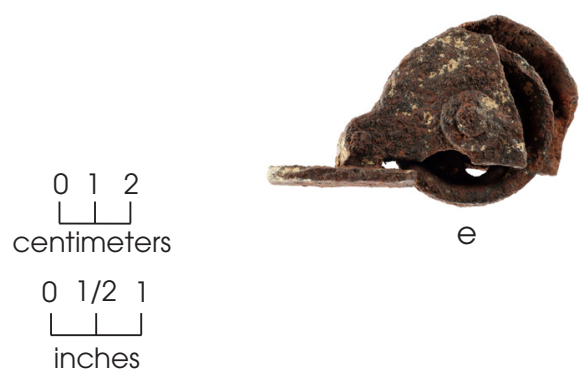

Figure 11.21. Photographs of selected architectural and household items from the house block. (a) Rectangular strap hinge; (b) triangular butterfly hinge; (c) door knob plate; (d) twisted iron lightning rod segment; (e) window sash pully mechanism. 
was found in the midden about $23 \mathrm{ft}(7 \mathrm{~m})$ east of the probable southeast corner of the house (in Unit EU E1). It has four screw holes, one in each corner, and a 13/16-inch hole through the center for the knob spindle to go through. Notably, this is an old-fashioned style that has no keyhole, indicating that the corresponding doorknob would not lock. Because this doorplate was found in the midden, it may indicate that the Williams family replaced an older door at some point. The lack of other diagnostic or more modern (i.e., turn-of-the century) door hardware perhaps should not be surprising. A valuable door and door hardware might have been removed by the Williams family when they left the property, and old doors and hardware are often removed from abandoned farmhouses by others.

One of the more interesting architectural artifacts recovered from the house block is a 21-inch-long section of a twisted-iron lightning rod found in EU 34 (see Figure 11.21d). The section has one broken end, while the other end has a white metal attachment with a 3/8-inch male screw attachment. A full lightning rod system would have required a stand for attaching to the roof, and would have likely been elaborately decorated, perhaps with a large glass bulb attached. In addition, it would have required numerous insulator clamps for attaching the ground wire to the side of the house as it ran to a ground-post driven into the earth. No other rod sections, decorative rod stand, or rod mounting clamps were found, begging the question: Was this heavy iron rod picked up and brought to the farm for another purpose? The rod section is bent into a long curve, and its broken end is battered with its edges bent in a spiraling direction as if it had been used as a drill or perhaps a soil auger.

While it has been suggested that the Williams house had a single door on its south wall, it is also likely that it had at least one window to allow a cross breeze. A single window would have been most effective if it were on the north side of the house. And if the structure had a loft, it may have had a small window high up on the west gabled end (opposite the chimney) to create a draft through the house. But it is notable that no flat window glass was found. This could mean that the house did not have windows at all, that it had windows without glass panes, or that the Williams family was very lucky and never broke any of their window panes or did a very good job cleaning up broken windows. But it is very unlikely that the house had no windows, and logic dictates that it probably had at least one or two. Assuming the house did have one or more windows, were they glass pane windows or simply openings with shutters? The answer may be both.

It seems unlikely that the Williams family could have had glass windows for 30 years without a single pane being broken and entering the archeological record! But what if they had open shuttered windows at first but added woodframe glass windows later on? It is plausible that a family that upgraded by adding a wood-burning stove ${ }^{122}$ might also have added fancier pane windows as well. Historical evidence shows that window glass was often considered a luxury and was very expensive initially but that it became more accessible and less expensive over time. An informant reported that a log cabin built in 1862 in Tyler County had glass windows but that this was so rare that people came from miles around just to see them (Crosby 1972:18). What made window glass such a luxury was not its availability but its cost. One can imagine that the cost of buying and transporting window glass panes to remote rural areas (without breaking it) was high before the railroad and good roads.

Two interesting artifacts found in EU 31 suggest that the Williams home may have had open windows with shutters early in its occupation, but that the family added a wooden frame and glass window a few years before they left. The artifacts are window sash pulleys (see Figure 11.21e), which are the interior parts to a wooden sash window casing. The pulleys are located inside the interior casing and are hidden from view when the window is installed. They serve as pulleys for strings and counterweights that helped raise and lower a single vertical pane, or sash. The upper window sash, probably a frame containing four or six separate glass panes, was immobile, while the lower window sash was similar but slid up and down with the aid of strings, the sash pulley mechanisms, and counterweights. While individual window sashes and the exterior hardware are easily removed and often taken intact from old houses, the window casements and interior hardware are difficult to remove and are almost always left in place. Interestingly, while one of the sash pulleys was

\footnotetext{
${ }^{122}$ Eighteen pieces of cast-iron stove were recovered (see Table A.11).
} 
from the general surface collection in the house area, the better-preserved specimen (see Figure $11.21 \mathrm{e}$ ) was found in EU 31, an excavation unit along the north wall of the house in the northeast corner. This would have been an ideal spot for a window to provide cross-ventilation and well as allow light into the kitchen area near the fireplace. But all this speculation is tempered by the fact that window sash pulleys would have needed interior counterweights, and none of these were found (or perhaps they were not recognized).

The next type of architectural evidence to examine with respect to the house is the nails. Table 11.4 summarizes the cut nails, wire nails, and fence staples found in different analysis units. The house block excavations yielded 1,540 cut nails and 388 wire nails along with a few hundred nail fragments (without heads). The nails with heads provide a minimum number of individual nails, and these appear to be fairly evenly distributed throughout the house block, with no significant concentrations apparent (Figure 11.22). Within the 90 units comprising the house block, the average density of nails was 21.4 nails per $\mathrm{m}^{2}$, with the ratio being 4 cut nails to every 1 wire nail. Assuming that the Williams house deteriorated naturally and that no major wooden components were hauled off the site, the total number of nails is far too low to account for a wood-frame house (e.g., a board and batten structure). Even if the 661 cut nails and 92 wire nails found in the midden had been part of the house (e.g., a porch area that fell and was dragged over to the midden), the total number of nails $(\mathrm{n}=2,681)$ is still much too low to account for an entire wood-frame house (again assuming no substantial components were robbed). However, this relatively small number of nails and low nail density would be expected if the house were a log cabin.

It is interesting to compare the density of 21.4 nails per $\mathrm{m}^{2}$ for the Williams house area to nail densities for log structures in northeast-central Texas (Jurney and Moir 1987:83-96). Jurney and Moir (1987:95-96) report the following nail densities for log structures: ${ }^{123}$

- $\quad 1.3$ to 5.2 nails per $\mathrm{m} 2$ for a pristine $\log$ structure

- $\quad 12.2$ and 12.0 per $\mathrm{m} 2$ for two log structures that had frame roofing and flooring

- 25.2 to 33.2 nails per $\mathrm{m} 2$ for two log houses that had extensive remodeling and framing

To further examine the possibility that the Williams house was a log structure, the nail

\footnotetext{
${ }^{123}$ Jurney and Moir provide data as nails per 50x50$\mathrm{cm}$ unit. Their density data were multiplied by four to convert to nails per square meter.
}

Table 11.4. Square cut nails, wire nails, and fence staples by analysis unit

\begin{tabular}{l|c|c|c|c|c|c|c}
\hline & \multicolumn{2}{|c|}{ Number of Specimens } & \multicolumn{3}{c}{ Density $\left(\right.$ No. per $\left.\mathrm{m}^{2}\right)$} \\
\hline Analytical Unit & $\begin{array}{c}\text { Area } \\
\left(\mathrm{m}^{2}\right)\end{array}$ & Cut Nails & Wire Nails & $\begin{array}{c}\text { Fence } \\
\text { Staples }\end{array}$ & Cut Nails & Wire Nails & $\begin{array}{c}\text { Fence } \\
\text { Staples }\end{array}$ \\
\hline House Block & 90 & 1,540 & 388 & 64 & 17.1 & 4.3 & 0.7 \\
\hline Chimney Base & 1 & 24 & 3 & 2 & 0.3 & 0.0 & 0.0 \\
\hline Subfloor Pit & 2 & 120 & 94 & 11 & 1.3 & 1.0 & 0.1 \\
\hline $\begin{array}{l}\text { Trash Midden } \\
\text { (East and Slope } \\
\text { combined) }\end{array}$ & 27 & 661 & 92 & 39 & 50.8 & 7.1 & 3.0 \\
\hline Outbuilding & 14 & 52 & 15 & 0 & 3.7 & 1.1 & 0.0 \\
\hline Yard Area & 7 & 48 & 15 & 0 & 6.9 & 2.1 & 0.0 \\
\hline TOTAL & 141 & 2,445 & 607 & 116 & 17.7 & 4.4 & 0.8 \\
\hline East Midden & 14 & 545 & 83 & 17 & 38.9 & 5.9 & 1.2 \\
\hline Slope Midden & 13 & 116 & 9 & 22 & 8.9 & 0.7 & 1.7 \\
\hline
\end{tabular}




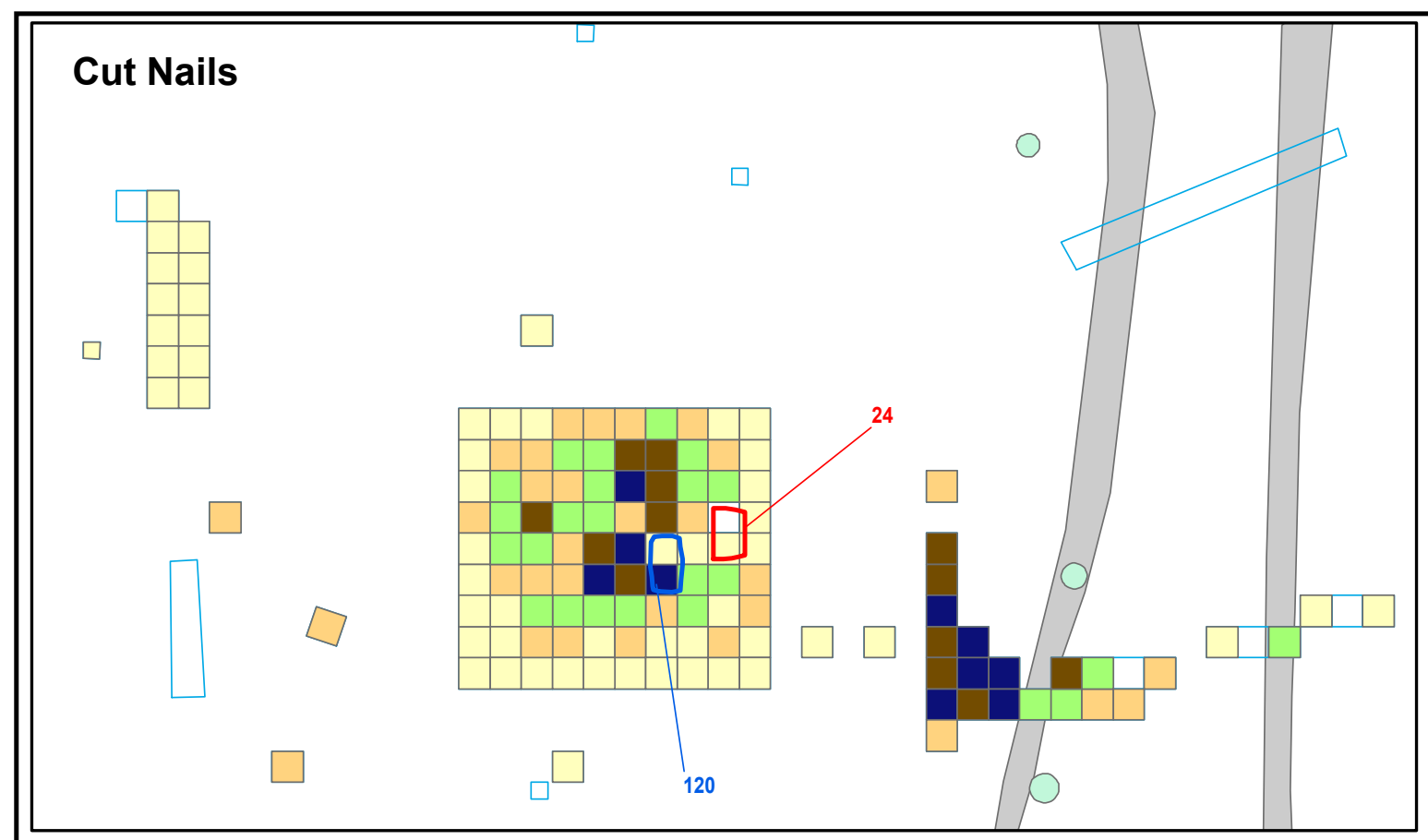

\section{Wire Nails}

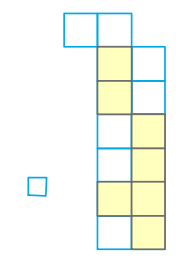

.
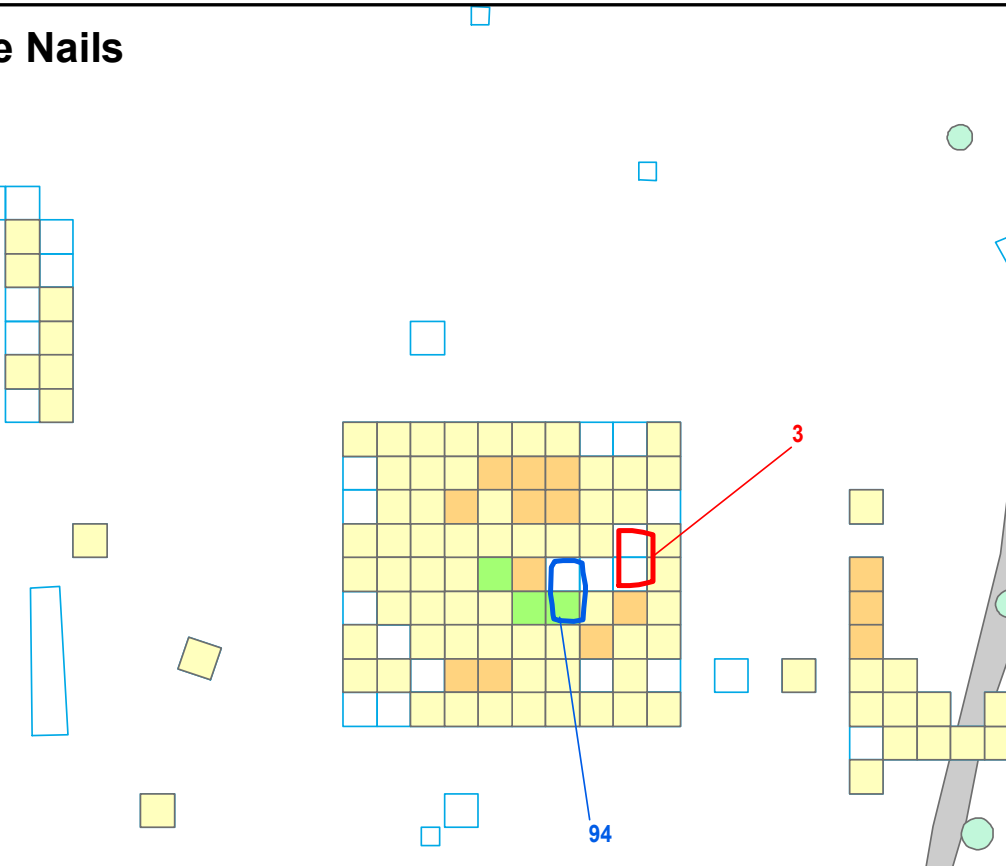
Nails
$\square 1-10$
$\square 11-22$
$\square 24-40$
$45-62$
$67-93$

Chimney Base

Subfloor Storage Pit

Excavation Unit

Large Tree

Rock Alignment

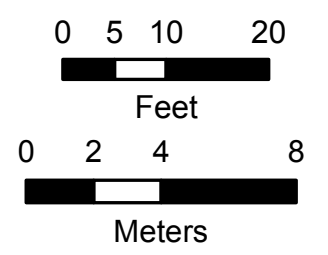

Figure 11.22. Maps showing distributions of cut nails and wire nails in the house block, yard area, midden, and outbuilding. 
density data for the house block was compared with similar data from the dwelling areas of two nineteenth-century log cabin sites in Navarro and Grimes Counties, Texas. At 41NV386, a total of 171 nails (25 cut and 146 wire; fragments excluded) were recovered from six $1 \times 1-m$ excavation units in the house area (Skinner and Craver 2008:Table 2), resulting in a density is 28.5 nails per $\mathrm{m}^{2}$ in and immediately around the house. The structure at 41 NV386 was a single-pen log structure initially occupied between 1840 and 1860 (Skinner and Craver 2008:26). At 41GM410, 248 nails (both wire and cut) were recovered from 21 1x1-m units within the house block excavations, resulting in a nail density of 11.8 nails per $\mathrm{m}^{2}$ (data extracted from Skinner et al. 2008:Appendix A). Based on the ratio of density of nails, the archeologists inferred that the 41GM410 structure was probably a log cabin, which is a logical interpretation given that the structure was probably built in the late $1840 \mathrm{~s}$ and occupied primarily before the Civil War (Skinner et al. 2008:46-50). The nail density for the Williams farmhouse $\left(21.4\right.$ per $\left.\mathrm{m}^{2}\right)$ falls right between the nail densities for the Navarro $\left(28.5\right.$ per $\mathrm{m}^{2}$ ) and Grimes County (11.8 per $\mathrm{m}^{2}$ ) $\log$ homes. The paucity of nails supports the idea that the Williams house was a log cabin, and the relatively low number of wire nails suggests that there were some minor structural additions or alterations that postdate the original construction.

Within the Williams farmstead house block, the cut nails were most concentrated near the probable center of the house. Perhaps this was where more parts of the house containing nails (such as the roof and floor) ended up as the house collapsed, or possibly it was an area where several pieces of furniture or other objects made with nails had been. For reasons unknown, the midden produced an even higher ratio of cut to wire nails than did the house block ( 7.2 cut to wire nails in the midden vs. 4.0 cut to wire nails in the house block), and the cut nails were much more concentrated in 11 units in the western end of the midden than anywhere in the house block (see Figure 11.22). This concentration gave rise to three speculative ideas. One is that some part of the original house was removed and discarded in this location, perhaps during a remodeling episode in which a porch, roof, or floor were replaced. Another possibility is that parts of another old structure were discarded in this location, perhaps a small shed that was torn down and replaced. The third notion is that there may have once been a small wooden structure (e.g., a chicken coop) located in this area prior to the accumulation of the eastern midden deposits. There is no viable way to objectively evaluate these ideas or determine the ultimate origin of the cut nail concentration in the eastern midden deposits.

The coming of the railroad to the Austin area would have made all types of mass-produced items more easily accessible and reduced the cost of bulky construction materials such as cut lumber. It is likely that milled lumber would have become much more affordable after the International and Great Northern Railroad was completed from Austin to San Antonio in 1881 (see Chapter 5). Prior to that, the cost of buying and transporting enough milled lumber to build a house would have been significant. This is especially true in 1871, when Ransom Williams acquired his land just as the Bear Creek section of southern Travis County was being settled. In contrast, there would have been a large supply of good hardwood trees, including oaks, on Williams's property, and he would have had to clear the trees off of the flat areas to convert them into cultivated fields. With the incentive to clear many trees on the property, Williams would have had a large supply of big logs available at no additional cost.

Many of the artifacts recovered at the farmstead are woodworking and carpentry tools that a pioneer settler would have been needed to construct a log cabin in the 1870s. An axe would have been needed for chopping wood, and one was found in the slope midden with a metal detector (Mapped Artifact 49; Lot 440). This is an old hand-forged iron axe head with its butt end intensively battered by use as a wedge. It was discarded into the midden because the butt end split, rendering it virtually useless. Several drawknives were found, including one complete 12-inch drawknife blade that had been discarded (found in upper fill of the subfloor pit in EU 61; Lot 335). This large drawknife was the precise tool needed to shave logs and create flat surfaces so they could be stacked for the cabin walls. A very distinctive turnbuckle (found in EU 30; Lot 139) indicates that Williams had a bucksaw, and many fragments of saw blades were recovered (e.g., EU E6; Lot 307). A bucksaw was the perfect type of hand saw for cutting logs to their appropriate lengths and cutting the end 
notches for the corners. Ten auger bits ranging in diameter from 5/16-inch to 3/4-inch were found (see Table B.36). The larger ones would have been used to bore holes for pegging logs together at the joints. The fact that six of the ten auger bits are broken testifies to their hard use life. Williams probably would have used the $16-\mathrm{oz}$ claw hammer head found in EU 79 (Lot 229) for nailing down shingles and flooring and the 7 $1 / 4$ inch by $15 / 8$-inch wedge found in the house area (general surface collection; Lot 382 ) for splitting shingles and other small pieces of wood.

Two woodworking tools that Williams probably owned but were not found at the site are a froe and an adze. Both would have been used in log cabin construction - a froe for splitting shingles and an adze for thinning wood planks. It is notable that distinctive adze-like marks were found inside a large opening in the giant oak tree just southeast of the house. Honeybees may have occupied this opening while the Williamses lived on the farm, as they currently occupy a large knothole in the large neighboring oak tree. Perhaps an adze or something similar was used to create a larger opening in the trunk to facilitate harvesting honey (see Tree Features in Chapter 6). So even in the absence of the actual tool, we have probable evidence for an adze at the farmstead.

With all of the woodwork occurring on the farmstead, one of the most important tools would have been a grinding wheel. Williams would have needed some kind of grinding stone for sharpening his axe, drawknife, froe, adze, and other blade tools. Although no grinding stone was found, parts of the grinding stone mechanism were found. These include a crank handle (EU 73; Lot 218) and a matching wheel bracket (EU 28; Lot 329) and wheel cover (EU 26; Lot 134) from a hand-cranked grinding wheel. That these associated pieces were found up to $7 \mathrm{~m}$ apart within the house block probably represents post-abandonment disturbance. It is doubtful that bioturbation (i.e., tree roots) moved these large objects this far, so in this case it is more likely that the grinding wheel was already in pieces or removed before the final collapse of the house or that someone removed the stone long after final abandonment.

Historical evidence from the Bear Creek community and surrounding areas indicates that many of Williams's neighbors built log cabins when they first settled in the area (see Chapter 5). In 1854, a Kentucky immigrant named Carpenter arrived and built a log cabin at the mouth of Bear Creek where it empties into Onion Creek, and Tennessee immigrants named Thomas and Fielding built log homes near Mountain City in 1855. Additional historical evidence for the use of log cabins by early settlers in the area comes from the Onion Creek community in Hays County, located about 7 miles southwest of the Williams farmstead. The Onion Creek community dates from ca. 1851 to 1883 , and at least eight of the homesteads there probably had log cabins (Roberson 1972:41, 44, 103).

Victor Labenski, a Polish immigrant, built a log cabin in 1850 that was located only a few miles east of the property that Williams purchased two decades later (see Chapter 4). The Labenski family lived in the area for many years, and Victor's son Daniel purchased the 120 -acre property just east of the Williams farmstead in 1872. It is not known if Daniel Labenski built a log cabin there before he built his larger home (Marilyn McLeod, personal communication 2010). It is likely Ransom Williams built a log home that was very similar to the Victor Labenski cabin (see Figure 4.3). The cabin fell into ruin many years ago, but undated architectural drawings and notes made by University of Texas architecture students before its collapse reveal many of the important details. The notes were transcribed by one of Labenski's descendants, Marilyn McLeod (personal communication 2010). ${ }^{124}$ The details of the Labenski cabin are summarized as follows:

- It was a "single pen log cabin"; the measured drawings show a 16x16-ft single pen with a porch extending out about $9 \mathrm{ft}$ 2 inches in the front and a shed room projecting $9 \mathrm{ft} 10$ inches attached to the back.

- It was built ca. 1850-1854.

- The foundation was reported to be "Hand hewn oak sills on cut limestone piers."

- The walls were "Hand hewn oak logs joined at the corners with a square notch."

- The "chinking material" was "native limestone set in lime mortar."

\footnotetext{
${ }^{124}$ The Victor Labinski (mispelled) log cabin documents are listed in the online inventory of documents in the "Texas Architecture Archive" of the University of Texas, School of Architecture (Texas Architecture Archive 2010).
} 
- The floor was "Random width pine tongue and groove boards surface nailed with square cut nails," while the floor joists were "native cedar logs hewn flat on top surface."

- The ceiling had exposed joists of sawn pine wood and it appeared to have a sleeping loft accessed from the interior by ladder or stair."

- It had a "pitched or gabled" roof with a 5/12 slope and wood shingles "applied to 1 x 4 nailer on round native cedar pole rafters."

- The gables were "enclosed with horizontal pine clapboards, square nailed."

- Its porch had been removed but the materials were onsite and the porch was mapped on the floor plan.

- The rear shed was "box frame construction with vertical cedar board and batten walls and cedar random width floor. All square nailed."

- The fireplace had been dismantled but the "native limestone foundation" was intact.

It is interesting that no windows are mentioned in the architectural notes or are clearly depicted in any of the photographs or sketches of the Victor Labenski log cabin.

The autobiography of Gus Birkner (18611956) provides further evidence that log cabins were built in the area. Birkner lived in central Texas most of his life, and he wrote an autobiography that was transcribed by a relative (Chambers n.d.). It provides many details regarding life in southern Travis County in the late $1800 \mathrm{~s}$. Birkner recalled that he was a teenage boy when he moved to the "Slaughter farm" in southern Travis County with his father in 1874 (Chambers n.d.:6). He said: "We lived in a little log room with a shed attached. The shed room had only a dirt floor, but the log room had a wooden one." Birkner went on to state that: "In 1875 we moved to Bear Creek and lived in the old Picken log house, previously a school building, containing one room." Birkner also stated that he and his father moved into a small wood-frame house nearby about six months later. This evidence indicates that wood-frame and log houses were both being used on Bear Creek about 1875, and the houses he mentioned would have been fairly close to Ransom Williams's property.
If the Williams farmhouse was a single-pen $\log$ cabin, as we suspect, ${ }^{125}$ what were the 1,928 nails used for? It is likely that the majority of these nails, which were scattered all across the house block (see Figure 11.22), were associated with some part of the structure (e.g., roofing nails, flooring nails, nails in doors and door frames, and nails in window frames and shutters), although some portion of the nails could also have been furniture nails or hanger nails (i.e., nails in wall to hang objects from). The 1,928 nails from the Williams house block is about 50 percent of the total number of nails estimated $(\mathrm{n}=3,854)$ for a single-pen log cabin in Freestone County in northeast central Texas (Jurney and Moir 1987:Table 6.1). Even if the 753 nails found in the midden represent portions of the original Williams house that were moved away from the house block, the total number of nails in the house block and midden combined is 2,681 (see Table 11.4). This is still a reasonable amount of nails for a small log cabin. Comparing the number of cut $(\mathrm{n}=2,201)$ and wire $(n=480)$ nails in both areas, the ratio is 4.6 cut to 1 wire nail.

To investigate this issue further, the cut nails recovered from the house block were examined and sorted into size groups (as discussed in more detail in Chapter 8). The sample was limited to the cut nails because they likely represent the initial construction, while the wire nails probably represent later additions or repairs. The 1,540 cut nails (excluding fragments without heads) were sorted into four size groups (Table 11.5), and the common historic use for each size of nail is listed based on an analysis conducted at Richland-Chambers Reservoir in northeast central Texas by Jurney and Moir (1987:87 and Table 6.2). Most of the cut nails (66 percent) from the Williams house block are small nails (less than 1.75 inch), which were commonly used for wood shake roofing and roof battens. The medium, large, and extra large nails are more commonly used for superstructure framing, wallboards, and other tasks. Medium to extra large nails combined account for only 403 cut nails. If the Williams house were a log cabin, this evidence would suggest that most of

\footnotetext{
${ }^{125}$ Documentary evidence found after this chapter was written confirms that the house was a log cabin. This evidence is presented in Chapter 14 in a section called "Addendum: Historical Recollection of the Williams Log Cabin."
} 
Table 11.5. Cut nails found in the house block excavations by size group

\begin{tabular}{l|c|c|c|c|l}
\hline Size Group & Penny Weight & $\begin{array}{c}\text { Length } \\
\text { (inches) }\end{array}$ & $\begin{array}{c}\text { No. of } \\
\text { Nails }\end{array}$ & Percent & \multicolumn{1}{|c}{ Historical Use* $^{*}$} \\
\hline Small & 5D or smaller & 1.75 or less & 1,021 & 66.3 & Wood shake roofing and roof battens \\
\hline Medium & 6D to 8D & $2-2.5$ & 155 & 10.1 & $\begin{array}{l}\text { Frame superstructure, wall boards, } \\
\text { and wall battens }\end{array}$ \\
\hline Large & 8D to 10D & $2.5-3$ & 171 & 11.1 & $\begin{array}{l}\text { Frame superstructure, wall boards } \\
\text { and batten, flooring, window frames, } \\
\text { door jambs }\end{array}$ \\
\hline Extra Large & 10D or greater & 3 or greater & 77 & 5.0 & Joists and sills \\
\hline Other** & - & - & 116 & 7.5 & - \\
\hline
\end{tabular}

* The historical uses are derived from analyses of historic structures at Richland-Chambers Reservoir by Jurney and Moir (1987:83, 87, Table 6.2).

**Includes nails that appear complete but are too deteriorated to accurately size. Many are rusting away or are head fragments with most of the shank missing.

the small nails were used for roofing and most of the larger nails were used for flooring.

Additional archeological evidence for the house having had a wooden floor comes from the stratigraphy and the distribution of buttons (Figure 11.23). The house sits on an eroding limestone bench, and given the rocky nature of the local soils, a dirt floor would have been very uncomfortable and nearly impossible to walk on unless considerable effort were expended in preparing the surface. If that occurred, it is likely that many years of foot traffic would have created a hard packed surface that probably would have been detectable as a stratigraphic layer by the archeologists. Also, the constant sweeping of a dirt floor would probably have removed the natural rocks and most of the debris with each cleaning event, leaving very little behind. But if the house had a wooden floor, it is likely that many buttons and other small items would get lost between the floorboards, where they would have remained. Because buttons were found in almost every unit of the house block, it is likely that the Williams farmhouse had some type of wooden plank floor, and archeological evidence suggests that the wooden floor was present at some point during the farmstead's occupation.

\section{HOUSEHOLD FEATURES}

Two features associated with the house - the chimney base remnant and the subfloor storage pit-are described in detail in Chapter 7. The subfloor pit was about $3 \mathrm{ft}$ west of the chimney base, and its spatial proximity to the hearth is not coincidental (Figure 11.24). Samford (2007) discusses the various functions of subfloor pits and suggests that the three main functions of subfloor pits associated with antebellum slave quarters in Virginia were: (1) for food storage, (2) as a "locker" for store personal belongings, and (3) as a secret location for ritual concealment. Since no archeological evidence, circumstantial or otherwise, supports the argument for the Williamses' subfloor pit having served a ritual concealment function or as a personal storage locker, we can assume that their subfloor pit probably served as a food storage compartment of the type typically called a "root cellar" or "potato cellar" (Gross et al. 1993; Jurgelski et al. 1996; Kimmel 1993; Samford 2007). While food could also be stored in larger, aboveground structures such as corn cribs or "potato houses" (Abernathy 1979:162), many people used small subsurface pits placed inside the house, where it was completely protected from the elements. Historically, these pits were used for the storage of bulky vegetables such as sweet potatoes.

The proximity of the subfloor pit and the fireplace also support that idea that its primary function was for the underground storage of vegetables. A spatial association between chimney hearths and food storage pits is strong in oral traditions and in archeological contexts 


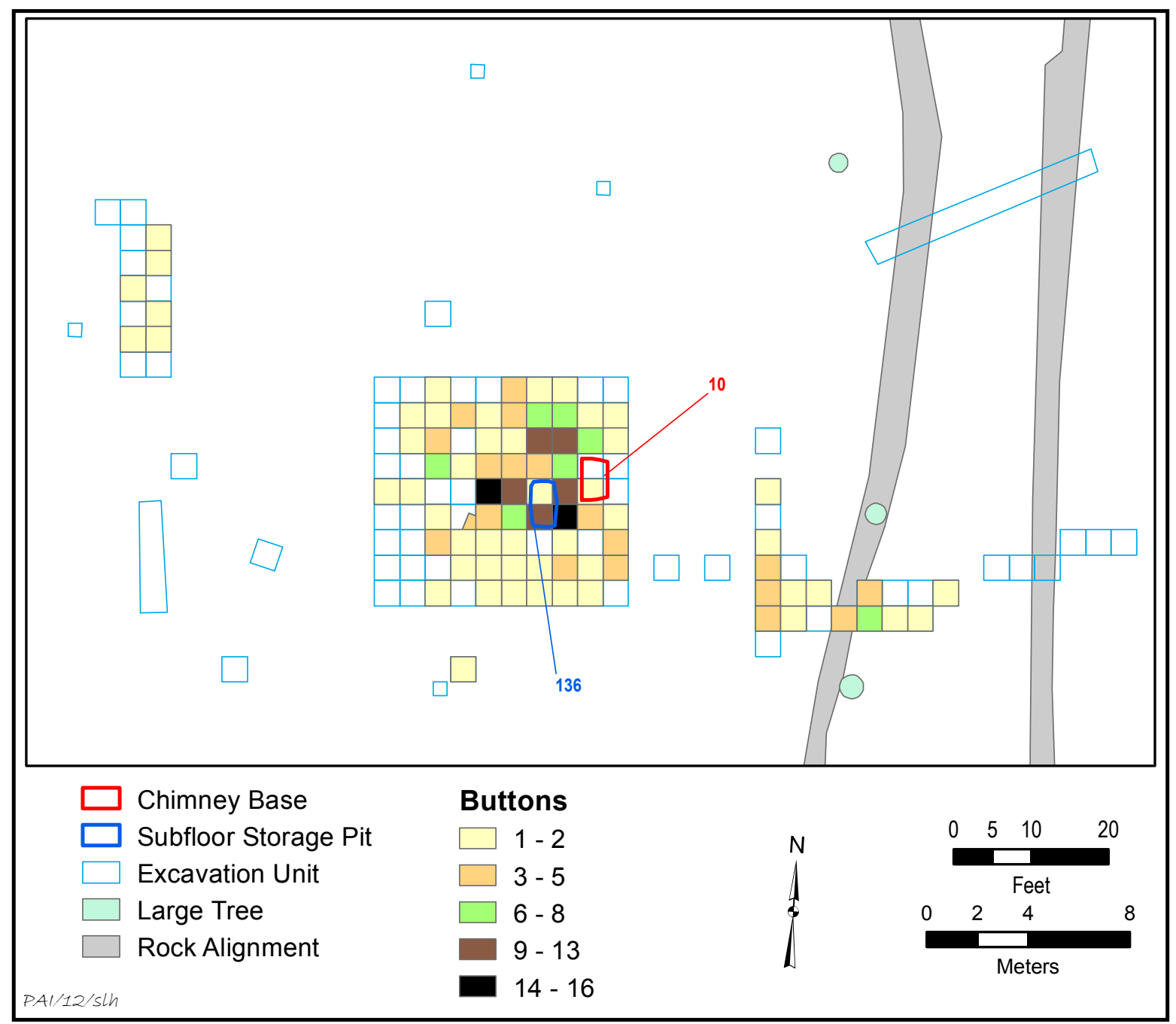

Figure 11.23. Distribution map of buttons in the house block, yard area, outbuilding, and midden.

(Dunnahoo 1982:44; Jurgelski et al. 1996:24; Samford 2007). In cold winter months, the residual heat provided by the fireplace would help to regulate the air temperature above the pit and underneath the floor. This would allow the food to stay cold but keep it from freezing. Conversely, in the hot summertime, the limestone and surrounding ground would provide a cool, subfloor environment with the proper amount of humidity for storing bulky plant foods.

In Arkansas, these types of subfloor pits varied considerably in size and were called "sweet potato cellars" or "potato holes." They were also called "before hearth cellars" because of where they commonly occurred in the house (Jurgelski et al. 1996:24). Dunnahoo (1982:44) provides a description of the before hearth cellars in the Ouchita Mountains:

A sweet potato cellar would generally be about four feet deep into the ground. Some cellars were lined with rocks; others had bare earthen walls with footholds cut into them. If a cellar were not lined with rocks, sand would usually be spread in the bottom of it to keep the potatoes dry. A cellar was always cleaned out in the spring and sand in it hauled out in buckets either to be cleared of trash and put back in the cellar or else replaced altogether with fresh sand. Cleaning 


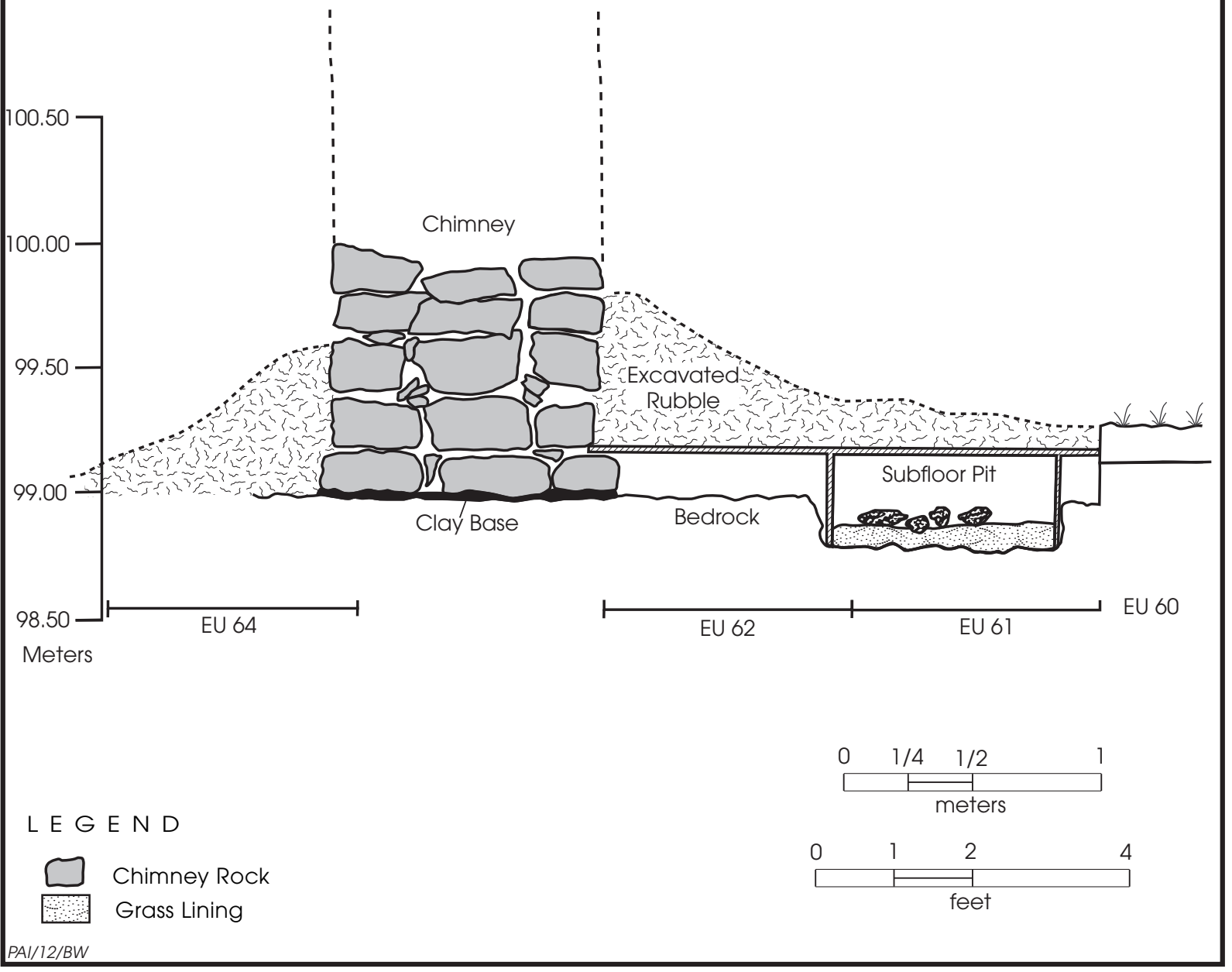

Figure 11.24. Schematic profile showing the relationship of the fireplace, the reconstructed wooden floor, and the reconstructed subfloor storage pit. In this illustration, the pit edges are lined with wood and the limestone bottom is lined with grass. Plant foods are stored in the pit, which is covered with a wooden hatch at the same level as the wooden floor.

out a sweet potato cellar was usually a chore for the children of the family.

Some of these cellars were clearly much deeper than the subfloor pit in the Williams house, but it would have been quite difficult to dig a deep pit in the solid limestone bedrock at the Williams farm.

Samford (2007:131) states that in Virginia, sweet potatoes were the primary food stored in subfloor pits in front of fire hearths. Compared to other root vegetables, sweet potatoes require higher temperatures and less humidity, with optimal temperatures ranging between 50 and 60 degrees (Samford 2007:132). The climate of central Texas is mild year-round with the exception of very hot periods in the summers. The main goal of the Williamses' subfloor pit would have been to keep the sweet potatoes at a consistent temperature to keep them from spoiling or sprouting. Samford (2007:132) goes on to state that other foods stored in similar conditions were pumpkins, winter squash, and green tomatoes, all of which could have been 
grown and stored in the subfloor root cellar at the Williams farmstead.

The charred plant remains recovered from the farmstead provide some hints on the Williams family diet and suggest some of the foods that might have been stored in the pit. A variety of different plants were identified (see Chapter 10). Interestingly, one charred fragment of sweet potato was recovered from the subfloor pit, providing substantive evidence that the Williams family grew and stored sweet potatoes on the farm. The recovery of charred peach pits in the midden, house block, and subfloor pit suggests that peaches could have been stored in the pit. We also know that the Williamses had a hand-cranked corn sheller (surface collected from the corral complex by ACSG), and it is possible that they stored dried corn kernels in the pit as well, some of which may have been intended as seed corn for planting each spring. When plant foods were placed in the pit, it is likely that the bottom of the pit was lined with grass to serve as insulation and a moisture barrier.

While the exact function of the Feature 1 subfloor pit cannot be known with certainty, when the archeological and historical evidence are considered together (see Chapter 7), the most plausible explanation is that the Williamses' subfloor pit was used for storage of perishable food items. Local oral history shows that subfloor pits were indeed used by African Americans in central Texas. Lillie Grant, an 86-year-old who grew up in the Antioch Colony area of Hays County, remembered the potato cellar under her house. In a 2009 oral history interview, she stated: "We had a big pantry with food in it like potatoes and things like that and onions. It was cool. You know, the houses were built up off the ground and it made the vegetables cool; we put our potatoes underneath there" (Franklin 2012:498). Grant then confirmed that she was talking about a food storage pit accessed through the floor.

Because the subfloor pit in the Williamses' house was backfilled with trash after its abandonment as a storage facility, the contents of the pit reveal nothing about its function. But the trash fill does indicate that the Williams family intentionally abandoned and filled in the pit at some point. The obvious questions are: When and why did they quit using the subfloor storage pit? There are two important chronological clues to when the subfloor pit was backfilled. The first is that the 214 nails found in the pit have a very different ratio of cut nails to wire nails that does the house block or midden (see Table 11.4). The ratio of cut to wire nails is only 1.25 to 1 in the storage pit, while it is 4.0 to 1 in the house block and 2.7 to 1 in the trash midden. This suggests that the midden was backfilled with household trash in the latter half of the Williams family occupation, probably after 1890 and possibly around the turn of the century, at a time when wire nails were more common in construction than cut nails.

The second clue is that some of the artifacts from the pit have distinctive markings with known dates of manufacture. The best way to estimate when the storage pit might have been abandoned is to look at all of the temporally diagnostic artifacts and to ascertain the maximum age (no older than) of the youngest datable artifacts. For various reasons, it is assumed that the backfilling of the subfloor pit occurred quickly rather than over a long period of time (see Chapter 7). Among the 247 artifacts with distinctive markings (see Table B.6), 20 of them are from the subfloor pit (see Lots 331-344, 454, and 457-462). While most of these items were manufactured beginning in the 1860s, 1870 s, or 1880 s, there are three specimens with beginning manufacture dates in the 1890s:

- A transfer-printed sherd from Lot 335 refits with other sherds in Ceramic Vessel No. 33 (see Table B.3). This dinner plate has a maker's mark identifying it as the Kenwood pattern made by the Alfred Meakin company of Tunstall, England. It has a particular backstamp that was only used from 1891 to 1897.

- A transfer-printed sherd from Lot 339 refits with other sherds in Ceramic Vessel No. 38 (see Table B.3). This saucer has a maker's mark identifying it as the Kenwood pattern made by the Alfred Meakin company of Tunstall, England. It has a particular backstamp that was only used from 1891 to 1897.

- A glass lid closure for a wide mouth food jar (Glass Container No. 97; see Table B.4). It is a Shies (1898) closure with a patent date of January 11, 1898.

Collectively, the abundance of wire nails, the Alfred Meakin transfer ware, and the Shies 
jar lid closure all suggest the 1890s, and the jar lid provides a maximum age for the backfilling event as 1898 or later.

Why the Williams family quit using the subfloor pit can never been known, but there are some plausible explanations. It is possible that they built a larger aboveground storage facility, such as a potato house or corncrib, that eliminated their need for the smaller pit. ${ }^{126}$ Aboveground storage had some definite advantages, but it was not as efficient for cooling as a belowground root cellar. It is also possible that the Williams family purchased an icebox, eliminating the need for the storage pit. Commercial icehouses were operating in Austin by the 1880s (Woolrich and Clark 2012). The Austin Ice Factory and the Capital Ice Factory were advertising in the 1885-1886 Austin City Directory, while the Lone Star Ice Company (owned by A. J. Zilker) advertised production of 60,000 pounds of ice per day in the 1893-1894 Austin City Directory (Morrison \& Fourmy 1885-1886, 1893-1894). In the 1893-1894 city directory, the Austin Ice Factory advertised that they could ship "to any part of the state," but it is not certain whether ice delivery would have been affordable in the remote rural farming areas of southern Travis County in the 1890 s.

The subfloor pit was spatially and functionally related to another house block feature: the chimney base. The main purposes of having a fireplace in the home were to provide heat and light. Heat from the fire would have warmed the home during cold weather and helped maintain the temperature in the storage pit, where food was stored. The hearth fire would have illuminated the house at night as the kids did schoolwork and played with their toys on the

\footnotetext{
${ }^{126}$ Aboveground food storage for root crops is described by Gage (2012:41-55) as "Field Root Pits." Located in fields away from houses and barns, these facilities protected food crops (mostly root foods) by placing them directly on the ground or inside a shallow pit or trench, and then constructing an aboveground mound with insulating layers of grass or straw covered by earth. One unpublished historical recollection (Sparks 1955) described these features as used in Limestone County, Texas: "They had long sweet potato banks where they stored bushels of sweet potatoes for the whole winter. The banks are built like a long roof house on the ground with dry corn stalks and covered with heavy layer of dirt had an opening at front and they would never freeze there regardless of the hard winter" (Sparks 1955:15). It is notable that potato banks and field root pits would leave little if any detectable archeological signature.
}

floor, or while Ransom played his harmonica or Jew's harp. The fireplace was very important to family, and it would have been the only means of cooking indoors until the Williams family acquired their wood-burning stove. The recovery of several cast-iron stove pieces indicates that they did acquire a wood-burning stove, but it is not known when they purchased it. Even after they got the stove, the fireplace would still have been used on occasion, but the family would not have relied upon it for all their heating and meal preparation. In addition, it is likely that the family cooked many meals outside, especially during the hot summer months. And the excavations recovered many cast-iron vessel fragments (including dutch oven body, feet, and lid fragment) that could have been used both for indoor hearth cooking or outdoor open-fire cooking (see Table B.7).

One artifact recovered from the firebox excavation suggests some sort of spiritual beliefs or ritual activity associated with the hearth. A single, complete projectile point (typed as a Darl; tip broken during excavation) was found among the layered basal stones of the inside chimney box. That this projectile point was intentionally placed there is unquestionable since the fireplace footprint had been excavated to solid limestone bedrock before building the chimney firebox (Figure 11.25). The point was the only item found at the bottom of the firebox. A broken arrow point (typed as an Edwards) found within the yard area (in EU W8; Lot 287) is the only other projectile point found at the Williams farmstead. This small fragmentary point could have been in its original prehistoric location or it might have been picked up nearby by a member of the Williams family and eventually discarded or lost in the yard. But the context of the dart point in the bottom of the hearth is unique.

There is considerable historical evidence to suggest that the projectile point in the Williamses' chimney was a spiritual offering of some type. There are archeological examples of projectile points and other Native American artifacts associated with African American ritual beliefs and conjuring:

- A cache of unusual artifacts was found in the slave quarters at the Levi Jordan Plantation in Brazoria County, Texas. It contained a projectile point and two 

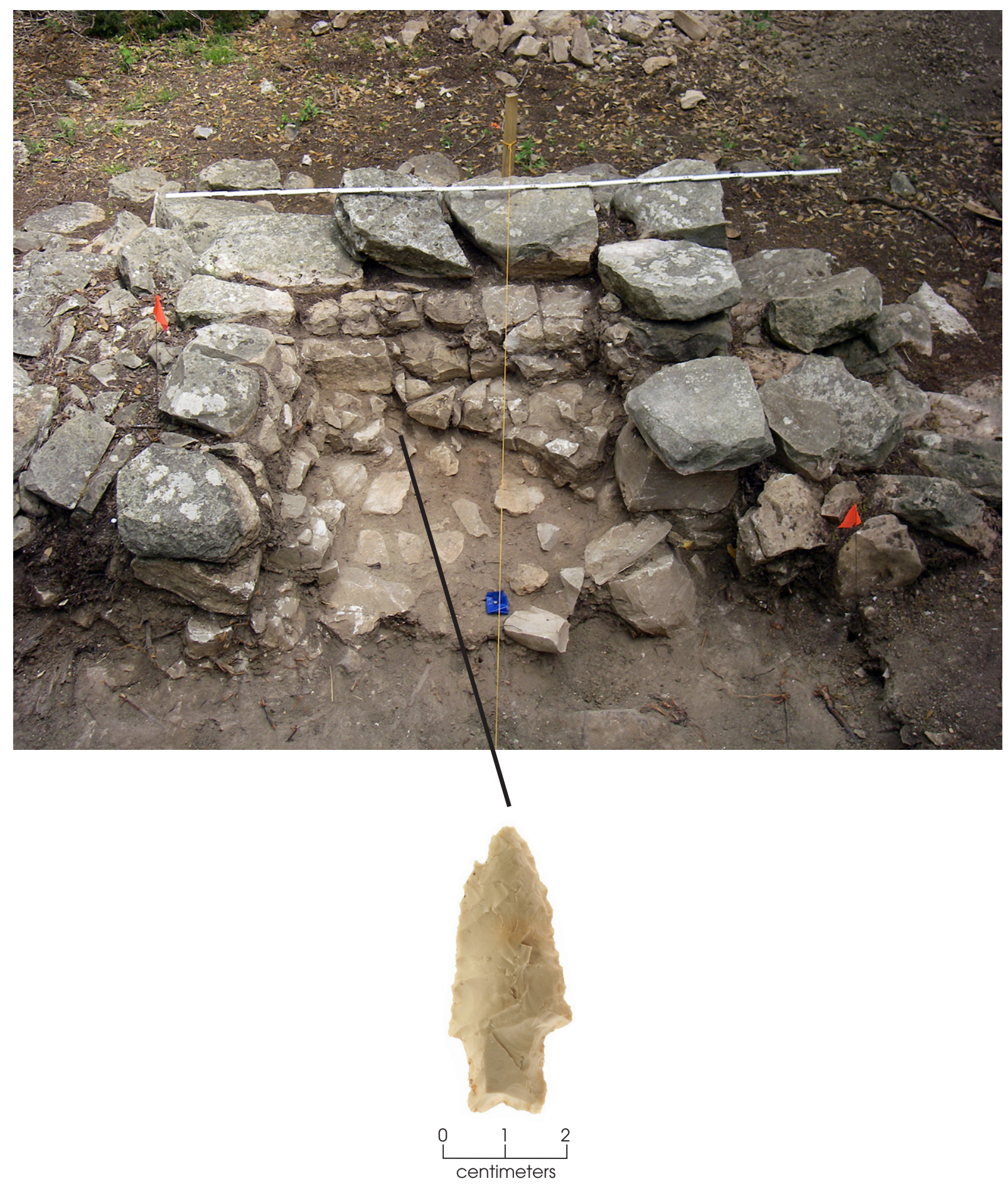

Figure 11.25. Prehistoric dart point found in the bottom of the chimney firebox.

scrapers. The cache dates between 1841 and 1891, and it may have been a minkisi charm (Brown and Cooper 1990:16-17; Wilke 1997:85-86).
- Galke (1992:137) reports a cache found near the footing of a chimney at the Nash Site in Manassas National Battlefield Park, Virginia, that contained six quartz 
crystals, a piece of galena, and a quartz projectile point. It was probably placed there by African Americans and may represent "spiritual or magical items" possibly contained in an African minkisi or charm bag (Goode 2009:18-19; also see Jones 2000).

- Projectile points are still considered to be important items in mojo bags (Russell 1997:74).

- Projectile points at the Hermitage Plantation in Tennessee were probably picked up and used as strike-a-lights in some ritual context (Russell 1997:73-74).

- Wilkie (2000b:186; 1997:100) mentions the recovery of crystals and curated projectile points from the Oakley and Riverlake plantations that were recovered from underneath houses, yard areas, and midden contexts. She notes that they are "religiously and magically important artifacts."

Interestingly, Wilkie (1994, 2000b) also cites an informant who provided insight into the potential spiritual significance of projectile points among African Americans. The informant, who was interviewed in Mississippi in the 1920s, spoke of how "arrowheads" were fashioned by God, not man, and could be used to bring good luck (Puckett 1926:319; Wilkie 1994:267). To use it properly, the projectile point was struck with a knife to throw a spark. Eventually, the spark would ignite the fuel or "punk" for a very small fire and it would smolder into ash. The ash would then be wrapped in newspaper and carried as a good luck charm (Wilkie 2000b:189).

Although there is no evidence of the point from the Williams chimney being struck against metal, perhaps it was placed in the firebox because of its connection with fire (i.e., flint and steel can make fire), and its placement at the bottom may have symbolic meaning because heat and smoke rise upward. In African American spiritual traditions, chimneys, doors, and windows were openings where good and bad spirits could enter the home. Another possibility is that Ransom Williams placed the point in this specific spot to ensure good luck when he began building his new home and his new life as a freedman. This type of belief would be similar to the placement of coins beneath building cornerstones for good luck, which eventually evolved into the practices of foundation (i.e., groundbreaking) ceremonies, commemorative cornerstones, and time capsules associated with public buildings (Jarvis 2002; Thurston 1912). The projectile point may also have had special meaning for Williams because of its association with Native Americans. Chireau (2009:56) notes that there are many connections between African American conjuring and Native American spiritual beliefs, and it is possible that a former slave might have assigned special significance to a projectile point found on his new farm.

One other object is mentioned here because of its possible ritual association. An 1877 Seated Liberty dime was found immediately in front of the fireplace (EU 52, Lot 21). Its context is such that it could easily have been dropped through the floorboards and lost. But dimes are often associated with African American ritual beliefs, as are hearths. Kemmers and Myrberg (2011) argue that the final depositional context of a coin found in an archeological site (i.e., its "tertiary context") may have a great deal of significance that archeologists often overlook. We looked for some significance associated with the 1877 date, but it does not match any known important event associated with the Williams family. The two oldest boys were born in 1876 and 1878 , so the coin is not a commemoration of either of these events. We must acknowledge that the dime near the hearth could have been an intentional placement associated with some spiritual belief, but in this case we can never know for sure.

\section{A SWEPT YARD?}

A grid of shovel tests was laid out around the original 9x10-m block, with shovel test locations spaced every $2 \mathrm{~m}$ within a $20 \times 24-\mathrm{m}$ area surrounding the house block (see Figure 11.3). The purpose of these shovel tests was to examine the hypothesized yard area. Heath and Bennett (2000:38) define a yard as:

...the area of land, bounded and usually enclosed, which immediately surrounds a domestic structure and is considered an extension of that dwelling. A yard is set aside for particular personal or group uses, including, but not limited to, food production and 
preparation, care and maintenance of animals, domestic chores, storage, recreation, and aesthetic enjoyment. It is at once a part of the domestic compound, and a mediating space between the natural, public world and the constructed, private world of the dwelling.

The "immediate active yard" in an idealized farmstead is considered to be the area within about $20 \mathrm{ft}(6 \mathrm{~m})$ of the house (Jurney et al. 1988:6-8, Figures 1.3 and 1.4). At the Williams farmstead, the house porch (hypothesized earlier in this chapter) and yard were multifunctional family activity areas where adults and children could work and play together. Except in the most inclement weather, most daytime activities would have occurred outside, and this would probably have included cooking, eating, socializing, childcare, and doing laundry. Archeologically, yard areas can often be distinguished from other kinds of activity areas, especially if they were enclosed by fences and maintained in some manner.

The excavation of 113 shovel tests within the testing grid yielded 318 artifacts (Figure 11.26). Eighty of the 113 shovel tests were positive, with most of the recovered artifacts being either kitchen and household items or architectural specimens. Small fragments of glass and ceramic dominate the kitchen and household group, while the architectural artifacts are comprised mainly of nails and nail fragments. Overall, the artifacts recovered from the yard area shovel tests are few in number, small in size, and highly fragmented.

One of the ideas behind the systematic shovel test grid around the house block was to test the hypothesis that the Williams family had a swept yard. The swept yard (also called a swept-earth yard) was a widespread Southern tradition that was practiced by many rural farmers but was especially common among African Americans. Many researchers believe that the swept yard had is roots among African tribal groups, and that this tradition maintained some of its original spiritual meanings long after it was transferred to the new world (Davenport 1961; Gundaker 1993; Heath and Bennett 2000; MacGaffey 1986; Raver 1993; Thompson 1984, 1990; Westmacott 1992). Before grass-covered lawns became the norm, swept yards were certainly practical in terms of safety. Keeping the vegetation removed limited hiding places for all types of critters, especially snakes, and removing the small debris kept barefoot children from cutting their feet (Battle-Baptiste 2010:88). In early plantation contexts, Battle-Baptiste (2010:88) notes that yard sweeping "was both a social and spiritual ritual that united the community in ways that would be overlooked by non-African observers." For the enslaved populations, the well-maintained swept yards were important boundary markers that had many levels of social and spiritual meaning.

In an attempt to examine the possibility that the Williams family had a swept yard, we looked at the relative artifact density per $\mathrm{m}^{2}$ for the shovel tests in the yard area. Each shovel test measured $30 \times 30 \mathrm{~cm}$, equal to $900 \mathrm{~cm}^{2}$, which is 11.11 percent of the area of a $1 \times 1-m$ excavation unit $\left(10,000 \mathrm{~cm}^{2}\right)$. The total artifact count for each shovel test can be multiplied by 11.11 to calculate the density of artifacts per square meter for each shovel test. The total number of artifacts from all of the shovel tests is 318, and they were recovered from a total excavation area of $10.17 \mathrm{~m}^{2}$ (113 units/11.11). The average artifact density in the shovel test grid is then calculated to be 31.27 artifacts per $\mathrm{m}^{2}$ (318 artifacts $/ 10.17 \mathrm{~m}^{2}$ ). So the average artifact density of 89.87 artifacts per $\mathrm{m}^{2}$ in the house block is almost three times higher than the average artifact density across the entire shovel test grid.

When the shovel tests from the yard area are separated from the total number of shovel tests, the density value drops even more. Of the 113 shovel tests dug, 105 are considered to be within the yard area, while the remaining 8 on the west side of the shovel test grid are within the midden area (see Figure 11.26). Using the same mathematical calculations mentioned above, a total of 243 artifacts were recovered from $9.45 \mathrm{~m}^{2}$ (105 units/11.11) of yard area shovel tests. The average artifact density for yard area shovel tests is then calculated to be 25.7 artifacts per $\mathrm{m}^{2}\left(243\right.$ artifacts $\left./ 9.45 \mathrm{~m}^{2}\right)$. As a result, the average artifact density for the yard is over three and a half times lower than the artifact density of 89.87 artifacts per $\mathrm{m}^{2}$ within the house block.

From the seven 1x1-m units excavated in the yard area, 296 historic artifacts were recovered (including the unknown and unidentifiable artifacts, but excluding 30 unmodified 


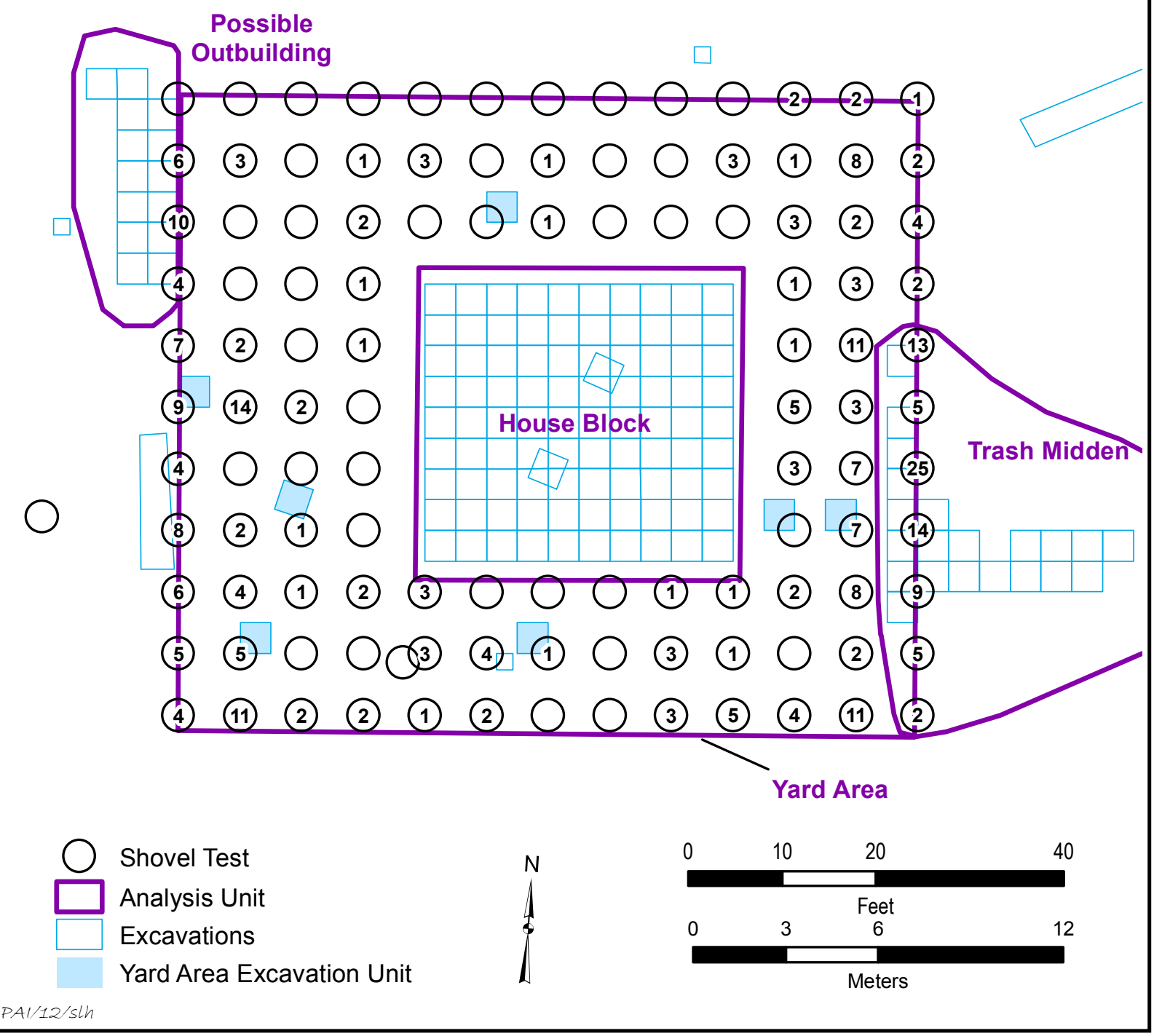

Figure 11.26. Map of shovel test recovery in the yard area around the Williams house. Numbers indicate the artifact counts in each shovel test.

chert flakes). So the average artifact density for these units is 42.3 artifacts per $\mathrm{m}^{2}$, which is just under half of the average artifact density in the house block. And even this number is probably misrepresenting the yard area because 73 (24.6 percent) specimens are small, unidentifiable fragments of thin metal that are likely to be from one or two crushed tin cans. In addition, $81(27.3 \%)$ specimens are nails and nail fragments that may not have been deposited during the Williams occupation and most likely ended up in the yard area after the house was abandonment and collapsed. Combined, almost 52 percent of the artifacts recovered from shovel tests are fragmentary nails or unidentified metal fragments, and these items probably inflate the average artifact density for these seven units.

Based on the overall low artifact density within the yard area, coupled with the fact that the recovered artifacts are small and highly fragmented, it is likely that the Williamses' yard was indeed a maintained surface. This data does 
not prove that this area was a swept yard in the sense that they kept all vegetation removed and periodically swept the earth to remove debris, but this artifactual evidence would be consistent with such behavior. The shovel test recovery shows that there are concentrations of small artifacts about 18 to $20 \mathrm{ft}$ to the south, west, and north of the house block excavations, with lesser artifacts in the areas closest to the house. On the east side of the house, the significant concentration of artifacts begins about 15 to $16 \mathrm{ft}$ behind the chimney and denotes the west edge of the midden. This large jump in artifact frequency probably coincides with the location of a former north-south fence that marked the yard edge at one time. About $10 \mathrm{ft}$ farther east, the north-south rock alignment and former barbedwire fence mark the edge of the topographic flat and another yard boundary. The overall artifact pattern suggests a well-maintained yard that probably extended about $20 \mathrm{ft}$ around the house on three sides, but the yard area on the east side may have changed through time. It is likely that the Williams family spent some effort making sure that the yard area, which was probably always enclosed by a barbed-wire fence, was periodically cleaned and kept free from debris.

At the Williams farmstead, the high frequency of artifacts inside the house footprint and the low frequency of artifacts in the yard are probably related. In a discussion of refuse disposal at tenant houses in South Carolina, Trinkley (1983) observed that many small items accumulated under the houses, and that the yards were exceptionally clean. He noted that: "Apparently the practice of sweeping dirt yards is of some antiquity and is still observed today. The debris may be swept under the house, adding to the natural accumulation, or carried away from the house" (Trinkley 1983:34). The observation suggests that the Williamses probably pushed the small debris under their house when they were sweeping their yard.

We can never prove or disprove that the Williamses were practitioners of the swept-yard tradition, but the current archeological evidence certainly makes a strong circumstantial argument. If the area immediately around the Williamses' house was indeed a swept yard, the implications are significant. This would mean that a West African tradition had survived and was still practiced by African American freedmen in Texas in the last quarter of the nineteenth century. The underlying meanings of traditions can and do change through time, so there is no way to know if the Williamses kept their yard swept in accordance with some spiritual belief or if it was simply a practical matter related to health and safety. Regardless, the archeological evidence for a swept yard at this rural farmstead is probably a reflection of the Williamses' identity as a southern African American farm family. The possible implications of this and the African origins of the swept yard are discussed more in Chapter 14.

\section{THE FARMSTEAD AS A COLLECTION OF ACTIVITY AREAS}

Using the house location as a starting point, and considering the other landscape features and topography, the archeologists were able to piece together a fairly complete picture of the working farmstead while the fieldwork was in progress (see Chapter 7). But in terms of the material culture, most of the excavations are associated with the farmhouse and the immediate surrounding area because this is where the material culture was most concentrated. Despite the fact the most of the artifacts come from a relatively small section of the 45-acre farmstead, the material culture can reveal a great deal about the activities that occurred all across the property. The artifacts associated with the domestic portion of the site provide many insights into the day-to-day activities on the farm.

As is true of most late-nineteenth-century farms in Texas, the Williams farmstead was a self-sufficient, single household unit of production and consumption, meaning that various crops and animals were raised on the farm, consumed on the farm, and likely marketed nearby for a profit as a source of income (Groover 2008:127). According to Groover (2008:127), simple economic farm activities could impact "daily material life" in such a way as to influence the "arrangement of the farm and house lot, the function and placement of outbuildings, the types of food consumed by the household, gender roles in the household, and the standard of living experienced by the site's residents." Instead of focusing just on the house, it is important to examine the farm as a working system.

As a self-sufficient unit, the farmstead would have consisted of several integral parts, 
all supporting the efficient operation of the larger system. The house served as the base of domestic operations, but there were typically many other outbuildings and features that served specific functions, such as barns for sheltering livestock and sheds for storing various tools and equipment, especially the large items associated with agriculture-wagons, plows, harnesses, and other horse gear. In order to subsist, various crops and livestock were raised for both family consumption and as cash crops sold locally. This provided a source of food and income for the family. Keeping the livestock out of the crops and the property would have been another task, and the rock and barbed-wire fences were erected to delineate property boundaries and subdivide the property into functionally distinct segments. Having a nearby source of water would have been key to the survival and welfare of the farm. Large amounts of water would be used by the family for drinking, cleaning, and washing clothes, and even larger amounts of water were needed for the livestock and the garden. It is likely that the field crops were not irrigated but depended solely on rainfall. All of these farm components were interrelated, and each would have influenced the placement of the others to create the most efficient system and farm layout for the family's needs.

The idealized farmstead described by Jurney et al. (1988:6-8, Figures 1.3 and 1.4) suggests that many other structures and features were likely present on the Williams farmstead. An idealized farmstead would include most of the following structures and features: the house and an active yard; a peripheral yard; a well or cistern; a privy; a smokehouse; a barn; a livestock corral; storage cellar; storage or work shed; cultivated land; pasture land; and a stock pond. Many of these structures and features are present at the Williams farmstead, but no evidence was found for many types of structures, which makes it impossible to determine what else may have existed. The house location was known based on the presence of the chimney base and foundation stones. Following the initial survey of the property and shovel testing around the house, concentrations of artifacts showed the possibility of an outbuilding just northwest of the house. Large artifacts in this area, such as a wagon wheel hub and segments of cultivator chain, indicate that this structure might have been a carriage shed or something similar. It may have even been a multipurpose structure that served as storage and a stable.

Another architectural feature evident north of the main house is the series of limestone walls constructed of naturally occurring limestone that was stacked by hand. Many of the rocks were probably cleared from the fields to facilitate plowing and harvesting, but others were removed from the rocky wooded slopes simply because they were exposed and easily accessible. These rock walls, with some remnants of barbed-wire fencing on them in places, served as livestock fences between grazing pasture and the field crops; they also formed small corral-like enclosures near an excavated stock pond. In one area, where several of the rock walls converge north of the house location, the walls came together to create a small pond for holding water, and not far from the pond, a collection of barrel bands located on the surface. The unusually large number of barrel bands suggests that water was commonly transported from Bear Creek to the site for a variety of purposes.

Horses were an important part of the farmstead, and their presence is well documented historically and archeologically. In 1872, Ransom Williams registered the script letters RA as his livestock brand with Travis County. Unlike most of the other brands in this section of the registry, Ransom's brand had a notation that it was a "horse brand" (Travis County Register of Marks and Brands 1872). In addition, tax records show that Ransom paid taxes in Hays on a large number of horses or mules he owned before and right after he purchased his farm. In 1870 he owned six horses or mules worth $\$ 120$. In 1871 he owned nine horses or mules worth $\$ 190$. In 1872 he owned six horses or mules worth $\$ 120$. And in 1873 he owned nine horses or mules worth $\$ 180$ (Hays County Tax Records, 1870-1873). This was at a time when most African Americans owned only one or two horses or mules (see Chapter 5).

Archeological evidence also indicates that Ransom owned an unusual amount of horse gear and harnesses, along with some wagons or carriages. Horse gear and wagon-related artifacts recovered at the farm include:

- 15 horseshoes and muleshoes (see Table B.31)

- 33 horseshoe nails (see Table B.32) 
- 47 harness buckles of various sizes and types (see Table B.30)

- 70 items of horse tack, including three bridle bits, snap buckles, a bolt snap, numerous cinch rings, a dee ring, harness rivets, a harness cockeye, a breast strap slide, and an iron letter " $R$ " broken off of his livestock brand (see Table B.33).

- 89 wagon or carriage pieces, including wagon box staples and straps, side board brackets, clevises and clevis pins, wagon brake locks and brake shoes, whiffletree clips and straps, a wagon box rod collar, a wagon wheel skein, and wagon nuts (see Table B.34).

Horseshoes outnumbered muleshoes 13 to 2 at the farmstead (see Table B.31), and it is suspected that most of Williams's animals were horses rather than mules. Given the fact that Ransom Williams owned so many horses and so much horse gear, along with several wagons or carriages, it is possible that he was in the business of raising or breeding horses or that he used horses and wagons to haul things for other people.

Currently, the Williams property is completely overgrown with juniper trees and a mix of small underbrush. But the 1937 aerial photograph clearly shows the property boundaries and where the cultivated fields were located in relation to the house. Archeologically, a number of farming artifacts were recovered, including plow parts and cultivator chains (see Table B.47). ${ }^{127}$ These would have been horse-drawn implements and been used in conjunction with the abundant horse gear and harness parts (see Tables B.30-B.34). In addition, parts of a cotton scale (a counterweight and hanger hooks; see Figure 8.25b-d) found in the house block would have been used as part of a large scale to weigh cotton or other bulk farm crops. As for what crops were grown, corn was probably one of the most important crops based on the recovery of charred corn from the midden (see Appendix D) and a hand-operated corn sheller from the corral complex. Corn would have been eaten by

\footnotetext{
${ }^{127}$ Two artifacts were identified as cotton bale ties just as the final version of this report was being prepared. They are described at the end of Chapter 8 in a section called "Addendum: Cotton Bale Ties." However, these items were not added in to the counts of farming-related artifacts anywhere in the body of this report.
}

the family and probably fed to the horses and mules. Several charred peach pits were also recovered (see Appendix D), perhaps indicating the presence of one or more peach trees on the farm. Wild persimmons currently grow in the vicinity of the house and the outbuilding. Although no persimmon seeds were recovered archeologically, it is possible that these trees were transplants or naturally grew here during the Williams occupation.

As with many rural farms, a garden was likely planted to provide the family with an abundance of fresh vegetables. Charred sweet potato remnants were also recovered and could possibly indicate that sweet potatoes were grown and a preferred crop. In addition, the subfloor storage pit under the house may have served as storage for sweet potatoes. Despite the lack of physical evidence revealing the location of a garden, the pruning shears (EU 42, Lot 19) and a garden hoe (surface collection, Lot 34 ) found in the house block and another garden hoe found in the outbuilding (EU W4, Lot 283) provide definitive evidence of domestic gardening. The garden was probably somewhere close to the house.

Interestingly, no privy location was found during any of the fieldwork. Based on the shallow soil covering the dense limestone bedrock, excavation of a large enough privy hole in this environment would be very difficult. It is more likely that the privy holes where relatively shallow and that the wooden privy was moved frequently. Logic would dictate that the privy locations were downslope, to the east or northeast of the house, where the prevailing southerly winds would carry odors away from the house and where surface runoff would not impact any household activity areas. Logic would also suggest that the privy locations were east of the trash midden so that one could carry out garbage on the way to the outhouse.

Running a family farm involved everyone doing his or her share of work. The division of labor was often along gender lines, with specific agricultural jobs falling to the men and work in the house carried out by the women. While Ransom likely worked outside tending to the horses and working the farm, Sarah would have been responsible for much of the child rearing and other traditionally defined domestic duties. When the children were in school, Sarah would have been busy with a variety of farm and household duties. While the gender-based division of 
labor was true as a general rule, it does not mean that this was always the case or that there were no exceptions. The oral history data suggests that there was a fair amount of overlap between men's and women's roles (see Chapter 12). For the farm to run most efficiently, all members of the family had to help out and work in any way needed, especially during critical farming times such as crop planting and harvest. Children had their own set of chores that probably included feeding the animals, fetching eggs from the yard, and picking fresh fruits and vegetables. And they often helped out in various capacities when the adults needed help.

\section{CONCLUSIONS}

Excavations at the Williams farmstead focused around the house due to the nature of the physical remains and the goals of the archeological project. But the discussions in this chapter look at the farm as a holistic system and examine the spatial distributions of material culture and features associated with the entire farm operation. Examining the farmstead as a system allowed us to extract information about the Williamses' daily lives on the farm in the late nineteenth century. Archival data and oral history research provide complementary evidence that, along with archeological evidence, presents an fuller picture of the spatial layout of the farm and the many activities that occurred in day-to-day life. It is not surprising that many of artifacts overlap by functional group across the farmstead. Because the farm is an integrated system, no one activity can be singled out without another activity being implicated in the discussion. Every aspect of the farm was connected. The Williams farm was not just a farmhouse but a collection of interrelated places and people working together to create a self-sufficient system. 